\title{
Marek Leykam. Hacia una arquitectura de resistencia.
}

Francisco Requena Crespo

TESIS DOCTORAL

Director: Prof. Dr. José Manuel Barrera Puigdollers.

Departamento de Proyectos Arquitectónicos.

Universidad Politécnica de Valencia.

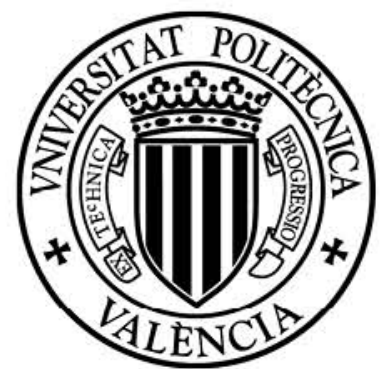

Diciembre 2015 
A mi familia, por darle sentido. 

ÍNDICE

AGRADECIMIENTOS

17 RESUMEN / RESUM

ABSTRACT / STRESZCZENIE.

I. INTRODUCCIÓN

I.I. PREÁMBULO

I.2. ORIGINALIDAD DEL ENFOQUE.

I.3. APROXIMACIÓN AL OBJETO DE ANÁLISIS.

1.3.I Entorno académico de Marek Leykam.

1.3.2 Influencias profesionales y primeros proyectos

1.3.3 Transcurso de la II Guerra Mundial.

1.3.4 Primeros pasos en la reconstrucción de Varsovia.

II. HIPÓTESIS DE TRABAJO.

2.I Influencia de la Escuela Filosófica de Lvov-Varsovia.

2.2 Formalización de un lenguaje arquitectónico a través de la lógica.

2.3 Interpretación de la arquitectura a través de la liturgia. 


\section{I. DIRECCIONALIDAD.}

3.I.I Edificio de Información Militar del Ministerio de Defensa en Varsovia.

3.I.2 Instituto Geológico de Varsovia.

3.I.3 Edificio NIK Jefatura de la Industria del Acero y el Carbón de Varsovia.

3.I.4 Oficina Central de Estudios y Proyectos de Construcción Industrial de Varsovia.

3.2. ADIRECCIONALIDAD.

3.2.I Edificio Okrąglak de Poznań.

\subsection{LINEALIDAD}

3.3. I Arcos de la Plaza Central de la Exposición de Territorios Recuperados de Wrocław.

3.3.2. Museo de las Batallas de Revolución y Liberación de Varsovia.

3.3.3. Monumento a la Victoria en el eje Saski de Varsovia.

\subsection{INTERTEXTUALIDAD.}

3.4. I. Fábrica de Camiones de Lublin.

3.4.2. Instituto General de Investigaciones Tecnológicas de Varsovia.

3.4.3. Pabellón de Polonia de la Exposición Agrícola de Moscú.

3.4.4. Sede de la Presidencia del Gobierno de Varsovia.

\subsection{ANTAGONISMO}

3.5. I. Estadio del Decenio de Varsovia. 
3.6. INTERDISCURSIVIDAD.

41

3.6. I. Casa de la Cultura de Lublin.

3.6.2. Instituto de Ciencias Experimentales y Medicina Clínica de Varsovia.

3.6.3. Escuela de Arte de Nałęczów.

3.7. HIPERTEXTUALIDAD.

3.7. I. Ordenación de la Fachada Este de Varsovia.

3.7.2. Torre en la Ronda George Washington de Varsovia.

3.8. EPIFONEMA.

3.8. I. Albergue Dom PTTK en Plock.

3.8.2. Instituto de Educación Física AWF de Poznań.

IV. ANÁLISIS DEL MÉTODO PROYECTUAL DE MAREK LEYKAM.

V. MENSAJE TRANSMITIDO POR LA OBRA DE MAREK LEYKAM.

VI. CONCLUSIONES

ANEXO I. SUPERVIVENCIA DE LAS OBRAS.

ANEXO II. LISTA DE PROYECTOS.

BIBLIOGRAFÍA.

REFERENCIAS DE LAS IMÁGENES. 
0.01. Artículo "O wnętrzu współczesnym" (El interior contemporáneo). Publicado en la revista Arkady
$1936, n^{\circ} 7$ p. 375-377. 


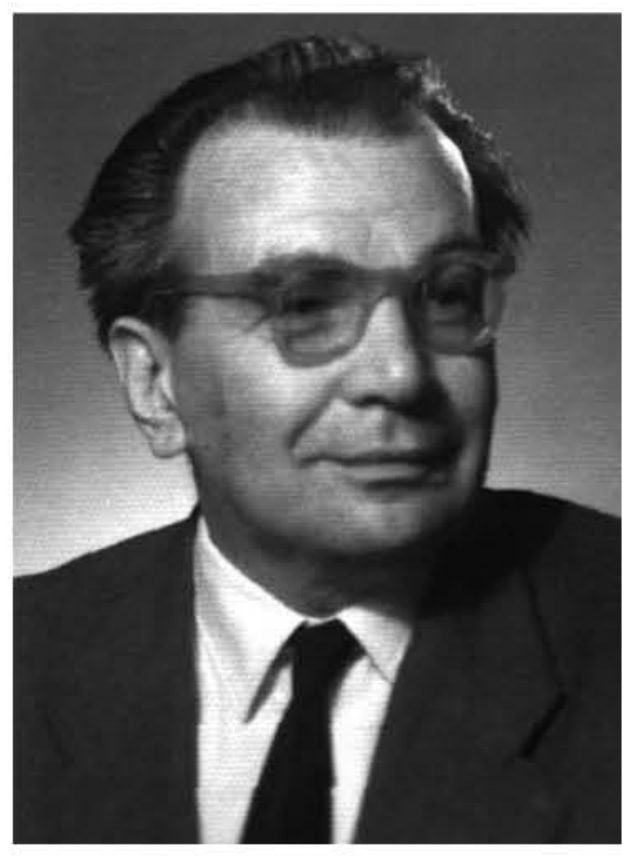

"La arquitectura es el arte de componer el espacio y la vida." 0.01

Marek Leykam (1908-1983) 

La presente tesis doctoral no hubiera sido posible sin el apoyo de su director, el Prof. Dr. José Manuel Barrera Puigdollers, titular de proyectos de la Universidad Politécnica de Valencia, cuya incansable búsqueda de relaciones entre la arquitectura y el pensamiento contemporáneo han sido un estímulo constante para esta investigación, dando lugar a reflexiones y conversaciones de cuya profundidad y consecuencia es imposible no quedar en deuda a través de estas líneas.

La contribución de la profesora de la Universidad Politechnika Poznańska Karolina Skalska ha resultado asimismo fundamental, habiendo mostrado siempre gran confianza e interés por el avance de las investigaciones, y realizando muy significativas aportaciones en momentos en los que un razonamiento adecuado resultaba crucial para hacer avanzar la investigación. Su compañía en las visitas a la obra de Leykam ha resultado igualmente determinante para comprender la dimensión de su trabajo como arquitecto y las implicaciones de su obra en la sociedad polaca del s. XX.

Tanto la Univesidad Politechnika Poznańska como la Univesidad Politechnika Warszawska y los colegios de arquitectos SARP Poznań y SARP Warszawa se han implicado en este trabajo ofreciendo todo el material que tenían disponible y una plena capacidad de acceso a sus archivos. La escasez de investigaciones publicadas sobre el trabajo de Leykam en polaco, y su ausencia generalizada en español, no han hecho sino revalorizar aun más cualquier información disponible. Sirvan estas líneas para agradecer a todas aquellas personas que han hecho posible estos intercambios, particularizando en el Instituto Polaco de Cultura en Madrid que facilitó el acceso a la figura del arquitecto e historiador del arte Tadeusz Barucki, que gentilmente puso a mi disposición toda la información de su archivo personal.

Mención aparte a esta nota merece el apoyo incondicional de Marta Skalska, que creyó desde el principio en este proyecto y ha colaborado impagablemente en la tarea de velar por la adecuada interpretación de los textos polacos que se recogen en esta tesis, matizándolos con aportaciones que resultan imperceptibles para cualquiera que no conozca en profundidad la cultura social y arquitectónica de Polonia, enriqueciendo profundamente el contenido de todo el trabajo. Sin su complicidad permanente y su inquebrantable aliento durante mis largos periodos de ausencia o falta de implicación en el estudio de arquitectura que compartimos habría sido imposible desarrollar esta investigación.

Habida cuenta de mi evidente gratitud hacia familiares y amigos, siéntase citada asimismo en esta nota cualquier persona que haya compartido inquietudes con respecto a esta tesis a lo largo de estos años, o simplemente quien esté siendo partícipe en estos momentos de la satisfacción de ver que algún día tuvo un final.

A todos, muchas gracias. 


\section{RESUMEN.}

El arquitecto polaco Marek Leykam contribuyó a reformular el papel del arquitecto moderno como auténtico gestor de un esfuerzo colectivo, interviniendo con eficacia en la reconstrucción de Polonia tras la II Guerra Mundial mediante una arquitectura de gran simbolismo y representatividad atenida a un método proyectual coherente derivado de su prioridad por la lógica y la razón, que no solo le permitió responder a las necesidades materiales de la sociedad, sino actuar conscientemente sobre la base de sus problemas sociales derivados de la pérdida de identidad y el desarraigo de la población superviviente ante la propia idea de ser humano.

Bajo unas condiciones de partida de caos, en las que tuvieron que unir fuerzas todos los agentes disponibles en aras de un objetivo común que formaba parte de los requerimientos vitales básicos de la población, Leykam articuló un método proyectual coherente basado en la optimización de las posibilidades técnicas y constructivas de cada momento, el máximo aprovechamiento de los recursos y la eficacia en la ejecución, a través del cual generar una respuesta razonada al contexto de cada obra sin que sus soluciones quedasen determinadas por accidentes circunstanciales.

El conjunto de proyectos de Leykam reconstruye de forma continua una trama abierta a ser completada por la interacción consciente de todas las personas que entran en contacto con su trabajo, contemporizando una postura firme y contraria a los planteamientos de dominación que estaban teniendo lugar en Polonia después de 1945 tanto en la esfera artística como en la social, y dando lugar a una obra que, alejada de la utopía, no tuvo pretensión de ser revolucionaria pero sí de ejercer una resistencia sobre la cual se sentasen las bases de una sociedad estable que recuperase la fe en su convivencia comunitaria compartiendo rutinas, pautas y repeticiones a modo de actos de liturgia.

Mediante la arquitectura, Leykam agitó así la conciencia colectiva sobre la necesidad de reestructurar la sociedad polaca desde la ausencia de imposiciones autoritarias de carácter subjetivo, hecho al que aludió a través de una arquitectura basada en proposiciones lógicas que permitiesen administrar racionalmente las jerarquías y distribuir equitativamente los espacios y sus perspectivas visuales independientemente de cuáles fueran sus funciones. Mediante este procedimiento, era posible poner de manifiesto asimismo la necesidad de no trabajar alejado de los avances técnicos, ni carecer de mecanismos democráticos para organizar una sociedad más justa e igualitaria.

El objetivo de esta tesis es demostrar la existencia de un método proyectual coherente a lo largo de toda la obra de Marek Leykam, reconstruyendo retrospectivamente sus patrones, analizando las implicaciones semióticas de su arquitectura y poniendo de manifiesto su preocupación por la búsqueda de soluciones a los problemas sociales en una época marcada por un sentimiento colectivo de alienación. 
L'arquitecte polonès Marek Leykam va contribuir a reformular el paper de l'arquitecte modern com autèntic gestor d'un esforç col-lectiu, intervenint amb eficàcia en la reconstrucció de Polònia després de la II Guerra Mundial mitjançant una arquitectura de gran simbolisme i representativitat atinguda a un mètode projectual coherent derivat de la seva prioritat per la lògica i la raó, que no només permetia respondre a les necessitats materials de la societat sinó actuar conscientment sobre la base dels seus problemes socials derivats de la pèrdua d'identitat $i$ el desarrelament de la població supervivent davant la pròpia idea d'ésser humà.

Sota unes condicions de partida de caos en què van haver d'unir forces tots els agents disponibles en nom d'un objectiu comú que formava part dels requeriments vitals bàsics de la població, Leykam va articular un mètode projectual coherent basat en l'optimització de les possibilitats tècniques i constructives de cada moment, el màxim aprofitament dels recursos i l'eficàcia en l'execució, a través del qual generar una resposta raonada al context de cada obra sense que les seves solucions quedessin determinades per accidents circumstancials.

El conjunt de projectes d'Leykam reconstrueix de forma contínua una trama oberta a ser completada per la interacció conscient de totes les persones que entren en contacte amb el seu treball, contemporitzant una postura ferma i contrària als plantejaments de dominació que estaven tenint lloc a Polònia després de 1945 tant en l'esfera artística com en la social, i donant lloc a una obra que, allunyada de la utopia, no va tenir pretensió de ser revolucionària però sí d'exercir una resistència sobre la qual s'asseguessin les bases d'una societat estable que recuperés la fe en la seva convivència comunitària compartint rutines, pautes i repeticions com d'actes d'una litúrgia.

Mitjançant l'arquitectura, Leykam agità així la consciència col-lectiva sobre la necessitat de reestructurar la societat polonesa des de l'absència d'imposicions autoritàries de caràcter subjectiu, fet al que va al·ludir a través d'una arquitectura basada en proposicions lògiques que permetessin administrar racionalment les jerarquies i distribuir equitativament els espais $i$ les seves perspectives visuals independentment de quines fossin les seves funcions. Mitjançant aquest procediment, era possible posar de manifest, així mateix, la necessitat de no treballar allunyat dels avenços tècnics ni mancar de mecanismes democràtics per organitzar una societat més justa $i$ igualitària.

L'objectiu d'aquesta tesi és demostrar l'existència d'un mètode projectual coherent al llarg de tota l'obra de Marek Leykam, reconstruint retrospectivament els seus patrons, analitzant les implicacions semiòtiques de la seva arquitectura i posant de manifest la seva preocupació per la recerca de solucions als problemes socials en una època marcada per un sentiment col-lectiu d'alienació. 
The Polish architect, Marek Leykam, has contributed to reformulate the role of the modern architect as an authentic manager of a collective effort, effectively intervening in the reconstruction of Poland after World War II by generating a highly symbolic and representative architecture following a consistent design methodology based on his priority for logic and reason, which not only allowed him to meet the material needs of society, but to act consciously on the basis of their social problems arising from the loss of identity and uprooting of the surviving population from the very idea of human being.

Under chaotic starting conditions, in which all available agents had to join forces in pursuit of a common goal which was part of the basic vital needs of the population, Leykam articulated a coherent design method based on optimization of the technical and constructive possibilities of the moment, maximization of resource usage and effective implementation, through which to generate a reasoned response to the context of each work without its solutions being determined by circumstantial accidents.

The set of Leykam's projects continuously reconstructs an open frame to be completed by the conscious interaction of all the people who come into contact with his work, contemporizing a firm posture, contrary to the ideas of domination that were arising in Poland after 1945 in both the artistic and social sphere, and resulting in a work that, far from utopia, was not intended to be revolutionary but did aim to exercise a resistance on which to lay the foundations of a stable society that could recover its faith in its community life by sharing routines, patterns and repetitions as liturgical acts.

Through architecture, Leykam thus stirred public awareness of the need to restructure Polish society in the absence of subjective authoritarian impositions, a fact to which he alluded through an architecture based on logical propositions that would allow the hierarchies to be managed rationally and spaces and their visual perspectives to be equally distributed regardless of their functions. By this method, it was also possible to demonstrate the need to work taking technical progress into account and to have democratic mechanisms to organize a more just and egalitarian society.

The purpose of this thesis is to demonstrate the existence of a consistent design method throughout the work of Marek Leykam, by retrospectively reconstructing patterns, analysing the semiotic implications of his architecture and demonstrating his concern for finding solutions to social problems in an era characterized by a collective sense of alienation. 
Polski architekt Marek Leykam przyczynił się do określenia roli nowoczesnego architekta jako rzetelnego przedstawiciela zbiorowego wysiłku, biorąc czynny udział w odbudowie Polski po II Wojnie Światowej. Poshugując się językiem architektury symbolicznej i reprezentacyjnej, podporządkowanym konsekwentnej metodzie projektowej opartej na atrybutach logiki i rozumu, nie tylko realizował potrzeby mieszkańców, lecz także świadomie oddziaływał na społeczeństwo okaleczone przeżyciami wojny.

W warunkach chaosu Leykam wykreował szereg mechanizmów przydatnych w tworzeniu architektury, opartych na możliwościach technicznych i konstrukcyjnych, optymalizacji procesu budowlanego oraz skuteczności realizacji budynku, które niezależnie od geometrii bryly, dawały logiczną odpowiedź na każdy z towarzyszących budynkowi kontekstów.

Projekty Leykama tworzą otwarty dialog, kompletowany przez świadomą interakcję jednostek mających kontakt z dziełem architekta, wzbudzając nieugiętą postawę sprzeciwu wobec dominacji władz, zarówno w sferze artystycznej jak i społecznej. Twórczość Leykama, daleka od utopii, nie usiłowała być rewolucyjna, lecz stworzyć fundamenty oporu, na których mogłoby oprzeć się społeczeństwo odzyskujące wiarę w człowieka, doświadczając wzorców, schematów i iteracji na miarę aktu liturgicznego.

Swoją twórczością Leykam usiłował rozbudzić zbiorową świadomość potrzeby restrukturyzacji polskiego społeczeństwa wolnego od dyktatury władzy. Architektura Leykama opierała się na logicznych regułach, które umożliwiały racjonalne i zrównoważone zarządzanie przestrzenią i proporcjami niezależnie od przypisanych jej funkcji, manifestując tym samym opór przeciwko ograniczeniom jakim było odizolowanie od postępu technicznego i brak demokratycznego systemu kontroli.

Celem niniejszej pracy jest wykazanie istnienia metody projektowej w twórczości architekta Marka Leykama, poprzez retrospektywne odtworzenie wzorców i analizę implikacji ideologicznych autora, mając na względzie odmienne nurty myśli w powojennej Polsce i jej analogie z sytuacją społeczno-polityczną. 

I. INTRODUCCIÓN. 



\section{I.I. PREÁMBULO.}

Para una adecuada comprensión de la obra del arquitecto polaco Marek Leykam, es fundamental no dejar pasar los acontecimientos históricos, culturales y sociopolíticos que motivaron las necesidades que dieron lugar a que su trabajo pudiera ser realizado. Atender esa realidad es imprescindible para que sus proyectos no queden limitados a una dimensión compositiva o técnica que no daría muestra de la reflexión alcanzada por su obra, dejando al margen sus respuestas frente a cada una de las esferas que abarcan sus manifestaciones arquitectónicas.

La fuerte personalidad del colectivo de docentes de la Escuela de Arquitectura de Varsovia en la década de 1930 -entre los que cabe destacar la importante influencia del profesor Rudolf Świerczyński-, comprometidos a producir una arquitectura pretendidamente 'no utópica' -rango distintivo con el racionalismo idealista-, que fuese la consecuencia de procesos deductivos racionales y supiese responder a los problemas históricos y sociales del país, supuso un punto de partida necesario para que Leykam fuese asimilando en esa dirección todos los estímulos que acumuló en sus estancias en el extranjero, pudiendo desarrollar a su regreso una arquitectura de carácter innovador y único en Polonia, que más allá de las referencias utilizadas fue capaz de dar una respuesta autónoma y concreta a las necesidades específicas de la población, tanto en el plano físico como en el psicológico e identitario.

Las prácticas que realizó en el estudio de Auguste Perret le permitieron, ya en 1934, entrar en contacto con uno de los maestros que en aquellos momentos mejor podía mostrarle las posibilidades técnicas del hormigón armado. Tras un periplo como constructor, Perret se encontraba en ese momento de nuevo inmerso en el mundo académico, instruyendo a los jóvenes arquitectos acerca de sus conocimientos sobre el material en un taller propio, dependiente de la École des Beaux-Arts de París. Los avatares de la II Guerra Mundial, llevaron a Leykam a entrar en contacto asimismo con el profesor Otto Rudolf Salvisberg, de la ETH de Zúrich, de quien recibiría, de nuevo, una visión marcadamente técnica de la profesión, de manos de otro maestro que también interpretaba el oficio como una actividad principalmente práctica y funcional. Este hecho permitió a Leykam abundar en la importancia de la eficacia constructiva, especialmente a partir de la utilización de proporciones geométrico-dimensionales en las obras, con el objetivo de alcanzar la máxima precisión gracias al control de la modulación y la estandarización de todas las partes.

La crueldad de la guerra condujo sin embargo a Leykam a reflexionar profundamente sobre la pérdida de valores del ser humano contemporáneo, adoptando una posición más humanista respecto a la profesión y tremendamente crítica con el poder político, transformando su visión de la arquitectura desde una manifestación de un hecho técnico y artístico, hacia un 'instrumento comunicativo' capaz de manifestar, a través de la lógica, un mensaje ideológico de oposición a la irracionalidad institucionalizada que le aproximó a una posición comprometida con una recuperación de la identidad colectiva y la restitución de la fe en la propia convivencia en comunidad. 



\section{I.2. ORIGINALIDAD DEL ENFOQUE.}

La originalidad de esta tesis radica en una lectura de la obra del arquitecto polaco Marek Leykam que trasciende el valor de su trabajo desde el punto de vista exclusivamente técnico, constructivo, estético y compositivo, para explorar su vertiente ética, política y social, habida cuenta de que, a través de sus manifestaciones construidas, tomó partido -como veremos-, en los conflictos ideológicos abiertos en la fracturada sociedad polaca tras la II Guerra Mundial.

Leykam no solo supo interpretar rápidamente la nueva realidad de su entorno resolviendo con eficacia sus encargos como arquitecto, sino que, con gran agudeza, fue capaz de reflexionar sobre la crisis identitaria en la que se vio sumida Polonia después de 1945. Su preocupación por optimizar las posibilidades técnicas y constructivas del momento, sumada a su convicción sobre la existencia de un significado trasladable a la sociedad en cada uno de los procesos que daban lugar a las formas arquitectónicas -conclusión a la que llegó en el estudio sobre el arte litúrgico que realizó en su doctorado en 1943 (Véase p.149 y ss.)- le llevaron a mantener una actitud resistencia frente a la hegemonía de impulsos ordenantes subjetivos como base sostener cualquier estructura de carácter jerárquico, siendo la arquitectura el medio a través del cual canalizar públicamente esta manifestación, que contenía implicaciones ideológicas.

A través de un conjunto de características comunes en la arquitectura de Leykam, esta tesis reconstruye su método proyectual, un proceso continuo de búsqueda coherente de una lógica racional en el que no dejó de lado el contexto cultural, histórico y social al que se adscribían sus construcciones. La compresión que Leykam alcanzó durante su época de formación de la técnica arquitectónica, sumados al fuerte compromiso social que fundamentó su periplo en la guerra, le llevaron a desarrollar una arquitectura marcada por la eficiencia y la racionalidad que fue capaz de ofrecer una rápida respuesta a la emergencia nacional existente en el país tras la destrucción material y la falta de personal e infraestructuras básicas, y al mismo tiempo fue capaz de emitir un mensaje con implicaciones ideológicas en la medida en que establecía paralelismos entre las causas sociales y los procesos proyectuales que daban lugar a las formas arquitectónicas.

Las aportaciones de Marek Leykam a la arquitectura contemporánea no han recibido a día de hoy el reconocimiento que merecen debido a la falta de investigación arquitectónica sobre su obra, el carácter poco mediático de su figura y sus comprensibles reservas iniciales respecto a la difusión de su trabajo, mantenidas sin embargo todavía a día de hoy por su familia. Un conjunto muy limitado de historiadores de la arquitectura polaca han realizado un análisis profundo de su obra, dejando pendiente siempre alguna parte de sus proyectos o bordeando de forma tangencial su compromiso político e ideológico, lo cual aporta un valor significativo a esta investigación, que además traslada su trabajo a una cultura en la que hasta el momento resulta prácticamente desconocido. 

I.3. APROXIMACIÓN AL OBJETO DE ANÁLISIS. 
1.01 Marek Leykam.

1.02 Diploma de estudios de Marek Leykam en el

Instituto Stefan Batory, 1927. 
"Se acercó a una escultura y dijo: 'Aquí tenéis una escultura. Aquí están las tres dimensiones, así y asá (..) Y yo, el artista que ha creado todo ello ¿dónde estoy yo? Es que yo estoy fuera de las tres dimensiones que he trazado."

Mijaíl Bajtín sobre Kazimir Malévich. ${ }^{1.00}$

Marek Leykam, de nombre Maurycy Jan Lewiński Leykam, nació el 4 de septiembre 1908 en Varsovia hijo del profesor de geología Jan Piotr Lewiński y su segunda esposa Elżbieta Leykam.

Su padre, originario de la emergente ciudad de Lublin, se trasladó a Varsovia en 1984 para estudiar en la Facultad de Ciencias Naturales de la Universidad de Varsovia, desde donde alcanzó cierto reconocimiento como investigador tras sus estudios sobre las formaciones del Jurásico Superior en Góry Świętokrzyskie, lo que le permitió pasar a formar parte del equipo docente del Departamento de Geología de la Universidad de Varsovia en 1919 como profesor asociado y en 1924 como profesor titular. ${ }^{1.01}$

Este hecho sería determinante para que el joven Marek tuviese la oportunidad de estudiar entre 1919 y 1927 en la recién inagurada Escuela Secundaria y Preparatoria Stefan Batory ${ }^{1.02}$ de Varsovia, fundada por el educador Tadeusz Łopuszański, quien tras visitar Inglaterra, Francia, Alemania y Suiza se había marcado como objetivo establecer en Polonia una escuela que importase los modernos métodos de enseñanza basados en las nuevas corrientes pedagógicas del s.XX. ${ }^{1.03}$

El Instituto Stefan Batory había comenzado las clases el 1 de septiembre de 1918 y contaba entre sus profesores con destacados académicos polacos como Stanisław Młodożeniec (literatura), Stanisław Arnold (historia), Stanisław Malec (física) o Gustaw Michał Wuttke (geografía), que habían accedido a formar parte de este experimento pedagógico de carácter innovador en la zona, que basaba sus enseñanzas en la idea de fomentar el desarrollo de habilidades prácticas sobre la base de los conocimientos teóricos impartidos a los estudiantes. ${ }^{1.03}$

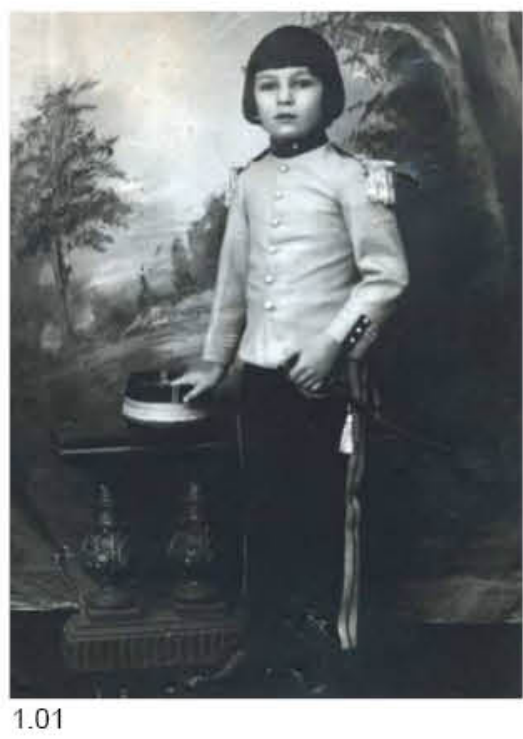

1.01

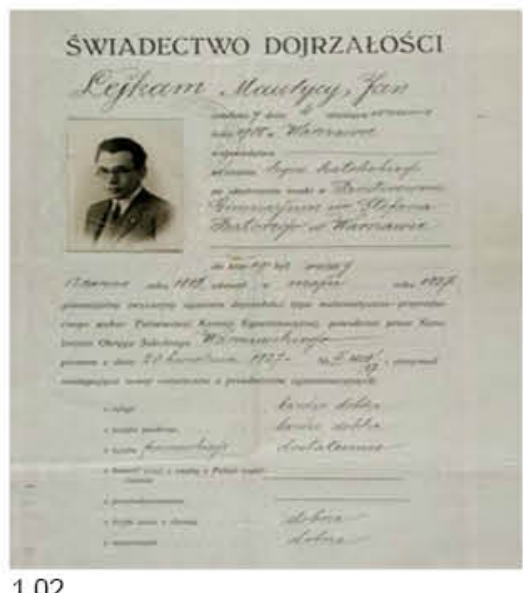

1.02

1.00. Comentarios realizados por Mijail Bajtin acerca de Kazimir Malevich en entrevis Muntañola Thornberg, 2006. p 29.)

1.01. Ref.: Annales Societatis Geologorum Poloniae 1.02. Gimnazjum i Liceum im. Stefana Batorego. 1.03. Ref.: Fundación Tadeusz Łopuszański.

1.04. Szkoły Malarstwa i Zdobnictwa przy PI. Teatralnym 
1.03 Postal del Instituto Stefan Batory de Varsovia.

1.04 Vista general del Instituto Stefan Batory de Varsovia en 1925.

1.05 Plano de Situación del Instituto Stefan Batory de Varsovia

según el proyecto de Tadeusz Tołwiński.

1.06 Planta Baja del Instituto Stefan Batory de Varsovia según el

proyecto de Tadeusz Tołwiński.

1.07 Planta Primera del Instituto Stefan Batory de Varsovia según el

proyecto de Tadeusz Tołwiński.

1.08 Puerta de acceso al Instituto Stefan Batory.

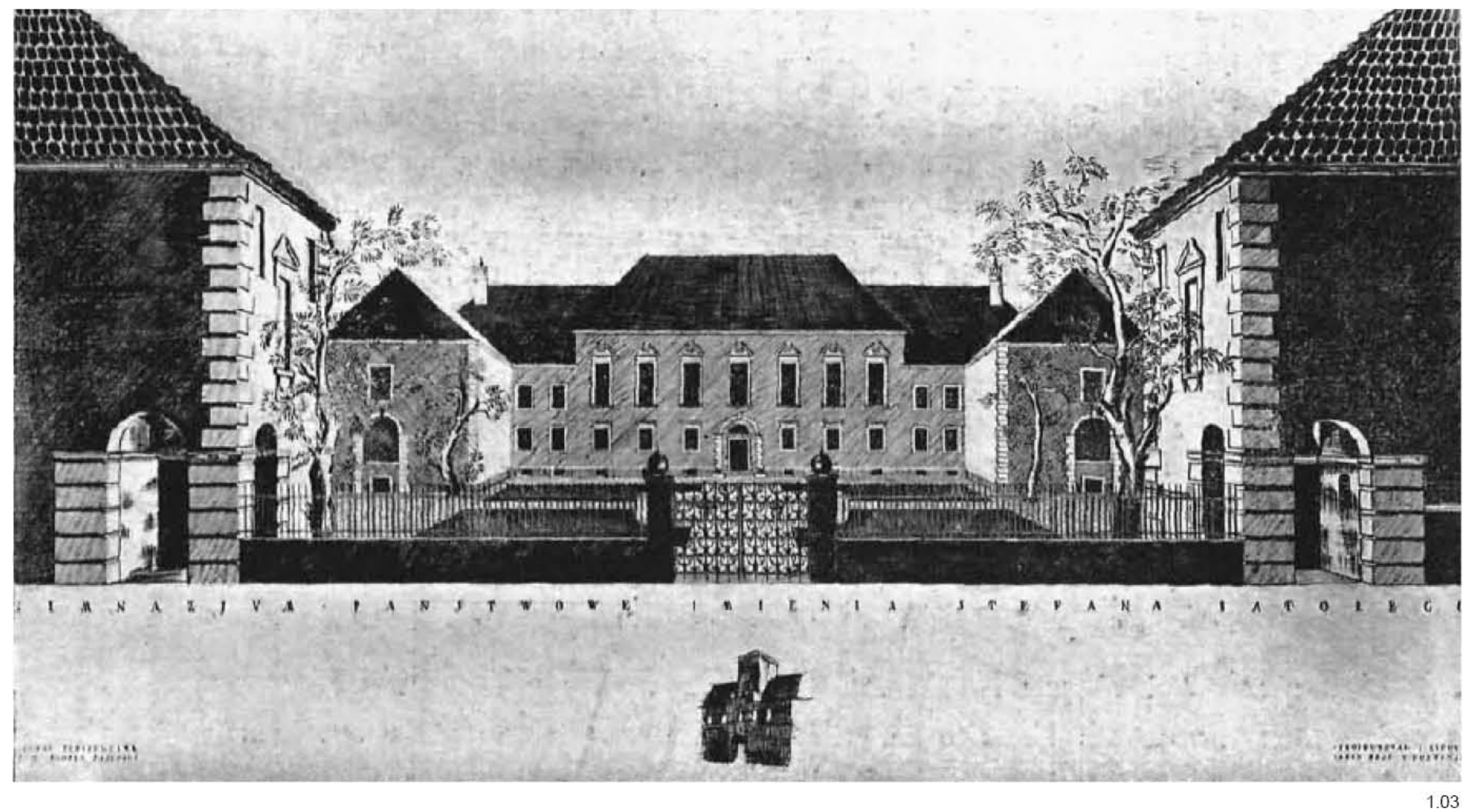



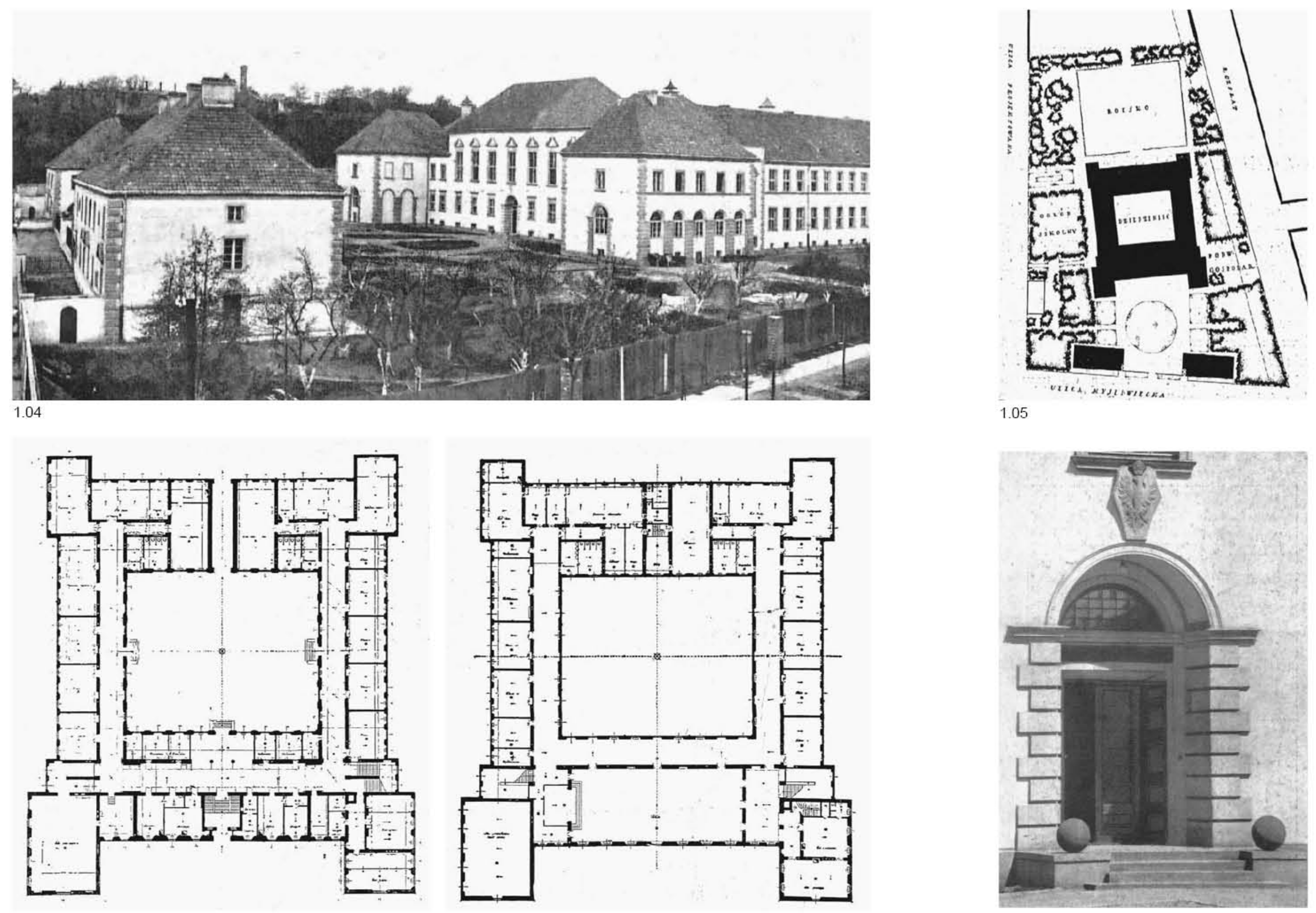

1.05

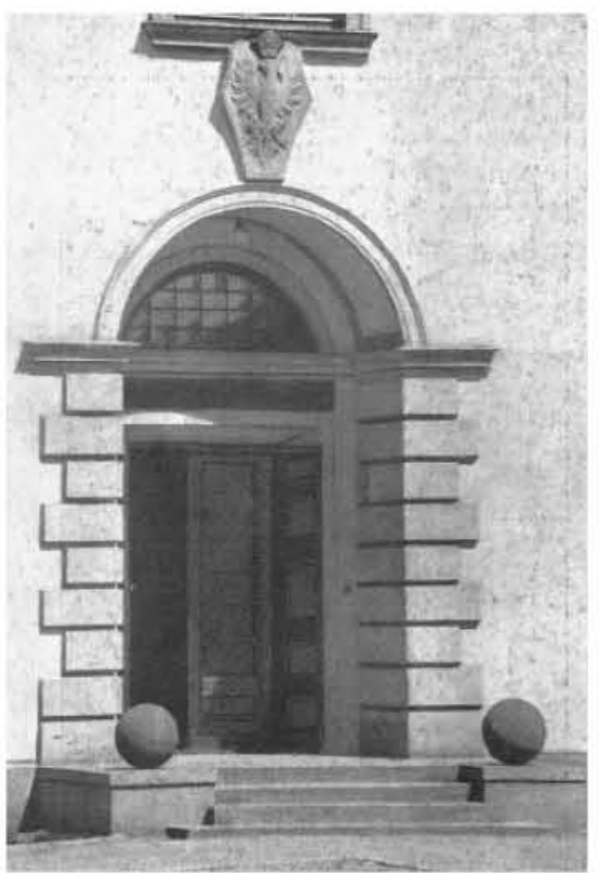


1.09 Corredor interior del Instituto Stefan Batory de Varsovia en 1925.

1.10 Alzado Principal del Instituto Stefan Batory de el proyecto de Tadeusz Tołwińsy.

1.11 Alzado Lateral del Instituto Stefan Batory de Varsovia segun el proyecto de Tadeusz Tołwiński.

1.12 Valla y puerta de acceso principal al Instituto Stefan Batory de Varsovia en 1925.

1.13 Sala de actos del Instituto Stefan Batory.

1.14 vestibulo principal del Instituto Stefan Batory.
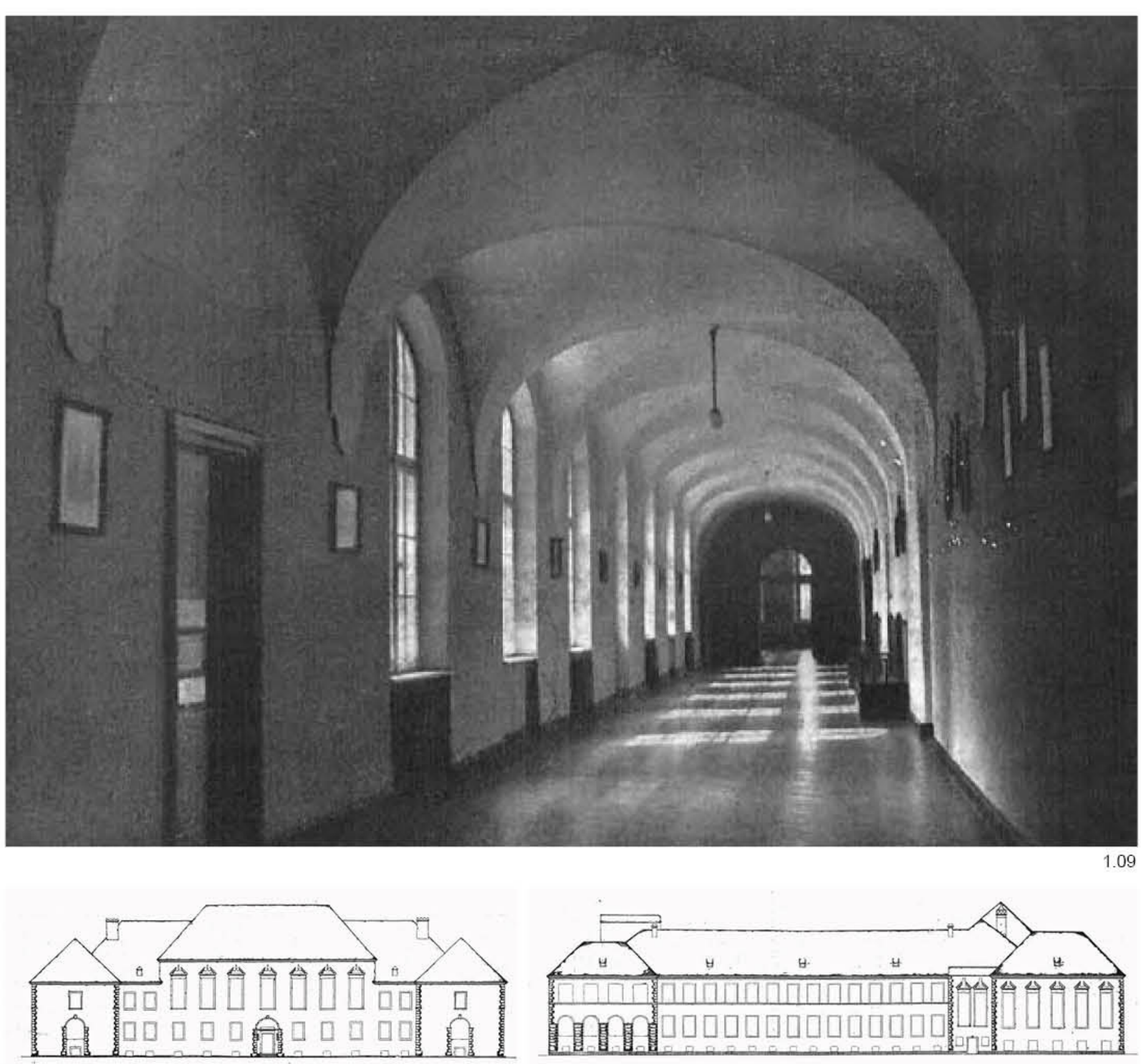

1.10

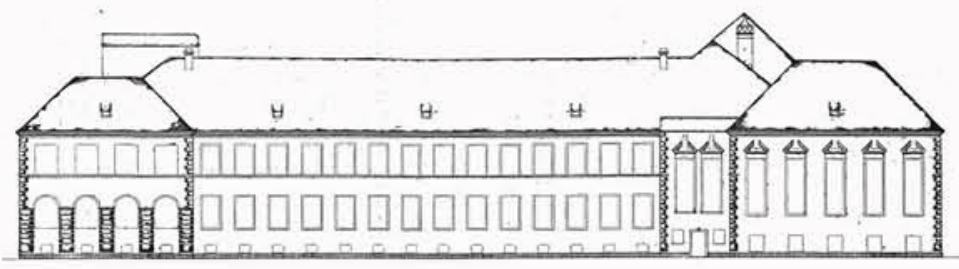

1.1 
Fruto del ambiente creativo de este instituto, Marek Leykam se fue interesando poco a poco por el mundo del arte. En el curso de 1925, decidió apuntarse a clases nocturnas en la Escuela de Pintura y Decoración en la Plaza del Teatro ${ }^{1.04}$, y al curso siguiente asistió a la Escuela de Bellas Artes Wojciech Gerson ${ }^{1.05}$, desde la que pudo preparar su acceso a la Facultad de Arquitectura de la Universidad Politécnica de Varsovia ${ }^{1.06}$ en el año 1927.

Los espacios recorridos durante 8 años en el Instituto Stefan Batory iban a tener gran influencia en el despertar artístico de Leykam. Lopuszański era consciente de que, adaptar el nivel de enseñanza de los jóvenes polacos a los nuevos sistemas pedagógicos que había conocido en centroeuropa, pasaba por generar un ambiente adecuado para liberar su potencial físico e intelectual a través de su relación con el entorno, por lo que promovió -junto al primer ministro Antoni Ponikowski-, ${ }^{1.07}$ la construcción del edificio del Instituto Stefan Batory según el proyecto del arquitecto Tadeusz Tołwiński. Tras haber estudiado en la Escuela de Arquitectura de Karlstuhe (1905-1911), Tołwiński había tenido a su vez la oportunidad de visitar Suiza, Italia, Francia, Rusia, Alemania y Reino Unido, familiarizándose con los espacios docentes que estaban siendo responsables de construir ese entorno, capaz de fomentar el desarrollo personal a través del aprendizaje y la experimentación de los estudiantes.

El recorrido que realizó diariamente el joven Leykam sobre los amplios pasillos de su instituto, la adecuada proporción del patio central -junto a la equilibrada composición de sus volúmenes adyacentes- y la delicadeza con que Tołwiński resolvió los interiores y las entradas de luz en cada sala, permiten reconstruir hoy la experiencia de un joven Leykam que, almacenando recuerdos, solidificó una memoria personal de sensaciones constructivas que podremos ver reflejada en sus futuros proyectos y en su manera de interpretar la arquitectura.

Una prueba evidente de la influencia creativa que ejerció el Instituto Stefan Batory sobre sus estudiantes fue el hecho de que no fue Marek Leykam el único destacado arquitecto de su promoción. Junto a él estudiaron Jan Andrzej Bogusławski, quien también lograría en 1927 el acceso a la Facultad de Arquitectura de Varsovia -obteniendo posteriormente la plaza de profesor y erigiéndose autor de proyectos como la Torre Residencial Smolna ${ }^{1.08}$ en Varsovia (1966) o la Catedral de Stalowa Wola (1956-74)-, y Stanisław Kolendo, autor del Instituto de Investigación Química en la calle Rydygiera 8 de Varsovia en 1950 y también compañero de Leykam en el importante concurso para la realización de la Mezquita de Varsovia en $1936(2.30)$.

El ambiente en la Facultad de Arquitectura de Varsovia recordaría mucho al joven Leykam las experiencias vividas en Instituto Stefan Batory, puesto que las cátedras de proyectos arquitectónicos prestaban en aquel momento mucha atención a todas las novedades que llegaban desde Europa, tanto a nivel estético y compositivo como a nivel constructivo, atendiendo a las nuevas técnicas basadas en sistemas prefabricados y la utilización de materiales que ofrecían nuevas posibilidades; como el vidrio plano de grandes dimensiones, el acero laminado y, por supuesto, el hormigón armado.
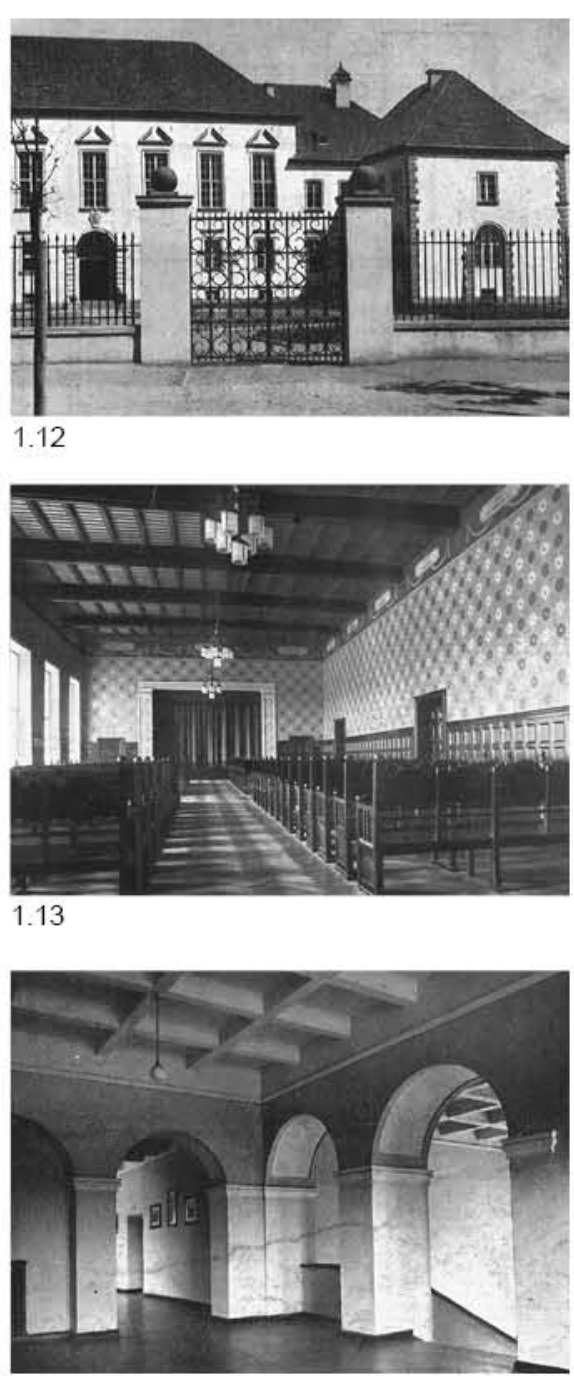

1.14

1.05. Ogólnokształcąca Szkoła Sztuk Pięknych im. Wojciecha Gersona.

1.06. Wydział Architektury Politechniki Warszawskiej

1.07. Antoni Ponikowski (1878-1949) academico y politico, fue primer ministro entre 1921-22.

1.08. Wieżowiec mieszkalny na ul. Smolnej w Warsz 
1.15 Iglesia del Arcángel San Miguel de Varsovia (Cerkiew św Michała Archanioła w Warszawie), 894 y demolida en 1923.

1.16 Fotografía aérea de la plaza Piłsudski (en ese y publicada en la revista Światowid" de 1933 .

En el centro la Catedral de San Alejandro Nevsky de Varsovia (Sobor sw. Aleksandra Newskiego w Warszawie) construda por orden del zar Alejandro entre 1894 y 1912 y demolida en Leon Benois, a varios edificios ortodoxos por parte de las autoridades polacas tras la independencia de 1919

1.17 Entrada de la caballería alemana en Varsovia el 05 de agosto 1915 duranter I

1.18 Bombardero dirigible alemán SL2 sobrevolando Varsovia en 1914.

1.19 Edificio principal de la Universidad Politécnica de Varsovia a principios del siglo XX.

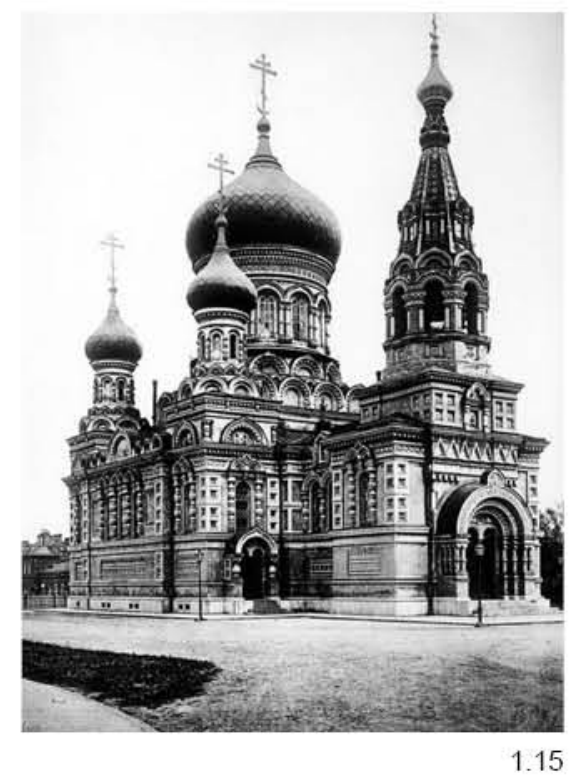

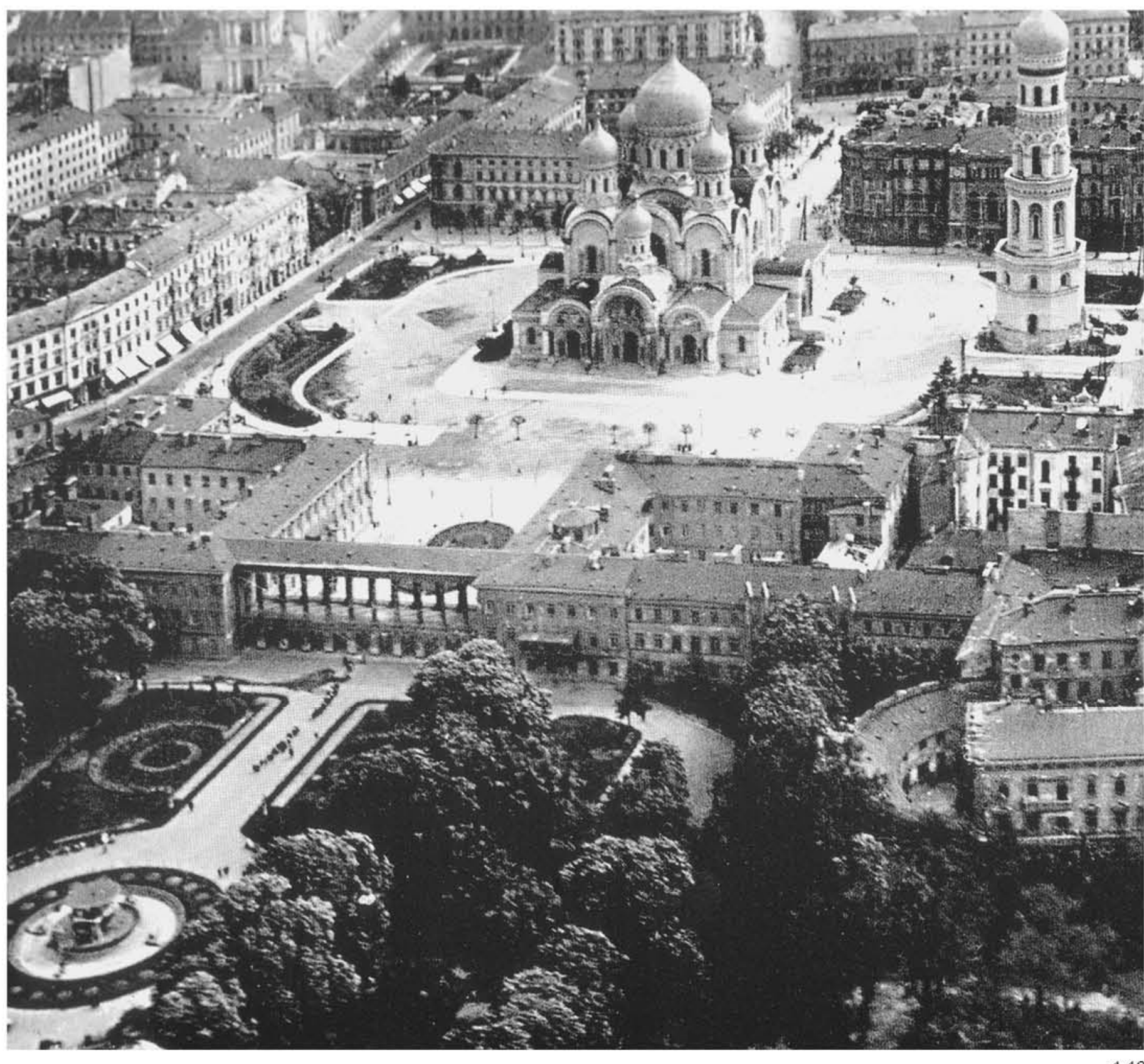


En otoño de 1915, y tras haber estado privados de estado oficial desde 1795, toda una generación de arquitectos polacos que había visto cerrada la Escuela de Bellas Artes de Varsovia en 1863 y no había tenido más remedio que desplazarse a estudiar arquitectura a San Petersburgo y Moscú -o viajar a las universidades europeas de Viena, Dresde, Karlsruhe, Graz, Darmstadt y Zúrich-, encontró, tras la expulsión del Imperio Ruso por parte de las Potencias Centrales, su gran oportunidad de recuperar la docencia y la práctica de la arquitectura en una Polonia nueva e independiente.

El 15 de noviembre 1915 fue fundada la Universidad Tecnológica de Varsovia ${ }^{1.09}$-la primera Universidad Politécnica polaca-, con cuatro departamentos: Arquitectura, Ingeniería Mecánica y Eléctrica, Ingeniería Química e Ingeniería Civil y Agrícola. El primer decano de la Escuela de Arquitectura de Varsovia fue Mikołaj Tołwiński, quien provenía de la Academia de Bellas Artes de San Petersburgo, al igual que sus compañeros de docencia Józef Dziekoński, Czesław Domaniewski, Kazimierz Skórewicz, Jarosław Wojciechowski y Jan Fryderyk Heurich. En el primer equipo de profesores estaba también Rudolf Świerczyński, proveniente de la Politécnica de Darmstadt; el ingeniero Zygmunt Straszewicz, de la Escuela Politécnica de Zúrich; Karol Jankowski que provenía de la Universidad Técnica de Riga; y finalmente Tadeusz Tołwiński, autor del proyecto para el Instituto Stefan Batory, cuya alma máter fue la Universidad de Karlsruhe.

Los objetivos de la Escuela estuvieron marcados desde el principio por las necesidades de un país que tenía latente en su sociedad la demanda de generar una identidad propia que les desarraigase del ámbito de influencia soviético. La capacidad económica de Polonia tras la I Guerra Mundial era escasa, máxime si se tiene en cuenta que continuó inmersa en la Guerra Bolchevique hasta 1921, pero la independencia del país había despertado un ímpetu de desarrollo a todos los niveles que tuvo su reflejo en la arquitectura como responsable de construir los espacios de una sociedad libre y moderna. De esta forma, comenzó a hacerse patente una nueva época que permitía dejar atrás un periodo de dominación al que la arquitectura no había sido ajena.

La catedral ortodoxa erigida a San Alejandro Nevsky en Varsovia por orden del zar Alejandro III en 1894 y completada en 1912 según el proyecto del arquitecto Leon Benois, fue ya un claro ejemplo de la consciencia con que la sociedad polaca percibía la capacidad que tenía la arquitectura para expresar ideología. La ubicación de la catedral, en el centro de la plaza Saski y acompañada de un campanario de $70 \mathrm{~m}$ de altura que lo convertía en uno de los edificios más altos de la ciudad, fue interpretada como un signo absoluto de dominación soviética sobre Polonia y, tras el abandono de Varsovia por parte de la comunidad ortodoxa durante la I Guerra Mundial, comenzaron a alzarse numerosas voces que solicitaban su demolición.

Al finalizar la Guerra Bolchevique, las autoridades polacas tomaron la decisión de demoler la catedral cuando apenas llevaba 10 años en pie y rebautizaron la plaza con el nombre del capitán polaco que había dirigido las tropas en aquel enfrentamiento, Józef Piłsudski. Este hecho significó entonces toda una reivindicación política y al mismo tiempo arquitectónica, símbolo de un tiempo nuevo donde la forma y la imagen de los edificios debía estar en consonancia con las aspiraciones de una sociedad libre e independiente. ${ }^{1.10}$
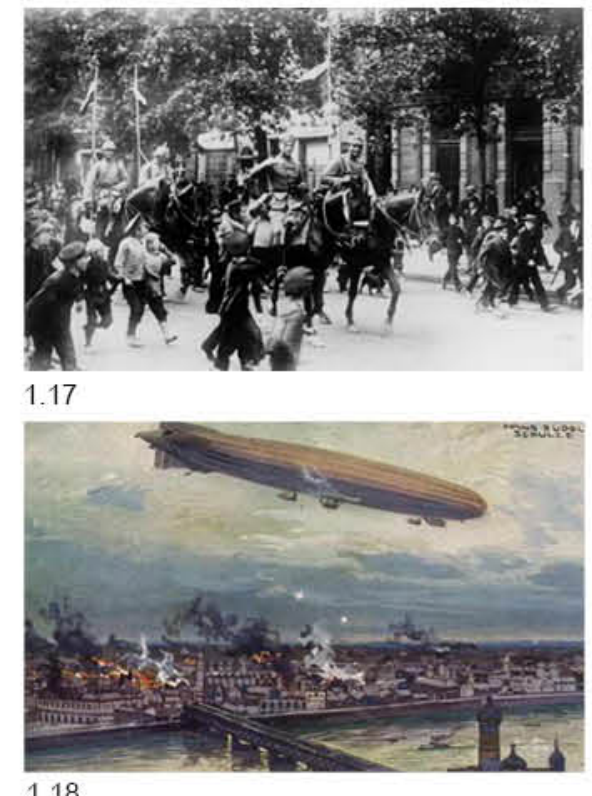

1.18

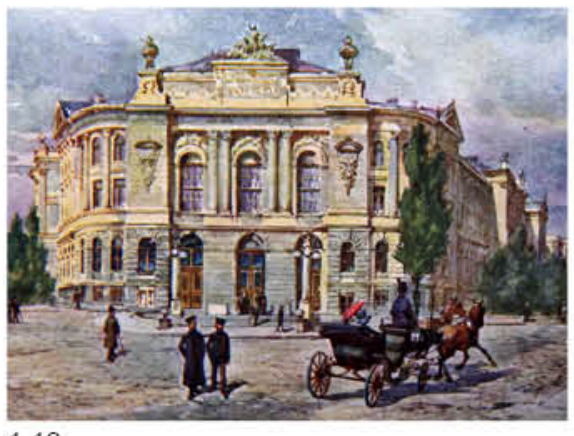

1.19

109. Ref.: Página oficial de la Universidad Politécnica de Varsovia (pw.edu.pl).

1.10. La mayoria de iglesias ortodoxas de Varsovia también fueron demolidas, con la excepción de la Catedral de Santa Maria Magdalena y la iglesia de San Juan Clímaco.

La demolición de la catedral de San Alejandro Nevsky duró 2 años y requirió más de 15.000 explosiones. Sus materiales fueron aprovechados para la construcción de monumentos o elementos como las escaleras de acceso a las tumbas reales de la Catedral de Wawel en Cracovia. (Giergoń, 2007) 
1.21 Escuela de Economía de Varsovia (1919-1925) del arquitecto Jan Witkiewicz.

1.22 - 1.24 Alzados y plano de situación de la (1925-1931) del arquitecto Jan Witkiewicz.

1.25 Caja General de Ahorros de Cracovia (1925) del arquitecto Adolf Szyszko-Bohusz.

1.26 Viviendas para profesores en la Universidad Jaguelonica de Cracovia (1924-26). Arquitectos: Jurkiewicz.
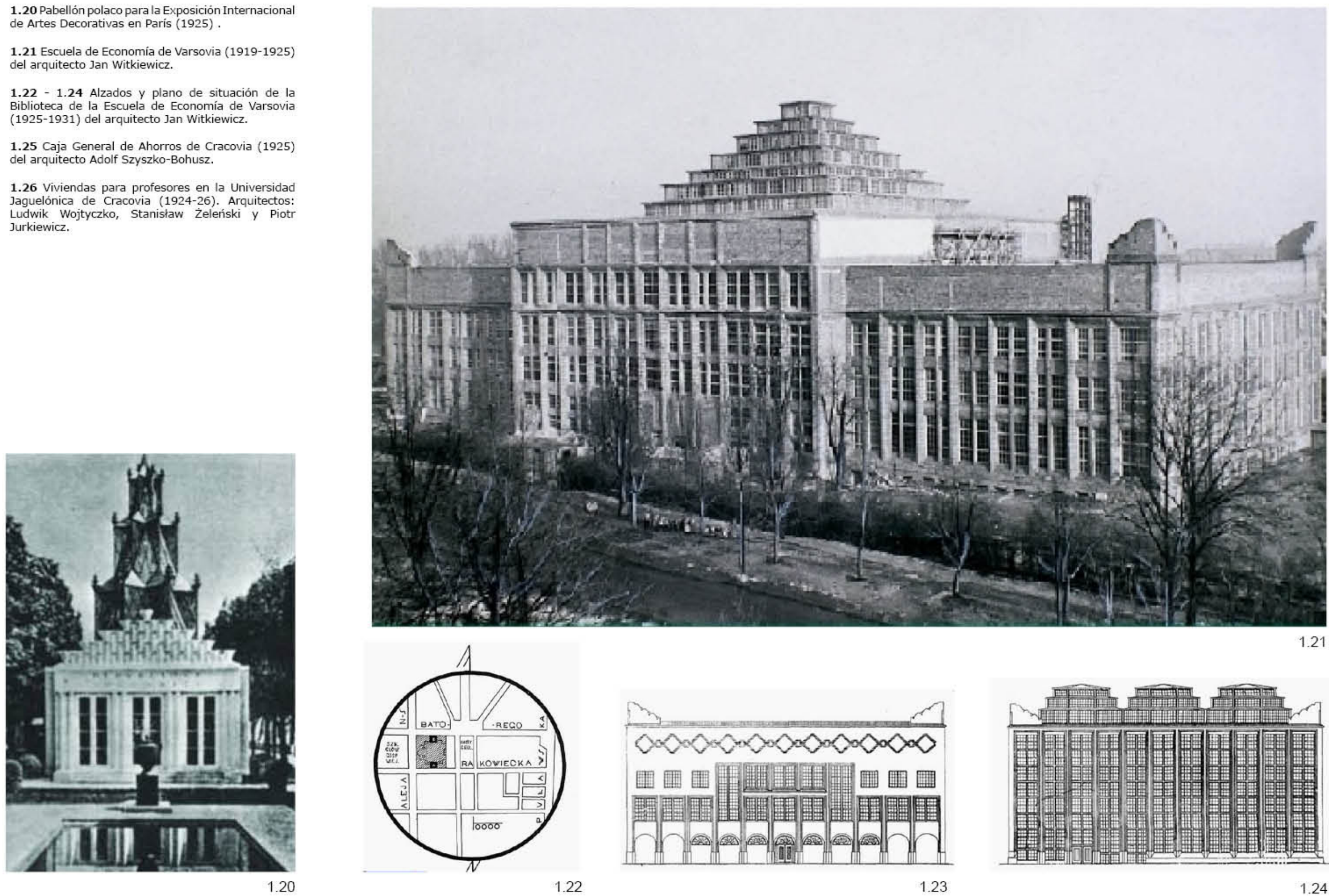
En este contexto, los representantes de la arquitectura polaca más destacados comprendieron rápidamente la obligación moral que existía con una sociedad que buscaba reconstruir su orgullo como país olvidando el pasado. Mientras la generación más experimentada que regresaba a Polonia empezó a construir sus primeros edificios, marcados por las novedades que habían aprendido en sus escuelas de origen, las optimistas ideas que surgían de las vanguardias fueron acogidas con entusiasmo en Polonia por la nueva generación de arquitectos, que identificaba ideológicamente sus objetivos renovadores con las demandas sociales del país. ${ }^{1.11}$

Los arquitectos de aquella primera generación docente que se estableció en la Universidad Tecnológica de Varsovia tras la independencia del país, procedían de universidades fundamentalmente soviéticas (San Petersburgo y Moscú), pero también alemanas (Karlsruhe, Darmstadt, Múnich,...) en un momento de fuerte influencia del Deutscher Werkbund ${ }^{1.12}$

Jan Witkiewicz alias Koszczyc, había estudiado en la Universidad Técnica de Múnich, y tras participar en la I Guerra Mundial -donde fue detenido y encarcelado en Lublin-, volvió a Varsovia en 1919 para iniciar su estudio de arquitectura. Su obra más destacada, el edificio principal de la Escuela de Economía de Varsovia ${ }^{1.13}$ en la c/ Rakowiecka (posteriormente Av. de la Independencia), construida entre 1918-25 (1.21) y realizada enteramente con estructura de hormigón armado, transmite ya una cierta depuración en la forma -dentro de un orden clásico-, y una ornamentación que recuerda elementos de la arquitectura tradicional polaca -como los frontones triangulares que coronan las esquinas del edificio-. El escalonamiento de la pirámide central retrotrae a la estética de elemento fabril, cuestión que ya había sido explorada en obras que conocía de su época de estudiante, como la Factoría Química de Luban (1912) del arquitecto Hans Poelzig. Junto a este edificio, construyó también la Biblioteca de la Escuela de Economía (1.22 - 1.24), entre 1925-31.

Una de las obras más representativas de esta época en Polonia, fue el Pabellón Nacional para Exposición Internacional de Artes Decorativas de París en 1925 del arquitecto Józef Czajkowski (1.20), quien tras haber estudiado en Múnich y Viena, había recalado en la Escuela de Bellas Artes de París. Esta era la primera Exposición Internacional a la que acudía Polonia desde su independencia y la influencia alemana estuvo muy presente en su pabellón, que hacía una clara alusión al diseño del Pabellón de Cristal para la Exposición de Colonia de 1914 de Bruno Taut. La obra de Czajkowski parece reinterpretar de forma directa esta obra, obteniendo -de nuevo- una representación cristalina de una cúpula a través de elementos proporcionales, aunque esta vez basados en la geometría del octógono. ${ }^{1.11}$

Los arquitectos provenientes de universidades rusas, como la Academia de Bellas Artes de San Petersburgo o la Escuela de Moscú, desarrollaron una arquitectura de tendencia mucho más clásica. Tal es el caso de Adolf SzyszkoBohusz, graduado en San Petersburgo, que fue autor del edificio de la Caja General de Ahorros de Cracovia ${ }^{1.14}$ en 1925 (1.25); Marian Lalewicz, que construyó el edificio del Banco Estatal de Agricultura ${ }^{1.15}$ en Varsovia en 1926-27; o Ludwik Wojtyczko, Stanisław Żeleński y Piotr Jurkiewicz que construyeron las viviendas para profesores en la Universidad Jaguelónica de Cracovia ${ }^{1.16}$ en 1924-26 (1.26). ${ }^{1.11}$

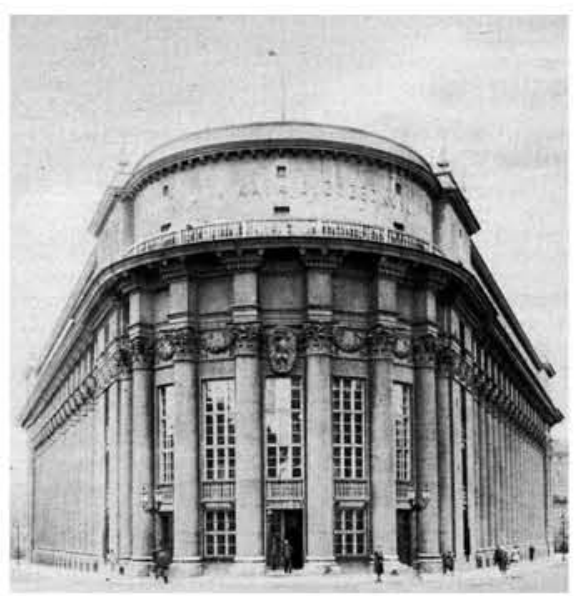

125

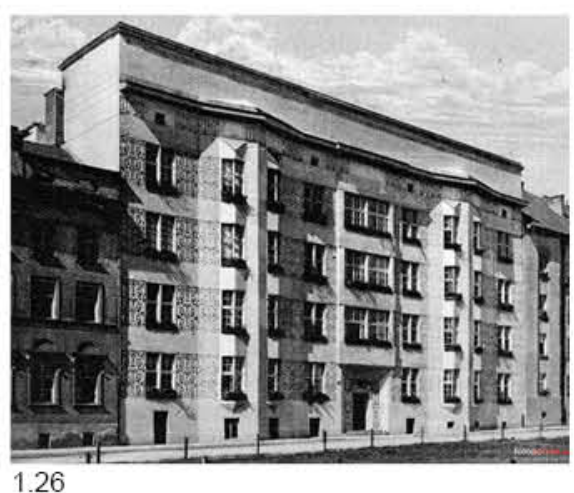

1.26

1.11. Niezabietowski, 1995

1.12. Deutscher Werkbund, considerada como la precursora de la Bauhaus, fue una asociación mixta de arquitectos, artistas e industriales fundada en Múnich en 1907 por Hermann Muthesius.

1.13. Szkoła Główna Handlowa w Warszawie.

1.14. Gmach Pocztowej Kasy Oszczędności w Krakowie. 1.15. Panstwowy Bank Rolny

1.16. Dom profesorów Uniwersytetu Jagiellońskiego w Krakowie. 
1.27 Dibujo de Rudolf Świerczyński para el proyecto del Edificio de Economía del Banco Nacional de Warszawie) 1928-1931.

1.28 Planos del proyecto de 1925 para el Edificio del Banco Nacional de Economía de Varsovia (Gmach 1928-1931. Arquitecto: Rudolf Ś '́wierczyński.

1.29 - 1.33 Planos del proyecto de Banco de Sociedades Cooperativas conocido como Casa de las Aguilas (Bank Towarzystw Spółdzielczych, Dom pod Orlami) 1912-1917. Arquitecto: Jan Heurich.

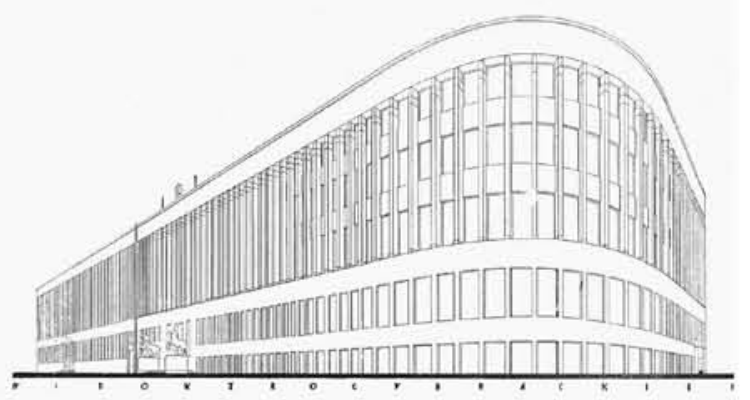

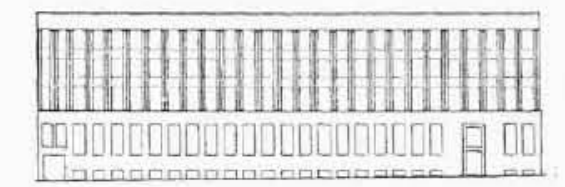
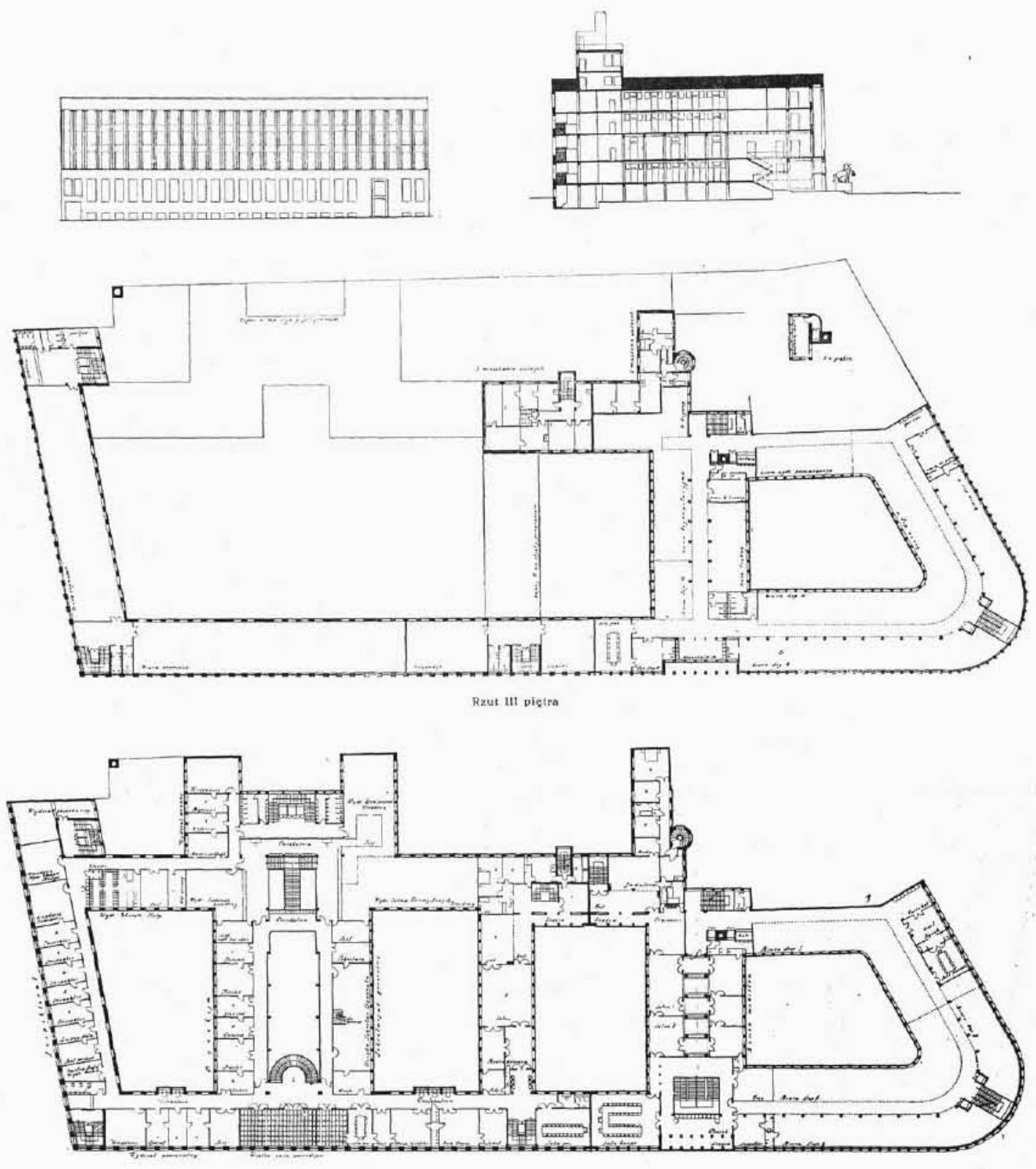


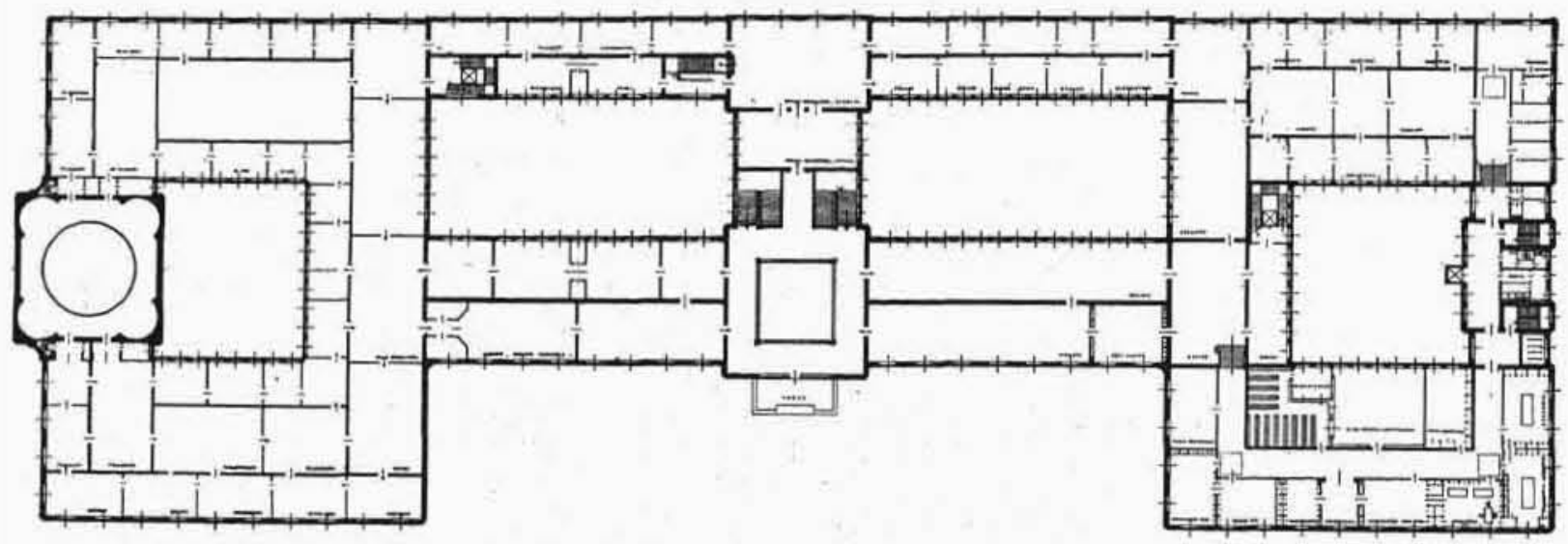

1.29

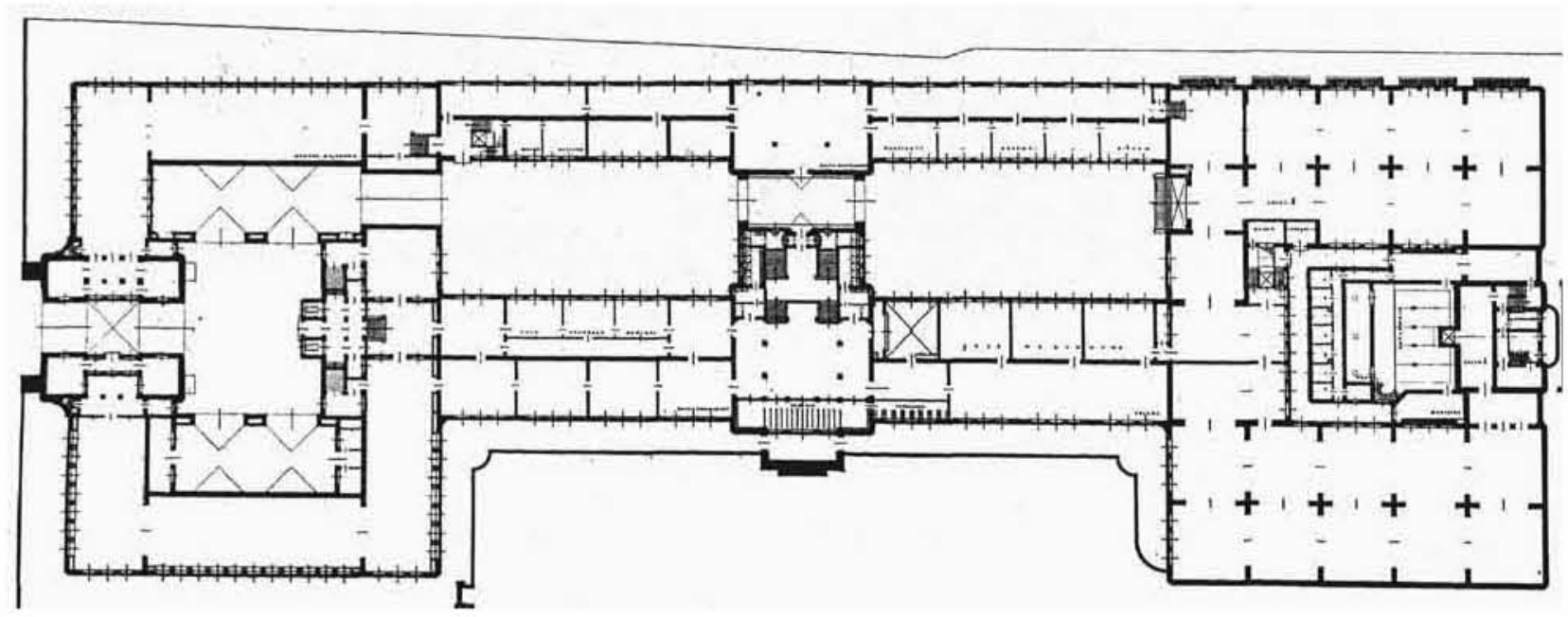

1.30

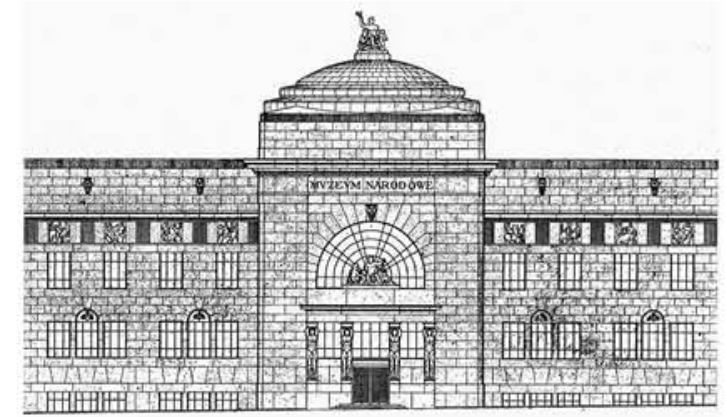

1.31

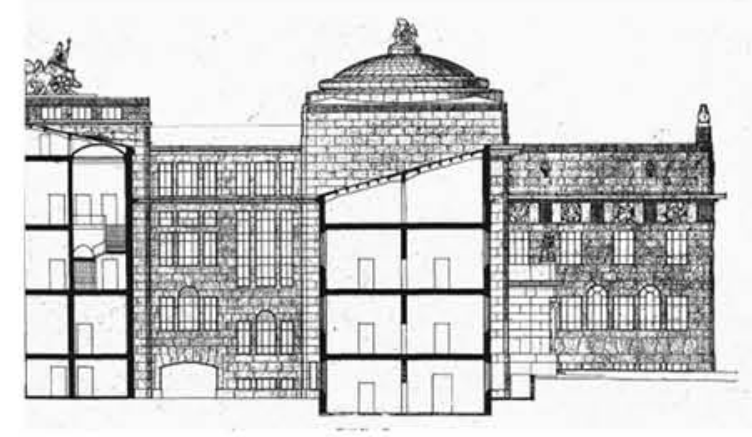

1.32

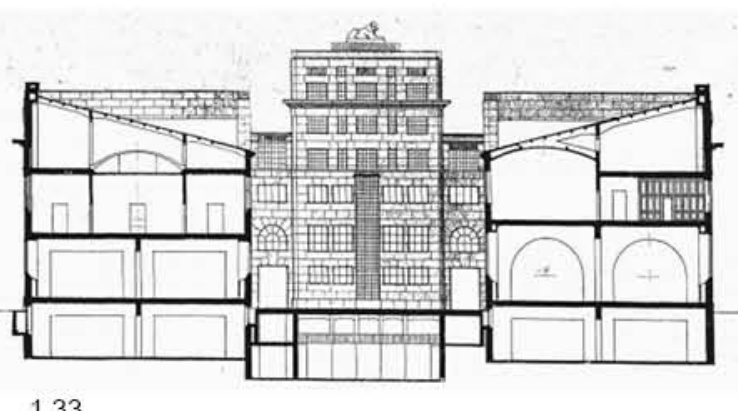


1.34 Composición de Karol Kryński (1900-1944) publicada por la revista Blok no2 en mayo de 1924.

1.35 Portada de la primera revista BLOK, publicada el 8 de marzo de 1924

1.36 Montaje fotográfico publicado en la primera 1924.

1.37 Composición de Kazimir Malévich (18791935) publicada por la revista Blok n03-4 en junio de 1924

1.38 Composición de Władysław Strzemiński mavo de 1924 . mayo de 1924.

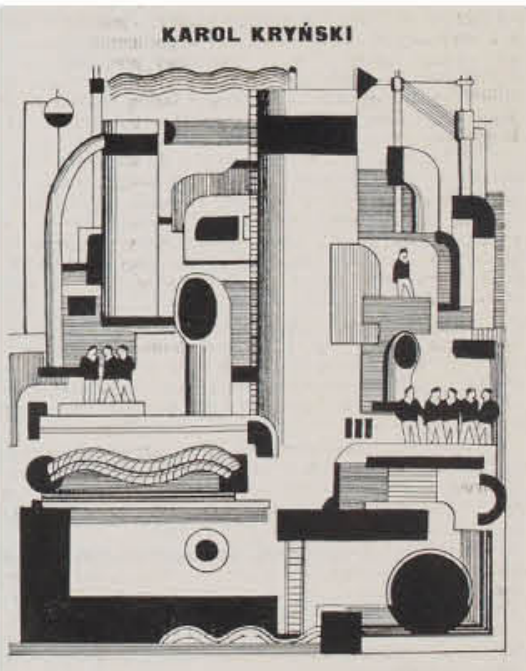

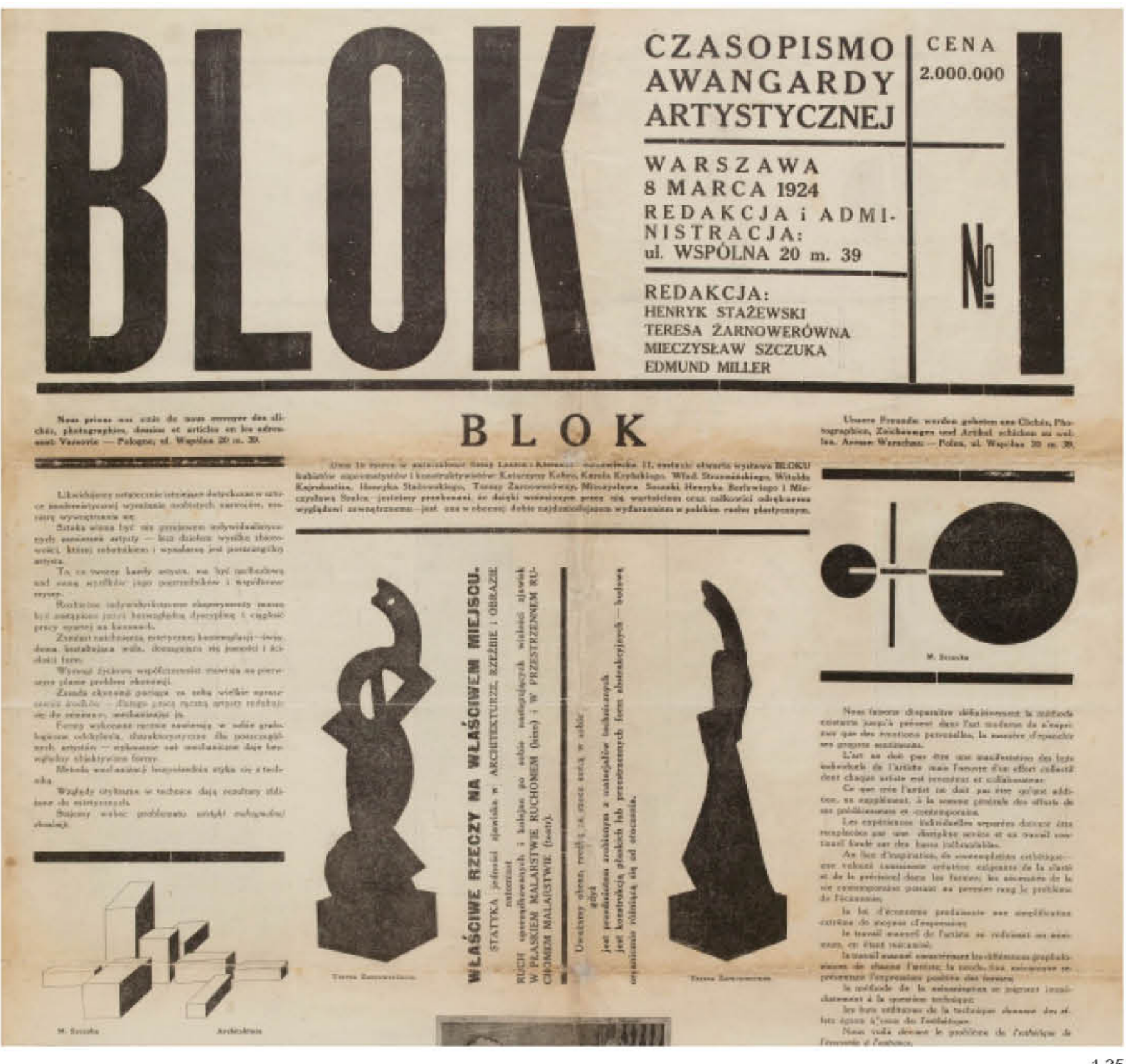




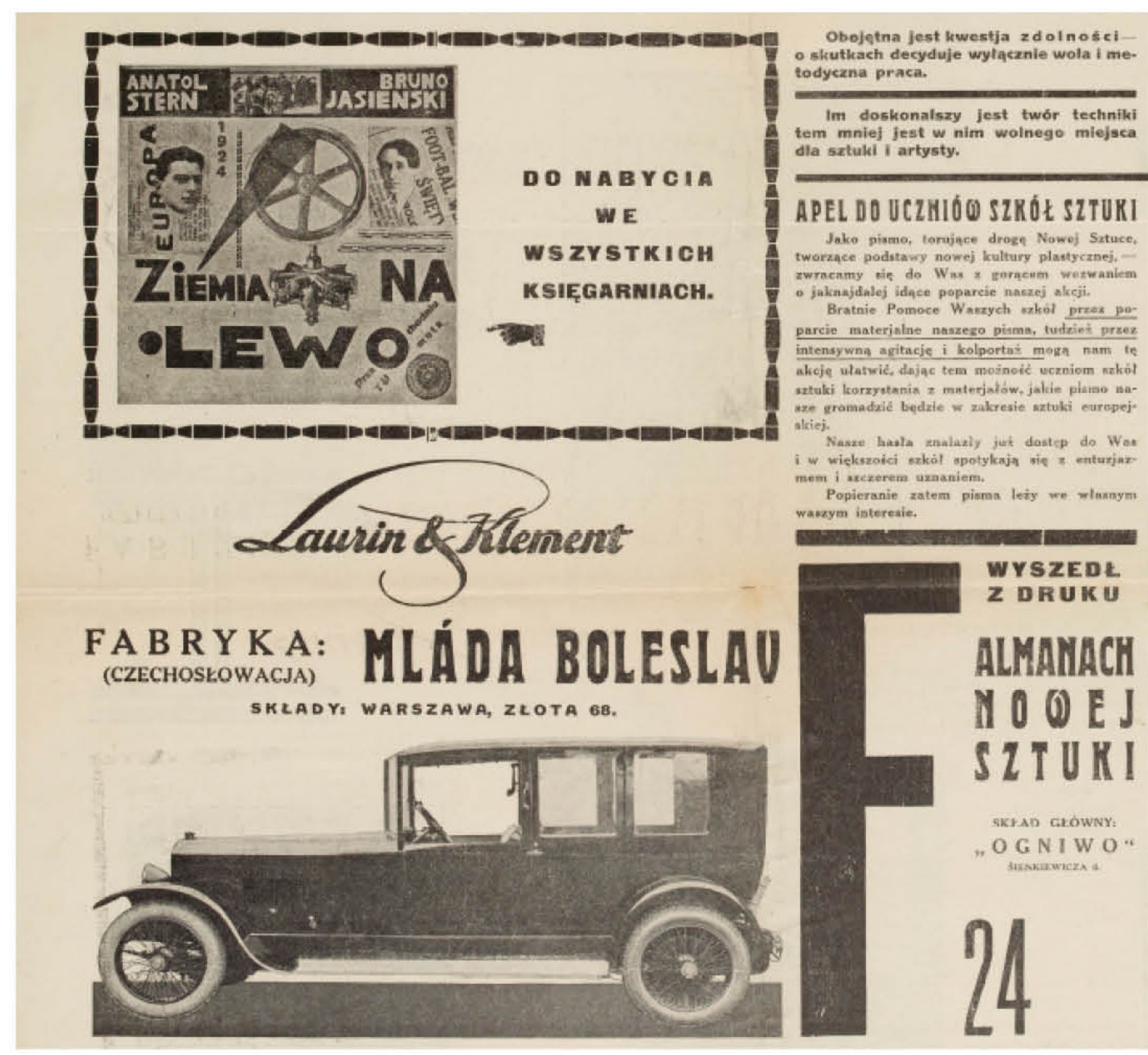


1.39 Composición de Teresa Żarnowerówna (18971949) publicada por la revista Blok no 6-7 en septiembre de 1924.

1.40 Portada de la revista BLOK no 5, publicada en julio de 1924.

1.41 Portada de la revista BLOK n० 10 , publicada en junio de 1925.

1.42 Composición de Henryk Stażewski (18941988) publicada por la revista Blok no $3-4$ en junio

1.43 Composición de Karol Krinski (1900-1944) publicada por la revista Blok no $3-4$ en junio de 1924

1.44 Composición de Władysław Strzemiński (1893-1952) publicada por la revista Blok no 6-7 en

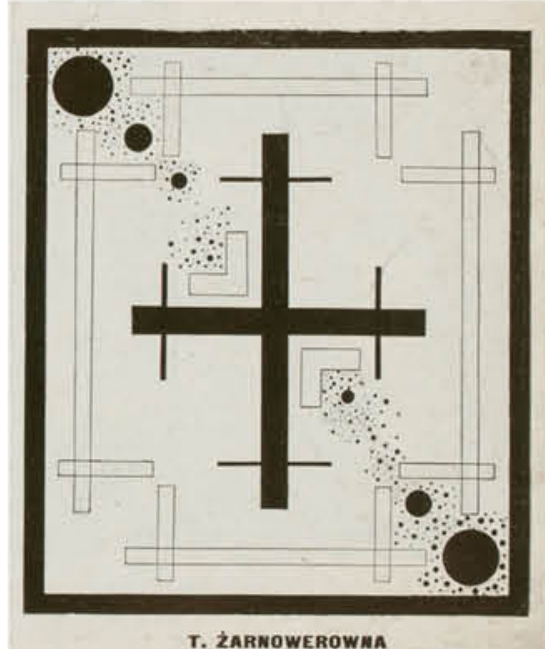

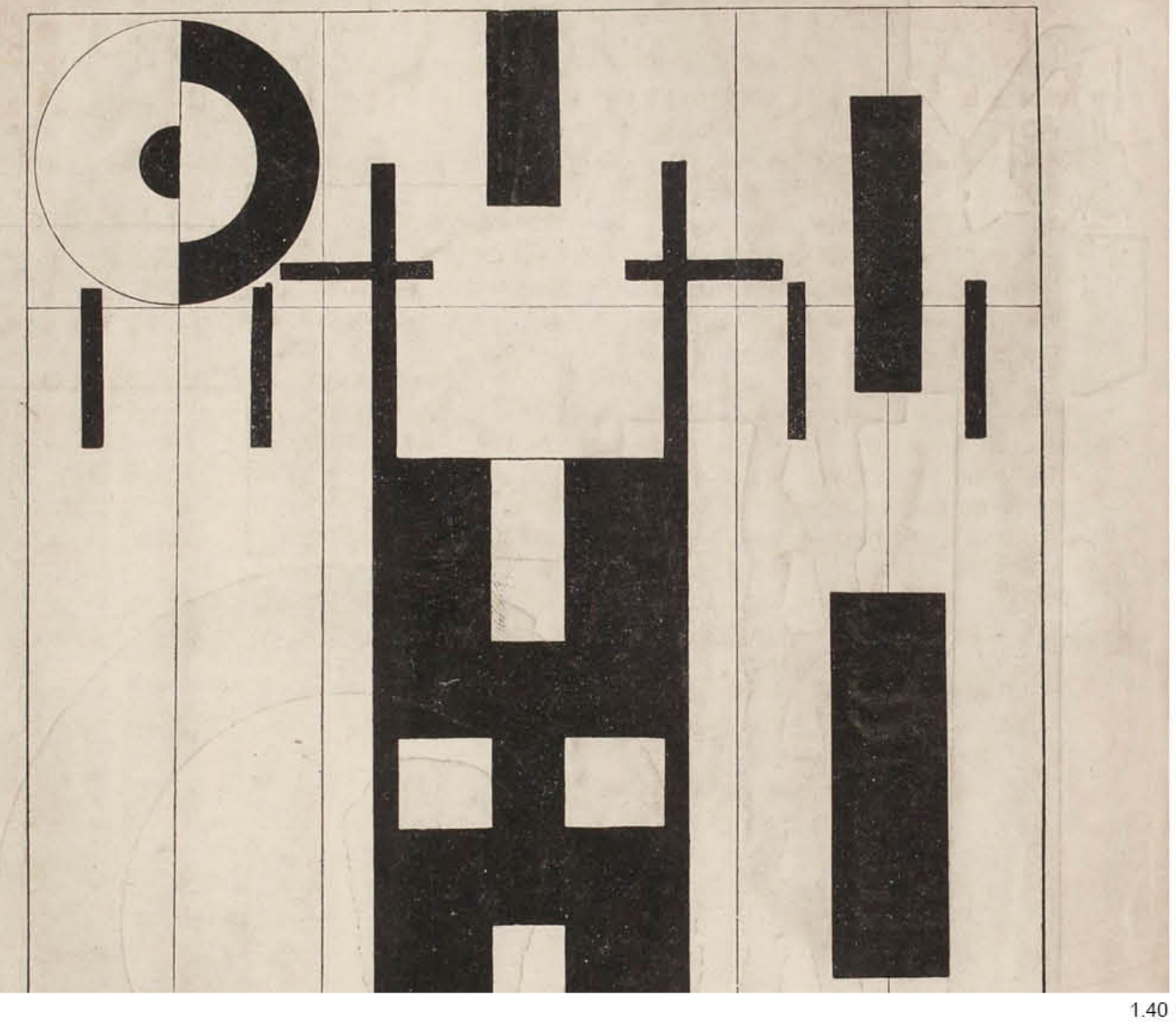



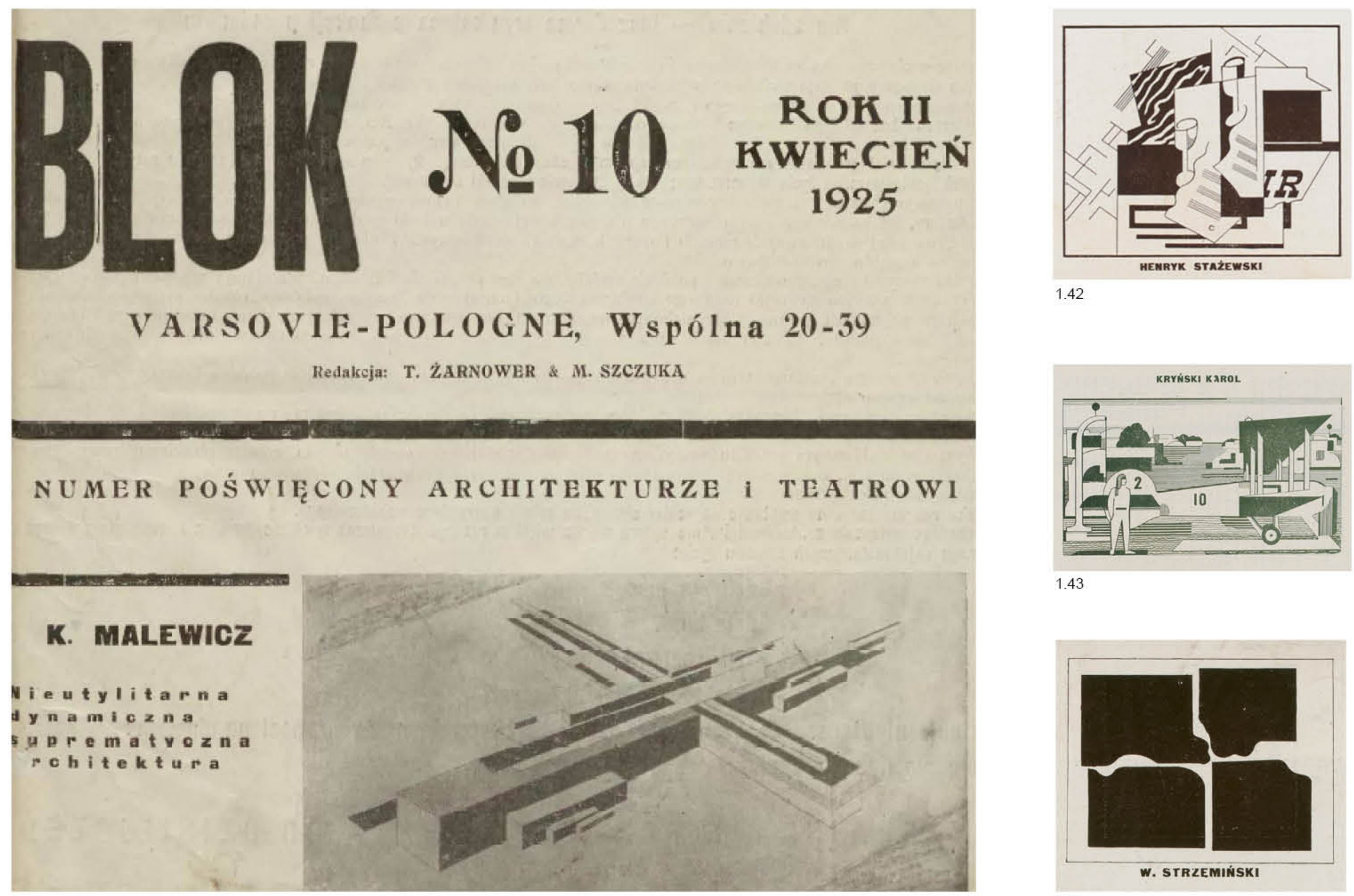

1.42

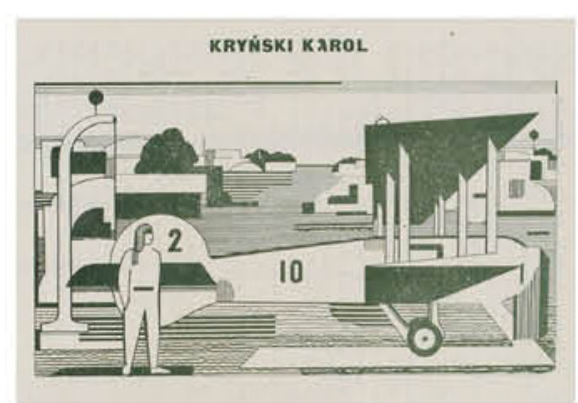

1.43

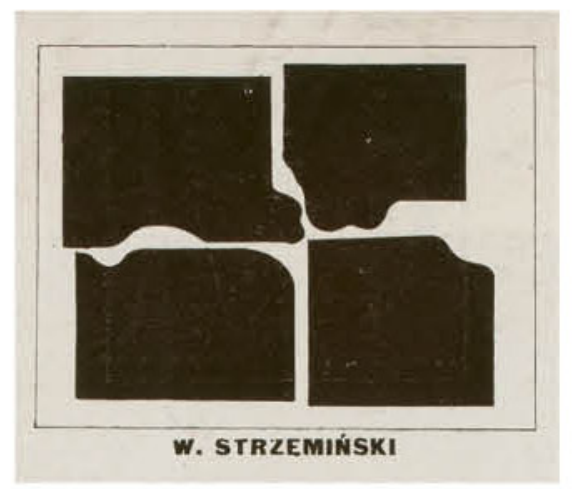


1.45 Composición de László Moholy-Nagy (18951946) propiedad de la Bauhaus de Weimar (En el
texto: Klisza Właściwość "Bauhaus in Weimar") publicada por la revista Blok no 8-9 en noviembre de 1924.

1.46 Dibujo de Teresa Żarnowerówna (1897-1949) publicada por la revista Blok no 8-9 en noviembre

1.47 Manifiesto de Władysław Strzemiński (18931952) sobre el Nuevo Arte publicado junto a una

1.48 Fotografía de la exposición de la obra de László Moholy-Nagy (1895-1946) realizada en 1923 publicada en la revista Blok no 8-9 en noviembre de

1.49 - 1.50 Composiciones arquitectónicas de revista Blok no 8-9 en noviembre de 1924.

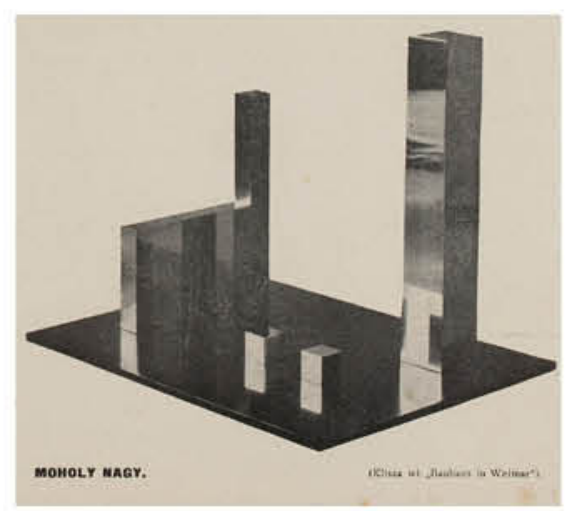

1.45

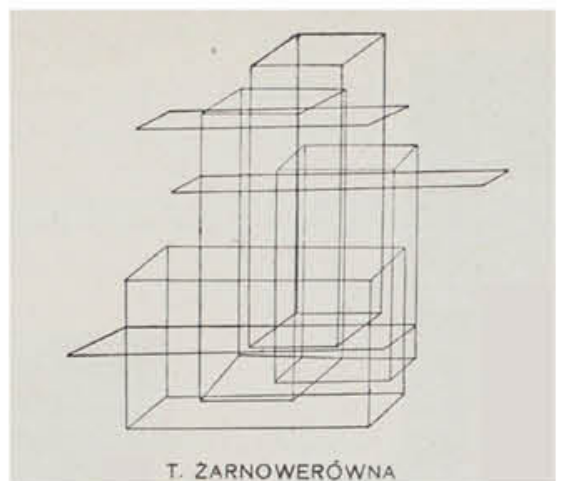

1) Te, eg ale prawnie naryos NUwa szroxa, opty te daskosalosicl formy plastyezaet

\section{form}

2) Do anslizy dtiedziny plastyki nit motemy sto-

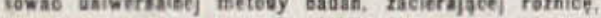
istnieläea pomicdry plastyka a innemi driedrisami.

3) Dakionatoic drita sztuki ausi byc uma trescia-

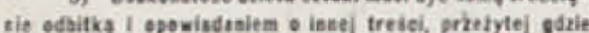

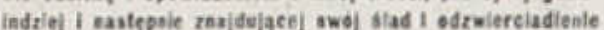
w postael daleh stoki.

NB. Deleto sztuki plastyoznej nio gowisno byo rowniez opawiadaniem o tretioi finia dzisiejarego. Niech miar osiagnileccia dopjero dtis.

4) Sotaka klasycras osiagneta pewien poriem do.

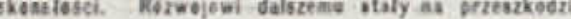

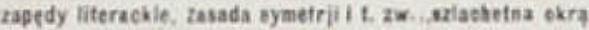
Dlose" knteltion.

5) Develo sztui musi byd zbudowane wedtay praw

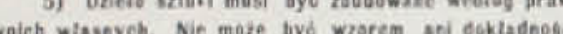

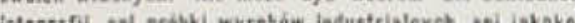
rekbagdz rreer inn.

6) Dzilo ortaki plastyezoej aic wyraha nie, Ozielo aztukl aie jest zankiem ezegokoiniek. Oao jest (intrieje sumo proze sip.

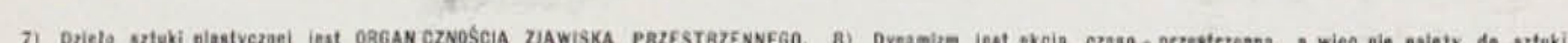
plastfernej 9) Dzien dzisiejazy przekroezy? kierunki sztuki t. zw. nowti: kubizm, futoryzm, sugrenatyzm, egrustowane na plerwisstku dynamieznym. 10) Kubizm, wy.

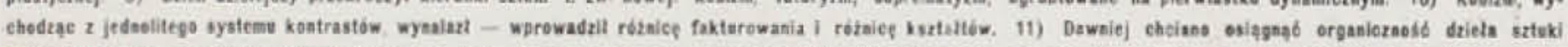

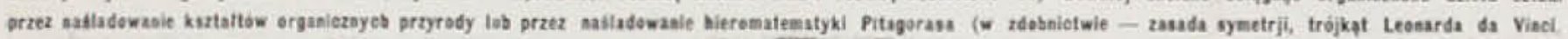

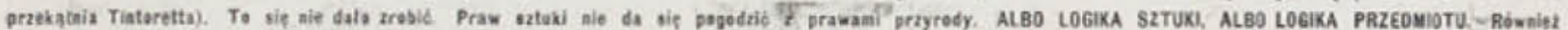

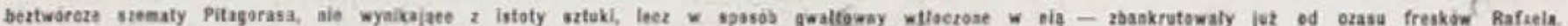

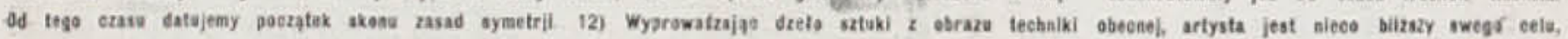

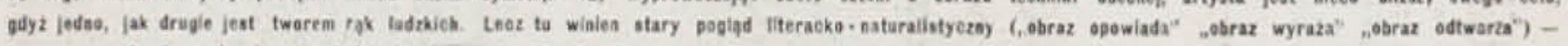

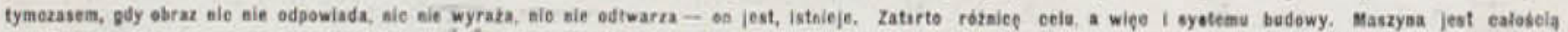

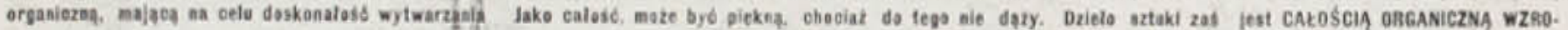
kOWA. I jake calosib mote byo pięne, ehoeiaz rowajez do tego nie dąy.

\section{W. STRZEMIN่SKI}


Hasta la aparición de las vanguardias, la arquitectura polaca del momento se caracterizaba por la monumentalización de la forma, ${ }^{1.19}$ utilizando a menudo grandes divisiones verticales mientras los detalles de órdenes arquitectónicos se iban obviando o simplificando, tal como ocurre en el Banco Nacional de Economía ${ }^{1.17}$ en Varsovia 1928-31 (1.27) (1.28) de Rudolf Świerczyński; el Museo Nacional en Varsovia de Tadeusz Tołwiński (1927-34); o al Banco de Sociedades Cooperativas de 1917 del arquitecto Jan Heurich (1.29)-(1.33).

Estas tendencias hacia la simplificación y la monumentalidad sobrevivieron en la arquitectura pública polaca casi hasta mitad de los años $30,{ }^{1.19}$ momento en que una nueva generación de vanguardia tomó el protagonismo constructivo en Polonia, al mismo tiempo que sus homónimas europeas perdían influencia en sus respectivos países, dando paso a las obras más significativas de la vanguardia polaca. ${ }^{1.19}$

La inauguración de una exposición de arte en Vilnius en 1923, realizada por Władysław Strzeminski y Vytautas Kairiūkštis 1.18 , es considerada el inicio de un movimiento que concluiría en Polonia con la fundación del grupo Blok, en el que también participaron Karol Kryński, Henryk Stażewski, Mieczysław Szczuka y Teresa Żarnowerówna ${ }^{1.20}$. El grupo se formalizó con la publicación de una revista homónima cuyo primer número salió a la venta el 8 de marzo de 1924, siendo heredera de los contenidos publicados en revistas contemporáneas de vanguardia como De Stijl (1917), L'Espirit Nouveau (1920) y Proletkult (1917) entre otras. ${ }^{1.20}$

A los pocos días de publicar el primer número se celebró una exposición en el taller de vehículos Laurin-Clement, cerca de la c/ Mazowiecka de Varsovia, en la que se sumaron al grupo nuevos miembros como Henryk Berlewi, Katarzyna Kobro o Mieczysław Szulc, mientras que, poco después, se unieron también Jan Golus, Marja Nicz-Borowiakowa y Aleksander Rafalowski. Aquel primer número de la revista se basaba en el catálogo de la exposición que había tenido lugar en Vilnius, y en él se representaban las piezas expuestas comentando su relación con el cubismo, el constructivismo y el suprematismo. 1.20

Por primera vez, la idea de construcción aparecía como un postulado artístico en Polonia debido a las publicaciones de la revista Blok. ${ }^{1.19}$ Los textos de Szczuka que acompañaban a la revista abordaron desde el primer número la complicada relación del constructivismo con las demandas sociales, un asunto de especial relevancia en aquel momento en Rusia, habida cuenta de la marginación que las vanguardias estaban comenzando a sufrir en su propio país desde la llegada al poder de Stalin en 1924 -quien las consideraba "arte decorativo"1.21. Las vanguardias pasaron a ser interpretadas en los ámbitos de poder comunista como "demasiado elitistas" 1.21 para formar parte de un aparato de propaganda oficial, y fueron rápidamente relegadas al no ser consideradas capaces de comunicar adecuadamente los principios e ideas de la revolución social que los dirigentes soviéticos pretendían hacer llegar a la población que no tenía formación. ${ }^{1.21}$

La revista Blok fue adquiriendo progresivamente un acercamiento a la técnica y su lenguaje se centró cada vez más en la composición, hasta finalizar empleando inspiraciones y referencias de carácter arquitectónico. Las pinturas comenzaron

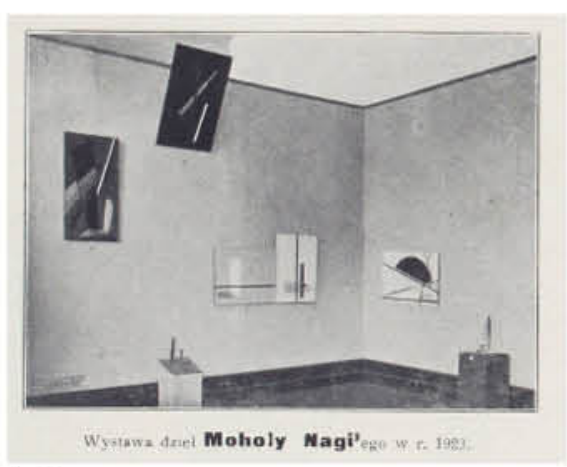

1.48

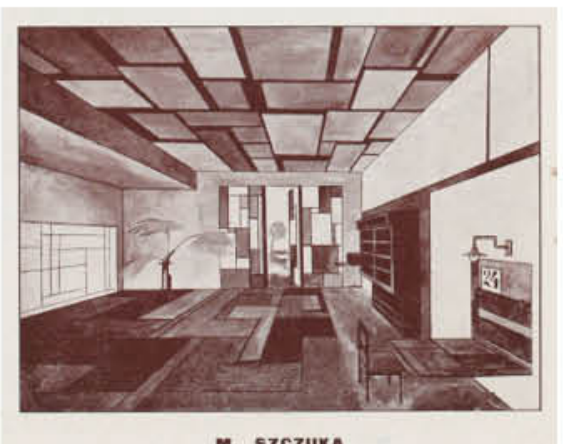

1.49

m. szczuxn

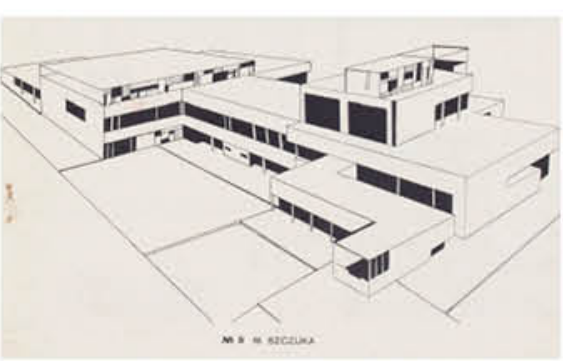

1.50

1.17. Gmach Banku Gospodarstwa Krajowego w Warszawie

1.18. Liutkus, 2008. p. 1

1.19. Niezabietowski, 1995. p. 1

1.20. Wróblewska, 2010. p. 1

1.21. Fontán del Junco, 2011. 
1.51 Composición de Charles Edouard Jeanneret Le no 3-4 en junio de 1924 .

1.52 Proyecto de Cine realizado por Teresa Zarnowerowna, piotr Kozhiski y Antoni Karczewski y publicado en la revista Blok no 11, de maze de

1.53 Tribuna de Lenin, 1920 de El Lissitzky (18901941) publicada por la revista Blok no 8-9 en noviembre de 1924

1.54 Composición publicada por la revista Blok no 2 en mayo de 1924.

1.55 Viviendas de J.J.P. Oud cortesía de la revista MERZ (Klisza czasopisma MERZ) publicadas en la revista Blok no 8-9 en noviembre

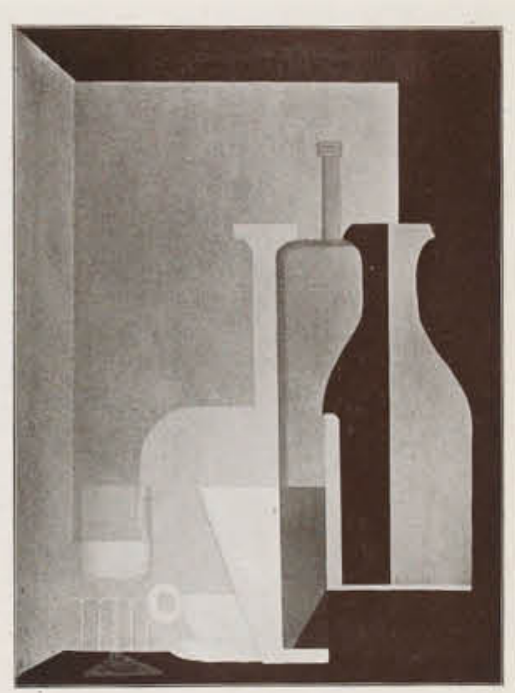
JEAMUERET

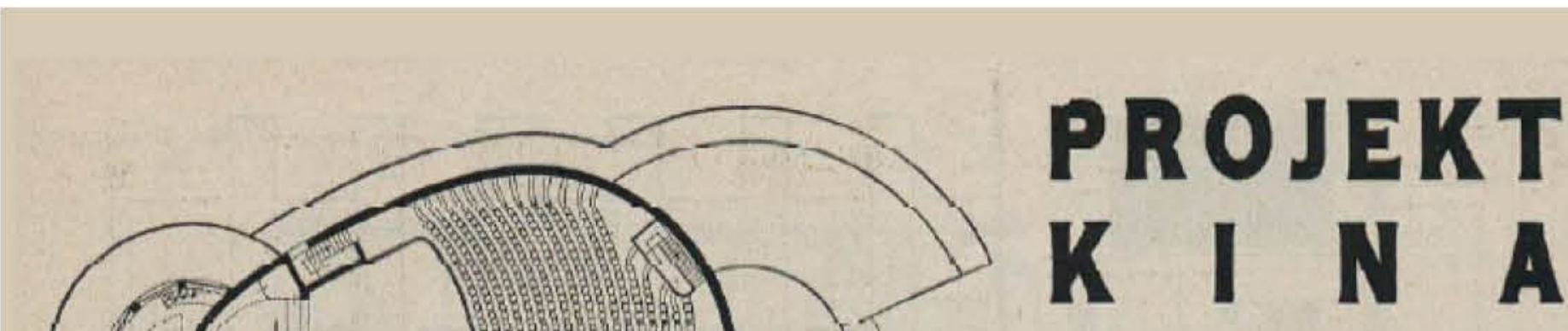

T E R E S A

INRNOWEROWNA

P I O T R A N T O N I KOZINSKI KARCZEWSKI

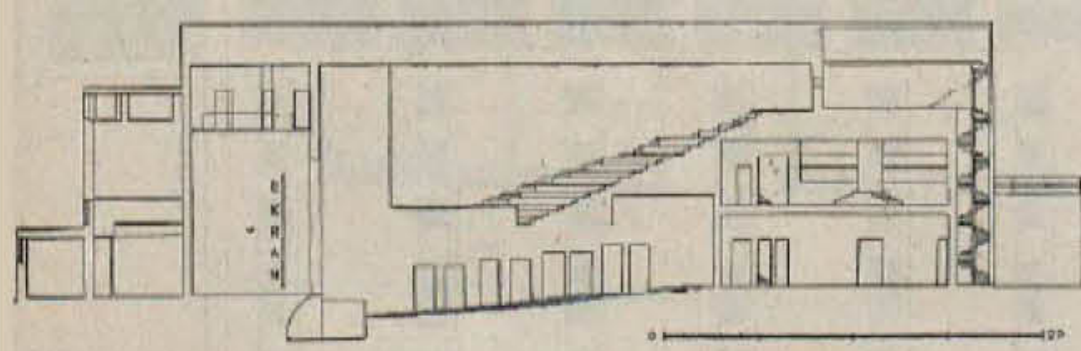

ate. Jhe

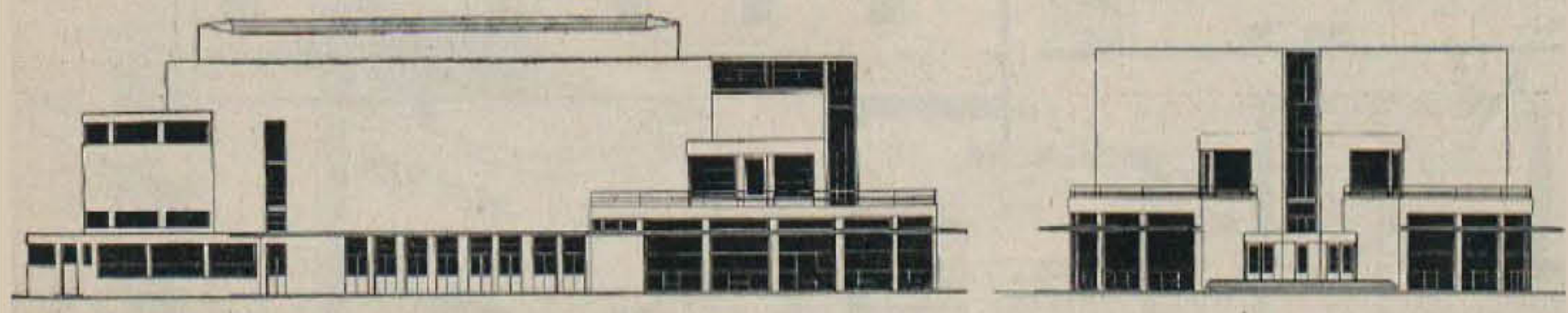


a ser explicadas mediante los lenguajes de la aritmética o la mecánica. Las obras de los miembros de Blok en sus primeros números estaban basadas en la estética de la máquina, y la idea de belleza fue reemplazada por la noción de una forma lógica, mientras que el propósito creativo no era la experiencia o la contemplación estética, sino el producto diseñado para su uso social. El artista, debía tomar así la posición de un constructor, y su trabajo, debía servir para cumplir funciones específicas del circuito social, aunado el arte con el trabajo y, en definitiva, con la propia vida. ${ }^{1.20}$

Las reuniones del grupo Blok tuvieron lugar entre 1924 y 1926 en el estudio de Pełczyński en la calle Szczygła nº 10 de Varsovia, y en sus actas publicadas quedaban patentes sus preocupaciones sobre las nuevas formas de las civilización modernas tras la experiencia de vivir en grandes ciudades de países industrializados. ${ }^{1.20}$ Los miembros del grupo Blok creían en la "autonomía del arte y la libertad en la exploración artística" ${ }^{1.20}$ y consideraban que los artistas tenían derecho a "la limpieza de laboratorio." (...) El estado creativo no puede subordinarse a las exigencias de utilidad. (...) Creemos en la necesidad de combinar el arte y la vida para formar todos los acontecimientos humanos e influir activamente en los procesos que tienen lugar en el mundo moderno." 1.20

Tanto Władysław Strzeminski como Katarzyna Kobro habían estado en contacto durante su formación con la vanguardia rusa. Strzeminski había tenido clases con Kazimir Malévich en 1919, y trabajó en su taller como ayudante -donde tuvo ocasión de conocer a Tatlin-. Mieczysław Szczuka, por su parte, inspiró muchas de sus creaciones en las obras constructivistas de Tatlin y Rodchenko y Teresa Zarnowerowna mantuvo en sus obras referentes del suprematismo, movimiento con el que compartía la búsqueda de una forma abstracta y universal, desde un punto de vista tanto artístico como arquitectónico. ${ }^{1.19}$

Malévich visitó Varsovia en 1926, y su presencia derivó en una fuerte influencia de las ideas suprematistas, que se reflejaron en las creaciones de los artistas y arquitectos polacos del grupo Blok, tal como recoge la historiadora Magdalena Wróblewska ${ }^{1.20}$, que apunta que "las disposiciones espaciales abstracto-geométricas creadas por Malévich conformaron prototipos de formas arquitectónicas modernas que resultaron muy significativas para el proceso de formación de un nuevo lenguaje en la arquitectura polaca de vanguardia." 1.20

En los primeros números de la revista Blok queda reflejada la clara influencia de los constructivistas rusos, llegando a inspirarse claramente en el grafismo y la tipografia de la revista Proletkult. Estas primeras referencias fueron sin embargo abandonadas progresivamente, en la medida en que los miembros del grupo Blok se aproximaban a formas arquitectónicas que requerían a su juicio un contexto creativo menos abstracto.

La atención de los arquitectos vanguardistas polacos se centró entonces en las propuestas formales de la Bauhaus o De Stijl, movimientos que también habían tenido un origen similar en los planteamientos formales y estéticos de la vanguardia rusa. La revista Blok publicó artículos y diseños de arquitectos como Mies van der Rohe, Theo van Doesburg, Piet Mondrian, Thomas Gerrit Rietveld y J.J.P. Oud entre otros. Entre los socios de la revista se encontraba

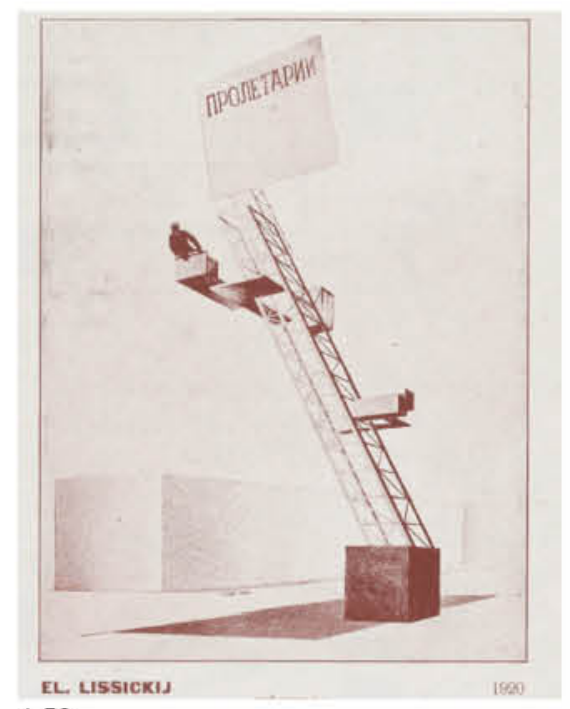

1.53
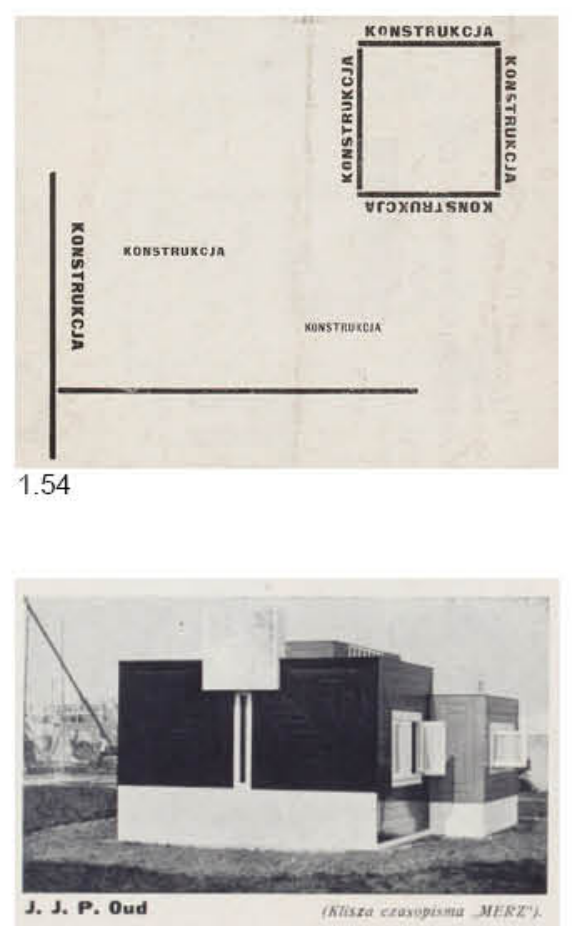

1.55 
1.56 Casa Schröder en Utrech Rietveld realizada en la revista BLOK no 11 , de marzo de 1926.

1.57 Proyecto de vivienda realizado por Teresa Zarnowerowna (1897-1949) publicado en la revista

1.58 Proyectos de vivienda realizado por interior de Staszewski publicado en la revista BLOK no 10 , de julio de 1925.

1.59 Composición de Sybold van Ravesteyn publicado BLOK $n^{\circ} 11$, de marzo de 1926

1.60 Villa d'Avray del arquitecto Robert Mallet marzo de 1926.

1.61 Proyecto de vivienda realizado en 1924 por el arquitecto Gabriel Guevrekian y publicado en
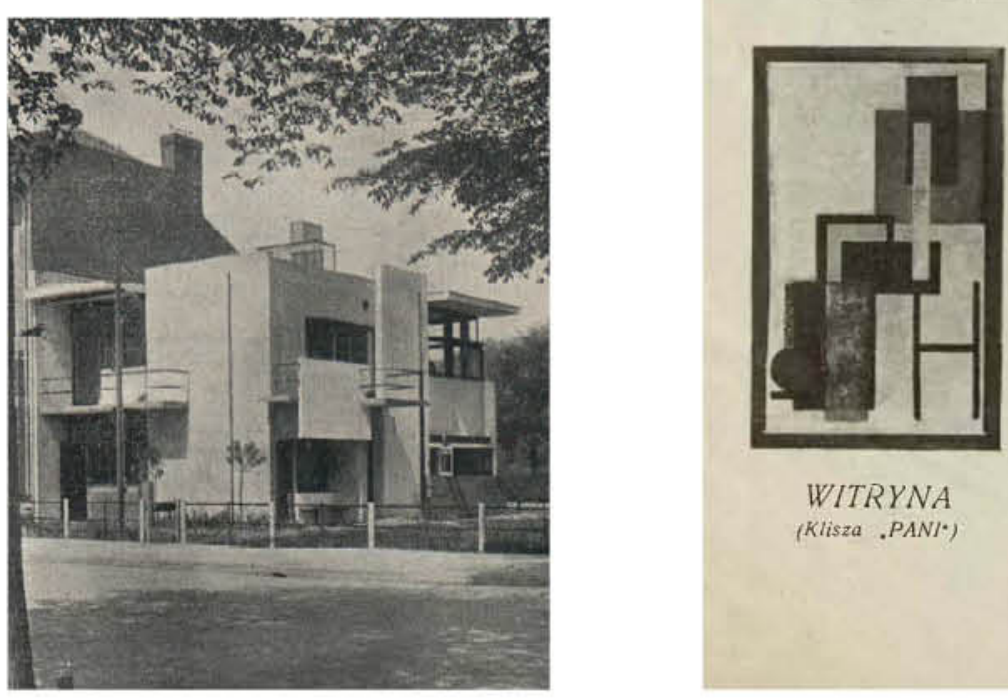

WITRYNA

(Klisza .PAN! .
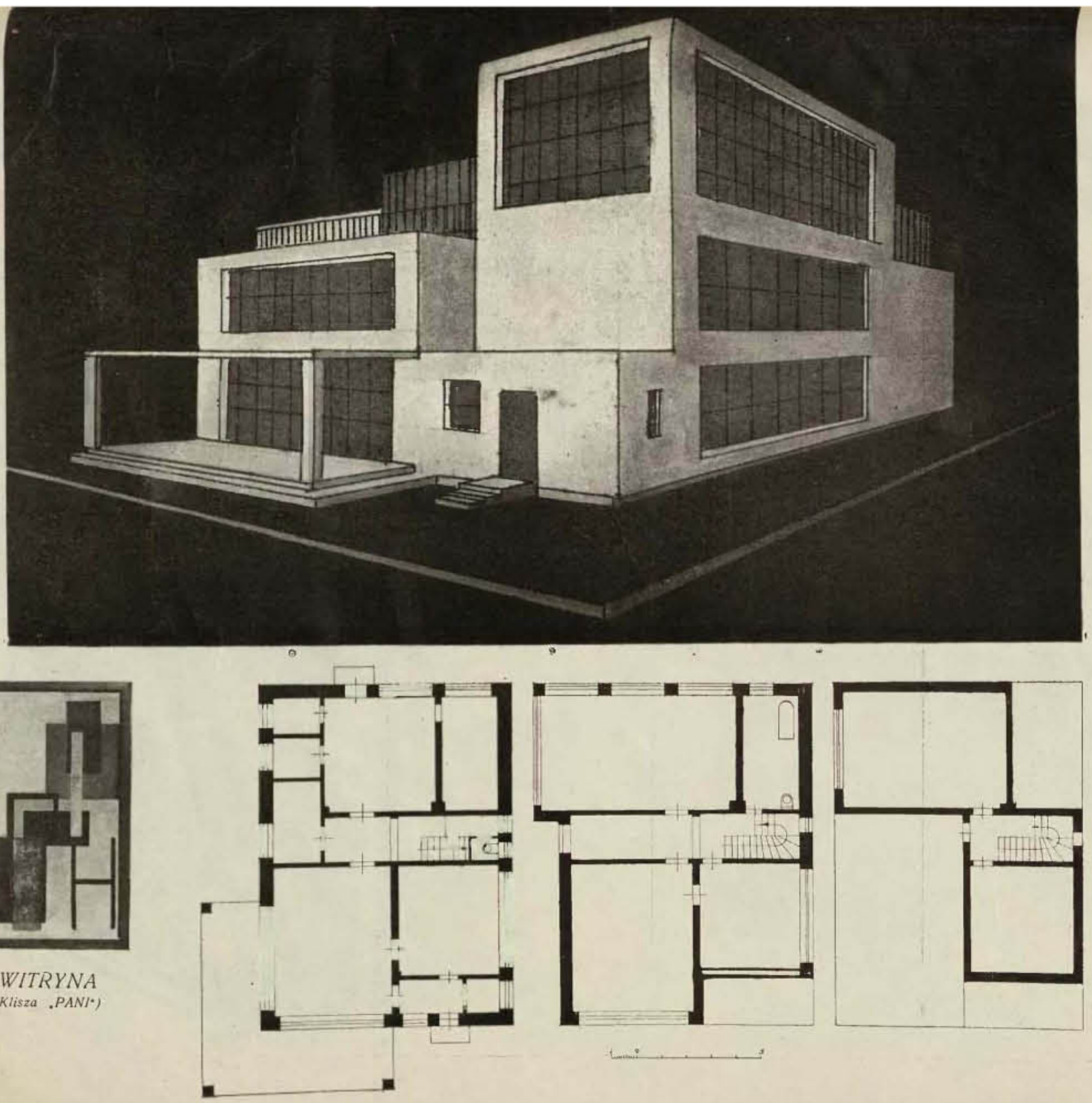

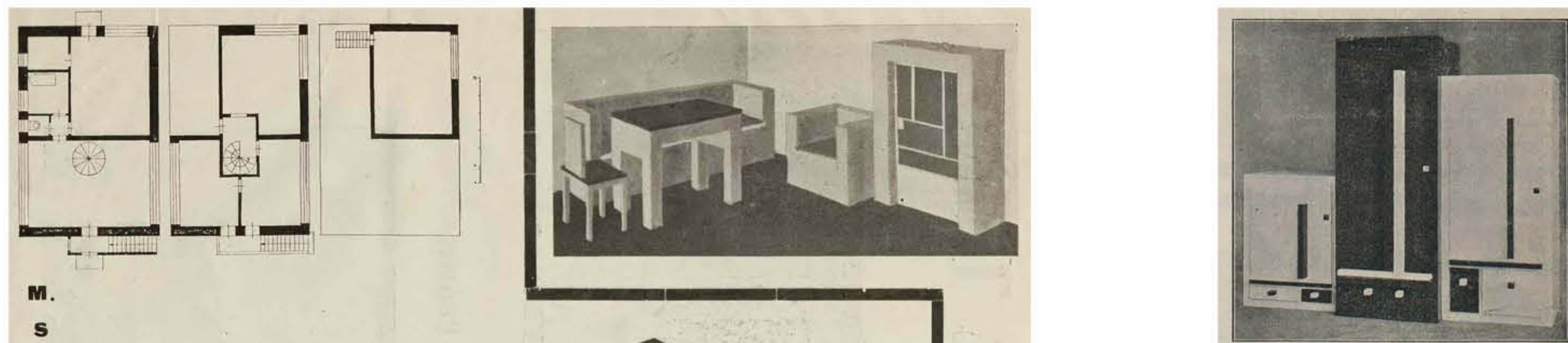

m.
s
$\mathbf{z}$
$\mathbf{c}$
$\mathbf{z}$
$\mathbf{U}$
$\mathbf{K}$
$\mathrm{A}$

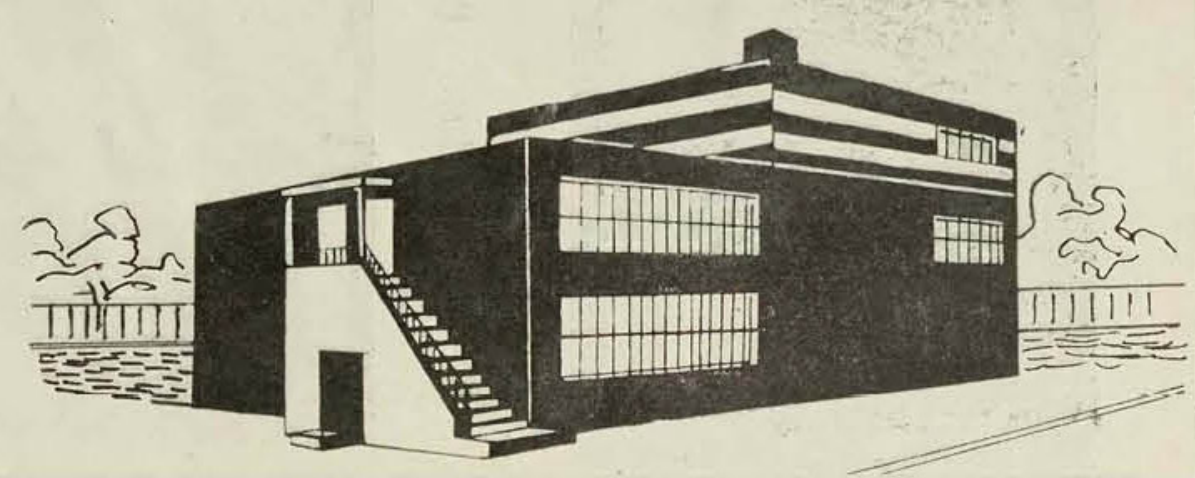

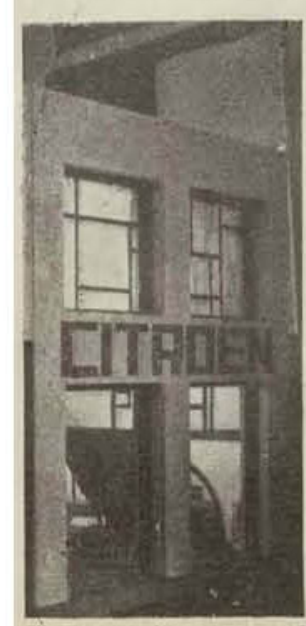
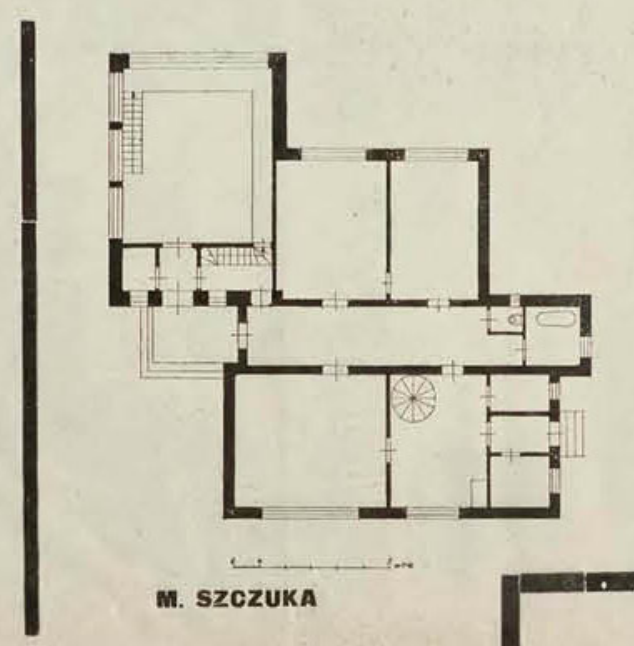

m. szczuka

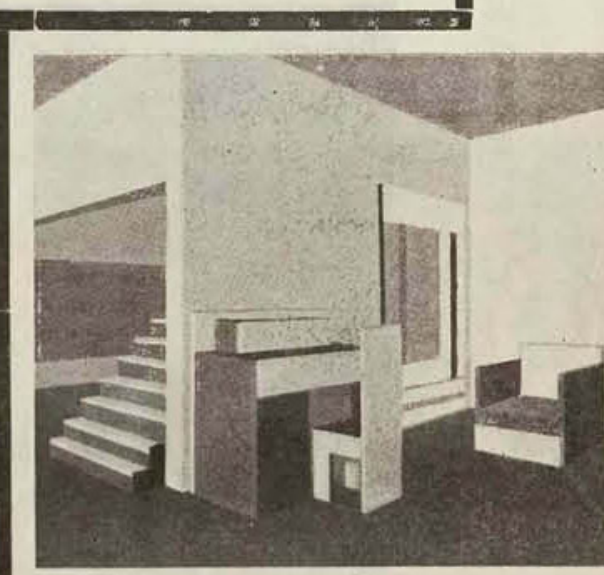

H. STAZEW SK I
S. YAM RAYESTEYM 1.59

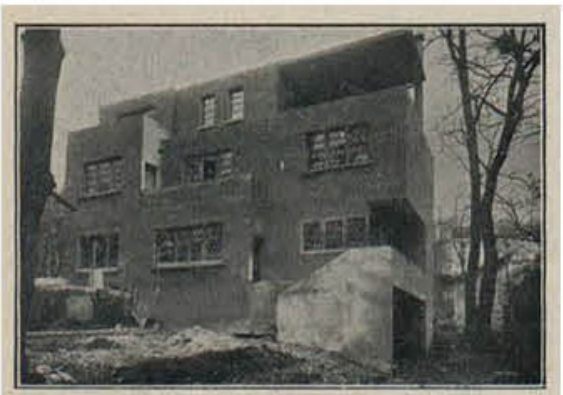

ROB. MALLET STEVENS

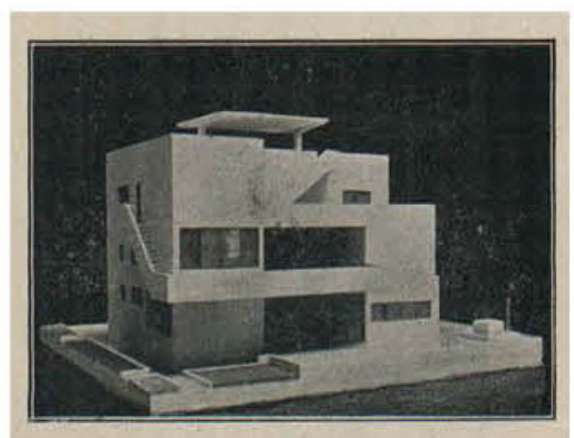

GAB. GUEVREKIAH 
1.62 - 1.65 Planos e imágenes de las viviendas en arquitectos Bohdan Lachert y Joseph Szanajca.

1.66 Viviendas en hilera en Saska Kepa (Varsovia) realizada en 1937 por Szymon \& Helena Syrkus.

1.67 Viviendas en hilera en la calle Katowicka en Varsovia (1928-29) de los arquitectos Bohdan

1.68 Propuesta de Bohdan Lachert, Joseph Szanajca y Stanisław Hempel para el concurso para la construcción del edificio de la Liga de las Naciones de Ginebra en 1927.

1.69 Propuesta de Szymon Syrkus y Henryk edificio de la Liga de las Naciones de Ginebra en 1927
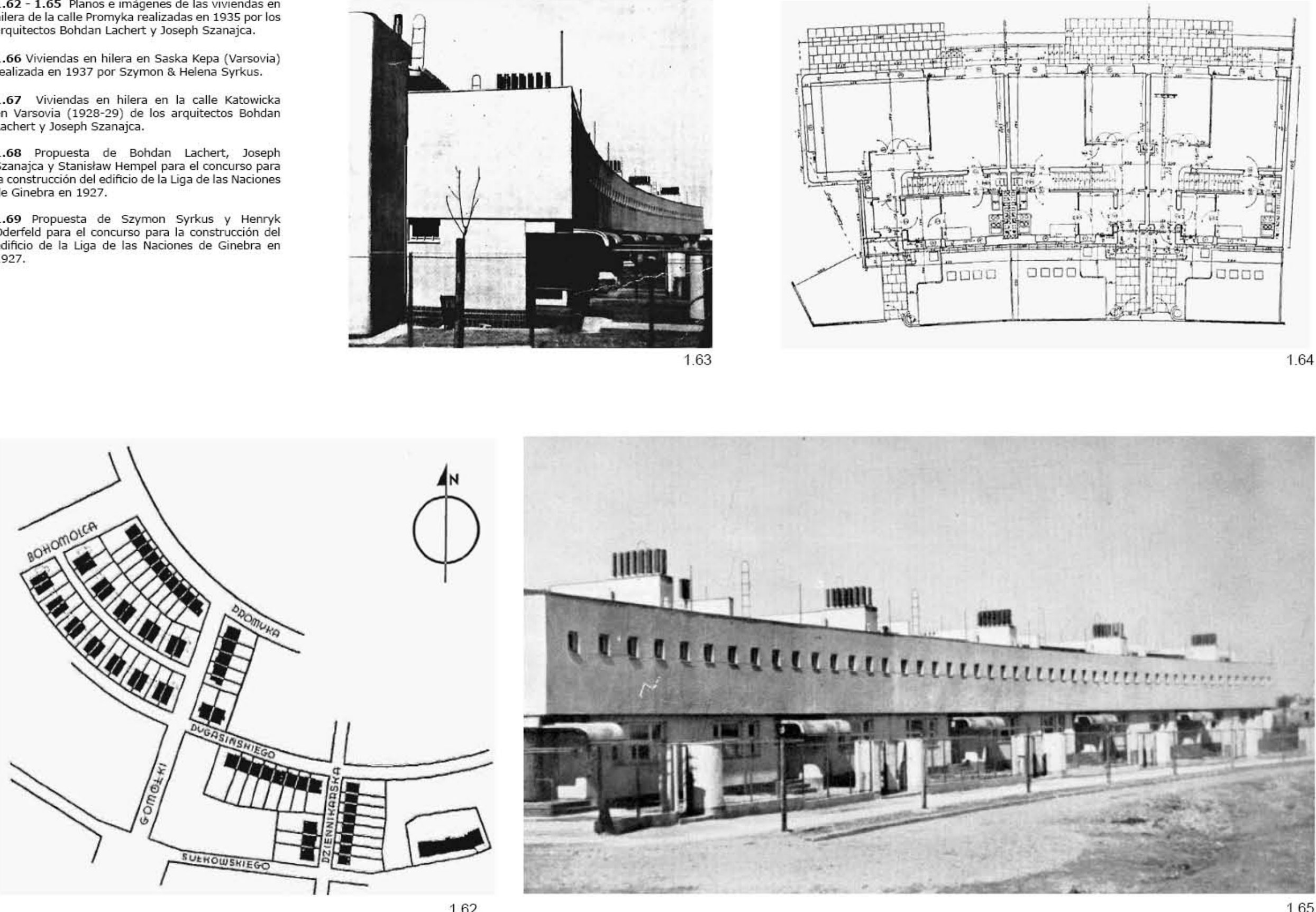
la nueva generación de arquitectos que serían futuros profesores de Leykam: Szymon Syrkus, Bohdan Lachert, Józef Szanajca o el matrimonio Brukalski. ${ }^{1.19}$

La fascinación del grupo Blok por las creaciones del constructivismo ruso, el suprematismo y el neoplasticismo holandés pronto resultaría sin embargo demasiado utópica para una Polonia en pleno proceso de expansión, que tenía la necesidad de construir físicamente su nueva realidad con celeridad. En 1926, las diferencias internas entre los miembros del grupo Blok dieron lugar a su ruptura, y Władysław Strzeminski, Jan Golus, la escultora Katarzyna Kobro y la arquitecta Marja Nicz-Borowiakowa decidieron formar un nuevo grupo con un mayor acercamiento a la práctica arquitectónica llamado Praesens. 1.20

A este grupo se unieron varios arquitectos recién graduados en la Facultad de Arquitectura de la Universidad de Varsovia, como Barbara \& Stanisław Brukalski; Bohdan Lachert; Józef Szanajca y Szymon \& Helena Syrkus, dando lugar a las obras más representativas de la arquitectura polaca de vanguardia, particularmente las viviendas en hilera en Saska Kepa de Szymon \& Helena Syrkus en 1937 (1.66); la casa residencial en la calle Katowicka en 1928-29 (1.67) y las viviendas en hilera en la calle Promyka en 1935 de Lachert y Szanajca (1.62-1.65); y la vivienda del matrimonio Brukalski en la calle Niegolewskiego en 1927-28 (1.70-1.74), todas ellas en Varsovia, además de la Villa Dr. Bernstein del matrimonio Syrkus en 1934 en c/Jasiowa, 6 de Konstancin-Jeziorna (1.75-1.78). ${ }^{1.19}$

El grupo Praesens no solo se convirtió en el núcleo de la arquitectura vanguardista en Polonia. sino también en el representante polaco en los Congrès Internationaux d'Architecture Moderne (CIAM) ${ }^{1.22}$, vinculación que comenzó a raíz de la participación de los equipos polacos de Bohdan Lachert y Józef Szanajca -junto al ingeniero Stanisław Hempel (1.70)- y de Szymon Syrkus con Henryk Oderfeld (1.71), en el concurso para la construcción del edificio de la Liga de las Naciones de Ginebra en 1927, ${ }^{1.19}$ que dio origen -por iniciativa de Le Corbusier- al primer congreso CIAM en el castillo de la Sarraz propiedad de Hélène de Mandrot en 1928.

Szymon Syrkus participó como representante de Praesens en el primer CIAM exponiendo la dispersión que comenzaba a producirse en Varsovia tras la independencia el país hacia pequeñas unidades individuales de vivienda, así como presentando el proyecto "Varsovia Funcional", realizado junto a su esposa Helena Syrkus y la colaboración de Jan Chmielewski. ${ }^{1.19}$

Los postulados del grupo Praesens también fueron enunciados por Szymon Syrkus, quien pretendía "a modo de experimento, un enfoque arquitectónico ante las nuevas oportunidades, no solo artísticas, como podría parecer, sino también sociales." ${ }^{1.19}$ En octubre de 1926, el grupo Praesens inaguró su primera exposición en la Galería Zacheta en Varsovia y un año después participó en la organización de la exposición "La Era de la Máquina"en Nueva York, muestra en la que serían expuestas obras de algunos de sus miembros, como Stanisław Brukalski, Józef Malinowski, Władysław Strzemiński, Szymon Syrkus, Henryk Oderfeld , Bohdan Lachert, Józef Szanajca y Lech Niemojewski, entre otros. ${ }^{1.19}$

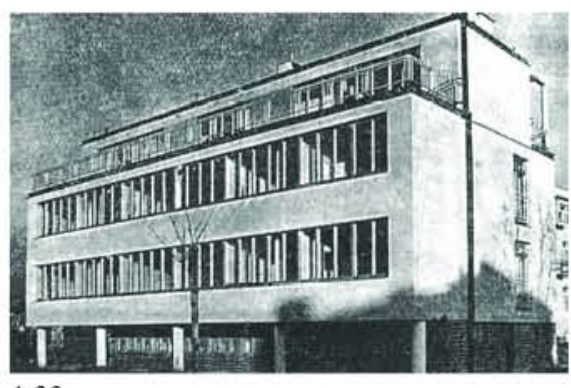

1.66

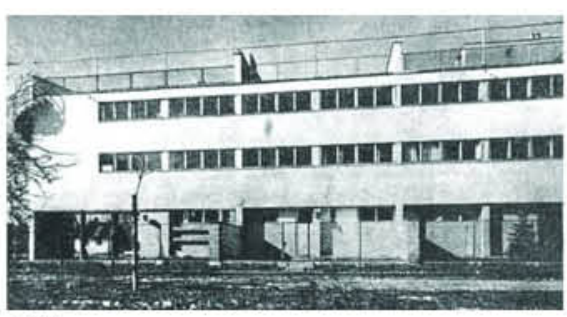
1.67

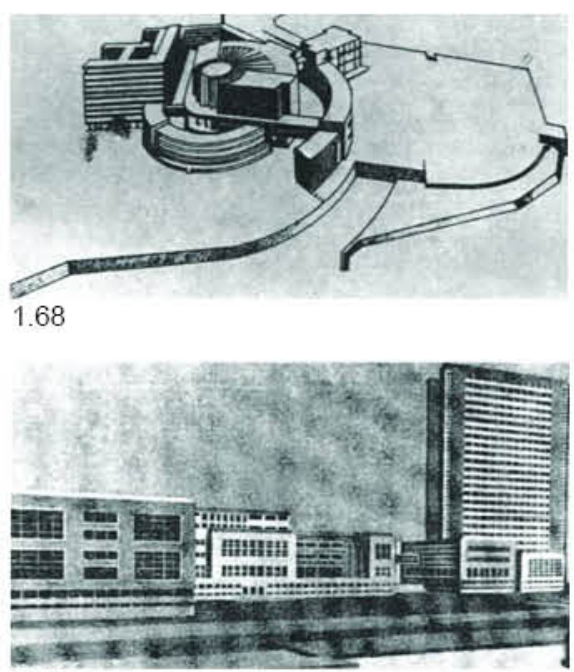

169

1.22. Congrès Internationaux d'Architecture Moderne (CIAM) fueron una serie de reuniones realizadas con objeto de promover la arquitectura y el urbanismo modernos. Fuente: Mumford, 2002

1.23. Sedlmayr, 2008. Cit. Op. Cit. 1.19 


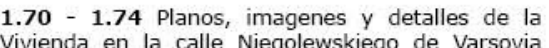
realizada por los arquitectos Stanisław Brukalski y Barbara Brukalska en 1927-28.

1.75 - 1.78 Planos, imagenes y detalles de la Villa

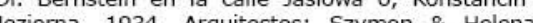
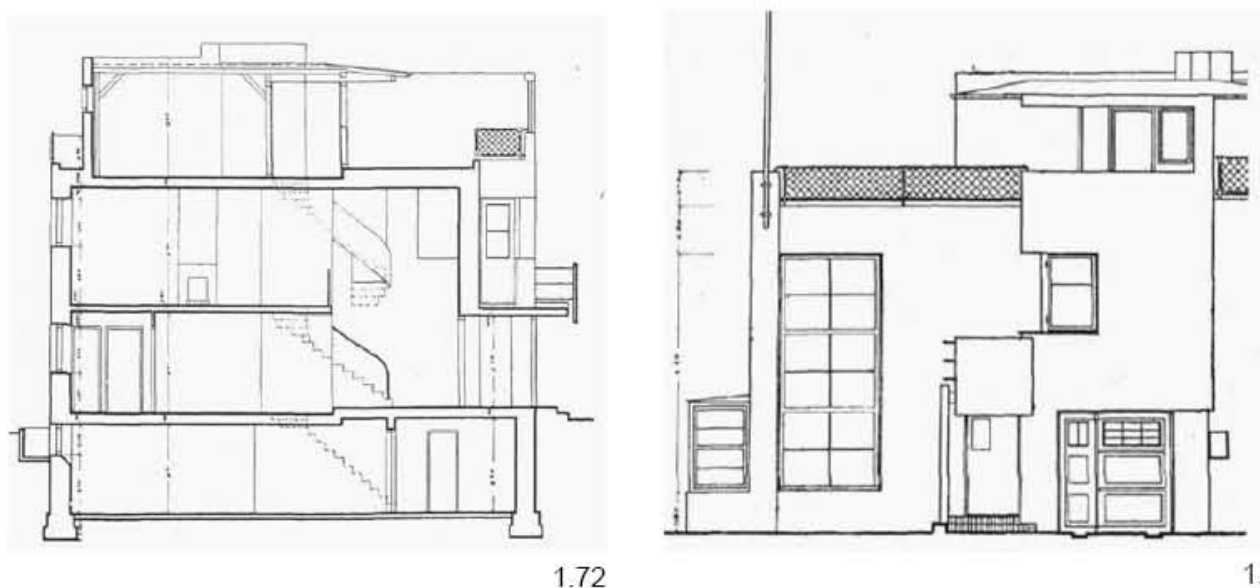

1.73
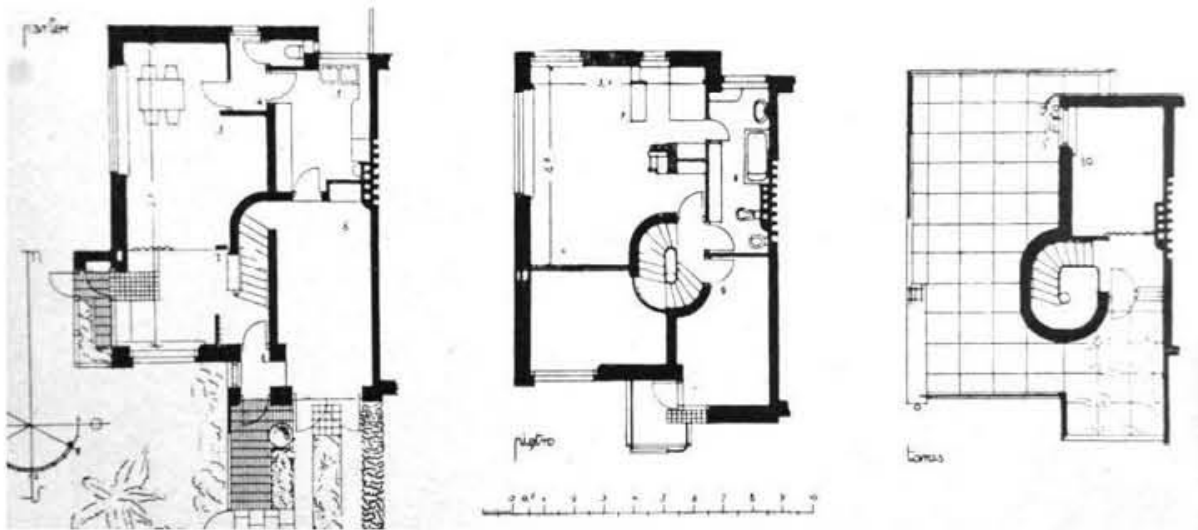

1.71

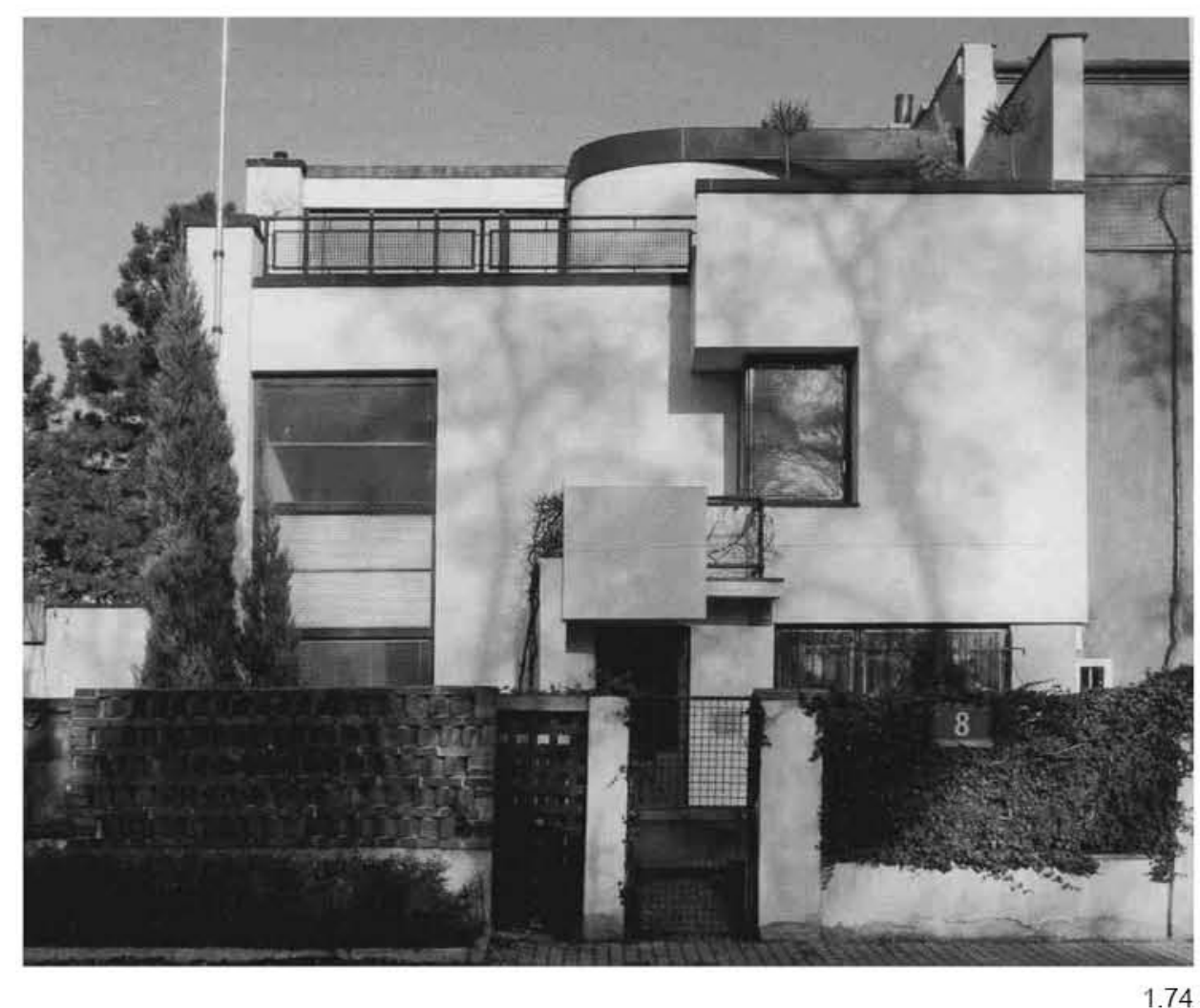



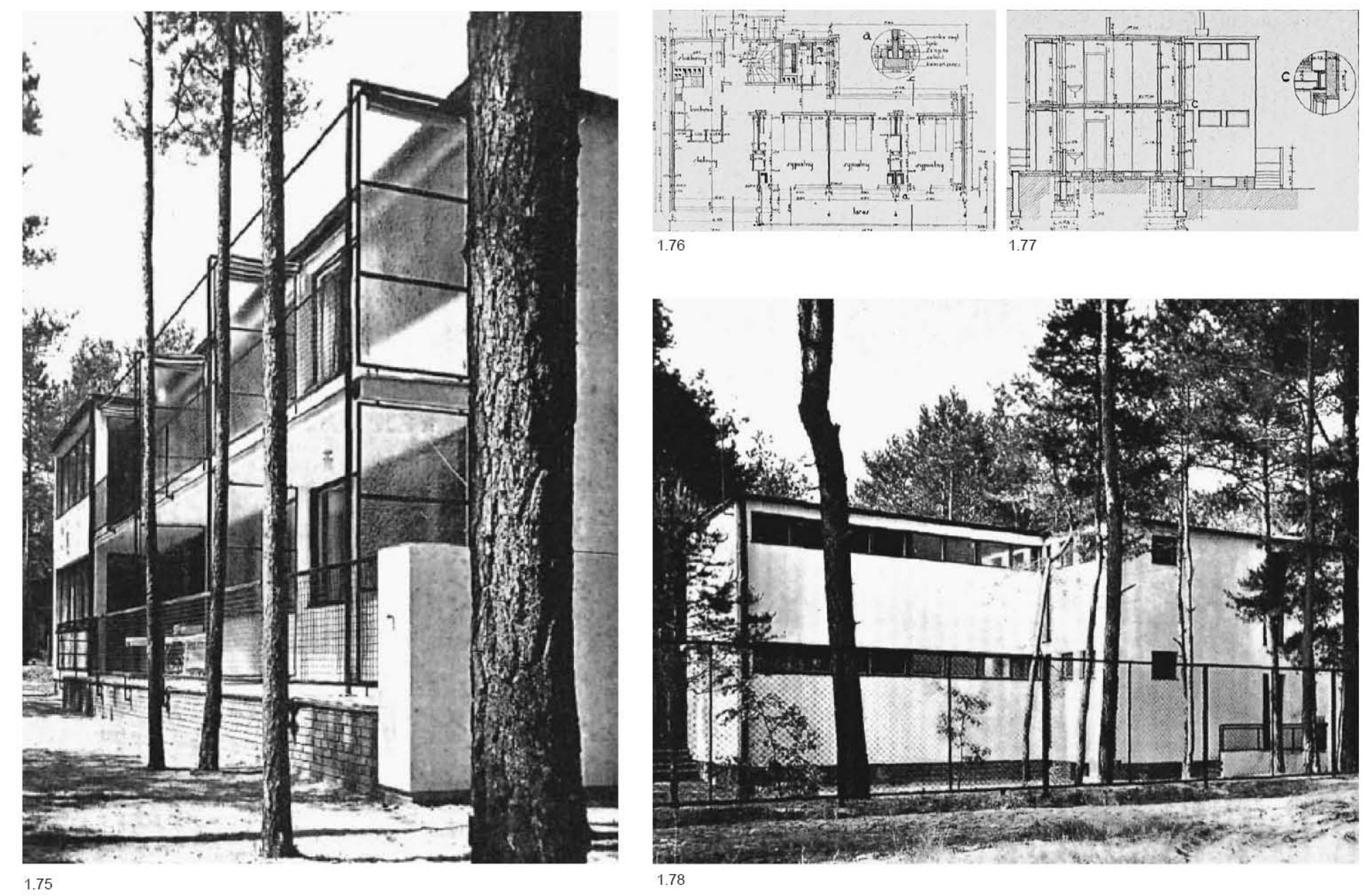

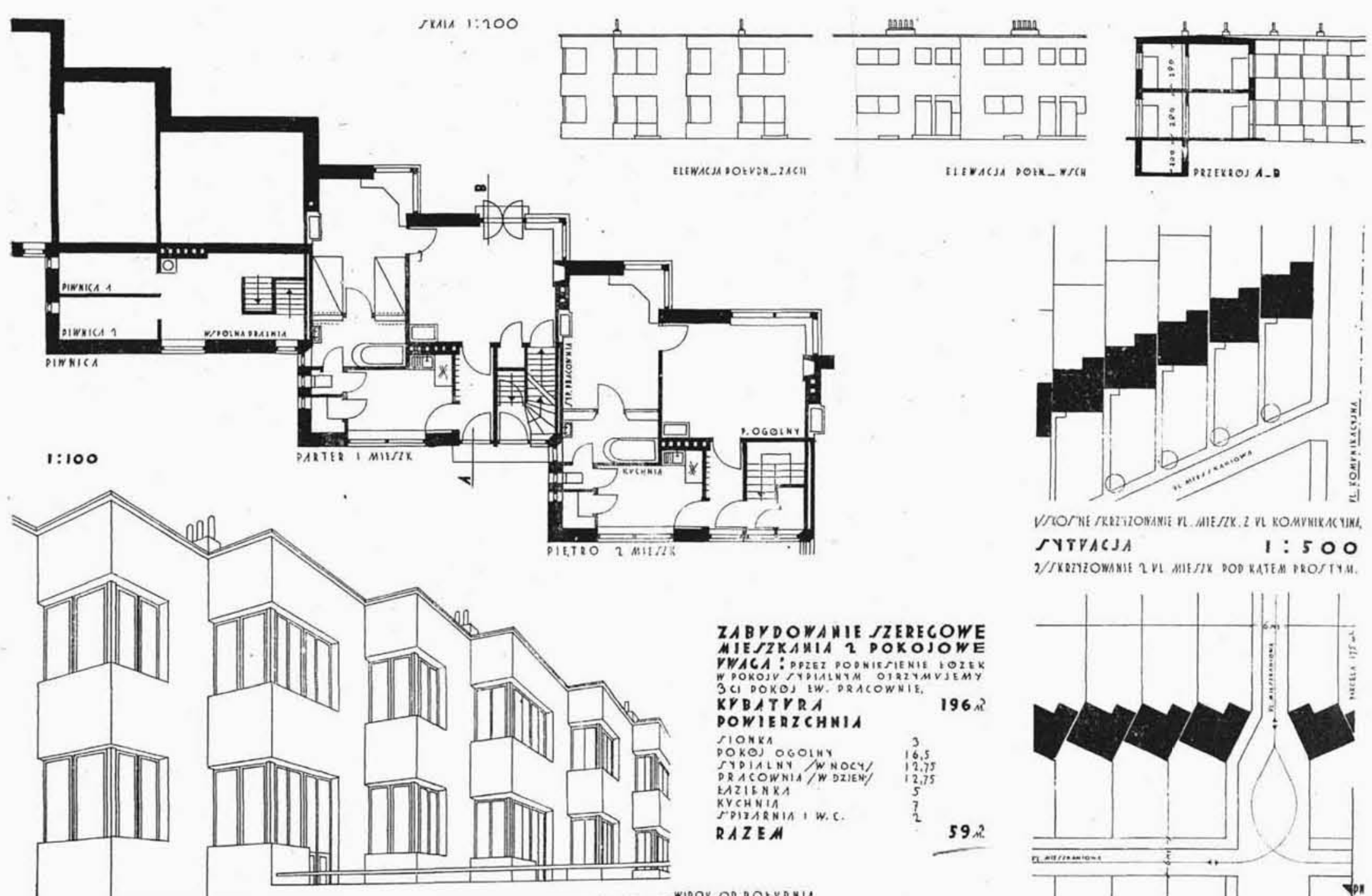

ZABYDOWAWIE JZERECOWE MIEFZKAYIA 2 POKOJOWE WWACA : PPZEZ POOWIS RIENIE LOZEK 3CI DOKOS tW. DRACOWNIE, 196 KYBATYRA
DOWIERZCHNIA SlOKkn SYDIAL HY W NOCY

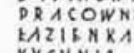
SPCHNIA RAZEA

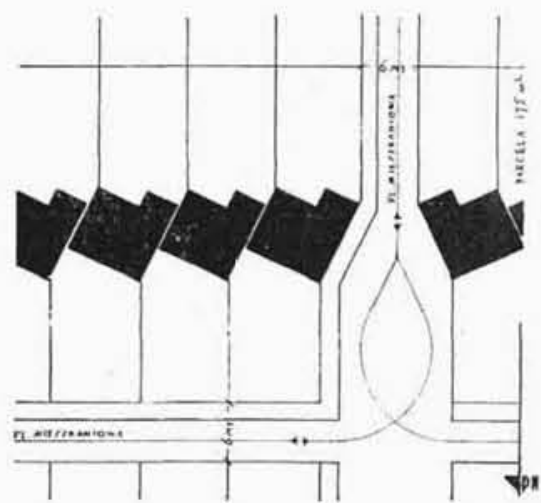

ARCH.: BOHDAN LACHERT, LECH NIEMOJEWSKI I JOZZEF SZANAJCA (S. A.P., WARSZAWA), PROJEKT KONKURSOWY ZABUDOWANIA SZEREGOWEGO MIESZKAN 2.POKOJOWYCH. Ne 16 a. NAGRODA 1. 
Tal como señala el arquitecto, Prof. Dr. Hab. Andrzej Niezabietowski, ${ }^{1.19}$ "las características formales de la arquitectura vanguardista polaca indicaban una convergencia con los aspectos visuales formales que estaban presentes en la arquitectura funcionalista de Europa Occidental." 1.19

El Prof. Dr. Hab. Bohdan Lisowski, también arquitecto e investigador, afirma que 1.24 "en la vanguardia polaca estaban presentes los conceptos de espacio y sus consideraciones visuales, mientras la característica más sobresaliente de su arquitectura era la predilección por la llamada libertad de formaciones, la penetración del espacio (es decir, la comunicación entre el espacio cerrado y sus alrededores), la multiplicidad visual (o intensidad visual constante en todas las vistas de una composición arquitectónica) y la sencillez, síntesis y claridad de formaciones, caracterizadas por el uso de grandes planos homogéneos, así como la aversión a la decoración y la eliminación de la ornamentación a favor de diseños y texturas." 1.19

Al igual que había ocurrido con el grupo Blok, los puntos de vista de los miembros del grupo Praesens fueron encontrando fricciones que dieron con el final de la organización en 1930, tras haber publicado dos únicos números de su revista. Los arquitectos el grupo se centraron en la práctica proyectual en sus oficinas, y Strzeminski decidió abandonar el grupo en 1929, seguido de Stażewski y Kobro en 1930. ${ }^{1.19}$

En este contexto cultural comenzó Marek Leykam sus estudios en la Universidad Técnica de Varsovia en 1927. siendo una de las primeras promociones que recibiría clases de ambas generaciones al mismo tiempo; por un lado los experimentados arquitectos Rudolf Świerczyński, Tadeusz Tołwiński, etc.. de formación mayoritariamente rusa o europea, y que habían retornado a Polonia a raíz de la independencia del país; y por otra parte de los jóvenes asistentes involucrados activamente en movimientos polacos de vanguardia, como Stanisław Brukalski, Bohdan Pniewski, etc.. a los que complementaba la inclasificable figura del suizo Edgar Norwerth, cuya obra resultaría fundamental para la nueva generación de jóvenes. ${ }^{1.25}$

La enseñanza en la Facultad de Arquitectura de Varsovia estaba estructurada en 1927 -año en que Leykam empezó sus estudios- en torno a diferentes cátedras. El profesor Karol Jankowski era el responsable del diseño urbano y ordenación del territorio, y entre sus objetivos estaba la "definición de normativas y los condicionantes que afectan a formas arquitectónicas relevantes." ${ }^{1.25}$ La cátedra de construcción estaba dirigida por el profesor Rudolf Świerczyński, y en ella se pretendía "objetividad en la búsqueda de la economía de material y mano de obra", ${ }^{1.26}$ y se prestaba especial atención a las "consecuencias de la utilización de nuevos materiales, la prefabricación de los edificios y el diseño de prototipos que permitiesen su construcción en serie". 1.25

Según recoge la investigadora Izabella Wisłocka ${ }^{1.26}$, Świerczyński centraba sus objetivos docentes en el "conocimiento de los conceptos modernos de vivienda", cuestión que era planteada académicamente como un asunto cuya "solución es urgente (..) de ella depende no solo el aspecto del país sino la salud espiritual y física de las generaciones futuras." 1.26

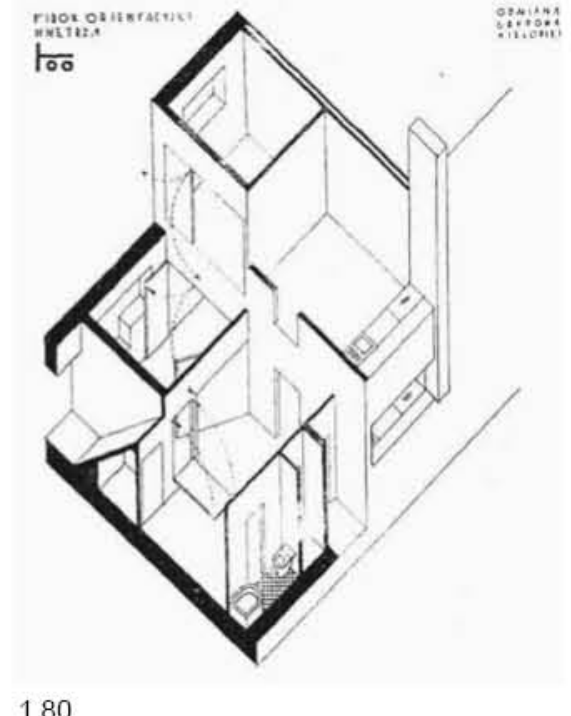

1.80

1.24 A partir del texto de Niezabietowski, el resumen de Lisowski es considerado basado en la generalización de afirmaciones no citadas de $\mathrm{S}$ Giedion y H. Sedlmayr.

1.25. Jur, 1977. p 12-16.

1.26. Wisłocka, 1968. p 168-169. 
1.81 - 1.85 Planos, imágenes y dibujos del Instituto arquitecto Edgar Norwerth.
Blewa cja zachodnio-południowa gmachu glównego C. I. W. F. 1, B00.
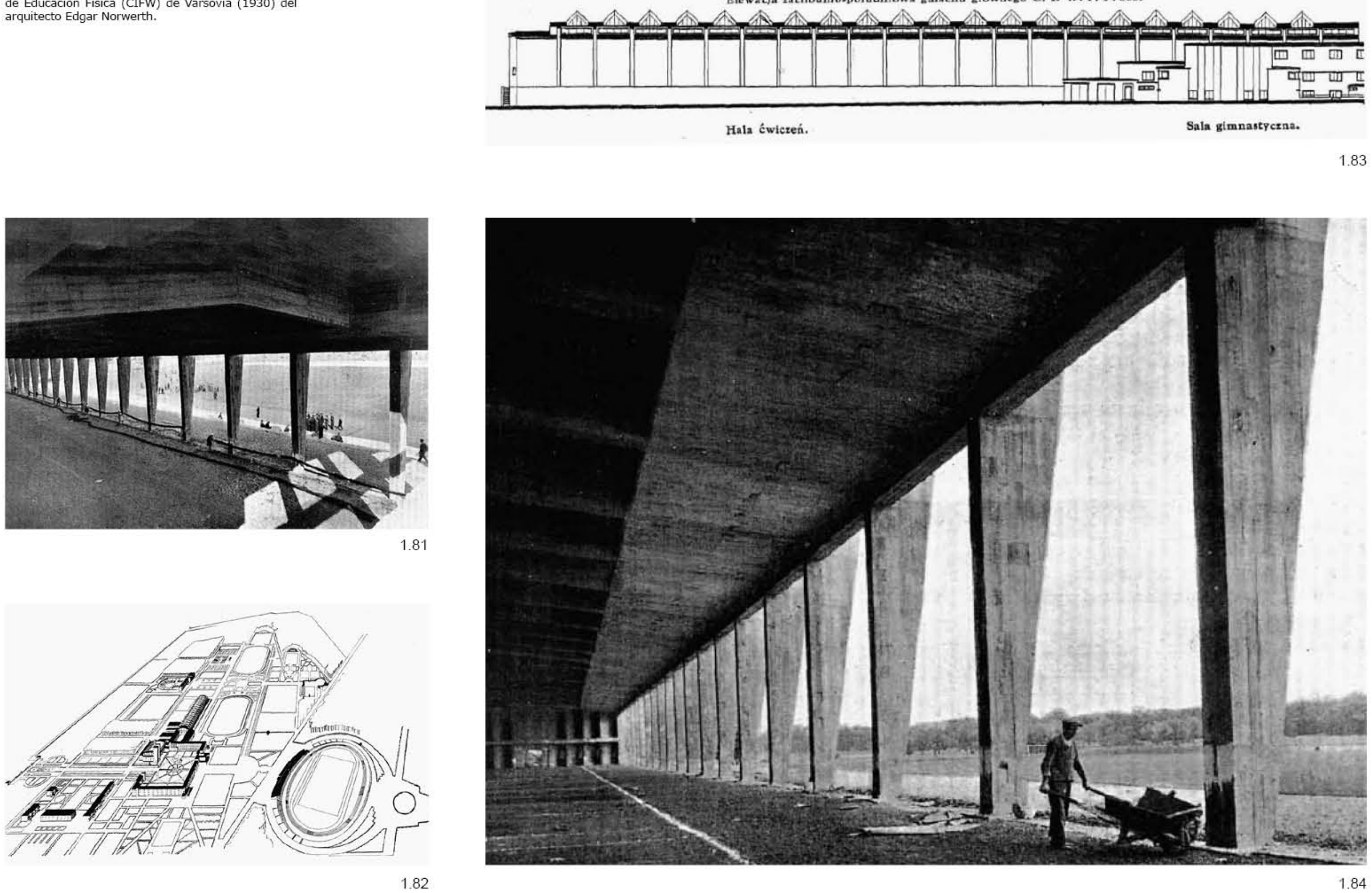


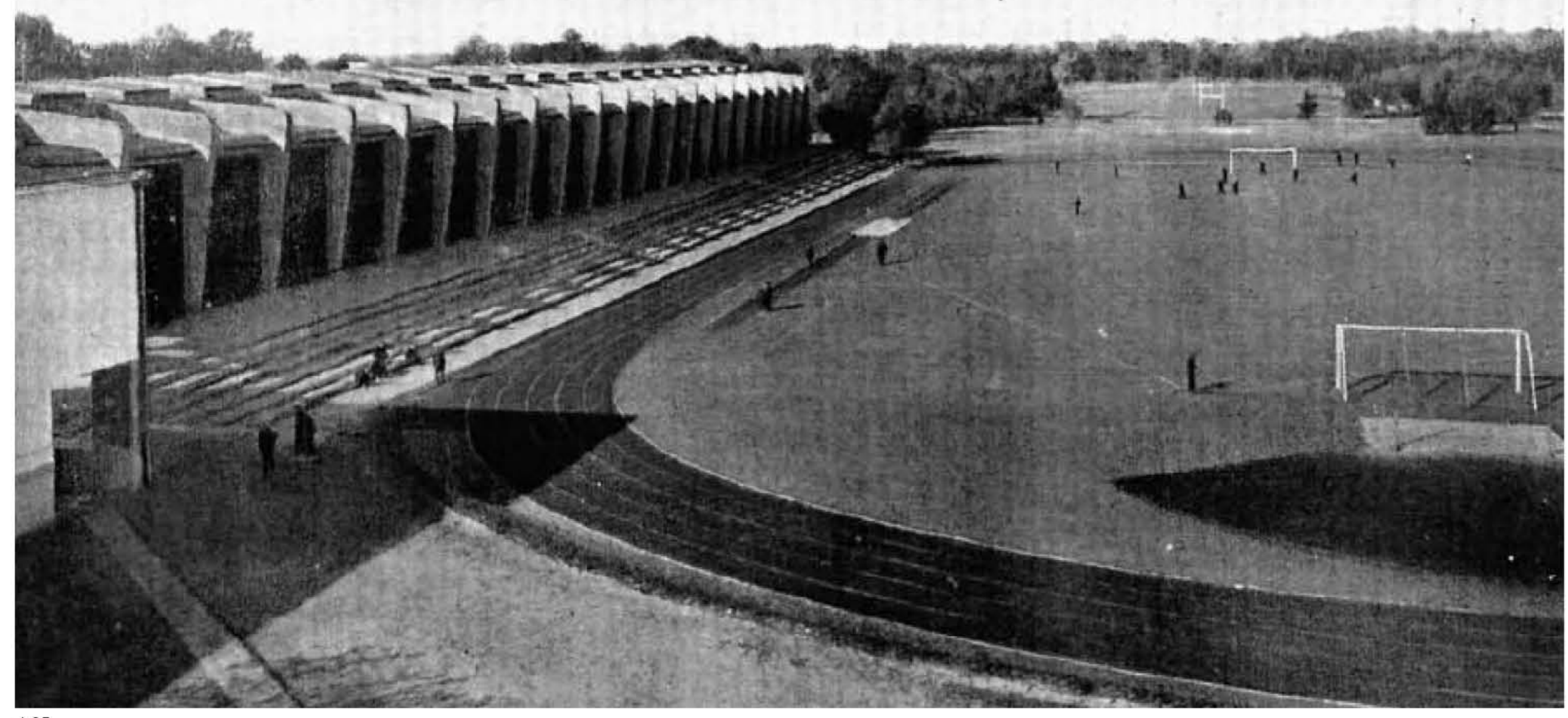


1.86 - 1.91 Pabellón de la compañia Bogusław
Herse en la feria nacional PWK Poznań (1929) del arquitecto Bohdan Pniewski.

1.92 - 1.94 Bocetos de Edgar Norwerth sobre la construccion del Insticuto de Educación Fisica
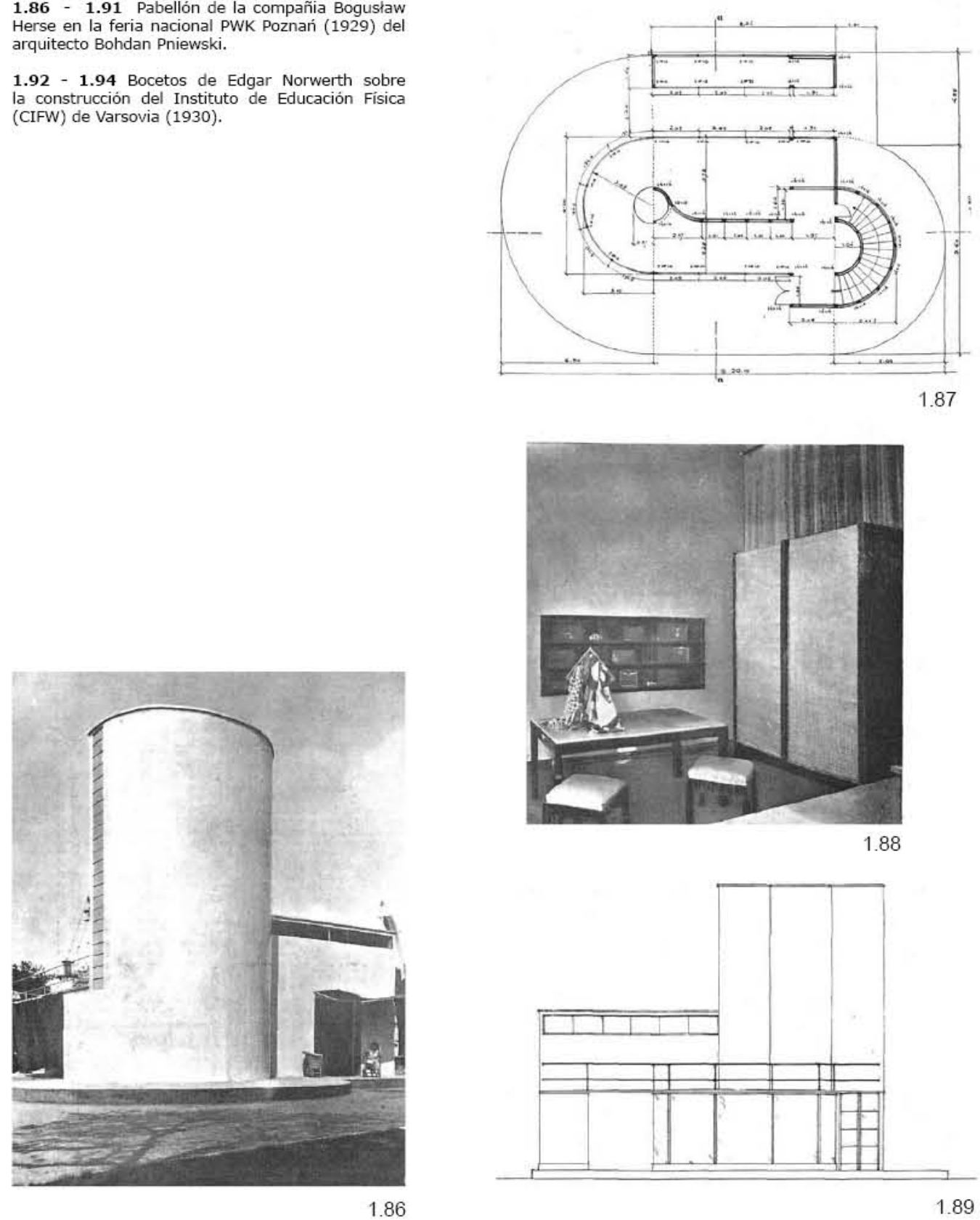
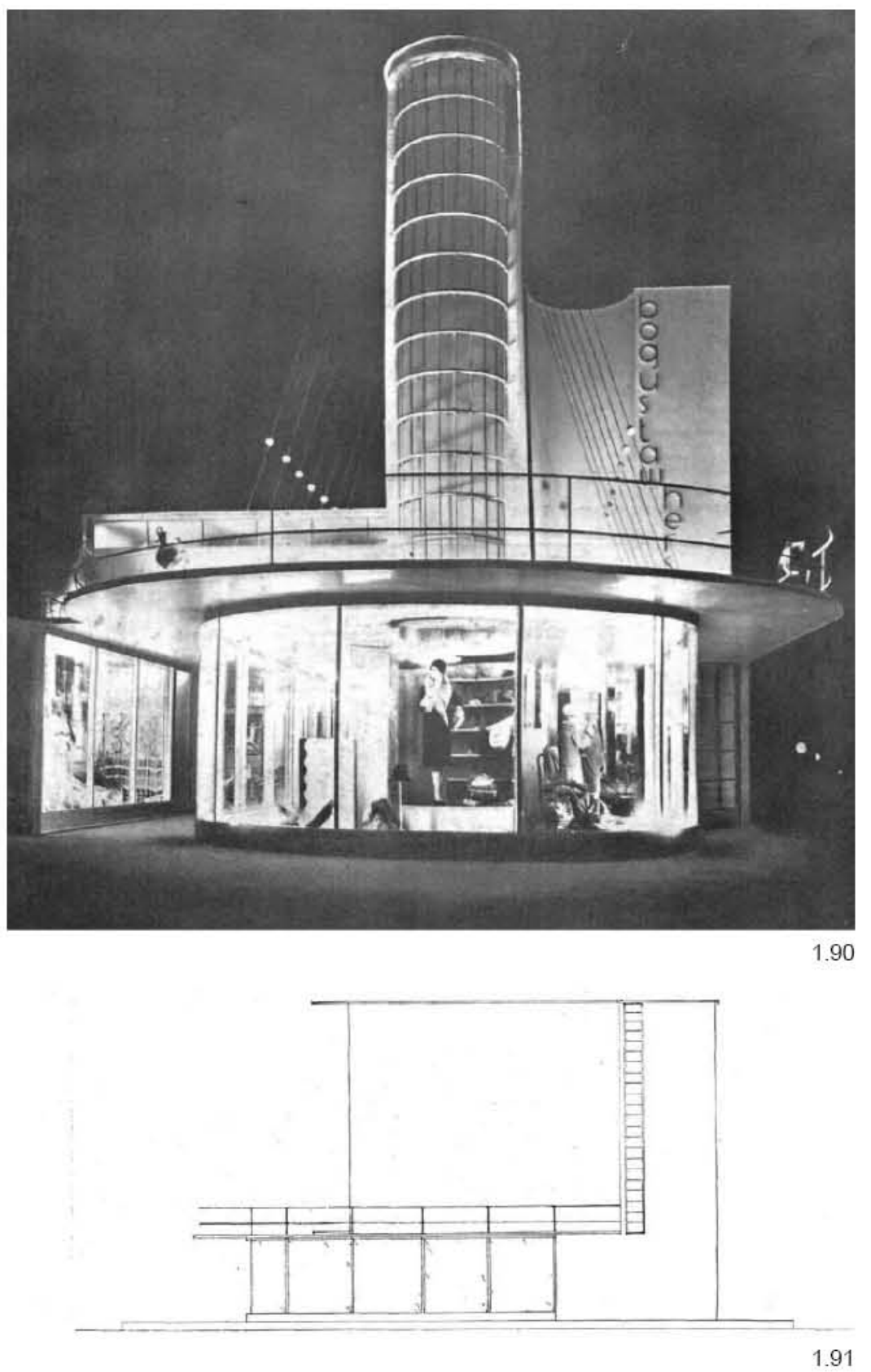
El profesor Stanislaw Noakowski era responsable de las clases de historia del arte y la arquitectura, y desde su taller se instruía a los alumnos en el aprendizaje de la arquitectura histórica, a través del dibujo detallado de las obras y la organización de viajes para visitar los edificios que habían sido estudiados en las clases teóricas. ${ }^{1.27}$

A partir de 1925, la Facultad de Arquitectura de Varsovia había experimentado significativos cambios en su plantilla de profesores, y había aproximado sus contenidos docentes al interés por la modernidad y las vanguardias arquitectónicas europeas, aunque manteniendo en el plan de estudios la importancia dada a las referencias históricas en las asignaturas artísticas. ${ }^{1.25}$ Estos cambios afectaron principalmente a las cátedras de proyectos e historia de la arquitectura -de la que, a partir de 1928, se hizo cargo el profesor Lech Niemojewski- modernizando el programa y acercándolo al estudio de proyectos que estaban siendo construidos en época reciente con nuevos materiales y renovada plasticidad. ${ }^{1.25}$

En el estudio que realiza Wisłocka ${ }^{1.26}$ sobre los objetivos docentes de la Facultad de Arquitectura de Varsovia en el periodo de entreguerras -y particularmente en los años en que Leykam comenzó sus estudios-, ya se apunta claramente a la existencia de una "prioridad por el aprendizaje de las soluciones adaptadas a los problemas sociales por encima de las cuestiones artísticas". 1.26

El profesor Stanisław Hempel, arquitecto e ingeniero, fue incorporado a la Facultad de Arquitectura en 1930, y también fue profesor de Leykam, introduciendo por su parte cambios en la docencia basados en la necesidad de que los arquitectos aprendiesen los "métodos de razonamiento para la resolución de problemas estructurales". Al mismo tiempo hubo una "reducción de temas históricos y artísticos en favor de aspectos técnicos y de diseño." ${ }^{1.26}$ La relación entre Hempel y Leykam continuará al finalizar la II Guerra Mundial, siendo colaboradores en la Exposición de Terrenos Recuperados de Wroclaw en 1948 (p. 215 y ss).

Uno de los arquitectos cuya obra resultó más influyente en la generación de estudiantes en la que se incluye Marek Leykam fue sin duda el profesor Edgar Norwerth. ${ }^{1.25}$ Nacido en Ginebra en 1884, Norwerth había recibido su formación en la escuela moscovita Vjutemas, y fue el creador de una interesante obra teórica y práctica, sirviéndose del conocimiento de las corrientes predominantes de la vanguardia del momento. El trabajo de Norwerth ofrece una interesante síntesis de los planteamientos docentes expuestos en este capítulo desde su particular interpretación de la problemática de la arquitectura moderna, basada en la necesidad de simplificar las obras haciendo referencia expresa a sus soluciones tectónicas. ${ }^{1.28}$

Desde este perspectiva, el Instituto de Educación Física (CIFW) de Varsovia (1.83-1.85) realizado por Norwerth en 1930, supuso un referente para jóvenes arquitectos que compartían aula en sus clases -como Zygmunt Stępiński, Jan Bogusławski, Stefan Kolendo, Marian Spychalski, Maciej Nowicki o el propio Marek Leykam- debido a la potente expresividad de su estructura vista, la importancia dada a la seriación de elementos y su persistente búsqueda de la proporción a través de la modulación y la simplicidad de los detalles constructivos.
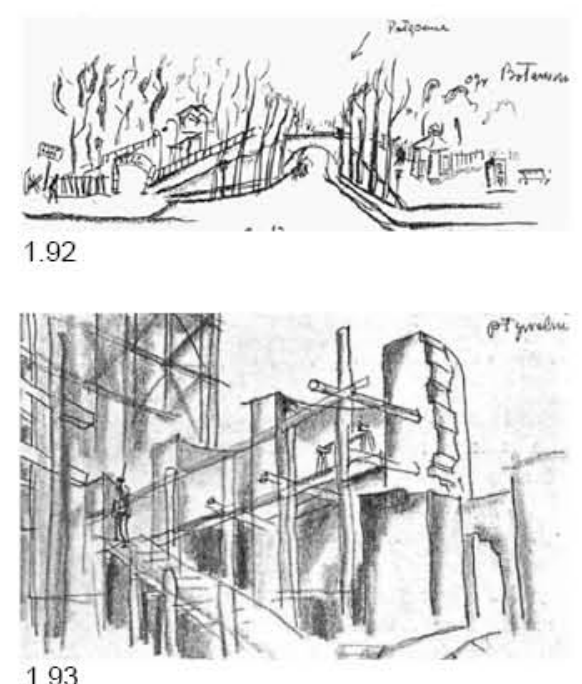

1.93

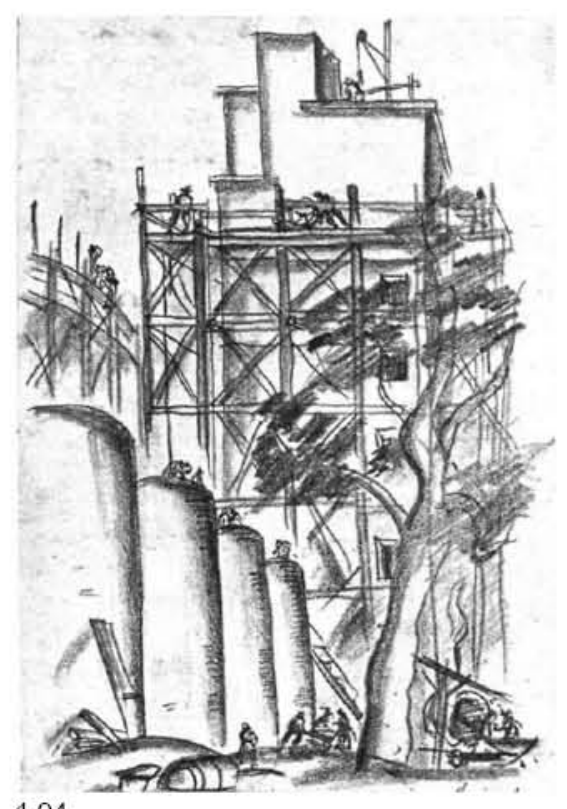

1.94

1.27. Miworski, 1966. p 52. Cit. Op. Cit 1.19 .

1.28. Łoza, 1954. 

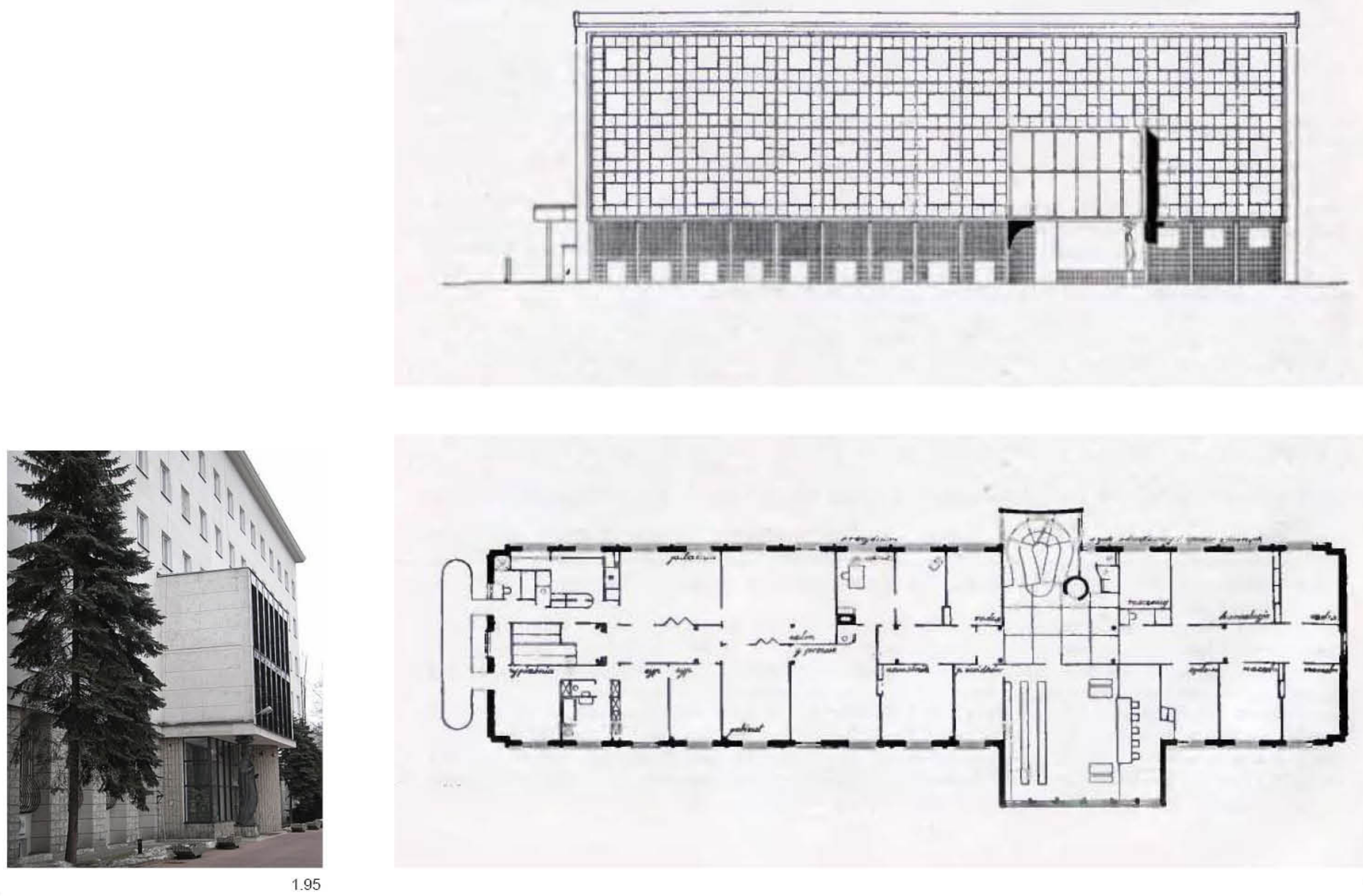
Sin embargo el profesor más reconocido y apreciado por los jóvenes estudiantes de la Facultad de Arquitectura de Varsovia a finales de los años 20 era Rudolf Świerczyński, tal como señala Wisłocka y como queda recogido en publicaciones de la época de sus propios alumnos. Świerczyński inculcaba a sus alumnos "el rigor del pensamiento lógico para la resolución de proyectos." 1.26

El propio Marek Leykam escribió un artículo en $1936^{1.29}$ en el que hablaba con admiración del trabajo de su profesor: "No me atrevo a analizar los pensamientos que dieron forma al diseño de la Oficina de Patentes (1.95-1.97) de mi adorado profesor Rudolf Świerczyński. No veo la necesidad de buscar la lógica razón de las líneas que forman la fachada, porque estoy arrebatado - igual que muchos de nosotros - por la plusvalía artística de profesor Świerczyński. Estoy feliz de tener la oportunidad de presentar planos del edificio, cuya construcción está a punto de comenzar. El proyecto del Prof. Świerczyński de la Oficina de Patentes, después de haber recibido el primer premio en un concurso ha sido desarrollado a nivel de proyecto para ser construido y se situará en la calle Rozbrat. Tiene en la planta baja un salón, una biblioteca, arriba una sala de conferencias, oficinas y vivienda." 1.29

Leykam presta atención en el artículo a las características constructivas de la obra: "La estructura está apoyada en hileras de pilares que en la planta baja soportan el peso de las fachadas de las plantas superiores mientras los cerramientos exteriores de planta baja están formados por ladrillos de vidrio. El núcleo de escaleras libremente arrojado fiera de la línea de la edificación se apoya en dos puntos en el plano curvado portante. Los tabiques se dibujan libremente en el plano. La fachada de piedra gana una imagen pronunciada gracias al dibujo de la piedra pulida. Un bloque simple de dos tramos, aislado por el cerramiento del núcleo de escaleras, se desplaza hacia el exterior proyectando el volumen de la sala de reuniones que queda apoyado sobre una escultura (1.95). Son los elementos más simples; de estos elementos, gracias a las proporciones y la elegancia, creó el profesor Świerczyński, un proyecto sobre el que solo puedo repetir que estoy feliz de contárselo a los lectores." 1.29

Como resumen de esta época, cabe recoger de nuevo el planteamiento de Niezabietowski, según el cual "la arquitectura vanguardista polaca del período entreguerras, y especialmente de los años treinta, llegó a un nivel comparable a los altos estándares predominantes en la arquitectura moderna tanto en la Europa Occidental como en la Oriental, ya que mantenía una relación notable con los conceptos innovadores forjados por ellos. Polonia, debido a su situación entre el Este y el Oeste, siempre había sido el crisol de Europa, donde se mezclaban varias ideas para producir nuevos valores. Lo que se aprendió de la experiencia de esa época ha sido bien utilizado para contribuir al desarrollo posterior." ${ }^{1.19}$

Leykam, al igual que otros arquitectos de su generación, comenzó desde este contexto educativo una búsqueda personal en la que el pensamiento lógico era el marco de trabajo desde el que explorar soluciones a los problemas de la arquitectura contemporánea, siendo heredero de una línea docente que consideraba estas soluciones, a su vez, inequívocamente vinculadas a la resolución de problemas sociales, y en la cual se planteaba la práctica de la arquitectura desde una perspectiva pretendidamente 'no utópica'. ${ }^{1.31}$ Estos planteamientos resultan fundamentales para entender el posterior trabajo de Leykam, y su preocupación por el contexto social en el que su obra se debía desarrollar.
1.29. Artículo titulado "Columna Arquitectonica" Revista Plastyka pp 295-296. (Leykam, 1936).

1.30. Todos los números publicados de las revistas Blok y Praesens han sido consultados directamente del original.

1.31. Ambos conceptos -la vinculación de la arquitectura a la solución de los problemas sociales, y la premisa de plantear una arquitectura 'no-utópica' - forman parte de forma explícita de los objetivos docentes de varias cátedras de proyectos y construcción de la Facultad de Arquitectura de Varsovia en las que estudió Leykam entre 1927 y 1933. Véase los programas oficiales de la Universidad Politécnica de Varsovia (1927-28 a 1932-33) ó Wisłocka, 1968, p 168-169. 
2.01 Grabado alegórico de la cabaña primitiva de

Vitruvio realizado por Charles-Dominique-Joseph

edición (1755) de "Essai sur l'architecture" de Marc-

Antoine Laugier: 
Finalizados los estudios de arquitectura, Marek Leykam no trató de formar parte de ningún grupo polaco de vanguardia y sus esfuerzos se centraron en el estudio de la historia de la arquitectura, tratando de elaborar a través de ella una interpretación contemporánea propia del hecho proyectual. En ese contexto cabe interpretar su primer proyecto, un sencillo prototipo de vivienda presentado al concurso organizado por el banco BGK ${ }^{2.01}$ en 1933.

La propuesta de Leykam contenía un carácter alejado de las formulaciones vanguardistas del momento, basando sus referencias en la interpretación gráfica del mito de la cabaña primitiva; que había tenido un momento significante en el grabado que había realizado Charles-Dominique-Joseph Eisen para el frontispicio de la segunda edición de "Essai sur l'architecture"en 1755, representado la descripción hecha en el ensayo por Marc-Antoine Laugier.

La propia descripción de Laugier contiene los principios que fueron sedimentando en Leykam una primera interpretación de la arquitectura que fue consolidándose posteriormente a lo largo de su vida profesional. En su texto original, señala:

"El hombre quiere hacerse un alojamiento que le cubra sin sepultarlo. Algunas ramas caídas en el bosque son los materiales propios para su designio. Escoge cuatro de las más fuertes y las alza perpendicularmente disponiéndolas en un cuadrado. Encima coloca otras cuatro de través, y sobre éstas coloca otras inclinadas que se unan en punta por dos lados. Esta especie de tejado está cubierto de hojas los bastante apretadas entre sí como para que ni el sol ni la lluvia puedan penetrar a través de él; y he ahí al hombre ya alojado. Es cierto que el frío y el calor le harán sentir su incomodidad en esta casa abierta por todas partes, pero entonces llenará los espacios comprendidos entre los pilares y se encontrará guarnecido. ${ }^{2.02}$ [...] es el tipo sobre el que se han elaborado todas las magnificencias de la arquitectura. Los defectos fundamentales se evitan y la auténtica perfección se consigue aproximándose a su sencillez de ejecución" ${ }^{203}$.

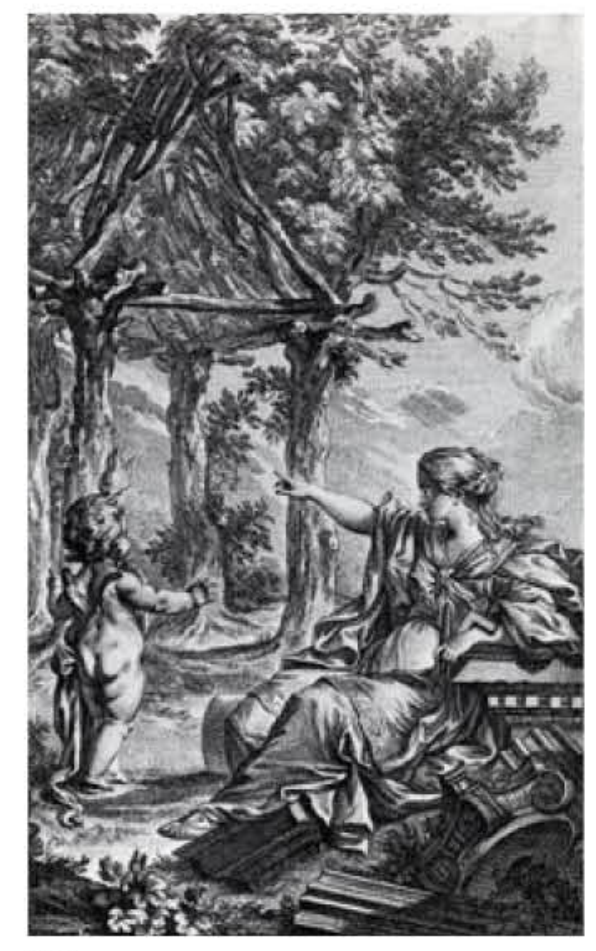

2.01

2.00. "La arquitectura es el arte de hacer cantar el punto de apoyo." Citado en Encyclopédie française'16, p. 12, de Gaston Berger - Publicado por So

2.01. Bank Gospodarstwa Krajowego.

2.02. Essai sur l'architecture, ed. cit., pp. 8-10. (Ref. Trad: Calatrava, 1991)

2.03. Essai sur l'architecture, ed. cit., pp. 8-10. (Ref. Trad Echaide, 1990). 
2.02 - 2.06 Proyecto de casa de madera presentado á concurso orga casa der BGK para 1933. Arquitecto: Marek Leykam

2.07 Gottfried Semper, ilustración de Der Still in 1863. La cabaña caribeña de la Gran Exposición de

1851

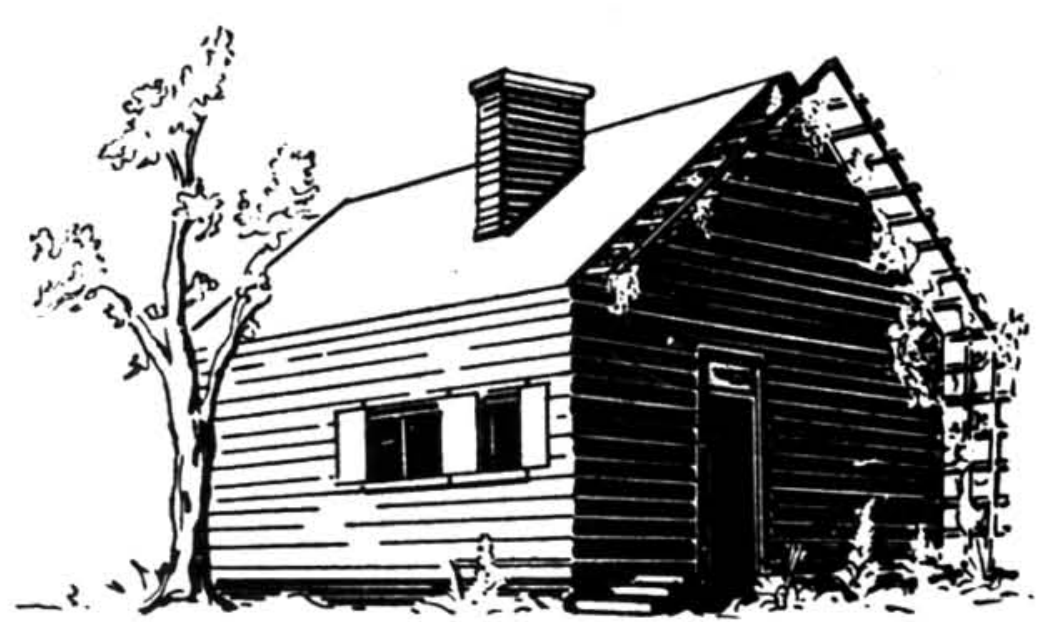

204

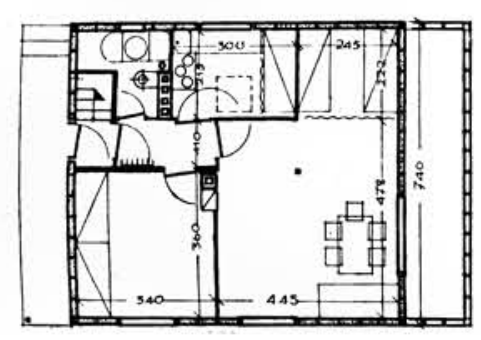

2.02

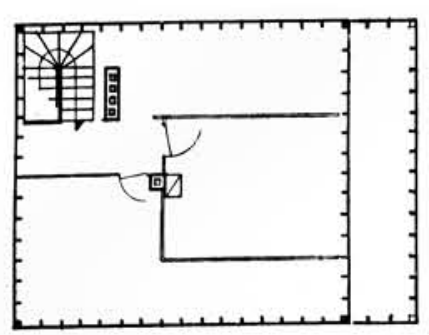

2.03
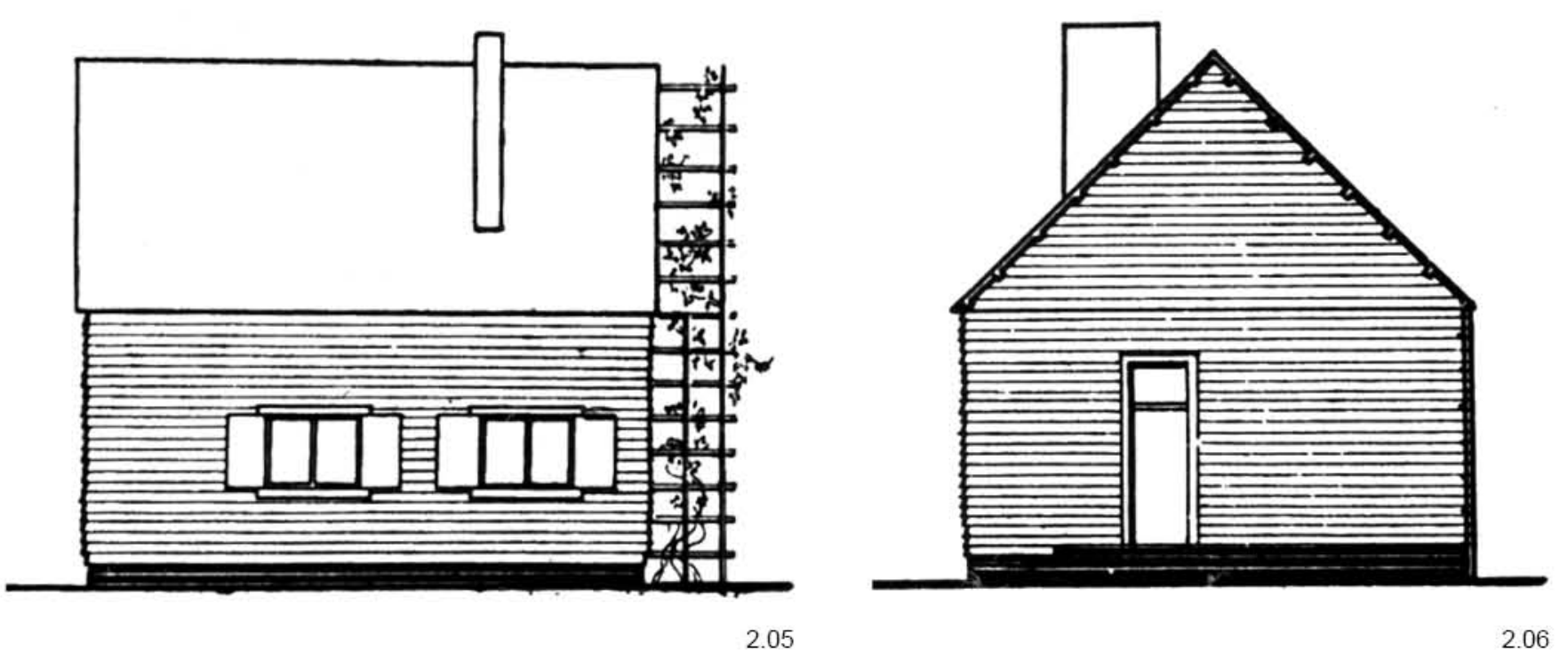
En 1850, Gottfried Semper había elaborado asimismo una interpretación de la primera cabaña basándose en el modelo de Cabaña caribeña que había podido conocer en su visita a la Exposición del Palacio de Cristal en $1851^{2.04}$. A través de este modelo, Semper centraba ya la atención en el "relleno del hueco y la importancia del muro de carpintería interno" ${ }^{2.04}$ Este proceso, era el que había permitido -según la interpretación de Semper ${ }^{2.04}$ - "adaptar la arquitectura a las diferentes condiciones ambientales y permitir el asentamiento del hombre, una evolución similar a la transformación de la cabaña tectónica en el megaron esterotómico griego rodeado de columnas". ${ }^{2.05}$

Leykam plantea en esta vivienda un basamento continuo en el que no queda exteriorizada la diferencia entre estructura y cerramiento, pero sí se presta atención a la relación interna entre estructura portante y piel exterior dentro del plano de fachada. Los elementos modulares portantes del cerramiento en el contorno exterior de la casa son objeto de un ritmo constante a lo largo de todo el volumen de la pieza, tanto en los paramentos laterales como en la cubierta. Esta formulación constructiva es expresada por Leykam en el exterior a través del pórtico de la fachada de acceso, cuyos elementos quedan al descubierto semienvueltos en una planta trepadora que traza una 'alegoría visual' con las ramas de árbol entrelazándose entre la estructura de la primera cabaña, según el grabado original que acompañaba el texto del abad Laugier en 1753, permitiendo que permanezca el despiece de los elementos tectónicos y destacando la importancia dada a la modulación.

La intersección de la cubierta y las fachadas de este prototipo se resuelven sin resaltar las intersecciones en las aristas, manifestando así la importancia del volumen como elemento continuo sin que exista predominancia de planos. Fachada y cubierta son indiferentes a nivel conceptual a pesar de la diferenciación a nivel de grafismo. La atención prestada al ritmo y la modulación de los elementos portantes de fachada y cubierta, tiene como objetivo la lógica constructiva del prototipo, de forma que pueda resolverse de manera sencilla su construcción y resulte barata su mecanización.

En 1934 Leykam recibió una beca de la Universidad Politécnica de Varsovia para realizar un año de prácticas en un prestigioso estudio de París, como premio al rendimiento académico que había tenido durante los 6 años de estudio. ${ }^{2.06}$ Existía en aquel momento en la Facultad de Arquitectura de Varsovia una gran gestión por parte de sus responsables del talento de los jóvenes estudiantes, y notables promesas de la arquitectura polaca como Maciej Nowicki ${ }^{2.07}$ y su futura esposa Stanisława Sandecka, pudieron hacer prácticas en la oficina de Le Corbusier, mientras que Marek Leykam fue incorporado al estudio de Auguste Perret ${ }^{2.06}$ en su recién inagurada sede de la Rue Raynouard 51-55. ${ }^{2.08}$

La influencia de la cultura francesa en Polonia durante el periodo de entreguerras, es algo que queda patente en la cantidad de publicaciones de la época de todos los ámbitos sociales que tienen a este país como referente cultural. Revistas polacas de arquitectura y diseño como Arkady, Plastyka, Architektura i Budownictwo, etc.., contienen multitud de referencias a los debates artísticos llevados a cabo en Francia, y en ese contexto, las colaboraciones docentes entre ambos paises durante el periodo de entreguerras fueron constantes, formando parte del contexto educativo en el que fue instruida la generación de jóvenes graduada en la década de los 30 en la Escuela de Arquitectura de Varsovia.
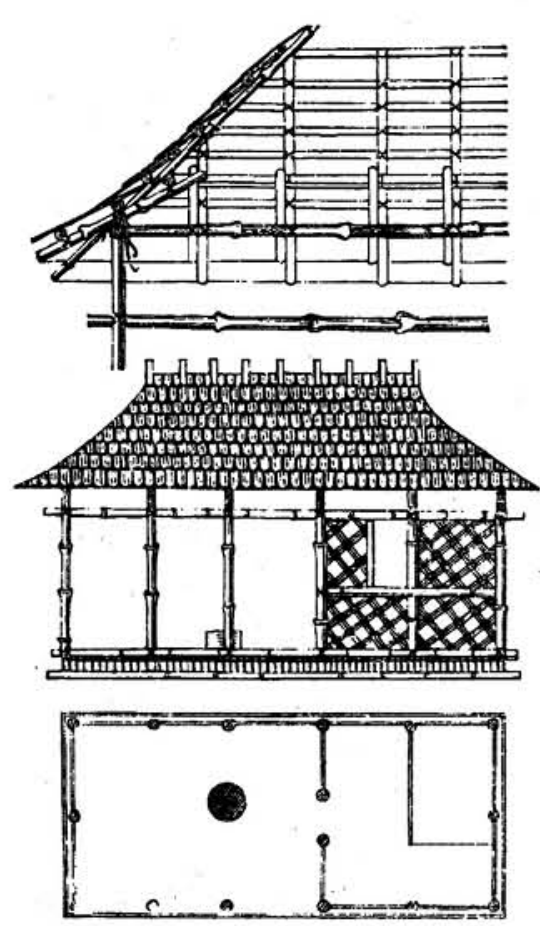

2.07

2.04. Frampton, 1995. p. 90.

2.05. Henry Francis Malgrave. "Gustav Klemm and Gottfried Semper" Res (1985), p 76. Cit. Op. Cit. 2.04. p. 90

2.06. Jur, 1997. p.15

2.07. Stiller, 2012.

2.08. El edificio que albergaria al sede de su estudio en el número 51-55 de la rue Raynouard se había inagurado en el año 1932 
2.08 - 2.09 Sistema constructivo de hormigón armado de .

2.10 Oskar Hansen en el estudio de Pierre Jeanneret de París a finales de los 40 .
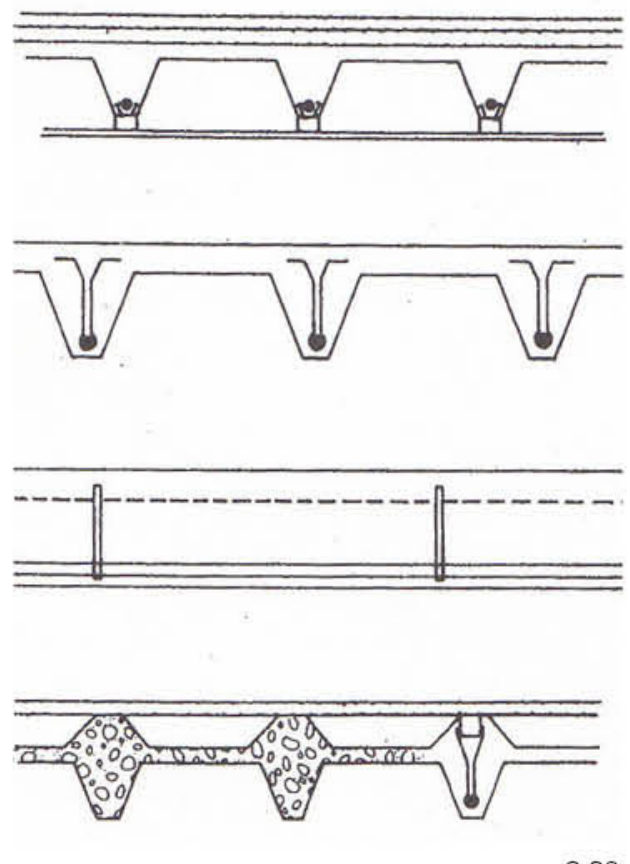
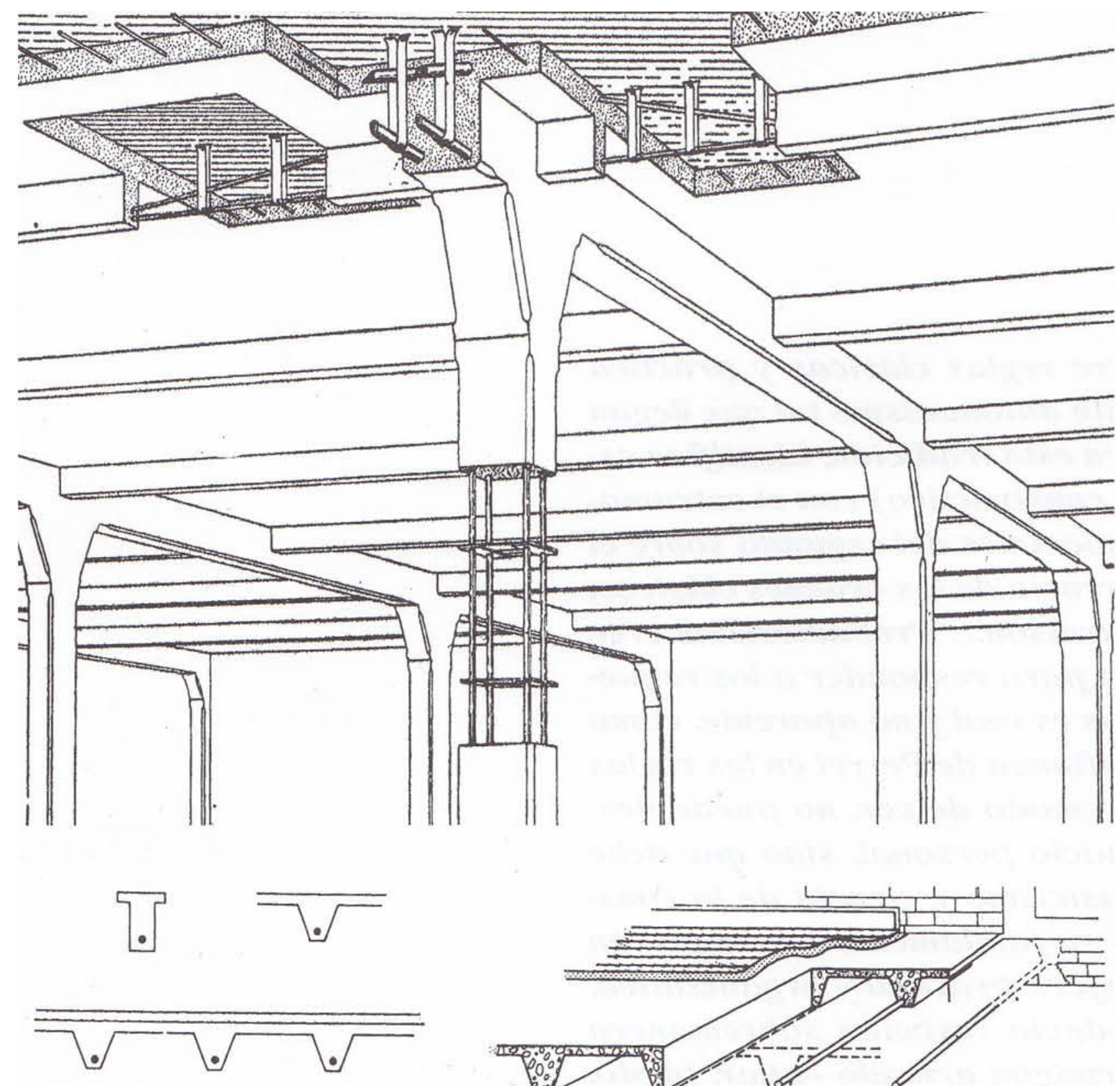

प5.

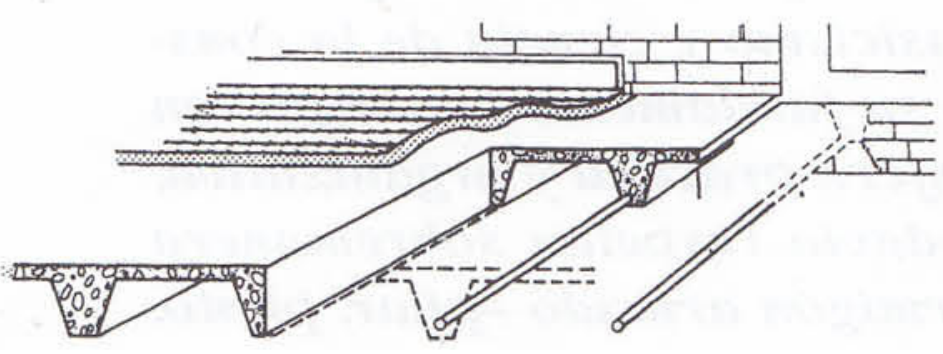


A través de este intercambio de estudios, Leykam pudo entrar en contacto con uno de los técnicos que mejor podía introducirle en la realidad práctica de una de las innovaciones tecnológicas que habían determinado la modernidad en la arquitectura ${ }^{2.09}$ : el hormigón armado, un compuesto elaborado con una mezcla de cemento hidráulico perfeccionado por Louis Vicat en $1800^{2.11}$, de alta resistencia a compresión; combinado con hierro, un material que comenzaba a estar disponible masivamente debido a su producción industrial ${ }^{2.09}$ y que era capaz de aportar al conjunto resistencia a tracción y flexión. ${ }^{2.10}$

Si bien las primeras pruebas de esta combinación habían sido patentadas por Joseph Monier en $1849^{2.12}$, la sistematización de su uso no llegó hasta que François Hennebique perfeccionó el sistema constructivo (2.08-2.09); planteando la utilización de bloques reforzados con barras de hierro longitudinales en su cara inferior para la resolución de forjados, muros y pilares en un sistema de $1897^{2.11}$. Sería precisamente la empresa de Auguste Perret la primera en utilizar este material en edificación ${ }^{2.13}$

La particularidad que hizo que Perret se convirtiese en pionero en este campo, vino dada por su condición de partícipe de la empresa de construcción familiar, algo que resultaría común en posteriores maestros de Leykam, quienes a pesar de su vinculación académica, tuvieron como parte fundamental de su aprendizaje la responsabilidad de dirigir su propia empresa de construcción, adquiriendo una visión sobre el oficio marcadamente práctica y funcional.

La innovación que suponía el hormigón armado no fue transmitida desde los círculos académicos hasta llegar a manos de Perret, sino que fue adquirida por la empresa de su familia por vía empresarial, ya que el autor de la patente del sistema constructivo -Hennebique-, la administraba bajo licencia solo a contratistas ${ }^{2.11}$. El certificado de "Contratista Hennebique" adquirió rápidamente gran prestigio en París, y, cuando la empresa de la familia Perret la adquirió, se hizo con la posibilidad de emplear un innovador sistema en sus obras que comenzaron a utilizar ya en el edificio de viviendas del $n^{\circ} 25$ bis de la rue Franklin en París (2.11) en 1902. ${ }^{2.11}$

Unos años antes, el joven Auguste Perret -que había participado con 15 años junto a su hermano Gustave y su padre en la construcción de algunos pabellones para la exposición Universal de París de 1889-, ${ }^{2.14}$ tuvo que interrumpir sus estudios en la École des Beaux-Arts de París antes de terminar la carrera de arquitectura, a pesar de la brillantez que indicaba su expediente académico ${ }^{2.15}$ y la tutela docente que estaba recibiendo de manos del profesor Julien Gaudet, debido a las necesidades de la empresa constructora de su familia, que había empezado a tener una gran expansión incluyendo encargos fuera del país. ${ }^{2.11}$

El fallecimiento del patriarca de los Perret, Claude-Marie Perret, en 1905, obligó a los hermanos a hacerse cargo de la empresa familiar creando la empresa "Perret Frères, entreprise générale de travaux publics et particuliers, béton armê" 2.102 .18 , que en 1907 se convertiría en "Perret Frères, architectes, constructeurs, béton armé". 2.10 2.19

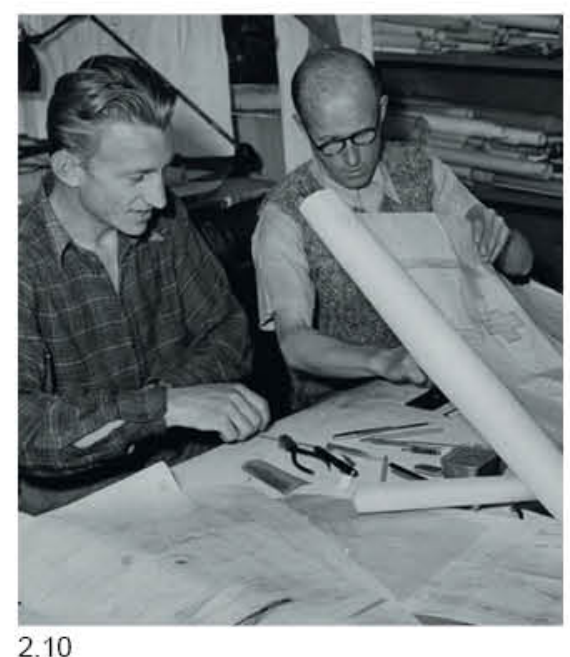

2.10

2.09. Solà-Morales, 2011. p. 48

2.10. Paricio, 1994. (Cit. Op. Cit 2.09.)

2.11. Frampton, 1995, p. 123-155.

2.12. Shaeffer, 1992.

2.13. CEAC 1982. p 179

2.14. González Cárdenas, 2005. p. 118

2.15. Entre los años 1894 y 1895 recibió varios premios en reconocimiento a sus proyectos de clase. Op. Cit. (2.07)

2.16. Hitchcock, 1998. p 450

2.17. Benévolo, 2002. p 349-360

2.18. Según Op. Cit. 2.15 la empresa era: $A \& G$ Perret Architectes.

2.19. Según Op. Cit. 2.15 la empresa era: Perret Frères Entrepeneurs. 
211 Edificio de apartamentos en el $n^{0} 25$ bis de la Franklin, Paris 1902. Auguste Perret.

2.12 Interior de Le Palais du Bois de Porte Maillot, 1924. Auguste Perret.

2.13 Auguste Perret en su estudio. Sobre el fondo los dibujos del Teatro de la Exposición y Notre Dame du Raincy, 1925.
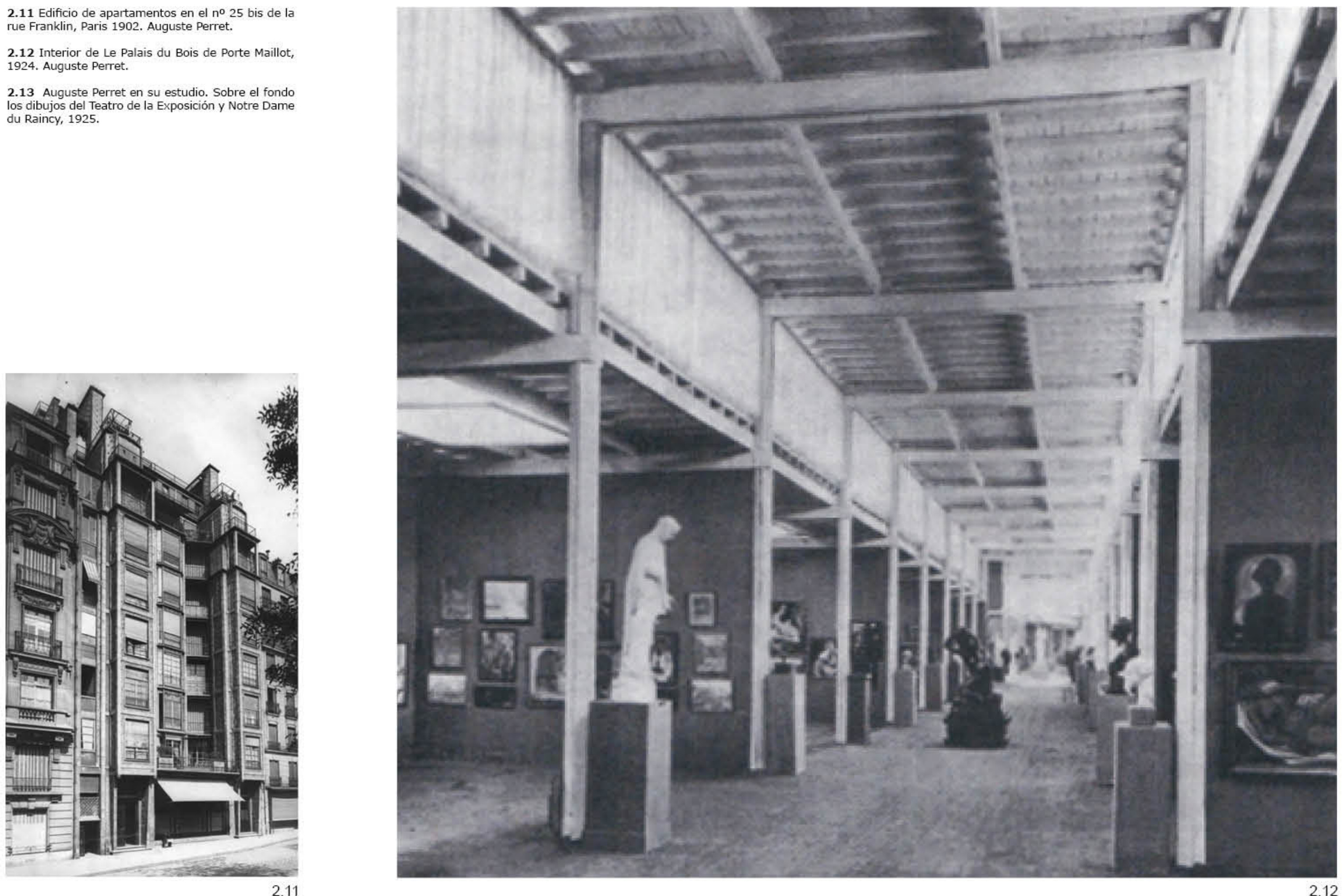
Cuando Leykam entró a trabajar al estudio de Perret en 1935, Auguste se encontraba en un momento de retorno a la vida académica y docente, después de haber estado más de 20 años construyendo con hormigón armado y se encontraba muy involucrado en la tarea educativa realizada en su taller, dependiente de la École des Beaux-Arts, con el objetivo de enseñar a los jóvenes arquitectos el uso del hormigón armado. ${ }^{2.11}$

Como señala H.R.Hitchcock " a principios de los años 20 cuando una generación más joven de arquitectos de toda Europa se dedicaba a estudiar el hormigón armado como el más moderno material de construcción, Perret era el arquitecto que más podía ofrecerles." ${ }^{2.16}$

La estimulante experiencia de un experto constructor que tras una prolongada actividad empresarial se dedicaba a la docencia, resultaría extremadamente instructiva para el joven Leykam, que comenzó a forjar junto a él una interpretación de la profesión basada en un desarrollo fundamentado en la lógica constructiva de este material, dando prioridad a los principios de técnica que permitan abordar las necesidades de la obra, anticipándose desde el orden tectónico a sus particularidades para ofrecer una solución eficaz y precisa, que alcanzase la expresividad a través de la perfección en su ejecución.

Benévolo contextualiza a Perret como el "heredero de Durand, Labrouste, Dutert, Eiffel" 2.17, realizando una definición de su trabajo en la que se traslucen los principios que sirvieron de referencia a Leykam para estructurar su interpretación de la arquitectura a partir del interés que ya había mostrado por la arquitectura clásica desde su época de estudiante: "Perret,.. identificó espontáneamente el entramado de hormigón (que es un hecho constructivo) con el entramado volumétrico y transpone las exigencias y asociaciones espaciales del segundo sobre el primero. De aquí la exigencia de simetría y la continua sugerencia de los órdenes clásicos, si no como presencias formales, sí como términos de comparación." 2.17

La influencia de las obras de Perret en la arquitectura posterior de Marek Leykam da fe de la importancia que el joven polaco otorgó a su trabajo. Las soluciones que pudo estudiar a nivel de detalle en varias de sus obras, como el Garage Marboeuf en la 51 de rue Ponthieu, 1905 (2.14-2.15); el Palais du Bois en Porte Maillot, 1924 (2.12); o las Iglesias de Notre-Dame du Raincy, 1922-25 (2.16-2.20) y Santa Teresa de Montmagny (2.21) de 1926 resulta hoy fundamental para comprender su trabajo posterior, por lo que haremos una breve reseña sobre ellas.

El Garage Marboeuf en el número 51 de la rue Ponthieu, París, 1905 (2.14-2.15), fue el primer edificio de la historia en mostrar plenamente una estructura de hormigón con vigas y pilares vistos, tanto en el interior como en el plano de fachada ${ }^{2.10}$, en el cual se rellenaban huecos con paños acristalados. Si bien en el alzado se manifestaba al exterior un entramado estructural -tal como observa Kenneth Frampton 2.11-, esta solución fue "manipulada tectónicamente" para expresar este 'efecto' con una finalidad estética; ya que no existe correspondencia entre las ménsulas y capiteles del interior de la nave y la trabazón exterior ortogonal de las vigas y pilares en el plano de fachada. ${ }^{2.11}$

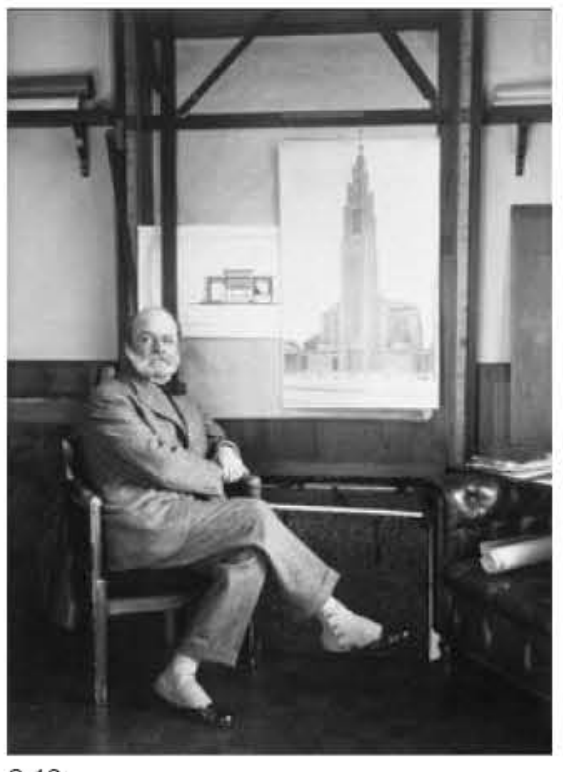

2.13

2.20. Quintans, 2012 

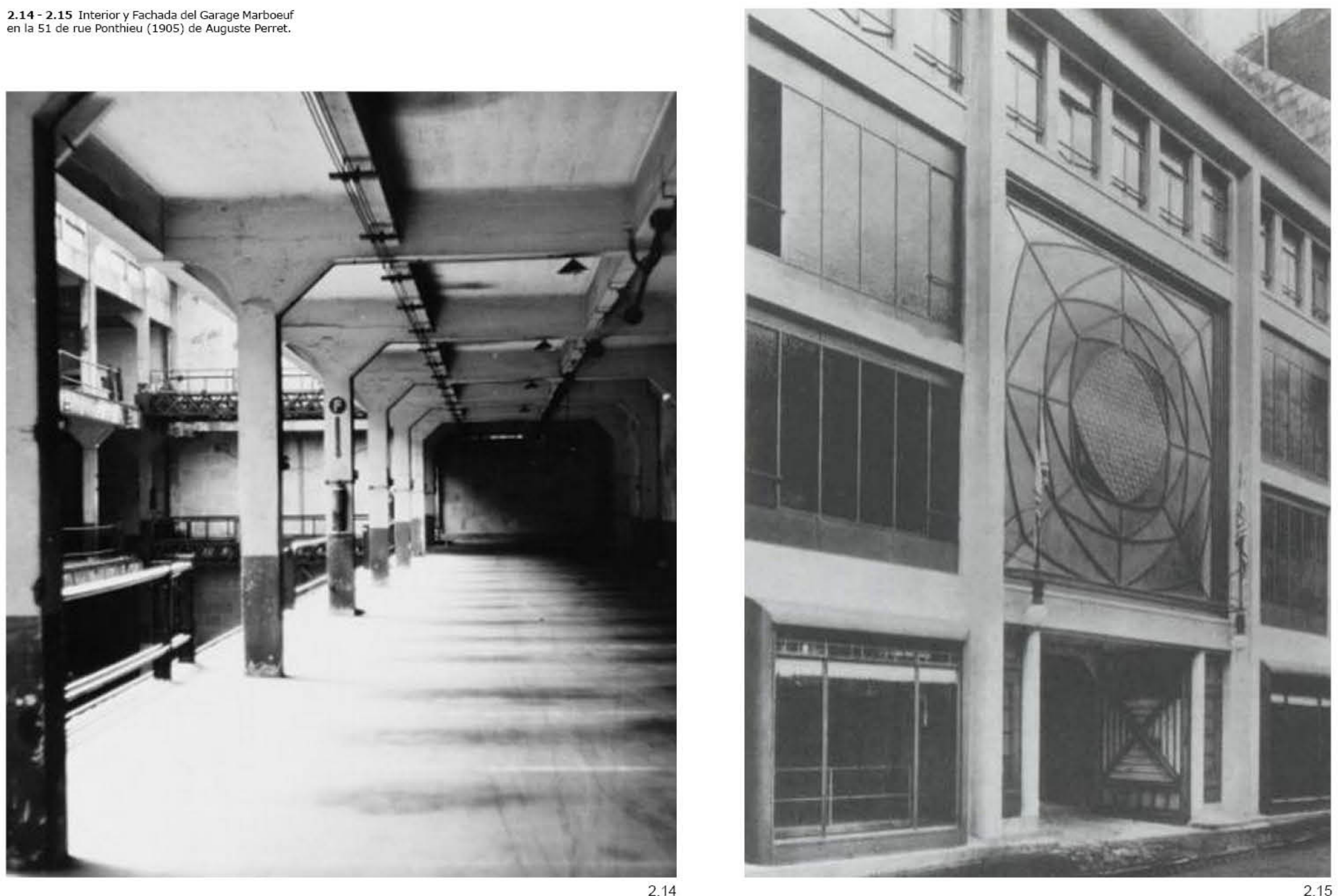
Compositivamente "Ios marcos corredizos de las ventanas industriales de cristal oscuro expresan la naturaleza utilitaria de las galerías situadas a ambos lados de la nave central, mientras que la ventana rosetón, fijada con barras vidriadas casi de la misma sección, representan el espacio honorífico de la presencia pública, es decir, la abertura a través de la cual aparecen peatones y automóviles" 2.11 .

La manifestación en fachada de las diferencias espaciales del interior del edificio no se traslucen en la posterior arquitectura de Leykam, pero sí podemos establecer un paralelismo entre la interpretación canónica que hace Perret de la importancia de la expresión compositiva de la estructura en fachada -según las leyes que formularía en sus proyectosy la obra posterior de su joven aprendiz polaco.

El propio Perret afirmó: "Las condiciones que impone la naturaleza son permanentes, las que impone el hombre pasajeras. El clima con sus rigores, los materiales con sus propiedades, la estática con sus leyes, la óptica con sus deformaciones, el sentido universal de las líneas y de las formas, imponen condiciones que son permanentes... Los grandes edificios de muestra época tienen un esqueleto, una estructura de acero o de hormigón armado. La estructura es al edificio como el esqueleto al animal; como el esqueleto del animal, rítmico, equilibrado, simétrico, contiene y sostiene los órganos más variados y más diversamente situados, de la misma forma se debe componer la estructura de un edificio, rítmica, equilibrada y también simétrica" ${ }^{2.21}$, una lectura que -como veremos en capítulos posteriores-, perfectamente podría haber sido suscrita por Leykam.

Tal como señala Frampton, Perret había creído encontrar en el hormigón armado un "sistema homogéneo perfecto con el que reconciliar el cisma de doscientos años de antigüedad que yacía en el mismo corazón del ideal greco-gótico,... combinar las asperezas de la forma platónica con la expresividad tectónica del racionalismo estructural " 2.11. Como consecuencia de su formación académica en la École des Beaux-Arts, en la cual "imperaba el clasicismo entendido como la repetición y el aprendizaje de la arquitectura a partir de la teoría de los estilos y los tratados hechos desde el renacimiento" 2.12 , Perret había establecido en sus composiciones un "paralelismo entre las reglas clásicas y la técnica constructiva" ${ }^{2.17}$, un criterio que también adoptó claramente Leykam, como se podrá comprobar en el análisis de su obra construida posterior a la II Guerra Mundial (véase p. 189 y ss.).

En la Iglesia de Notre-Dame du Raincy (2.15-2.18), realizada entre 1922-25 en memoria a los caídos en la batalla del Ourcq durante la Primera Guerra Mundial ${ }^{2.11}$, Perret alcanzó -en opinión de Bruno Zevi 2.22 - "la más pura formulación de su estilo en hormigón armado, casi veinte años después de que apareciera por primera vez en la Rue Franklin". ${ }^{2.22} \mathrm{Su}$ estructura comprendía una red de 28 columnas de hormigón, cilíndricas y exentas, dentro de una envoltura hermética no portante. ${ }^{2.11}$ Las columnas en cuestión, de 37 pies de altura cada una de ellas y con un espaciado longitudinal de 33 pies, eran de forma afilada, con una base de 17 pulgadas que disminuía hasta las 14 pulgadas de diámetro de la parte superior, y en ellas destaca la presencia de hormigón visto sin revestimiento. ${ }^{2.11}$
2.21. A. Perret, Contribution à une théorie de l'architecture, Paris, 1952, trad. it. de E.N. Rogers Op. Cit. Op 2.17.

2.22. Zevi, 1980. p 109 
2.16 - 2.18 Secciones e imágen interior de la

Iglesia de Notre-Dame Le Raincy, 1922-25. Auguste
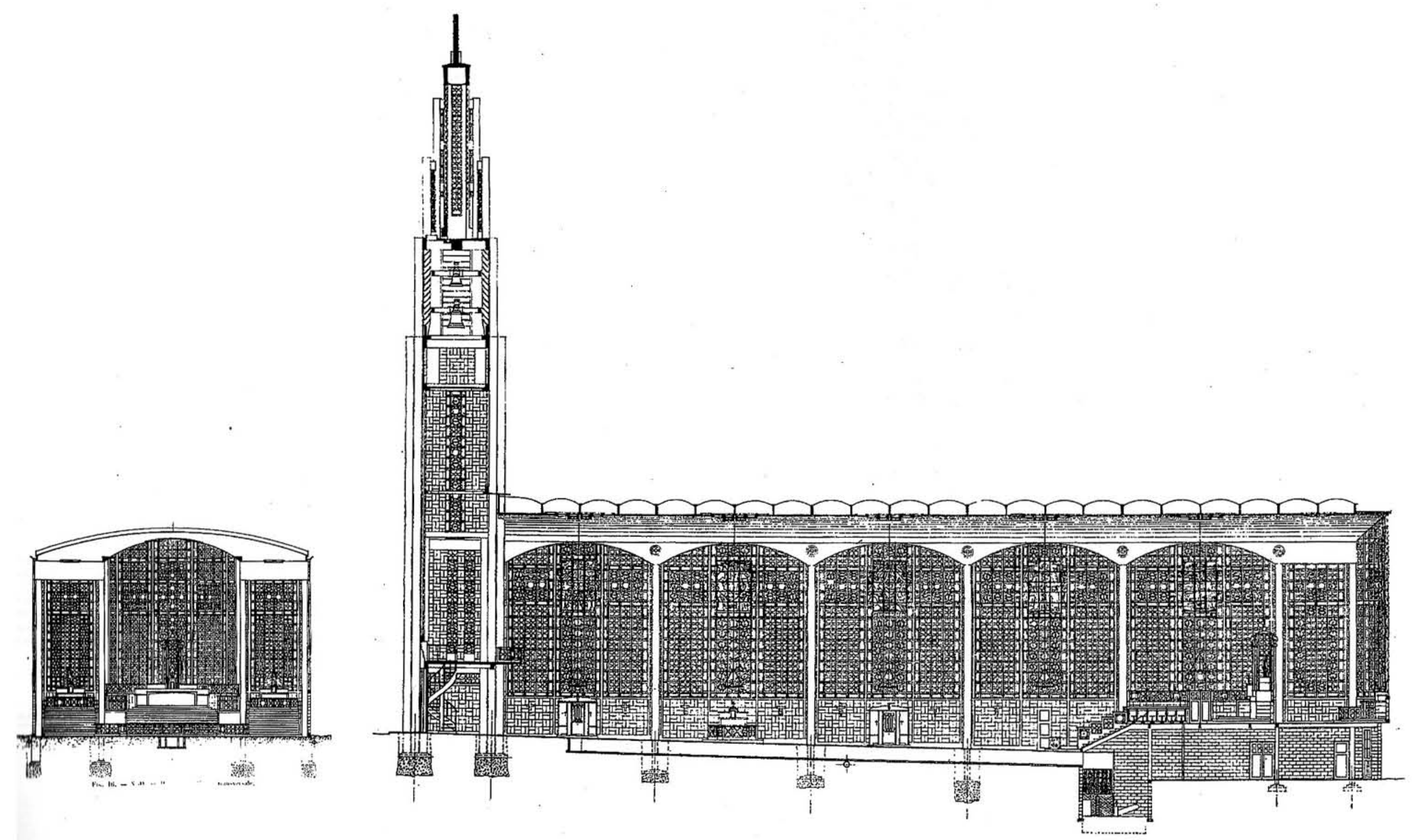


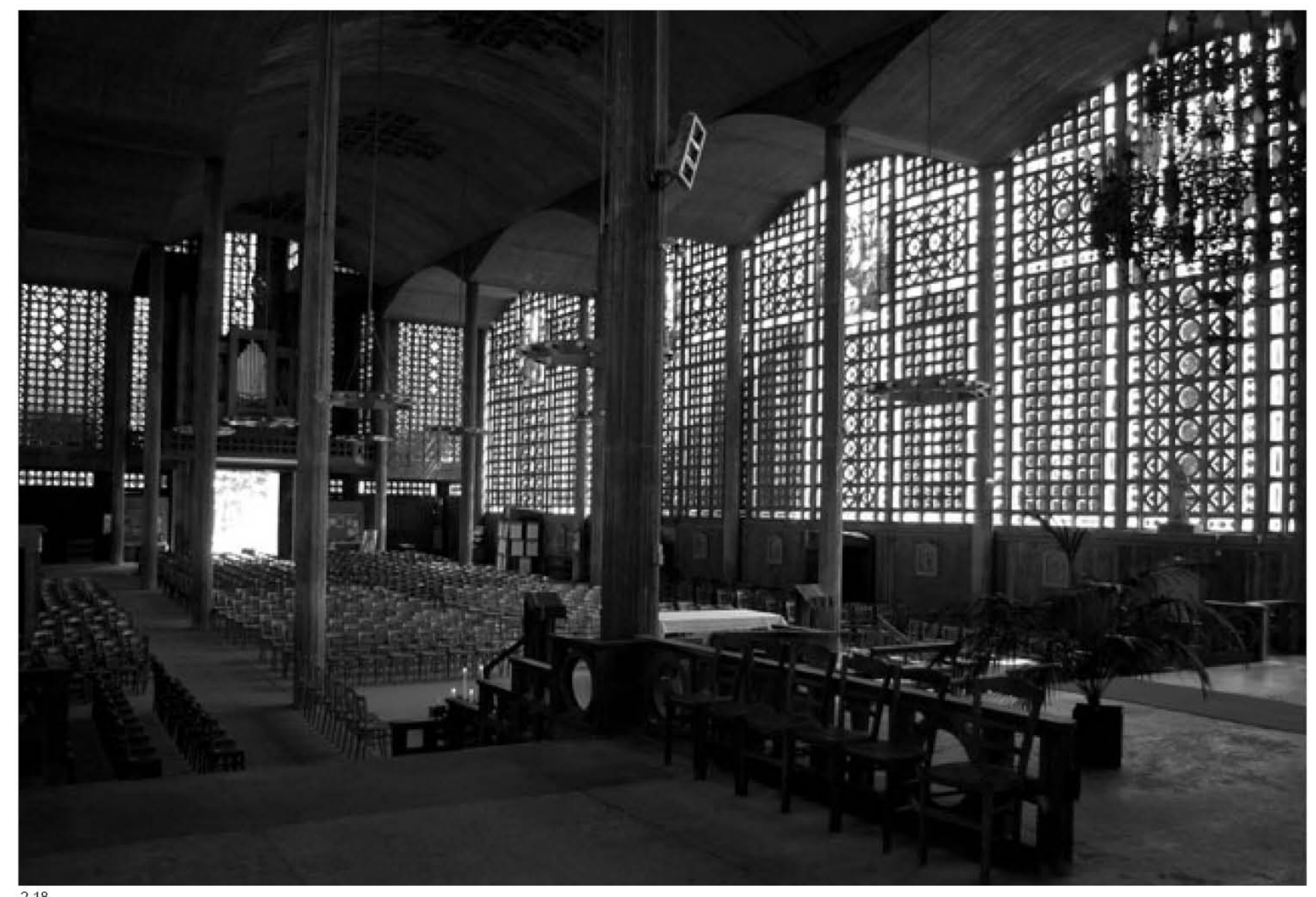


2.19 - 2.20 Planta e imagen interior de la Iglesia de Notre-Dame Le Raincy, 1922-25. Auguste Perret. 2.21 Imagen exterior de la Iglesia de Santa Teresa en Montmagny, 1926. Auguste Perret.

2.22 Detalle de los claustra en la Catedral de Orán, 1902-1908. Auguste Perret y Albert Ballu.

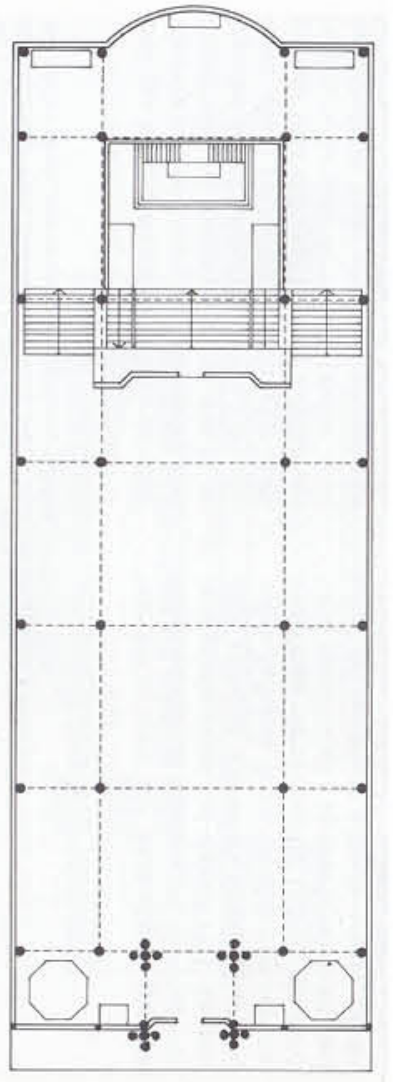

2.19
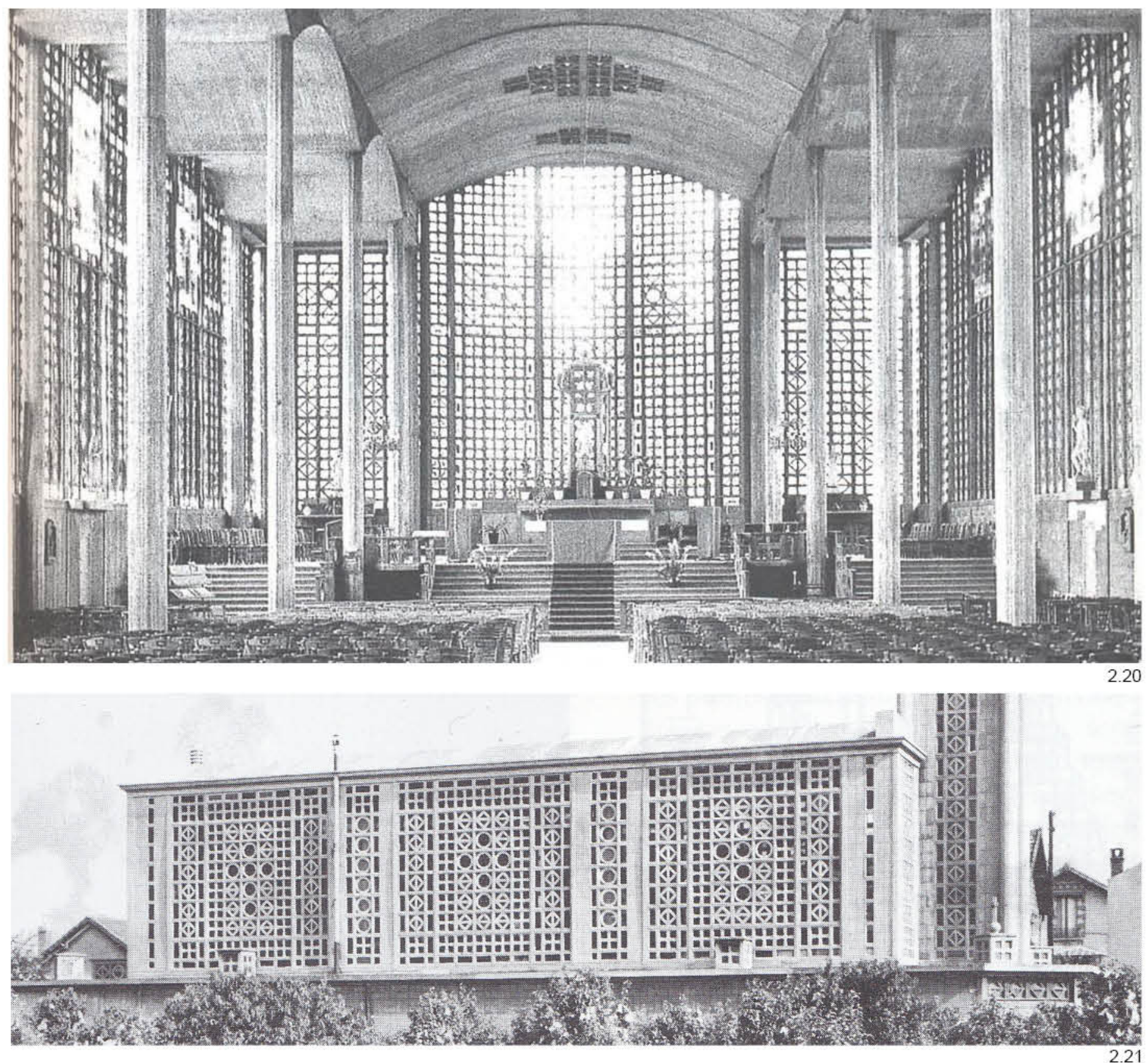
En una carta a "The American Architect" en 1924, Perret escribió: "Lo normal es que el grupo exterior de columnas estuviera empotrado en los muros de cerramiento, distinguiéndose cada una de ellas por una leve proyección. En este edificio hemos aislado completamente las columnas del muro, permitiendo que los muros transcurran libremente fiera de ellas. Al diseñar todas las columnas exentas se forman cuatro hileras de columnas en vez de las dos habituales. El mayor número de columnas en el campo de visión tiende a incrementar enormemente el tamaño aparente de la iglesia, produciendo una sensación de espacialidad y grandiosidad. El tamaño menor de las columnas, su mayor altura y la falta de detalles que pudieran distraernos ayudan materialmente a producir este efecto". ${ }^{2.11}$

De nuevo, Perret trata de canalizar a través de la estructura la expresividad del edificio, siendo plenamente consciente de los efectos que una mayor o menor cantidad de columnas repetidas crean en la percepción y en la 'sensación de espacialidad' del espectador. Destaca a su vez en este proyecto la "instrumentalización arquitectónica de la luz" 2.11 algo que planteará también en similares términos Leykam en sus tres proyectos religiosos (véase p.72, p.108 y p.134).

Como señala Zevi, "la voluntad de establecer una simbiosis entre lugar religioso y mundo que lo rodea arremete contra la cerrazón de caja, pespunteando y filtrando las paredes, negándolas para exaltar el esqueleto". ${ }^{2.23}$ El perímetro de la iglesia está formado por un muro de 183 pies de extensión, ensamblado con paneles prefabricados de dos pies cuadrados albergando cada uno de ellos aberturas rectangulares, triangulares o circulares rellenas de cristal coloreado o transparente, dispuestas en forma de retículas geométricas simétricas, de tal modo que producían un amplio patrón cruciforme en el centro de cada intercolumnio. ${ }^{2.11}$

Este relleno, obra del artista simbolista Maurice Denis ${ }^{2.11}$, iba siendo alternado cromáticamente en cada intercolumnio según el espectro natural, consiguiendo así una "articulación rítmica del muro cortina mediante el tratamiento de este como una construcción en relieve, donde algunos nervios horizontales y verticales están más pronunciados que otros debido a las uniones de los claustra ${ }^{2.24}(2.22) .{ }^{2.11}$

La importancia que otorgó Perret a los elementos prefabricados de hormigón armado en la composición de las fachadas de las iglesias de Notre-Dame du Raincy y Santa Teresa de Montmagny resultó enormemente influyente para Leykam tras su vuelta a Polonia en 1935.

Tras organizar ese mismo año, junto con el profesor Mieczysław Kotarbiński de la Academia de Bellas Artes de Varsovia, un concurso (2.29) para la ordenación paisajística de Zułów ${ }^{2.24}$, Leykam se presentó a dos concursos en 1936 en los que quedaría, en ambos, en segunda posición: la solución del Muelle y propuesta para el Centro de Vela en Gdynia (2.34-2.37) al que concurrió junto a Marian Spychalski, y el concurso para la construcción de la Mezquita de Varsovia (2.23-2.28), en el cual quedó por detrás de su compañero Stanisław Kolendo ${ }^{2.25} \mathrm{y}$ por delante de Maciej Nowicki y Stanisława Sandecka.

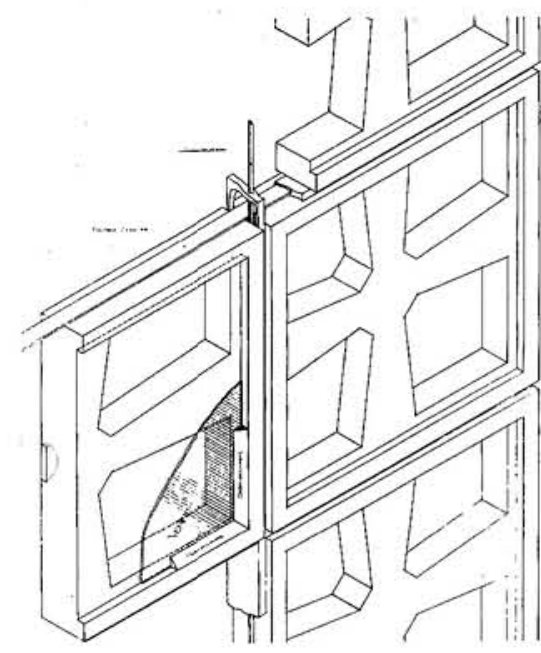

2.22

2.23. Ibid., p 80

2.24. Paneles de hormigón prefabricado con diferentes aberturas. (Op. Cit. 2.10.) 
2.23 - 2.28 Concurso para la Mezquita de Varsovia 1936. Arquitecto: Marek Leykam. $2^{\circ}$ Premio.

2.23 Vista interior del proyecto.

2.25 Alzado desde la calle Zimorowicz.

2.27 Axonometrí.

2.28 Plano de situación.

2.29 Organización del concurso para la ordenación profesor Mieczystaw Kotarbirisk. Leykam junto a 2.30 Imagen del $1^{\text {er }}$ Premio del concurso para la
Mezquita de Varsovia, 1936. Arquitecto: Stanisław Kolendo.

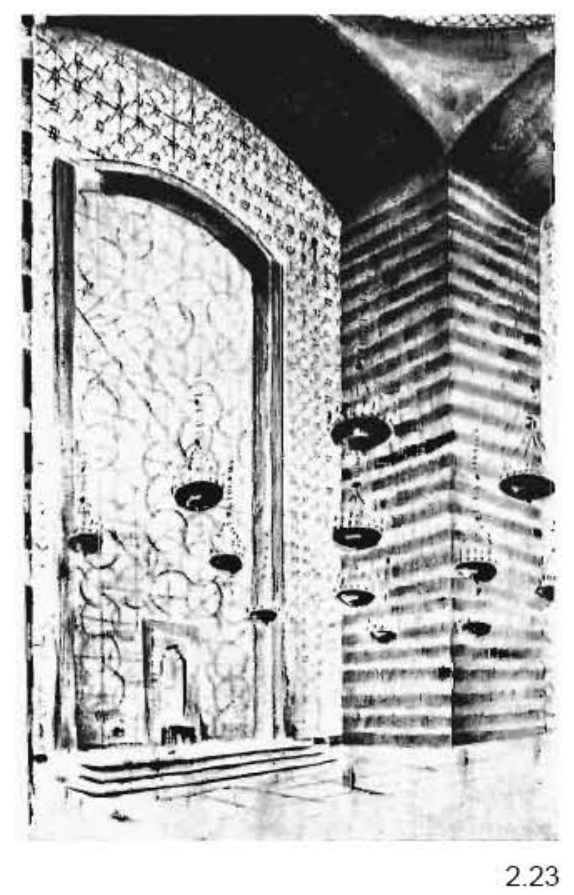

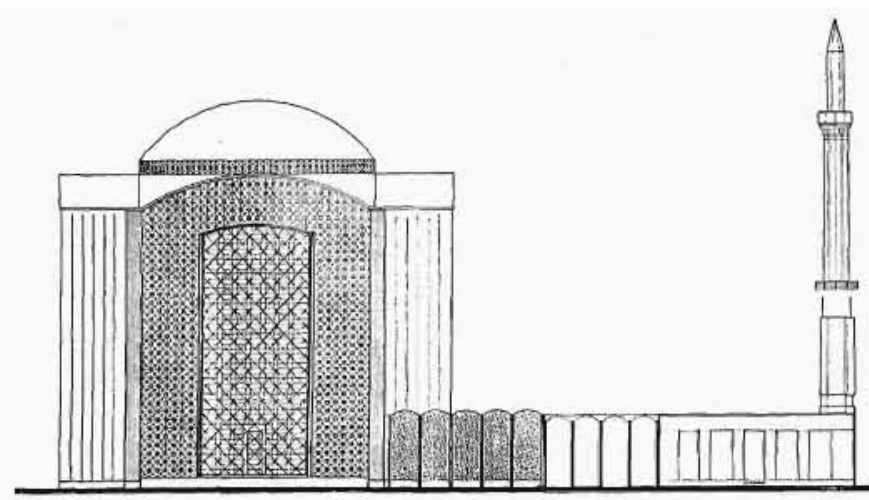

2.24

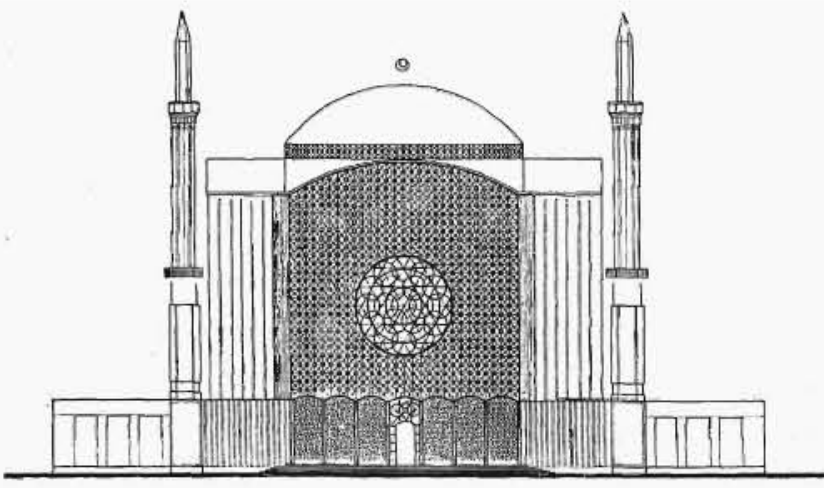

2.25

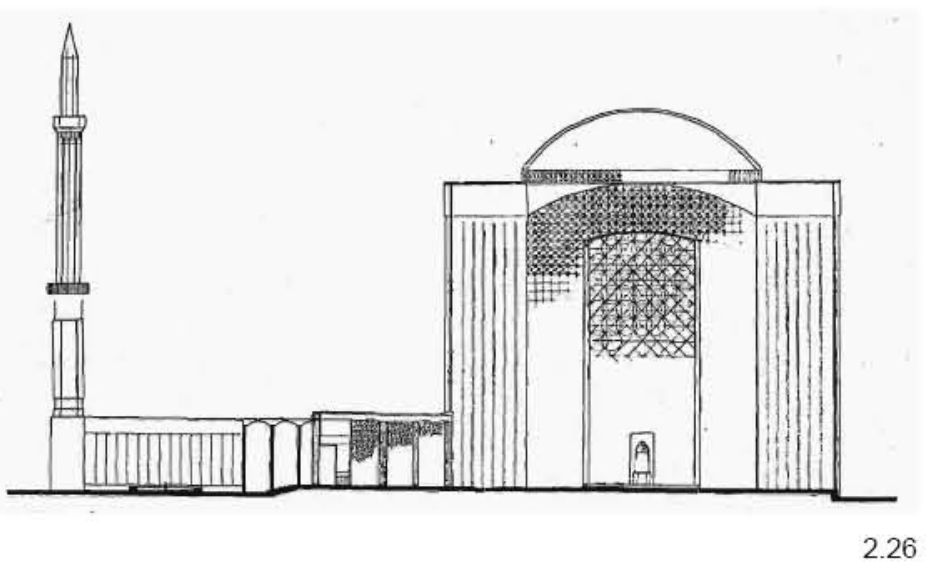

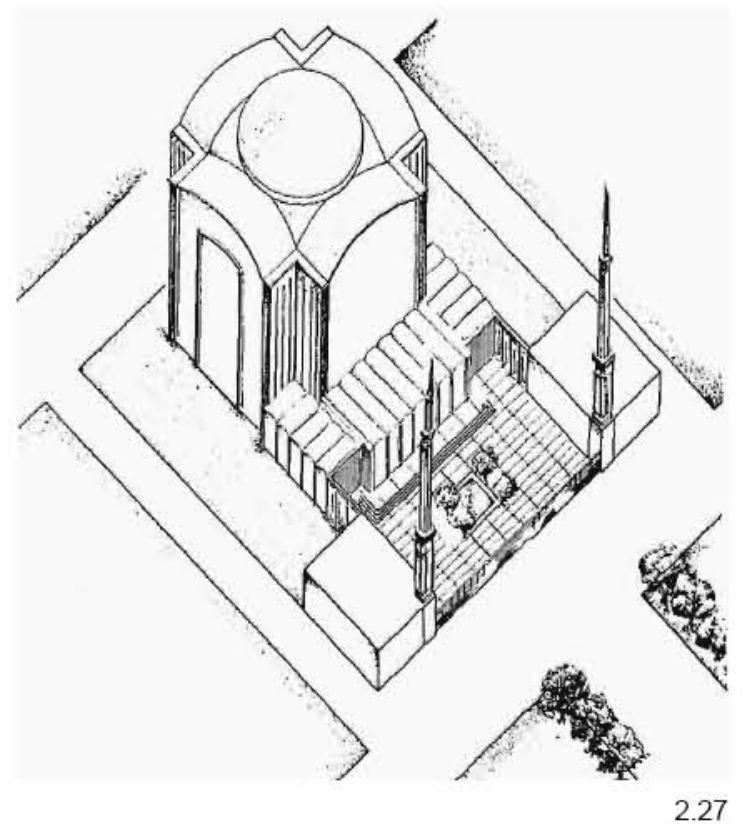
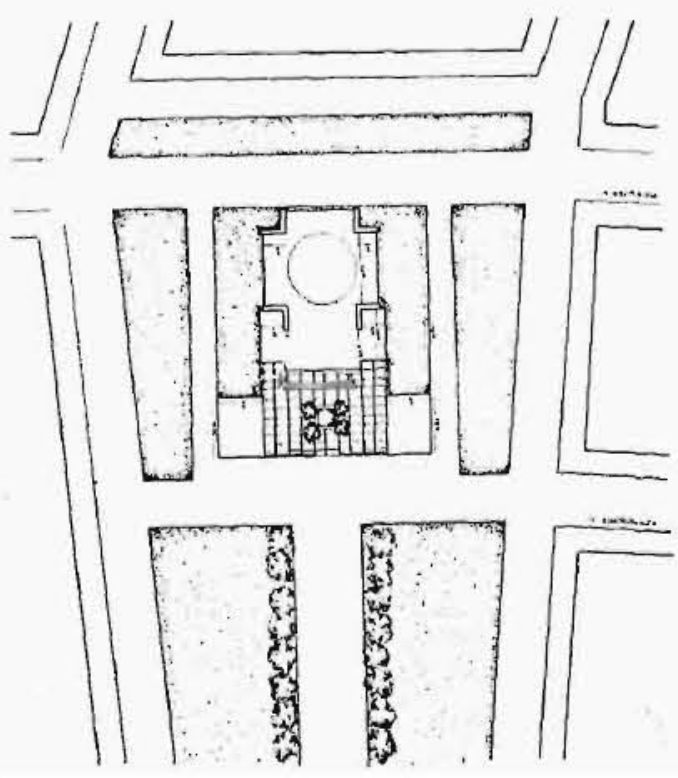
En la propuesta de la Mezquita de Varsovia (2.23-2.28) se hace patente por primera vez en la obra de Leykam la importante influencia de su maestro Auguste Perret, tanto en la formalización del proyecto como en su propuesta estructural y la definición del cerramiento y sus detalles constructivos. La tipología de iglesia de planta central hace alusión a su vez a un tipo por el que Leykam mostraría predilección durante el planteamiento de su doctorado en 1943. La planta de cruz griega de esta iglesia se resuelve geométricamente en volumen con la intersección de dos bóvedas de arco rebajado, una sección similar al arco utilizado por Perret en la nave central de Notre-Dame du Raincy (2.20), coronadas por una cúpula rebajada cuyo perfil es paralelo al trazado de los arcos de las bóvedas.

Si bien la estructura todavía no formaba parte de la expresión formal del edificio, Leykam se detuvo a precisar con detalle los huecos que formaban parte de los muros de exteriores de fachada tomando como referencia los bloques de "claustra" que había observado en el estudio de Perret en 1934; sirviéndose de ellos para explicar la importante aportación expresiva que supone el filtrado de la luz en un recinto religioso.

La trascendencia de la celosía basada en patrones geométricos en la cultura musulmana hizo que Leykam dedicase un gran esfuerzo gráfico a representar esta solución. El plano de la fachada de acceso contenía un rosetón que singularizaba el acceso mientras que el resto de paños situados en los extremos de las bóvedas mantenían el criterio de celosía, como acabado principal unificando la solución y enfatizando una visión compacta del conjunto, ya acentuada por el escaso desarrollo de las naves laterales.

El jurado del proyecto resaltó en su momento "las transparencias del plano", aunque consideró que "la puerta de entrada no es adecuada para una iglesia". Reconociendo la "calidad arquitectónica de la propuesta", finalmente no le otorgaron el premio porque "el volumen se acentúa demasiado poco (..) y las proporciones de minaretes no son correctas". ${ }^{2.26}$ En una entrevista posterior realizada por Leykam ${ }^{2.27}$, éste comentaría con el tiempo que "detesta"su propuesta aunque puntualiza seguidamente que "no es menos mala que la del ganador, Kolendo (2.30) sin duda la peor de las tres, aunque sí fue una representación muy realista de una mezquita." 2.27

Leykam describe su proyecto explicando que en aquel momento estaba inmerso en una especie de "juego romántico,.. pintoresco" ${ }_{2.27}$ y lamenta principalmente que "desde el grafismo no era posible expresar el contenido de la arquitectura, (...) algo que sí está presente en los materiales con que se construye, vidrio, piedra, acero, .. pero desde el dibujo no es posible demostrar al mismo nivel que desde la materialidad." 2.27

A pesar del tiempo transcurrido, en sus palabras se trasluce el recuerdo de quien todavía tiene presente el esfuerzo que tuvo que realizar para expresar gráficamente la emoción que haber visto materializadas estas ideas en sus visitas a las iglesias de Notre-Dame du Raincy y Santa Teresa de Montmagny, a pesar de que no nombra directamente sus referencias.

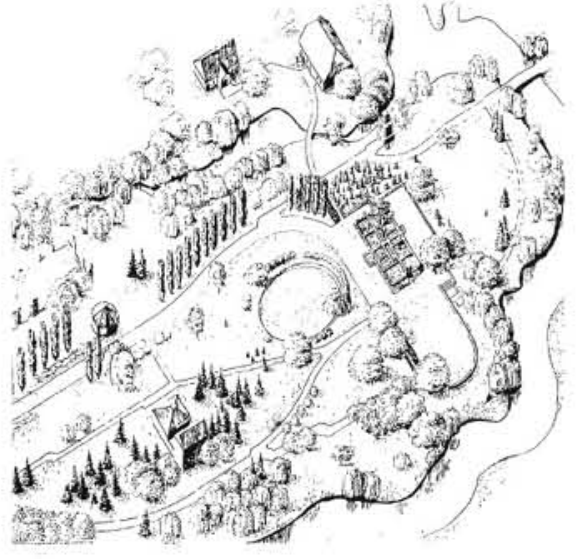

2.29

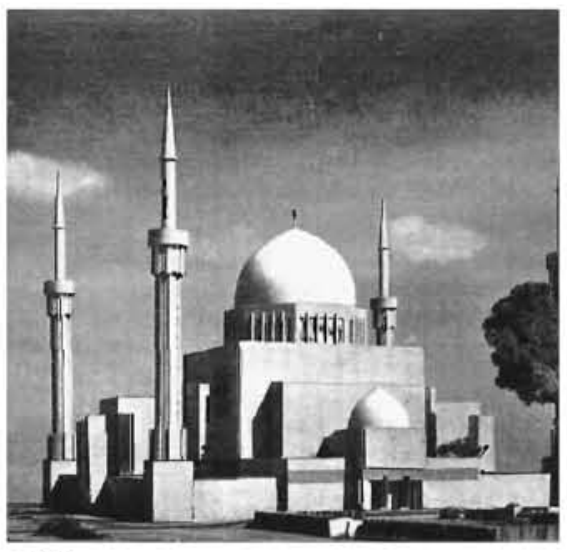

2.30

2.24. Zalavas (en polaco: Zułówo) es un pueblo de la actual Lituania, en la ribera del Mera, cerca de Švenčionys.

2.25. Stanisław Kolendo y Marek Leykam habian asistido juntos al instituto Stefan Batory etnre 1919 y 1927

2.26. Architekturai Budownictwo, nº 1936 pp.182-192

2.27. Entrevista grabada: "Wywiad z prof. Markiem Leykamem" 1957. Fuente: Ipnaleczow.com 
2.31 - 2.33 Concurso para la Mezquita de Varsovia,

2.31 Sección longitudinal.

2.32 Maqueta.

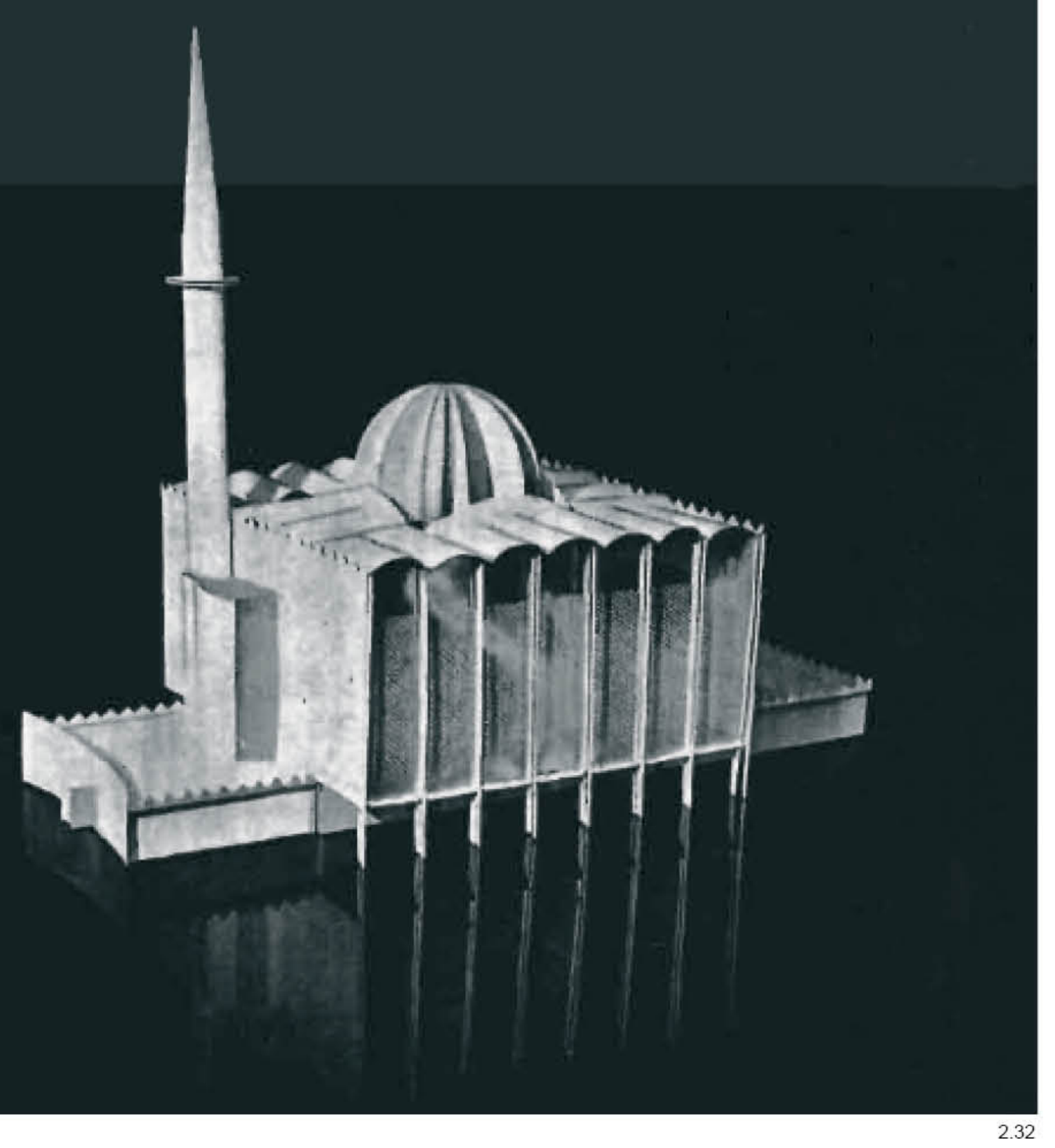


La posterior evolución de su arquitectura hacia una mayor presencia expresiva de los elementos tectónicos le lleva a confesar en esta entrevista su "gran predilección" 2.27 por el proyecto que realizaron en su momento Maciej Nowicki y Stanisława Sandecka (2.31-2.33) "una maravillosa síntesis gráfico-espacial, (...) que había merecido el primer premio sin duda alguna".2.

La propuesta para el Concurso de la Mezquita de Varsovia de Nowicki y Sandecka resolvía la representatividad del edificio a través de la rítmica y la escala de sus elementos estructurales, generando una interesante galería previa al acceso que impresionó a Leykam por la expresividad de su trama dentro de la compacidad del volumen y su capacidad para evocar la monumentalidad.

La solución de cubierta estaba formada por un perímetro de placas abovedadas moduladas con la misma cadencia que las esbeltas columnas de fachada, y en su centro, quedaba introducida una cúpula que no buscaba continuidad con estos elementos, sino que se distanciaba de ellos para recrear formalmente el concepto de patio tradicional de la arquitectura musulmana, mediante un vacío central que recogiera la luz. Nowicki y Sandecka, presentaron un diagrama estructural (2.33) que mostraba la importancia de la estructura como elemento articulador pero que al mismo tiempo hacía hincapié en la evocadora imagen de un vacío recreado en el centro de la mezquita.

El jurado consideró el acceso "no apropiado para un templo".2.26 aunque sí reconoció el "buen intento de búsqueda de nuevas formas en esta tipología de edificio." ${ }^{2.26}$ Cabe señalar a este respecto que los criterios de selección de proyectos por parte de los jurados de aquella década fueron bastante cuestionados con posterioridad. En opinión del investigador polaco Andrzej Jur, ${ }^{2.28}$ se puede apreciar retrospectivamente que "las obras más destacadas de esta época raramente ganaban los primeros premios aunque a menudo se encontraban entre las primeras posiciones, lo que no solo demostraba el oportunismo de los jueces, sino ponía en cuestión la idoneidad de realizar concursos en aquel momento." 2.28

En el concurso para muelle y Centro de Vela en Gdynia ${ }^{2.29}$, Leykam concurrió junto su compañero de clase Marian Spychalski, un arquitecto cuyo compromiso político le llevó a abandonar la arquitectura para formar parte del partido comunista y que en 1945 llegó a ser alcalde de Varsovia ${ }^{2.30}$; siendo este hecho fundamental para Leykam, ya que se convirtió en uno de sus principales valedores ${ }^{2.31}$, permitiendo que pudiera desarrollar su arquitectura sin interferencias en un contexto marcado por el intervencionismo del estado en la decisiones artísticas y arquitectónicas.

En este concurso, Leykam y Spychalski presentaron una propuesta a escala urbana y territorial que incluía una definición volumétrica a escala conceptual y una distribución funcional de las áreas de proyecto. La maqueta del proyecto, mostraba un recorrido continuo que establecía un eje de la ciudad, extendiendo el ensanche de Gdynia mediante una serie de bloques de manzana hasta conectarlo con el puerto de mar a través de una rotunda pieza abierta en peine hacia el sur, que contenía -como elemento representativo-, una torre que singularizaba la importancia del Centro de Vela (2.35).

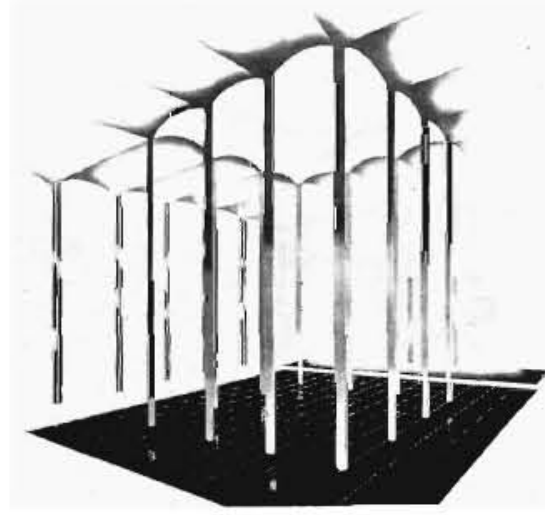

2.33

2.28. Jur, 1977. p. 28

2.29. Projekt konkursowy na Molo i Ośrodek Żeglarski w Gdyni.

2.30. Spychalski, 2015

2.31. La importante influencia de Marian Spychalski en los ámbito de poder del Partido Comunista en Polonia no es objeto de esta tesis, pero cabe destacar que fue jefe del Estado Mayor del Mando fue recibido de la delegación que debia establecer el Consejo Nacional Polaco (Krajowa Rada Narodowa; KRN) siendo uno de los autores del Manifiesto PKWN que proclamaba el Comité Polaco de liberación Nacional, cuyo reconocimiento marcó el devenir político de Polonia tras la II Guerra Mundial. Fuente: Op. Cit. 2.30.

2.32. Springer, 2011. p. 53 

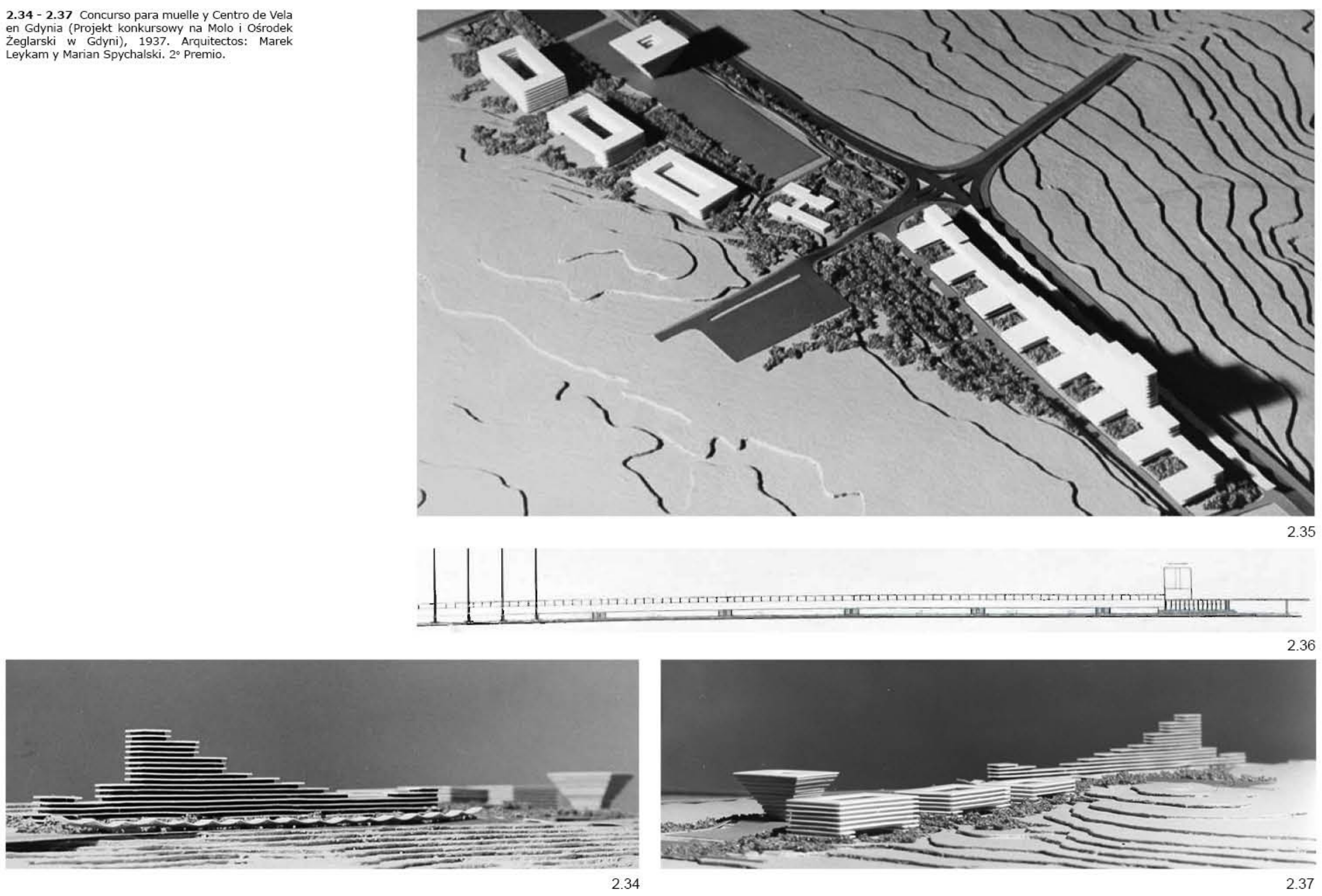
El trabajo de Leykam y Spychalski fue premiado por el jurado debido a la "buena relación de la propuesta con las áreas adyacentes y su armonización con los terrenos y edificios existentes." 2.28 Sin embargo el reconocimiento con el segundo premio impidió que ambos arquitectos pudieran desarrollar su oficina al quedarse, de nuevo, sin la posibilidad de materializar su obra.

La falta de perspectivas laborales de los concursos de arquitectura y las escasas oportunidades de construir fueron determinando el camino de Marek Leykam hacia actividades de carácter divulgativo a nivel académico y se incrementó su colaboración en revistas y publicaciones especializadas durante los siguientes años.

Desde que regresó de París en 1935, Leykam estaba desempeñando labores de asistente a la docencia en el Taller de Modelado Arquitectónico y Escultura ${ }^{233}$ de la Facultad de Arquitectura de Varsovia junto a Jan Goliński, y durante los siguientes años fue involucrándose en la elaboración de publicaciones y artículos dirigidos a "potenciar la imaginación artística del alumno." 2.28

A partir de 1935 colaboró en el "Instituto para la Promoción Artística de Varsovia"(IPS) ${ }^{2.34}$, a través del cual se creó el "Estudio de Interiores y Equipamiento" 2.35 encabezado por Stefan Sienicki, con el objetivo de "desarrollar -haciendo caso a las necesidades del mercado-, patrones para la producción industrial de productos de artesanía, (..) y explorar soluciones y formas históricas para que los resultados de la investigación y el diseño pudieran alcanzar un mayor espectro de población." 2.28

Entre marzo y abril del 1937, Leykam participó como miembro del IPS ${ }^{234}$ en una exposición de mobiliario y decoración interior denominada "Architektura Wnętrz" 2.36 (lit.: Interiorismo) organizada al efecto en su sede de Varsovia en la que también participarían destacados arquitectos y diseñadores como Jan Bogusławski (2.38), Kazimierz Prószynski (2.40) o M. Smolikowski (2.42).

Leykam estuvo encargado de la decoración de un comedor (2.39), que resolvió con muebles pulidos de madera de abedul y sillas con asiento de cuero que destacaban por su respaldo de estructura de madera realizada con listones de marcada proporción vertical dotando al asiento de cierta solemnidad. ${ }^{2.36}$ Leykam redactaría asimismo el catálogo de la exposición y los principales textos teóricos.

El interés por el periodismo y la divulgación llevaron a Leykam a publicar diversos artículos en las revistas de arquitectura más destacadas de la época como Architektura i Budownictwo; Arkady; y particularmente Plastyka; para la cual informó sobre el Congreso de vivienda de Praga en 1935 y realizó diversos artículos de opinión durante el año 1936. Todos los artículos escritos por Leykam en estas publicaciones han sido traducidos al español expresamente para este trabajo y figuran en el anexo de la presente tesis.
2.33. Gabinet Modelowania Architektonicznego i Rzezbiarskiego

2.34. Instytut Propagandy Sztuki (IPS). Instituto para la Promoción Artística de Varsovia, fundado con el fin de promover el arte moderno polaco. (www.ispan.pl).

2.35. Studium Wnętrza i Sprzetu.

2.36. Architektura i Budownictwo, no5 1937 p. 233-244 
2.38-2.42 Decoración interior y muebles expuestos Varsovia, 1937.

2.38 Jan Bogusławski.

2.39 Marek Leykam.

2.41 Stefan Sienicki.

2.42 M. Smolikowski i Ska.

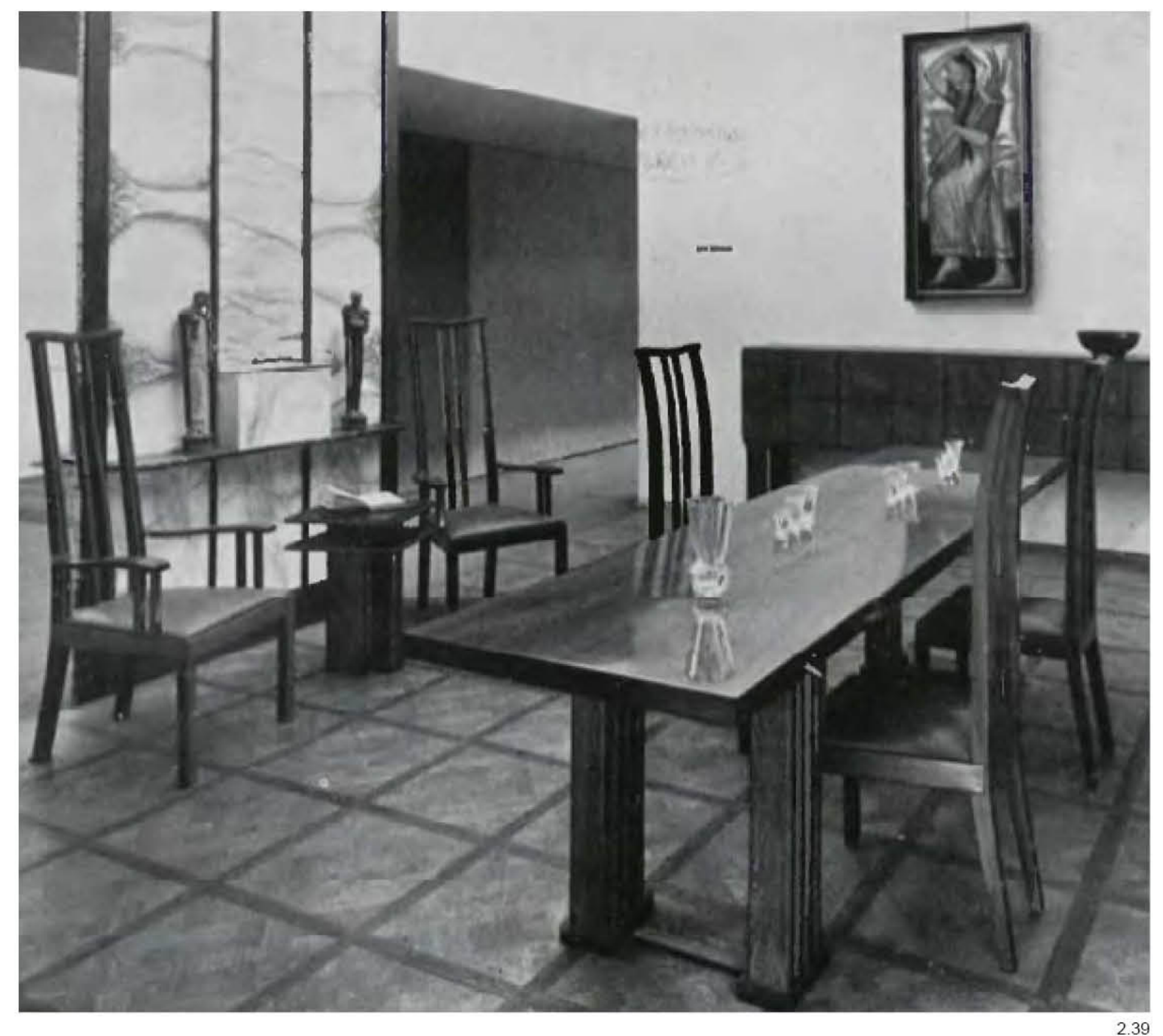


En sus textos Leykam reivindica el trabajo de la mente en el "instante ordenante por encima del impulso irracionaf' ${ }^{2.36}$ y muestra su fe en las leyes de la lógica y en el adecuado uso de las "herramientas de control" ${ }^{2.36}$, así como el "la 'profundización' de la experiencia como base para ejercer la profesión." 2.37

En su artículo "Reflexiones de un arquitecto" ${ }^{2.38}$, Leykam expone: "Cada vez que la mente humana se pregunta sobre la validez de una doctrina, se lo pregunta a sí misma. El consentimiento o la creencia en una doctrina la encuentra en sí mismo y de repente ve que el creador de las hipótesis y los dioses es él mismo, el pensamiento humano. $Y$ entonces: o puede creer en la anarquía de su fierza, o, siendo incapaz de comprender la razón y profindizando en todos los sentimientos, creer en lo absoluto." ${ }^{2.38}$

Los artículos que Leykam escribió en esta época entremezclan conceptos artísticos con valoraciones sociales, económicas y políticas en las que sus opiniones son expresadas de forma clara y sin ambigüedad. Con el paso del tiempo, estos textos han adquirido gran valor para interpretar su pensamiento y su obra, ya que al finalizar la II Guerra Mundial su actitud hacia los medios de comunicación cambió radicalmente y trató de mantenerse ajeno a cualquier publicidad mediática de su trabajo o de su propia imagen; rehusando aparecer en fotos e incluso negándose a colaborar con los escasos investigadores y arquitectos que le solicitaron información. ${ }^{2.39}$

En el periodo de entreguerras, Leykam subrayó la necesidad de crear a través de la obra arquitectónica los estímulos emocionales asociados a los valores artísticos específicos, aunque esto fuese a costa de la depreciación de los aspectos utilitarios y acentuación del momento creativo. Al mismo tiempo Leykam se mostró abiertamente contrario al funcionalismo: "las formas arquitectónicas deben albergar finciones mucho más allá del mero utilitarismo (...) y alcanzar un grado de autonomía que les permita expresar la individualidad tanto del creador como de sus usuarios." ${ }^{2.37}$

Con respecto a este tema resultaría en varias ocasiones muy concluyente: “(...) la finción no puede crear la forma (...) un elemento construido, para ser cierto y quedar estrictamente definido en sus necesidades recibe una forma, pero la forma no resulta de la función".

"Es el objeto, con su forma, el que cumple las funciones para las que fue creado." (...) "Los funcionalistas nos hablan del canon de un mundo ideal, en el que el apartamento debe ser una función de descanso biológico definido por el volumen de aire limpio, el porcentaje de soleamiento interior, la superficie de suelo en que el "individuo" colocara su mobiliario "estandarizado" y "funcional", los instrumentos de descanso... una arquitectura llevada al marco de la construcción dibujada según la aceptación de las leyes biológicas pero carente de realidad, proporción y belleza." 2.37

"Cuando imaginamos el canon del mundo ideal de la comodidad universal, o mejor dicho, la pereza en general, veremos el ideal de la vida vegetativa en las condiciones más cómodas." 2.37
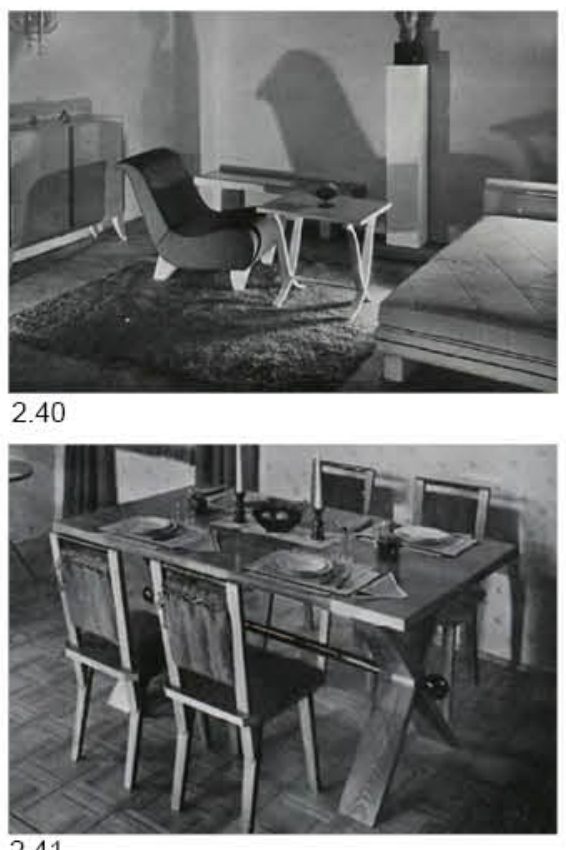

241

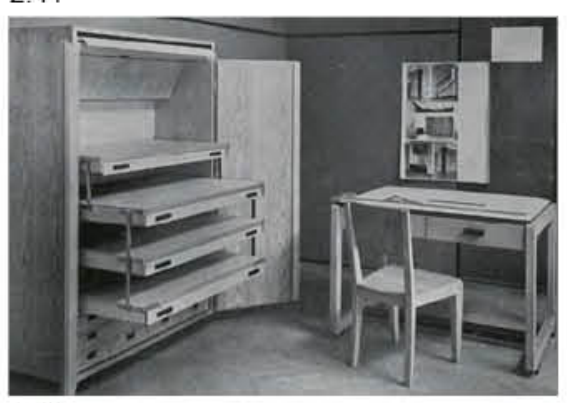

2.42

2.37. Articulo "Kolumna architektoniczna" (Columna arquitectónica) publicado en la revista Plastyka $1936 \mathrm{n}^{0} 4$ p. 295.

2.38. Artículo "Z rozważań architekta" (Reflexiones de un arquitecto) publicado en la revista Plastyka $1937, n^{0} 1$ p. $31-34$

2.39. Tal como queda reflejado en la escasez de documentación gráfica y escrita sobre su trabajo,
y las declaraciones posteriores de arquitectos e
investigadores interesados por su obra como Jur (1977) o Springer, (2011) 

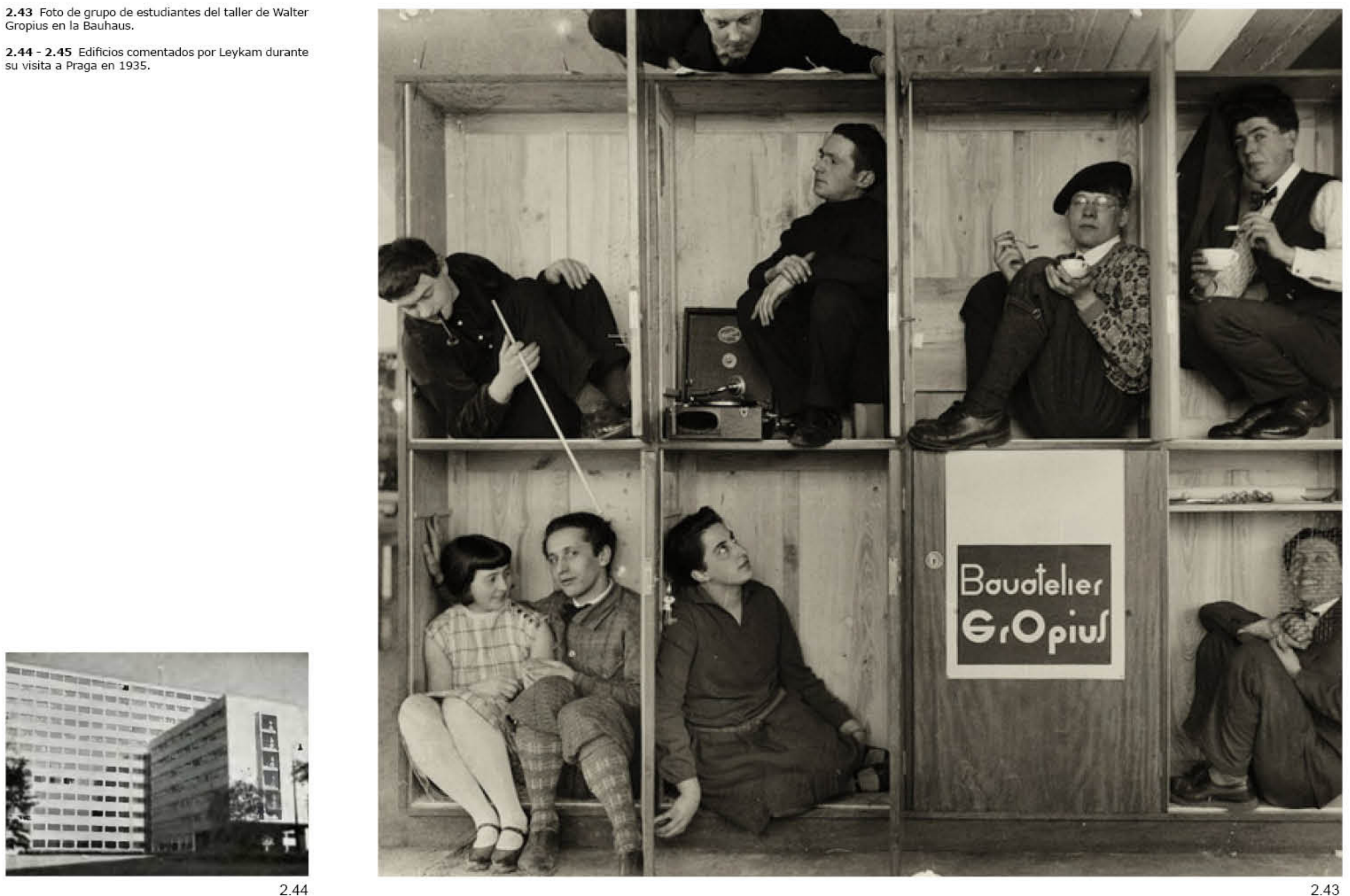
Para Leykam las "Casas de la Comuna" propuestas en la Unión Soviética eran un caso extremo de la "dictatorial pasión por el funcionalismo". En sus notas, no tienen ningún reparo en evaluar de forma desafectiva el trabajo de compañeros como Walter Gropius, sobre el que comentaría al respecto de un conjunto de viviendas que visitó para la revista Plastyka en 1936, “Qué interiores alemanes quería ver Walter Gropius en estos armarios? ¿La monótona unificación de habitaciones abarcando la monótona unificación de la esquematizada vida vegetativa que después de un trabajo monótono, aturdido y esquematizado en la cadena de montaje, estarán obligados a vivir los alemanes que habiten en esa plantilla?" 2.38

Sus críticas van encaminadas también a los aspectos formales de edificios diseñados en la vanguardia polaca, a los que considera parte de una especie de "esnobismo modernista", basado en una serie de elementos repetitivos extraídos de los originales: "largas bandas de ventanas, ménsulas y pilares (..) cuyos dispersados, pero simétricos grupos entretienen con la expresión de novedad." ${ }^{2.40}$ Leykam admiraba el "puritanismo de la construcción de acero y vidrio, y las paredes lisas y desnudas (..) traspasadas cien veces por ventanas horizontales que emocionaban a la imaginación con su expresión espacial." No estaba de acuerdo sin embargo con el "juego de formas independiente." ${ }^{2.41}$ En su visita a Praga para asistir al Congreso de la Vivienda de Praga de 1935 (2.44 - 2.45) comentó: "La composición de aspectos formales "no humanos", es inaceptable en la arquitectura. La forma arquitectónica debe estar saturada de un contenido 'humanista' mucho más amplio que una simple fórmula matemática incluida en las funciones humanas cotidianas". ${ }^{2.41}$ Este planteamiento teórico resultará fundamental para comprender su obra posterior.

Leykam aprobaba la "actitud psicológica" que Jan Goliński aportaba al diseño de interiores, teniendo en cuenta las "amplias necesidades de sus habitantes, (...) tanto estéticas como todas aquellas que la larga historia de la vida talló en los profundos yacimientos de la mente humana." ${ }^{2.41}$ Otra de las ideas expresadas por Leykam, tienen que ver con el "contenido humanista (...) en su forma más "completa" ${ }^{2.41}$ cuestión que lo aparta de la tradición clásica. En "Crónica de arquitectura", publicado en la revista "Plastyka" 2.41 , Leykam plantea sus criticas -por lo general muy favorableshacia las obras de varios arquitectos que habían sido profesores suyos, como Czesław Przybylski, de quien comenta su proyecto de reconstrucción de la Comandancia de la Ciudad de Varsovia; o Bohdan Pniewski a quien se refiere en su comentario sobre el edificio de los Tribunales de Grodzk, en Varsovia.

También alaba Leykam en sus artículos a J. Koszczyc-Witkiewicz "por la consistencia y propósito de sus contenidos proyectados", aunque su mayor reconocimiento queda para Rudolf Świerczyński", de quien ensalza insistentemente su proyecto de la Oficina Nacional de Patentes (1.97-1.99), una obra en la cual "la simplicidad, la proporción y la gracia se fissionaron en un todo". Leykam expresa una idea de arquitectura asociada a la obra de Świerczyński que hará suya en trabajos posteriores "la belleza es una sabiduría que crea lo obvio y así, lo perfecto." ${ }^{2.41}$ El planteamiento de Leykam queda resumido finalmente en una famosa sentencia publicada en 1936 en la revista "Arkady": "La arquitectura es el arte de componer el espacio y la vida." 2.40

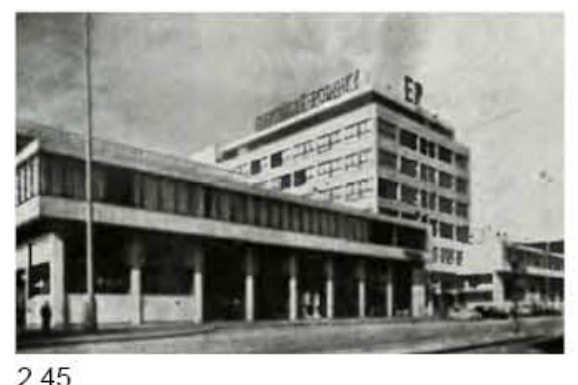

245

240. Articulo "O wnetrzu współczesnym" ("E interior moderno") publicado en Arkady $1936, n^{\circ} 7$ p. 375-377.

2.41. "Spostrzeżenia $z$ architektury czeskiej kongresu mieszkaniowego w Pradze". Plastyka $1935, n^{\circ} 5-6$ p. 122 


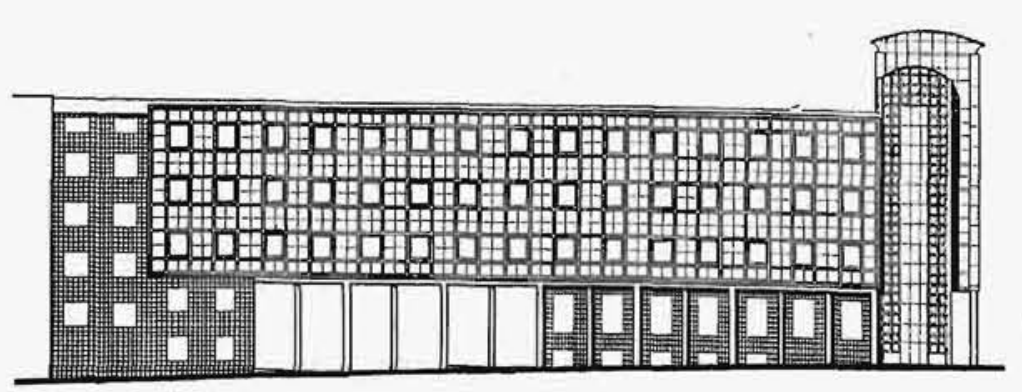

2.47
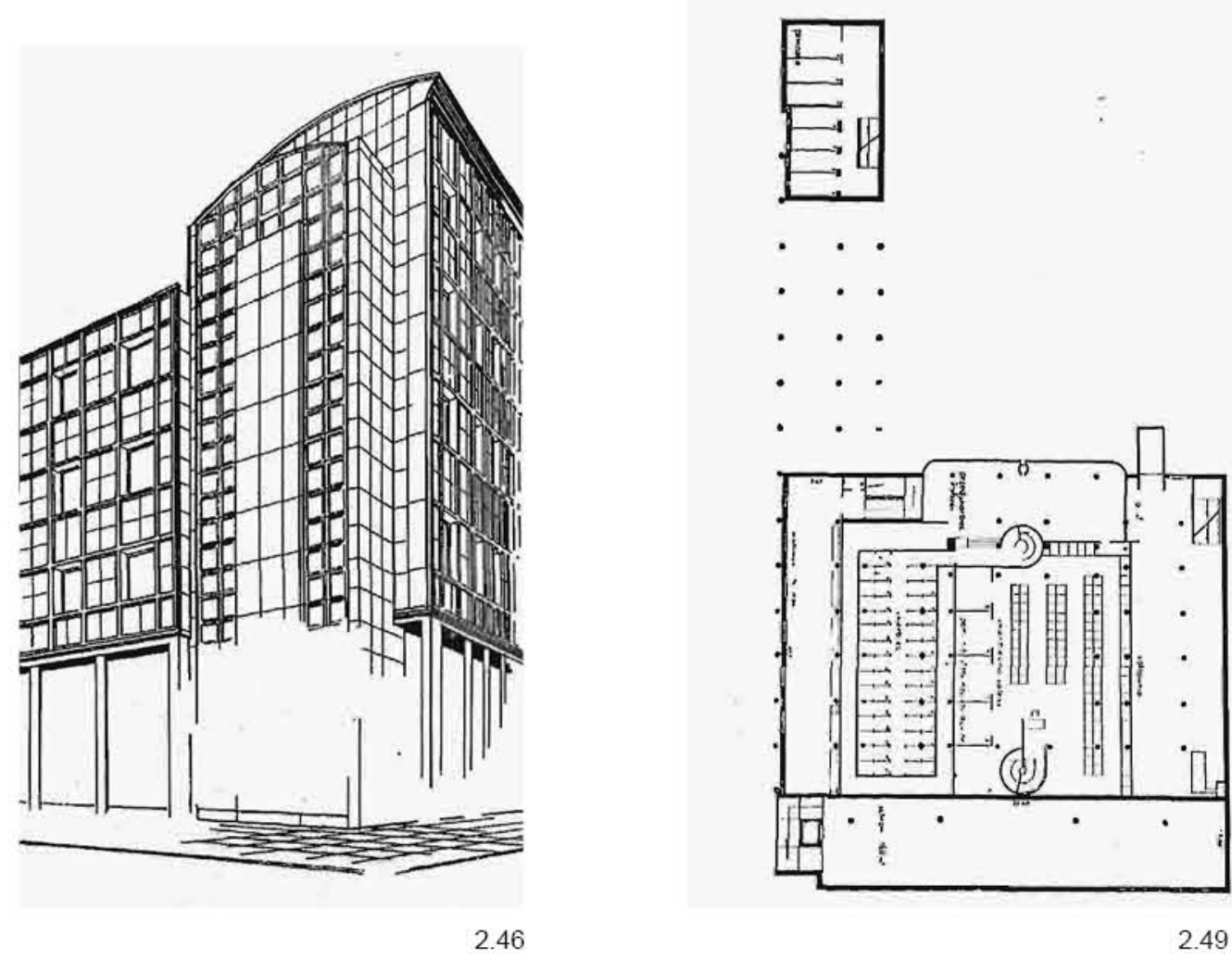
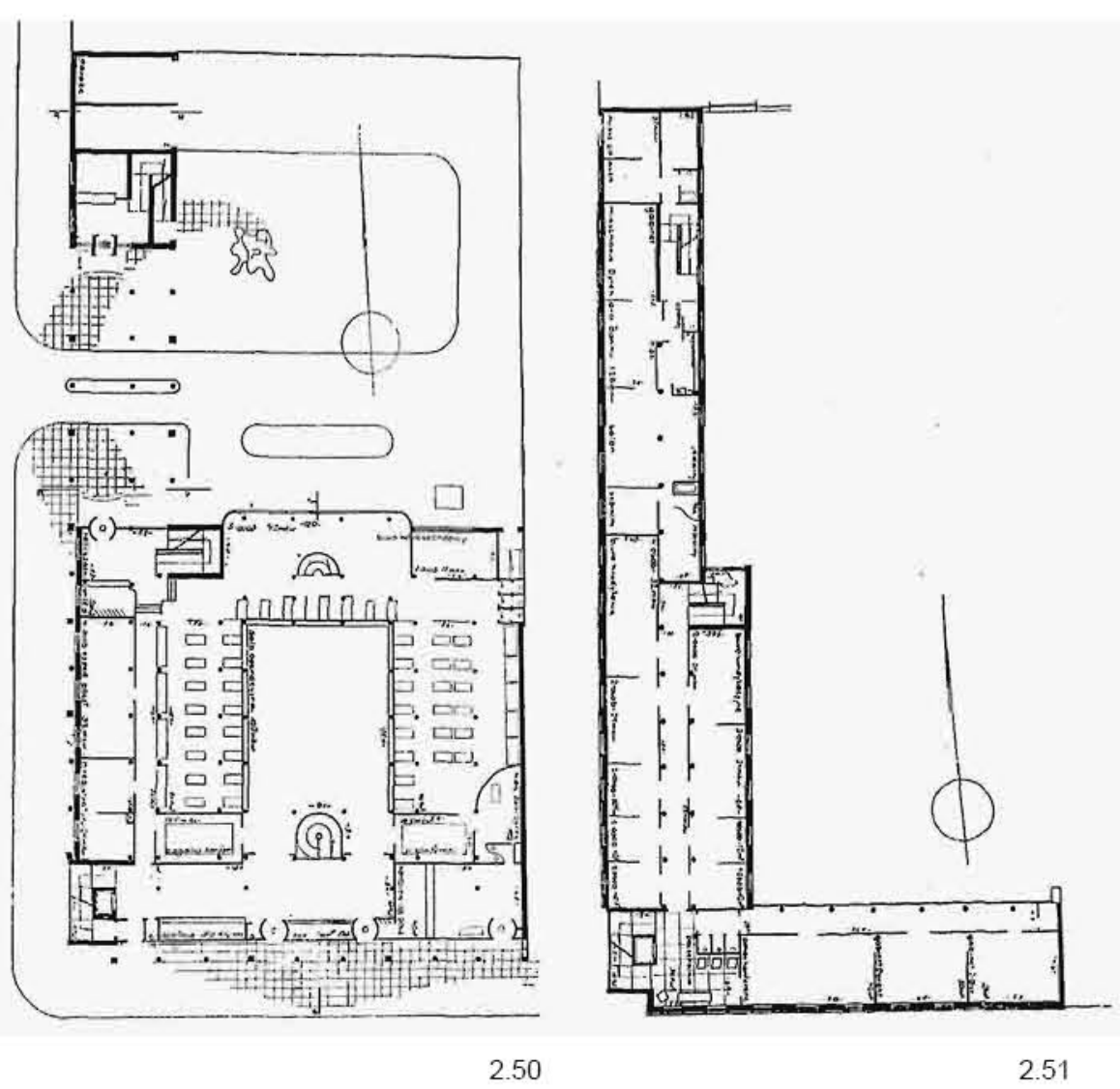

2.51 
En 1938, Leykam retomaría de nuevo los concursos de arquitectura para presentar una propuesta del Banco Nacional de Economía de Poznań (2.46-2.52) galardonada con un cuarto premio. Emplazado junto a Plaza de la Libertad y a lo largo de la calle Nowowiejskiego, las dimensiones de esta parcela y su geometría en forma de L, sumado a los requerimientos programáticos del banco determinaron en gran medida las posibilidades de desarrollo en planta del edificio como se puede observar comparando las propuestas de los equipos participantes. ${ }^{2.42}$

En este concurso resultó determinante la solución del interior y la propuesta de fachada. Leykam presentó una ordenada organización de espacios interiores y concentró sus esfuerzos en la definición de las fachadas que, una vez más, detalló con minuciosidad. Basado en la superposición de tramas cuadradas, el proyecto resuelve los dos volúmenes perpendiculares que albergan el programa de oficinas a partir de planta primera con paneles modulares de esta proporción.

Desde la Plaza de la Libertad se reconocen 36 cuadrados (9x4), que quedan subdivididos en 16 piezas $(4 \mathrm{x} 4)$ cuyo centro (2x2) está destinado a contener huecos del doble del tamaño unitario respecto las dimensiones de cada panel. (2.52) Con el mismo criterio se resuelve el alzado del volumen de oficinas abierto a la calle Nowowiejskiego, pero su diferencia de altura y longitud lleva a emplazar en este alzado 45 cuadrados en una proporción de 15x3. (2.47)

A nivel de planta baja, el proyecto de Leykam planteó una galería porticada, siendo la primera vez que en uno de sus proyectos se manifestaba el orden de una fachada a través de la rítmica estructural. El cerramiento retranqueado de planta baja que resuelve la galería contiene asimismo una modulación cuadrada sobre la que se integra las puertas de acceso a la sala principal. La prominente inclinación de la calle Nowowiejskiego no impide a Leykam persistir en el esquema formal convirtiendo las puertas en ventanas a medida que el descenso de la cota de la calle va impidiendo que a través de ellas se pueda acceder.

Desde el propio grafismo, Leykam pretende significar los volúmenes de oficinas del resto de la composición, acentuando su vuelo sobre la planta baja. La galería a cota de calle acentúa su presencia tectónica manteniéndose incólume ante las necesidades de circulación en el edificio que incluyen las entradas principales y secundarias y un acceso para personal y vehículos de servicio en la calle lateral. (2.47)

Al igual que pasó con multitud de proyectos de la época, este concurso iba a quedar interrumpido un año más tarde por el estallido de la II Guerra Mundial, un hecho que sumió en el caos a toda Polonia interrumpiendo uno de los periodos más florecientes de su historia y abocándola a un periodo tremendamente largo y dramático de destrucción.

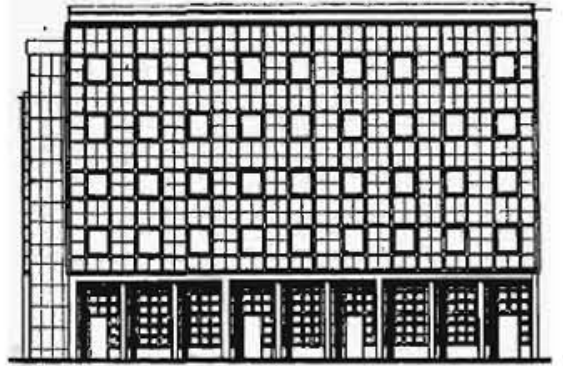

2.52

2.42. Se puede consultar información sobre las propuestas que recibieron los 4 primeros premios en la revista Architektura i Budownictwo, $n^{0} 1$ del año 1938. pp. 30-38 


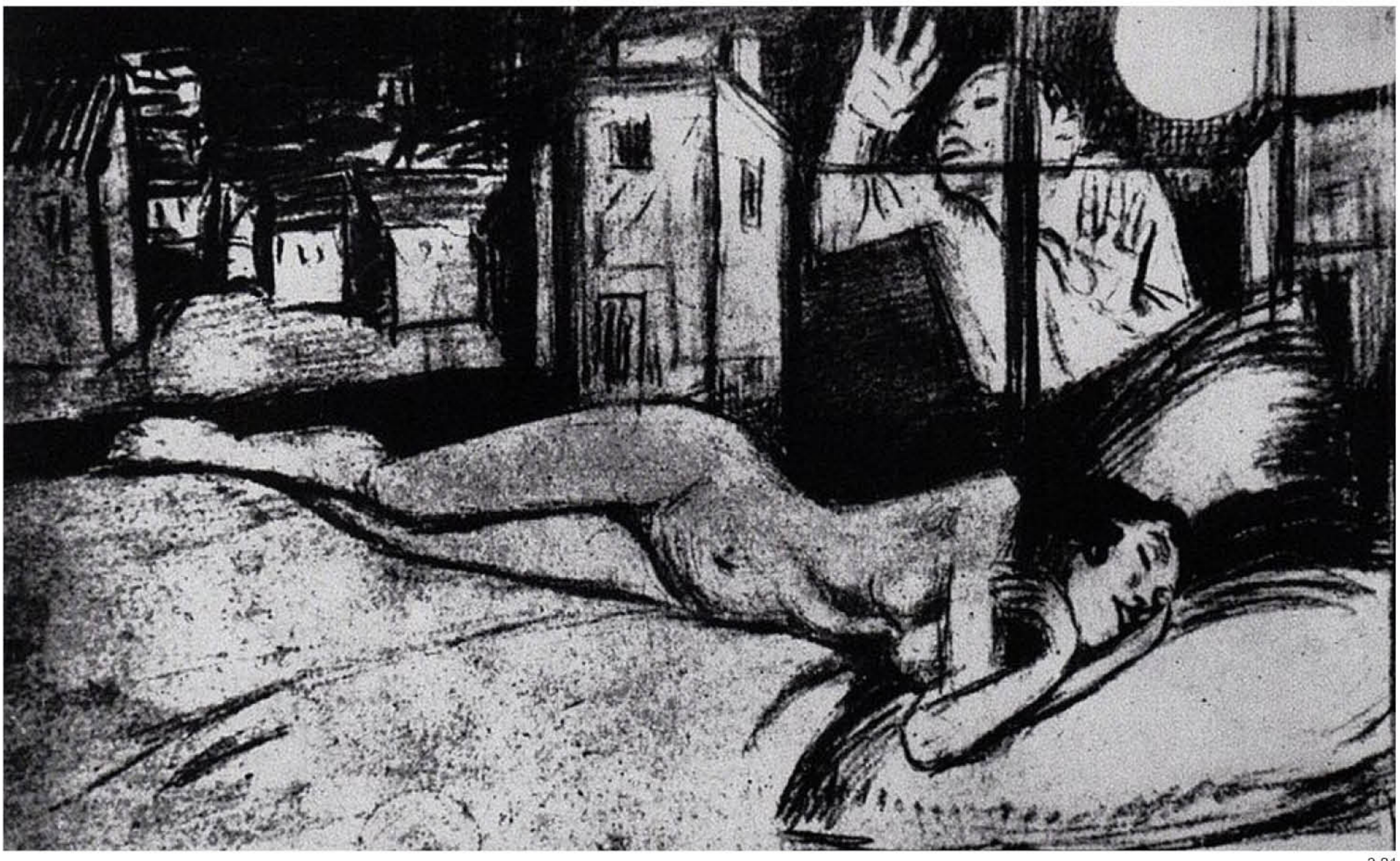


"El hombre se ha puesto la meta de conquistar al mundo, pero entre tanto ha perdido su alma. (...) Hemos llegado al caos intelectual."

Aleksandr Solzhenitsyn. "Solzhenitsyn: A Soul in Exile" 3.00

E1 23 de agosto de 1939, la Unión Soviética y la Alemania nazi llegaron a un acuerdo firmando el pacto RibbentropMólotov ${ }^{3.01}$, por el cual ambas potencias acordaban "no agredirse mutuamente en el futuro". ${ }^{3.01}$ Este acuerdo contuvo además un "protocolo adicional secreto" ${ }^{.01} 3.02$ donde estaba escrito el "reparto de Europa del este y central fijando los límites de influencia alemana y soviética, determinando que ambos Estados fijaban pactos para no interferir en sus respectivas zonas mientras reconocían los intereses de cada uno sobre ciertos territorios." 3.02 En el caso de Polonia, una vez invadida, había sido acordado su "reparto entre ambos estados mediante un común acuerdo que tuviese en cuenta los intereses mutuos". 3.01

Una semana más tarde, el 1 de septiembre de 1939, Alemania invadió Polonia con el pretexto de un supuesto ataque polaco previo sobre un puesto fronterizo alemán en Gleiwitz. ${ }^{3.01}$ Aunque los bosques y las carreteras mal construidas de Polonia resultaban un tanto problemáticas para el avance, las características de la llanura polaca ofrecieron una ventaja para el desplazamiento de los blindados alemanes y el 8 de septiembre, los nazis llegaron a Varsovia tras sorprender a las defensas polacas con una forma de asalto a gran velocidad bautizada desde entonces como Blitzkrieg (guerra relámpago). ${ }^{3.03}$

E1 17 de septiembre, la Unión Soviética, siguiendo su acuerdo secreto con Alemania, invadió a su vez Polonia por el este, convirtiendo las defensas polacas en un caos mediante la apertura de un segundo frente. La defensa polaca era incapaz de aguantar una lucha en dos frentes a la vez y un día más tarde, tanto el presidente polaco como el

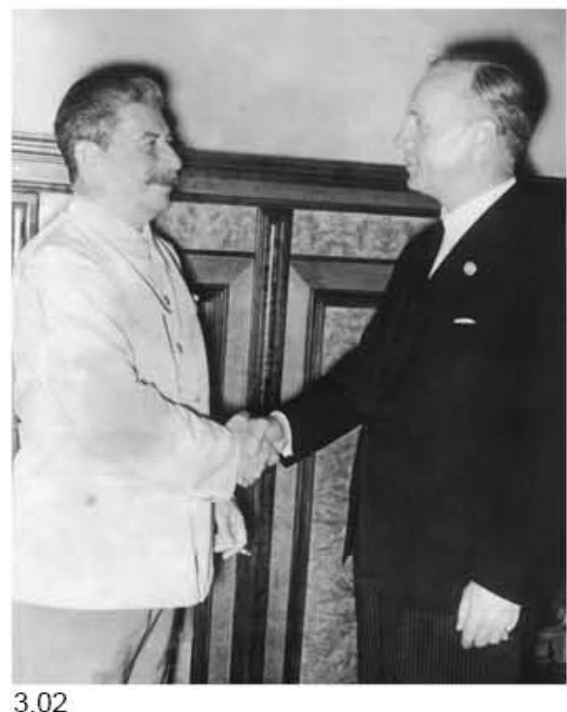

3.02

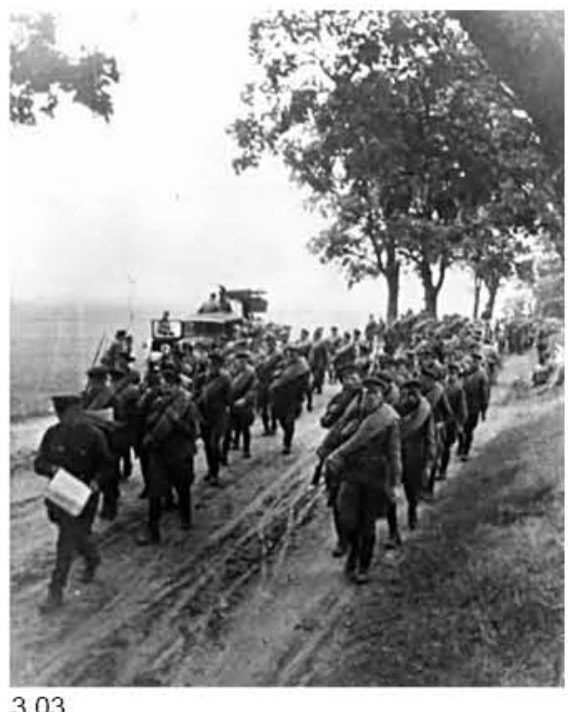

3.00. Pearce, 2007

3.01. Plakans, 1995. p. 142; 174- 181

3.02. Este documento es de Dominio Público. Fue difundido durante los juicios de Nuremberg en 1946. 3.03. Encyklopedia Warszawy, 1994. 
3.04 Profesores polacos de Bydgoszcz antes de ser fusilados el 9 de septiembre de 1939 por miembros del Volksdeutscher Selbstschutz.

3.05 Bombarderos alemanes Heinkel He 111 bombardeando Varsovia en septiembre de 1939 .

3.06 Fosa común con cadáveres de oficiales del ejército, policías, intelectuales y civiles polacos asesinados en masa por la Comisariado del

Pueblo para Asuntos Internos (NKVD) dirigida por Lavrentiy Beria entre abril y mayo de 1940, y exhumados en abril de 1943.

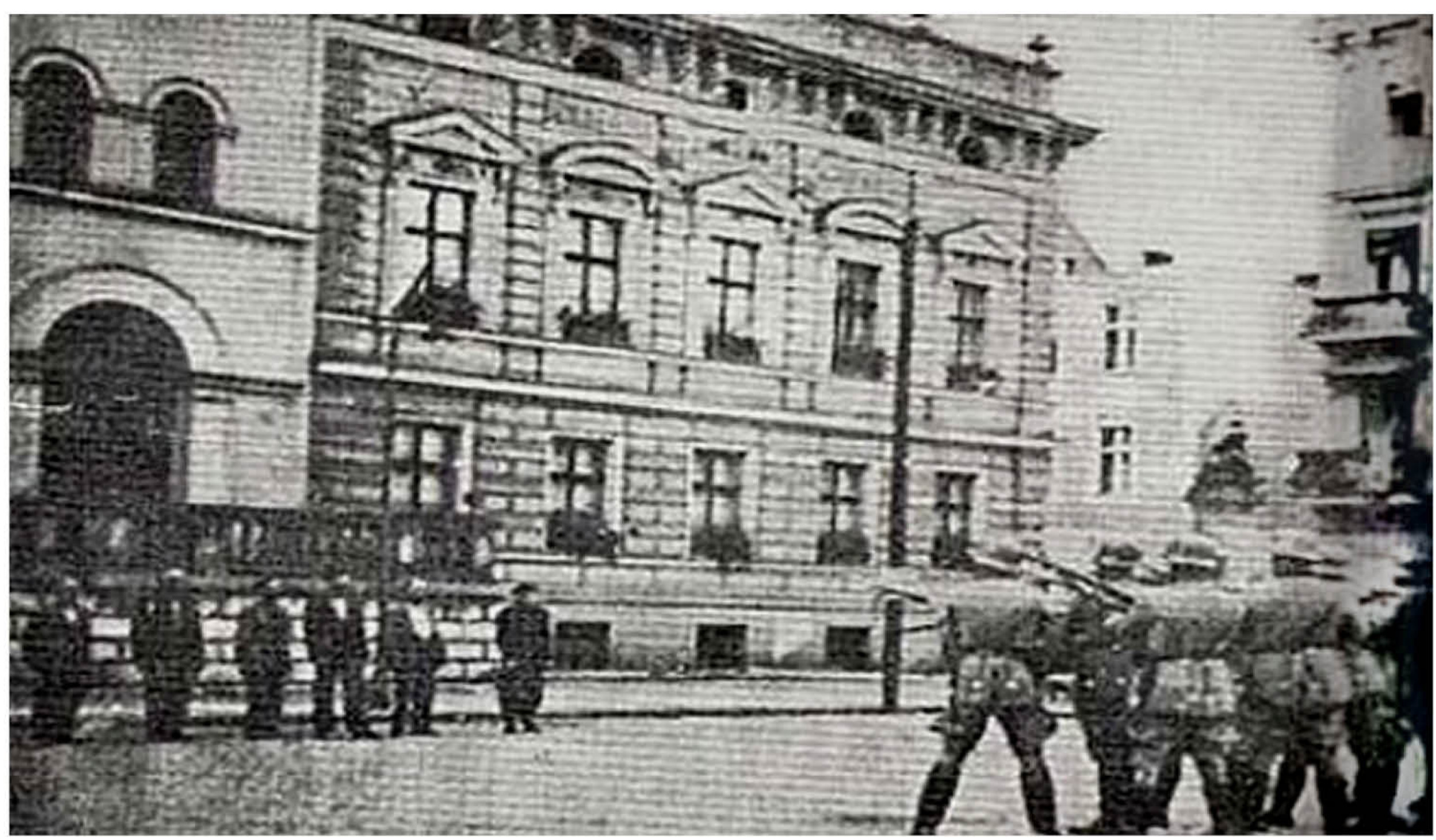


comandante en jefe huyeron a Rumanía. El 1 de octubre, después de un mes de asedio a Varsovia, las fuerzas invasoras entraron en la ciudad. Las últimas unidades polacas se rindieron el 6 de octubre. Polonia, sin embargo, nunca se rindió oficialmente a los alemanes. Algunas tropas polacas se fueron a países vecinos y la Polonia ocupada consiguió crear un poderoso movimiento de resistencia y contribuyó con fuerzas militares significativas al esfuerzo aliado durante el resto de la II Guerra Mundial. ${ }^{3.03}$

La invasión de Polonia terminó abruptamente con una corta pero floreciente época de prosperidad en el país dando origen a un largo periodo de sufrimiento y desesperanza. En la Polonia ocupada por Alemania, la calidad de vida de los polacos, especialmente de los judíos, se empezó a deteriorar rápidamente debido a la existencia de un "plan secreto de genocidio por parte del partido nazi, (..) el Generalplan Ost" ${ }^{3.05}$ (...) que consistía en una limpieza étnica que permitiese ampliar lo que Hitler llamó "Lebensraum" ${ }_{3.04}$ el "espacio vital" que reclamaba para la Alemania del III Reich. ${ }^{3.05}$

Las relaciones históricas entre polacos y rusos propiciaron que la población de Polonia fuera igualmente humillada cuando se encontraba bajo dominio soviético, aunque en este caso no predominaron los prejuicios raciales sino las interpretaciones de carácter ideológico. ${ }^{3.03}$ En la llamada Masacre de Katyń (3.06), más de 22.000 oficiales polacos fueron ejecutados en masa, junto a reconocidos intelectuales, docentes, artistas y políticos del país. ${ }^{3.03}$

La Universidad de Varsovia se convirtió en un punto importante de represión por parte de los invasores de uno y otro bando. Hasta 41 profesores de la Politécnica fueron asesinados en 1939, entre los que estuvo el prof. Oskar Sosnowski, un brillante arquitecto y creador del Instituto de Arquitectura Polaca, que fue abatido por soldados alemanes en el patio del edificio de la Escuela de Arquitectura mientras intentaba guardar los archivos que contenían los planos de los edificios históricos de Polonia, que debían proporcionar información para la futura reconstrucción de Varsovia después de la guerra. El gran arquitecto del grupo Praesens Józef Szanajca también falleció en su coche durante el bombardeo alemán de Tomaszów Lubelski. 3.06

Habida cuenta del exterminio que la población polaca estaba sufriendo indiscriminadamente, muchos arquitectos pasaron a formar parte de las filas del ejército mientras otros optaron por emigrar. Entre los que huyeron de Polonia, una gran mayoría de arquitectos encontraron un punto de encuentro en Reino Unido, donde en 1940 se formó la Asociación de Técnicos de Polonia en Reino Unido ${ }^{3.07}$ en la que trabajaron inicialmente arquitectos como J. Zakowski, Z. Celarski, B. Schmidt y R. Ostrowski entre otros, con una actividad dirigida a la difusión del conocimiento en la arquitectura polaca a través de conferencias, exposiciones (Londres, Glasgow, Edimburgo, Liverpool,..) y publicaciones, con el apoyo logístico y económico del British Council. ${ }^{3.06}$

Con la ayuda del gobierno polaco en el exilio, y apreciando la necesidad de preparar a los profesionales para la reconstrucción de posguerra del país, se organizaron, a su vez, en cooperación con las autoridades británicas, la Escuela
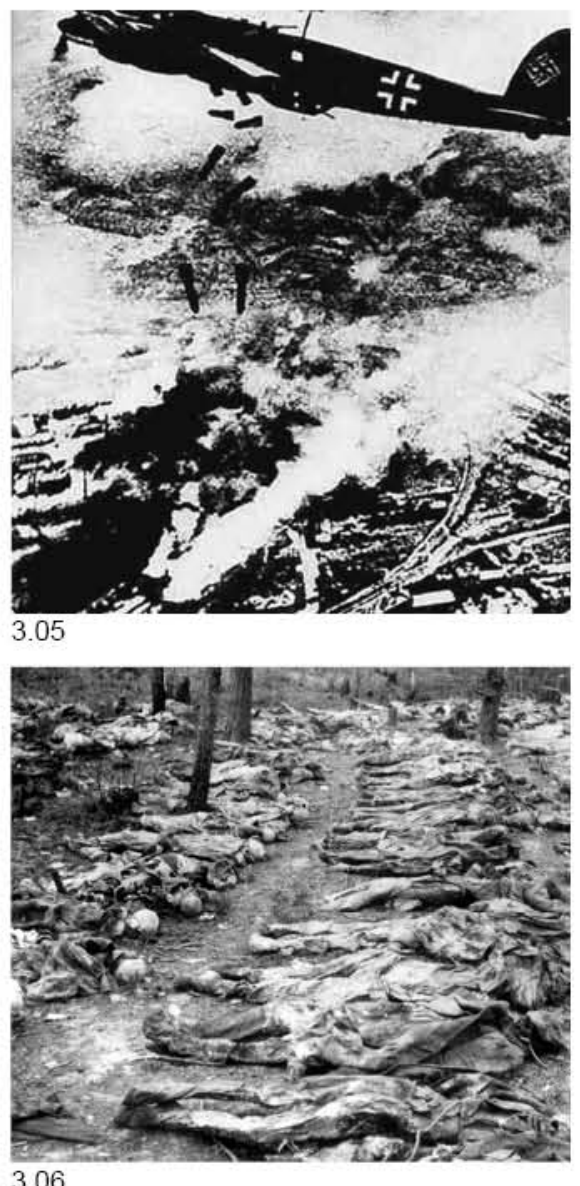

3.06

3.04. Expresión de Friedrich Ratzel politizada tras los textos de Rudolf Kjellén. En "Mein Kampf' Hitler escribió: "los alemanes tienen el derecho moral de adquirir territorios ajenos gracias a los cuales se espera atender al crecimiento de la población”.

3.05. Eichholtz, 2004. p. 800-808.

3.06. Barucki, 2014

3.07. Stowarzyszenie Techników Polskich w Wielkie Brytanii.

3.08. Szkoła Architektury przy Uniwersytecie w Liverpool.

3.09. Władysław Eugeniusz Sikorski (1881-1943) presidente del gobierno y comandante de las fuerzas armadas polacas al comienzo de la II GM. 
3.07 Segunda División Polaca de Fusileros de Infantería que formaba parte

3.08 3.09 Soldados polacos armados como parte del ejército francés entre

diciembre de 1939 y julio de 1940.

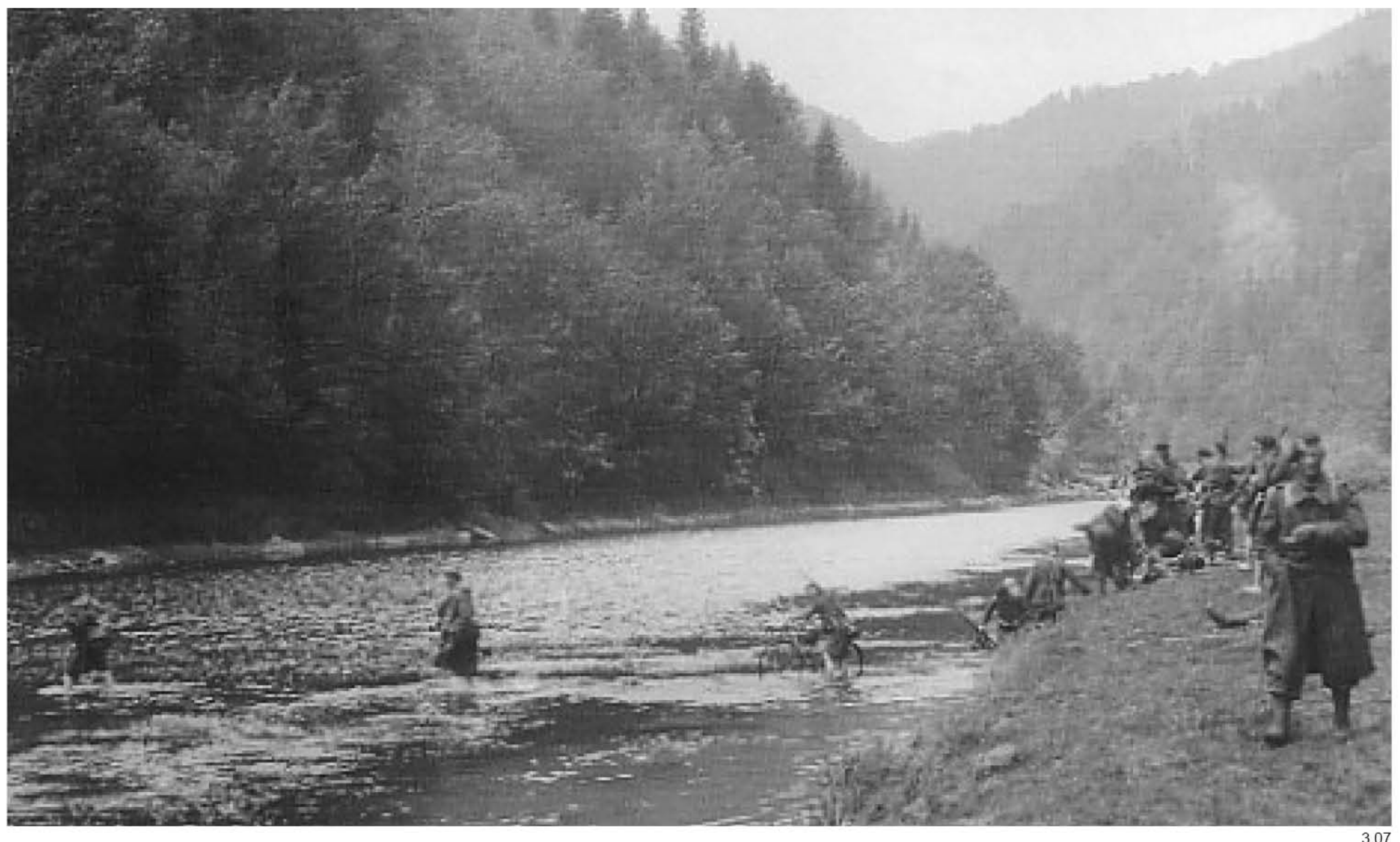


Polaca de Arquitectura de la Universidad de Liverpool ${ }^{3.08}$ a la que acudieron los estudiantes del Ejército polaco que tuvieron la posibilidad de acceder a Gran Bretaña.

La nueva Escuela de Arquitectura de Liverpool fue inagurada en 1942 por el primer ministro polaco del gobierno en el exilio, el general Sikorski ${ }^{3.09}$, y en ella pudieron completar sus estudios 22 arquitectos polacos. Trabajaron a su vez como profesores arquitectos como Leopold Toruń, Bolesław Szmidt o Witold Klębkowski procedentes de la Facultad de Arquitectura de la Universidad Tecnológica de Varsovia, y varios docentes de la Facultad de Arquitectura de la Lviv como Władysław Czarnecki, Kazimierz Dziewoński o Karol Śmigielski. ${ }^{3.06}$ Entre los arquitectos que pasaron a formar parte del ejército se encontró sin embargo Leykam, quien tras participar en la resistencia de Polonia en septiembre de 1939, formó parte de la infantería que participó en la campaña de Francia de 1940 en el bando Aliado. 3.06

Dentro del Tercer Ejército Francés fue integrada a finales de 1939 la Segunda División Polaca de Fusileros de Infantería ${ }^{3.10}$ de la que pasó a formar parte Leykam bajo las órdenes del General Bronisław Prugar-Ketling. ${ }^{3.11}$ siendo su objetivo proteger la parte sur de la Línea Maginot ${ }^{3.12}$ a lo largo del río Rhein como parte de la $2^{\text {a }}$ División de Infantería del $45^{\circ}$ cuerpo del $8^{\circ}$ ejército francés. La localización de esta misión tan cercana a la frontera con Suiza fue el hecho que permitiría a toda la división refugiarse en Suiza en el verano de 1940, tras la retirada del ejército francés.

La capitulación de los franceses el 25 de junio de 1940 dejó a todas las divisiones polacas de Francia el dilema de continuar en el frente o abandonar, y mientras algunas divisiones continuaron luchando a pesar de las llamadas al armisticio y la desmovilización, otras optaron por la rendición o la retirada siendo la mayoría abatidas por el ejército alemán. La infantería polaca del destacamento del que formaba parte Leykam defendía la zona Belfort y tuvo la fortuna de poder cruzar la frontera cuando los primeros tanques alemanes invadían ya su retaguardia. ${ }^{3.13}$

A los pocos días de entrar en Suiza el destacamento polaco acampó en Aeschi (3.10), un pueblo de Jura a las afueras de Solothurn y, según el relato de Leykam, un técnico responsable de patrimonio de la ciudad encargó a su compañía durante aquel verano una serie de trabajos que incluían excavaciones arqueológicas en las que encontraron un camino romano, los cimientos de unas viviendas del siglo III - IV d. C y numerosas cerámicas, bronces y monedas -un material que figura hoy en una sala en el museo local de la ciudad-. Finalmente, en octubre de 1940 se ofreció a los refugiados polacos con formación académica la posibilidad de que continuasen sus estudios como alternativa a la realización de trabajos en el campo, y muchos de ellos tomaron esa opción, siendo el punto de partida para que Leykam llegase a estudiar en la ETH de Zúrich.

La inclusión de este conjunto de reseñas históricas sobre las circunstancias en las que Leykam afrontó la II Guerra Mundial, han sido consideradas necesarias en esta tesis puesto que fundamentan la comprensión del contexto político y social en el que se desarrolló su trabajo e influyeron de forma determinante en su interpretación de la realidad.

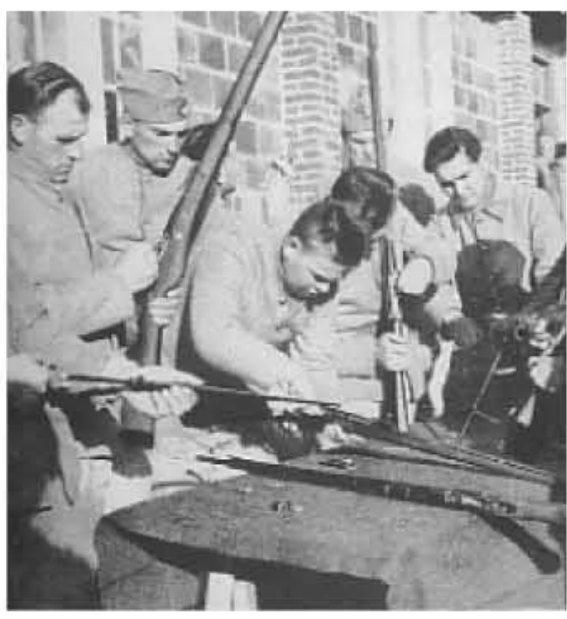

3.08

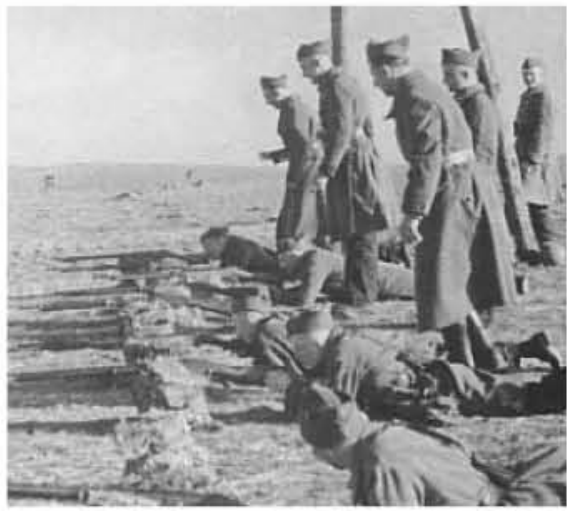

3.09

3.10. $2^{\circ}$ Dywizja Strzelców Pieszych (2 DSP).

3.11. Bronisław Prugar-Ketling, General de División del Ejército Polaco (1891-1948)

3.12. Fortificación defensiva construida por Francia a lo largo de su frontera con Alemania e Italia princip $15 \mathrm{~km}$ de pripcis

3.13. Barucki, 2000. p183-186.

3.14. Según el relato de M. Leykam. Op. Cit: 3.13 
3.10 3.12 Segunda División Polaca de Fusileros de Infantería formando en el campamento y realizando Suiza durante el verano de 1940.

3.11 Adolf Hitler con Arno Breker y Albert Speer en Paris el 23 de junio de 1940 tras la firma del armisticio.

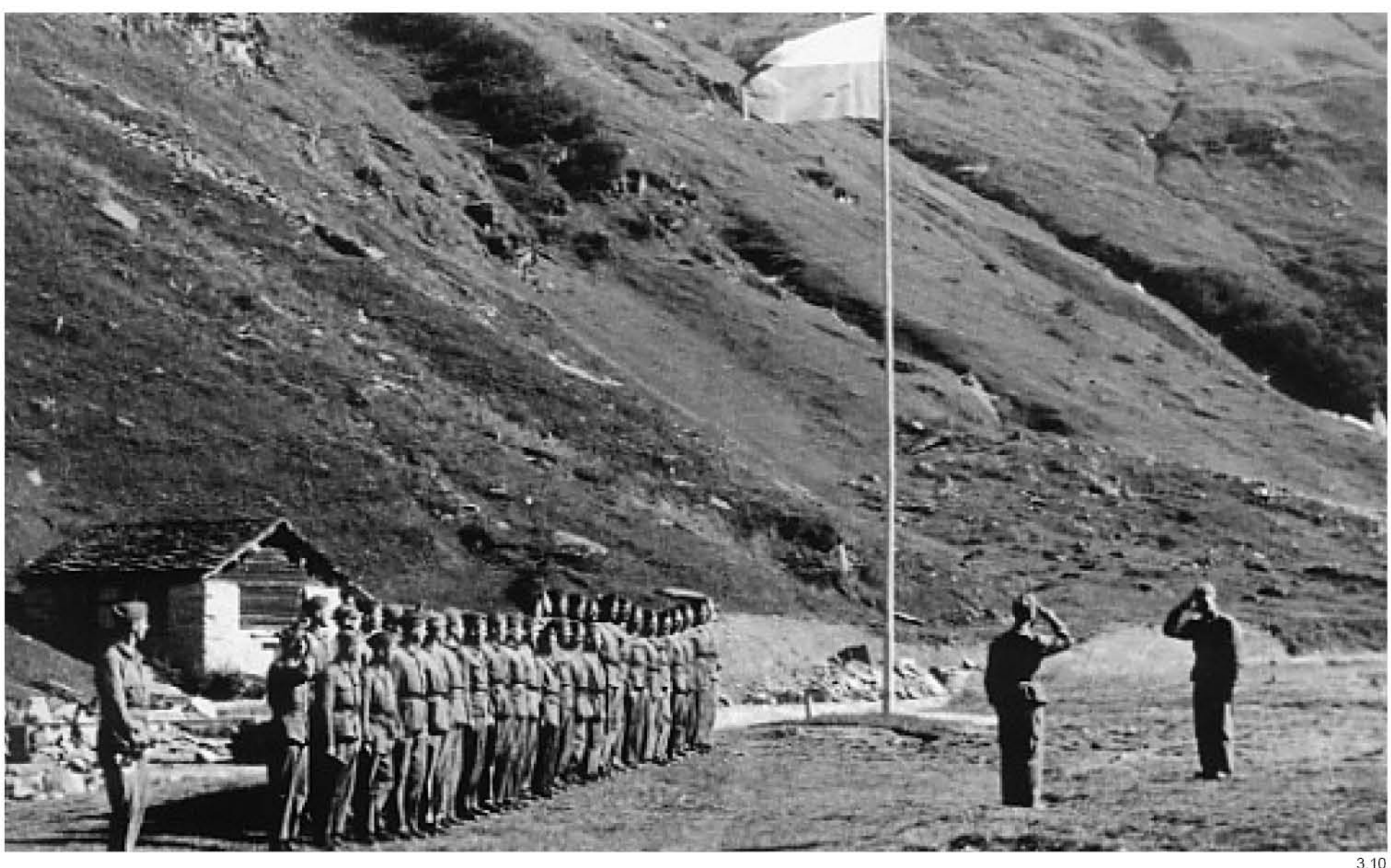


Para una adecuada comprensión de la obra de Leykam es fundamental no dejar pasar los acontecimientos históricos que motivaron las necesidades que dieron lugar a que construyera sus obras. Atender esa realidad es imprescindible para que sus proyectos no queden limitados a una dimensión compositiva o técnica que no daría muestra de la reflexión alcanzada en cada una de las esferas que abarcan sus objetos arquitectónicos.

En las crónicas de guerra que redactó Marek Leykam, se puede observar un esfuerzo narrativo autobiográfico muy alejado de la cobertura distante que permitió que se hiciese de su trabajo arquitectónico, temeroso como era de las dificultades que podía acarrearle una interpretación de su obra entendida como pronunciamiento en favor de un conjunto de valores de carácter moral y político distantes de la doctrina oficial en el país.

Su rechazo a hablar de si mismo y de su obra durante toda su carrera como arquitecto tras la II Guerra Mundial, contrasta con las explicaciones que difundió sobre sus vicisitudes en la guerra, llenas de pormenores que han sido obviados en esta tesis, pero que pueden ser consultados en op. cit. 3.13. Esta circunstancia puede interpretarse como una expiación del sentimiento de culpabilidad que le producía haberse librado de una gran parte del conflicto armado al haberse refugiado en Suiza, una situación que podría ser interpretada como privilegiada respecto de arquitectos de su país.

La estigmatización del exiliado, que no regresaba a combatir en la resistencia del país, marcó enormemente a toda una generación de intelectuales y creadores polacos que pasaron la guerra en el extranjero; como Kazimierz Wierzyński, quien tras su huida a Francia se refugió en Estados Unidos, o Witold Gombrowicz, que tras haber sido invitado a cubrir la travesía desde el puerto de Gdynia del barco Chrobry con un contingente de emigrantes polacos a Argentina, decidió permanecer allí al ser invadida Polonia en 1939.

La II Guerra Mundial provocó una catástrofe humana que rompió en Polonia cualquier lazo afectivo que pudiera existir con la idea de nacionalismo. La destrucción material y social hundió cualquier manifestación de superioridad o capacidad de expresión de fuerza que el pueblo polaco pudiera sentir orgullo de demostrar, derivando el pensamiento de los intelectuales del país en los primeros años de postguerra hacia una nueva organización social constituida por una comunidad multiracial y multicultural, en la que todos los ciudadanos tuvieran las mismas posibilidades y los mismos derechos; visión constituida en gran parte gracias a las aportaciones menos traumatizadas de los intelectuales que no habían vivido la Guerra en Polonia, entre los que se encontraba Marek Leykam.

En Varsovia, la destrucción material y humana fue alcanzando durante el desarrollo de la guerra cada año niveles más dramáticos. Durante las ejecuciones llevadas a cabo por el ejército alemán en 1943 fue fusilado en la calle el profesor Stefan Bryła ${ }^{3.16}$ (3.15), Decano de la secreta Facultad de Arquitectura de la Universidad Tecnológica de Varsovia -que se mantenía en funcionamiento de forma clandestina-, y la misma suerte corrió Mieczysław Kotarbiński, el profesor que había organizado junto a Leykam el concurso de Zułów en 1935 (Véase p. 77). ${ }^{3.13}$

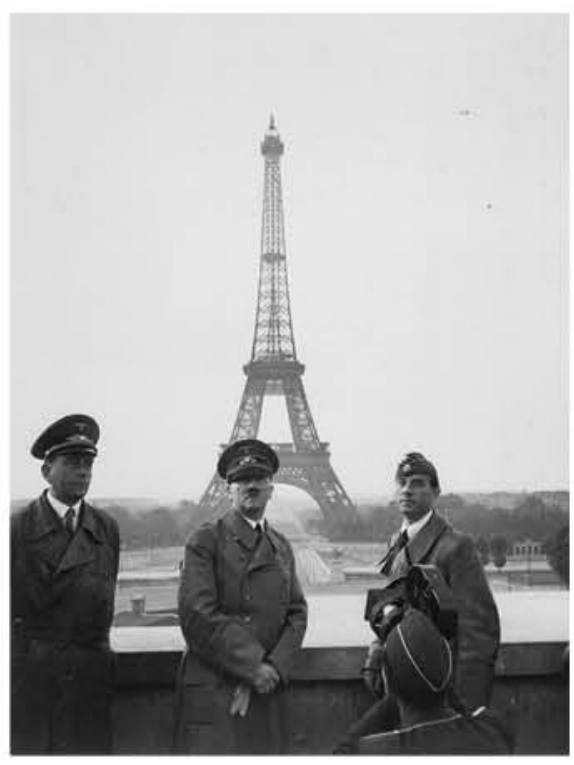

3.11

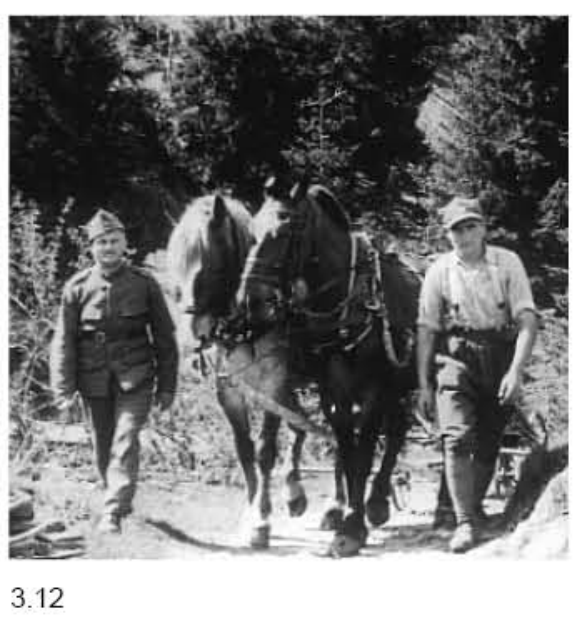

3.15. Andrzej Tadeusz Bonawentura Kościuszko (Mereszowszczyzna, 1746 - Solothurn, 1817). Fue un ingeniero y líder militar polaco que se convirtió en heroe nacional en Polonia y Bielorrusia además de Independencia. brillantes generales de Polonia y Lituania. 
3.13 Población civil llenando sacos de arena en el de Varsovia durante el Levantamiento de Varsovia en agosto de 1944

3.14 Hora " $W$ " del Levantamiento de Varsovia el 1 de "Agosto de 1944. El arquitecto Stanisław Jankowski sobre los números 8 y 10 de la plaza de Cásimiro el Grande (pl. Kazimierza Wielkiego)

3.15 Fotografía del arquitecto e ingeniero de la construccion stefan aryla (1886-1943) pionero en asesinado en la calle por soldados nazis el 3 de diciembre de 1943.

3.16 Maciej Nowicki en la Escuela de Construcción

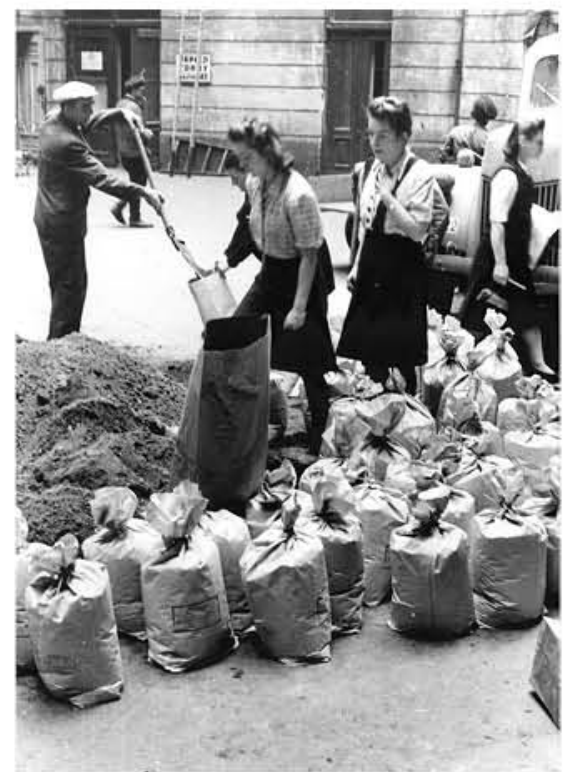

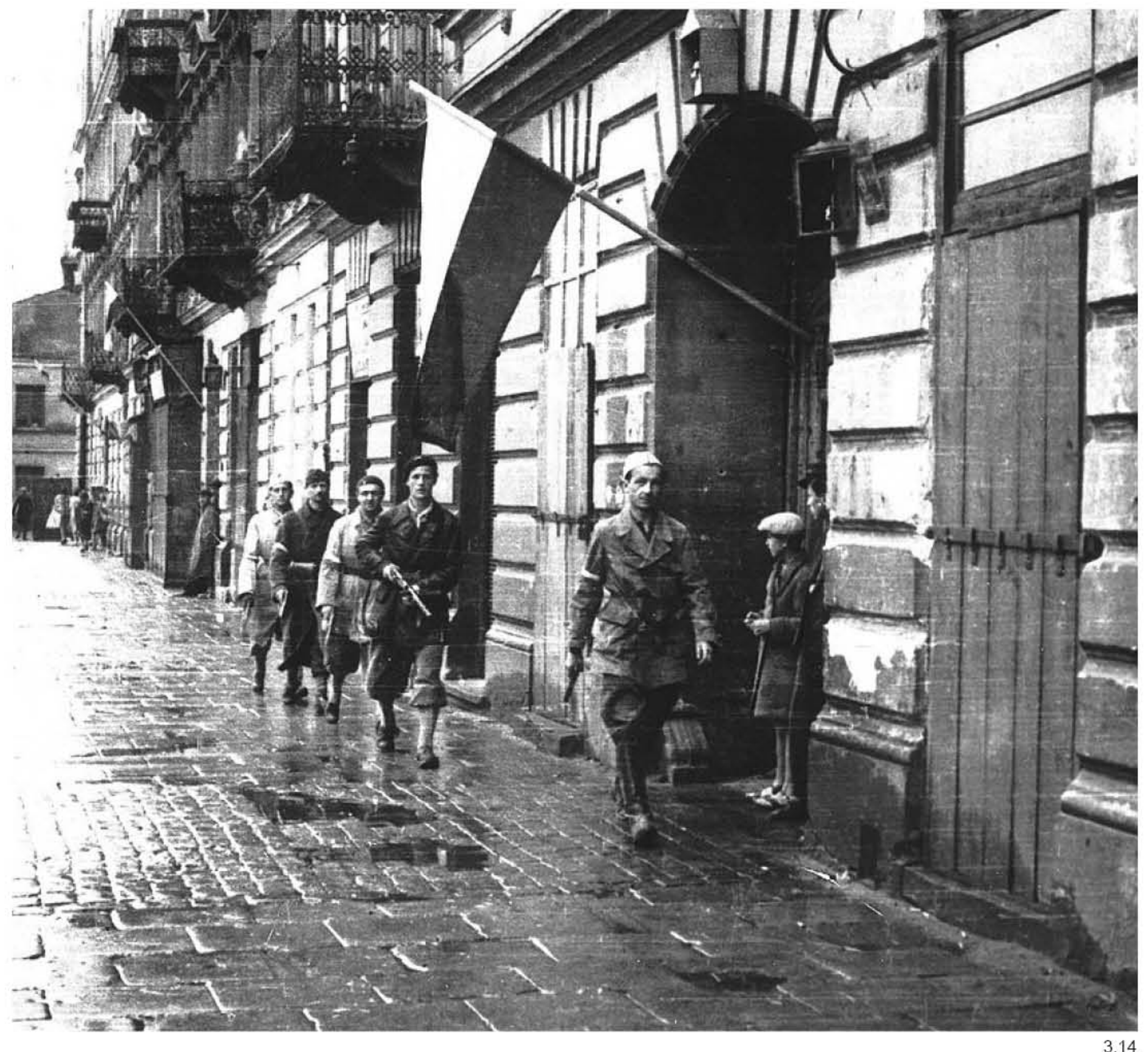


A pesar de las condiciones desfavorables, los arquitectos que permanecieron en Varsovia trataron de mantener la actividad y continuaron impartiendo la docencia a través de la autorizada Escuela de Construcción. Maksymilian Goldberg ${ }^{3.17}$ dio clases de historia de la arquitectura y dibujo técnico dentro del propio ghetto de Varsovia hasta su muerte en 1942, e incluso llegó a dirigir varias tesis doctorales, como la de Juliusz Żórawski, quien defendió su trabajo "Impacto psicológico de la arquitectura sobre el ser humano"(1943); ó Kazimierz Wejchert que presentó "La ciudad polaca como cuestión urbana" (1944). Se organizaron incluso concursos de arquitectura cuya información pasaba de boca en boca, como el "Diseño de 3 tipos de casas en el mercado de una pequeña ciudad" en 1943, al que se presentaron 32 proyectos, o el "Concurso para una casa lúdica en un pequeño pueblo cercano a Varsovia", que recibió 25 propuestas. ${ }^{3.13}$

En 1944, se realizó además un concurso para la construcción de una calle al que fueron presentados 25 proyectos y hubo intención de publicar los resultados, pero lo impidió el estallido del levantamiento de Varsovia en 1944. Se crearon, asimismo, pequeñas construcciones que con el tiempo adquirieron relevancia en la arquitectura polaca como la Villa en Podkowa Leśna (1943-1944) de Maciej Nowicki, que fue reconstruida en 2009. Pero el Levantamiento de Varsovia, en el que también moriría uno de los docentes más apreciados de la Politécnica de Varsovia, Marian Lalewicz, resultó ser un nuevo y dramático episodio de destrucción en el país. Su resultado fue el anticipo de la realidad a la que Polonia debió enfrentarse al finalizar II Guerra Mundial, la eliminación de cualquier atisbo de reafirmación nacional y el abandono por parte de las potencias Aliadas ante la tutela dominante de la Unión Soviética. ${ }^{3.13}$

Con la sensación general de que el conflicto bélico estaba llegando a su fin, el primer ministro polaco en el exilio Stanisław Mikołajczyk ${ }^{3.18}$ trató de negociar con Stalin el reconocimiento de la frontera Polaca y su independencia al finalizar la guerra habida cuenta que los ejércitos polacos estaban combatiendo junto a los Aliados en el Frente Occidental pero su negativa acompañada del comportamiento de la URSS con los territorios recuperados a los alemanes hizo temer a los dirigentes polacos la dificultad de la empresa. Mikołajczyk instó entonces al Ejército Patriótico de Polonia (Armia Krajowa) a levantarse contra la dominación Nazi a escasos días de la llegada del Ejército Rojo, con el objetivo de recibir los contingentes de liberación en una posición de fuerza que les permitiese negociar en mejores condiciones su autonomía y su futuro autogobierno. ${ }^{3.03} 3.19$

El 13 de julio de 1944 las tropas del Ejército Rojo habían llegado a la antigua frontera polaco-soviética, y el 29 de julio, las primeras tropas soviéticas llegaron a los suburbios de Varsovia. El 1 de agosto el Armia Krajowa puso en marcha el Levantamiento con el objetivo de liberar Varsovia antes de que lo hiciera la Unión Soviética, pero los soviéticos en vista de los acontecimientos detuvieron sorpresivamente su avance y pasaron a bloquear cualquier vía de abastecimiento terrestre o aérea que tratase de llegar a Polonia por parte de los Aliados. Las fuerzas insurgentes polacas fueron abandonadas a su suerte por el ejército que se suponía que venía a liberarlas. Durante más de 4 meses las unidades soviéticas permanecieron acampadas y bloqueando sus aeródromos, mientras el ejército alemán se ocupó de sofocar la rebelión masacrando material y humanamente Varsovia con la connivencia de Moscú. ${ }^{3.19}$
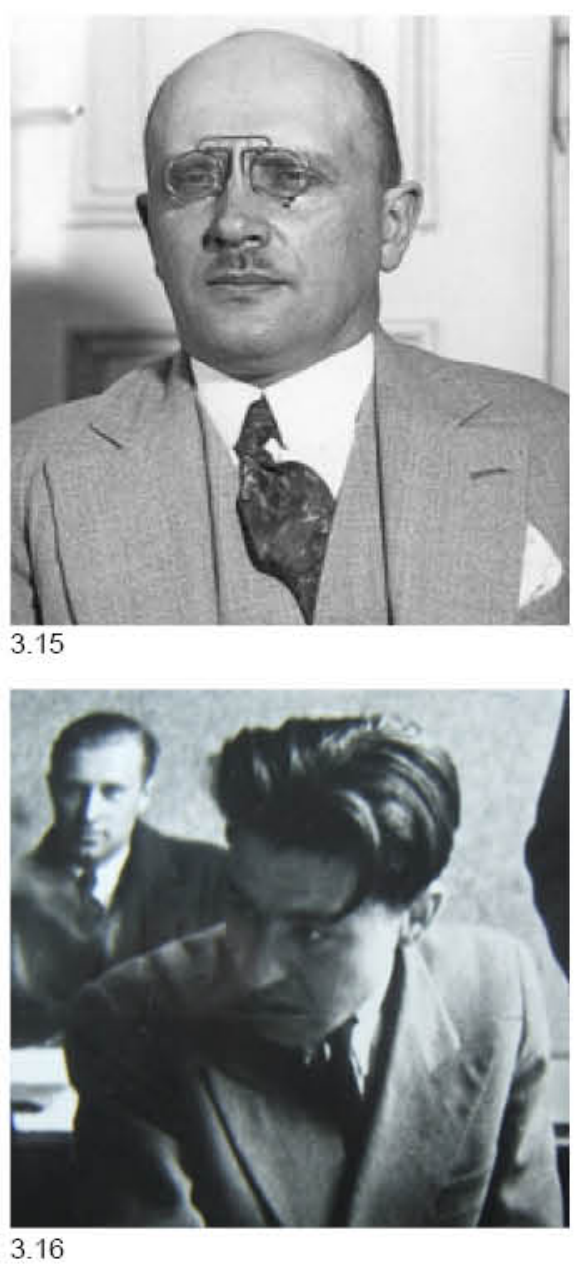

3.16

3.16. Stefan Bryła (1886-1943) Arquitecto e ingeniero de la construcción, uno de los pioneros en la construcción de estructuras soldadas.

3.17. Maksymilian Goldberg (1895 - 12 agosto 1942) Arquitecto polaco de origen judío, autor de la casa de la Prensa en c/ Marszałkowska 3/5 (1927-1929).

3.18. Stanisław Mikołajczyk (1901-1966) Viceprimer ministro (1940-1943), pasó a ser primer ministro de gobierno polaco en el exilio y en julio de 1943 tras la muerte de Wladyslaw Sikorski en Gibraltar.

3.19. Véase Davies, 2005 
3.17 Soldados de infantería alemanes en las calles de Varsovia durante el Levantamiento de Varsovia en

3.18 El 28 de agosto de 1944 el edificio Prudential fue alcanzado por un misil de 2 toneladas con un la calle Copérnico, 28. Fotosiafí: Sylwester craun.

3.19 Soldados alemanes dinamitan planificadamente Varsovia de 1944.

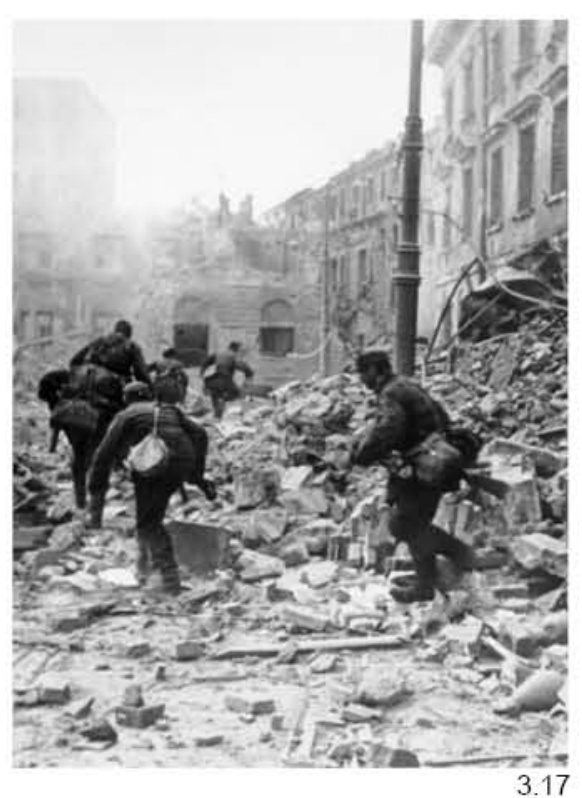

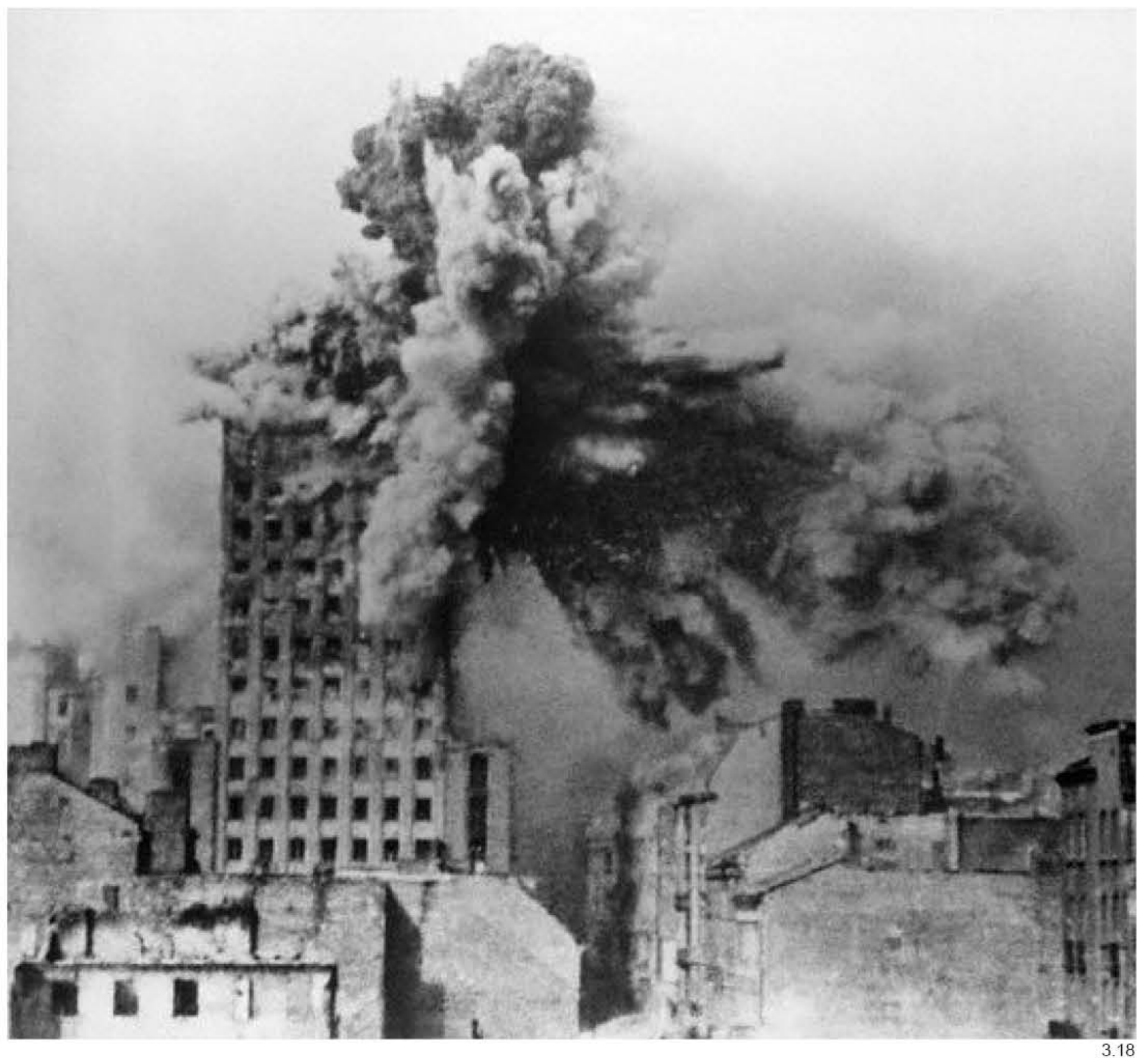


La capitulación no fue sino un punto y seguido para la destrucción de Varsovia. ${ }^{3.20}$ Durante el Levantamiento más de 18.000 soldados del AK y 250.000 civiles polacos murieron, ${ }^{3.21}$ en episodios tan dramáticos como la matanza de Wola en la que fueron ejecutados 40.000 civiles en un solo día. Una vez que la capital polaca estuvo vacía, los nazis continuaron demoliendo la ciudad edificio por edificio al dictado de las órdenes de Hitler, que había conminado a "arrasar Varsovia sin prisioneros, un ejemplo aterrador para el resto de Europa." ${ }_{3.22}$

Tropas de ingenieros alemanes llegaron a la zona para planificar la demolición controlada de todos los edificios que habían sobrevivido. Con la ayuda de explosivos y lanzallamas, fueron arrasando la ciudad casa por casa, prestando especial atención a los monumentos históricos, archivos nacionales, bibliotecas y puntos de interés más significativos. ${ }^{3.03}$ En enero de 1945 se calcula que el $85 \%$ de los edificios de Varsovia habían sido destruidos. ${ }^{3.03}$ La poca actividad de reconstrucción o finalización de los edificios empezados antes de la guerra -como las viviendas en la colonia Żoliborz del matrimonio Brukalski en 1940; las viviendas en la plaza Unia Lubelska de Bohdan Pniewski en 1940-1944; o la restauración de la casi terminada estación principal de tren, del arquitecto Czesław Przybylski, que había sido quemada en junio de 1939-, resulto ser en vano, al ser de nuevo arrasada toda la ciudad en 1944. ${ }^{3.13}$

La ocupación alemana de Varsovia salvaguardó para su uso algunos de los mejores edificios de la ciudad, como el Instituto Stefan Batory de Tadeusz Tolwiński (1.03-1.14), que fue dedicado a la enseñanza de los jóvenes provenientes de las escuelas de élite alemanas (Deutsche Oberschule). Del mismo modo, las mejores partes de la ciudad fueron asignadas a los distritos habitados exclusivamente por alemanes. En 1940 ya se había separado con un muro el "ghetto" para la población judía, pero el futuro de Varsovia según los planes alemanes llegó a ser trazado y ya contemplaba una demolición masiva para limitar la ciudad a un punto del tránsito alemán hacia el Este. Estos planes se encuentran entre los dibujos de 1940 de H. Gross y O. Naumberger, y en 1942 de P. Pabst, y fueron diseñados por Albert Speer. ${ }^{3.23}$

Algunos equipos de arquitectos polacos permanecieron en Varsovia, como Szymon Syrkus, quien trabajó en los planes de desarrollo de la ciudad en el estudio de urbanismo del edificio de la Facultad de Arquitectura de la Universidad Tecnológica de Varsovia, dirigida por Tadeusz Tolwiński. Los institutos PAU ${ }^{3.24}$ fueron destinados a realizar estudios sobre la región y la ciudad de Varsovia, dirigidos por Jan Chmielewski, mientras que Zygmunt Skibniewski dirigió un equipo para el estudio de los barrios residenciales del norte de Varsovia, Barbara Brukalska un equipo para la expansión del barrio WSM en Żoliborz; Szymon Syrkus un equipo para la expansión del barrio WSM en Rakowiec; y Stanisław Dziewulski un equipo para diseñar una zona industrial al oeste de Varsovia. ${ }^{3.13}$

La División de Fusileros polacos refugiada en Suiza recibía con estupor los sucesos acontecidos en Varsovia. Sus trabajos para el ejército suizo no solo sirvieron para pagar la deuda de su internamiento y su educación, sino que fue recaudada gran cantidad de dinero para ayudar a los civiles de Polonia. Solo en 1943 se recogió entre los soldados un cuarto de millón de francos, lo que les permitió enviar a casa, entre otras cosas, el equipamiento completo de un hospital. ${ }^{3.13}$

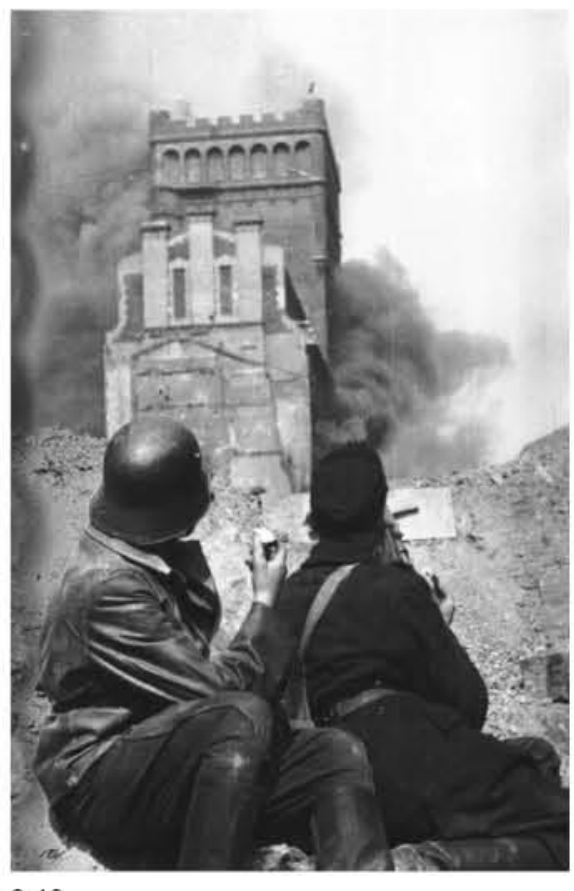

3.19

3.20. Davies, 1979 .

3.21. Getter, 2004. p. 71-72.

3.22. Sawicki, 1949. p.41

3.23. Albert Speer (1905-1981) fue el arquitecto jefe de Adolf Hitler y Ministro de Armamento y Guerra de Tercer Reich durante la Segunda Guerra Mundial. Se puede encontrar información sobre estos dibujos en Op. Cit. 3.13.

3.24. En 1940 fueron creadas una serie de Institutos de Vivienda, Arquitectura y Urbanismo (PAU) Spółdzielczość Mieszkaniowa SPB Pracowni Architektoniczno-Urbanistycznej (PAU). 


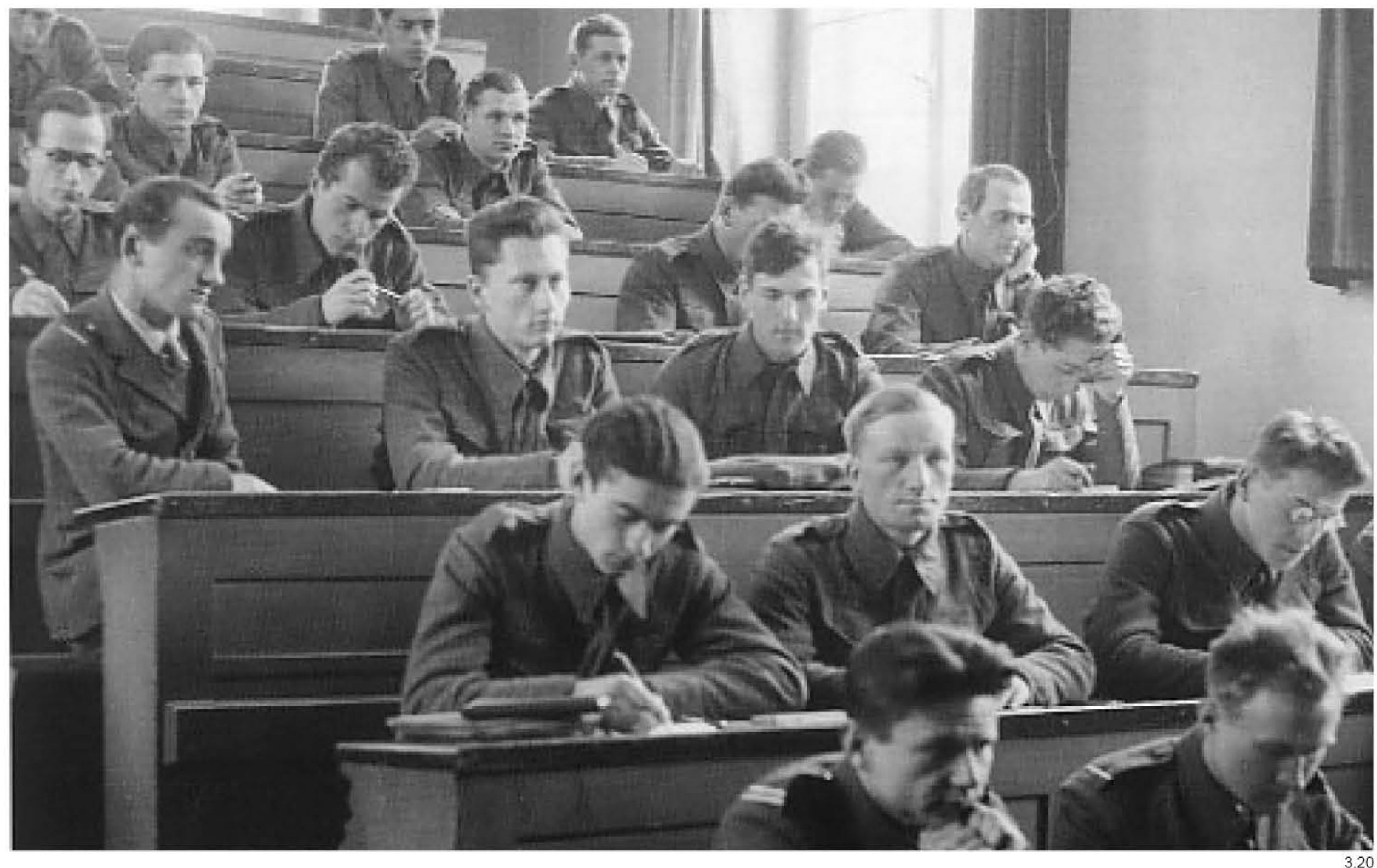


Las universidades de Friburgo y Zúrich, junto con la HEC de Saint Gallen y un campamento que formó el Lycée en Wetzikon proporcionaron cursos de especialidades principalmente técnicas. Bajo ese programa, Marek Leykam fue desplazado a Winterthur, donde se encontraba el campo académico de la ETH ${ }^{3.25}$ junto a su comandante Włodzimierz Prochaska ${ }^{3.26}$, también arquitecto, y tuvo la oportunidad de convertirse en asistente del grupo polaco de estudiantes de arquitectura. ${ }^{3.14}$

En los años 1940-1942 sus clases y conferencias tuvieron lugar en Winterthur, mientras que a partir de 1942 empezaron a desarrollarse en Zúrich, y desde 1944, cuando era obvia la victoria de los aliados, tuvieron lugar en Zúrich a excepción de las de dibujo técnico, que tenían lugar en los salones del museo Gewerbe. En 1942, Leykam lograría permiso del rector de la ETH de Zúrich para imprimir cuadernos de notas para los estudiantes polacos y poco después el gobierno polaco en Londres reconoció oficialmente su universidad con sede en Winterthur. En 1943 obtuvieron permiso para expedir diplomas oficiales y en 1944 la ETH reconoció también la Universidad y permitió a los alumnos homologar sus títulos. ${ }^{3.14}$

La ETH de Zúrich era en aquel momento una institución rica no tanto por las altas tasas de matrícula como por la cantidad de donaciones del sector industrial, ya que se educaba a los estudiantes principalmente para trabajar en las empresas asociadas a la universidad. A los arquitectos polacos se les equipó con herramientas gráficas, material de escritura y apuntes, y tuvieron acceso a todas las bibliotecas suizas e incluso a algunas alemanas. ${ }^{3.14}$

La formación técnica que los arquitectos polacos adquirieron en Suiza resultó clave en la reconstrucción de Polonia en los años venideros, ya que la composición de la ETH de Zúrich en esos momentos hizo que en el contenido de las asignaturas de proyectos existiese una visión práctica de la arquitectura basada en la participación de los estudiantes en estudios de arquitectura para realizar prácticas, su inclusión en visitas de obra y la dirección de sus contenidos hacia unas composiciones de carácter constructivamente eficaz. ${ }^{3.14}$

Las clases de proyectos estaban dirigidas por los profesores Hess, Dunkel, Salvizberg y más tarde por Platz, combinando diseño con correcciones de construcción y estructuras. Además de conferencias, los estudiantes tuvieron acceso a numerosas visitas docentes a edificios de Zúrich y viajes a las zonas en la que iban a proyectar. Toda esta información fue recogida en cuadernos y fotocopiada a partir de diapositivas que suministraba la cátedra sirviendo de referencia a los arquitectos polacos a lo largo de toda su carrera. ${ }^{3.14}$

Los proyectos desarrollados en la ETH Zúrich eran controlados por asistentes y profesores, y al final del semestre se realizaban exposiciones y una sesión crítica con los estudiantes en la que se mostraba el diseño realizado y se discutía con el autor. La evaluación del profesor se realizaba en sesiones críticas abiertas y publicas en las que todos podían participar. El proyecto debía incluir los principales cálculos estructurales, los dibujos y la valoración de los costes del proyecto, es decir, tenía que dar pruebas de conocimiento real de diseño y estaba planteado para ser construido. ${ }^{3.14}$

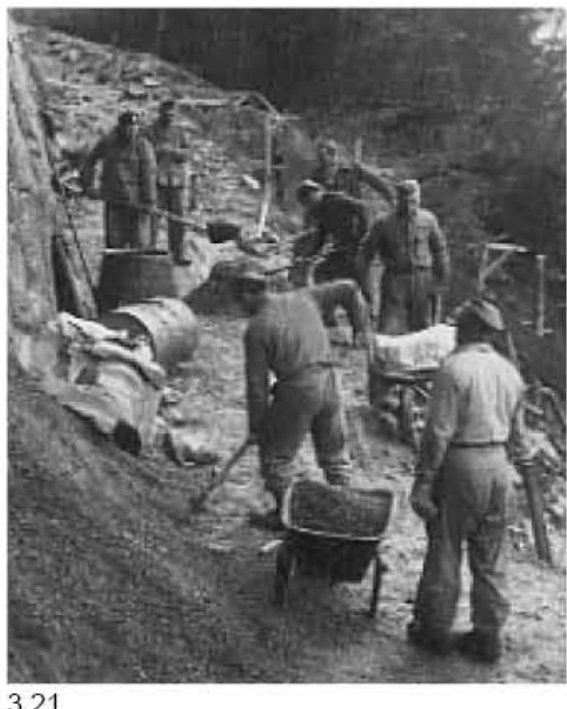

3.21

3.25. Eidgenössische Technische Hochschule Zürich.

3.26. Włodzimierz Prochaska (1900-1992). En los años 1927-1939 había sido un importante construc tor en Gdynia. Tras la guerra construyo el Pabellón la Politecnica de Gdańsk (1964-71). 
3.22 Edificio principal de la ETH (Eidgenössische
Technische Hochschule) de Zürich (1861-1864) de los arquitectos Gottfried Semper y Gustav Zeuner en Zürich (Suiza)

3.23 Cartel anunciador de la exposición de arte en el museo Gewerbe entre septiembre y octubre

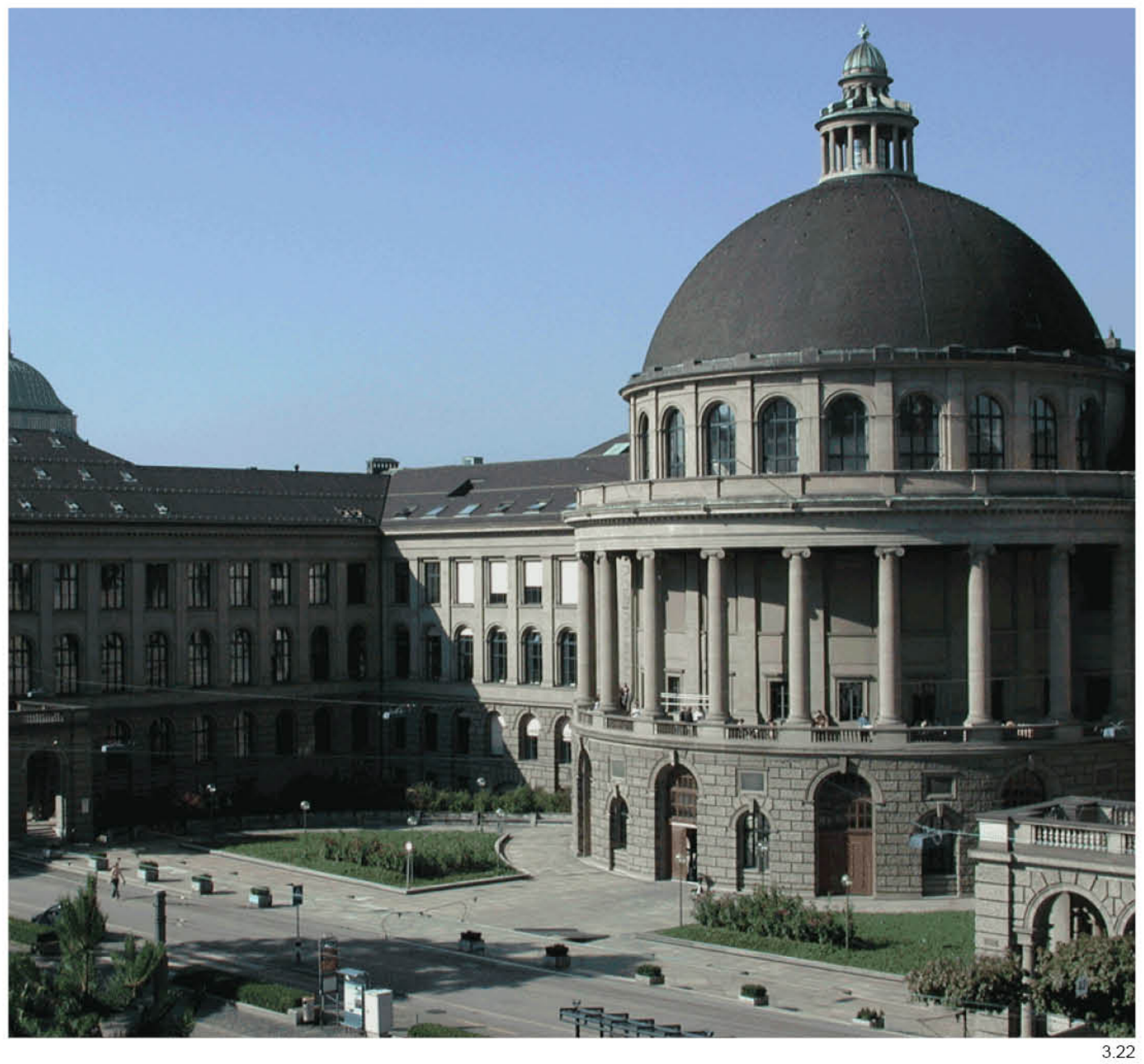


Además de trabajar y estudiar, su estancia en Suiza ofreció a Marek Leykam la posibilidad de familiarizarse con sus experiencias nacionales en el campo de la arquitectura y el urbanismo. El largo periodo de paz que había tenido el país hizo que el arquitecto pudiera convivir con un desarrollo económico y cultural muy superior al que había conocido en Polonia y pudiera establecer, en base a sus anotaciones y estudios, un conjunto de planes a largo plazo que podían ser desarrollados al volver a casa. ${ }^{3.29}$

En Suiza existía, y continua existiendo a día de hoy, un pensamiento colectivo marcadamente funcional en lo económico y disciplinado en lo moral. La experiencia con los materiales prefabricados estaba siendo satisfactoria en el país, debido a la precisión con que desarrollaban las soluciones y el cuidado por la calidad técnica de las mismas, así como la permanente confrontación con las necesidades de los habitantes. Por su parte, las reflexiones en torno a la planificación regional también eran, y siguen siendo, el resultado de un desarrollo urbano dirigido desde los cantones y pueblos, pero coordinado a escala nacional teniendo en consideración la necesidades de cada área y permitiendo la participación de los ciudadanos y potenciales usuarios en cada nuevo proyecto. ${ }^{3.29}$

La presencia en aquellos años de formación de Otto Rudolf Salvisberg en la ETH de Zúrich influenció sobremanera al joven Leykam debido a su forma de entender la arquitectura, en consonancia con las enseñanzas que el aprendiz polaco había recibido de Perret. Salvisberg, graduado en 1904 en la escuela técnica en Burgdorf, había trabajado en el taller de Robert Curjel y Karl Moser en Karslruhe antes de partir a Berlín en 1908, donde había trabajado en la construcción asociado a una inmobiliaria de la que se independizó para establecer su propio negocio en 1914 como constructor. Su formación técnica le llevó a la promoción y la producción constructiva de grandes asentamientos y urbanizaciones para trabajadores en el ámbito de Berlín, Baviera y la cuenca del Ruhr, siendo responsable del levantamiento de más de 1000 casas entre las que se encuentran barrios como "Onkel Toms Hütte" (La cabaña del tío Tom) en 1926 junto a Bruno Taut y Hugo Häring. ${ }^{3.27}$

El programa de estudios suizo establece, todavía hoy, una diferencia muy clara entre los estudios técnicos de construcción con los que contaba Salvisberg, desarrollados en un Fachhochschule, y el perfil académico de quienes han formado parte de una Universidad Politécnica. Sin embargo, en 1930, Karl Moser - tras la negativa de la ETH de Zúrich a aceptar a Hans Schmidt como catedrático por "razones políticas" 3.27- decidió proponer a Salvisberg como catedrático en su lugar.

A raíz de aquel nombramiento, Salvisberg comenzó a formular fundamentos teóricos respecto a la arquitectura, un aspecto del que hasta ese momento se había mantenido al margen, interpretando la profesión desde una perspectiva práctica como correspondía al ejercicio que había hecho en su carrera profesional. En su conferencia "Técnica y expresión formal en la construcción" ${ }^{3.28}$, Salvisberg formuló su adhesión a la concepción moderna en estos términos: "EI adversario de la nueva arquitectura se aleja principalmente de todo aquello que es inhabitual y se remite al patrimonio formal de épocas pasadas (...). No intuye nada de la evolución de la forma, no conoce el sentido profundo que hay en la técnica, en la verdadera expresión formal de la nueva arquitectura." 3.28

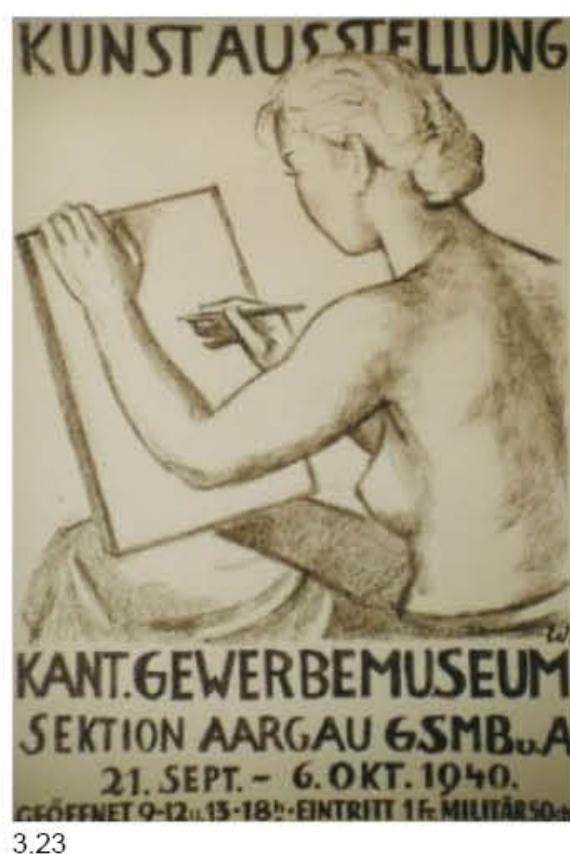

3.27. Lichtenstein, 1977. p. 61-69.

3.28. Salvisberg, 1933. Op. Cit. 3.27

3.29 Jur, 1977 p $32-36$ 

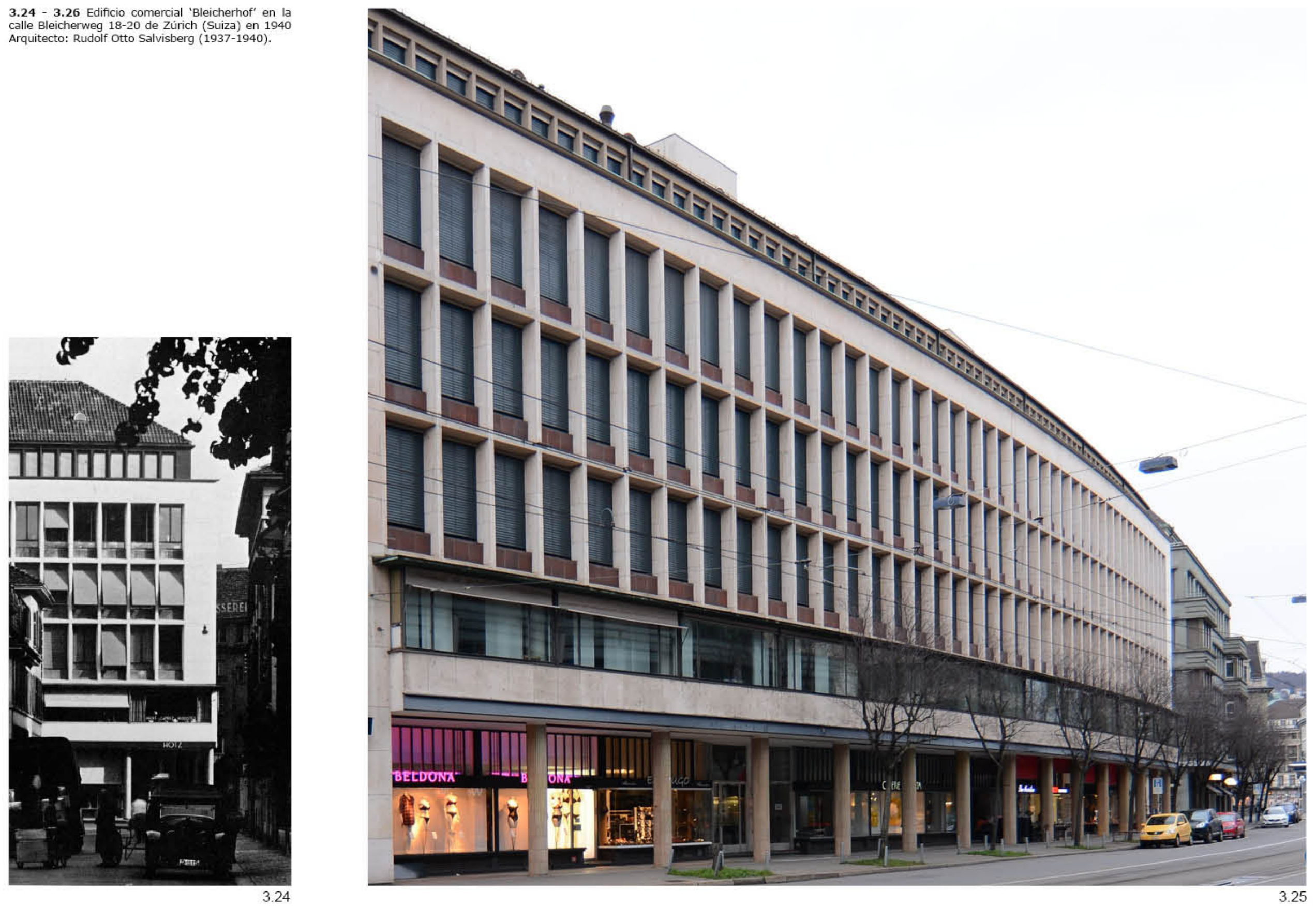
En 1933, Salvisberg afirmaba: "El arte de la construcción es la facultad de conjuntar sistemáticamente, de acuerdo con conceptos y métodos técnicos adquiribles por aprendizaje, unos elementos arquitectónicos individuales en una unidad armónica, estructurada estéticamente. (...) Sin un sentido ennoblecedor, que vaya más allá de la lucha por la existencia. El hombre se contentaría con el "objetivismo" de construir, con la síntesis lógica de acuerdo con puntos de vista racionales." ${ }^{3.27}$. Esta idea de 'sentido ennoblecedor', enlaza con una visión humanista de la arquitectura que será compartida por Leykam y fue adquirida por el polaco a raíz de su estancia en Suiza. ${ }^{3.27}$

La propuesta arquitectónica de Salvisberg era, en definitiva, la de un técnico que pretendía que el programa fuera el que encontrase su verdadera ordenación, y la construcción resultase consecuente con las posibilidades técnicas sin dejar de formar parte de la expresión formal del edificio. Desde una simplicidad extrema, Salvisberg demostraba a sus alumnos sus principios a través de la visita a sus obras, tales como el edificio "Bleicherhof" Stockerstrasse 38 de Zúrich (3.253.26), construido a partir de 1938 , y finalizado en 1940 . ${ }^{3.27}$

Tras la muerte de Salvisberg, el edificio 'Bleicherhof' fue considerado un "prototipo de la reconstrucción de la época inicial de la postguerra". ${ }^{3.27}$ El planteamiento de proyectar construcciones sencillas desde la técnica y la expresión constructiva, entroncó en la Europa de postguerra con la necesidad de una rápida reconstrucción, y propició la aparición de una importante escuela de continuadores de las teorías de Salvisberg entre los que se iba a encontrar Marek Leykam, que en Polonia concentró esa necesidad de una producción rápida y eficaz de la arquitectura para hacer frente al caos organizativo y humano presente en el país durante la segunda mitad de los años 40 . Con una forma de proyectar basada en la prioridad de la modulación y las relaciones de proporcionalidad de todos los elementos para optimizar la prefabricación, Leykam tomó de Salvisberg esa predisposición por establecer procesos que permitieran integrar en todo momento los avances de la técnica, redundando en construcciones cada vez más eficaces como objetivo primordial. ${ }^{3.27}$

Según Leykam había aprendido de Salvisberg, "Las construcciones deben ser sencillas, y en caso de necesidad, hay que hacerlas parecer más sencillas todavía" 3.27 La "arquitectura debe ser una plasmación neta y correcta del presente": "No estamos ante una búsqueda de un nuevo mundo, sino ante una evolución de la forma hacia la objetividad" "3.27 Salvisberg se quejaba en repetidas ocasiones de "la desunión de nuestro tiempo" 3.27 , y a través de la arquitectura trataba de buscar "un presente que fivera el equilibrio entre pasado y futuro." 3.27

Tras las enseñanzas de Rudolf Świerczyński y su paso por el estudio de Auguste Perret, Leykam encontró en Salvisberg una reflexión complementaría sobre una misma idea de arquitectura basada en la prioridad de la técnica constructiva y búsqueda de una manifestación 'expresiva', en la medida en que fuera consecuencia lógica de la eficiente construcción, la optimización de los recursos y la simplicidad y eficacia de la dirección de obra. Esta evolución es muy relevante puesto que dota de 'pretensión de realidad' a los principios arquitectónicos.

A pesar de que Leykam intentó repetidamente fugarse de Suiza ${ }^{3.30}$ a través de Francia y España para llegar a Inglaterra

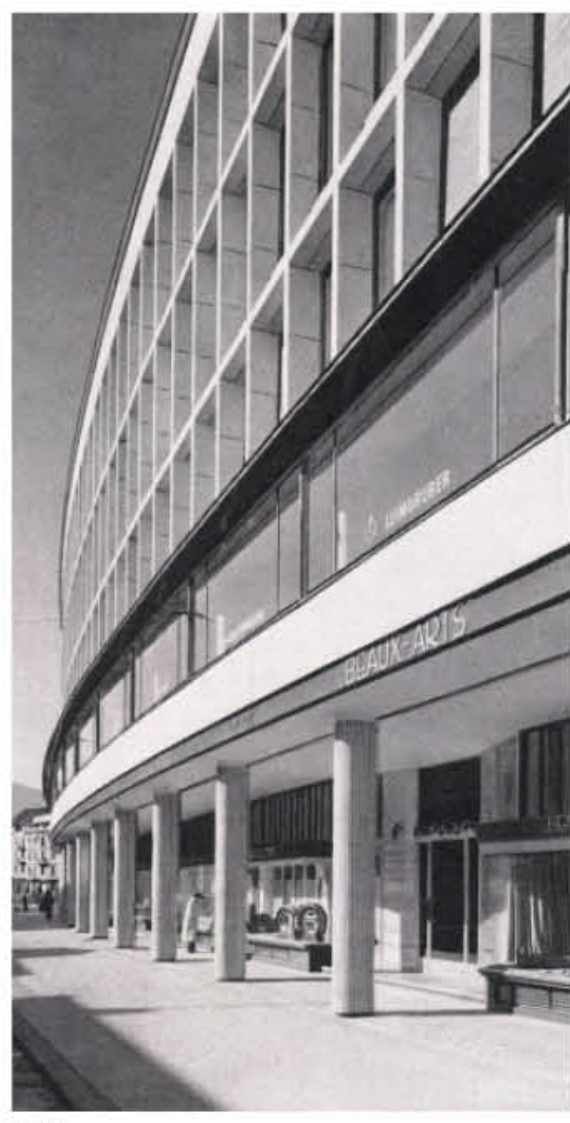

3.26

3.30. Springer, 2011. p 41-72 
3.27 Portada del catálogo de la exposición de la de Winterthur.

3.28 - 3.30 Capilla construida en el Cementerio caidos en la II Guerra Mundial, 1943. Arquitecto: Marek Leykam.

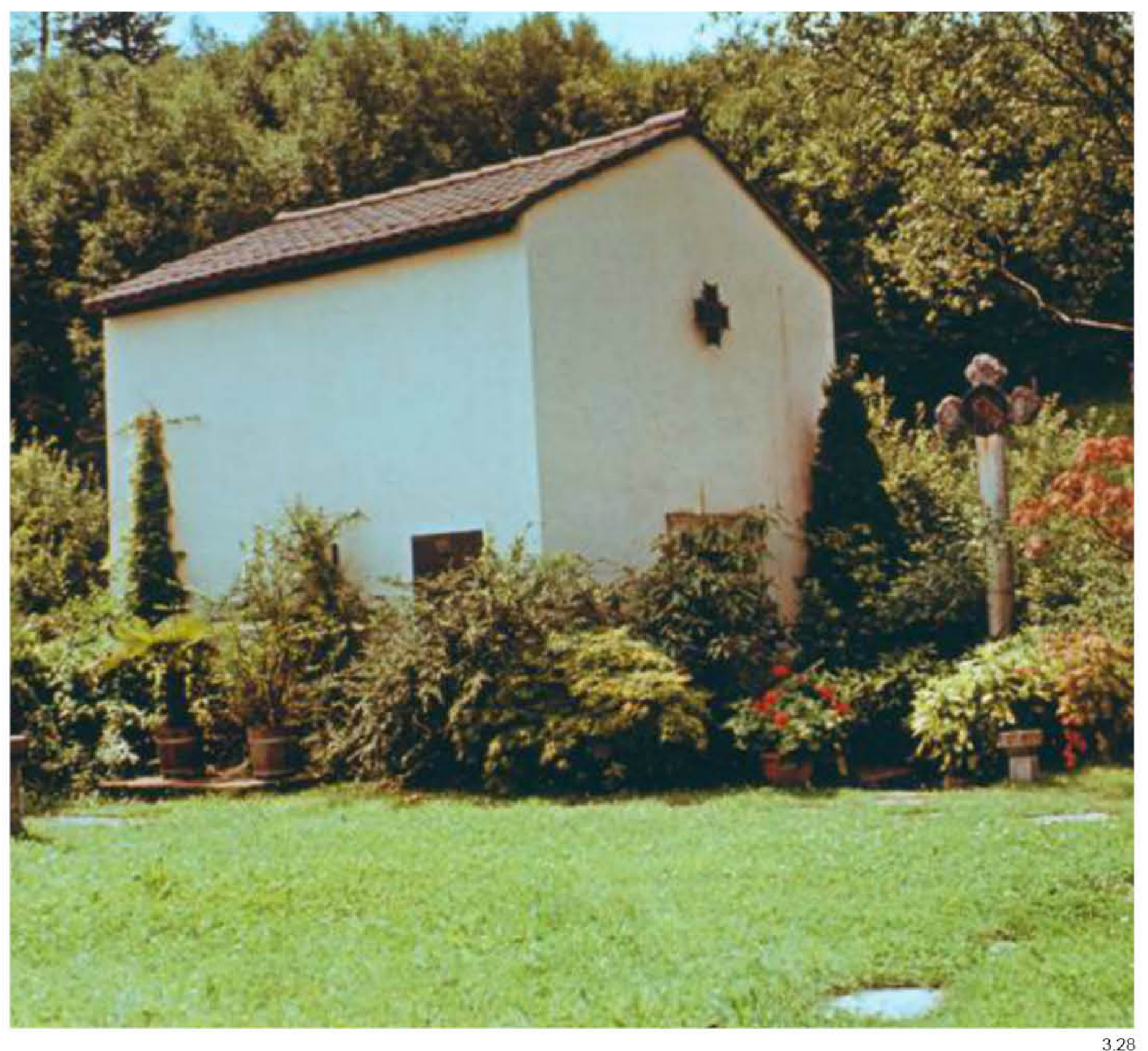

ILSSTELLENGSK ITUIOC DEB ISTEHNIKHTES VOM

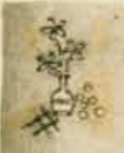


tras las noticias que había recibido sobre la apertura de una Escuela de Arquitectura en Liverpool, los cinco años que permaneció en Suiza resultarían, a tenor de los acontecimientos posteriores, extremadamente beneficiosos para su formación y para el futuro desarrollo de su arquitectura, debido a la familiaridad que adquirió respecto a las técnicas de prefabricación en una sociedad técnicamente muy avanzada y las deliberaciones que tuvo oportunidad de llevar a cabo en un ambiente pacífico sobre la futura reconstrucción del país.

En 1943 se publicó en Suiza un libro sobre composiciones artísticas y literarias de la División de Fusileros Polacos llamado "Estacionario" 3.13 , en el que se encuentran fotos de una modesta capilla construida por Marek Leykam en el Cementerio de Solothurn (3.28) en Homenaje a los soldados caídos en la II Guerra Mundial. Esta ascética pieza guarda una cierta similitud formal con el prototipo de vivienda presentado en 1933 (2.02 - 2.06), aunque la poca información que existe sobre su construcción deja poco margen al estudio de sus circunstancias y motivaciones, más allá del detalle del recortado vuelo de los faldones de cubierta y la curiosidad simbólica de la alusión al icono de la cruz griega en la fachada principal.

Resultan de gran interés, sin embargo, los dibujos y maquetas (3.31-3.35) del proyecto no realizado de esta capilla, que remiten de nuevo a los planos que Leykam presentó en 1936 para el concurso de la Mezquita de Varsovia (Véase p. 76 y ss.), aportando luz sobre su tendencia desde el inicio de su carrera a realizar planteamientos de carácter autoreferencial, aunque no como recreación subjetiva de su trabajo, sino como parte de un método de búsqueda de la coherencia interna y la continuidad de las soluciones formales y constructivas a través de la arquitectura.

El proyecto de Capilla en homenaje a los soldados polacos caídos en la II GM, junto al cementerio de Solothurn (1943), contenía de nuevo una bóveda rebajada de arco carpanel al igual que el proyecto de Mezquita de Varsovia (2.23 - 2.28), detalle que Leykam había heredado a su vez de la Iglesia de Notre-Dame du Raincy de Perret (2.16 - 2.18). En los extremos de esta bóveda se situaban fachadas abiertas mediante texturas que permitían el filtrado de la luz, referenciando de nuevo la soluciones de las obras citadas cuyo origen estaba en la solución de "claustra" prefabricados ensayados por primera vez por los hermanos Perret y Albert Ballu en la Catedral de Orán, 1902-08 (2.22) y que Leykam conoció mientras trabajaba en se estudio en 1934. Esta textura le permite crear de nuevo un tamiz que enfatiza la importancia de la luz en el recinto religioso aunque en este caso el patrón, a diferencia de todas la referencias anteriores, no es exclusivamente geométrico sino que queda recargado tras su trama con la definición de motivos heráldicos con los escudos de armas de diferentes cantones suizos.

Las capillas laterales definen sus huecos con una textura de similares características en las fachadas frontales y laterales, aunque los vacíos están reescalados y enmarcados en la fachada lateral. Las capillas quedan pautadas así por una rítmica concordante con la modulación del alzado, que no permite generar una lectura de esta fachada como un plano abierto y permeable.

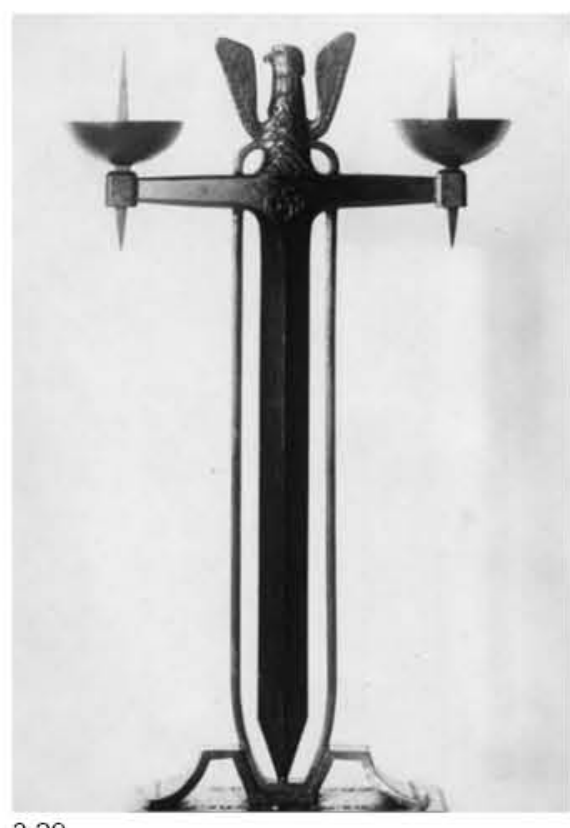

3.29

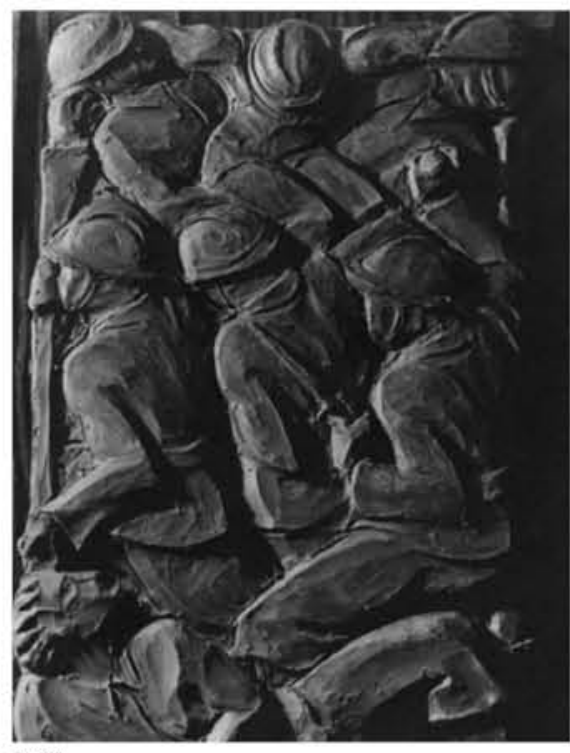

3.30 
3.31-3.35 Proyecto para la Capilla en el cementerio
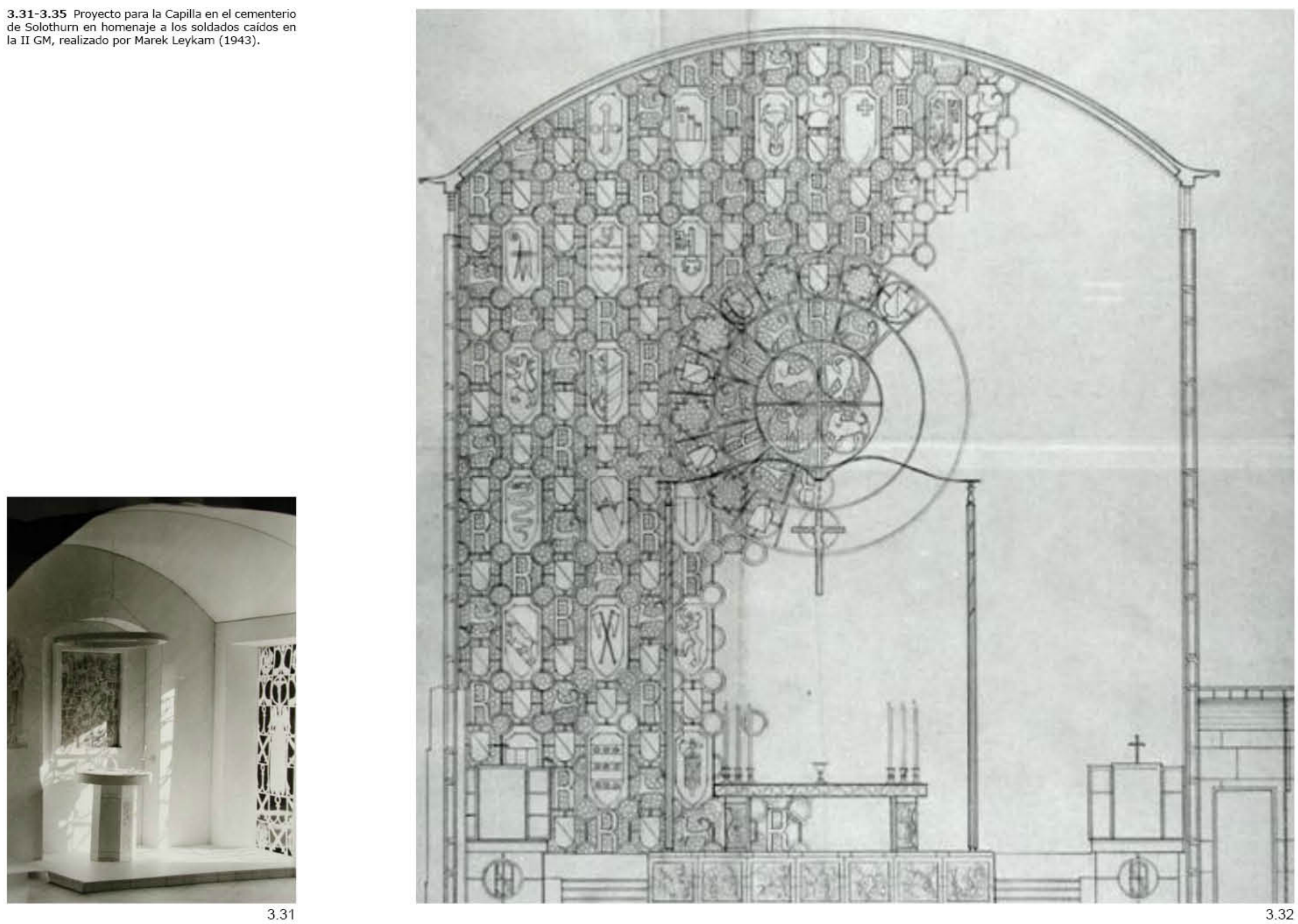

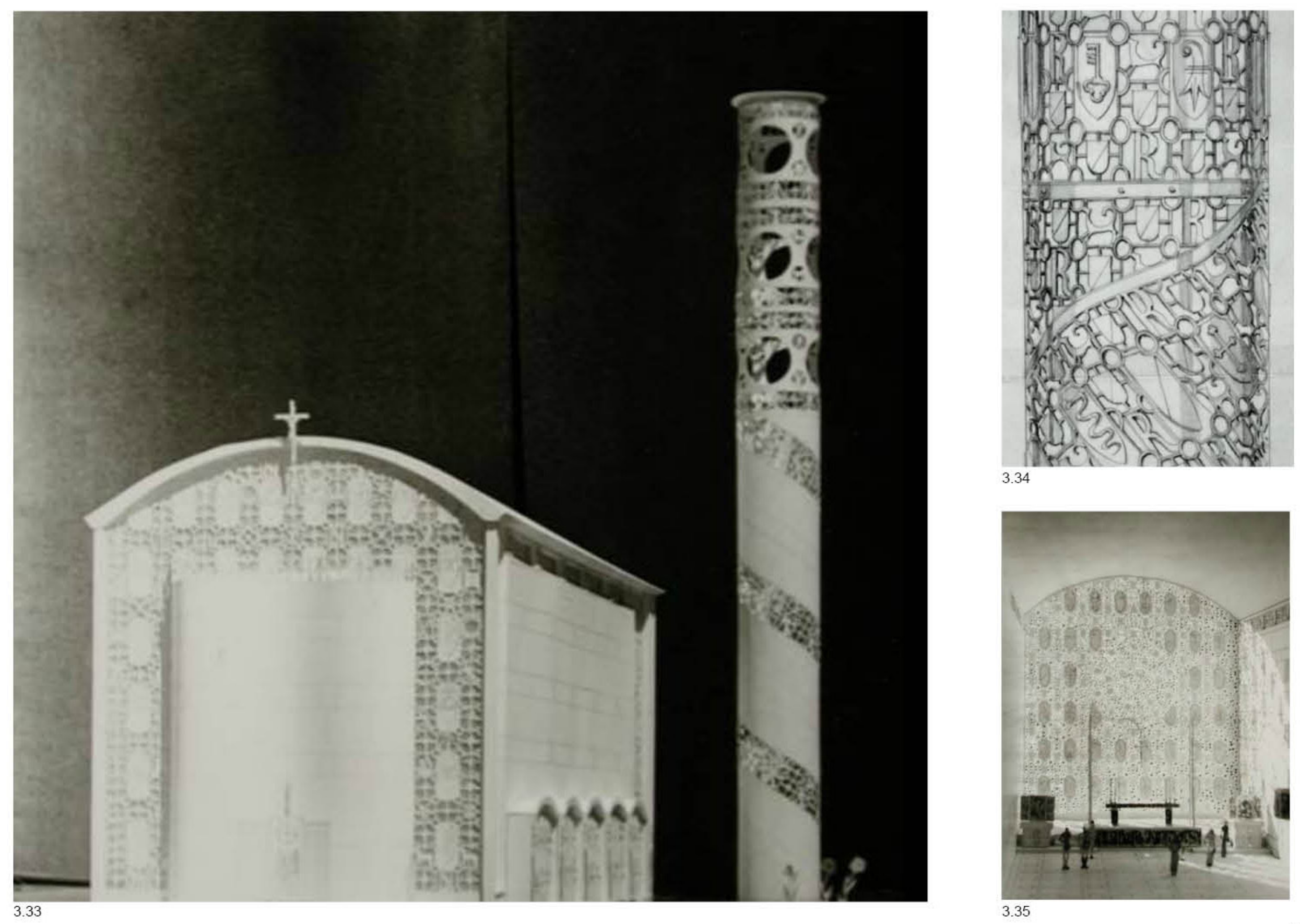
3.36 Condecoración a la Segunda División de Fusileros de Polonia. En la foto: Marek Leykam.

3.37 Ruinas de Varsovia en enero de 1945. Plaza del mercado en el casco antiguo.

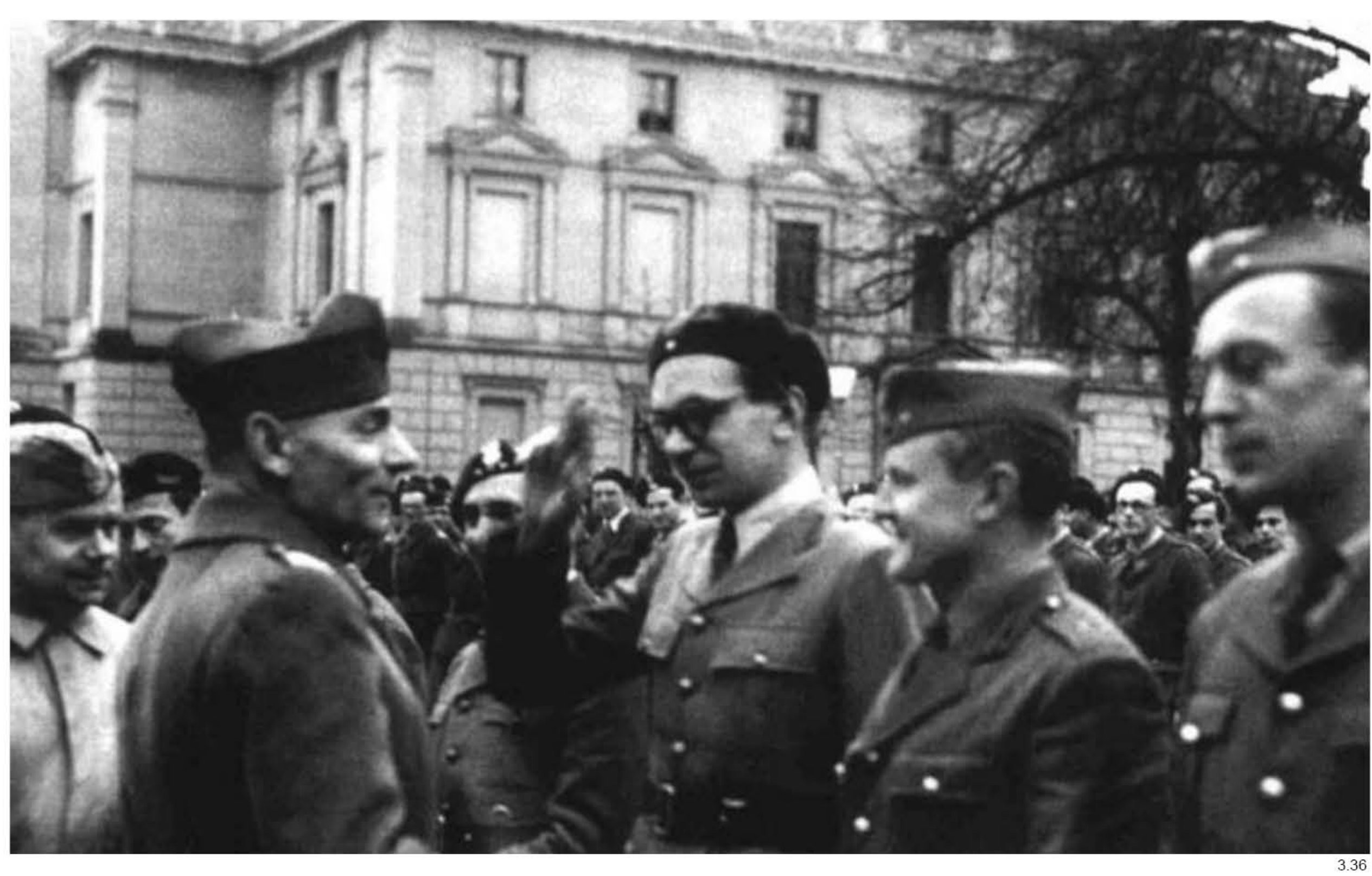


La diferencia radical que proponía Leykam entre el carácter abierto o cerrado de cada plano de fachada todavía no se percibe con rotundidad en estas obras, aunque sí comienza a entreverse al igual que ocurría en el concurso del Banco Nacional en Poznań (2.39-45), donde es incluso más contundente, expresando una de las características fundamentales de la obra de Leykam: la lectura de la direccionalidad.

La principal consecuencia que supuso para Leykam su tiempo en Suiza durante la guerra fue, sin embargo, su profundo desencanto sobre la pérdida de valores que había supuesto esta sinrazón que condujo a la humanidad a tanta destrucción. Leykam inició a través de sus textos una profunda reflexión sobre la barbarie de aquellas luchas y las ideas que absurdamente las sostenían, planteando la necesidad de recuperar los fundamentos éticos y morales en la sociedad, un aspecto que, en aquel momento, encontraba profundamente ligado a su sentimiento religioso. ${ }^{3.31}$

En realidad toda una generación de polacos quedó profundamente marcada por los acontecimientos de aquella guerra tan cruel y sanguinaria, compartiendo en gran medida un sentimiento colectivo de desarraigo y vuelta a la duda propiamente existencial. Un ejemplo de aquellos sentimientos quedó reflejado en la obra de la filósofa polaca María Ossowska: ${ }^{3.32}$

"Existe la creencia común de que en los combates que están ocurriendo ante nuestros ojos la lucha se ha vuelto más violenta y más intensa, al menos en relación a lo que ocurría en Europa a finales del siglo XIX y el comienzo de nuestro siglo.

Sin embargo, la cuestión es que las reglas del juego limpio se han desprendido de la eficacia de las directrices morales y está ocurriendo todo lo contrario: como la calidad moral ha disminuido, esa ausencia está otorgando a la lucha una especial crueldad." 3.33

Al finalizar la II Guerra Mundial ${ }^{3.34}$ Leykam regresaría inmediatamente a Varsovia -una ciudad arrasada en su práctica totalidad-, con la necesidad de programar una rápida reconstrucción que en realidad se hizo extensiva a todo el país. Desde una prioridad por la ejecución rápida y sencilla que economizase los recursos, el planteamiento metódico permitió a Leykam colaborar en este propósito con multitud de proyectos realizados en pocos años aprovechando al máximo los medios disponibles y las condiciones existentes, mediante un conjunto de proyectos que funcionaban como variaciones dentro de una misma idea.

Sobre esa base común, que surgió no solo como fruto de su experiencia docente sino como consecuencia de la profunda reflexión llevada a cabo en sus textos (véase p 149 y ss.), Leykam generó una posición estable que supuso un punto de apoyo de carácter continuo en una época de grandes pulsiones, ofreciendo una resistencia consistente no solo frente a las posiciones subjetivas en plano cultural y arquitectónico sino frente al relativismo en la esfera ética y su reflejo en el ámbito político y social.

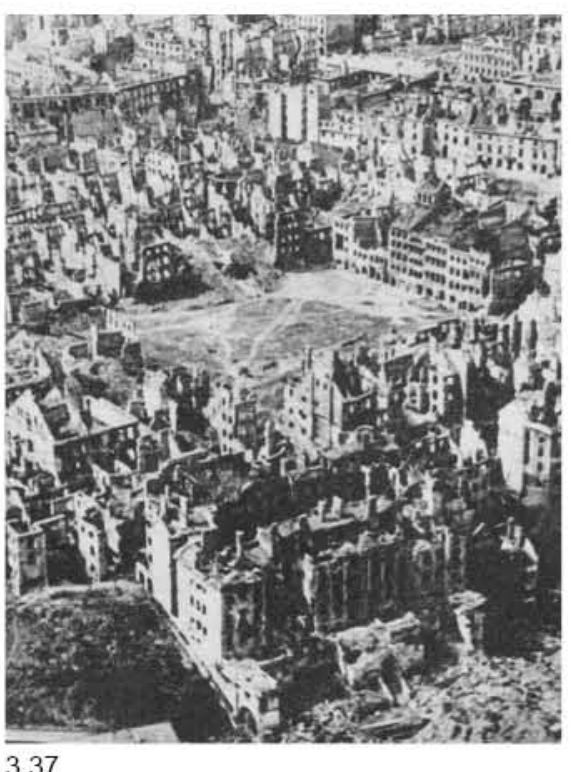

3.37

3.31. Véase cap. 2.2.3 de esta Tesis: "Interpretación de la arquitectura a través de la liturgia" p. 169 y ss.

3.32. Maria Ossowska (1896-1974), fue una socióloga y filosofa social polaca, alumna de Tadeusz Kotarbiński y miembro de la Escuela de Lvov-Varsovia. Véase su relación con la obra de Leykam en p. 153 y ss.

3.33. Artículo "O pewnych przemianach etyki walki" (De algunas transformaciones éticas en conflicto). Fuente: Godlewski, 2013

3.34. Por su participación en los combates de Francia durante la II Guerra Mundial, Leykam recibio la Croix de Guerre, Croix du Combattant y Medaille des Evades. En Polonia, fue galardonado con la Cruz de Caballero de la Orden de la Restitución de Polonia (Krzyżem Kawalerskim Orderu Odrodzenia Polski) Cruz de Plata al Mérito (Srebrnym Krzyżem Zasługi), la Medalla Décimo Aniversario (Medalem X-lecia) y otros premios. Fuente: Krzyżakowa, 1983. 
4.00 Conferencia de Yalta (Crimea) 11 de febrero de 1945. De izquierda a derecha: Winston Chyre his

4.01 "Escena en la mesa. Grupo de tres" $(16 \times 22 \mathrm{~cm})$ Bruno Schulz. tras la ocupación de Polonia en 1939.

4.02 Primer manifiesto del Comité Polaco de Liberación

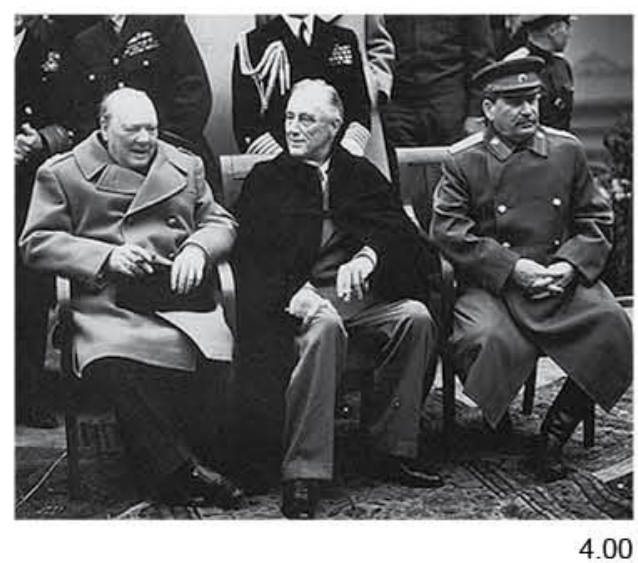

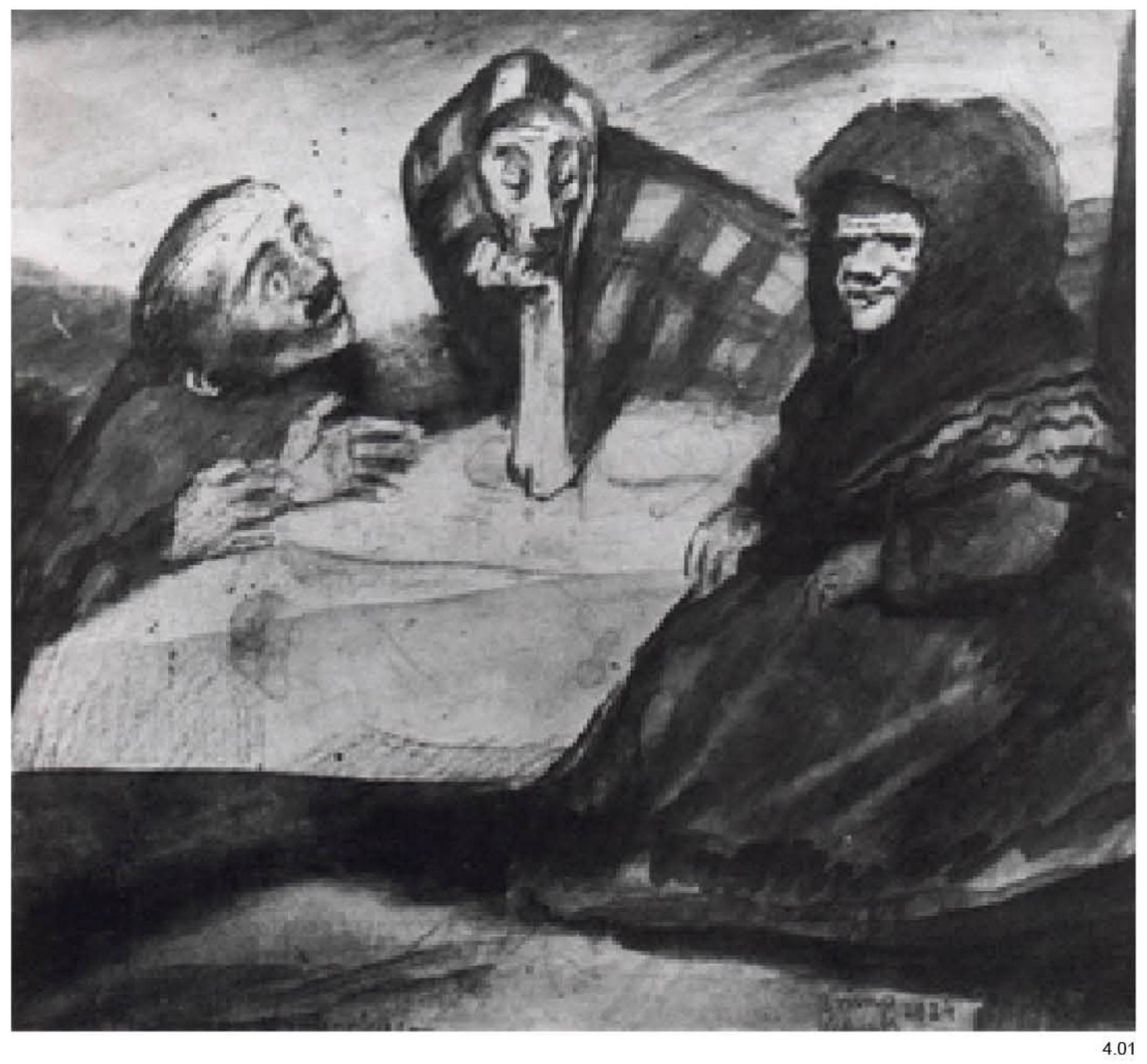


"Camino escéptico entre los escombros de la cultura. A lo largo y ancho de mis ojos veo escombros por todas partes. Camino entre ruinas a lo largo y ancho del pensamiento humano insaciable. (...) Me encantaría jugar al arbitraje y poder juzgar las controversias entre los problemas espectrales, juzgarlos con malicia con la única intención de llevar esta situación al absurdo."

Bruno Schulz.

Wędrówki sceptyka. ${ }^{4.00}$

Terminada la II Guerra Mundial y teniendo en cuenta los términos acordados en la Conferencia de Yalta ${ }^{4.01}$, la administración del poder en Polonia debía ser legitimada "a través de unas elecciones democráticas", 4.02 pero la destrucción de Varsovia, el mayor centro potencial de resistencia contra la nueva ocupación, facilitó la "imposición del régimen comunista y la sovietización del país." 4.03

El 23 de julio de 1944 el Ejército Rojo había tomado Lublin y establecido un Comité Polaco de Liberación Nacional ${ }^{4.04}$ (PKWN ) controlado por la Unión Soviética ${ }^{4.05}$ que comenzó replanteando el retroceso de las fronteras de Polonia hasta la Línea de Curzon ${ }^{4.06}$ deslegitimando así las reivindicaciones del Gobierno Polaco en el exilio. ${ }^{4.03}$

El PKWN extendió su control sobre Polonia según avanzaba el Ejército Rojo, creando su propia administración y recurriendo al arresto o ejecución de miembros de la Armia Krajowa cuando lo consideró necesario. ${ }^{4.07}$ El 31 de diciembre de 1944, tras recibir el permiso de Moscú, el Comité de Lublin se transformó en el Gobierno Provisional Polaco, solo reconocido por la URSS ${ }^{4.07}$. El Partido Obrero Unificado de Polonia (PZPR), ${ }^{4.08}$ bajo el mando de Bolesław Bierut como primer secretario "establecería así un papel dominante en la sovietización de la sociedad polaca." 4.09

Al descubrir de nuevo un poder totalitario en Polonia tras la II Guerra Mundial, multitud de filósofos, docentes, investigadores, artistas y arquitectos como Marek Leykam pusieron su atención en la institución de identidades colectivas que democratizasen de forma efectiva las manifestaciones irracionales de poder absoluto en favor de actuaciones que, a través de su contenido ético, pudiesen devolver a la población la fe en el equilibrio y la justicia social.

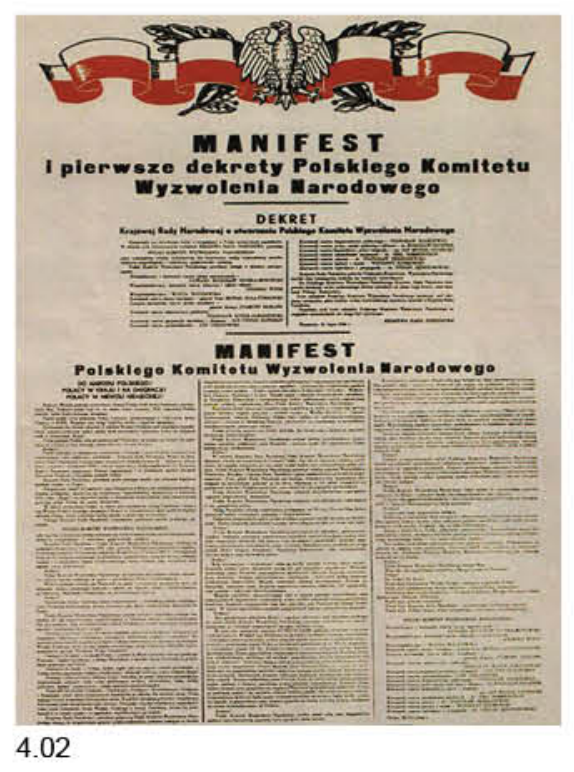

4.00. Artículo Wędrówki sceptyka (Nomadismo escéptico). Bruno Schulz publicado en la revista "Tygodnik llustrowany" 1936, $\mathrm{nr} 6$.

4.01. Conferencia de Yalta (4-11/02/1945) reunión mantenida por I. Stalin, W. Churchill y F. D. Roosevelt, para acordar disposiciones finalizada la II GM.

4.02. Véase "Declaración de la Europa Liberada" 4.03. Cit. Museo del Levantamiento de Varsovia
(Muzeum Powstania Warszawskiego) www 1944 pl 4.04. "Polski Komitet Wyzwolenia Narodowego" (PKWN). Popularmente: Gobierno de Lublin (Komitet Lubelski)

4.05. El gobierno contaba con 5 comunistas, 3 solialistas, 4 miembros del Partido Campesino, y dos independientes. Fuente: Janczewski (1972) p. 429.

4.06. La linea Curzon fue una frontera entre Polonia y la URSS propuesta por Lord Curzon, durante la guerra ruso-polaca de 1919-1920. Parte de Grodno en el norte, hasta Brest y sigue el curso del rio Bug hasta los Cárpatos.

4.07. Janczewski (1972)

4.08. Polska Zjednoczona Partia Robotnicza (PZPR).

4.09. Blazynski (2003). 
4.03 Los generales Dwight David Eisenhower y Marian

de septiembre de 1945.

4.04 Tierras añadidas y sustraidas de Polonia tras la IIGM.

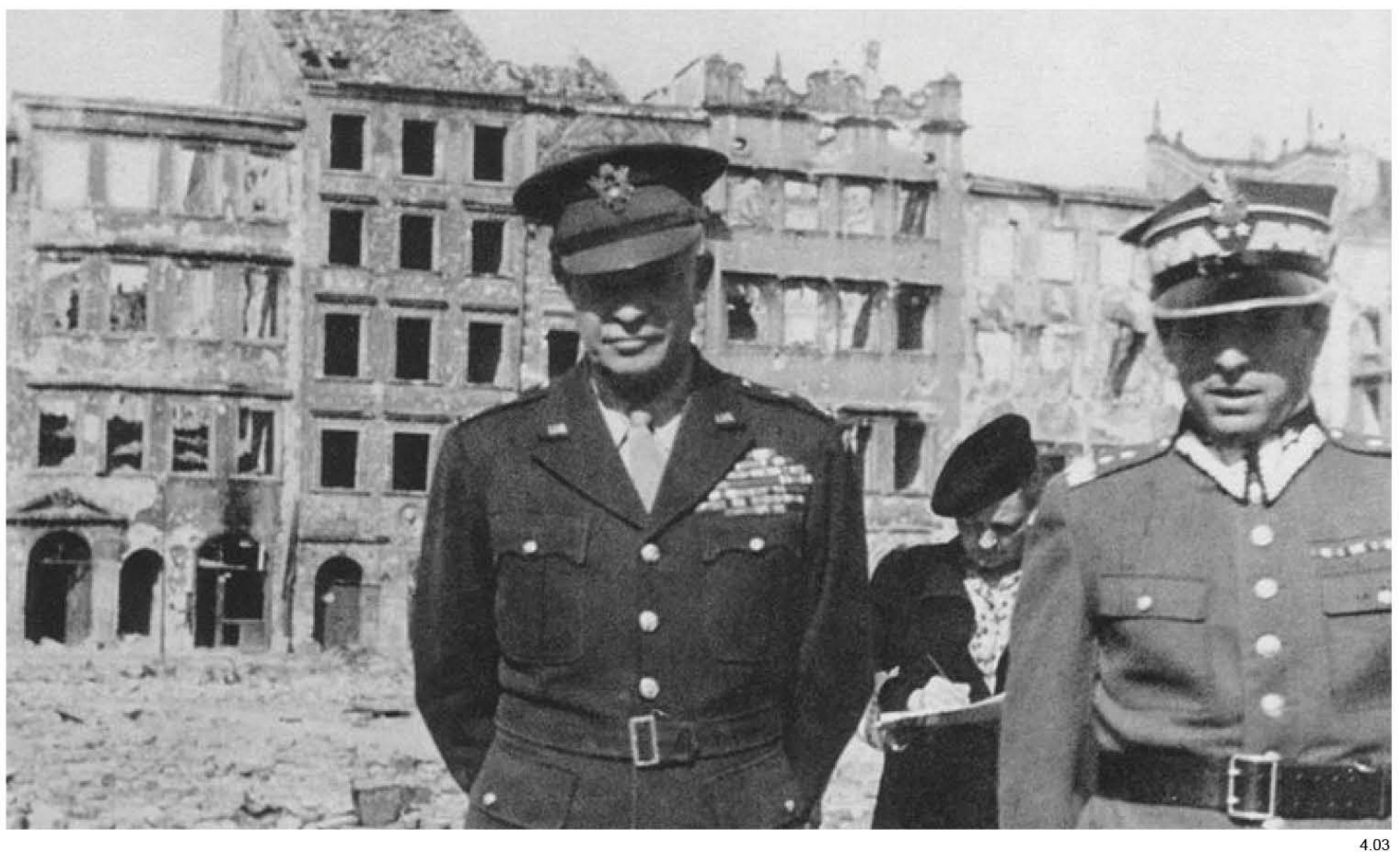


En Yalta, Churchill y Roosevelt habían aceptado implícitamente la legitimidad del PKWN ${ }^{4.10}$, lo que había provocado que la tutela tras la liberación del país tuviera un guión únicamente comprensible desde la óptica de las ambiciones soviéticas. Los vencedores de la II GM habían decidido que Polonia tendría que ceder a la URSS los territorios tomados después de la I GM en 1918 obteniendo como contrapartida la administración de una parte del territorio alemán (4.04), pero quedando todo el país bajo los designios de un gobierno nombrado desde Moscú. ${ }^{4.09}$

En "Escena en la mesa. Grupo de tres" (4.01) Bruno Schulz ya había recogido esa sensación de abandono y miseria del pueblo polaco en la figura de un hombre desencajado que miraba con desesperación a la gran figura femenina que gobierna la escena en el extremo derecho en alusión a la madre Rusia. En esta composición, cuya intensidad alegórica no pierde el paralelismo geográfico, la figura materna retira la mirada a su desencajado interlocutor e ignora el plano que aparece extendido sobre la mesa en la que todos se apoyan. No resulta menos significativa que su expresión de enojo la vestimenta de la figura central del grabado: un edificio como abrigo, como piel, la arquitectura como cobijo fundamental que protege a la población del frío y la crudeza exterior. Toda la esperanza de la figura central está en ese plano que la figura más potente de la composición ignora con desdén.

Cabe recordar que la ingente labor que suponía la reconstrucción del país se iba a ver lastrada por las dificultades del nuevo gobierno para adquirir una base estable que legitimase su poder debido a la desconfianza de una parte importante de la población hacia el nuevo régimen y las disputas sobre las nuevas fronteras posteriores a la guerra, que no llegaron a establecerse firmemente hasta mediados de $1945 .{ }^{4.10}$ Polonia había sufrido enormes pérdidas materiales y humanas. Si en 1939 había 35.1 millones de habitantes ${ }^{4.11}$, al final de la guerra solo se contabilizaban 19.1 millones en el interior de sus fronteras ${ }^{4.11}$, y el primer censo posterior a la guerra, de febrero de 1946, reflejaron solo 23.9 millones ${ }^{4.10}$. Cerca de unos 6 millones de ciudadanos polacos, un $21.4 \%$ aproximadamente, murió entre 1939 y $1945 .{ }^{4.10}$

El 14 de febrero de 1945 por decreto del Consejo Nacional ${ }^{4.12}$, se creó la Oficina para la Reconstrucción de la Capital (BOS $)^{4.13}$ por orden del arquitecto Marian Spychalski ${ }^{4.14}$, quien había sido coautor -junto a Leykam- del concurso para el Centro marítimo de vela en Gdynia en 1936 (2.34 - 2.37) y en 1945 fue nombrado alcalde de Varsovia (4.03). La dirección de la oficina estuvo a cargo de Jan Zachwatowicz y Piotr Biegański, y desde ella se gestionaron todos los trabajos encaminados a la reconstrucción de la capital, entre los que se incluyeron proyectos tan importantes como la ruta WZ (Trasa W-Z), que atravesaba mediante un túnel la calle Miodowa.

Leykam regresó a Polonia en 1945 muy desmejorado físicamente por el escaso reparto de comida y los diversos arrestos que tuvo que sufrir durante su estancia en Suiza por las numerosas ocasiones en que intentó huir a Inglaterra con idea de integrarse en la Escuela de Arquitectura de Liverpool ${ }^{4.15}$. Nada más llegar a Varsovia, retomó su actividad como docente en la Facultad de Arquitectura de la Universidad Tecnológica de Varsovia impartiendo clases de Historia de la arquitectura medieval ${ }^{4.16}$, y trabajando como asistente en el Departamento de Historia del Arte y la Arquitectura ${ }^{4.17}$ entre

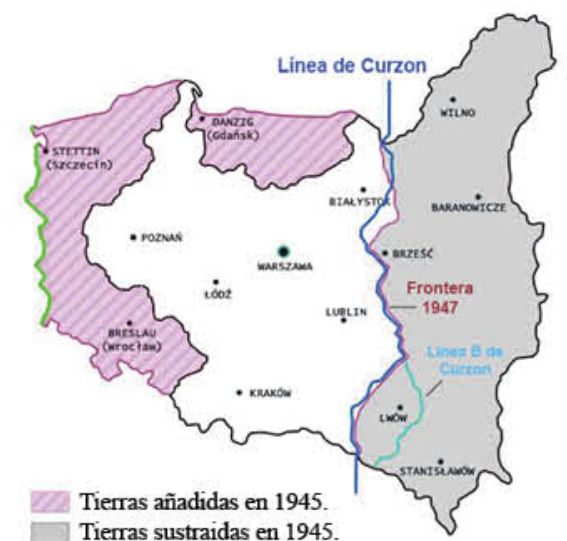

4.04

4.10 Davies, 1979

4.11. Piotrowski, 1997

4.12. Krajowa Rada Narodowa (KRN) fue el cuerpo político creado durante la Segunda Guerra Mundial por el Partido de los Trabajadores de Polonia (PPR) de un autoproclamado parlamento polaco. Fue iniciado por Wladyslaw Gomulka y porteriormente reconocido por la URSS.

4.13. Biuro Odbudowy Stolicy (BOS), cuyo acrónimo fue el sobrenombre ironico "Boze Odbuduj Stolicę" (Dios reconstruye la capital).

4.14. Marian Spychalski era miembro del Partido Comunista Polaco (Komunistycznej Partii Polski; KPP) desde 1931. En 1944 fue miembro del Consejo Nacional (KRN) y en marzo de 1944 fue enviado por Wladyslaw Gomulka a Moscú como parte de la delegación del Consejo Nacional recibida por Stalin. Spychalski tomo parte en la formación del PKWN y fue uno de los redactores de su primer manifiesto (2) en 1944. En mayo de 1945 se convertiria en uno de los miembro del Buró Politico del Comité Central
(Biuro Polityczne KC PZPR).

4.15. Springer, 2011. p 42

4.16. Historię architektury średniowiecznej.

4.17. Katedrze Historii Architektury i Sztuki.

4.18. Szkołą Inżynierską w Szczecinie

4.19. Katedrę Budownictwa Użyteczności Publicznej.

4.20. Jur, 1977. 
4.06 Fotografía de la Plaza Warecki, actualmente plaza del

Levantamiento de Varsovia (Powstańćó Warszawy) tras la II GM.

4.07 El gueto de Varsovia arrasado, en pie la Iglesia de San Agustín

(Swęty Augustyn), 1945.

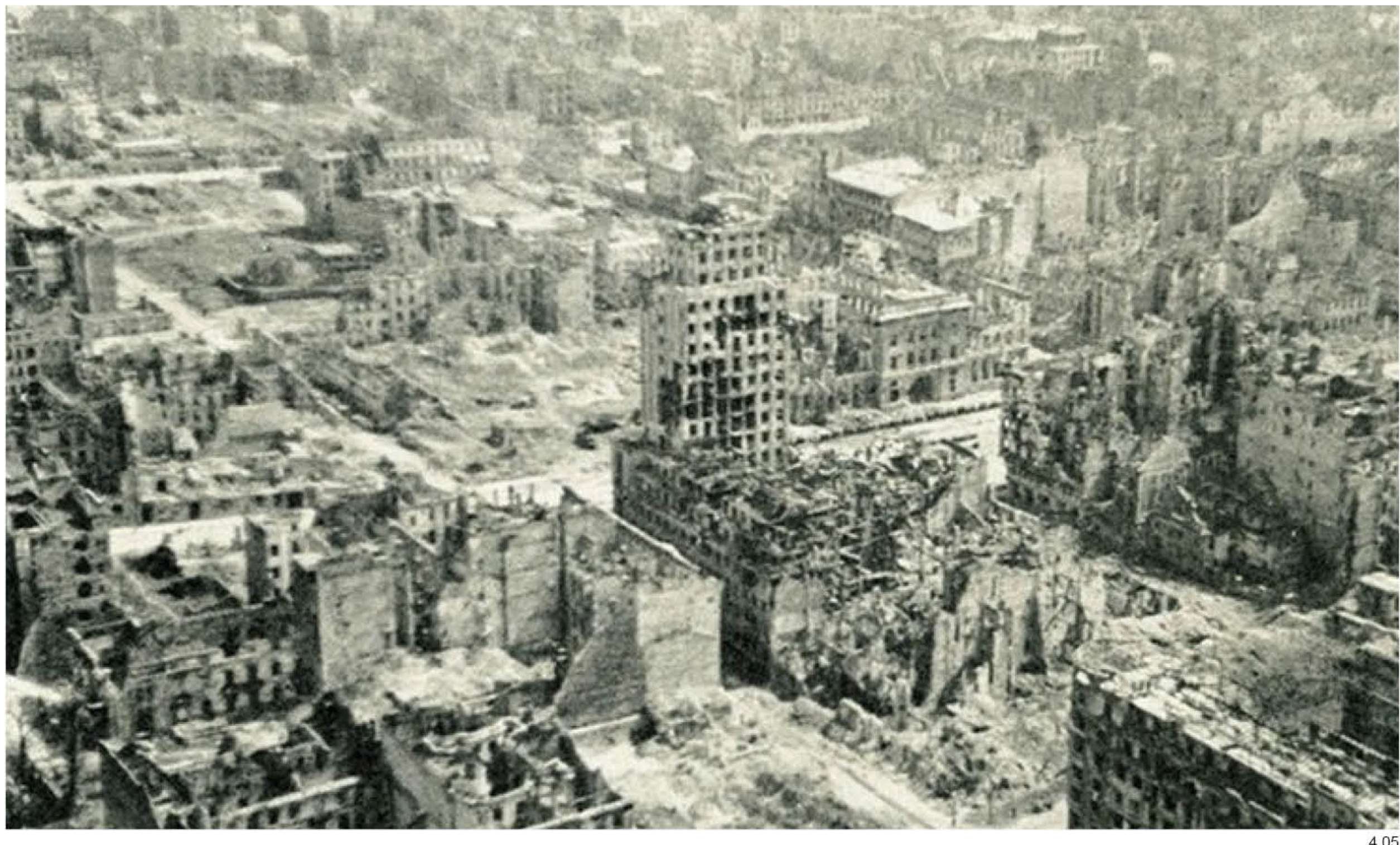




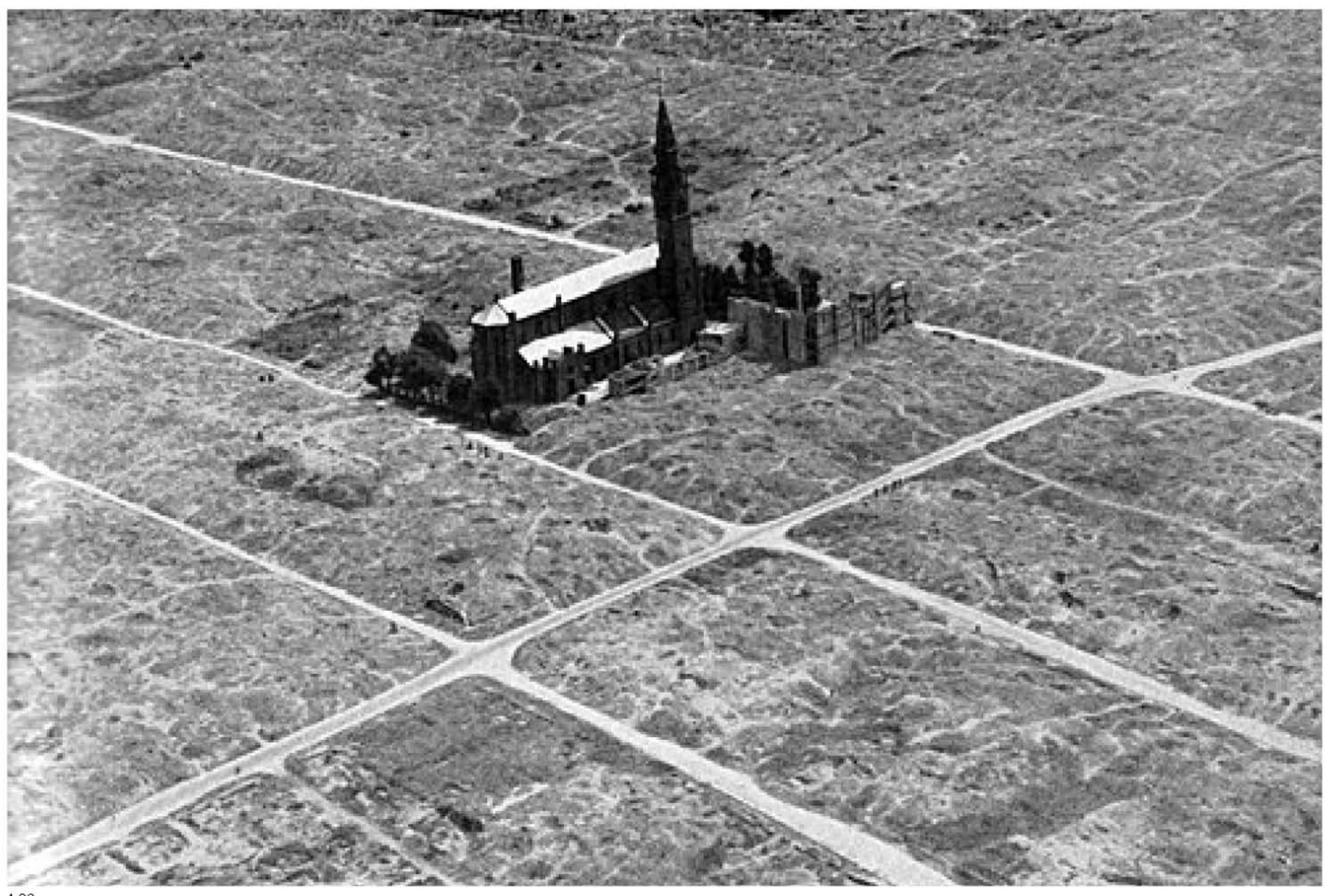


4.07 - 4.08 Ciudad Vieja (Rynek Starego Miasta) durante el proceso de reconstrucción de Varsovia Ciudad (BOS) en el trieno 1947-49.

4.09 Stanisław Jankowski presentando el diseño de (Trasy Bohaterów Starówki) en julio de 1947.

4.10 Laboratorio de la Oficina de Reconstrucción de la Ciudad en Varsovia (BOS).

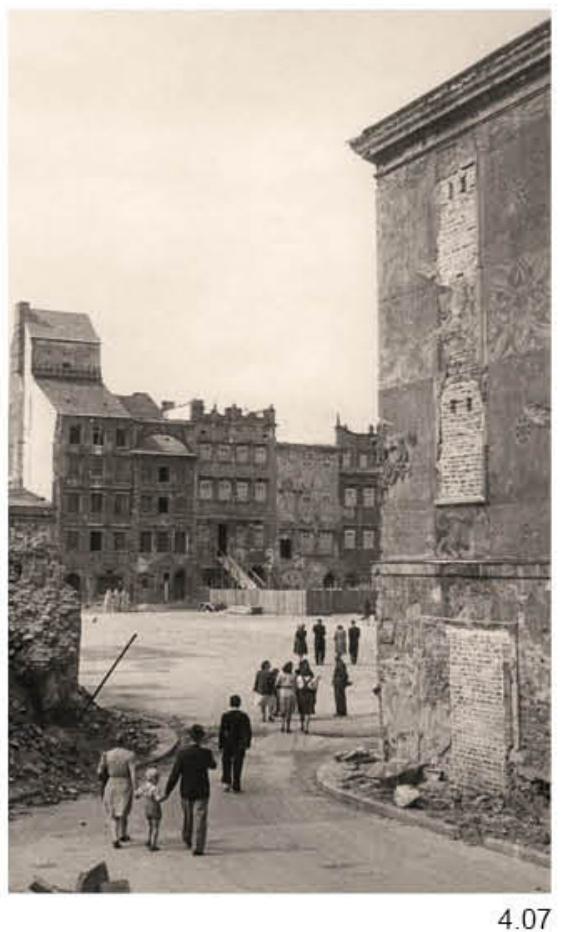

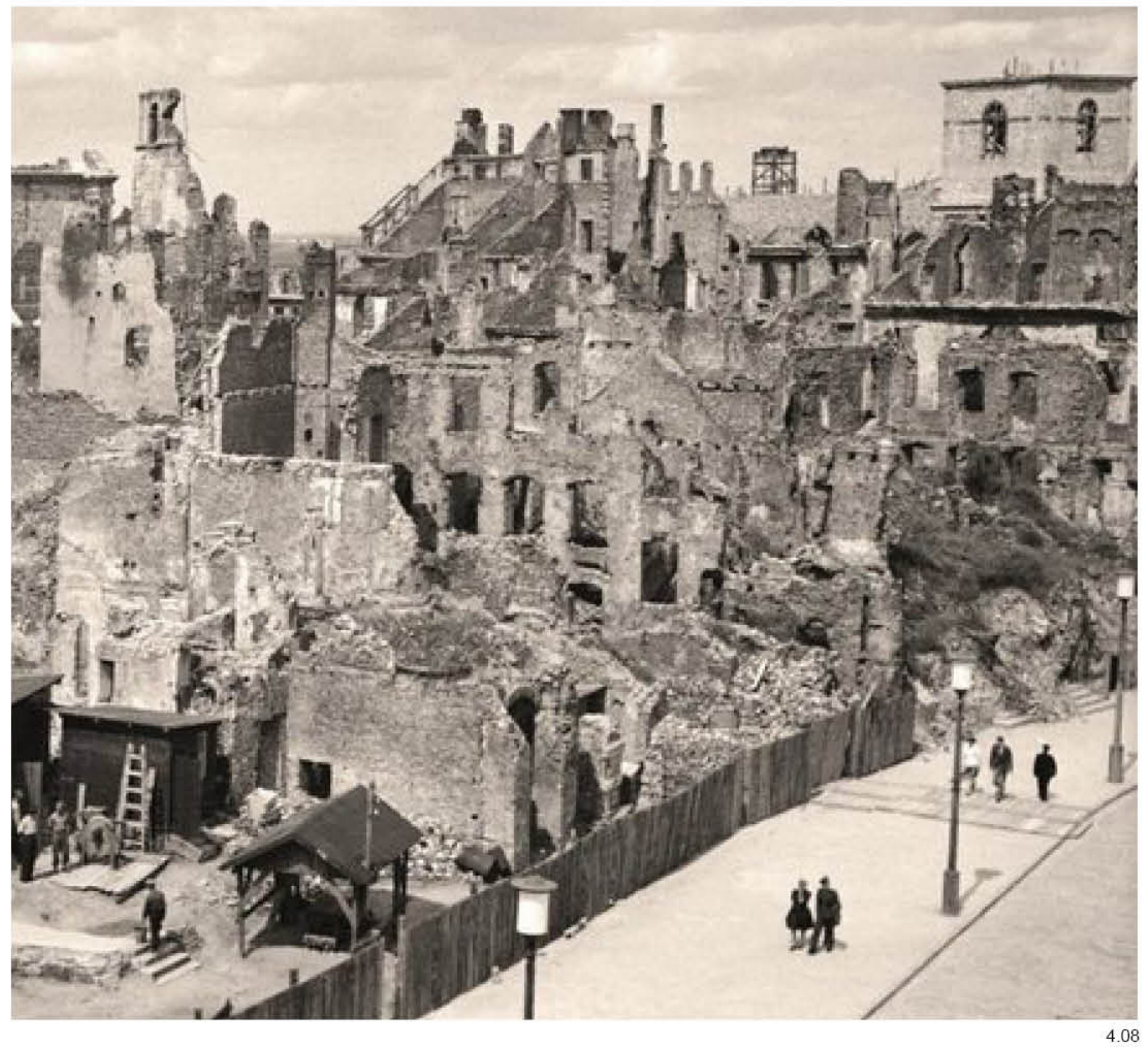


1945 y 1948. También logró una plaza de profesor asociado en la Escuela de Ingeniería en Szczecin 4.18 en la Cátedra de Servicios Públicos de Construcción ${ }^{4.19}$ durante 1949 y 1950.

La devastación de la guerra había propiciado a nivel arquitectónico y urbanístico una situación "única y sin precedentes" 4.20. La destrucción de ciudades como Varsovia alcanzaba el 75\% $\%^{4.20}$ teniendo en cuenta el total de infraestructuras: industria, red energética, medios de comunicación, ... y a ello se sumaba la carencia del personal técnico cualificado necesario para cubrir en poco tiempo esta necesidad. En esas circunstancias fueron llamados a trabajar todos los técnicos disponibles independientemente del papel que hubiesen jugado en la guerra, como quedó patente en el caso de Stanisław Jankowski Agaton ${ }^{4.21}$, uno de los líderes del Alzamiento de Varsovia (3.14) que tras haber huido a Inglaterra en 1946 con la entrada del Ejército Rojo en Varsovia recibió un trabajo como arquitecto en Polonia ante la falta de personal convirtiéndose en uno de los encargados de la ruta WS (4.06) en la oficina BOS. ${ }^{4.13}$

El papel de los arquitectos iba a resultar obviamente clave en la reconstrucción del país. El diseño de nuevos edificios y conjuntos urbanos era urgente y su trabajo debía ser capaz de ajustarse a las necesidades básicas de la población con celeridad, centrando la atención en las soluciones a gran escala de las ciudades y sus espacios de interacción no solo a nivel interurbano sino también territorial.

Para favorecer estas posibilidades se tomó la revolucionaria decisión de "nacionalizar toda la industria y la mayor parte de los terrenos urbanos" ${ }^{4.20}$ creando una situación desconocida hasta el momento en la que era posible planificar racionalmente las ciudades sin tener que dar preferencia a los intereses particulares o ser objeto de grandes trabas administrativas, en la medida en que la excepcionalidad del momento se abordó permitiendo que los urbanistas pudieran centrar sus preocupaciones en velar por la adecuada reconstrucción conjunta, teniendo presente como objetivo prioritario el beneficio de toda la comunidad. ${ }^{4.20}$

Bajo la tutela de la BOS ${ }^{4.13}$, se auspició en 1947 el primer Plan Nacional ${ }^{4.20}$ que contenía las directrices generales para el desarrollo de varias zonas del país, teniendo en cuenta tanto sus relaciones mutuas como los intereses del conjunto de regiones. Se establecieron como prioritarias las relaciones funcionales entre los centros de producción y los servicios de cada área y se propició el desarrollo de la industria en aquellas zonas que afectasen en menor medida el desarrollo de los recursos naturales del estado. 4.20

Como señala Jankowski ${ }^{4.21}$ este plan fue posible sin embargo gracias al trabajo clandestino realizado en Varsovia durante la guerra en los años de ocupación. A pesar de las redadas, las persecuciones nocturnas y el terror que los planificadores de la ciudad tenían a los miembros de la Gestapo, muchos arquitectos trabajaron en varios proyectos para futuro desarrollo de la ciudad, conscientes de que esta era otra forma de resistencia en su lucha contra el ocupante. ${ }^{4.21}$ En el marco del Laboratorio de Arquitectura y Urbanismo ${ }^{4.22}$ se llevaron a cabo estudios sobre vivienda bajo la dirección

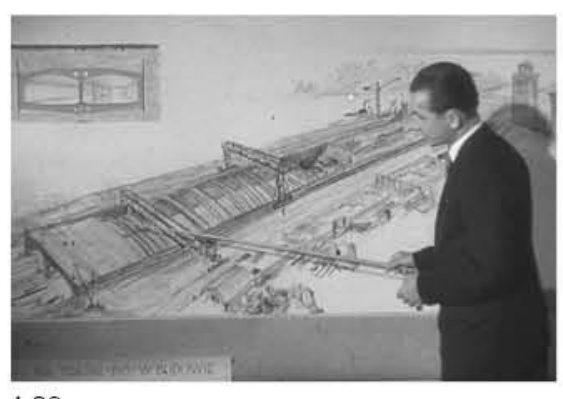

4.09

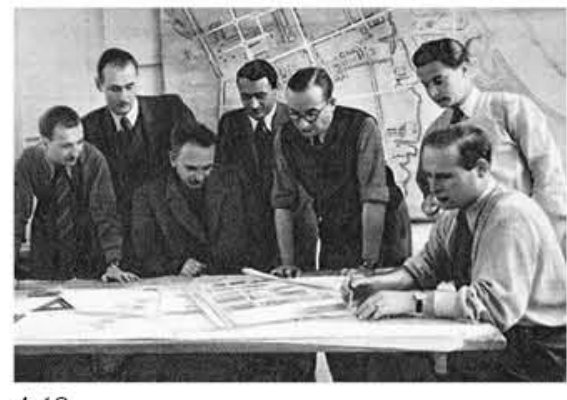

4.10

4.21. Jankowski | Ciborowski, 1971. Fragmentos extraidos de stanislawjankowskiagaton.pl.

4.22. Pracowni Architektoniczno-Urbanistycznej. 
4.12 Reunión en obra durante el periodo de Reconstrucción de la Ciudad en Varsovia (BOS)

4.13 Josef Sigalin explica las maquetas de la Ruta WZ al presidente Boleslaw Bierut.

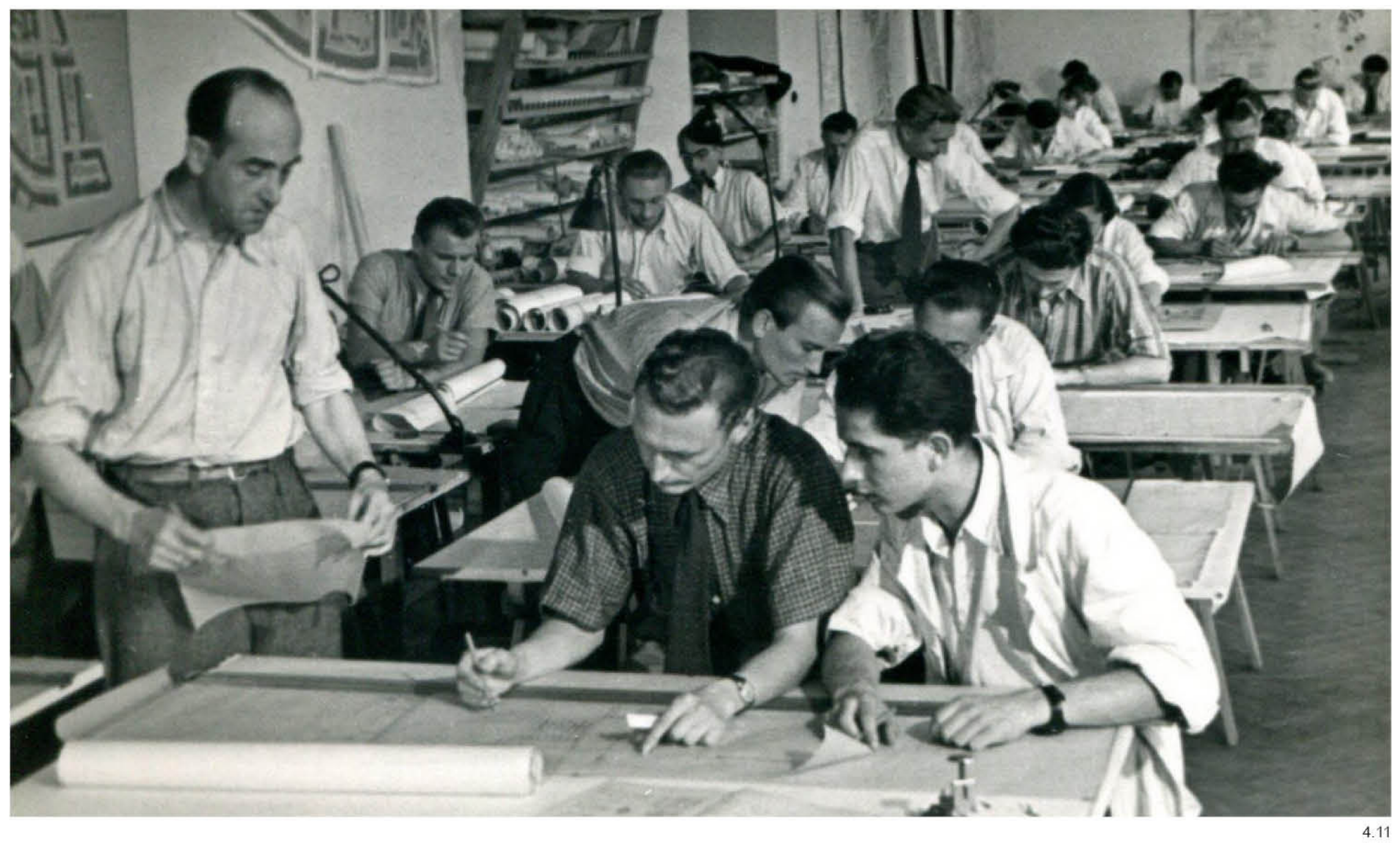


de Szymon Syrkus, y después de su arresto y deportación a Auschwitz, continuaron realizándose bajo la dirección de su esposa Helena Syrkus. La guerra había dado lugar a multitud de situaciones en las que la experiencia arquitectónica había sido determinante, puesto que los conocimientos de construcción fueron útiles en la construcción de bunkers, refugios, barricadas, etc.. y las habilidades visuales de los arquitectos resultaron indispensables para el camuflaje y la producción de propaganda que tan relevante resultó en aquella época. ${ }^{4.23}$

Las instalaciones de la Facultad de Arquitectura de Varsovia, que también habían seguido operativas en la clandestinidad, permitieron a un grupo de profesores y asistentes realizar estudios secretos bajo la dirección del profesor Tadeusz Tołwiński, que posteriormente salieron a la luz. El arquitecto Jan Chmielewski realizó un análisis del Complejo Municipal de Varsovia, mientras que los arquitectos Zygmunt Skibniewski, y Kazimierz Stanisław Marczewski desarrollaron, a nivel de esquema, un plan urbanístico para Varsovia que se convirtió en el punto de partida para el proyecto del Plan General elaborado después de la liberación. ${ }^{4.21}$

Un tema especialmente importante para la arquitectura de la posguerra, no solamente en Polonia sino a nivel mundial, fue la industrialización de la construcción, el estudio de las posibilidades de la estandarización y los potenciales problemas asociados al manejo de su técnica. El programa de industrialización ya había comenzado a estudiarse en las universidades polacas en el período de entreguerras, y en él jugaría también un importante papel el trabajo del grupo Praesens, uno de cuyos representantes más destacados, Szymon Syrkus, fue uno de los arquitectos más activos en el análisis de sus posibilidades. La investigación sobre la prefabricación tuvo lugar por parte de los arquitectos polacos en las facultades establecidas en el exilio, principalmente las de Liverpool y Zúrich. La necesidad de iniciar tras la guerra una rápida reconstrucción de los países era un problema que estaba en la mente de los docentes en ambos lugares y sobre esta técnica se realizaron numerosos estudios. ${ }^{4.20}$

En Polonia, las primeras revistas técnicas del periodo de postguerra (1945-48) como "Przegląd Budowlany" (Revista de la Construcción), "Inżynieria i Budownictwo" (Ingeniería y Construcción), "Cement" (Cemento), publicaron numerosos artículos sobre el auge que estaba adquiriendo a nivel mundial la técnica del prefabricado, e informando acerca de los sistemas de prefabricación disponibles en Polonia, además de las normativas que existían al respecto en el país. ${ }^{4.20}$

Si bien la principal investigación que se desarrolló dentro de Polonia en los primeros años de postguerra estuvo asociada al trabajo del Instituto de Urbanismo y Arquitectura tal como se ha comentado, la aplicación de sus conceptos fue muy lenta y progresiva. "El primer sistema de prefabricación completa de fachada fue desarrollado por Marek Leykam" ${ }^{4.20}$ gracias a las enseñanzas que había recibido en la ETH de Zúrich y el proceso práctico que pudo experimentar en el estudio de Auguste Perret. Posteriormente se empezaron a incorporar de forma más corriente a la arquitectura polaca construcciones con elementos prefabricados, pero solamente el desarrollo de la industria creó las bases para la industrialización real de este sector económico a nivel local. ${ }^{420}$

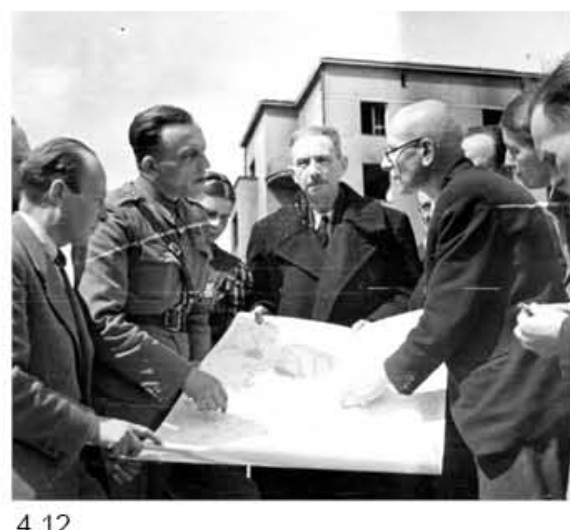

4.12

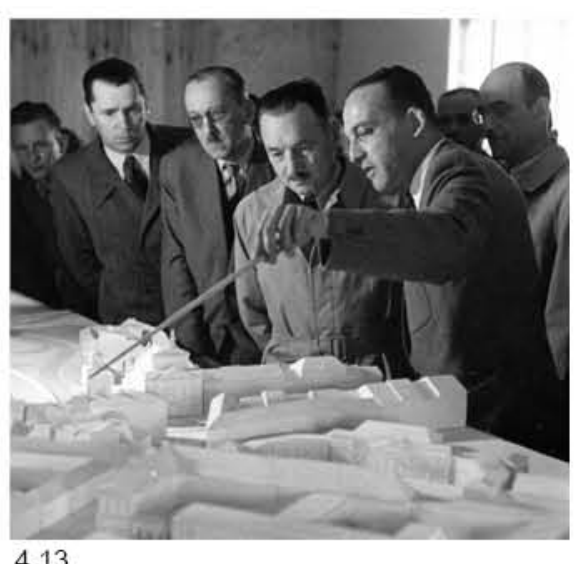

4.13

4.23. Cohen, 2012 


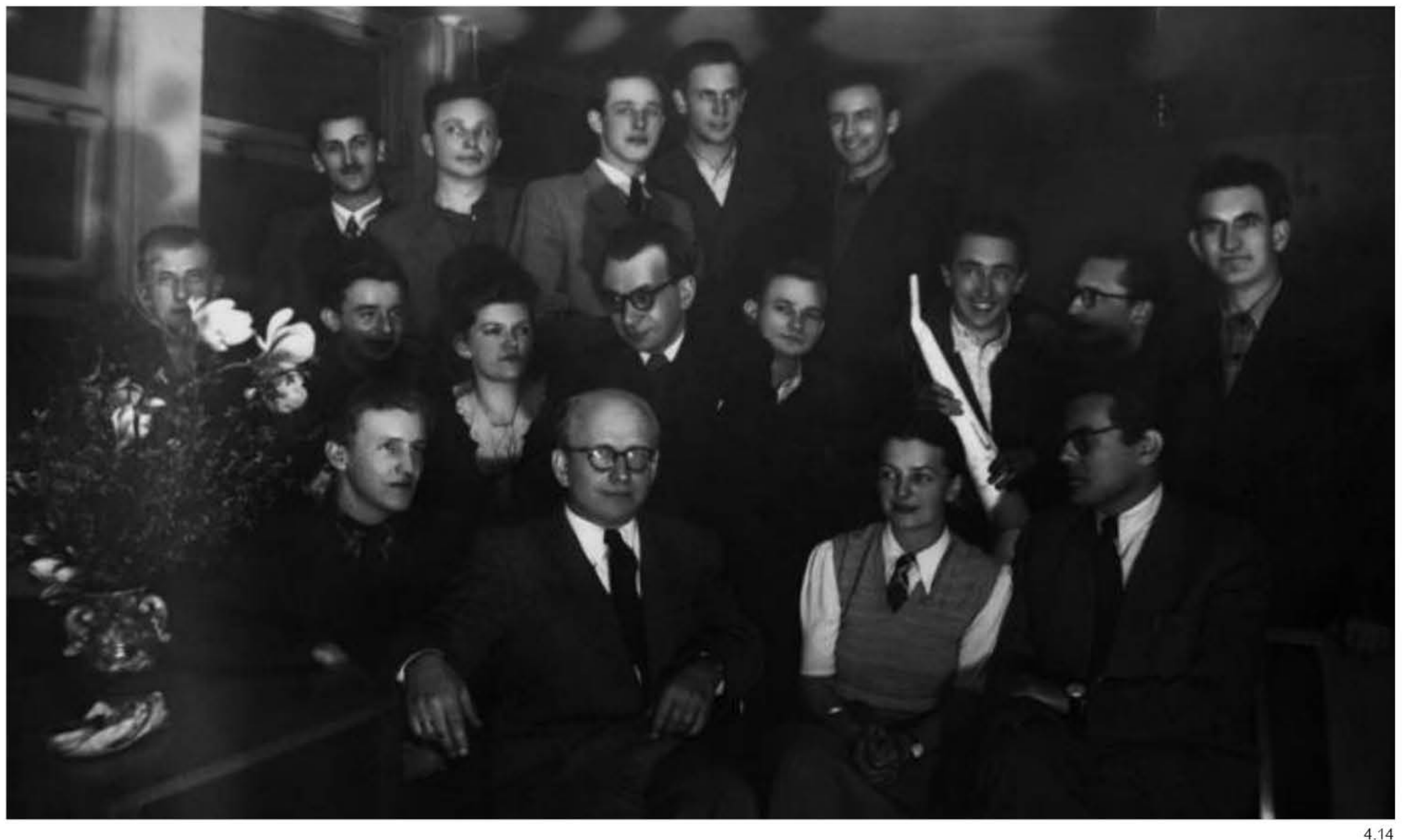


Respecto a los planes de reconstrucción cabe señalar que muchos de ellos fueron abandonados en los años 50 a pesar del ímpetu inicial, no solo como resultado de los cambios en la política y la economía de años posteriores, sino por la debilidad de muchas autoridades que no fueron capaces de coordinar sus planes de desarrollo con el resto de instituciones. ${ }^{4.20} \mathrm{La}$ decisión de reconstruir Varsovia hizo que gran parte de los medios y esfuerzo creativo se concentrasen en la capital. La Oficina Central de Planificación (CUP) ${ }^{4.24}$ encabezada por Czesław Bobrowski fue la institución encargada de ocuparse de la preparación de la reconstrucción del país con un plan de desarrollo económico de tres años ${ }^{4.25}$, del cual supervisó su ejecución.

En los primeros años después de la II GM, la reconstrucción se centró principalmente en los complejos históricos y en la satisfacción de las necesidades básicas de complejos residenciales y administrativos. Muchos de los arquitectos estuvieron ocupados en la reconstrucción de edificios parcialmente destruidos, pero también construyeron multitud de nuevos proyectos, entre los que destacaron por su rapidez de ejecución los que realizó Leykam en este primer trienio de financiación (1947-49); en el cual puso en marcha y supervisó seis edificios con un sistema de construcción y detalles de ejecución muy similares.

Leykam había regresado a Polonia en 1945 con "gran voluntad de trabajar" ${ }^{4.26}$. De inmediato se unió a las iniciativas para la reconstrucción y se integró en el año académico 1945/46, dando clases en la recién recuperada Escuela de Arquitectura de Varsovia dentro del edificio de la Universidad Tecnológica de Varsovia que se estaba reconstruyendo. Al mismo tiempo, participó en el relanzamiento de la Asociación de Arquitectos de Polonia (SARP) y fue miembro del primer consejo de administración. ${ }^{4.26}$

Entre 1945 y 1950 fue profesor asistente en la catedral de Historia del Arte y Arquitectura, y desde 1948 dirigió la Cátedra de Proyectos Públicos en la Facultad de Arquitectura de la Universidad Técnica de Szczecin (4.14). Al mismo tiempo fue co-fundador y uno de los redactores de los primeros números de la revista "Architektura". El investigador Andrzej Jur apunta que los testimonios de colaboradores de Leykam en esa época le describían como un "hombre de alta cultura, con un excelso conocimiento de la arquitectura y el arte, una actitud social muy sincera e inteligible en el trato con la gente, y, sobre todo, un hombre totalmente comprometido con su trabajo y convencido de la rectitud de su camino. Un camino que ya en aquel momento estaba sometido a fuertes críticas a nivel mediático y popular." 4.26

Tras el final de la II Guerra Mundial, la perspectiva y el protagonismo de los concursos también cambió completamente con respecto al papel que jugaron en el periodo de entreguerras en Polonia, especialmente durante la década de los 30 como se han comentado. A partir de 1945, en ninguna convocatoria se regalaron esfuerzos, los equipos que se presentaron en los primeros años de la reconstrucción eran altamente recompensados por el esfuerzo realizado, no solamente con premios, sino también con la posibilidad de construir algún otro edificio si habían demostrado un nivel destacado en su presentación. Los miembros del jurados eran conscientes de la responsabilidad que acarreaba la reconstrucción del país

4.24. Centralny Urząd Planowania (CUP).

4.25. Plan Trzyletni. Fue un plan de recuperación económica puesto en marcha en Polonia entre 1947 y 1949

4.26. Jur, 1977. p 67-69 
4.15 - 4.17 Iglesia de San Antonio (Antoniuskirche) en Baslea, sliza (1925-27). Arquicto: Kall Moser. 4.18 - 4.20 Concurso para la Iglesia del Nuevo
Monasterio Dominicano de Poznań (1946). 1er premio.

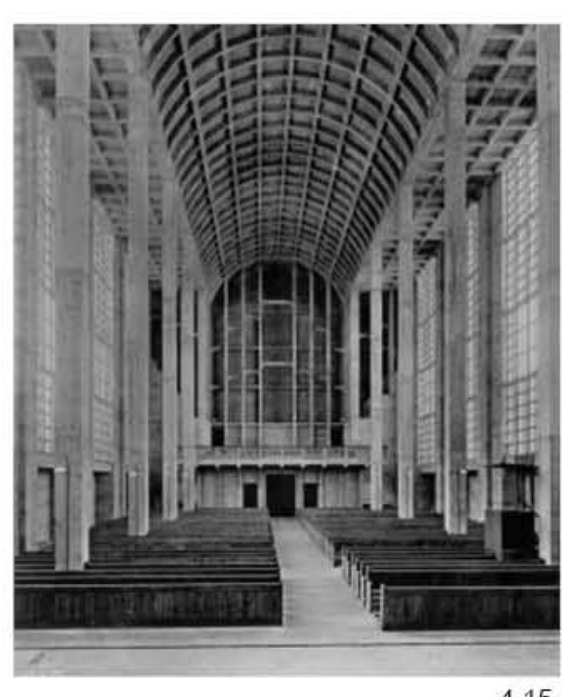

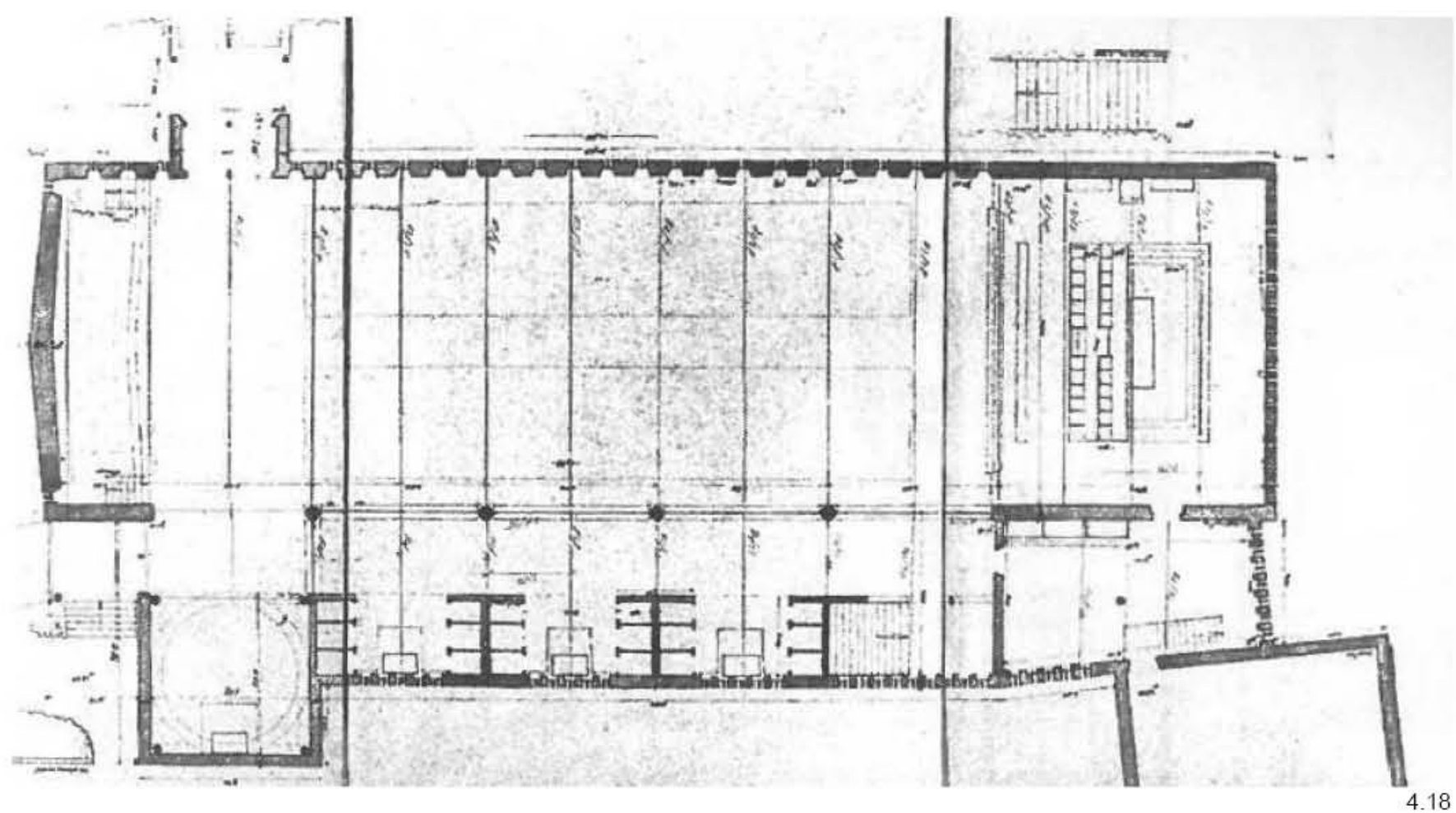

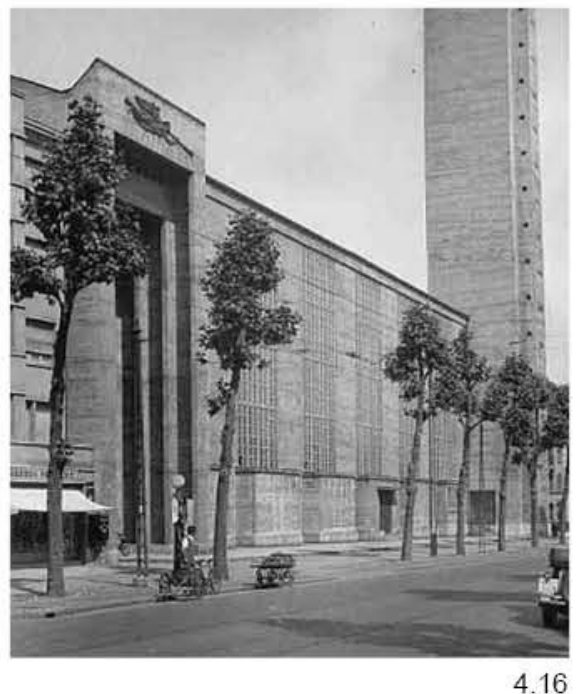


y los arquitectos que concurrían a los concursos recibían condiciones justas y el ratio de equipos era siempre reducido, situación que no venía dada únicamente por la naturaleza de la convocatoria, sino porque, debido a la cantidad de trabajo, muchas veces incluso varios de los estudios unían sus fuerzas para presentar propuestas en común.

En 1946 Leykam se presentó a un concurso de arquitectura del que apenas ha trascendido documentación ${ }^{4.27}$, la Iglesia del Nuevo Monasterio Dominicano de Poznań (2.43-2.45). La convocatoria y los condicionantes previos de este concurso se desconocen pero en el Monasterio de Poznań se conserva únicamente un copia del proyecto ganador, que fue el de Marek Leykam. En 1939 ya se había realizado un primer concurso para esta iglesia, ganado por el arquitecto Cybichowski. Si bien no se conocen los argumentos por los que fue cancelado este proyecto, el investigador Andrzej Kusztelski apunta que "probablemente para las nuevas autoridades de Poznań, el edificio de la iglesia era demasiado 'dominante' y por ello no obtuvo permisos para ser construido tras la II Guerra Mundial." 4.28

La nueva iglesia diseñada por Leykam se situaba a lo largo del eje norte-sur, adyacente con la esquina noroeste del monasterio existente (2.44). La ubicación del templo vino dada por la necesidad de conectar con el antiguo monasterio, y Leykam trató de reconstruir la geometría del patio interior con una pieza que se insertase en su interior, recibiendo luz lateral por ambas fachadas. El proyecto adopta una tipología bastante novedosa de dos naves, siendo una de ellas principal y la otra secundaria, por lo que evita conscientemente la simetría a pesar de reconstruirla posteriormente en alzado, aprovechando la prominencia del volumen que enmarca el acceso lateral por el noroeste. La mitad del espacio de la nave lateral se dividió en pequeñas capillas o confesionarios. Una vez más, Leykam utilizó como referente formal la iglesia de Notre-Dame en Le Raincy de Perret en el tratamiento del alzado, que se intuye permeable con una trama formando un gran rosetón central. El tratamiento de los muros laterales y la modulación de la propuesta, con el acceso lateral, remiten asimismo a la Iglesia de San Antonio en Basilea (Suiza) obra del arquitecto Karl Moser en 1925-27 que Leykam tuvo ocasión de visitar durante su estancia en el país.

La solución adoptada por Leykam está basada en la modulación de la trama de pilares y se resuelve en la nave central con una bóveda de arco rebajado, mientras queda situado en alzado, como elemento dominante, un esbelto mástil coronado por una cruz cuya escala y proporciones parecen remitir a los dibujos del Doctorado de Leykam en los que quedaban relacionados objetos de la liturgia junto a construcciones arquitectónicas.

En palabras de Kusztelski, "manteniendo la impresión de compacidad y unidad del interior necesario para una liturgia colectiva, Leykam, gracias a la adecuada formación del espacio y manipulación de la luz natural, creó en el templo propuesto también un conjunto de lugares para la devoción privada. Esta ascética arquitectura favorecía la concentración y la tranquilidad. Hay que destacar a su vez la 'no-ortodoxidad' de la solución del presbiterio, tanto en lo que se refiere a la posición del altar y el celebrante, anticipando las soluciones del Concilio Vaticano II, como en la ubicación del coro, lo que indica una actitud de búsqueda por parte de arquitecto." 4.28

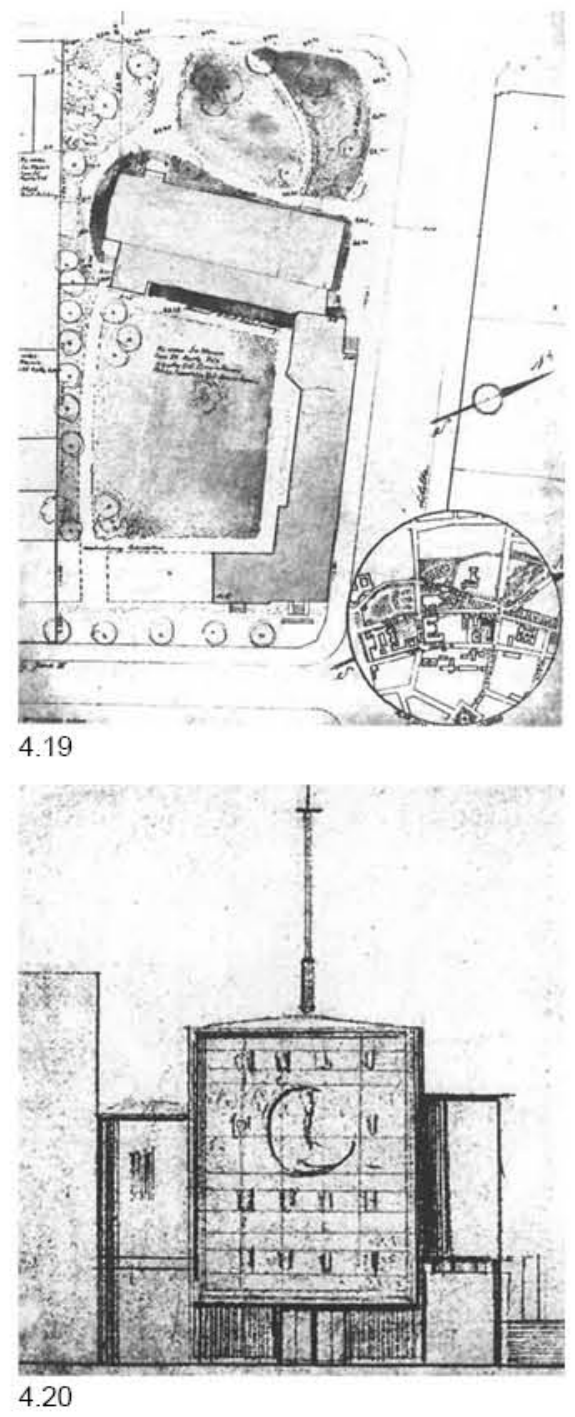

4.27. En el Monasterio de Poznań existe documentación al respecto de este proyecto, únicamente citado por Andrzej Kusztelski (Op. Cit. 4.28.).

4.28. Kusztelski, 1999. p. 296-318. 
4.21 4.22 Concurso para la Estación Central de Tren de Varsovia, 1946. Arquitectos: Marek Leykan,

4.23 4.24 Supermercado Supersam de Varsovia, 1962. Arquitectos: Jerzy Hryniewiecki, Maciej
Krasinski y Ewa Krasińska.
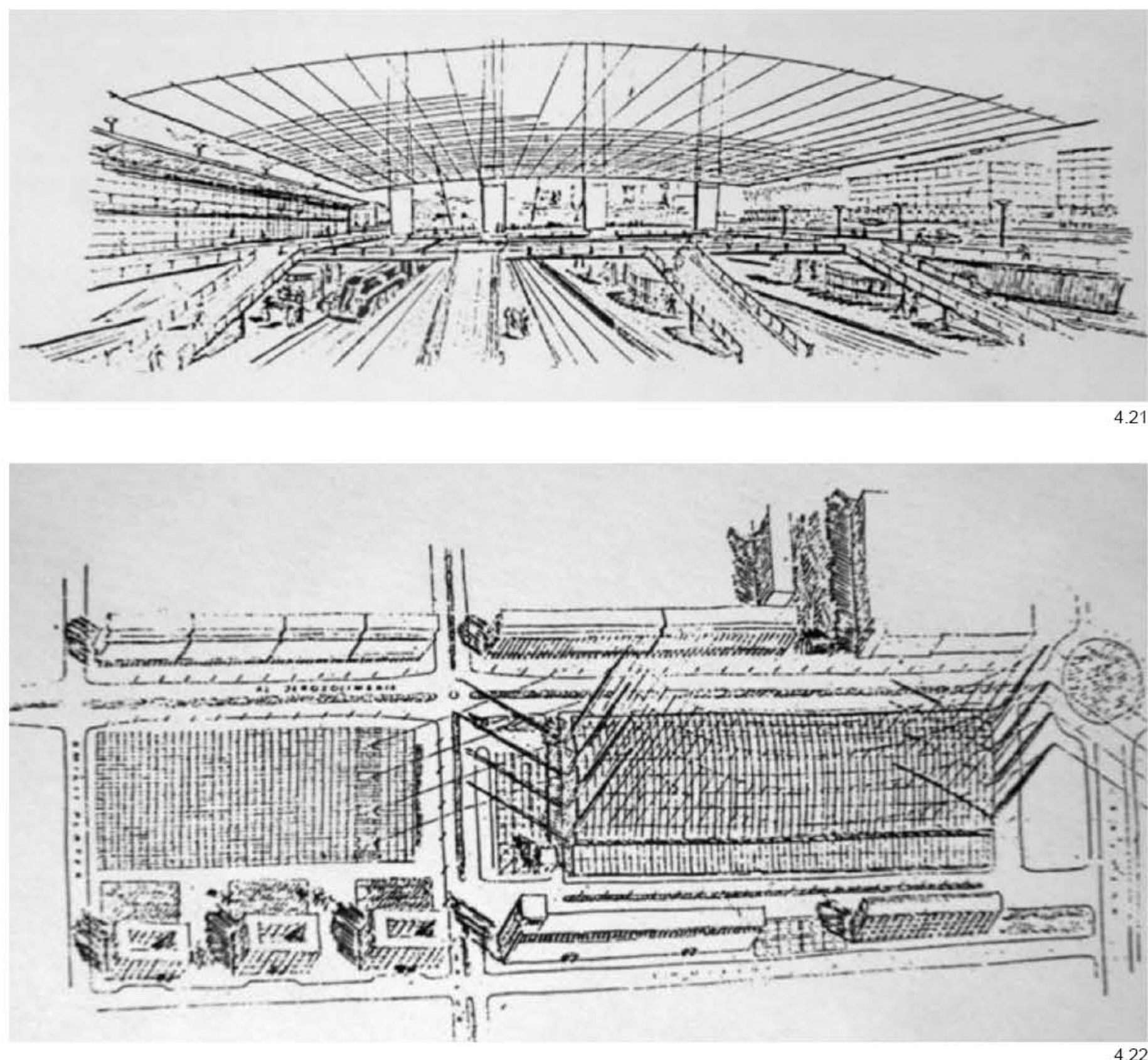
El jurado del concurso valoró "el modernismo enriquecido de la solución incluyendo la ornamentación estilizada." Aunque el proyecto de Leykam obtuvo el primer premio, los representantes de la Iglesia Dominica no consideraron adecuada su propuesta y decidieron no construirla. En opinión de Kusztelski, el proyecto representaba una "absoluta novedad en la arquitectura religiosa polaca", pero se canceló probablemente porque su propuesta fue percibida como "poco religiosa y no encontró apoyo del cliente y los inversores." 4.28

En septiembre de 1946 Leykam se presentó -junto a Jerzy Hryniewiecki y Jerzy Staniszkis- a un nuevo concurso: la Estación Central de Trenes de Varsovia ${ }^{4.29}$ situada entre la Avenida Jerozolimska y las calles Chałubińskiego y Żelazna ${ }^{4.26}$. A esta convocatoria concurrieron 17 proyectos, de los cuales 6 recibieron premios además de los ganadores -Arseniusz Romanowicz y Piotr Szymaniak-, que presentaron un proyecto que tuvo que ser transformado posteriormente. Las bases del concurso se redactaron con mucha precisión, pero al mismo tiempo con gran rigidez en sus condicionantes, lo que provocó que muchas de las propuestas coincidieran en sus soluciones a nivel funcional.

El proyecto de Leykam, Hryniewiecki y Staniszkis, -en colaboración con su antiguo profesor Stanisław Hempel que fue responsable de la estructura-, planteó un desafío a estas bases tratando de escapar del prototipo de estación que propiciaba el cumplimiento de la convocatoria. Su planteamiento se basaba en una demostración de técnica desde la que probablemente esperaban obtener otros encargos tras el veredicto del jurado, sorprendiendo por su originalidad más que por la verosimilitud de su solución.

Una gran cubierta, suspendida por cables de acero, fue desarrollada en dibujos y bocetos (4.21 - 4.22) levitando sobre los andenes emplazados en la localización prevista, quedando cubiertos por una gran malla tensada. El área de proyecto aparecía en su proyecto cubierta pero sin cerramientos laterales; directamente a disposición de la calle, desde la que se podía acceder a la estación sin divisiones y por tanto sin la transición a un espacio climatizado.

Para el tensado de esta estructura se plantearon dos hileras de cuatro postes alineados con los extremos cortos del solar, que dejaban los cables posteriores a cada poste extendidos fuera de la parcela asignada al edificio. Los tensores de testigo, que debían emplazarse en el suelo, eran alcanzados pasando los cables por encima de las avenidas adyacentes para llegar a clavarse en las áreas de aparcamiento y parque dispuestas en la convocatoria al efecto.

La radicalidad del proyecto no solo estaba en la estructura. Para enfatizar la fluida transición entre interior y exterior, los arquitectos no dudaron en desafiar de nuevo las bases del concurso, y situar todo el programa en los edificios adyacentes emplazados en la Avenida Jerozolimska, potenciando así el efecto de integración de la estación en la ciudad. Un único gran espacio recibía al viajero extendiendo la zona de andenes mediante anchas rampas de evacuación directamente a la calle, en una distribución marcadamente expresiva pero funcionalmente cuestionable, en la que todo el programa necesario para el funcionamiento de la estación debía ser trasladado al otro lado de la concurrida Avenida Jerozolimska.
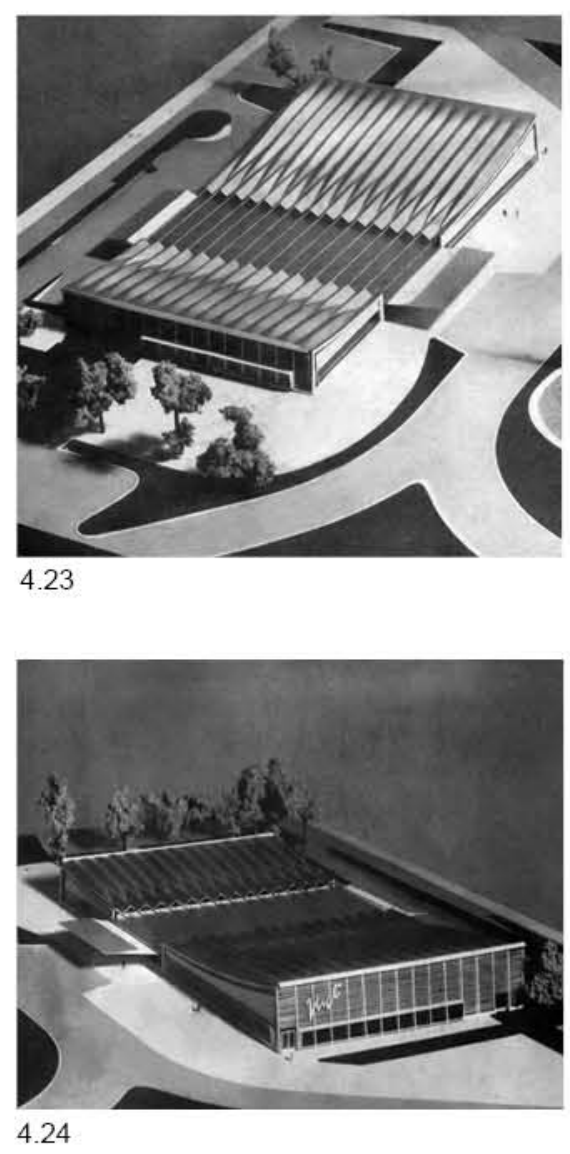

4.29. Konkurs na projekt Dworca Centralnego Warszawa. 

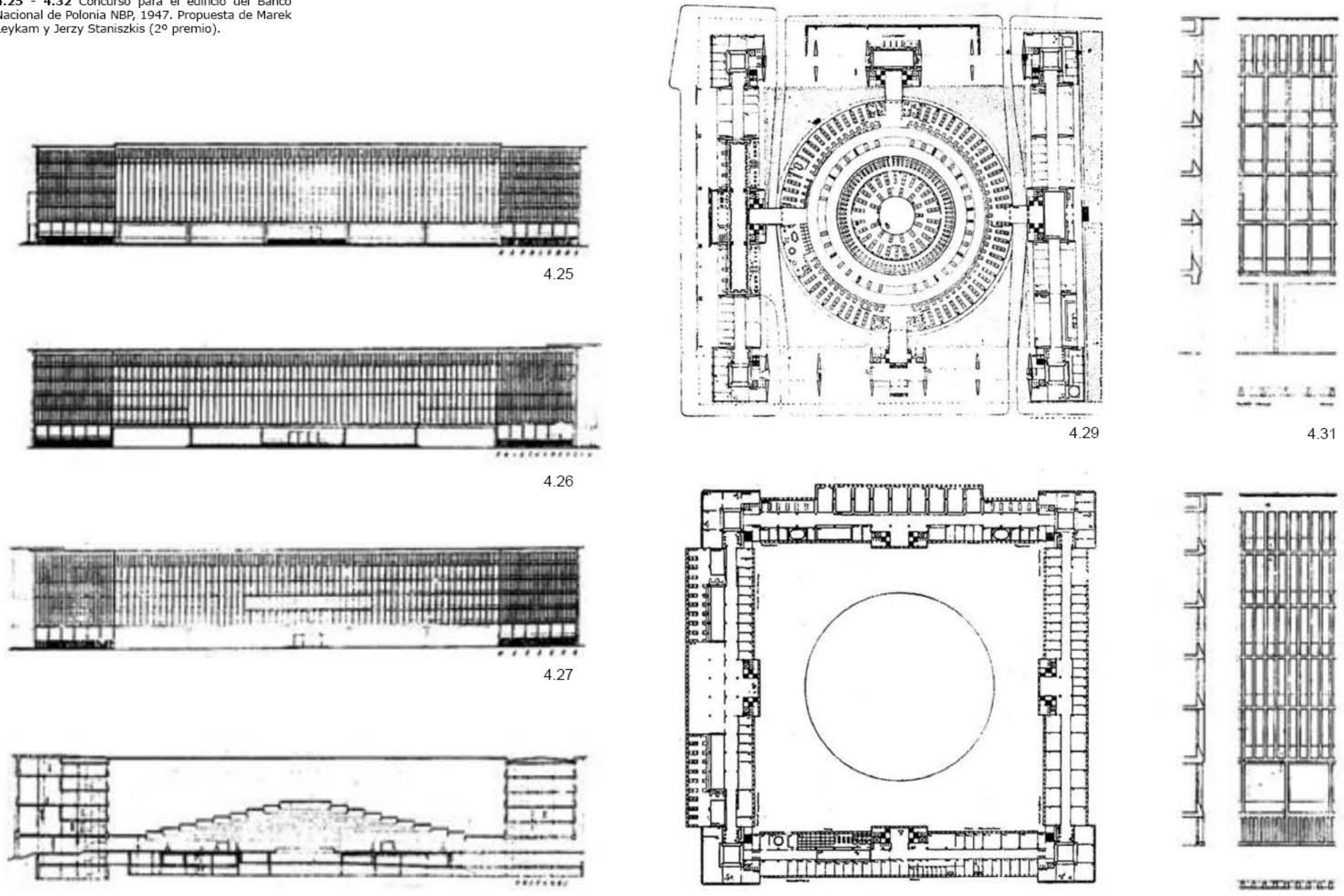
A nivel técnico y formal la propuesta podría haber resultado extremadamente novedosa en el país, ya que no existían precedentes de una malla tensada de esta luz. El hecho de que las estructuras tensiles no fueran planteadas con posterioridad por Marek Leykam, hace pensar que la apuesta técnica fue impulsada principalmente por el profesor Hempel y Jerzy Hryniewiecki. El primero solía encaminar sus trabajos hacia la experimentación en múltiples campos de las estructuras y el segundo sí recogería el testigo de esta solución en el futuro para plantear en 1959 el concurso de una de sus obras más destacadas, el supermercado Supersam de Varsovia (4.23-4.24). Staniszkis por su parte también planteó como proyecto un Parasol (Pawilon MTP) para la Feria Internacional de Poznań en 1958, donde una cubierta de tela tensada se extendía más allá de la huella teórica del edificio.

Sí que se percibe en este concurso el interés de Leykam por manifestar la importancia expresiva de la estructura en la imagen formal del edificio, y al mismo tiempo su contundencia respecto a la necesidad de definir una direccionalidad en sus edificios. El resultado final del concurso otorgó al equipo de Leykam, Hryniewiecki, Staniszkis y Hempel un cuarto premio, así como el reconocimiento por parte del jurado de la "audacia" de su proyecto, lo que les llevó a recibir invitaciones posteriores, así como la elección de Leykam y Hempel para participar, poco tiempo más tarde, en la Exposición de los Territorios Recuperados de Wrocław en 1948, en la que presentaron un conjunto de esculturas de marcado carácter estructural.

En septiembre de 1947, se convocó un concurso para el edificio del Banco Nacional de Polonia (NBP) en Varsovia en el que Leykam concurrió junto a Jerzy Staniszkis. ${ }^{4.26}$ La convocatoria se prologó hasta enero de 1948 y a ella concurrieron 12 equipos. El programa incluía una serie de directrices mucho más abiertas que el concurso de la Estación de Tren, definiendo únicamente el posible volumen y la altura máxima (6 plantas), y ofreciendo por tanto gran libertad en el planeamiento de los accesos aunque sí mostrando una clara preferencia por la prefabricación de la solución de fachada, hecho que estaba siendo experimentado ya por Leykam en Varsovia, como podrá verse en capítulos posteriores.

La propuesta planteaba un bloque de manzana cerrada de seis plantas (4.25 - 4.32) con un patio central en el que se emplazaba una gran sala circular con acceso desde el nivel de planta baja. Las fachadas estaban resueltas por una retícula de elementos prefabricados modulada en función del tamaño de ventana, que variaba únicamente de ritmo duplicándose en el perímetro exterior (4.31) con respeto al interior (4.32) para obtener una mayor privacidad. En planta baja ambos módulos de subestructura prefabricada se aligeraban aunque manteniendo un criterio constante en todo el nivel de acceso.

Tal como sería habitual en todos los proyectos de Leykam en esta época, un mismo detalle constructivo servía para resolver toda la fachada del edificio sin distinciones sobre el programa interior o elementos de acceso salvo puntuales singularidades, que siempre quedaban en cualquier caso integradas en la trama principal y venían marcadas por el ritmo constante de modulación que derivaba del posicionamiento de la estructura. 

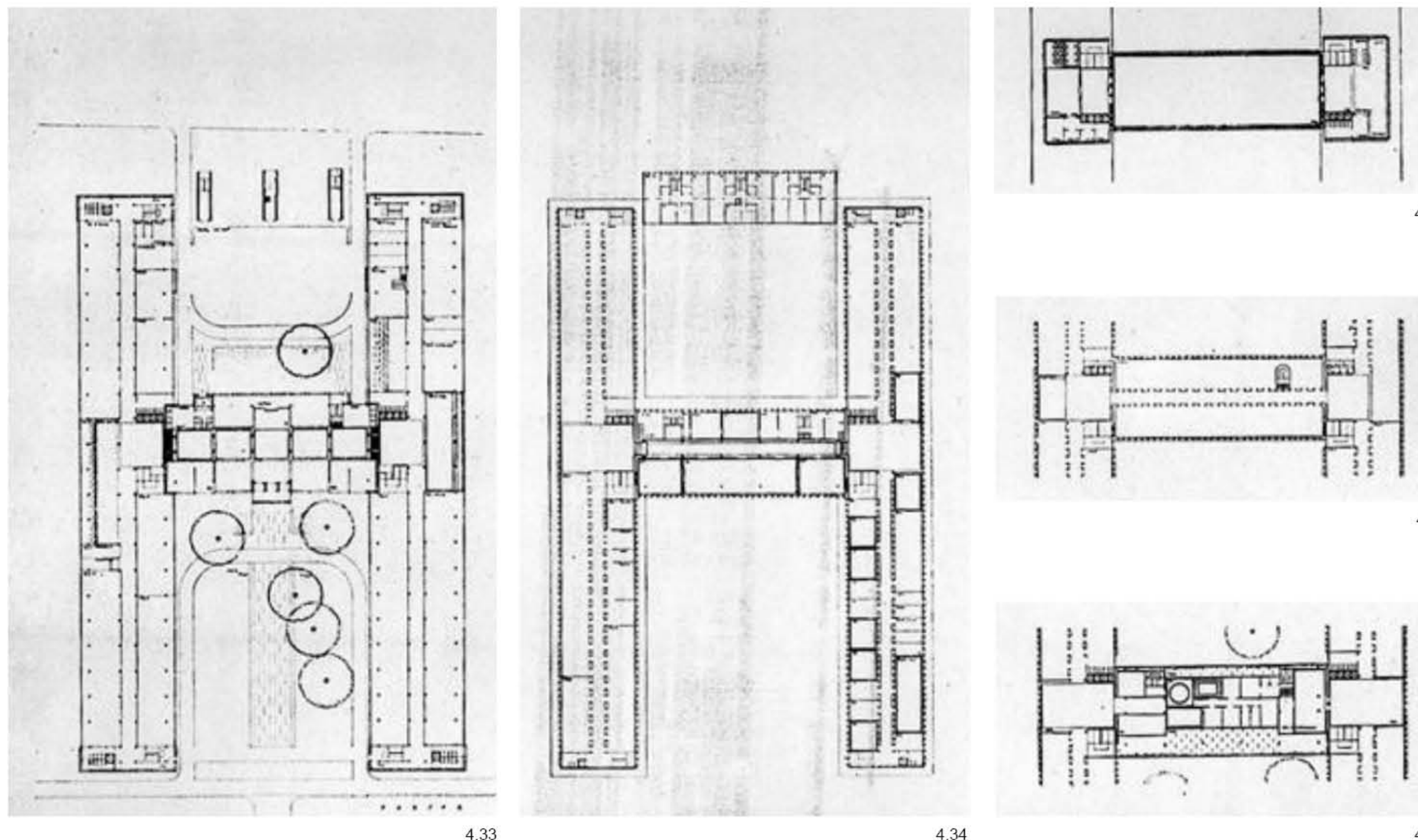
En 1948 Leykam se presentó en solitario al concurso del edificio del Ministerio de Hacienda de Varsovia ${ }^{4.30}$ (4.33 4.39), en un solar emplazado entre las calles Świętokrzyska, Czackiego, Traugutta y Nowy Świat. El programa de la convocatoria incluía una serie de directrices sobre las necesidades de limitar la altura a 7-8 plantas en la parte central del solar y en él se especificaba la necesidad de realizar una separación volumétrica de proyecto en varios bloques por motivos funcionales. ${ }^{4.26}$ Ante estos requerimientos, Leykam planteó un conjunto de bloques conectados mediante una planta en forma de $\mathrm{H}$ resuelta con un bloque conector de 8 plantas y dos alas de 7 plantas, además de un bloque longitudinal situado en el perímetro de 3 alturas como filtro de entrada al complejo.

El concurso preveía dos fases, por lo que en esta primera entrega no se detallaron despieces de fachada -a pesar de que la modulación de las plantas permite intuir que hubiera estado perfectamente prevista, a tenor de la posición de la estructura cuyos ejes tenían correspondencia en todos los bloques de la propuesta-. La distribución en planta estaba marcada por la funcionalidad, con espacios de uso situados a ambos lados de un corredor central, aunque la rigidez geométrica de la solución conjunta obligaba a situar amplios espacios de descongestión en las intersecciones de los bloques con objeto de evitar que existiesen ámbitos de trabajo sin iluminación directa.

Leykam fue invitado a participar en la siguiente fase junto a Bohdan Lachert, Stanisław Rychłowski y Stanisław Bieńkowski, y en el proyecto detallado contó con la colaboración de Jerzy Hryniewiecki. ${ }^{4.26}$ La propuesta detallada supuso para Leykam un replanteamiento completo de su solución. La intersección de los bloques, que ya había provocado problemas funcionales en la distribución, fue descartada puesto que obligaba a detallar demasiadas particularidades en la fachada prefabricada que había que detallar, por lo que ambos arquitectos decidieron buscar una geometría que les permitiera reproducir toda la fachada con una sola sección de detalle llegando así a la geometría de edificio cilíndrico con un patio central. Este proceso de proyecto da idea de la importancia central que particularmente Leykam otorgaba a la solución de fachada tal como puede verse en toda su obra posterior.

El gesto de delimitar geométricamente el proyecto en torno al trazado de un círculo ya había sido esbozado por Leykam en la sala auditorio del concurso para el Banco Nacional de Polonia en 1947 (4.25-4.32). La geometría circular resultaría también muy utilizada en proyectos posteriores de Leykam, tanto a nivel de volumen -por la formalización de cilindros o su vaciado en forma de patios-, como a nivel de trazado, a modo de trama para organizar diferentes distribuciones funcionales.

La propuesta de bloque en forma de $\mathrm{H}$, dio paso a un gran bloque de manzana en forma de cilindro con patio central concéntrico al perímetro exterior, que se elevaba hasta las 10 plantas para resolver todo el programa manteniendo únicamente el bloque de 2 alturas y planta baja que permitía resolver el acceso al solar. Con esta solución se conseguía resolver el plano de fachada con una única sección de detalle, realizando a su vez una conexión natural entre ambos bloques, el circular y el longitudinal, y flexibilizando la posible adición de piezas, tal como se intuye en el pabellón de planta baja adjunto a uno de los laterales del cilindro.

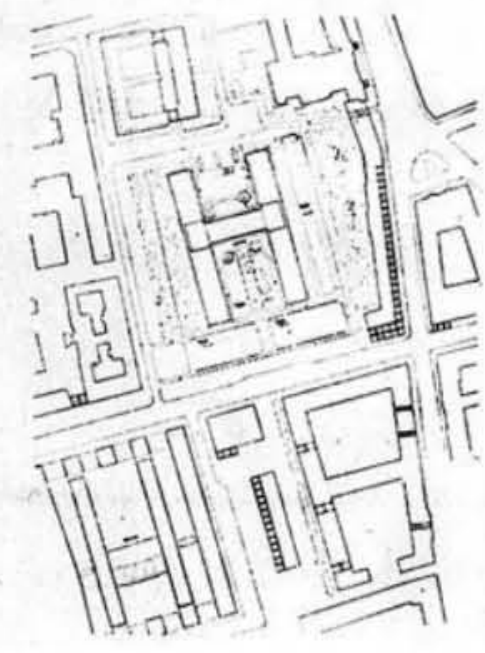

4.38

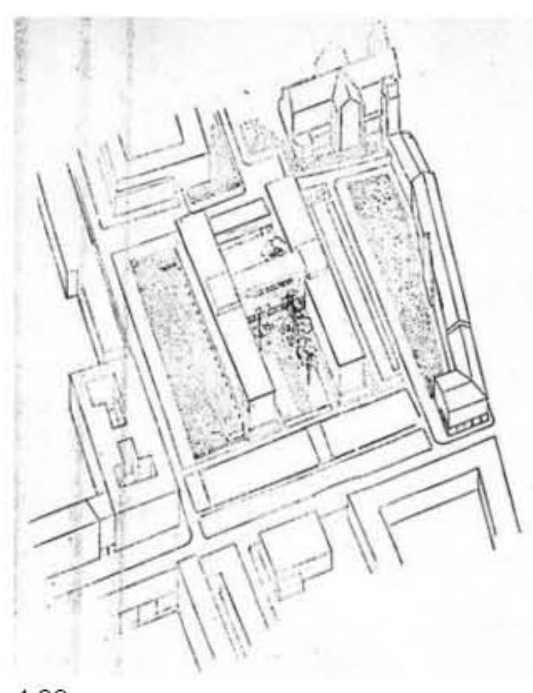

4.39

4.30. Ministerstwo Skarbu Państwa w Warszawie. 

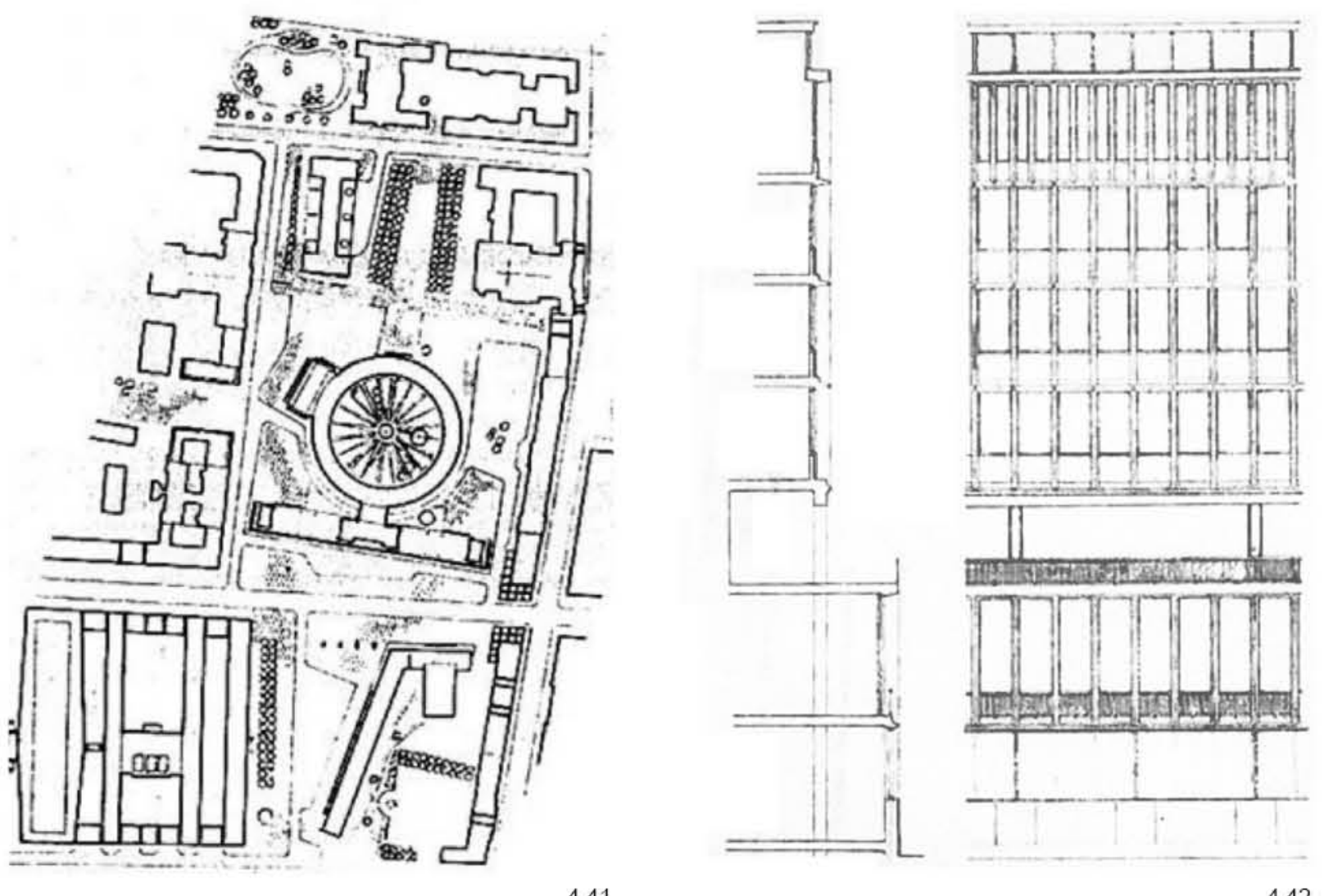

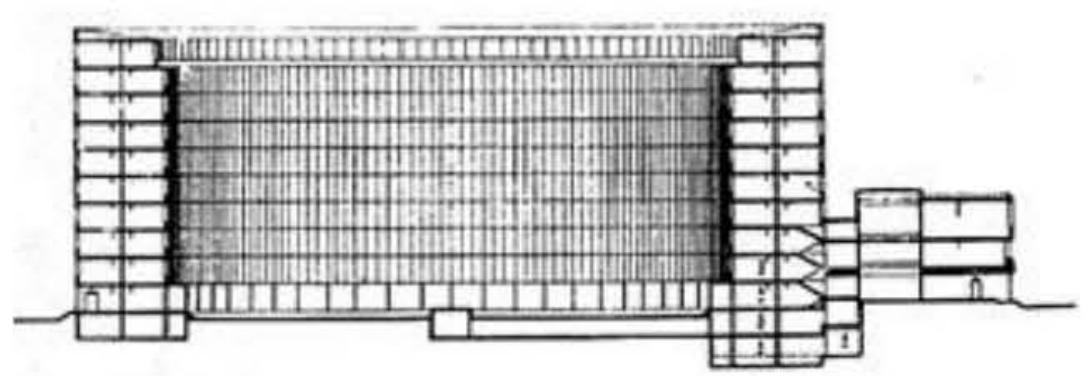

4.43

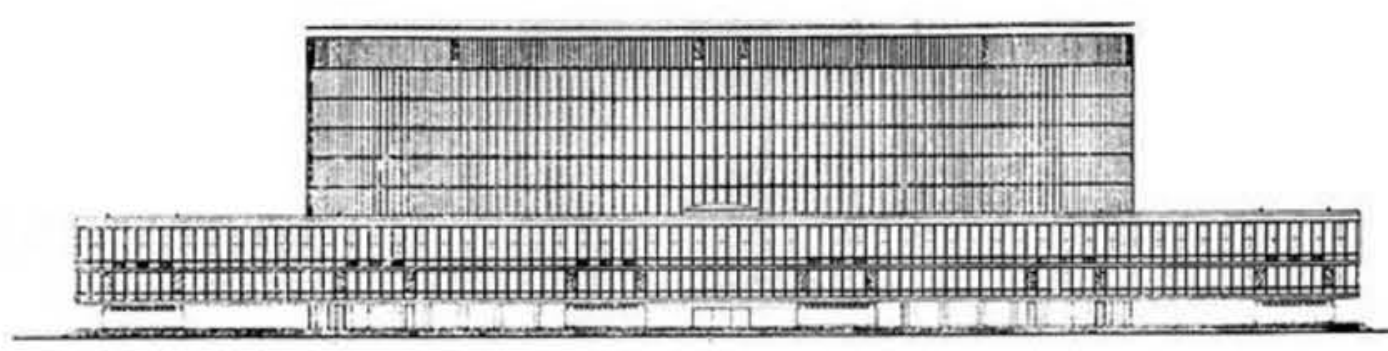

4.44 
La respuesta direccional, que es siempre objeto de estudio en los proyectos de Leykam, en este caso fue resuelta mediante la generación de una figura de carácter 'adireccional'. Las proporciones matemáticas del proyecto dan idea, asímismo, de la importancia otorgada por Leykam a la geometría y la métrica sencilla en sus proyectos: un cilindro de $90 \mathrm{~m}$ de radio en planta sobre el trazado de la fachada exterior, y $60 \mathrm{~m}$ sobre el trazado de la interior, con $30 \mathrm{~m}$ de altura total ( 10 plantas de 3 metros de altura libre), permite proporcionar adecuadamente el patio para un correcto soleamiento ya que la altura de la edificación coincide con la mitad del diámetro del círculo del patio central.

La solución de fachada también fue dibujada con gran detalle mediante elementos prefabricados tal como estaba siendo característico en esos momentos en la obra de Leykam. En este proyecto los montantes verticales tiene preferencia de paso sobre las piezas prefabricadas que marcan la altura de la barandilla definiendo una línea horizontal opaca al exterior. Las ventanas se alinean con el plano del antepecho quedando retranqueadas sobre los montantes y completan la altura hasta la cara inferior del forjado superior, el cual también manifiesta su canto en el plano de fachada definiendo una nueva línea horizontal en la composición. Con el propósito de evitar las particularidades, la fachada por encima del nivel de planta baja cambia de módulo en todos los bloques para evitar accidentar la composición en función de las singularidades del acceso, aunque sigue formando parte de la modulación general al ser coincidente con 1/2 del módulo de la estructura. La fachada del resto de alturas esta subdividida a 1/6 del módulo de la estructura, mientras que en la planta superior se duplica esta subdivisión pasando a representar 1/12 del módulo estructural.

Esta duplicidad del módulo de la última planta, se debe la compensación visual del efecto óptico que produce el ojo humano al observar una trama de montantes verticales como la que tenía prioridad de paso en la fachada de este edificio desde una posición como la de un observador a la altura de paso del peatón. En su doctorado de 1943 Leykam ya había hecho hincapié en la importancia de compensar este efecto analizando la importancia que los arquitectos griegos habían dado a este hecho en la realización de varios templos dóricos, observándose con especial maestría en el Parthenon de Atenas.

Desde su primer encuentro con la fachada del Garage Ponthieu en 1934, Leykam no había dejado de buscar en sus fachadas un equilibrio basado en la prioridad de paso de los diferentes montantes y tampoco había dejado pasar la oportunidad de ver como el propio Perret había duplicado los montantes verticales en el último nivel de la fachada del garaje para corregir esta perturbación visual, otorgando al mismo tiempo un mayor peso a la composición.

El resultado de este concurso coincidiría temporalmente con el momento en que comenzaba a implantarse en Polonia el Realismo Socialista, por lo que el proyecto de Leykam y Hryniewiecki fue fuertemente atacado por los partidarios de este nuevo estilo y la propuesta ganadora fue la desarrollada por los arquitectos Rychłowski y Bieńkowski. Leykam continuaría en busca de la máxima de su maestro Perret, recordando que "aquel que sin traicionar las condiciones modernas de un programa o el uso de materiales modernos produce una obra que parece haber estado siempre puede estar satisfecho. El asombro y la excitación son emociones perecederas, sentimientos contingentes y anecdóticos. El alma verdadera del Arte (...) nos debe conducir al deleite en su forma más pura." 4.31 

II. HIPÓTESIS DE TRABAJO 

"Nosotros queremos quedar libres de unilateralismos, queremos ser lo más abiertos posible. El dogma, el único dogma de la sociedad, será nuestra convicción de que el dogmatismo es nuestro peor enemigo."

Kazimierz Twardowski Discurso de inaguración de la Sociedad Filosófica Polaca en Lvov, 1904. 6.00

Durante la II Guerra Mundial, Leykam se sintió determinado a buscar un nuevo camino para la manifestación artística que no dejase de lado ninguno de los elementos que componían la experiencia cognitiva desarrollada en la Escuela Filosófica de Lvov-Varsovia, ${ }^{6.01}$ a saber: lógica, matemáticas, filosofía y religiosidad.

Merece la pena en este punto contextualizar someramente el posicionamiento de esta particular escuela de pensamiento para entender su influencia en la obra de Marek Leykam y su futura relevancia social en Polonia, en un momento en que -tras la II Guerra Mundial-, las posiciones ideológicas habían comenzado una ofensiva de connotaciones morales y políticas contra los postulados defendidos por el racionalismo, principalmente desde la institucionalización del Realismo Socialista.

La Escuela de Lvov-Varsovia, considerada por investigadores como Jan Woleński como el movimiento más importante en la historia de la filosofía polaca, fue establecida por Kazimierz Twardowski, quien tras haber estudiado en Viena a finales del s. XIX y convertirse en discípulo de Franz Brentano, regresó a Polonia con el propósito de instaurar en el país una nueva forma de hacer filosofía basada en una "labor compartida entre científicos y docentes desde la formulación de métodos de investigación basados en una actitud metodológica." ${ }_{6.03}$
6.00. "Przemówienie na otwarciu Polskiego Towarzystwa Filozoficznego we Lwowie" (Discurso de inaguración de la sociedad filosófica polaca en Lvov) publicado en Przeglad Filozoficzny $n^{\circ} 7$. Op. Cit. Op. 6.02. p 37 .

6.01. Laescuela de Lvov-Varsovia es la denominación bajo la que se asocian un conjunto de pensadores polacos del s. XX de carácter anti-irracionalista y no-positivista de filosofia cientifica y analitica. (Perzanowski, 1998)

6.02. Dominguez Prieto, 1993.

6.03. Woleński, 2014 
El programa de la escuela se estableció, en principio, en torno a la docencia tras la reconstrucción de la vida académica nacional al finalizar la I Guerra Mundial, y como maestros participaron en ella filósofos como Tadeusz Kotarbiński, Kazimierz Ajdukiewicz, o Jan Łukasiewicz; conjuntamente con matemáticos como Zygmunt Janiszewski o Alfred Tarski; y pensadores católicos como el padre Innocenty (Józef) Bocheński o el padre Jan Salamucha. ${ }^{6.03}$

Esta particular agrupación de disciplinas resultó una combinación única en la que confluyeron la mayoría de filósofos polacos de la primera mitad del s. XX, dando lugar a multitud de trabajos relacionados con la filosofía, psicología, sociología, lingüística teórica e historia del arte entre otros. ${ }^{6.03}$

Los objetivos que la Escuela de Lvov-Varsovia fijó para los artistas se convirtieron en las características distintivas que acabarían forjando la imagen del agente cultural polaco de postguerra, entendido como aquel que no solo afrontaba su tarea desde la eficiencia y la honestidad, sino también desde la responsabilidad social que derivase de sus actuaciones, influyendo mediante los valores que transmite su trabajo en la mejora de la vida de la comunidad. ${ }^{6.03}$

Los planteamientos de la Escuela de Lvov-Varsovia derivaron finalmente de dos grandes tradiciones filosóficas ${ }^{6.04}$ : la brentaniana, trasladada a Polonia por Kazimierz Twardowski, pero también la russelliana, que fue introducida en Polonia por los tres primeros lógicos modernos polacos seguidores de Bertrand Russell: Leon Chwistek, Jan Łukasiewicz y Stanisław Leśniewski; quienes desarrollaron todos su trabajo principalmente en el marco de la filosofía lógica y la filosofía del lenguaje. ${ }^{6.03}$

Los postulados de la escuela de Lvov-Varsovia se caracterizaron por un posicionamiento marcadamente racionalista debido a su prioridad por los planteamientos basados en la lógica y las matemáticas. Respecto a la filosofía del lenguaje la escuela de Lvov-Varsovia fue "responsable de la aparición de nuevas antinomias semánticas, dibujando los rudimentos de una semántica basada en la antropología psicológica." ${ }^{0.04}$.

En estasideas comienza a percibirse su influencia del 'Formalismo Ruso' - cuyos miembros abogaban por el establecimiento de un método "científico" para el estudio del lenguaje- y de los métodos de análisis literario estructuralistas desarrollados por el Círculo Lingüístico de Praga, cuya relación con la obra de Leykam será abordada posteriormente.

Las reglas de la nueva semántica descritas por la Escuela de Lvov-Varsovia fueron planteadas desde la lógica las expresiones humanas, "entendiendo la lógica como un conjunto de reglas que fincionan como herramientas para la mente" ${ }^{6.04}$. Mediante teoremas resultaba posible demostrar la limitación de la mente humana: "Hay una noción empírica, correctamente definida metodológicamente, que ningún ser humano es capaz de usar adecuadamente." 6.04 
El planteamiento arquitectónico de Leykam está en consonancia con los fundamentos teóricos de la Escuela de filosofía de Lvov-Varsovia basados en la trascendencia, no solo social y cultural, sino también política e ideológica de las manifestaciones construidas que, albergando un proceso lógico en su planteamiento y su desarrollo, podían transmitir valores al ser interpretadas como resistencia frente el irracionalismo.

Según la filosofa polaca Maria Ossowska "es imposible entender la cultura de un país sin entender los 'patrones" culturales que la inspiran." "6.05 Ossowska escribió en 1946 un ensayo en el cual explicaba que tras la II GM el patrón social polaco ya no podía establecerse en torno a un ser elitista ni clasista, -a diferencia de la mayoría de los modelos desarrollados en el pasado-, y hacía hincapié en la necesidad de poner el acento en la socialización y la capacidad para organizar la vida colectiva. ${ }^{6.05}$

El ideal polaco de postguerra se establecía en torno a aquellas figuras que con su actitud avivaron la resistencia ante la dominación del país manteniéndose preocupados por la rectitud moral de sus afirmaciones, la honestidad y la precisión de su trabajo, fuese este técnico o artístico. ${ }^{6.06}$

La actividad pedagógica de la Escuela Filosófica de Lvov-Varsovia constituyó un claro referente para el establecimiento de los 'patrones de referencia' que formalizaron la imagen prototípica de intelectual polaco, al que Leykam, desde la arquitectura, trató de aproximarse.

Esta teórica figura a la que ajustarse, implicaba implícitamente un compromiso con la denuncia de la falta de autonomía y el carácter autoritario ${ }^{6.06}$ de los propósitos, invitando a los ciudadanos polacos a desarrollar habilidades de pensamiento independiente para contribuir a su mejora a través de sus obras, evitando cualquier perjuicio de expresión insuficientemente justificado que pudiera afectar a sus trabajos, aunque albergara trazas de veracidad basadas en convenciones acordadas.

Los objetivos pedagógicos asociados a la revalorización de prototipo de intelectual en Polonia que puso en práctica la Escuela de pensamiento de Lvov-Varsovia, se convirtieron en características distintivas de todos aquellos que ejercieron a través de su trabajo algún tipo de resistencia al control ejercido por el estado durante la postguerra polaca, afrontando su tarea desde la eficacia y al mismo tiempo desde la responsabilidad social.
605 . Ossowska, 1946 p 1.

6.06 Con carácter autoritario -tomando la definición de Erich Fromm- nos referimos a la estructura de la personalidad que constituyó la base humana del totalitarismo. Fromm, 1941. p 243 

"El posicionamiento racionalista exige de nosotros un esfuerzo para que toda manifestación pueda ser comprendida desde la lógica y no solo eso sino que sea intersubjetivamente comunicable y verificable por todos los individuos."

Kazimierz Ajdukiewicz. "An attempt at a proof of the ontological principle of contradiction" 6.07

Uno de los propósitos fundamentales de Marek Leykam fue crear una arquitectura que pudiera ser el resultado de una práctica metódica y alcanzase la capacidad de cumplir los requisitos de la crítica científica, estableciéndose desde un principio de racionalidad y con el apoyo de una argumentación lógica, para mantenerse fiel al principio ético de emprender, como creador, una búsqueda honesta de conceptos 'claros' y 'distintivos'.

La arquitectura de Leykam no solo tratará, por tanto, de respetar unos principios fundamentales asociados a la técnica -como la claridad y la precisión en sus formulaciones- sino que, al mismo tiempo, se planteará la condición de pertenencia a un proceso social y su capacidad de ser transmisora de valores derivados de la legitimidad, la fiabilidad y la perseverancia de su trabajo, que hagan partícipe a la sociedad polaca de un mensaje de resistencia frente al irracionalismo que había sido elevado a la categoría de dogma desde el poder político durante la II Guerra Mundial e institucionalizado en el país durante la posguerra posterior.

El ambiente intelectual y la confluyente actividad magisterial de profesores de carácter filosófico y matemático en Polonia durante la década de 1930 hizo proliferar estudios a partir de los cuales la lógica se utilizaba para comunicar formalmente aspectos de la realidad, sin constituirse sin embargo en una "nueva realidad" ".03.

"Los símbolos representan objetos, pero no los reemplazan" ${ }^{6.03}$ diría Twardowski. Desde la lógica, resultaría imposible -siguiendo su argumentación-, comunicar una nueva interpretación de lo existente, puesto que, "si bien es factible
6.07. "An attempt at a proof of the ontological principle of contradiction". Works Dordrecht, Kluwer A.P. 1992, p. 31. Op. Cit. Op. 6.03 .

6.08. A propósito de Twardowski en 6.02.. p. 48. 
6.09. "Cosa" en el sentido aristotélico de "sustancia primera"

6.10. A propósito de Kotarbitiski, en 6.02. p. 249.

6.11. Twardowski, Kazimierz. "Wyldady $z$ teoril poznania" Archiwum Mistodi Filozofil i Mysli Spolecznej" p.268. Citado por 6.02 p. 441 realizar una interpretación de los símbolos, las relaciones formales entre símbolos necesariamente deben trascenderse remitiéndose a los objetos." 6.03

"Solo los cuerpos existen. Y por otra parte, todo lo que es, es "cosa" 6.09 , de lo que se deduce que todas las cosas son cuerpos. (...) Asimismo, todo cuerpo es tridimensional. Como sabemos, lo que tiene una dimensión espacial exige el accidente "cantidad" y la cantidad solo se da en las sustancias materiales, por lo que de todo ello deduciremos que todas las cosas siempre son materiales." 6.10

Para Twardowski, toda verdad era absoluta y todo símbolo (o relación de símbolos) debía estar puesta en lugar de un objeto. Cuando una proposición es relativa, es debido a las limitaciones del lenguaje o del entendimiento pero no porque un juicio sea en sí mismo relativo. ${ }^{6.03}$

Cabe significar en este punto la diferencia entre juicio y oración. El juicio no pertenece al entendimiento personal sino que es "absoluto sobre algo en el mundo". ${ }^{6.03} \mathrm{La}$ oración es una forma lingüística concreta con la que un sujeto (éste no atemporal ni absoluto) expresa el contenido de un juicio. "En los juicios, toda verdad es absoluta, mientras que en las oraciones caben relativismos. ${ }^{6.03}$

Muchas oraciones no consiguen expresar todo el contenido del juicio absoluto que quieren transmitir, derivando en abundantes elipsis que son suplidas con las circunstancias, como el contexto en el que la oración es expresada:

"En lo referente a los juicios no se puede hablar de verdad relativa sino únicamente absoluta. Todo juicio es o verdadero ( $y$ entonces es verdadero en todo lugar y para siempre) o no es verdadero (y entonces no lo es en ningún lugar y nunca).

(...) Un juicio afirmativo es verdadero si su objeto existe, un juicio negativo es verdadero si su objeto no existe; un juicio afirmativo es falso si su objeto no existe, un juicio negativo es falso si su objeto existe". ${ }^{6.11}$

Ni los símbolos ni las leyes de la lógica pueden separarse de las cosas reales, puesto que esta disyuntiva produce un puro formalismo. La lógica posee una función simbólica que no se entiende en si misma, sino en conexión con los seres reales. Al mundo real se accede por medio del entendimiento, y el contenido de los juicios que propician el entendimiento se expresa con oraciones.

Desde la lógica, por tanto, se podría codificar un lenguaje que propiciase el entendimiento. La arquitectura, por su parte, podría sumarse a esta estructura significante a través del razonamiento deductivo que pudiera resultar inherente a cada uno de sus planteamientos, estableciendo así un lenguaje que le permitiese relacionarse con todas las materias que tengan acceso al pensamiento lógico, incluida la filosofía. 
Los lógicos polacos de la Escuela de Lvov-Varsovia consideraban que desde su campo de estudio estaban haciendo una aportación socialmente muy importante ante las circunstancias históricas, al ser capaces de enlazar las diferentes ciencias y los procedimientos racionales de las humanidades a través del razonamiento lógico y, con esa misma transcendencia fue entendido su mensaje en la sociedad polaca después de $1945 .{ }^{6.03}$

La lógica matemática llegó a ser considerada en Polonia una ciencia autónoma separada de las matemáticas y la filosofía, insistiendo en la necesidad de cooperación de los representantes de todos los campos en los que podría ser utilizada la lógica, entre los que se encontraba la arquitectura y ante cuyos postulados la obra de Marek Leykam resulto especialmente significativa. ${ }^{6.03}$

El filósofo Jan Lukasiewicz, consideró la lógica como la actividad que representaba la moralidad del pensamiento y la expresión, planteando como necesaria una "reforma filosófica en Polonia con el fin de evitar los errores del pasado, para lo cual era necesario retornar al proceder lógico y axiomático desde el que afrontar con honestidad la generación de conceptos claros y principios evidentes." 6.03

Para Łukasiewicz, cualquier sistema lógico correcto debería ser coherente y, -sintáctica y semánticamente-, completo, basándose en conjuntos independientes de términos y axiomas primitivos. Por lo tanto, la dependencia de los términos o axiomas primitivos era considerada como un defecto esencial. A cerca del estilo, Eukasiewicz apunta:

"Tenemos la sensación de estilo, -en el sentido más riguroso de la palabra-, siempre que se de la multiplicidad, la complicación heterogénea de la vida, sometida a un proceso de simplificación y la idea primaria, particular, elevada al rango de Universal: es decir. cuando se da una estilización. una modelización de lo concreto y particular." ${ }^{6.12}$

Leykam consideraba que la arquitectura requería una reformulación desde la comprensión de los métodos lógicos modernos, postulando una clara diferenciación entre el contenido presentado por la modernidad y las analogías formales que de forma arbitraria estaban siendo adoptadas de forma subjetiva dejando de lado el origen de sus significados y el hecho social, la sociedad ante la que se plantean.

Este posicionamiento tiene que ver en su conjunto con la profunda preocupación de la Escuela de Lvov-Varsovia de no abundar en una tiranía monocorde de la razón sino en la capacidad de los sistemas lógicos de pensamiento de aceptar la necesaria presencia de reflexiones subjetivas de carácter humano, poseedoras de una dosis controlada y acotada de irracionalidad mostrando así una preocupación que estaría posteriormente en el eje central de la obra de Marek Leykam como podremos estudiar en el análisis de su trabajo posterior, donde comprobaremos cómo, en lo referente a las reglas de composición la lógica resultó ciertamente influyente en la definición de sus formulaciones compositivas y constructivas. 


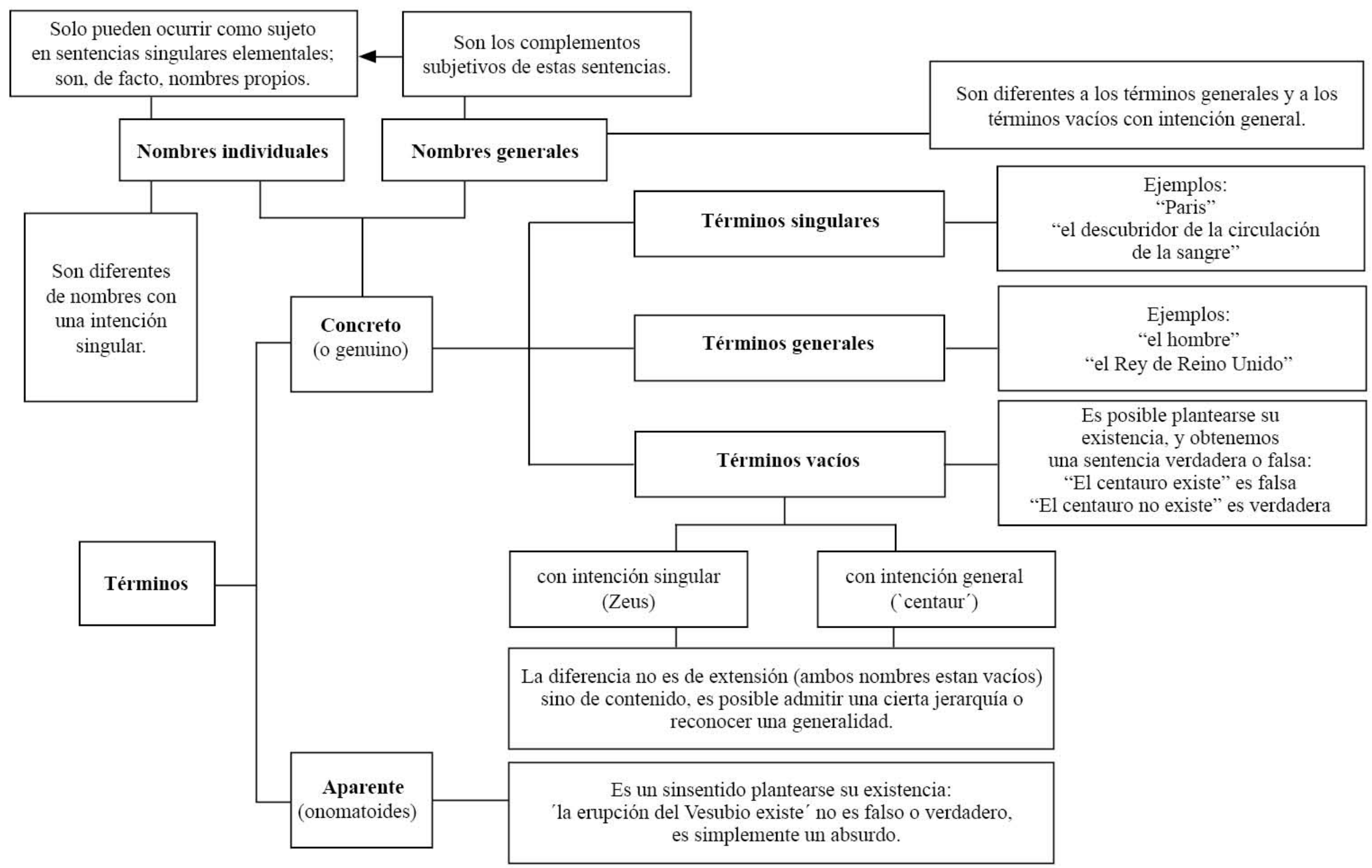


La obra teórica del filósofo Roman Ingarden, en la trató de argumentar lógicamente contra el idealismo a través del análisis de la obra de arte y en sí de la propia arquitectura, también ejercería gran influencia en la obra de Leykam. Para Ingarden los valores de una obra artística no se agotan en el valor separado de sus diferentes estratos. Las obras no existen por separado sino que forman una "unidad orgánica". ${ }^{616}$ Los 'estratos' son diversas formas de dependencia mutua, y la influencia -las armonías o desarmonías- entre los estratos pueden contribuir a añadir solo méritos o deméritos a la obra, que, sin embargo, es constituida esencialmente como un todo. ${ }^{6.17}$

La obra de arte en su conjunto es -para Ingarden- una "armonía polifónica" en la que, al igual que en una pieza de música, la voz de cada cantante puede prestar cualidades estéticas propias al valor de la totalidad. Los mayores 'valores' de la obra están en su manifestación del conjunto, sin perjuicio de que puedan ser expresadas interrelaciones complejas de valores entre elementos a nivel individual. ${ }^{6.17}$

Ingarden se plantea la obra musical como una formación esquemática llena de lugares de indeterminación (por ejemplo, puede ser indeterminada la cantidad exacta de ruido que va a emitir la nota que se va a reproducir, cuánto tiempo debe mantenerse, etc..) conformando así, mediante su presencia, diferentes adaptaciones.

El trabajo de la música, además, es siempre pautado y se extiende en el tiempo, no contiene ninguna función esencial que permita representar el conjunto de sonidos de la obra al mismo tiempo. En una obra arquitectónica, sin embargo, existe un marco a partir del cual las relaciones con los objetos físicos más básicos pueden dar lugar una teoría general social y cultural. Según Ingarden:

"La obra arquitectónica plantea una objeción findamental a la opinión de que las obras de arte son objetos puramente intencionales que tienen su punto de partida en los estados intencionales de sus creadores y espectadores (...) Después de todo, la catedral de Notre Dame de París no parece ser menos real que los muchos edificios de viviendas que se interponen en su vecindad, en la isla sobre la que fue construida, en el río que fluye cerca, etc.." . 6.18

Para Ingarden la obra arquitectónica no es un mero objeto "real" independiente y aislado, puesto que su existencia como obra requiere no solo su creación por parte de un arquitecto, sino también los "actos reconstructivos"a través de los cuales el usuario o espectador adopta una cierta actitud hacia el objeto real, ayudando, y de hecho reconstruyendo a través de él sus propiedades sensibles y estéticas. ${ }^{6.17}$

Tomando como ejemplo una bandera, Ingarden subraya como su potencialidad no debe ser identificada con el simple trozo de tela, ya que este contiene diferentes propiedades esenciales y tiene como base adicional su manera de ser partícipe en las actividades intelectuales de la comunidad, que la aceptan y la dotan de significado incrustándola en las normas de la acción. ${ }^{6.17}$ 6.13. Kotarbinski, T. "Filozor, Studia Fiozoficzne"
(1957). Traducción inglesa incluida en Gnosiology,
Wroclaw-Oxford, Pergamon Press, 1966, p514. Citado por 6.03

6.14. Kazimierz Ajdukiewicz Cit Op. Cit. 6.03.

6.15. Jan Łukasiewicz. Cit Op. Cit. 6.03

6.16. La idea de constitución de una "unidad orgánica" es adoptada literalmente por Leykam en sus textos para hacer referencia a la obra en sus textos para hacer referencia a la obra arquitectomica (Vease p. $375-377$.)

6.17. Thomasson, 2012

6.18. Roman Ingarden, Cit. Op. Cit 6.17 
Extrapolando este ejemplo a la arquitectura, una iglesia no es idéntica al verdadero edificio sobre el que se fundó la Iglesia original, sino que ha de posibilitar la creación a través de actos de la consagración y preservación, las actitudes adecuadas para la celebración de los rituales y la memoria espiritual de una determinada comunidad.

En virtud de su dependencia secundaria de actos de conciencia, la iglesia es dotada de diversas propiedades (sociales, culturales, morales...) que un mero montón ordenado de materiales de construcción no puede tener. Los objetos culturales y sociales no pueden por tanto quedar limitados a la ruta reduccionista de identificarlos con sus bases físicas, ni la ruta subjetivista de tratarlos como meras construcciones fruto de un acto personal. La arquitectura encuentra así su lugar entendida como producto de los actos comunes de la conciencia y la existencia manifestada en formas específicas, idea que recorrerá la obra de Leykam articulada como un continuo doble sentido de implicaciones técnicas y constructivas, y al mismo tiempo ideológicas y sociales. ${ }^{6.17}$

Ingarden había distinguido entre el mero objeto físico y la obra de arte a través de lo que el llama "concreción" de la obra de arte, lo que considera la "verdad del objeto estético". ${ }^{6.17}$ La obra de arte en sí misma, -en el caso de la mayoría de las formas de arte como la literatura, la pintura o la música..-, contiene lo que Ingarden llama "formación esquemática" ${ }_{6.17}$ es decir, que contiene ciertos "lugares de indeterminación", muchos de los cuales están completos tras una interpretación individual o una lectura particular de la obra. Estas indeterminaciones son sin embargo generalmente parciales y deben ser completadas por el espectador o usuario al abordar una reconstrucción mental de la obra, profundizando en la escena imaginaria a partir de la base o esqueleto que se presenta frente a él. ${ }^{6.17}$

Aunque estemos hablando de una obra de arte completamente figurativa, siempre habrá un espacio -según Ingardenque quedará indeterminado para que el espectador pueda completarlo conjuntamente con lo que está pensando; lo que ocurre inmediatamente antes o después del momento representado; los acontecimientos históricos que rodean la obra; etc... Los espectadores reproducen actos reconstructivos que complementan las indeterminaciones de la obra, 'concretándola', dando 'forma' a un objeto estético total, en el que confluyen aspectos materiales con aspectos sociales y emocionales. ${ }^{6.17}$

Mientras un objeto físico posee las propiedades físicas de un valor neutral, la obra de arte puede poseer dos propiedades "axiológicamente neutrales" según Ingarden ${ }^{6.17}$ la posesión de una estructura de oración (p. ej.: llevar manchas de color dispuestas de cierta forma, ..) y adquirir cualidades de valor artístico que se fundamentan en su estructura (p. ej.: la claridad u oscuridad de la expresión, la técnica según la cual los materiales han sido trabajados, el equilibrio según el cual han sido compuestos, etc.)

Leykam se preocupará en gran medida por entender el papel que juega la conciencia en la obra de Ingarden y participará activamente con sus textos y su obra construida en esa llamada a la constitución de los valores estéticos que, sin abrazar 
el subjetivismo, otorga a la arbitrariedad de los juicios que emanan de la comunidad la capacidad de concretar la obra arquitectónica a través de sus valores.

A pesar de que en la obra arquitectónica existen "potencialmente" valores éticos, sociales y políticos, estos se manifiestan en los objetos creados a través de la "concreción" que hace de la obra arquitectónica el conjunto de la sociedad, caracterizando el objeto construido de valor estético y al mismo tiempo ético. Las teorías de Ingarden servirán asimismo a Leykam para elaborar su comprensión de la arquitectura como un lenguaje en el que se emite el juicio que no puede dejar marginada la identificación de los múltiples tipos de valor, ya sean de carácter técnico, compositivo, moral, ideológico, cultural, histórico, social...

"La obra de arquitectura no se remite solo a los actos de su creador sino a los actos reconstructivos del espectador, a su findación en forma real plenamente decidida de una manera particular" "6.18

Como resultado de los muchos conflictos aparentes ante los que ha de enfrentarse el arquitecto al realizar su trabajo, Leykam se plantea de forma lógica, la adecuada administración de la dosis de subjetividad e idealismo que considera intrínsecas a la obra arquitectónica, puesto que derivan de su presencia pública, dando lugar a un modelo de conducta que pudiera ser asociado racionalmente a su posicionamiento ideológico respecto a la manera en que la población polaca debía en aquel momento replantearse el poder que ejercían sobre ella las ideologías políticas totalitarias.

A partir de estas reflexiones Leykam dará lugar a una obra arquitectónica que se manifestará heredera de la lógica y la razón, en continuidad con la tradición metodológica polaca de la escuela de Lvov-Varsovia, siendo capaz de transmitir a través de sus obras un mensaje continuo de equidad, reparto del poder a través de mecanismos de control democráticos, ausencia de jerarquías dominantes e igualdad de oportunidades en el conjunto de sus espacios, contribuyendo a codificar socialmente la idea de permanente equilibrio y justicia social.

No quedaba al azar la necesidad de que los receptores de su mensaje alcanzasen su comprensión del contexto históricofilosófico de Polonia, para lo cual resultaron fundamentales sus continuas referencias al trabajo de la Escuela Filosófica de Lvov-Varsovia, la cual, a través de sus textos, estableció la relación del arte con sus valores éticos y morales, manifestándose en contra de todos los convencionalismos y conminando a los agentes sociales a combatir, desde la acción creativa -en cada una de sus disciplinas-, el relativismo intelectual.

Leykam estableció a partir de estos planteamientos un conjunto de las operaciones, recursos, funciones y mecanismos, utilizados de forma consistente a lo largo de toda su obra, a través de los cuales nos resultará posible reconstruir en esta tesis su metodología proyectual expresada de forma coherente mediante un conjunto de constantes a las que se aplican variables que el usuario y espectador de la obra pudiese ser capaz de apropiarse, concretando, por si mismo, un determinado mensaje de contenido, no solo cultural, sino social, político y moral. 
"El pensamiento creativo empezará a buscar su desarrollo entre los pensamientos religiosos, las oraciones de bendición al pueblo y el amor al prójimo cuando se haya derrumbado la fe en los logros del socialismo, los espejismos del comunismo, la fe en la igualdad y la fraternidad de la sociedad, y, en medio de los estallidos de las armas, toda la riqueza de los países se encuentre consumida por la construcción de herramientas para asesinar al prójimo."

Marek Leykam, "Sztuka religijna Wczoraj i dzis" 6.19

Durante el transcurso de la II Guerra Mundial, Leykam adquirió plena conciencia de que, como arquitecto, iba a tener la posibilidad de dar una respuesta a un conjunto de necesidades que no solo iban a venir marcadas por la prioridad de una reconstrucción física, sino por la restitución de la fe en la convivencia pacífica y solidaria de la población y, en definitiva, por la restitución del propio concepto de vida en comunidad.

En los escritos que llevó a cabo durante sus últimos años en el exilio en Suiza se trasluce su deseo de que exista en el futuro una arquitectura en Polonia capaz de ser evaluada objetivamente, de forma que los arquitectos pasen a ser agentes sociales llamados a mejorar las condiciones de vida de su pueblo desde la honestidad intelectual y sin sucumbir a las interferencias ideologías o intereses externos planteados desde las corrientes políticas totalitarias.

El trabajo del arquitecto no era imaginado por Leykam como una tarea exclusivamente destinada a la realización de proyectos, sino como una actividad de marcada responsabilidad social en la que era necesario participar aportando contenidos claros, didácticos e interpretables desde las habilidades racionales, respetando los principios éticos y la prioridad del bien colectivo, algo fuertemente ligado a un compromiso ideológico que trascendía al ámbito moral.

Leykam advirtió en su obra escrita que era posible contribuir desde la arquitectura a que la sociedad recuperase la identidad tras una situación tan catastrófica como la acontecida tras la II Guerra Mundial, definiendo un lenguaje comunicativo que les permitiera entender su presente en continuidad con la historia, sin caer en la mímesis literal de las preexistencias anteriores ni en el dictado de cánones arbitrarios impuestos por directrices ideológicas, resistiendo a través de códigos que pusieran al alcance de la comunidad las herramientas que les permitieran recobrar la confianza en el ser humano como ente racional.

6.19. Artículo "Sztuka religijna Wczoraj i dzis" (Arte religioso de ayer y hoy) publicado por Marek Leykam en la Revista Plastika $\mathrm{n}^{\circ} 13$ de 1939. 
Ya en 1939 Leykam había escrito un artículo para la revista "Plastika"en el que consideraba que el arte contemporáneo había entrado en un periodo de banalización en el que los resultados obtenidos eran pura apología de determinadas formas autoimpuestas, cuestión que debía reconducirse desde una comprensión de la transcendencia y la espiritualidad del arte, para lo cual critica la desconexión del arte moderno con el estudio del arte religioso, al que considera completamente ignorado en el siglo XX.

Para Leykam el enriquecimiento de las formas asociadas a los objetos litúrgicos venía dado por la importancia de su representatividad simbólica, y por tanto estaba asociada a los motivos utilizados para su formalización. En una breve reseña histórica, recordará como en el arte del Renacimiento tardío y el Barroco temprano, el tumulto y la acumulación de encargos hizo que las obras se convirtieran en objetos que dejasen de servir principalmente a Dios, para pasar a depender poco a poco de mecenas ilustrados.

La cooperación en las épocas de grandes estilos se había acabado en el siglo XIX, y Leykam se lamenta en sus textos de que el arte litúrgico y el arte moderno se encuentren en ese momento enfrentados cuando sería necesario un entendimiento mutuo. Reflexionando sobre la dificultad de construir un arte verdaderamente moderno Leykam llega a la conclusión de que su ausencia es debido a la falta de mecenazgos, ya que las grandes fortunas se habían alejado del entendimiento del arte de la época en la que vivían, frivolizando su necesidad y vulgarizando su importancia espiritual. Citando a Leykam:

"La época de las grandes fortunas se aleja cada vez más en la oscuridad del pasado. (...) En el barroco todavía un mecenas construía una iglesia, fundaba altares, capillas, órganos, esculturas o pinturas... Fundaba costosas obras de los maestros más destacados. (...) Por ejemplo, Miguel Ángel esculpió la tumba de mármol del Papa Julio II y Wit Stwosz tardó 15 años en tallar un altar gigante de Santa María.

(...) Hoy no tenemos estos grandes fundadores que podían permitirse el desarrollo de sus fantasías no siempre para la gloria de Dios, como para el orgullo de preservar el nombre del fundador en las obras - para no escatimar en el coste de la creación de estas obras maestras. (...) Hoy unas pequeñas cuotas recogidas en las bandejas de la iglesia, distribuidas más adelante de manera más económica, crean baratijas de materiales endebles realizadas por malos contratistas.

(...) No hay espacio entre el clero y los artistas, pero la omisión de estos últimos ha servido para el abaratamiento del clero, para el beneficio de los ignorantes. Baratijas doradas, esculturas repintadas y oleografías de tenderetes,.. así son los interiores de las iglesias contemporáneas para su abaratamiento cada vez más a menudo construidas por aficionados. Tal es el estado del arte sacro contemporáneo, con pocas excepciones." 6.19 
El "hundimiento del arte" ${ }^{6.19}$-según Leykam-, entroncaba con la problemática provocada por una búsqueda de nuevos caminos de desarrollo distintos de los contemplativos; un camino que se podía haber encontrado en un contexto definido por el entendimiento, poniendo en valor el significado esencial de los objetos, tal como ocurría en el arte litúrgico, pero que no fue logrado. Así, el arquitecto polaco denuncia:

"La fealdad, el mal gusto, la cutrez, estos son los atributos de la mayoría de los objetos que se hacen hoy al servicio de Dios, una fealdad que ofende la elemental sensibilidad estética. Y todo ello con las posibilidades de desarrollo del arte religioso renacido, porque estas posibilidades se componen de muchas causas esenciales en el perfil contemporáneo." 6.19

Leykam hará pronto una puntualización en sus estudios sobre el arte religioso, dando a entender que su interés es principalmente epistemológico. Según Leykam el arte religioso abarca el concepto de arte de una forma más amplia, incluyendo todas las manifestaciones de arte relacionadas con la temática religiosa, como la pintura, la escultura, la arquitectura, etc.., que habían sido parte consustancial en la evolución del arte mientras el arte litúrgico, el objeto principal de su estudio, es aquel que permite realizar una reducción sistemática de su comprensión enfocada a las necesidades específicas del rito y la naturaleza de sus piezas, sin que ello suponga dejar de lado la posibilidad de entender el origen y el desarrollo de su simbología desde el punto de vista moderno, -que es lo que había sido banalizado, no únicamente el arte litúrgico-, haciendo extensiva esta carencia al arte moderno en general.

En un ambiente claramente prebélico, Leykam ya había planteado en 1939 su determinación al estudio de la analogía del arte litúrgico y el arte moderno con el propósito de buscar un nuevo camino para la manifestación artística que no dejase de lado las lecciones que ofrecía la importancia del arte religioso, pero evitando la abstracción de las manifestaciones artísticas contemporáneas que consideraba absolutamente vacías de contenido por su pérdida de valores y su reflexión en torno al objeto alejada de su contexto significante en tanto que hecho social.

"La escultura en el altar, en el cirio pascual, en la pila bautismal,.. la pintura en la policromía del altar, en el mosaico del fondo de una patena, el ostensorio, los cálices y candelabros, el bordado y el tejido de la vestimenta litúrgica,.. ese es el arte en forma de objetos que cumplen el servicio litúrgico." 6.19

El paralelismo que establece entre la importancia ética y moral asociadas al arte litúrgico y la arquitectura, tuvieron continuidad con las reflexiones que realizará posteriormente en Suiza durante su tesis doctoral, en las que consideraba que el desarrollo de arte moderno estaba siendo sumergido en investigaciones teóricas, problemáticas y textuales que rechazan la temática, el simbolismo y la 'literariedad' de la composición en la pintura y la escultura. ${ }^{6.19}$

La creación de una nueva forma bajo nuevos métodos de cálculo y nuevas posibilidades de diseño era posible según 
6.02 - 6.03 Chiesa del Sacro Nome di Gesù (Iglesia Jacopo Barozzi da Vignola, $1568-1580$.

6.04 Boceto de Leykam de la planta de Il Gesù.

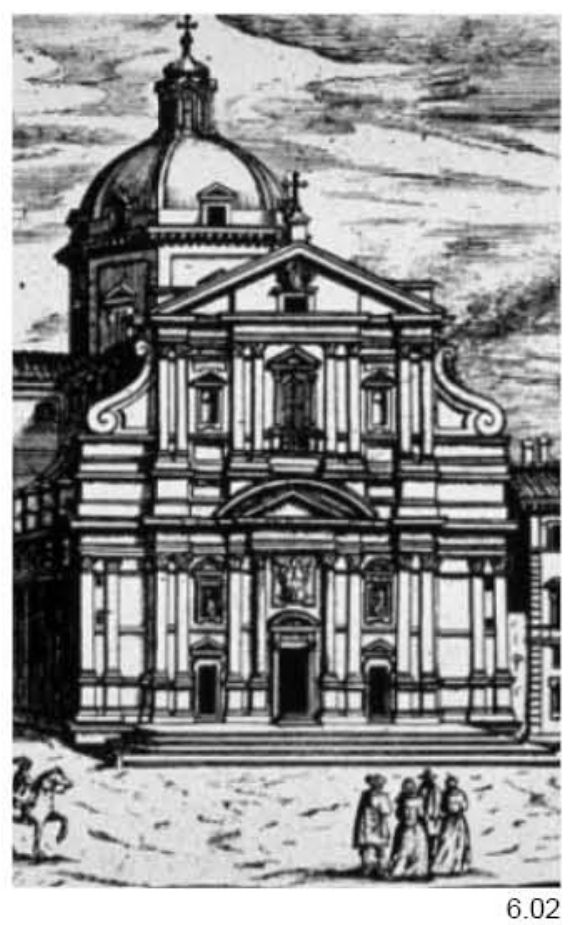

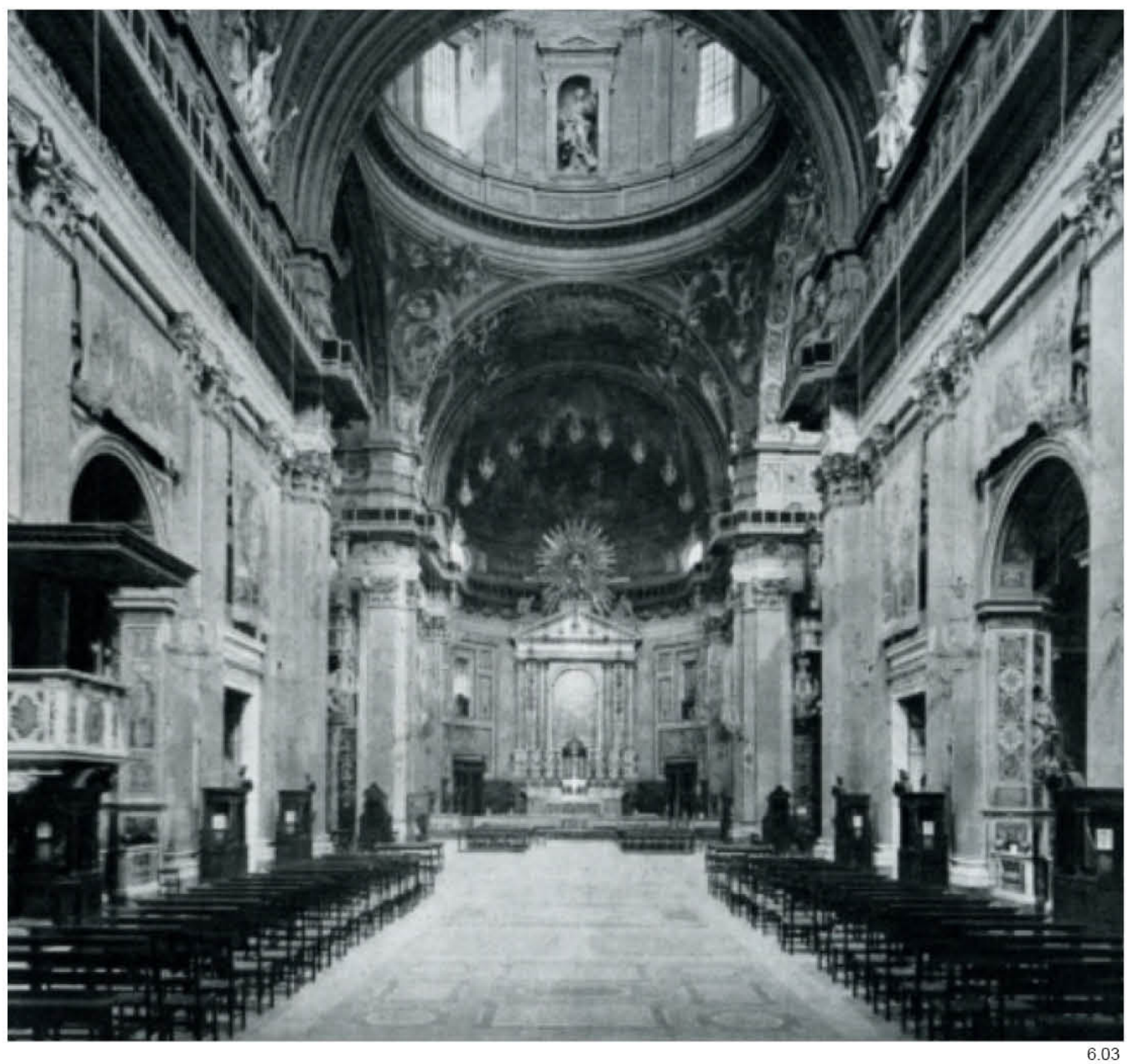


Leykam, no solo para la arquitectura sino también para todas las artes planteadas al servicio de las exigencias humanas, como era el caso de las litúrgicas, una actitud que defiende en todo momento como esencial. La importancia de estudiar el arte litúrgico radicaba por tanto en la necesidad de adquirir plena conciencia de su capacidad de dotar de un mayor impulso a la nueva formulación del arte y la arquitectura, haciendo a ambas confluir en una expresión plenamente actual que entroncase con las motivaciones morales del ser humano en un contexto integrador, generando así una estética que pudiera llegar a ser entendida como contemporánea. De este modo, señalará:

"El arte debe alcanzar una expresión a través de los conceptos abstractos mediante los cuales piensa, siente y ama, su objetivo debería ir cambiando y adaptándose de tal modo que exprese el sentido esencial de la manera más profunda, y al mismo tiempo, más simple posible." 6.19

Es a través de la atención prestada a los detalles constructivos y la comprensión de la transcendencia simbólica de la composición en los elementos litúrgicos como Leykam considera que es posible abstraer conceptualmente la vinculación existente entre la arquitectura y la espiritualidad, debido a su capacidad transmitir valores en tanto hecho comunicativo. En una descripción de la Iglesia del Gesù (6.02-6.04) Leykam concluye:

"Cómo de inmensas serían las perspectivas que nos ofrecería una comparativa de la forma de la repetida ciegamente hasta hoy y desarrollada en otras condiciones iglesia de Il Gesù en Roma del año 1568, con las posibilidades de construcción de los métodos de cálculo modernos y las potencialidades estáticas de elementos de carga como el hormigón armado, con paredes en función del relleno y su imponente iluminación gracias al desarrollo de los nuevos materiales.

(...) La arquitectura barroca de Il Gesù (6.02-6.04) y de las iglesias jesuitas es arquitectura: la escultura de los muros gruesos, estructura y el contraste del claroscuro de sus fachadas, su superficie... La ingeniería contemporánea permite construir una arquitectura de cerramientos finos que oponga a las composiciones de muros la composición del espacio. Nace así la posibilidad de formar nuevas reglas compositivas, nuevas formas, y sin embargo, hoy en día se construye con formas obsoletas, con la utilización de nuevos materiales pero sin la comprensión de su esencia, desde el error de soluciones baratas cutres e ignorantes." 6.19

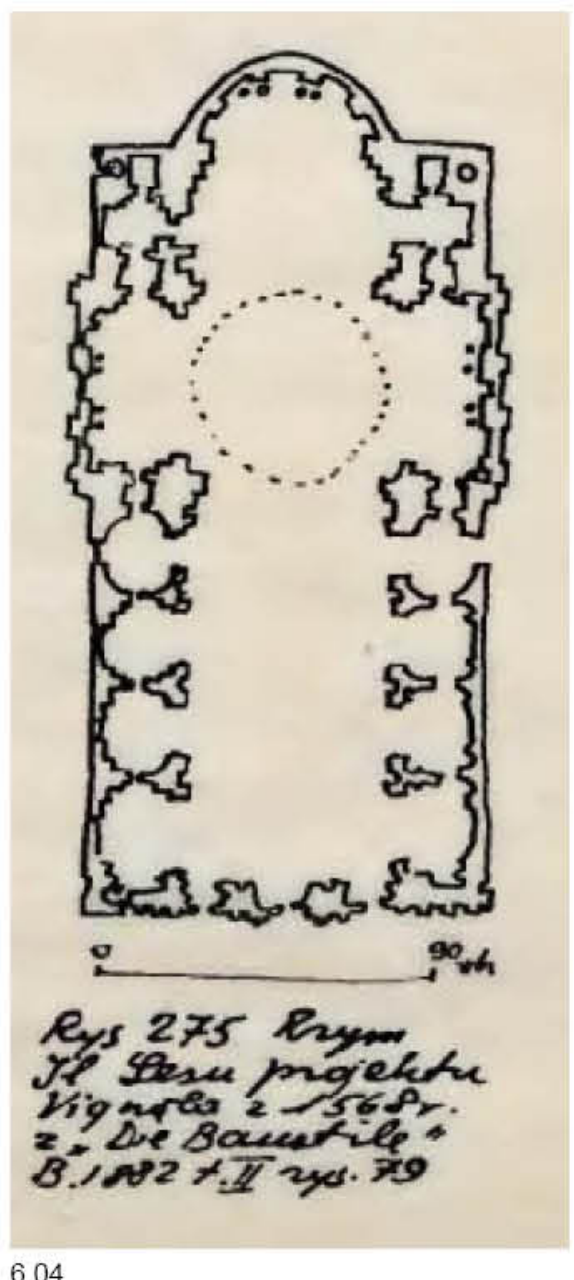

6.04

Leykam no pretende tan solo alcanzar un mayor entendimiento de los fenómenos que permiten transcender a la liturgia del hecho a su significado espiritual, sino que se plantea aprender a interpretar un lenguaje a través del cual sea posible posteriormente transmitir, a través de su futura obra arquitectónica, un conjunto de valores esenciales que hagan confluir la pretendida renovación expresiva del arte moderno con las motivaciones éticas de una sociedad desconsolada por la irracionalidad de las guerras y el sinsentido de los regímenes políticos que la gobiernan, ofreciendo un contexto integrador que desde la comprensión de la universalidad del espíritu humano pudiera llegar a propiciar una estética entendida verdaderamente como contemporánea. 
6.05 Retablo de la capilla Królewski Dzwon Zygmunt de Wawel, Cracovia.

6.06 Retablo de la Iglesia Sant'Anna dei Lombardi, Napoles.

6.07 Santuario della Madonna de Mongiovino, Iglesia de San Biagio de Montepulciano, San Pedro de Roma (proyecto), Basilica di Santa Maria della Steccata, Parm

6.08 Tesis Doctoral original de Marek Leykam "Arte Litúrgico" ("Stuka Liturgiczna").

6.09 Marek Leykam durante su estancia en Suiza (1940-1945)
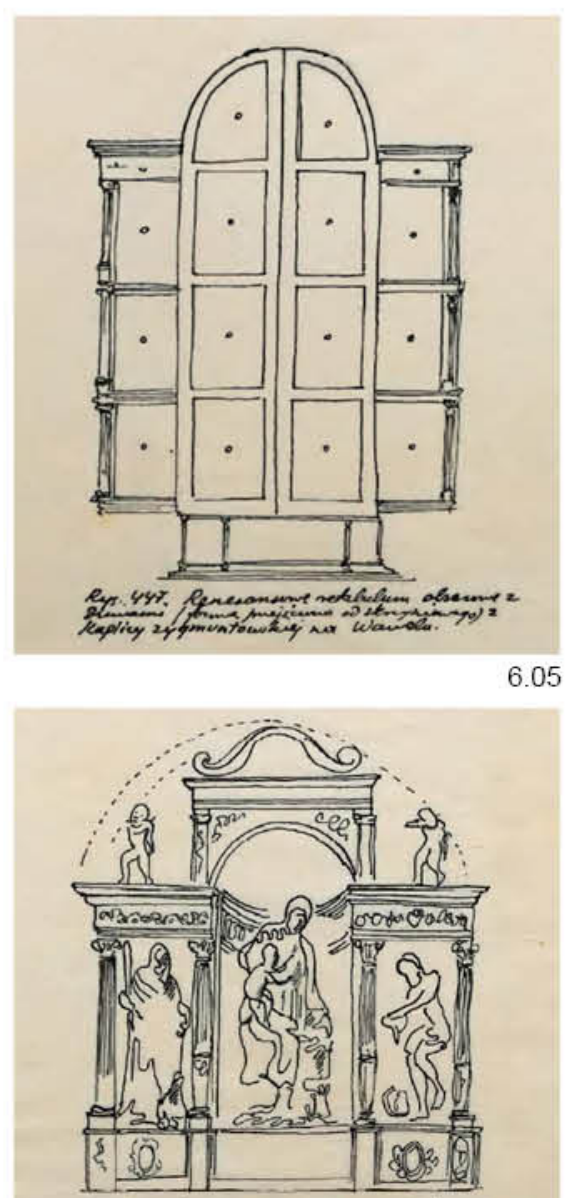

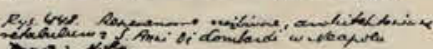

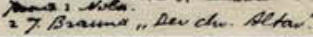

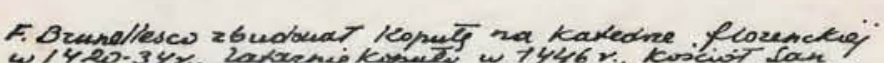
daroneos w

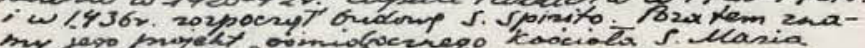

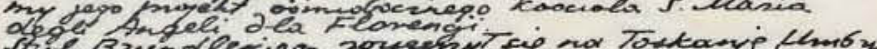

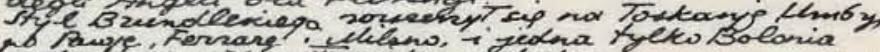

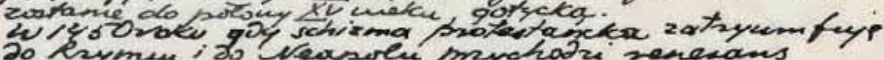

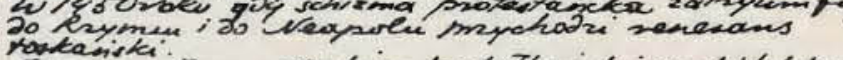

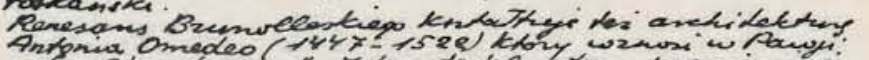

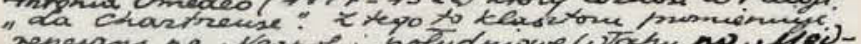

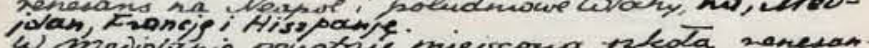

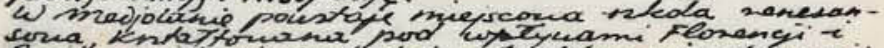

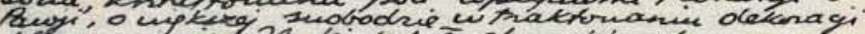

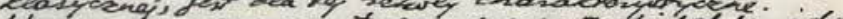
cyst troing serengo

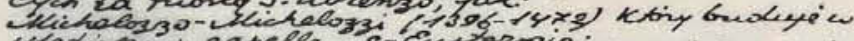

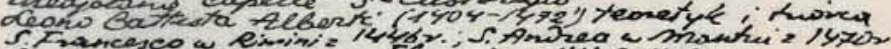

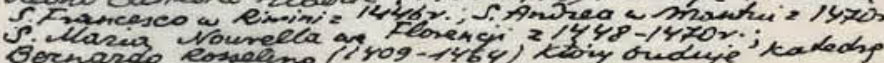

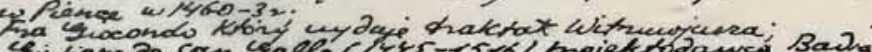

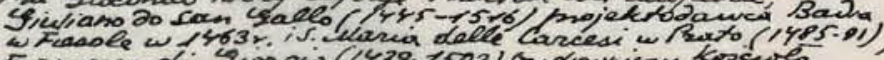

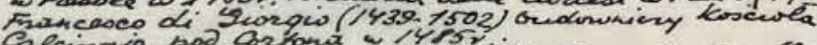

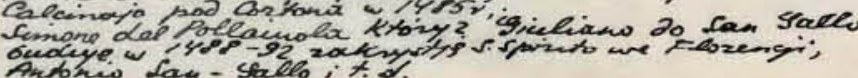

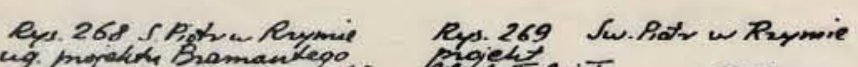

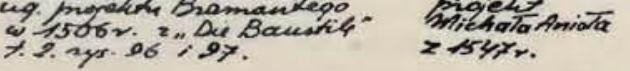
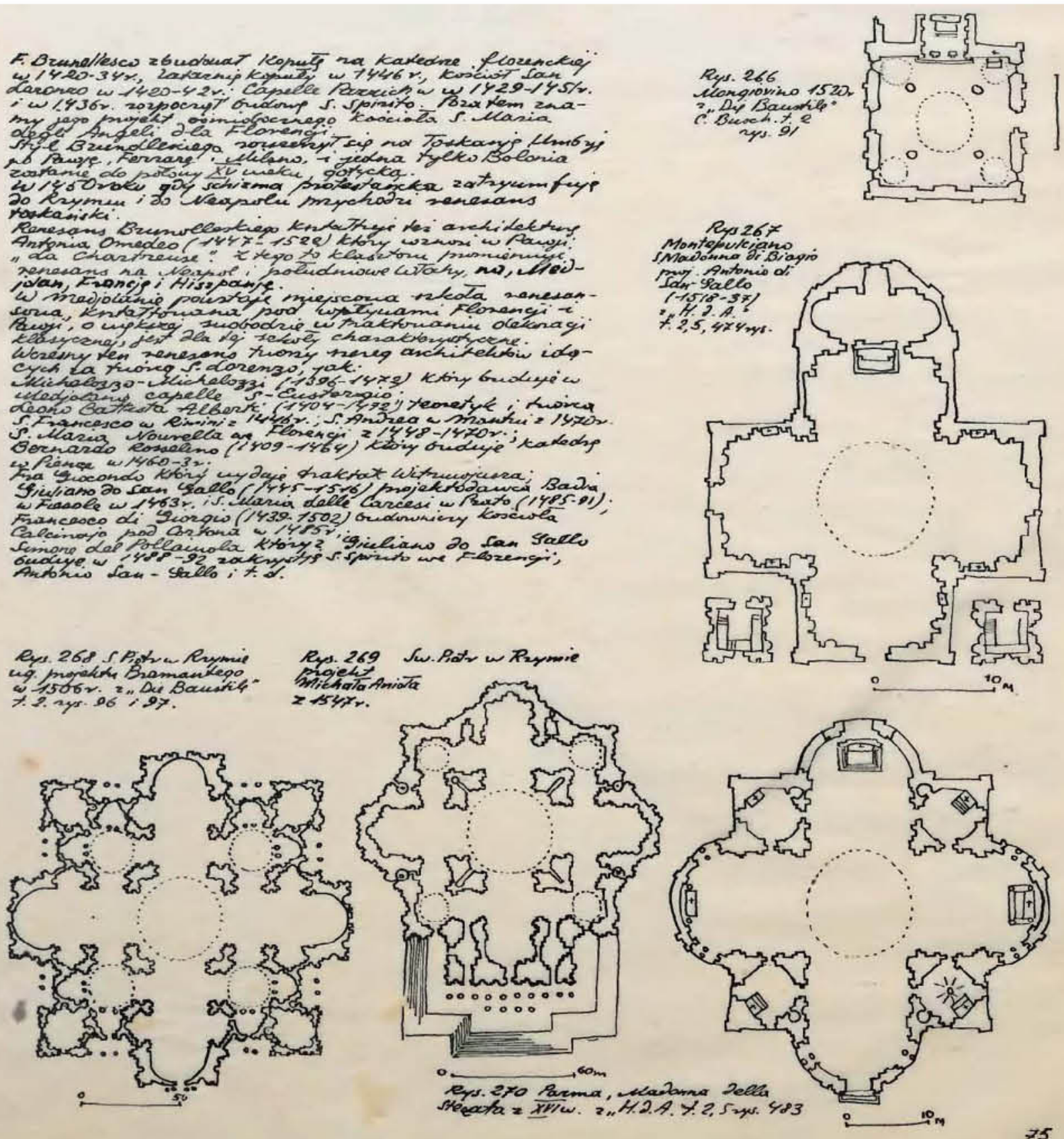

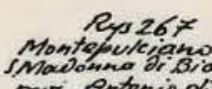

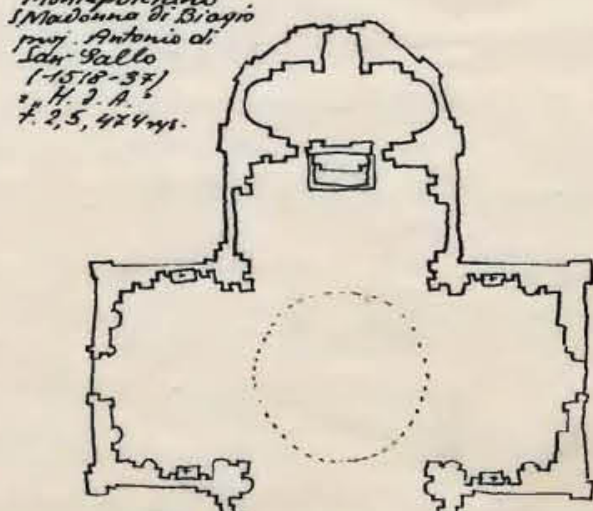

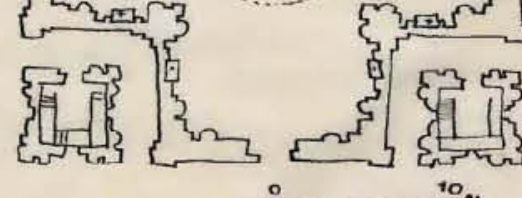


Durante su estancia en Suiza, Leykam había tenido ocasión de ampliar esta búsqueda de una arquitectura a través del estudio del arte litúrgico mediante su doctorado (6.10-6.30), un extraordinario documento no publicado hasta el momento y dibujado a mano por Marek Leykam, firmado bajo el nombre de Jan Lewinski ${ }^{6.20}$, registrado en Zúrich en 1943 con el título de "Sztuka Liturgiczna" ${ }^{6.21}$ (6.08) en el que a lo largo de las 177 páginas define su entendimiento de la arquitectura mediante el estudio de los elementos propios del arte litúrgico, con los que establece un paralelismo que le permite abstraer una idea asociada a las construcciones arquitectónicas desde la conceptualización de sus características expresivas derivadas de sus propiedad de carácter compositivo, espacial y tectónico. ${ }^{6.22}$

El trabajo de Leykam no abarca la totalidad del arte litúrgico, puesto que según el mismo explica, no engloba la música litúrgica, la poesía litúrgica,... En sus textos acota como arte litúrgico aquel que es entendido como "plástica artística de la liturgia". ${ }^{6.23}$ Pero incluso esta limitación no es suficiente, ya que en las consideraciones que realiza posteriormente todavía acota más su ámbito de estudio.

"Mi intención es argumentar sobre la arquitectura y su relación con la Liturgia bajo el aspecto de las necesidades que asociamos a los objetos litúrgicos, la influencia en la formación plástica del espíritu de los conceptos litúrgicos." 6.23

Los estudios que realiza Leykam sobre el arte litúrgico no serán, sin embargo, meramente el trabajo a través del cual pretende contrarrestar la banalización del arte, sino que contienen un trasfondo político e ideológico en la medida en que el arquitecto considera esta vacuidad asociada a la irracionalidad del poder político y la pérdida de valores morales en la sociedad moderna.

A través de este trabajo, Leykam hace extensiva su denuncia sobre la situación del arte litúrgico al conjunto de la arquitectura de su época, refugiado en un código que le permite evitar la eventual censura de aquellos años, conocedor como era de la carga ideológica y las implicaciones políticas que contenían sus manifestaciones.

La creación de nuevas formas arquitectónicas se había vuelto posible bajo los nuevos métodos de cálculo y nuevas posibilidades constructivas que ofrecían lo nuevos materiales, pero era necesaria una nueva interpretación de la profesión que permitiera que ésta fuera entendida desde su compromiso ético con la sociedad y alcanzase la posibilidad de dignificar las exigencias espirituales de todos los seres humanos, del mismo modo que lo habría logrado la arquitectura que era canalizada a través de la liturgia, dejando al margen las arbitrariedades y los dogmas, para ser puesta al servicio del arte y frente a su compromiso con la sociedad y con la propia historia.

Tratando de definir el alcance de su trabajo, Leykam diferencia tres tipos de arte asociados a la Iglesia: el arte de la religión, arte de las construcciones eclesiales, y el arte litúrgico. El arte religioso era considerado por Leykam inabarcable
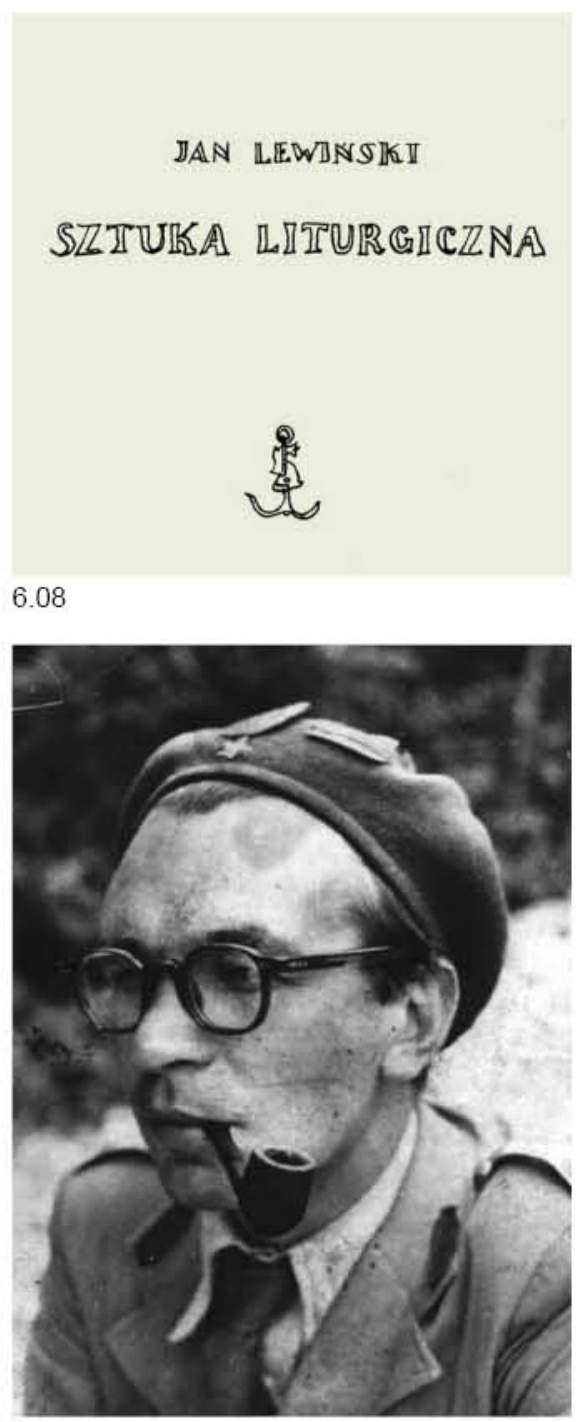

6.09

6.20. Su nombre real era Maurycy Jan Lewiński. 6.21. Lit.: Arte Litúrgico.

6.22. Los siguientes dibujos estan tomado del original inédito. Wydane Staraniem Komitetu Kulturalno Oswiatowego D.S.P.

6.23. Leykam, 1943. p 1-6. 
6.10 Cimborrio de la Iglesia de Santa María delle Grazie al Calcinaio.

6.11 Cimborrios en las iglesias de Santa Maria in Civitate, Santa Maria delle Grazie de Milán y Basilica di Santa Maria Maggiore de Roma.

6.12 - 6.13 Detalles tallados en piedra en el alzado (6.

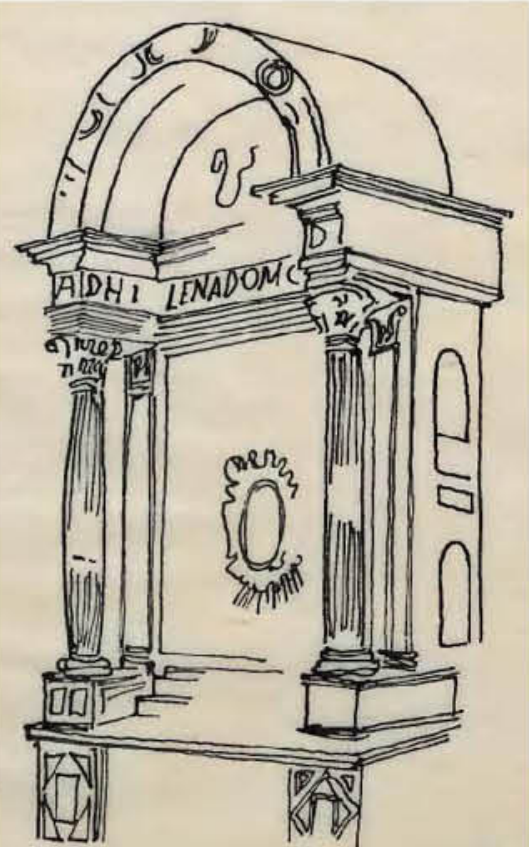

6.10

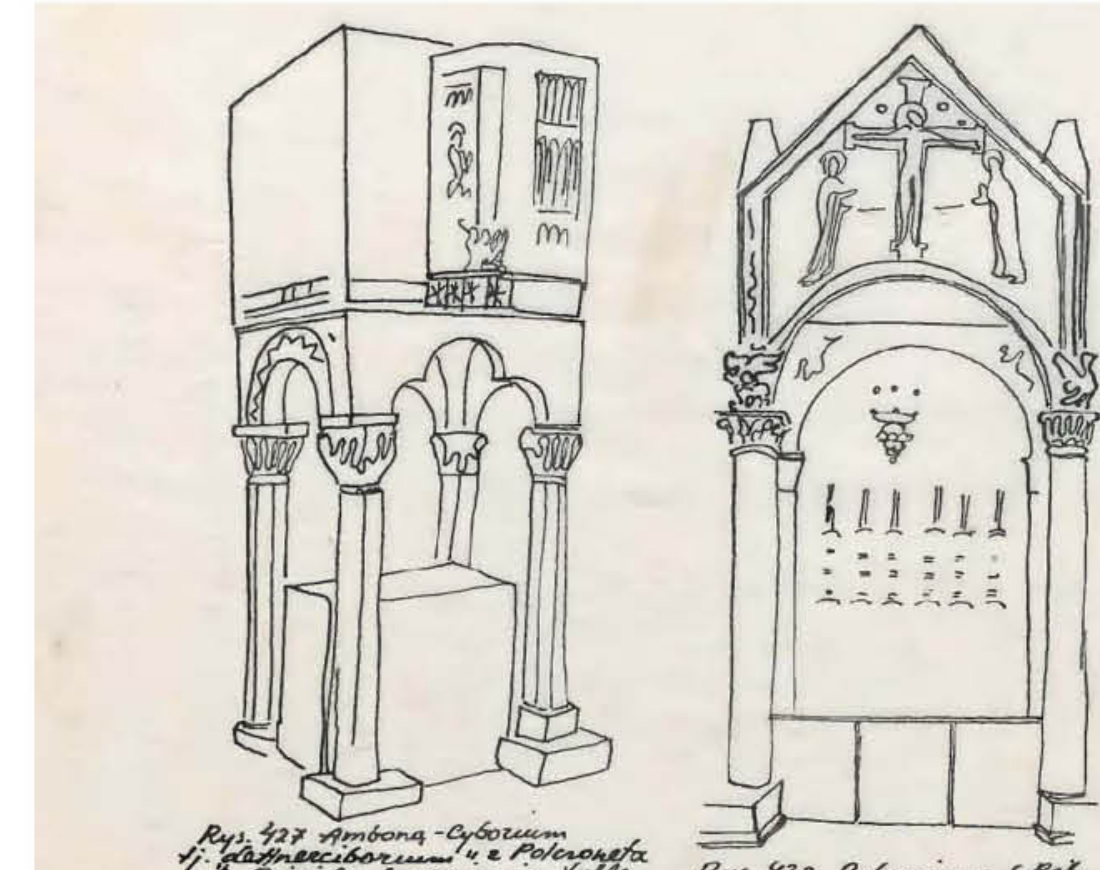

Rys. 42x fombong-Cyborcuin

50 eys. 433

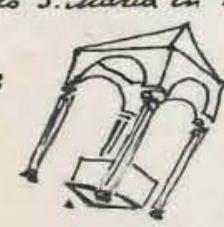

.

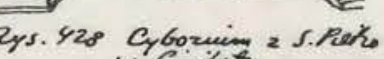

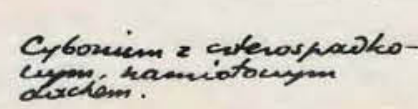

curcions ramiotonym

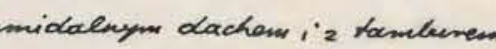

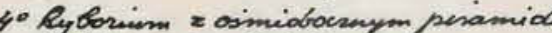

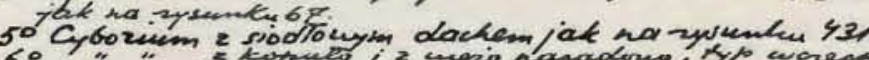
cucreso-renp-

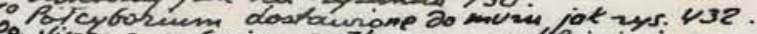

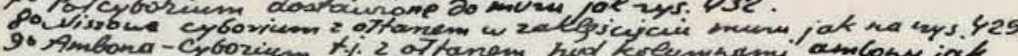
vemi andony jak

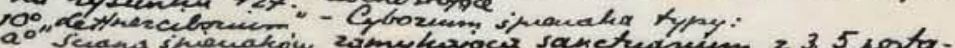

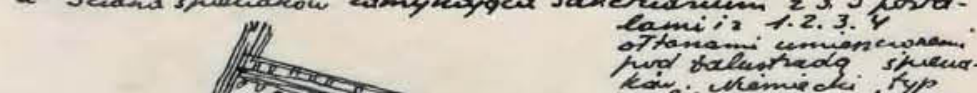

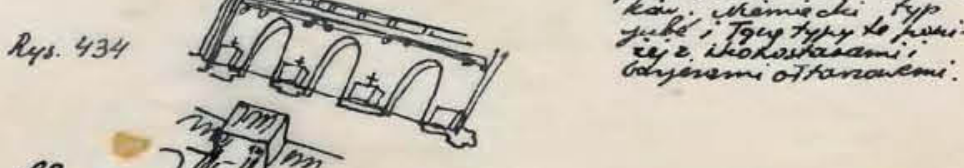
Bo

Rys 435

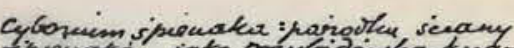

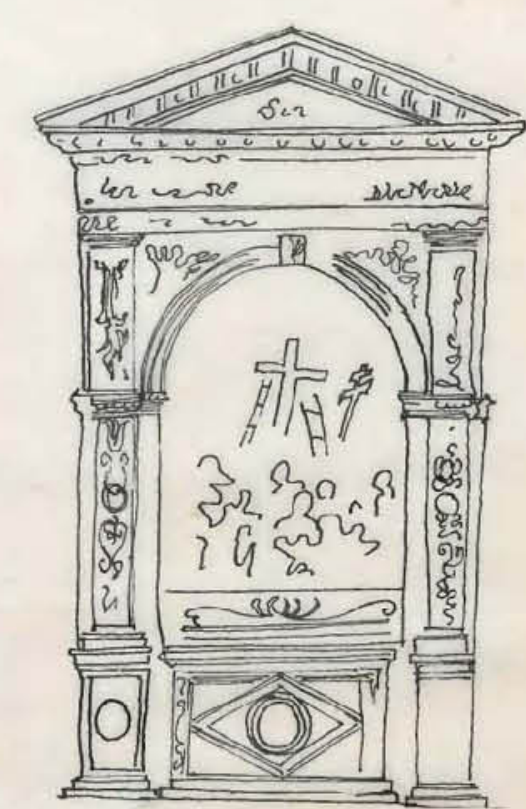

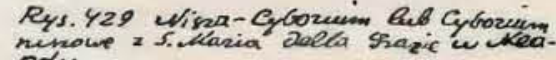

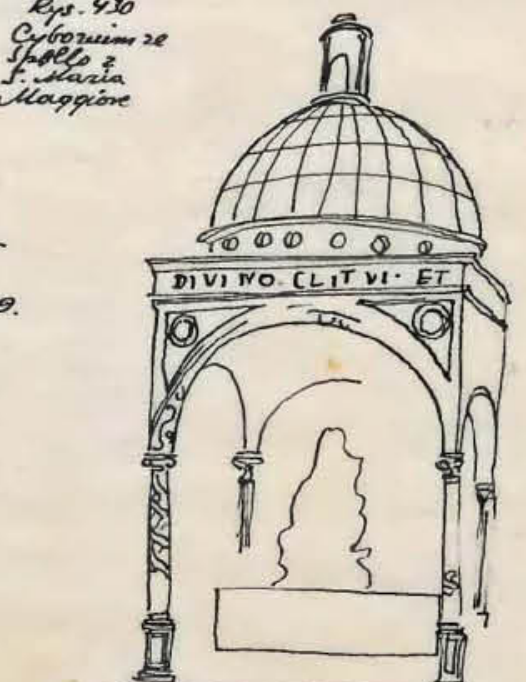


ya que "sl ámbito es tan amplio que va más allá de la fe". ${ }^{6.23} \mathrm{El}$ objeto de su trabajo era un arte que provenía de diferentes creencias y el propio arte religioso ya se establecía más allá de los muros de las iglesias abarcando la totalidad de los temas religiosos, incluyendo el arte asociado a la vida de un individuo fuera del culto oficial, como es el caso de la pintura religiosa de casas privadas, reclinatorios, etc.

Como una parte del arte religioso, Leykam identifica el arte con el que pretende trabajar, como aquel que incluye todo lo que abarcan los muros de los edificios relacionados con el culto: iglesias, capillas y campanarios, cementerios, etc... Posteriormente todavía acota un poco más esa definición para plantear el arte litúrgico como "aquel que está directamente relacionado con el rito litúrgico", ${ }^{6.23}$ omitiendo aquellos objetos situados en el interior de las iglesias no relacionados con la Liturgia y que son innecesarios para la celebración de los ritos como las pinturas o las lápidas.

Para simplificar su razonamiento posterior, Leykam acude a una cita de un texto del libro de Romano Guardini " $E 1$ espíritu de la Liturgia", ${ }^{6.24}$ en el que la oración litúrgica es "una oración común y colectiva, correspondiente no al temperamento de un individuo, sino a la vida interior de la comunidad, a la vida creada por diferentes temperamentos, pero correspondiente a todos los individuos de la comunidad." 6.24

El primer objetivo de la liturgia no es -según interpreta Leykam- un culto individual de Dios, sino un culto público de la Iglesia. "El culto y la adoración de Dios a través de la unidad espiritual, de oraciones de rituales definidos." ${ }^{623}$ Existe en la Liturgia una transición desde la oración individual, a través de elementos subjetivos como cánticos en la lengua popular, las devociones, etc.. hacia el hecho social de agrupar a un conjunto de personas en torno a un rito. La liturgia no es además una única y exclusiva oración colectiva, se desarrollan a su lado oraciones locales características según condiciones contextuales, ya sea por cuestiones nacionales, raciales, históricas y sociales... La Liturgia en definitiva, es un acto colectivo en tanto "Lex orandi" que desarrolla la vida y regula las oraciones no litúrgicas.

La oración litúrgica está dominada y animada para Leykam por el dogma como resumen de las doctrinas teológicas, y debería ser "la elevación del corazón llevado por el pensamiento, ya que el pensamiento solo tiene el privilegio de ser el único valor universal y accesible a todos." ${ }^{2.24}$ Guardini llama a la Liturgia la verdad dogmática vestida de oración: "La verdad os hará libres" . ${ }^{6.24}$ El elemento emocional de una simple expresión domina todo el contexto, pero para Leykam desde la oración, y por tanto desde la arquitectura, es necesario articular "sentimientos simples y relevantes" 6.24. La forma de una oración común debería ser "dramática en el diálogo" ${ }^{2.24} \mathrm{y}$ el modelo en el que se fija para reflejar el espíritu de la arquitectura es el tipo de oración que tiene lugar en el coro de una iglesia, donde tenemos acción interior y una forma exterior de esta acción que entiende y comparte el conjunto de la comunidad.

Sobre la comunidad litúrgica Guardini había señalado que el individuo debe en primer lugar; sacrificarse y negarse a sí mismo lo que otros no tienen, dejar el "yo", dedicar a la comunidad parte de su independencia y adoptar positivamente

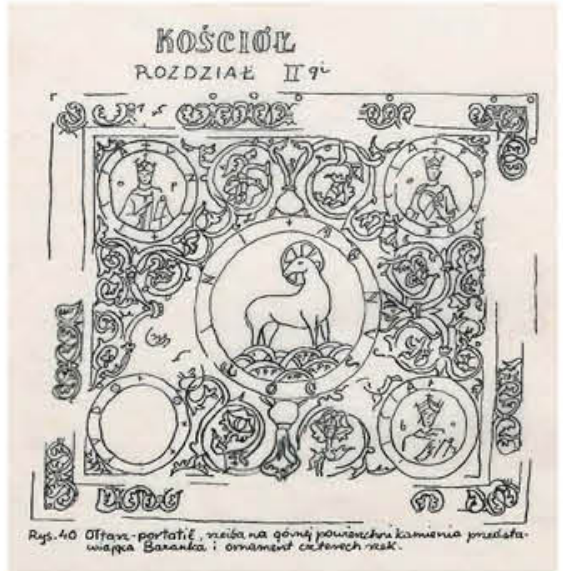

6.12

BAPTYSTERJUM ROZDZIAL

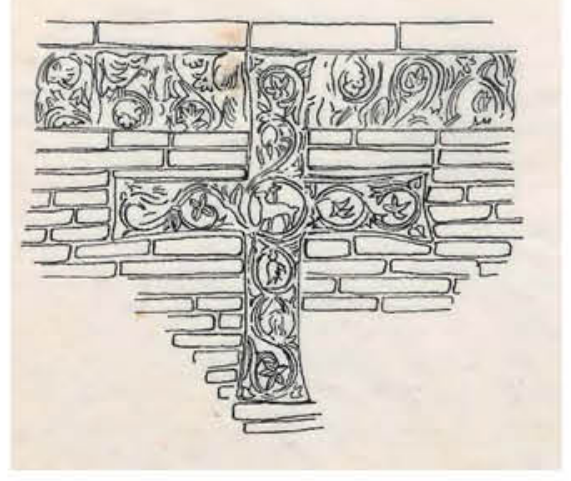

6.13

6.24. Romano Guardini "L'esprit de la Liturgia" de la colección "Ecclesia Orans", redactada por Ildefons Herwegen, citado por Op Cit. 6.23 
6.14 Reliquia, cruz metáliza del s. XII en el Claustro de Engelberg (Suiza).

6.15 Comparativa de diferentes plantas de iglesias: San Savin Poitou s. XI, Notre Dame la Grande

6.16 Comparativa de diferentes plantas de iglesias bizantinas de Estambul: Iglesia de San Sergio y San Baco, San Jorge y San Andres.

6.17 Tabernáculo de la Catedral de Siena.

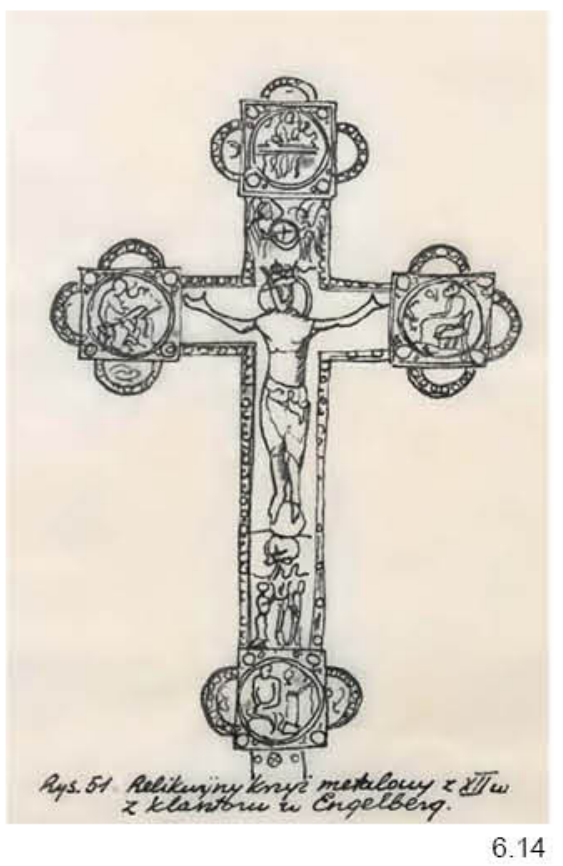

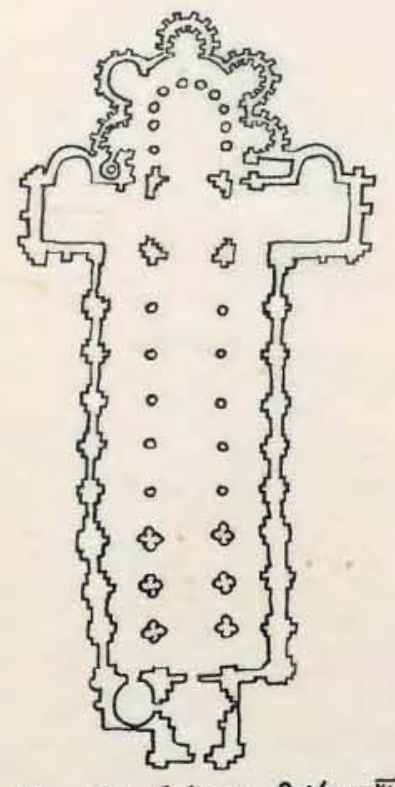

Reys. 177 S. Savin, Boitou, $\bar{X}$ wiek.

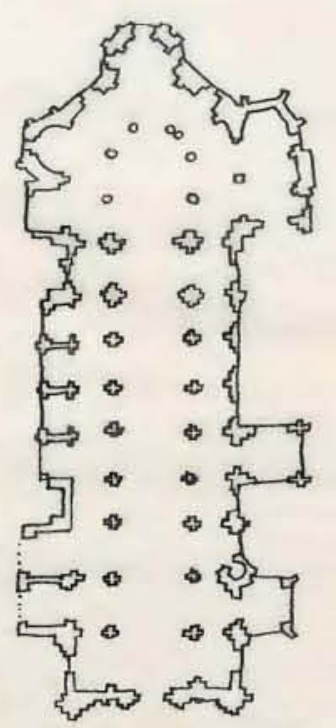

Rys. I78 N-Dame La cyzande

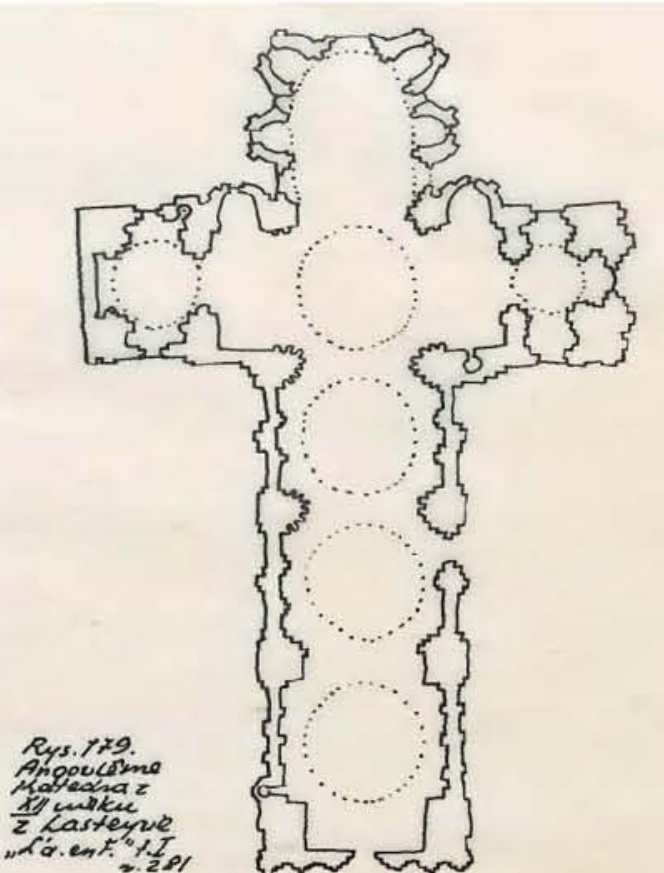

6.15

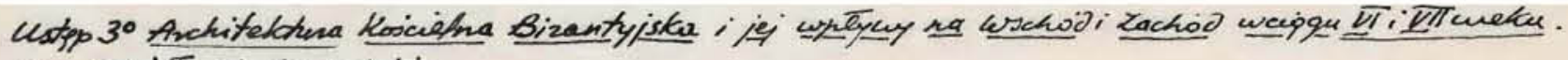
A. Hoicivey Thestyrianistip.

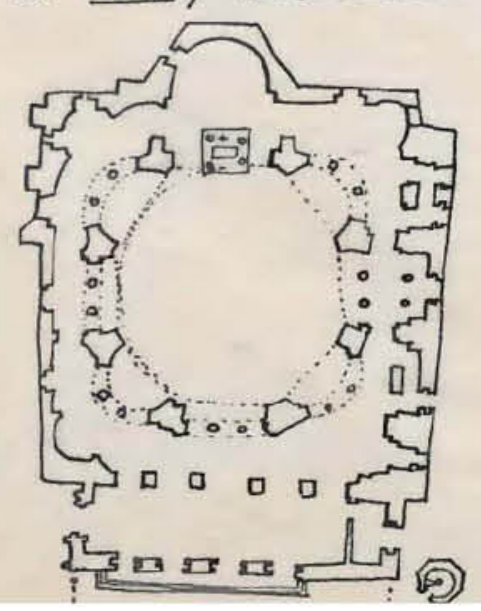

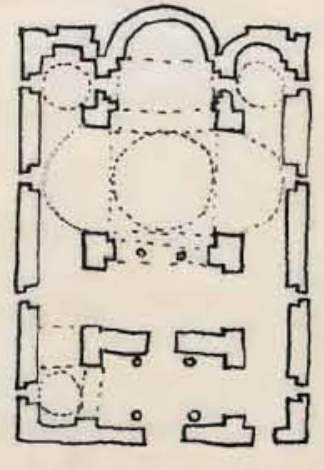

Rys. 125 
en la acción aquello de su yo propio que hay en la comunidad. "Escucha, de pie en una fila en su sitio, escucha, leal, las ideas que son ajenas a él ahora, pide cosas, que a menudo no son para él interesantes (directamente) y se conecta con los ritos sin ni siquiera entender o conocer su profundidad." ${ }^{6.24}$ Pero esto no significa una renuncia a la personalidad, la unidad se tiene que expresarse solo en dirección espiritual en la comunidad, con el objetivo de alcanzar la fe y los sacramentos.

"La oración desciende a todos los vecinos, pero ellos oran por separado, unidos en un solo pensamiento, palabra, dirección y miran hacia el mismo objetivo. De ahí lo dominante de la dirección y del altar en los interiores de las iglesias católicas romanas, donde vemos en forma de paredes de las iglesias la elocuencia de estas verdades." 6.24

La cita de Guardini sirve a Leykam para establecer un paralelismo según el cual a través de la definición de liturgia se puede establecer una definición de arquitectura:

"Si la palabra liturgia la cambiamos por la palabra arte o arquitectura, encontraríamos en estas definiciones la más fuerte determinación de doctrinas de composición. Sagrada, simple, fierte, así debería ser una oración asociada con la realidad y de manera que el hombre encuentre en ella toda su vida. Rica en pensamientos e imágenes de lenguaje sencillo, accesible a un hombre corriente y estimulante para el hombre cultural." ${ }^{6.23}$

El estilo es considerado por Leykam "todo lo que distingue de forma especial las formas propias y personales (..) de la divulgación exterior de una cosa determinada, una expresión sinónima y precisa. (...) Cuando algo se manifiesta fuertemente a través de su existencia o actuación su naturaleza, y al mismo tiempo no demuestra y no acentúa la naturaleza de sus partes, estamos ante algo que manifiesta estilo." ${ }^{6.23}$

Por lo tanto, "la liturgia tiene estilo. (...) El templo griego, el Partenón, nos impone más fuertemente la sensación de estilo que una catedral gótica, aunque ambas creaciones están llenas de la misma fuerza determinante y aunque diferentes en sus géneros, ambas se imponen con la misma elocuencia." 6.23

"Comparando el templo griego con la catedral gótica, en el templo griego hay mayor subordinación, sin más, de las partes para la expresión del conjunto. Ambas creaciones tienen su propio estilo, pero delante del Paestum sentimos una sensación mucho más fuerte que delante de la catedral de Reims. Así como las obras de Giotto nos imponen una impresión de un estilo más intenso que los poderosos cuadros de Grünewald. Al igual que la estatua de faraón egipcio tiene más elocuencia de estilo que el inolvidable San Juan de Donatello." 6.23

"El estilo adquiere aquí un carácter especial cuando en la obra todos sus detalles, desde lo singular y lo particular hasta general, directamente desaparecen. Todo lo estrecho del tiempo y espacio, todo lo que vale solo para el individuo está

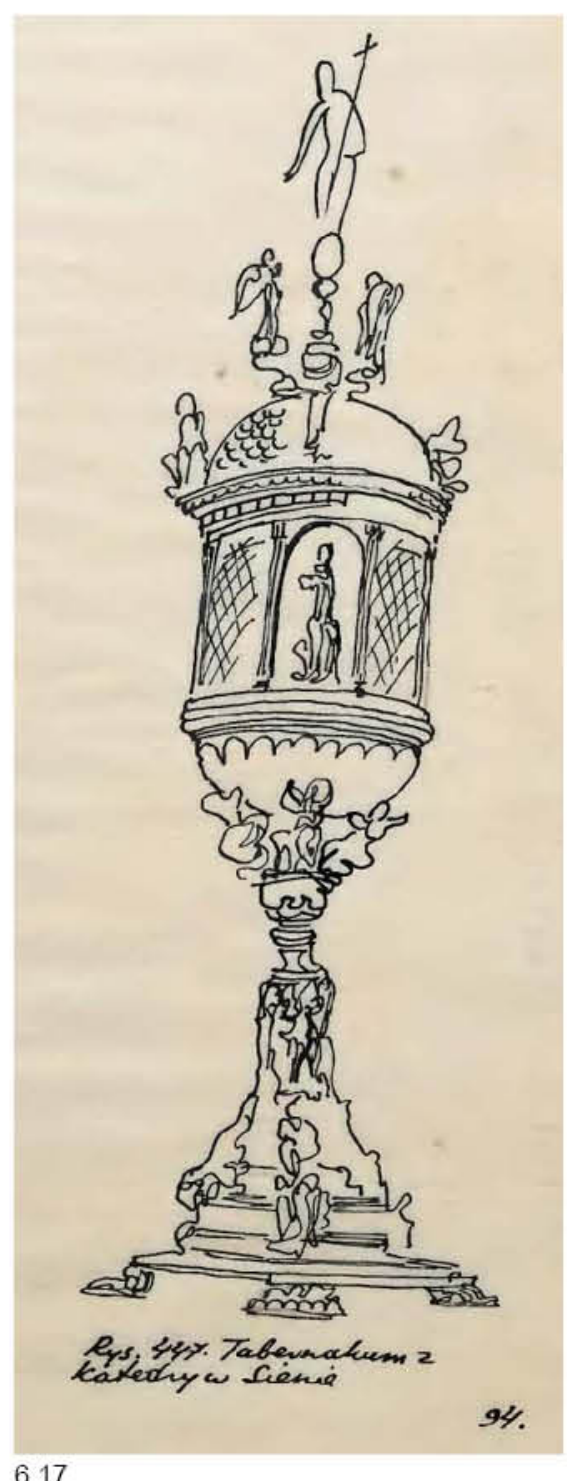

6.17 
6.18 Arbotantes en la sección constructiva de la Catedral de Saint-Étienne de Toulouse (Francia).

6.19 Cimborrio de San Nicolás de Bari.

6.20 Baptisterio de la Archibasilica de San Juan de Letrán en Roma.

6.21 Baptisterio en Oued Ramel (Tunez)

6.22 Baptisterio de la Basilica Paleocristiana de Son Pereto en Manacor (Mallorca).

6.23 Baptisterio en Tigzirt.

\subsection{Baptisterio efesio del s. V.}

6.25 Planta y sección de una Patena de Elche (España).

6.26 Cáliz de oro en la iglesia de Kremsmünster, Austria s. VIII.

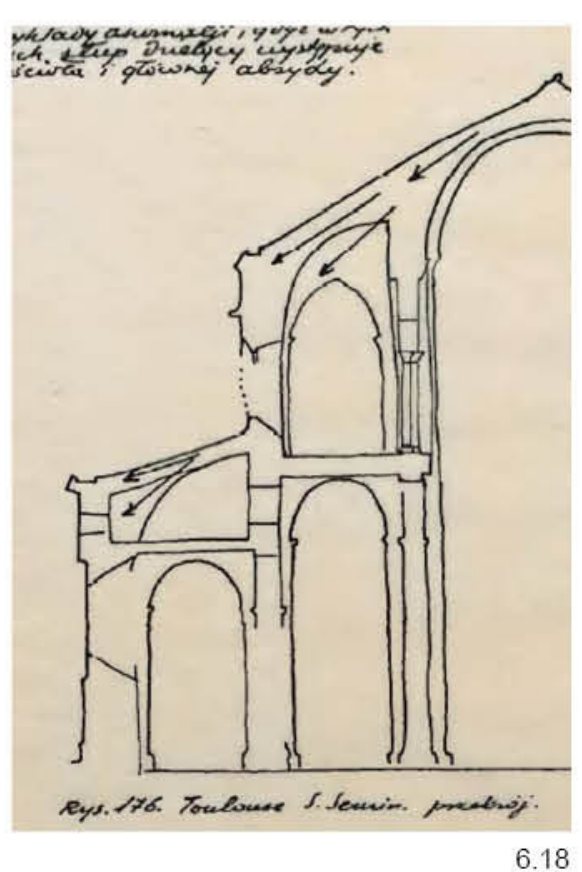

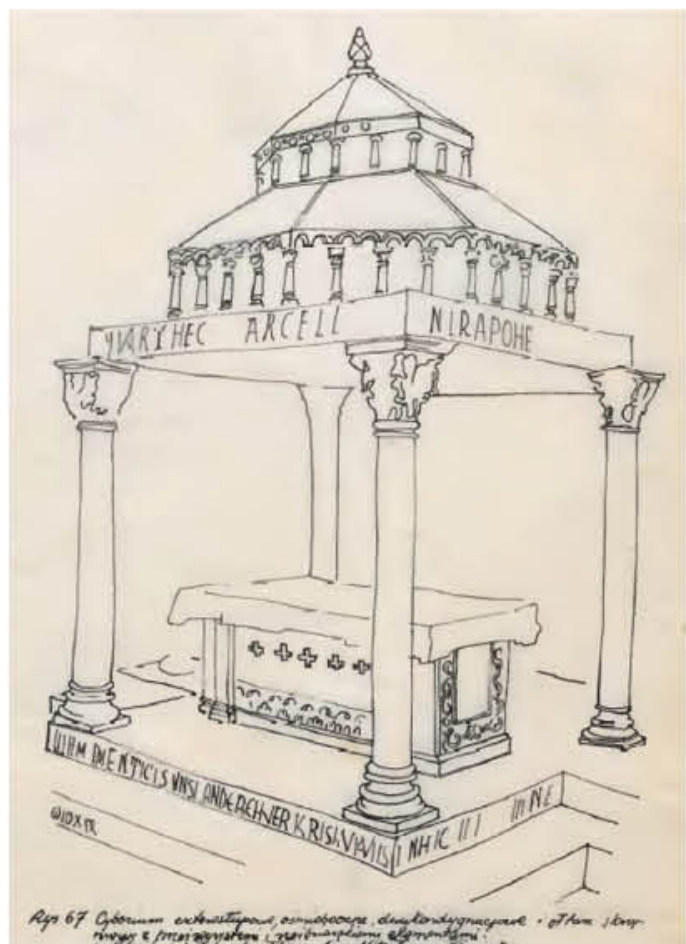

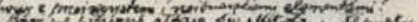

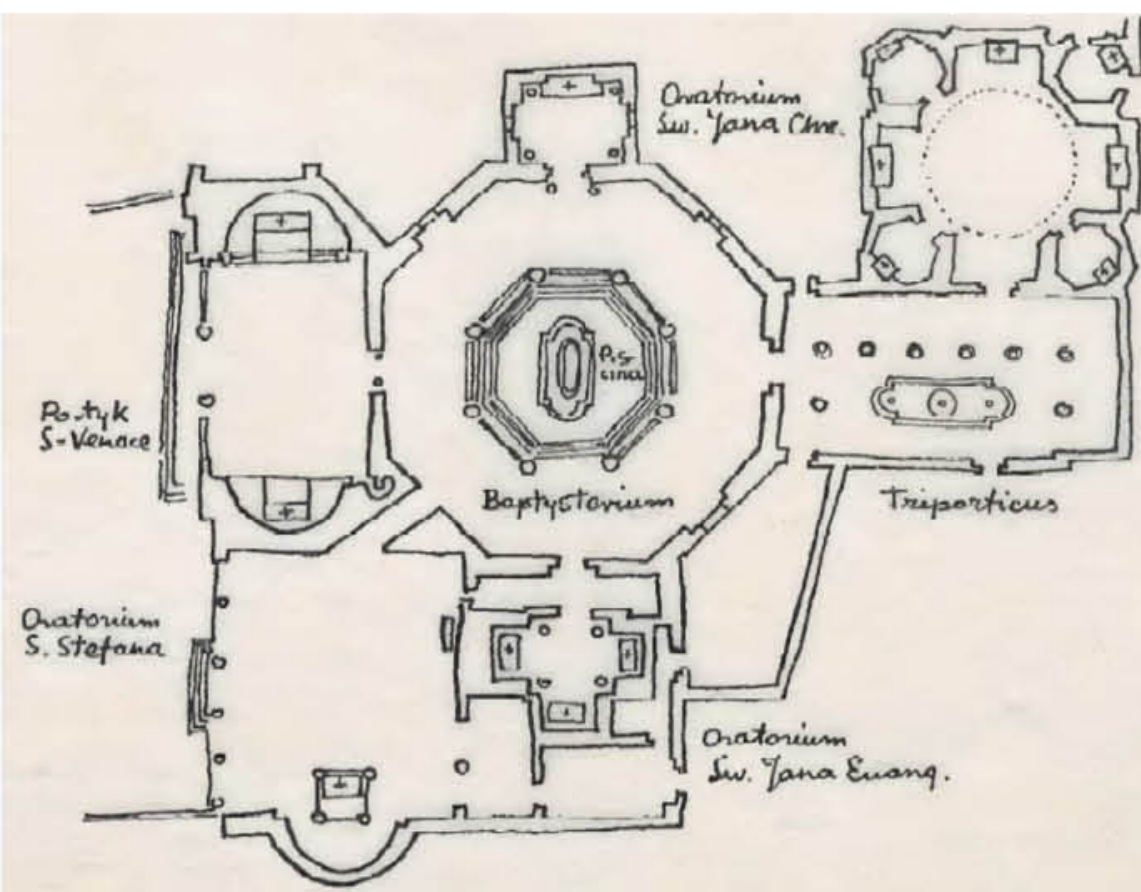

Rus.6. Baptysterium laterrisiskie. w Rrumin.

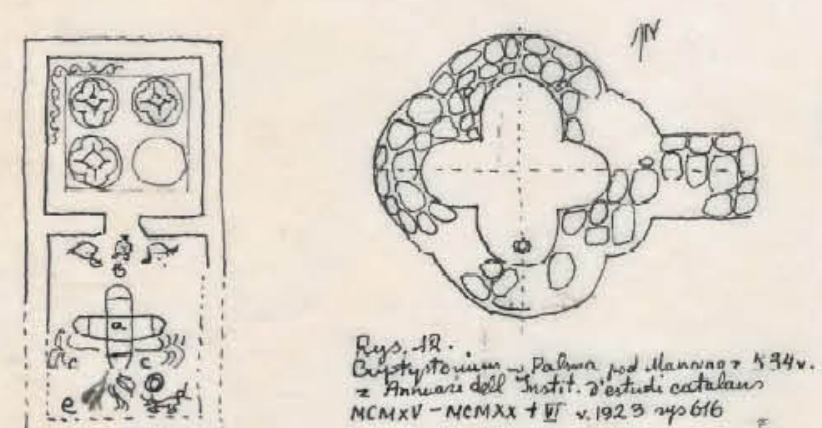

Ramel

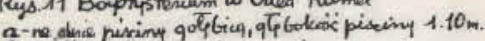

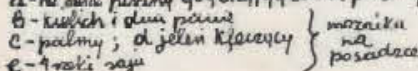

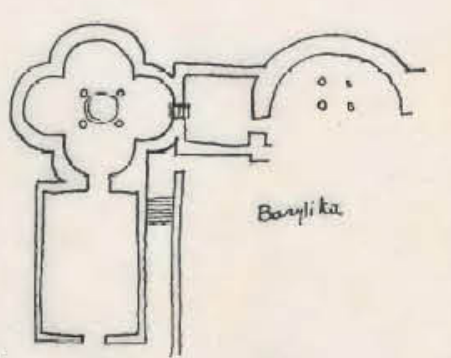

¿
5 maniw

Puys 13. Boptysterium wTiqzint w Afrya (Tunis)
$Y^{\prime \prime}$

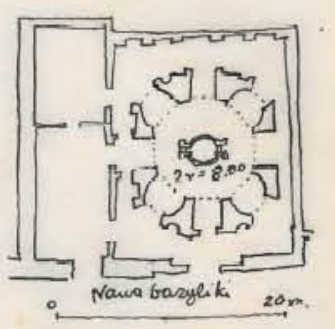

Rey 14 Baptystexim

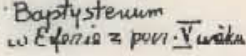


dominado por lo necesario para todos los tiempos y para todos los hombres, así en la Arquitectura como en la Liturgia. (...) La emoción más inquietante, aunque se reduce a una forma más simple, es eternamente la razón mental, que se convierte en elocuente para todos, en comprensible. El movimiento impulsivo recibe una medida que rechaza todas las resultantes. La realidad simple está cambiando y recibe una línea tipo. Simplemente se estiliza, se "procesa" ${ }^{6.23}$

Según Leykam, "una obra nacida solamente del pensamiento, del cálculo, del concepto teórico,.. no tiene estilo. Estamos ante una obra vacía y muerta, un esquema". Por contra, "cuando la estilización es exagerada, rompe con la realidad, viene sequedad, rigidez de cánones teóricos". La "visión viva (...) es el acto de creación de formas según un concepto abstracto". En opinión de Leykam "un estilo verdadero, incluso en las formas desnudas conserva su vigor de expresión. (...) La liturgia cuyas formas el tiempo pulió y perfeccionó, tienen estilo en todo, mostrándonos los caminos que debe seguir el concepto de arte litúrgico." ${ }^{6.23}$

Citando de nuevo a Guardini, Leykam trata de describir el significado de la forma atendiendo a la patena en la que esta situada en la liturgia la hostia consagrada, describiendo con gran detalle la suave línea generada por la concavidad de este disco, para lo cual toma como referencia la sección de una patena localizada entre las reliquias de Elche (España). (6.25): "Esta línea que va más allá de los horizontes, como si repitiese la cavidad de una mano levantando hacia el cielo, es la oblea de la Hostia. En ella se ilustra con elocuencia el pensamiento dogmático contenido en una forma simple." ${ }^{6.23}$

Este ejemplo sirve a Leykam para extrapolar de nuevo el arte litúrgico a su personal interpretación de la arquitectura: "Esta es quizá una de las más elocuentes imágenes que ilustran el camino que debería seguir el pensamiento plástico contemporáneo al estudiar la formación del arte litúrgico: el estilo litúrgico surge de la naturaleza y del concepto de la viva expresión, al igual que la arquitectura." 6.23

Leykam hace hincapié en la diferencia entre la ofrenda en la mano desnuda y en la patena: "la horizontalidad de la patena destaca la horizontalidad del cuerpo. Es como una superficie ampliamente abierta hacia arriba, hacia Dios, en un fierte contraste con una mano levantada. Este significado tan fierte esta realzado por la suave concavidad en línea. Todo en la liturgia tiene un doble significado: impresión y expresión, impresión que intensifica la verdad con su dinamismo, expresión que explica la verdad." 6.23

Sobre el "simbolismo litúrgico" y siempre sobre la cita de Guardini, Leykam subraya que en la liturgia, "todo: el acto, gesto, movimiento, la ropa, el equipo, ... está lleno de imágenes y saturado de significado". De esta forma, "el símbolo nace siempre cuando lo espiritual encuentra su expresión en lo material externo. Pero solamente entonces, cuando surge de la necesidad real." Para Leykam el símbolo es en realidad "un reflejo natural de un proceso mental claramente definido que solamente se puede interpretar desde su contenido, con una única interpretación comprensible para todos." ${ }^{6.23}$ Poniendo el ejemplo de un símbolo simple, como el gesto de arrodillarse, Leykam vuelve a precisar:

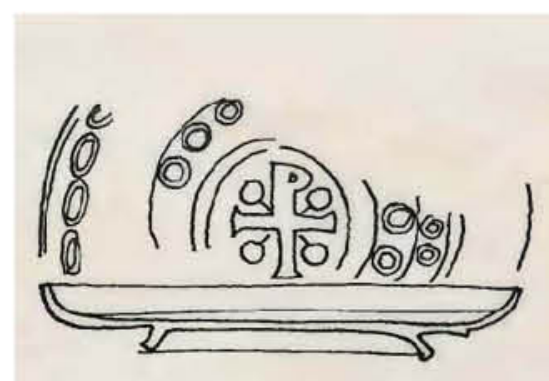

Rys.69\%. Pateraz Clane whisprangi:

6.25

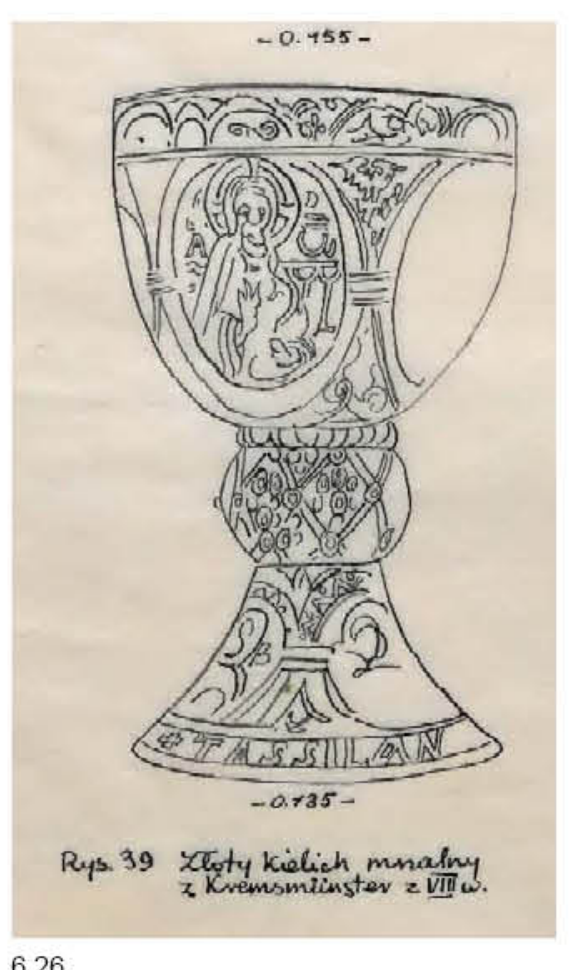

6.26 
6.27 Púlpito de la Abadia de Santa Maria del Lago en Moscufo, Abruzzo.

6.28 Claustro de San Simón Estilista cerca de Alepo, Siria (s. V) e Iglesia de San Clemente de Ankara (Turquia).

6.29 Dibujo de Mans simbolizando los 7 dones del Espitiru ca celebración litúrgica según su estructura portante.

6.30 Virgen María en su huida a Egipto y anunciación del Espírito Santo en los mosaico de Santa María la Mayor (Roma).

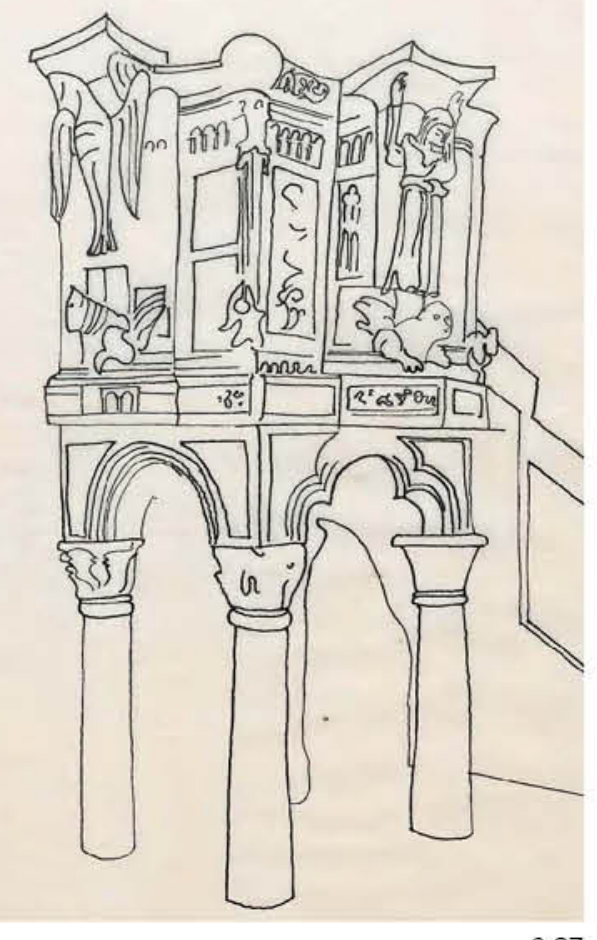

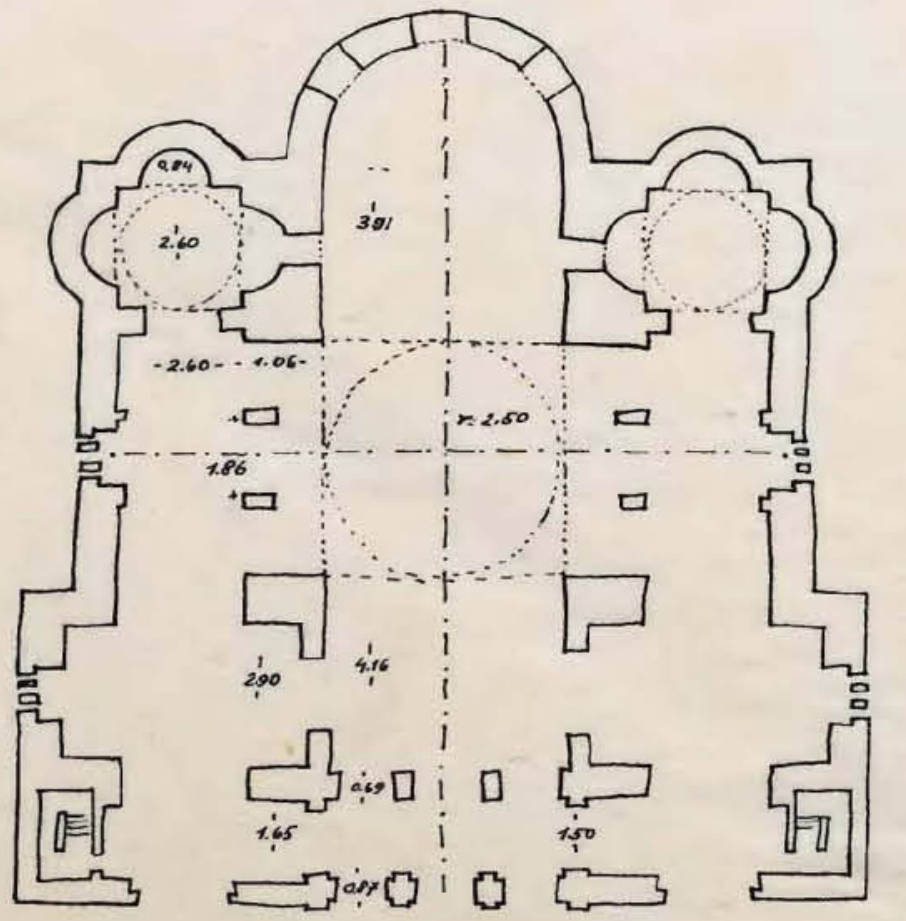

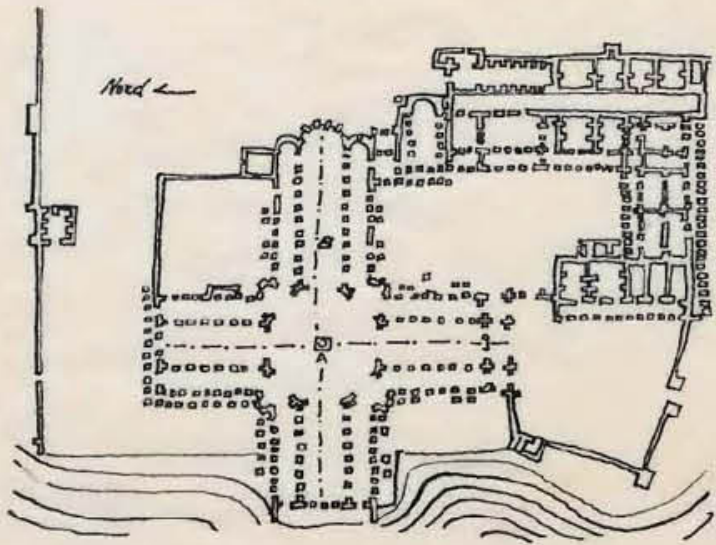

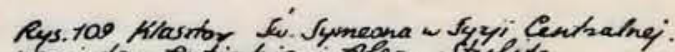

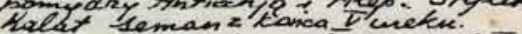

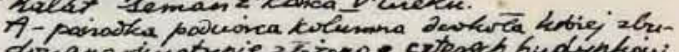

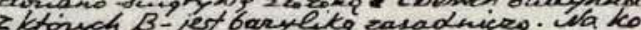

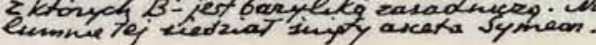

W craqu Turake aypocerna sy jat jui zae nacritem poryze; formontun plan w

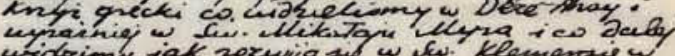
inidrimy jak soruija sf w dew kementse w

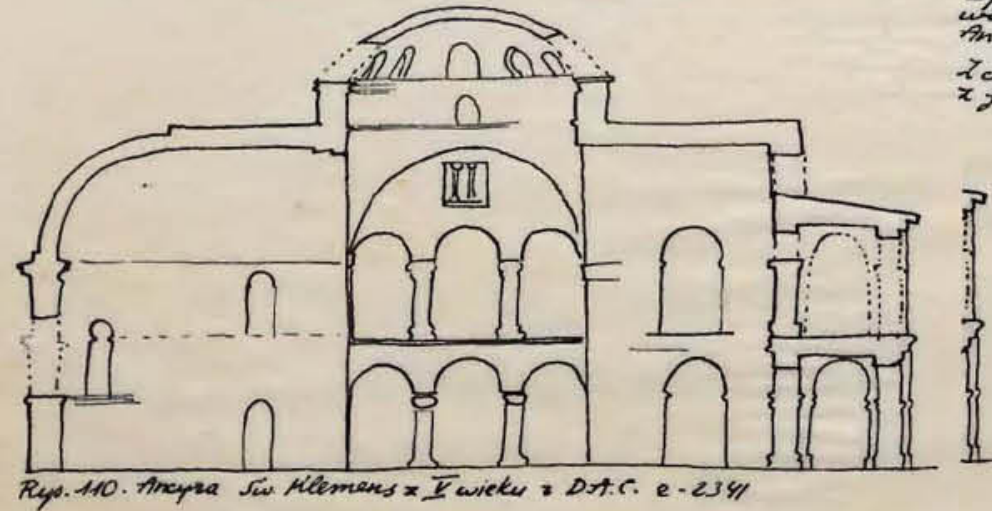

cy crarem soxwinie isp ten typ treyia qreckego

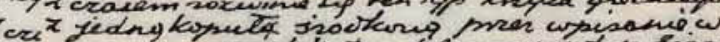

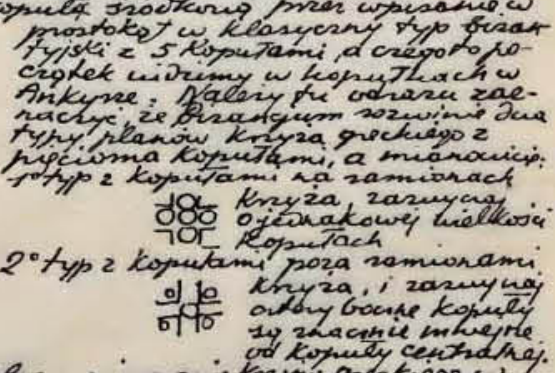

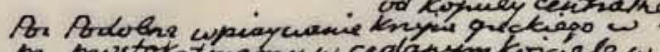
u mustoxgtmamy wion 


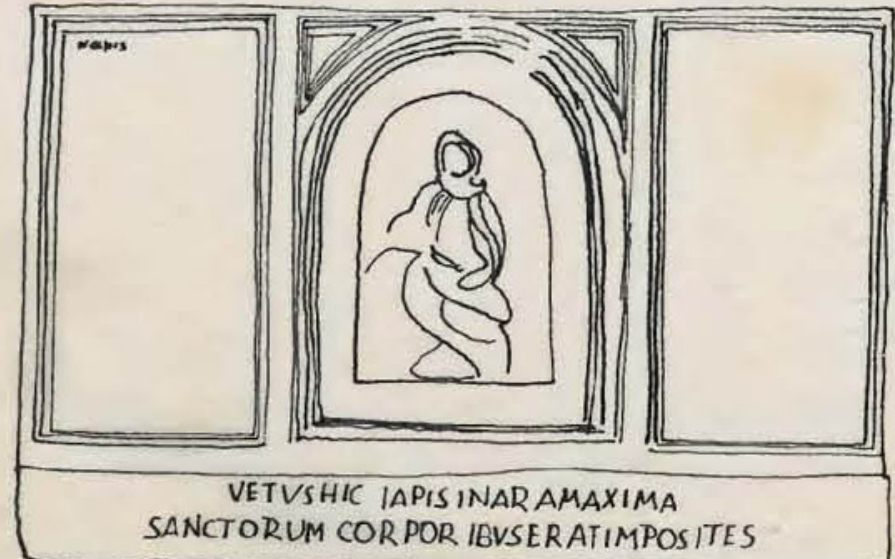

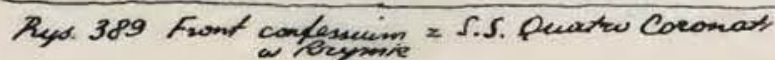

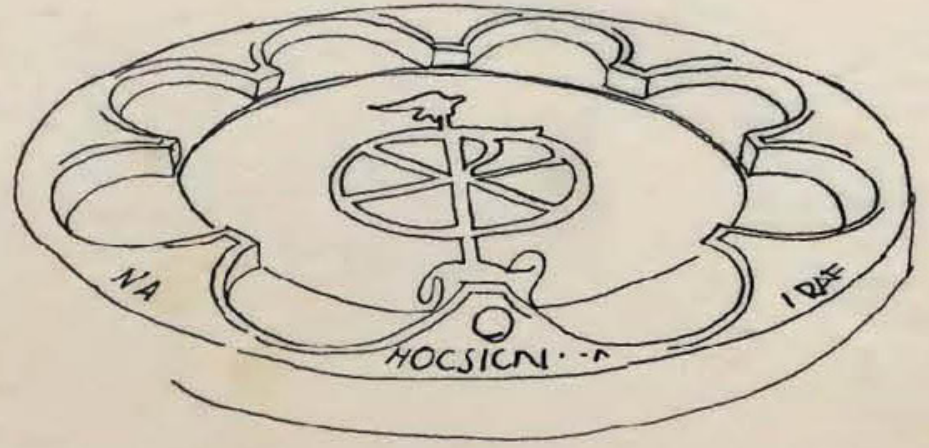

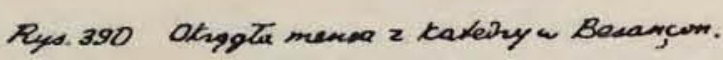

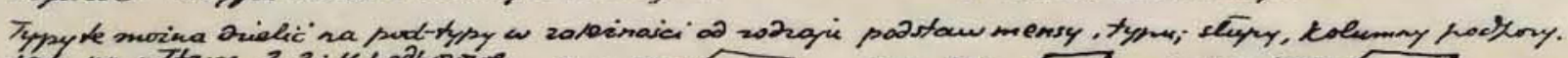

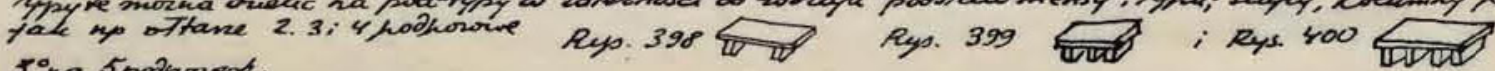
soma spopposed

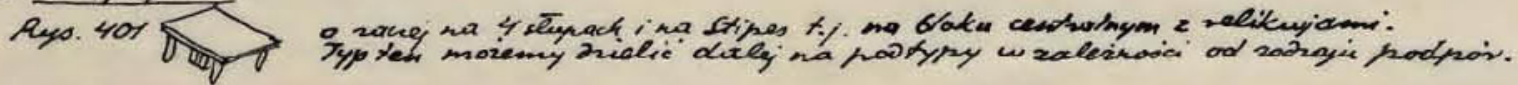

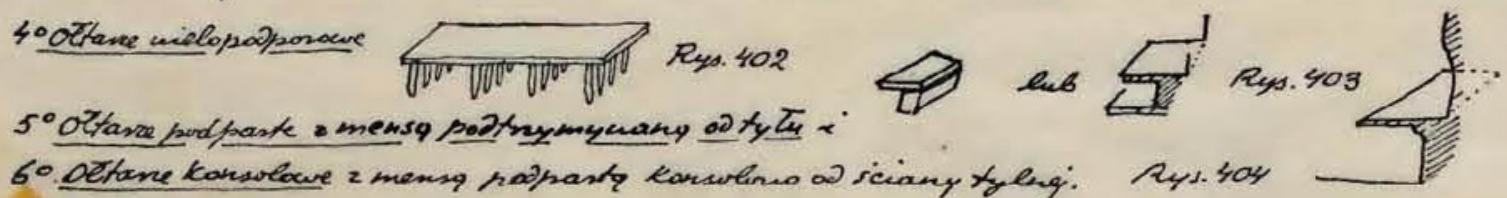

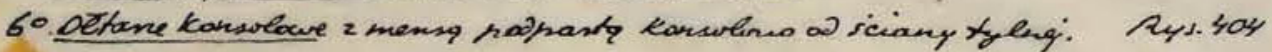

Rys.392 垈

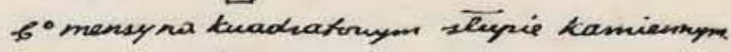
Reys. 393 प्रिए

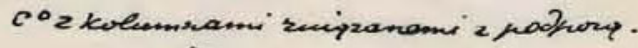

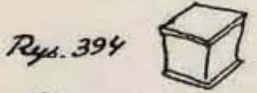

$d^{\prime}=$ podmenouary hodstaup merasy.

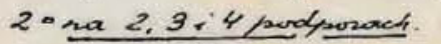

Aिय.395 बिए :

and aund partanat heb ra dunch ko

Rys.396 णिए

b0 OTtan trojinoing.

Res. 39\% on

C. Otan ateronoin.

Beprovadea rassphupipa thasy-

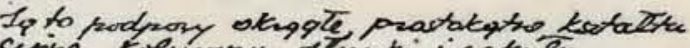

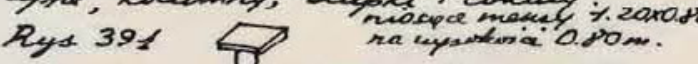

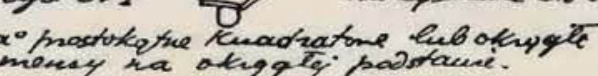

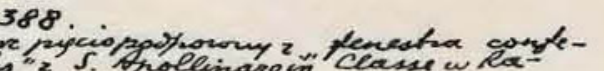
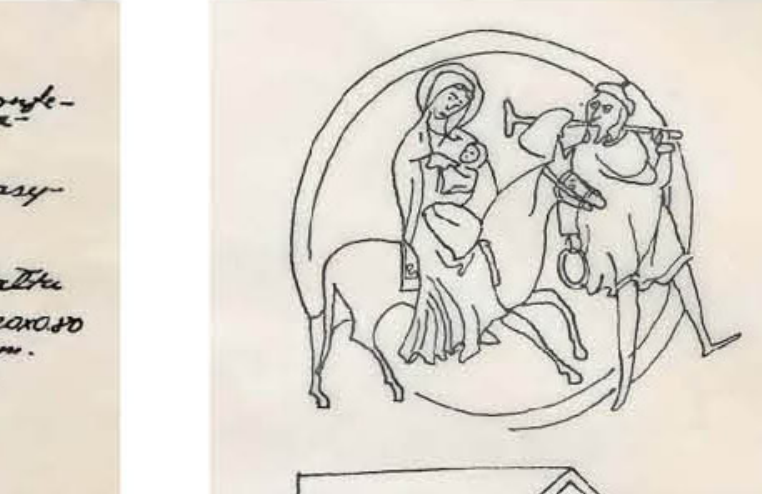

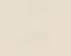

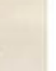


6.31 Iglesia de Saint-Michel-d'Entraigues en Angoulême (Francia).

6.32 Estudio de plantas de las Iglesias de Sant'Andrea Q Quininale y Santa annunziata di Parma. Evolución de las geometrias planteadas.

6.33 Púlpito (Ambona) de la Abadía de Fiesole. Piero di Cecco, circa 1460

6.34 Labrado sobre un púlpito de madera en la Iglesia de Santa Radegunda 581 d.C. En las esquinas simbolos

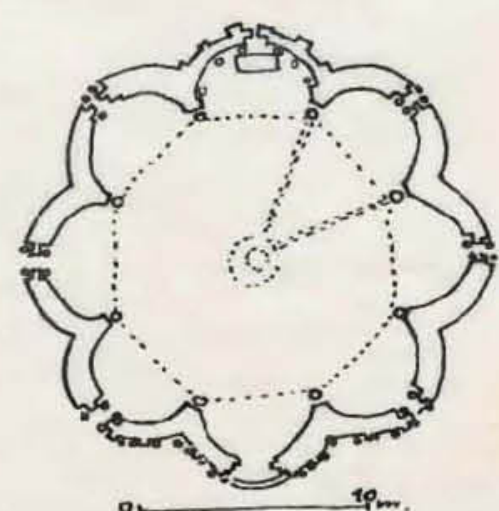

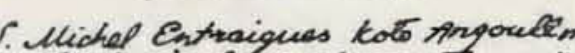

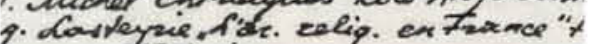

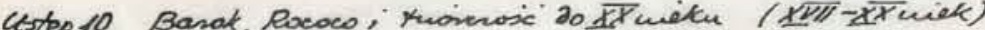

ㅁ.
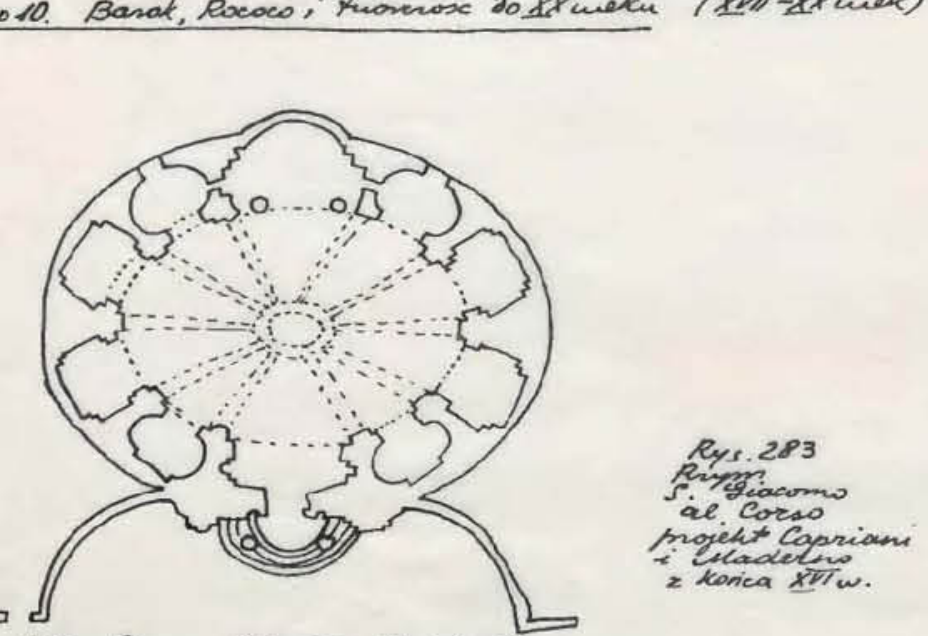

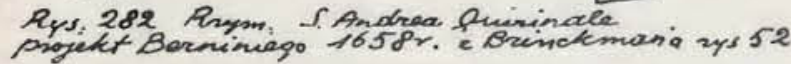

Bramante Michat Aniot, Viquel w poinmm

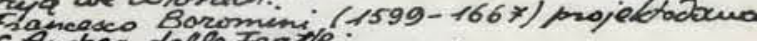
Caclo Maderera (-1556-1639) " "

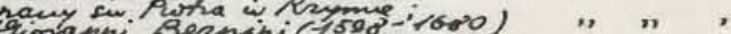

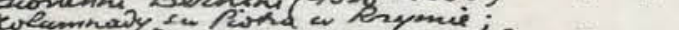
Fartana Domerico (1543-160k) " " "

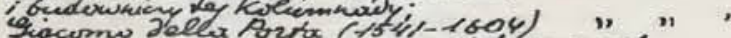

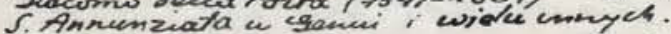

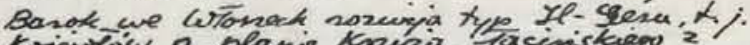

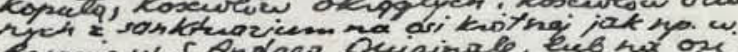

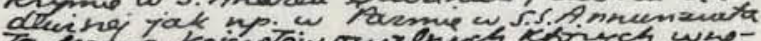

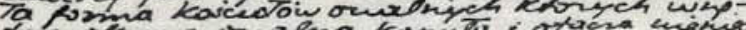

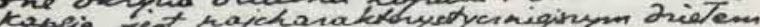

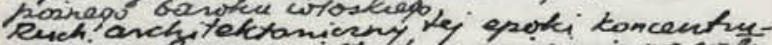

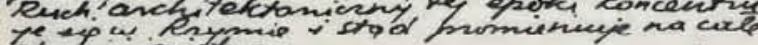

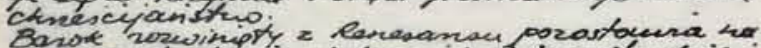

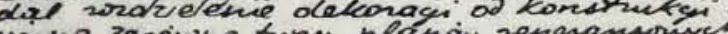

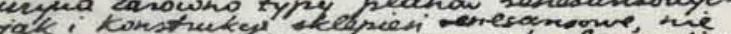
upsouadrage Rerd uy

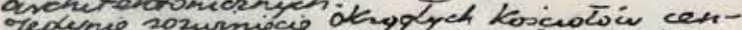

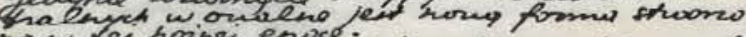

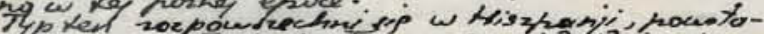

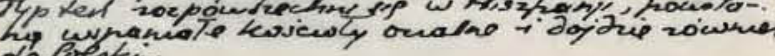

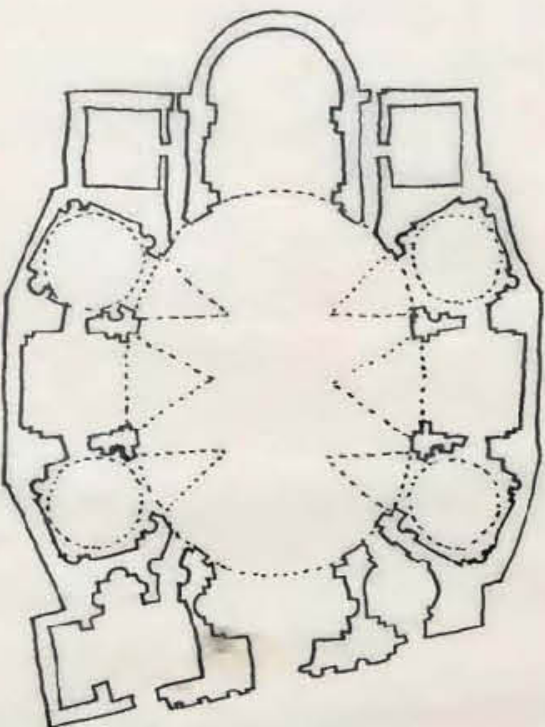

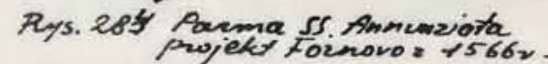

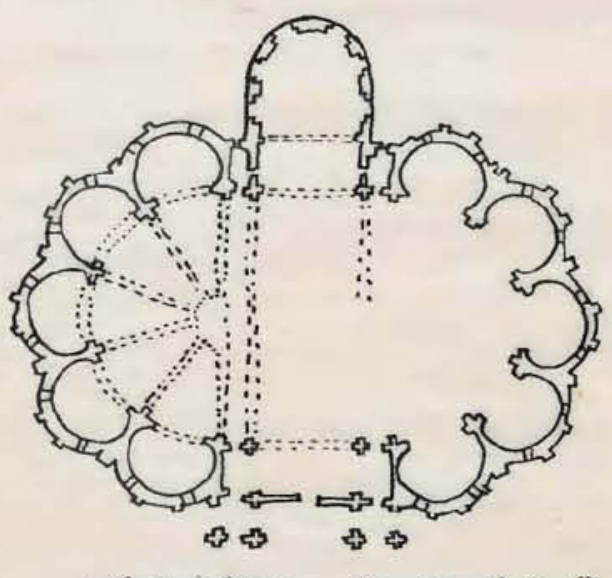

2A. Bronoteman "Banke 
"Cuando nos arrodillamos, las cosas externas, gracias a la intensificación interior del hombre a través del símbolo, adquieren nuevos elementos. La expresión es una prolongación de la extensión del cuerpo más allá de sus límites naturales." ${ }^{6.23}$

Sobre "La Liturgia como un juego", Leykam comenta la posición de Guardini sobre el concepto de utilitarismo. "En la liturgia no hay un propósito exactamente utilitario, sino que contiene en sí el centro del sentido. (...) Dice Guardini que en la Ciencia no vemos propósito, sino sentido: en la Verdad, no ve tampoco Guardini un propósito práctico en el arte, pero ve sentido de la existencia en el arte. Sentido en el reflejo de la belleza de la Verdad en la "Veritatis Splendor". El sentido como el contenido de la vida." 6.23

Leykam opina que es muy acertada y correcta la nota de Guardini acerca del sentido del arte fuera del utilitarismo, y la determinación con que el utilitarismo coloca el punto de gravedad fuera del tema, algo de lo que se olvida la arquitectura contemporánea. La liturgia para Leykam tiene un propósito utilitario según el cual todo gesto y oración desarrollan la vida espiritual de los fieles, pero también tiene un fin en si misma: "El arte litúrgico no es una etapa sino un logro. (..) aunque en la Liturgia el hombre no dirige miradas a sí mismo, sino a Dios." ${ }^{6.23}$

"La Liturgia no tiene delante el propósito utilitario, sino una actuación ante el Señor. Actuar como los querubines cuyo único sentido es mover las alas ante los ojos de Dios sin un fin. (...) Al igual que el espectador no debe exigir más del arte que la relajación, la respiración, el movimiento libre,.. encontrar lo mejor de sí mismo, el hombre ante la Liturgia debe ver arte y actuación. No crear sino ser él mismo una obra de arte. He aquí la esencia de la Liturgia. Convertirse en una obra de arte viva ante Dios sin otro propósito." 6.23

Leykam cita el libro "Von heiligen Leichern" de Romano Guardini para rescatar un texto del teólogo italiano sobre el agua bendita: "La ambigüedad del agua demoníaca, expresada con tanta fuerza en los rituales de las bendiciones la hemos sentido todos: en el flujo incesante de los ríos, en los remolinos que se cruzan en el profindo orden del líquido, el agua es, a la vez, suave y terrible, da vida y la quita, es transparente y llena de enigmas. Lo malo es en ella mágico, atrayente y pagano. El que no lo ha sentido no conoce la Naturaleza." ${ }^{6.23}$

Según la interpretación que hace Leykam de este texto, el poder de la Liturgia es convertir el agua, de elemento malo y peligroso "que nos puede hace temblar de miedo" ${ }^{6.23}$ en un elemento "transparente y claro: útil, humilde, valioso e inocente.(...) La propia fiuente del baptisterio se convierte en el seno de la fertilidad celestial." ${ }^{6.23}$

Reside por tanto en el significado que otorgamos a los elementos y los objetos su capacidad de transmitir un mensaje determinado independientemente de su utilidad. La liturgia, sin buscarlo, adquiere así la capacidad real de generar o incluso de simplemente otorgar valor a una obra de arte, algo que Leykam plantea que debe ser retomado en la arquitectura:

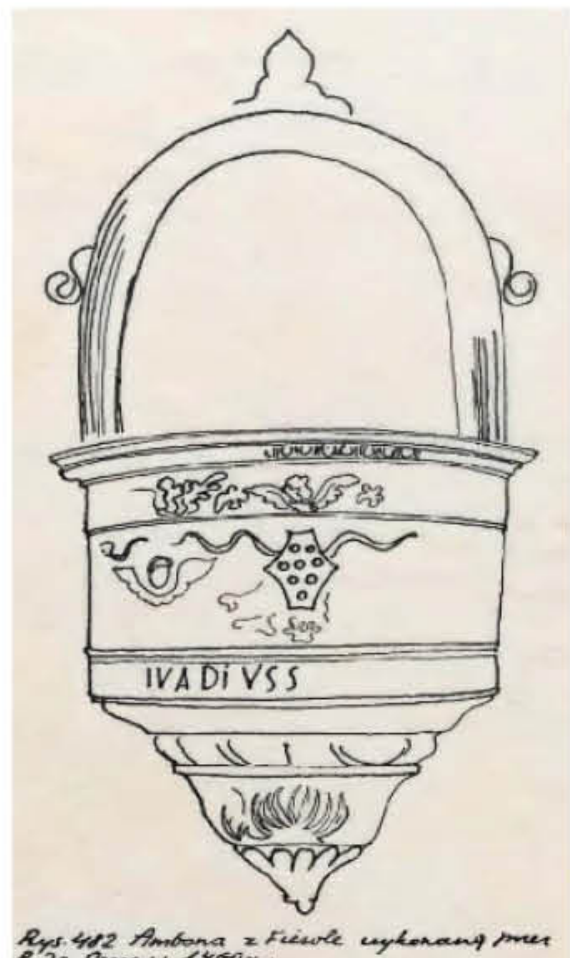

6.33

6.33

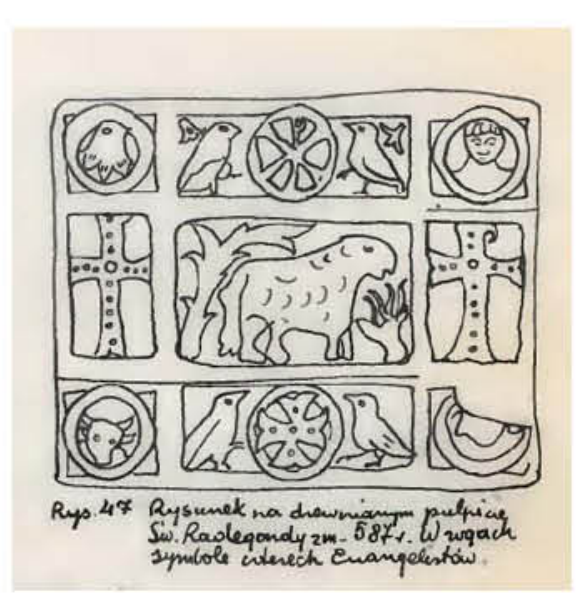

6.34 
6.35 Retablo articulado en madera de la Iglesia de S. Jacobo (Jakobskirche) de Rothenburg (Alemania).

6.36 Esquema de un retablo barroco de un altar lateral.

6.37 Retablo gotico-renacentista (transición entre articulado y pictórico) en el Museo de Bellas Artes de Valencia. (Retablo Eucarístico del Convento de la Puridad). s. XV-XVI.

6.38 Cimborrio de Bolsena s. IX-X.

6.39 Reliquia Sarcófago gótico en la cripta de santa Eulalia en la Catedral de Barcelona (s. XIV)

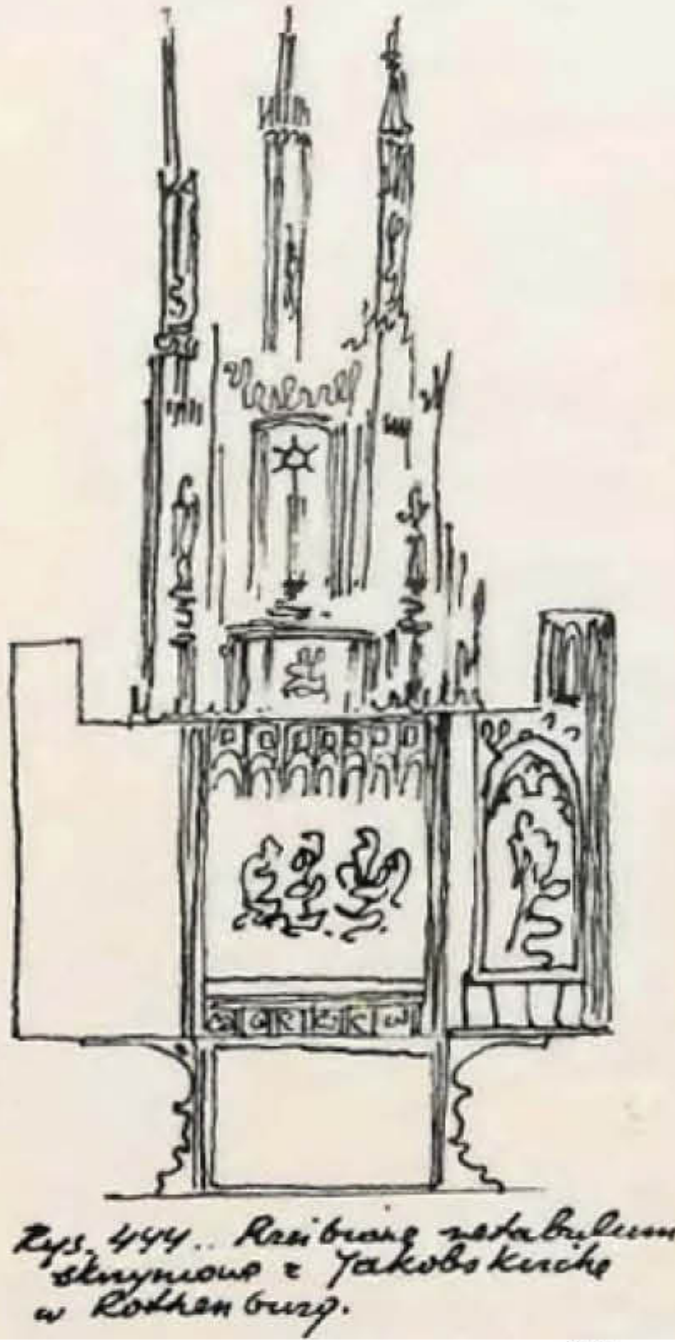

6.35

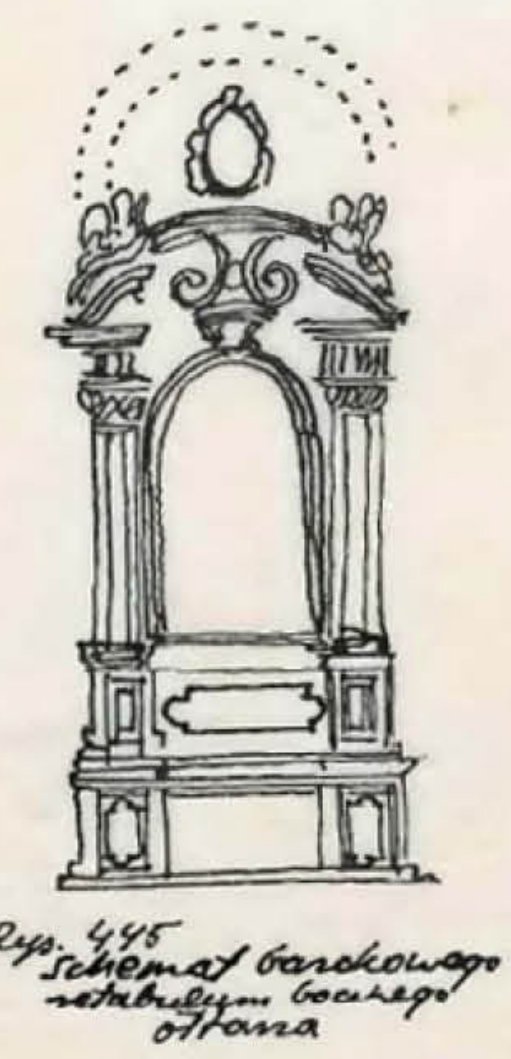

6.36

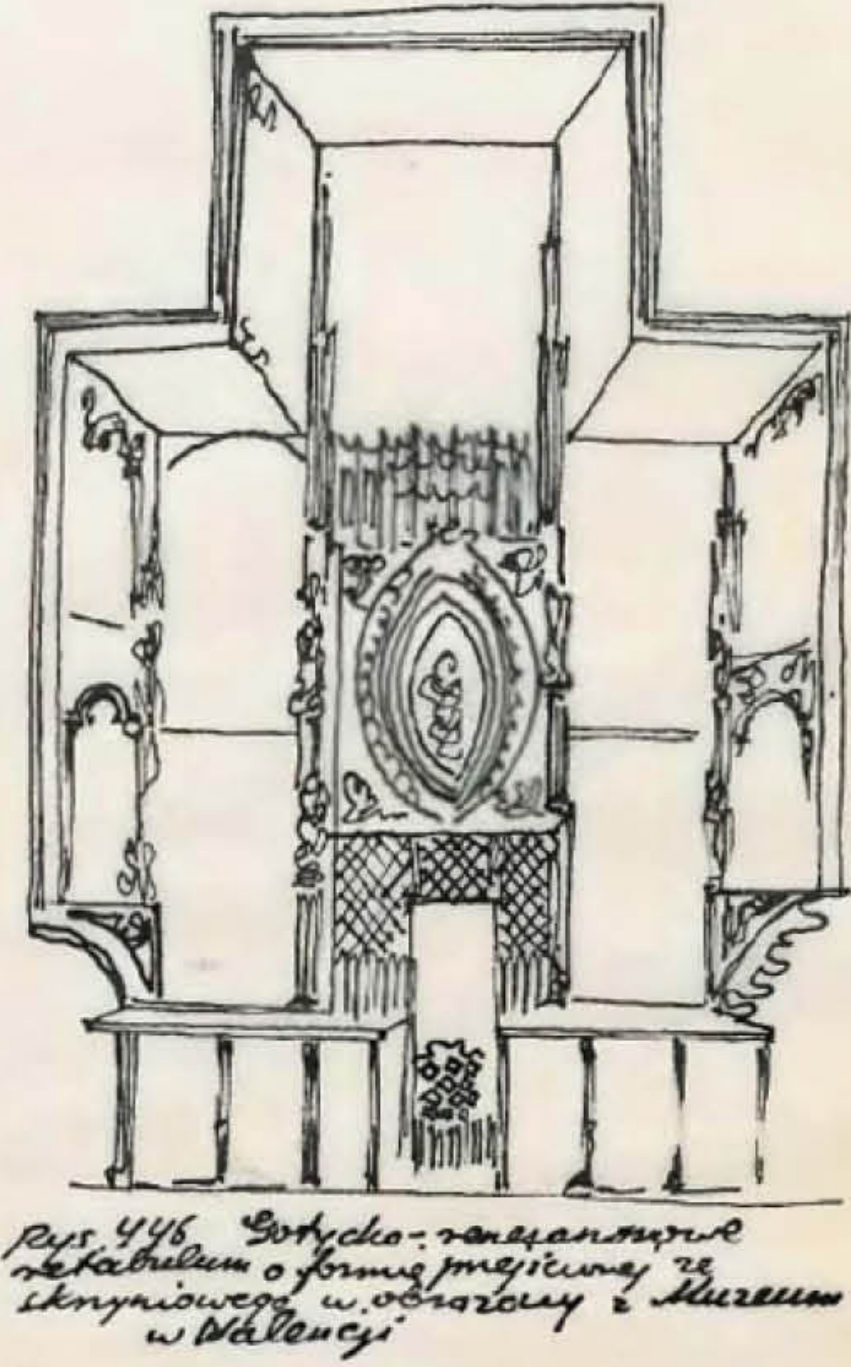

Dalewer 
"La Iglesia no buscaba convertir la Liturgia en obra de arte, no obstante, en sí misma contenía tantos elementos de belleza, que, por sí misma, se desarrolló convirtiéndose en obra de arte, y el principio que le dio forma actuando desde el interior fue la esencia misma del cristianismo." ${ }^{6.23}$

Cabe señalar en este punto que la Escuela de Filosofía de Lvov-Varsovia ya había discutido en 1936 la posición de la Iglesia Católica respecto a las artes modernas, y el contexto en el que podía ser interpretada la religión desde el punto de vista del arte. Durante el III Congreso de filósofos polacos de Cracovia los miembros de la escuela habían realizado un llamamiento a todos los especialistas de diferentes disciplinas para que hicieran uso de la lógica en sus actividades para estudiar el mecanismo de símbolos que utilizaba la doctrina católica para, mediante métodos científicos, dotar de mayor inteligibilidad a su mensaje y contemporaneidad a su significado, lamentando que desde la lógica moderna la simbología cristiana estuviera siendo ignorada en la modernidad o incluso condenada a causa de la confusión entre su lógica interna y las opiniones particulares de los que profesan estas creencias.

La utilización de la Liturgia por parte de Leykam como medio a partir del cual alcanzar una definición de arquitectura no denota únicamente la importancia que otorgaba al simbolismo sino una búsqueda personal de un método comunicativo que le permitiese dotar de un nuevo sentido a la arquitectura moderna permitiendo su renovación ya que la consideraba desconectada de la sociedad y sus motivaciones espirituales, hecho que había quedado de manifiesto por el desarraigo de los regímenes políticos que gobernaban el sinsentido de la guerras.

La elección de la liturgia no era por tanto nada casual ya que el término liturgia, del latín liturgía, y este del griego $\lambda \varepsilon i \tau o v \rho \gamma i \alpha$ significa "servicio público", y en una época caracterizada por la ruptura violenta de los principios éticos fundamentales Leykam adquirió una comprensión del trabajo del arquitecto como un agente cuya tarea no se reducía exclusivamente a la realización de proyectos, sino que en un contexto histórico tan significativo, resultaba necesario recuperar ese conjunto de valores sociales y principios colectivos abandonados.

Leykam ya era por tanto consciente, durante su estancia en Suiza, de que como arquitecto iba a tener la posibilidad de transmitir cualidades deontológicas y generar conciencia ideológica a través de la arquitectura y tenia asimilado que su tarea le iba a ofrecer la posibilidad de llevar a cabo esta práctica al ser el vehículo a través del cual debían materializarse los ideales y las demandas de una sociedad rota por la II Guerra Mundial.

A lo largo de su trabajo trató de buscar esa comunión que permitía a la liturgia agrupar a la comunidad en torno a un mensaje escenificando el rito de la celebración, una prueba de que la arquitectura estaba relacionada con la espiritualidad y que las manifestaciones construidas podían resultar el significante de un mensaje donde un conjunto de convenciones morales compartidas por la sociedad fuesen portadoras de un significado que podía ser transmitido a través de la interacción con los individuos, generando intrínsecamente sentido a la propia convivencia en comunidad.

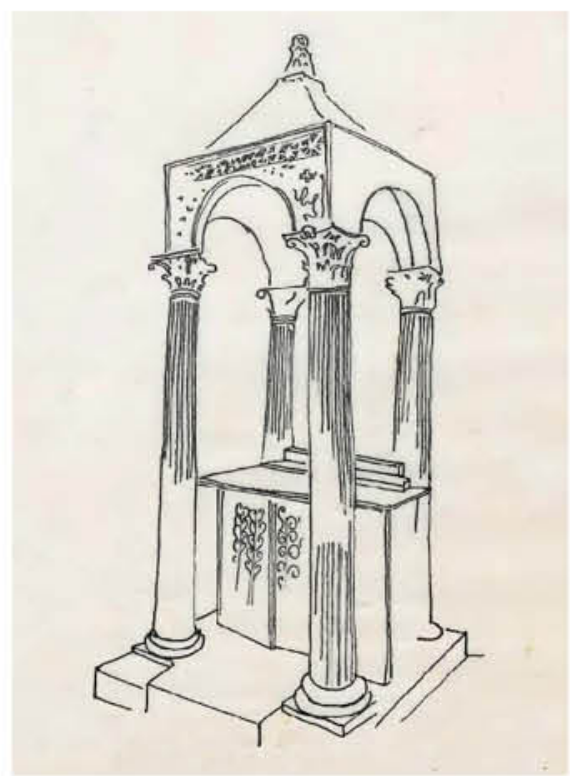

6.38

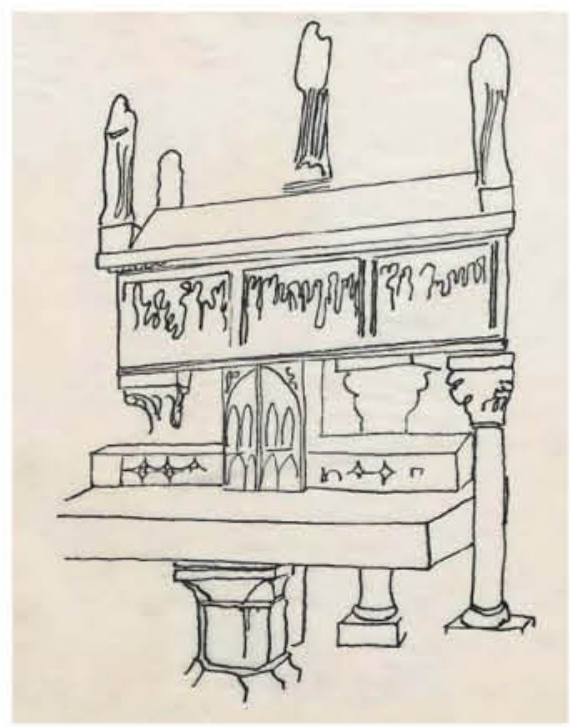

6.39 
Nota: Para realizar el siguiente análisis se han agrupado las obras de Leykam en función de sus principales características en torno a categorias

composituas y semioticas, resultando valida esta

del lenguaje adquieren en la obra de Leykam un del lenguaje adquieren en la obra de Leykam un

No se trata sin embargo de subdivisiones estancas.

No se trata sin entas argo de subdiviones estancas.

Existen proyectos que podrian pertenecer a varias

categorias, mientras que el criteno temporal ha sido

mayor legibilidad secuencial de la investigación. 
III. ANÁLISIS DE LA OBRA ARQUITECTÓNICA DE MAREK LEYKAM TRAS LA II GUERRA MUNDIAL. 
7.01 Edificio de Información Militar del Ministerio de Defensa (Gmach Zarzadu Głównego Informacji Wojska Polskiego) en Marek Leykam y Jerzy Hryniewiecki.

$7.02-7.03$ Ruinas de Varsovia y trabajos de reconstrucción

por parte de la población civil. (1946 - 1950)

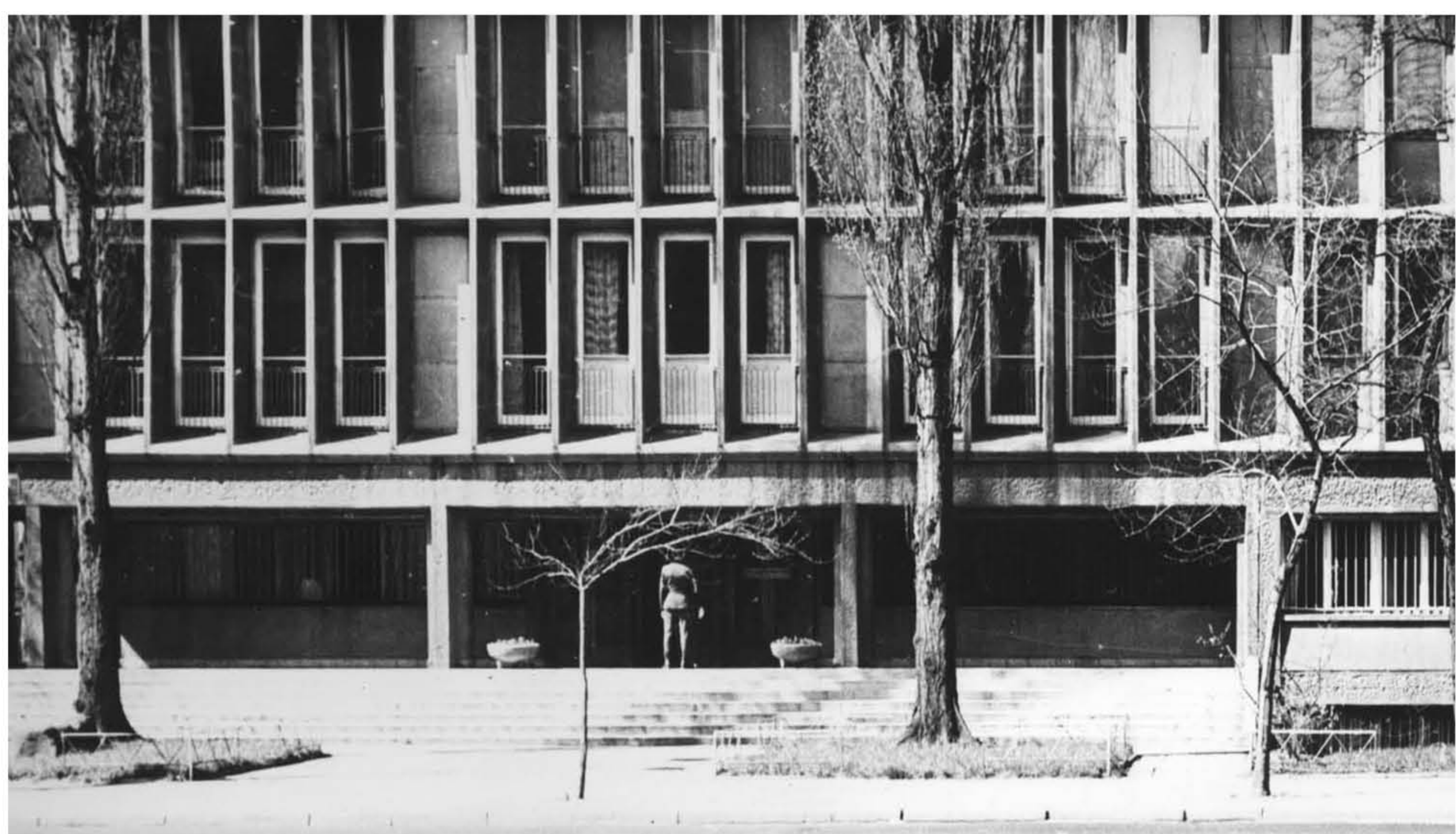




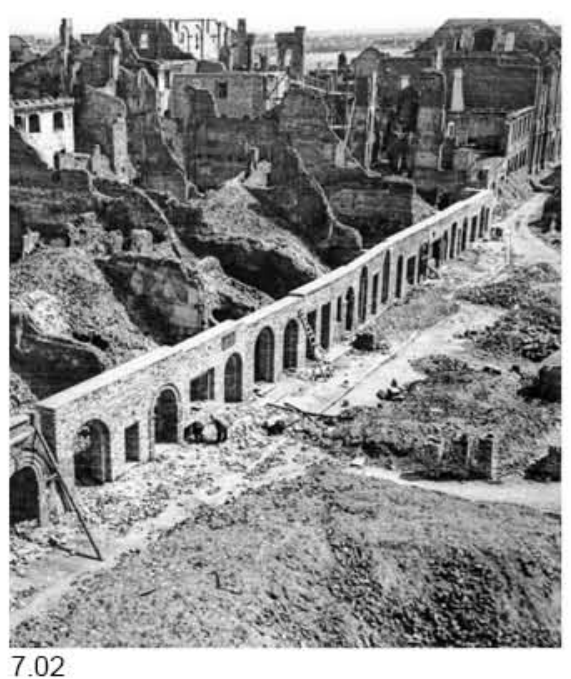

"Analiza i konstrukcja pojęć podmiotu działającego i kultury." 7.00

La obra construida de Marek Leykam en los primeros años tras el final de la II Guerra Mundial, se caracterizó por la capacidad de ofrecer una rápida respuesta a la emergencia social existente en el país tras la destrucción de la capital, Varsovia, y la falta de infraestructuras en el conjunto del territorio.

Entre 1945 y 1950, Leykam proyectó y dirigió simultáneamente 6 proyectos de más de $10.000 \mathrm{~m}^{2}$, sometidos todos ellos a un ritmo de obra frenético, lo que le llevó a priorizar la construcción eficiente en base a un armazón sencillo que optimizase los recursos, resolviendo la estructura mediante una modulación constante en base a la cual se organizaban las diferentes partes del edificio mediante módulos proporcionales.

La simplicidad y el orden resultaban requisitos indispensables en un momento de caos en todo el país (7.02), en el que gran parte de los trabajadores eran colaboradores improvisados de las obras (7.03), población civil o simplemente futuros empleados de los edificios que se estaban construyendo. Las órdenes, en una situación como ésta, debían ser fácilmente comprensibles para todos los trabajadores y las soluciones del proyecto debían ser lo suficientemente concisas para no prestarse a malinterpretación.

Los edificios que veremos a continuación recibieron popularmente el apodo de "Żyletkowiec", por la rotunda manifestación de la estructura de fachada en forma de "cuchillas" 7.01 . La prefabricación de la fachada fue un elemento

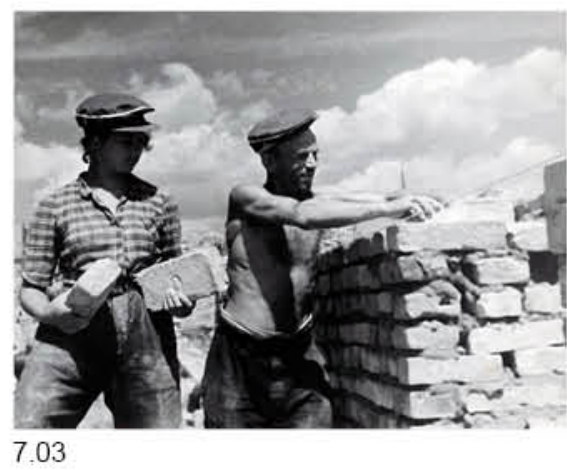
działajacego i kultury."Tadeusz Kotarbiński. Publicado en "Kulturologia polska XX wieku", 2013.

7.01. Sin traducción al castellano, la palabra Żyletkowiec es una adjetivación del termino polaco "Żyletka" que significa "Hoja de afeitar".
7.00. Artículo "Analiza i konstrukcja pojęć podmiotu 
7.04 Edificio de Información Militar del Ministerio de Defensa (Gmach Zarzadu Głównego Informacji Wojska Polskiego) en c/ Leykam y Jerzy Hryniewiecki.

7.05 Otto Rudolf Salvisberg en su estudio en 1938.

7.06 Construcción de la fachada del Edificio de Información Militar c/ Chałubińskiego 3a, Varsovia.

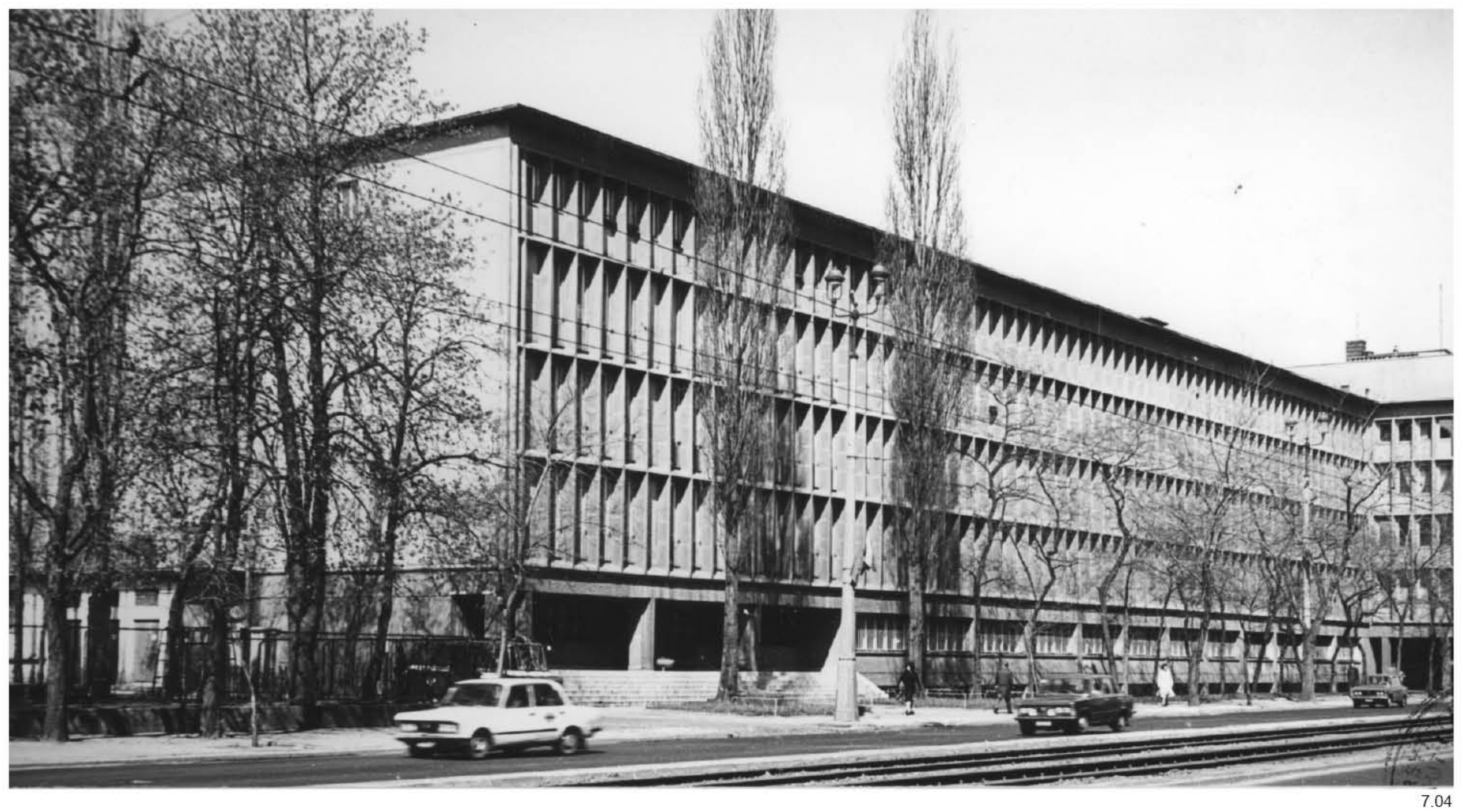


fundamental en las obras polacas de postguerra desarrolladas por Leykam y, tratando de aprovechar al máximo sus posibilidades, fueron eliminadas todas las particularidades de los edificios para dar prioridad a un módulo constructivo siempre constante que permitiese la coordinación sencilla del mayor número de partes estandarizadas.

Como alumno de Salvisberg en la ETH de Zúrich en 1940, Leykam había tenido la oportunidad de aprender la eficacia de la obra planteada desde el control de la modulación y la estandarización de todas sus partes. Las visitas de obra durante la construcción del edificio Bleicherhof en 1940, fueron fundamentales para que el arquitecto polaco adoptase un método de proyecto basado en la generación de fórmulas matemáticas, mediante las cuales definir proporciones entre las partes y acotar, a partir de métodos verificables en obra, las posiciones de todos los elementos.

Su asistencia al estudio de Auguste Perret en 1934 le había permitido aproximarse asimismo a la estructura como fenómeno estético, trascendiendo a la prioridad del orden estructural planteado desde la optimización de sus posibilidades tectónicas, para buscar en él una manifestación expresiva que pudiera venir acompañada incluso de cierta manipulación en los elementos constructivos de fachada con objeto de mostrar con mayor claridad las posibilidades teóricas de la solución. Incluso aunque en esa época no fuese la solución más rentable por motivos económicos, sí era predecible que fuese factible alcanzar esa simplicidad en el futuro con un avance de los medios de producción y las técnicas de construcción.

Durante estos años, y en general a lo largo de toda su obra, los proyectos de Leykam se caracterizaron por la coherencia de sus planteamientos, en los cuales se trataron de evitar las singularidades y las soluciones se centraron en una búsqueda de la expresividad a través de la superposición y la jerarquización de paso de los diferentes elementos que constituían la composición de fachada. ${ }^{7.02}$

El tratamiento del espesor de cada plano y la valoración de sombra producida por cada elemento tienen gran interés en el trabajo de Leykam, pues denota su preocupación por el detalle constructivo como base para la creación de efectos expresivos particulares dentro de la genericidad volumétrica y programática que imponían las circunstancias.

El volumen de los edificios estudiados en este capítulo venía dado en la mayoría de casos por el cumplimiento de las recomendaciones realizadas por la oficina de reconstrucción y planeamiento BOS en sus planes estratégicos. Leykam planteaba en todos los casos el máximo aprovechamiento de la edificabilidad asignada y la definición del volumen era inmediata a partir de estos parámetros en función de las proporciones del solar y las normativas existentes. Debido a lo frenético de los trabajos, la distribución interior era planteada de forma genérica para una posterior redistribución por parte de los futuros usuarios. Desde el módulo de la estructura sí que existía, no obstante, una aproximación a la distribución, en la medida en que los gestores de cada espacio tuvieran en cuenta la relación estructura-cerramiento que había sido propuesta en fase de proyecto.

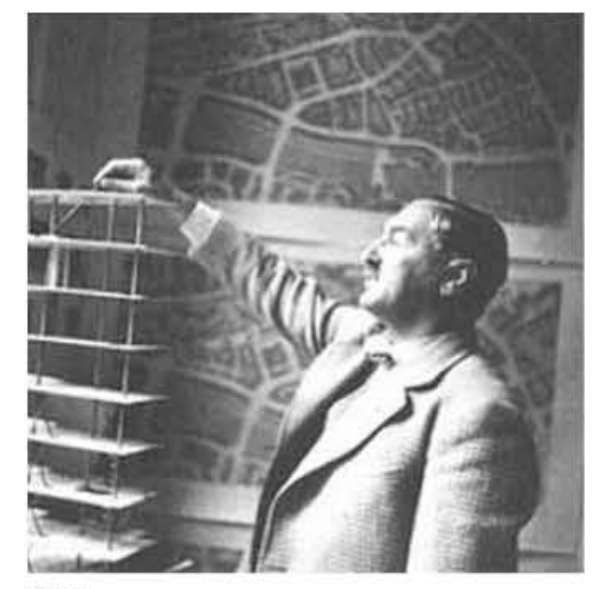

7.05

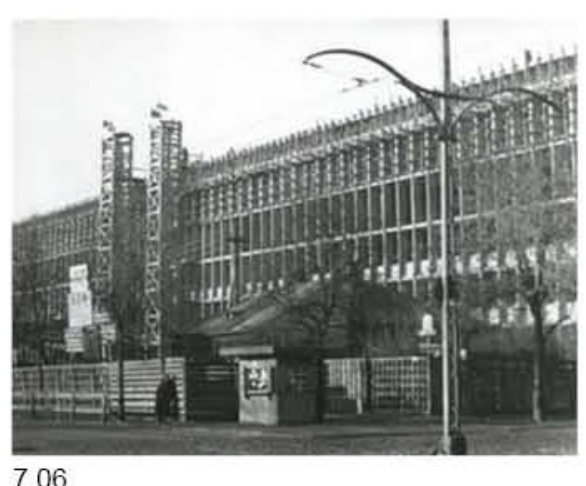

706

7.02. En ese sentido el propio Salvisberg también habia declarado: "Debemos proyectar desde la voluntad de que las construcciones sean sencillas, sencillas todavia." Litchtenstein 1977 p 69. 
7.07 Edificio de Información Militar del Ministerio de Defensa

Chałubińskiego 3a, Varsovia $(1946-1950)$. Arquitectos: Marek

Leykam y Jerzy Hryniewiecki.

7.08 Detalle tipo de la fachada del Edificio de Información Militar

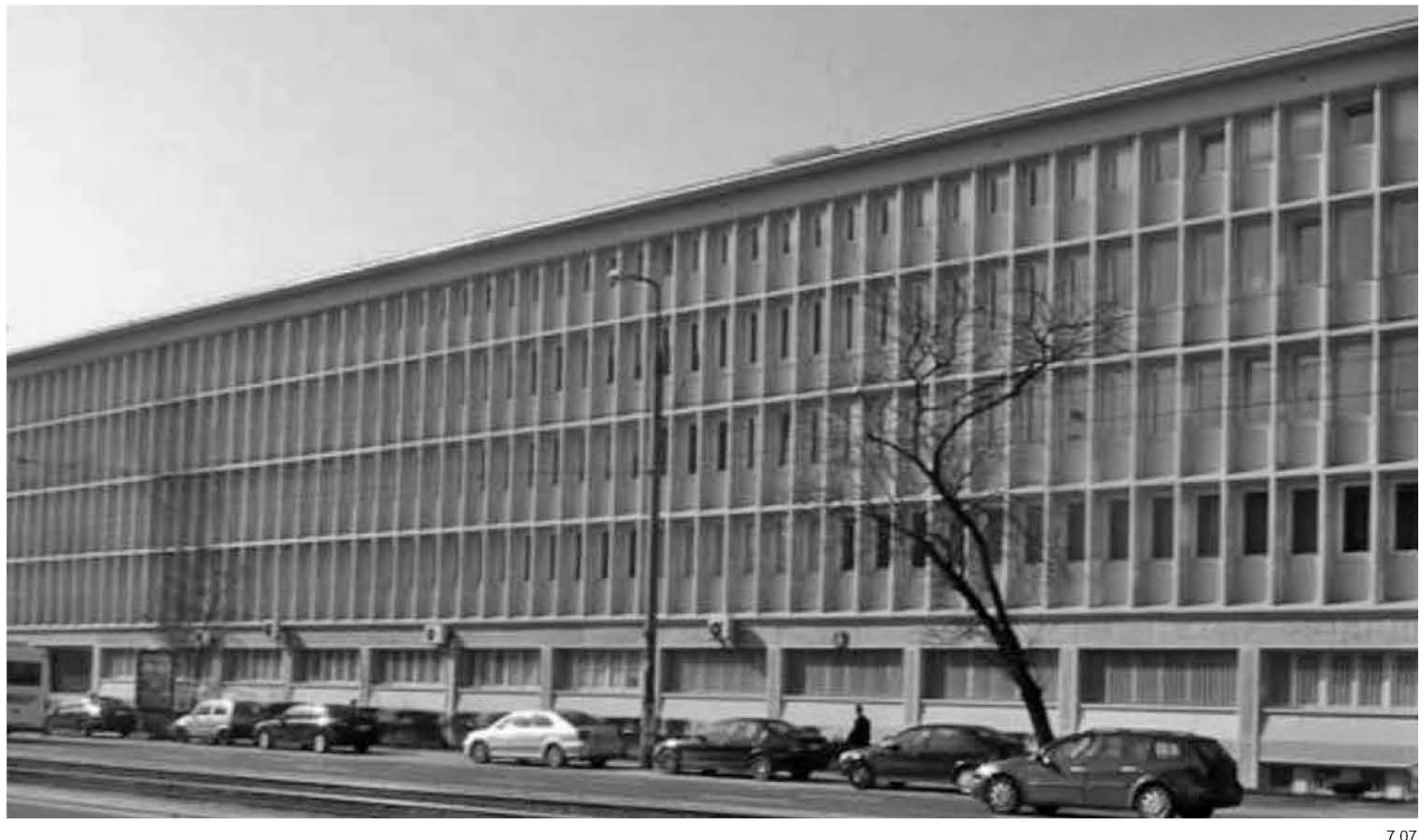


Por norma general los bloques de Leykam presentaban una estructura de pórticos transversales de tres vanos, ajustando el vano central a las necesidades de recorrido de paso de un corredor central que debía servir de distribución a los ámbitos situados a ambos lados del mismo, hasta el plano de fachada. El forjado se resolvía mediante losas prefabricadas de hormigón para facilitar una mayor rapidez en la ejecución, y la fachada iba variando sus detalles para singularizar la cada edificación.

\subsubsection{Edificio de Información Militar del Ministerio de Defensa en Varsovia.}

En 1946, Leykam recibió el encargo de construir -junto a Jerzy Hryniewiecki- el Edificio de Información Militar para el Ministerio de Defensa ${ }^{7.03}$ en la calle Chałubińskiego 3a de Varsovia, muy cerca del centro de la ciudad, en una de las avenidas que estaban destinadas a ser ejes principales de la reconstrucción y rodeado por edificios de oficinas que también estaban siendo construidos en ese momento.

El edificio constaba de 5 plantas de $3,33 \mathrm{~m}$. de altura, más un sótano, alcanzando una altura de cornisa de $18,50 \mathrm{~m}$ y una longitud total de 85 metros repartida en 17 pórticos y 16 vanos de $5,33 \mathrm{~m}$. Todas la plantas, salvo la baja y la superior, fueron resueltas en sus alzados longitudinales con una retícula regular de costillas de hormigón prefabricado de $10 \mathrm{~cm}$ cuyas proporciones se ajustaban al módulo de $2: 5$ (1,33 $\mathrm{m}$ de ancho y 3,33 de altura). Los huecos interiores de esta trama fueron rellenados con ventanas prefabricadas de $0,90 \times 1,90 \mathrm{~m}$., dejando en los laterales amplias tolerancias de más de $20 \mathrm{~cm}$. El relleno del hueco se produjo in situ, aunque estaba preparado para recibir un elemento prefabricado ${ }^{7.04}$, lo cual provocó que este edificio fuera el menos industrializado en su desarrollo de todos cuantos se realizaron en su estudio en esta época. La profundidad de las costillas $(0,40 \mathrm{~m})$ propiciaba, a su vez, un efecto brise-soleil un tanto atenuado por la falta de ajuste de las ventanas, pero muy persistente en la generación de un ritmo que aportaba homogeneidad a la fachada a pesar del rebaje de los huecos insertados en el cerramiento.

El ritmo de la retícula se mantiene inalterado hasta la última planta, donde fue reducido a una proporción de 2:4 (1,33 $\mathrm{m} \times 2,66 \mathrm{~m}$ ) para recortar el hueco del acristalamiento hasta un cuadrado de $0,9 \mathrm{~m}$ de lado manteniendo la pieza de antepecho en $1,33 \mathrm{~m}(1,00 \mathrm{~m}+0,33$ forjado). La proporción recortada de este hueco tiene que ver con la definición formal de la fachada vista desde el exterior, puesto que no hay diferencias espaciales ni elementos programáticos en el interior que justifiquen esta variación.

Mediante la reducción del módulo de la última planta, la trama de fachada definida en los alzados longitudinales permite que ésta pueda coincidir una hipotética extensión vertical de su serie de montantes horizontales con el perímetro exterior de la fachada del edificio. Para priorizar esta sincronía, el último 1/5 del módulo de la última planta es sustituido por el canto del forjado de cubierta, recortando así la altura de los montantes verticales y haciendo coincidir la línea horizontal más elevada de la malla de fachada con la línea que define la cornisa de remate superior.
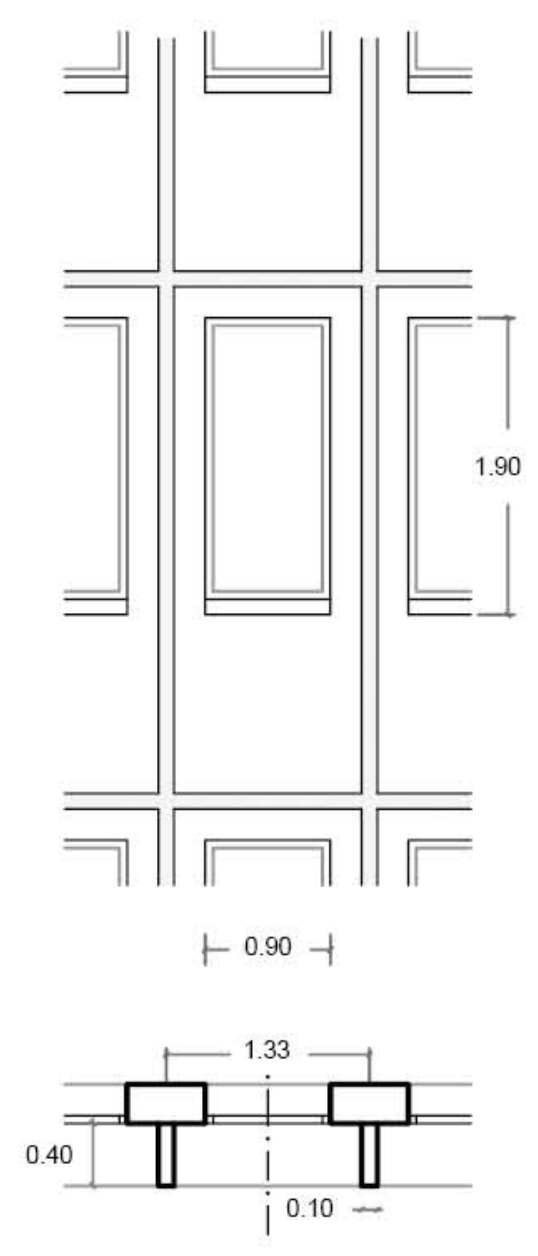

7.08

7.03. Gmach Zarządu Głównego Informacji Wojska Polskiego (MON).

7.04. Jur, 1977. 


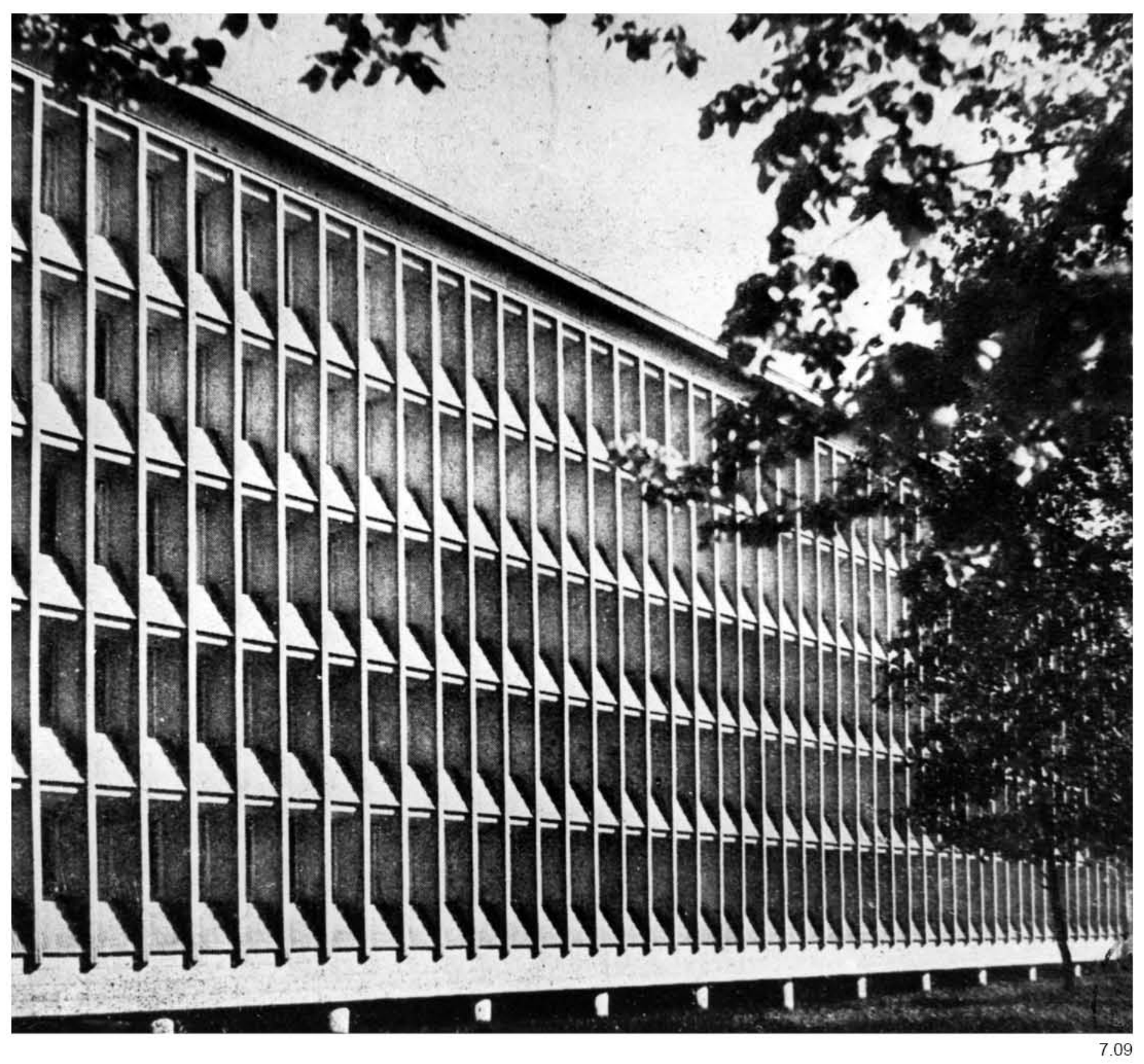


La disminución de la altura del módulo de fachada de la última planta aporta asimismo un cierto apoyo a la corrección visual del efecto que induce al ojo humano a distorsionar el trazado de una trama de montantes verticales al ser observado desde una posición no frontal, como ha sido comentado anteriormente en el proyecto del Ministerio del Tesoro Público de Varsovia (4.33-4.39).

Las divisiones de planta baja se sitúan cada $5,33 \mathrm{~m}$, coincidiendo con los ejes estructurales. Sobre una trama de pilares en fachada se sitúa una viga que define formalmente la discontinuidad del plano de planta baja con la fachada situada sobre ella. La escala de esta planta, cuya altura es de 4,00 metros, permite que las ventanas de los sótanos asomen sobre ella hasta $1,33 \mathrm{~m}$ con la misma modulación que los ventanales corridos hasta interrumpirse en el pórtico de entrada, que es precedido por unas escaleras a lo largo de tres vanos.

El uso de ritmos impares no resulta casual, puesto que permite evitar una lectura duplicada de la composición que establezca comparaciones literales y focalice la atención en las simetrías, haciendo hincapié por el contrario en la continuidad de la trama a nivel lineal. Cada vano tiene en su interior 3 módulos enteros de fachada e interrumpe los dos extremos para situarlos alineados a ejes de la estructura en el punto medio $(1 / 2-3-1 / 2)$. Si realizamos una lectura vertical del alzado, las 3 plantas intermedias contienen igualmente una fachada de igual módulo completo, mientras los niveles superior e inferior contienen un módulo reducido (1/2 - 3 - 1/2).

Una de las principales características de la obra de Leykam es la atención a la direccionalidad que deriva de la interpretación de la trama urbana. En este conjunto de edificios, Leykam toma partido claramente por manifestar de forma rotunda su direccionalidad, definiendo como permeables las fachadas longitudinales orientadas a este y oeste y cegando mayoritariamente los testeros. En este caso el testero norte sirve a su vez para resolver la conexión con la parte de la sede del Ministerio de Defensa que había sido restaurada y a la que este nuevo edificio servía de ampliación.

La coincidente sección constructiva de los montantes también resulta destacable en este proyecto, al haberse producido todas las intersecciones de la fachada al mismo nivel, sin definir jerarquías de paso ni diferencias en el detalle constructivo entre elementos los horizontales y verticales.

\subsubsection{Instituto Geológico de Varsovia}

En 1947 Leykam recibió el encargo de diseñar la Sede del Instituto Geológico de Varsovia ${ }^{7.05}$ en la calle Rakowiecka $\mathrm{n}^{\circ} 4$, una institución de la que había formado parte su padre hasta que falleció en enero de 1939. En este proyecto participaría el arquitecto Czesław Witold Krassowski y el cálculo de la estructura sería llevado a cabo por el ingeniero Stanisław Zalewski. ${ }^{7.04}$

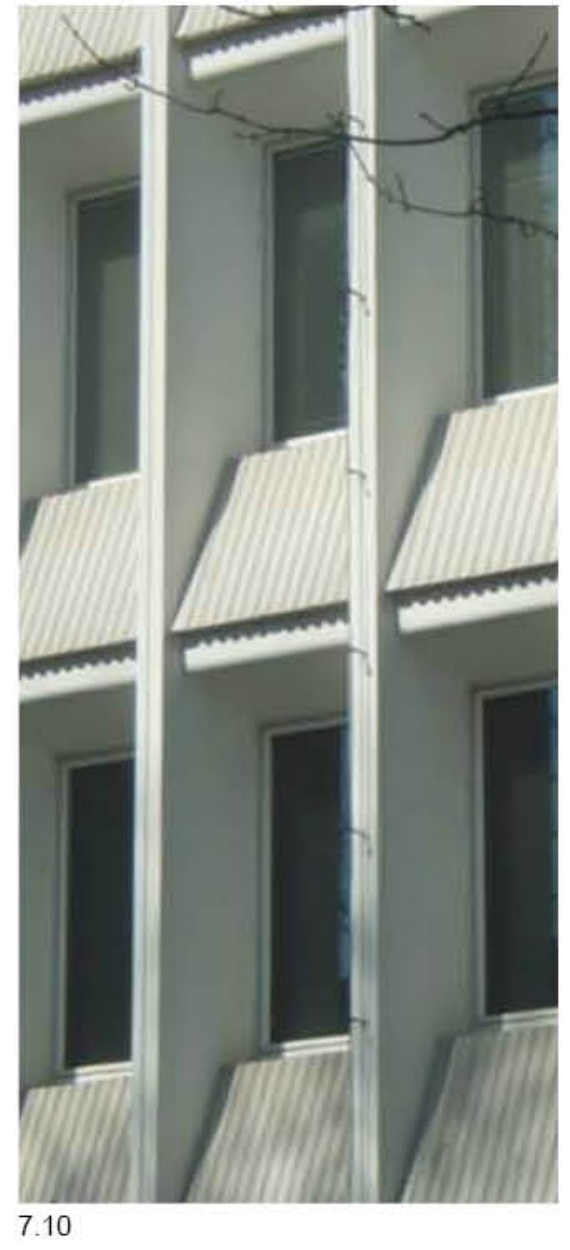

7.05. Państwowy Instytut Geologiczny (PIG). EI padre de Leykam, Jan Lewiński habia sido fundado del Laboratorio Geológico Polaco (Pracownia Geologiczna en 1901. Fuente: pgi.gov.pl 
7.11 Fachada del Instituto Geológico (Instytut Geologicznego) de

Krassowski Czestaw (1949-55).

7.12 Detalle tipo de la fachada del Instituto Geológico de Varsovia.

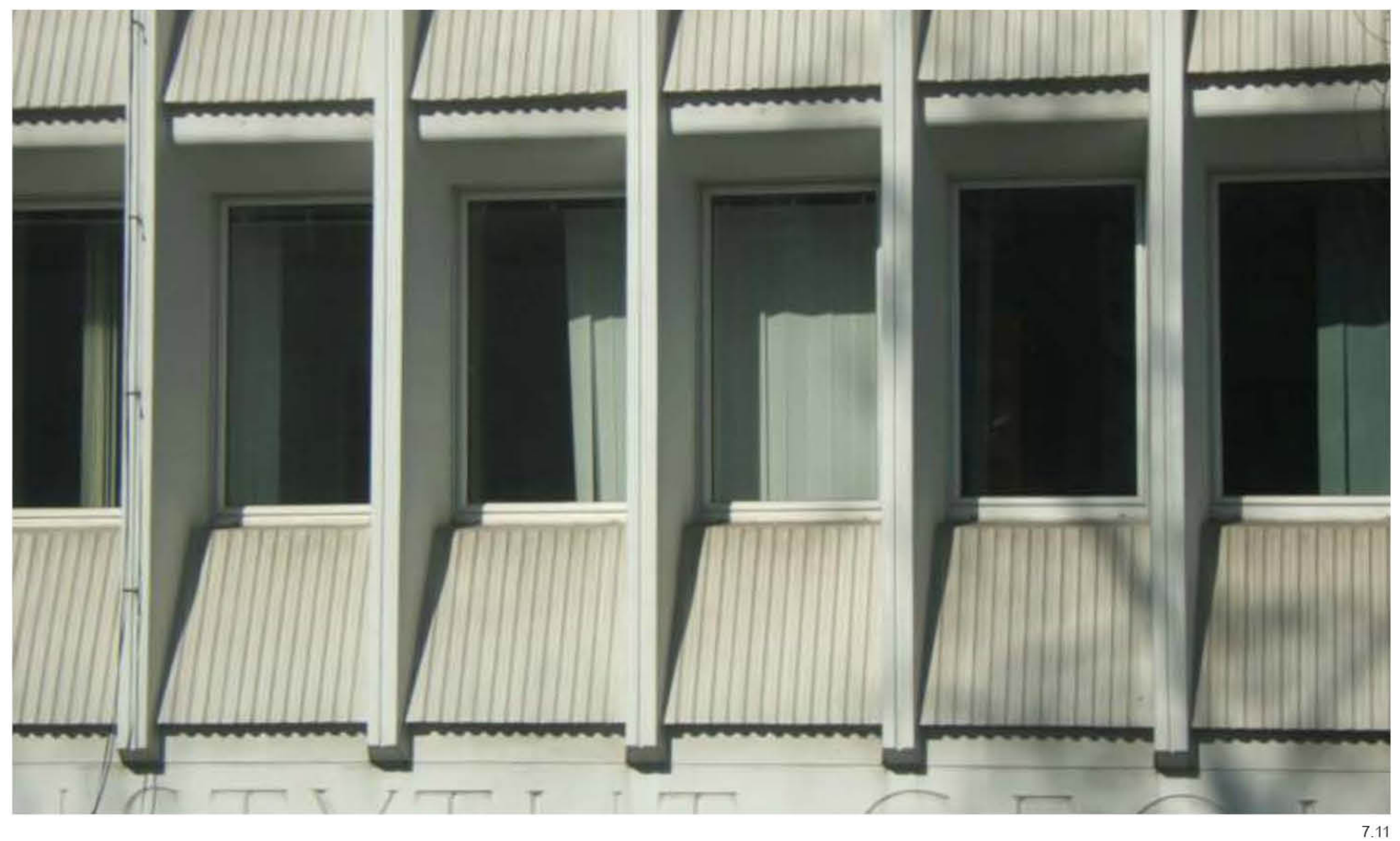


La calle Rakowiecka, situada en el barrio de Mokotów, está alejada tres kilómetros del resto de edificios Żyletkowiec, que -a lo largo de la calle Wspólna- podían ser visitados de forma conjunta por Leykam durante las obras en apenas 900 metros. Planificada con un mayor esponjamiento que la calle Chahubińskiego, la calle Rakowiecka alberga las edificaciones retranquedas tras un filtro verde sin alineamientos tan prolongadamente continuos como en el centro de la ciudad. El contexto en cualquier caso no modificaba los planes de Leykam, puesto que -como se ha comentado- la volumetría de sus proyectos estaba centrada en lograr el máximo aprovechamiento de las variables urbanísticas que le venían dadas por normativa y su manifestación expresiva estaba sujeta a las variaciones a nivel de detalle que pudieran ser introducidas en el sistema de fachada.

Retranqueado de la calle por un filtro verde de separación de 22 metros, este bloque de planta rectangular y 5 alturas se resuelve con una trama de fachada continua de cinco niveles, sin diferencias en la manifestación del alzado en planta baja ni en la última altura, tal como ocurría en el bloque anterior.

A lo largo de $90.6 \mathrm{~m}$ de largo y 21.3 de ancho se distribuyen en este bloque 18 pórticos transversales de tres vanos separados por intervalos regulares de $5,33 \mathrm{~m}$ a ejes. Continuando con la rítmica propuesta en el Edificio de Información Militar (1/2 - 3 - 1/2), la distribución vertical de las fachadas longitudinales da lugar a 4 subdivisiones de $1,33 \mathrm{~m}$, situando los puntos medios de los módulos extremos alineados con los ejes de los pórticos transversales. La retícula trazada en los alzados longitudinales sí contiene esta vez jerarquía de paso. Los montantes verticales mantienen la continuidad a lo largo de toda la fachada con una sección de $0,50 \mathrm{~m} \mathrm{x} \mathrm{0,10} \mathrm{m} \mathrm{cuya} \mathrm{esbeltez} \mathrm{está} \mathrm{acentuada} \mathrm{a} \mathrm{nivel} \mathrm{visual} \mathrm{por} \mathrm{la} \mathrm{hendidura}$ que recorre verticalmente su canto a lo largo del eje, creando el efecto óptico de superposición de dos piezas de $0,05 \mathrm{~m}$, mientras que los elementos intersticiales entre costillas verticales crean un plano horizontal mucho más difuminado, con la novedad con respecto al bloque anterior de estar constituidos por piezas ya completamente prefabricadas.

El detalle del plano horizontal de esta fachada evita entrar en conflicto con la rotundidad de las costillas verticales redondeando el canto inferior de la pieza de base por oposición al canto rectificado de las costillas verticales e introduciendo un nuevo plano, que surge como consecuencia de la inclinación de la pieza de hormigón prefabricado de tabla ranurada que formaliza exteriormente el antepecho hasta la cota interior de $0,90 \mathrm{~m}$ sobre el piso.

Las ventanas se ajustan esta vez mucho más al hueco, siendo de $1,10 \mathrm{~m}$ x $1,90 \mathrm{~m}$, mientras que la altura de planta del edificio se mantiene igual que en el bloque anterior en $3,33 \mathrm{~m}$ al igual que el antepecho, $1,33 \mathrm{~m}$. El volumen completo esta circundado por un marco que se manifiesta con forma de rectángulo al exterior completando la cornisa y conformando la base de planta baja, así como la expresión en fachada del canto de los testeros laterales.

Los testeros norte y sur, a pesar de no ser completamente ciegos, mantienen una composición marcadamente opaca al haber abierto visuales únicamente al final de los corredores de cada planta. Esta predominancia del lleno sobre el vacío en

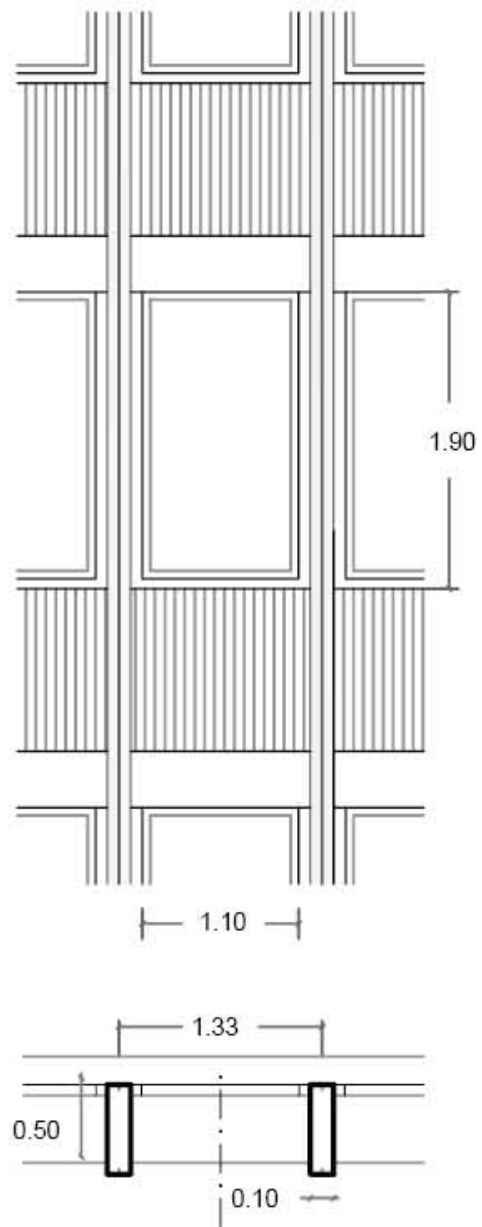


7.13 Edificio NIK (Najwyższa Izba Kontroli). Cámara Ciudad de Varsovia en c/Marszatkowska no 82-84. Marek Leykam y Jerzy Hryniewiecki. Proyecto:1946 obra 1950-52.

7.14 Detalle tipo de la fachada de la Cámara Ciudad de Varsovia.

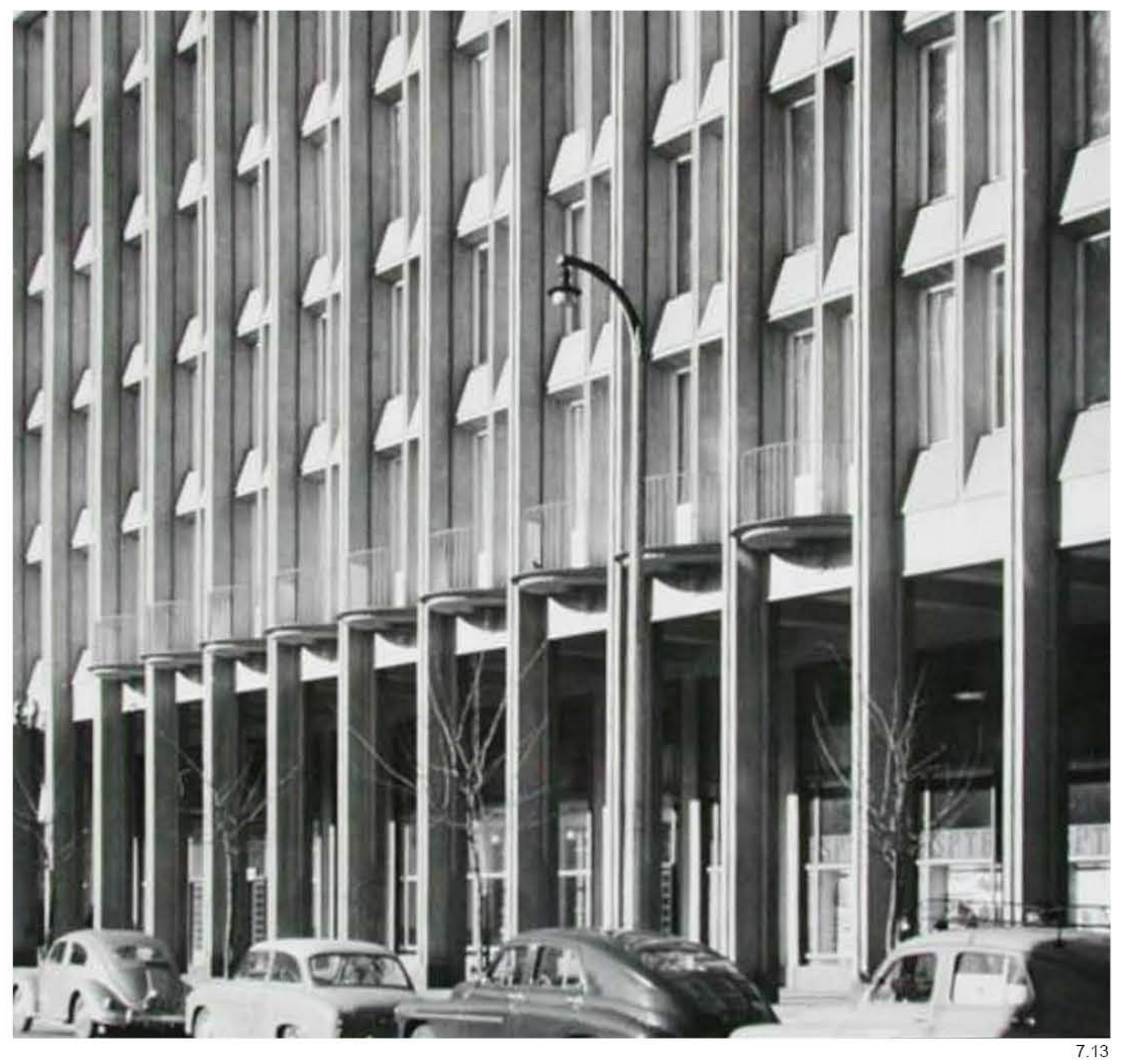


los extremos del volumen, por oposición a las fachadas longitudinales orientadas a este y oeste que son mayoritariamente permeables, vuelve a hacer hincapié en la determinación con que Leykam afrontaba la direccionalidad de los edificios, derivada de los rotundos contrastes que significaban para él los cambios de plano en las figuras geométricas.

Una vez más, la modulación del edificio venía dada por una proporción matemática, con la que eran gestionados todos los elementos y desde la que eran estructuradas todas las relaciones entre los diferentes elementos prefabricados con carácter global. A través de un módulo se podía definir todo el conjunto, desde la escala urbana hasta el detalle.

\subsubsection{Edificio NIK Jefatura de la Industria del Acero y el Carbón de Varsovia.}

En el Edificio de la Cámara Suprema de Control y Tribunal del Distrito de la Ciudad de Varsovia ${ }^{5.06}$ en la calle Marszałkowska $n^{\circ} 82-84$ Leykam introdujo cambios significativos respecto a los dos bloques anteriores dentro de su esquema proyectual. Si bien este edificio fue planteado en 1946, la obra se desarrollo a principios de los 50 , en un contexto en el que el Realismo Socialista comenzaba a ser una realidad cuyas consecuencias analizaremos posteriormente.

A diferencia del resto de Żyletkowiec, el volumen condiciona gran parte de las soluciones al estar conformado por un bloque de manzana abierto. Dadas las dimensiones de la parcela, 85 x $60 \mathrm{~m}$, y el ancho máximo de bloque de $16 \mathrm{~m}$, Leykam resuelve un volumen en forma de U abierta al norte utilizando la misma modulación para todo el conjunto.

En el extremo sur en la calle Wspólna el conjunto queda dividido en 21 módulos de 2,86 m, mientras que en los extremos este y oeste en las calles Marszałkowska y Krucza, la subdivisión fue de 29 módulos manteniendo el intereje de 2,86 $\mathrm{m}$ en todo el perímetro. De esta forma la fachada podía leerse en continuidad tanto exteriormente como interiormente y era utilizado el mismo módulo en todos los paramentos, optimizando la cantidad de piezas prefabricadas y agilizando el proceso de construcción.

El edificio NIK contiene de nuevo 5 alturas al igual que los anteriores, resueltas con una retícula de similares criterios. La altura de planta se mantiene en $3,33 \mathrm{~m}$, pero el conjunto queda sobreelevado por una galería perimetral de 6,66 metros de altura que recorre exteriormente el conjunto y eleva la altura total del edificio hasta los $24 \mathrm{~m}$. Bajo el patio interior están ubicados los garajes a los que se puede acceder desde la calle Żurawia (7.15).

La retícula principal de fachada estaba constituida por piezas prefabricadas de plementería según detalle (7.14) hasta completar el vano de $1,33 \mathrm{~m}$ de anchura y $3,33 \mathrm{~m}$, de las mismas dimensiones que los dos bloques anteriores, aunque en este caso la estructura deja de estar alienada con el punto medio del módulo de fachada para ser coincidente con su trama en uno de cada dos módulos. Surgen así finas costillas estructurales de 20x60 cm con una acanaladura en el centro del canto al igual que ocurría en el bloque de la calle Rakowiecka para acentuar su verticalidad.

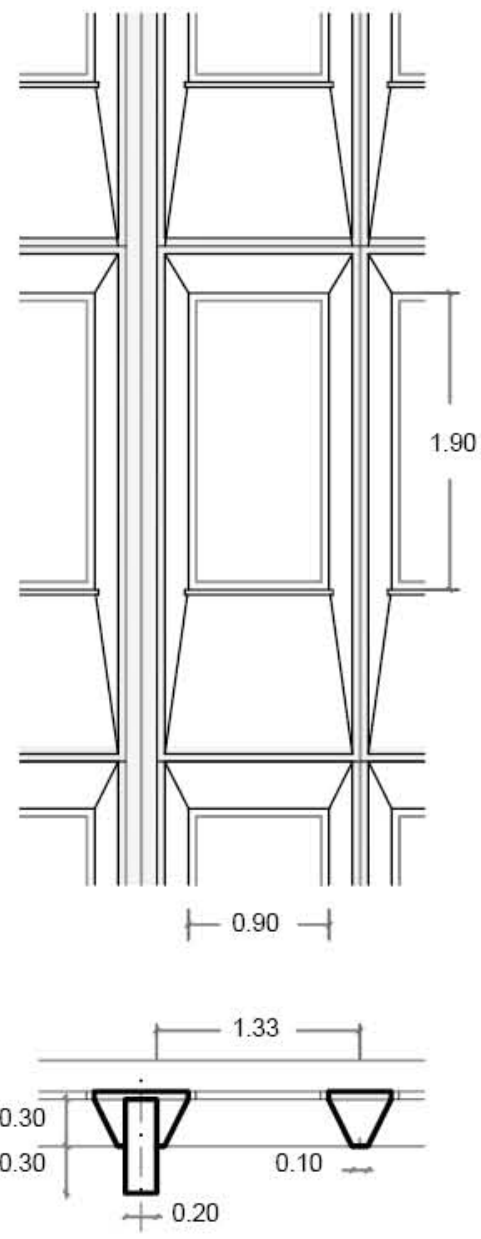

7.14

7.06. Najwyższa Izba Kontroli (NIK). 


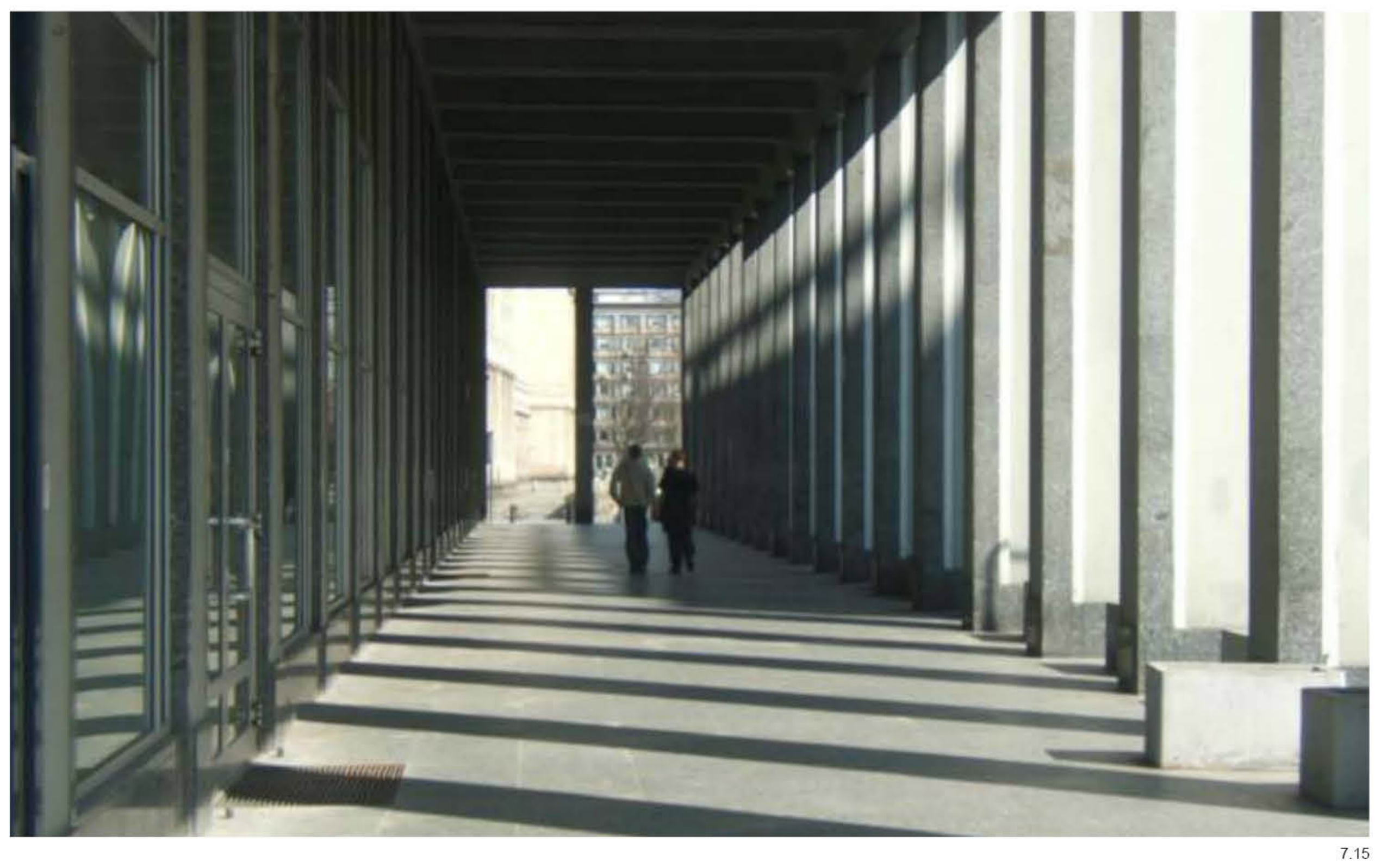




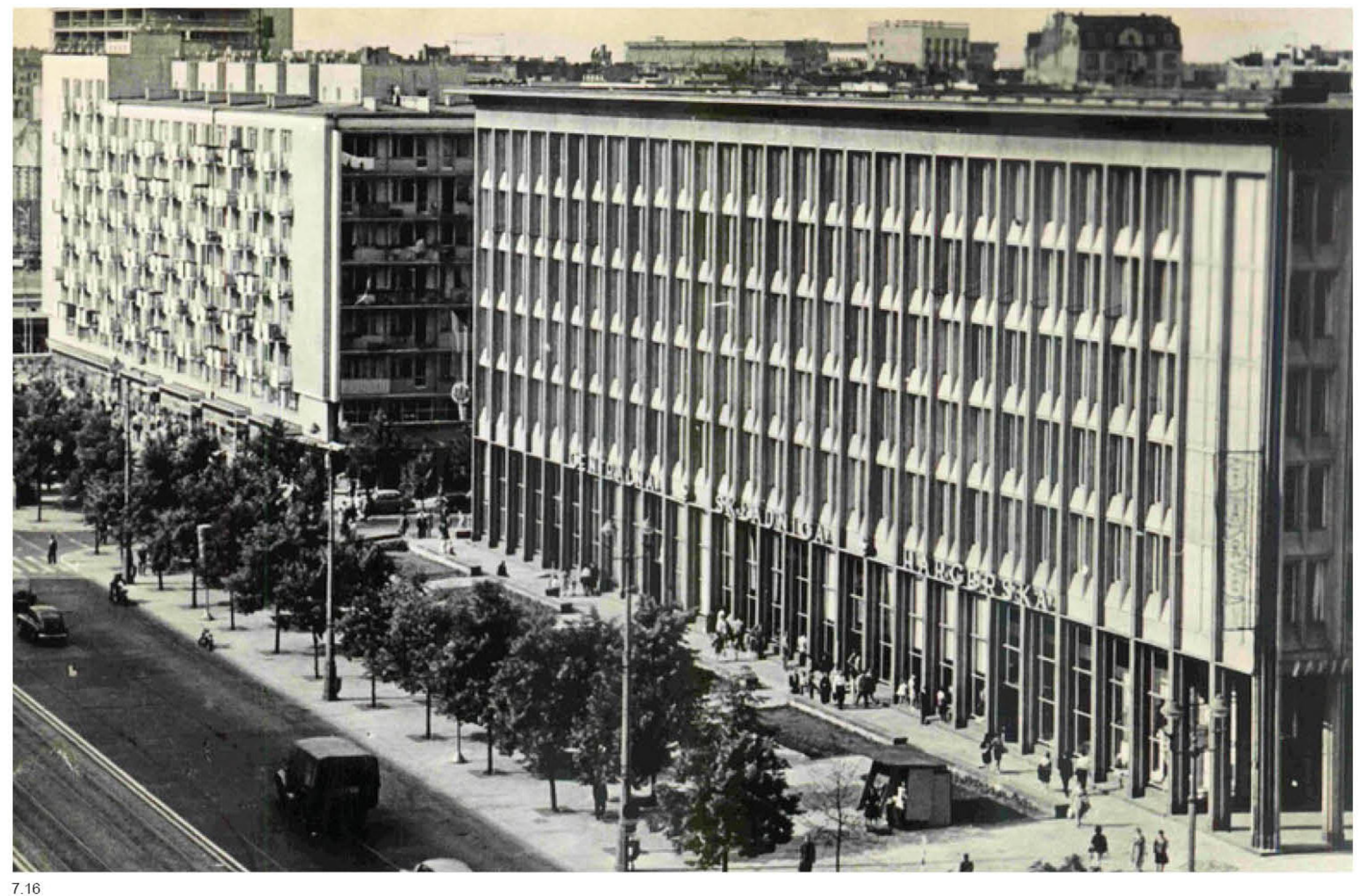


7.17 Patio interior de Edificio NIK de Varsovia (1946-50). Marek Leykam y Jerzy Hryniewiecki.

7.18 - 7.20 Detalles de los encuentros en esquina en el Edificio NIK.

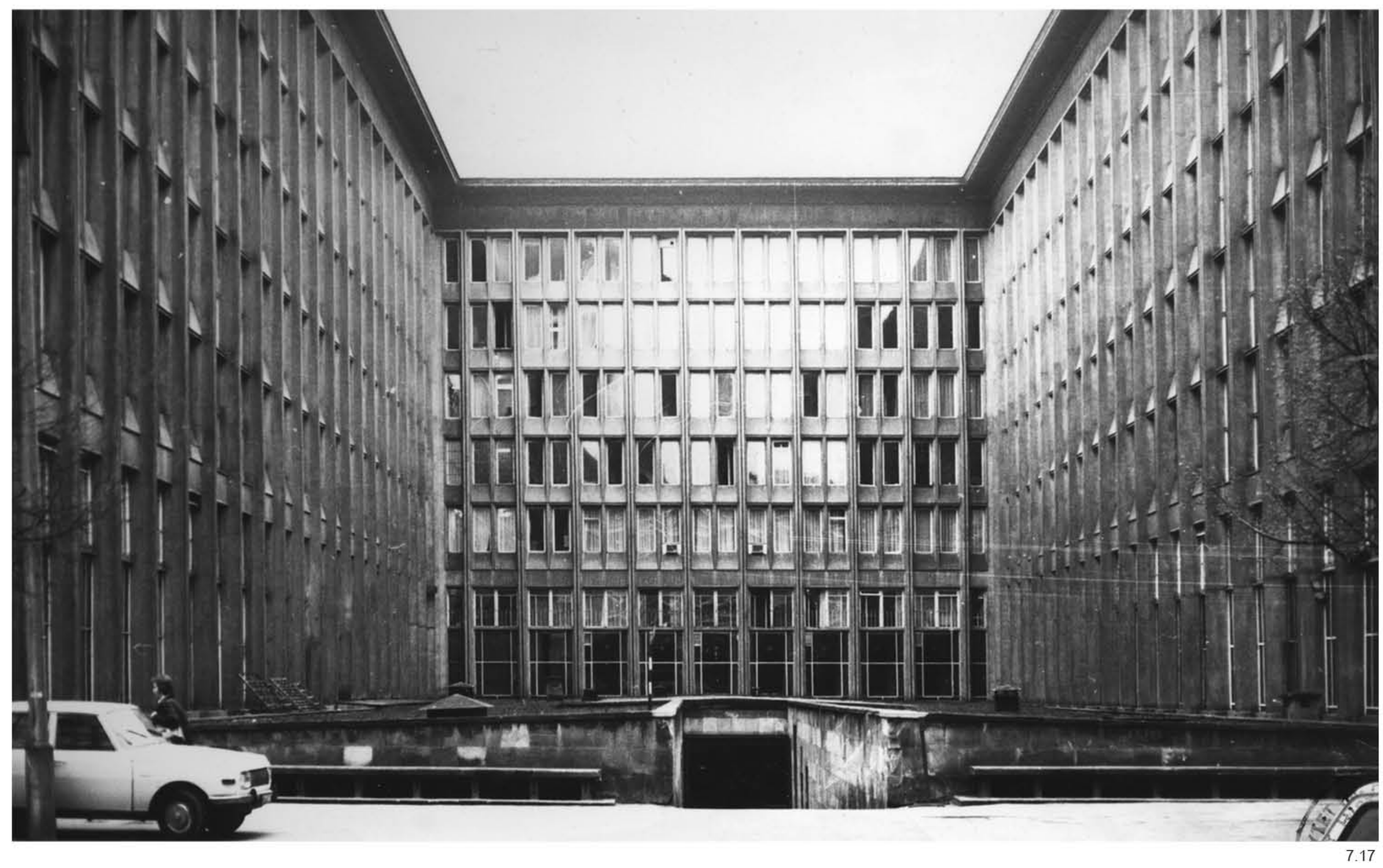


Si bien estas piezas estructurales tienen jerarquía de paso, la trama de la fachada tiene intersecciones en el mismo plano a nivel horizontal y vertical aunque se pueda realizar una lectura vertical del conjunto debido a sus proporciones ( 1,33 $\mathrm{m}$ x 3,33 $\mathrm{m}$ de hueco y $0,90 \mathrm{~m} \times 1,90 \mathrm{~m}$ de ventana) y la asociación visual que produce ver grupos de dos módulos en continuidad durante 5 plantas.

En este caso, la fachada tiene mayor profundidad que los bloques anteriores a pesar de que los módulos prefabricados que contienen las ventanas son solo de $0,30 \mathrm{~m}$ ya que las costillas estructurales sobresalen del plano de los módulos de ventana $0,30 \mathrm{~m}$ más, acentuando su incidencia en la modulación y la verticalidad del conjunto. La galería que recorre la planta baja (7.15) nos remite a soluciones anteriores de Leykam como la del Banco Nacional de Economía de Poznań (2.39-2.45), en la que, al igual que en este edificio, el cerramiento retranqueado de planta baja se resolvía con la misma modulación que la fachada superior, creando un equilibrio de claroscuros mediante las diferencias de sombra que provocaban las diferentes profundidades de las tramas de fachada y la propia posición de sus planos en la edificación. La fachada está coronada por un muro perimetral y una cornisa que hace hincapié en la importancia que para Leykam tenía establecer un diálogo con el orden clásico.

Conceptualmente Leykam trató de dar más complejidad a la lectura de la fachada que la propuesta básica de una trama en continuidad a lo largo del perímetro. Sin renunciar a esta primera interpretación, Leykam no deja de lado su interés por mostrar la direccionalidad de cada plano del volumen, realizando una segunda lectura del bloque de manzana abierta como si se tratase de una adición de tres bloques lineales adosados en sus extremos, para lo cual trató de hacer reconocibles los testeros tanto reales como hipotéticos (7.13).

Sus proyectos continuaban así teniendo una lectura direccional que venía dada por los planos de la figura geométrica a la que se ajustaban tomando partido por la permeabilidad o la opacidad de cada uno de ellos para que de su contraste surgiese una consecuencia derivada de la interpretación del contexto urbanístico.

En la fachada norte hacia la calle Żurawia los dos testeros de los bloques este y oeste se manifiestan predominantemente ciegos, dejando de nuevo un vano para albergar los huecos abiertos que iluminan el corredor central, mientras que el bloque alineado con la calle Wspólna mantiene ciegos los dos primeros módulos de los extremos recayentes sobre las calles Marszałkowska y Krucza, en los que en lugar de ventanas situó paneles prefabricados para significar conceptualmente el imaginario testero que permitiera a este volumen ofrecer una lectura de una superposición individual de bloques en un conjunto con forma de $U$.

Los testeros alineados a la calle Żurawia se dividen en 5 módulos y medio de $2,86 \mathrm{~m}$ de ancho $(2,66 \mathrm{~m}+0,20 \mathrm{~m})$ en los que se sitúan paneles de hormigón prefabricado ciegos, a excepción del módulo central coincidente con la iluminación del corredor. Ese medio módulo del testero es importante para resolver la intersección en esquina de los bloques (7.16),
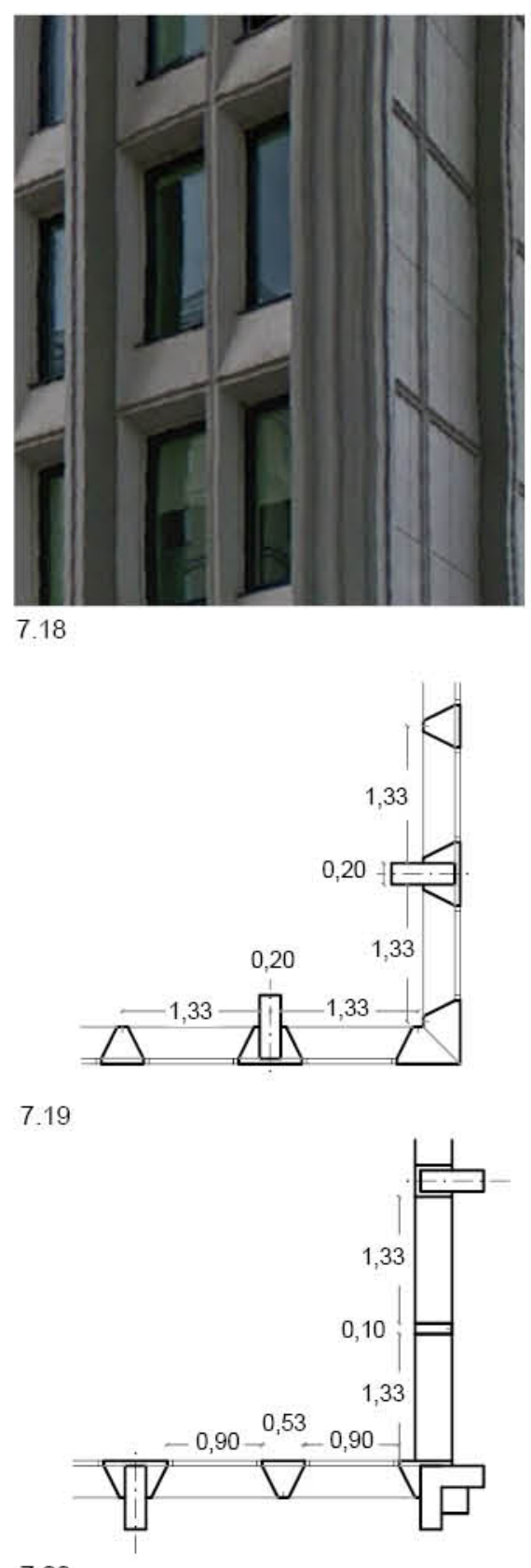

7.20 
7.21; 7.23 Proyecto de Reconstrucción de Le Havre (1946-64). Auguste equipo.

7.22; 7.24 Planos del proyecto de reconstrucción de Le Havre (1946-64). Auguste Perret y equipo.

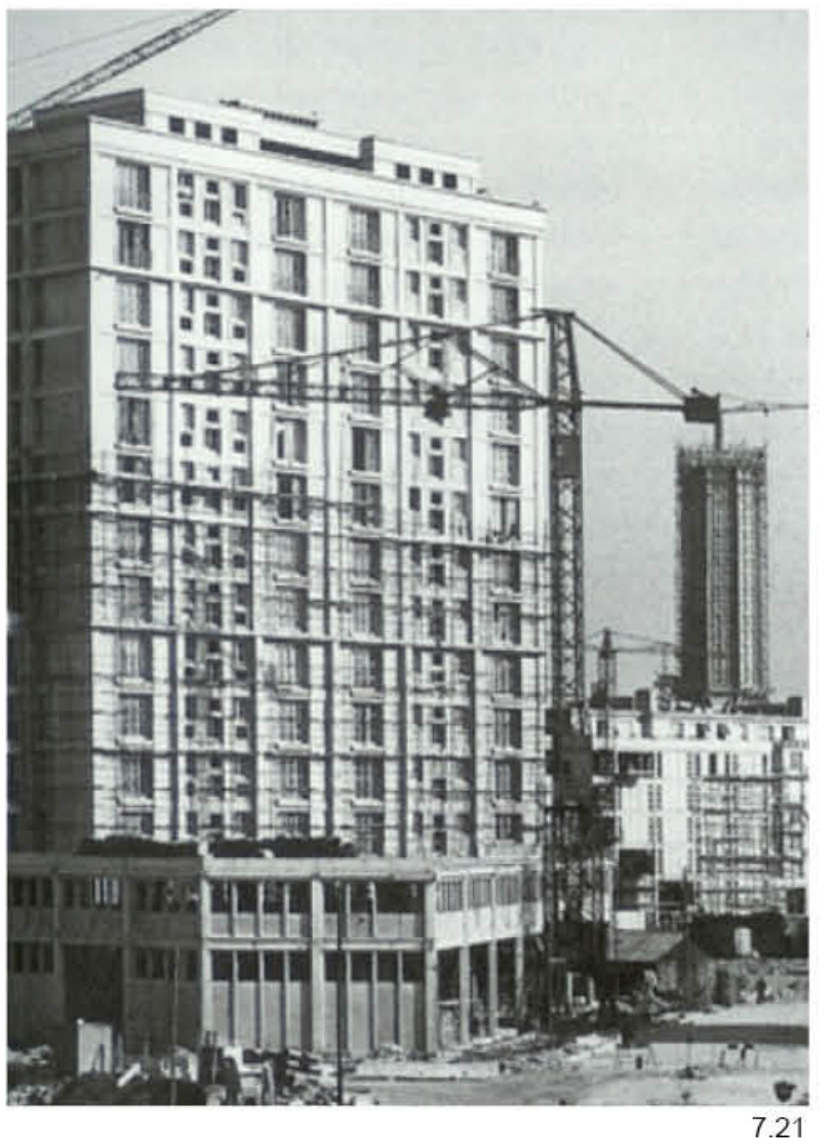

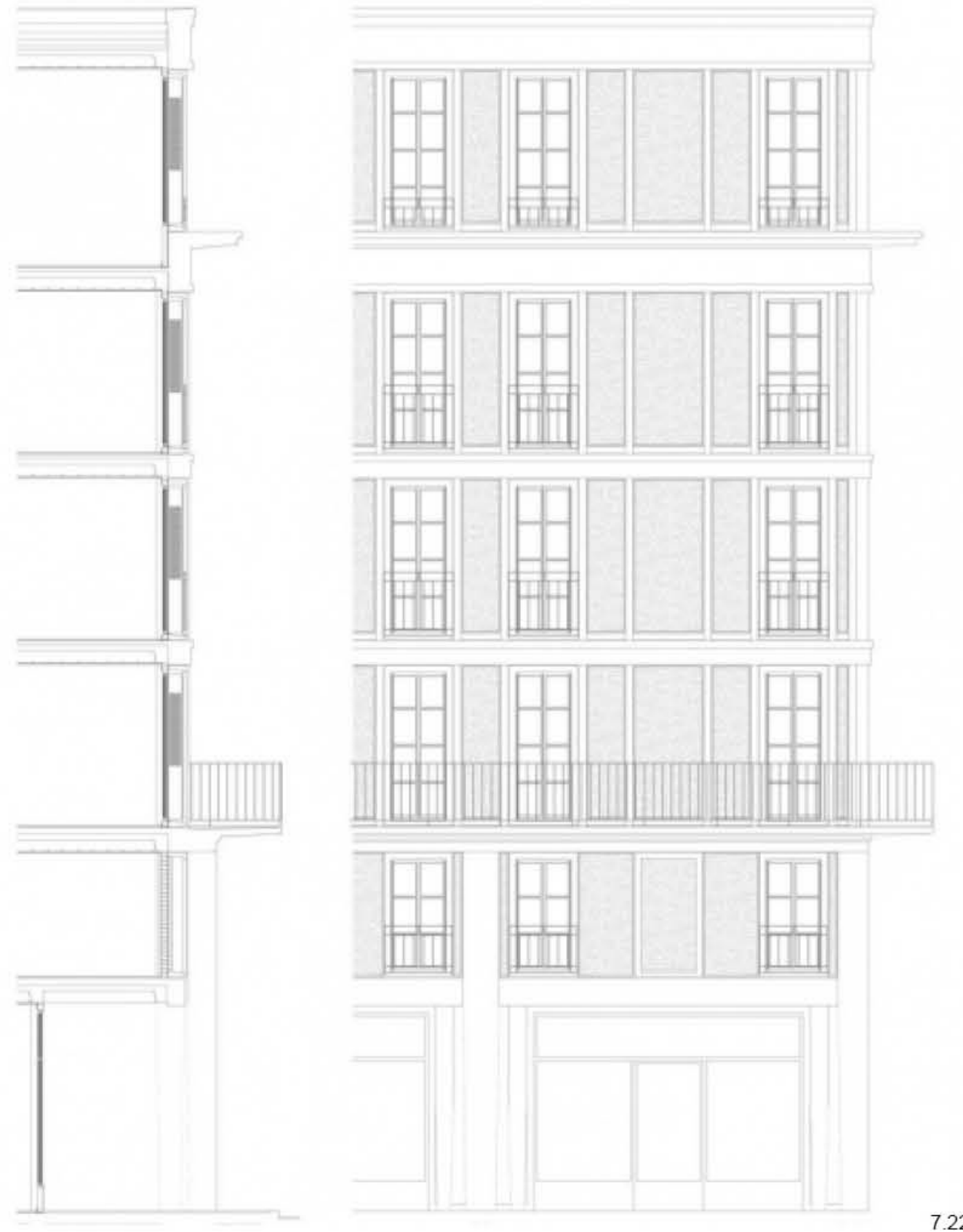


que se plantea interiormente en el punto medio de la trama, a diferencia de la intersección exterior, que se produce duplicando pilares (7.17-7.18). La estructura de hormigón armado fue calculada una vez más por Staniław Zalewski ${ }^{7.04}$ al igual que en los edificios anteriores.

El acentuado de la fachada con elementos estructurales verticales tiene referentes cercanos a Leykam en proyectos como el Edificio de Economía del Banco Nacional de Varsovia de 1928-1931 de su profesor Rudolf Świerczyński, y está en consonancia con proyectos contemporáneos de su mentor Auguste Perret, que entre 1945 y 1950 estaba encargado de la reconstrucción de la ciudad francesa de Le Havre (7.19-7.20).

En el proyecto de reconstrucción de Le Havre, Perret había encontrado una ciudad en condiciones similares a la Varsovia en los primeros años de postguerra, sometida a los bombardeos tanto del ejército nazi en 1940 como posteriormente del bando Aliado en 1944, que, con el objetivo de destruir la resistencia nazi, arrasó la ciudad entre el 5 y 6 de septiembre de 1944 mediante ataques aéreos.

Tal como explica González Cárdenas, el proyecto de la reconstrucción de la ciudad de Le Havre corresponde a un ideal propio de la época, la creación de un conjunto homogéneo en el que todos los detalles serían construidos bajo un mismo esquema creando así una especie de obra de arte total a escala urbana (Gesamtkunstwerk). ${ }^{7.07}$ Perret no solo dirigió el Taller de la Reconstrucción de la ciudad, sino que se reservó para sí mismo la concepción y construcción de algunos proyectos entre los cuales estaban los edificios públicos más importantes. ${ }^{7.07}$

El plan general para la reconstrucción de Le Havre consistió en la creación de "cerca de 200 manzanas cuadradas de 100, 50 o 20 metros de lado, de diferentes alturas organizadas según las coordenadas solares. (...) Todas las manzanas, independientemente de sus dimensiones se estructuraron a partir de un módulo de 6,24 metros de lado y para asegurar una unidad arquitectónica, los alineamientos de las fachadas y la organización del espacio urbano fueron definidos a partir de un módulo uniforme que responde al ancho óptimo del pórtico de hormigón en aquel momento. Se aplicó un módulo general divisible por 6, 8 o 12, para adaptarse a los problemas de cada uno de los inmuebles y solucionar las diferentes escalas. Este dispositivo estético ofrecía ventajas materiales al abrir la vía de la estandarización y a la experimentación de nuevas técnicas." 7.08

Perret consideraba que la armonía era un elemento partícipe de la ciudad, elemento que era visible en todos los espacios y desde todas las perspectivas: "Face à l'eau, on construira un véritable front de mer, on le découvrira du large avant de débarquer. Il incarnera la France aux yeux des étrangers, en offrira une image noble et monumentale. D'ailleurs, ce qui distinguera Le Havre, c'est une architecture qui obéira à une loi d'harmonie." 7.09

Tal como la entendía Perret, en un criterio que Leykam compartirá durante su trabajo en la reconstrucción de Polonia

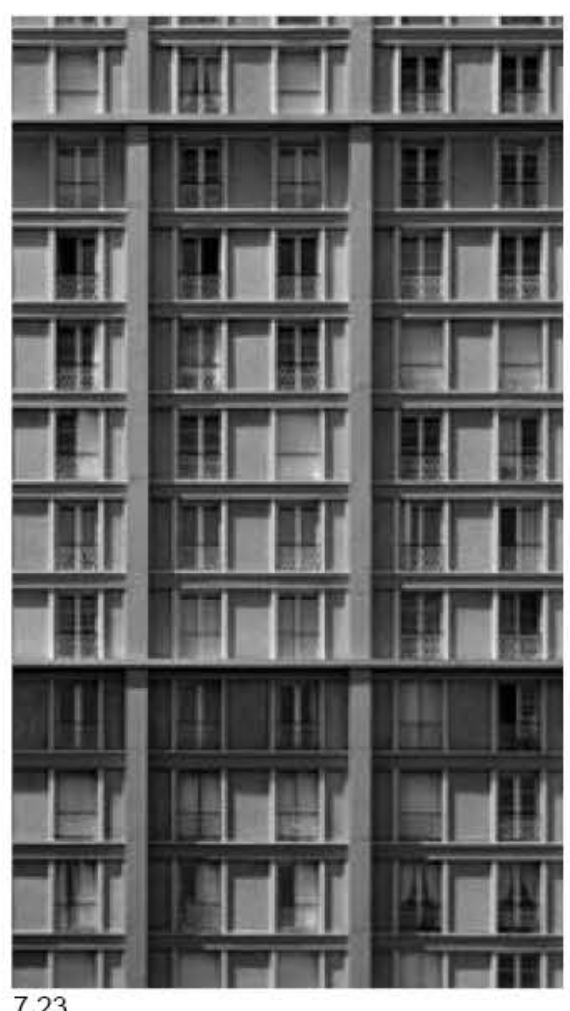

7.23

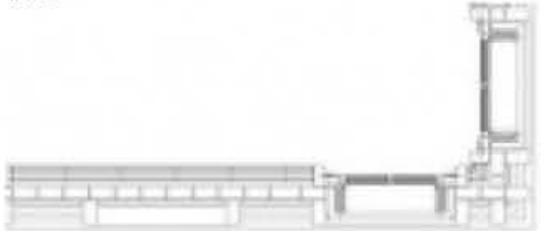

724

7.07. González Cárdenas, 2005. p. 114

7.08. Collins, 1959. Citado por 5.07

7.09. "De cara al agua, se construirá un verdadero frente hacia el mar, que se descubrirá mucho antes de desembarcar en el puerto. Este representará a Francia a los ojos extranjeros, y ofrecerá una imagen noble y monumental. Además, lo que distinguirá le Havre, será una arquitectura que obedecerá a una ley de armonia. Cohen, 2002 (Op. Cit. 7.07. p 115. 
7.25 -7.26 Oficina Central de Estudios y Proyectos de Construcción

Przemysłowego) en of St. Bárbara no1 Varsovia. Arquitectos:

Marek Leykam y Władysław Pieńkowski (1950-52).

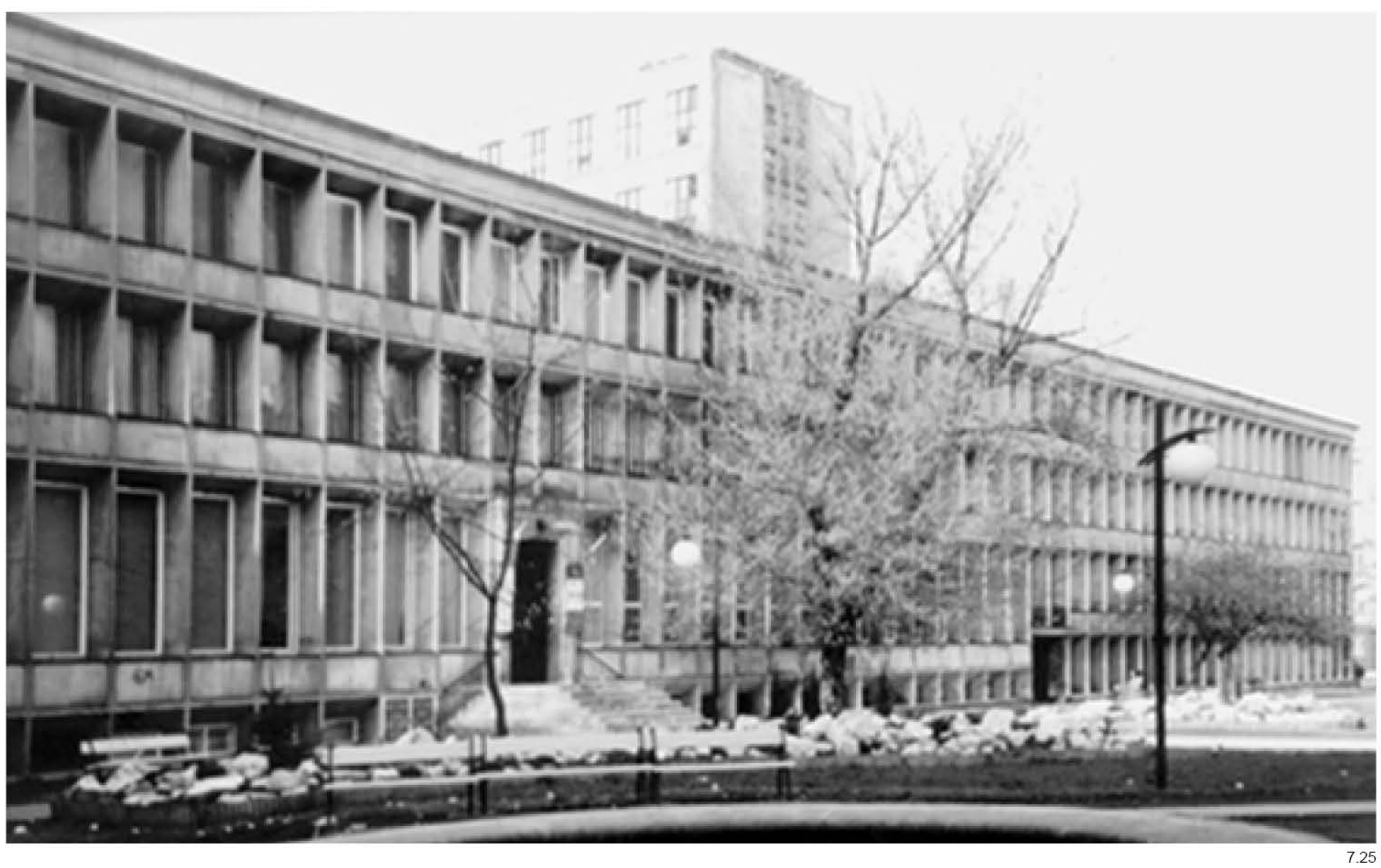


en los primeros años de postguerra: "La estructura es la que regula la ciudad, modulándola." 7.07 A pesar de aplicar una forma reticular, Perret buscaba la "construcción de una perspectiva que lo guiara"7.07 para lo cual se sirve del "manejo simultáneo de diferentes escalas de intervención." 7.07

"La particularidad de Le Havre venía del hecho de haber optado por un plan director de reconstrucción, en el que la arquitectura de la ciudad resultaba de la interpretación de una teoría de la arquitectura heredada de la Escuela de Bellas Artes, pero también de un plano base de trama ortogonal, que si bien determina las dimensiones básicas de la forma urbana, decide de paso las dimensiones mínimas al interior de la vivienda: una trama macro que define el espacio urbano, no está en contravía de la definición del elemento más pequeño al interior de la vivienda." 7.08

\subsubsection{Oficina Central de Estudios y Proyectos de Construcción Industrial de Varsovia.}

En el año 1952 Leykam terminará -en colaboración con el arquitecto Władysław Pieńkowski y de nuevo con el ingeniero de estructuras Stanilaw Zalewski- ${ }^{7.04}$ la Oficina Central de Estudios y Proyectos de Construcción Industrial ${ }^{7.10}$ en la calle Santa Bárbara ${ }^{\circ} 1$ de Varsovia.

La principal particularidad de este edificio es la flexibilidad con que Leykam maneja, después de cuatro proyectos "Żyletkowiec", un método proyectual que deriva de una expresión sistemática y coherente de la lógica constructiva. El esquema a partir del cual se resuelve este proyecto ofrece un equilibro sencillo entre los diferentes accidentes del programa que le permite optimizar todavía más los elementos prefabricados sin perder expresividad en su formalización.

El bloque de la Oficina Central de Estudios se desarrolla esta vez en 4 plantas de altura y $91 \mathrm{~m}$ de fachada a lo largo de la calle Wspólna (sur) y Santa Bárbara (norte) y enfrenta 15 metros de testero a las calle Poznańska (este) (7.25) y calle Santa Bárbara (oeste). Leykam, que ya había empezado los trabajos del edificio Okrąglak en Poznań en el que se enfrentó a la solución de un cilindro con el mismo sistema de fachada, decide no diferenciar los planos del volumen dejando sin manifestar la direccionalidad del prisma para resolver el conjunto de las fachadas mediante un sistema modular de 1,65 $\mathrm{m}$ de intereje continuo a lo largo de los 4 alzados y sin diferenciar la planta baja del resto de alturas.

El módulo esta vez cambia de tamaño y proporción pasando de la relación de 2:5 entre altura y anchura de los huecos de fachada a 1:2 (1,66 m/3,33 m), conteniendo así en este ancho el acceso principal sin alterar la trama de fachada. La altura de planta baja requiere más altura en algunos tramos, hecho que se resuelve mediante una variación en la altura de hueco de 1,33 m hasta 4,33 m dentro de la misma modulación vertical de 54 vanos continuos de 1,66 $\mathrm{m}$ a lo largo de 91 $\mathrm{m}$ de longitud (90,6 $\mathrm{m}$ a ejes). De este modo, un tercio de bloque queda resuelto con una altura de 3 plantas y un sótano de $1,33 \mathrm{~m}$ y dos tercios tienen 4 plantas.

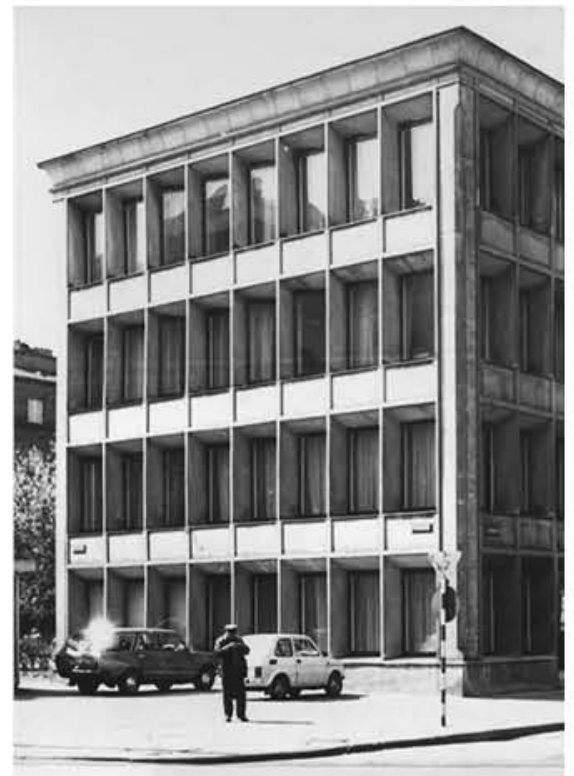

7.26

7.10. Centrala Biura Studiów i Projektów Budownictwa Przemysłowego. 
7.27 - 7.29 Fachada y detalles de la Oficina Central de Estudios y Proyectos de Construcción Industrial en c/ St. Bárbara n०1

(1950-52).

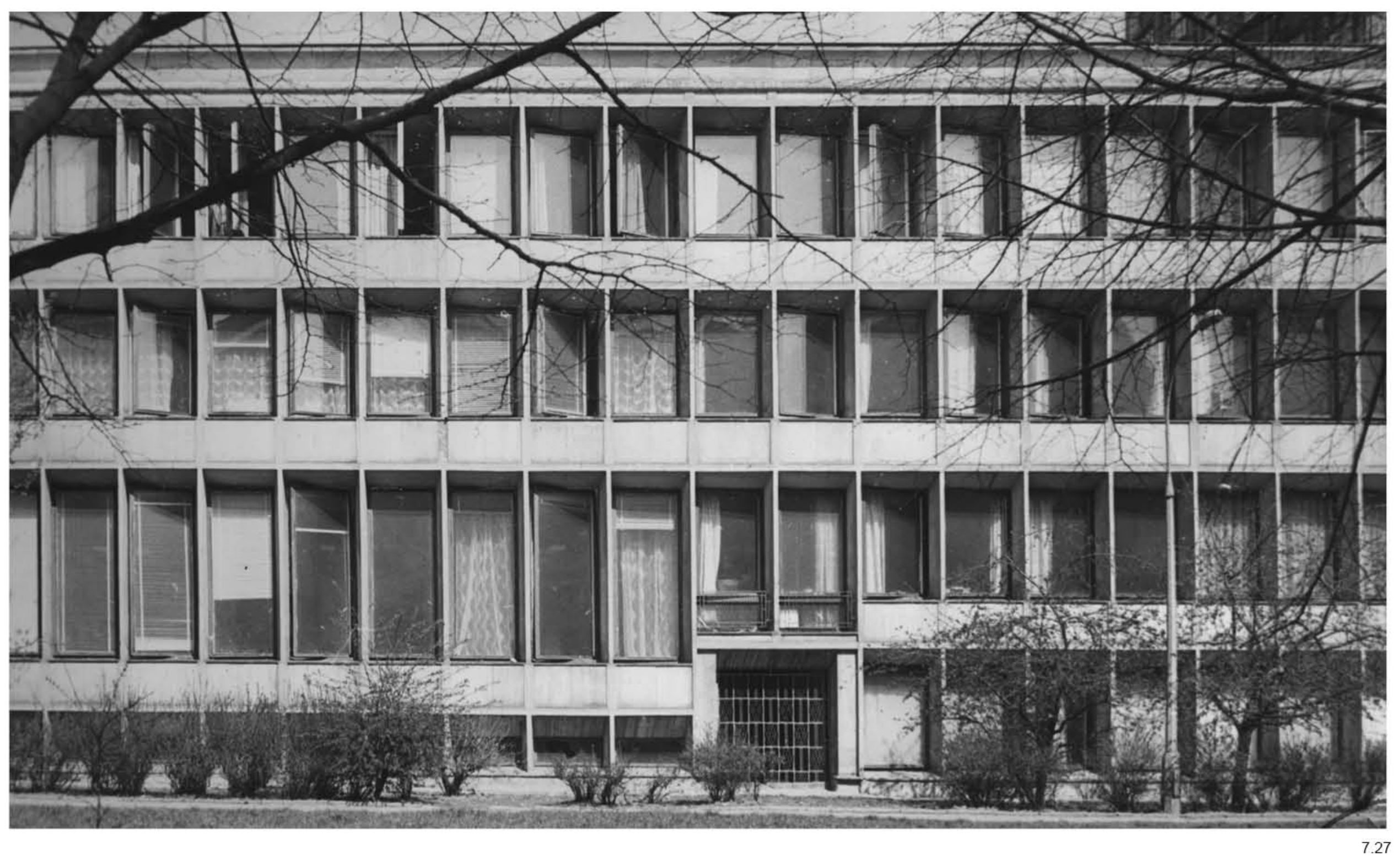



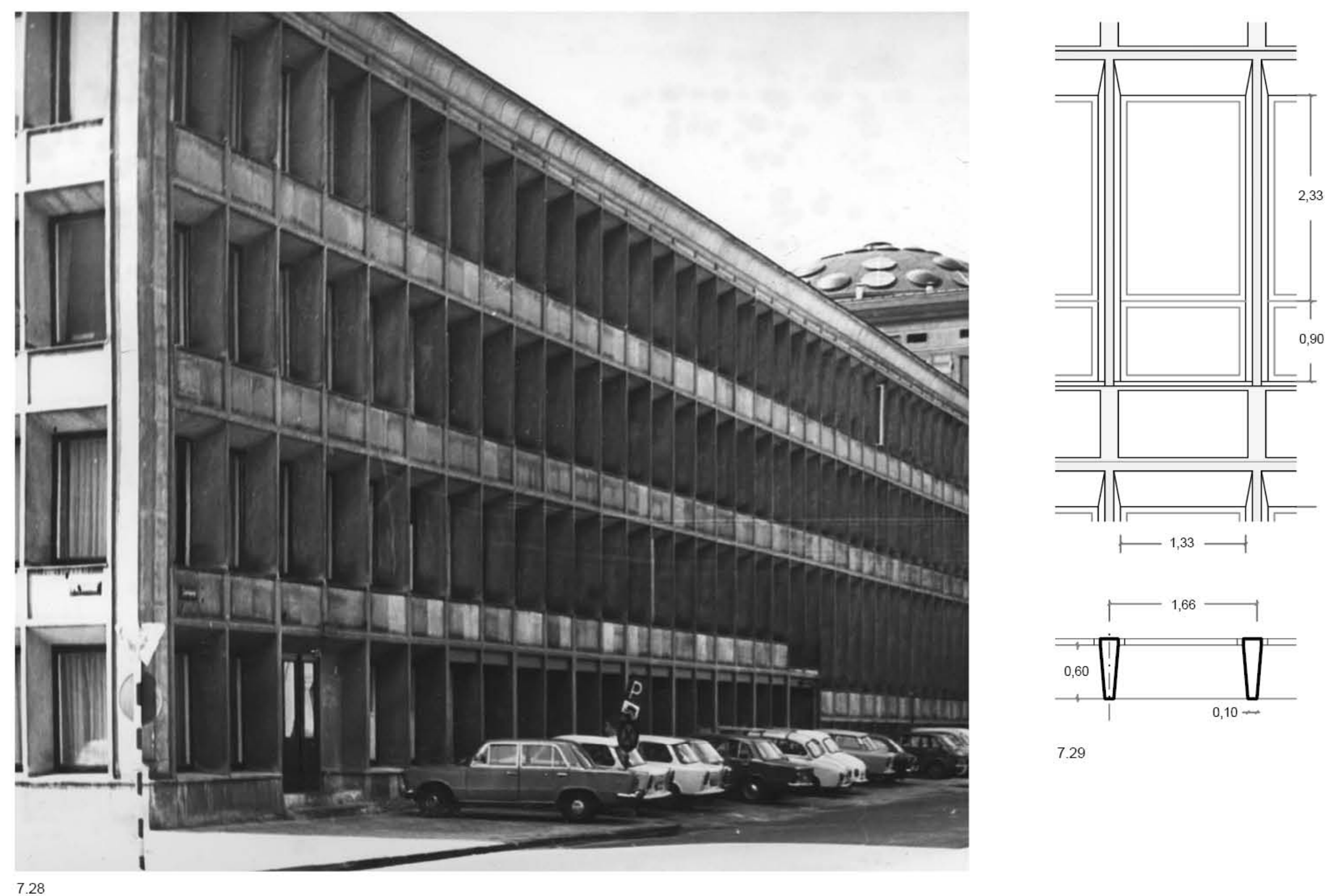

7.29 


\section{ŻYLETKOWIEC.}

\section{Localización:}

\section{Dimensiones:}

Intereje Porticos Transv.:

$\mathrm{N}^{\circ}$ vanos fachada

Tamaño de vano fachada:

Proporción vano fachada:

$\mathrm{N}^{\circ}$ vanos fachada / portico:

Tamaño de Ventana:

Profundidad de Fachada:

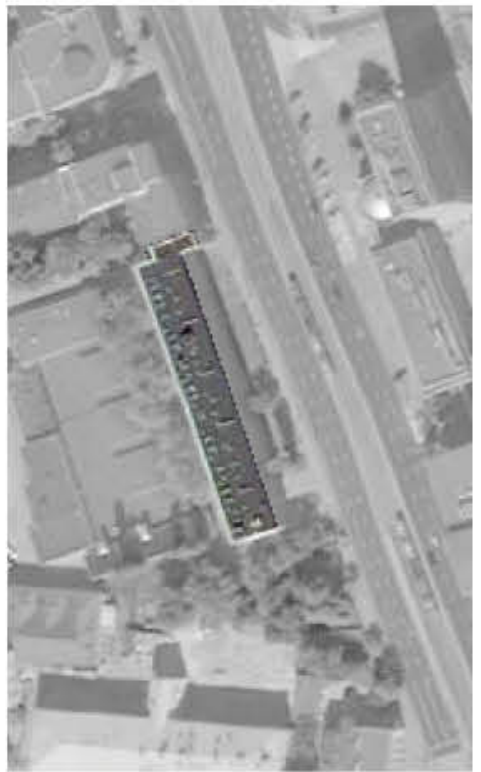

C/ Chałubińskiego 3a.

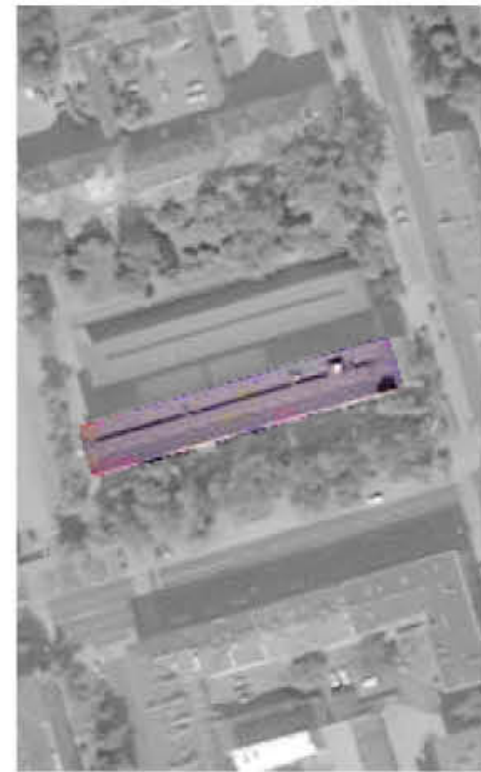

C/ Rakowiecka nº4.

$91 \times 20 \mathrm{~m}$

$533 \mathrm{~cm}$.

$72(18 \times 4)$

$133 \times 333 \mathrm{~cm}$

$1: 2,5$

$1 / 2-3-1 / 2$

$190 \times 110 \mathrm{~cm}$.

$50 \mathrm{~cm}$.

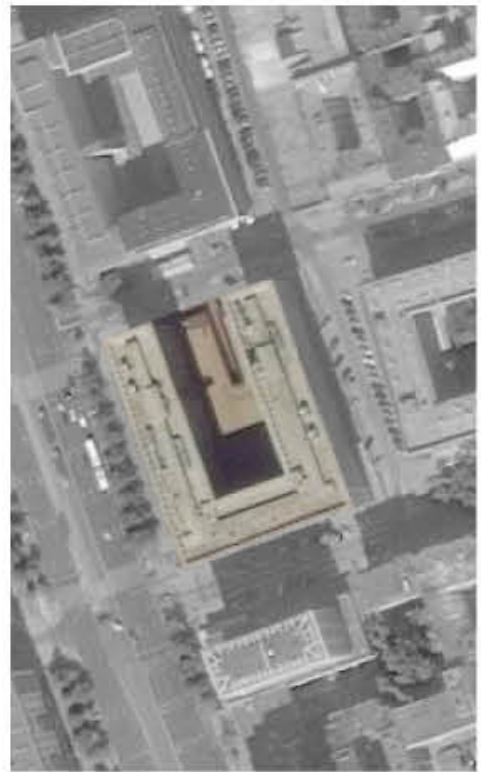

C/ Marszałkowska nº 82-84.

$81 \times 59 \mathrm{~m}$ (anch: $16 \mathrm{~m})$

$533 \mathrm{~cm}$.

$42+50+42[(21+29+21) \times 2]$

$2 \times(133 \times 333 \mathrm{~cm})$.

$2 \times(1: 2,5)$

2

$190 \times 90 \mathrm{~cm}$.

$30+30 \mathrm{~cm}$.

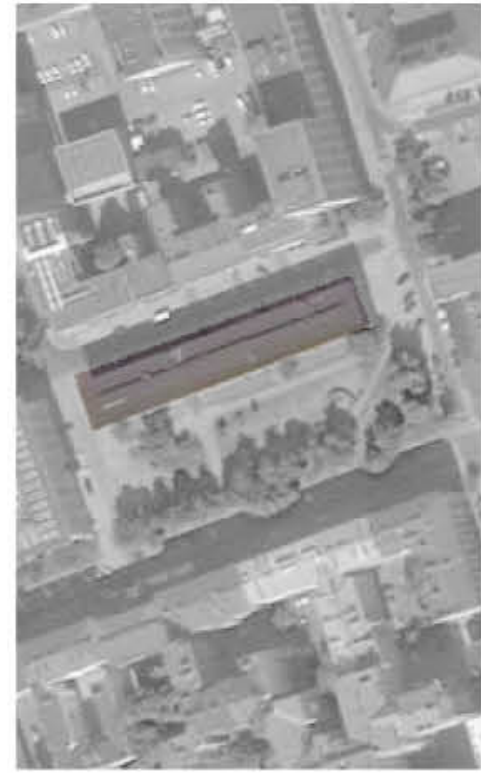

C/ Sta. Bárbara nº 1 .

$91 \times 15 \mathrm{~m}$

$500 \mathrm{~cm}$.

54

$(166 \times 333 \mathrm{~cm})+90 \mathrm{~cm}$

$1: 2$

\section{3}

$233+90 \times 133 \mathrm{~cm}$

$60 \mathrm{~cm}$. 
El ritmo de fachada es uniforme en los cuatro alzados y las divisiones horizontales tienen mayor grosor compensando la prioridad de paso de los montantes verticales y su continuidad, a diferencia de las piezas de antepecho, que se adaptan a los accidentes del proyecto como el acceso o las diferentes alturas requeridas. La cornisa queda, esta vez, insertada en la trama de módulos horizontales y es menos prominente que en los ejemplos anteriores, dando al volumen una lectura continua en fachada sin diferenciar la planta alta como solía ser habitual. La gran profundidad de las costillas y la inclinación de los cerramientos producen, de nuevo, un juego de claroscuros que aumenta la expresividad plástica de la fachada.

Una vez más, el proyecto de Leykam podía ser definido mediante fórmulas matemáticas, a través las cuales establecer las proporciones que dictan la posición todos los elementos del edificio. El propio Leykam afirmaba "la parte verificable de factores debería ser admitida como elemento de la composición siendo un resultado del cálculo matemático." 7.04

Los edificios Żyletkowiec, construidos en los mismos años y separados por pocas calles de distancia, son en realidad variaciones edificadas de un mismo proyecto, que supo adaptarse a las circunstancias y sobrevivir a las urgencias que existían en Varsovia entre 1946 y 1950 por reconstruir la capital gracias a la claridad de su planteamiento y la tenacidad de Marek Leykam y sus colaboradores en llevarlo a cabo, sin abandonar nunca la búsqueda de la expresividad a través de la lógica y el orden manifestado en la diferentes tramas del edificio, quedando el proceso relacionado de forma sencilla a través de la proporción y constituyendo, de esta forma, uno de los principios básicos de su método proyectual.

Los proyectos de Leykam establecían proporciones que podían ser controladas por relaciones numéricas simples. Esa expresión arquitectónica es consecuencia del intento de obtener un sistema proyectual que fuese capaz de singularizar los edificios a través de variaciones que optimizaran de los elementos industrializados disponibles en ese momento en el país.

Investigadores como Jur consideran los edificios Żyletkowiec de Leykam como los "primeros ejemplos en Polonia de una actitud estructural coherente que abarcaba con sus categorías todos los elementos de la obra arquitectónica." ${ }^{7.04} \mathrm{La}$ reducción del tamaño de las piezas portantes al mínimo resultante de los cálculos, la relación del módulo estructural con los elementos de cerramiento y consecuentemente con la definición de los espacios interiores y su manifestación exterior con carácter expresivo, así como su relación con la trama urbana a través de la lectura de su direccionalidad y su jerarquía son los principales indicios de una actitud que tenía como propósito optimizar la construcción incluyendo la evolución de la técnica como un futurible que permitiese a cada proyecto integrar los avances tecnológicos sin dejar de lado la economía de medios.

Las posibilidades técnicas mostraron a Leykam un camino con el que fue consecuente como ningún otro arquitecto de la época en Polonia, evitando cualquier obstáculo que supusiese una dificultad para la estandarización de las fachadas en el mínimo número de elementos, maximizando así las propiedades y otorgando verdadero sentido a la prefabricación.

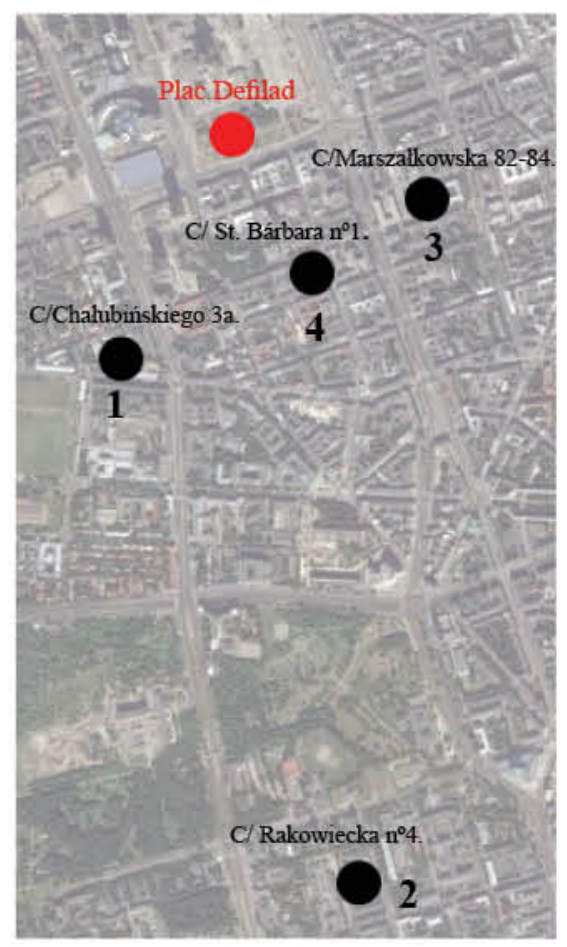


7.30 Detalles de fachada comparados de los 4

entre 1946 y 1950
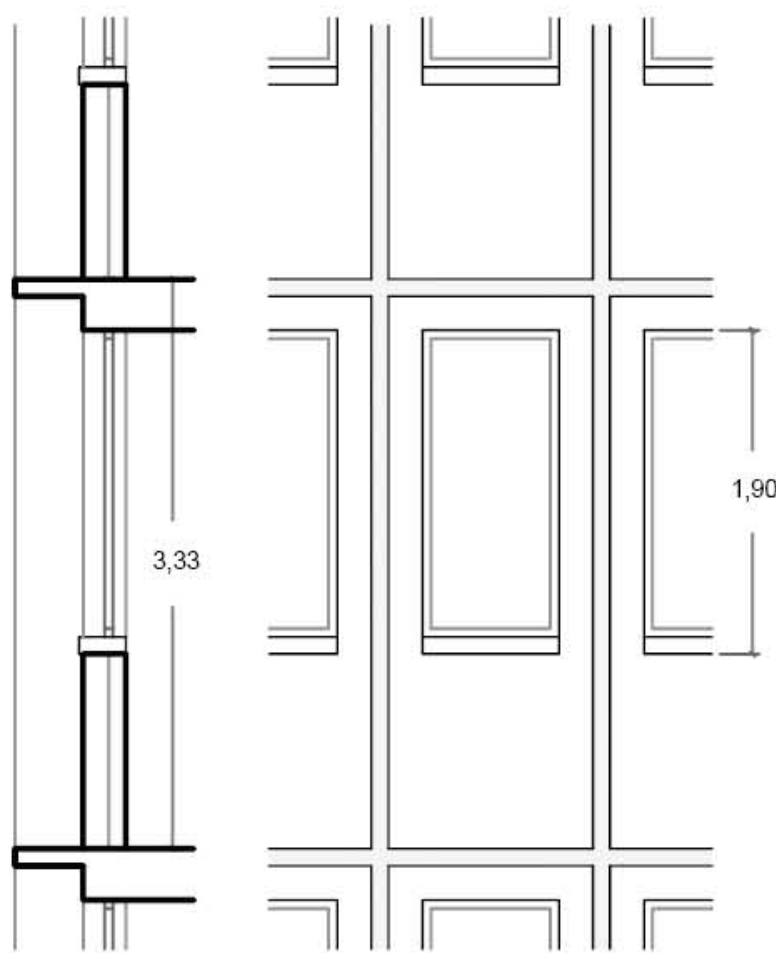

$\vdash 0,90 \dashv$

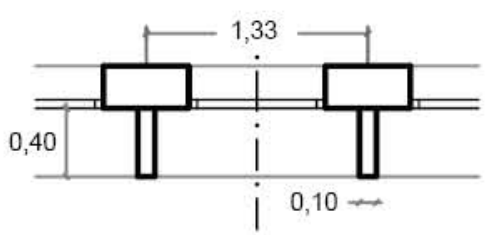

C/ Rakowiecka $n^{\circ} 4$
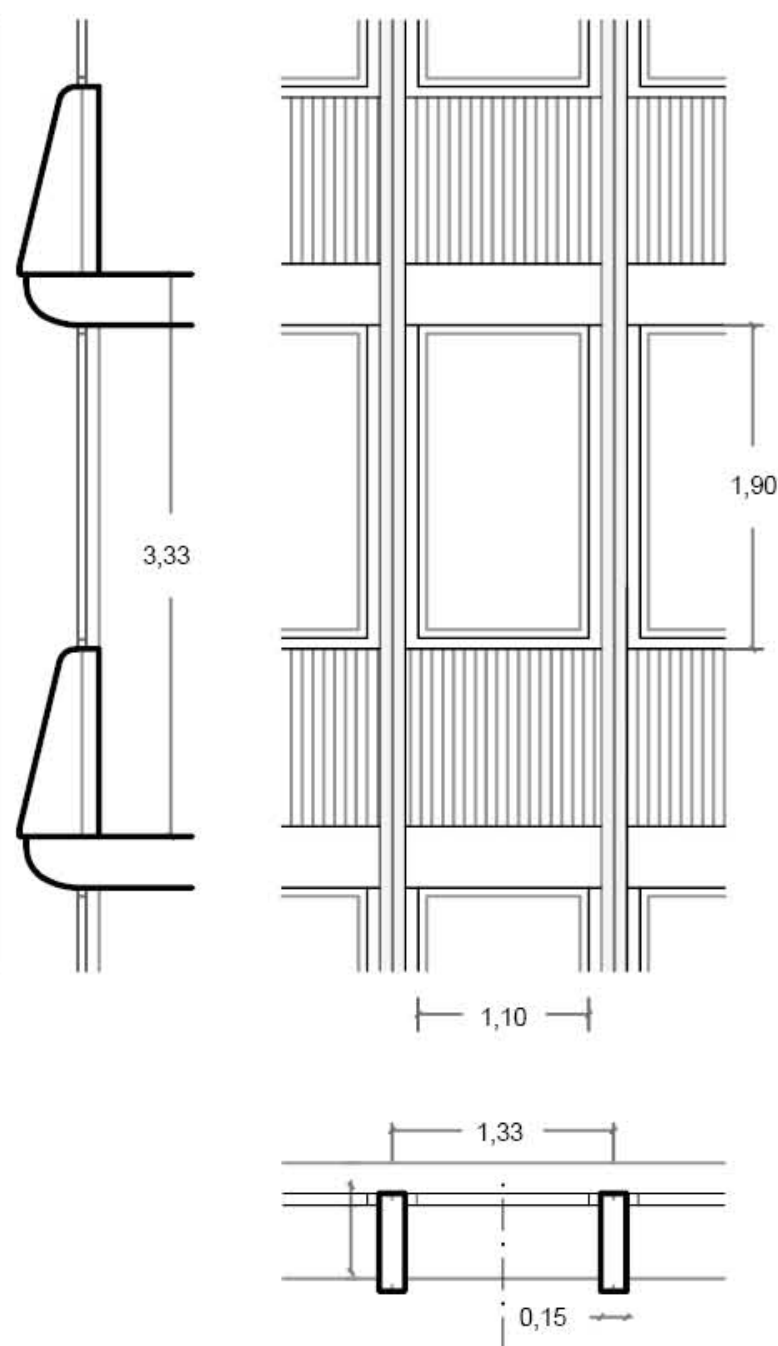

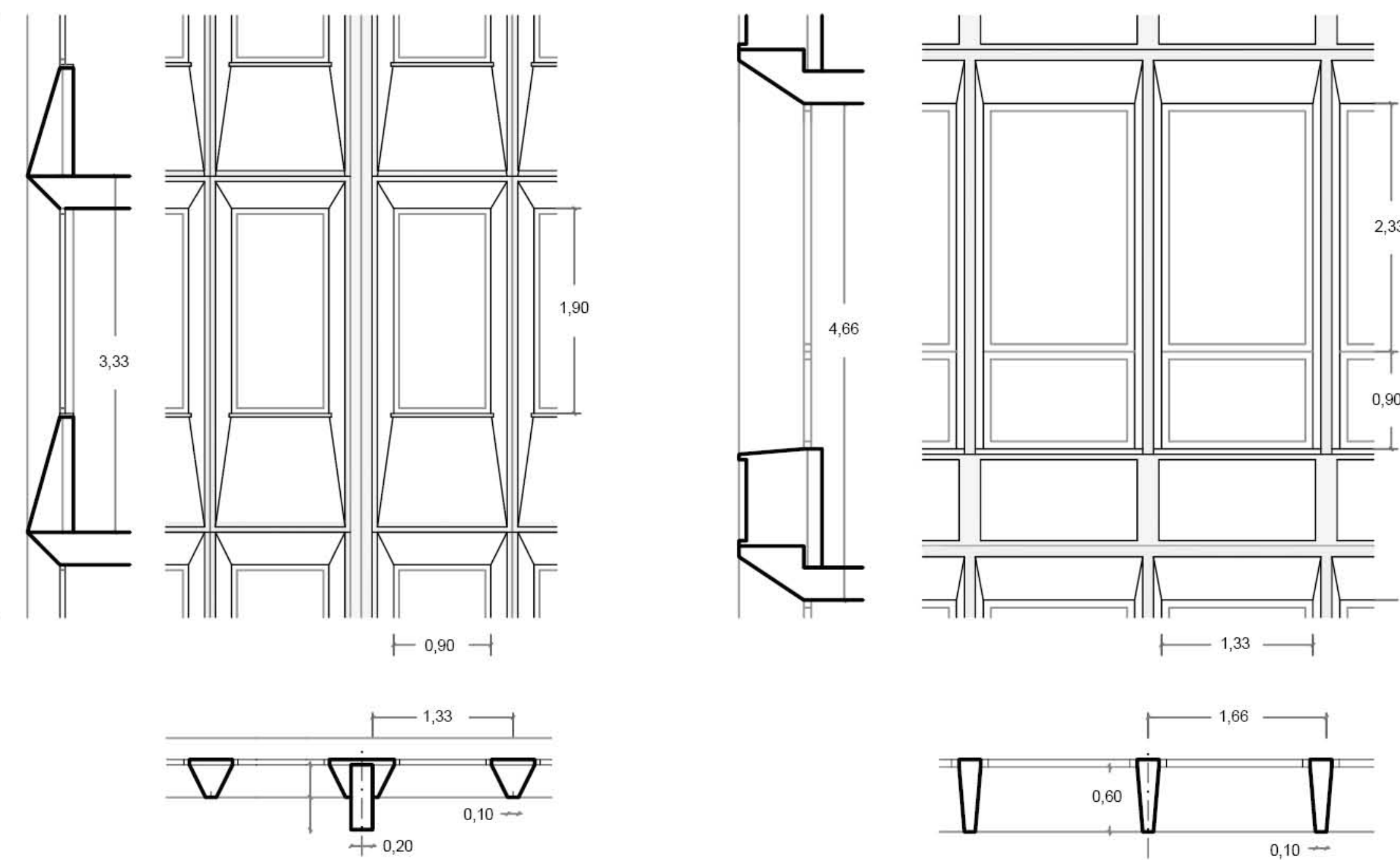
8.01 - 8.06 Páginas de la Tesis Doctoral original de Marek Ley la Escuela de Winterthur en 1943 bajo el titulo de "Arte Liturgico" ("Sztuka Liturgiczna").

8.01 Pila Bautismal románica en Berneuil (Somme).

8.02 Templete San Pietro in Montorio de Roma (1502-10). Capilla Pellegrini. Iglesia de Santa Anastasia (Verona). Iglesia Madonna di Campagna (Turín).

8.03 Iglesia de San Gregorio el Iluminador (Armenia).

8.04 Basilica de Santo Stefano Rotondo, Roma.

8.05 Policandilum bizantino.

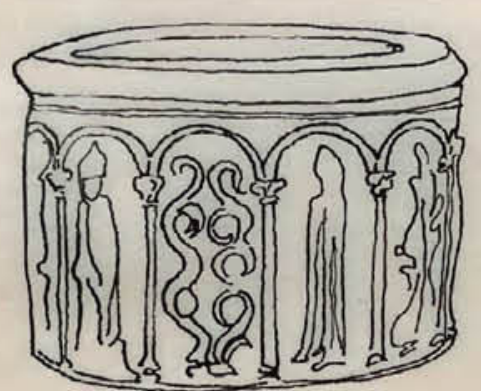

Chrcilinier kamianns * Bernenil (Somme) romaingt
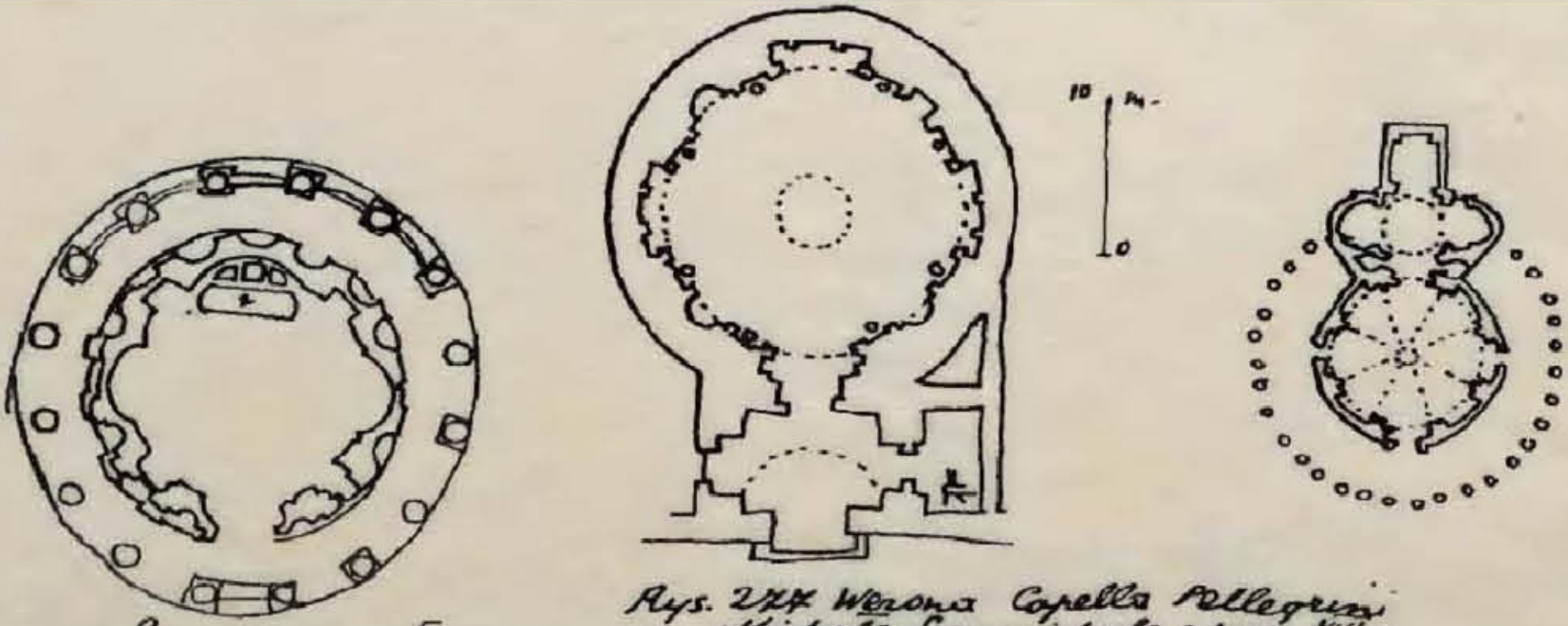

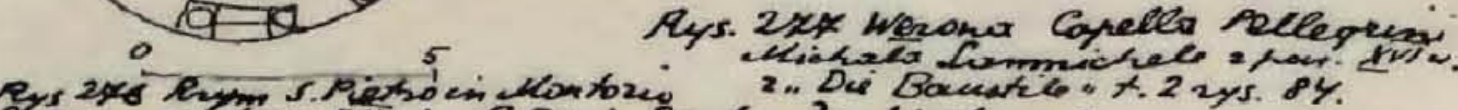

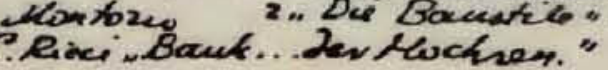

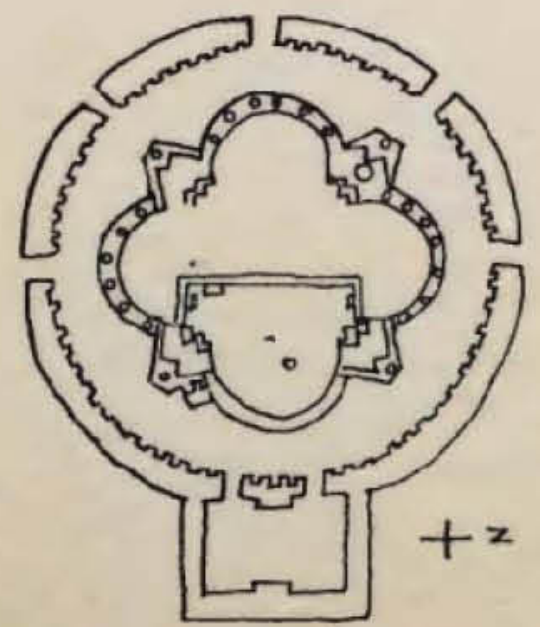

$\omega$ oudynky tym catery twlewny noorg

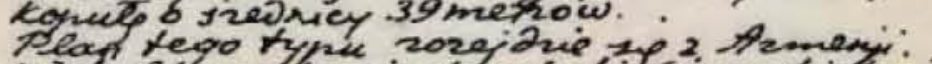

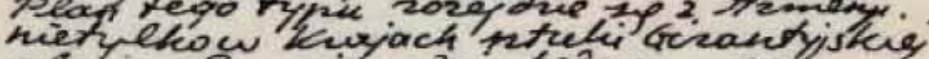

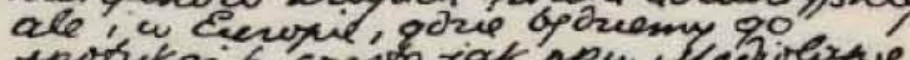

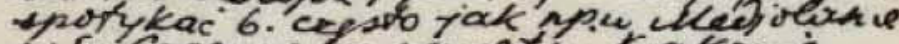

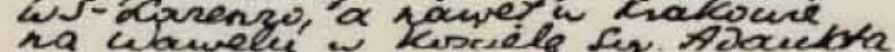
2 hace. 7 weter e) Ifughakatif mamy jedwonauarg

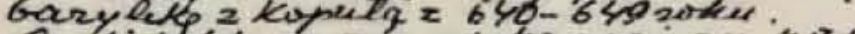
Anchitblutua amenista wagou hard-

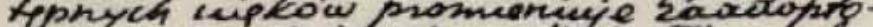

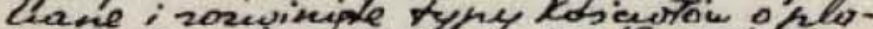

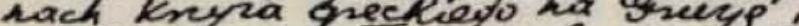

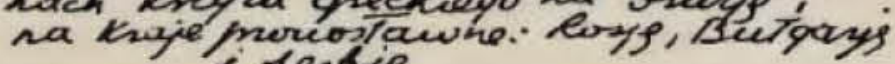

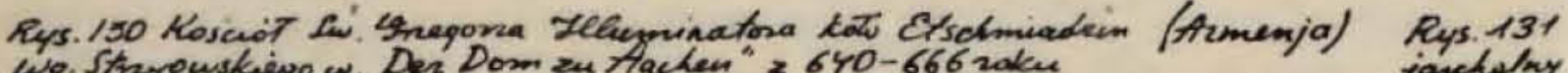


"Nuestro presente es una época diferente, inédita. Existe una composición plástica nueva, que ya no es de volúmenes, sino de espacio."

Marek Leykam. "O wnętrzu współczesnym" 8.00

Durante la redacción de su Doctorado en Zúrich en 1943, Leykam ya había planteado el propósito de no crear un obra de arte según su propio estilo sino hacer desaparecer de su obra el estilo, haciendo referencia con sus construcciones a conceptos abstractos que pudieran reducir la manifestación expresiva a las formas más simple posibles, capaces de obtener un resultado elocuente, universalmente comprensible e interpretable desde la razón. ${ }^{8.01}$

Todos los detalles, desde lo singular y lo particular hasta lo general, debían desaparecer en la obra de Leykam para que el destinatario de su arquitectura estuviese dominado por aquello que fuese necesario, no solo para él, sino para todos los seres humanos que pudieran entrar en contacto con su trabajo, y para todos los tiempos.

Tras un análisis de los Żyletkowiec de Varsovia, se puede reconocer ya el intento de Leykam de mantener un método proyectual coherente en todos sus edificios, que fuera capaz de aportar expresividad e individualidad a las soluciones, únicamente mediante la generación de variaciones que no dejasen de reconocerse como singularidades dentro de un hilo conductor, a través del cual fuera posible reconstruir una idea común de arquitectura, y mediante su definición, un proceso proyectual coherente que organizase las soluciones desde un punto de vista consecuente y racional.
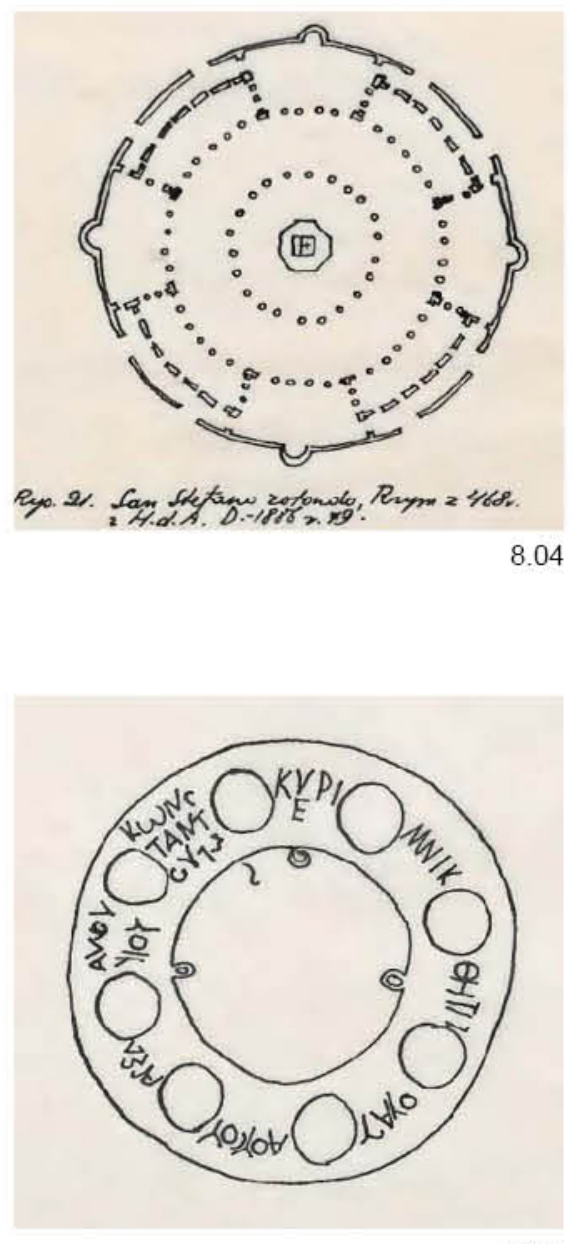

8.05

8.00. Artículo "O wnętrzu współczesnym" (El interior contemporáneo). Publicado en la revista Arkady $1936, n^{0} 7$ p. $375-377$

8.01. Leykam, 1943. 
8.06 Baptisterio de Nocera.

8.07 Iglesia de Nisse en Anatolia.

Binbirkilisse Kara Dagh.
Iglesia en Gerasa (Jerash) Palestina. Derbe de Salacia.

Thaura (Cilicia)

8.08 Iglesia della Madonna di Campagna, Verona.

8.09 Baptisterio de Pisa (1152-1363).

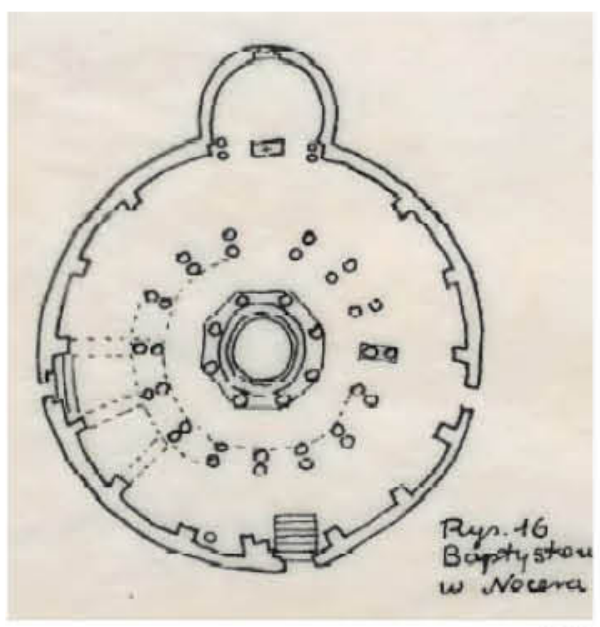

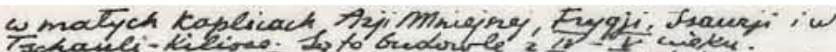

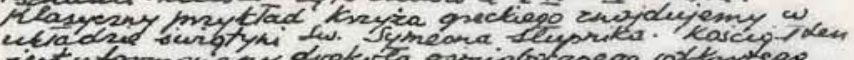

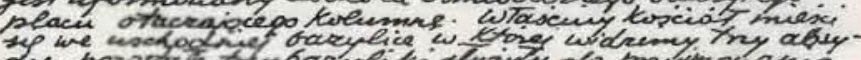
eiennych pielonymoz.

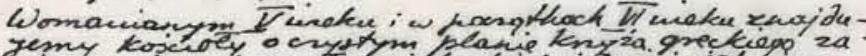

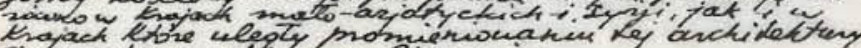
e medeunysteien \& Bizanquin.

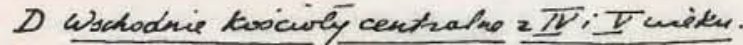

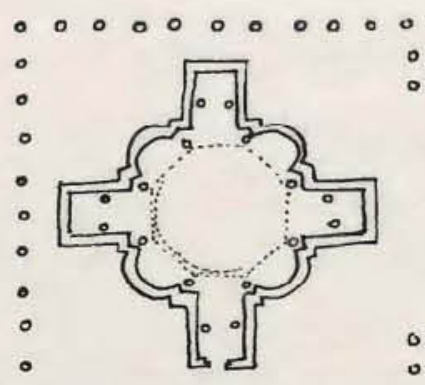

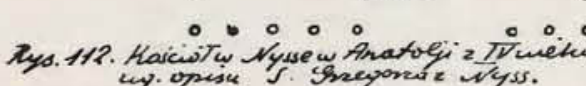

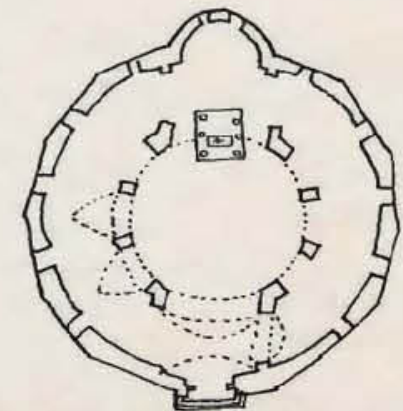

Rys. 114 Binovitalive

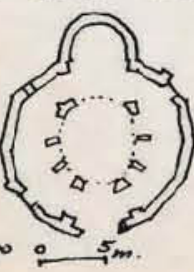

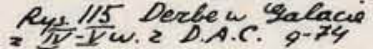

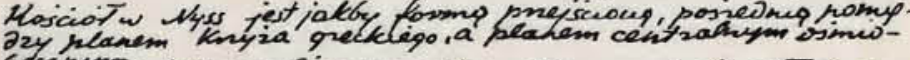

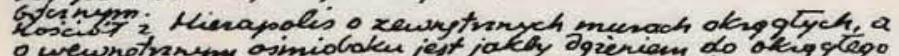

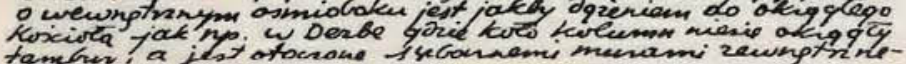

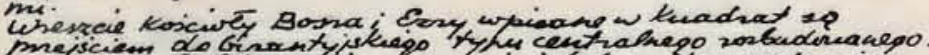

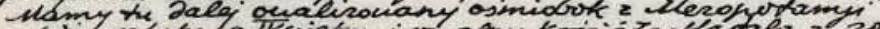

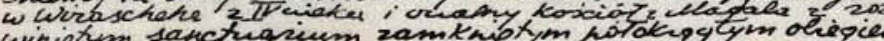
siciden.

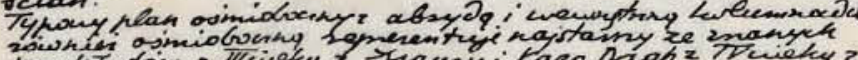

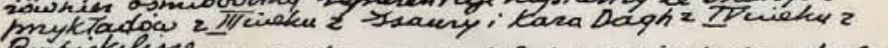

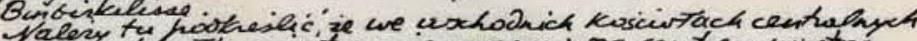

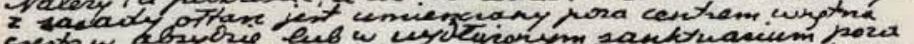

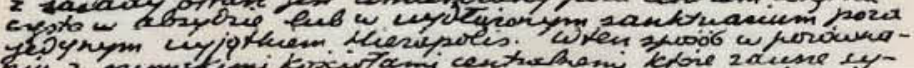

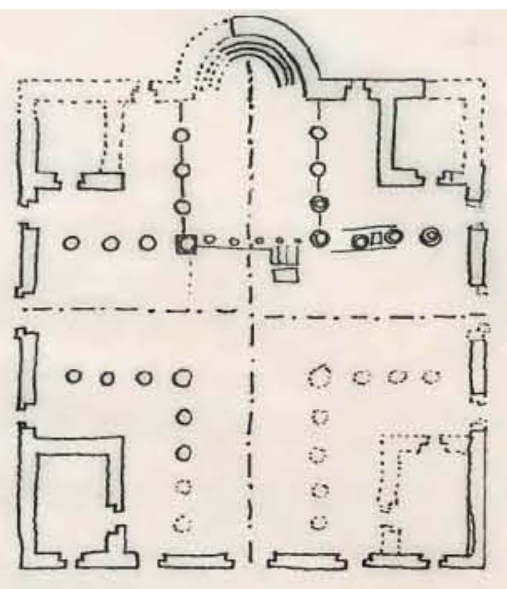

$00000^{2} 00000$ Rys. 11 Serasa, Paleoty

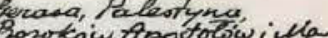
ung.w. Orow foot D.A.C. p-9521.

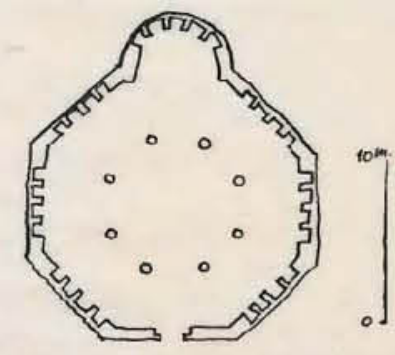

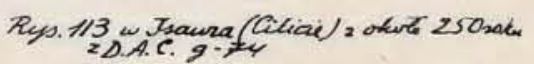

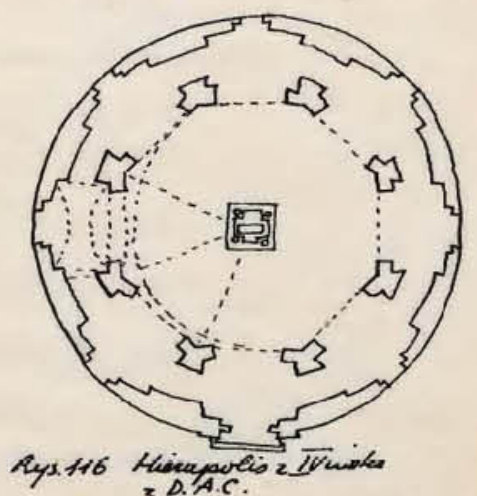


En 1948 Leykam recibió un encargo que le obligó, sin embargo, a depurar el método de trabajo que estaba desarrollando mientras construía los Żyletkowiec adaptándolo a nuevos condicionantes, para lo cual tuvo que hacerlo confluir con las conclusiones a las que había llegado tras los análisis de las obras de arte litúrgico planteadas en su Doctorado (8.01 8.07), conjuntamente con la experiencia teórica y práctica que le habían aportado las colaboraciones con sus maestros, principalmente Perret, Salvisberg y Świerczyński.

Esta confluencia fue llevada al extremo en esta obra, debido a que Leykam supo reaccionar ante la evidencia de que la lógica racional, a partir de la cual estaba estructurando sus decisiones proyectuales en los bloques varsovianos, no era capaz de responder a un contexto como el de Poznań, en el que era necesario establecer un diálogo con la historia sin abandonar la relación con la trama y con el pasado del lugar. A diferencia de lo que ocurría en Varsovia, en la ciudad de Poznań la destrucción había sido menor y la trama urbana preexistente no había sido puesta en duda por los nuevos planes urbanísticos desarrollados, si bien muchos de los condicionantes por los cuales había sido generado su trazado, respondían a un momento histórico que había quedado descontextualizado con la destrucción de varios edificios y espacios significativos de la ciudad.

El centro comercial Dom Towarowy estaba destinado a emplazarse en la intersección de las calles Mielżyńskiego y 27 Grudnia de Poznań, formando parte de un solar cuya geometría era compleja como resultado de su ubicación junto a un complejo cruce calles en el que también confluían los tramos finales de las travesías Fredry y Gwarna, dando lugar a un vacío urbano trapezoidal frente a su fachada principal que todavía hoy se encuentra resuelto sin una clara jerarquía de paso a nivel viario.

En 1921, en el solar del proyecto se situaba la sede principal del Banco Azucarero ${ }^{8.02}$ (8.10), uno de los muchos bancos surgidos en Polonia tras la independencia del país, en este caso actuando en colaboración con el cártel de fabricantes de azúcar. Durante la II Guerra Mundial el edificio fue destruido, y el Banco al completo renunció a la licencia y se disolvió completamente en $1946,{ }^{8.03}$ por lo que la ciudad se planteó construir en este solar un centro comercial debido a su cercanía al centro y su importante localización estratégica como nexo de unión entre la Ciudad Vieja y el nuevo ensanche de Poznań. Aunque las opiniones resultaban contradictorias sobre el grado de destrucción del edificio existente y la posibilidad de conservarlo, finalmente se tomó la decisión de demolerlo y se solicitó a Leykam -quien en 1948 había adquirido ya una cierta fama en Polonia por el desarrollo de estructuras prefabricadas de fachada-, un proyecto en el lugar a través de un encargo directo en el que no medió concurso. ${ }^{8.04}$

Durante los primeros años de postguerra se había llevado a cabo una reconstrucción mimética de los edificios cercanos a la plaza central de Poznań, con el argumento de recuperar las imágenes que muchos habitantes tenían en la mente de los edificios anteriores a la guerra asociados a un tiempo de paz y prosperidad, sin embargo este solar estaba llamado

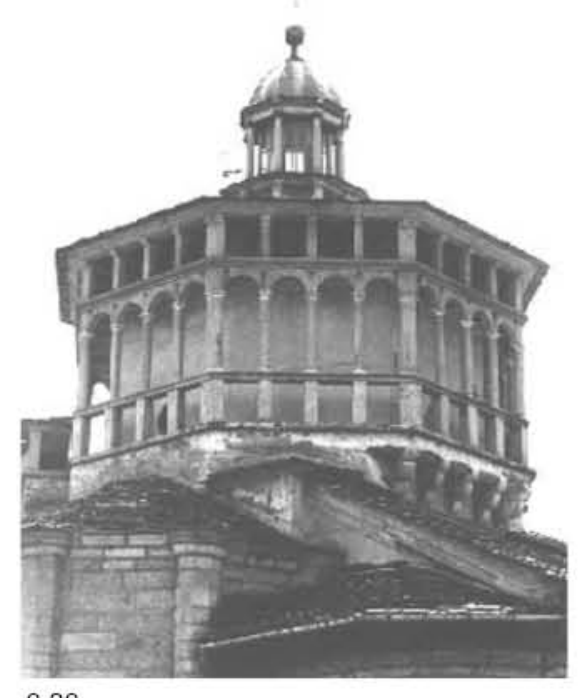

8.08

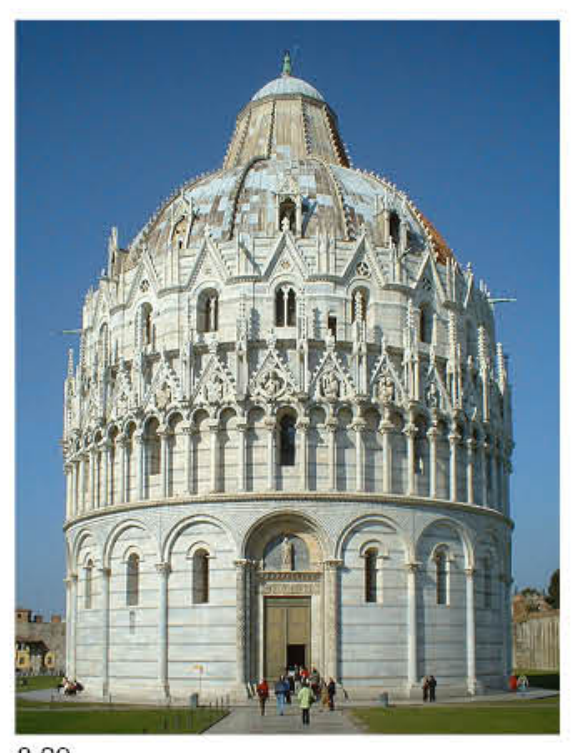

8.09

8.02. Bank Cukrownictwa w Poznaniu

8.03. Fuente: muzeum.waw.pl

8.04. Jur, 1977. p $45-57$. 
8.10 Edificio del Banco Azucarero (Bank Cukrownictwa) de Poznań (1921-1945) en el solar del futuro Dom Towarowy Okraglak.

8.11 Primera version del Edificio comercial (Dom Towarowy) Okragglak presentada por Marek Leykan 8.12 Torre Górnoślaska de Poznań (1911). Arquitecto: Hans Poelzig.

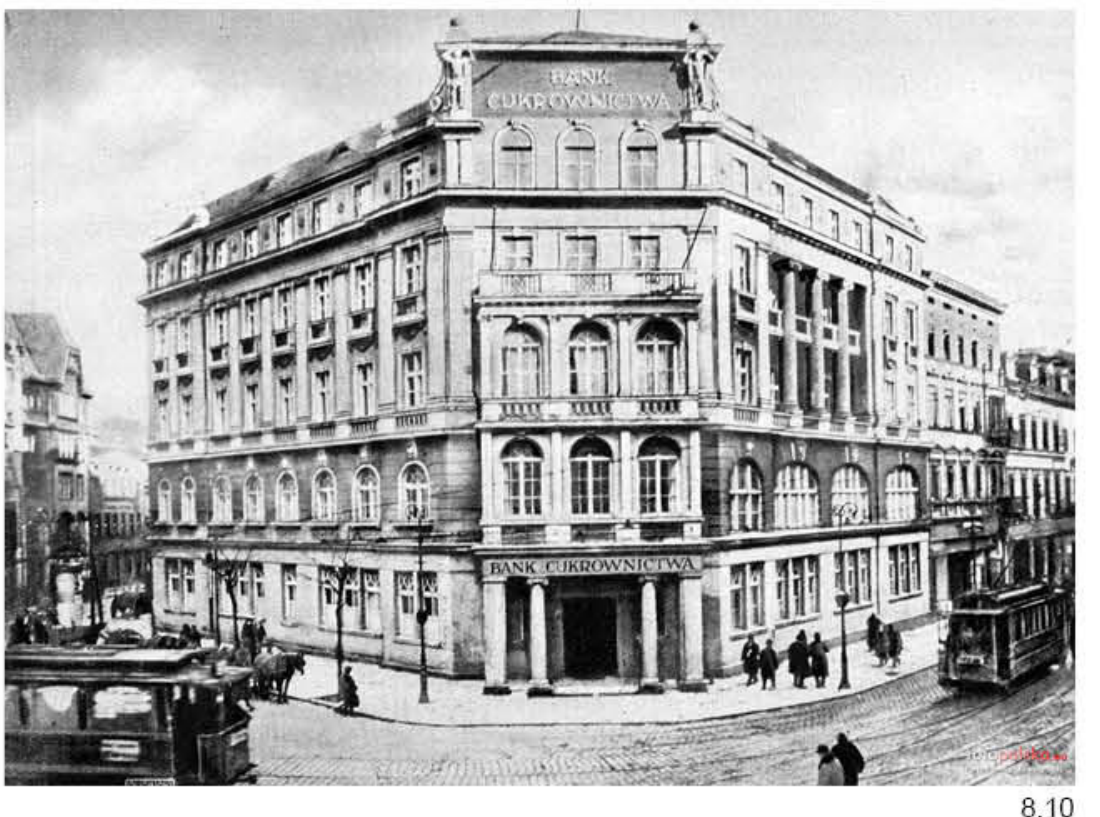

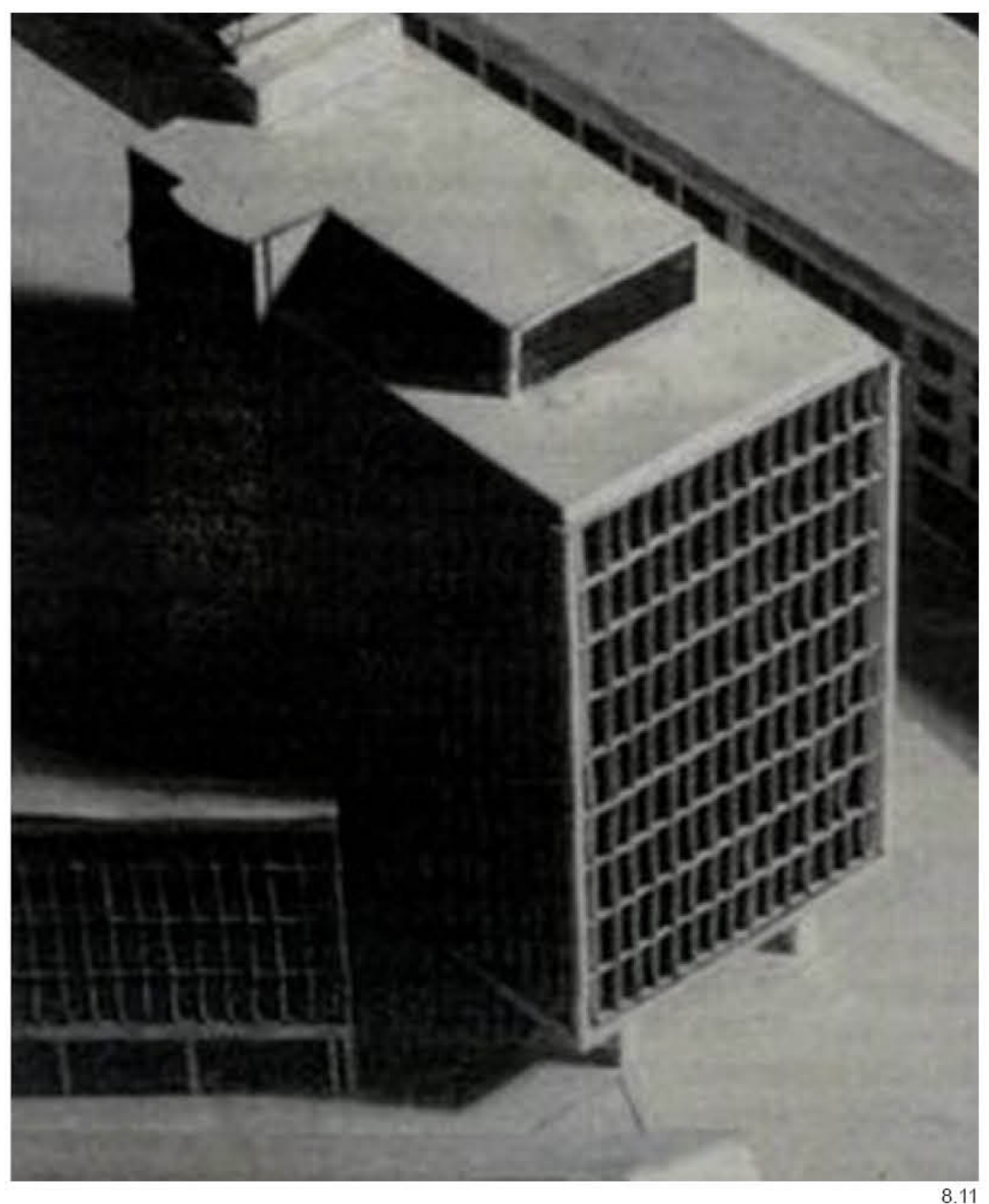


a constituir un punto de encuentro nuevo de la ciudad sin una conexión necesariamente tan literal que diera paso a un barrio que recuperase una imagen renovada y moderna de Poznań, situado entre la ciudad vieja (Stary Rynek) y el área universitaria hasta el ámbito delimitado por las vías del tren.

En un primer momento Leykam presentó una solución (8.11) ${ }^{8.05}$ que trataba de resolver la compleja confluencia de direcciones en la trama urbana tejida frente al solar ubicando dos prismas rectangulares alineados con las dos calles tangentes a la parcela, Mielżyńskiego y 27 Grudnia. El volumen sur, alineado con la calle 27 Grudnia, constaba de nueve plantas además de una altura adicional retranqueada en cubierta, mientras que el volumen norte, alineado con la calle Mielżyńskiego se resolvía en tres alturas. Ambas piezas quedaban elevadas una planta sobre el nivel del suelo generando un retranqueo que permitía el acceso cubierto desde la calle a través de una galería continua que relacionaba a la vez ambos volúmenes desde la escala peatonal.

Con una modulación constante de 15 columnas y 9 filas, Leykam resolvió la fachada de un bloque sur -que estaba encaminado a dar una respuesta al complejo cruce de calles situado frente al solar-, mientras se decantó por dar mayor importancia a la dirección perpendicular a la 27 Grudnia en detrimento de la calle Mielżyńskiego -cuya jerarquía en la composición del cruce quedaba atenuada por la situación de un bloque de tres plantas en el extremo norte de la intersección-, y se limitó a extender el testero con el que los edificios de esta calle acometían al solar.

La relación entre estos dos bloques venía dada por una proporción constante en su modulación y en sus soluciones de fachada, tal como venía siendo habitual en la obra de Leykam, pero cuando trató de definir el contraste direccional de cada uno de estos volúmenes, ambos entraron en conflicto por la complicada intersección a la que tenían que responder. En el bloque norte, Leykam tuvo clara la necesidad de establecer un contraste radical que resolviese con la mayor permeabilidad posible el plano de fachada abierto a la calle Mielżyńskiego, mientras el plano testero del bloque quedaba cegado dirigiendo su fachada hacia el interior del cruce. En el bloque sur, la solución de cegar el extremo corto dejando una fachada opaca en dirección al interior del hueco dejaba patente, sin embargo, la falta de integración de la pieza en la trama urbana general.

Leykam -que en aquellos momentos había decidido hacer permeables y resolver con el mismo tratamiento todas las fachadas de un bloque, independientemente de su dirección en el edificio de la calle Santa Barbara de Varsovia (8.25)-, consideró por segunda vez en este proyecto que no existía problema en solucionar mediante un tratamiento permeable todos los planos de fachada independientemente de su dirección, pero la presencia de dos piezas dentro de la parcela le hizo replantearse este criterio de nuevo y modificar su solución, ya que la decisión de dotar de permeabilidad indistintamente a todas las fachadas del bloque sur no solo implicaba diferenciarlo del bloque norte, sino que, al mismo tiempo, evitaba que se pudieran desarrollar las mismas condiciones de visibilidad en los espacios interiores de ambos bloques, lo cual era otro de los axiomas del método proyectual de Marek Leykam, como hemos visto en el capítulo anterior.

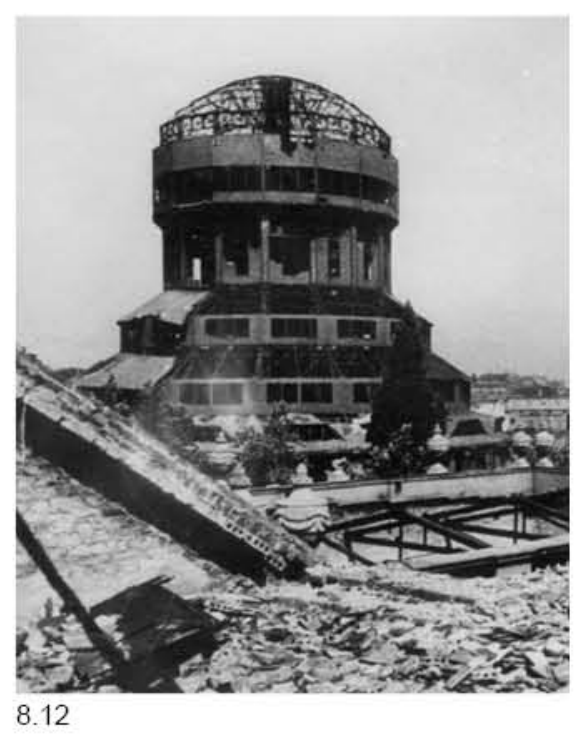

8.05. Fuente: Archiwum/Elżbieta Podolska. Articulo publicado en Głos Wielkopolski. 19/04/11 
8.13 Marek Leykam (centro) junto al equipo de Okraglak (1948-54).

8.14 Obra del edificio Okraglak (1948-54).

8.15 - 8.16 Edificio comercial (Dom Towarowy)
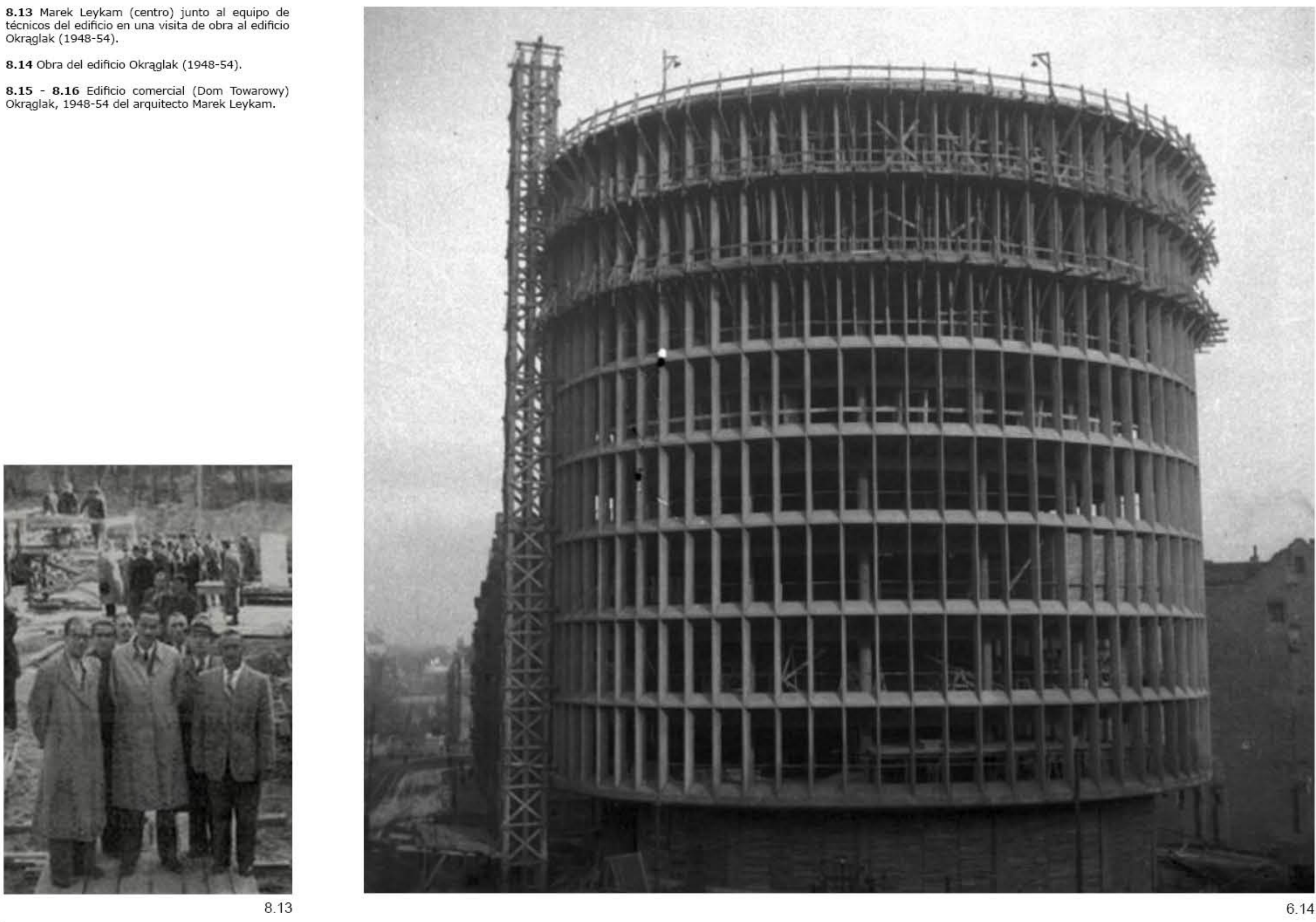
Las plantas más bajas del bloque de 9 alturas interrumpían las perspectivas visuales por la cercana presencia del bloque de 3 alturas, mientras las plantas más altas quedaban liberadas dejando en entredicho la premisa de generar, a través de la arquitectura, espacios que no solo eliminasen las singularidades, sino que lograsen -en la medida de lo posible- una relación en igualdad de condiciones con el contexto que les rodeaba.

La muestra de que Leykam se encontraba ya disconforme con esta solución, queda patente al observar las fotos de la maqueta que han trascendido hasta nuestros días (8.11), en las que una fuerte sombra cae sobre el punto más complejo del proyecto ocultando el conflicto que provocaba la difícil decisión de permeabilizar o no la fachada norte del volumen sur, alineado con la calle 27 Grudnia.

Tras la presentación de esta maqueta, Leykam convino que los condicionantes del proyecto le estaban obligando a tomar una serie de decisiones de carácter arbitrario que no estaban siendo determinadas por la lógica racional ni la adecuada lectura de la trama urbana del lugar, y decidió replantearse de nuevo la solución con otro proyecto a pesar del volumen de trabajo que estaba afrontando en esos momentos su oficina.

La importante influencia de las iglesias bizantinas que Leykam había dibujado en su tesis doctoral, como la iglesia de Nisse en Anatolia, Binbirkilisse en Kara Dagh, Jerash en Palestina, Derbe de Salacia, Tsaura en Cilicia, la Iglesia de Hierápolis siglo IV, etc... (8.01-8.06) sumado al exhaustivo análisis y conocimiento de obras como el Tempiete de San Pietro in Montorio de Bramante, la Iglesia della Madonna di Campagna en Verona (8.08) o el Baptisterio de Pisa (8.09) condujeron a Leykam a liberar su propuesta de la forma tras llegar a los conclusión de que no era necesariamente el prisma rectangular la mejor solución para optimizar el aprovechamiento de los espacios construidos en este caso.

Surgió así la posibilidad de situar una figura cilíndrica, a través de la cual no solo era posible optimizar las condiciones de uso de los espacios interiores, sino que existía la gran ventaja de no tener que definir la direccionalidad de los planos, puesto que a nivel conceptual, la geometría del cilindro implicaba el desarrollo de un número infinito de planos en su generatriz y en su formalización intervendrían tantos segmentos como fuesen necesarios para la reconstrucción real del imaginario plano curvo.

Tal como había estudiado y dibujado en sus bocetos, en multitud de ejemplos a lo largo de la historia de la arquitectura había sido contrastado el hecho de que la distribución de las estancias en el interior de un edificio con forma cilíndrica era perfectamente capaz de maximizar el aprovechamiento de los espacios interiores, siempre que la trama que ordenase el edificio fuese radial.

Cabe señalar, asimismo, que en aquellos momentos existía en la ciudad de Poznań un importante debate público en torno al futuro del edificio más representativo de la ciudad, la Torre Górnośląska (6.12) construida por Hans Poelzig en 1911 y que había sido parcialmente destruida durante los últimos combates de la II Guerra Mundial. ${ }^{8.06}$ Esta coincidencia

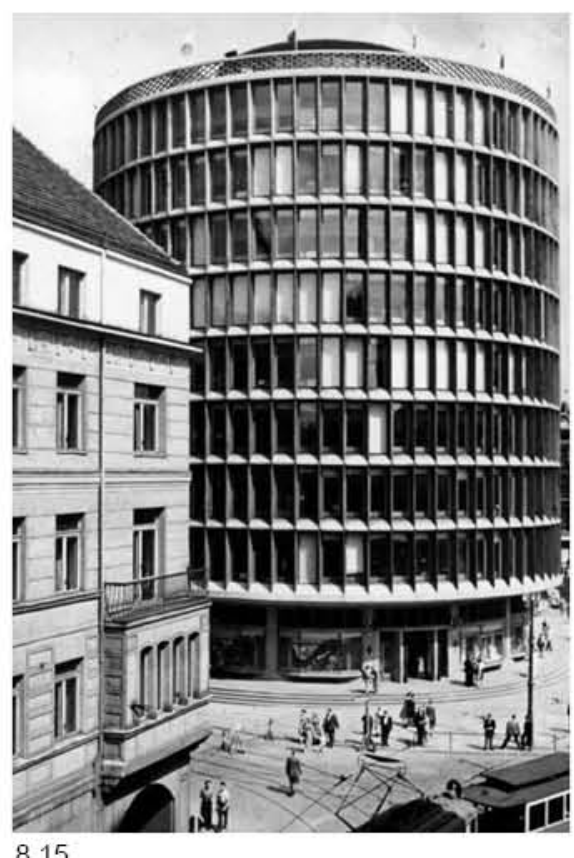

8.15

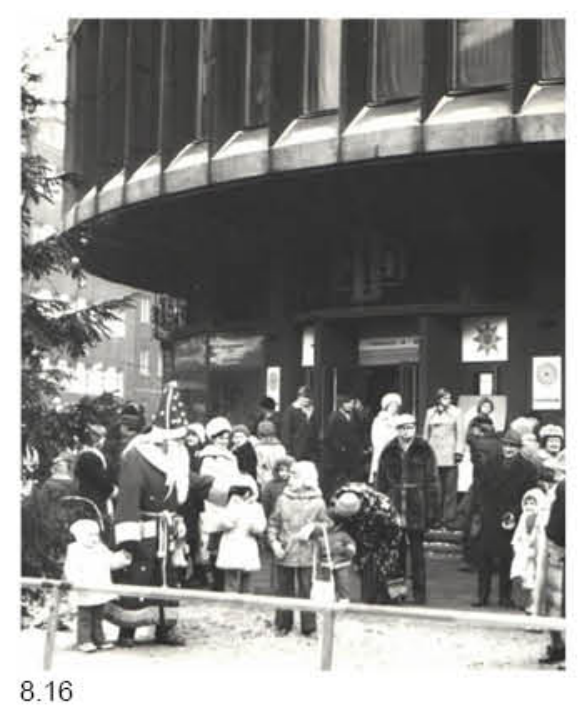

8.06. Zalesiński, 2014. 
8.17 - 8.18 Planta y alzado esquemático del edificio comercial Dom Towarowy Okraglak, 1948-54 de Marek

$8.19 ; 8.21$ Escaleras interiores del Dom Towarowy

8.20 Edificio comercial (Dom Towarowy) Okraglak, 1948-54 del arquitecto Marek Leykam.
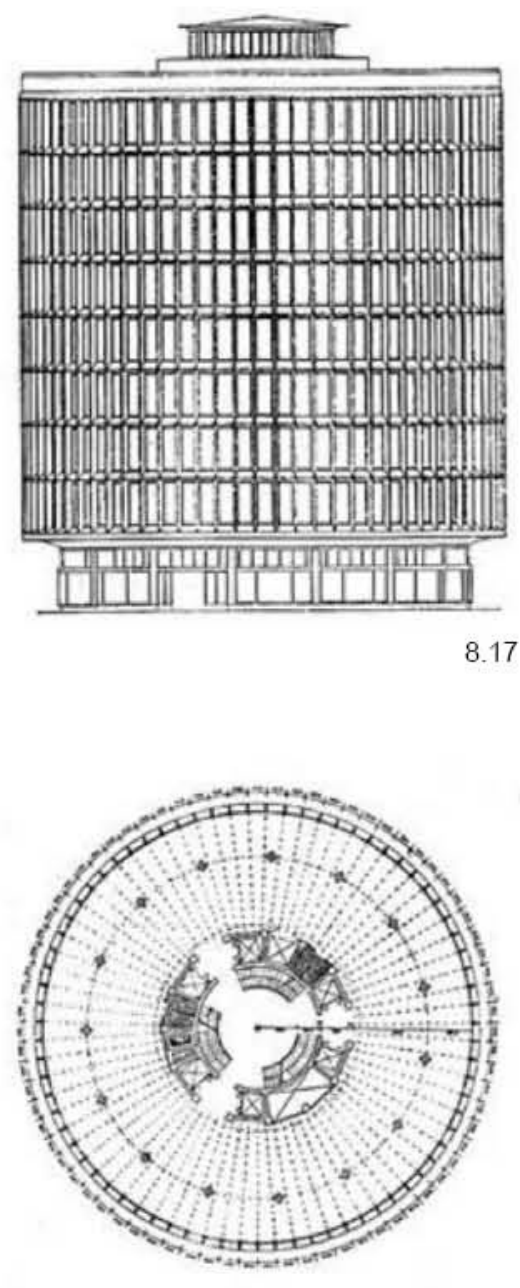

8.18

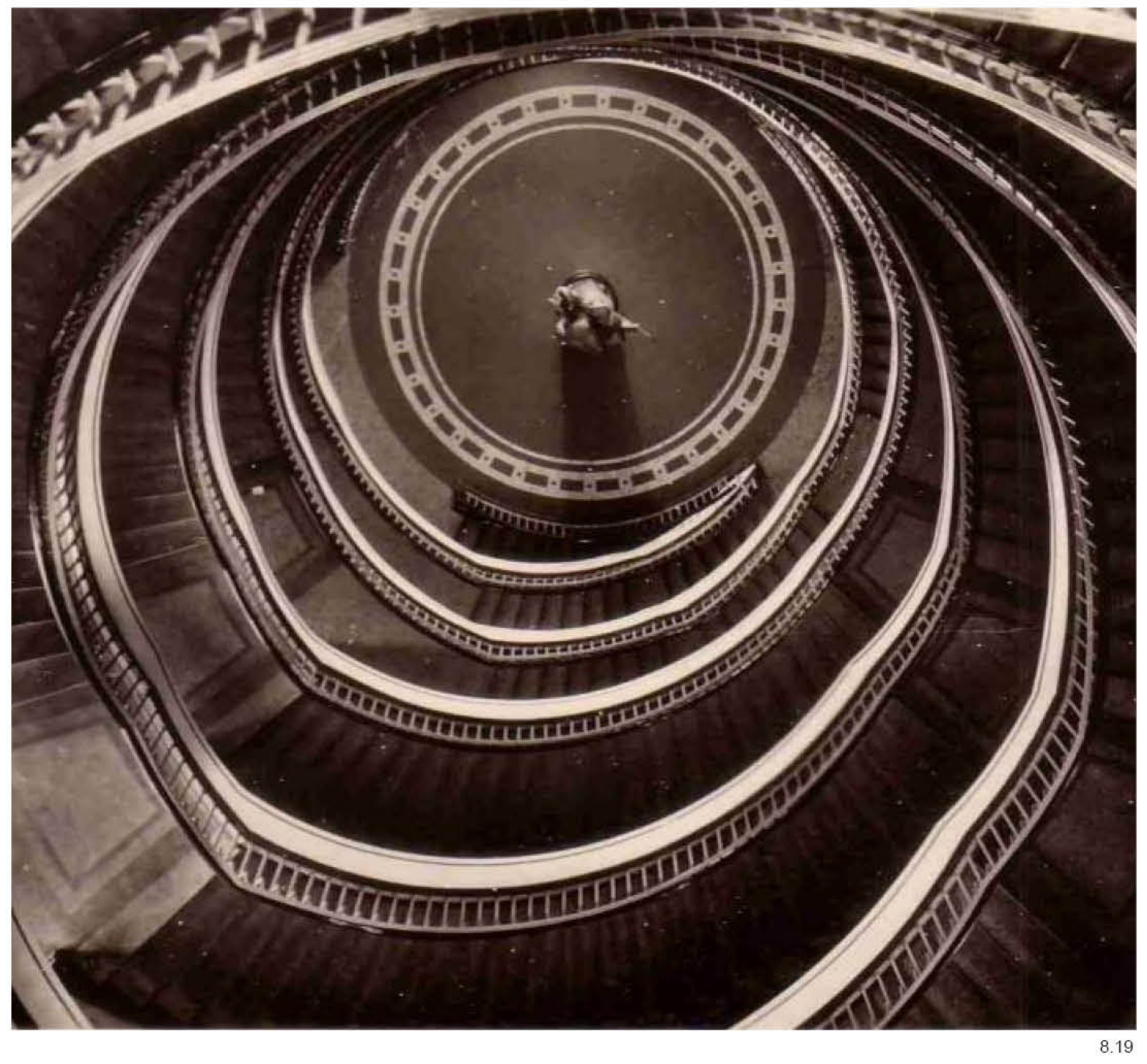


histórica puede hacer pensar que existió algún tipo de influencia en el desarrollo de las deliberaciones en torno al proyecto por parte de Leykam ante la presencia en el imaginario colectivo de un proyecto en el que la geometría cilíndrica y la modulación radial eran parte esencial de su concepción, pero esta conjetura puede descartarse teniendo en cuenta que estamos en realidad, ante una variación más del mismo método proyectual utilizado por Leykam en el resto de su obra.

Finalmente Leykam tomó la determinación de redactar una segunda propuesta que recondujese el volumen principal hacia la geometría de un cilindro, pudiendo plantear así a lo largo de toda la fachada la misma solución constructiva sin que surgiesen los conflictos de jerarquía y direccionalidad de la pieza que derivaban del análisis de su propuesta anterior, ni conflictos en las perspectivas visuales, ahora si claramente unificadas.

El volumen de tres plantas y planta baja retranqueada situado al norte se mantuvo para albergar una parte del programa y al mismo tiempo dar una respuesta a la línea de fachada de la calle Mielżyńskiego, estableciendo una relación entre ambos volúmenes a través del módulo de fachada y su propuesta constructiva pero independizando las formas de manera que en un contexto mucho más abierto la composición podía ser interpretada como un equilibrio de masas que no guardaban relación a nivel formal.

La solución final quedó constituida en volumen por un cilindro cuyo diámetro -34 metros- coincidía con su altura máxima (1:1) y que contenía 8 niveles en su parte central además un volumen sobre cubierta y una planta baja retranqueada $(1+8+1)$ bajo la que se desarrollaban dos sótanos.

Los análisis del terreno obligaron a descartar una propuesta de mayor altura y envergadura que fue planteada en un primer momento con 10 niveles del zócalo debido a la inestabilidad del suelo generada por la cercana presencia de nivel freático en el solar. ${ }^{804}$ Los planes de cimentación también fueron modificados obligando a situar en la base una losa continua que solucionase el apoyo en todo el perímetro de la edificación. En torno al eje central del cilindro, Leykam trazó una serie de círculos que fueron delimitando los diferentes planos de la edificación, todos ellos basados en relaciones de proporcionalidad sencillas, tal como solía ser habitual en su arquitectura.

Un primer círculo de radio 3 metros delimita la barandilla de la escalera, generando un gran vacío central a modo de ojo (6.19) que se mantuvo cubierto por una malla a los pocos años para evitar la proliferación de casos de suicidio en su interior. Con un paso libre de $1,50 \mathrm{~m}$, la escalera que rodea el vacío central se resuelve con tres tramos superpuestos cuyos puntos de desembarco están separados $120^{\circ}$ en cada uno de los niveles, dando lugar a tres punto de acceso en cada planta desde la escalera y generando así tres recorridos, independiente pero superpuestos, de evacuación.

Superada la generatriz imaginaria que delimita los tres tramos de escaleras circulares, puede establecerse otra línea de modulación trazando una equidistancia de 3 metros hacia el exterior del edificio desde el círculo que genera en planta

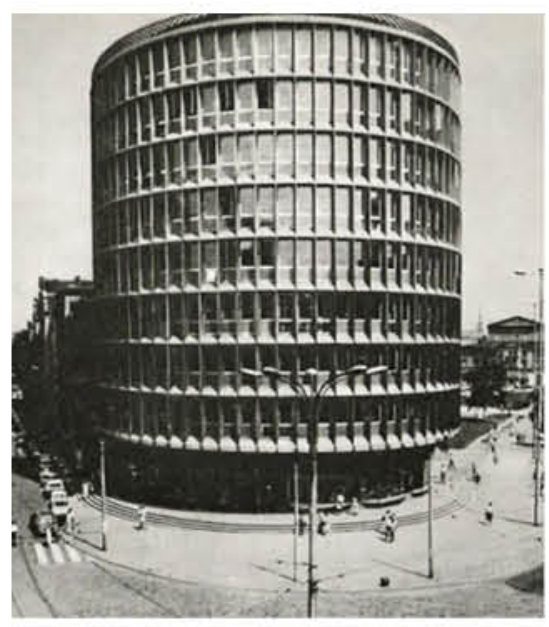

8.20

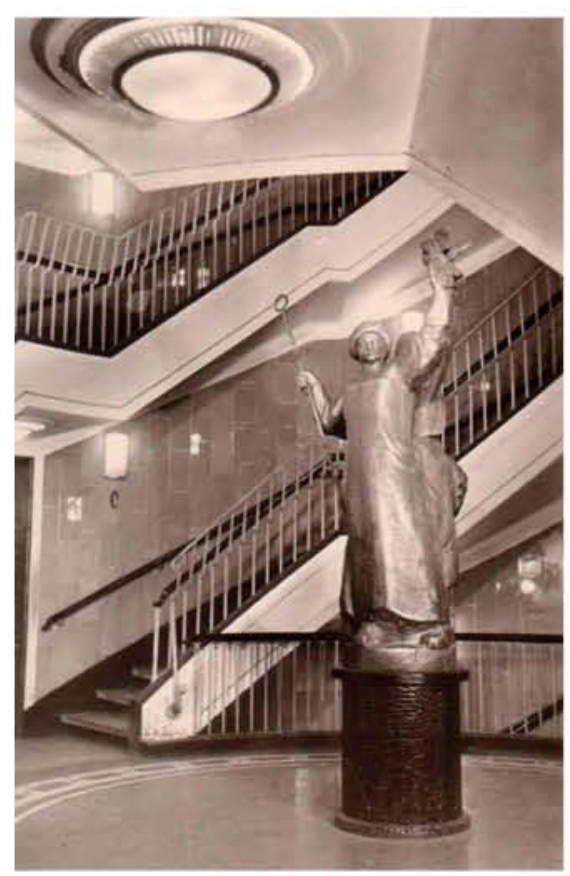

8.21 
8.22 Plano de situación del Dom Towarowy Okraglak. 1. Edificio Okraglak; (1) Marek Leykam.

8.23 Sección Constructiva A-A del Dom Towarowy Okraglak.

8.24 Planta baja (estado actual). 1-Hall de recepción, 2-Superficie de alquiler, 3-Aseos, 4-Recepción.

8.25 Planta baja (proyecto original): 1-Vestibulo, 2-Superficie comercial, 3-Hall, 4-Aseos, 5-Hall, 6-Conserjería, 7-Oficin

8.26 Planta primera. Las plantas comerciales eran divididas según las necesidades de los responsables de cada área, 1-Vestibulo, 2-Superficie de alquiler, 3-Aseos.

8.27 Planta novena, 1-Vestibulo del ascensor, 2-Sala de conferencias, 3-Cocina, 4-Aseos, 5-Cuartos de instalaciones, 6-Terraza.

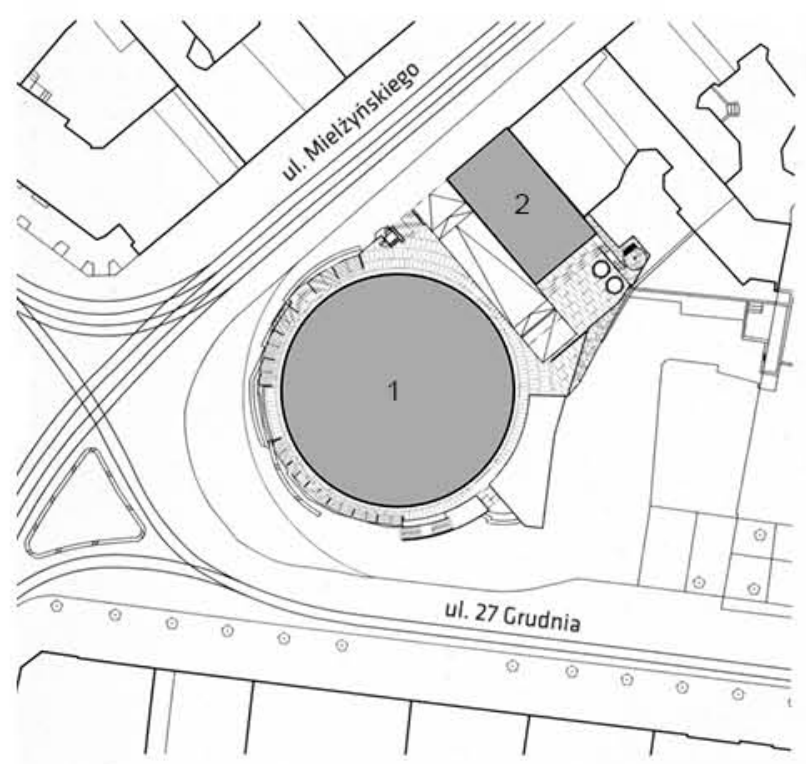

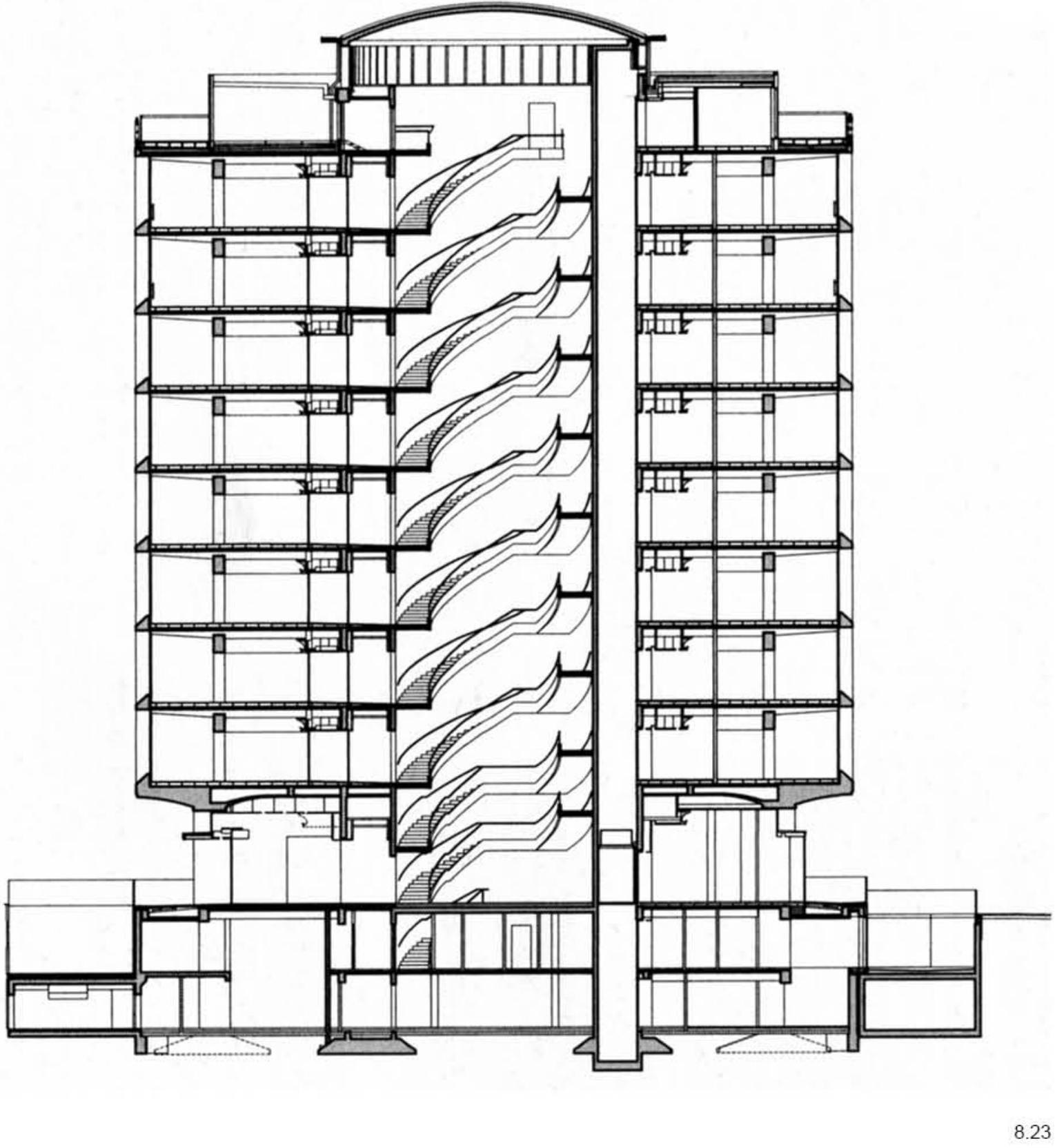



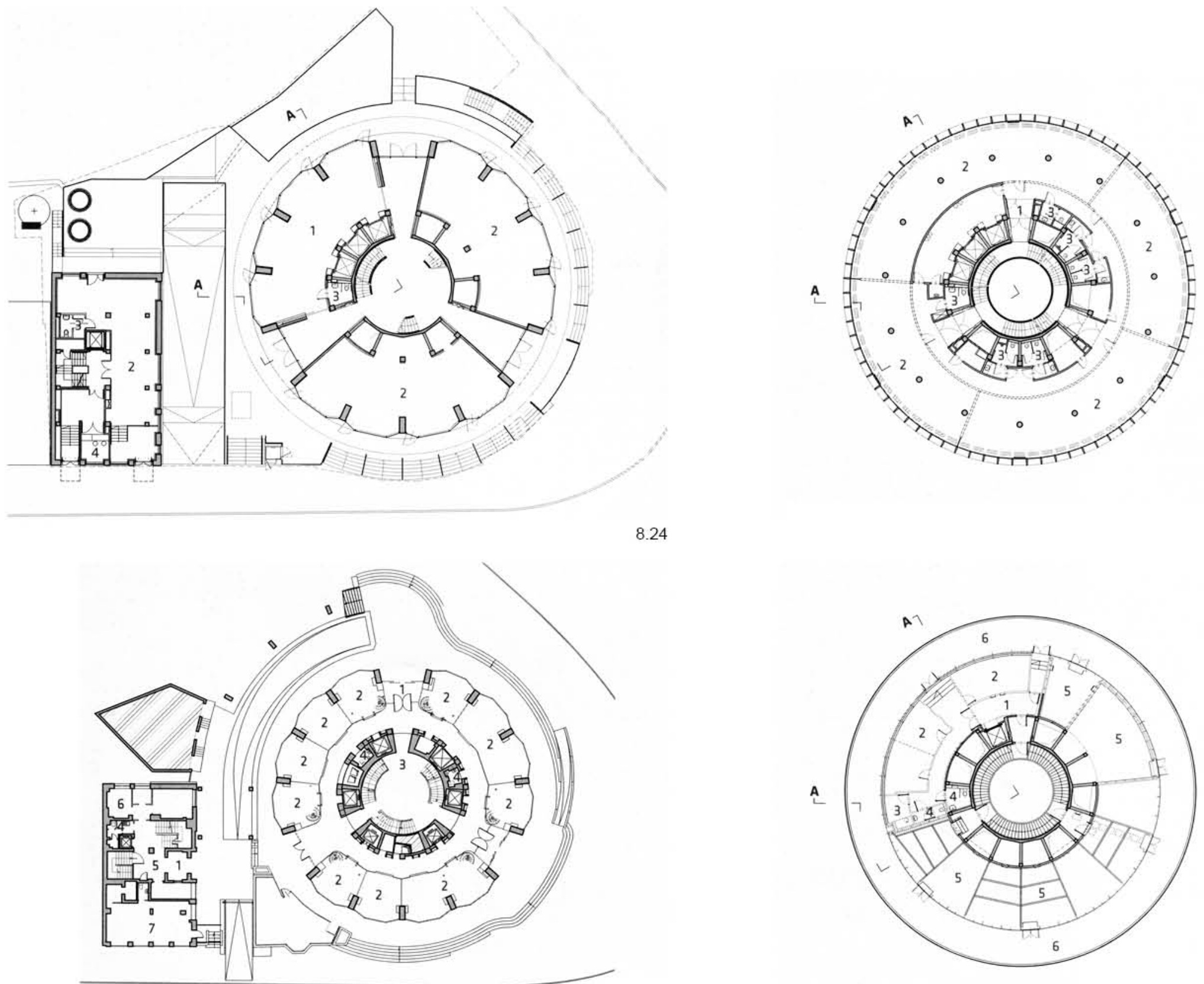


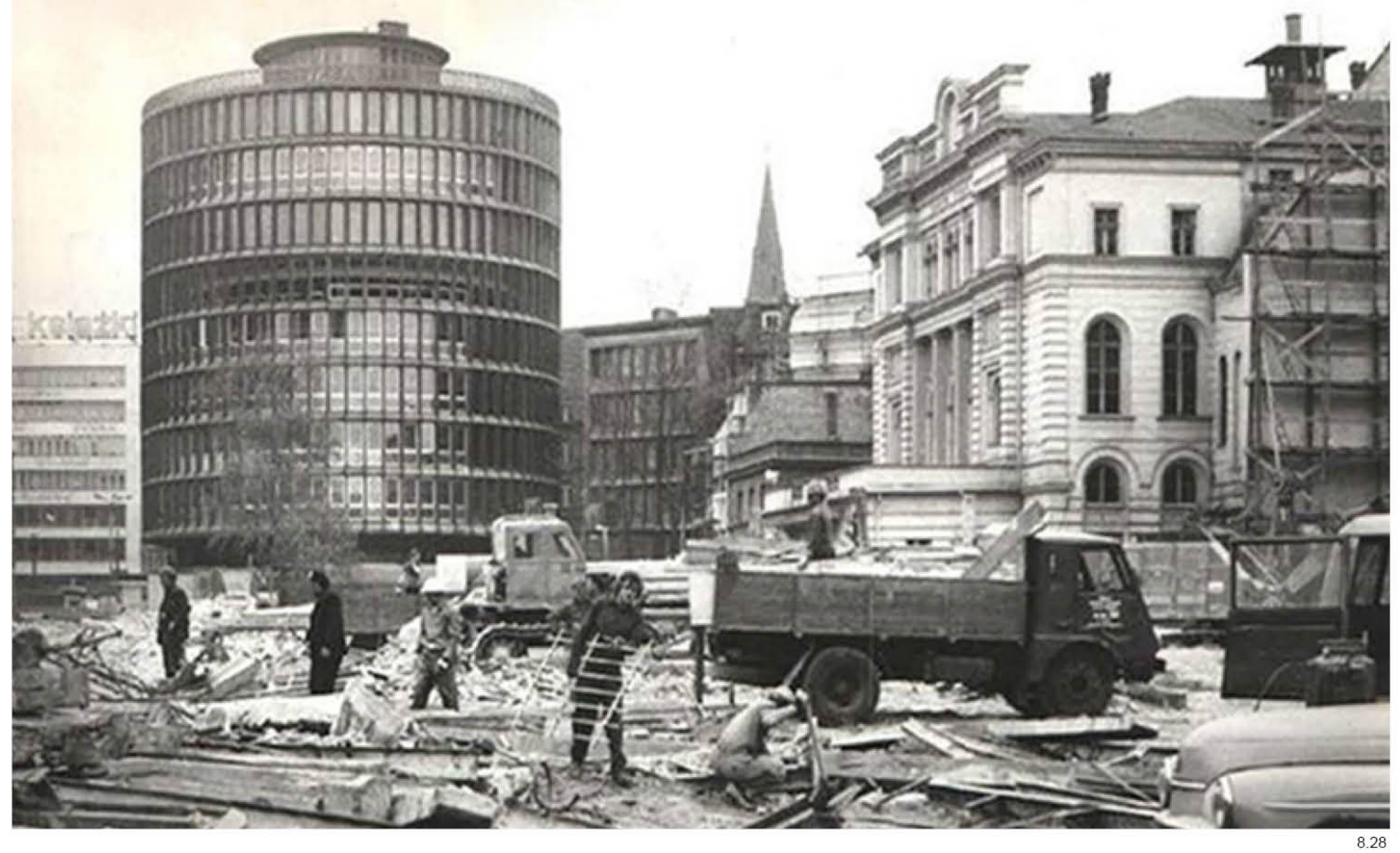


la intersección de esta generatriz con el plano de cada forjado. En el interior de esta banda confinada entre ambas líneas se genera un ámbito en el que se albergan servicios como cuartos de aseo y locales auxiliares y de mantenimiento y el conjunto de ascensores.

La banda de servicios queda interrumpida regularmente por los tres pasos provenientes de cada uno de los desembarcos de escalera que existen en cada planta, y tras ellos se accede a un espacio de corredor concéntrico con el espacio anterior cuya anchura es de nuevo de 3 metros. En este espacio se genera un recorrido intermedio entre la banda de servicios y los espacios de uso del edificio, que están ya situados entre esta banda y la fachada exterior del edificio.

La zona servida del edificio estaba reservada originalmente a comercios y contenía, por planta, una superficie aproximada de $500 \mathrm{~m}^{2}$ definida por el espacio confinado entre dos círculos de radio $10,5 \mathrm{~m}$ y $16,5 \mathrm{~m}$, cuyo centro coincide con la proyección del eje del cilindro del edificio. Todos los espacios comerciales estaban en contacto con la fachada y, tal como pretendía Leykam, no existían jerarquías en su ubicación derivadas de la solución proyectual, lo que era asociado con una idea democrática de distribución igualitaria de oportunidades para todos aquéllos que acudiesen a vender.

Los espacios de uso no fueron delimitados y, una vez definido el contenedor, este ámbito quedó abierto y conectado de forma que los propietarios fueron los encargados de ir delimitando el ámbito de cada tienda con particiones inicialmente ligeras que no interrumpieron la continuidad del recorrido circular a lo largo de la planta (8.30)

La estructura del edificio estaba contenida en las generatrices de dos cilindros coaxiales coincidentes con el eje del cilindro que alberga el volumen del edificio, siendo los radios de sus bases 7,00 metros y 13,00 metros. El plano de fachada también es estructural pero queda en voladizo, y su carga queda apeada en planta baja y es recogida por los pilares del cilindro de $13,00 \mathrm{~m}$ de radio, que pasan a ser muros apantallados de 1,50 x 0,60 m de sección horizontal. La posición de los pilares puede determinarse de forma precisa sabiendo además que todos están contenidos en 16 planos, cuya intersección coincide con el eje del cilindro principal del edificio y están separados entre si mediante intervalos constantes de 24 grados.

La generatriz de referencia del plano estructural de radio 7,00 metros contiene sus pilares integrados en los muros de la banda de servicios, adoptando estos una geometría rectangular que simplifica su ejecución y reduce su coste, mientras que la segunda línea de referencia estructural, de radio $13,00 \mathrm{~m}$, contiene pilares que quedan vistos ya que se encuentran situados en el interior de los espacios comerciales. Leykam tomó la determinación de resolver estos pilares con una sección circular de $25 \mathrm{~cm}$ de radio, que evitase que hicieran referencia expresa a su direccionalidad en un contexto abierto como la zona comercial.

Las relaciones de proporcionalidad seguían muy presentes en la obra de Leykam y de nuevo las fracciones sencillas dominan cada uno de los segmentos de forma que las órdenes en obra fueran sencillas de ejecutar, transmitir y verificar.

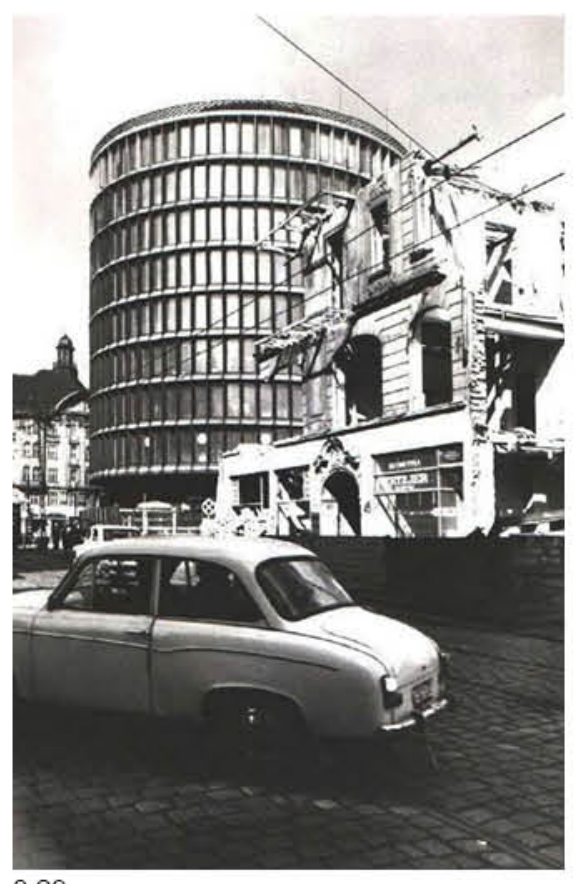

8.29

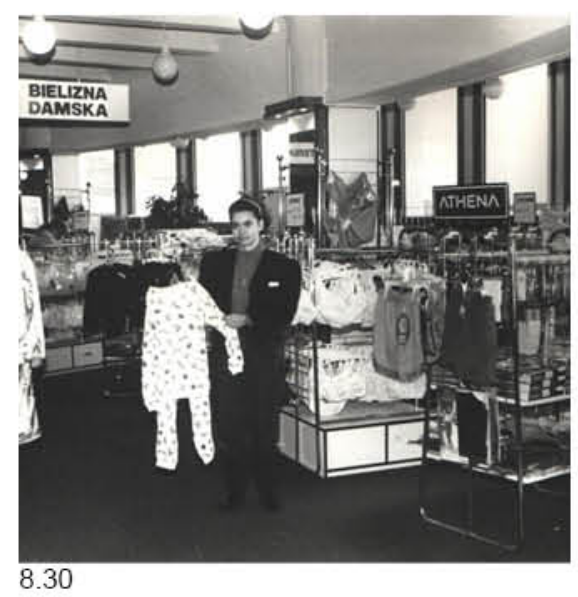


8.31 - 8.34 Detalles constructivos del edificio comercial (Dom Towarowy) Okraglak de Poznań (1948-54). Arquitecto Marek Leykam.
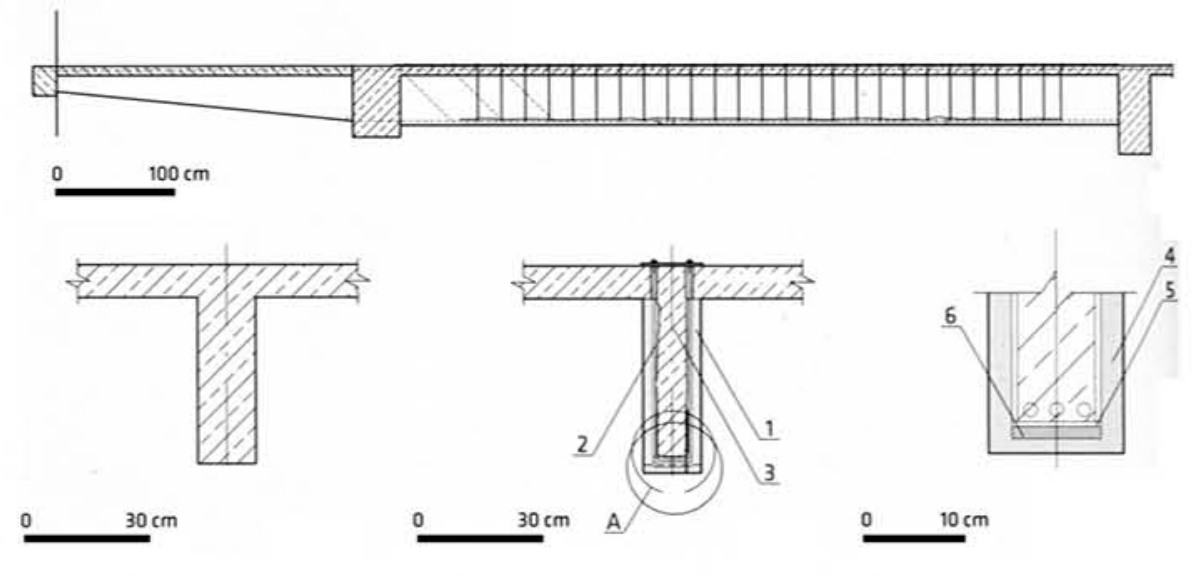

6.31

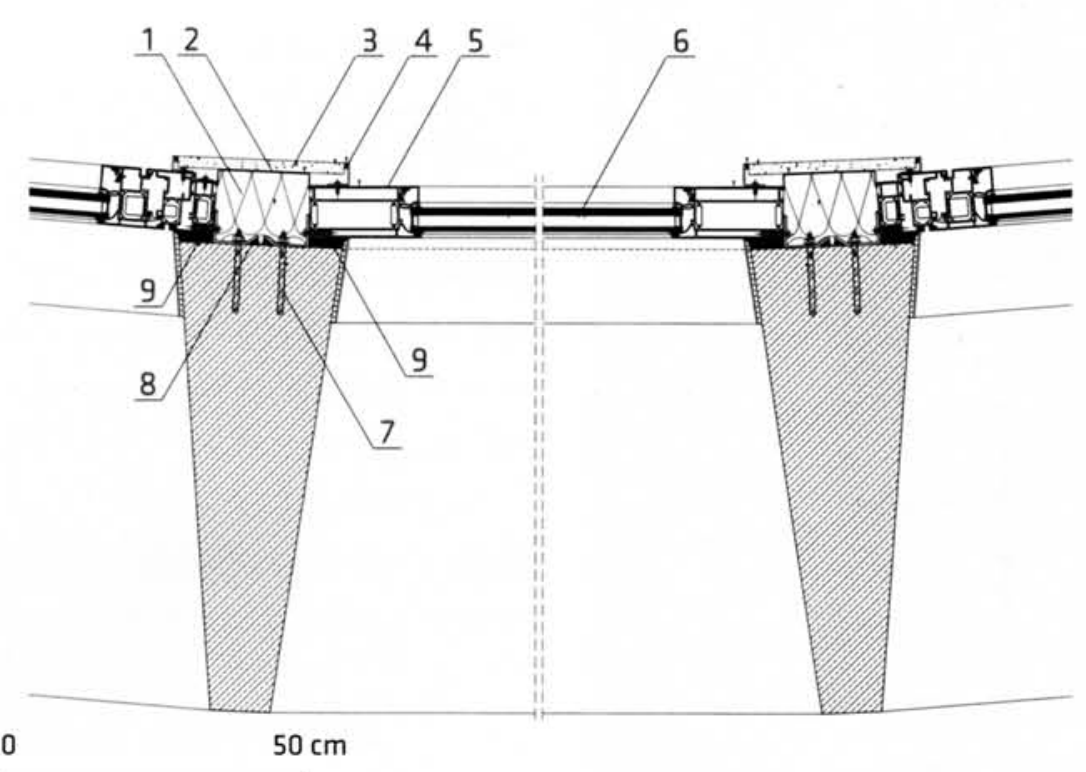

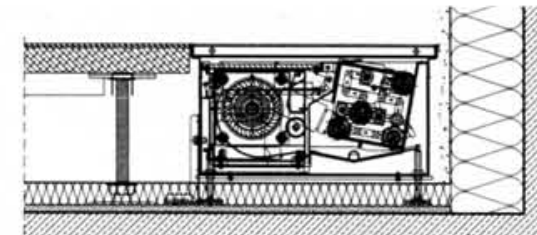
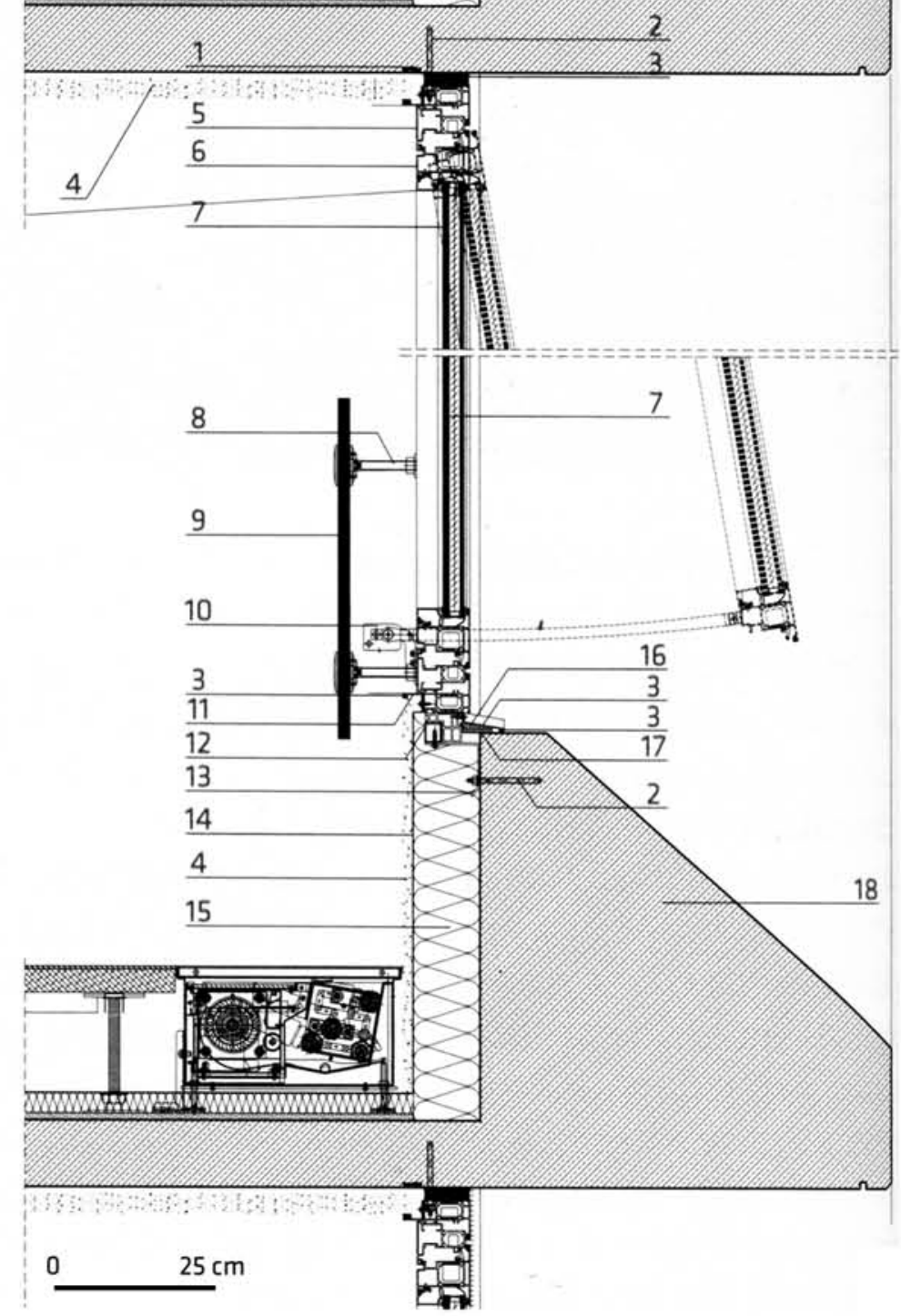

8.33 
Todos los círculos concéntricos que delimitan ámbitos del proyecto en planta están resumidos con esta serie de radios: $3 \mathrm{~m}-4.5 \mathrm{~m}-7.5 \mathrm{~m}-10,5 \mathrm{~m}-16,5 \mathrm{~m}-17 \mathrm{~m}$. Si adoptamos el módulo de 3 metros como unitario, la rítmica de la serie es: $1-1 / 2-1-1-2-1 / 6$

Leykam consideraba que la parte verificable de factores debería ser admitida como elemento de la composición siendo resultado de un cálculo matemático, para lo cual buscó de nuevo relaciones numéricas simple definidas por un módulo proporcional adoptando la lógica de nuevo como principal instrumento proyectual mediante la utilización de procesos deductivos que permitan alcanzar orden constante. El proyecto alcanzaba así una manifestación expresiva de elocuente derivada de un orden continuo y racional.

Tal como es habitual en la arquitectura de Leykam, existe -de nuevo en este proyecto-, una relación constante entre estructura y cerramiento: 75 montantes verticales están distribuidas a lo largo de la fachada en intervalos constantes de $4,8^{\circ}$ mientras 15 pilares situados en intervalos de $24^{\circ}$ establecen una relación $1: 5$ con respecto al cerramiento. La posición de los pilares en planos que coinciden con los puntos medios de los módulos de fachada establece una rítmica 1/2 - 4 - 1/2 a diferencia del ritmo 1/2 - 3 - 1/2 utilizado en Żyletkowiec como el edificio de Información Militar en la calle Chałubińskiego (8.04) o el Instituto Geológico de Varsovia en la calle Rakowiecka (8.09-8.10).

El Dom Towarowy fue el primer edificio de Poznań que utilizaba una fachada prefabricada de hormigón armado. ${ }^{8.04}$ Leykam optó por solucionar los elementos de fachada al mismo nivel, sin generar prioridades de paso ni establecer jerarquías a nivel visual. Tanto los elementos verticales como los horizontales se entrecruzan dando lugar a una malla homogénea sobre la directriz del cilindro entre las plantas 1 y 8 , cuya distancia a ejes es verticalmente $3,33 \mathrm{~m}$ y horizontalmente $1,33 \mathrm{~m}$ invariablemente.

El detalle constructivo genera asimismo un estrechamiento de la pieza prefabricada exterior, al igual que en edificios anteriores (8.29), en busca de una manifestación lo más ligera posible de la solución en alzado. El sistema en su conjunto, es sin embargo el más simple de cuantos había utilizado Leykam hasta el momento, puesto que no existen más elementos que las piezas prefabricadas que recorren toda la altura y anchura del hueco y el acristalamiento interior.

El interior del proyecto fue decorado con elementos propios del Realismo Socialista, como la escultura central situada sobre el ojo de la escalera (8.21) o los grabados sobre los accesos principales con motivos figurativos referentes a las estaciones, obras de los artistas Zbigniew Bednarowicz y Edmund Lubowski ${ }^{8.07}$, mientras Leykam se reservó detalles como la barandilla superior que rodeaba la terraza de la cubierta en el perímetro del edificio (8.34), en la que realizó un homenaje a su maestro Perret mediante una composición que hacía referencia a los "claustra" que el arquitecto francés había ideado para las barandillas de la Iglesia de Santa Teresa de Montmagny (2.21).

El edificio del Dom Towarowy pasó a ser un emblema de la ciudad de Poznań, adoptando el término 'Okrąglak'
8.31 Detalle de la parte inferior de la viga después Dobre (dna malla, 2 - estribos $\emptyset 6,3$ - viga, 4 - nuevas barras de los estribos $\emptyset 6$, 5 - capa de nivelación, 6 - chapa de refuerzo

8.32 Sección horizontal a través de una ventana

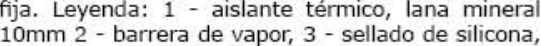
acrílica, 4 - capas de acabado, 5 - perfil de marco de aluminio, 6 - vidrio aislante, seguro, 7 - anclaje de acero 8 - chapa de acero galvanizado, 9 - sellado de

8.33 Sección vertical a través de la ventana
giratoria. Leyenda: 1 - estera de calentamiento, 2 anclaje de acero, 3 - sellado de silicona, 4 - capas de acabado, 5 - perfil de marco de aluminio, 6 - perfil de hoja de aluminio, 7 - vidrio aislante, seguro, con del vidrio, 9 - barandilla, vidrio seguro, 10 - auxiliar para ventanas compensadoras, 11 - chapa de aluminio, $2 \mathrm{~mm}, 12$ - perfil de acero galvanizado, 25 $\times 30 \times 2 \mathrm{~mm}, 13$ - chapa de acero galvanizado, 14 barrera de vapor, 14 - aislante térmico, lana mineral, - pieza prefabricada de hormigón

8.34 Detalle de la barandilla superior de hormigón armado del Dom Towarowy Okraglak.
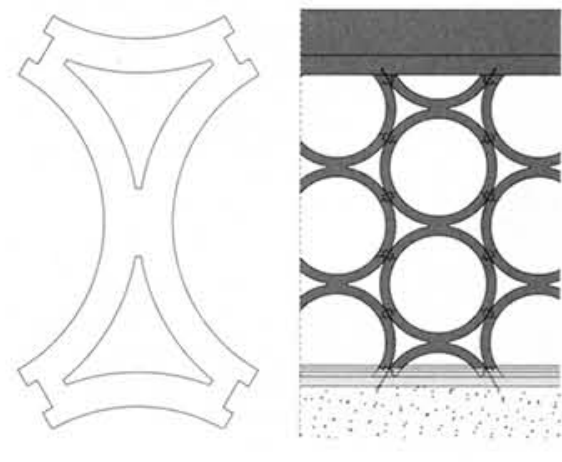

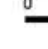

8.34

8.07. Ponikiewski, 2014 


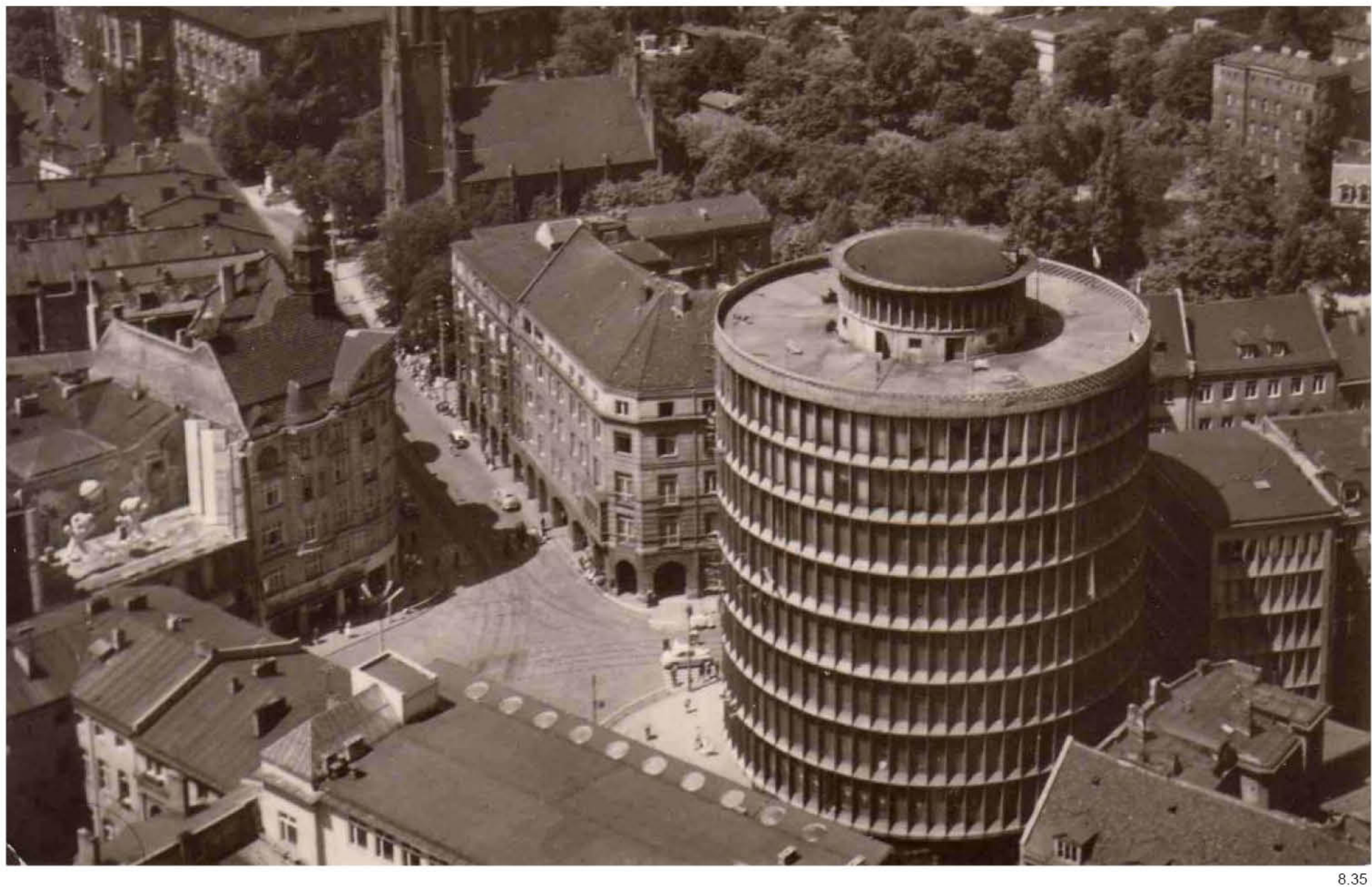


derivado de la palabra redondo, y siendo interpretado posteriormente por críticos como Springer como "símbolo de la resistencia ante el Realismo Socialista" ${ }^{8.08}$, por su confluencia en el tiempo con un estilo del que no participó, puesto que había sido planificado y comenzado a construir en una época anterior.

El edificio Okrạglak fue capaz asimismo de sintetizar la lógica constructiva de los edificios Żyletkowiec, independizándola de la geometría de volúmenes prismáticos a los que había estado adscrita, y logrando así universalizar las características del método proyectual de Leykam; estableciendo con mayor claridad los argumentos por los que eran tomadas cada una de las decisiones y los principios básicos en los que se sustentaban sus proyectos, así como depurando los detalles constructivos realizados para liberarlos de aquello que durante la construcción de los bloques anteriores había resultado superfluo; agilizando así su construcción y simplificando su ejecución.

En el método proyectual de Leykam quedan recogidos finalmente como únicos elementos capaces de generar incertidumbres, aquéllos que derivan de los condicionantes urbanísticos y normativos, los cuales debían ser afrontados desde la lógica y el pensamiento racional para lograr que estructura, forma y función pudieran conformar un todo unitario, tal como había definido Leykam en su doctorado, una "obra de arte en la que no existan singularidades entre las partes sino que se manifieste de forma elocuente como un 'todo' en el que los detalles directamente desaparezcan." 8.01

Las características comunes a toda la obra de Leykam quedaron expuestas en este proyecto, que adquiere el significado de un auténtico manifiesto: máximo aprovechamiento del espacio construido: simplicidad tectónica, establecida mediante una reducción al mínimo de las piezas portantes; rítmica constante de los elementos estructurales; y relación de proporcionalidad entre estructura y cerramiento a través de una numeración sencilla.

A partir de estos elementos, Leykam continuará desarrollando en el futuro una búsqueda de la expresividad a través de la manifestación de las soluciones tectónicas, entendida como una forma de ejemplificar la necesidad de respetar la economía de medios y definir las bases sobre las que la técnica permitiría en el futuro mejorar la construcción liberando a los trabajadores de la pesada carga del trabajo manual en la construcción.

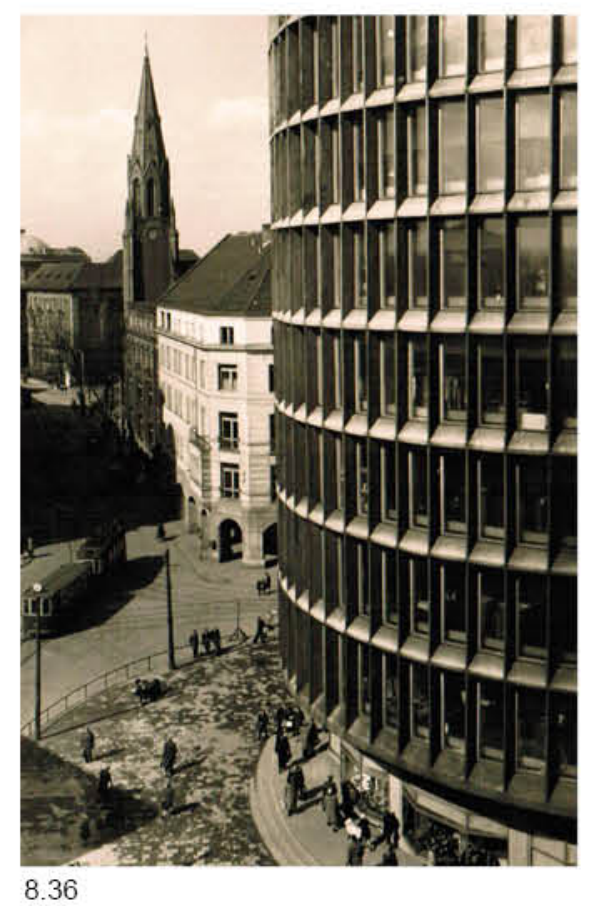

8.08. Springer, 2011 
9.01 Plaza de acceso a la "Exposición de Territorios Recuperados" de Wroclaw, 1948.

9.02 El presidente polaco Bolesław Bierut, inagurando la "Exposición de Territorios

Recuperados" en Wroclaw, el 21 de junio de 1948 .

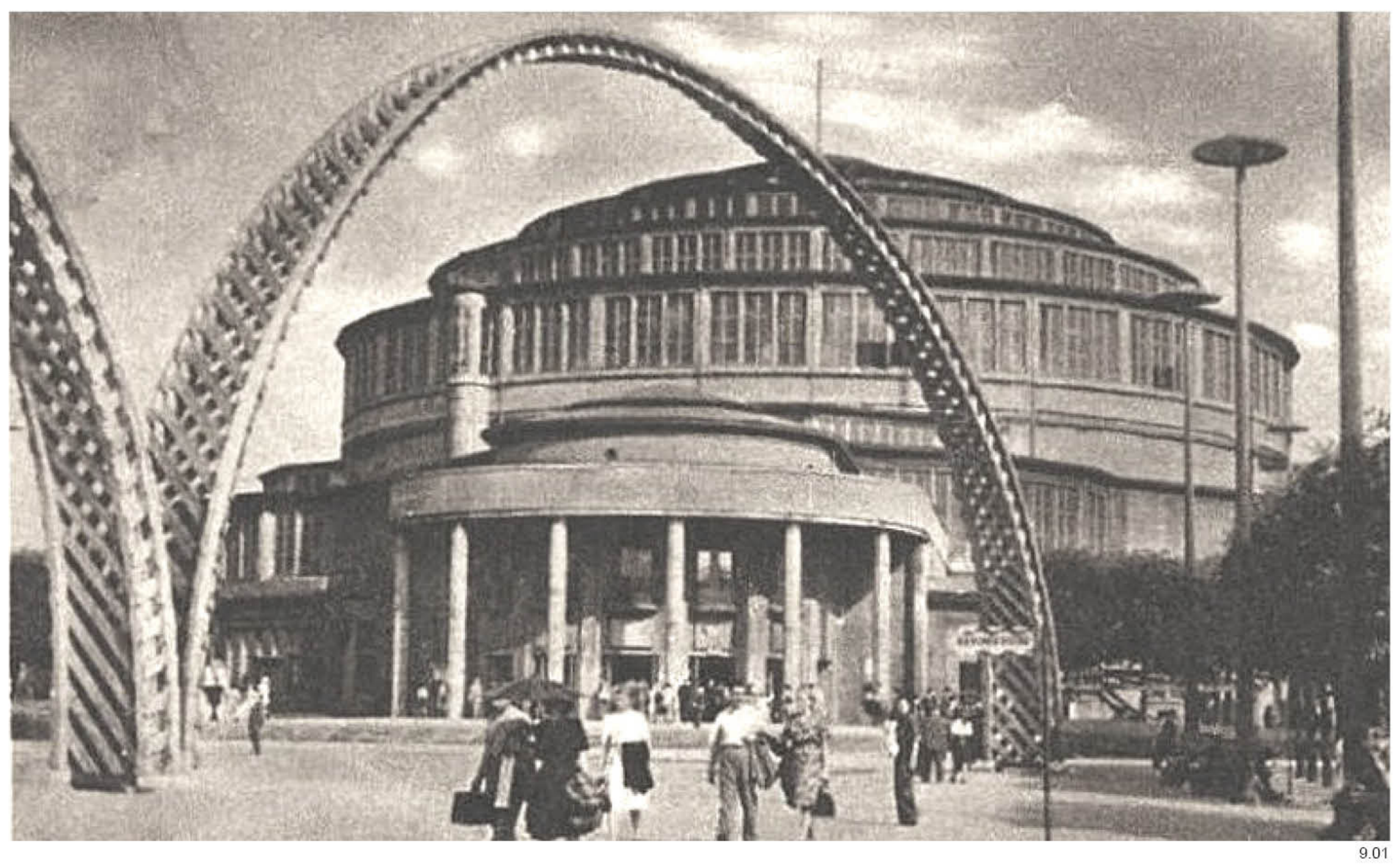


"A través de la forma se están generando doctrinas que tienen como resultado situaciones aparentemente sin salida, ya que parecen definidas y sin embargo quedan ocultas y son invisibles bajo el sueño del "ser humano feliz".

Marek Leykam, 1937. "Z rozważań architekta" 9.00

En 1948 se celebró en Wrocław la Exposición de Territorios Recuperados ${ }^{9.01}$, un encuentro que pretendía mostrar la importancia de las tierras anexionadas a Polonia tras la Segunda Guerra Mundial y explicar los planes de reconstrucción que se estaban llevando a cabo en estas áreas ${ }^{9.02}$, en un momento en que el gobierno de Polonia había sido instado a rechazar la ayuda del Plan Marshall e invitado a subvencionarse a través de un plan soviético quinquenal. ${ }^{9.01}$

La gran inauguración de la exposición, el 21 de julio de 1948, fue un importante evento estatal al que acudió personalmente el presidente de Polonia Bolesław Bierut, junto al primer ministro Józef Cyrankiewicz y en él se dieron cita importantes artistas polacos como Jan Cybis, Stanisław Dawski, Xawery Dunikowski, Eryk Lipiński, Henryk Stażewski, Bohdan Urbanowicz, Jerzy Wolff y los hermanos Stanisław y Wojciech Zamecznik. ${ }^{9.03}$

Durante la exposición se mostraron los logros de la industria electromecánica y metalúrgica, además de la minería y los modelos de los pueblos pesqueros y ganaderos de los nuevos territorios polacos. Al alcance de los visitantes quedaron productos como pasteles y salchichas, medias de algodón y seda, muebles de oficina e incluso lápidas y velas de la iglesia aunque muchos de ellos no estaban disponibles cotidianamente para los pobladores de esta región. ${ }^{9.03}$

\subsubsection{Arcos de la Plaza Central de la Exposición de Territorios Recuperados de Wrocław.}

El recinto elegido para la muestra resultaba especialmente significativo. El Palacio del Pueblo (Hala Ludowa) de Wrocław había sido construido según el proyecto del arquitecto Max Berg entre 1910 y 1913, cuando la ciudad formaba parte del Imperio alemán con objeto de conmemorar el centenario de la derrota de Napoleón en Leipzig en 1813. ${ }^{9.04}$

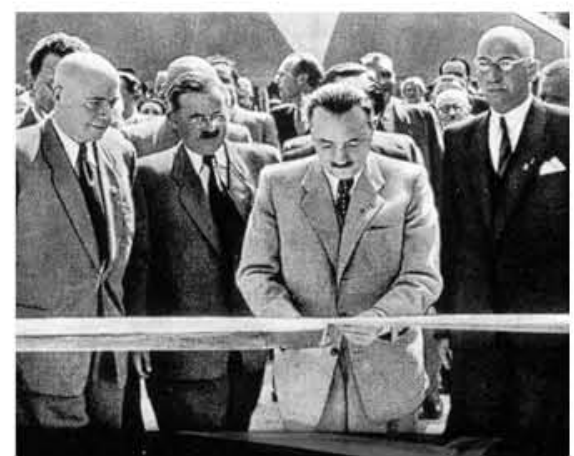

9.02
9.00. Artículo "Z rozważań architekta" ("Reflexiones de un arquitecto") Publicado en la revista Plastyka $1937, n^{0} 1$ p. 31

9.01. La "Exposición de Territorios Recuperados" (Wystawa Ziem Odzyskanych) fue un evento celebrado en Wroctaw del 21 de julio al 31 de octubre de 1948.

9.02. KronikaRP Secuencias video PKF 48/28 WFDiF Varsovia. Fuente: kronikarp pl.

9.03. Jarosiński (2009).

9.04. Página oficial Hala Ludowa, halastulecia.pl. 
9.03 9.04 Sección transversal y planta del Centro Ludowa) de Wrockaw, 1911-13 del arquitecto Max Berg.

9.05 Sala central del Centro del Centenario, Wroctaw, 1911-13 Arquitecto: Max Berg.

9.06 9.07 Construcción de los hangares para dirigibles de Only (Francia) 1916-23 del ingeniero Eugene Freyssinet.

9.08 Construcción del puente de Plougastel-Daoulas (Francia) $1926-29$ del ingeniero Eugene Freys
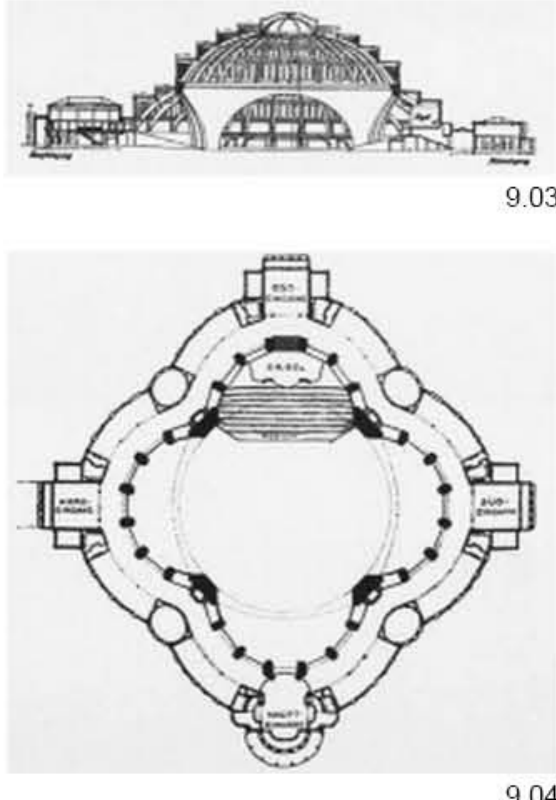

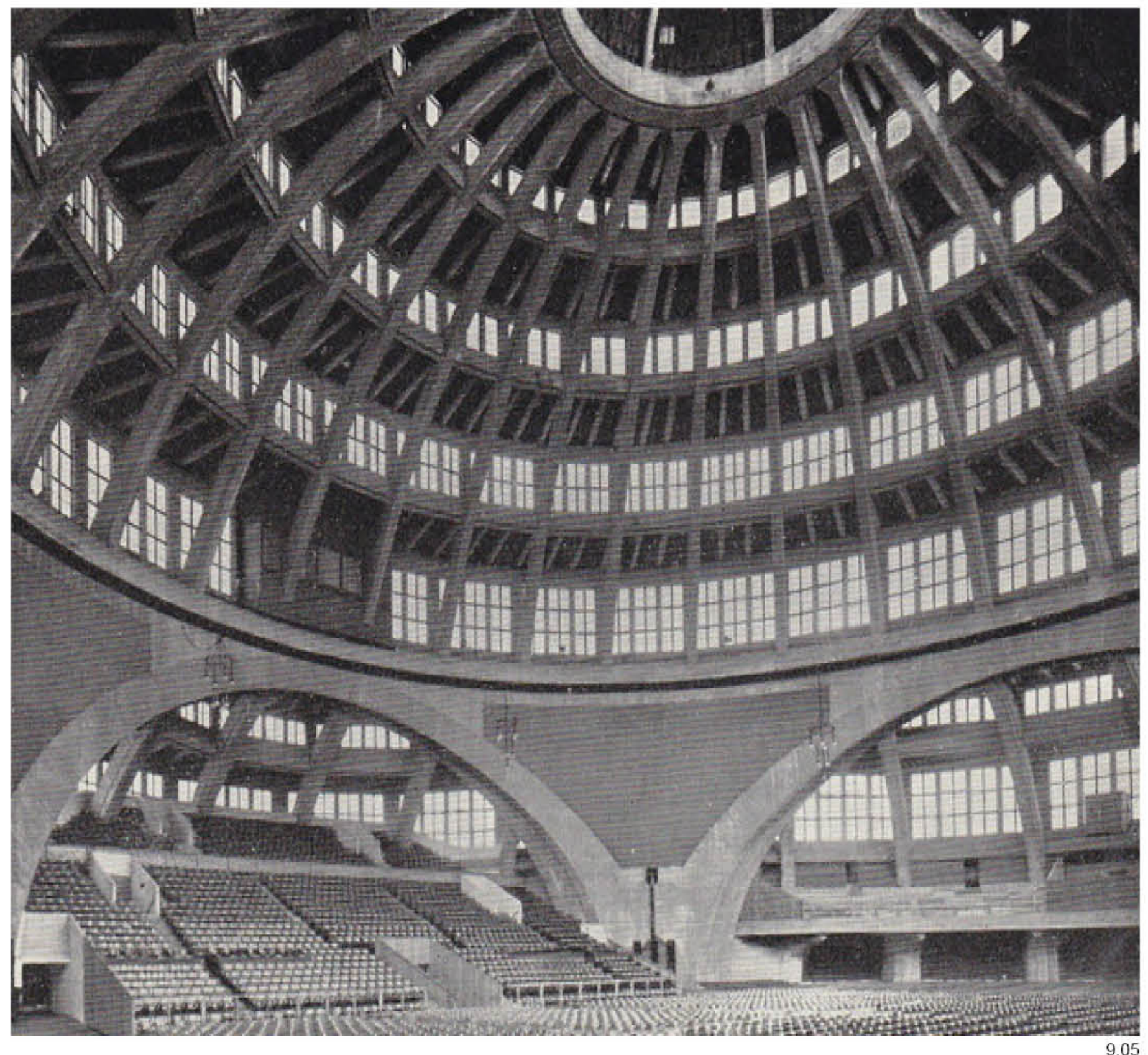


La estructura de hormigón armado de este edificio, le permitía inscribir en su interior un círculo de $65 \mathrm{~m}$ de diámetro y alcanzar la cota de $42 \mathrm{~m}$ de altura. Los nervios de la cúpula descansaban sobre cuatro grandes arcos de descarga de 19 metros de altura y 41 metros de luz cada uno, contenidos en la hipotética generatriz de un cilindro cuyo eje ortogonal al suelo coincidía con el centro de gravedad de la figura cuadrifólica descrita en planta. ${ }^{9.05}$

La cúpula, que consta de 32 costillas que descansan sobre un anillo de diámetro 65 metros, culminaba en un anillo comprimido de 14,4 metros de diámetro estabilizado mediante tres anillos concéntricos dispuestos en intervalos regulares a diferentes alturas formando las bases de los cuatro niveles de paredes acristaladas en una disposición aterrazada que generaba la imagen escalonada de la cúpula, permitiendo a su vez las entradas en luz a través de las ventanas laterales situadas en los anillos concéntricos. ${ }^{9.05}$

La luz máxima de la cúpula tal como estaba planteada, podía haber salvado 73 metros pero la incertidumbre generada por la novedad de este sistema constructivo en hormigón armado por parte de los trabajadores y la propia constructora llevó a su arquitecto, Max Berg, a reducir la luz hasta los 65 metros actuales para que no existiera desconfianza en su estabilidad durante las obras. ${ }^{9.05}$

La utilización del arco en hormigón armado sería ensayada en estructuras de mayor luz unos años más tarde gracias a la introducción del hormigón pretensado en la construcción. Los hangares gemelos para dirigibles del ingeniero francés Eugène Freyssinet en Orly (1916-23), alcanzaron una altura de 62.5 metros ${ }^{9.06}$ mediante arcos autoportantes, mientras que el puente que proyectó en Plougastel (1926-29) era capaz de atravesar el estuario de Elorn, en Bretaña, mediante tres arcos de 188 metros de luz para un vano total de 888 metros. ${ }^{9.07}$ Leykam por su parte también había conocido la utilización del arco en estructuras de hormigón armado al visitar durante su estancia en el estudio de Perret el edificio del Atelier Esders (9.09) terminado en 1919.

La ordenación exterior que Marek Leykam debía replantear en la explanada de acceso de la Exposición de Territorios Recuperados se enmarcaba sin embargo en un contexto de incipiente Realismo Socialista en Polonia en el que todos los mensajes que el Estado deseaba transmitir al pueblo a través del arte debían ser expresados por los autores de forma directa, inmediata y comprensible para la sociedad, por lo que se solicitaba una traslación literal de las metáforas.

El director artístico de esta exposición, Jerzy Hryniewiecki, ${ }^{9.08}$ había encargado a Marek Leykam en 1948 la composición de la plaza de acceso principal, en la cual ya desde la convocatoria existía la obligación de realizar un homenaje de forma clara y expresa para el pueblo sobre el trabajo de los cesteros (Koszykarstwo) de la cuenca del Oder que después de la II Guerra Mundial se habían agrupado formando talleres cooperativos para la producción y venta de objetos decorativos y de uso cotidiano (cestas, platos, muebles, incluso vallas..) realizados todos ellos con la técnica de trenzado de mimbre tradicional en la región (9.13).

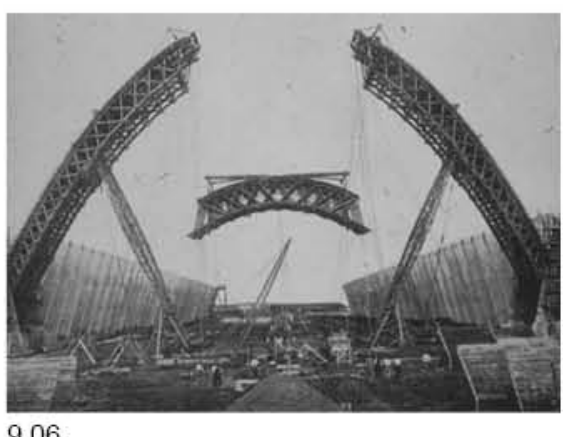

9.06

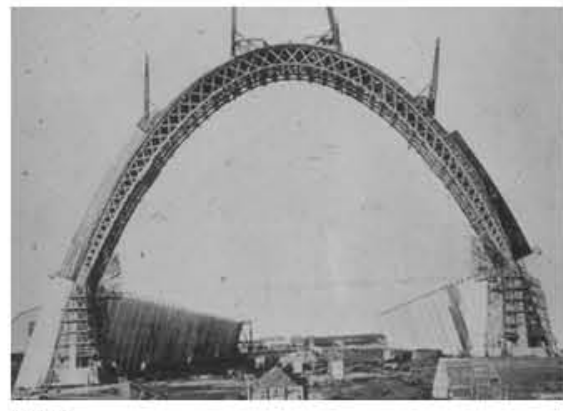

9.07

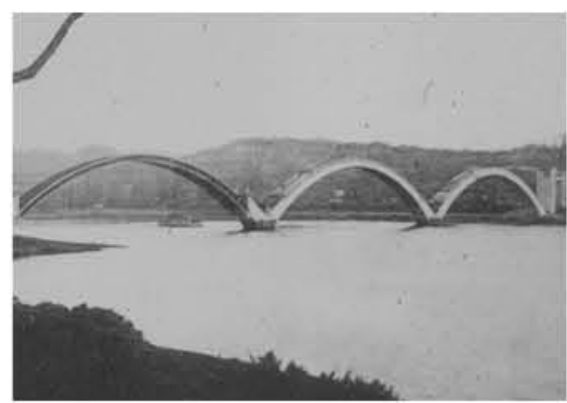

9.08

9.05. Ilkosz | Grajewski, 2007. p.1.

9.06. Bennet, 1999. p.1

9.07. International Database for Civil and Structural Engineering (structurae.net)

9.08. Jur, 1977. p. 49-56. 
9.09 Vista interior del Atelier Esders (1919). Arquitecto. Auguste Perret.

9.10 9.11 Plaza de entrada frente al Palacio del Pueblo (Hala Ludowa) durante la "Exposición de

9.12 Espiral escultórica "Robotnik" (lit: : trabajador) de K. Dunikowski situada en la plaza de entrad de la "Exposición de Territorios Recuperados" de Wrockaw, 1948.
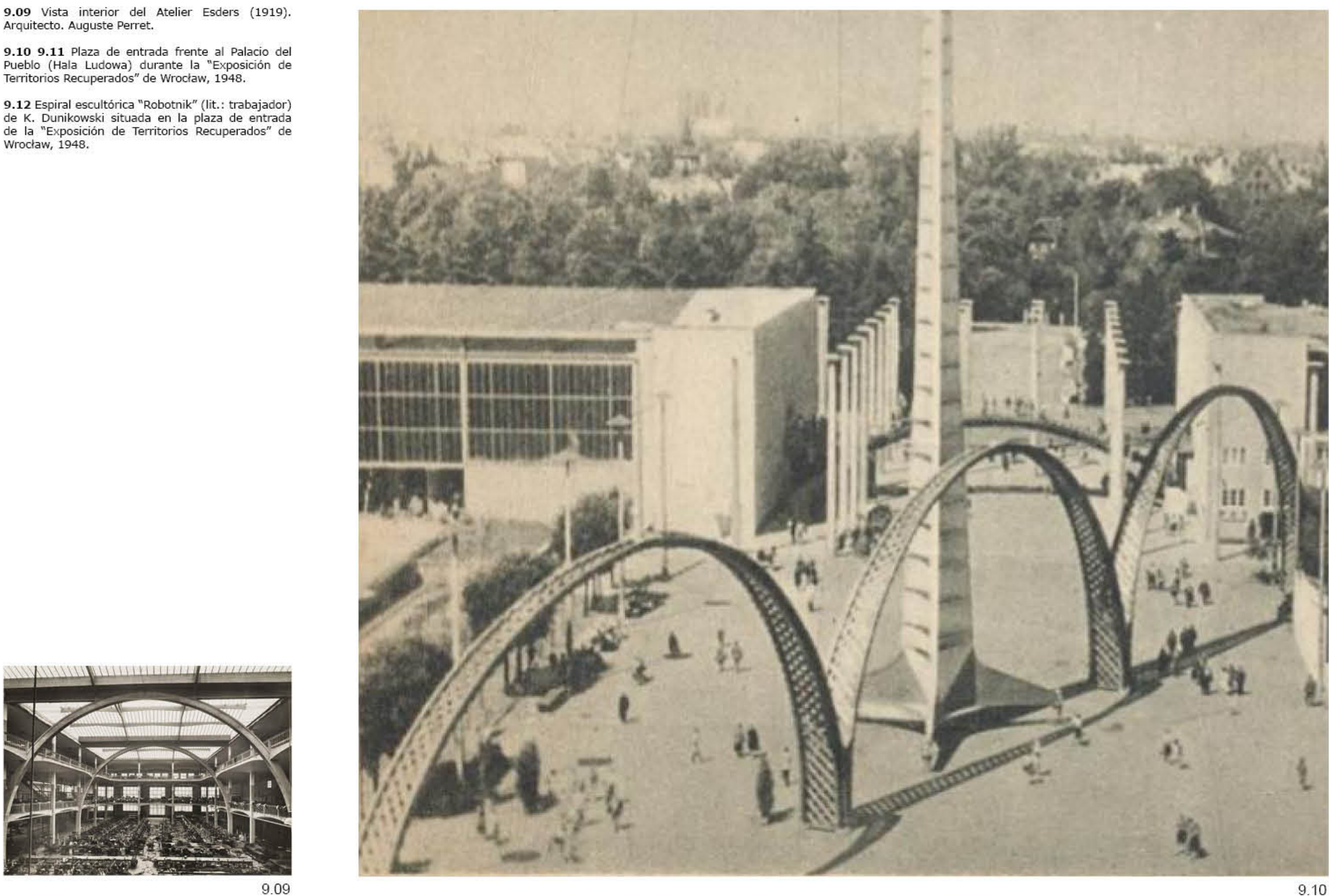
Leykam supervisó una ordenación en la cual un conjunto de tres arcos de perfil semicircular contenidos en un mismo plano conformaban una diagonal entre uno de los accesos a la Exposición y el acceso al edificio del Palacio del Pueblo. Cada arco alcanzaba una altura de 15 metros y salvaba una luz de 30 metros hasta los 90 metros de recorrido total. ${ }^{9.09}$ Los tres arcos eran autoportantes y su estructura era autónoma debido al ensanchamiento progresivo de su base con respecto al punto de coronación.

El material elegido para construir este arco fue la madera debido a la necesaria traslación literal de la metáfora que era necesario establecer con los artesanos de cestería de las tierras polacas. En la tabla de cada arco se podía percibir un trenzado de piezas de madera que representaba de forma alegórica aunque de proporción sobreescalada el aspecto de las fibras entrelazadas que tejen el asa de una cesta de mimbre tradicional.

Las autoridades que describieron la obra establecieron relaciones con los lemas políticos del momento. El Subsecretario de Estado Victor Koscinski, comisionado del gobierno para esta exposición, describió esta escultura como: "Tres grandes arcos atravesando el patio de honor que significan tres años de duro trabajo en el que nuestras espaldas han tenido que agacharse para trabajar en los terrenos recuperados." 9.09

Lejos de la alegoría oficial, los tres arcos establecían una continuidad formal con el interior de la sala que el público se dirigía a visitar. Los cuatro arcos de hormigón diseñados por Max Berg en el interior del Palacio del Pueblo tienen una altura libre aproximada de 16 metros, ${ }^{9.06}$ muy similar a los arcos de la plaza exterior, y el plano curvo que los contiene da paso a un plano recto que atraviesa la plaza con la libertad de un objeto recién destensado de una posición forzada que se hubiera visto obligado a mantener.

La alineación de los tres arcos sobre el mismo plano y la coincidente altura de su cénit, permiten una lectura continua del conjunto como una repetición de vanos que funciona como nexo de unión entre dos ámbitos, un 'puente' en fase de desarrollo que debe permitir la comunicación y las posibilidades de avance de las comunidades representadas en el interior de la sala del Palacio del Pueblo.

Los tres arcos contrastaban asimismo con la fuerte simetría del patio de acceso, acentuada por hileras de árboles situadas a ambos lados de la entrada. Desde la puerta principal del perímetro exterior hasta el Palacio del Pueblo se podía observar una composición que resultaba curiosamente equilibrada al haber respetado en cualquiera de sus alzados la simetría que regía la ordenación del lugar, haciendo coincidir el centro de gravedad de la pieza con el eje principal que marca la simetría de los edificios, pero quedando muy alejada de la simetría real en volumen que ofrecía una visión del conjunto en tres dimensiones.

Este juego de establecer una relación compositiva con un eje de gravedad al que sin embargo finalmente la composición

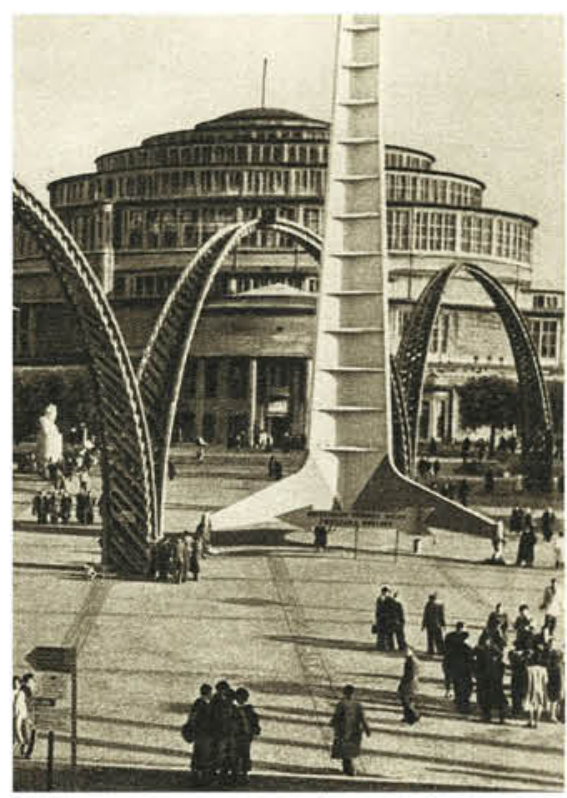

9.11

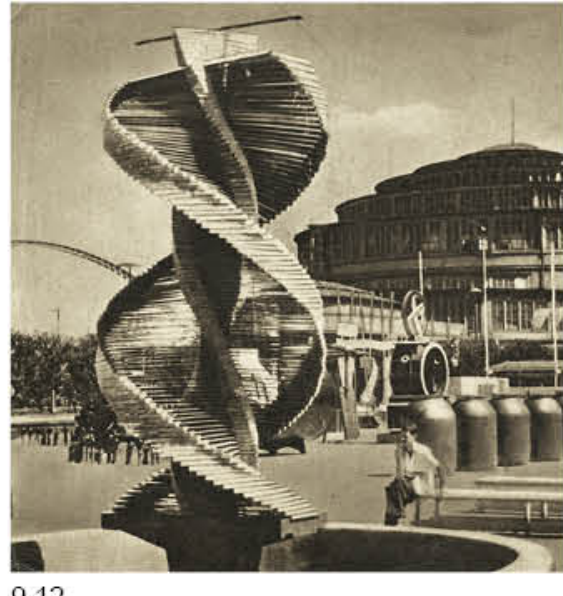

9.12

9.09. Bukowski (1985) 
9.13 "Koszykarze" (Cesteros) uno de los grupos a gran escala de productos de mimbre tras la II mercado en Opole.

9.14 Cimbra para la construcción de los Tres Arcos Wrockaw, 1948.

9.15 - 9.18 Izado de escultura "Iglica" (Aguja) del ingeniero stanislaw Hempel durante los dias previos a la inaguración de la "Exposicion de Teritonios Recuperados" de Wroclaw, 1948.

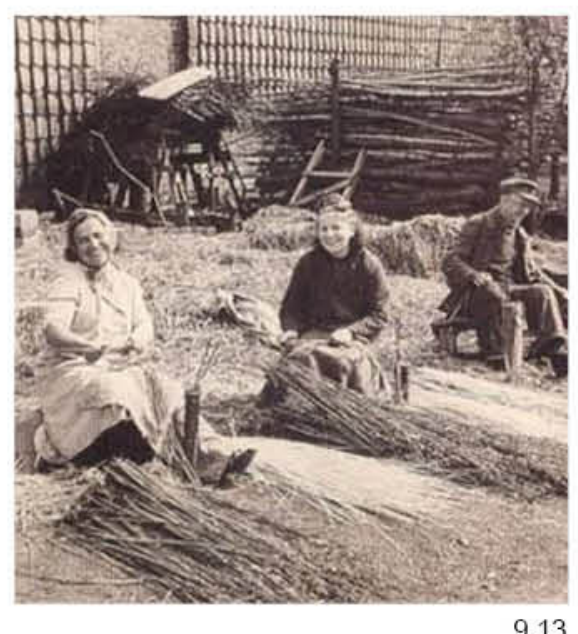

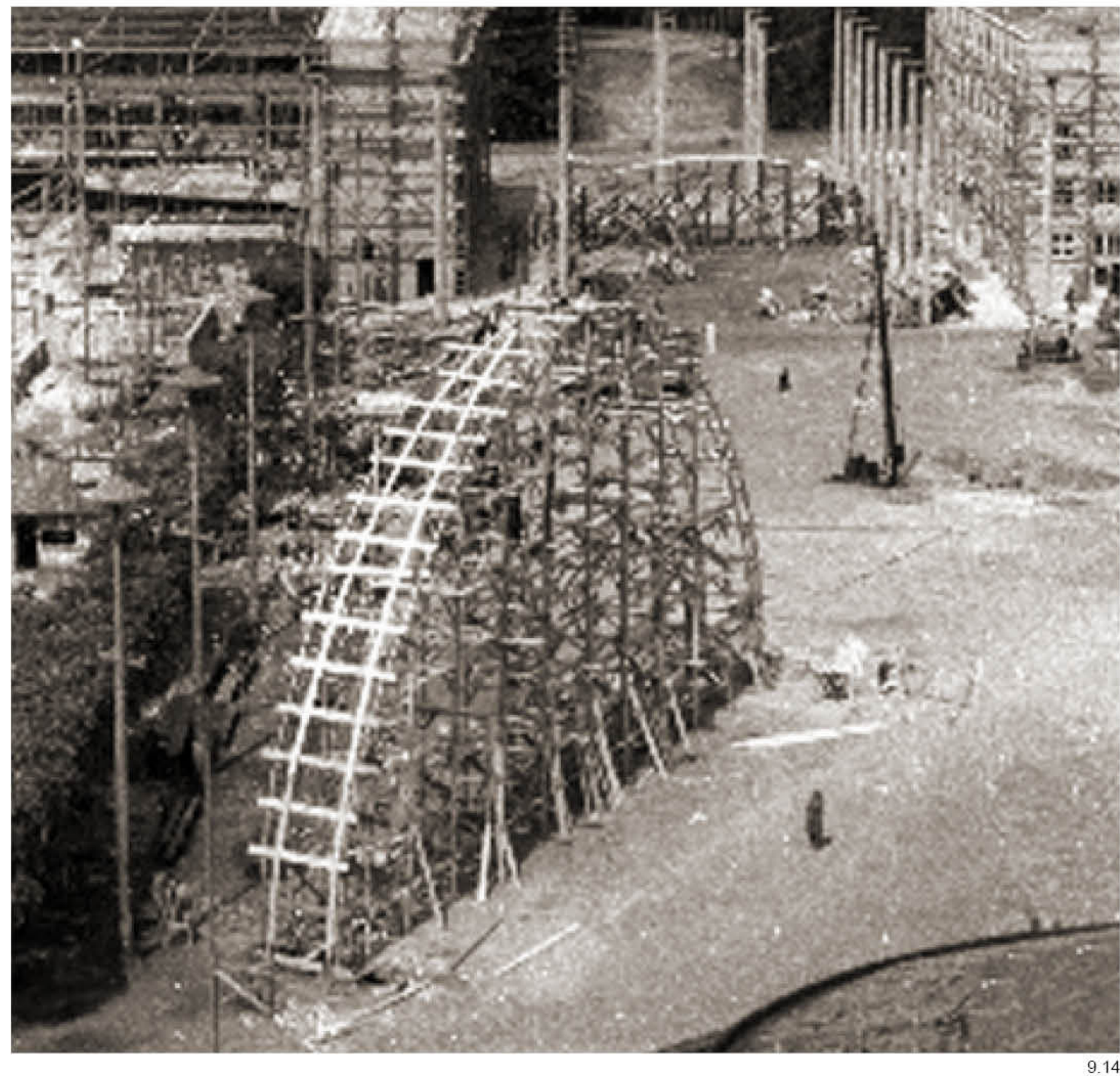


volumétrica resulta esquiva cuestionando su carácter dominante fue utilizado de nuevo por Leykam en un importante proyecto posterior, la Fachada Este de Varsovia (13.15), en la que un símbolo de poder del Realismo Socialista como el Palacio PKiN también era sutilmente desplazado del eje de gravedad de la composición por una ordenación cuyos elementos eran coincidentes en sus centro de masas con la rígida pieza central y eran percibidos en alzado como parte de una composición simétrica.

En el extremo de la plaza se situaba además una espiral conocida como "Robotnik" (lit.: trabajador) del artista K. Dunikowski (9.12), cuya forma torsionada fue trasladada posteriormente a un proyecto de carácter simbólico posterior de Leykam, el Museo de las batallas revolucionarias y libertarias (9.21).

Los tres arcos establecieron asimismo mediante referentes literales una relación a través de la geometría con la importancia histórica que la obra de Max Berg había tenido en la historia del hormigón armado como referente previo a las estructuras pretensadas que el ingeniero Eugène Freyssinet había realizado en construcciones como el hangar de dirigibles de Orly (1916-23) o el puente de Plougastel-Daoulas de 1926-29 (9.06-9.08).

Una gran cantidad de puentes polacos habían sido destruidos durante la II Guerra Mundial, entre los que se encontraba el emblemático puente Józef Poniatowski de Varsovia destruido en 1944 y reconstruido en 1946 por el ingeniero Stanisław Hempel, una estructura de acero que a lo largo de 8 vanos de diferente luz era capaz de salvar un paso de 509 metros de ancho sobre el río Vístula. El profesor Hempel fue el autor de la estructura central de la plaza, "Iglica" (Aguja), una pieza adyacente a los tres arcos que estaba destinada a ser el símbolo del 'resurgimiento' de las comunidades de los Territorios Recuperados.

El 3 de julio 1948 se elevaba sobre la plaza de la exposición la estructura de Hempel en el vano que dejaba libre el arco central que todavía estaba pendiente de montar (9.16), quedando el espacio necesario para la puesta en pie de esta esbelta estructura de acero de 106 metros de altura, formada por una serie de secciones de acero que iban desde los 3 metros de canto hasta los $21 \mathrm{~cm}$ de diámetro y $4,5 \mathrm{~cm}$ de su antena. La base articulada sobre tres soportes, permitía la estabilidad del conjunto que tenía un peso total de 44 toneladas, y para cuyo izado fue necesaria la utilización de 7 plataformas elevadoras $(9.15-9.18)$.

El recinto ferial de Wroclaw fue inagurado finalmente el 21 de julio, en una exposición que se extendería durante 100 días hasta el 31 de octubre de 1948, y el acceso quedó dominado por los tres arcos de madera y la presencia de la Aguja de Stanisław Hempel. El recinto fue visitado por más de 1,5 millones de personas entre los que figuraron ilustres visitantes como el pintor Pablo Picasso. ${ }^{9.03}$

El acceso a la Exposición de las Tierras Recuperadas fue el primer trabajo en que Leykam tuvo que adaptar su trabajo a una expresión artística en un contexto artístico imbuido por el incipiente Realismo Socialista, que obligaba a realizar

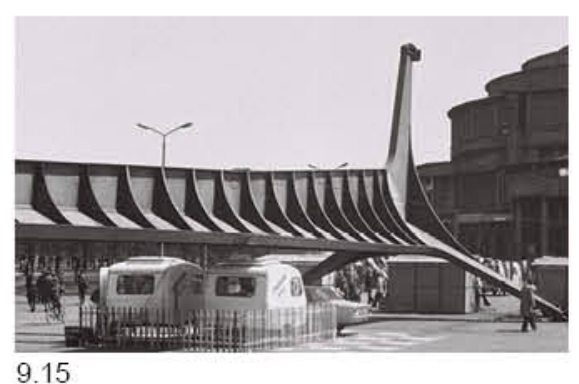

9.15

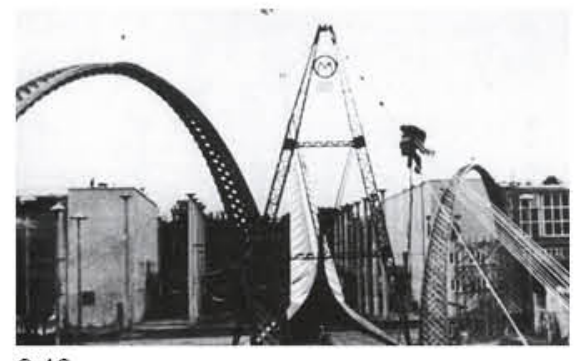

9.16
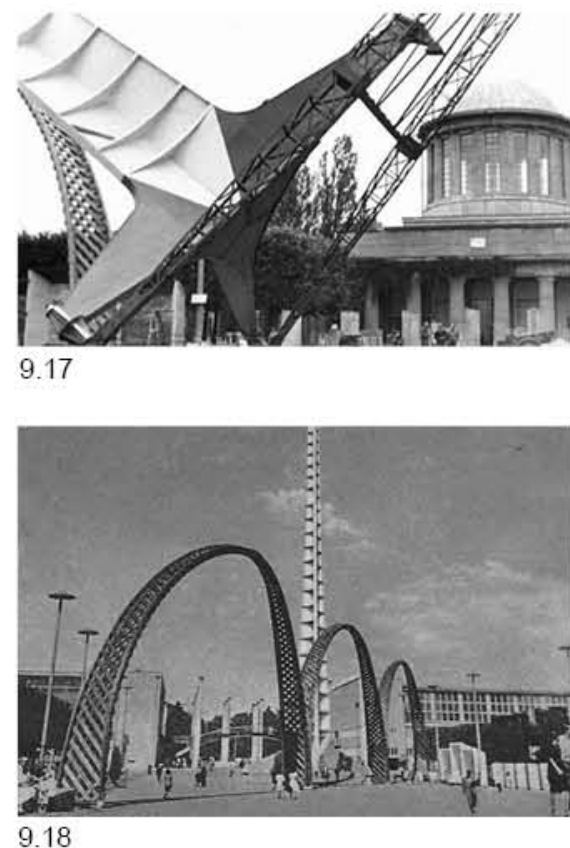

9.10. Muzeum Rewolucji w Warszawie, 1964 

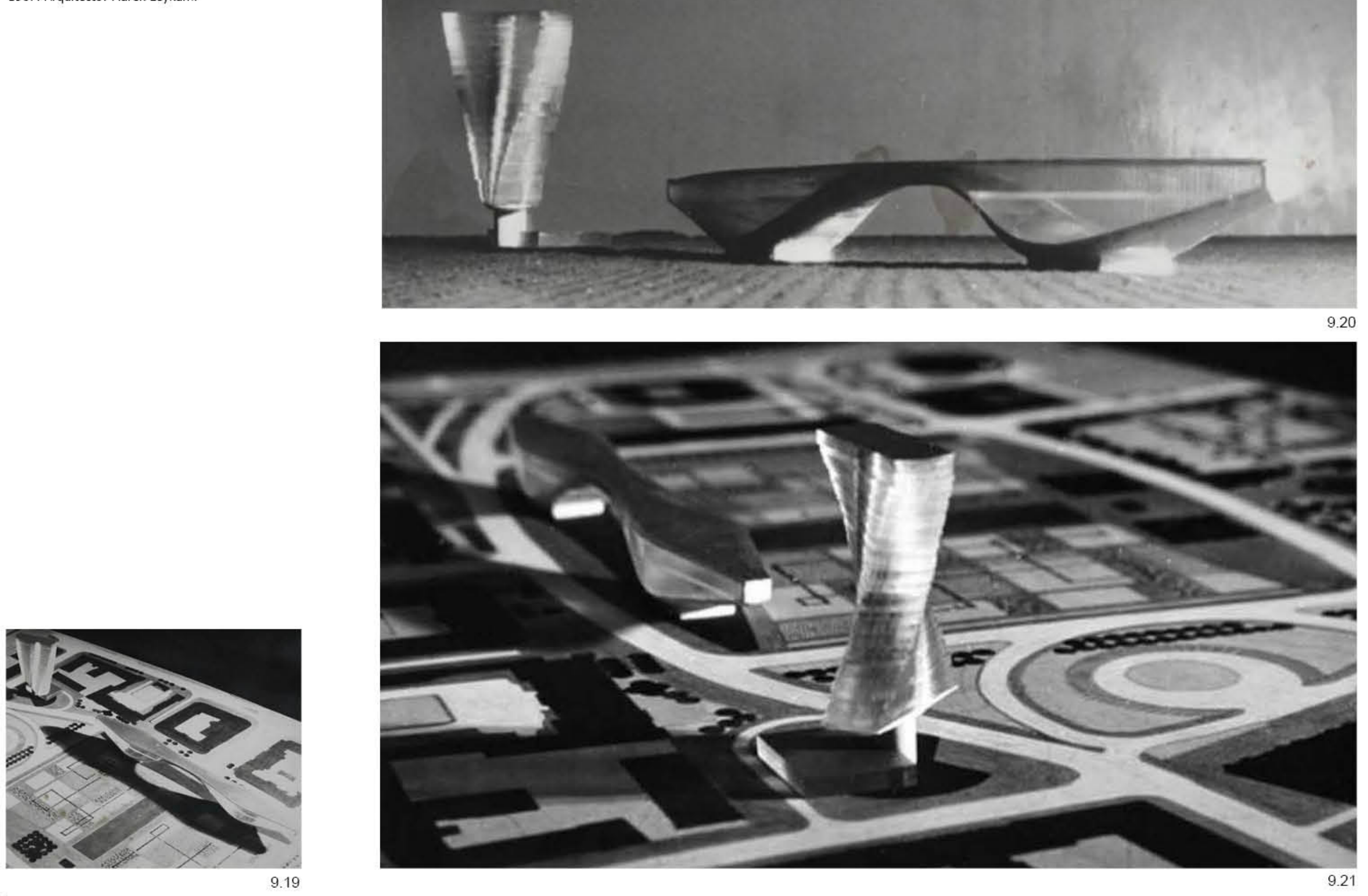
una traslación literal de la experiencia visual a las composiciones presentadas. La propuesta de situar estas piezas atravesando el patio en diagonal, supuso asimismo un gesto que, a nivel perceptivo, permitía imaginar dibujado en el aire el trazo de un objeto que se desplazase rebotando a lo largo de la explanada de acceso, trasladando así una sensación de dinamismo en un lugar dominado por la estática aguja triunfante planteada por Stanisław Hempel y la propia simetría del Palacio del Pueblo.

Con el paso del tiempo, tanto los Tres arcos como la Aguja se convirtieron en símbolos de la Exposición de los Territorios Recuperados, aunque en la actualidad en el lugar solo es posible visitar Iglica, que todavía permanece en pie. A partir de esta primera experiencia, los proyectos que Marek Leykam recibió en el futuro asociados a formas representativas o monumentales de carácter conmemorativo encontraron en esta exposición un lugar común y un punto de partida desde el que referenciar su trabajo.

\subsubsection{Museo de las Batallas de Revolución y Liberación de Varsovia}

En 1964 Leykam se presentaría al concurso del Museo de las Batallas de Revolución y Liberación 9.10 (9.19-9.21), con un proyecto aparentemente descontextualizado de su propuesta arquitectónica que, sin embargo, cabe interpretar en clave escultórica como un proyecto en continuidad con las representaciones literales que llevó a cabo en la Exposición de las Tierras Recuperadas. Resuelto con un ejercicio formal que no tiene correspondencia aparente con la simplicidad constructiva y la inmediatez geométrica característica de sus edificios construidos, el Museo de las Batallas de Revolución y Liberación se abordó desde la representatividad de la forma, manteniendo únicamente la simplificación geométrica que implicaba que las soluciones volumétricas fueran modulables a través del trazo de superficies regladas.

El análisis del esquema viario del área de proyecto propició que Leykam decidiese separar el programa en dos partes situando dos elementos contrapuestos a escala territorial que remiten inexcusablemente a una formalización alegórica de los dos tipos de batallas a las que refiere el museo reproduciendo simbólicamente una figura libre y otra en forma de sólido de revolución.

De las imágenes del concurso se deduce que el conjunto de piezas traslada de nuevo un mensaje literal a través de la representatividad de la forma. Al igual que en la Exposición de los Territorios Recuperados, la idea del puente esta presente en la pieza horizontal al mismo tiempo que la generación de un gran arco cuyo vano permite enmarcar las visuales que abren a los espacios adyacentes.

Del mismo modo que había ocurrido en el proyecto no construido para la capilla de Solothurn (3.43), un hito vertical a escala territorial establece el contacto visual con los observadores del edificio que lo contemplen desde largas distancias mientras que una pieza marcadamente horizontal compensa la composición desarrollando el programa a una escala 


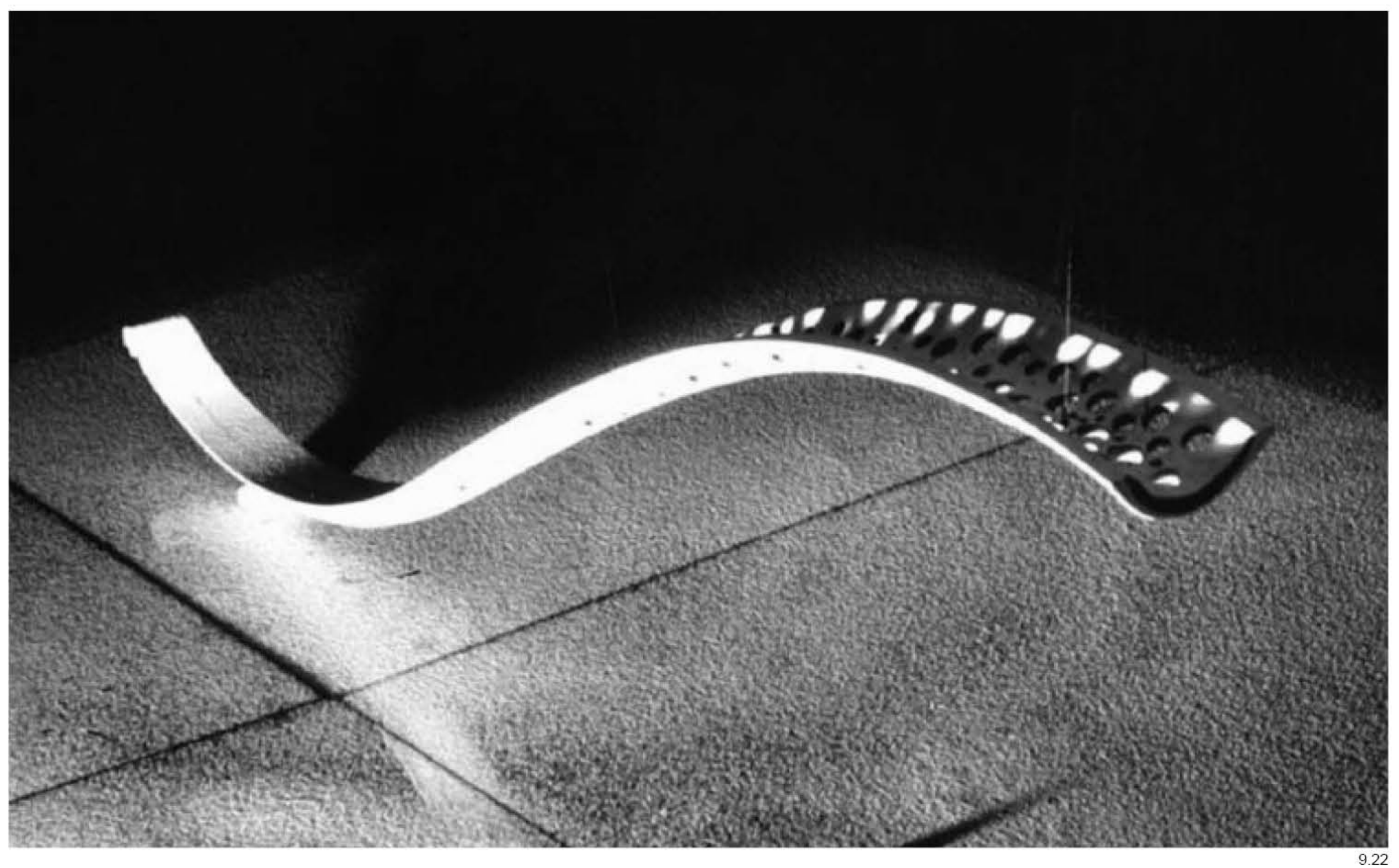


cercana al espectador creando un equilibrio a nivel urbano y una lectura conjunta de la ordenación. La pieza horizontal se resuelve desde la maqueta mediante dos plataformas, una inferior oscilante en alzado y una superior plana que tienen una proyección en planta similar. La sinuosa figura que trazan en planta les permite acentuar la imagen de movimiento que el conjunto del Museo de la Revolución planteado por Leykam pretende transmitir.

A pesar de la aparente complejidad formal, las soluciones de alzado quedan contenidas en un plano ortogonal al suelo que puede ser resuelto técnicamente sin dificultad, aunque la composición general no hubiera optimizado las piezas prefabricadas ni maximizado el aprovechamiento del espacio, tal como era habitual en sus soluciones arquitectónicas.

La torre torsionada del conjunto tiene un marcado carácter icónico, enfatizando el desplazamiento de la figura para alcanzar su actual posición. La esbeltez de su base proyecta la atención sobre el eje de rotación sobre el que se ha producido el giro y deja a la vista el importante alarde estructural que supondría su ejecución. La geometría, una vez más, sigue siendo trasladable a una superficie plana ya que el volumen final es el resultado de la torsión de un prisma de bases iguales y de proporción rectangular.

\subsubsection{Monumento a la Victoria en el eje Saski de Varsovia}

Ese mismo año, Leykam participaría en otro concurso abierto en que la geometría del arco resultaría de nuevo su propuesta básica a nivel conceptual: el monumento a los Héroes de Varsovia ${ }^{9.11}$, anunciado en febrero de 1957 y resuelto en abril de 1958 tras un largo periodo de deliberación. ${ }^{9.08}$

El número de participantes que concurrió a este proyecto fue muy elevado -se entregaron 196 propuestas-, debido a que la convocatoria se realizó a nivel internacional y la intención de este concurso era constituir un gran símbolo para el país, un proyecto que asociase la imagen de Polonia a un icono a nivel mundial.

Sin embargo, a pesar de este gran interés despertado, por circunstancias políticas y económicas finalmente el concurso quedó desierto y la propuesta quedo cancelada, sin ni siquiera otorgar el primer premio como compensación. Leykam concurrió a este concurso junto a Czesław Czułowski y su ingeniero de estructuras habitual Stanisław Zalewski, y su propuesta fue reconocida con una de las cinco menciones de honor.

Dado que desde las bases ya existía libertad en torno a la propia ubicación del monumento, el equipo de Leykam ubicó la propuesta en el interior del Jardín Saski, y planteó a nivel urbano una serie de elementos a lo largo de la avenida principal que recorría el eje del jardín, como una lámina de agua enmarcada por dos hileras de árboles que recorría sinuosamente la avenida.

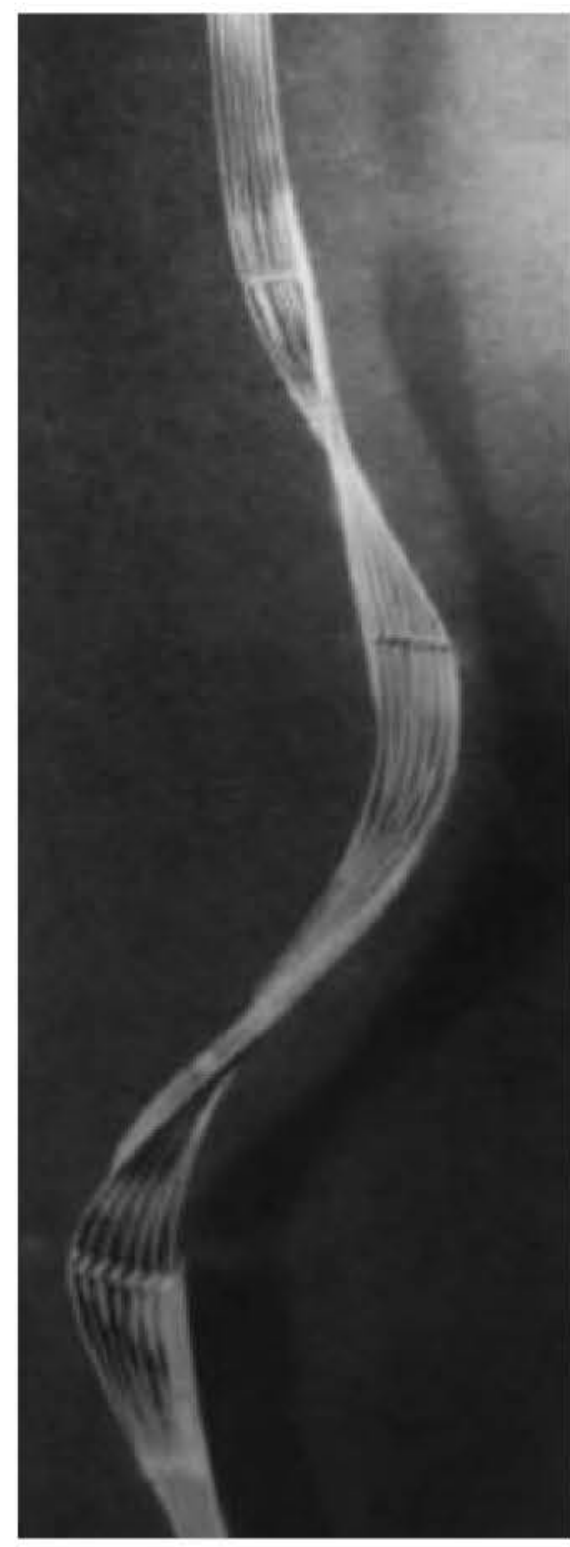

9.23

9.11. Monumento a los Héroes de Varsovia, posteriormente Monumento a la Victoria (Pomnik Zwyciestwa) en el eje Sask. 
9.24 Boceto del Gateway Arch (Puerta hacia el Oeste) que sería parte del Monumento a la (1963-1965). Arquitecto: Eero Saarinen.

9.25 Proyecto de monumento a la Victoria (Pomnik Zwyciestwa) en el eje Saski de Varsovia, 1964.

9.26 Eero Saarinen obsrevando la maqueta del Gateway Arch (Puerta hacia el Oeste), parte del Monumento a la Expansión Nacional de Jefferson en San Luis, Misuri (1963-1965). Arquitecto: Eero

9.27 Proyecto de monumento a la Victoria (Pomnik Arquitecto: Marek Leykam.

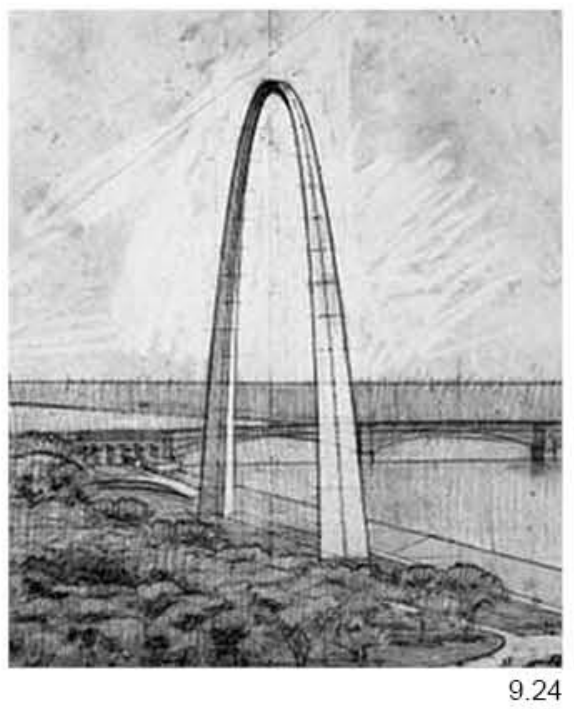

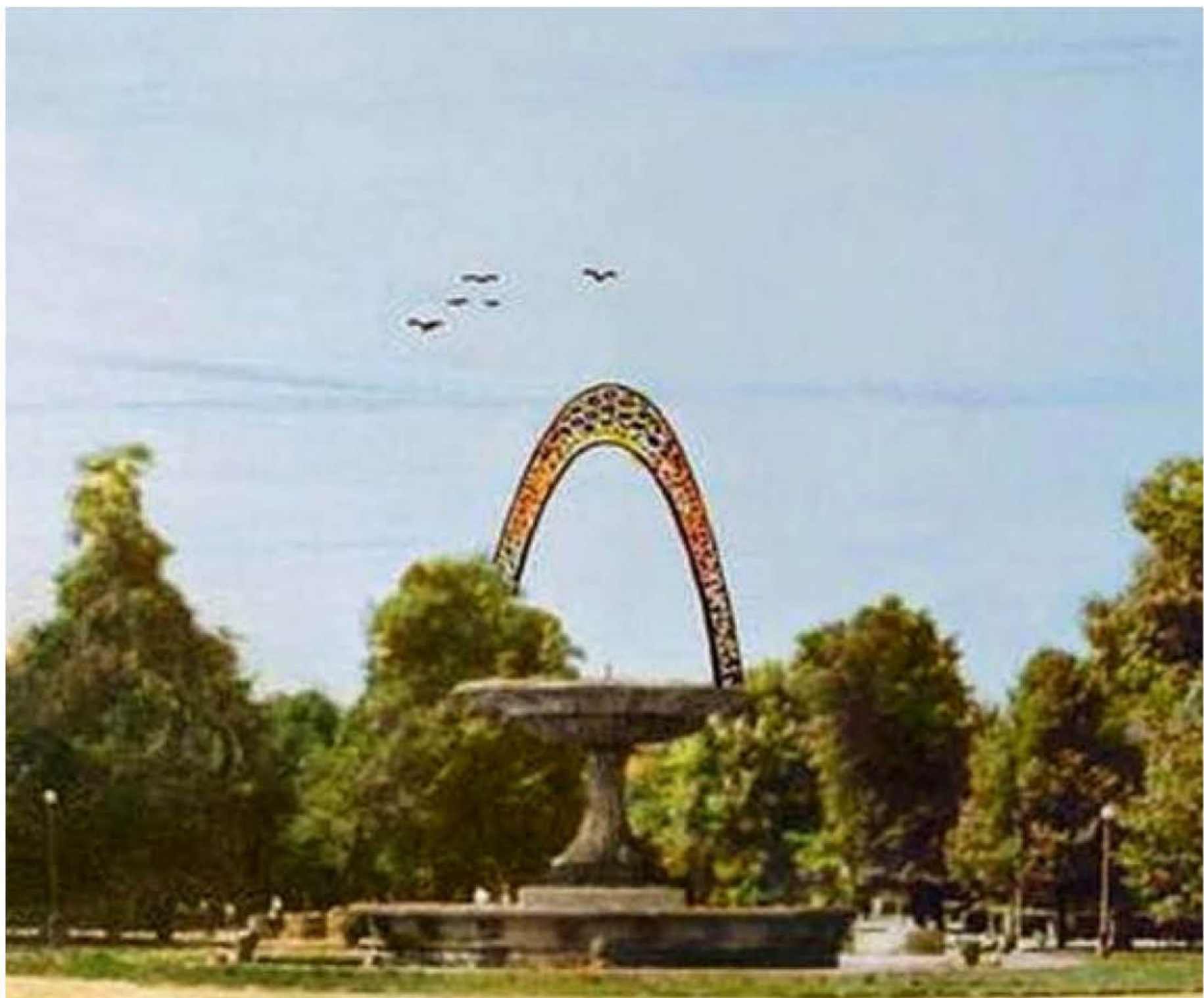

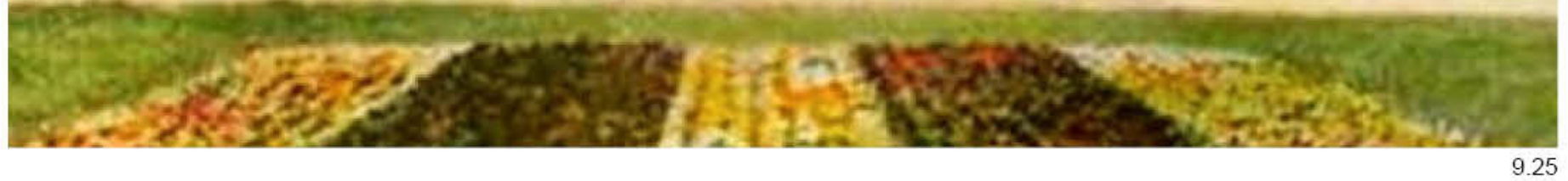


A nivel paisajístico, ya en la intersección de los jardines Saski con la calle Marszałkowska, el equipo de Leykam plateó una estructura de acero en vertical en forma de cinta torsionada (9.23) compuesta por siete tiras de metal conectadas en varios puntos por travesaños horizontales, que ofrecía una imagen sinuosa que enlazaba la escultura con la lámina de agua que había traído el recorrido del visitante hasta el lugar.

La ligereza de esta escultura y la idea de movimiento asociada a la pieza, queda patente en la marcada presencia de sus fibras mostrando una delicada estructura longitudinal, lo que llevó a críticos como Jur a asociar este proyecto con la obra del escultor suizo Max Bill. ${ }^{9.08}$

Del proyecto del Monumento a la Victoria han trascendido una serie de imágenes que dan idea del nivel de definición con que Leykam afrontaba los detalles constructivos, tal como hemos visto en presentaciones de concursos anteriores como la Mezquita de Varsovia en 1936 (2.23 - 2.28), el edificio del Banco Nacional BGK (Bank Gospodarstwa Krajowego w Poznaniu) de Poznań en 1937 (2.39 - 2.45), o particularmente el proyecto no realizado para la Capilla en el cementerio de Solothurn en homenaje a los soldados caídos en la II GM, realizado en Zúrich en 1943 (3.31-3.35).

La propuesta de Leykam está basada en el trazado de un gran arco en forma de catenaria, una icónica propuesta que remite la versión propuesta en 1947 por Eero Saarinen y el ingeniero de estructuras Hannskarl Bandel para el Gateway Arch de Saint Louis $(9.24 ; 9.26)$, obra que sin embargo no fue posible construir hasta 1963 y que no fue finalizada hasta octubre de 1965

Desde la etapa del concepto definida a través de un bocetos (9.25), el proyecto de este monumento pasa directamente a una serie de maquetas de detalle en las que se define la materialidad del arco mediante una serie de texturas entre las que se incluyen perforaciones artesanales sobre un bloque cerámico a través del cual se puede intuir la importancia dada por Leykam al filtrado de la luz que permita generar contrastes de colores y matices que cambien la percepción del arco según la distancia de observación.

Al igual que en los Tres Arcos de la Exposición de los Terrenos Recuperados, el proyecto del Monumento a la Victoria Leykam establece una traslación literal de patrones artesanales cerámicos que potencia las posibilidades expresivas a nivel perceptivo de esta obra, pero la aleja de una lectura que permita codificar su trabajo como un búsqueda integral de soluciones racionales a todas las escalas. A pesar de todo, Leykam mantuvo el sentido de la proporción, el cuidado por el detalle constructivo y la simplicidad diagramática a nivel general desde la idea de linealidad.

Los proyectos escultóricos de Leykam buscaban la representatividad a través de formas geométricas abstractas que mantuvieran una idea de continuidad asociada al movimiento y el paso del tiempo, sin embargo, las circunstancias políticas condujeron a una materialización invariablemente asociada a reminiscencias literales de la tradición polaca, lo que da una idea de la fuerte instrumentalización ideológica del arte oficial en Polonia en aquellos momentos.

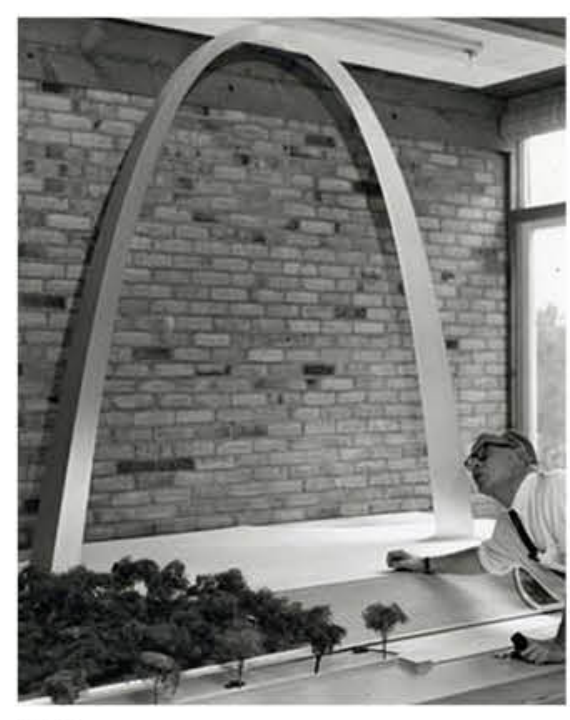

9.26

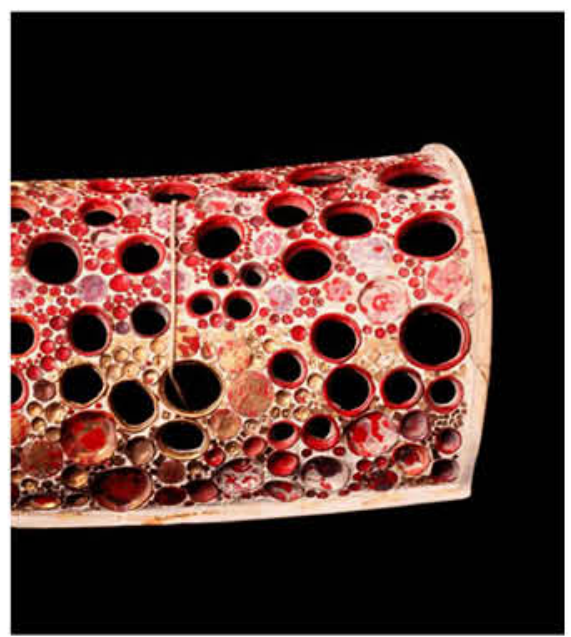

9.27 
10.01 Cartel anunciando la financiación, a reconstruccion en Berlin Oeste, Alemania.

10.02 Manifestaciones durante el "Hungerwinter" de 1947 (invierno del hambre). El 31 de marzo miles de Krefeld (Alemania) en protesta por la escasez de alimentos. En el cartel: Queremos carbón (dinero). Queremos pan.

10.03 El presidente de los Estados Unidos Harry S.

de abril de 1948 .

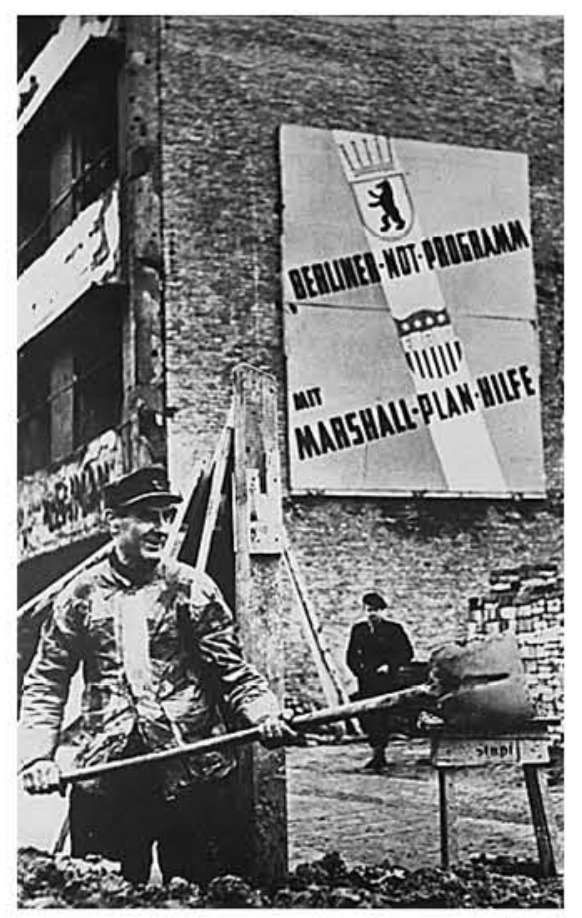

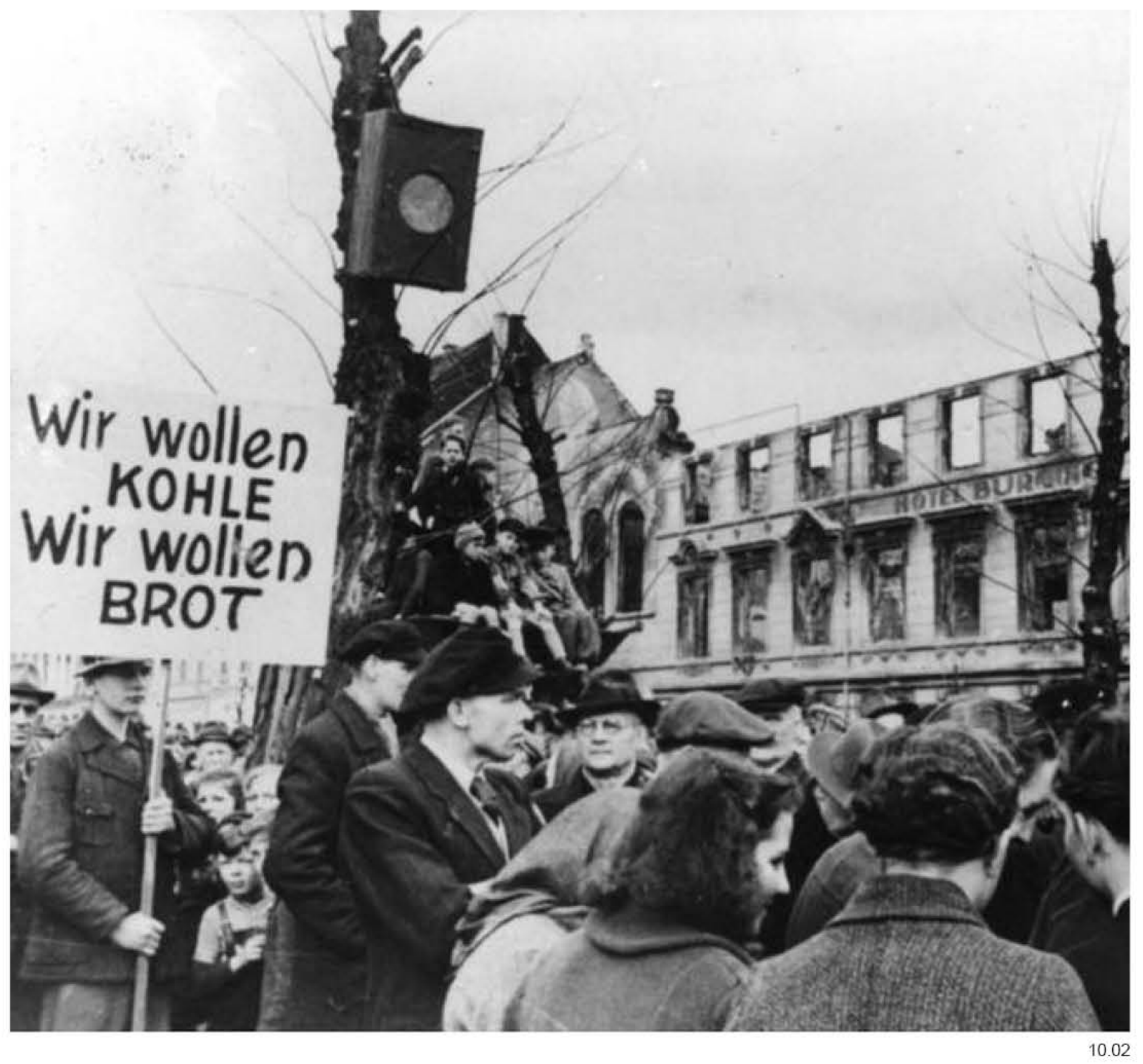


"Cuando la vida se teje con estambres legalistas surge una atmósfera de mediocridad moral que paraliza los más nobles impulsos humanos."

Aleksandr Solzhenitsyn. "A World Split Apart". ${ }^{10.01}$

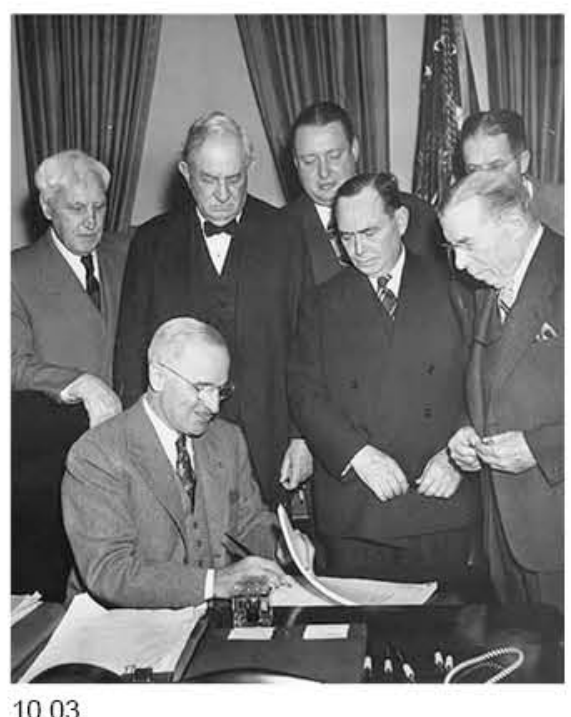

10.03

En el verano de 1947 el presidente Harry Truman, a instancias del Secretario de Estado George Marshall, decidió adoptar medidas para contribuir a la recuperación europea a través de un plan encaminado a su rehabilitación financiera mediante una aportación económica que recibiría el nombre de Plan Marshall. ${ }^{10.02}$

El 12 de julio de 1947 fueron convocados en París los representantes de todos los países de Europa que habían participado en la Guerra a excepción de España y los pequeños estados de Andorra, San Marino, Mónaco y Liechtenstein. La URSS fue también convocada, así como la mayoría de países del incipiente bloque oriental, pero la consigna emitida desde Moscú tras una reunión previa mantenida también en París por el Ministro de Asuntos Exteriores soviético Viacheslav Mólotov y sus homólogos de Gran Bretaña y Francia fue la de no acudir y negarse a la creación de este plan, decisión que se haría extensiva a los países situados bajo el control soviético y que significaría un momento clave en las posibilidades de desarrollo y reconstrucción de naciones como Polonia tras la II Guerra Mundial. ${ }^{10.03}$

El primer ministro polaco, Józef Cyrankiewicz, fue particularmente conminado a rechazar cualquier ayuda del plan a cambio aceptar un acuerdo alternativo de comercio quinquenal con la URSS, hecho que marcaría la dependencia económica de la nación y al mismo tiempo su tutela social y cultural en la medida en que todos estos ámbitos quedaban relacionados bajo la dirección de los círculos políticos soviéticos. ${ }^{10.04}$

10.01. "A World Split Apart" Discurso pronunciado por Aleksandr Solzhenitsyn en la Universidad de Harvard el 8 de junio de 1978 .

10.02. La norma JCS 1067, que ordenaba a las fuerzas estadounidenses de ocupación que "... no llevasen a cabo ninguna medida para la rehabilitación económica de Alemania", fue reemplazada por la JCS 1779 que, en su lugar, establecía que "Una ordenada y próspera Europa requiere la contribución económica de una estable y productiva Alemania." Ref: Pas de Pagaille! Time 28 de julio de 1947

10.03. Hogan, 1987.

10.04. Articulo: "Poland: Carnations". Monday, Feb. 09,1948 . Fuente: content.time.com 
10.04 El barrio de Nowa Huta en 1960 .

$\mathbf{1 0 . 0 5}$ Maqueta del plan general de la ciudad de Nowa Huta en 1951.

10.06 "En la cuenca del Don", 1947. Alexander Denek. Oleo sobre lienzo.'

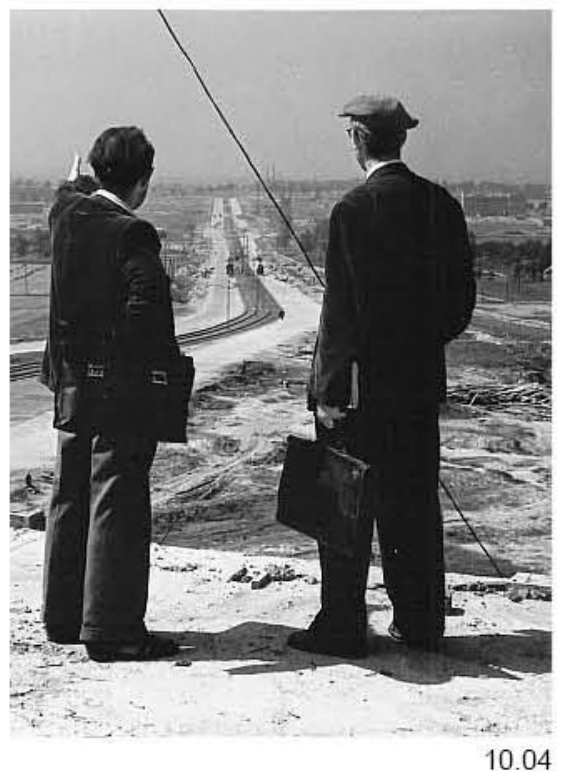

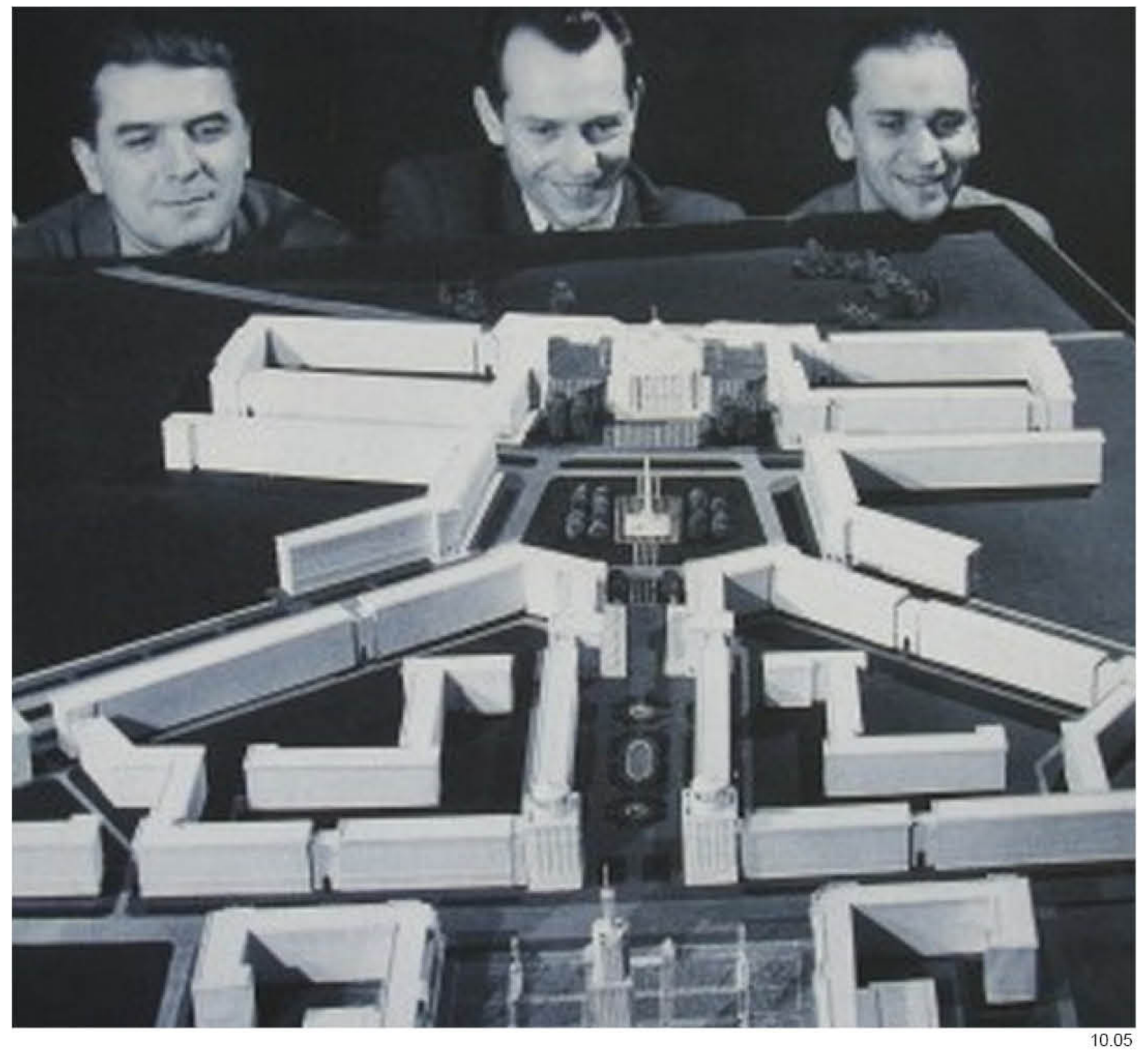


Una de las ciudades alemanas incluidas en territorio polaco tras el nuevo orden fronterizo, Schreiberhau, que había pasado a llamarse Szklarska Poręba ${ }^{10.05}$, había celebrado entre el 22 y 27 de septiembre de 1947 la conferencia de dirigentes de Partidos Comunistas (KPSS) ${ }^{10.06}$ con el objetivo de dar una respuesta al Plan Marshall para los países de influencia soviética, así como consensuar una política de contención de los Estados Unidos, para lo que fue fundada la Oficina de Información de los Partidos Comunistas y Obreros (Kominform) en sustitución de la antigua Kominterm, y el establecimiento de los Consejo de Ayuda Mutua Económica (COMECON) ${ }^{10.07}$ a iniciativa de la URSS.

El conjunto de medidas planteadas en Sklarska Poreba por el presidente de la KPSS, Andréi Aleksándrovich Zhdánov, incluía la llamada Doctrina Zhdánov ${ }^{10.08}$, que había sido concebida en oposición a la Doctrina Truman, y cuyo objetivo era marcar la separación economía y política de los países soviéticos, los cuales pasaban a formar parte del control educativo, artístico y social que ejerció la URSS sobre sus países satélites en los siguientes años.

Andréi Zhdánov planteaba la necesidad de movilizar todas las fuerzas que la Unión Soviética tuviera disponibles para combatir ideológicamente el "imperialismo" al que oponía la "democracia" ${ }^{10.08}$. Entre estas fuerzas incluía las artes, que deberían ser reformuladas en base a los principios de la "interpretación verdadera y concreta de la realidad en su desarrollo revolucionario." 10.09

Tomando como premisa la base socialista de que todos los bienes y medios de producción materiales pertenecen a la comunidad en su conjunto, Zhdánov entendió que los medios de producción de arte debían ser igualmente controlados y utilizados como herramienta frente a los valores burgueses y reaccionarios. ${ }^{10.10}$

Surgía de esta forma un nuevo estilo en los países de la URSS impulsado por parte del KPSS y conocido en adelante como Realismo Socialista, cuyo objetivo era "colaborar en la transformación ideológica de los trabajadores, educándolos en el espíritu del socialismo, reduciendo toda la cultura a una clave donde un símbolo dado corresponde a un valor moral simple, [...] expandiendo el conocimiento de los problemas sociales y las vivencias de las personas por medio del arte, glorificando los roles de los humildes y de la clase obrera y la lucha por su emancipación." ${ }^{10.09}$

Todos los artistas de la Unión Soviética tuvieron que adaptarse rápidamente a este nuevo estilo que ya había comenzado a fomentarse en Rusia desde que Stalin implantase el sistema centralizado en 1928. En 1932, durante la celebración del XVII Congreso del Partido Comunista (KPSS), se habían declarado los objetivos de los diferentes grupos de artistas y el concepto de Realismo Socialista fue definido oficialmente por primera vez en el Primer Congreso de Escritores de la Unión en 1934. ${ }^{10.10}$

El 10 de febrero de 1948 sería firmado el decreto Zhdánov, por el que se exigía a todos los artistas, arquitectos, escritores, intelectuales y representantes de la cultura en general de la Unión Soviética que se "ajustasen a las directrices del

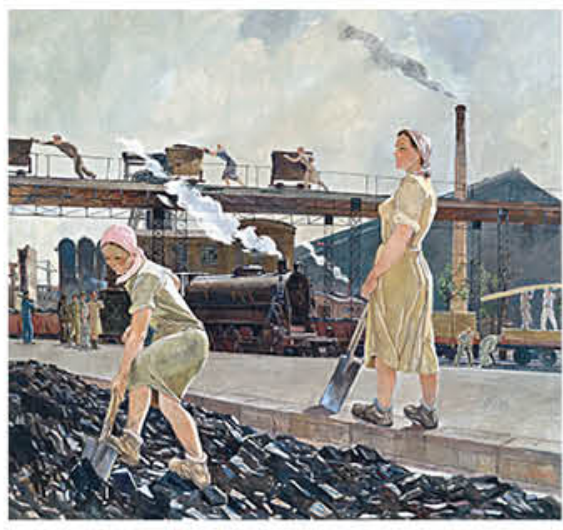

10.06

10.05. El nombre de Szklarska Poręba significa literalmente "compensación de cristal", debido a al principal activo económico de la ciudad, su fábrica de vidrio, fue una de las compesaciones que recibia Polonia.

10.06. Kommunistíchieskaya Pártiya Soviétskogo Soyúza, KPSS.

10.07. El Consejo de Ayuda Mutua Económica (Sovet ekonomicheskoy vsaymopomoshchi SEV en inglés COMECON y en español CAME o CAEM fue una organización de cooperación económica formada en torno a la URSS por diversos paises socialistas cuyo objetivo era el fomento de miembros.

10.08. Informe de la doctrina Zhdánov, 22 de septiembre de 1947, publicado el 5 de octubre d'Humanité

10. 09. Congreso de Escritores Socialistas. Moscú, 1934

10.10. Fontán del Junco, 2011. 
10.07 Mujeres paseando por Nowa Huta en los 60 s. 10.08 Maqueta del proyecto de Nowa Huta.

10.09 Kto kogó?, 1932 (¿Quién podrá con quién?) Alexandr Deineka. Oleo sobre lienzo, 131 × $200 \mathrm{~cm}$. Galería Estatal Tretyakov, Moscu
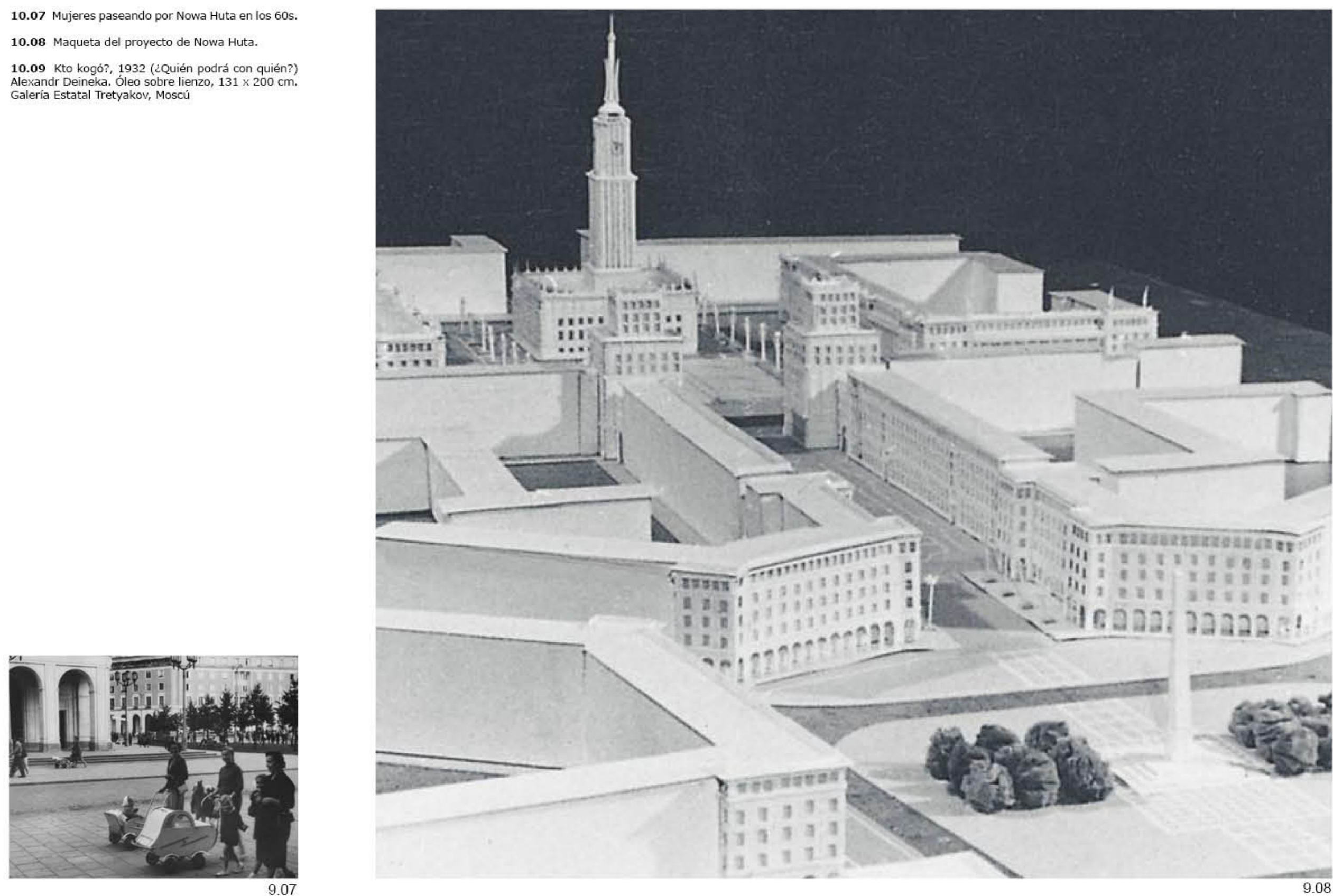
Realismo Socialista en sus trabajos creativos, ante la amenaza de persecución y exhortación a la formulación pública de arrepentimiento en caso de desobediencia." 10.08

En los siguientes años en Polonia el control sobre los proyectos de arquitectura hizo que fuese extremadamente complicado un desafío al Realismo Socialista como estilo oficial soviético. A partir de 1950 se planteó en Varsovia la construcción del Palacio de la Cultura y la Ciencia ${ }^{10.11}$, el edificio más alto de Polonia -que alcanzaría $230 \mathrm{~m}$ cuando fue terminado en 1955- según el proyecto del arquitecto Leo Rudniew. Una vez más era elevado en Polonia un símbolo de la arquitectura soviética heredero de los significados sociales y políticos de edificaciones como la Catedral de San Alejandro Nevsky (1.16).

En esas mismas fechas (1949-54) comenzaba la construcción de la que sería la mayor ciudad de nueva planta del país, emplazada 10 kilómetros al este de Cracovia. Su nombre era Nowa Huta (lit. nueva siderurgia), una ciudad planificada por el equipo de urbanistas de Tadeusz Ptaszycki para albergar a más de 200.000 residentes que construirían ellos mismos la ciudad para pasar a ser los trabajadores de la industria siderúrgica que sería allí mismo construida, Huta im Lenina ${ }^{10.12}$, en su momento una de las mayores acerías de la Unión Soviética.

Aunque la libertad artística había sido drásticamente restringida, hubo variedad de interpretaciones en términos de estilo y de temática dentro de su propósito de resultar accesible a las masas. En pintura destacaron obras como la de Alexandr Deineka ${ }^{10.13}$, que utilizaba temas que apenas habían sido empleados en arte anteriormente como los deportes, la aviación, las fábricas, transporte público, las minas, la agricultura,.. como símbolos de una nueva era.

Los cuadros de Deineka trataban de trasladar el movimiento propio de las vanguardias, convirtiéndolo en elementos figurativos que pudieran ser aceptados dentro de las nuevas directrices artísticas de la iconografía oficial, que consistía en la representación optimista de la fuerza del capital y del trabajo.

El Realismo Socialista fue formulado en la arquitectura polaca por el propio primer ministro Bolesław Bierut, quien publicó un artículo en la revista Architektura titulado "La arquitectura de Polonia ante la creación de las bases del socialismo." 10.14

El artículo de Bierut, mas allá de las premisas ideológicas, contenía algunos enunciados para la creación arquitectónica y las formas de su organización y control. De acuerdo con estos postulados "las ciudades socialistas serían lo contrario de las ciudades capitalistas, a su incontrolada edificación y máxima explotación de la tierra se opondrían barrios integralmente planeados, con una malla regular de amplias avenidas y plazas." ${ }^{10.14}$

Este discurso es considerado el origen del Realismo Socialista en la arquitectura polaca, un momento en que la nueva

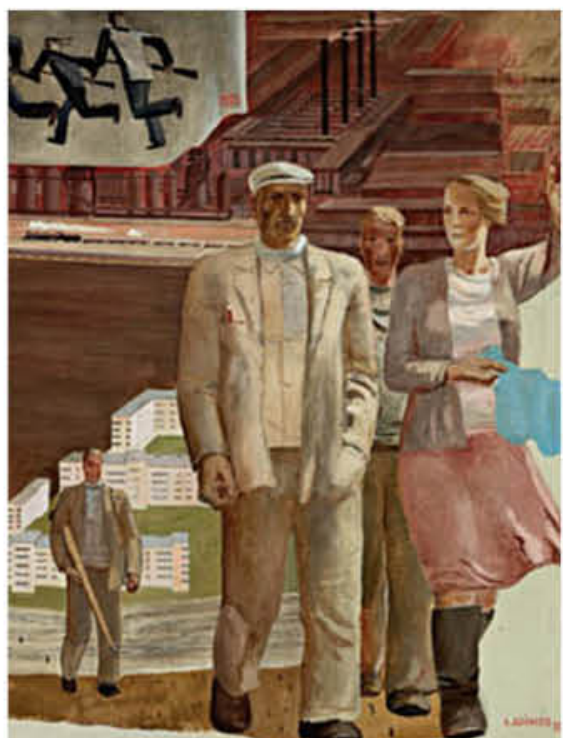

10.09

10.11. Pałac Kultury i Nauki.

10.12. Huta im. Lenina (literalmente siderurgia de Lenin) actualmente es hoy propiedad de ArcelorMittal bajo el nombre de Huta im. T. Sendzimir, siendo la segunda mayor fundición de Polonia.

10.13. Aleksandr Aleksandrovich Deineka (1899 1969) fue un artista soviético nacido en Kursk, que inició su formación en el departamento gráfico de las Vjutemas de Moscú, y durante su trayectoria profesional fue reconocido con los galardones más importantes de la Unión Soviética, entre ellos el Premio Lenin, el título de Artista Meritorio de la el de Artista del Pueblo de la URSS y el de Héroe del Trabajo Socialista.

10.14. "Architektura polska w obliczu budowy podstaw socjalizmu", publicado en la revista "Architektura n 1/ 1949. Cit. 6.15. 
10.10 "1952" Alexandr Deineka. Museo Regional de Bellas Artes de Volgogrado.

10.11 Discurso de Bolesław Bierut durante el Congreso de Unidad del Partido (Kongres Jedności) de enero de 1949.

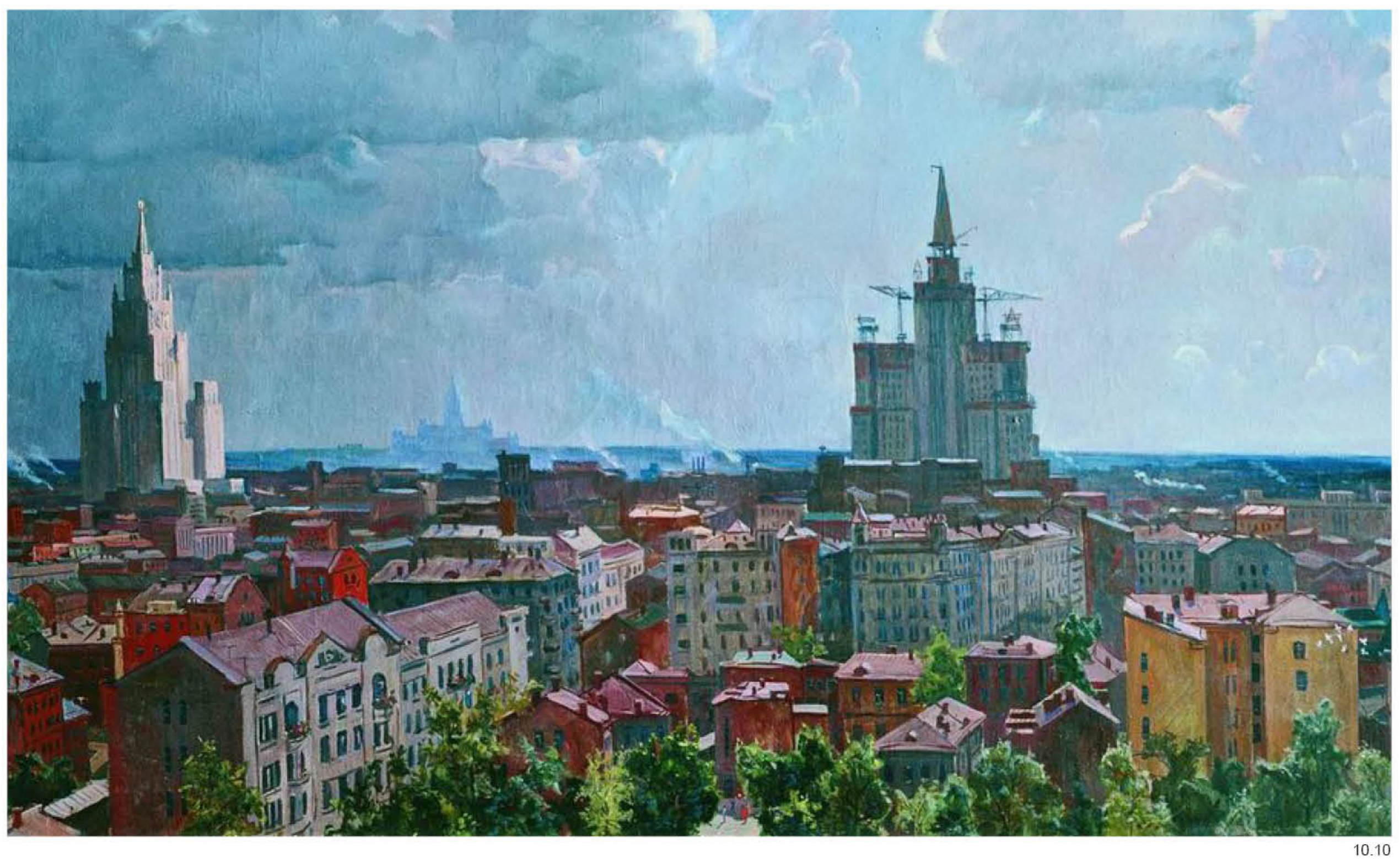


estética desarrollada por la vanguardia de los años de entreguerras y resultante del desarrollo de la construcción sería reemplazada por una "belleza formal no especificada en la práctica pero equivalente a la ornamentación clásica y decoración pseudomonumental." ${ }^{10.15}$

El texto presentado por Bierut también informaba a los lectores sobre el nombramiento de un sistema de "organización y de control de la actividad arquitectónica" ${ }^{10.14}$ para lo cual se estableció el "Comité de Arquitectura bajo la supervisión del Consejo de Ministros." ${ }^{10.16}$ La tarea principal del Colegio de Arquitectos de Polonia, SARP pasaba a ser a partir de entonces la de "vigilar a través del Comité de Desarrollo de la Arquitectura que la construcción tuviese valores socialmente indispensables de la obra arquitectónico-artística." ${ }^{10.14}$ El enunciado de Bolesław Bierut finalizó postulando la "erradicación de todas las tendencias decadentes, retroactivos y las que contemplaban el pasado capitalista." ${ }^{10.14}$

La nueva doctrina surgida en base a este ambiguo planteamiento se puso en práctica rápidamente debido a la financiación administrativa y el apoyo de una parte de los arquitectos. ${ }^{10.15}$ Seis meses después del citado artículo, se celebró un Debate Nacional de los Arquitectos del Partido ${ }^{10.17}$ en junio de 1949, bajo el lema "Lucha por la arquitectura de realismo socialista en el contenido y nacional en forma." ${ }^{10.18}$

A pesar de las complejas discusiones de todo este período de reuniones, no terminó de formularse una definición inequívoca del Realismo Socialista en arquitectura -ni en el ámbito polaco ni en el conjunto de países soviéticos- que formulase los parámetros a los que había que atenerse para respetar el estilo.

Durante varios meses sí fueron surgiendo lemas en consonancia con las reivindicaciones sociales y de carácter nacional en distintos encuentros, pero los postulados referidos a la naturaleza de esta arquitectura terminaban exaltando los "gustos estéticos de las más amplias capas de la población" ${ }^{10.15} \mathrm{e}$ iban cincelándose con las diferentes construcciones y artes auspiciadas por los diferentes comités de control.

Las formas del Realismo Socialista en arquitectura empezaron a basar sus composiciones en los referentes de la arquitectura clásica que había sido construida en Polonia durante el Renacimiento, el Barroco, y sobre todo el Clasicismo. "Sobre la base del clasicismo se creaba un conjunto ornamentado de cuerpos edificados según los patrones traídos directamente de la Unión Soviética." ${ }^{10.15}$ La especificidad de Polonia se limitaba a unos ciertos adornos y combinaciones de detalles vernáculos que trataban de transmitir una imagen tradicional de todo el edificio. ${ }^{10.15}$

Detrás de estas composiciones a nivel volumétrico y su expresión en las fachadas exteriores se escondían interiores cuyo resultado estaba "completamente inadaptado a las necesidades de la vida moderna." 10.15 "La idea de la representatividad en la práctica se transformó en la superficialidad, y la "nueva forma" resultó ser un conglomerado de varios estilos del pasado." ${ }^{10.19}$

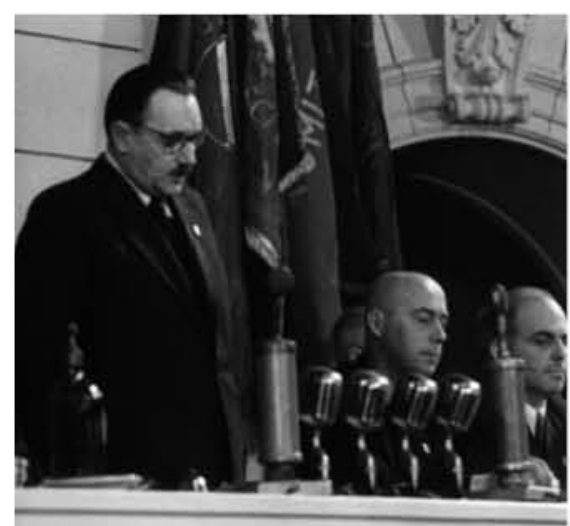

10.11

10.15. Jur, 1977. p $64-75$

10.16. Komitet Architektoniczny przy Radzie Ministrów.

10.17. Krajowa Narada Architektów Partyjnych.

10.18. Walka o Architekturę Socjalistyczną w treści i narodową $w$ formie. Cit. 6.15 .

10.19. Olszewski, 1970. p. 29. Cit. Jur, 1977. p 71. 
10.12 Construcción del proyecto "Nowe Tychy" en

10.13 Zona residencial Marszałkowska (Marszałkowska Dzientica Mieszkaniowa) Varsovia, durante la Marcha

10.14 Palomas en un edificio de la calle Piwna en la Ciudad Vieja (Stare Miasto), 1953

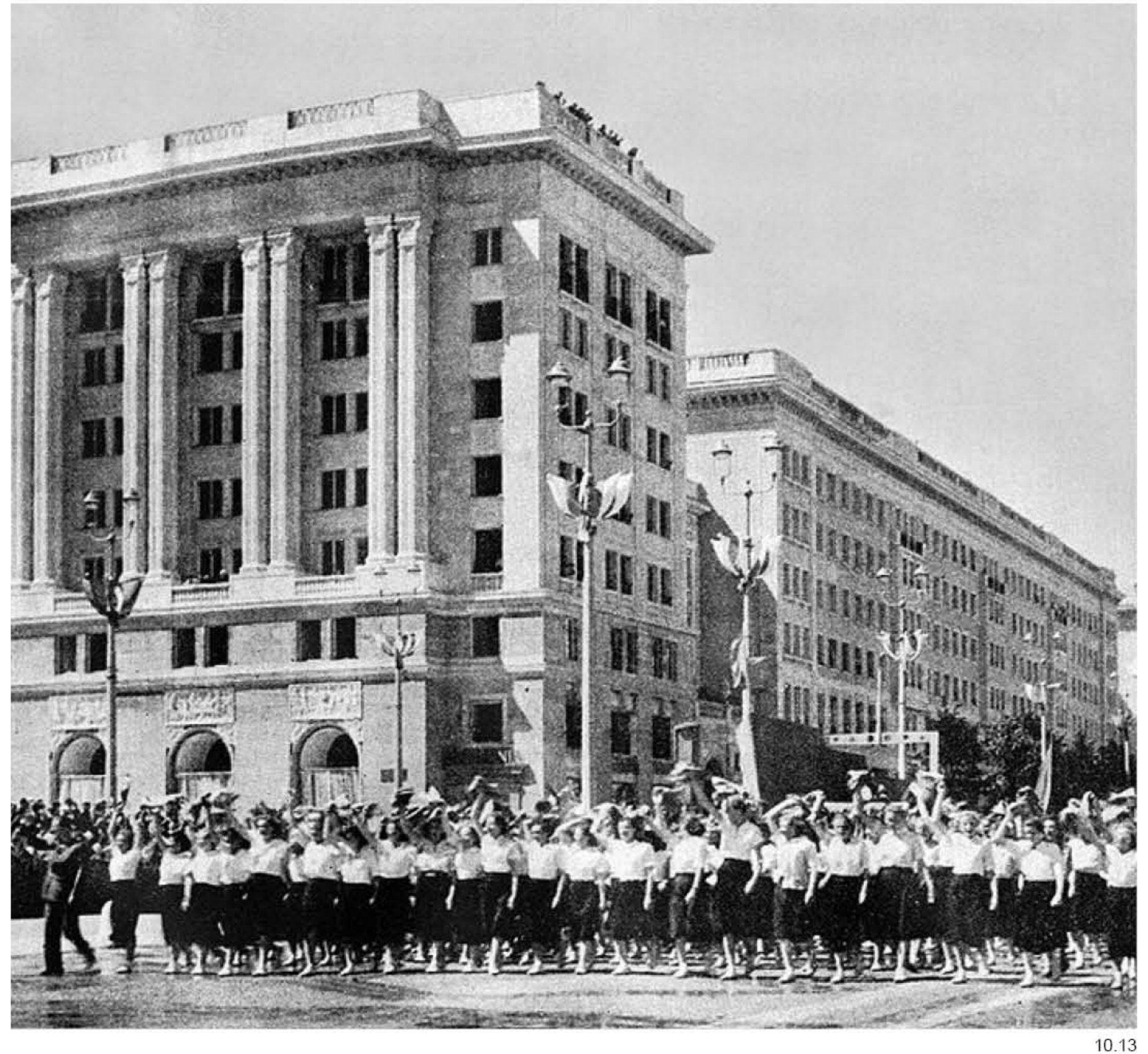


En la construcción de los edificios durante el Realismo Socialista polaco se utilizaron principalmente técnicas de construcción tradicionales (10.14) y se emplearon materiales naturales de alta calidad (mármol, calizas,..) en los edificios públicos con un tratamiento artesanal de los detalles, y la prefabricación quedó relegada a un segundo plano dejando de lado los avances en este campo que habían surgido durante los primeros años de la reconstrucción de postguerra. ${ }^{10.15}$

Multitud de artesanos trabajaron en la elaboración de costosas ornamentaciones en un periodo en que la demanda de arquitectura para cubrir necesidades básicas en Polonia seguía siendo enorme, dejando patente la paradoja de haber constituido un estilo encaminado a acercar el arte al pueblo y satisfacer las que era consideradas sus inquietudes estéticas, teniendo en cuenta las que se consideraban sus capacidades y dentro lo alejado que se suponía que estaba la modernidad de sus posibilidades de interpretación, y lograr como resultado de su imposición estilística un aparcamiento de las técnicas constructivas capaces de responder a las verdaderas necesidades del pueblo, ya que a través de la estandarización y las construcciones industrializadas se estaban realizando las edificaciones que eran capaces de cubrir con mayor celeridad y eficacia las demandas de la sociedad.

Los edificios y conjuntos urbanísticos más característicos de Realismo Socialista de Polonia fueron construidos en Varsovia: la zona residencial Marszałkowska Dzielnica Mieszkaniowa, MDM, Muranów (10.13), Nowa Huta (10.07 10.08) y Nowe Tychy (10.12) diseñado por Kazimierz Wejchert y Hanna Adamczewska.

La influencia del Realismo Socialista no se limitó al ámbito artístico y arquitectónico, ya que según diferentes críticos de la época su implantación "provocó una fuerte reducción en el nivel de educación, frenado de investigación y experimentos científicos." ${ }^{10.15}$ Los arquitectos vivieron durante este periodo grandes dificultades para desarrollar su labor en relación con los movimientos contemporáneos debido al control ejercido sobre las publicaciones arquitectónicas de referencia, la desorganización de los comités encargados del control arquitectónico, la burocratización del trabajo de las oficinas de proyectos y la completa paralización en la aplicación de nuevos métodos de construcción. ${ }^{10.15}$

Durante los primeros años de Realismo Socialista en Polonia la arquitectura de Marek Leykam sufrió fuertes críticas ${ }_{10.15} 10.20$ debido a la falta de adaptación al criterio oficial en las obras que estaba terminando de construir, tanto los Żyletkowiec de Varsovia como el Dom Towarowy Okrąglak de Poznań. Las acusaciones no se limitaron a desprestigiar su obra sino que apelaron a su falta de capacidad profesional e hicieron decaer el número de encargos oficiales que llegaron esos años a su oficina. ${ }^{10.15}$

El carácter especialmente fuerte de Leykam le llevo a sostener acaloradas discusiones públicas y a enemistarse con varias personalidades de la arquitectura polaca del momento, partidarios todos ellos del Realismo Socialista. Según comenta Piotr Gawłowski 10.21 "Leykam estaba seguro de que era un arquitecto excepcional y que solo él tenía razón, y que no estaban a la altura de su nivel deberían adaptarse a su criterio".

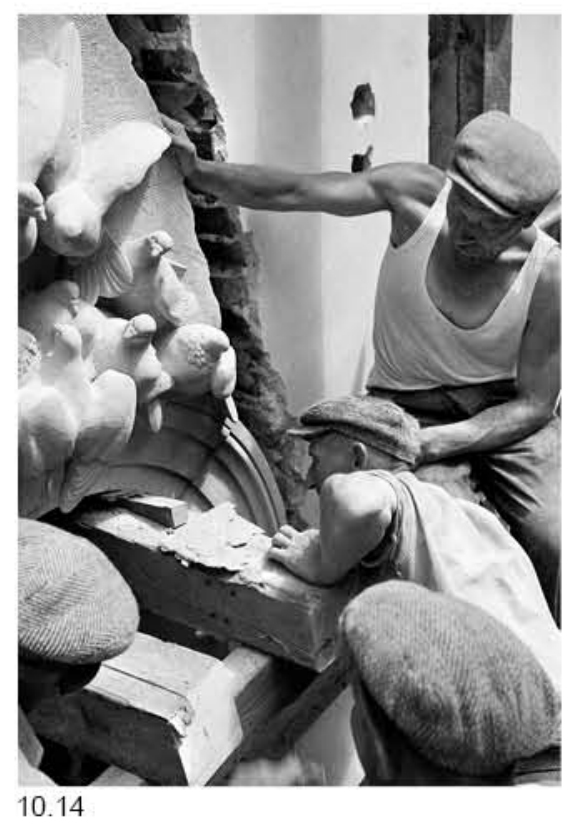

10.14 
10.15 Zygmunt Steppiński, Józef Sigalin, Stanisław Jankowski y

Dzielnica Mieszkaniowa de Varsovia en 1950.

10.16 Marek Leykam.

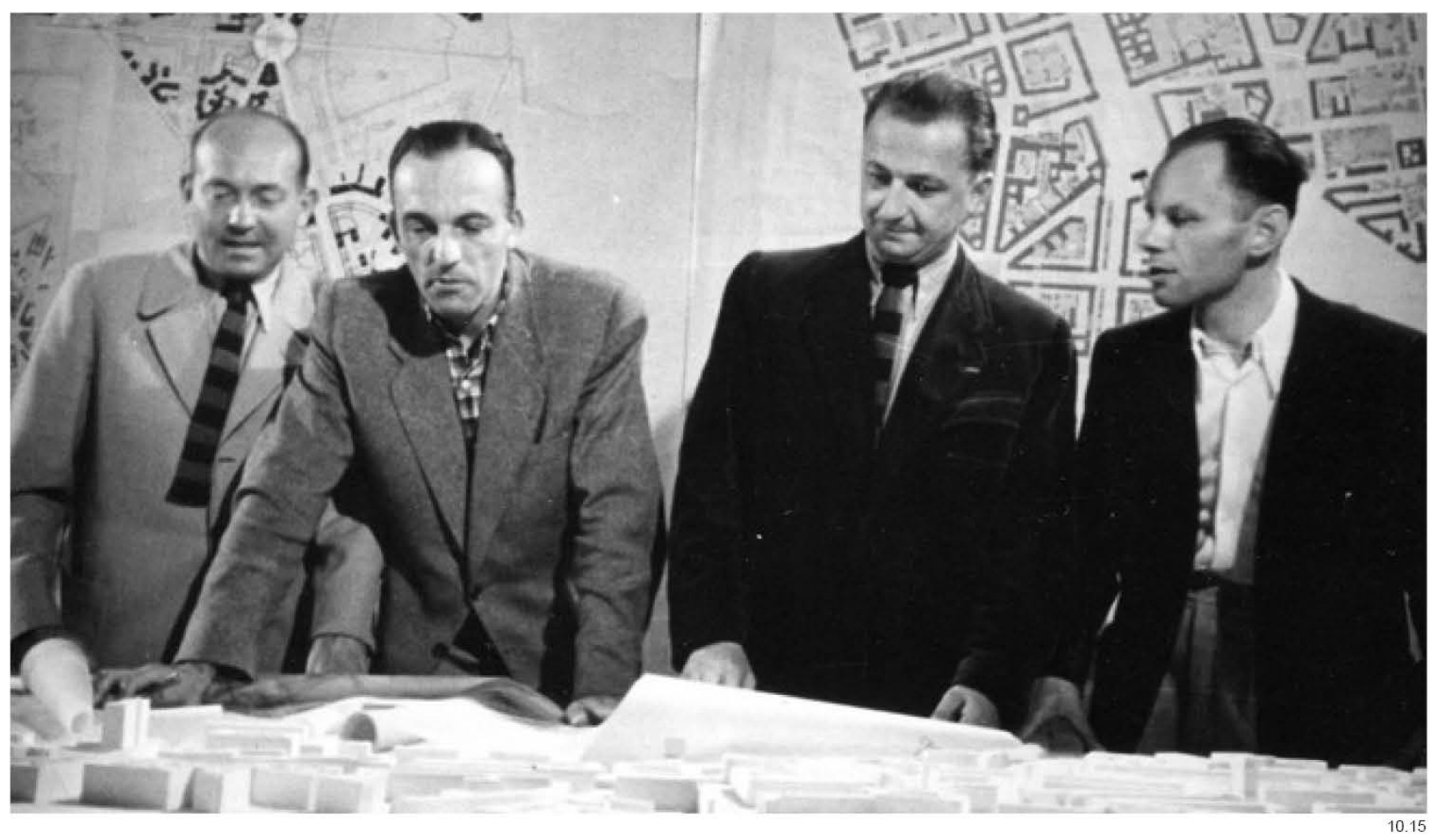


En reuniones al más alto nivel en las sedes de Comité de Desarrollo de la Arquitectura y el Colegio de Arquitectos de Polonia (SARP), Leykam llegó a levantarse y marcharse de un encuentro en presencia del presidente del país Bolesław Bierut -según relato de los presentes-, acusando a los consejeros del partido de "diletantes extremos e ignorantes de arquitectura" 10.15 en un momento de la historia de Polonia en que, en palabras del periodista F. Springer, "no cerrar un cajón con llave o no precintar un armario podían significar la prisión." ${ }^{10.20}$

Existen citas recogidas por Springer ${ }^{10.20}$ en las que contemporáneos de Leykam relatan sus desplantes en encuentros para consensuar el Realismo Socialista en la sede del SARP con afirmaciones como: "No voy a participar más en esta discusión puesto que es absurda, abandonando la sala dando un portazo." ${ }^{10.20}$ Un contemporáneo de Leykam, el arquitecto Jan OkoloKulak, recuerda asimismo en sus memorias que Leykam se negó a cooperar con la revista Arquitectura durante los años del Realismo Socialista afirmando que "con analfabetos no iba a hablar de literatura." 10.20

Cabe señalar que Leykam se sabía poseedor de cierta independencia dentro del sistema de control que imponía el partido comunista por sus fuertes vínculos personales con algunos altos cargos como su antiguo compañero de clase, el también arquitecto Marian Spychalski, primer presidente de Varsovia y jefe de la Dirección General de la Información del Ejército Polaco con quien había realizado concursos en sus primeros años de ejercicio profesional ${ }^{10.22}$ y al que debía parte de los encargos que le habían recibido directamente, como la sede del organismo que dirigía (10.27). ${ }^{10.23}$ La caída en desgracia de Marian Spychalski dentro del partido comunista entre 1951 y 1953 pudo haber tenido alguna relación asimismo con el descenso de encargos de su oficina en esos años. ${ }^{10.24}$

\subsubsection{Fábrica de Camiones de Lublin.}

Para continuar construyendo durante los años del Realismo Socialista, Leykam tuvo que adaptar su trabajo a las nuevas condiciones y buscó refugió en los encargos que iba recibiendo de edificios de carácter industrial, trabajando entre 1949 y 1954 en la Fábrica de Camiones de Lublin ${ }^{10.25}$, la Fábrica Cementera ${ }^{10.26}$ y los Talleres Cartográficos de Varsovia. La forma, tamaño y composición de los edificios industriales proyectados por Leykam en esta época fueron consecuencia de las necesidades funcionales derivadas de las actividades de producción, aunque pueden observarse algunas soluciones que desvelan su lucha por mantener la continuidad de su arquitectura.

La fachada de la Fábrica de Camiones de Lublin (10.17) está realizada, de nuevo, con un alzado que traza una malla de montantes verticales y horizontales, en la que no existen prioridades de paso y todos los encuentros se producen al mismo nivel. La estructura de fachada tiene una profundidad de $20 \mathrm{~cm}$ y canto de $8 \mathrm{~cm}$ y los intersticios están acristalados en base a una trama que mantiene un vano uniforme y cuadrado de $60 \times 60 \mathrm{~cm}$. Los muros superior e inferior que conforman el marco perimetral del volumen -siguiendo el mismo criterio compositivo que los Żyletkowiec- tienen

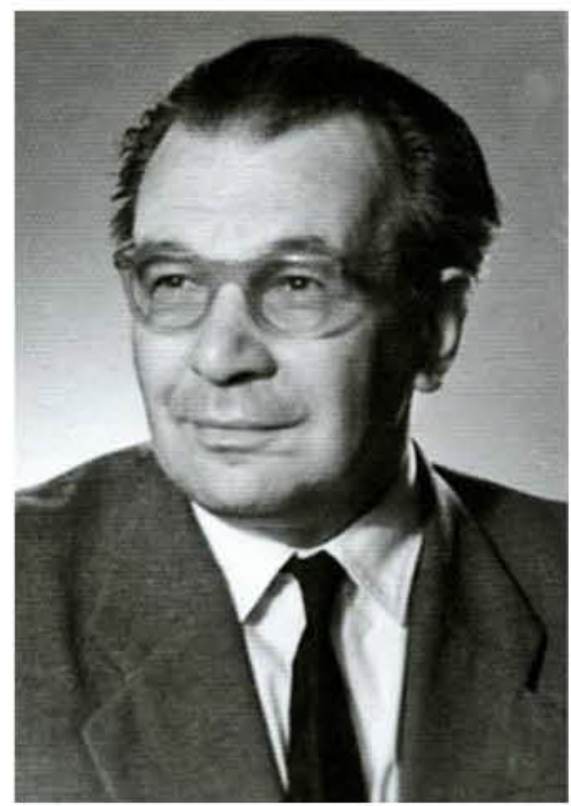

10.16
10.21. Piotr Gawłowski es doctorando por la Universidad Técnica de Łódz y está preparando una tesis doctoral sobre Leykam aun no publicada (2015). Cit. 10.20 .

\subsection{Spychalski, 2015. p 82}

10.23. Leykam y Hryniewiecki habian sido elegidos por Spychalski como arquitectos de la sede Dirección General de la Información del Ejército

10.24. Marian Spychalski fue acusado en noviembre de 1949 de desviación a la derecha nacionalista retirado de sus cargos en el gobierno y expulsado del Comite Central del Partido Comunista. En mayo intentar cambiar el sistema politico acusado de polaco permaneciendo en la cárcel del estado torturas fisicas y psicológicas hasta 1953 en que fue exhonerado y restituido de todos sus cargos. Cit. Błażyński, 2012. 
10.17 Fábrica de Camiones de Lublin (Fabryka Samochodów Ciężarowych w Lublinie), 1949-50. Arquitecto: Marek Leykam.

10.18 Fábrica cementera de Varsovia (Cementownia Warszawa), 1953-56. Arquitecto: Marek Leykam.

10.19 Proyecto para el Instituto General de Investigaciones Tecnológicas de Varsovia (Instytut Podstawowych Problemów Techniki), 1951. Arquitectos: Marek Leykam, Jerzy Hryniewiecki y Czesław Rajewski.
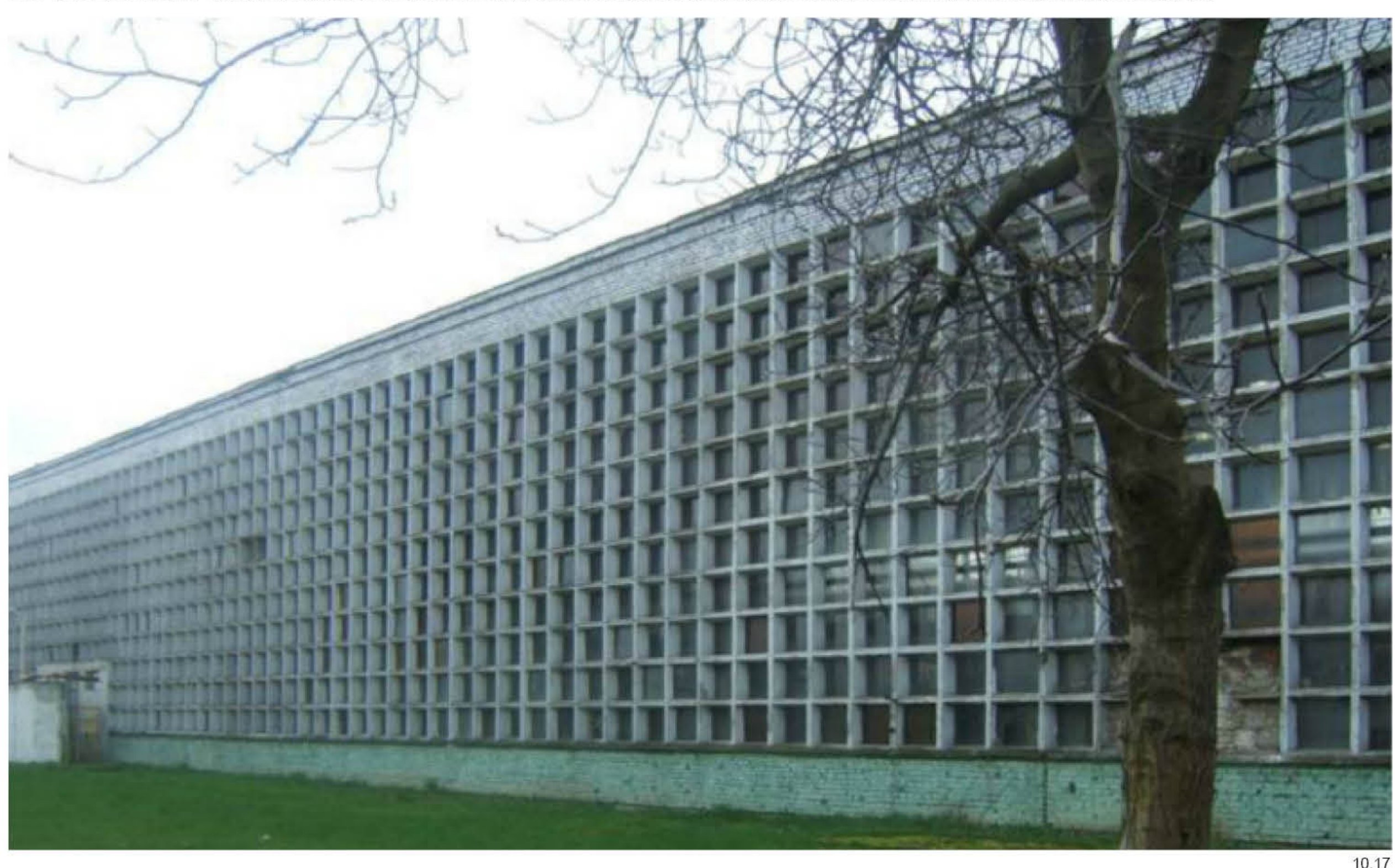
ambos $76 \mathrm{~cm}(60+8+8)$ integrándose en la trama y están realizados en tabique de ladrillo caravista, dando idea del abandono que estaban sufriendo en aquellos años los procesos de estandarización e industrialización de los edificios.

El planteamiento de la direccionalidad del volumen sigue estando presente en este proyecto al quedar predominantemente ciegos los testeros de la fábrica donde fueron ubicados los accesos de los camiones y personal y resolver con una solución continua y permeable las fachadas longitudinales a lo largo de $90 \mathrm{~m}$ de desarrollo.

\subsubsection{Instituto General de Investigaciones Tecnológicas de Varsovia.}

Durante estos años, Leykam continuó vinculado a la docencia, estableciendo contacto con la nueva generación de arquitectos polacos como Krassowski, Krasinski, Marcolli, Akwinger, Wróbel, Krajewska, Michalowski,.. entre otros. En 1951 decidió sin embargo volver a tomar parte en los concursos organizados por SARP, a pesar de que era consciente de que obligatoriedad de adaptarse a los criterios del Realismo Socialista implicaría plantear soluciones que difícilmente podrían adjuntar a su argumentario arquitectónico.

En 1951, Leykam presentó junto a Jerzy Hryniewiecki y Czesław Rajewski una propuesta para el Instituto General de Investigaciones Tecnológicas de Varsovia (Instytut Podstawowych Problemów Techniki), en la que se puede intuir a partir de las perspectivas que han trascendido a nivel de boceto (10.19) un intento de continuar el proceso de proyecto de los Żyletkowiec de Varsovia, creando una trama de fachada que ya desde el propio grafismo agrupa proporcionalmente partes de la fachada dentro de una modulación regular. Este proyecto no fue reconocido y quedó relegado por no adaptarse a los estándares de la época, y en los siguientes años los concursos a los que concurrió el equipo de Leykam han sido interpretados por algunos críticos de arquitectura polacos como una "crítica irónica" 10.20 o incluso una "burla al estilo oficial. ${ }^{, 10.20}$

\subsubsection{Pabellón de Polonia de la Exposición Agrícola de Moscú.}

De nuevo con Hryniewiecki, Leykam presentó ese mismo año una propuesta para el Pabellón de Polonia de la Exposición Agrícola de Moscú ${ }^{10.27}$ (10.22) cuyas formas venían en gran medida forzadas por el programa de la competición, en el que se instaba a "realizar formas arquitectónicas nacionales"10.15. Situación similar fue la acontecida en los concursos para el diseño de la Casa del Ejército polaco de Varsovia ${ }^{10.28}$ (10.20) -en el que Leykam se presentó junto a Bolesław Malisz y Marian Sulikowski (10.19) y se solicitaba "un plan de ordenación de carácter clasicista" 10.15, haciendo referencia desde la propia memoria a la composición de los jardines del Palacio de Versalles-, y el concurso para el Arco de Liberación (Euk Wyzwolenia) de Lublin (10.21).

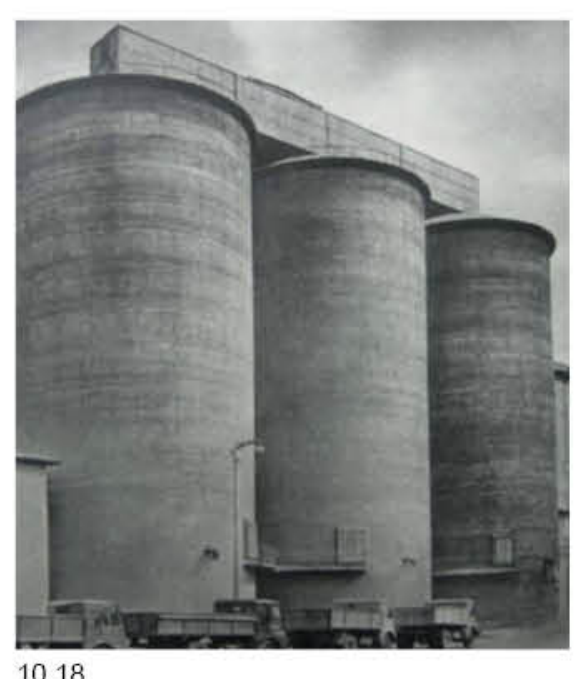

10.18

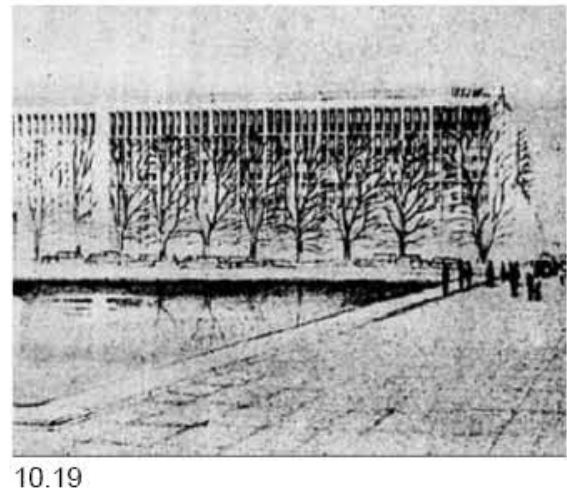

10.25. Fabryka Samochodów Ciężarowych w Lublinie, $1949-50$.

10.26. Fabryka Cementownia Warszawa, 1953-56.

10.27. Projekt Konkursowy na Polski Pawilon na Wystawe Rolniczą w Moskwie, 1951

10.28. Dom Wojska Polskiego, 1953 
10.20 Concurso para el diseño de la Casa del Ejército polaco

10.21 Imagen del concurso para el Pabellón de Polonia en la y Jorzy Hryniewiecki. Moscu, 1951. Arquitectos: Marek Leykam

10.22 Concurso de Proyectos del Arco de Liberación (kuk Wyzwolenia) Lublin, 1951. Arquitectos: Marek Leykam y Jerzy Hryniewiecki.

10.23 Primera versión no realizada de la Sede de la Presidencia del Gobierno en la c/ Wspólna no62 de Varsovia. Arquitecto: Marek Leykam.

10.24 Segunda versión no realizada de la Sede de la Presidencia del Gobierno en la c/ Wspólna nº62 de Varsovia. Arquitecto: Marek Leykam.
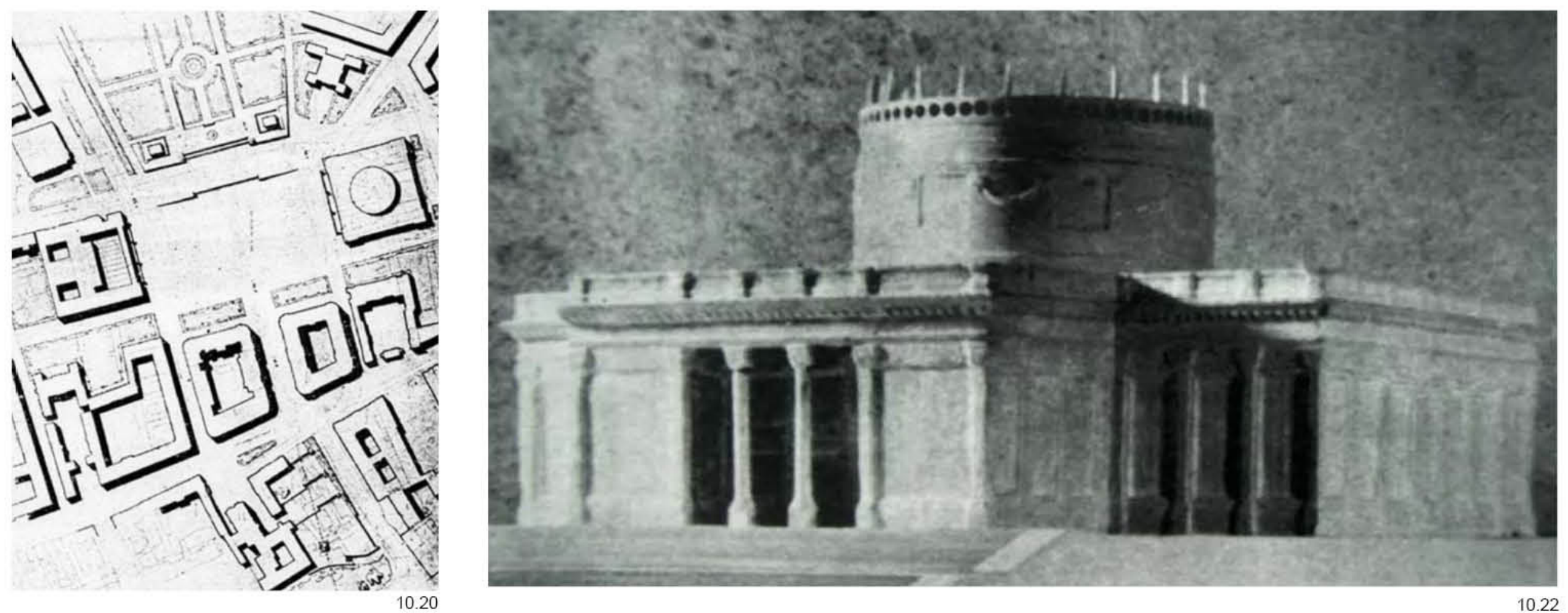
Durante el periodo que duró el Realismo Socialista, Leykam construyó un único edificio bajo la premisa de adaptarse a estos principios, aunque -como ha quedado explicado- eran criterios que no estaban definidos y resultaban de la subjetividad del supervisor. Este edificio fue la Sede de la Presidencia del Gobierno en la calle Wspólna $n^{\circ} 62$ de Varsovia realizado entre los años 1950-52, un encargo que llegó a sus manos gracias a la intermediación de Marian Spychalski, primer alcalde de Varsovia, compañeros de estudios de Leykam y con quien había realizado el concurso del Centro de Vela en Gdynia en 1936 (2.34 - 2.37). A día de hoy este edificio es considerado el "mayor desafio construido a las formas aceptadas por parte del Realismo Socialista" 10.20 , habiendo sido capaz de superar todas las cribas del Comité de Control sin eliminar una segunda lectura que permitió a Leykam realizar una propuesta en continuidad con el planteamiento arquitectónico de su obra anterior.

La Sede de la Presidencia del Gobierno tuvo un proyecto inicial que fue descartado por no ajustarse a las directrices del Realismo Socialista (10.23-10.24), en el que Leykam presentó un diseño de 13 plantas con estructura de hormigón armado y una composición de fachada que respetaba los criterios ya comentados de Żyletkowiec, con la particularidad de inclinar las fachadas laterales para crear un éntasis que fuera capaz de compensar visualmente la deformación que produce el ojo humano al observar la trama de montantes verticales desde la cota de la calle. La altura libre de la última planta también fue aumentada para favorecer la corrección de este efecto.

El desarrollo de esta propuesta da muestras del estrecho control al que eran sometidos los proyectos durante los primeros años del Realismo Socialista en Polonia. Tras el rechazo del primer proyecto (10.23), Leykam presentó una versión modificada en la que se puede ver lo molesto que le resultaba hacer cambios con criterios tan puramente subjetivos (10.24). En la entrada al edificio Leykam situó cuatro columnas jónicas tal como advirtió que era del gusto de los supervisores sin molestarse siquiera en desplazarlas hacia el centro de la fachada. A ambos lados del acceso aparecieron dos estatuas que no tienen relación entre ellas (una estatua ecuestre y otra de un león en un pedestal en una posición lateral) y todo el edificio fue coronado por una balaustrada tallada con cuatro "héroes" en pedestales. ${ }^{10.29}$ La simplicidad y austeridad de esta propuesta todavía provocó fuertes críticas en el Comité de Control. ${ }^{10.16}$ Leykam consideró que iba a ser imposible seguir adelante con este proyecto respetando su habitual método de trabajo y trató de resolver el encargo con una nueva propuesta que tuviera como inspiración directa las soluciones clásicas.

El volumen de 13 plantas fue abandonado y Leykam presentó al poco tiempo un nuevo proyecto de únicamente 6 alturas y planta cuadrada que dejaba de lado la idea de crear un contraste a escala urbana entre el Żyletkowiec de la calle Santa Barbara y el nuevo edificio de la Sede Presidencial. Ambas piezas pasaban a entenderse por separado a pesar de ser contiguas y haberse construido en los mismos años ya que el breve lapso de tiempo entre ellas coincidió con la formalización del control del arte y la arquitectura llevado a cabo durante el Realismo Socialista. Las circunstancias
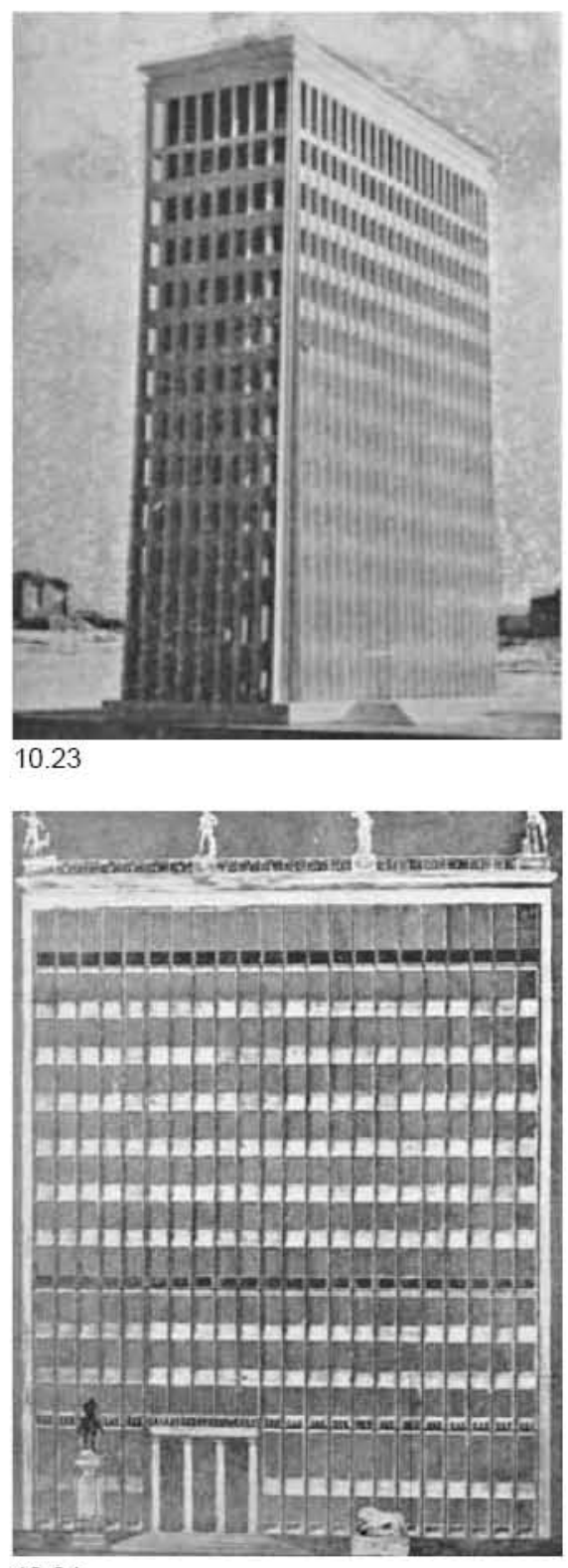

10.24

10.29. Zieliński, 2009. p 184 
10.28 Maqueta con la ordenación urbanistica Barbary en contraste con la Sede de la Presidencia del Gobierno.

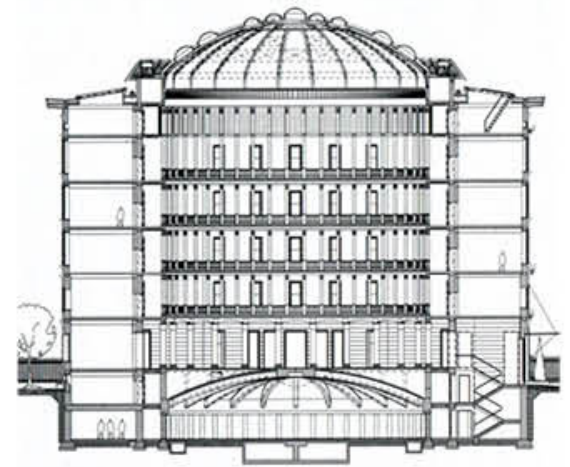

10.25
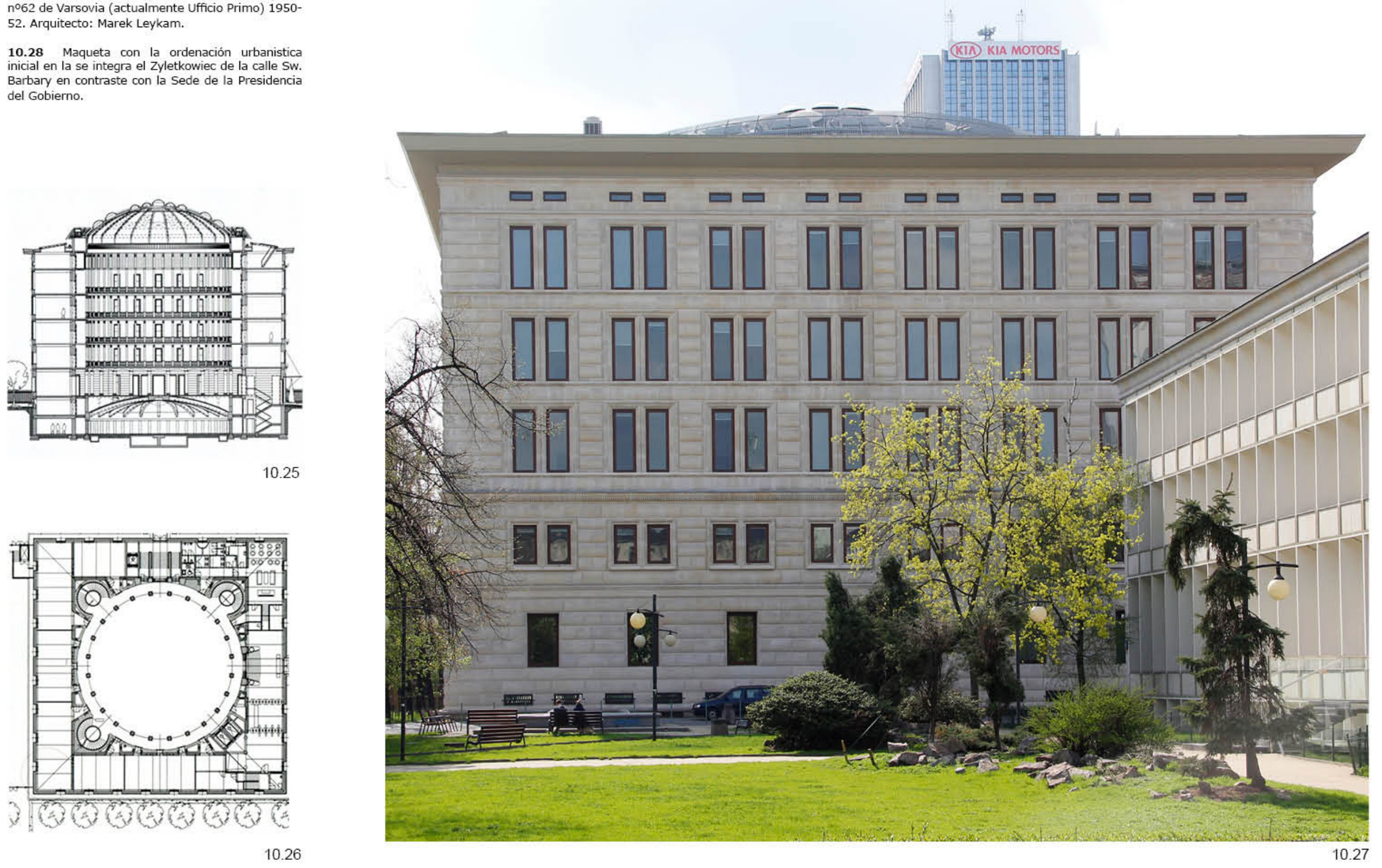
históricas determinaron así una composición urbanística que el arquitecto había tratado de ordenar de forma conjunta, y que finalmente tuvo que ser reconducida hacia una disposición más aleatoria, cuya lectura, a escala territorial, resultase de carácter individual. (10.28).

Con respecto a las referencias clásicas empleadas por Leykam para desbloquear el control del Realismo Socialista y poder realizar un proyecto que tuviera relación con su propuesta arquitectónica, existen diferentes aportaciones a las que esta tesis suma una nueva e inédita interpretación. Según Paweł Giergoń, la propuesta de Leykam hace referencia, en sus fachadas exteriores, a la arquitectura del "Renacimiento italiano". 10.30 "Se pueden encontrar similitudes entre la Sede de la Presidencia del Gobierno y edificios como el Palazzo Strozzi (1538), y el Palazzo delle Assicurazioni Generali (1871) ambos en Florencia. Especialmente este último, construido como un edificio comercial para su uso como oficina de una compañía de seguros, que pudo ser el punto de referencia hipotético para la implementación de este proyecto." ${ }^{10.30}$

Sin embargo, la solución interior del patio circular del edificio, entendido como la propia operación de sustracción de un cilindro sobre un prima de base cuadrada, parecen hacer referencia también al Palacio de Carlos V de Granada (España) del arquitecto Pedro Machuca (10.37-10.41), del mismo modo que el desarrollo interior del patio encuentra un referente en la estructura del Retablo Mayor de la Catedral Vieja de Salamanca (España), que fue dibujada a mano por el propio Leykam en 1943 durante la realización de su Doctorado en la ETH de Zúrich (10.30-10.36).

Los intersticios del patio interior pueden ser interpretados asimismo en continuidad con el bloque adyacente de la calle Santa Bárbara (10.27), en consonancia con el método compositivo racional que estructuraba los Żyletkowiec. La extracción del cilindro sobre el volumen prismático puede ser entendida como el negativo de la fachada de Dom Towarowy Okrąglak de Poznań situado en el interior de la Sede de la Presidencia del Gobierno.

A nivel compositivo, dos cuadrados y dos círculos con centros de gravedad coincidentes son las figuras geométricas que delimitan los contornos construidos más importantes de este proyecto. Un cuadrado de $45 \mathrm{~m}$ define la posición de la fachada exterior de 22,5 $\mathrm{m}$ de altura (2:1) simétrica, mientras que un segundo cuadrado de $31.75 \mathrm{~m}$ delimita las oficinas dando paso a una banda de servicios contenida entre el cuadrado más pequeño y el más grande de los círculos, de 30 $\mathrm{m}$ de diámetro, en la que quedan recogidas tres escaleras de caracol y un núcleo de ascensores además de los baños y áreas de servicio auxiliares. De la equidistancia entre el círculo de 30 de diámetro y un segundo círculo de $25 \mathrm{~m}$ surge un corredor de $2,5 \mathrm{~m}$ de anchura perimetral al patio interior de $25 \mathrm{~m}$ de diámetro y $25 \mathrm{~m}$ de altura hasta la coronación de la linterna superior (1:1).

Las cuatro fachadas fueron resueltas de forma idéntica con un acabado de fachada de sillares de mampostería. Cada uno de los alzados exteriores tratan de adaptarse al ritmo 1-3-1 habitual en las composiciones de fachada de Leykam

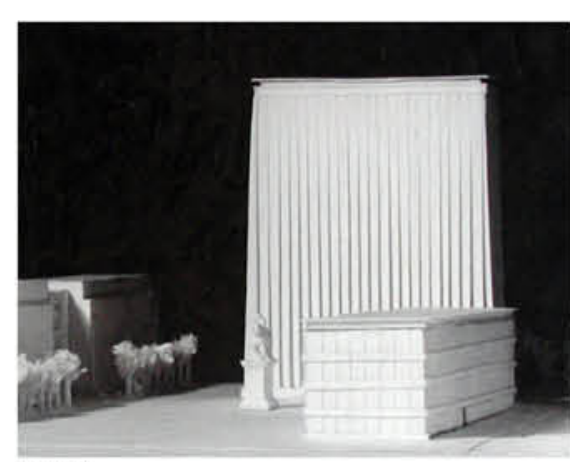

10.28

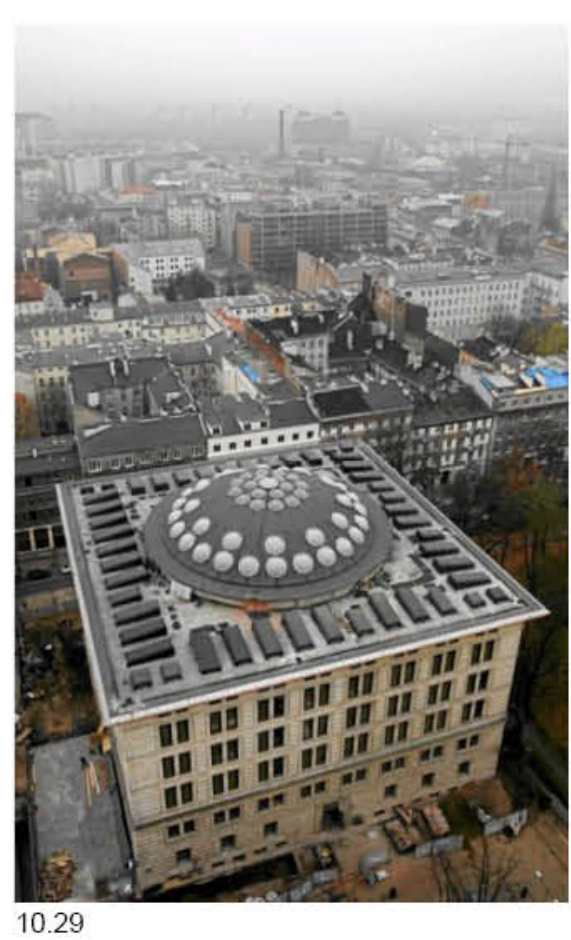

10.30. Giergón, Paweł (2010) Przebudowa dawnego Biurowca Prezydium Rządu przy UI. Wspólnej, 62. Fuente: sztuka.net 09-10-2010. 
10.30 Sección de la cúpula de la Basílica de San Lorenzo de Florencia de Filippo Brunelleschi.

10.31 Detalles de la catedral de Amiens y el Priorato de Saint-Thibaut de violet le Duc.

10.32 - 10.33 Planta y sección catedral de SaintLoulis des Invalides de París.

10.34 Detalles individuales de las Tablas del Retablo mayor de la Catedral de Salamanca (España).

10.35 - 10.36 Imagen y boceto del Retablo mayor de la Catedral Vieja de Salamanca (España).
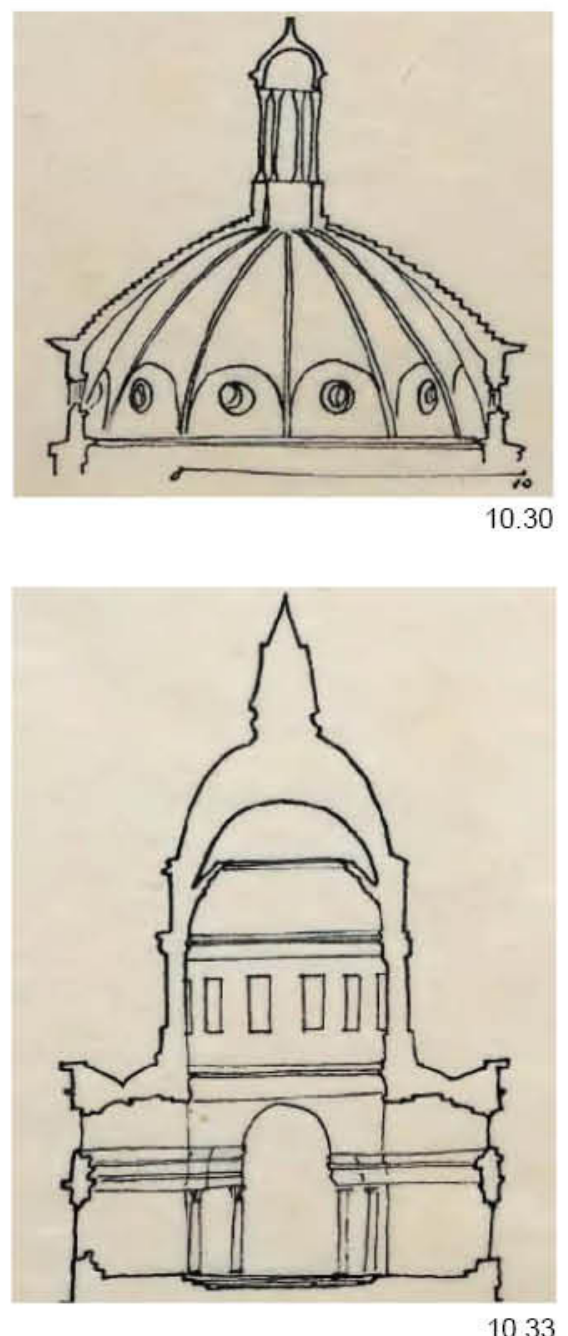
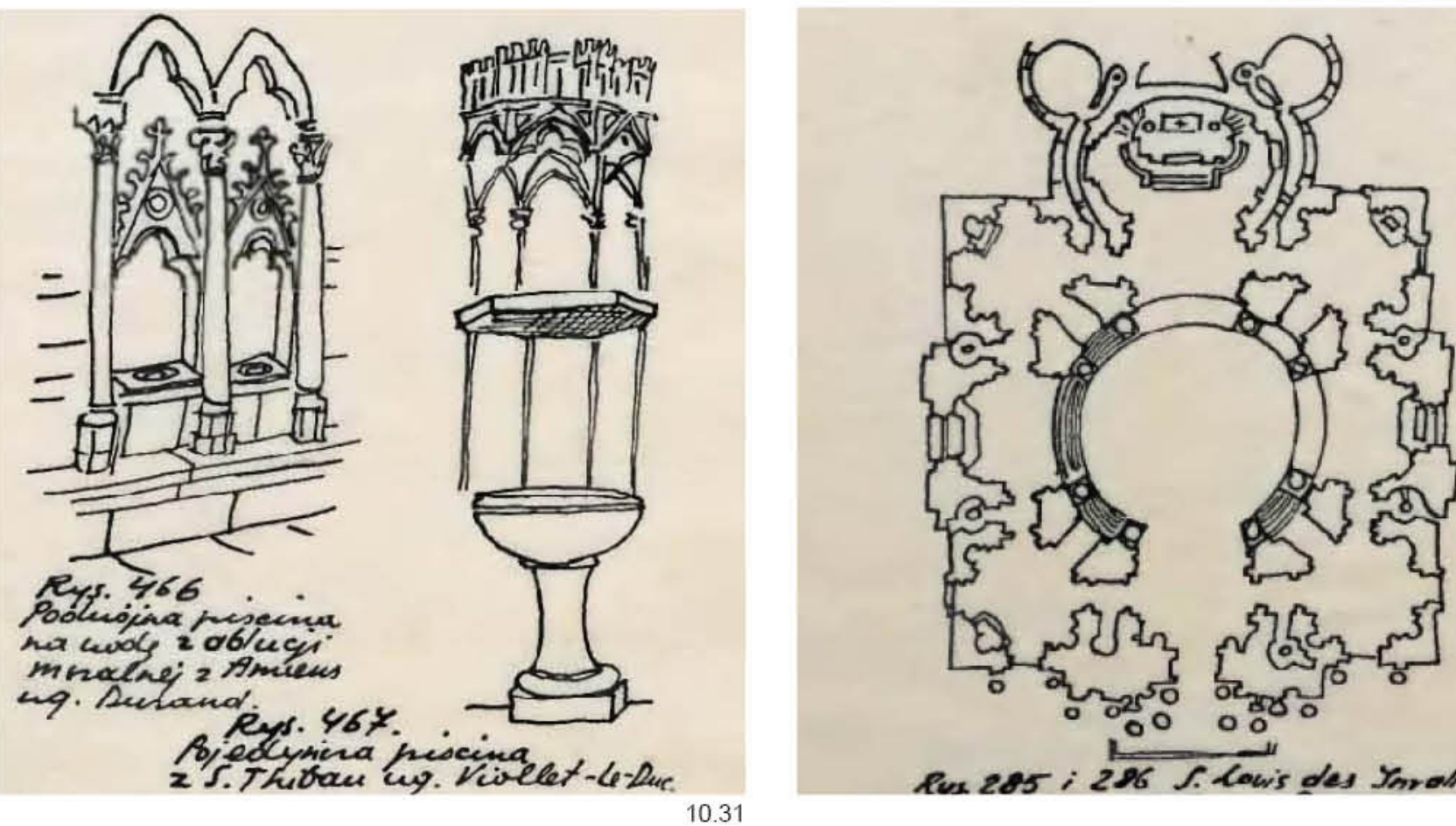

Rux $285 ; 296$ S. lowis des Toratides p
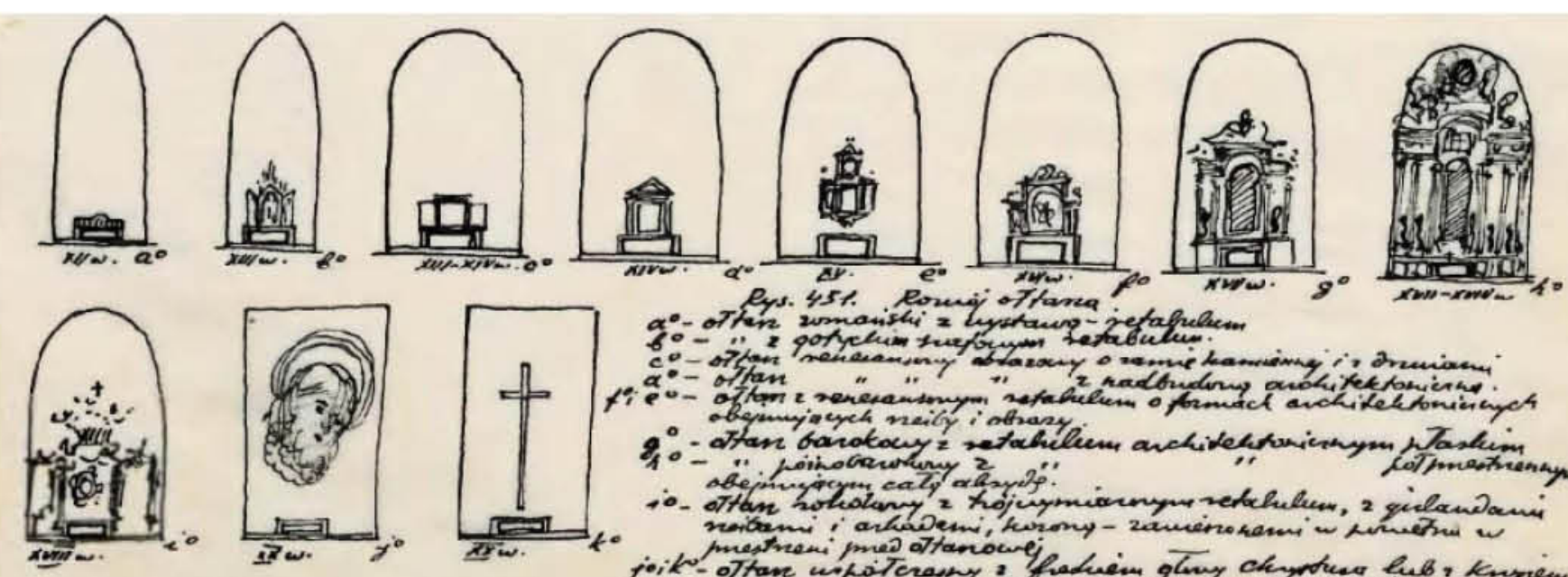

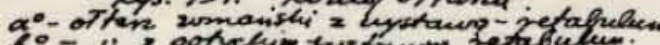

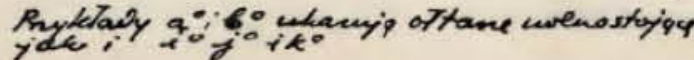

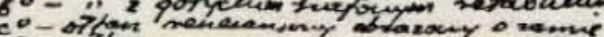

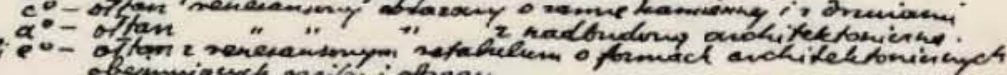

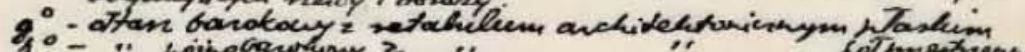

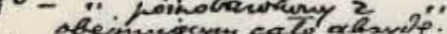

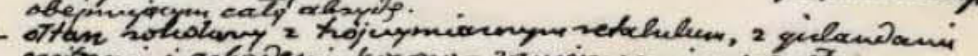

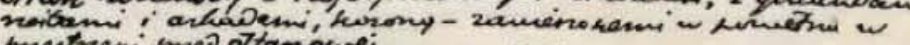

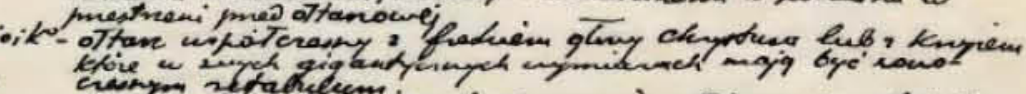

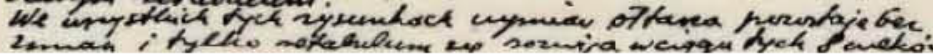




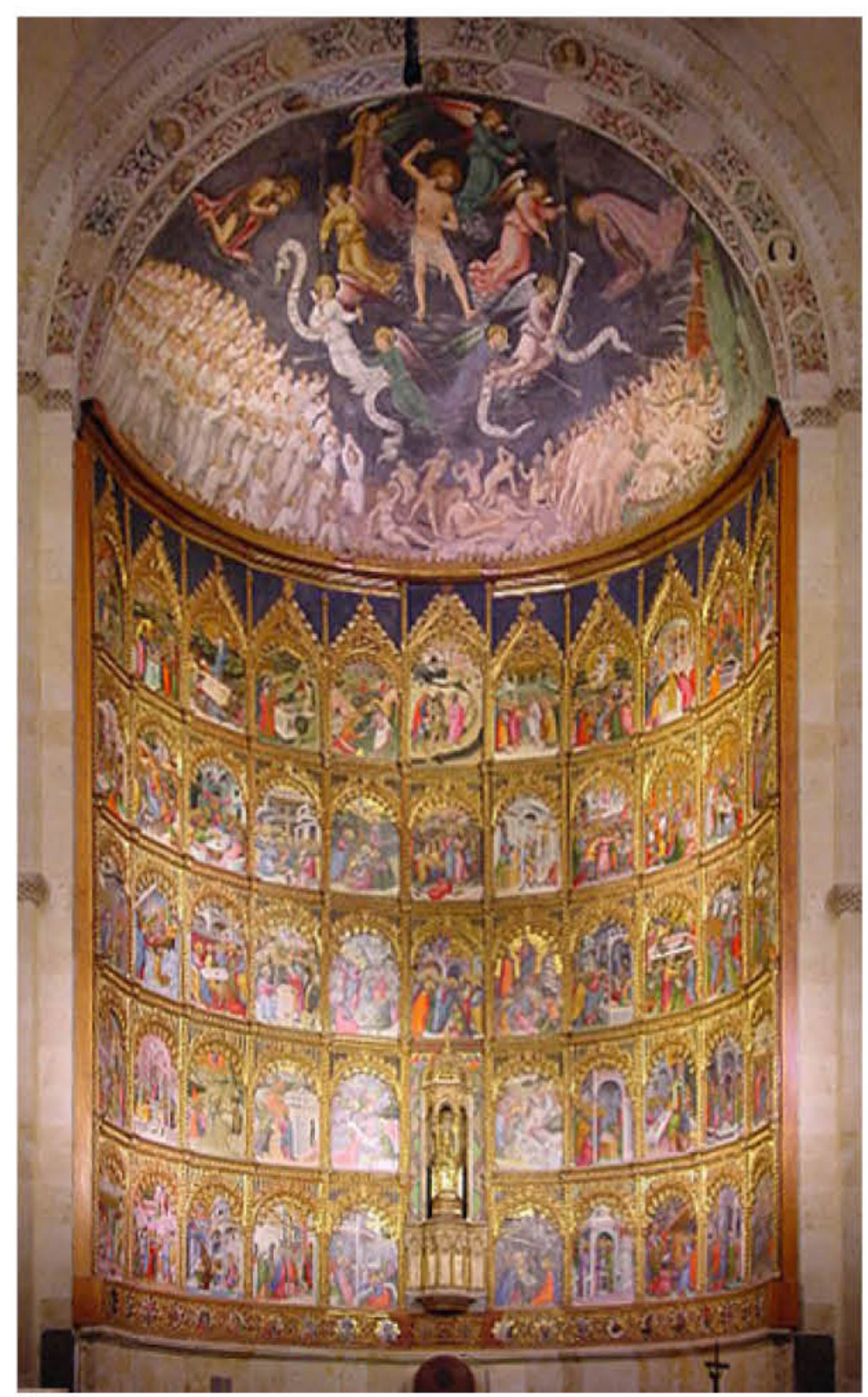

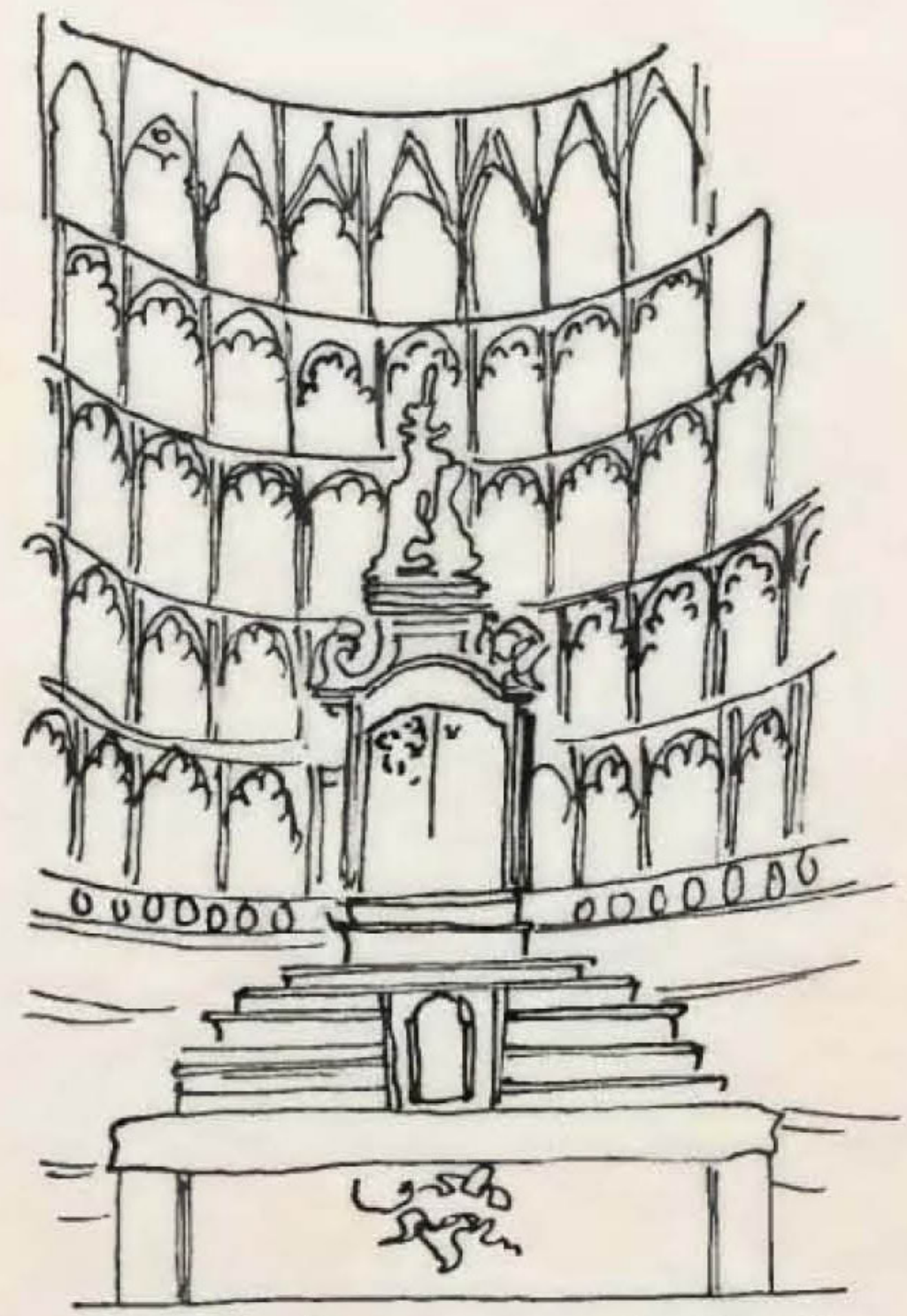

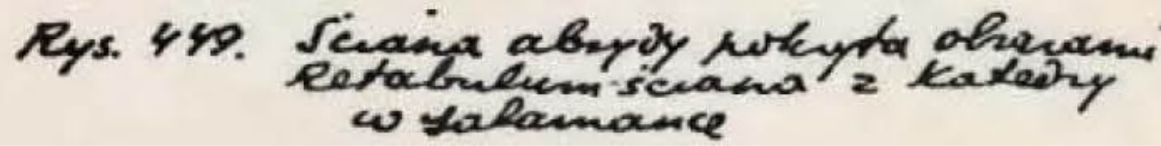



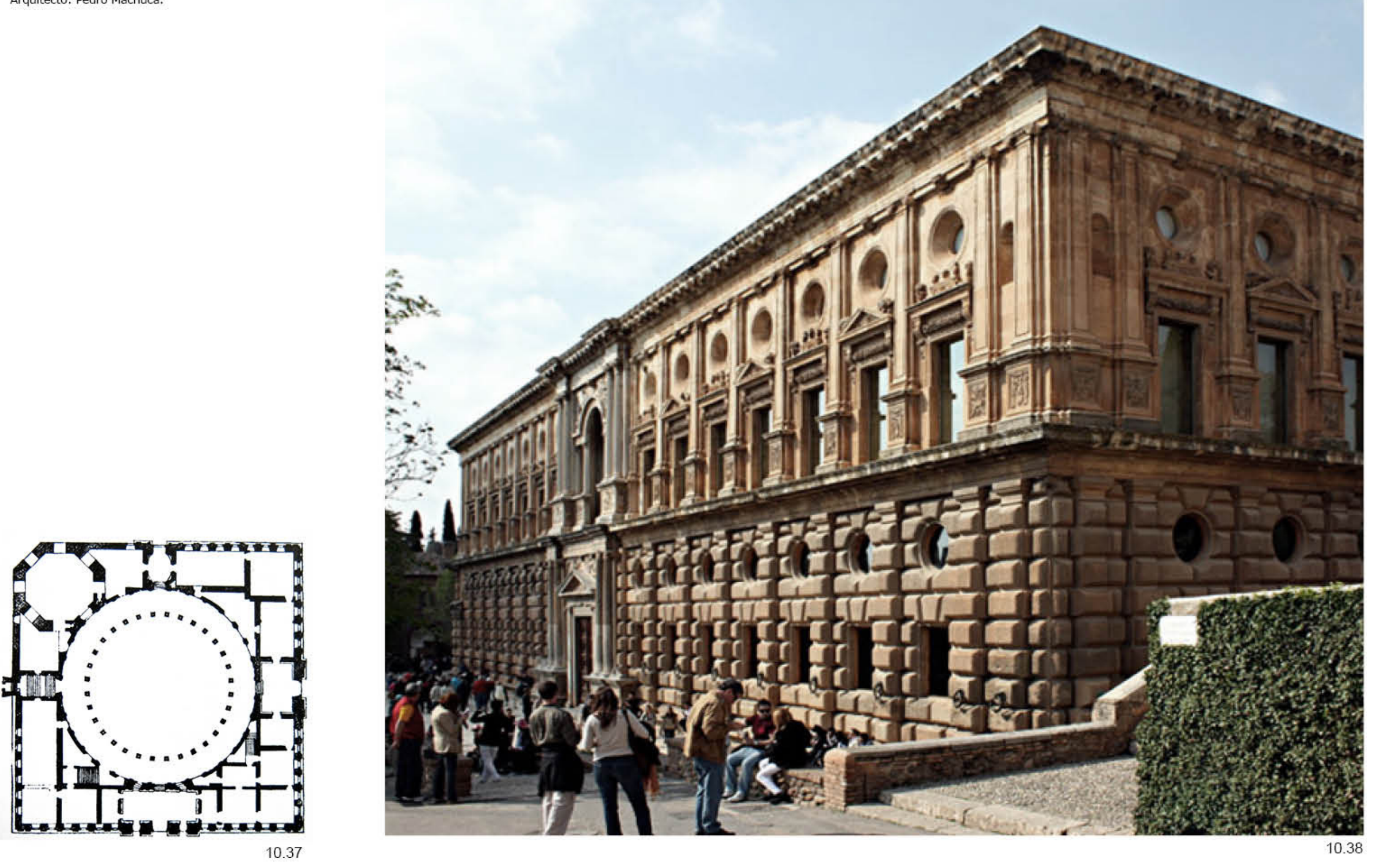

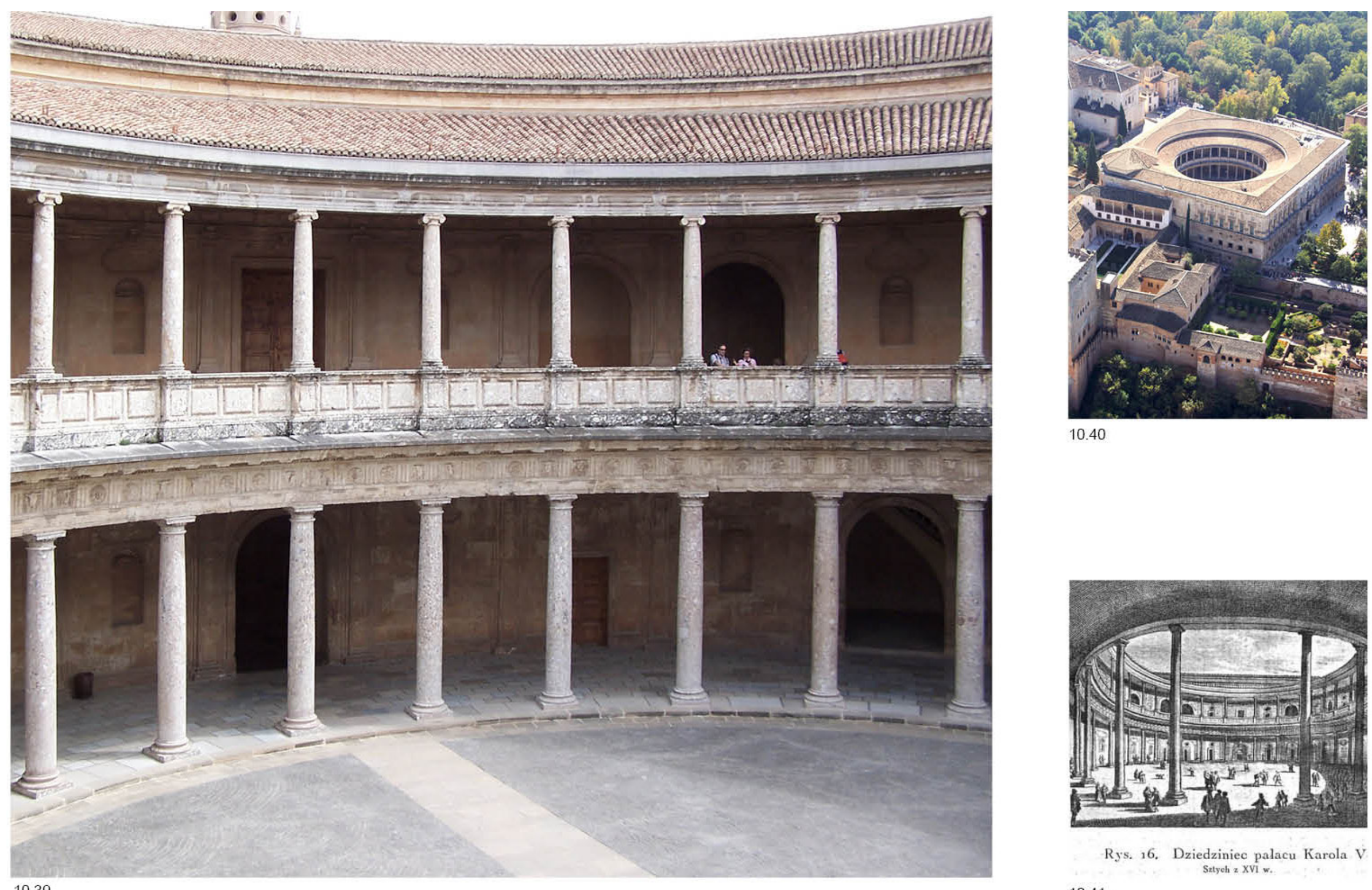

10.40

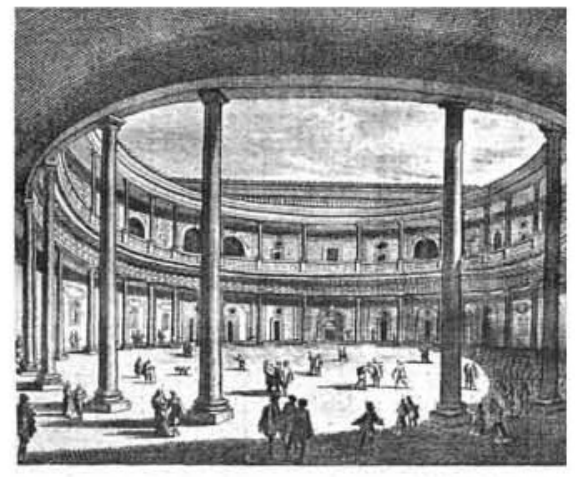

Rys. 16. Dziedziniec palacu Karola V 10.41 
10.42 - 10.43 Patio interior de la sede de la

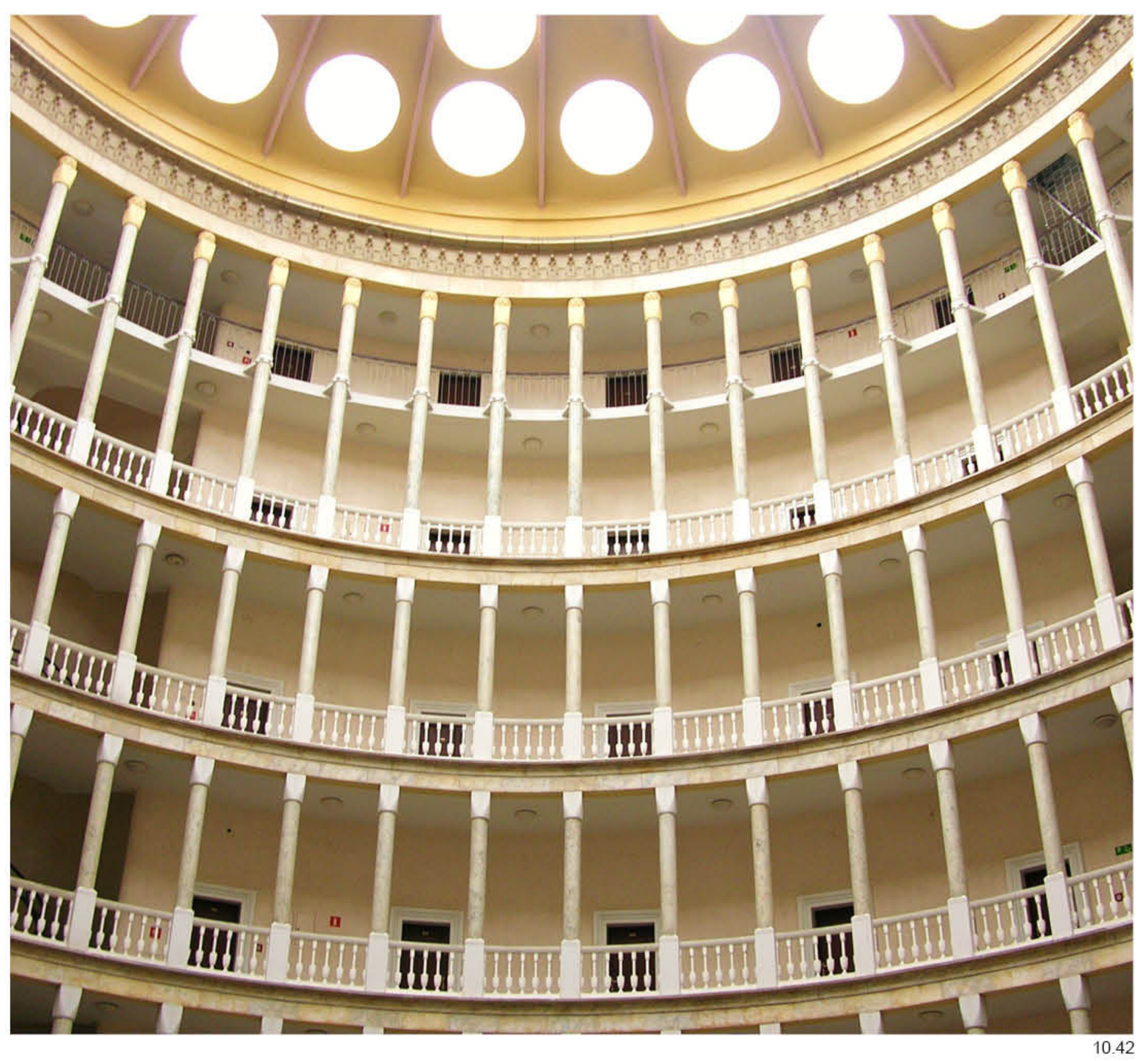


asociando las dos primeras plantas y una parte del sótano con la misma textura de sillares y un tamaño proporcional de huecos, así como emplazando todas ellas bajo una línea de cornisa intermedia que da paso conceptualmente al siguiente nivel de fachada.

En las tres plantas intermedias se puede reconocer más claramente la presencia de 27 módulos de 1,65 m, un tamaño de hueco que coincide con el módulo de la Oficina Central de Estudios y Proyectos de Construcción Industrial en la calle Santa Barbara (10.27). Leykam había renunciado a la posibilidad de entablar un diálogo a escala territorial entre ambos edificios por la imposibilidad de que su primer proyecto superase los controles del comité encargado de velar por la implantación de las formas del Realismo Socialista, pero a nivel de detalle constructivo y modulación si continuaba haciendo alusiones directas mediante las relaciones matemáticas entre ambos y su continuidad en la proporción.

Ambos edificios comparten un módulo de fachada de 1,65 m, de nuevo cercano al 1,61 del número áureo, con el interesante contraste de que el primero lo utiliza en la modulación de un rectángulo para la fachada exterior y el segundo para la modulación de un círculo en la fachada interior.

Esta persistencia en la búsqueda de una modulación matemática constante, a pesar de las circunstancias históricas que rodean ambos proyectos y sus diferencias de forma y de resolución, da muestra de la fe absoluta de Leykam en la racionalidad del método proyectual y su confianza en que, a través de la lógica y el razonamiento objetivo de cada solución, era posible crear una arquitectura expresiva desde la desaparición de las singularidades y la manifestación de la universalidad como un conjunto 'realizado' de variaciones, a las que había que encontrar sentido a través de un esfuerzo intelectual que permitiese abstraer conceptos y asociarlos mediante el pensamiento racional.

Los 27 módulos de la Sede de la Presidencia del Gobierno se distribuyen, tras duplicar el acabado opaco de las esquinas completando de forma simétrica cada una de las plantas, con dos módulos abiertos por uno cerrado, manteniendo, de esta forma, una rítmica que permitía asociar este proyecto con el método de trabajo de los Żyletkowiec, si bien en su formalización hubo que hacer referencia literal a los acabados clásicos y a una construcción artesanal para cumplir con las exigencias del Comité de Control, que velaba por el cumplimiento de las arbitrarias premisas del Realismo Socialista.

La planta superior contiene un tamaño de hueco proporcionado con el vacío de la planta semisótano a pesar de no coincidir posicionalmente, lo que permitió hacer una segunda lectura de la composición de fachada según el ritmo 1-3-1, si tenemos en cuenta el criterio de asociar los tipos de hueco en fachada e interpretamos el hecho de que, en la planta superior, estén más unidos que en la semisótano como una forma de corregir la deformación visual del observador.

La cornisa vuelve a ser un elemento prominente en la Sede de la Presidencia del Gobierno, algo que parece impuesto por parte de supervisores exteriores teniendo en cuenta la simplificación que este elemento estaba adoptando en la

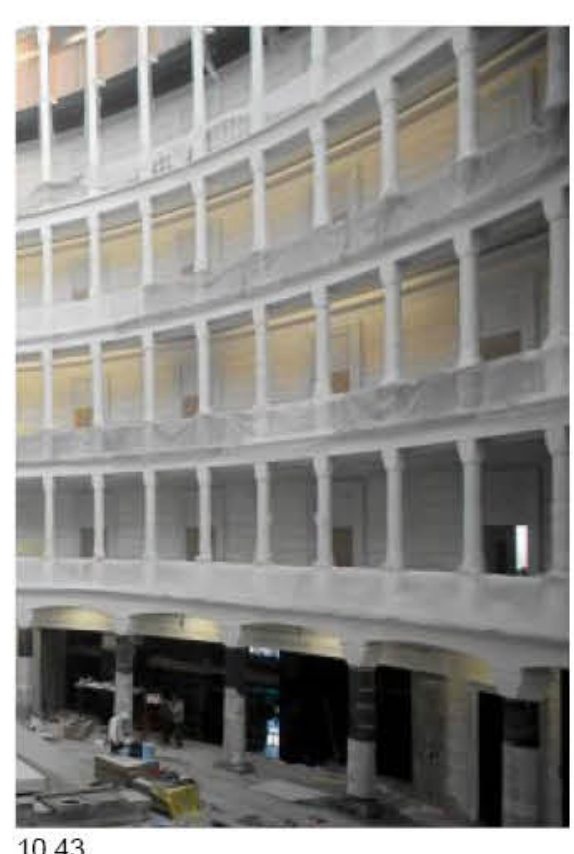

10.43 
10.44 - 10.45 Patio interior de la sede de la Presidencia del Gobierno en la e/ Wspolna no 62 de Varsovia (actualmente Ufficio Primo) 1950-52. Arquitecto: Marek Leykam.

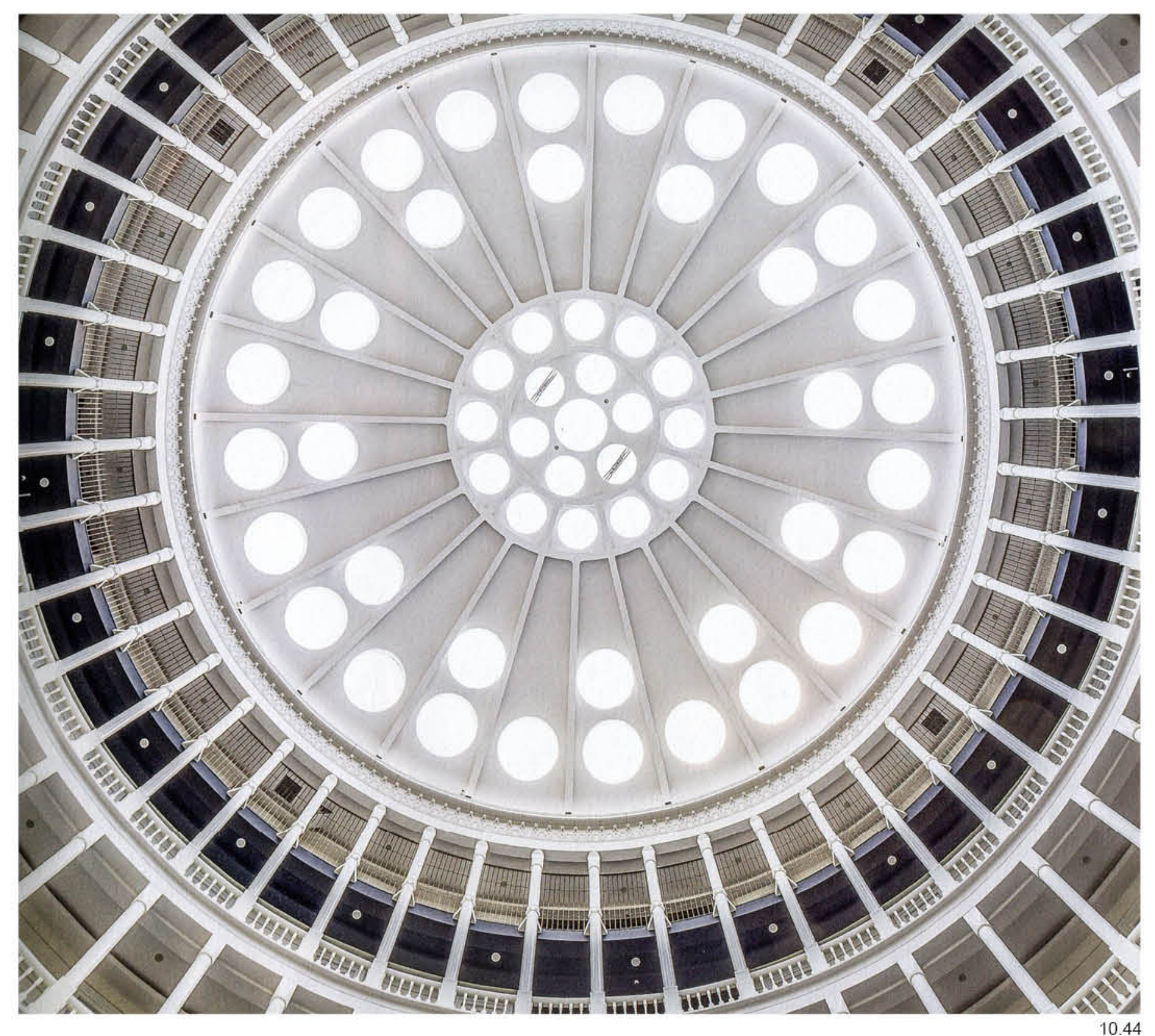


arquitectura de Leykam en proyectos anteriores como el bloque de la Oficina Central de Estudios adyacente en la calle Santa Barbara aunque entra dentro de su lenguaje en esta época.

El cilindro que delimita el patio interior tiene como base un círculo de $25 \mathrm{~m}$ de diámetro y en su perímetro se sitúan 48 módulos distribuidos en intervalos de $1,65 \mathrm{~m}$ a ejes, un número nuevamente cercano al áureo y que coincide exactamente con el utilizado por Leykam para modular la fachada exterior del propio edificio y del Żyletkowiec de la calle Santa Barbara. Los vanos a ejes entre las columnas del patio interior también respetan la proporción 2:1 al elevarse hasta los $3,30 \mathrm{~m}$ de altura. Los seis niveles de columnas que forman este patio (10.41 - 10.42) admiten una lectura compositiva de nuevo con un ritmo 1-3-1, debido a la variación del detalle constructivo que modifica la jerarquía de paso de los elementos, situando, en la última planta, el fuste de la columna con prioridad sobre el canto del forjado que había quedado interrumpido en las tres plantas intermedias, y, diferenciando a su vez el conjunto, a nivel de la planta baja, donde se apean las cargas de una de cada dos columnas, hasta constituir 24 puntos de apoyo de $3,30 \mathrm{~m}$ de intereje (1:1).

Los acabados interiores, incluidas las columnas, fueron revestidos en mármol y cabe destacar que la composición no correspondía literalmente a ningún orden clásico, sino que se adoptó una simplificación propuesta por el autor que fue aceptada por el Comité de Control. Por encima del edificio, se eleva una cúpula que cubre la superficie del patio interior y alberga una serie de aberturas circulares que recuperan la iluminación cenital, tomando como referencia la formalización de la iluminación central de la cúpula de la Basílica de San Lorenzo de Florencia de Filippo Brunelleschi, que Leykam había dibujado en su doctorado en 1943 (10.29).

Debajo del hall, en el sótano del edificio, se situaba una sala de conferencias con capacidad para 400 personas, formado por una sala de cubierta abovedada con una estructura de costillas radiales de hormigón armado, que originalmente fue diseñada para servir de refugio local antiaéreo para la defensa del Presidente. Entendiendo la codificación como un método que permite convertir el carácter de un lenguaje en un símbolo de otro sistema de representación, aplicando normas o reglas estructuradas mediante una secuencia ${ }^{10.31}$, estamos ante proyecto que busca una continuidad con todas las obras anteriores de Leykam a nivel esquemático, y por tanto trata de ejemplificar su resistencia frente a la sumisión que suponía aceptar el conjunto de normas subjetivas impuestas temporalmente durante el Realismo Socialista.

En la Sede de la Presidencia del Gobierno, Leykam fue capaz de generar así una obra que -siendo aceptada por todos los comités encargados de velar por el cumplimiento de los parámetros del Realismo Socialista- no perdió la correspondencia con el resto de su trabajo, manteniendo el discurso de un método proyectual coherente que optimizaba recursos y acciones y resultaba, en su conjunto, una oposición ${ }^{10.32}$ frente a un sistema que controlaba incluso las creaciones artísticas y arquitectónicas a través de impulsos ordenantes subjetivos, haciendo alusión a la lógica y la razón como criterios básicos para estructurar cualquier proceso organizativo, tanto en el arte como en la vida.

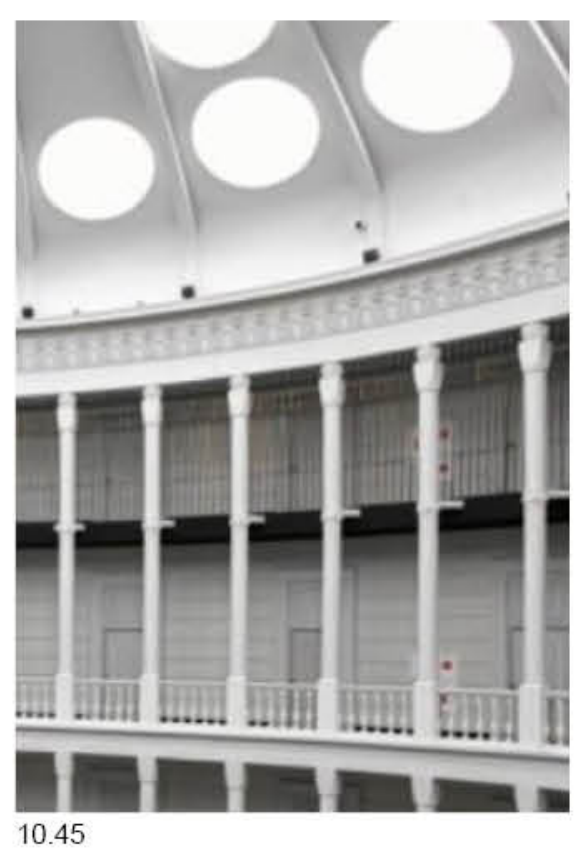

10.31. Según la definición del diccionario de la R.A.E. 10.32. Personas cercanas a Marek Leykam y colaboradores como Tadeusz Mycek o Jerzy y colaboradores como Tadeusz Mycek o Jerzy
Majewski, han hecho referencia a este proyecto como una burla expresa al comunismo realizada por Leykam. (Véase Springer, 2011. p. 42)

Sin embargo, ha faltado dar continuidad a esa visión explicando que no estamos ante un hecho aislado. El resto de proyectos de Leykam se basan también en el mismo método proyectual y contienen la misma intención de expresar una resistencia, aunque su formalización se haya materializado de manera diferente por cuestiones circunstanciales (Véanse fig 15.09 y 15.10 en p. 358,360 ). 


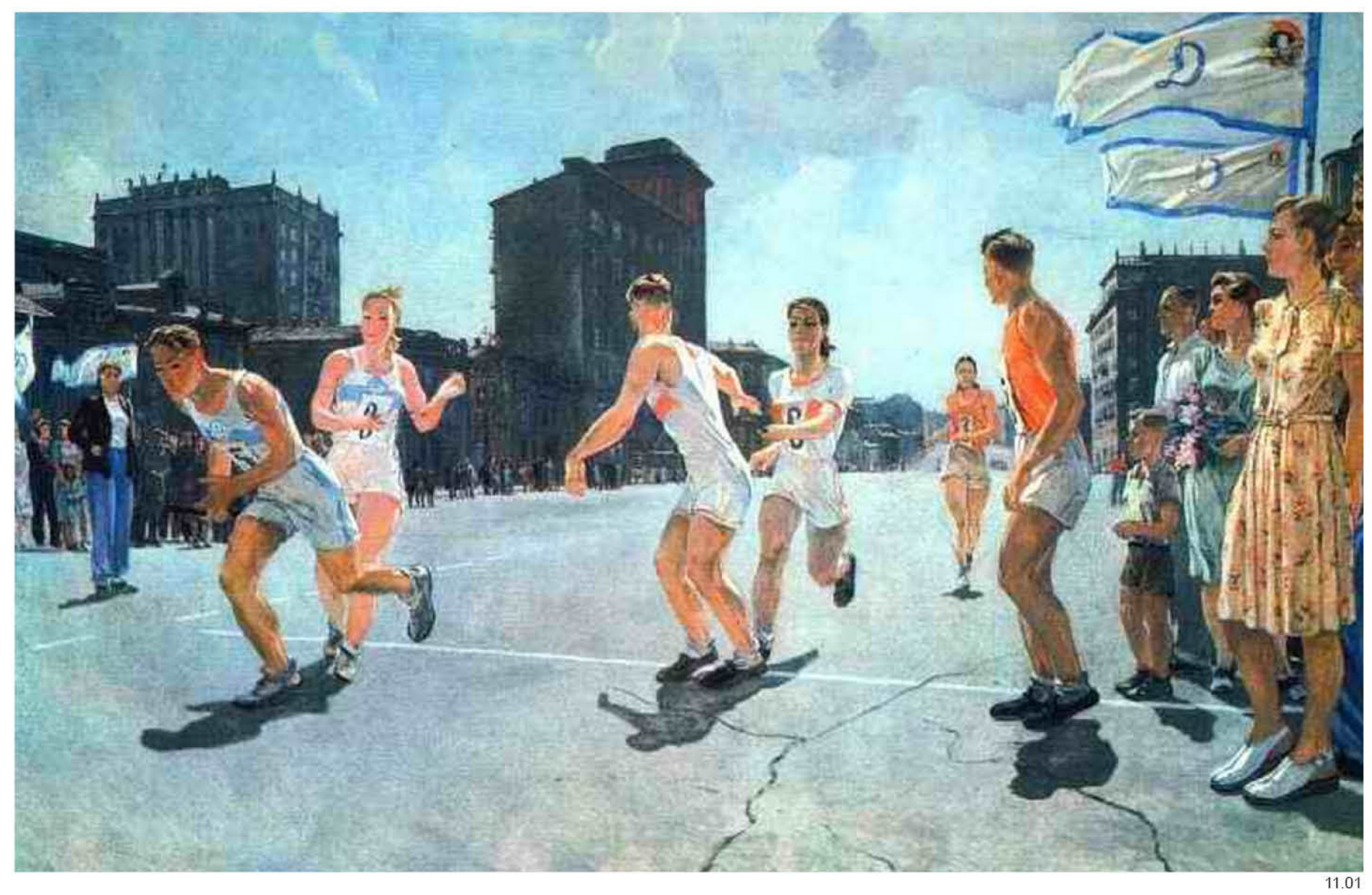


"La creencia en la posibilidad de superar conflictos económicos y políticos por una mera aproximación a la cultura es utópica. Sin embargo, la cultura tiene carácter simbólico y puede prevenir la transmisión y proliferación de conflictos en la medida en que participa de todas las esferas de la vida."

Antonina Kłoskowska. "Sąsiedztwo narodowe i uniwersalizacja kultury." 11.00

Desde el final de la II Guerra Mundial se planteó en Varsovia la necesidad de construir un gran recinto deportivo que permitiese a los polacos canalizar sus aspiraciones sociales a través de la visualización de los logros deportivos soviéticos. ${ }^{11.01}$ Las manifestaciones artísticas de la época dan idea de la importancia que el deporte había adquirido en la URSS como vehículo de transmisión de ideología política, debido a su capacidad de empatizar con la sociedad y ofrecer estímulos y recompensas que evitasen a los ciudadanos caer en la letanía y la desmotivación.

Los cuadros de Alexander Deineka son un buen reflejo de la función cultural que había adquirido el deporte y su evolución a tenor de los acontecimientos históricos. Si bien unos años antes de la II Guerra Mundial se podía percibir un contexto militar en sus dibujos sobre el deporte, durante la postguerra se identifica la necesidad de unificar a la sociedad en torno a los valores competitivos y la solidaridad del espíritu deportivo.

En el poster "Mujer deportista" de 1933 (11.02), Deineka mostraba una mujer cercana al espectador vestida con un uniforme deportivo mientras el resto de personajes de la escena aparecían alejados de ella, realizando actividades propias, no solo del deporte, sino simultáneamente de las necesidades de un ejército. Las figuras en segundo plano estaban situadas sobre un contexto indeterminado que no permitía asociarlas con exclusividad al ámbito deportivo, mientras sus vestimentas ampliaban esa ambivalencia deportiva y militar.

Las miradas y el esfuerzo de los personajes de fondo se dirigen a una zona imaginaria situada en el flanco izquierdo del cuadro fuera de las posibilidades de observación del espectador y ocupando el lugar del pasado en una imaginaria línea temporal. La figura de la mujer se sitúa en el centro de la composición, separada de este contexto por un círculo físicamente construido que quedaba abierto e incompleto por el lado derecho en dirección hacia el futuro que estaba por venir, al que

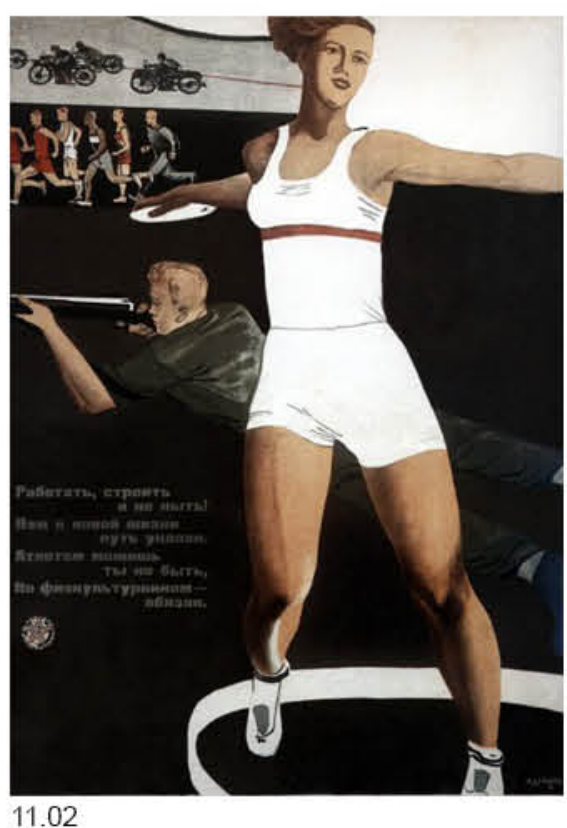

11.02

11.00. Kłoskowska Antonina (1991) "Sąsiedztwo narodowe i uniwersalizacja kultury." (EI barrio nacional y la universalización de la cultura") Cit. Szpociński, 2011. P. 80-81.

11.01. Giegoń (2009) 
11.03 Reconstrucción mimética de la plaza del Casco Viejo (Stary Rinek) de Varsovia, 1951.

11.04 Excavaciones para la cimentación de los sotanos del Palacio de la Cultura y la Ciencia (Pałac Kultury i Nauki) de Varsovia, 1952. Lev Rudnev.

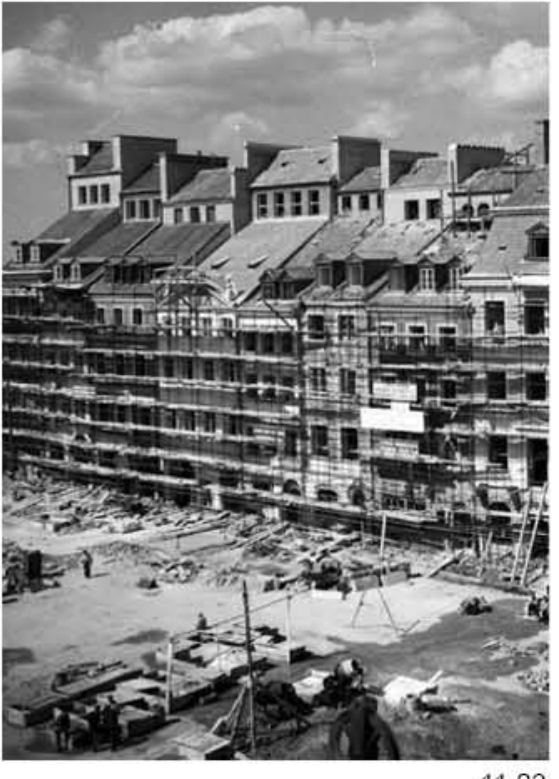

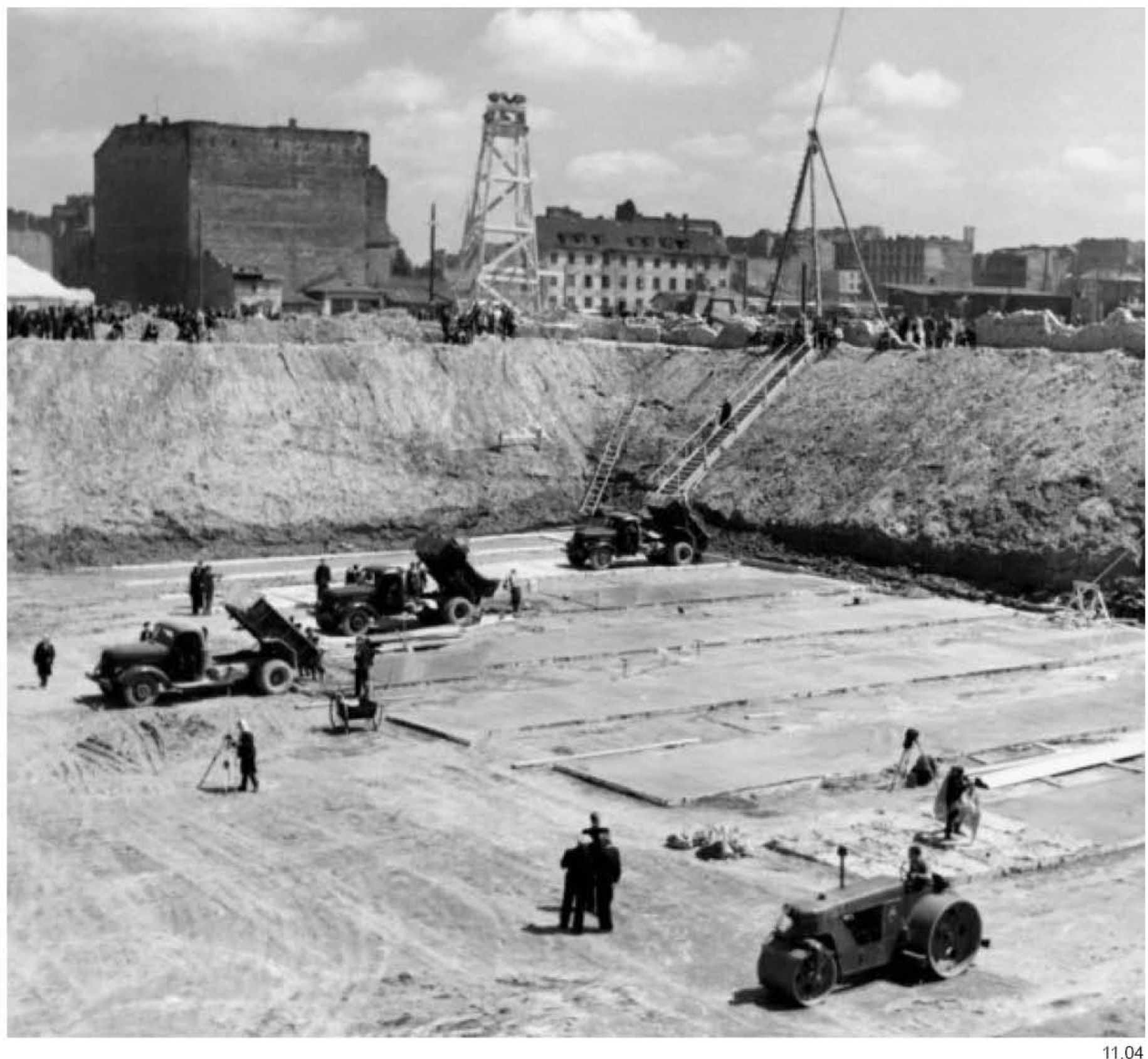


dirigía su mirada siguiendo la analogía cronológica. Su figura aparecía articulada a modo de bisagra entre un momento de esfuerzo y acumulación de trabajo coincidente con la carga que su propio cuerpo sobre disco que pretende lanzar, y un tiempo de paz y tranquilidad representado a su derecha sin movimiento alguno y en ausencia de actividad ni tensiones. ${ }^{11.01}$

La representación del deporte adquiere un contexto urbano en "Paso del testigo en la prueba de relevos del anillo B", 1947 (11.01) habida cuenta de la falta de instalaciones deportivas tras la destrucción propiciada por la II Guerra Mundial. Los deportistas desarrollan su actividad en las calles participando en una prueba de relevos, lo que acarreaba implícito el esfuerzo solidario de un equipo para alcanzar un fin. Hombres y mujeres comparten esta vez tareas en una carrera que les dirige a la izquierda del cuadro, representando el pasado que se ha perdido y se pretende recuperar. Las grietas en el suelo forman parte del camino de quienes están por detrás mientras que en cabeza se sitúan aquellos corredores que tienen el camino ya despejado, aunque todos ellos cuentan con el apoyo entregado de la sociedad.

El contexto arquitectónico de los cuadros de Deineka refleja asimismo la sobredimensión de los vacíos urbanos surgidos como consecuencia de la destrucción en los primeros años de postguerra. Las fachadas de los edificios aparecen dibujadas según el ideario estético del Realismo Socialista, cuya imposición resultó más relajada tras la muerte de Stalin en 1953. Las restricciones y la aplicación del decreto Zhardov se tornaron más laxas y en ese contexto histórico la Asociación de Arquitectos Polacos (SARP) convocó un concurso para la realización de un estadio deportivo en Varsovia en 1953.

\subsubsection{Estadio del Decenio de Varsovia.}

Para la ubicación del futuro Estadio Nacional fueron planteados los terrenos del área de Czerniaków, las zonas de Powiśle en el Puerto de Invierno, el Parque de Cultura y Recreación, el entorno de la Ciudadela, Fort Szczesliwicki y los alrededores de la estación del sur en Mokotów, pero finalmente se decidió convocar el concurso en el barrio de Praga, uno de los centros de la ciudad en la orilla este del río Vístula, que había sido completamente arrasado durante los meses posteriores al Levantamiento de Varsovia y cuya amplitud había hecho que fuera estudiado como uno de los posibles lugares donde situar la sede del Palacio de la Cultura y la Ciencia de Varsovia (PKiN). ${ }^{11.01}$

El edificio PKiN se estaba erigiendo en esos momentos al otro lado del río Vistula, como la obra culminante del Realismo Socialista en Polonia. El arquitecto Lev Rúdnev y su equipo habían estado visitando los conjuntos históricos de Cracovia, Kazimierz, Chełmno, Płock, Sandomierz, Zamość y Toruń en busca de los motivos nacionales tratando de crear un edificio que "crease una imagen de belleza uniforme combinando en un todo arquitectónico y proporcionando al mismo tiempo un vínculo con la antigua Varsovia." "11.02

El perímetro del solar elegido para el concurso del estadio nacional quedó delimitado por el espacio interior que

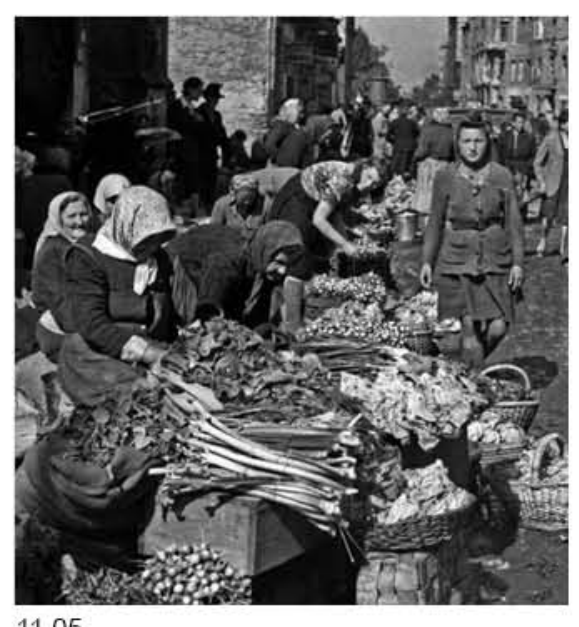

11.05

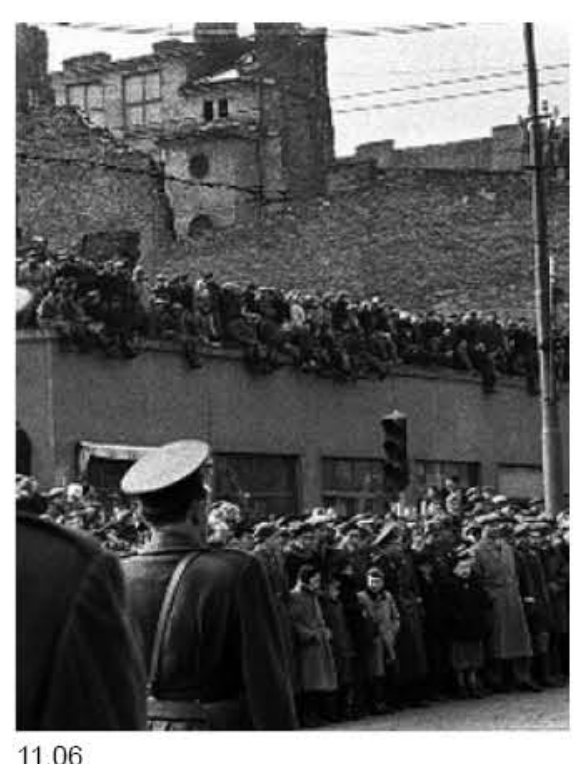

11.06

11.02. Historia del Palacio PKiN. Fuente: pkin.pl 
11.07-11.08 Construcción del Palacio de la Cultura

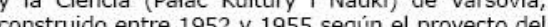
arquitecto Lev Rudnev.

11.09 Perspectiva del proyecto para el Estadio del Decenio en el barrio de Praga presentada por

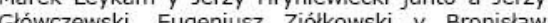
Gawryluk en el concurso convocado en 1954 .

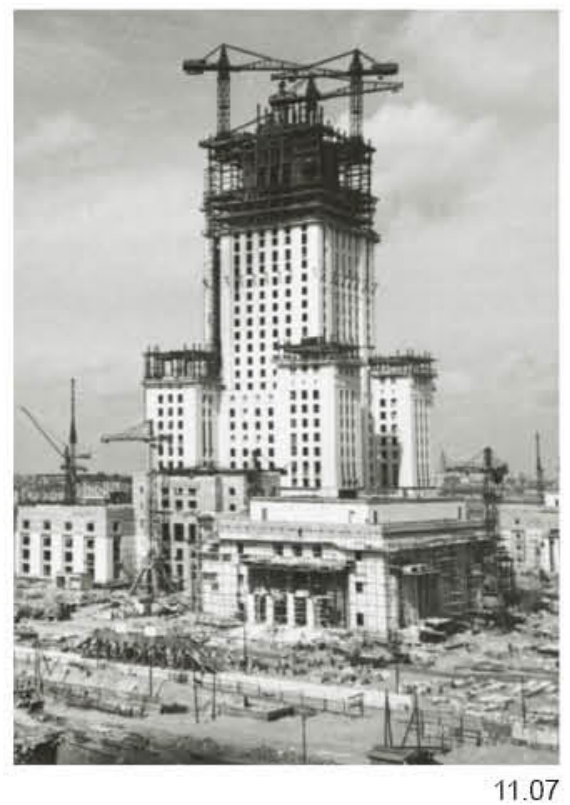

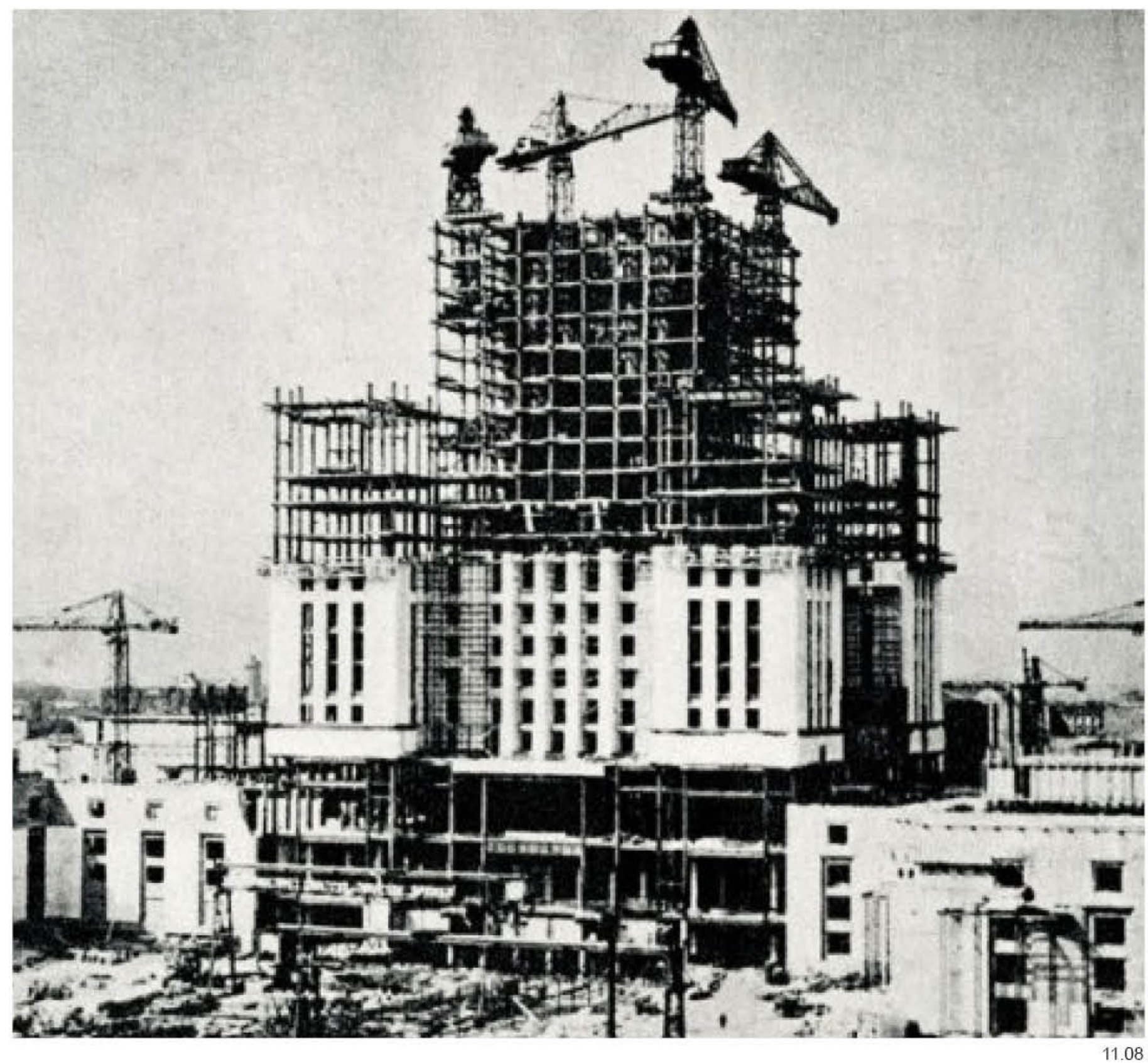


conformaban la calle Zieleniecka, la Avenida Poniatowski y el río Vístula. El programa preveía la construcción de algunos campos de entrenamiento complementarios, un centro de entrenamiento militar, pabellones y salas de deportes y una piscina móvil sobre el río Vístula, además de una serie de muelles para deportes acuáticos que finalmente no fueron realizados. ${ }^{11.01}$

El edificio proyectado debía tener en principio capacidad para 37.500 espectadores, pero este requerimiento fue ampliado para albergar un aforo de 60.000 personas distribuidos en 15.000 asientos y 45.000 de pie, que debía estar relacionado compositivamente y funcionalmente con el Parque Skaryszewski, actuando como un equivalente al Parque Cultural y Recreativo en del litoral izquierdo del río en el área de Powiśle. ${ }^{11.01}$

El primer concurso convocado al efecto fue ganado por el equipo de Jerzy Hryniewiecki, Zbigniew Ihnatowicz y Jerzy Soltan pero, según la opinión del jurado, ninguna solución había tenido en cuenta las expectativas básicas de la convocatoria, ni las de la entidad pública promotora -el Comité Director de Cultura Física (GKKF) ${ }^{11.03}$-, y por tanto sentenció que ninguno de aquellos proyectos estaba en condiciones de ser realizado. ${ }^{11.01}$

La principal condición a la que no se ajustaba ninguna propuesta fue la escasa utilización de los residuos de la ciudad, parte de los cuales la GKKF pretendía utilizar en este proyecto como base. El estadio era una de las estructuras más grandes que iban a construirse en Varsovia, y requería una gran cantidad de materiales que se pretendía que el proyecto reutilizase a partir de las ruinas de la ciudad. El jurado consideraba que la construcción debía evitar una estructura para las gradas, ya que estas podían quedar apoyadas directamente sobre el 'relleno' que formaban esos escombros, un problema que la ciudad de Varsovia necesitaba resolver. Los plazos de tiempo que los equipos estimaron necesarios tampoco convencieron a los promotores públicos, puesto que se pretendía que el estadio estuviera preparado para albergar el V Festival Mundial de la Juventud y los Estudiantes ${ }^{11.04}$ en el verano de 1955, para lo cual restaban apenas dos años siendo el plazo de los proyectos presentados no inferior a 4 años en ninguno de los casos ${ }^{11.01}$.

En enero de 1954, el equipo de GKKF encargó a uno de los equipos participantes en el primer concurso ${ }^{11.05}$ la realización de una serie de análisis para determinar una nueva propuesta teniendo en cuenta la comunicación exterior que debía tener el estadio. Los resultados de su trabajo mostraron que podían existir dificultades de acceso si el estadio superaba la capacidad de 70.000 espectadores y reflejaron que el área limitada por los viaductos impedía la realización de un complejo más grande de equipamiento deportivo. Este análisis sirvió a GKKF para tomar la decisión de volver a convocar un nuevo concurso restringido esta vez únicamente a tres equipos. ${ }^{11.01}$

Dentro del equipo de Jerzy Hryniewiecki, Jerzy Soltan se mostró en total desacuerdo con los cambios y la nueva propuesta de realizar un estadio sobre una base rellena de escombros y Zbigniew Ihnatowicz también se mostró defensor del concepto original y así que ambos decidieron abandonar el equipo. Hryniewiecki aceptó por su parte las condiciones

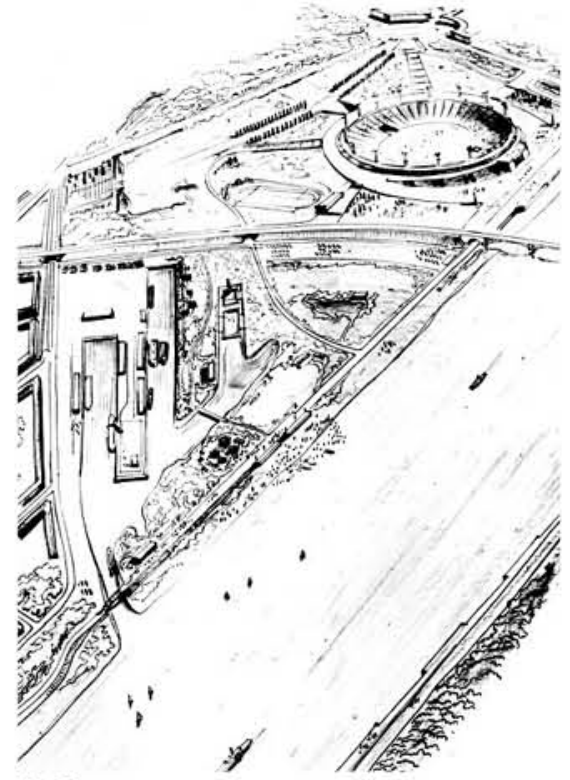

11.09

11.03. Glowny Komitet Kultury Fizycznej. Era la autoridad principal del pais en el ambito de la estaba supervisado por el primer ministro.

11.04. V Festival Mundial de la Juventud y los Estudiantes (V Światowy Festiwal Młodzieży i Studentów) fue un encuentro internacional que reuniendo a cerca de 31.000 jovenes de 114 paises Przyjaźń).

11.05. Concretamente al equipo formado por los arquitectos J. Brzuchowski. D. Bredy, J. Mariański, J. Łowiński, L. Tomaszewski. 
11.10 De izquierda a derecha: Bronisław Gawryluk, Zbigniew Pawelski, Jerzy Hryniewiecki, Tadeusz del concurso del Estadio del Decenio de 1954.

11.11 Boceto del concurso presentado por Marek Leykam y Jerzy Hryniewiecki junto a Jerzy Gawryluk para el Estadio del Decenio en 1954.

11.12 Palacio de la Cultura y la Ciencia (Pałac Kultury i Nauki) de Varsovia, construido entre Rudnev.

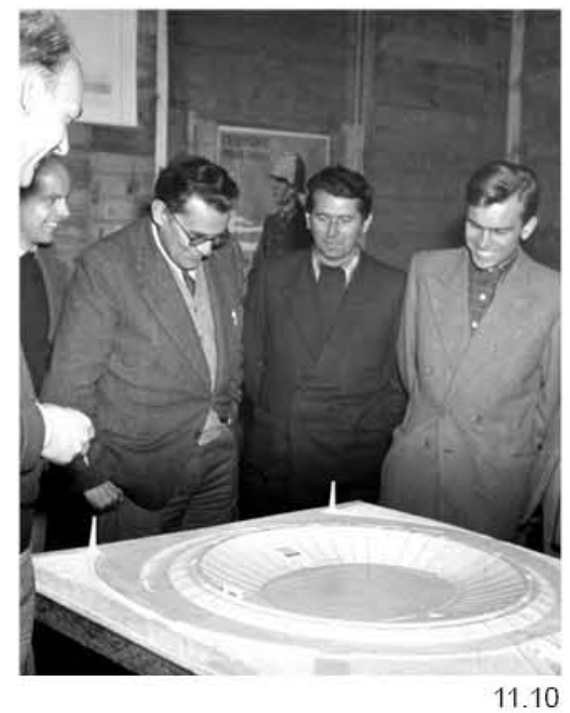

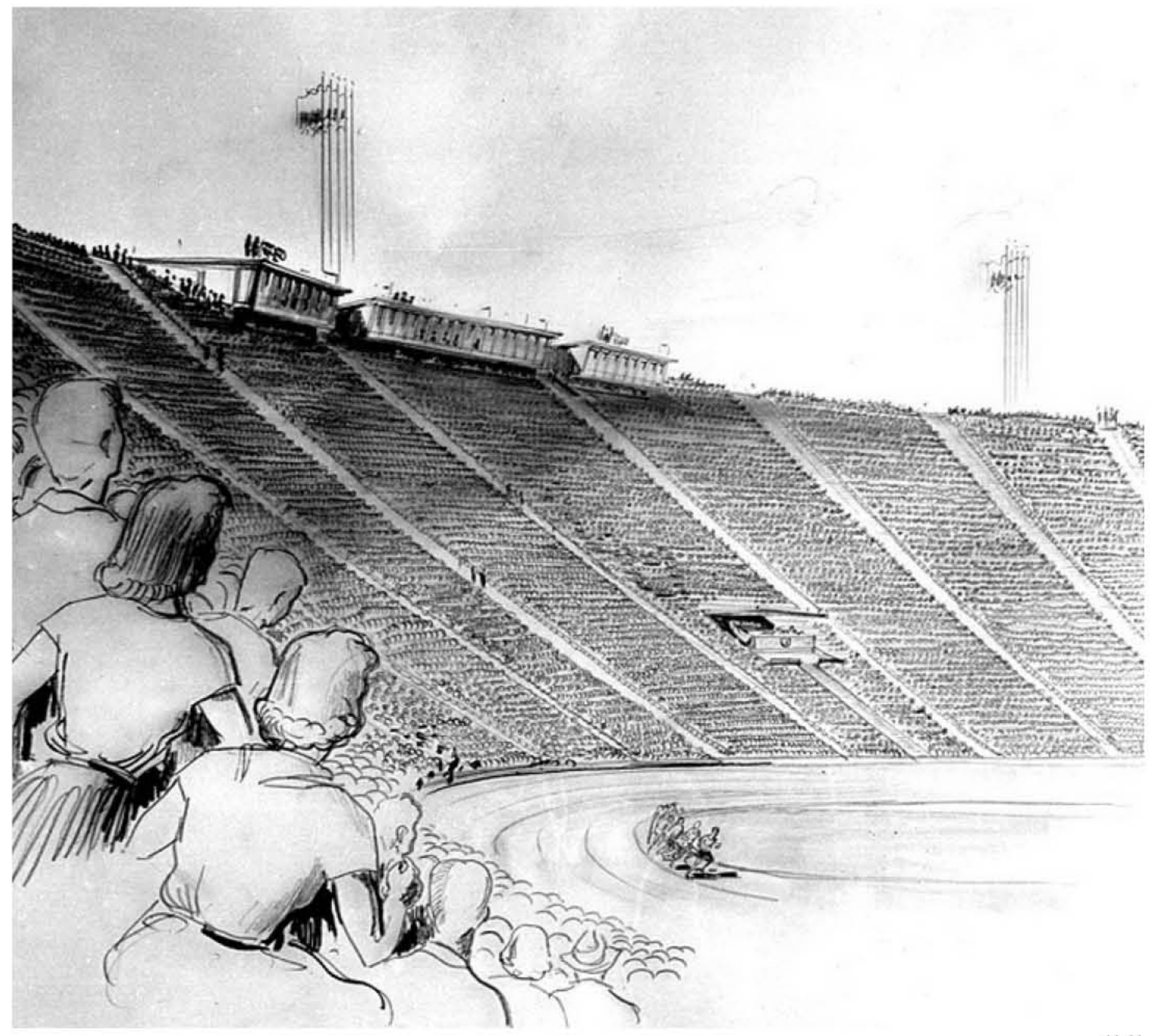

11.11 
del concurso y contactó con Marek Leykam y varios jóvenes arquitectos de la Oficina de Conservación de Monumentos que dirigía el prof. Piotr Biegański -de la Universidad Tecnológica de Varsovia-, como Jerzy Główczewski, Eugeniusz Ziółkowski y Bronisław Gawryluk para presentar una nueva solución. ${ }^{11.01}$

En aquel momento Hryniewiecki y Leykam no poseían un estudio capaz de coordinar a todos aquellos jóvenes y el trabajo se desarrolló en el apartamento de Jerzy Główczewski en la calle Chmielna de Varsovia. El nuevo equipo rechazó los planteamientos iniciales del equipo anterior y planteó el proyecto desde el más absoluto pragmatismo y el cumplimiento de los objetivos de la GKKF. El estadio debía contener un campo de futbol con pista de atletismo a su alrededor y el nuevo equipo inscribió el programa en figuras geométricas regulares cuyo trazo era en todo momento verificable en obra sin necesidad de acudir a los planos, tomando como referencia el círculo central del terreno de juego. ${ }^{11.01}$

El trazado de una elipse confinaba de forma eficiente la pista de atletismo, y desde ella hasta un círculo de radio que inicialmente fue trazado en $120 \mathrm{~m}$, quedaba delimitada la gradería mediante un trazado geométrico de curvas concéntricas. Ambas figuras resultaban sencillas de verificar en obra, puesto que la elipse es, a su vez, la proyección orientada de la circunferencia. La gradería inicial era capaz de albergar cerca de 40.000 personas sentadas. ${ }^{11.01}$

Más allá del concepto de contenedor regular, la principal innovación del proyecto era la facilidad con que podía ser ejecutado en obra, una de las características principales de toda la obra de Leykam. Desde el trazado geométrico, la posición de cada fila, de cada escalón, de cada grada,... era mesurable desde una referencia a partir de la cual el conjunto de soluciones era proporcional y se regía por constantes. Era factible pensar que la ejecución de los trabajos podría lograr una coronación precisa conservando todos los elementos la misma altura y sin escalonamientos imprevistos hasta su culminación desde la planeidad y la continuidad de todos los elementos, a pesar de la modestia de las herramientas disponibles. ${ }^{11.01}$

El proyecto se adaptó asimismo a las recomendaciones del programa de incluir únicamente asientos en lugar de áreas de pie y tratar de no diferenciar a los asistentes según el lugar en el que estuvieran sentados. Desaparecieron las tribunas salvo el palco de autoridades, y el proyecto se redujo a los elementos de programa necesarios. Este ejercicio de pragmatismo fue aceptado por el jurado, concediendo al equipo el primer premio y el encargo de tenerlo terminado en el plazo aproximado de un año. ${ }^{11.01}$

La proximidad del V Festival Mundial de la Juventud y los Estudiantes también afectó a las obras del Palacio de la Cultura y la Ciencia, que se aceleraron para llegar a tiempo también a la inaguración de esta cita. De este modo los dos edificios de escala monumental que estaban siendo construidos en esos momentos en Varsovia quedaban asociados a una inaguración conjunta formando parte de la misma celebración. Los arquitectos del estadio habían percibido ya esa simbólica presencia de su proyecto en contraposición a la torre PKiN y trataron de acentuar esa dualidad situando el proyecto frente el orden preestablecido mediante un conjunto de referencias de carácter antagónico.

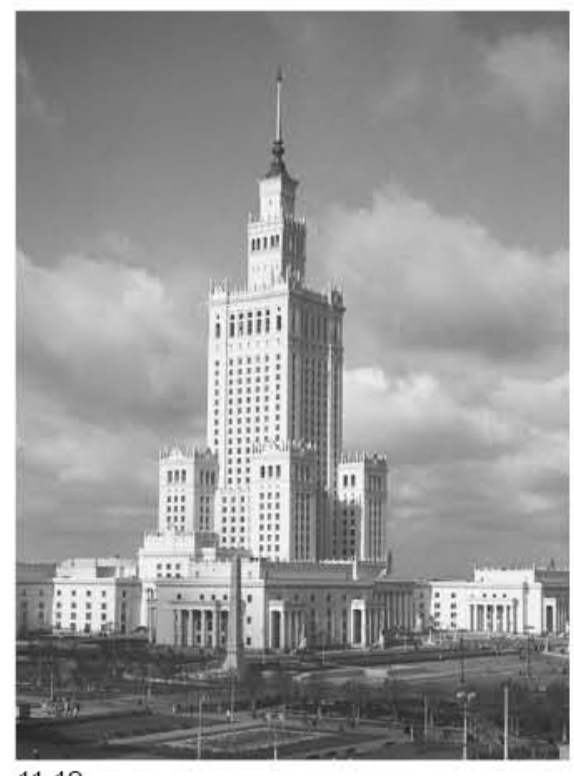

11.12 
11.13 11.14 Sección transversal y planta del proyecto para el Estadio del Decenio, Marek Leykam, Jerzy y Bronisław Gawryluk, 1954.

11.15 Trabajadores en la obra del Estadio del Decenio,

11.16 - 11.18 Distribución y asentamiento del terreno de Varsovia, 1954.

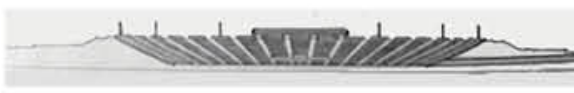

11.13

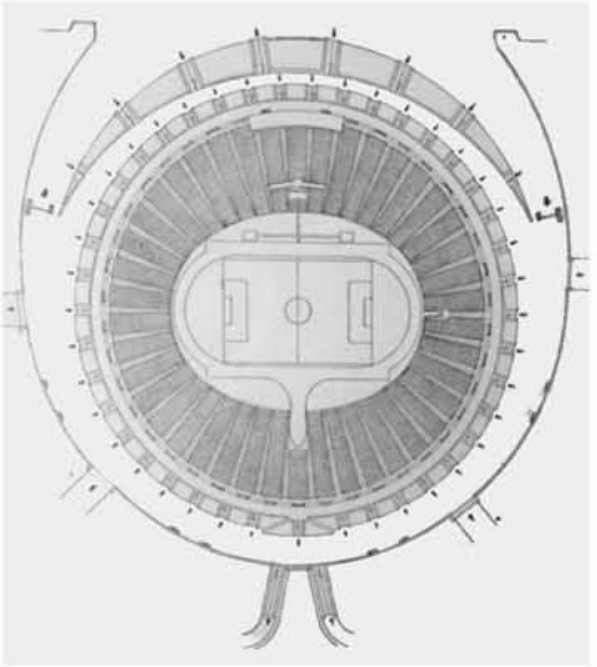

11.14

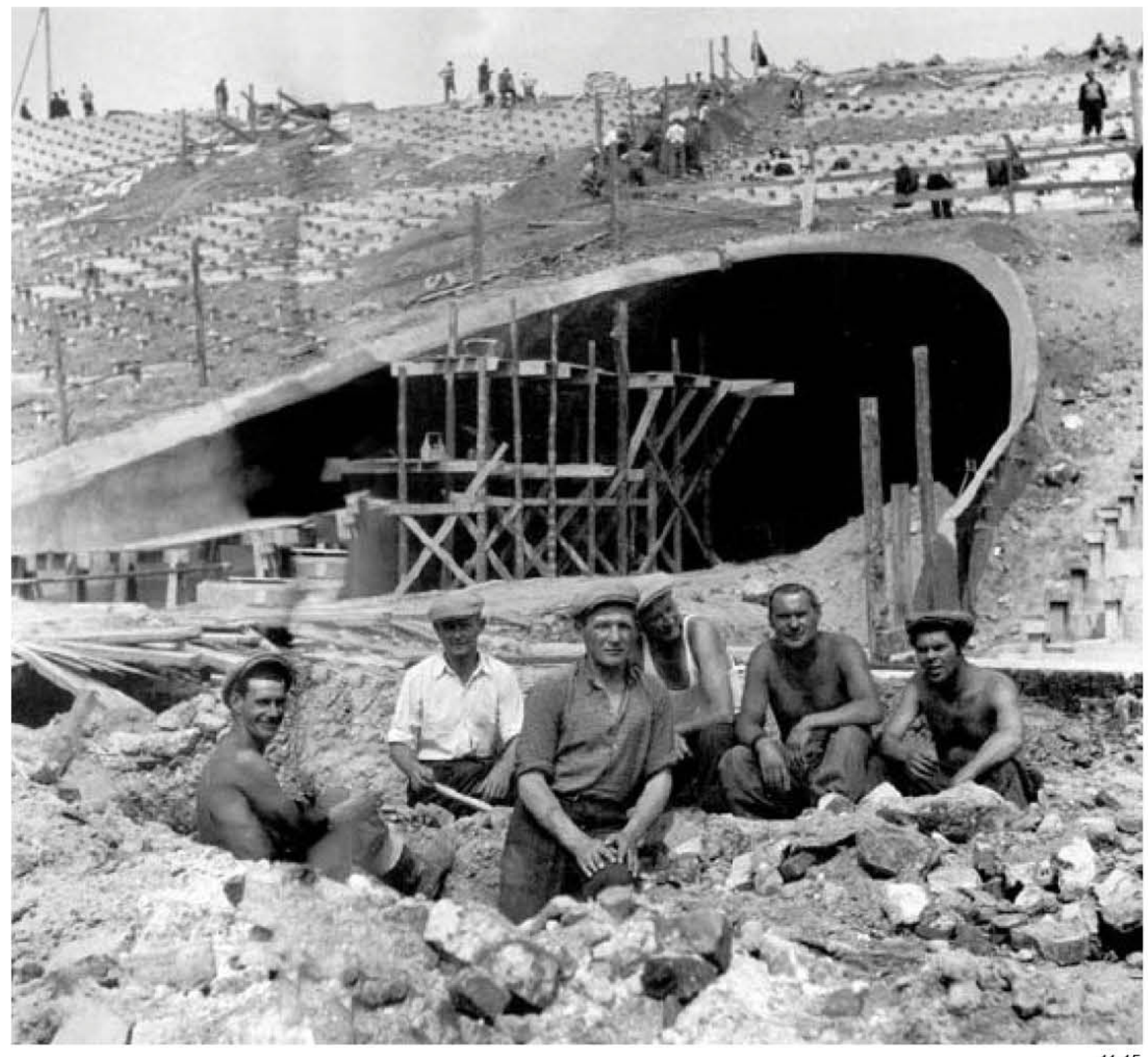


La escasez de tiempo ante la inminente inaguración del evento fue clave para que las autoridades gubernamentales aceptaran la eliminación de todos los elementos que formaban parte de la estética historicista habitual en los proyectos del Realismo Socialista (escaleras monumentales, obeliscos, columnas..) El estadio, a su vez, fue dividido en 42 sectores como contraposición a los 42 pisos de altura que tenía el Palacio de la Cultura y la Ciencia y su altura total prevista -230 metros- coincidía con la propuesta inicial prevista para el diámetro del estadio, aunque su construcción daría finalmente lugar a un diámetro algo mayor.

La cesión del testigo que había representado Deineka en su cuadro de 1947 estaba a punto de representarse a la vista de toda la sociedad, en una inaguración conjunta de dos edificios cuyos planteamientos resultaban opuestos ante la mirada de cualquier espectador por muy ajeno que fuese a la arquitectura. Se trata de un símbolo y su correspondiente antagónico, cuyas implicaciones políticas convertían la obra en un auténtico referente ideológico y social.

La propia ubicación del estadio en el centro histórico de Praga lo situaba frente al otro centro histórico de la ciudad en la calle Marszałkowska -donde estaba construyéndose el edificio PKiN-, al otro lado del río Vístula. La presencia volumétrica de ambos iba a resultar también un claro contraste entre la afirmación y la dominante presencia sobre su entorno de la torre PKiN y el enterramiento y la introversión de un estadio, que no presentaba fachada alguna y trataba de desaparecer en el paisaje a pesar de su monumental escala. La accesibilidad y facilidad de evacuación del recinto deportivo al que se podía acceder a pie y dominar visualmente por completo desde la corona perimetral iba a contrastar además con la estructura defensiva y compartimentada planteada para la torre, acentuando esa diferencia por las diferencias decorativas entre un edificio proyectado desde la más absoluta austeridad y simplicidad de los detalles, y otro que había sido planificado desde la ostentación y la dominación sobre su contexto como una forma de manifestación del poder. ${ }^{11.01}$

Las obras del estadio comenzaron el 2 de agosto de 1954 y la construcción fue supervisada por Marek Leykam junto a Jerzy Hryniewiecki y Czesław Rajewski, a los que se unieron Danuta y Julian Krajewski, el urbanista Stefan Koziński y la paisajista, Maria Wyganowska, además de los jóvenes arquitectos Jerzy Główczewski, Eugeniusz Ziółkowski, Bronisław Gawryluk, Zbigniew Pawelski y Waldemar Dzierżawski. Oficialmente, todos ellos estaban empleados en el estudio de arquitectura denominado "Estadio" ("Stadium") y a ellos se sumaba el equipo de ingenieros liderado por Zygmunt Roszkowski. ${ }^{11.01}$

La zona del proyecto había albergado anteriormente un vertedero y un primer reconocimiento del terreno reveló que existían algunas capas de residuos que tuvieron que ser eliminados, para lo que se utilizó maquinaria pesada importada de la Unión Soviética. Desde ese momento se cerraron los vertederos de Varsovia y durante varios meses comenzó a rellenarse la base del estadio con camiones de escombros procedentes de toda la ciudad. ${ }^{11.01}$

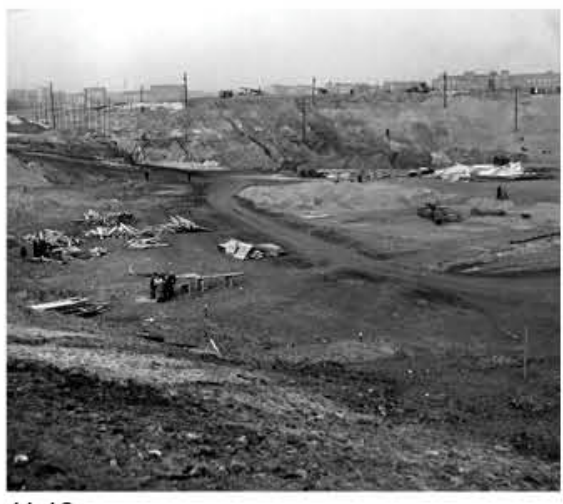

11.16

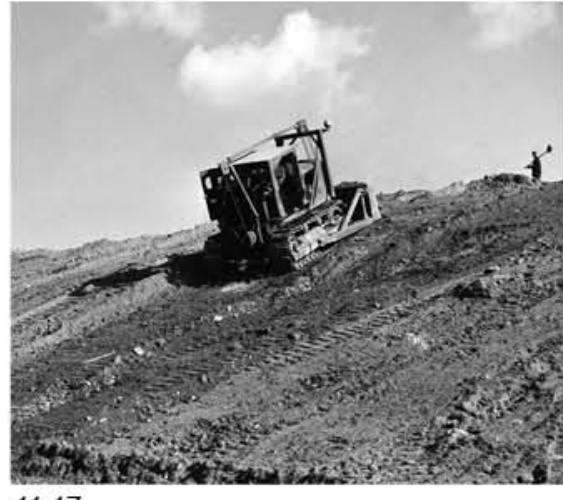

11.17

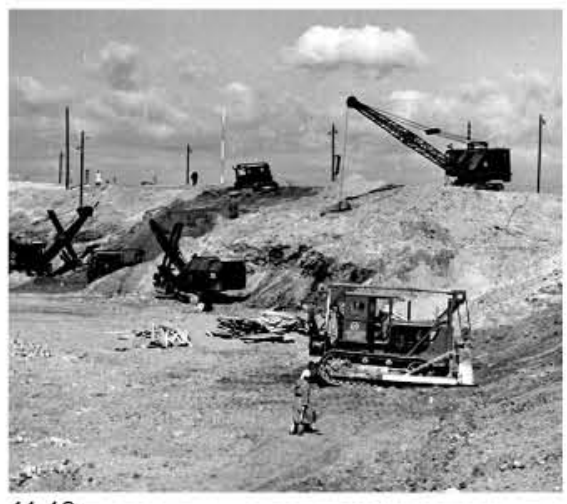

11.18 
11.19 Fórmula matemática para el trazado de las

$$
y=e^{1 / 2(a+x)^{2}}\left[\int 0^{1 / 2(a+x)^{2}} d x+c\right]
$$

11.20 Trabajadores en la obra del Estadio del Decenio

11.21 Esquema y dimensiones de los principales

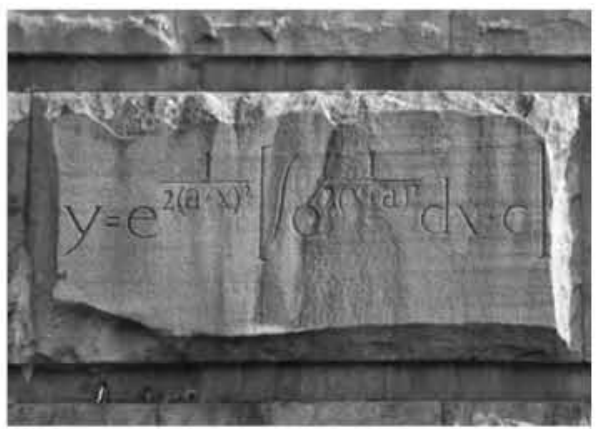

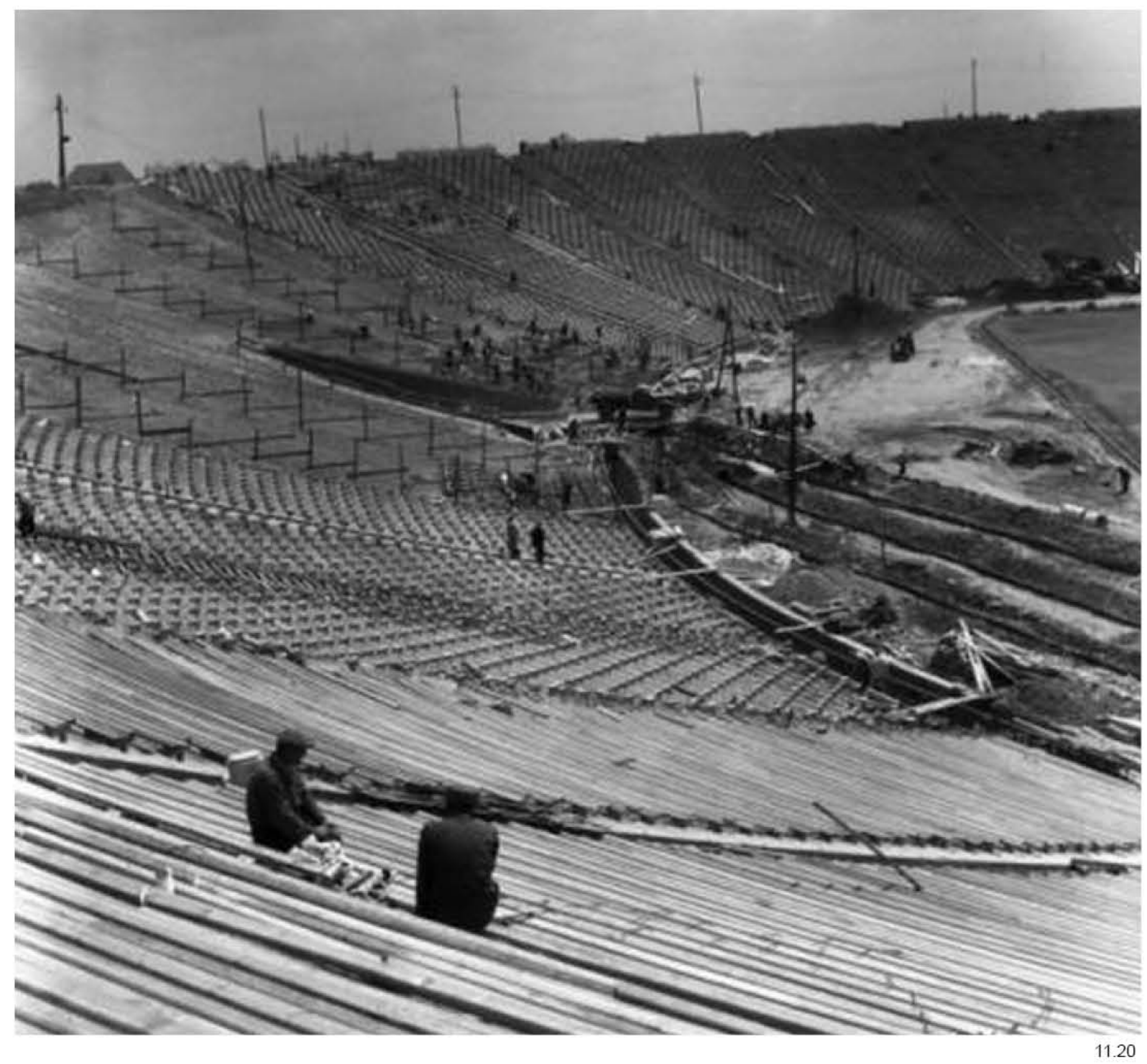


La cantidad de material era tan grande que los cálculos realizados junto con los miembros del Laboratorio de Arquitectura del Paisaje dirigido por Maria Wyganowska mostraron que la cantidad de residuos disponibles permitía construir el terraplén para un estadio casi tres veces más grande de lo previsto. Este hecho, unido al fácil acceso a la arena de la orilla del río cercano, obligaron al equipo de Leykam cambiar el diseño inicial del graderío por uno de similares características pero de mayor capacidad. La pista deportiva mantuvo las dimensiones olímpicas pero la grada se amplió hasta una capacidad de 70.000 personas con el proyecto ya en fase de ejecución. ${ }^{11.01}$

El puente de Poniatowski pasó esos meses a ser una cadena interminable de camiones y carros trayendo al futuro estadio miles de toneladas de escombros, mientras que en la orilla del río se ancló un barco con equipamiento que permitían sacar la arena del río Vístula a través de enormes tubos y llevarla directamente al solar. El cambio de proyecto trajo consigo además una revisión de los cálculos matemáticos que permitían trazar con precisión todas las curvas del proyecto, tanto la nueva elipse al pie del terreno de juego, como la nueva corona circular y todo el trazado de las gradas. El encargado de esta comprobación fue arquitecto del equipo Eugeniusz Ziółkowski en quien Leykam no confiaba ya que pidió de forma independiente al conocido especialista en el campo de la geometría, el profesor Edward Otto del Instituto de Matemáticas de la Academia Polaca de Ciencias, una verificación. ${ }^{11.06}$

Tras dos semanas de revisión el profesor y sus asistentes trajeron al estudio de Leykam los resultados de este cálculo, así como una ecuación que permitía hallar la pendiente de todas las curvas, pero Ziółkowski no estuvo de acuerdo con el replanteo y fue capaz de puntualizar acertadamente aquella ecuación. Aquella fórmula fue tallada en piedra y a la finalización del proyecto fue situada en el muro de contención de la entrada más representativa al estadio desde el río Vístula (11.19).

El verdadero problema al que tuvo que adaptarse el trazado continuo de estas curvas en las gradas fue la perdida efectiva del número de filas de asientos para compensar la inclinación en los tramos de mayor inclinación (11.21). Como factor nivelador de estas diferencias se utilizaron los dos tramos colindantes de escaleras a diferentes niveles que separaban los diferentes sectores de las tribunas en las que se cambio el número de las gradas. El nivel de la corona del estadio se mantuvo uniforme gracias al pequeño aumento de la altura de los asientos y un estrechamiento de filas en los sectores norte y sur, de este modo el aumento de la inclinación de gradas se pudo corregir.

En invierno de 1954 se completó la construcción de las laderas de la cuenca y la compactación del terreno además de la construcción de los túneles que conducían al estadio y la tribuna de honor aunque las expectativas geodésicas de asentamiento del terreno no fueron las previstas y en la cuenca del estadio fue necesario retirar el exceso de tierra, tarea que fue llevada a cabo manualmente por cerca de dos mil personas. ${ }^{11.01}$

El estadio había planteado situar bajo los escombros 3 pasos subterráneos en forma de túnel con bóveda de cañón en
Talud
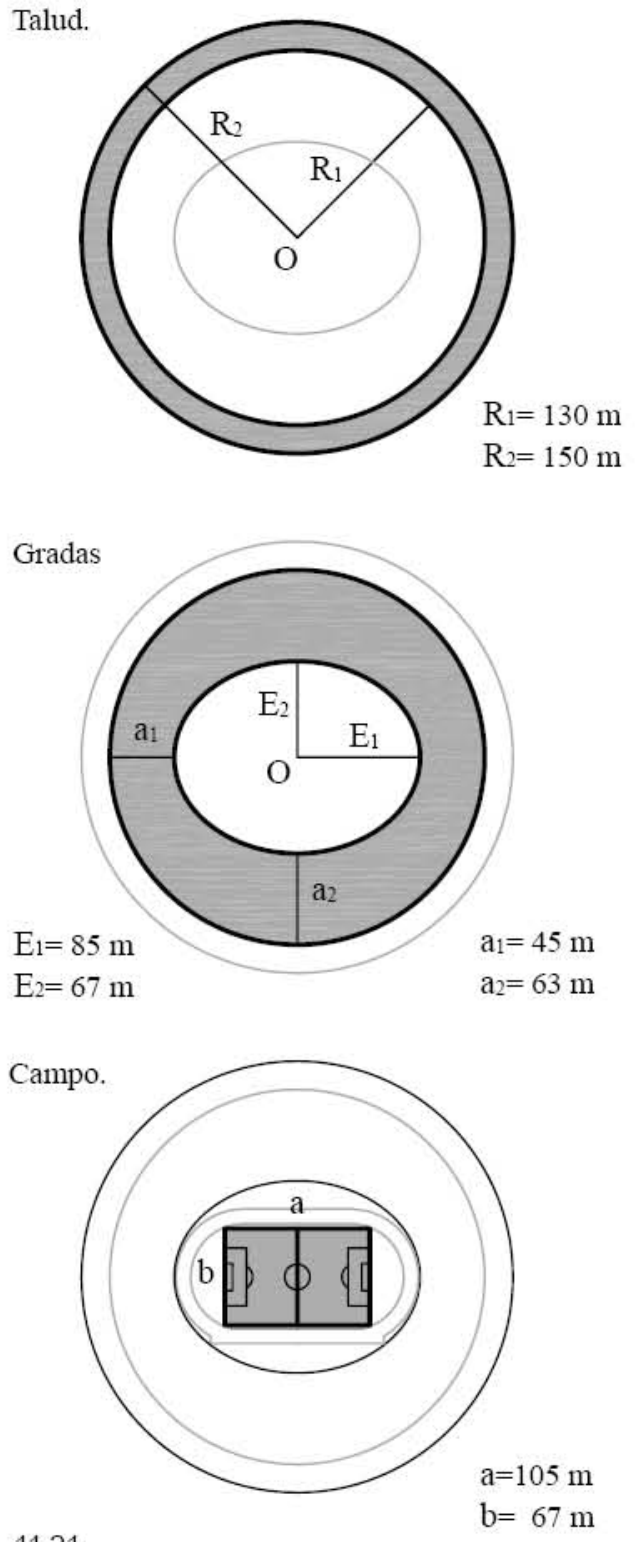

11.21 $\mathrm{b}=67 \mathrm{~m}$

11.06 Hardej, 2012 
11.22 Visita de la obras del Estadio del Decenio.

11.23 - 11.24 Pabellón de prensa y valla exterior
del Estadio del Decenio. Arquitectos: Danuta Krajewska y Julian Krajewski.

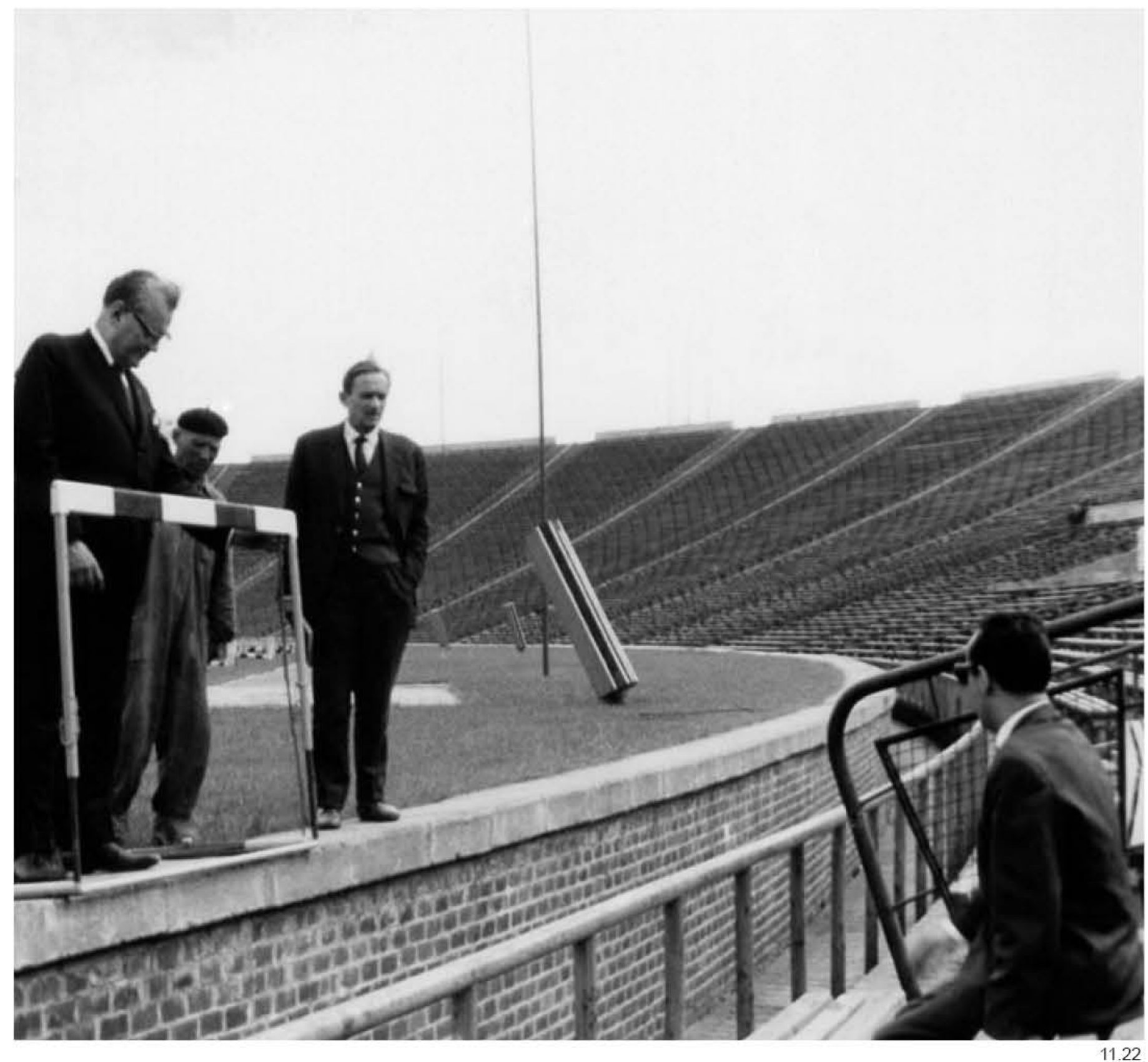


hormigón armado. El primero de ellos, de 80 metros de largo, conectaba al este con la calle Zieleniecka, el segundo, de 60 metros de largo, se dirigía al lado oeste conduciendo directamente a la tribuna de honor y el último de 120 metros, se dirigía al norte y unía directamente el estadio con el pabellón deportivo, quedando destinado a uso exclusivo de deportistas y personal de mantenimiento del estadio.

La cota del campo se trazó en el nivel $+4,63 \mathrm{~m}$. sobre el nivel del río y la corona perimetral superior a una altura de $+23,00 \mathrm{~m}$. Las gradas del estadio fueron divididas en 42 sectores, con una tribuna de honor con acceso independiente para las autoridades con capacidad para 50 personas, con la posibilidad de ampliarse a 200 plazas reduciendo el espacio destinado a los espectadores adyacentes. El principal material utilizado en los acabados fue la piedra arenisca. Sillares de mampostería fueron empleados en los muros de contención exterior además de su uso en la pavimentación de las escaleras exteriores y las plataformas de comunicación. La tribuna de honor fue revestida de mármol blanco y verde, mientras que las barandillas de hierro, la numeración de sectores y valla de la entrada principal fueron diseñados por Danuta Krajewska y Julian Krajewski. La parte más representativa del edificio, el acceso desde el río Vístula, fue revestida también con piedra arenisca mientras el suelo de la entrada fue resuelto mediante fragmentos de losas de piedra multicolor. ${ }^{11.07}$

En abril de 1955 visitó las obras el presidente Bierut y cuando quedaban poco más de unos meses, los organizadores encargaron al equipo de arquitectos el diseño de algunas edificaciones adyacentes no previstas. Se diseñaron así las piscinas para el club deportivo WKS Legia en la calle Lazienkowska utilizando el proyecto aun estudiantil de Jerzy Glówczewski mientras que los arquitectos Danuta Krajewska y Julian Krajewski proyectaron el pabellón de prensa (11.23) situado sobre las tribunas del estadio ${ }^{11.08}$. Los sobrantes prefabricados de hormigón utilizados como soporte de las gradas del estadio se utilizaron para la construcción de un anfiteatro en la ladera de Agrykola.

El 22 de julio, el estadio fue puesto en uso y bautizado con el nombre de Estadio del Decenio para conmemorar el aniversario del Manifiesto de Julio (véase 4.02). Durante los días 31 de julio - 14 de agosto de 1955, se convirtió en el escenario principal del V Festival Mundial de la Juventud y los Estudiantes, entrando en uso al mismo tiempo que el Palacio de la Cultura y la Ciencia (PKiN). El mero hecho de la eliminación de los elementos historicistas propios del realismo socialista había significado un hito en la arquitectura de Varsovia en aquel momento y la simplificación del proyecto fue interpretada con posterioridad como un fenómeno plástico símbolo de una nueva era.

A pesar de la escala del proyecto, los arquitectos habían logrado a su vez mantener el equilibrio entre la forma del edificio y la perspectiva espacial de la ciudad. El volumen del estadio se percibía visualmente incrustado en el entorno cuando era observado desde la orilla izquierda del Vístula, y no dominaba en la perspectiva del horizonte. Toda la zona fue diseñada además como parte de un parque cuya intención era que formase parte de un gran complejo de recreación con la posibilidad de ofrecer múltiples recorridos peatonales.
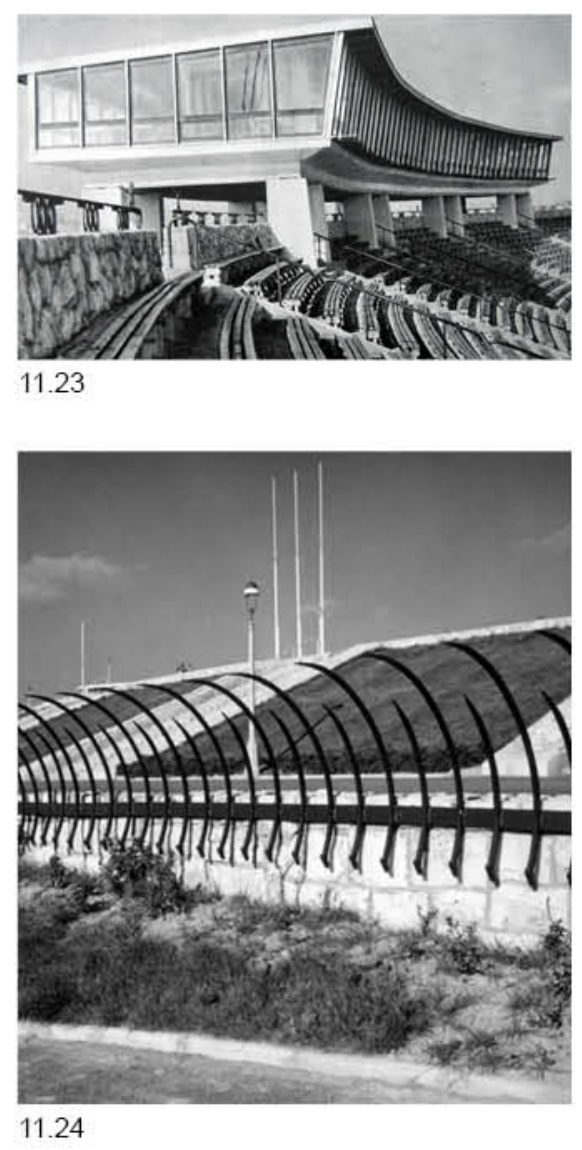

11.07. Jur, 1977. p $75-84$

11.08. Este pabellón se quemó en los años setenta y no fue reconstruido. 
11.25 - 11.27 31 de julio de 1955. Desfile de inaguración del V
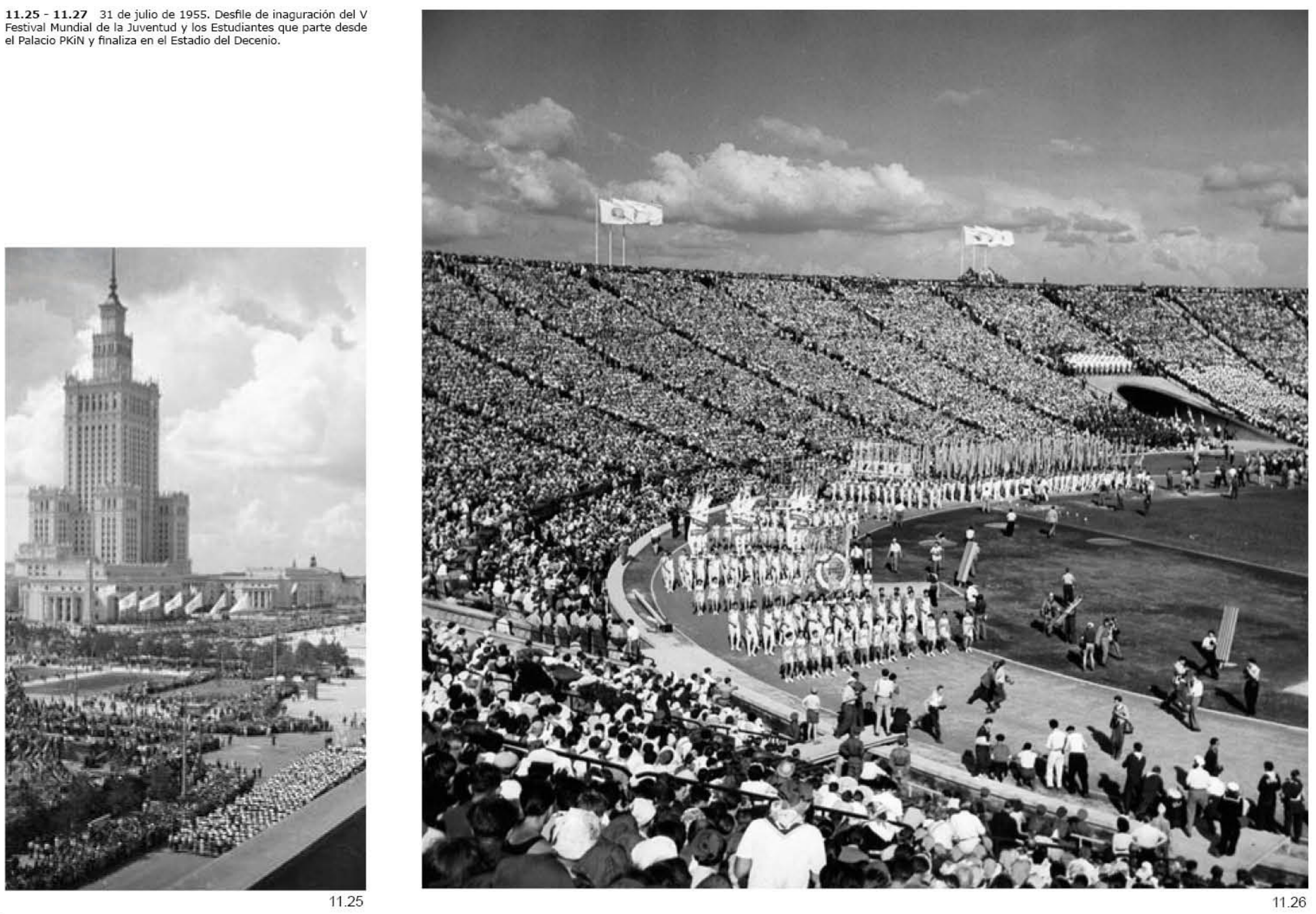


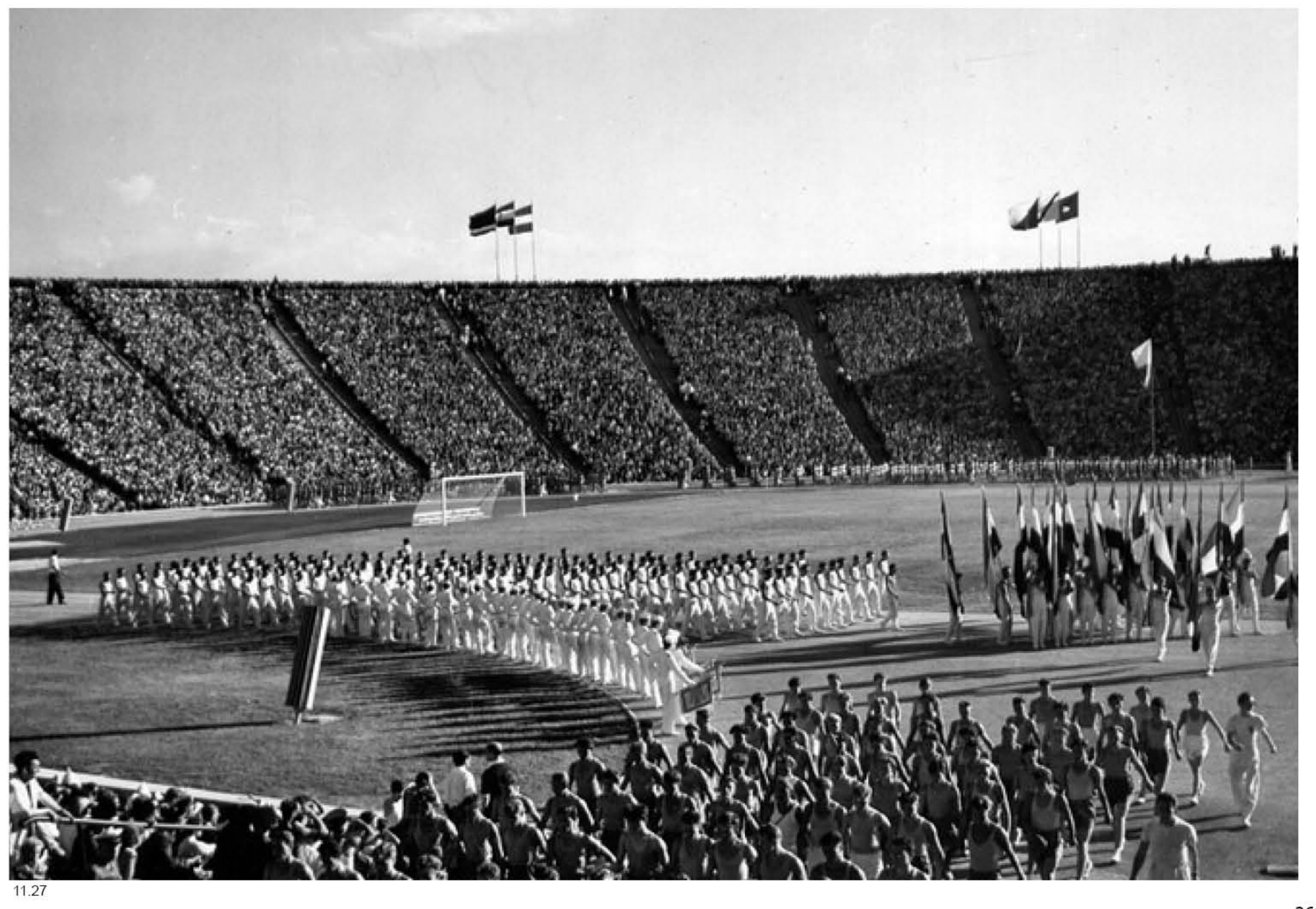


11.28 Tunel de acceso al Estadio del Decenio, 1955.

11.29 - 11.30 Estadio del Decenio, según el

proyecto de Marek Leykam, Jerzy Hryniewiecki,

Jerzy Główczewski, Eugeniusz Ziółkowski y

Bronisław Gawryluk, 1955.
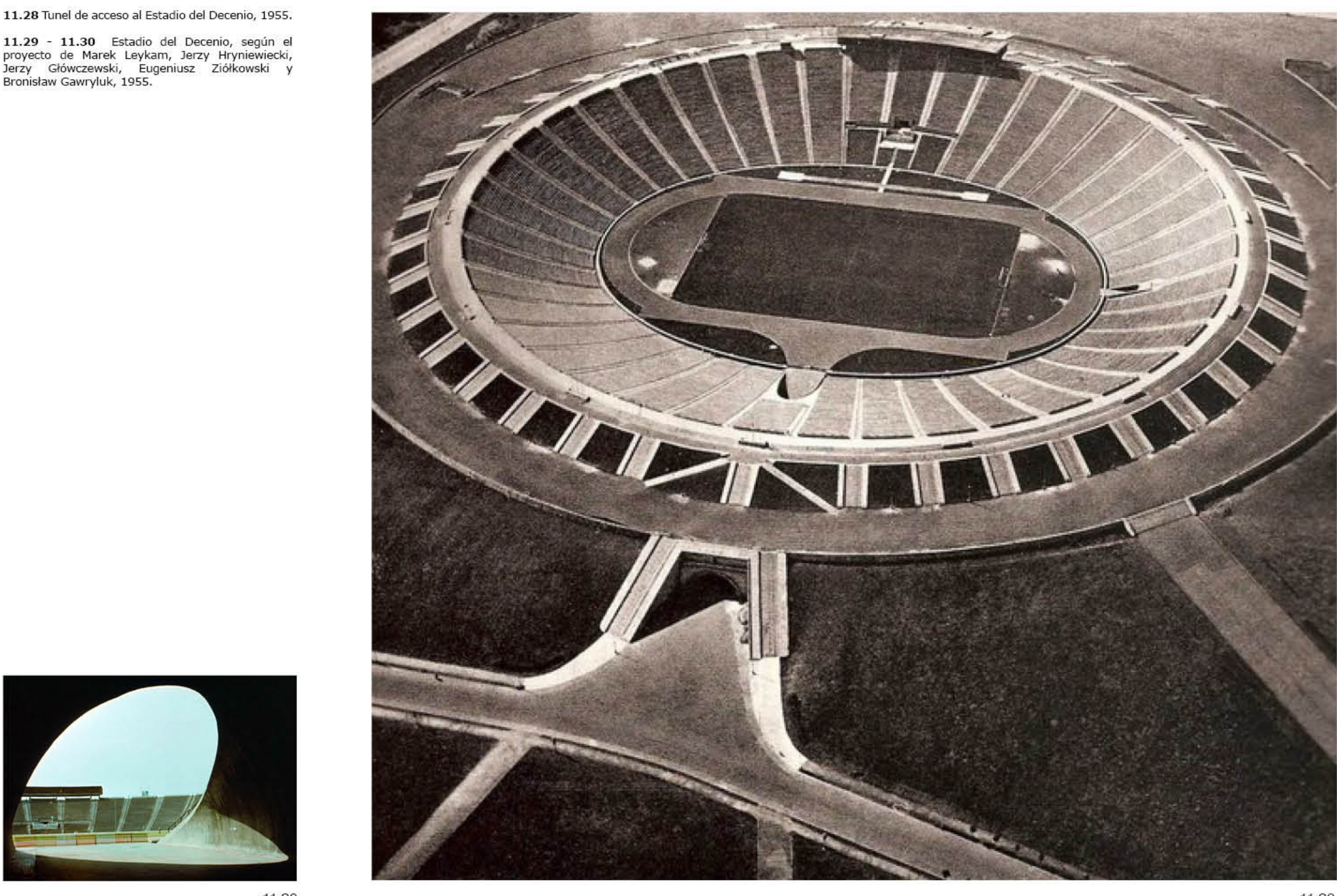
Participando del espíritu que había reconstruido muchos de los edificios de Varsovia durante los primeros años de postguerra, la construcción de este Estadio resulto en gran medida un acto social en el que trabajó gran parte de la comunidad, ya que muchas tareas fueron realizadas manualmente por trabajadores no calificados residentes en la cercanías, voluntarios de las escuelas de Varsovia y miembros de las asociaciones deportivas de todo el país. ${ }^{11.06}$

La corona superior del estadio, con una forma circular, creó una terraza peatonal que conectaba a través de escaleras con la corona inferior elevándose 2 metros por encima de esta cota y siendo delimitada por un muro de contención de piedra. El estadio contó con el túnel de la entrada principal en la prolongación del eje transversal hacia el este, mientras que, en el lado opuesto, se situaron finalmente: el túnel que conectaba la entrada bajo un pórtico cubierto que daba acceso vestíbulo con el palco de honor y el que unía el campo de entrenamiento con el pabellón deportivo y el campo principal de juego. Todas las líneas del proyecto estuvieron dirigidas por el trazo surgido de la integral de segundo grado grabada en las paredes (11.19). Además de las gradas, las tribunas y los muros perimetrales, con esta dirección se trazó una zanja a lo largo de un anillo concéntrico que cumplía el papel del canal de drenaje, y sirvió asimismo para alojar los espacios de jueces, periodistas, personal de la organización y agentes de seguridad. ${ }^{11.07}$

En el medio de la tribuna oeste, en la extensión del eje corto de la arena y a la altura de la mitad de la tribuna, se situaron finalmente los palcos de honor, mientras que en uno de los laterales quedaron alojados los vestuarios interiores, baños, duchas, sanitarios, 2 piscinas, salones y cafetería. Finalmente, los escalones y escaleras de la tribuna estuvieron compuestos de elementos prefabricados de hormigón armado, mientras en la construcción de los muros de contención de la coronación del estadio y la base del palco de honor se realizaron en bloques de piedra. Las paredes del túnel principal de acceso se revistieron con mármol. ${ }^{11.07}$

En el proyecto de Leykam y su equipo habían trabajado más de 50 técnicos de diversas especialidades, entre los que estuvo el grupo de matemáticos mencionado, dando idea de la importancia que para Leykam tenía la formulación clara del concepto desde la precisión que aporta el control absoluto de la modulación incluso en circunstancias en que la geometría era tan compleja de sistematizar, como el caso de este estadio.

Anivel de uso deportivo, el complejo contó finalmente con tres áreas. Además del estadio con sus tribunas, se construyeron campos de entrenamiento exteriores y el pabellón de deportes, mientras que a nivel de redes de comunicación, las vías principales Poniatowski y Zieleniecka, además de Wybrzeze Szczecinskie, la calle Targowa y la calle de Zamojski tenían todas un acceso fluido al lugar.

El proyecto de las zonas verdes exteriores fue resuelto a través de la avenida Zieleniecka generando un parque conocido como Skaryszewski, que finalmente se extendió más allá del espacio abierto previsto inicialmente para ello, llegando hasta Grochowo, mientras que en anchura recorría la distancia que separaba el estadio del río, conectándolo con el

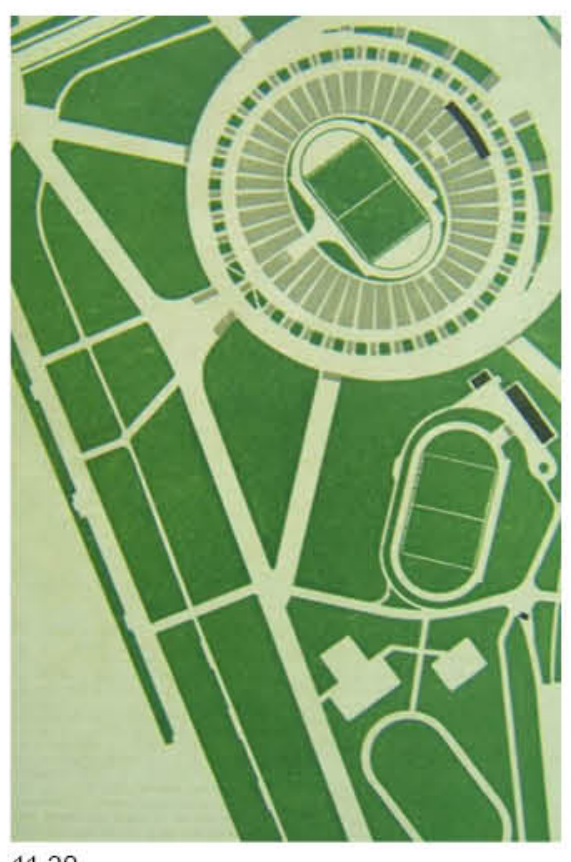

11.30 


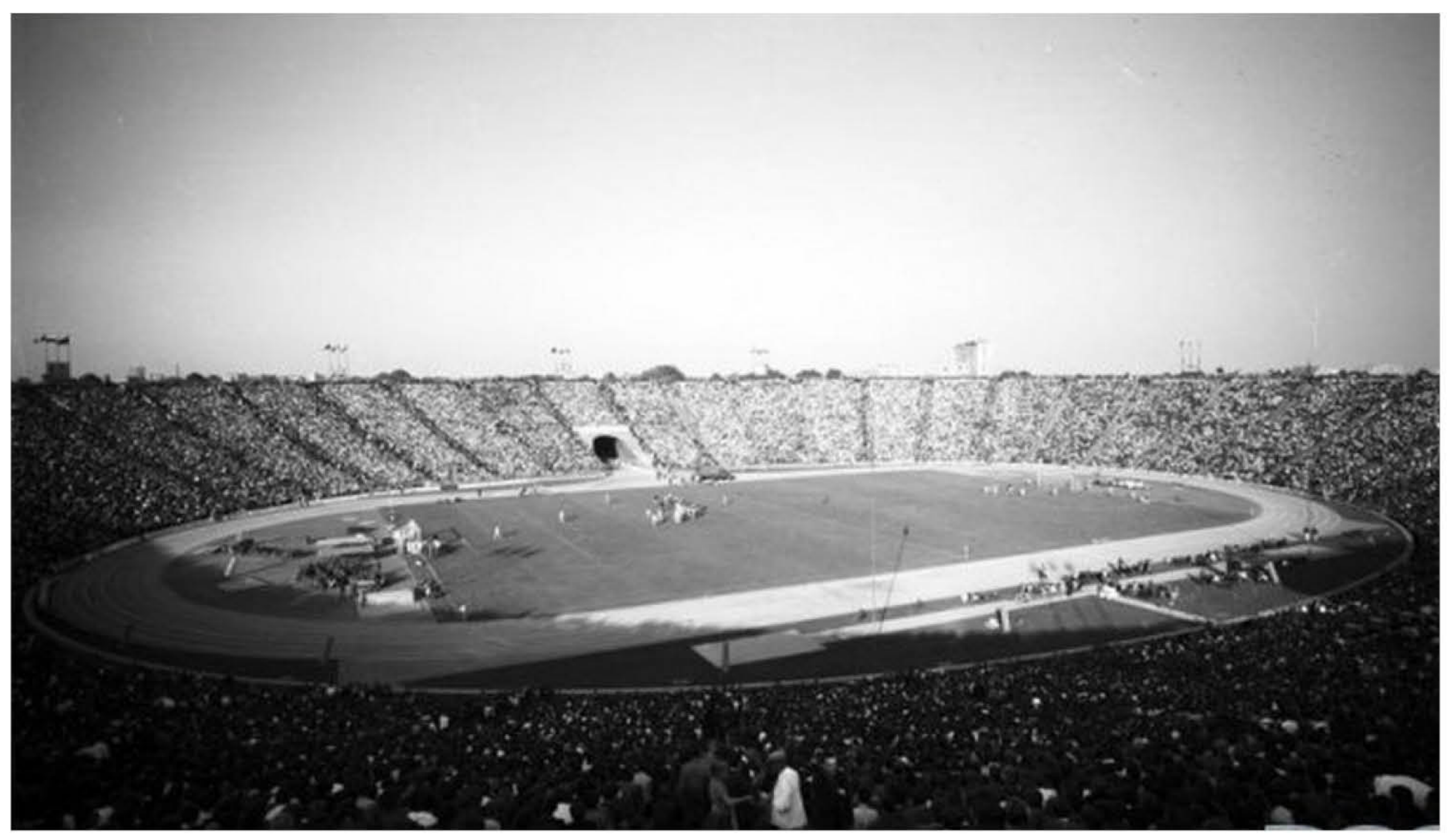


parque de Praga y el Parque Zoológico, un área verde que todavía se mantiene hoy en día. (11.30) La composición del estadio permitía que las terrazas del terraplén formasen una suave transición que, a nivel visual, era percibida en continuidad con el paisaje. El eje mayor de la elipse era paralelo al río y su sencilla transición hacia el parque permitía que los observadores pudiesen interpretar el parque en continuidad con el estadio desde una vista lejana al otro lado del río Vístula. (11.29)

La pureza y simplicidad de las formas geométricas de este estadio podían apreciarse tanto en el plano cómo en las diferentes partes que lo componían a nivel volumétrico y constructivo, aspirando a conseguir una visión del conjunto como "un todo en el que los detalles desapareciesen" 11.09 , constituido a partir de un ritmo sencillo de divisiones iguales que lograsen hacer construible una forma que proponía la compleja transición entre la formas de la elipse y el círculo.

Al crear unas condiciones de visibilidad óptimas para cada espectador, acoplado hábilmente a las fórmulas matemáticas, el Estadio del Decenio definió la escala y la forma de toda la instalación, y se convirtió en una solución del modelo de funcionalidad. Su adecuación en el tejido urbano integrado en el marco de un cinturón verde aportaba un interesante vacío de gran escala que, al mismo tiempo, servía para estructurar en forma de gran nodo la red de comunicación anexa al lugar. Todos los elementos de la composición del estadio interactuaban así positivamente, aunando su presencia urbanística tal como era percibido desde el otro lado del río Vístula y ofreciendo una imagen de conjunto en esta parte de la ciudad.

Leykam y su equipo lograron, asimismo, establecer con el proyecto un símbolo ideológicamente democrático al garantizar las condiciones óptimas de visibilidad para todos los espectadores, independientemente de su ubicación en el estadio, aunque detrás de ese discurso estaba el objetivo de racionalizar los recursos y atender a la economía del medios, facilitar la construcción y responder en un breve periodo de tiempo a un complejo programa funcional. Tal como explicaba posteriormente Hryniewiecki en un artículo de la revista Projekt:

\section{"Las formas modernas de la arquitectura son un lugar de encuentro del puro pensamiento matemático con las necesidades y propiedades fisiológicas del ser humano.[...] Las matemáticas, como una herramienta para ordenar y generalizar las leyes básicas de fisiología humana (...) permiten dotar de pureza al concepto, si bien son únicamente un medio para llegar a una forma construida, a la forma real." 11.10}

Leykam no era un arquitecto mediático y trato de minimizar sus apariciones en prensa comentando sus proyectos. A este respecto, Hryniewiecki poseía una personalidad mucho más extrovertida que le hizo significarse en multitud de eventos que tuvieran que ver con los proyectos que había desarrollado junto a Leykam. ${ }^{11.11}$ Las palabras de Hryniewiecki ofrecían, sin embargo, una visión concordante con la importancia que Leykam otorgaba a las matemáticas en los proyectos como punto de partida que le permitiera llegar desde la abstracción a la forma, desde el razonamiento lógico, analítico y racional a la expresividad de su materialización.

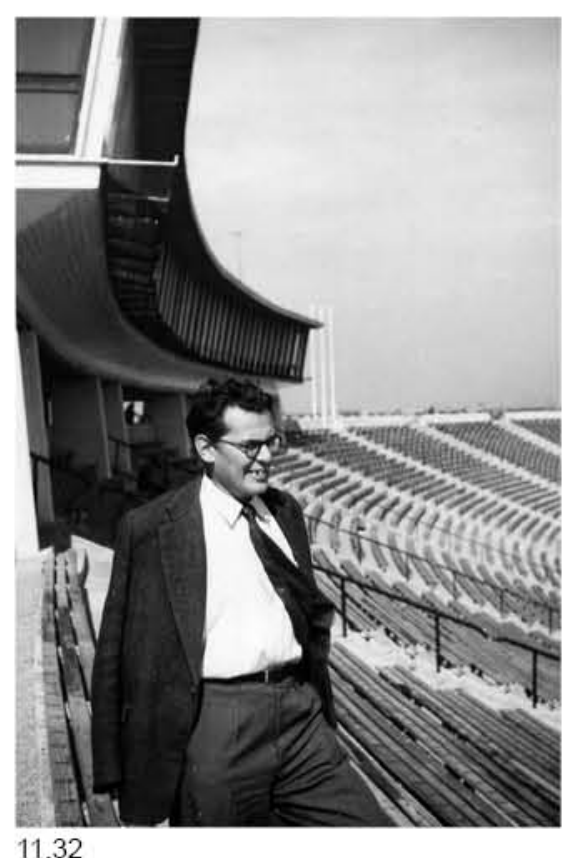

11.32

11.09 Citando las palabras del propio Leykam en su doctorado "Arte Liturgico" (Véase Leykam, 1943).

11.10. Artículo "Formy stadionów" (La forma de los estadios). Revista Projekt, 1956. Op. Cit. 9.08

11.11. Springer, 2011. p 53 
11.33 Estadio del Decenio de Varsovia ,1955. Arquitectos: Marek Leykam, Jerzy Hryniewiecki, Jerzy

11.34 Palacio de la Cultura y la Ciencia de Varsovia, 1955. Arquitectos: Lev Rudnev y equipo.

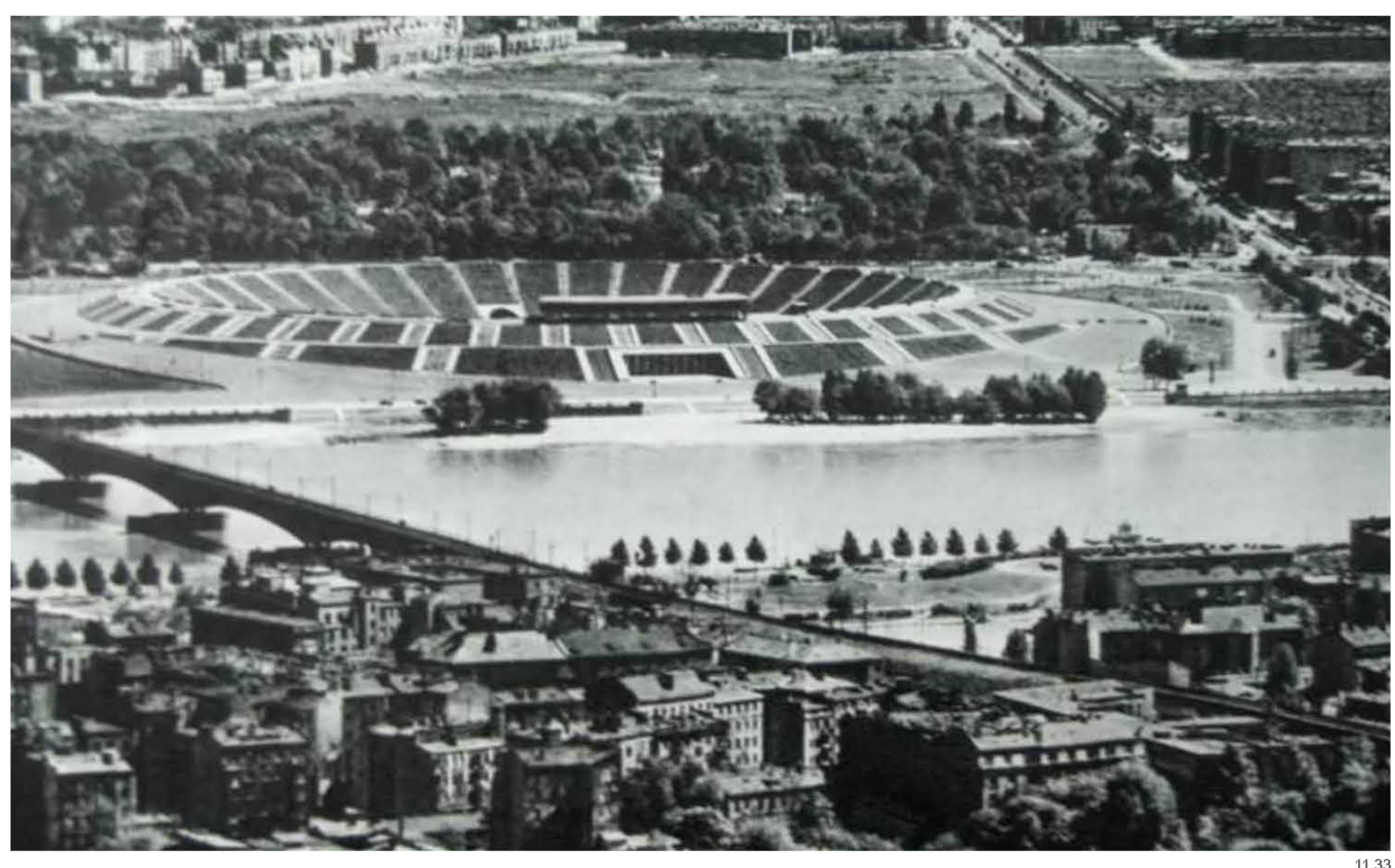




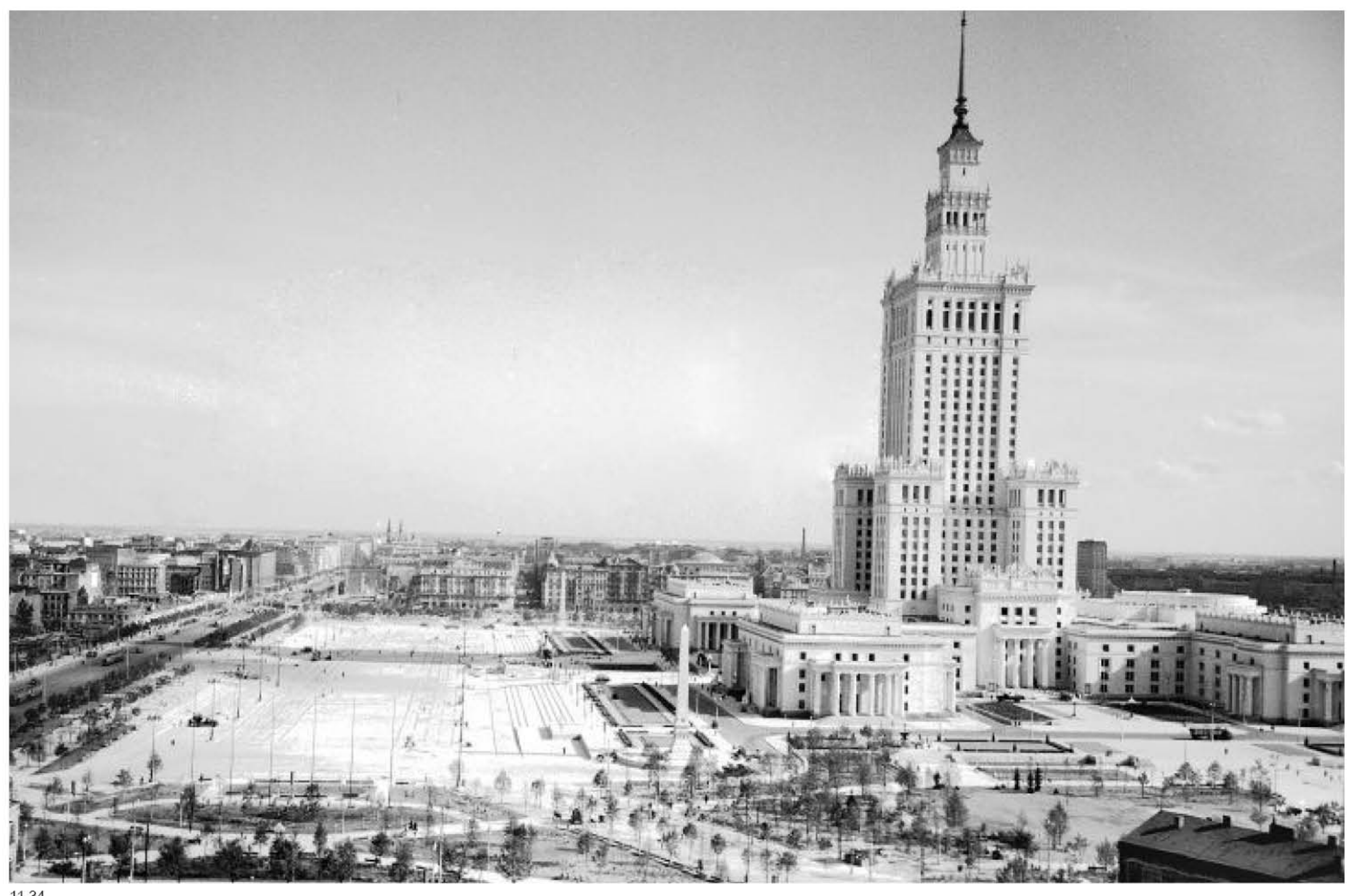


El antagonismo que el Estadio del Decenio suponía con respecto al palacio PKiN, es trasladado al terreno ideológico en la medida en que trasciende a la comparativa inherente a la realidad de los objetos, para comunicar con la concreción y la percepción que podían hacer de esta dicotomía los habitantes de Varsovia, tanto en el entorno cercano al Estadio como en las comparativas que ofrecen las distintas panorámicas de la ciudad. La traslación de las ruinas de los edificios demolidos otorgaba a las ruinas enterradas bajo sus gradas un carácter plenamente simbólico, que manifestaba el propósito de dar un nuevo rostro a la ciudad.

Conciliando los intereses de un monumento artístico, con la participación de la comunidad y las necesidades de la ciudadanía polaca, Leykam y su equipo se encargaron de acrecentar la conciencia popular sobre la importancia de respetar una herencia cultural irreemplazable e históricamente inherente a la sociedad polaca como la que deviene de la lógica y su interpretación, en tanto derivan de su uso mecanismos que priorizan la organización racional de las estructuras ya sean de carácter técnico o social, científico o sociológico, y, por tanto, ya hagan referencia a la formalización de un estadio o a la definición de una forma de organización de una sociedad.

La decepción de las esperanzas puestas en el subjetivismo había hecho renacer en Polonia el deseo de mantener las formas integradas en el paisaje natural, en armonía con su entorno, con el medio ambiente y con la civilización, asimilando las connotaciones emocionales que ello evocaba en una sociedad que estaba a punto de abandonar el Realismo Socialista tras la muerte de Stalin en 1953.

Los polacos iban a ser los encargados de unificar el soporte construido por este estadio, trasladándolo al ámbito ideológico en la medida en que eran partícipes de su planteamiento abiertamente democrático, siendo usuarios de una instalación en la que no existían jerarquías en la posición de los asientos y la definición de los accesos, abiertos a lo largo de todo el perímetro de forma que cualquier ciudadano podía acceder. La disposición del graderío daba lugar, por tanto, a un contexto de oportunidades en el que ninguno de los usuarios debía sentirse discriminado. Esa espontánea relación de todos los actos de conciencia de los habitantes de la ciudad es la que daba sentido a las transformaciones sociales de la obra, algo que todo el conjunto de la arquitectura de Leykam estaba dirigido a propiciar.

Si bien, a nivel absoluto, se podría considerar que esta obra plantea una transmisión de valores que proviene del pensamiento autónomo del arquitecto autor, ésta solo tiene consecuencias reales y por tanto, solo existe, bajo la condición de quedar integrada en tiempo y forma en la sociedad a partir de la cual adquiere su sentido.

La finalidad de los objetos construidos por Marek Leykam no está por tanto solo en la capacidad para abarcar las funciones para las que ha sido encomendada, sino para asentar en el tejido social un objeto que, a través de su uso, escenifique una cultura de convivencia igualitaria y democrática. Teniendo en cuenta la mente como la medida del conocimiento, Leykam antepone al instante ordenante fruto del irracionalismo el control racional de las emociones, aunque otorga a la emoción una función verificadora de valores a partir de los cuales la expresión cobra sentido. 
A través de su obra, Leykam reconstruye un mensaje que no hace sino manifestar cómo determinados actos toman consciencia cuando son integrados en la realidad social y, más que producir un elemento completamente nuevo, con la construcción de este estadio trasciende a sus propiedades intrínsecas fruto de su capacidad de dar respuesta a las necesidades prácticas , para ser insertado también en los requerimientos espirituales de la comunidad polaca, atendiendo así a una multiplicidad de actores sociales que son capaces de interiorizar esta situación.

El hecho de trascender al objeto estético no implica que la arquitectura de Leykam declinase la responsabilidad de atender a su formalización constructiva y proyectual de manera autónoma. Su interpretación no discurre hacia el sujeto, sino que está estrechamente asociada a la concreción que la sociedad en su conjunto pueda enmarcar a esta obra, en la medida en que interactúa con la vida de los que la utilizan.

La arquitectura de Marek Leykam estaba condicionada a la respuesta a un conjunto de condicionantes prácticos, siendo la interacción social la encargada de generar una determinada atmósfera cultural, política y social en la que se manifiesten los valores colectivos alcanzando un impacto en la mentalidad ética, moral y la ideológica de las personas que entren en contacto con su realidad material.

De este modo, decisiones técnicas y enfocadas a la eficacia constructiva y la resolución de problemas de distribución y equilibrio del trabajo -como las que han sido descritas en el presente capítulo- asumen, al mismo tiempo, el papel de ordenadoras de un conjunto social utilizando la arquitectura como símbolo antagónico del poder establecido.

El Estadio del Decenio de Varsovia ha ocupado, desde su finalización en 1955, un papel destacado en la historia de la arquitectura polaca hasta su destrucción en 2008. Sus formas sencillas y funcionales y su provocadora carencia de elementos decorativos en el periodo de madurez y al mismo tiempo de convalecencia del Realismo Socialista, hicieron que se convirtiera en un símbolo del fin de una era, un edificio que rompió radicalmente las tendencias de Realismo Socialista y se erigió como manifiesto de una "nueva dirección en la arquitectura de Polonia." 11.12

Para Leykam, este proyecto, sin embargo, solo fue un paso más. Una nueva variación dentro de un método proyectual persistente y constante que relaciona toda su obra de forma continua desde la prioridad por la eficiencia y la optimización de los recursos materiales y técnicos, pero principalmente desde la consciente necesidad de establecer un mensaje -a partir del paralelismo que considera claramente establecido entre la organización de la arquitectura y la organización de una sociedad- de resistencia, a partir del cual sea posible sentar las bases de una recuperación identitaria. 
12.01 Oscar Niemeyer explica sus proyectos y sus planes para la

政 1954.

12.02 Oscar Niemeyer recibiendo el Premio Lenin de la Paz en
1963 .

12.03 Oscar Niemeyer visitando una fábrica de Moscú en 1954

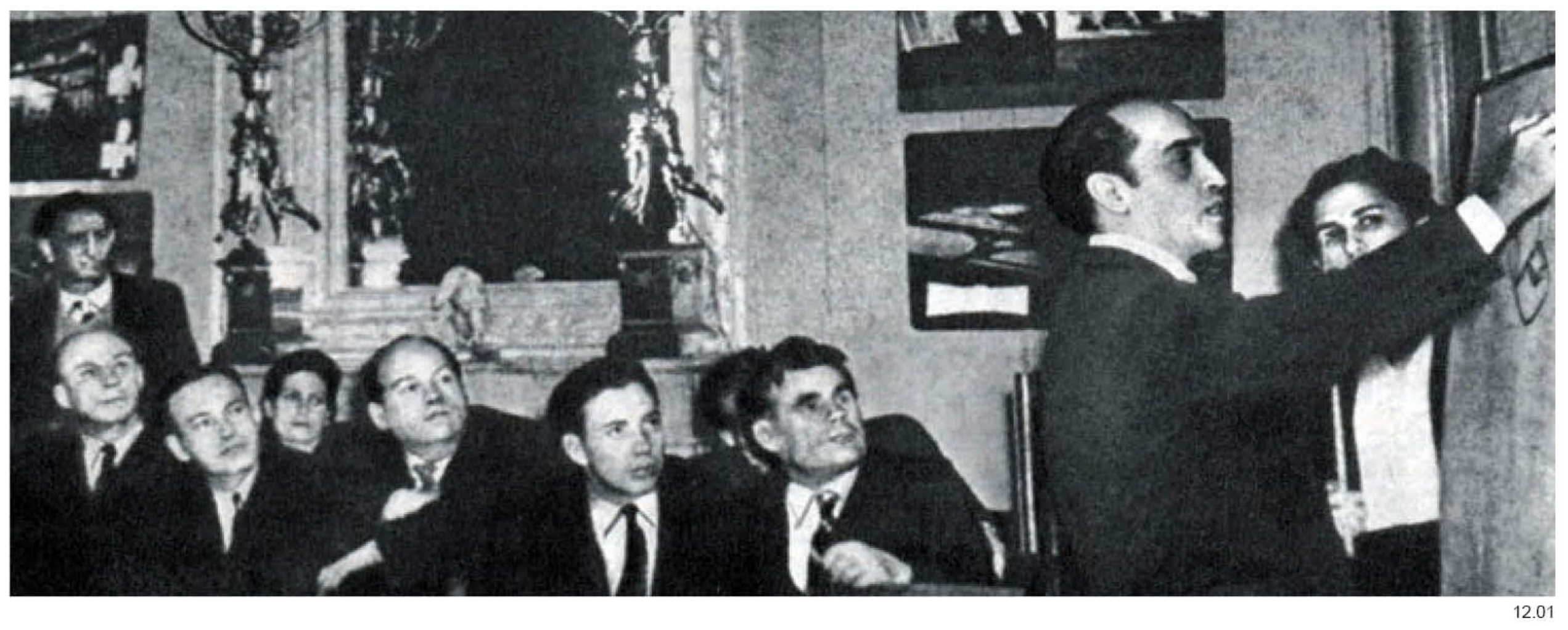




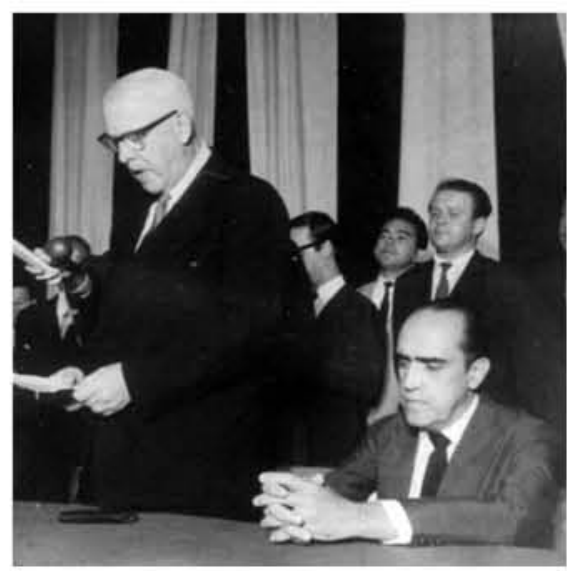

12.02

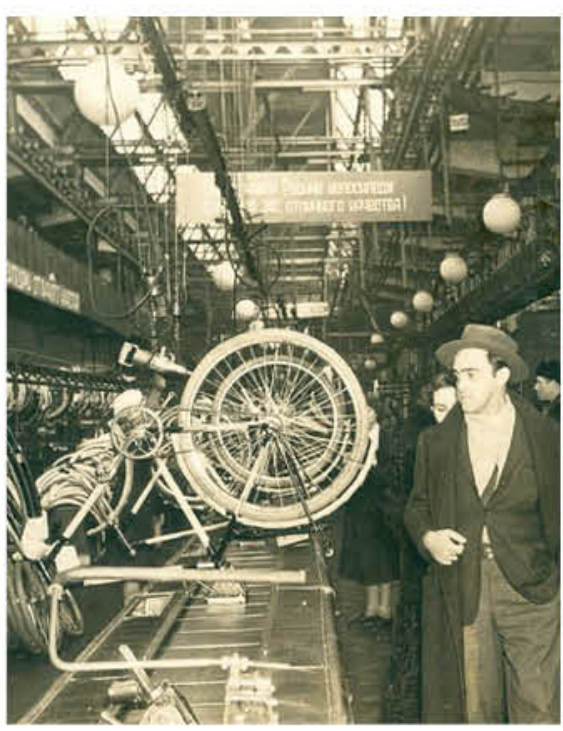

12.03

12.00. NIEMEYER, Oscar (1978) "A forma na arquitetura." Ed.: Cosac \& Naify, 2003. Cit. Lepori 2006. p. 125 .

12.01. Hite, 1986 
12.04 Bocetos de Oscar Niemeyer para la Escola Estadual Milton Campos.

12.05 Bocetos de Oscar Niemeyer para el Palacio

de Congresos de Brasilia.

12.06 Palacio de Congresos de Brasilia, 1956. Arquitectos: Oscar Niemeyer.

12.07 Bloque de Viviendas en Harnsaviertel, Berlin 1957. Arquitecto: Oscar Niemeyer.

81

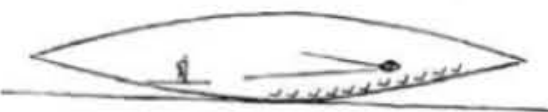

$+\sec$

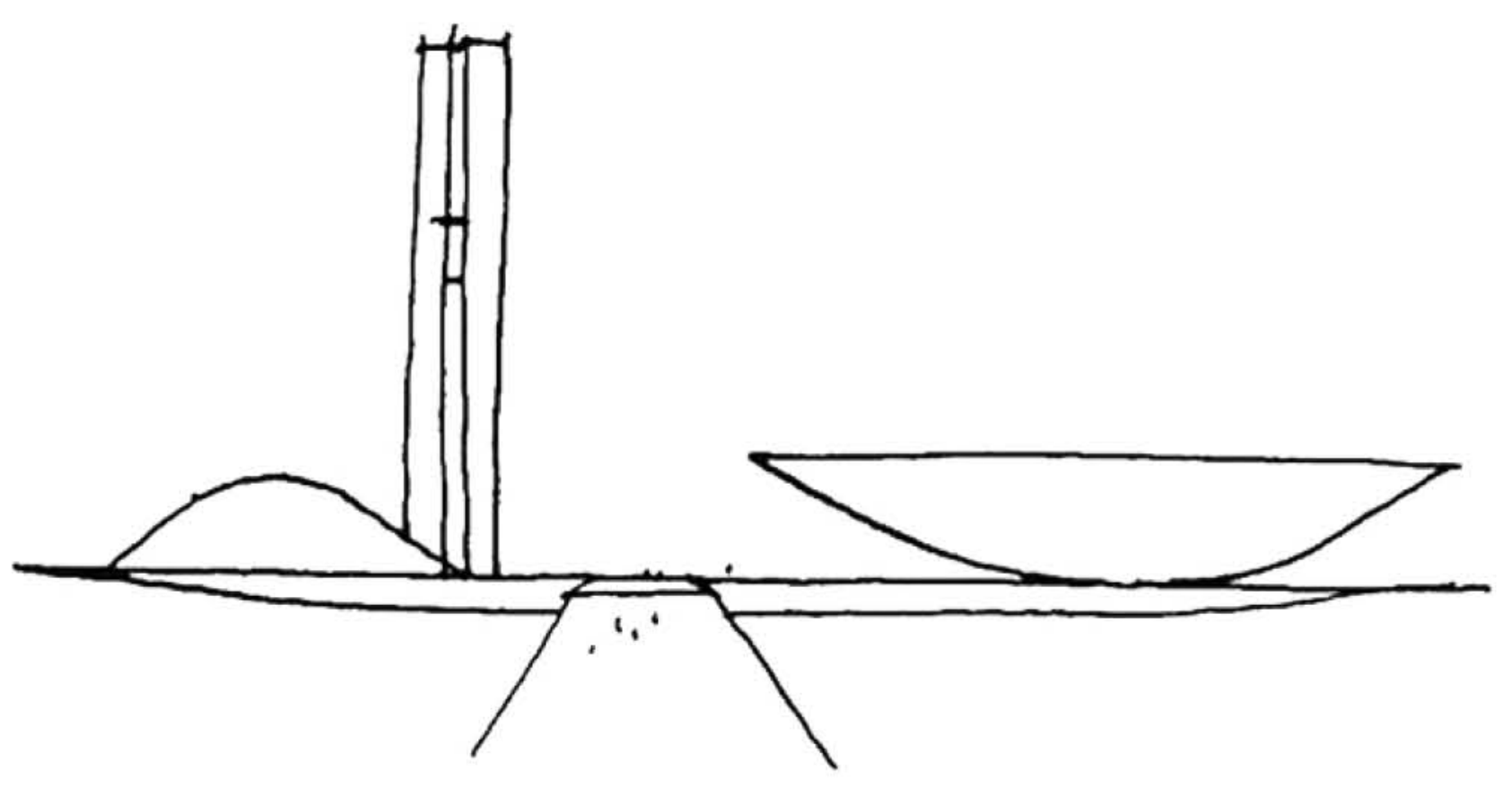


El motivo de este viaje a Europa de Oscar Niemeyer tuvo que ver con la invitación que recibió para ser uno de los arquitectos que construyesen un bloque de viviendas en el barrio berlinés de Hansa dentro del plan urbanístico para la reconstrucción de la zona devastada tras la II Guerra Mundial como parte del programa de la Internationale Bauausstellung (IBA) de 1957 en el marco de la exposición Interbau. ${ }^{12.02}$

En este viaje Niemeyer tuvo ocasión de visitar asimismo Polonia, Checoslovaquia y la Unión Soviética explicando en sus conferencias los planes que estaba desarrollando para la construcción de una ciudad de nueva planta, cuya información resultaba de gran interés para los arquitectos de estos países debido a las necesidades todavía latentes de reconstrucción en sus respectivas naciones. ${ }^{12.03}$ Los arquitectos polacos escucharon de forma directa de parte del arquitecto brasileño, cómo afrontar la tarea de planificar y construir el programa completo de una ciudad y cuáles eran sus propuestas al mismo tiempo que su discurso ideológico.

Después de haberse planteado en sus textos la imposibilidad de abordar desde la arquitectura la problemática social, Niemeyer se oponía consistentemente precisamente a la divulgación del concepto "arquitectura social" que según consideraba era "una creencia ingenua en la capacidad de resolver problemas complejos de la sociedad capitalista de una forma pacífica a través de la arquitectura con el uso de las decisiones simples y rentables de planificación y diseño con el rechazo de la construcción de prestigiosos acabados, (..) y consecuencia de ello el desarrollo de viviendas mínimas". ${ }^{2} .01$

Niemeyer no estaba de acuerdo en que existiese esperanza en resolver los problemas sociales de la sociedad capitalista a través de un medio profesional como la arquitectura: "Nos negamos a aceptar que tenemos las condiciones existentes para afrontar la arquitectura social" ${ }^{12.01}$ Durante la inaguración de uno de los edificios terminados en Brasilia Niemeyer exclamó: "Estamos amargamente ante los problemas de las condiciones sociales imperantes ... en contraste con el espíritu del plan maestro. Una creación no puede resolverse en el marco de la arquitectura ... Para eso, en primer lugar, necesitamos una base política socialista". ${ }^{12.01}$

Según Niemeyer "solo las reformas sociales podían aportar comodidad y libertad para todos", ${ }^{12.01}$ un punto de vista que el arquitecto mantuvo a lo largo de su vida: "Cuando la arquitectura del sistema social injusto toma la misma discriminatoria, el régimen, en vano, busca soluciones paternalistas demagógicas de arquitectura y urbanismo. Si queremos darle un contenido humanista a la arquitectura, esta debe estar directamente involucrada en la lucha politica para promover la transformación de la sociedad". ${ }^{12.01}$

Concebido como "símbolo de una próspera, feliz e independiente Brasil", la ciudad de Brasilia que bocetaba Niemeyer en Polonia en 1954 hacía sin embargo ya hincapié en un modelo de arquitectura inusualmente monumental para la nueva capital de Brasil. Promocionado por multitud de publicaciones, revistas especializadas y videos publicitarios,

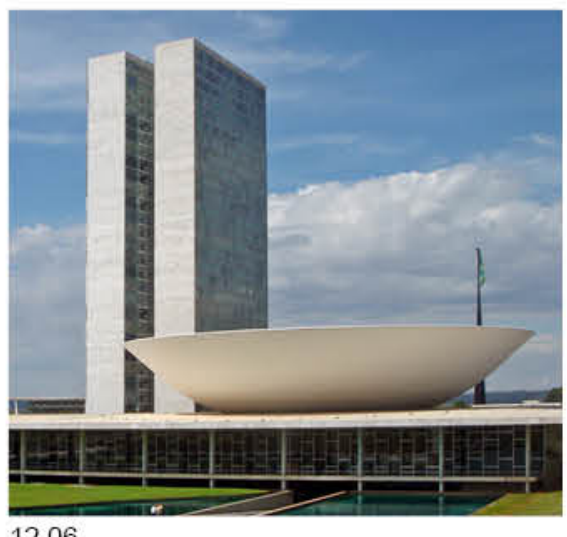

12.06

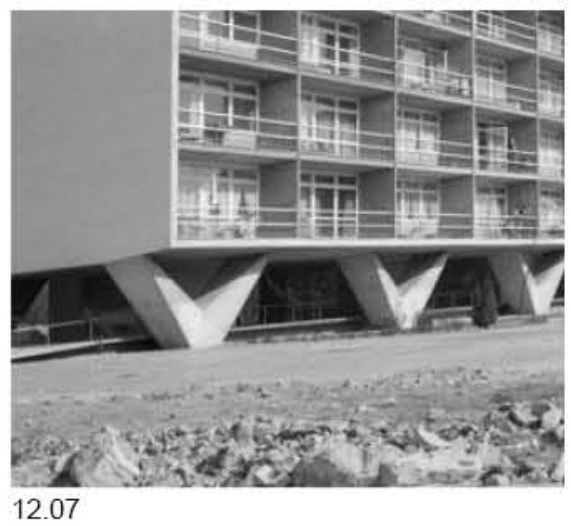

12.02. Interbau, Exposición Internacional que tuvo lugar del 6 de julio y al 29 de septiembre de 1957 (IBA'57) para la reconstrucción del barrio berlinés de Hansa en Berlín Occidental.

La gestión del plan general fue para Otto Banning y el concurso de diseño urbano fue ganado por Gerhard Jobst y Willy Kreuer. Los bloques de viviendas
construidos fueron proyectados por Alvar Aalto, Le construidos fueron proyectados por Alvar Aalto, Le Eiermann, Walter Gropius, Arne Jacobsen, Oscar Niemeyer, Max Taut y Hans Scharoun,... entre otros.

12.03. Fundación Oscar Niemeyer. Ref.: niemeyer.org 


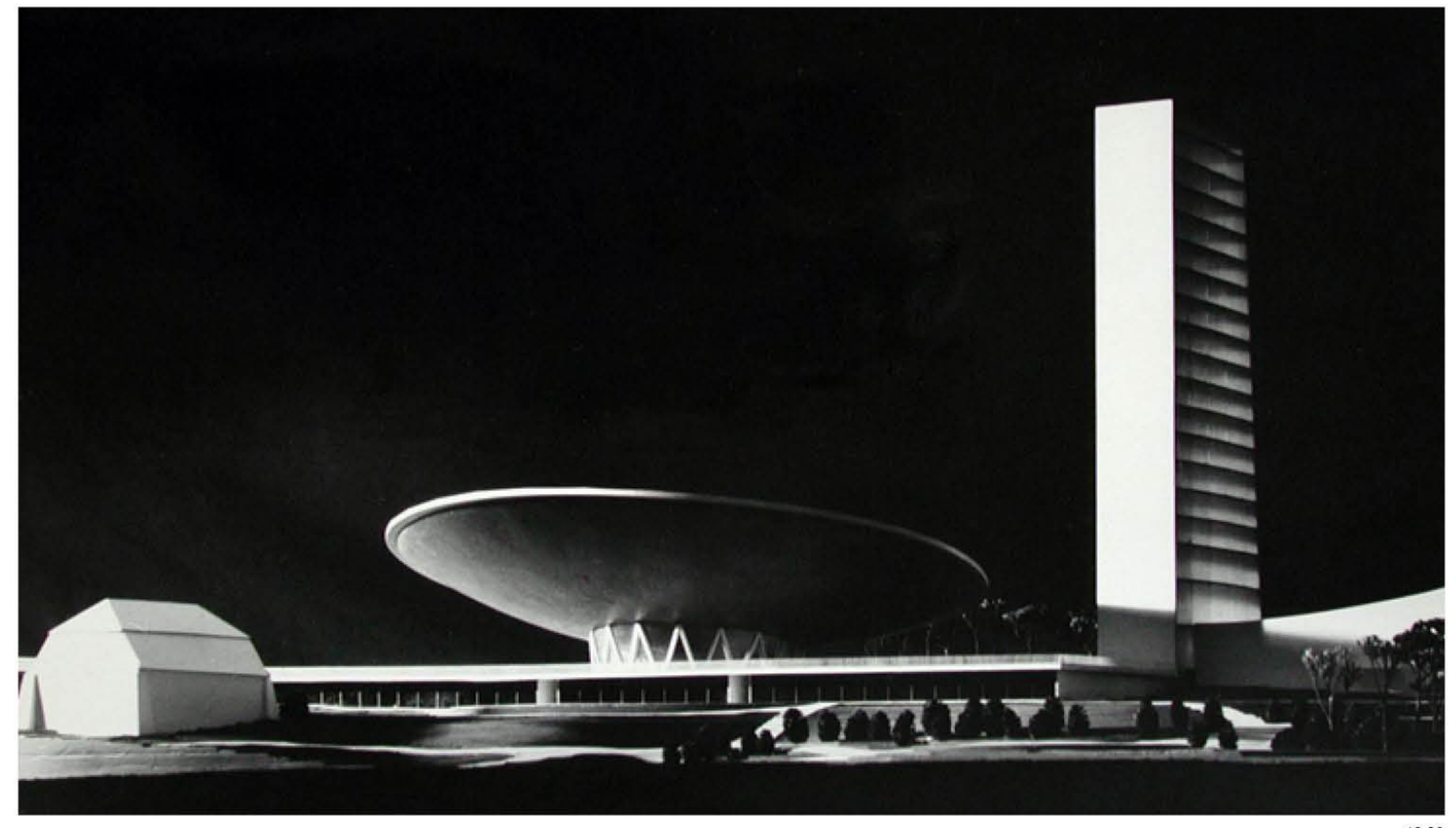


el proyecto de Niemeyer se convirtió, en palabras de los dirigentes políticos del momento en una "manifestación del milagro económico de Brasil que supondría sin embargo una base para el "fituro símbolo del resurgimiento y expansión del capitalismo en la nación." 10.01

Todos los proyectos de Leykam se habían significado por una búsqueda de la racionalidad y la lógica proyectual manteniéndose ajenos al manierismo de autor, pero la pérdida de referentes que tiene lugar en Polonia tras el final del Realismo Socialista y la fuerte influencia de estas conferencias, sumado al impacto de las publicaciones del trabajo de Niemeyer, hicieron que no únicamente su equipo, sino multitud de estudios de arquitectura polacos, se volvieran permeables a las publicaciones del momento y comenzasen a utilizar como referentes los trabajos de los arquitectos más significativos de los estados socialistas -que contaban con el beneplácito de las autoridades-, entre los que se encontraba Niemeyer, cuya cercanía con el país y sus asiduas visitas dejaron una gran impronta.

Niemeyer visitó Polonia posteriormente en varias ocasiones y formó parte de las discusiones de futuros proyectos clave de la reconstrucción de la capital, como la Fachada Este de Varsovia (13.20) participando en las sesiones de crítica públicas. A nivel personal, Niemeyer era asimismo respetado y admirado en los círculos de poder de la Unión Soviética, como muestra el hecho de que fuera galardonado en 1963 con el Premio Lenin de la Paz (12.02). ${ }^{12.03}$

Leykam no fue ajeno a la fuerte influencia de Oscar Niemeyer en la arquitectura polaca del momento y, dejándose llevar por el contexto, realizó una propuesta para la casa Cultura (Dom Kultury) de Lublin en 1956, claramente inspirada en los bocetos que Niemeyer había realizado en la sede de la Asociación de Arquitectos Polacos (SARP) en 1954 sobre el Congreso Nacional del Brasil, situado frente a la Plaza de los Tres Poderes en la nueva ciudad de Brasilia que se terminó de construir en 1956. (12.06).

En esas mismas circunstancias cabe interpretar otros proyectos polacos de la época, el Edificio Biprocemwap (1959-66) de la calle Morawskiego 5 en Cracovia (12.09) obra del arquitecto Wojciech Buliński, o la Imprenta Anczyca (1959-70) en la calle Wadowicka, 8 de Cracovia. (12.10), con clara influencia de obras de Niemeyer como el edificio de viviendas en el barrio de Hansa de Berlín.

\subsubsection{Casa de la Cultura de Lublin.}

En el concurso para la Casa de la Cultura de Lublin (1956), ${ }^{12.04}$ Leykam planteó una esbelta torre de 18 alturas (12.08), nuevamente direccional, que radicalizaba el contraste de caras del volumen cegando sus testeros y permeabilizando la fachada longitudinal. Por primera vez, el contorno del volumen no maximizaba el aprovechamiento espacial, puesto que la planta superior quedaba recortada por un plano de cubierta que no era paralelo a los generados por los forjados.
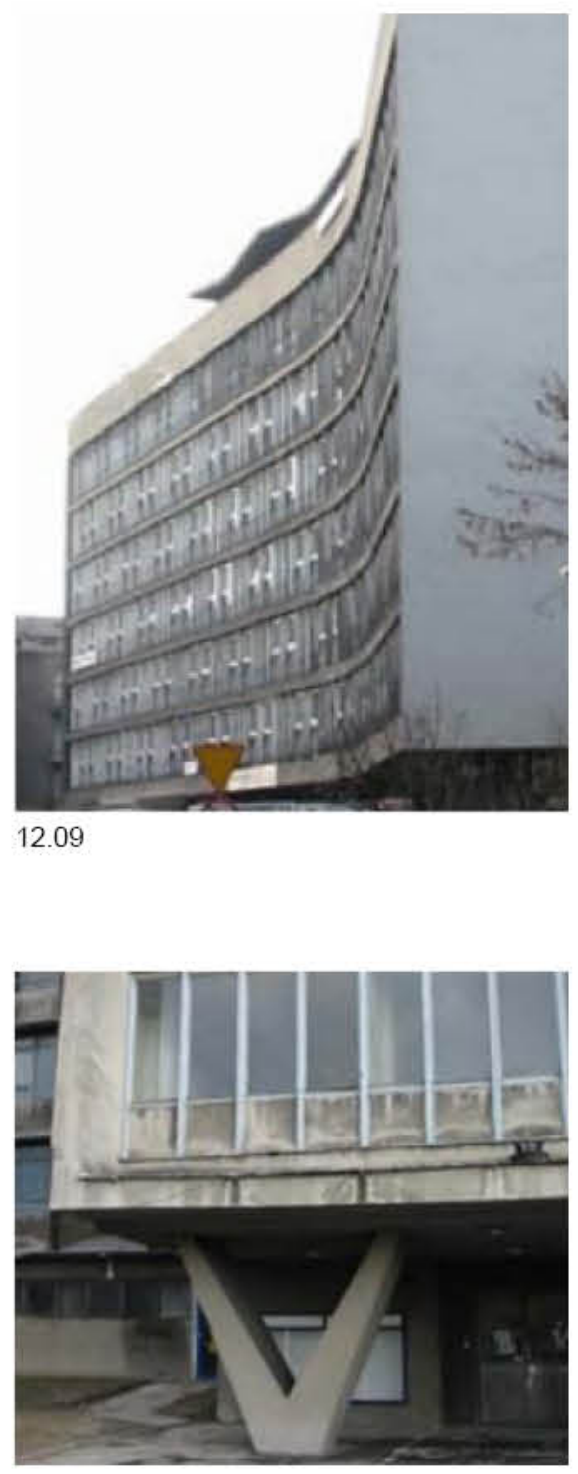

12.10

12.04. Dom Kultury w Lublinie, 1956 
12.11 Sección del auditorio del concurso de la casa Cultura (Dom Kultury) de Lublin, 1956.

Alzado de la propuesta para el concurso de la casa Cultura (Dom Kultury) de Lublin, 1956. Arquitecto: Marek Leykam.

12.13 - 12.14 Vista de la maqueta del concurso para la casa Cultura (Dom Kultury) de Lublin, 1956. Arquitecto: Marek Leykam.
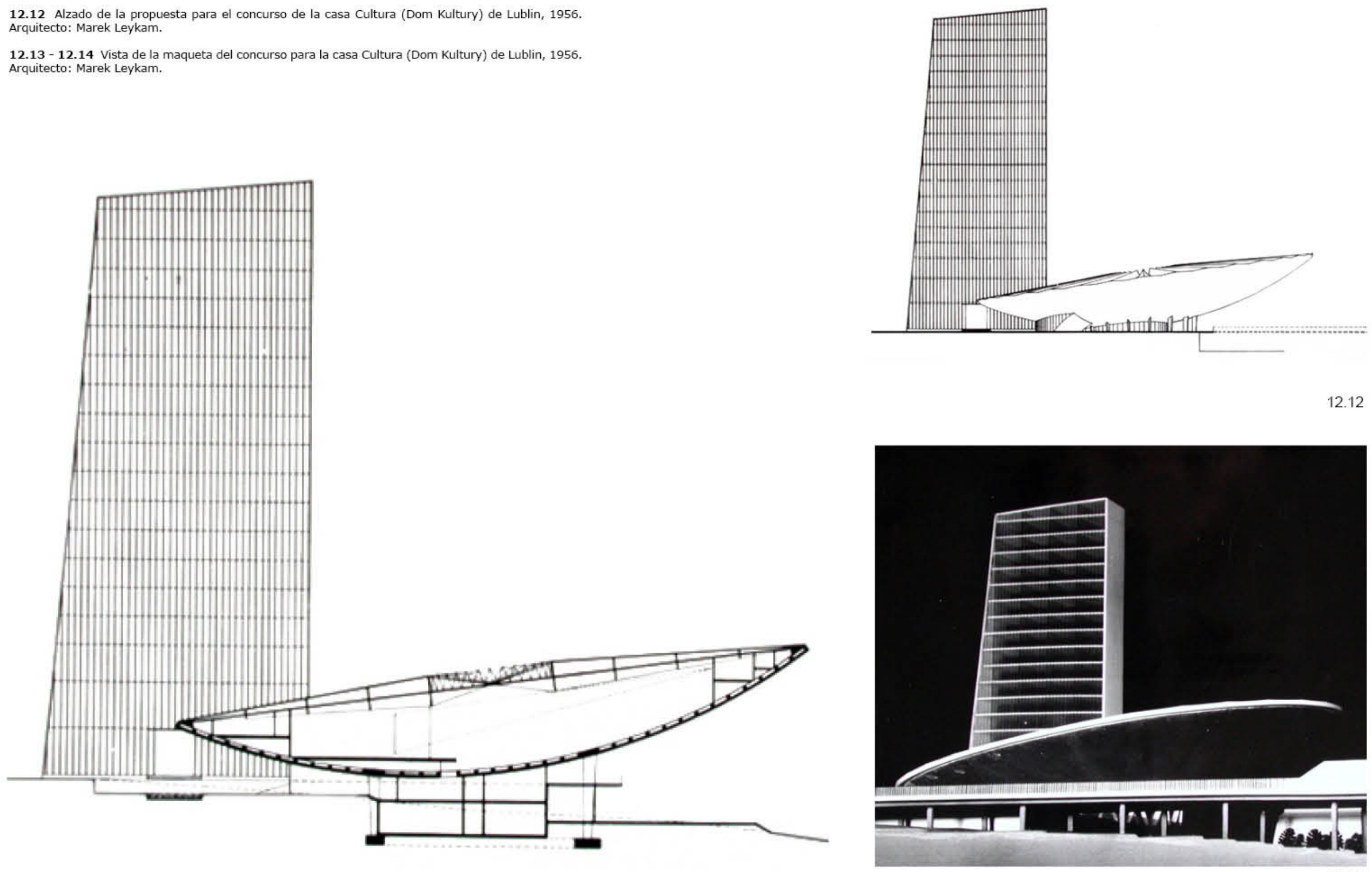

12.12

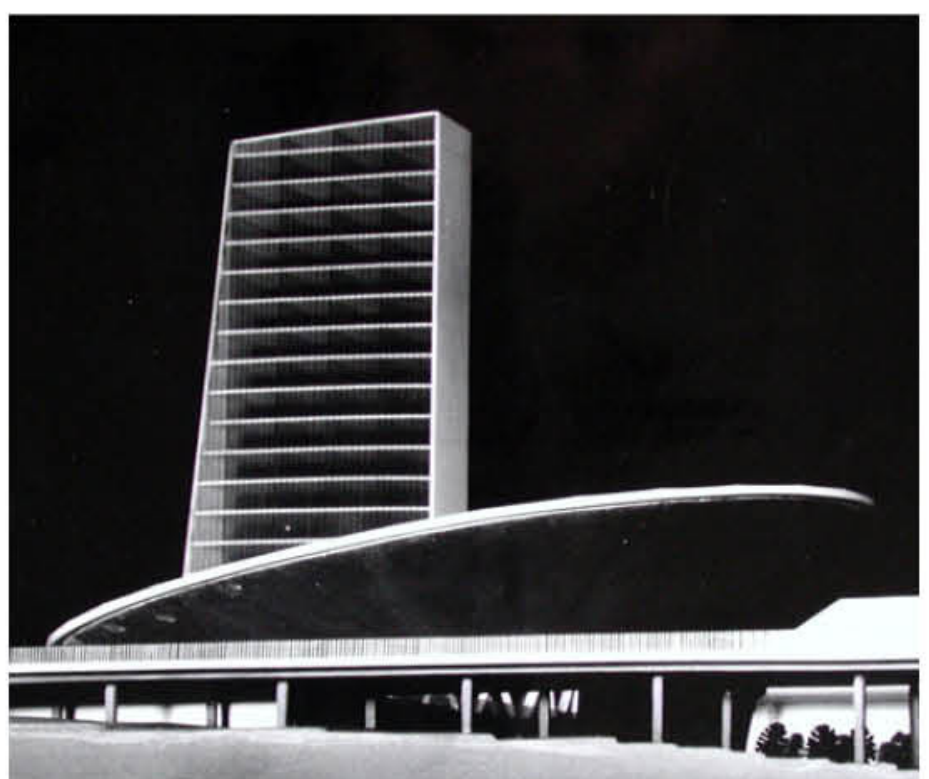




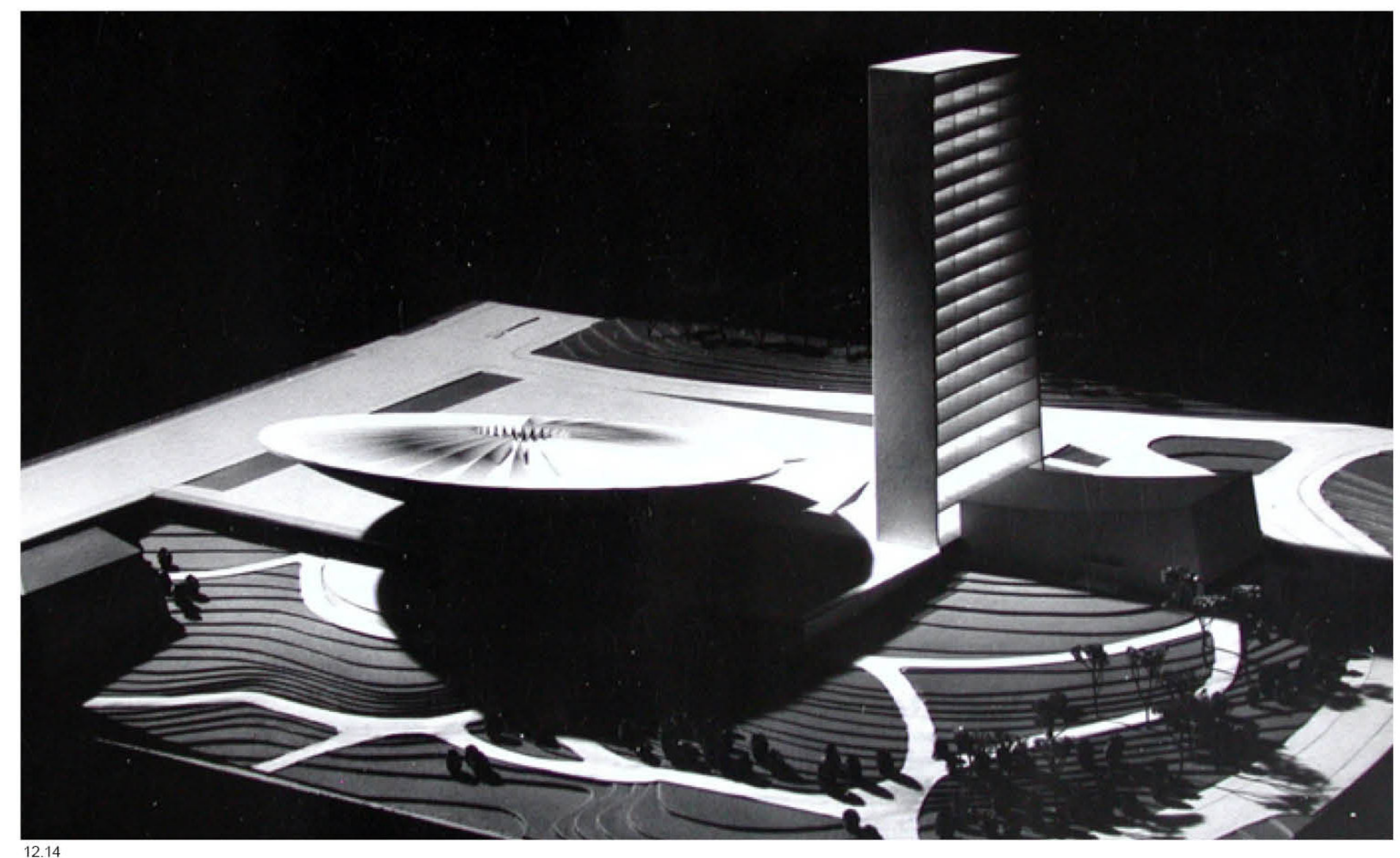


12.15 Proyecto para el Instituto de Ciencias Varsovia, 1964. Arquitecto: Marek Leykam.

12.16 - 12.18 Pabellón multiusos (Hala Widowiskowa) "Maciej Gintowt, Maciej Krasiński, Andrzej Żórawski y Jerzy Hryniewiecki.

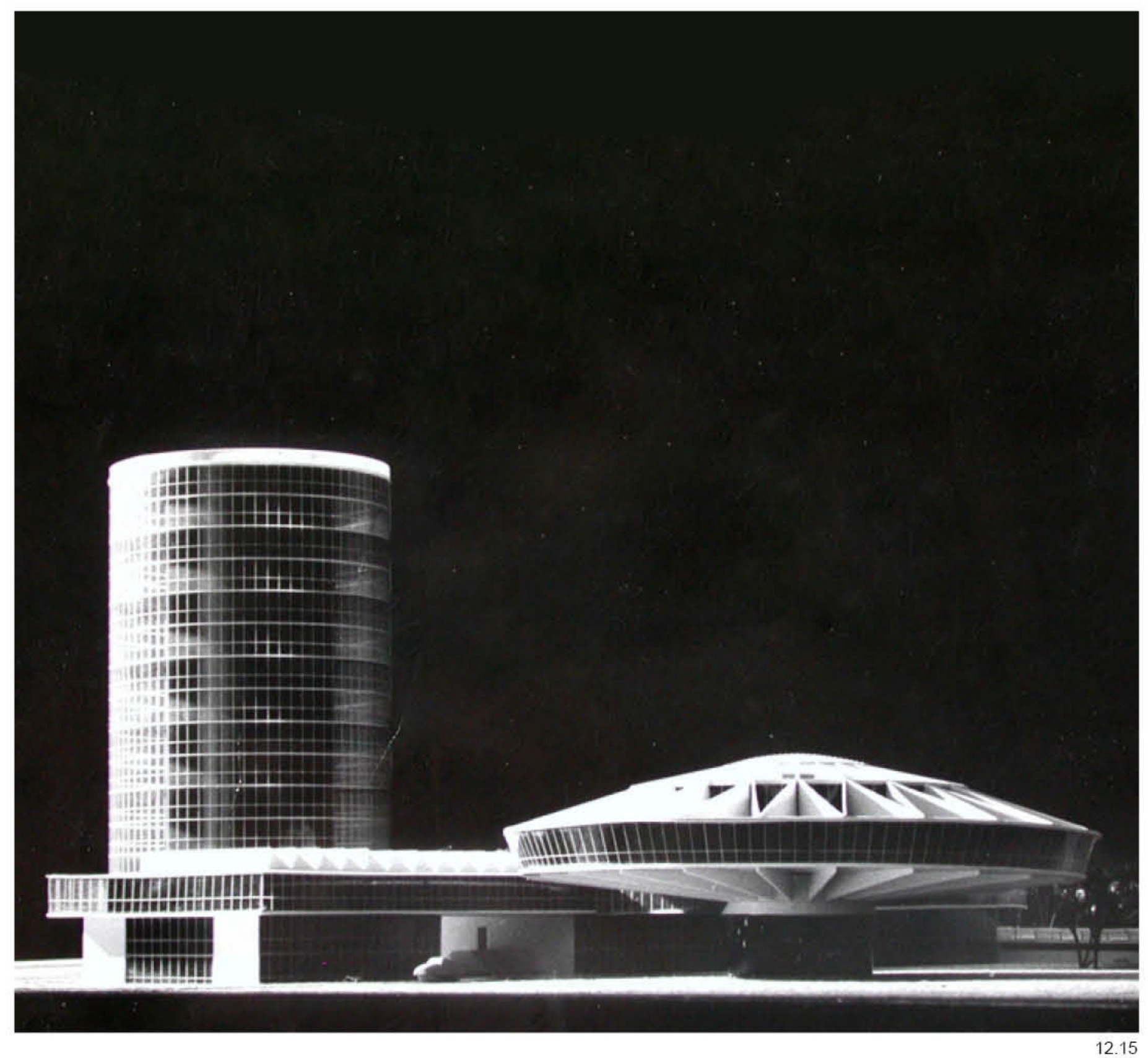


Del mismo modo, la inclinación de uno de los testeros laterales tampoco resultaba perpendicular a los planos de los forjados, por lo que se generaba volumétricamente una figura trapezoidal que puede ser interpretada desde la búsqueda de un efecto óptico determinado, pero que no pertenece a la lógica habitual de Leykam ni a lo que había sido hasta ese momento su forma de interpretar la arquitectura, como consecuencia de un metódico discurso proyectual basado en el aprovechamiento máximo del volumen, la racionalidad en la distribución de los espacios y la búsqueda de la expresividad a través de la tectónica mostrando como valor su capacidad de simplificar los detalles hasta hacerlos desaparecer en favor de la imagen de un conjunto que se manifestase de forma inequívoca, rotunda e imperturbable ante las necesidades ocasionales que el proyecto tuviera que resolver.

Atendiendo a las fotos de la maqueta de la Casa de la Cultura de Lublin $(12.08,12.13-12.14)$, las líneas de forjado horizontales se perciben en las fachadas longitudinales con cierta jerarquía sobre las verticales. Dentro de la composición, cabe interpretar por tanto que el tratamiento de estos planos se resolvería dando prioridad a las líneas coincidentes con el canto de los forjados, aunque a la vista de los dibujos de los alzados no queda claro como se determinaría esta diferenciación. A nivel de concepto sí que cabe entender dentro de la lógica racional esta prioridad como una forma de generar una compensación visual a la verticalidad de la torre, enfatizando los planos horizontales que equilibren perceptivamente el conjunto de la composición.

El volumen de la pieza de auditorio está llamado a compensar la verticalidad de la torre con una geometría que cabe contextualizar en una época marcada por la fascinación por las representaciones de objetos volantes tomadas de la literatura de ciencia ficción. A nivel de referentes arquitectónicos, existen multitud de menciones que podrían haber sido influyentes a través de las publicaciones de la época en los arquitectos polacos. A la vista de los proyectos realizados, la formalización de un "platillo volante" más significativa de Polonia vino esos años de la mano del compañero de Leykam Jerzy Hryniewiecki, quien junto a Maciej Gintowt, Maciej Krasiński, Andrzej Żórawski construyó el pabellón multiusos (Hala Widowiskowa) "Spodek" de Katowice entre 1964 y 1971 (12.16-12.18).

\subsubsection{Instituto de Ciencias Experimentales y Medicina Clínica de Varsovia.}

En 1964 Leykam presentó un proyecto para el Instituto de Ciencias Experimentales y Medicina Clínica ${ }^{12.05}$ (10.15) en el que de nuevo se muestra permeable a las influencias de la época, algo que hasta el momento no había sido habitual en su arquitectura. En este proyecto se planteaba un zócalo de 2 plantas que servía de base y plataforma de conexión entre un auditorio de nuevo con forma de "platillo volante" y un volumen cilíndrico de 12 plantas en el que se resolvía el programa del instituto.

Si bien en la maqueta Leykam todavía mantiene una trama de fachada que permita modular los elementos constructivos,

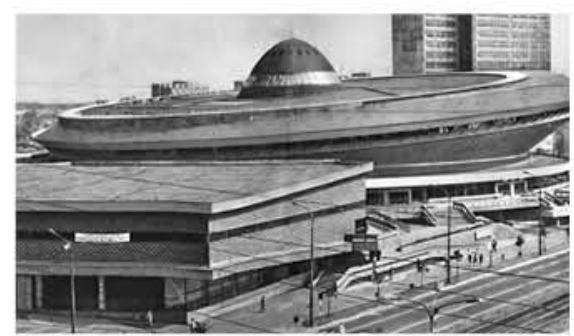

12.16

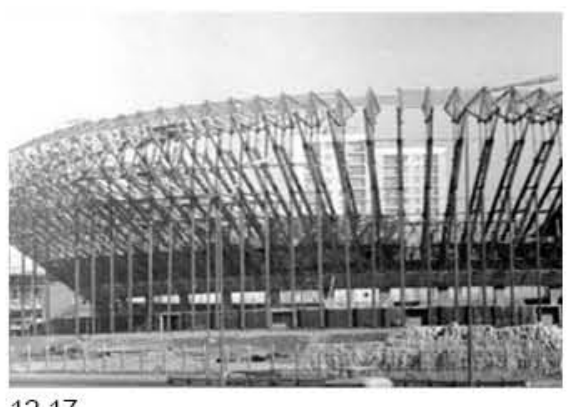

12.17

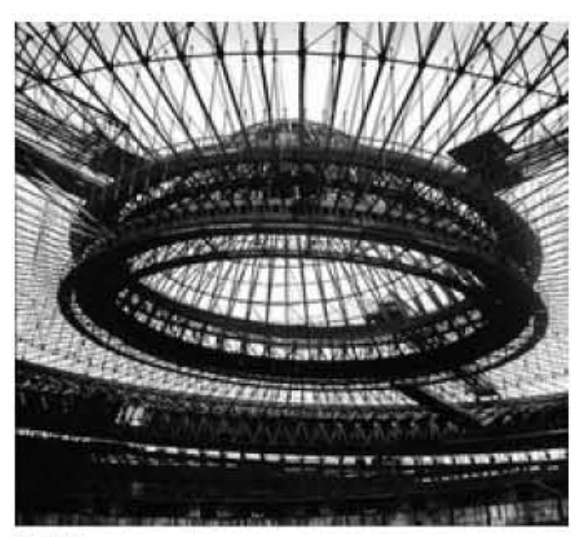

12.18

12.05. Instytut Medycyny Doświadczalnej i Klinicznej (PAN), 1964 
12.19 - 12.21 Imágenes de la obra y maqueta de la Escola Niemeyer, 1957.

12.22 Cartel propagandístico del proyecto de Hotel "Praia do Forte" en Jurerê. Arquitecto: Oscar Niemeyer, 1957.

12.23 Oscar Niemeyer junto a la maqueta de la Escola Estadual Milton Campos, 1957.
Mat.

12.24 Obras de construcción del Palacio de Congresos de Brasilia. Arquiterto: Oscar Niemeyer, 1956

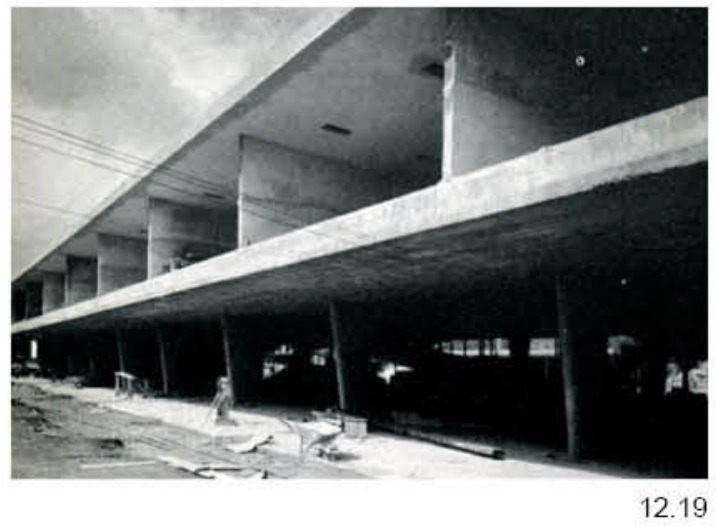

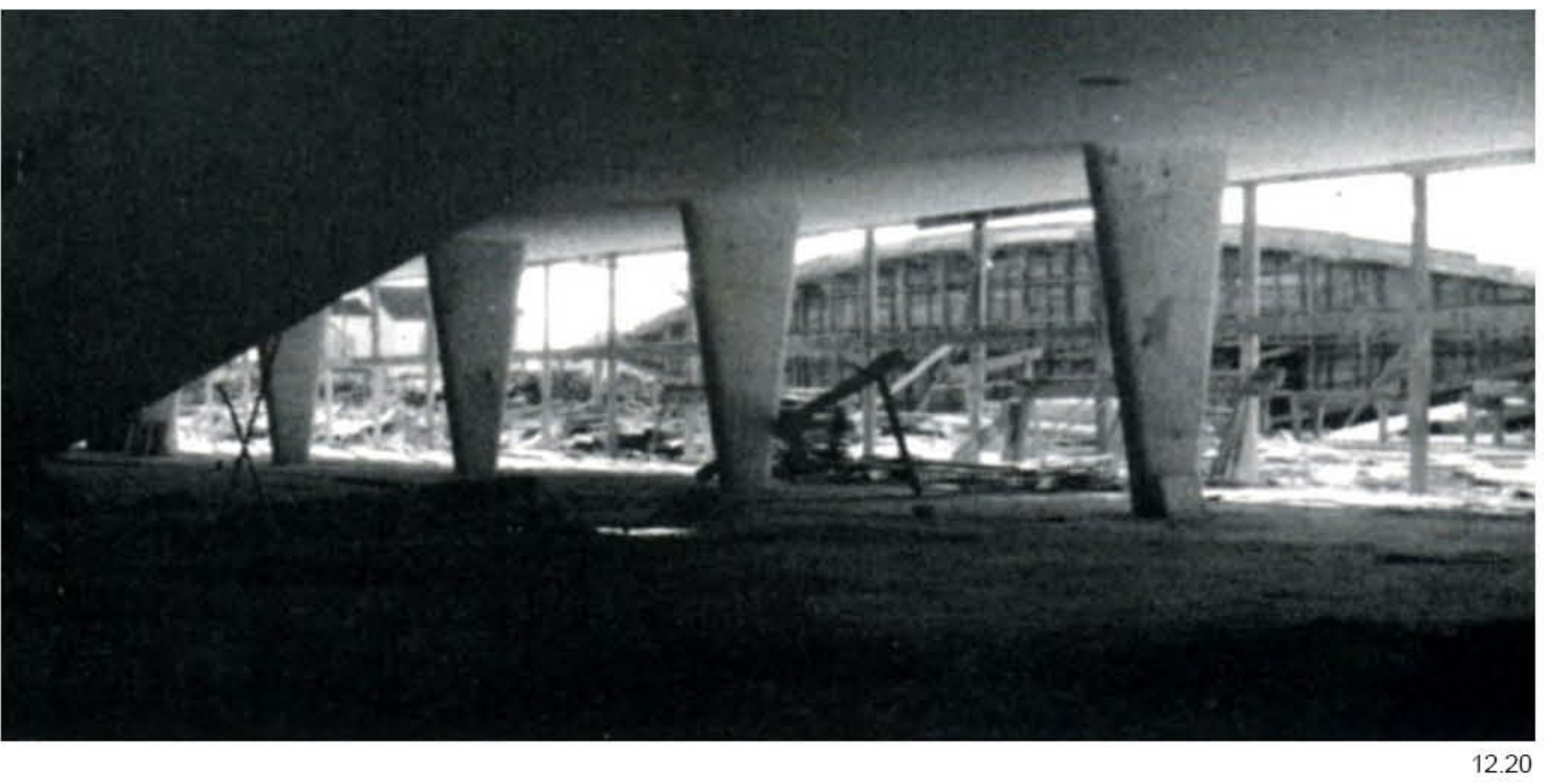

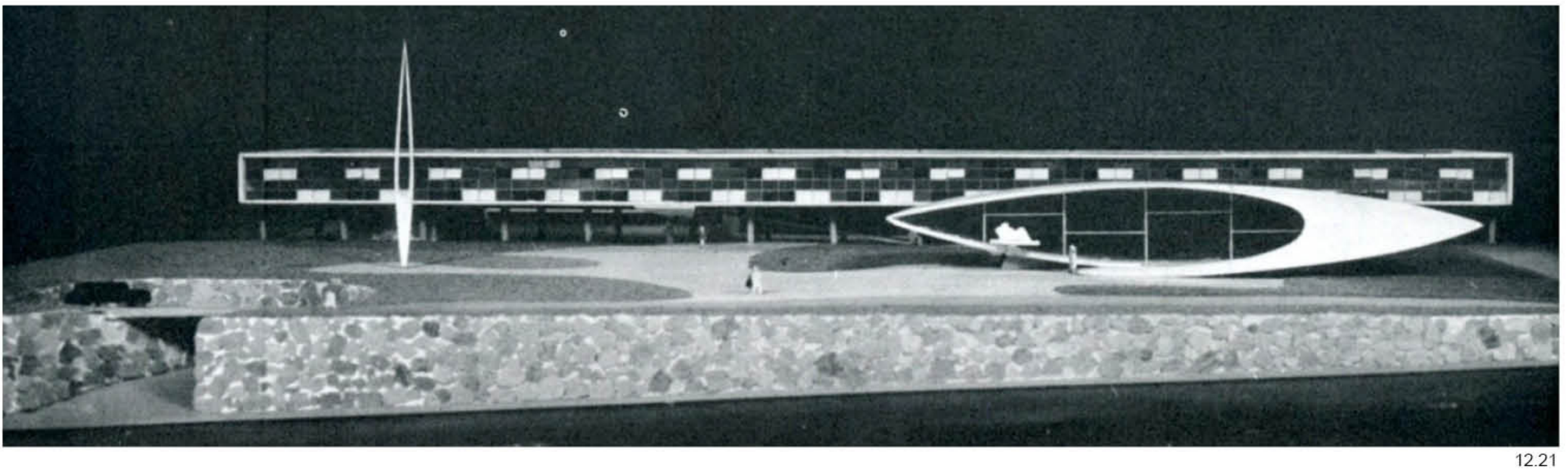


ésta comienza a resultar anecdótica a tenor de los accidentes de un proyecto, que presenta muchas singularidades especialmente en lo referente al auditorio cuyo anillo de fachada está inclinado diferenciando la altura y las proporciones de las piezas del zócalo.

La arquitectura de Leykam pierde en estos proyectos la intensidad que le confería la búsqueda de la optimización de los recursos constructivos y la necesidad de simplificar las obras para poder realizarlas en una época de absoluta necesidad de eficiencia y racionalidad. El contacto con la obra de Niemeyer, sin embargo, sirvió a Leykam de referente cuando tuvo que plantearse un inevitable cambio en la escala de sus proyectos. Las nuevas circunstancias de Polonia a partir de los años 60 invitaban, salvo casos excepcionales como el concurso de la Fachada Este de Varsovia, a una reconstrucción más pausada y sin el apremio y la densidad que acompañaba a los primeros años de postguerra.

A partir de 1955 Leykam comenzó a recibir encargos en contextos urbanos menos densos, cuyos programas resultaban más ligeros de contenido y con mayor vocación de responder de forma directa a la escala del peatón. La posibilidad de construir sin el apremio de la anterior década, ni la falta de mano de obra especializada que había persistido en épocas anteriores posibilitó algunos cambios en la arquitectura de Leykam que no tienen que ver con su método proyectual, que se mantuvo invariable en su búsqueda de la lógica y la proporción de los elementos tectónicos y manteniendo la premisa del máximo aprovechamiento interior del volumen construido estableciendo relaciones proporcionales entre los elementos estructurales y la ordenación del espacio interior.

Algunos de los proyectos de Niemeyer que Leykam pudo conocer en sus visitas a Varsovia, como el Hotel "Praia do Forte" (10.22) en Jurêre, el restaurante en esta propia localidad, el pabellón en el parque Ibirapuera o la Escola Estadual Milton Campos en Belo Horizonte (10.19-10.21), contienen soluciones adoptadas por Leykam en obras posteriores como la Escuela de Arte en Nałęczów, el albergue turístico PTTK en Plock o la Academia de Educación Física en Poznań.

El cambio de condicionantes surgido en los encargos de Leykam llevó al arquitecto polaco a reflexionar sobre posibilidades constructivas modernas en las áreas rurales de Polonia, y si bien sus propuestas continuaron basándose en la búsqueda de la expresividad a través de la tectónica y la formalización de un equilibrio y proporcionalidad desde el respeto por las reglas de composición clásicas, la influencia del entorno cultural y político del momento -marcados por la ruptura generalizada con las formas eclécticas promovidas por el Realismo Socialista y el rechazo de la decoración histórica- le llevaron a dotar de mayor protagonismo a la manifestación de las condiciones individuales y aceptar el uso de nuevas formas como las que adoptaba Oscar Niemeyer.

La diversidad de estas soluciones tuvo, en cualquier caso, una limitada influencia en el trabajo de Leykam. La libertad de lenguaje en el diseño de volúmenes y formas interesó al arquitecto de Varsovia únicamente en un número limitado de obras, en las que subjetivamente acentuó los aspectos formales de sus trabajos admitiendo que la expresión artística
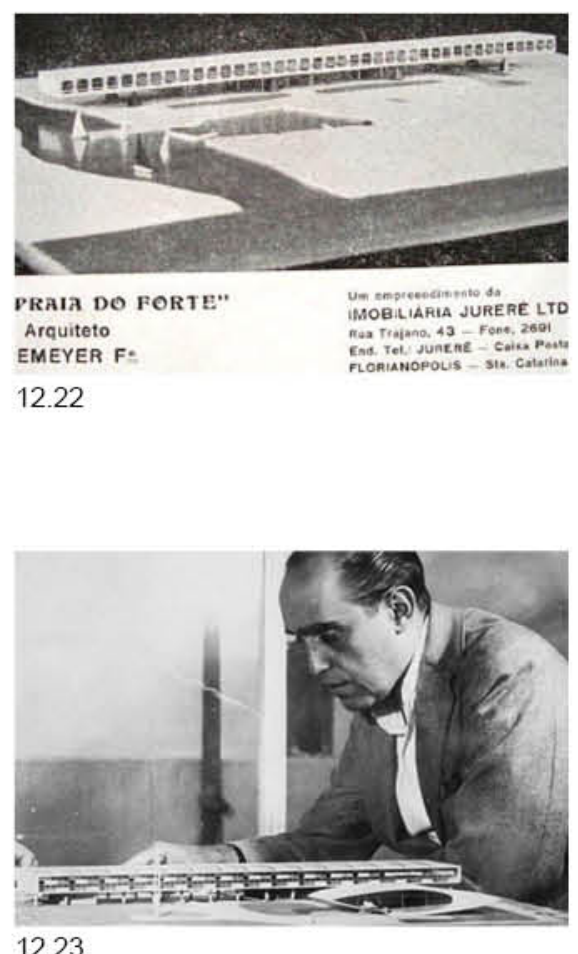

1223

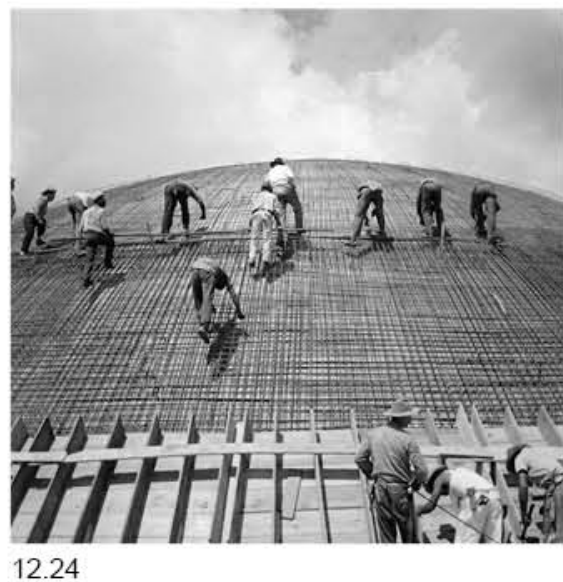




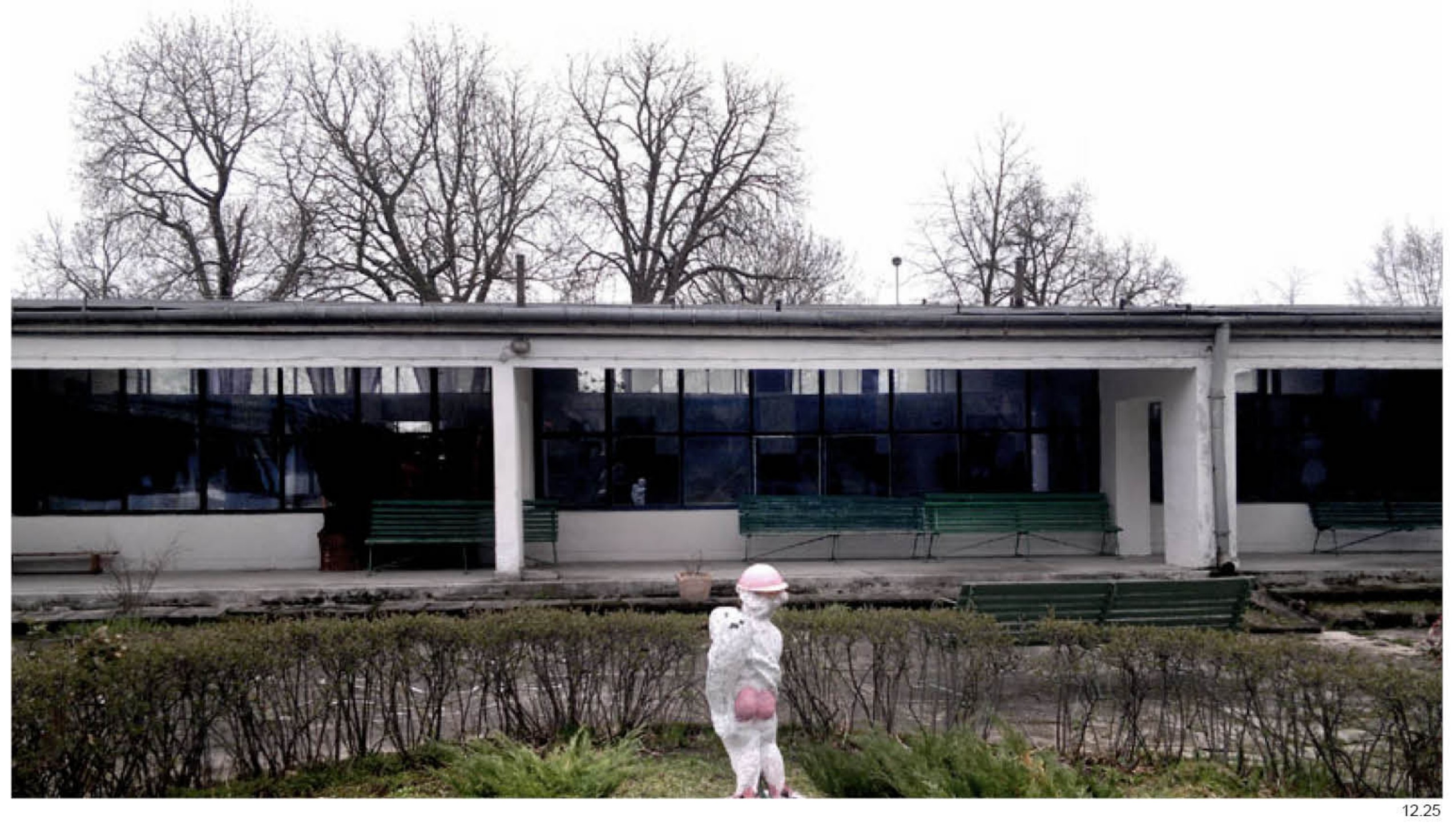


podía provenir no necesariamente de la construcción siendo también del tratamiento escultórico y emocional de la obra arquitectónica, aunque al poco tiempo su obra retornaría a la senda de la prioridad por la expresividad a través del impulso ordenante racional.

\subsubsection{Escuela de Arte de Nałęczów.}

En 1964, Leykam retoma las reflexiones iniciales de su etapa de formación durante el periodo de entreguerras para proyectar la Escuela de Arte de Nałęczów, $(12.24-12.26 ; 12.28)$ en la cual -manteniendo un compromiso con la escala del proyecto y su organización derivada del entendimiento de los espacios como lugares de refugio primitivo- trata de situar únicamente los componentes que considera esenciales, en busca de la sencillez más elemental y la manifestación construida más básica.

El volumen de la escuela se desarrollaba en planta baja, dando lugar a un conjunto de aulas cuyo espacio interior se proyecta en continuidad con una galería exterior que permite la reunión directa del alumno con los espacios naturales adyacentes. La rítmica estructural es la encargada de nuevo de organizar todos los ámbitos de uso y se convierte en el principal portador de valores estéticos. Los pórticos transversales acentúan la modulación del desarrollo y aportan unidad a una planta estructurada en forma de peine en E.

La inclinación de la cubierta permite una transición pausada entre la fachada de doble altura y las áreas interiores. Las ventanas contienen una subdivisión en módulos cuadrados de 80 x $80 \mathrm{~cm}$. y la relación entre estructura y cerramiento se produce a alineada a ejes, haciéndola coincidir con el módulo estructural. Las plataformas de terraza se extienden en voladizo para cubrir la galería previa a cada aula, mientras que el cerramiento acristalado mantiene una modulación constante de $80 \mathrm{x} 80 \mathrm{~cm}$.

La construcción de esta escuela se basó una estructura de pórticos transversales cada 6 metros que salvaban una luz de 8 metros con un canto de $30 \mathrm{~cm}$. Las nervaduras de la losa de forjado de hormigón armado quedaron vistas tanto en el interior como en el exterior, y la sección transversal inclinada permitía una transición entre los huecos de mayor iluminación en la fachada hacia la calle Polna (10.26) y los ámbitos de luz más atenuada abiertos a los patios interiores. La importancia de la Escuela de Arte de Nałęczów, radicó asimismo en el novedoso enfoque de la pieza como elemento que debe integrarse en el contexto, siendo uno de los primeros edificios en Polonia que resolvió de forma continua un desarrollo tan amplio únicamente en planta baja. A través de la relación constante del volumen con el lugar y la concisión y uniformidad de los detalles, Leykam lograba trasladar así su propuesta arquitectónica a un nuevo contexto sin renunciar a la capacidad de la estructura de manifestar a través del orden la expresividad artística que su obra desde la razón no dejaba de perseguir.
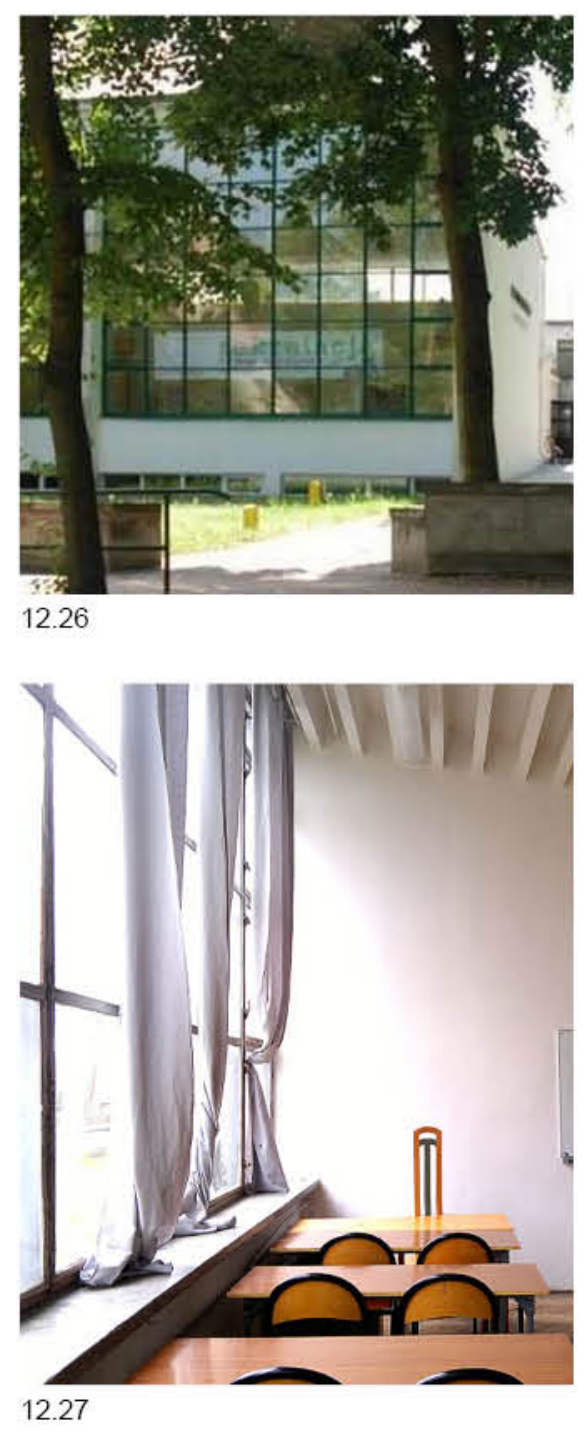


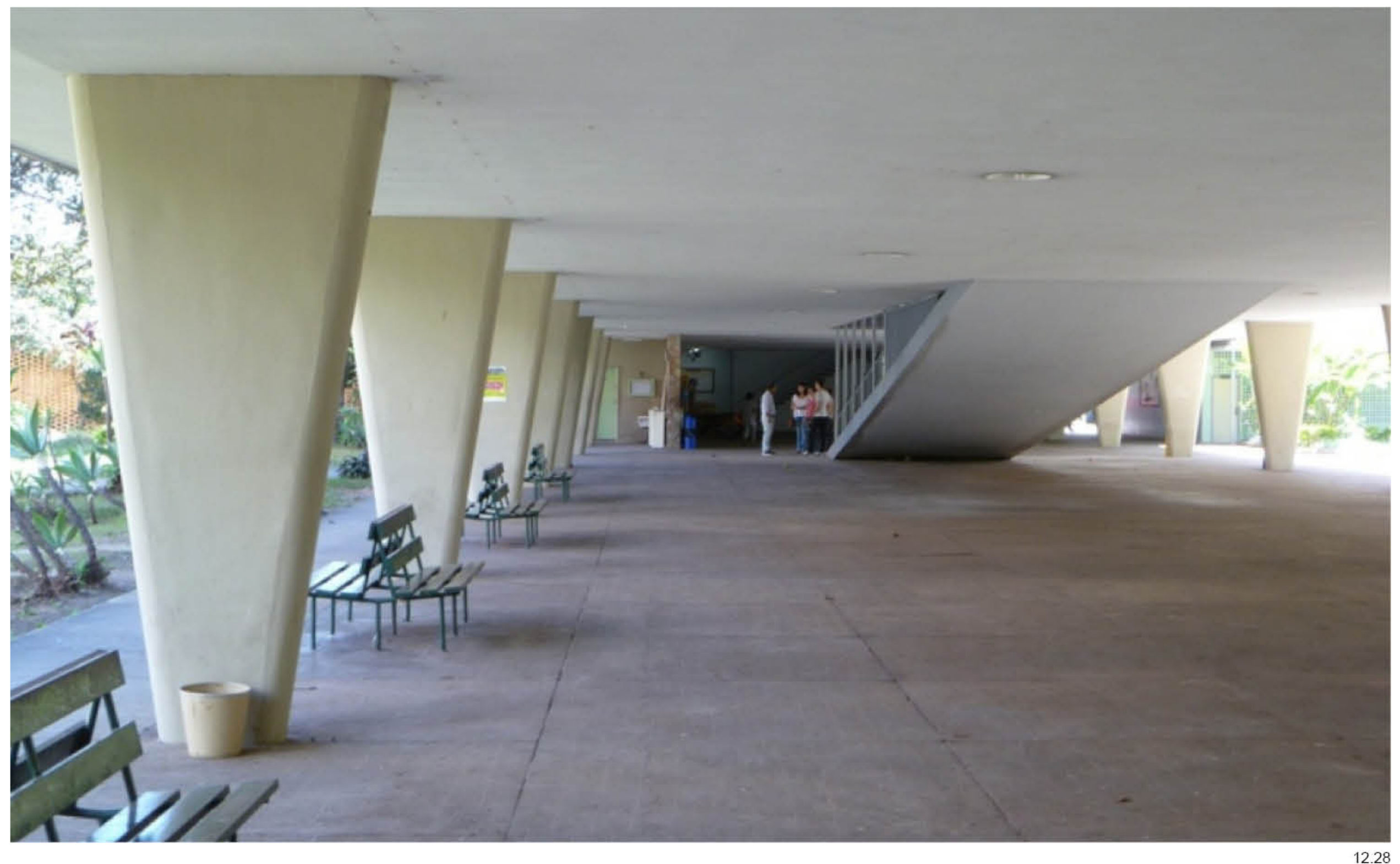




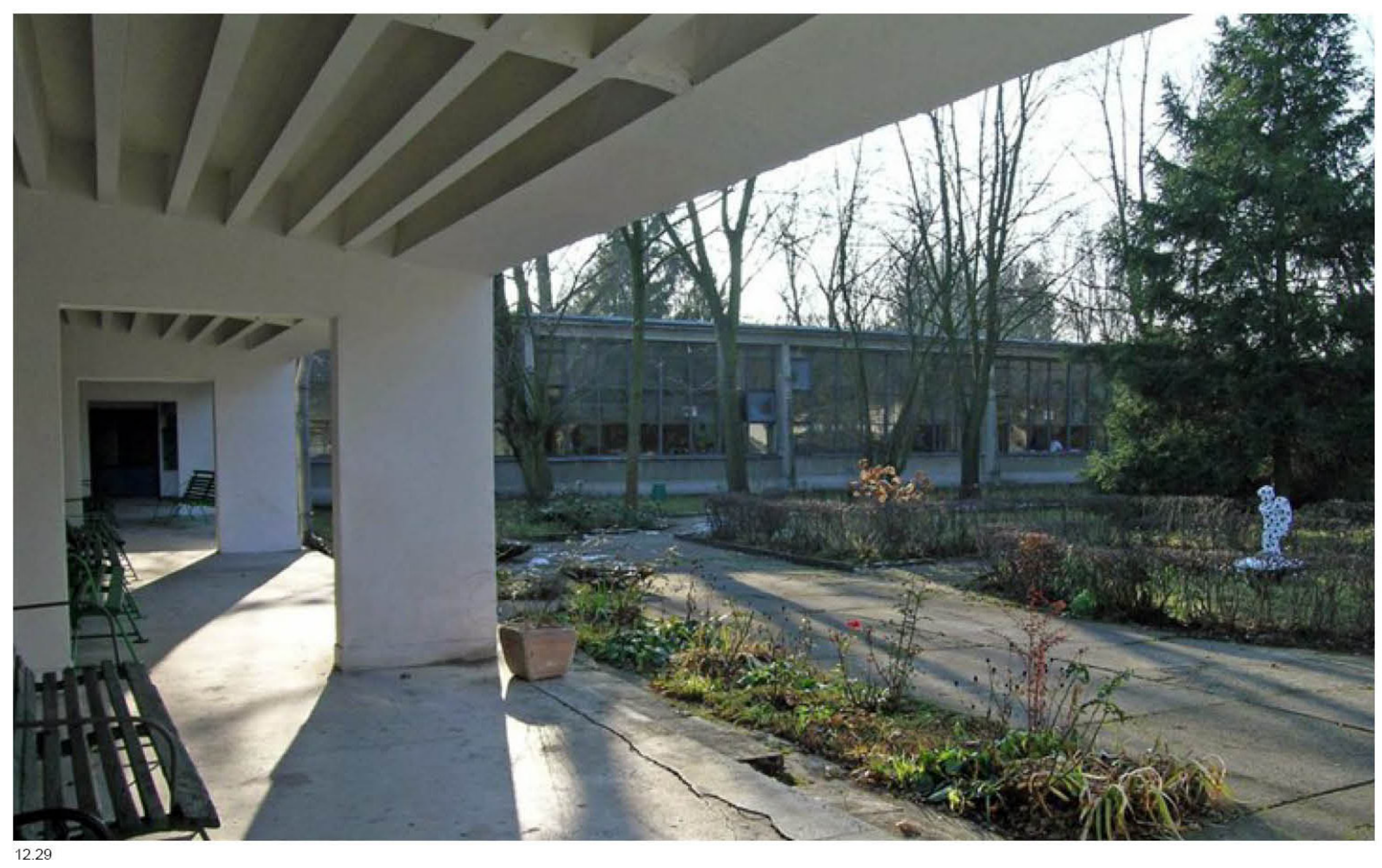


13.01 Stanisław Jankowski presentando los planes

para la reconstrucción de Varsovia hasta 1970.

13.02 Boceto de Concepto sobre la reconstrucción
de la calle Marszałkowska obra de Maciej Nowicki

en 1945 .

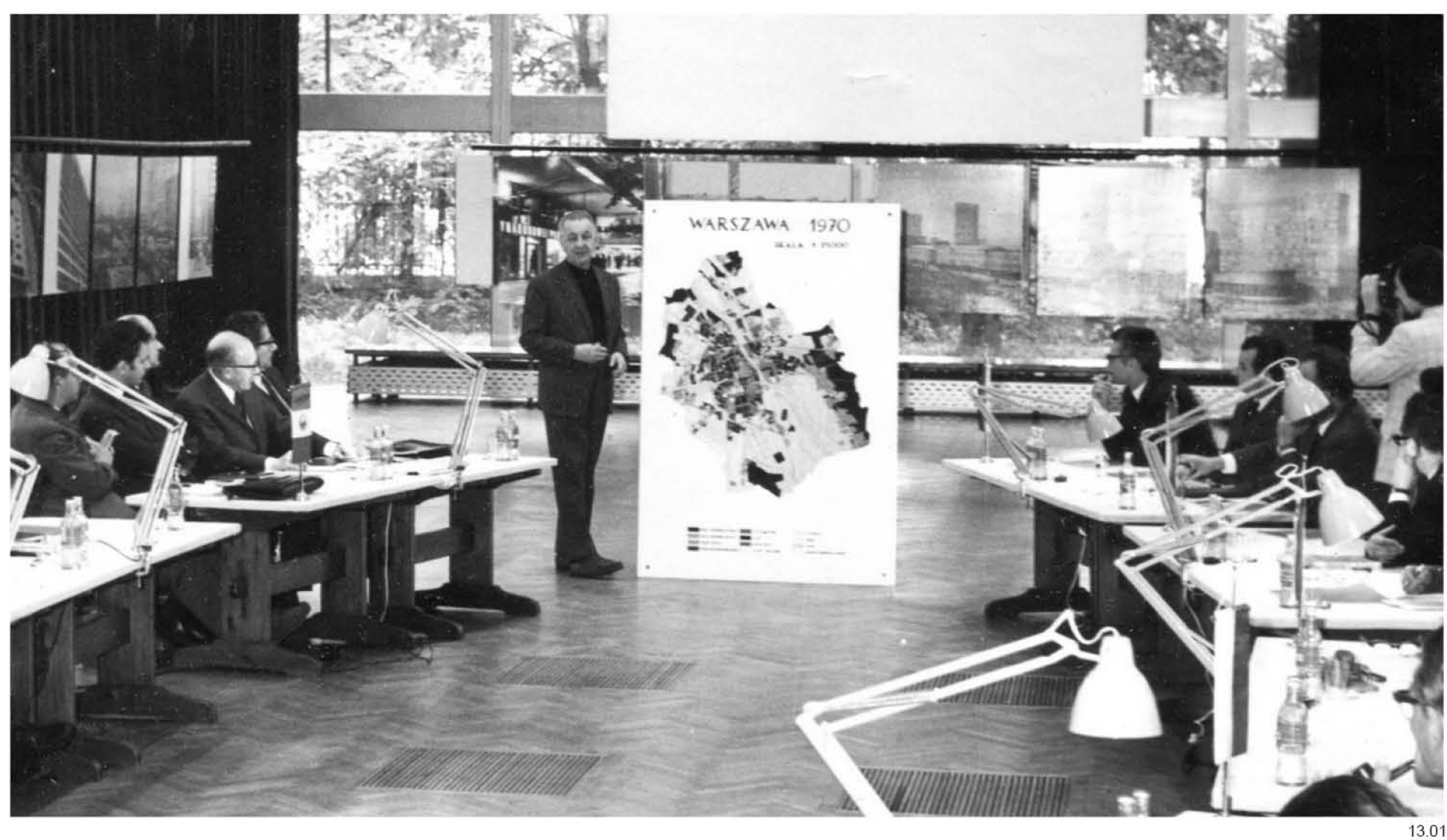


"En suma, ya que no se puede transformar, volvamos a las formas puras. Esta es la reforma que, a diferencia del espíritu revolucionario, consiste en el retorno a la forma primitiva. $Y$ esto significan todos los nombres de batalla y de anhelo que entonces corren por las bocas mejores: reformatio, restitutio, renasci, renovatio. La renovación no es innovación, sino al revés, volver a ser toda pureza lo que al principio se fue".

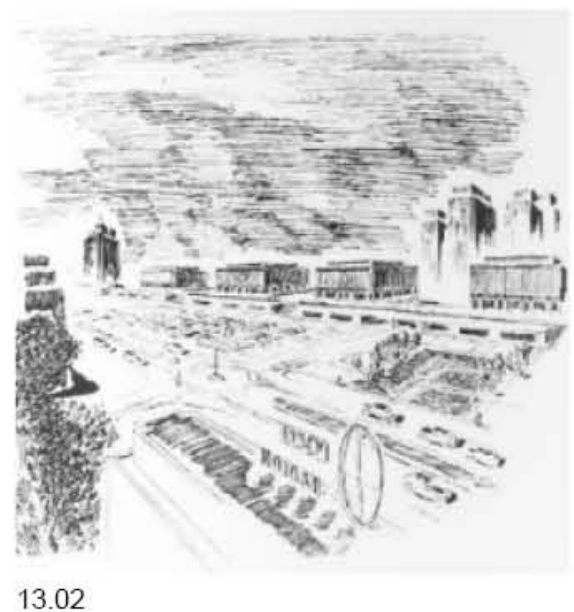

13.02

\subsubsection{Ordenación de la Fachada Este de Varsovia.}

Durante la primera década de postguerra los planes de reconstrucción del centro de Varsovia pasaron por diferentes etapas, pero a pesar de las múltiples propuestas y foros de discusión, la importancia estratégica de la calle Marszałkowska como eje principal sobre el que debía articularse el crecimiento de la nueva ciudad, generando una transición entre la plaza de la Estación Central de tren y el futuro ensanche, nunca estuvo en duda, ${ }^{13.01}$ como atestiguan incluso bocetos conceptuales de 1945 como el de Maciej Nowicki (13.02).

La llegada del Realismo Socialista en 1948 obligó, sin embargo, a los urbanistas de la oficina BOS ${ }^{13.02}$ a abandonar sus planes iniciales de reconstrucción debido a las nuevas directrices y referentes arquitectónicos y urbanísticos impuestos por el Comité de Control de Proyectos a partir de 1952 13.03. Junto con la imposición -o "regalo", tal como recoge la propaganda del momento- de la construcción del Palacio de Cultura y Ciencia en la plaza de la Estación, frente a la calle Marszałkowska, surgió la idea de crear una gran plaza central para la cual se organizó un concurso en 1952 ofreciendo como referentes en la convocatoria varios ejemplos de ordenaciones del clasicismo francés. ${ }^{13.04}$

Los resultados del concurso, sin embargo, no fueron satisfactorios para los organizadores y se nombró un equipo de arquitectos encabezado por Józef Sigalin para desarrollar el diseño de esta plaza. ${ }^{13.01}$ De las reuniones con numerosas personalidades políticas y burocráticas de Varsovia y la Academia de Arquitectos de Moscú ${ }^{13.04}$, surgió el planteamiento de transmitir con carácter mediático y propagandístico la idea de que el propósito general de este proyecto iba a ser convertir esta plaza en "la más grande de Europa." ${ }^{13.01}$

13.00. Ortega y Gasset, 2005.

13.01. Jur, 1977. p 78-97

13.02. Oficina para la reconstrucción de la capital (Biuro Odbudowy Stolicy, BOS)

13.03. Komitet Architektury i Urbanistyki PAN

13.04. Zieliński, 2009. 


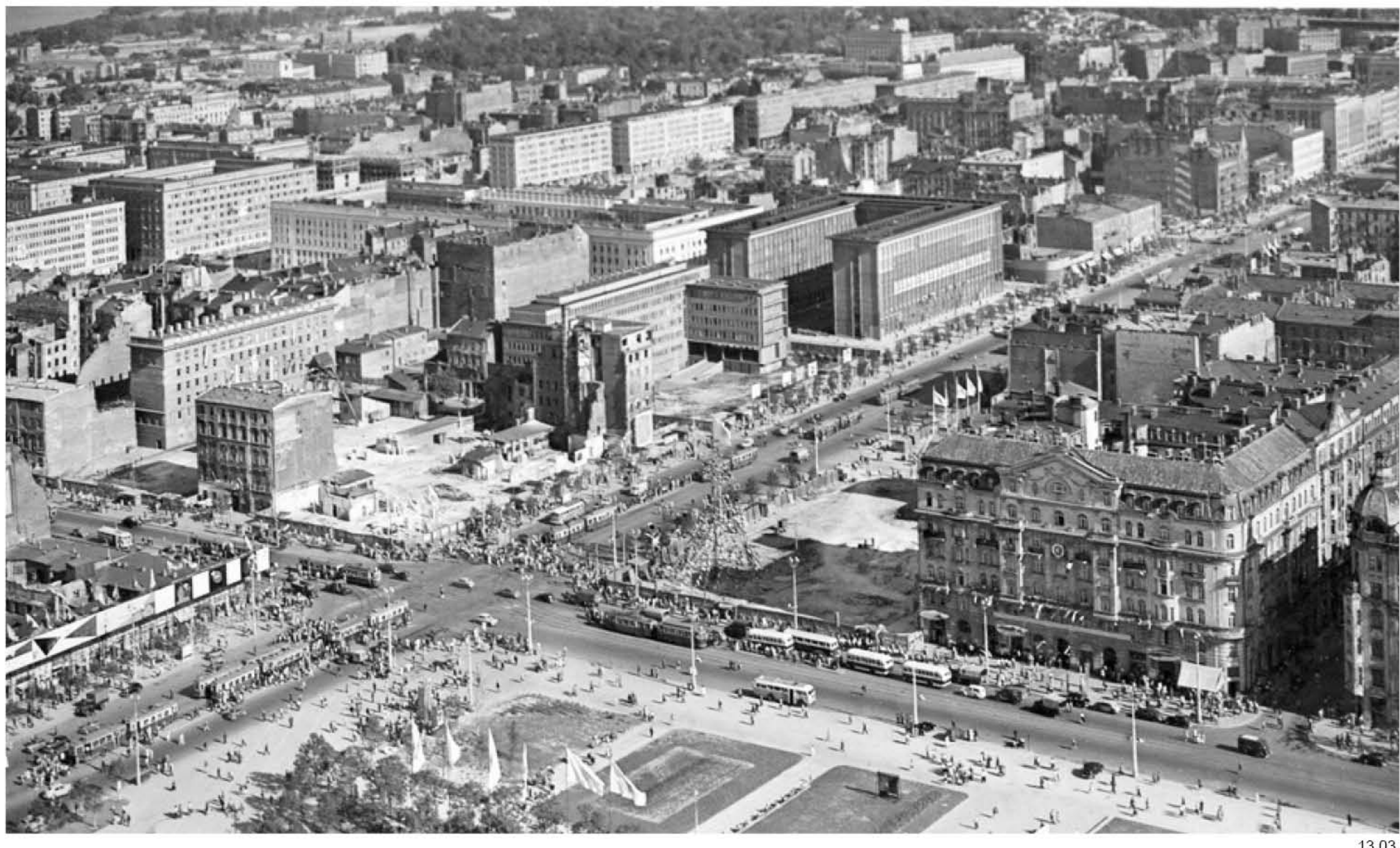


Dado que la prioridad en Varsovia había sido la construcción de edificios públicos, en la primera fase de la reconstrucción se decidió dotar asimismo al barrio -en el entorno de la calle Marszałkowska- de un programa residencial. Cuando en 1949 se completó la ruta WZ (Wschód-Zachód), una infraestructura viaria estratégicamente clave para Varsovia que conectaba las calles Młynarska y Radzymińska, las autoridades comenzaron a priorizar la inversión en los alrededores de este área llamada a ser el nuevo punto de encuentro emblemático de la ciudad (13.03). ${ }^{13.04}$

En un primer momento se extendió la calle Marszałkowska demoliendo varios edificios en el lado oeste en el tramo de la carretera Koszykowa, y posteriormente ensanchó aún más su sección en el tramo comprendido entre las plazas Konstytucji y Unii Lubelskiej. La calle no se prolongó, sin embargo, más hacia el sur, aunque su abrupto final se vio compensado por la reconstrucción del perfil a lo largo de la calle Waryńskiego. ${ }^{13.04}$

Los técnicos afines al Realismo Socialista había motivado una reinterpretación de la zona basada en la idea de esponjar al máximo la plaza para convertirla en un punto de encuentro de masas, concebido como un lugar para alberga desfiles y multitudinarias manifestaciones (13.05)

Durante el tiempo que duró al construcción del Palacio de la Cultura y la Ciencia PKiN y las áreas residenciales de Marszałkowska Dzielnica Mieszkaniowa (MDM), comenzó a debatirse la reconstrucción del perfil de la nueva plaza -rebautizada con el nombre de Iósif Stalin-, puesto que se había hecho necesario de delimitar y acotar el perímetro de misma, que en esos momentos tenía un gran lateral abierto que dificultaba su definición.

En 1953 se convocó un nuevo concurso para dar forma a la Fachada Este, que fue ganado por el equipo de arquitectos formado por J. Bogusławski, J. Knothe y Z. Stępiński, con una propuesta (13.04) en la que se alzaban una serie de bloques apantallados de cuatro plantas de altura, siguiendo un estandar de "clasicismo con vocación monumental" 13.01 según se recoge en el veredicto de los jueces.

Las plantas bajas de los edificios fueron conectadas mediante una galería resuelta con amplias arcadas y hacia ella se abrían varios locales comerciales. La propuesta hizo hincapié en las decenas de estatuas y bajorrelieves que estaban desplegadas a lo largo del recorrido -tanto exentas como incluidas en los alzados y detalles de los edificios-, rememorando a los representantes de las clases obreras. Los materiales principales propuestos fueron piedra arenisca y granito pulido, y en general la composición destacaba por la masividad de los volúmenes y su sobrecarga ornamental (13.05).

Este plan estaba basado en la proclama ideológica del Realismo Socialista de "construir el socialismo desde la parte creativa" "13.05 según la cual: "La idea de la ciudad socialista [...] encontraba la expresión en los barrios del centro de la ciudad a través de sus edificios, calles y plazas". ${ }^{13.05}$ El centro de Varsovia debía, así "complementarse con las nuevas aspiraciones y necesidades de la nación contemporánea dentro de los sistemas y principios del socialismo". ${ }^{13.05}$

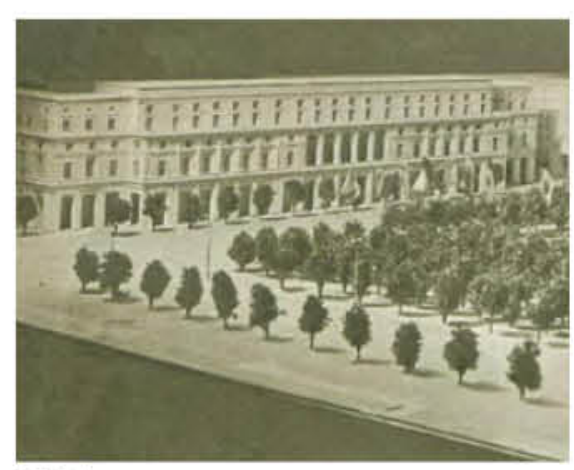

13.04

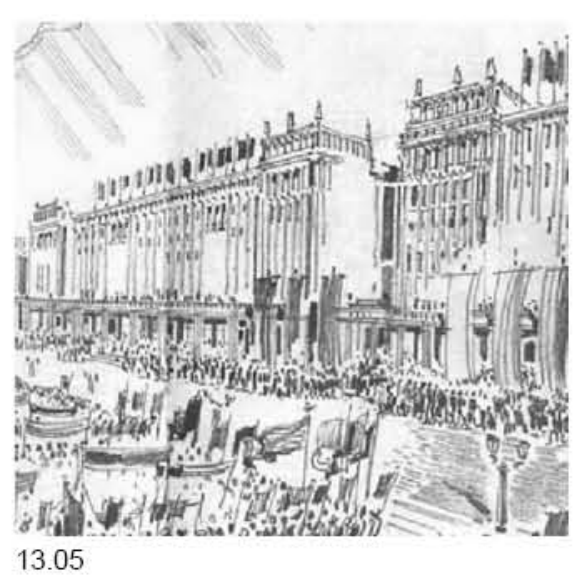

13.05. Strelbicka, 2013 
13.06 Plano de la reconstrucción del centro de Varsovia entre las calles Żelazna y Towarowa, 1950.

13.07 Plano de reconstrucción de Varsovia según el Plan de Zonificación, 1950.

13.08 Stanisław Jankowski explica a Jawaharlal Nehru e Indira Gandhi los planes de reconstrucción de Varsovia.

13.09 Propuesta de Fachada Oeste de Varsovia, 1957. M. Leykam, J. Hryniewiecki, C. Rajewskiy y J. Schuch.
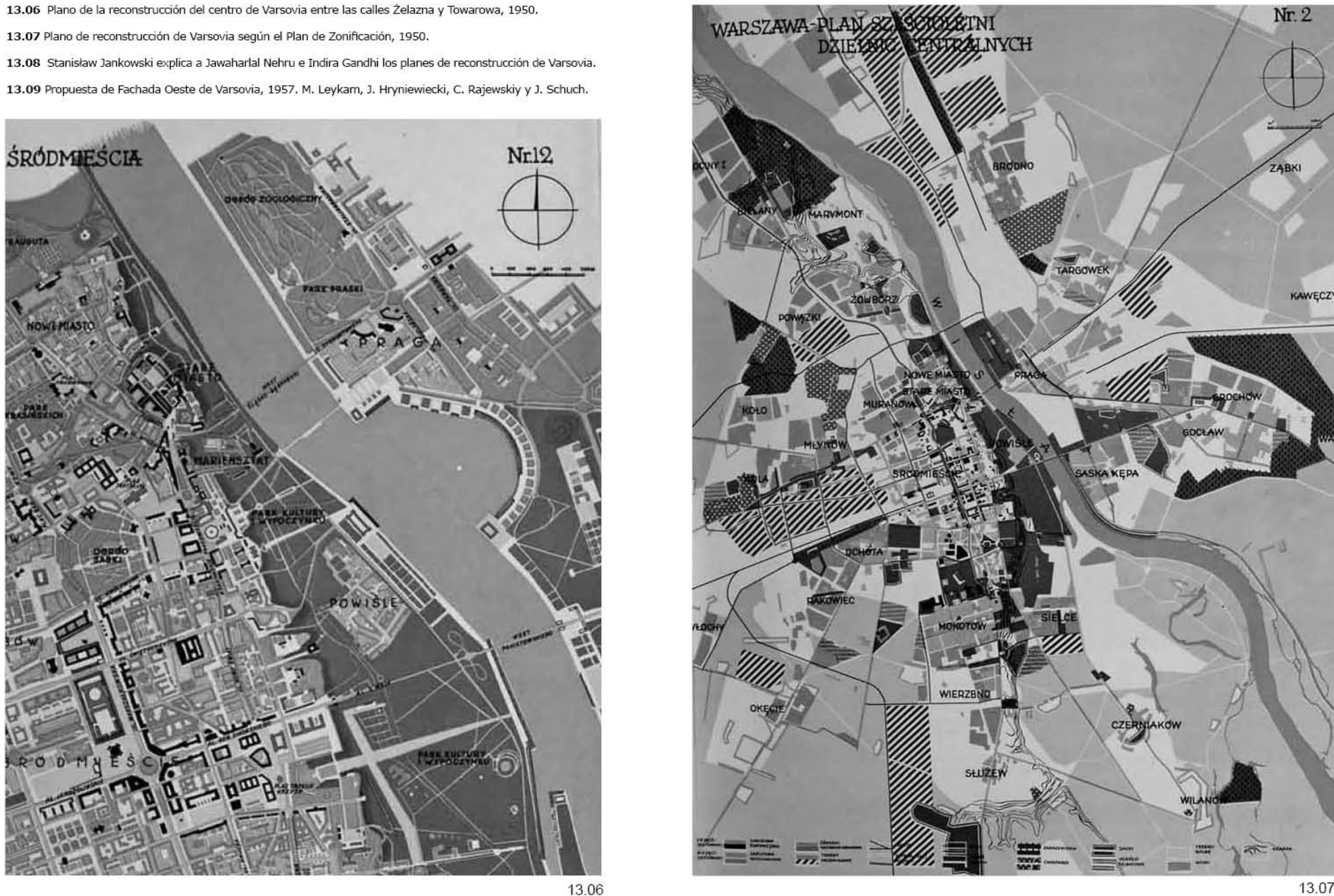
El final del Realismo Socialista, sin embargo, precipitó los acontecimientos y la propuesta de Bogusławski, Knothe y Stępiński cayó en el olvido a pesar de haber ganado el concurso de 1953. En 1955 comenzaron los trabajos para retomar el plan general de reconstrucción de Varsovia según los estudios de la oficina BOS (13.06-13.08), y se establecieron criterios de planeamiento basados en análisis racionales de datos objetivos, como las perspectivas de crecimiento demográfico, el estudio de la movilidad, el análisis de proporciones ideales y el reparto de las zonas verdes (13.07). Estos planes fueron aprobados en julio del año 1956, aunque la Fachada Este seguía sin resolverse, lo que animó a muchos arquitectos a desarrollar su propio concepto de edificación en este lugar y publicarlo directamente en medios de comunicación oficiales y revistas especializadas.

El equipo de Marek Leykam junto a Jerzy Hryniewiecki, Czesław Rajewski y Jan Schuch decidió proponer su propio proyecto en la revista Architektura en 1957 (13.09), en que la que ya se percibía a nivel de boceto la idea de situar una serie de edificios de gran altura que sirvieran de contrapeso al Palacio de la Cultura y la Ciencia (PKiN), integrando a escala del peatón un elemento cuya forma de cúpula semiesférica tenía como referente formas adoptadas por Oscar Niemeyer, como las del Museo Nacional de la República en el eje Monumental de Brasilia, 1956.

Esta primera aproximación fue el punto de partida del proyecto que presentaría Leykam junto a nuevos compañeros de equipo, en el concurso que sería convocado al efecto a finales de 1957 y que se resolvería el 30 de septiembre de 1958. Por motivos personales, la relación entre Leykam y Hryniewiecki se había roto en ese mismo año y ya no volvieron a trabajar juntos. Leykam concurrió a la convocatoria junto a C. Czułowski, A. Dzierżawski, Z. Pawelski y el ingeniero de estructuras S. Zalewski, mientras Hryniewiecki pasó a formar parte del jurado que presidió E. Wierzbicki. Al concurso se presentaron 39 propuestas, y el tribunal se reunió para estudiarlas del 3 al 12 de diciembre de $1958 .{ }^{13.01}$

El volumen planteado en la convocatoria era de aprox. $600.000 \mathrm{~m}^{3}$ y se solicitaba una propuesta para tres tipos de uso principales: comerciales y de ocio, residenciales y de oficinas y servicios. El elemento más claramente definido eran los espacios comerciales y tiendas, todas ellas situadas en planta baja, mientras que en las primeras dos plantas había una definición ambigua que permitía la localización de locales de gastronomía, establecimientos de servicios, salas de baile, discotecas, salas de espectáculos y 2 o 3 cines, mientras que por encima de la segunda planta se preveían espacios residenciales o el emplazamiento de un albergue u hotel.

El programa prácticamente no preveía espacios administrativos y de oficinas a nivel genérico, pero si determinaba la ubicación de empresas específicas: editoriales, agencias de fotografía, salas de exposiciones, oficinas de pasaportes, agencias informativas, agencias de publicidad, agencias de viajes, etc... Asimismo, se incluía una serie de disposiciones sobre las redes de comunicación, líneas de edificación obligatorias y una precisión específica sobre si el autor del proyecto preveía adaptar o demoler varios edificios existentes. Finalmente cada participante estaba obligado a definir las etapas de la realización del proyecto que había de presentar.
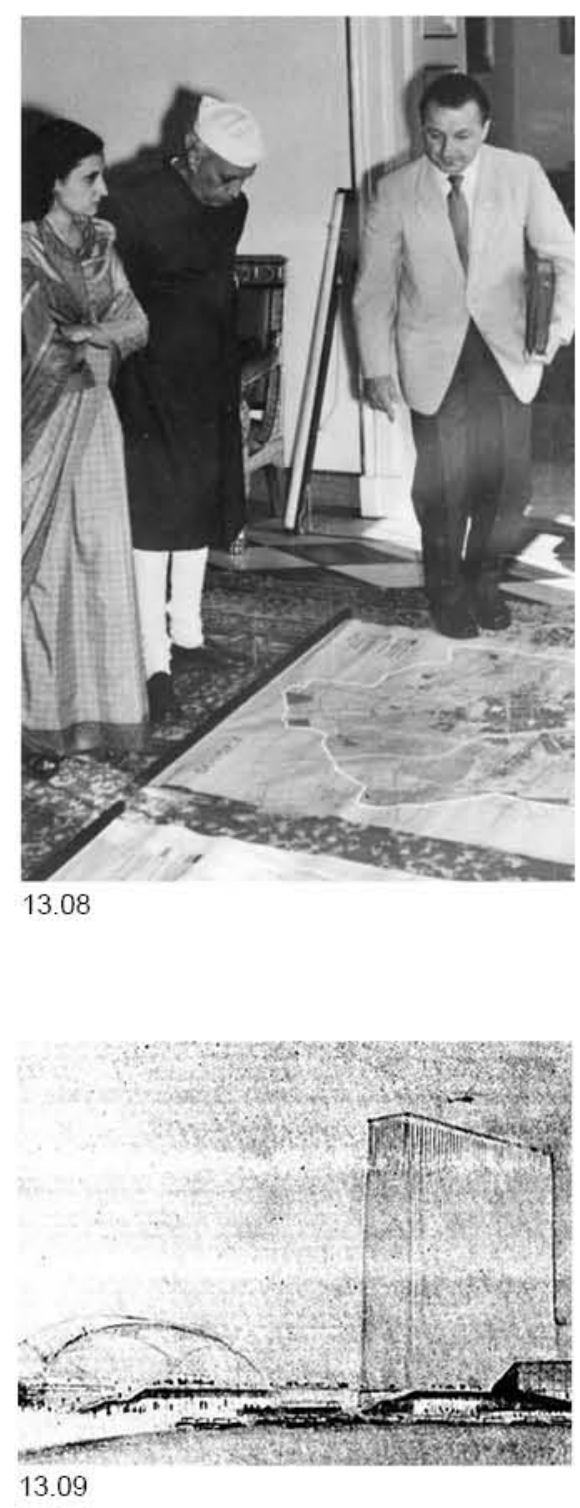


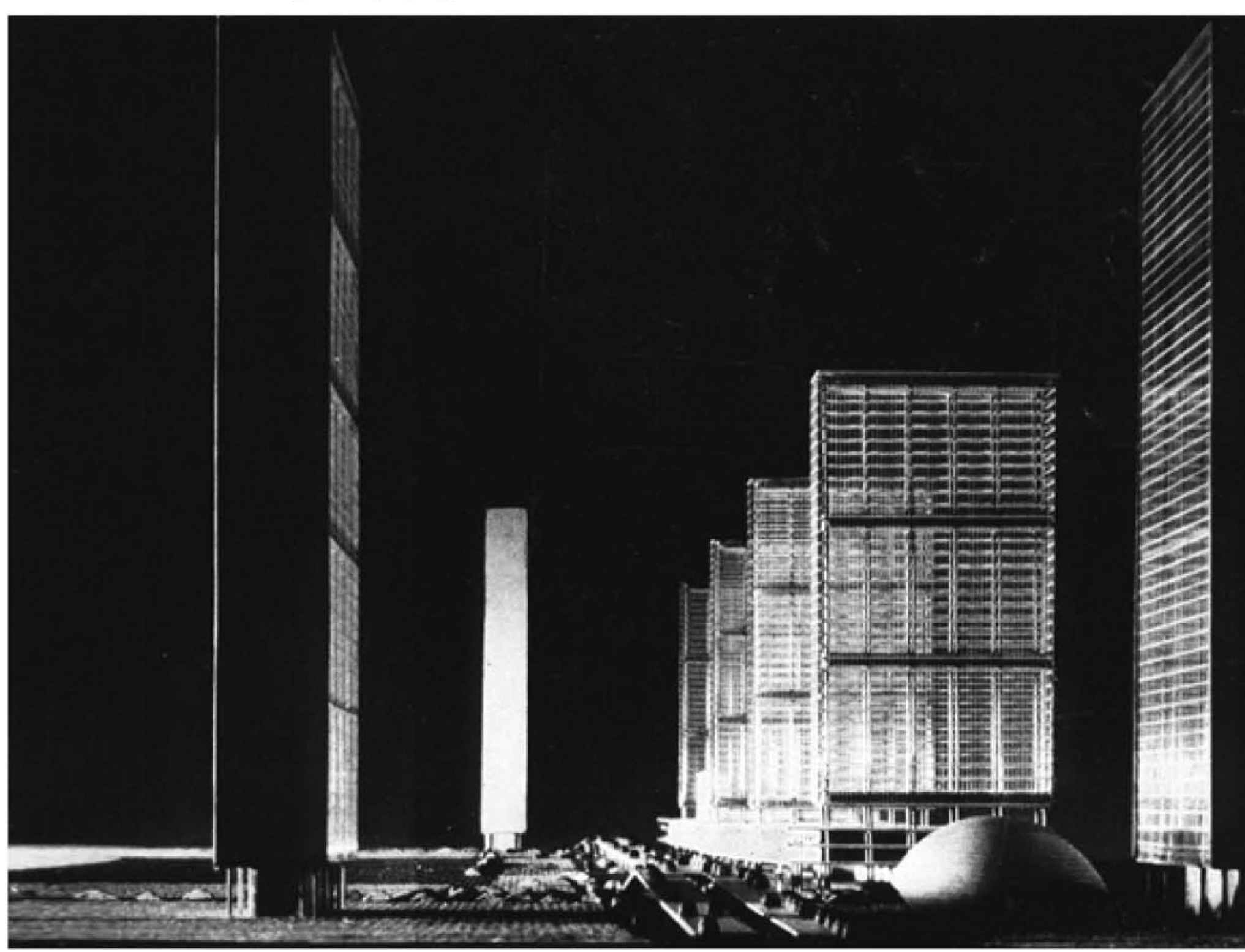


El proyecto de Marek Leykam planteó cuatro bloques perpendiculares a la calle Marszałkowska, que dirigían sus testeros hacia la plaza de Iósif Stalin, mientras que en las intersecciones de calle Marszałkowska con las avenidas Jerozolimska y Świetokrzyska se situaron 3 grandes rascacielos apantallados cuya altura determinaba la relación del conjunto con el Palacio PKiN. A escala de peatón se situó un zócalo comercial y de servicios tal como solicitaba el programa que conectaba los cuatro bloques más bajos y en la intersección junto a la calle Jerozolimska se emplazaba un auditorio cuyas formas ya habían sido esbozadas en el proyecto de 1957 (13.09).

Los siete bloques tienen una modulación común basada en la aritmética sencilla, tal como era habitual en los proyectos de Leykam. A partir de un módulo de 10 plantas -30 metros de altura-, los cuatro bloques perpendiculares a la calle Marszałkowska repetían este módulo 3 veces -90 metros de altura-, además de los 8 metros correspondientes a dos plantas del zócalo; mientras los bloques situados en las esquinas de la ordenación constaban de 5 módulos de 10 plantas -hasta alcanzar los 150 metros de altura- con zócalo retranqueado sobre la huella en planta que también se elevaba 8 metros para que las fachadas de todos los bloques. Todas sus modulaciones se estructuraban en torno al mismo plano imaginario, teniendo en cuenta que cada módulo de 10 plantas tenía una línea horizontal que destacaba su separación del siguiente creando una 'supraescala' a nivel territorial.

La idea conceptual de hacer coincidir las líneas horizontales de diferentes edificaciones, creando una perspectiva conjunta de escala urbana en una ordenación, remite de nuevo a un referente de Marek Leykam, Auguste Perret, que había estado trabajando hasta su muerte en 1954 en la reconstrucción de la ciudad francesa de Le Havre, también arrasada durante la II Guerra Mundial.

En la reconstrucción de Le Havre (13.10), Perret planteó la ordenación de un gran conjunto urbano mediante un trazado homogéneo en el que todos los detalles estuviesen sincronizados y llevados a cabo bajo el mismo patrón, buscando la creación de una "obra de arte total a escala urbana". ${ }^{13.06}$ Del mismo modo actuaría Leykam en Varsovia, manejando simultáneamente diferentes escalas para abarcar con una solución de conjunto los diferentes problemas urbanísticos derivados de la ordenación.

A nivel volumétrico, Leykam toma partido por radicalizar de nuevo el contraste direccional que marcan los cambios de plano de los diferentes bloques dotando de mayor permeabilidad las fachadas longitudinales de todas las piezas y cegando los testeros de todas las piezas de forma invariable en la ordenación, una decisión que se repite en la mayoría de sus obras construidas como hemos podido ver.

Este concepto da pie en este caso, además, a una lectura claramente política de la direccionalidad, puesto que Leykam dirige todos los testeros ciegos de forma invariable hacia la dirección visual del Palacio PKiN, símbolo del Realismo Socialista, una decisión que no debió pasar inadvertida por los miembros del jurado y representantes políticos presentes

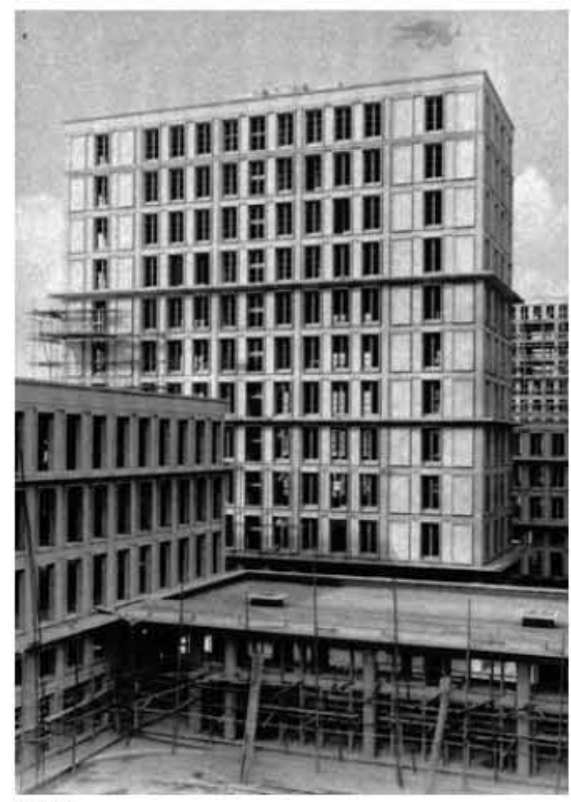

13.11

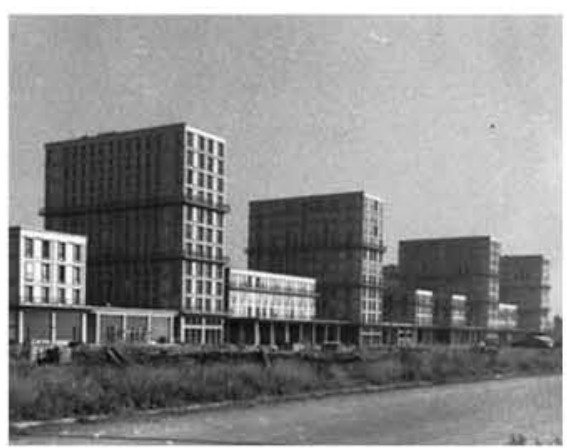

13.12

13.06. González Cárdenas, 2005 

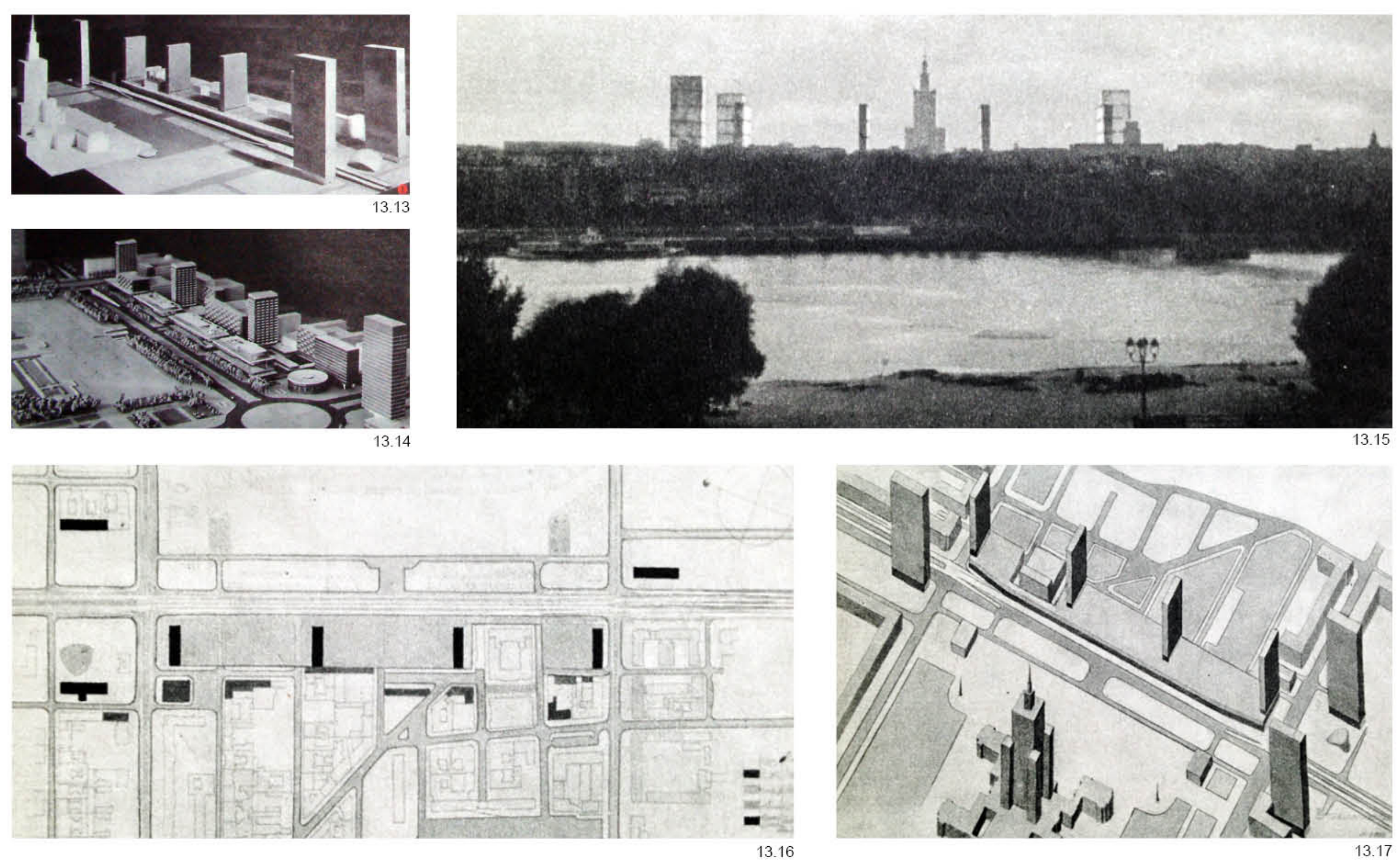
en las deliberaciones, muy preocupados por la relación que se estableciese entre la nueva ordenación y el símbolo del poder político de la ciudad.

En este caso, no solo las visuales desde el palacio encuentran testeros ciegos, sino que todas las fachadas permeables evitaban deliberadamente dirigir sus paños permeables de forma frontal al palacio PKiN, relegando las orientación de las vistas a una dirección cruzada que no permitiese percibir de forma armónica su simetría, desvirtuando así su importancia jerárquica y el propio canon de orden clásico de la composición (13.16 - 13.17).

A escala territorial Leykam trazó un desafío todavía mayor a las bases propuestas, habida cuenta que la recomendación del jurado era no discutir el papel dominante del palacio PKiN y estaba prohibido superarlo en altura. Su propuesta se plasmaba en un perfil de Varsovia dibujado en perspectiva (13.15), donde la torre PKiN quedaba alejada del centro de masas de la composición.

Si Leykam hubiese presentado un alzado, la vista habría sido simétrica con respecto a la torre -enfatizando su centralidad-, pero la decisión de visualizar los edificios en perspectiva y desde una posición lejana pretendía mostrar intencionadamente cómo la nueva ordenación estaba encaminada a ofrecer un marco de referencia que descentralizara ligeramente el palacio, sacándolo de contexto sutilmente, para dejar su eje de simetría prácticamente a las puertas de dominar la composición, pero fuera del centro. Al eliminar la posición dominante de la torre PKiN, desaparecía la rigidez compositiva y su presencia pasaba a ser integrada en un conjunto del que formaba parte como un elemento más.

Si atendemos a los artículos de la época, el resto de propuestas se ajustaron a las recomendaciones de los organizadores de subordinar su ordenación al papel dominante del PKiN y no trataron de competir en altura ni hicieron referencias explicitas a la lectura del perfil lejano del conjunto de la ciudad. Las discusiones en torno al programa reprocharon a Leykam que, una vez más, no hubiese respetado las bases y hubiese propuesto un significativo aumento de programa como consecuencia del volumen al que había llegado en su solución formal. Leykam justifico estos cambios argumentando que "había tenido en cuenta las necesidades del año 2000" ${ }^{13.01}$ y que "en Polonia existía una tendencia constante hacia una mayor demanda de diferentes tipos de servicios, hasta ahora poco desarrollados, pero que tenían un gran fituro por delante." 13.01

Leykam defendía la tesis de que un gran centro urbano en altura era una inversión clave para el país, que le permitiría afrontar con mayor tranquilidad la reestructuración pausada de las zonas rurales. La concentración de actividad en los centros permitiría "Iiberar tierra y evitar la construcción extensiva, lo que supondría para Polonia un coste desproporcionadamente mayor." 13.01

El concurso de la Fachada Este se resolvió finalmente el 22 de diciembre de 1958, tras varias fases de eliminación en las

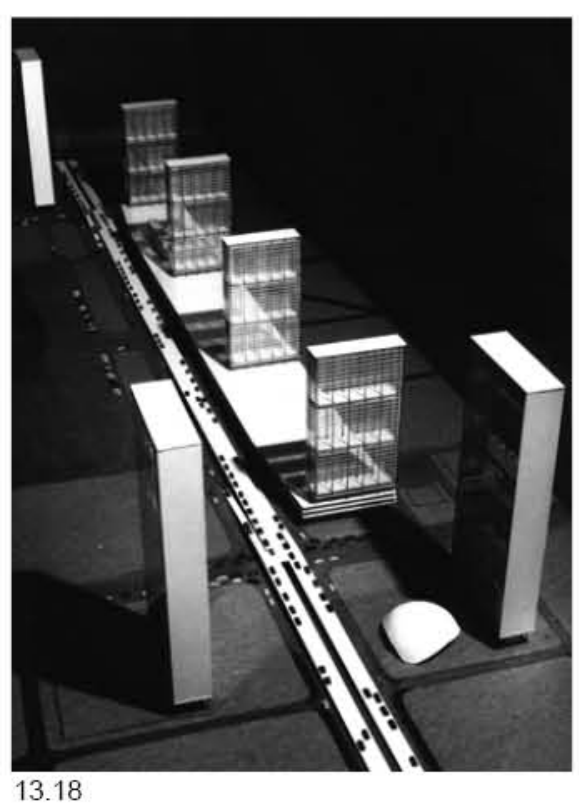

13.18 
13.19 Oscar Niemeyer observando una de las pe Varsovia, durante su visita a Polonia en 1972.

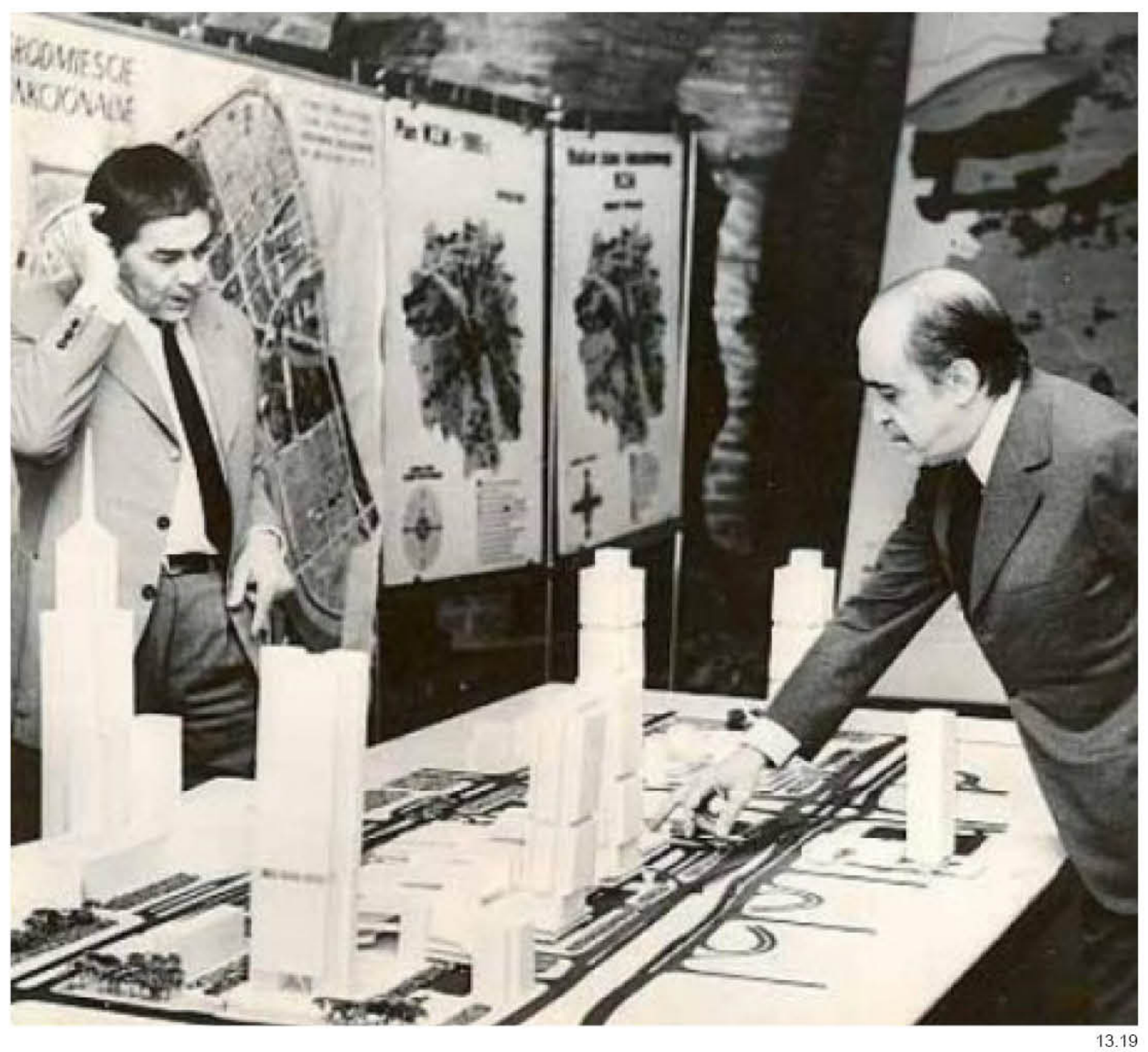


que se habían elegido 15 propuestas y se otorgaron dos primeros premios, dos segundos, y tres terceros. Los ganadores del concurso fueron los equipos de los arquitectos Zbigniew Karpiński y Kazimierz Wejchert y los segundos premios fueron para Marek Leykam y J. Z. Polak. ${ }^{13.01}$

El proyecto ganador (13.21), presentado por Zbigniew Karpiński, sugería dar prioridad a la horizontalidad de la ordenación singularizando los edificios que forman parte del zócalo haciéndolos llegar hasta 5 plantas de altura además del zócalo. A pesar de que estas piezas trataban de buscar similitudes resolviendo de forma idéntica su fachada a nivel urbano, se situaban de forma desalineada sobre el perfil de la calle Marszałkowska desvirtuando su continuidad.

Ambos extremos de la ordenación respondían, a su vez, de forma diferente a la parte central de la trama. En los entornos de las avenidas Jerozolimska y Świetokrzyska se resolvían, de forma autónoma y descoordinada, volúmenes con criterios diferentes a nivel formal y compositivo de los que habían conformado los extremos norte y sur de la composición.

Cumpliendo con las instrucciones de la convocatoria, todas las obras galardonadas fueron mostradas en una exposición al efecto realizada en las salas del Gran Teatro. Del 9 al 11 enero de 1959 tuvo lugar un debate sobre los proyectos en el que participaron arquitectos, urbanistas, economistas, ingenieros y otros profesionales relacionados con la construcción. Tras revelar los resultados y, especialmente tras la inauguración de esta exposición, se desató un importante debate público de gran transcendencia mediática en la ciudad. Las revista "Trybuna Ludu" y "Życie Warszawy" recogieron los argumentos del arquitecto jefe de Varsovia, A. Ciborowski, en las que evitando dar su opinión, subrayaba "Ia importancia de la edificación de la parte central de la capital" ${ }^{13.07}$ y pedía que se valorase "la factibilidad de los proyectos según las actuales capacidades técnicas" ${ }^{13.07}$. En los siguientes meses se realizaron multitud de sesiones críticas a nivel nacional. ${ }^{13.01}$

El mayor alcance mediático de este proyecto llegó con el debate retransmitido por la televisión nacional de Polonia TVP en el que opinaron arquitectos, funcionarios gubernamentales, economistas, escritores, personalidades de la cultura, habitantes de Varsovia y los propios autores de los proyectos. Durante los dos primeros meses de 1959, el concurso estuvo en el foco de atención de toda la sociedad mientras que el resultado no era definitivo a pesar del fallo del jurado, ya que el Consejo Científico Técnico-Económico bajo la presidencia del Consejo Nacional de la ciudad de Varsovia estaba preparando unas conclusiones analíticas antes de la elección definitiva de una de las obras para su realización. ${ }^{13.01}$

Durante las vistas públicas, multitud de críticos defendieron abiertamente la propuesta de Leykam y criticaron el proyecto ganador de Karpiński. La mayoría de estas opiniones fueron recogidas por la revista "Przegląd Kulturalny". Según recoge Matuszewski: "La mayoría de los oradores se pronunció bastante determinadamente a favor de la construcción del centro de la capital según el trabajo de Marek Leykam. Incluso se expresó a su favor el mismo presidente del jurado del concurso, el arquitecto Wierzbicki' ${ }^{13.08}$
13.07. Vease publicación "Dyskusja nad zabudowa centrum Warszawy" (Deliberaciones sobre la construcción del centro de Varsovia) p.1. (Op Cit. 13.01. p 99.).

13.08. La opinión de Matuszewski fue recogida por Stepowski en el articulo "Jutro bedzie za późn" Stępowski en el articulo "Jutro będzie za pożno" 3 de la revista "Nueva Cultura" en 1959 , p. 1 . Cit Jur, 1977. p.95. 
13.20 Propuesta final de Zbigniew Karpiński para el proyecto de la Fachada Este de Varsovia.

13.21 Propuesta original presentada por Zbigniew Karpinski para el concurso de la Fachada Este Varsovia.

13.22 - 13.23 Construcción de la Fachada Este de Varsovia según el proyecto del arquitecto Zbigniew Karpiński y su equipo.

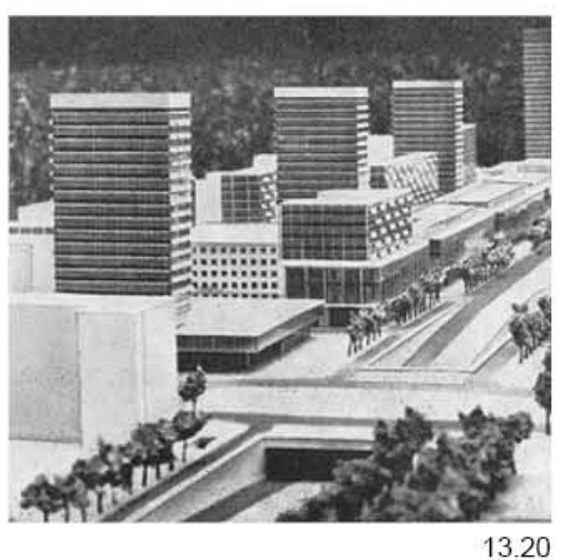

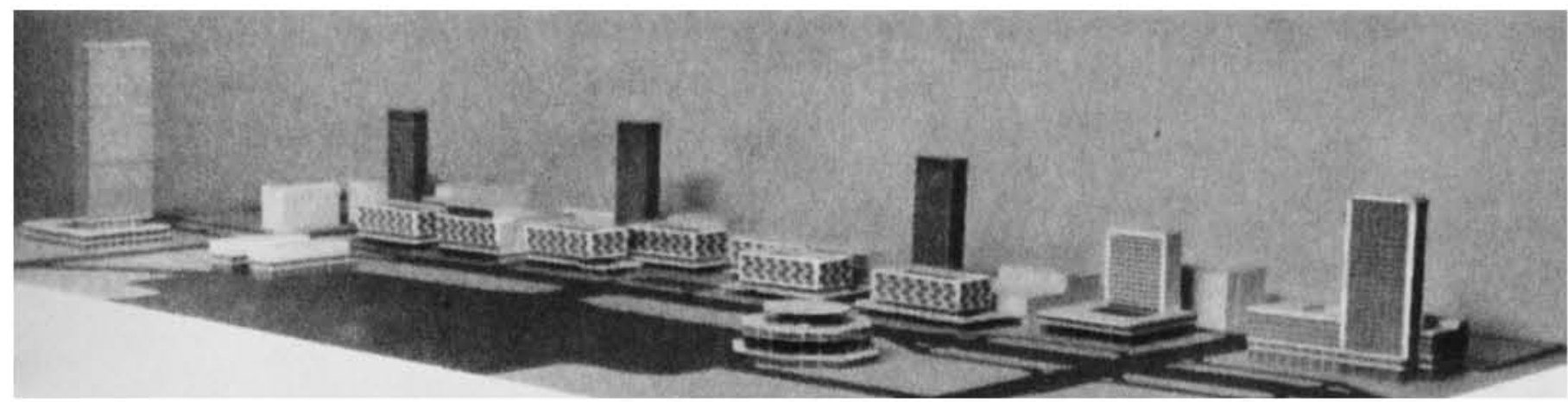

13.21

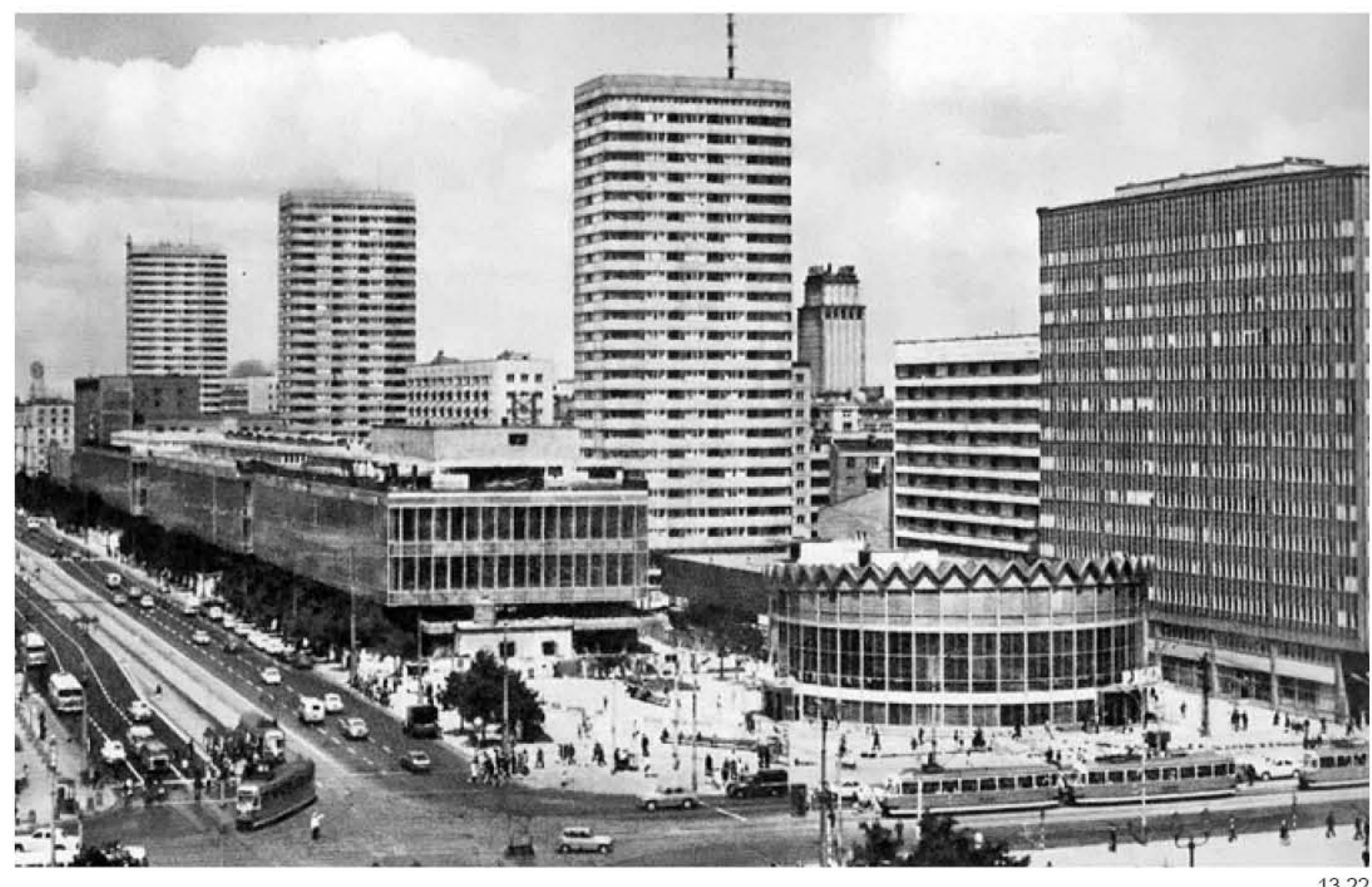


Pero las declaraciones de Władysław Gomułka ${ }^{13.09}$ fuertemente en contra del desarrollo a gran escala propuesto por Leykam, prevalecieron a los argumentos económicos y la posibilidad de una rápida realización y, finalmente, aunque el Consejo Nacional Técnico-Económico publicó en mayo de 1959 su informe considerando que el proyecto de Karpiński tenía una valoración inferior a la de Leykam, su propuesta se impuso debido al mayor reconocimiento de las autoridades y a él fue encargada la elaboración "recomendándole la inclusión de los valores de otros trabajos presentados." 13.01

Durante las sesiones públicas de crítica del proyecto, Karpiński había sido acusado de "excesiva fragmentación en muchos elementos de pequeña escala, descomposición y confisión funcional" ${ }^{13.01}$ además de "falta de una expresión arquitectónica" ${ }^{13.01}$. El miembro del jurado que más claramente se posicionó en contra de Karpiński y a favor de la obra de Leykam fue precisamente Jerzy Hryniewiecki. De sus numerosos discursos, el que más se suele citar es el fragmento de una entrevista para "Kurier Polski": "Ya es hora de que nosotros también nos unamos al progreso de la arquitectura y urbanismo mundial. El reflejo de este avance, entre las propuestas del concurso, es el proyecto de Marek Leykam. Hace énfasis en el conjunto, es moderno en su totalidad, y esta creado por el pensamiento de un arquitecto moderno. De un centro así no se avergonzaría ninguna capital del mundo" ${ }^{13.10}$.

El veredicto final del jurado determinó que el proyecto de Leykam no era adecuado puesto que "en las circunstancias actuales este tipo de intención de ejecución requeriría una masificación de un esfierzo extraordinario de la inversión y no sería suficiente compensado a los efectos de la utilidad" ${ }^{13.07}$ pero como consecuencia del entusiasmo con que fue recibido durante la exposición pública -según reflejan las crónicas y las opiniones de la época ${ }^{13.07}$, el arquitecto jefe de la ciudad, Ciborowski, decidió "aplazar la resolución sobre la ejecución del proyecto pendiente del estudio detallado sobre el programa" ${ }^{13.07}$. Tras esta declaración se encargó al equipo de Karpiński un nuevo planteamiento de un proyecto que contenía grandes similitudes con que había presentado Leykam, sin contar con su consentimiento. ${ }^{13.01}$

En el nuevo proyecto presentado por Karpiński, los bloques centrales de la propuesta fueron girados $90^{\circ}$ para dirigir sus testeros hacia la torre y el zócalo dejo de estar formado por piezas dispersas para agruparse y quedar alineado con la calle Marszałkowska tal como había planteado Leykam. Comparando la propuesta inicial de Karpiński (13.21) con su propuesta final (13.13) y esta última con la inicial de Leykam (13.12) se percibe el tremendo acercamiento a su propuesta durante en el proceso de reelaboración.

No obstante y a pesar de esta copia, el proyecto de Karpiński adolecía de las características que hacían tan singular la obra de Leykam. La diferencia en la proporción del volumen de los bloques ya no acentúa su esbeltez y su extraña relación con el zócalo interrumpe parte de sus visuales. Por su parte la falta de direccionalidad de las fachadas hace que el concepto principal de la relación con la plaza y el Palacio PKiN pierda sentido y además se abandona la interesante proporción entre las diferentes escalas que llevaba al proyecto de Leykam a relacionar las dimensiones de un detalle con las soluciones urbanas a escala territorial.

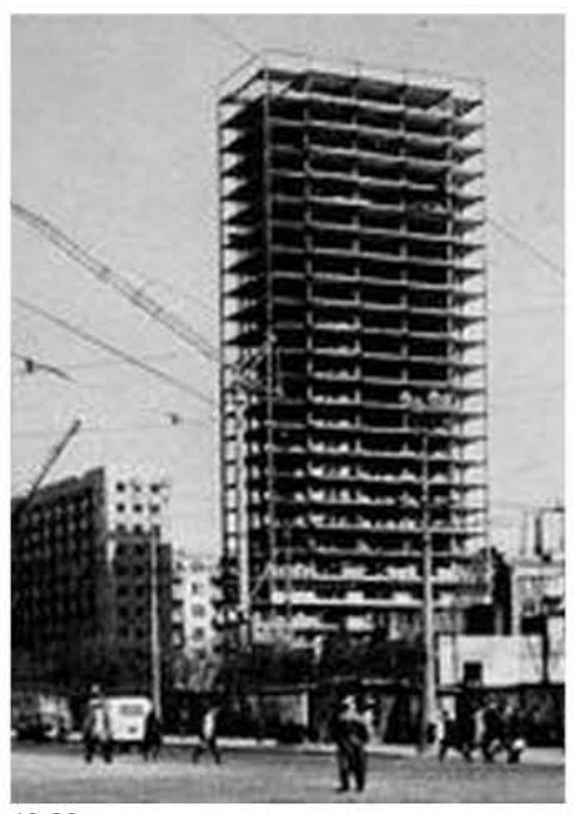

13.23
13.09. Władysław Gomułka se mostró contrario a la propuesta de Leykam en el III Encuentro del Partido Obrero Unificado de Polonia (III Zjazdu PZPR, Polska Zjednoczona Partia Robotnicza). Cit. Jur, 1977. p.97.

13.10. Cita de Hryniewiecki recogida por J. Stępowski en su artículo "Jutro będzie za późno" ("Mañana será tarde") publicado en la revista Fundamenty 1959, nr 2, p. 6-7. (Op Cit. 13.01. p 97.) 


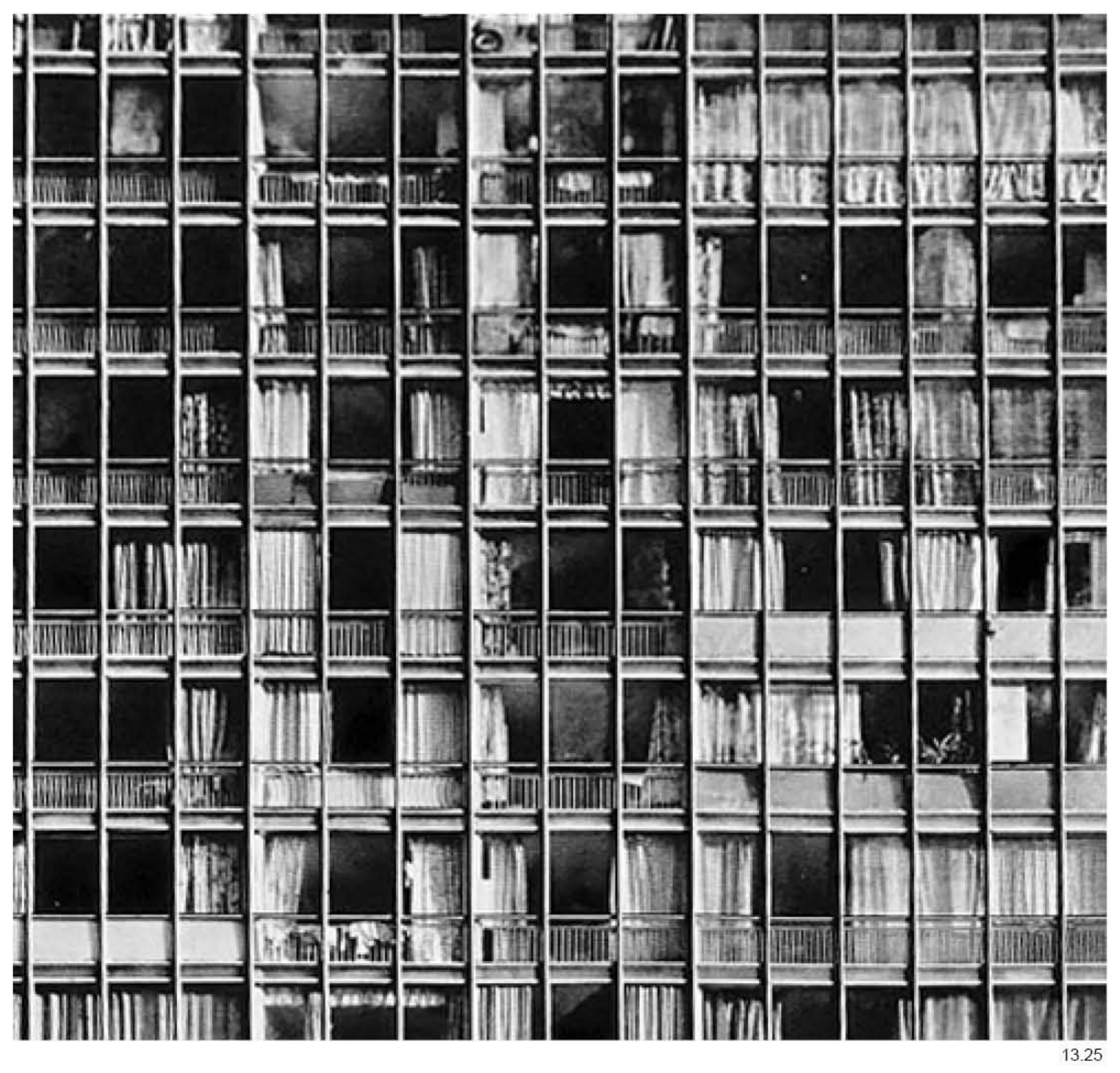




\subsubsection{Torre en la Ronda George Washington de Varsovia}

Leykam fue compensado en 1959 con la posibilidad de construir una torre al otro lado del Vístula en el barrio de Saska Kępa, concretamente en la Ronda George Washington 2b. En este proyecto Leykam trabajó con un muro cortina de fachada, un sistema constructivo que se utilizaba por primera vez en Polonia. ${ }^{13.01}$

La Torre de la Ronda George Washington constaba de 14 plantas, y en ella Leykam optó de nuevo por dotar de permeabilidad a las fachadas longitudinales y dejar los testeros ciegos a excepción de las visuales abiertas al final de los corredores central. La trama del muro cortina daba prioridad de paso a los montantes verticales y permitía que, a través del antepecho de barandilla, también se filtrara la luz.

La falta de experiencia con el sistema de muro cortina llevó a que el control térmico de los interiores no pudiera realizarse adecuadamente y al poco tiempo la fachada fue sustituida por un sistema de muro convencional, ya sin la supervisión de Leykam, que había abandonado su carrera como arquitecto.

Según explica Springer, ${ }^{13.11}$ cuando Leykam vio el resultado final construido del proyecto de la Fachada Este de Varsovia a finales de los 60 envió a SARP un requerimiento formal para que este diera su opinión sobre el asunto, puesto que consideraba que su idea había sido utilizada sin su permiso y el proyecto de Karpiński había utilizado -de forma banalsus análisis y su interpretación. Los miembros de SARP decidieron permanecer en silencio al no querer exponerse ante los responsables políticos y Leykam envió una segunda carta a la sede del colegio devolviendo su carnet de colegiado y no volvió a proyectar nunca más.

Con el concurso de la Fachada Este de Varsovia concluyeron todas las esperanzas que Leykam tenía depositadas en desarrollar una propuesta metropolitana que permitiese reconducir -con un desarrollo urbanístico moderno- el nuevo centro urbano de Varsovia que había emergido tras el vacío generado por la destrucción de la ciudad durante la II Guerra Mundial (véase p. 99 y ss.).

Durante los años siguientes, tras terminar las obras del Instituto AWF de Poznań, Leykam se dedicó únicamente a completar proyectos industriales de los que no hay registro, como la FSO Żerań, la Fábrica de Tractores "Ursus", la Empresa de Equipamiento Automovil "Polmo" en Praszka cerca de Wieluń, la Fábrica de Coches en Bielsko-Biala, la Fábrica de piezas de coches en Siedlce, Fundición Skoczów, así como un conjunto de proyectos para la Industria de Armamento Nacional de Polonia que son, todavía hoy, totalmente confidenciales. ${ }^{13.05}$

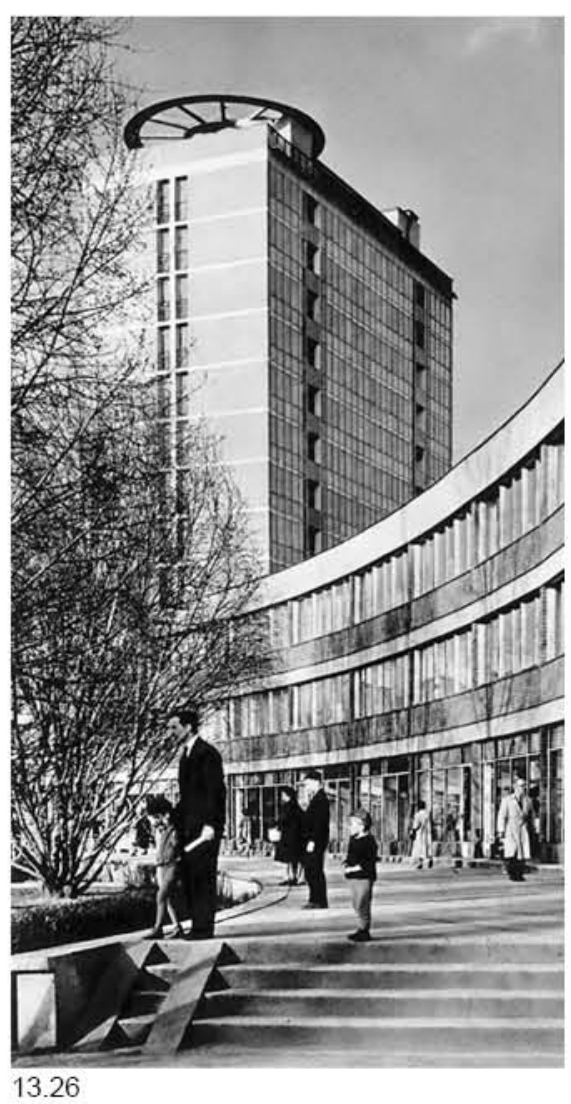

13.11. Springer, 2011. p $69-72$ 
14.01 Planta de la Iglesia de San Claudio al Chienti (s. XI).

14.02 Iconostasio de la Basílica de San Marcos de Venecia.

14.03 Mesa de altar con seis apoyos en la Catedral de Cremona.

14.04 Planta y sección de una Patena de Elche.

14.05 Trono en la catedral de San Nicolas de Bari.

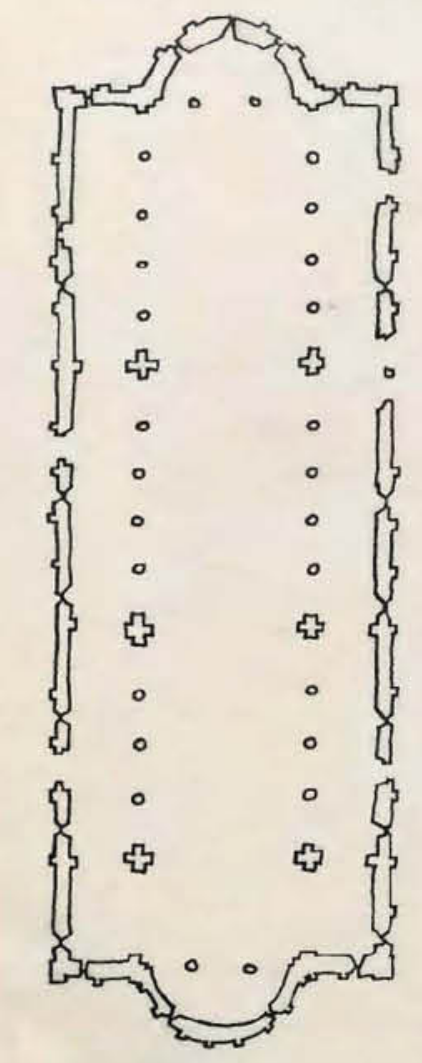

14.01

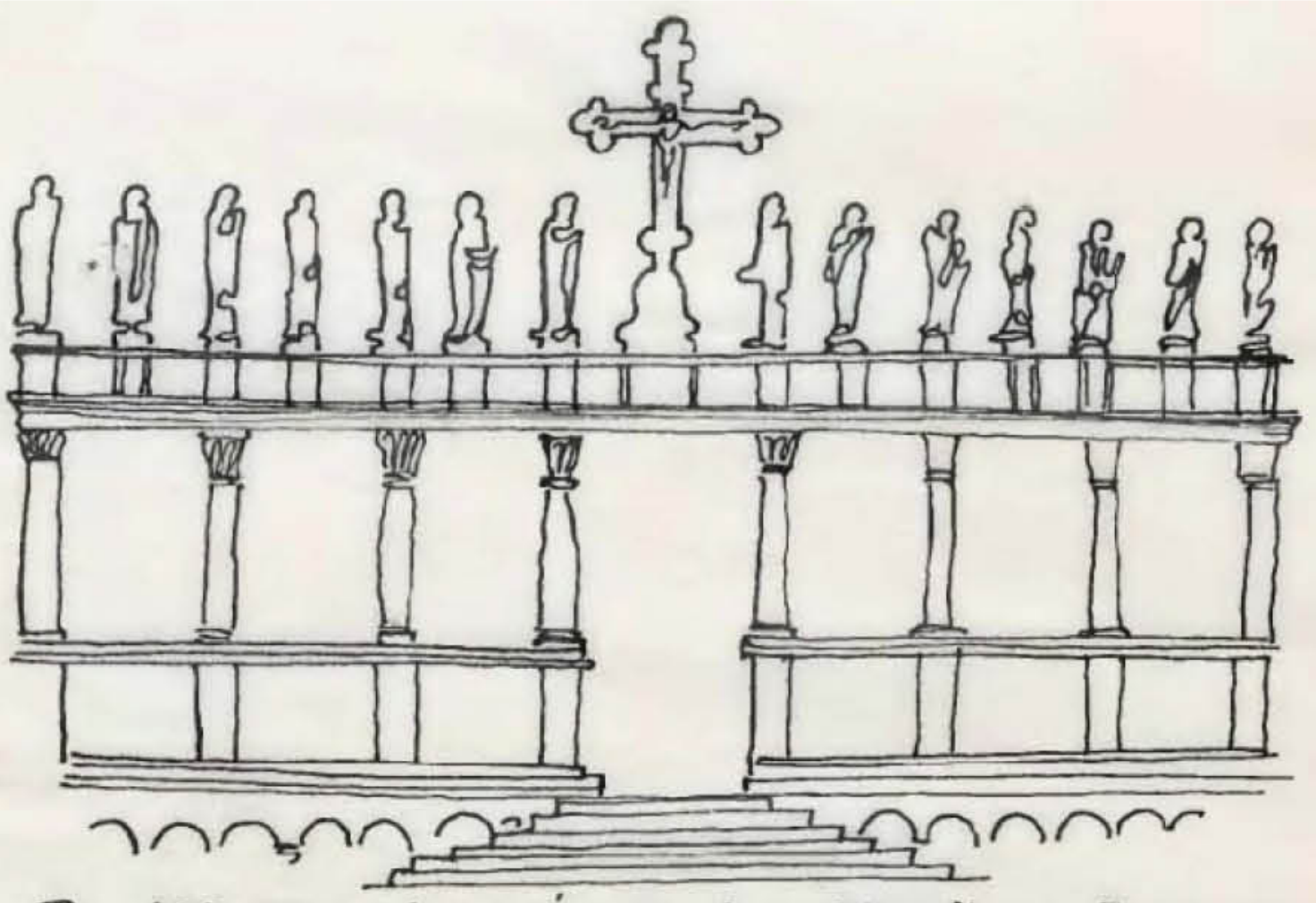

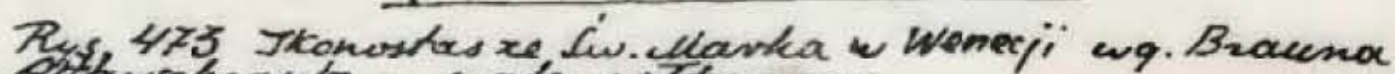

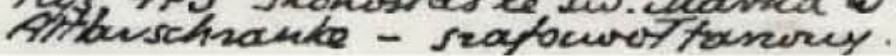

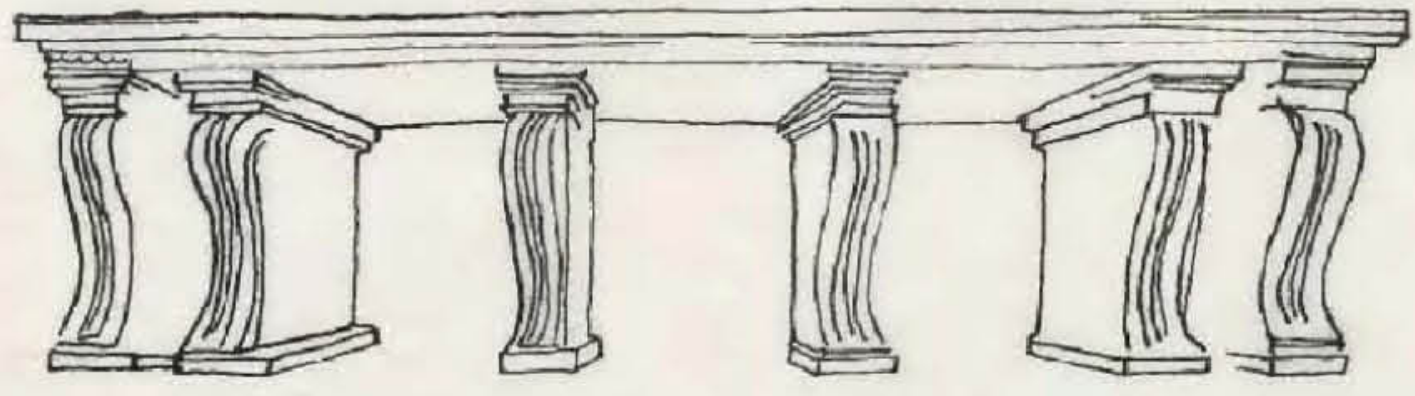

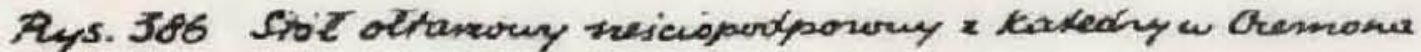




\subsection{Epifonema.}

"La belleza es la sabia creación de lo obvio y así, lo perfecto".

Marek Leykam

"O wnętrzu wspolczesnym" 14.00

A partir de la década de los 60, Leykam traslada sus propuestas a soluciones arquitectónicas de baja altura y marcada horizontalidad, debido a las diferentes necesidades de los encargos que fue recibiendo una vez remitida la presión urbanística asociada a la urgente necesidad de reconstruir rápidamente los centros de las principales ciudades polacas en los primeros años de posguerra.

En lugares como Płock -donde recibió el encargo de un albergue turístico-, Nałęczów -lugar en que proyectó una escuela de arte-, o el extrarradio de Poznań -ciudad en la que construyó una de sus últimas obras, el Instituto de Educación Física AWF-, era necesaria una relación mucho más inmediata con la escala de peatón y con el propio paisaje que la requerida en los programas de necesidades de los Żyletkowiec de Varsovia (7.01-7.30) o el Okrąglak de Poznań (8.01-8.36), lo que no fue óbice para que Leykam continuase planteando su arquitectura como una solución derivada de formas abstractas que generase expresividad a través de la manifestación del orden y la simplicidad de los elementos tectónicos.

Con el objetivo de evitar singularidades y aprovechar al máximo los volúmenes construidos, en esta serie de encargos Leykam varió únicamente el tamaño de la pieza en función del programa y propuso soluciones de baja altura y máxima relación con el terreno en el que se debían situar.

Desde la patena de Elche que dibujó en su doctorado en Zúrich en 1943 (14.04), Leykam continuaba definiendo a través de su trabajo un proceso continuo que lograse una interpretación única y universalmente comprensible de cada una de sus manifestaciones construidas, independientemente de su escala y su propósito final.

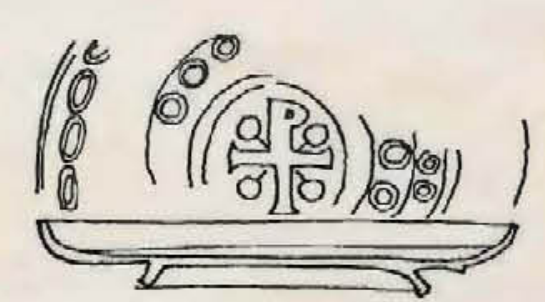

Mys.69\%. Ratuaz ceren whinganyi: 14.04

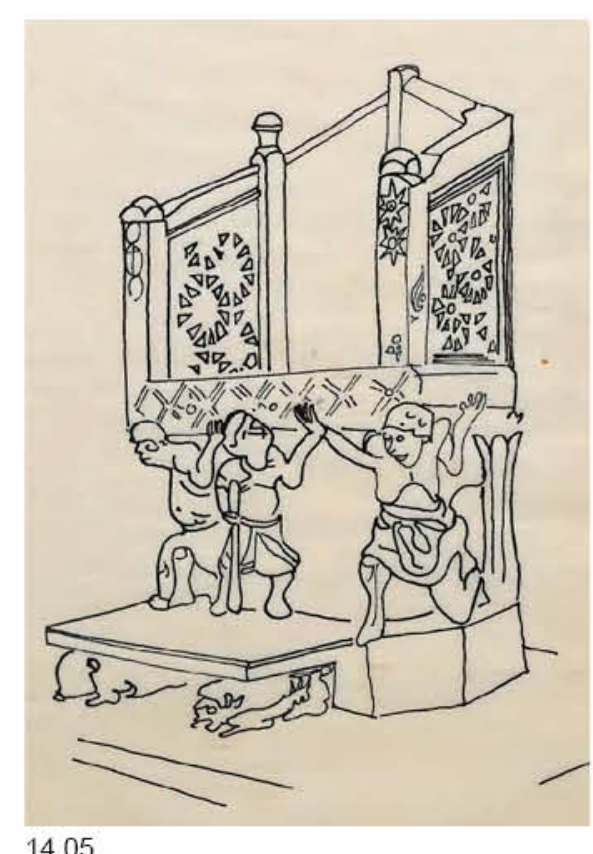

14.00. Artículo "O wnętrzu wspolczesnym" (EI interior moderno) Publicado en la revista Arkady $1936, n^{0} 7$ p. 375 


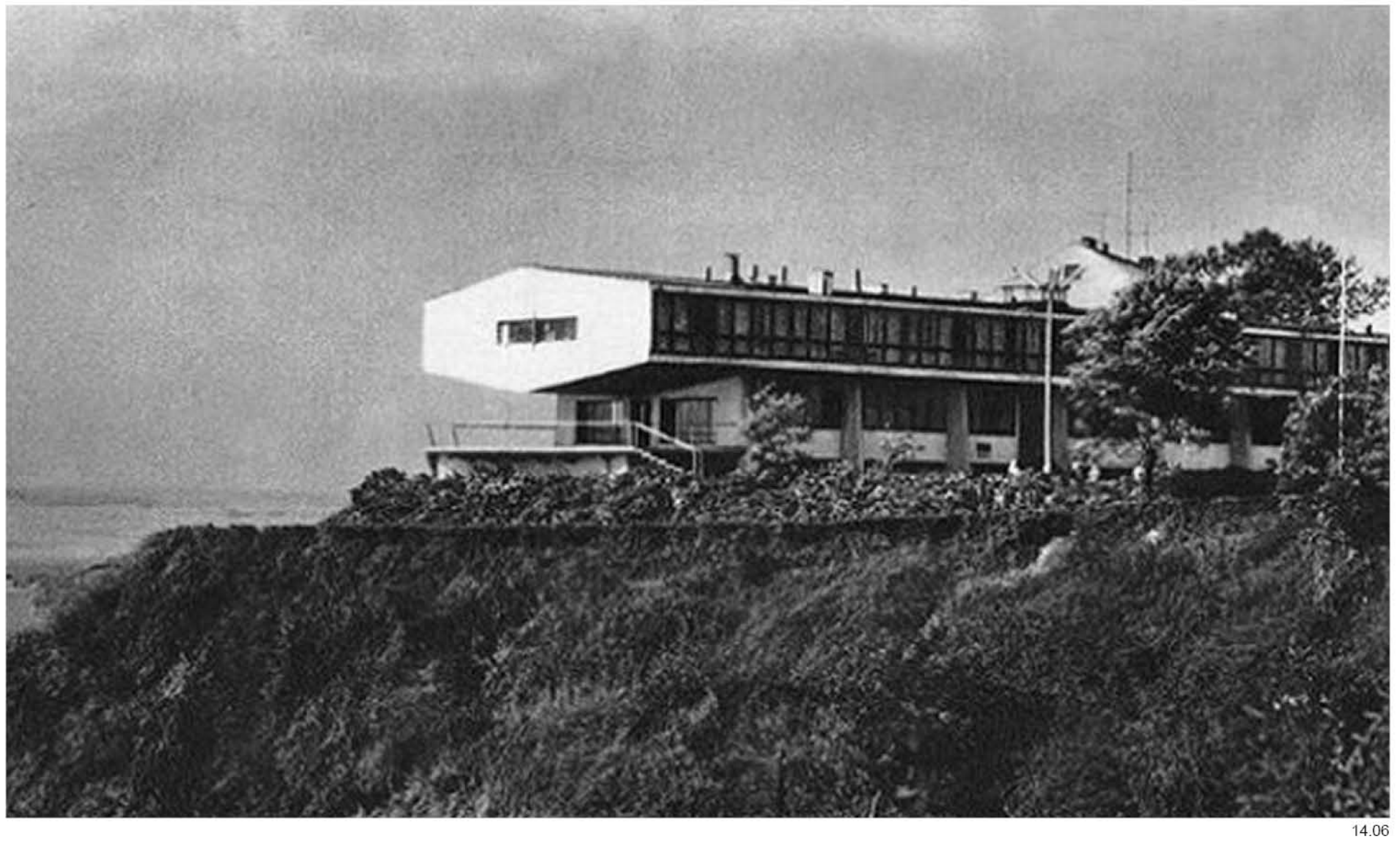


De la misma manera que grafió el Iconostasio de la Basílica de San Marcos (14.02) el Trono de la catedral de San Nicolás de Bari (14.05) o los Soportes de la mesa de altar de la Catedral de Cremona (14.03), Leykam interpretará esta serie de proyectos como una disyunción entre un nivel inferior con presencia de elementos estructurales que generan lectura continua a partir de la suma de sus discontinuidades, y un nivel superior donde quede soportado el peso principal de la composición desafiando a la gravedad con un volumen en el cual los elementos tectónicos están integrados en el contorno de la forma para ofrecer una lectura en continuidad con sus proporciones y su dirección.

En julio de 1956, Leykam participó como delegado de la Sociedad de Arquitectos Polacos -SARP-, en la Exposición Industrial en París, y al año siguiente fue comisario de la exposición polaca en la Trienal de Milán de 1957, donde entró en contacto con varios diseñadores de interiores polacos con los que comenzó a trabajar en los siguientes años en diferentes proyectos. ${ }^{14.01}$

\subsubsection{Albergue Dom PTTK en Plock}

En 1957, Leykam recibió el encargo de construir un albergue en la turística ciudad de Płock, $80 \mathrm{~km}$ al oeste de Varsovia. Emplazado directamente en la orilla del río Vístula, la ubicación del solar entre las calles Piekarska y Teatralny no determina la alineación del edificio, puesto que -en el esponjado contexto en que se sitúa-, realizará un sutil giro sobre la trama urbana que viene marcado por las construcciones adyacentes para poder orientar el volumen en una dirección prácticamente coincidente con eje de coordenadas geográficas norte-sur. Esta orientación propicia el acceso de las estancias al soleamiento de la tarde -en las habitaciones orientadas al oeste con vistas directas sobre el río Vístula-, y también el de la mañana -en las habitaciones orientadas al este, con vistas sobre la cercana Catedral de Płock y el Castillo de los Duques de Mazovia-.

El volumen está conformado por un rectángulo de $18 \mathrm{~m}$ de anchura y $54 \mathrm{~m}$ de longitud (3:1) en planta y tres alturas de $3 \mathrm{~m}$ cada una, que incluyen un semisótano sobre la cota de $1,50 \mathrm{~m}$ hasta una altura total de $7,5 \mathrm{~m}$. La estructura está formada por 8 pórticos transversales de $6 \mathrm{~m}$, además de dos voladizos de $6 \mathrm{~m}$ cada uno en los extremos. Cada pórtico tiene dos pilares apantallados de $25 \mathrm{~cm}$ y lateral trapezoidal de bases $1 \mathrm{~m}-1,50 \mathrm{~m}$ y luz $8 \mathrm{~m}$ para formar en su plano sendos voladizos de 3 metros en los extremos.

En los alzados longitudinales, el tamaño de hueco que generan los vanos estructurales tiene una proporción 2:1 (3 m de altura y $6 \mathrm{~m}$ de luz) y Leykam subdivide ese ámbito con 5 particiones verticales en 6 módulos que en el volumen superior alcanzan $1 \mathrm{~m}$ de ancho y $3 \mathrm{~m}$ de altura (1:3) a ejes con un parteluz horizontal fraccionando la ventana a $1 / 3$ de la altura a ejes dando lugar a dos piezas que idealmente son de proporciones $1: 2$ y $1: 1$, aunque quedan recortadas por el canto del forjado.

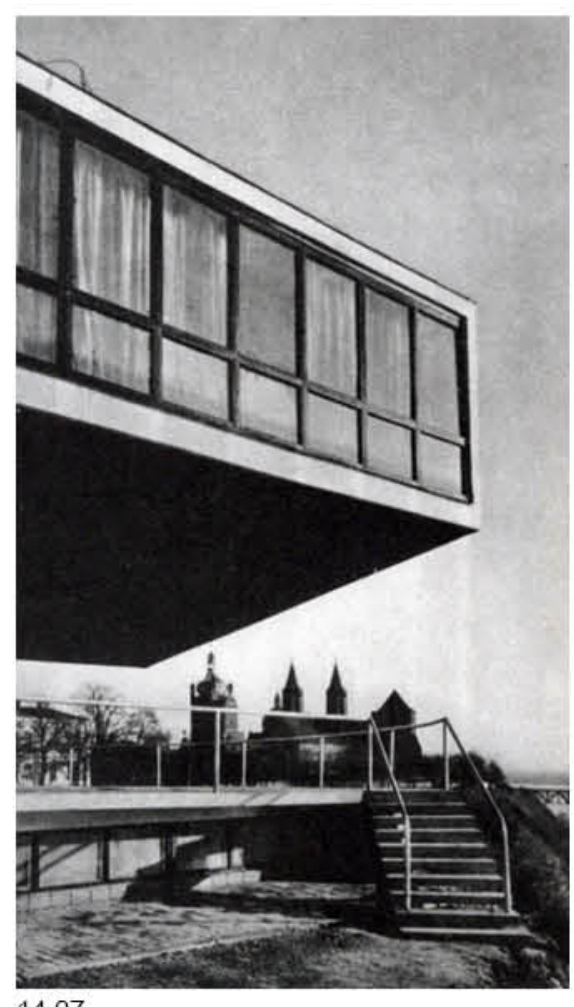

14.07

14.02. Zamek Ksiąząat Mazowieckich. 


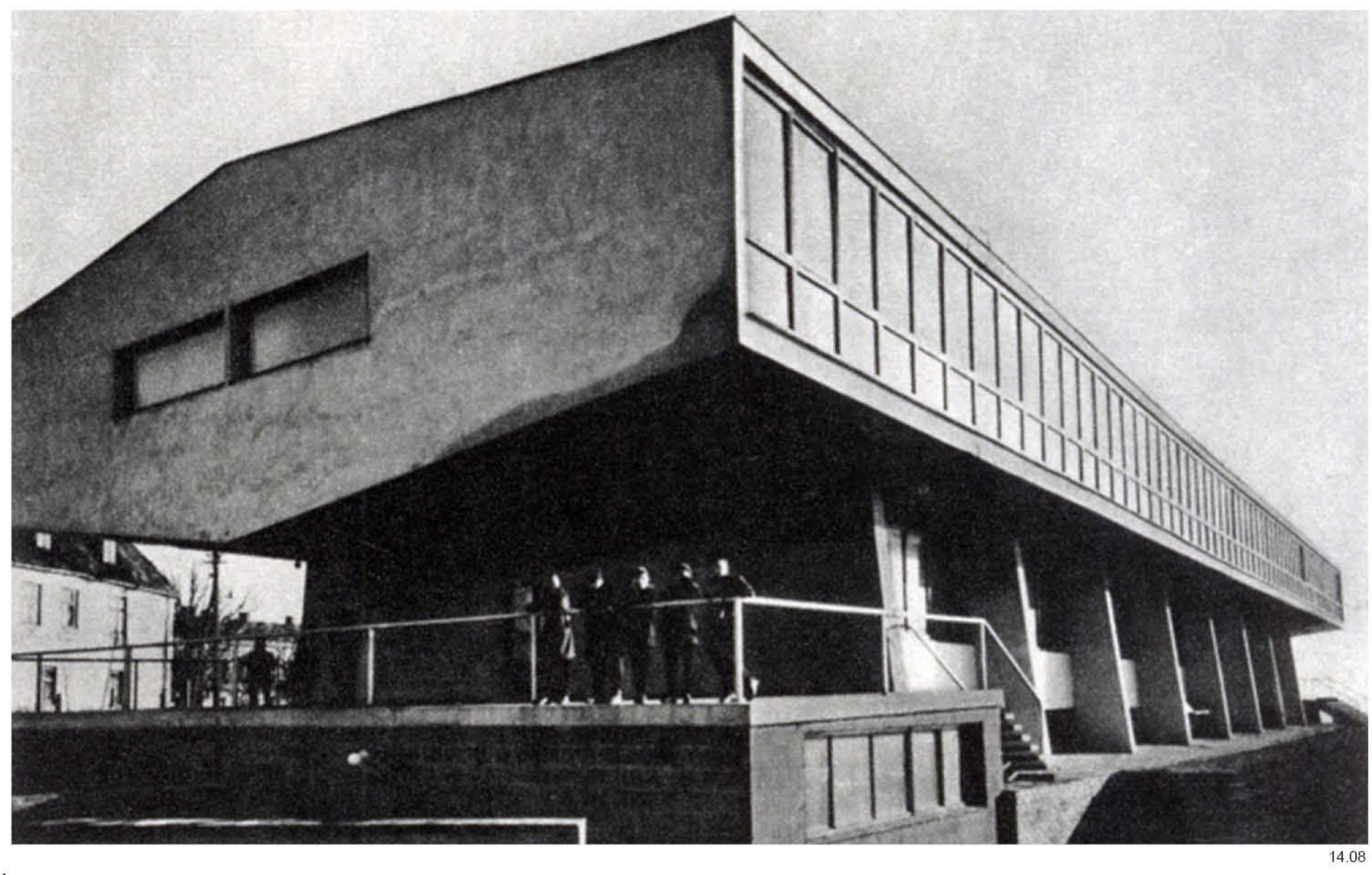




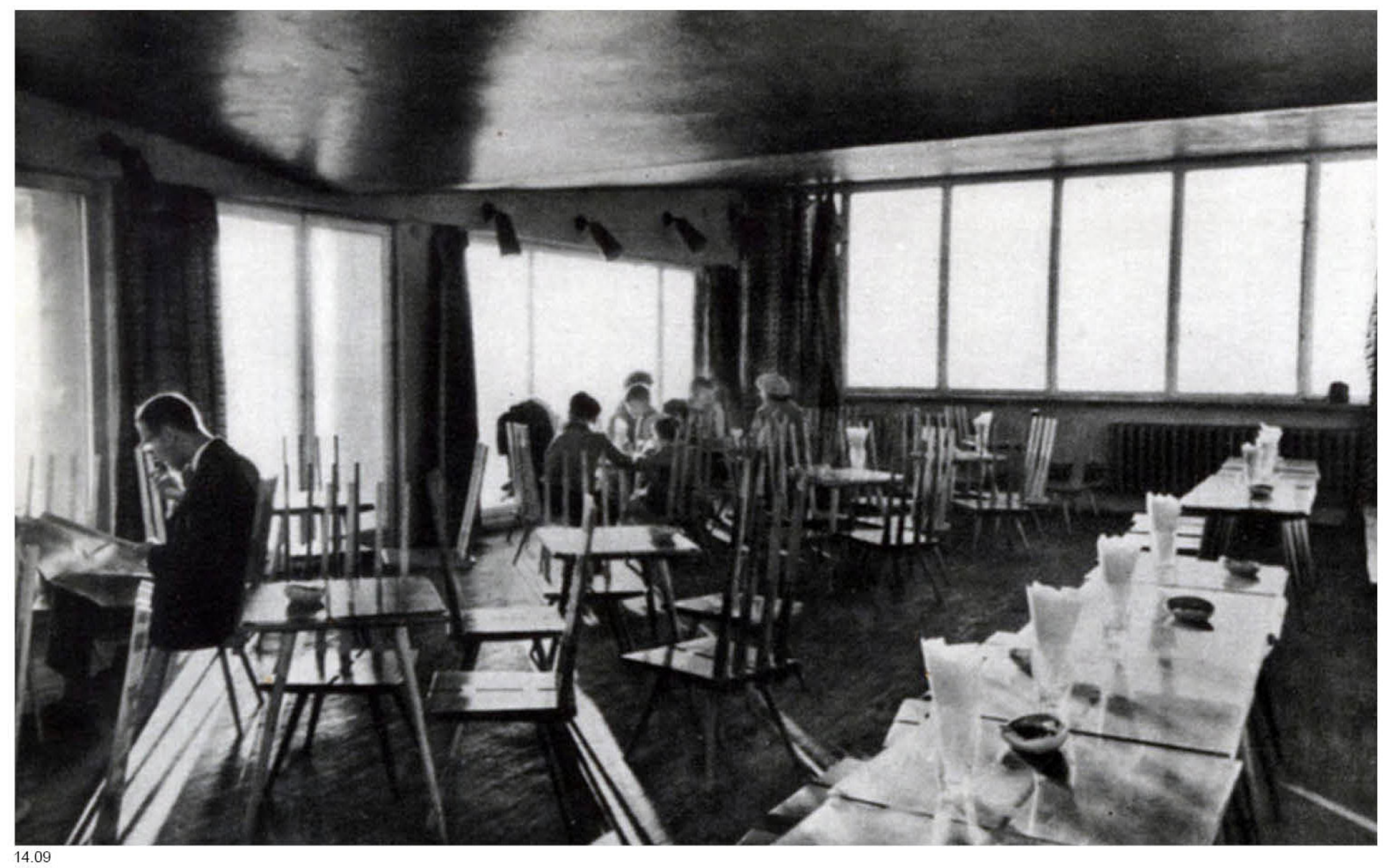


14.11 Plano de situación y planta de acceso en el albergue (Dom PTTK) en Płock, 1959-62. Marek

14.12 Vista interior del albergue (Dom PTTK) en Płock, 1959-62. Marek Leykam.
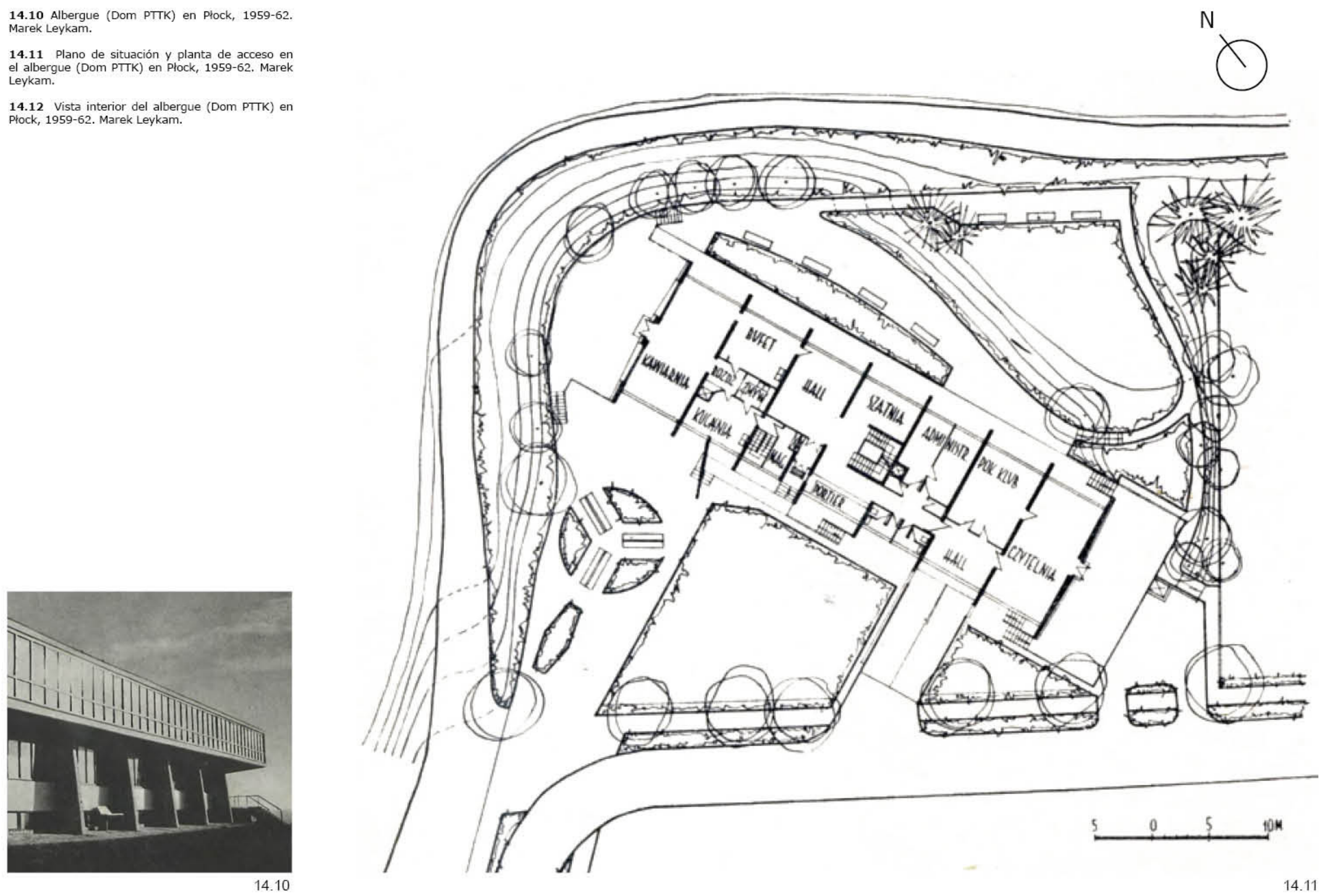
En el volumen de la planta superior los 6 módulos de ventana se resuelven de forma continua a lo largo de toda la fachada, mientras que en el alzado de planta baja la estructura sobresale del plano de fachada reduciendo el intereje de los módulos de ventana adyacentes $0.10 \mathrm{~m}$. El nivel de planta sótano está flanqueado, asimismo, por un muro horizontal de $0,90 \mathrm{~m}$ de altura que da pie a un conjunto de ventanas a nivel del suelo de $0,60 \mathrm{~m}$ de altura.

La inclinación de los soportes remite a los giros en el plano de la trama de fachada que Leykam había introducido por primera vez en el Żyletkowiec de la calle Rakowiecka (7.09-7.12) para potenciar su jerarquía a nivel visual, delimitando inequívocamente la importancia de cada elemento dentro de la composición.

En el caso de los alzados longitudinales, la horizontalidad del volumen superior domina todo el conjunto y los forjados tienen prioridad de paso sobre las carpinterías, mientras la estructura queda retranqueada y oculta en el volumen inferior. Los soportes estructurales sobresalen del plano de fachada haciendo patente su prioridad de paso, pero la inclinación de los pilares apantallados no permite que su presencia entre en conflicto con la dominante expresión horizontal del volumen de la planta superior, enfatizada además por voladizos de la pieza en ambas direcciones.

En los testeros del volumen de planta primera se dibuja un hexágono con dos aperturas en su centro que, si bien justifican su forma como parte de una solución que integre las líneas de los dos ejes de coordenadas existentes -al ser dos de sus lados perpendiculares a los planos de la estructura inclinada, dos simétricos a éstos sobre el eje de gravedad de la figura y los otros dos perpendiculares al plano del suelo-, más allá de su posible relación con la geometría de varios objetos litúrgicos dibujados por Leykam en su doctorado, no dejan de admitir la interpretación de una cierta concesión del arquitecto a la moda de finales de los años 50 que, -tal como ocurrió en esos años en la Iglesia Memorial del Káiser Guillermo I de Egon Eiermann en Berlín o el Pabellón Español de la Exposición Universal de Bruselas en 1958 de José Antonio Corrales y Ramón Vázquez Molezún, entre otras obras-, tomaba como referencia la figura del hexágono siendo aludida con diferentes pretextos, como por ejemplo su forma evocadora de la molécula de benceno, con las implicaciones de acercamiento metafórico a la ciencia que ello pudiera implicar.

El criterio de composición de fachada de este proyecto es similar a los Żyletkowiec, tomando partido de nuevo por el énfasis en la direccionalidad de la pieza acentuando el contraste de los cambios de plano de fachada. Leykam genera de nuevo la mayor permeabilidad en el alzado longitudinal del bloque mientras los testeros de ambos extremos se resuelven con una solución predominantemente opaca a excepción de la apertura de un hueco alineado con el corredor central.

Los voladizos del volumen superior (14.02) guardan una relación de proporciones simple con el tamaño de huecos de ventana y la altura de planta siendo en dirección longitudinal $6 \mathrm{~m}$ y el voladizo transversal $3 \mathrm{~m}$. Para realizar esta solución estructural, calculada por el ingeniero Stanisław Zalewski, se utilizó un forjado de losas prefabricadas de hormigón. ${ }^{14.01}$

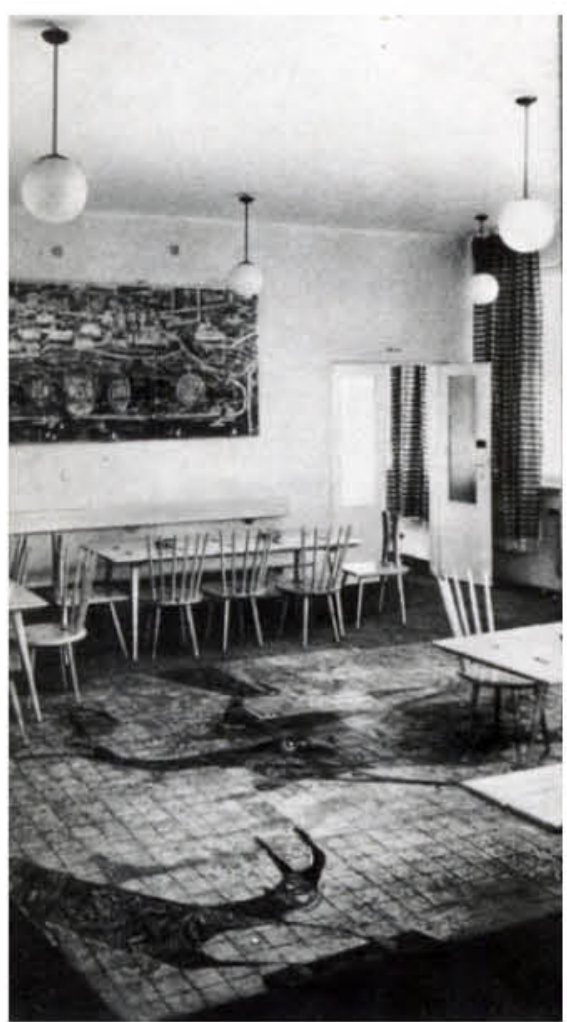

14.12 

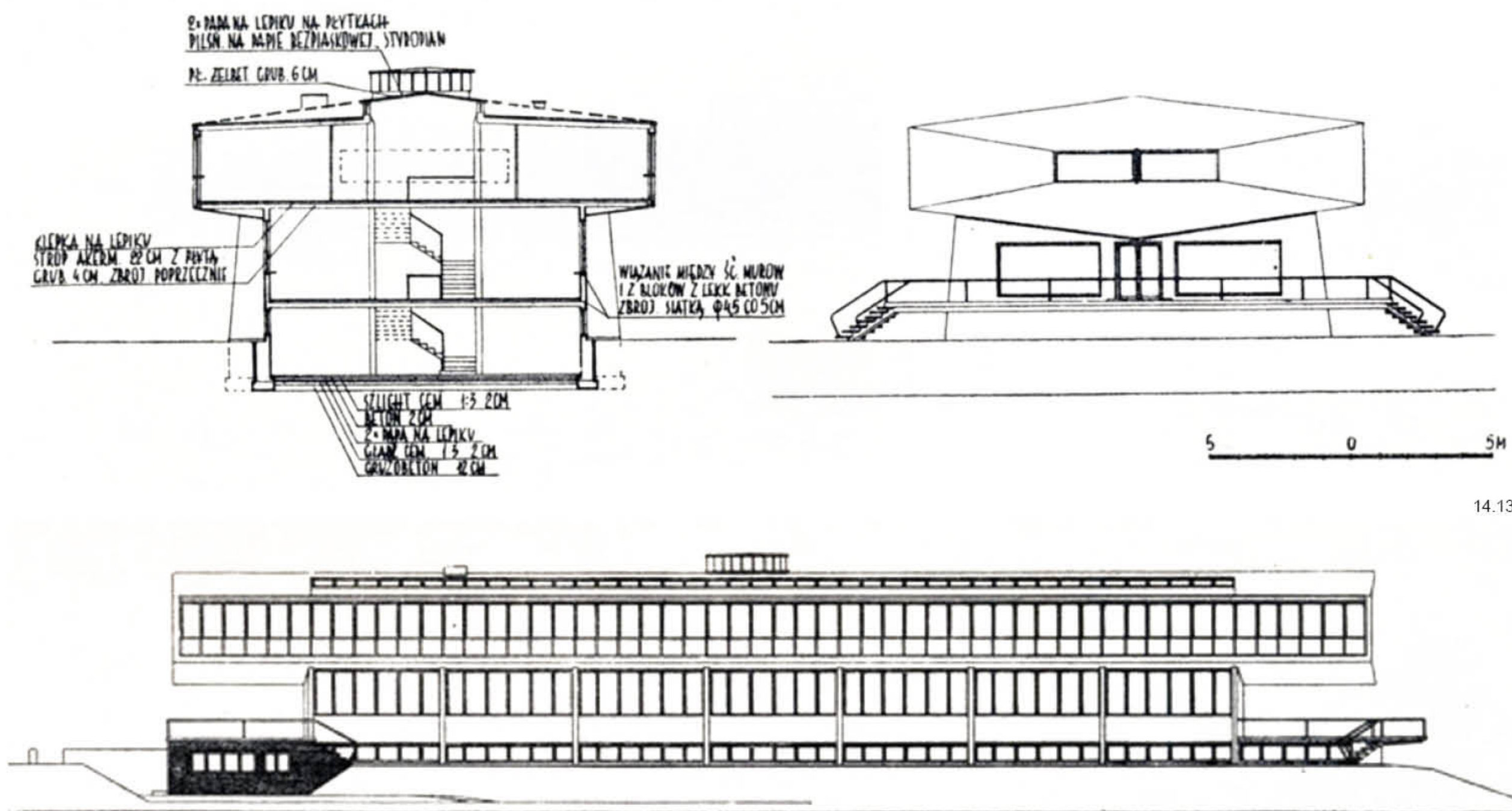
A nivel de distribución la planta semisótano del Dom Turysty PTTK Płock estaba reservada a garajes, sala de calderas, alquiler de equipos, cuartos de servicio y sanitarios, mientras que la planta baja contenía originalmente el acceso, una serie de salas de servicio y entretenimiento.

En la parte central del nivel de planta baja se situaba el hall, el espacio de guardarropa y una oficina de conserjería junto varias salas de servicio. En el lado norte, una cocina-buffet daba paso a una cafetería con una terraza en el mismo borde de la ladera, y en el lado sur un pequeño hall albergaba una amplia sala de lectura. Quedaba reservada finalmente una parte de la planta baja para exposiciones ocasionales que también estaba conectada con una terraza exterior.

La planta superior contenía el uso residencial del albergue. En una banda central aparecen recogidos todos los espacios de servicio, mientras que a lo largo de ambas fachadas se resolvieron 28 habitaciones de $3 \mathrm{~m}$ de anchura -a ejes-, y $6 \mathrm{~m}$ de profundidad. En los extremos del volumen se situaron dos grandes salas comunes con capacidad para 12 personas cada una. El módulo central recibe la luz a través de lucernarios ubicados en el techo y el pasillo a través de las ventanas superiores como se puede ver en la sección (14.13).

Alrededor del edificio Dom PTTK se diseñaron a su vez interesantes recorridos peatonales que conectaban el albergue directamente con la orilla del río, un trabajo que corrió a cargo de varios especialistas en diseño urbano de Varsovia que colaboraron con Leykam. Algunas partes de los espacios interiores fueron desarrolladas por artistas gráficos que el propio Leykam había conocido en la Trienal de Milán de 1957, como los diseños de cerámica del vestíbulo y los adornos de barro en la sala de lectura y la pared sur diseñados todos ellos por Lech y Helena Grzeskiewicz o las cortinas y elementos de textiles que bajo la dirección del profesor Antoni Kenar fueron diseñados por los alumnos de la Escuela de Diseño de Zakopane. El equipamiento y los muebles fueron diseñados asimismo en su totalidad por el arquitecto Czesław Czulowski y el gran mapa que se situó en su momento en el hall fue obra de los diseñadores Wanda Manteuffel y Ewa Kochowa. Todo el edificio, incluidos los exteriores, costó $7,5 \mathrm{mill} \mathrm{zl}$. $\left(1000 \mathrm{zl} / \mathrm{m}^{2}\right)$, contando el coste del amueblamiento y la calefacción central. ${ }^{14.03}$

Situado encima de una colina a modo de extensión natural del terreno, la lectura horizontal de la planta baja quedaba fusionada con el paisaje con un ritmo pautado y armónico al ser observado en movimiento por el camino que conduce hasta él desde la orilla del río Vístula.

"El estilo adquiere un carácter especial cuando los detalles desaparecen" ${ }^{14.04}$ había escrito Leykam en su doctorado en 1943. En esta nueva variación volumétrica marcada por las necesidades del encargo, Leykam mantuvo la misma búsqueda de la eficiencia y el orden constructivo que en el resto de su obra. La relación estructura-cerramiento y la prioridad por mantener una regularidad geométrica evitan en todo momento que el edificio pudiera quedar determinado por accidentes circunstanciales a pesar del complejo programa que debía resolver.

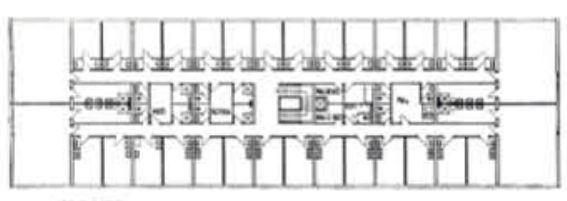

14.15

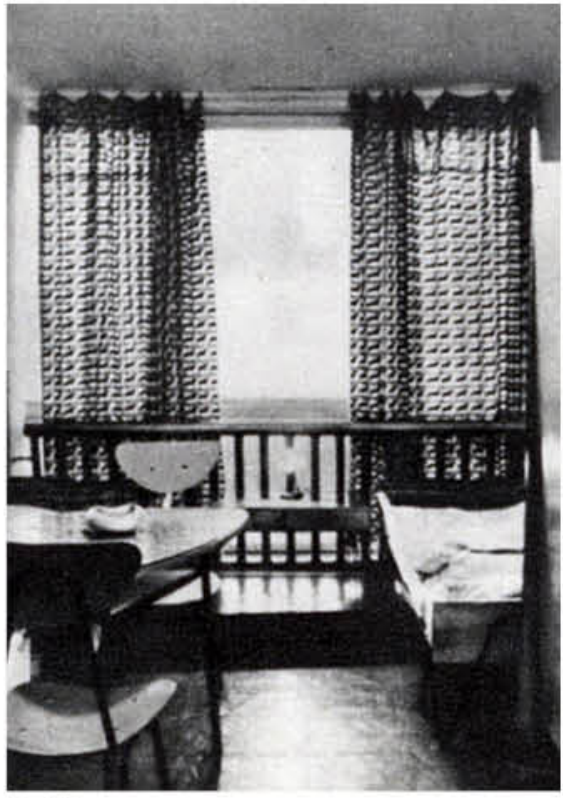

14.16

14.03. Bieńkowski, 2013.

14.04. Leykam, 1943 
14.17 Albergue (Dom PTTK) en Płock, 1959-62.

eykam.

14.18 Vista interior del albergue (Dom PTTK) en

Płock, 1959-62. Marek Leykam.

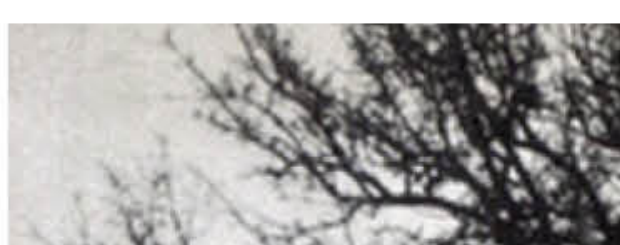

(4)

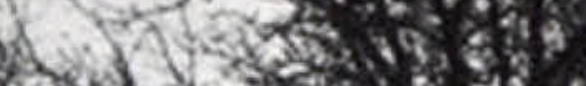

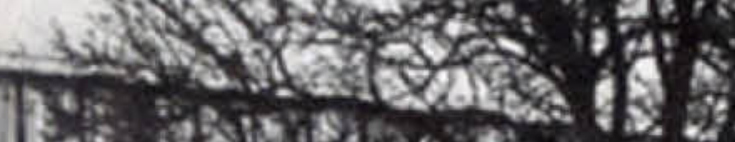

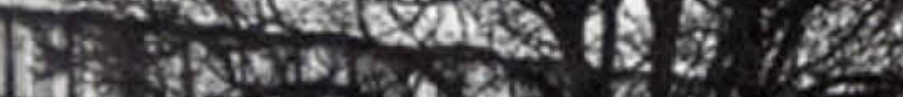

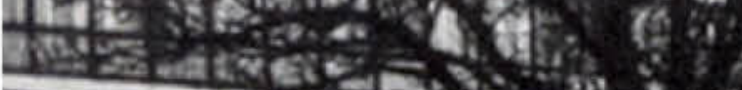

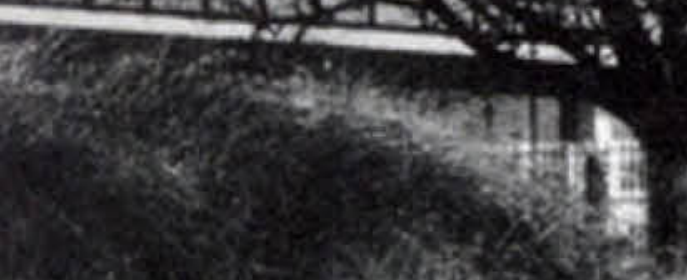

3.

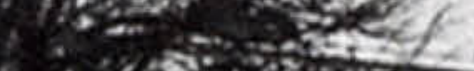

100

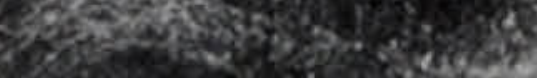
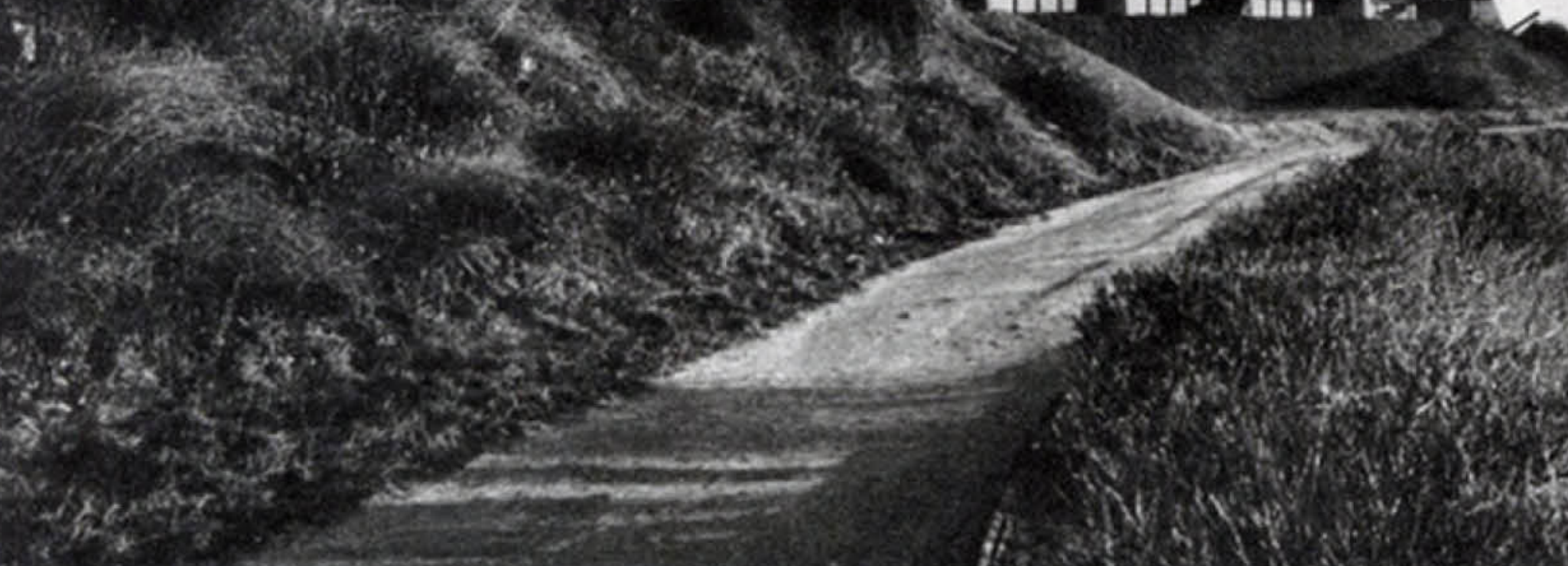

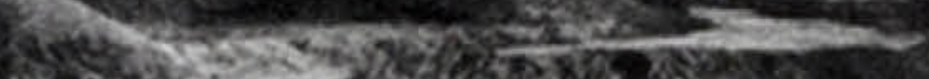
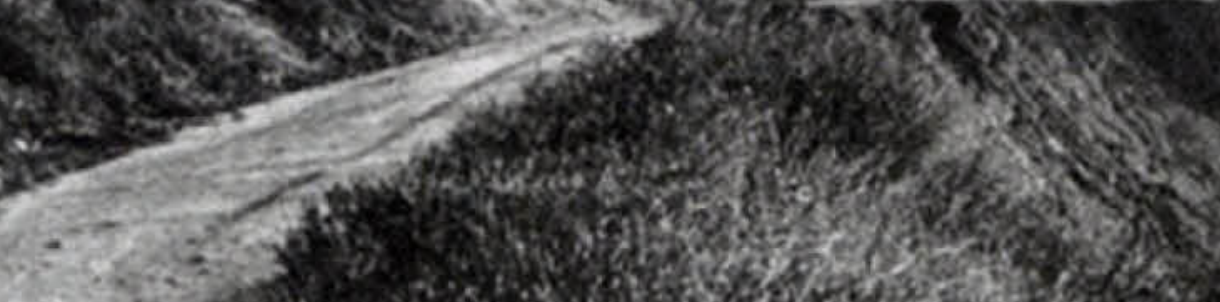


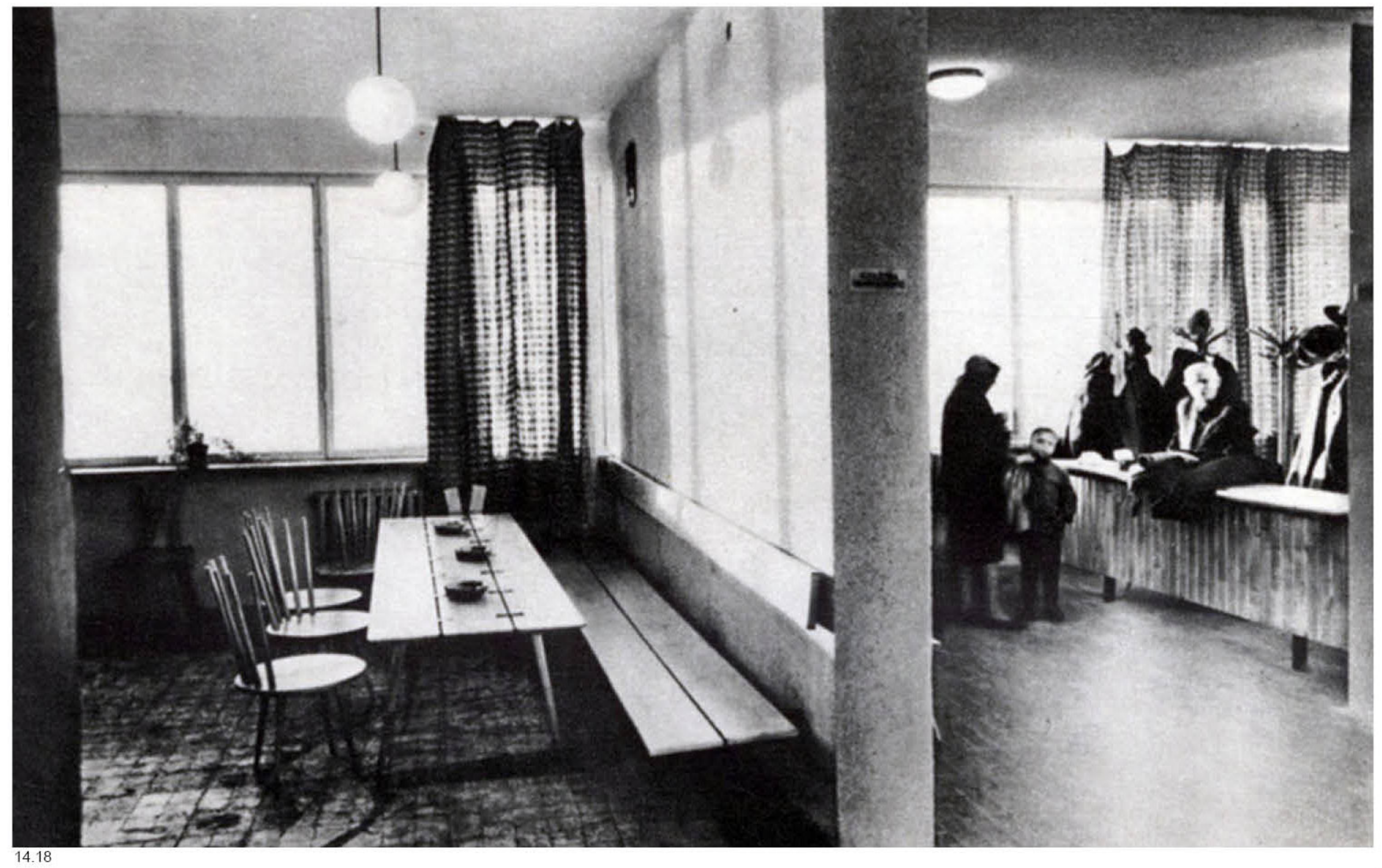


14.19 Instituto de Educación Fisica AWF de Poznań, 1965-72. Arquitecto: Marek Leykam

14.20 Maqueta del proyecto inicial del Instituto de Educación Fisica AWF de Poznań, 1965. Arquitecto:

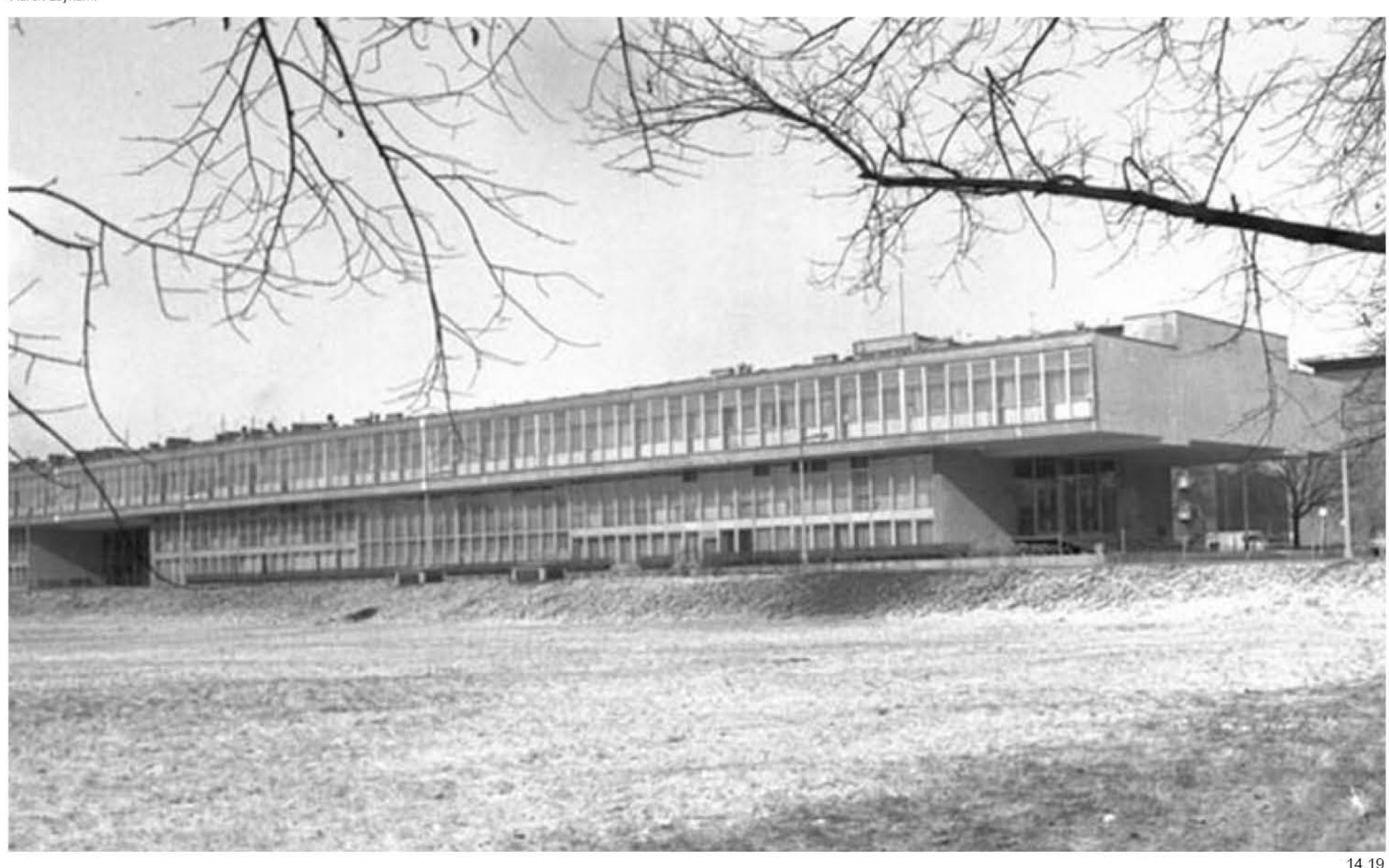


Al año siguiente de terminar el Dom Turysty PTTK de Płock, Leykam recibió el encargo de construir el edificio principal de la Academia de Educación Física en Poznań. ${ }^{14.05}$ Situado en una de las principales vías de tráfico de la ciudad, Królowej Jadwigi 29-37, y rodeado de varios campos de deporte éste sería a la postre el último proyecto construido de Marek Leykam y en cierta forma contiene una síntesis de toda su obra aunque como cualquier resumen es consecuencia de todo el recorrido completo que ha permitido llegar a ese conjunto de conclusiones.

En el solar del proyecto había tenido lugar en 1952 un accidente aéreo en el que murieron 9 personas y una docena resultaron heridos al fallar uno de los motores de un bombardero Pe-2 FT que debía aterrizar en Poznań la mañana del 10 de junio, pero el suceso fue silenciado por las autoridades polacas y no fue dado a conocer hasta 2003 debido a una desclasificación de documentos por lo que en el proyecto no contiene ningún tipo de alusiones conmemorativas ni homenajes al respecto. ${ }^{14.06}$

La influencia de la obra de Niemeyer sobre Leykam en esos años dio lugar a un primer diseño en el que se incluía un nuevo platillo volante que remitía a soluciones de proyectos anteriores como la Casa de la Cultura de Lublin (12.08, 12.13-12.14) de 1956 o el Instituto de Ciencias Experimentales y Medicina Clínica (12.15) de 1964.

Aunque de menor escala, este elemento semiesférico realizaba -de nuevo- una concesión a la moda del momento, al hacer alusión a la estética de naves extraterrestres de la literatura de ciencia ficción. Sin embargo, en el proyecto construido, esta pieza destinada a albergar un auditorio finalmente se descartó, al igual que fue cancelada la posibilidad de transitar por la cubierta, reubicando la sala de conferencias en planta baja, dentro del volumen prismático.

Puesto que las calles Królowej Jadwigii y Dębińska -sobre las que se sitúa el proyecto-, no son perpendiculares, Leykam optó por alinear el volumen perpendicularmente a la calle Dębińska para alinearlo con la trama del campus deportivo adyacente, generando un ensanchamiento en forma de cuña sobre el acceso desde la calle Królowej Jadwigi.

El volumen de edificio AWF de Poznań tiene una orientación cercana al eje de coordenadas geográficas este-oeste, y se resuelve de forma predominantemente permeable en las fachadas longitudinales mientras que los testeros quedaron cegados. Es interesante ver como la lectura direccional es la misma que en el albergue de Płock (14.19), a pesar de que en el caso anterior la pieza estaba orientada según el eje norte-sur, lo que nos permite concluir que no son las condiciones contextuales las que determinan la solución de la pieza a nivel formal.

El volumen de la planta superior tiene una anchura de $30 \mathrm{~m}$ y una longitud de $135 \mathrm{~m}(4,5: 1)$, mientras que en planta baja se recorta hasta los $25 \mathrm{~m}$ de anchura y se resuelve en varios tramos de diferentes longitudes, modulados todos ellos

14.05. Akademia Wychowania Fizycznego im. E. Piaseckiego w Poznańiu.

14.06. Każmierczak, 2009. p. 66. 

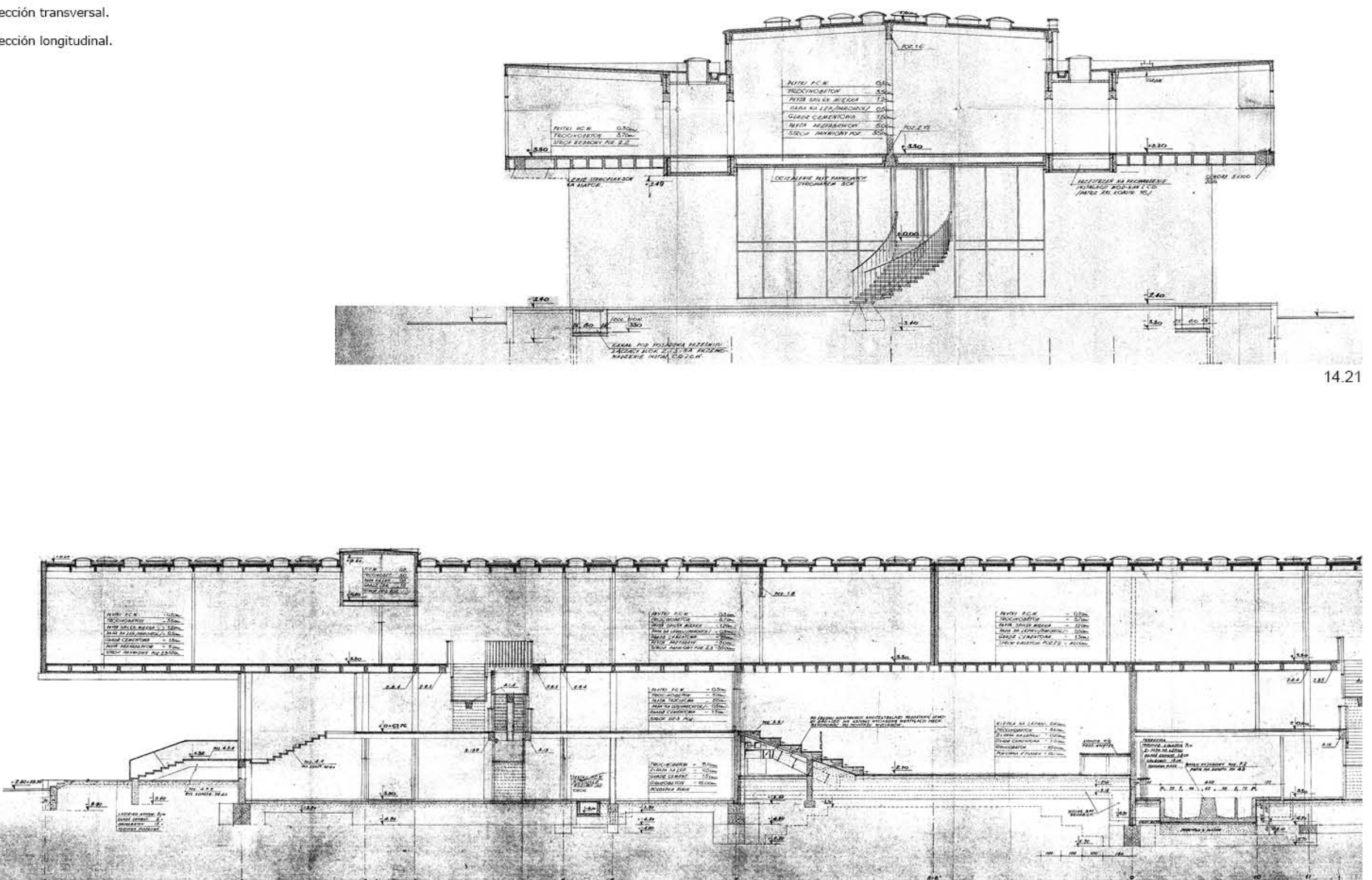
según la trama a ejes de estructura y fachada. La modulación estructural de nuevo condicionó la forma en la que Leykam resuelve la organización funcional del proyecto. Sobre un ritmo de 1-2-1,5-2-1,5-2-1, se generaron unos intervalos interiores entre pórticos de 24-18-24-18-24 $\mathrm{m}$ y dos voladizos en los extremos de $12 \mathrm{~m}$, lo que significa que -por primera vez- Leykam liberó la estructura de la condición, habitual en su método, de mantener una rítmica constante a lo largo de todo el volumen.

La manifestación expresiva de los elementos estructurales tampoco se mantuvo invariable a lo largo de toda la propuesta. En el nivel de planta baja se situaron pilares ocultos con el objetivo de resolver técnicamente algunos apoyos y al mismo tiempo ofrecer la apariencia de que la solución constructiva era más arriesgada y se estaban salvando luces de mayor dimensión. La modulación de fachada, sin embargo, sí que se mantuvo constante, siendo $1,2 \mathrm{~m}$ el intereje de toda la carpintería en los alzados longitudinales, tanto en la fachada longitudinal norte como en la sur.

En la planta sótano se situaron tres sectores de igual tamaño no comunicados y separados simétricamente respecto al eje transversal central del edificio, en los que se emplazan varios cuartos de mantenimiento en la parte este, salas de ejercicios en la parte oeste y una piscina en el espacio central, siendo el módulo del auditorio un espacio de doble altura que se desplaza hasta el nivel de planta baja en que está situado su acceso principal.

La planta baja también se divide en tres sectores diferenciados. El acceso está dominado por un gran espacio de recibidor a partir del cual se accede al núcleo de escaleras flanqueado por dos vestuarios a ambos lados. En la misma banda de servicios se resuelven los cuartos sanitarios, conserjería y comedor. El recibidor principal está comunicado a través de un corredor interior con el espacio de auditorio que ocupa los $25 \mathrm{~m}$ de anchura interior del edificio.

La siguiente unidad funcional se estructura con acceso directo desde el exterior, mediante un espacio de recibidor a doble altura que da acceso a un espacio que articula varias estancias, mientras se reconstruye una banda de oficinas resuelta por corredor. La planta superior es la única completamente conectada por comunicación interna, a través de dos bandas continuas servidas por corredores que recorren todo el volumen en sentido longitudinal.

Las tres bandas que surgen de esta composición en el volumen superior, contienen -en ambos laterales y con iluminación directa desde el exterior-, dos ámbitos de trabajo dedicados a oficinas, aulas y laboratorios, mientras que el espacio central se resuelve con mayor altura para generar un escalón que resuelva la iluminación de sus estancias con ventanales altos (14.21), albergando en su interior una biblioteca y varias salas de lectura orientadas hacia el oeste, y varios gabinetes médicos junto a un conjunto de salas de reuniones en dirección este.

En este caso Leykam, renuncia a la formalización de una figura en los testeros y quedan terminados mediante un cerramiento ciego que mantiene el mismo perímetro escalonado que la sección que desemboca sobre ellos. El voladizo 


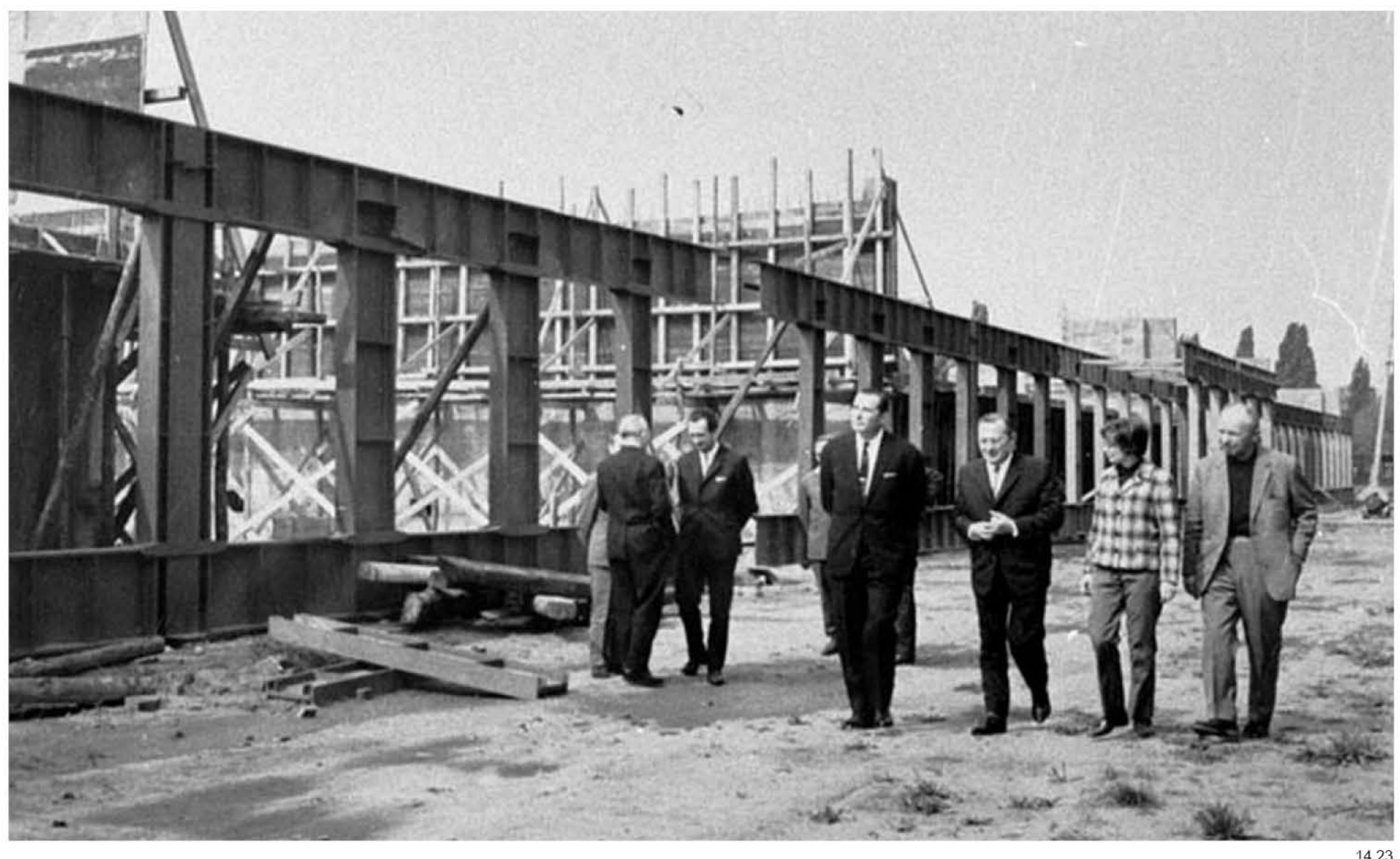


del volumen superior es proporcionalmente menor que el del edificio de Płock en dirección transversal (2,5 m) y es percibido únicamente en las vistas laterales. Otra diferencia respecto al albergue, es que la fachada de planta baja y planta sótano del Instituto de Educación Física AWF fueron conformadas siguiendo el mismo criterio compositivo y su modulación es continua (14.19). La planta baja esta elevada $1 / 3$ de su altura respecto al plano del suelo y las ventanas llegan hasta el nivel de acceso integrando los huecos de la planta sótano, que quedan separados solamente por una estrecha banda que recoge el canto del forjado y marca sutilmente la separación entre los dos niveles.

En este proyecto, Leykam mantiene la idea de resolver un 'todo' de forma continua, sin que el edificio se exprese a través de sus partes. A pesar de haberse alejado de la prioridad del orden constante de los elementos tectónicos, en su trabajo continúa creando una composición lógica y coherente, comprensible e interpretable para todos los que entren en contacto con su obra, gracias a la utilización de criterios racionales en la definición de sus proporciones y la estructuración del juego jerárquico en la resolución de sus fachadas.

A lo largo de toda su vida, Leykam había ido adaptándose a las variaciones volumétricas que venían determinadas por el contexto en que fueran ubicados sus edificios, manteniendo invariable su búsqueda del máximo aprovechamiento espacial y la regularidad geométrica. La formulación clara de estos conceptos adquirió sentido y eficacia debido a la prioridad por una métrica sencilla y el manejo de constantes proporcionales, a través de las cuales era factible alcanzar la precisión que permitiese optimizar el uso de sistemas prefabricados y desarrollos estandarizados.

El conjunto de obras construidas por Leykam tras la II Guerra Mundial supuso en su conjunto una muestra de eficacia que deja tras de sí la posibilidad de formular un método proyectual. En su proceso de trabajo quedaron finalmente como únicos elementos capaces de generar incertidumbres aquéllos que derivaban de los condicionantes urbanísticos y normativos, afrontados desde la lógica y el pensamiento racional para lograr que no predominase la atención del observador sobre las singularidades expresadas sino sobre el resultado final a nivel general.

El propósito de Leykam a lo largo de su vida no fue crear un obra arquitectónica consecuente con un determinado estilo sino hacer desaparecer el estilo de sus construcciones haciendo referencia a conceptos abstractos que permitieran reducir la manifestación expresiva de sus edificios a la forma más simple posible, logrando un resultado elocuente, universalmente comprensible e interpretable desde la razón. A este respecto Leykam trató de que la sociedad destinataria de su obra recibiese un trazado que se manifestase como una base sólida sobre la que reconstruir su presencia en el mundo, una arquitectura no revolucionaria pero sí resistente, a partir de la cual fuera posible reestructurar la vida en comunidad.

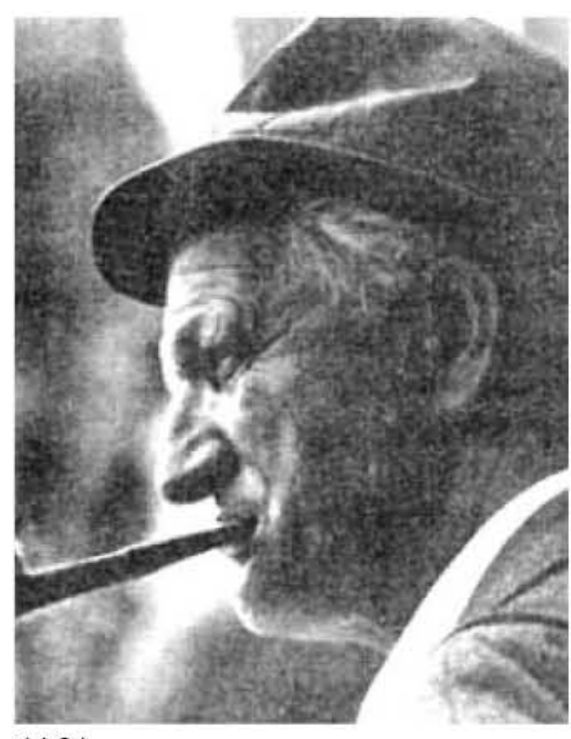

14.24 

IV. ANÁLISIS DEL MÉTODO PROYECTUAL DE MAREK LEYKAM. 

"Cuando los arquitectos encontraban reglas construían épocas diferentes. Se estudiaba minuciosamente el misterio de la composición de los triángulos egipcios, o los módulos griegos (..) pero se perdió la proporción y se olvidó el hombre para reencontrar la escala humana en las grandes catedrales góticas".

Marek Leykam. "O wnętrzu współczesnym" 15.00

Analizando la obra construida de Marek Leykam, podemos reconocer la presencia de un método de proyecto que se manifiesta en el uso sistemático de mecanismos de deducción lógica similares a las estructuras sintácticas de razonamiento científico estudiadas por la escuela filosófica de Lvov-Varsovia. En este capítulo analizaremos el esquema conectivo que surge de la generalización de su trabajo y las conexiones que se establecen entre sus diferentes obras debido a las formulaciones matemáticas comunes, para poder establecer con claridad si en el conjunto de su trabajo existe una base común.

Para describir el método proyectual de Leykam nos basaremos en el 'árbol de procesos' que describe la formulación de las estructuras sintácticas en un lenguaje de primer orden ${ }^{15.01}$, debido a que esta configuración comparte con su trabajo un principio organizativo fundamental: la linealidad en el uso de constantes y la interrelación de las mismas a través de variables. Este esquema nos permitirá ejemplificar a su vez, gráficamente, cómo se conecta la escala urbana con el detalle constructivo en la obra de Leykam, pero sobretodo, cómo se establecen invariablemente relaciones de proporcionalidad comunes en todos sus proyectos construidos.

Si las relaciones de proporcionalidad existen y son comunes a todo su trabajo, esto demostraría no solo la existencia de un método de trabajo coherente que nos permita observar a posteriori la sistematicidad de su proceso, sino también, la previsión de un margen acotado de subjetividad en su obra dentro de ese conjunto de fórmulas conectadas que plantea cada propuesta -condición necesaria para dar sentido a las diferentes constantes-, a partir del cual observar la capacidad de establecer relaciones directas entre los procesos organizativos arquitectónicos y las estructuras sociales, y por extensión la posibilidad de plantear, a través de la arquitectura, propuestas enfocadas a resolver problemas sociales, cuestión esencial en su trabajo que proviene ya de su época de formación académica en la Facultad de Arquitectura de Varsovia a finales de los años 20. (Véase p. 29 y ss).
15.00. Artículo "O wnętrzu współczesnym" (El interior contemporáneo). Publicado en la revista Arkady $1936, n^{\circ} 7$ p. $375-377$

15.01. Tendremos en cuenta las consideraciones al respecto de este lenguaje realizadas por Legris, 2001. 
15.01 Proyectos utilizados como muestra para

15.02 Instituto Geológico de Varsovia

15.03 Dom Towarowy Okrąglak, Poznań.

15.04 Sede Presidencia Gobierno, Varsovia.

15.05 Albergue Dom PTTK, Plock.

15.06 Estadio del Decenio, Varsovia.
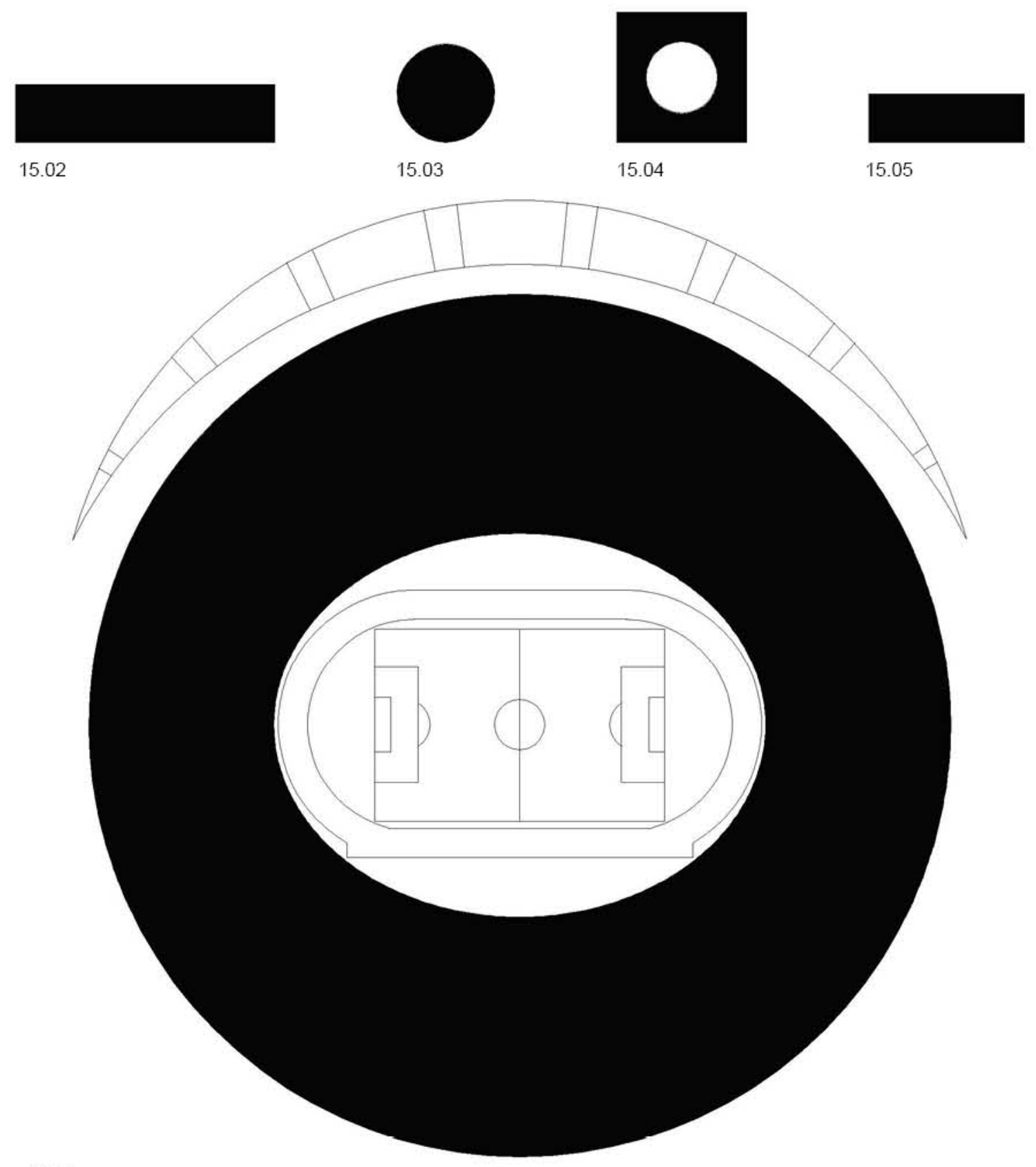
Para estudiar el método de trabajo de Marek Leykam, tomaremos como muestra 5 proyectos que podemos considerar 'representativos' de las diferentes etapas de su trabajo, realizados en condiciones históricas, sociales y políticas muy diferentes. Estas obras nos permitirán comprobar cómo, a pesar de sus contextos tan variados, existen similitudes esenciales en el trabajo de Leykam que pueden ser extrapoladas al conjunto de su obra bajo el mismo árbol de procesos deductivo y relacionados a través de proposiciones conectivas comunes. Quedará en evidencia de este modo, la existencia de un método proyectual continuo, coherente y consciente en la arquitectura de Marek Leykam, tal como esta tesis pretende demostrar.

Los proyectos utilizados como muestra son: el Instituto Geológico de Varsovia (15.02); el Edificio Dom Towarowy Okrąglak de Poznan (15.03); la Sede Presidencia Gobierno de Varsovia (15.04); el Albergue Dom PTTK de Płock (15.05); y el Estadio del Decenio de Varsovia (15.06). A lo largo de este apartado se proveen, en cualquier caso, herramientas para que -mediante los análisis de cada proyecto realizados en el apartado III de esta tesis- sea posible comprobar cómo todos los edificios construidos por Leykam que albergan una función determinada (excluiremos por tanto las esculturas) se ajustan al esquema de su método proyectual. En el diagrama 15.01, se pueden observar las relaciones de escala real entre estos cinco proyectos, que en lo sucesivo serán reescalados para mejorar la visualización de las comparativas realizadas.

A partir del esquema 15.07, distinguiremos cinco relaciones de proporcionalidad que, una vez resueltas, dan lugar a cuatro variables que determinarán la singularidad del proyecto: forma/volumen, volumen/estructura, estructura/fachada y fachada/cerramiento. Si bien la reconstrucción empírica de las constantes de forma, volumen, estructura, fachada y cerramiento (G, V, E, F, C), de forma aislada, nos permite únicamente etiquetar las características de cada proyecto en forma de código; la existencia de relaciones de proporcionalidad entre ellos, es la condición necesaria y suficiente ${ }^{15.01}$ para certificar la existencia de un lenguaje comunicativo construido a partir de la interacción humana, que se sirve de las formulaciones lógicas y relaciones conectivas para constituirse en hecho comunicativo, del mismo modo que ocurre con las entidades lingüísticas.

La existencia de relaciones de proporcionalidad en la obra de Leykam, será, por tanto, la que nos permita, en última instancia, determinar la conexión existente entre sus razonamientos deductivos; y es a partir de estos nexos como podemos considerar que existe un método proyectual estructurado en su trabajo que no deja de lado la interacción humana y es abarcable como hecho comunicativo para cualquier persona que entre en contacto con su arquitectura. El método proyectual de Marek Leykam aparece 'regimentado' o normalizado a través de las relaciones conectivas de proporcionalidad que relacionan todas sus escalas, $\mathrm{y}$, al mismo tiempo, particularizan cada uno de los proyectos al admitir un intervalo acotado de subjetividad, alcanzando así, el conjunto de su obra, una abstracción contenida por la utilización de la lógica y las proporciones aritméticas, sin dejar de lado la expresión irracional propia del ser consciente. No cabe contradicción por tanto en las palabras de Leykam cuando afirma: "Cada vez que la mente humana se pregunta sobre la validez de una doctrina, se lo pregunta a sí misma. El consentimiento o la creencia en una doctrina la encuentra
15.02. Artículo "Z rozważań architekta" ("Reflexiones de un arquitecto") Publicado en la revista Plastyka 1937 n n $^{1}$ p. 31 . 
en sí mismo y, de repente, se da cuenta que el creador de las hipótesis y los dioses es él mismo, el pensamiento humano. Entonces, puede creer en la anarquía de su fierza, o, siendo incapaz de comprender la razón, profundizar en los sentimientos y creer en lo absoluto." ${ }^{15.02}$

A través de los resquicios que propician las decisiones subjetivas en su método proyectual, Leykam continúa situando a la mente humana como una medida del conocimiento, pero antepone el instante ordenante racional al espacio de manifestación de los impulsos irracionales humanos, que quedan recogidos en un intervalo acotado y reglamentado. Para la formulación matemática queda una función únicamente verificadora de valores, puesto que, para Leykam, la lógica de pensamiento es solo una herramienta de control, no es ni siquiera una herramienta creativa. Las formas de sus proyectos se plantean como lugar de encuentro entre el puro pensamiento matemático y las necesidades básicas del ser humano. ${ }^{15.03}$

Leykam basa por tanto su método de proyecto en la utilización de la aritmética como una herramienta ordenante que le permita delimitar los trazados, pero al mismo tiempo acotar el espacio intelectual destinado a las manifestaciones subjetivas de la expresividad humana, dotando así de pureza al concepto y al mismo tiempo sirviéndose de su universalidad para llegar a una forma constituida a partir de la cual deberán confluir un conjunto de decisiones que le permitirán adquirir la concreción propia de una obra de arte que la acerque a la idea de belleza.

La aparente contradicción entre la formulación matemática que permite a Leykam alcanzar un elevado nivel de abstracción en su obra a través de su método proyectual y el impulso irracional con que finalmente son abordadas debido al margen para la elección subjetiva, puede ser comprendido a partir de estas palabras de Gilles Deleuze:

"Todas las sociedades son racionales e irracionales al mismo tiempo: son racionales en sus mecanismos, en sus engranajes, en sus sistemas de conexión, e incluso por el lugar que asignan a lo irracional. Sin embargo, todo ello presupone códigos o axiomas que no son fiuto del azar pero que carecen, por su parte, de una racionalidad intrínseca. (...) La razón es siempre una región aislada de lo irracional. No al abrigo de lo irracional, sino atravesada por ello y definida únicamente por un determinado tipo de relaciones entre los factores irracionales." 15.04

15.03. Véase el artículo "Kolumna architektoniczna" (Columna de arquitectura) publicado en la revista Plastyka 1936 n 4 p. 295.

15.04. Deleuze, 2002. p 139
La subjetividad en la obra de Leykam queda confinada por un número concreto de variables a través de las cuales el autor se otorga el derecho de intervenir en base a su interpretación de los diferentes condicionantes, o simplemente de forma arbitraria, aunque el propio método permite reconducir estas manifestaciones intencionales acotando su margen de influencia sobre la obra al estar definidas por un limitado intervalo de posibilidades. Las diferentes relaciones de proporcionalidad en la obra de Leykam están definidas en el esquema 15.07 y vienen dadas por la necesidad de 
conexión entre los principios axiomáticos que constituyen los ámbitos acotados que se deducen de la formulación matemática, aunque deben ser resueltos a tenor de una interacción.

En el árbol de procesos que recoge el método proyectual de Marek Leykam (15.08) se reconoce en primer lugar un análisis de las propiedades morfológicas de la trama urbana, entre las que podemos identificar la geometría de su tejido y los alineamientos que se desprenden de la imaginaria proyección de los planos de los edificios adyacentes así como la acometida que éstos producen sobre el área de trabajo, a partir de la cual ya pueden extraerse las primeras conclusiones.

La orientación de la parcela y la necesidad de adaptarse a un determinado tipo de soleamiento no es un condicionante significante en la obra de Leykam y prueba de ello es la existencia de edificios que bajo el mismo esquema compositivo se han situado en orientaciones opuestas. A partir de una lectura interpretativa de las propiedades morfológicas de la trama urbana, Leykam busca la obtención de aquellos parámetros que le permitan establecer si el proyecto debe dar una respuesta de carácter direccional o adireccional con respecto a su geometría en planta. En el caso de que las necesidades del lugar inviten a resolver una figura direccional Leykam se plantea la necesidad de establecer o no una jerarquía entre los lados de la figura resultante, hecho que provoca que la longitud de algunos de los planos predomine sobre otros.

De esta primera decisión se desprenden únicamente tres figuras geométricas que han sido constantes en la obra de Leykam teniendo en cuenta el objetivo primordial de alcanzar un máximo aprovechamiento de la edificabilidad asignada: rectángulo (direccionalidad jerárquica; G1), cuadrado (direccionalidad no jerárquica, G2) y círculo (adireccionalidad, G3). La ausencia de más figuras básicas no es debido a la carencia de geometrías esenciales sino a su limitación al ideal axiomático de modular unitariamente, para lo cual utilizará únicamente formas que deriven unívocamente de uno de los dos sistemas de coordenadas principales: cartesiano y polar.

A partir de la extrusión de estas superficies se derivan tres contornos volumétricos: prisma de base rectangular (V1), prisma de base cuadrada (V2) y cilindro (V3), cuyas proporciones vienen determinadas por el máximo aprovechamiento de la volumetría, el espacio útil y las necesidades del programa, mientras la existencia de patios viene dada, si existieran, por los siguientes condicionantes:

$$
\begin{aligned}
& \text { Si a patio en V1 } \mathrm{V}=\mathrm{V} 1-\mathrm{V} 1 / \mathrm{e} \text {; donde e } \epsilon \mathrm{R}+ \\
& \mathrm{Si} \text { G patio en } 22 \quad \mathrm{~V}=\mathrm{V} 2-\mathrm{V} 1 \\
& \mathrm{~V} 2 \text { - V2/ e ; donde e } \in \mathrm{R}+ \\
& \mathrm{V} 2-\mathrm{V} 3 \\
& \text { Si } 3 \text { patio en } \mathrm{V} 3 \quad \mathrm{~V}=\mathrm{V} 1-\mathrm{V} 1 / \mathrm{e} \text {; donde e } \epsilon \mathrm{R}+
\end{aligned}
$$


Leykam.

15.08 Esquemas conectivos agrupados en un árbol

de procesos que muestran el método de proyectual

de Marek Leykam.

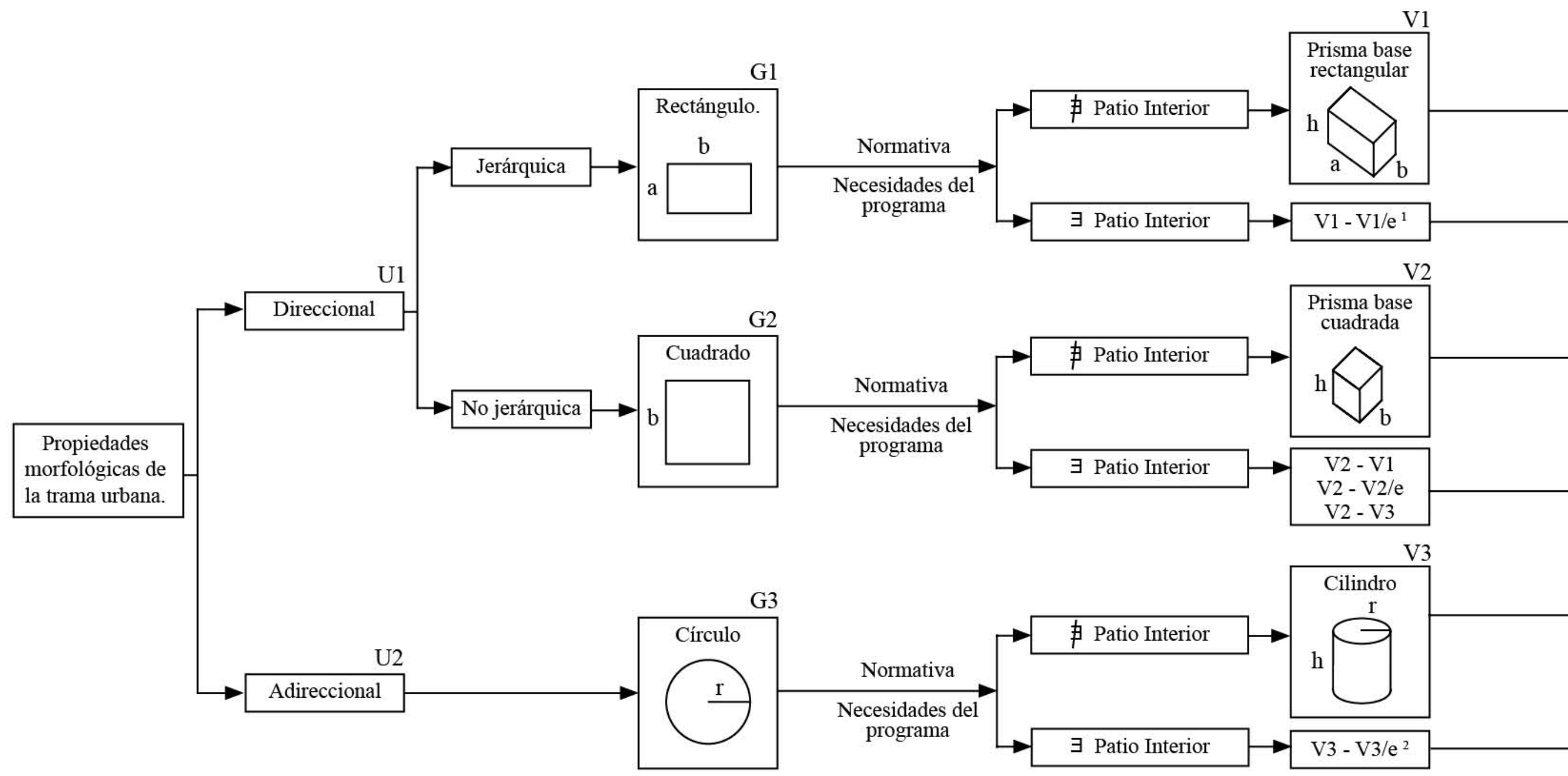

1.1. Donde $e \in \mathrm{R}^{+}$

1.2. Considerese la excepción V4 (elipse) en el caso del Estadio del Decenio 

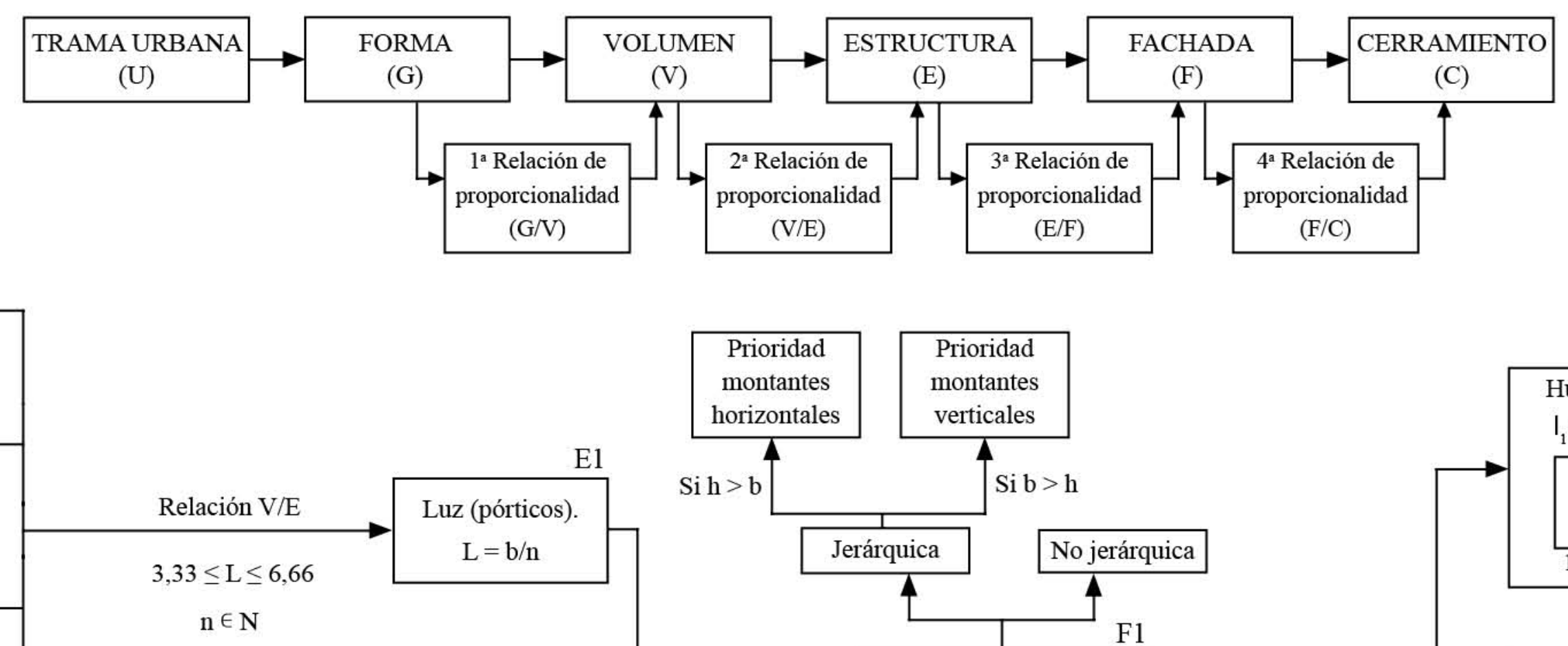

$\mathrm{L} \mid 1,33$ ò $\mathrm{L} \mid 1,66$
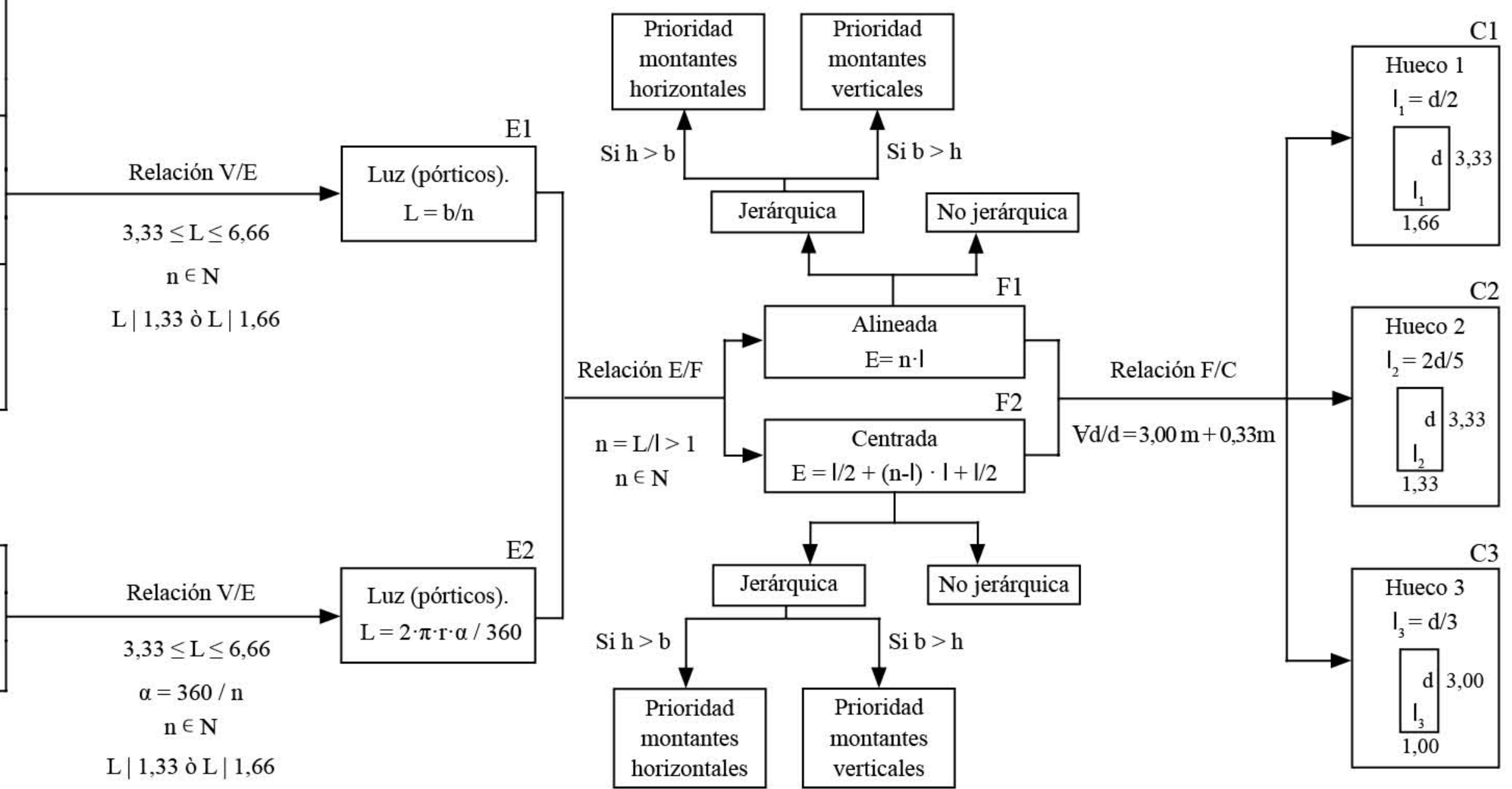

$\mathrm{L}$ | 1,33 ò $\mathrm{L}$ | 1,66 
15.09 Relaciones de proporcionalidad Volumen/

Estructura (V/E) en la obra de Marek Leykam.
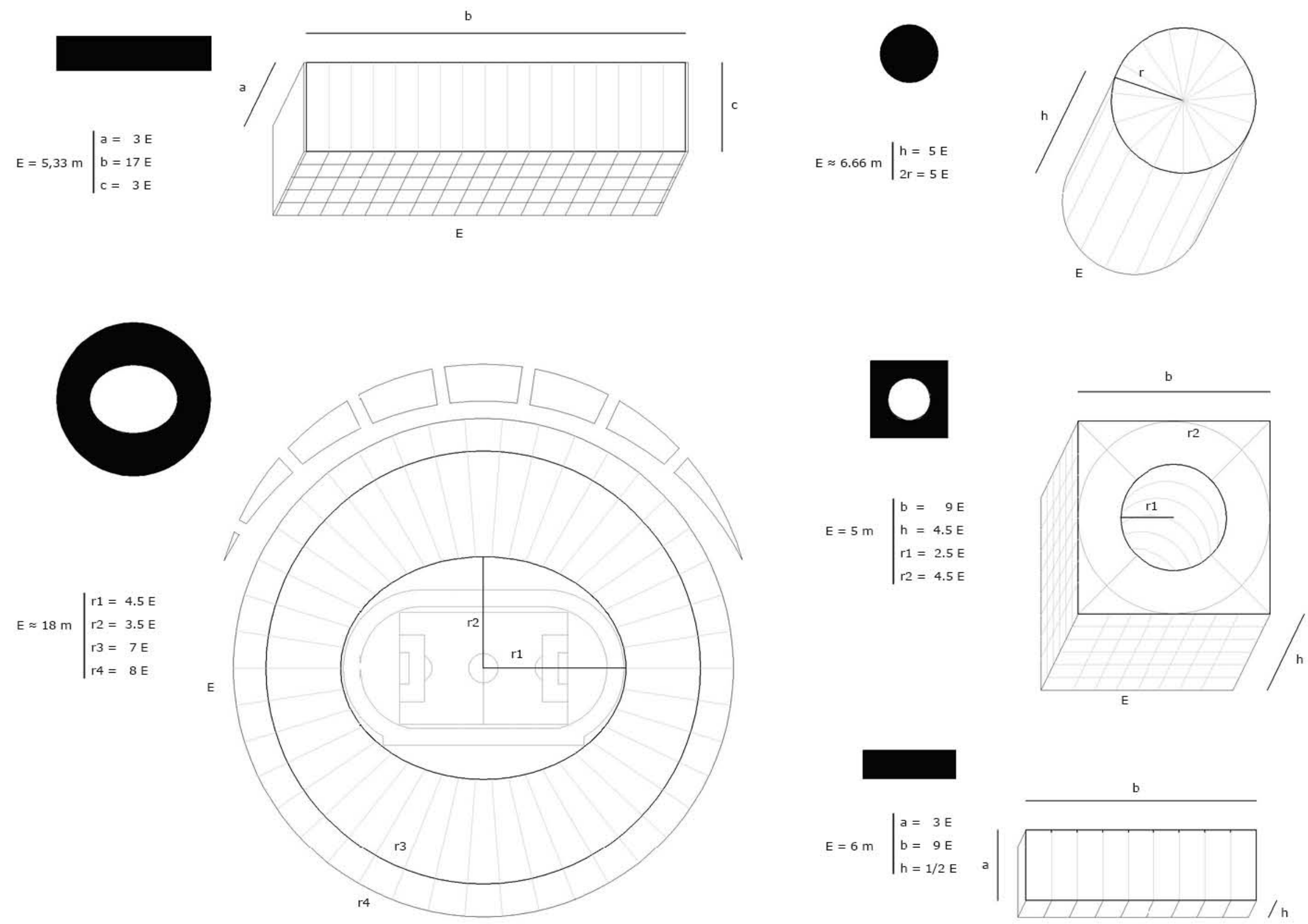
La presencia de patios y la propia formulación final del volumen no surge de la mera expresión matemática sino que a través de sus condicionantes van generándose intervalos de indeterminación acotados en los que puede desarrollarse una interpretación subjetiva por parte del autor. Las relaciones de proporcionalidad añaden a esta ecuación argumentos para definir estas inderterminaciones a través de la lógica, y tal como hemos visto en la obra de Leykam, son constantes las relaciones de proporcionalidad que le permiten ir resolviendo los intersticios no determinados de su arquitectura.

A nivel volumétrico, en ocasiones Leykam acentúa la direccionalidad enfatizando los cambios de plano de las figuras geométricas mediante un radical contraste de permeabilidades, siendo un efecto habitual en prismas de base rectangular en los cuales la fachada longitudinal (b) era predominantemente permeable, mientras los testeros laterales (a) en su mayor parte quedaban ciegos.

Esta lectura del volumen direccional que acentúa la jerarquía fue habitual en multitud de proyectos, entre los cuales podemos citar dos ejemplos analizados: el Instituto Geológico de Varsovia y el Albergue Dom PTTK de Plock, aunque no en todos los casos ocurría, como demuestra la solución de fachada de la Oficina Central de Estudios y Proyectos de Construcción de Varsovia (7.23) que se resuelve continua en todas sus caras.

La $2^{\mathrm{a}}$ relación de proporcionalidad (V/E) está regida por una constante que permite a la estructura adoptar un ritmo constante independientemente de la organización funcional. Los proyectos que se derivan de V1 y V2 optimizan su estructura con una modulación constante que atiende invariablemente a un sistema de coordenadas cartesiano mientras en el caso de V3 por una cuestión de eficiencia se determinaba el uso de un sistema de coordenadas polar. La separación entre pórticos viene dada por la ecuación $\mathrm{L}=\mathrm{b} / \mathrm{n}$ (E1) en el caso de V1 y V2 y L = 2 $\pi \cdot \mathrm{r} \cdot \alpha / 360$ (E2), cumpliéndose a su vez las siguientes condiciones:

$$
\begin{array}{ll}
\text { Si V1 ó V2 } & 3,33 \leq \mathrm{L} \leq 6,66 ; \mathrm{L} \mid 1,33 \text { ò } \mathrm{L} \mid 1,66 ; \text { donde } \mathrm{n} \in \mathrm{N} \\
\text { Si V3 } & 3,33 \leq \mathrm{L} \leq 6,66 ; \mathrm{L} \mid 1,33 \text { ò } \mathrm{L} \mid 1,66 ; \alpha=360 / \mathrm{n} ; \quad \text { donde } \mathrm{n} \in \mathrm{N}
\end{array}
$$

Los proyectos de Leykam establecían invariablemente relaciones de proporcionalidad entre volumen y estructura controladas por relaciones numéricas simples, aunque el proyecto daba lugar a soluciones individualizadas en función de su geometría que han sido analizadas en cada uno de los proyectos. Sirvan como ejemplo los casos abordados en este capítulo, grafiados en la figura 15.09, en los que se puede observar como invariablemente existen relaciones de proporcionalidad basados en relaciones numéricas simples entre el módulo estructural y las diferentes dimensiones que conforman el volumen.

A partir de estos esquema se puede reconocer el intento de Leykam de mantener una estructura consecuente en todos 
15.10 Relaciones de proporcionalidad Estructura/

Cerramiento (E/C) en la obra de Marek Leykam.

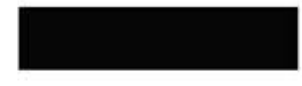

$E / C=4$

Centrada

$E=1 / 2 C-3 C-1 / 2 C$ donde, $\mathrm{C}=1,33 \mathrm{~m}$

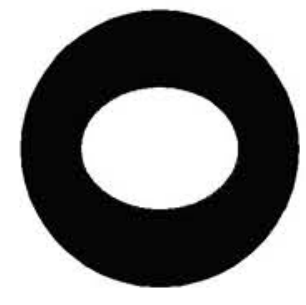

$E / C=1$

Alineada donde, $C \approx 18 \mathrm{~m}$
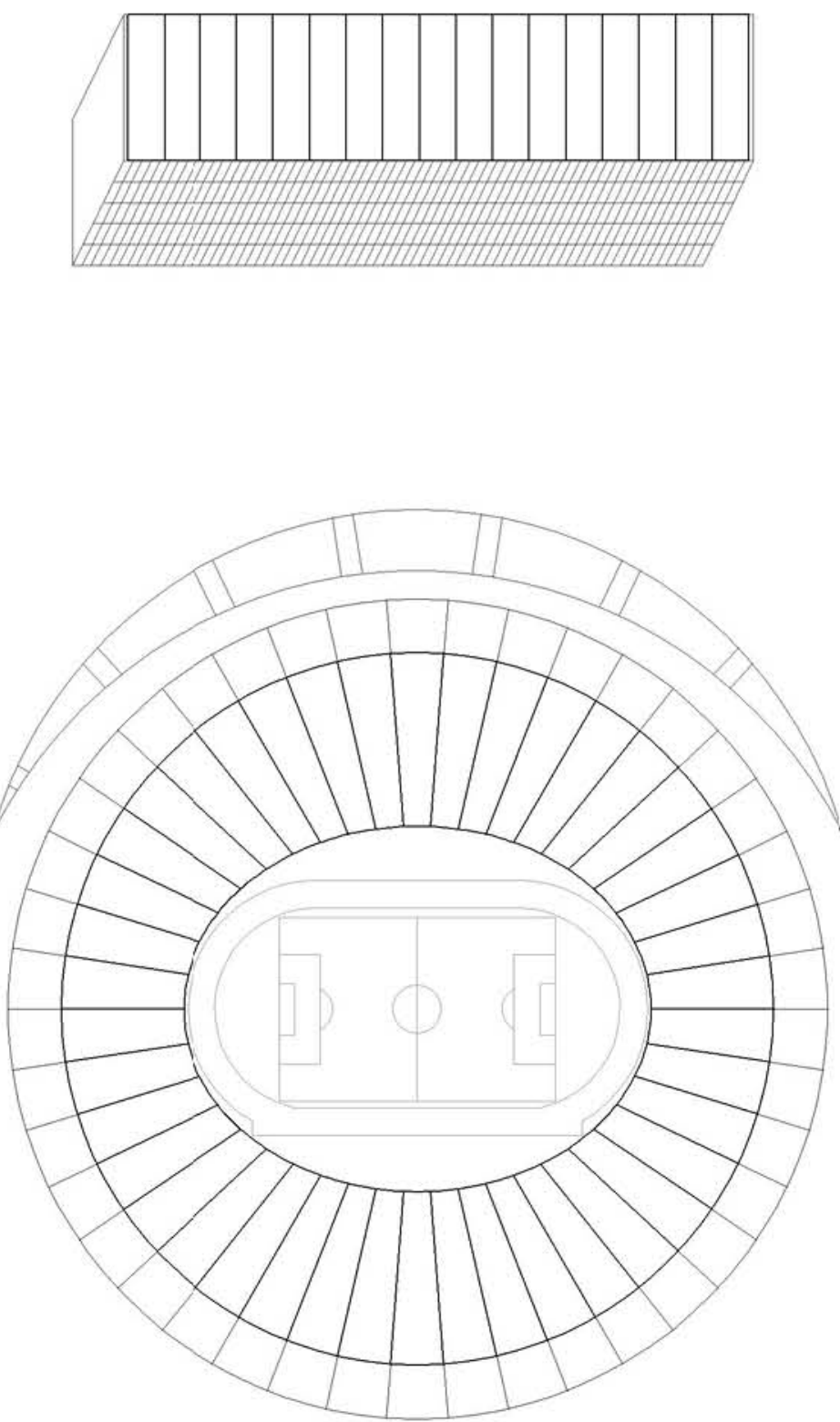

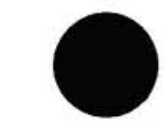

$E / C=5$

Centrada

$E=1 / 2 C-4 C-1 / 2 C$ donde, $\mathrm{C}=1,33 \mathrm{~m}$

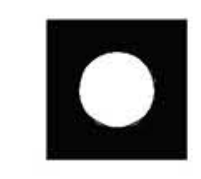

$E / C=3$

Centrada

$E=1 / 2 C-2 C-1 / 2 C$ donde, $\mathrm{C}=1,66 \mathrm{~m}$

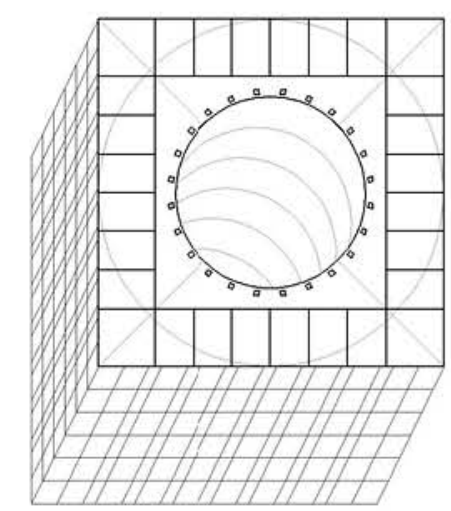

$E / C=6$

Alineada

donde, $\mathrm{C}=1 \mathrm{~m}$

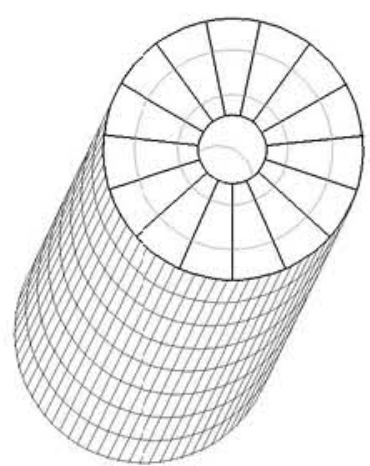

HIIIIIT
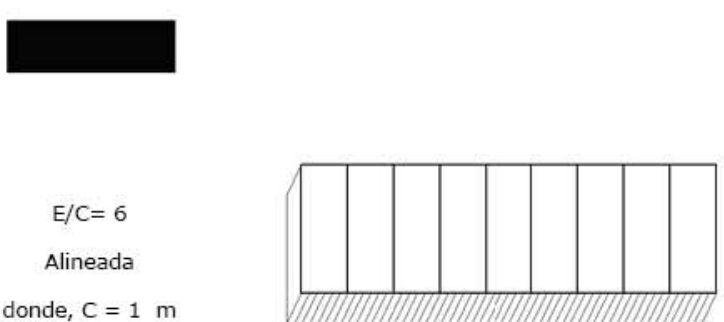
sus edificios que fuera capaz de aportar expresividad e individualidad a las soluciones, mediante la generación de variaciones en las que la subjetividad es tenida en cuenta, aunque su espacio de desarrollo es acotado, de manera que no dejen de reconocerse características comunes en su trabajo que permitan reconstruir una idea común basada en la racionalidad a partir de la cual transmitir un mensaje, cuyas características serán abordadas en el capítulo posterior.

Por norma general los bloques de Leykam presentan una estructura de pórticos de tres vanos, que en el caso de V1 resultaban transversales al lado mayor, quedando ajustados para hacer coincidir el vano intermedio con las necesidades de recorrido de paso de un corredor central, que debía servir de distribución a los ámbitos situados a ambos lados del mismo hasta el plano de fachada. Este esquema se repite en multitud de proyectos de Leykam, tales como los Żyletkowiec de Varsovia o la Academia de Educación Física AWF de Poznań.

La $3^{\mathrm{a}}$ relación de proporcionalidad del esquema (Estructura/Fachada) acota todavía más el ámbito de trabajo puesto que dada la posibilidad de rectificar en tramos la generatriz de las figuras derivadas de V3 ya no existen diferencias entre los distintos tipos de proyecto. Cualquier volumen generado por Leykam acabará confluyendo en una fachada que se establecerá en función de su posición respecto de la estructura.

Si la fachada alinea sus haces exteriores al plano que contiene la estructura, la disposición del vano quedará regido por $\mathrm{E}=\mathrm{n} \cdot 1$, mientras que si este plano se sitúa en el punto medio de los elementos de fachada, su disposición quedará regida por la fórmula $E=1 / 2+(n-1) \cdot 1+1 / 2$.

$$
\begin{aligned}
& \text { F1 (alineada). Si } E=n \cdot 1 ; \text { donde } n=L / 1>1 ; n \in N \\
& \text { F2 (centrada). Si } E=1 / 2+(n-1) \cdot 1+1 / 2.1 ; \text { donde } n=L / 1>1 ; n \in N
\end{aligned}
$$

El forjado queda resuelto salvo excepciones mediante losas prefabricadas de hormigón para facilitar una mayor rapidez en la ejecución mientras la altura total de planta es 3,00 $\mathrm{m}+0,33 \mathrm{~m}$ de forjado en todos los casos salvo las particularidades explicadas en los análisis de cada proyecto. A partir de esta relación constante surgen tres únicos tipos de hueco de fachada utilizados por Leykam invariablemente:

$$
\begin{array}{lll}
\text { Hueco } 1(\mathrm{C} 1) & 1_{1}=\mathrm{d} / 2 & 1_{1}=1,66 \mathrm{~m} \\
\text { Hueco } 2(\mathrm{C} 2) & 1_{2}=2 \mathrm{~d} / 5 & 1_{2}=1,33 \mathrm{~m} \\
\text { Hueco 3 }(\mathrm{C} 3) & 1_{3}=\mathrm{d} / 3 & 1_{3}=1,00 \mathrm{~m}
\end{array}
$$

Sin que exista un condicionante expreso surgido del contexto, sino como parte de una decision subjetiva reglamentada, 
los elementos de fachada adquieren en ocasiones cierta jerarquía de paso aumentando su importancia en la composición. Si bien la existencia o no de jerarquía resulta arbitraria, en caso de que exista venía regida por la siguiente condición:

Si $\mathrm{b}>\mathrm{h}$; prioridad de paso de los montantes verticales.

$\mathrm{Si} \mathrm{h}>\mathrm{b}$; prioridad de paso de los montantes horizontales.

A nivel de detalle constructivo, en ocasiones se acentúa la esbeltez de la pieza prefabricada con diferentes recursos que le permitan manifestar una composición exterior del alzado lo más ligera posible. La retícula principal de fachada en los proyectos de Leykam está formada habitualmente por piezas prefabricadas de plementería, hasta completar el vano de cerramiento (C). El esquema de la fachada a partir del cual se resuelve este proyecto trataba de ofrecer siempre un equilibro sencillo entre los diferentes accidentes del programa, que le permitiera optimizar los elementos prefabricados sin perder expresividad en la solución tectónica y compositiva a nivel expresivo y formal.

La profundidad de las costillas propicia a menudo un efecto brise-soleil que, además de acentuar la presencia de un ritmo, aporta homogeneidad a la fachada integrando vanos y cerramiento dentro de la propia geometría del hueco. Generalmente Leykam utiliza ritmos impares en la composición de fachada (F), hecho que le permite evitar una lectura duplicada de la composición cuyo plano comparativo resulte demasiado explícito y se preste atención a la intensidad de la simetría.

La jerarquía de paso de los cerramientos permite a Leykam enfatizar la manifestación expresiva del proyecto y al mismo tiempo adoptar una variable que le permita singularizar de forma sencilla y práctica cada una de sus obras. Desde una base aritmética pueden asumirse subjetividades que den lugar a variaciones perceptibles en la fachada sin eliminar la componente racional del conjunto del proyecto.

En ocasiones, las divisiones en fachada que no tienen prioridad de paso adoptan secciones de mayor grosor para ser aumentar su peso en la composición, restituyendo el equilibro del conjunto y evitando el excesivo protagonismo que podría ser otorgado a nivel perceptivo a alguna estructura jerárquica. El espesor de las fachadas permitía a Leykam establecer una ordenada transición de sombras y claroscuros que aumentaba la expresividad plástica del conjunto y al mismo tiempo individualizaba cada solución.

Las posibilidades técnicas de cada momento fueron mostrando a Leykam un camino con el que fue consecuente evitando cualquier obstáculo del proyecto que supusiese una dificultad para la estandarización del mismo, buscando con su método la realización de las obras mediante el mínimo número de elementos para maximizar el beneficio y acotar los plazos de ejecución. A través del control de la aritmética y la matemática Leykam podría asegurarse por tanto que su trabajo daría verdadero sentido al uso de la prefabricación. 
Esa expresión arquitectónica es consecuencia del intento de obtener un sistema proyectual que fuese capaz de singularizar los edificios a través de variaciones que optimizaran los elementos industrializados disponibles en ese momento en el país.

La reducción del tamaño de las piezas portantes al mínimo resultante del cálculo, la clara separación de la estructura y los elementos no estructurales, la constante separación de pórticos y pilares y la manifestación del esqueleto en el aspecto exterior del edificio son los principales indicios de una actitud coherente con respecto a la tectónica en la obra de Leykam, que tenía como regla principal incluir la optimización de la técnica dentro de los valores estéticos sin dejar nunca de lado la economía de medios.

En el método proyectual de Marek Leykam quedan recogidos como únicos elementos capaces de generar incertidumbres aquéllos que derivan de los condicionantes urbanísticos y normativos, los cuales debían ser afrontados desde la lógica racional y las relaciones de proporcionalidad así como las elección subjetiva del tipo de hueco o la existencia de jerarquía de paso de la fachada. De esta forma, los edificios que nos han servido de muestra para reconstruir el método de proyectual de Leykam contienen las siguientes constantes según el árbol de procesos de la figura 15.08:

\author{
Instituto Geológico de Varsovia \\ Sede Presidencia Gobierno de Varsovia \\ Dom Towarowy Okrąglak de Poznań \\ Estadio del Decenio de Varsovia \\ Albergue Dom PTTK de Plock
}

\author{
U1 G1 V1 E1 F2 C2 \\ U1 G2 V2-V3 E1/E2 F1 C1 \\ $\mathrm{U} 2 \mathrm{G} 3 \mathrm{~V} 3 \mathrm{E} 2 \mathrm{~F} 2 \mathrm{C} 2$ \\ U2 G3 V3-V4 E2 F1 \\ U1 G1 V1 E1 F1 C3
}

Sin embargo, no es este código, sino el conjunto de relaciones de proporcionalidad que nos ha permitido llegar hasta él a través de sus decisiones subjetivas conscientes, el que nos permite aseverar la existencia de un método comunicativo basado en la lógica que deriva de la estructura de un lenguaje comunicativo, adquiriendo su sentido, no por su constitución racional, sino por su capacidad para ser concretado por una comunidad de observadores.

Las diferencias de programa, función y requerimientos normativos en el contexto de las obras, así como las diferentes circunstancias históricas, políticas y sociales en las que se desarrolla su trabajo, no nos impide reconocer la existencia de este método común, enfocado a una construcción eficaz, práctica y sencilla que es capaz de mostrarse coherente en diferentes contextos en base a su aritmética común y la expresividad de sus elementos tectónicos, entroncando con una corriente filosófica de pensamiento opuesta a la supremacía del irracionalismo en la organización de los procesos que garantizan la convivencia en sociedad. 

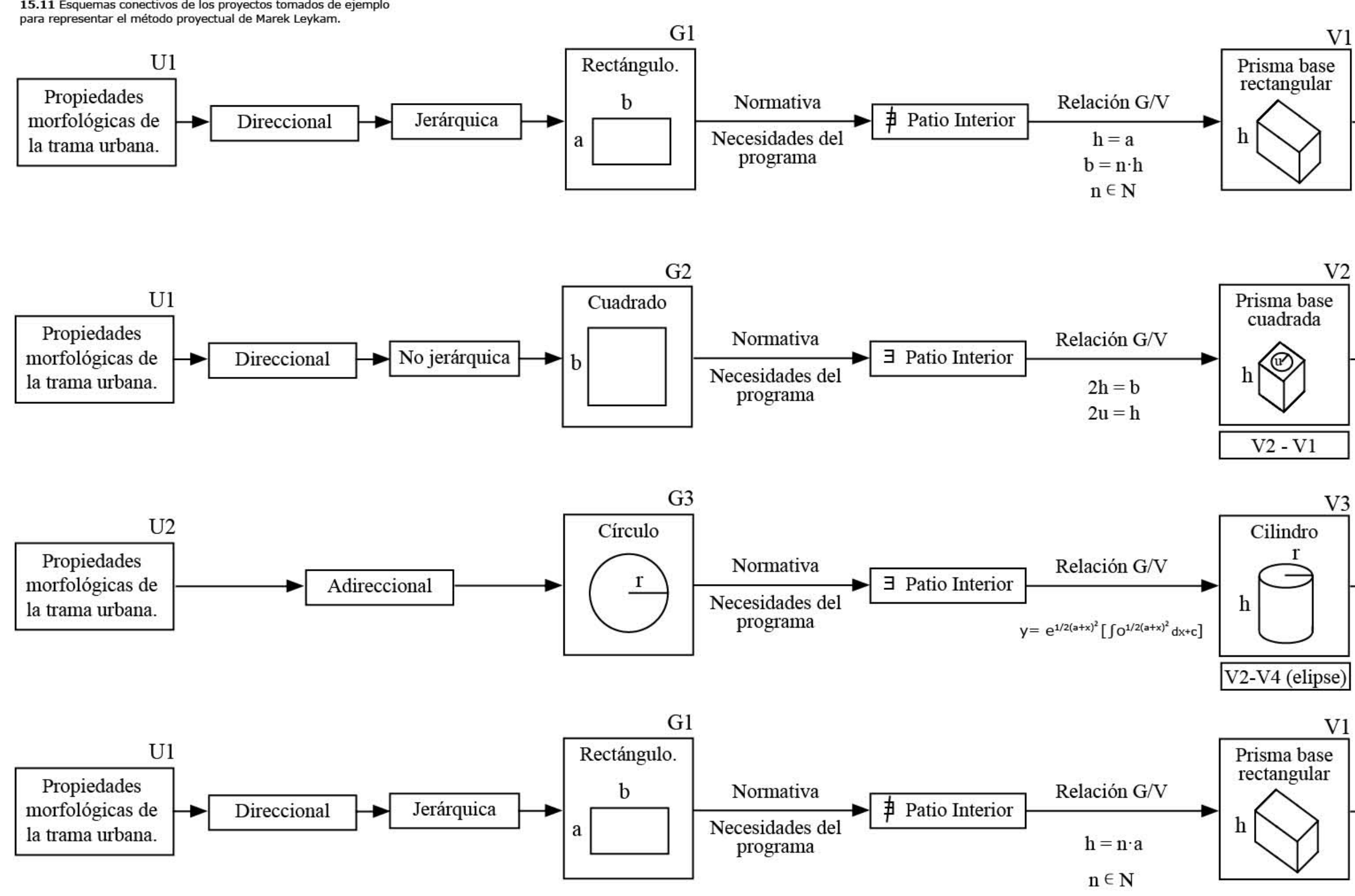


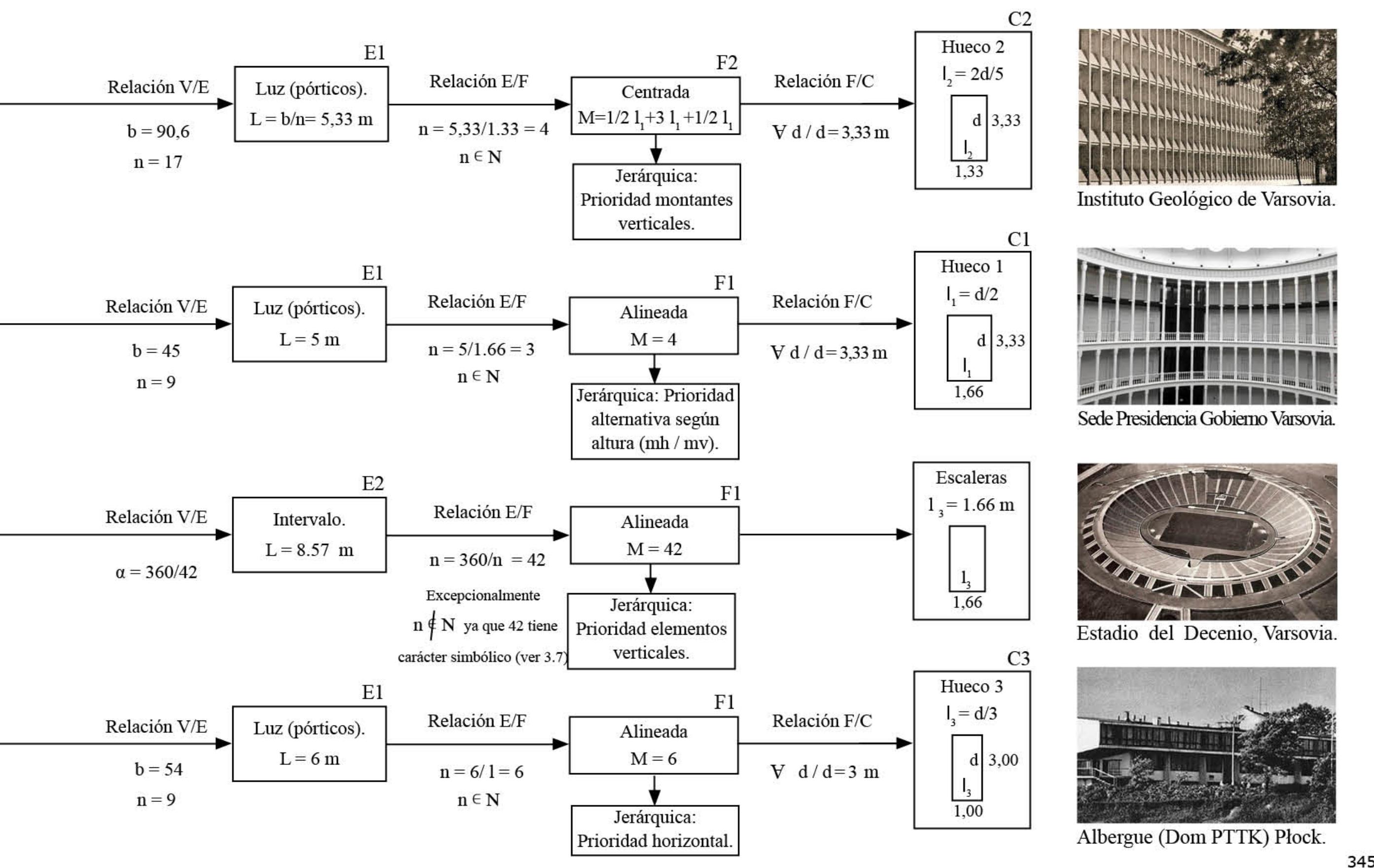




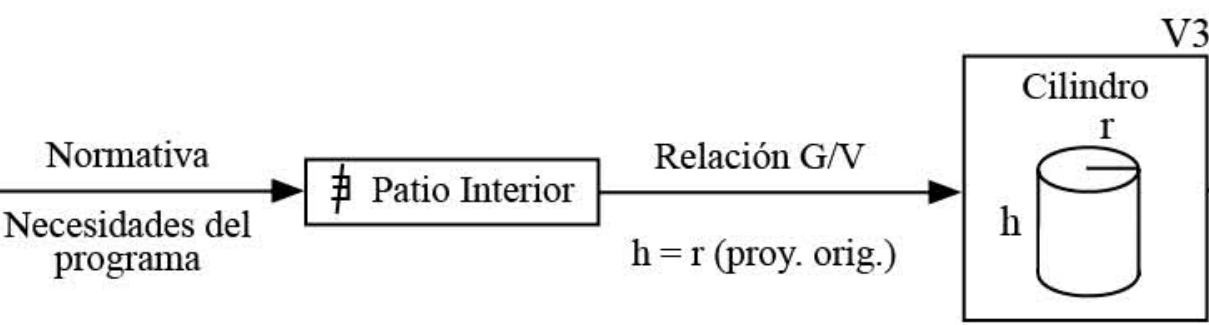

El método de trabajo de Leykam pretendía hacer confluir forma, función y estructura en una unidad, sirviéndose de la lógica para dar lugar a una obra en la que no dominasen las singularidades, sino que todas las soluciones a diferentes escalas quedasen unidas por relaciones de proporcionalidad. La arbitrariedad sí tiene cabida, aunque adscrita a un determinado intervalo de libertad, de manera que se acepte la necesidad de dar lugar a una cantidad de subjetividades fruto de la interacción humana, pero adscritas a un conjunto acotado de consecuencias.

El método de proyecto de Leykam se basaba en una consideración de su trabajo como un ejercicio proyectual establecido en base a factores verificables cuya intervención viniese dada por la elección de constantes de proporcionalidad que parten de relaciones numéricas sencillas.

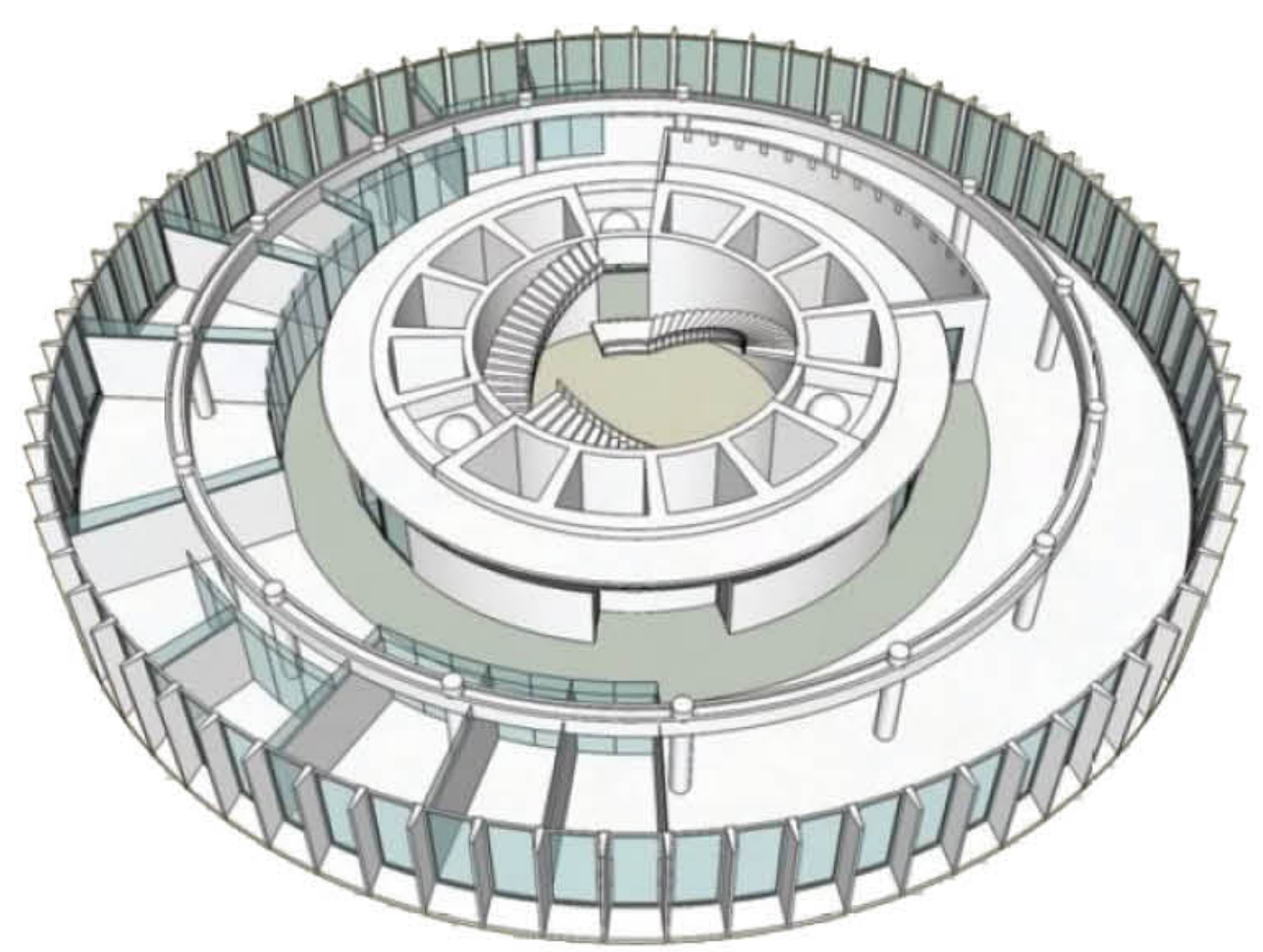

Haciendo referencia con su obra a 

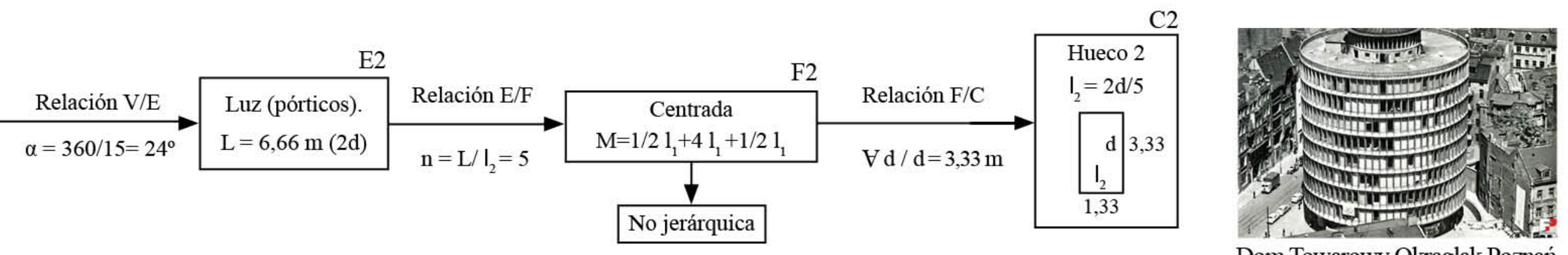

Dom Towarowy Okrąglak Poznań.

conceptos abstractos que pudieran reducir la manifestación expresiva a las formas más simples posibles, Leykam obtiene invariablemente como resultado proyectos comprensibles y universalmente interpretables a través de la razón, eliminando la tiranía que implicaba subjetivizar la obra en favor de un estilo a través de la generación de un método que mantuviera la capacidad de incluir la expresión artística permitiendo que esta adquiriese sentido en la concreción que deriva de la observación consciente de cada usuario que entrase en contacto con la obra cuando se encuentre en interacción.

A través de la adopción de un método lógico en su arquitectura Leykam fue capaz de comunicar asimismo un mensaje que entroncaba con el espíritu crítico de la época en Polonia, cuyas implicaciones derivaban de la necesidad de respetar principios igualitarios y democráticos en la organización de la sociedad. ${ }^{15.03}$

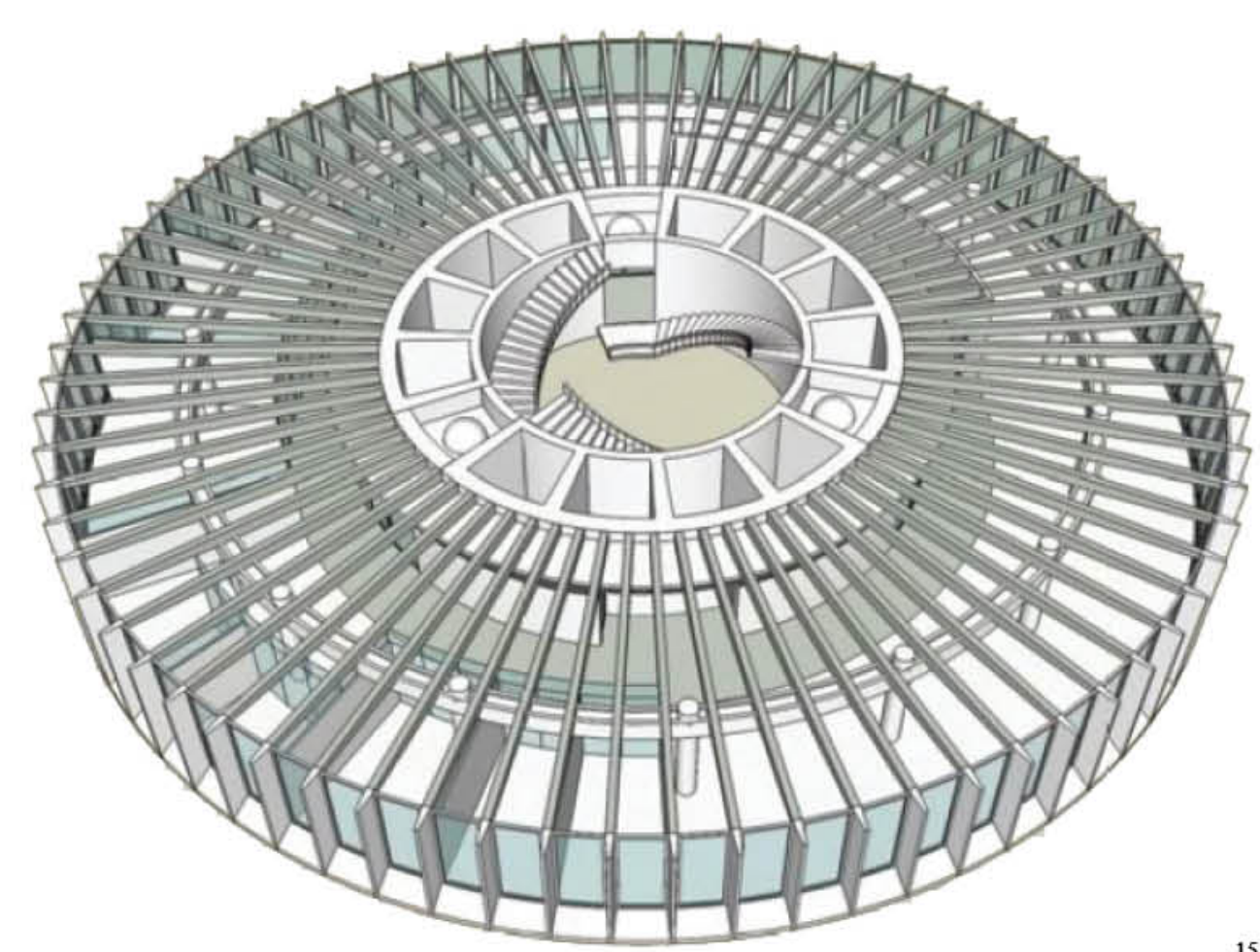

15.03. Véase p. 351 y ss. V. Mensaje transmitido por la obra de Marek Leykam. 
A partir de su método de trabajo, Leykam trató de resolver sus proyectos de manera continua relacionando las diferentes escalas, de forma que el resultado final no se expresase a través de sus partes sino como una entidad total, generando así una composición lógica y coherente en todos sus planos.

La distribución interior era planteada de forma genérica para una posterior redistribución por parte de los futuros usuarios, aunque del propio módulo estructural derivaba una aproximación a la distribución de cerramientos interiores, en la medida en que los gestores de cada espacio tuvieran en cuenta la relación estructura-cerramiento que había sido planteada a nivel teórico en fase de proyecto. La claridad de su planteamiento, permitió a Leykam atenerse a lo largo de su obra a un guión definido según el árbol de procesos estudiado (15.08), que no abandonará en ningún momento y que, tal como se puede comprobar, es capaz de recoger el conjunto de su trabajo. Ello no fue óbice para que Leykam mantuviese un margen para la expresión de la belleza a través de la imperfecta expresividad circunstancial. La utilización de la lógica permitía a Leykam regular el conjunto de tramas e instrumentos, a partir de los cuales debían surgir relaciones proporcionales destinadas a la variabilidad propia de los criterios de elección propios de la naturaleza humana en un contexto de libertad.

A partir de la capacidad de razonar inherente a las personas que entran en contacto con su obra, el método de Leykam abre la puerta a la existencia de una interpretación del significado de su expresión comunicativa expresada desde el lenguaje lógico. Todo aquello que en el método de Leykam queda sin definir, genera una libertad que debe ser resuelta según los diferentes tipos de necesidades que tenga cada contexto.

Los proyectos de Leykam se pueden explicar mediante la lectura continua de un proceso deductivo lógico en el que cabe arbitrariedad en la medida en que han de ser establecidas proporciones, valoraciones jerárquicas e interpretaciones de la trama urbana, así como la disponibilidad de tipos de hueco y el equilibro de la fachada en su composición. Cada uno de los edificios pasa a constituir, por tanto, una variación dentro del proyecto continuo, adquiriendo su singularidad en base a los requerimientos con que ha sido abordado el esquema general, pero permitiendo en cualquier caso al autor adaptarse a las circunstancias admitiendo acotadamente decisiones arbitrarias sin que por ello los accidentes del proyecto condicionen la construcción final.

La comunicabilidad de la obra de Leykam no deriva del establecimiento de relaciones lineales entre su método proyectual y la formulación de sentencias directas, sino que, a través de sus proyectos, se establece una base sobre la cual las personas que entran en contacto con su obra pueden concretar su propia lectura a partir de su experiencia sobre el objeto, atribuyendo a la obra únicamente la capacidad de despertar la conciencia sobre la realidad a través de la reconstrucción imaginaria del conjunto de procesos que han dado lugar al objeto. Sí que existe un paralelismo indudable entre su forma de entender la organización de un proyecto de arquitectura y su propuesta ideológica respecto a la adecuada organización de la sociedad. 
Leykam subrayaba a menudo la necesidad de lograr, a través de la obra arquitectónica, estímulos emocionales asociados a valores sociales. ${ }^{15.04} \mathrm{Su}$ arquitectura, por tanto, no solo organiza movimientos, acciones y contactos humanos, sino que trata de empatizar con las capacidades perceptivas, los esquemas imaginativos y el sentido de la estética de espectadores y usuarios, consolidando, a través de su manifestación construida, una jerarquía de valores de cuya observación consciente derivan conciencias que desbordan el ámbito de la conciencia individual, pasando a formar parte -a través del uso de las obras-, de la conciencia colectiva.

El método de proyecto de Marek Leykam no es, por tanto, únicamente una herramienta que le irá permitiendo agilizar los procesos, sino que a través de él le resultará posible hacer trascender su trabajo hacía la expresión de un mensaje coherente destinado al contexto político y social en el que se inserta, mediante un lenguaje lógico cuya interpretación resultaba asequible para todos aquellos que participaban de la época y comprendiesen el significado que en aquel momento estaban teniendo de las formulaciones racionales en una sociedad asediada por la sinrazón.

La arquitectura de Marek Leykam debe ser entendida, por tanto, no solo como un acto intencional relacionado directamente con un conjunto de significados que el arquitecto conscientemente pretendió expresar a lo largo de su vida, sino con una expresión diluida en el tejido social que definiese una estructura que resista a la desaparición de las estructuras colectivas, sobre la cual debía ser conformado un nuevo conjunto de relaciones que no sucumbiese ante los principios de dominación social.

Los edificios construidos por Leykam tienden por tanto a difuminarse en torno a un conjunto por la existencia de un modelo ideal que reconstruyen en cada una de sus variaciones, configurando así una especie de 'telar' discursivo. Las soluciones de cada proyecto son completadas por la conceptualización que realizan los usuarios y espectadores, concretando los mensajes a través de sus representaciones mentales, que le otorgan -literalmente- sentido.

Los actos reconstructivos que realiza cada espectador al entrar en contacto con la obra de Leykam -y al mismo tiempo al entrar en contacto con el resto de usuarios sobre ella-, son, por si mismos, la expresión de una actitud colectiva que proyecta, a pequeña escala, un modelo de sociedad. Mediante la utilización de cada espacio, los individuos conviven en condiciones de igualdad, equidad y democracia, sin tener restringida su libertad, ni condicionada su capacidad de elección sobre el conjunto de relaciones y posibilidades.

La obra de Leykam se materializa por tanto como una consecuencia lógica 'abierta' a ser concretada por la sociedad de su época, teniendo en cuenta el contexto histórico y cultural sobre el que se expresa y generando una traslación del hecho urbano al hecho comunicativo cuyas implicaciones trascienden a la arquitectura para abordar un ámbito también sociológico, como forma de afrontar los problemas del momento, que en el caso de Polonia eran principalmente de carácter estructural en lo técnico e identitario en lo social. 


"Los conceptos artísticos, económicos y políticos están desarrollándose constantemente, consistentemente y deliberadamente siguiendo una directriz impuesta, destacando la importancia de ciertas cuestiones que llegan a constituir doctrinas, formas y situaciones aparentemente sin salida, hasta que la voluntad social es capaz de inclinar esa intención."
Marek Leykam

"Z rozważań architekta" 16.00
A través de los textos, la obra construida y las ideas que han influido en el pensamiento de Marek Leykam desde los escritos de Romano Guardini hasta la filosofía de Kazimierz Twardowski o Roman Ingarden, ${ }^{16.01}$ hemos podido comprobar cómo, más allá de la corrección disciplinar, existe una intención por parte de Leykam de ofrecer una respuesta a través de la arquitectura a las circunstanciales sociales de su país desde una posición de resistencia frente a los principios de dominación subjetivos que consideraba fruto de una degeneración política y moral. ${ }^{16.02}$

El planteamiento que surge de su método proyectual tiene como resultado la generación de un modelo arquitectónico invariablemente alusivo a los ideales igualitarios y democráticos, estructurando de forma lógica los espacios y administrando de forma racional sus jerarquías, para evitar que surjan prioridades hegemónicas o sean creadas subjetivamente posiciones dominantes con respecto al conjunto de la composición. ${ }^{16.03}$

Queda en manos del ser humano la posibilidad de dotar a las obras de las adecuadas relaciones de proporcionalidad sobre la base de una estructura reglada, surgiendo la posibilidad de dar 'forma lógica' a los resultados arquitectónicos y ejemplificando así un escenario de convivencia en el que la sociedad domina, a través de procesos, la dictadura de los impulsos irracionales autoritarios.

A través de esta arquitectura Leykam plantea la necesidad de economizar el derroche de facultades humanas que estaba teniendo lugar en Polonia a través de la realización de obras rudimentarias mediante la creación de procesos que permitieran desarrollar el potencial de la tecnología, y que permitiese racionalizar los beneficios de la acción humana para evitar que recayesen solo en la clase privilegiada que controlaba los procesos, en aquel momento asentada en el aparato estatal.
16.00. Artículo "Z rozważań architekta" (Reflexiones de un arquitecto) Publicado en la revista Plastyka 1937 n 1 $^{1}$ p. 31

16.01. Véase Cap 2.1 p. 137 y ss.

16.02. Véase Cap 2.3 p. 149 y ss.

16.03. Véase Cap 4 p. 329 y ss 
16.04. Dunayevskaya, 2007. p. 11-27

16.05. Véase Kołakowski, 1971

16.06. Véase El Capital, p. III. p 1044. Cit. Prior Olmos, 2004. p 71
Se reconoce así entre los propósitos de Leykam, una oposición al aparato burocrático institucionalizado en Polonia que situó su obra en consonancia con el espíritu de la época moderna, sin que ello implicase un alejamiento de las posiciones marxistas, ya que la estructura gubernamental -según consideran autores como Dunayevskaya ${ }^{16.04}$ - "estaba transformando el marxismo en su contrario". Mientras Marx se había preocupado por la emancipación del ser humano frente al inevitable derroche de la vida que suponía el trabajo al servicio del capital, el modelo de sociedad comunista regimentado por Stalin tras la II Guerra Mundial había comenzado a fundamentar la dominación sobre la población bajo las mismas bases del capitalismo: pagar el mínimo a los trabajadores y obtener de ellos el máximo rendimiento. ${ }^{16.04}$

Cabe interpretar el mensaje emitido por la obra de Marek Leykam en consonancia por tanto con la filosofía de autores polacos como Leszek Kolakowski ${ }^{16.05}$, en una interpretación del marxismo según el objetivo de una sociedad sin clases compatible con la libertad. Según explicó Dunayevskaya:

"Cada generación debe enfrentarse al desafio de su tiempo. Nadie puede imaginar ilusamente el giro de la historia producido en nuestra época (...) podemos enfientarnos a este desafio siempre y cuando hayamos podido retornar al humanismo del marxismo y a la nueva dialéctica manteniéndonos al nivel de lo nuevo que hay en nuestra era. En nuestro tiempo de absolutos, cuando la revolución y la contrarrevolución están tan entrelazadas, los intelectuales "en general" deben salir de sus torres de marfil." ${ }^{6.04}$

En defensa del pensamiento humanista se produjeron, en Polonia tras la II Guerra Mundial, manifestaciones ideológicas a través de expresiones culturales, artísticas y sociales encaminadas a recuperar los elementos libertarios enraizados en la teoría marxista que habían sido abandonados por el comunismo soviético, si bien se tuvo que llegar a ellos a través de la codificación del lenguaje para salvar los peligros explícitos de establecer un desafío abierto al poder. ${ }^{16.05}$

El sistema político institucionalizado en los paises de influencia soviética tras la II Guerra Mundial se había convertido en la expresión de una "autoridad irreformable, monopolizada por un aparato gobernante que anulaba la satisfacción de las aspiraciones fundamentales de la sociedad" 16.04 lo cual se manifestaba en el arte y la arquitectura mediante la coacción hacia un modelo de expresión predeterminadamente subjetivo e irracional aplicado sobre las bases de la creatividad plástica, anulando la capacidad de las obras de completarse en base a procesos conscientes desarrollados por el usuario o espectador.

Leykam centró gran parte de su arquitectura y sus escritos en la adecuada proporción de las relaciones entre sujeto y objeto como hemos podido ver en su método proyectual, ${ }^{16.03}$ basando su propuesta en el propósito marxista de "lograr una reconstrucción de la sociedad sobre un muevo comienzo verdaderamente humano en el que el pleno y libre desarrollo de los individuos sea el principio rector." 16.06

En los escritos realizados en su doctorado en $1943^{16.02}$, Leykam ya había reconocido la importancia de recuperar la 
conciencia del ser humano y su espiritualidad, atribuyendo a los conflictos armados una sinrazón consecuencia de la pérdida de valores de la sociedad. ${ }^{16.02}$ Cabe entender por tanto su futura obra arquitectónica en clave marcusiana ${ }^{16.07}$, como un desarrollo autoconsciente de un ser humano que no acepta las circunstancias y orienta su negativa hacia la transformación social desde la actividad creativa.

Resultaría engañoso no hacer mención sin embargo a la existencia de una relación directa por parte de Marek Leykam con destacados dirigentes del partido comunista polaco ${ }^{16.09} \sin$ los cuales, sumados a la situación de urgencia por la reconstrucción de los primeros años del país tras la II Guerra Mundial, ${ }^{16.10}$ el desafío que estableció a las bases del control artístico y consecuentemente ideológico no habría sido posible.

Tomando en cuenta las circunstancias históricas esbozadas en esta tesis, puede valorarse la profundidad y la tremenda osadía de llevar a cabo una obra construida como la de Marek Leykam dado el contexto político y el control de las producciones artísticas que tuvo lugar en Polonia durante los primeros años de postguerra. A la excepcionalidad de su trabajo se sumó su denuncia sobre el enorme desperdicio de energía social y recursos que estaba teniendo lugar en el país, incrementado por el autoritarismo de los agentes de poder gubernamental.

Leykam expresa su crítica a través de la construcción de antagonismos. La sociedad polaca estaba siendo gobernada por un conjunto de mecanismos que, si bien tenían su fundamento teórico en una existencia humana libre y autónoma, estaban impidiendo en su materialización el desarrollo y la realización de la libertad y la razón, hecho que sistemáticamente quedaba patente por el contraste de su arquitectura con la producción de la época.

A través de la arquitectura Leykam se planteó reformular las relaciones humanas en sus obras a través de espacios equilibrados en base a la lógica y la razón, combatiendo así el irracionalismo elevado a la categoría de impulso ordenante de las estructuras colectivas. Mediante la preservación de la capacidad de los individuos de interactuar libremente en sus estancias, y proyectando a través de una metodología que garantice ámbitos sin posiciones de superioridad a partir de su forma, era devuelta a la sociedad la capacidad -a escala reducida-, de recuperar el control del sistema organizativo en el que conviven y la gestión autónoma de las consecuencias de sus actos.

Leykam escapó así del control hegemónico sobre las manifestaciones ideológicas asociadas a las obras de arte mediante un esfuerzo teórico consistente y constante por plantear cada trabajo como una continuidad racional en una sociedad atomizada por la tiranía de la subjetividad en la que las ideologías habían sido perversamente tergiversadas y elevadas a la categoría de dogmas, lo que evitaba que pudieran ser cuestionadas abiertamente y por lo tanto impedían la posibilidad de racionalizar el origen de los problemas sociales desde la base de unos principios que permitieran inclinar la voluntad mayoritaria hacia una nueva opinión. ${ }^{16.11}$

El hecho de haber establecido, a la vista de todos los habitantes de Polonia, un proceso racional de producción y
16.07. Aunque enunciada por Marcuse (Farr, 2014), esta idea no es exclusiva de su pensamiento. Participan de ella y realizaron importantes aportaciones filósofos como Gilles Deleuze. (véase
Deleuze, 1987)

16.08. Vease Kołakowski, 1971. p 1-21

16.09. Principalmente Marian Spychalski, como hemos podido ver en 1.3.1, 1.3.2 y 1.3.4.

16.10. Véase 1.3 .3 y 1.3 .4

16.11. Tal como había expresado el propio Leykam en Op. Cit. 16.00. 
ejecución de las obras durante los primeros años de posguerra, suponía toda una declaración de intenciones a través de la cual Leykam estuvo debilitando persistente y conscientemente la coherencia del poder político empatizando con una de las mayores preocupaciones sociales e intelectuales de la época en su país, la falta de democracia y de libertad. Cabe contextualizar este propósito 'leykamiano' a través de las palabras de Gilles Deleuze:

¿Cuál es la relación entre obra de arte y la comunicación? Ninguna. (...) La obra de arte no es un instrumento de comunicación, porque no contiene la mínima parte de información. Por el contrario, hay una afinidad fundamental entre la obra de arte y el acto de resistencia.

La música de Bach, es su acto de resistencia y de lucha activa contra la repartición de lo sagrado y lo profano. (..) Solo el acto de resistencia resiste a la muerte, sea bajo la forma de obra de arte, sea bajo la forma de una lucha de los hombres." ${ }^{16.12}$

Es clave en la obra de Leykam ese 'acto de resistencia' para cuya comprensión ha sido necesaria la contextualización histórica llevada a cabo en varias partes de esta tesis, que aparentemente puede resultar periférica a la arquitectura como disciplina pero que contiene los fundamentos que dan sentido a su respuesta en un determinado contexto político y social. La obra de Leykam adquiere su verdadera profundidad y dimensión cuando es comprendida en el marco de su fuerte compromiso político e ideológico manifestándose ante el poder como un auténtico acto de resistencia.

La arquitectura de Leykam comprende por tanto una postura según la cual la obra de arte trasciende como oposición frente a un determinado poder en la medida en que es ejercida como una herramienta ideológica frente a un acto de dominación hegemónico.

Así, su obra arquitectónica fue -en la segunda mitad del siglo XX en Polonia- todo un desafío frente a los mecanismos de poder que organizaban las estructuras sociales a conveniencia, promoviendo una resistencia colectiva a través de la redistribución de espacios que no significaba sino una lucha por la democracia, reivindicando una sociedad que estaba por constituirse, y aunando -como había sido su intención ya durante su época de estudiante en 1927- a través de la arquitectura una preocupación por los problemas sociales.

"Qué relación hay entre la lucha de los hombres y la obra de arte? Eso es exactamente lo que quería decir Paul Klee cuando dijo: "falta el pueblo". El pueblo falta y al mismo tiempo no falta. El pueblo falta, esto quiere decir que esta afinidad fundamental entre la obra de arte y un pueblo que todavía no existe, no es ni será clara jamás. Sin embargo, no hay obra de arte que no haga un llamamiento a un pueblo que no existe todavía." ${ }^{16.12}$

El momento clave en el desarrollo de Leykam se produjo cuando -en el desarrollo de la II Guerra Mundial-, percibió en la Liturgia el ejemplo esencial a través del cual argumentar la capacidad de las formas arquitectónicas de ofrecer 
un significado a una comunidad, perpetuando la institución de una identidad colectiva a través de pautas armónicas y repetitivas. Para Leykam la representatividad simbólica asociada a los motivos utilizados en la Liturgia y la importancia dada a su apropiación por parte de la sociedad, era un ejemplo de cómo vehicular una transmisión de valores como consecuencia de la interpretación consciente de un hecho estético por parte de la comunidad, que era escenificado durante cada una de las celebraciones.

Antes de la II Guerra Mundial, Leykam ya había criticado la deriva hacia la banalidad de la arquitectura moderna, ${ }^{16.02}$ se habían centrado en señalar la relación entre la apología de las formas 'insignificantes' y dogmáticas, y la pérdida de referentes en la estructura y la organización social.

Su obra posterior buscará por tanto, un nuevo camino para la arquitectura que no deje de lado la importancia de su manifestación pública en tanto expresión capaz de transmitir valores sociales, ni su relación histórica; pero no en tanto lectura lineal y formal de los objetos producidos sino en tanto interpretación de los significados de los objetos derivados de su inserción en un tejido social en cada época determinada y respondiendo a los condicionantes de su tiempo.

Leykam identifica en el lenguaje compartido por la comunidad durante la liturgia una capacidad de compartir significados a través de los objetos y al mismo tiempo denuncia las consecuencias de la reducción del arte litúrgico a una condición de "adorno retórico". La falta de atención al significado y la calidad de los objetos es considerada una parte del poso de degeneración e insignificancia moral que había sumido a la humanidad en una desidia y la había encaminado hacia el absurdo. ${ }^{16.14}$

En sus textos manuscritos ${ }^{16.15}$, Leykam reconoce la importancia de recuperar la conciencia del ser humano atribuyendo los conflictos armados una sinrazón consecuencia de la pérdida de valores, y plantea la necesidad de reformular las relaciones humanas a través de la concurrencia de mecanismos de control colectivos. A partir de ese propósito, Leykam sistematizará un método proyectual que no será únicamente una herramienta funcional que le permita agilizar los procesos, sino que a través de él podrá ejemplificar un ritual, una liturgia entendida como una cadencia repetitiva de procesos de resistencia, haciendo trascender su trabajo hacía la expresión de un acto público destinado al contexto social habida cuenta del barrido identitario que la población había sufrido.

Leykam planteó reflexiones que señalaban directamente a la degeneración moral como causante de la destrucción material y humana en la que el mundo se había visto sumido ${ }^{16.15}$, un pensamiento que entroncaba con las ideas expresadas por multitud de pensadores polacos de la época ${ }^{16.16}$. A través de su análisis del arte litúrgico, Leykam se planteó como objetivo establecer un mensaje comprometido con la restitución de procesos que pudieran dar lugar a significados durante la formalización de los objetos e interacción consciente mediante el uso de sus resultados.
16.14. Véase artículo Wędrówki sceptyka (Nomadismo escéptico) de Bruno Schulz. Publicado en la revista "Tygodnik llustrowany" 1936, nr 6.

16.15 Véase "Interpretación de la arquitectura a través de la Liturgia." Cap 2.3. p. 149 y ss.

16.16. Bruno Schulz, Maria Ossowska, Leszek Kolakowski,.. entre otros. A lo largo de la tesis se han citado -véase el inicio de los capitulosreflexiones que reflejaban el espiritu de la época y que estaban en consonancia con las motivaciones de la obra de Leykam. 
16.17. Escuela teórica literaria formada ca. 1915 , considerada una manifestación temprana del estructuralismo. Sus principales representantes fueron: Viktor Shklovski, Boris Tomashevski, luri Tiniánov, Borís Eichenbaum, Vladímir Propp y Román Jakobson. Véase Volek, 1995

16.18. El círculo lingüístico de Praga fue fundado por los lingüistas checos y rusos Bohuslav Havránek, Vilém Mathesius, Joseph Vachek, Bohumil Trnka, Roman Jakobson, Nicolai Troubehumil Trnka, Roman Jakobson, Nicolai Troubetzkoy y Serge
Karcevskij en 1926. Véase "Tesis de 1929" (Dominio público. Publicadas originalmente en (Dominio publico. Publicadas originalmente en Prague" (Prague, 1929).

16.19. A este respecto, véanse las consideraciones sobre M. Bajtin en Cap. 2.1.3. "La arquitectura contiene una responsabilidad social y es transmisora de valores éticos.

16.20. Véase Mukařovskỷ, 2011
Las formas construidas podrían así -para Leykam- generar un contenido capaz de unir a una comunidad en torno a un conjunto de valores en tanto hechos comunicativos comprensibles por parte de un colectivo, pero principalmente conducir a la sociedad hacia su propia aceptación como seres humanos, dando sentido a su identidad y estableciendo. de manera conjunta, unas pautas colectivas de conducta que todos pudieran asumir y respetar.

Mediante el arte litúrgico, Leykam encontró por tanto un ejemplo a través del cual argumentar la existencia de un contenido ético en la interpretación social de las obras arquitectónicas, un discurso que puede considerarse en continuidad con los planteamientos de escuelas de pensamiento como el Formalismo Ruso ${ }^{16.17}$ o el Círculo Linguístico de Praga ${ }^{16.18}$, cuya relación con la obra de Leykam ha sido planteada de forma tangencial en esta tesis ${ }^{16.19}$, pero que abren una interesante vía de investigación para quien este interesado en ahondar en la interesante relación entre sus planteamientos y la arquitectura de postguerra en Polonia y Checoslovaquia, así como respecto al significado social de los hechos estéticos ${ }^{16.20}$ en la arquitectura inmediatamente posterior a la II Guerra Mundial.

El espíritu de la Liturgia sublimaba para Leykam -interpretando a Guardini ${ }^{16.15}$-, el fruto de la 'soberbia omnipotente' de cada individuo en favor de la 'cultura colectiva'. Recuperar ese 'espíritu' resultaba necesario después de 1945, al permitir a la humanidad abordar, mediante actos sencillos, comunes y repetitivos , un proceso identitario colectivo que no era sino la forma de evitar que se cayese en la desesperación.

En la base más profunda de su discurso, Leykam, no defiende por tanto la tecnología como solución a los problemas del ser humano, ni se hace exaltación de ella por el hecho de insistir en trazados repetitivos de apariencia mecánica seriada: Si la sociedad había sobrevivido a la guerra no había sido debido a su fe en las técnicas más avanzadas, sino debido a su "fe" -en el sentido 'espiritual'- en la propia existencia humana y en su pertenencia a un colectivo y la recuperación de rituales o actos repetitivos era la manera restituir la fe en la convivencia pacífica y el sentido de la vida en comunidad.

El Estado, como distribuidor de los bienes materiales y garante de los derechos inviolables de la persona, se había convertido también en el custodio de los valores espirituales y la medida moral, pero había sido incapaz a través de sus estructuras, de frenar las ideas totalitarias que derivaron en el caos intelectual. ${ }^{16.08}$ Sin embargo la religión, que no muestra ninguna solución racional a los problemas del ser humano, en momentos de caos se había revelado capaz de dar cohesión, a través de un mensaje, a una comunidad evitando su autodestrucción y acentuando su resistencia frente a la desaparición de sus raíces identitarias.

Cuando todo estaba perdido, no quedaba otra opción que mantener la confianza en ese hecho 'espiritual' que constata Leykam Un proceso, -la liturgia- es por tanto un ritual que tiene para Leykam una vocación universal que permite adquirir conciencia de identidad colectiva. A través de la arquitectura, establecer un conjunto seriado de pautas -un método proyectual- no era sino la manera de plantear la recuperación de una identidad que en este caso ya no era la polaca, era la de la humanidad. 
La utilización de la lógica permitió a Leykam tramitar esta reflexión que había realizado durante los combates, y desde su método proyectual se propuso regular el conjunto de tramas e instrumentos a partir de los cuales debían surgir relaciones proporcionales destinadas a la variabilidad propia de los criterios de elección. Pero cuando Leykam planteó la necesidad de tomar como punto de partida un método de proyecto basado en el pensamiento racional, al mismo tiempo proclamaba el derecho de la sociedad polaca a establecer autónomamente su propia organización denunciando la falta de mecanismos de control abiertos y participativos, alejados de las jerarquías y el control autoritario por parte de los poderes públicos.

La convivencia de la comunidad alcanzaría plena autonomía para autogestionarse desde el momento en que entendiese los procedimientos a través de los cuales era capaz de satisfacer sus necesidades y sus liderazgos fuesen consecuencia de una ascendencia basada en principios lógicos que no entrase en conflicto con un modelo de convivencia tolerante e igualitario.

Sin jerarquías espaciales ni perspectivas visuales prioritarias dirigidas desde la concepción formal en ninguno de sus proyectos, Leykam trató de manifestar desde la arquitectura su búsqueda de la universalidad y equidad de las relaciones humanas en sus condiciones de vida y oportunidades, al mismo tiempo que mostró una preocupación por el uso racional de los recursos, la optimización de los medios y la eficacia de los procesos como medio para alcanzar la liberación de la sociedad ante el caos y la dominación en la que habían quedado sumidos.

El propósito de Leykam no fue por tanto un intento personal y aislado de ensalzar corrientes sociales para que por si mismas dieran forma a una nueva sociedad, sino de una inserción de elementos construidos en el tejido social que sobre la base de un posicionamiento ideológico fuesen capaces de despertar una conciencia colectiva que enfatizase la necesidad de afrontar el futuro desde la necesidad de unos principios de organización justos e igualitarios que retomasen desde sus orígenes un modelo de sociedad verdaderamente libre y democrática.

A través de una arquitectura no heredera de formas preimpuestas en la que los espacios eran tratados con equidad sin establecer lugares de preferencia dentro de los edificios y elaborando sus proyectos mediante un proceso que era consecuencia de un método, Leykam enfatizó la ausencia de estas características en el orden social polaco de postguerra, denunciando la subjetividad, el abuso de las jerarquías del poder dominante y la falta de democracia existente, mensajes que denotaban implícitamente una clara amenaza al orden político establecido desde el poder.

El acto irracional de pretender concentrar totalitariamente el poder durante la II Guerra Mundial era el mismo despotismo que estaba sumiendo al país en la institucionalización de la falta de libertad y el aprovechamiento de las plusvalías del trabajo en favor de una clase igualmente privilegiada por el mantenimiento por la fuerza del poder político en la época en que Leykam, a través de mecanismos racionales derivados de procedimientos deductivos lógicos, desarrollaba su obra arquitectónica aludiendo a una organización democrática de los espacios y un reparto equitativo de los programas 
de necesidades, así como una distribución acotada de las consecuencias de la subjetividad en una era dominada por el despotismo y la desigualdad social en favor del poder de los dirigentes.

El sistema básico del que parte Leykam no estaba fundamentado sin embargo en ideales racionales absolutos, ya que aceptaba la subjetividad inherente al concepto de belleza, al cual apelaba mediante el conjunto de interpretaciones emocionales de la mente humana. La necesaria concurrencia de mecanismos de control colectivos posibilitaba asimismo la adaptación de un determinado contexto urbanístico, histórico, social y cultural

Su marco teórico no desatiende por tanto la brecha existente entre lo ideal y lo real, ya que es precisamente a través de ese necesario equilibrio como puede establecerse un modelo de libertad catalizador de la acción social, al desligar a los individuos de la necesidad de reproducir con su trabajo aquellas partes que pudieran ser reconducidas a constantes del método proyectual y por tanto mecanizadas liberando al ser humano de la tarea de ejecutarlas.

La lucha contra el dominio absoluto del irracionalismo validaba en Polonia el compromiso de Leykam con las circunstancias en la medida en que ese desafio implicaba un ataque contra las mismas raíces del comunismo totalitario. El pensamiento irracional había tendido a desarrollar en Polonia posiciones favorables a la dominación desde las estructuras de poder, mientras que era desde la razón como se ejercía la presión sobre los problemas sociales denunciando las contradicciones de la organización social existente.

La expresión de esta autoridad canalizada en el arte por mandatos como el de atenerse a la obligatoriedad de los principios del Realismo Socialista mediante el cual se generalizaron modelos de expresión predeterminadamente subjetivos e irracionales, coaccionaba las bases de la creatividad anulando la capacidad de las obras arquitectónicas de ser concretadas mediante procesos conscientes desarrollados por el usuario o espectador.

Leykam elevó el conjunto de su obra a la categoría de hecho comunicativo fundamentado en la lógica puesto que a través de sus mecanismos pretendía escenificar la capacidad racional de transformar la realidad haciendo alusión a la necesaria concienciación de sus carencias estructurales en el sistema de organización, reivindicaba ideológicamente la falta de justicia, democracia, equidad y distribución racional de los recursos en una sociedad carente de mecanismos de decisión en torno al poder en igualdad de oportunidades.

Sin embargo, Leykam no trató de imponer como solución mecanismos racionales absolutos sino que apelaba a la sociedad -a través de un conjunto de intervalos de libertad- a convertirse en beneficiaría del dominio de la técnica pudiendo así alcanzar su libertad frente al trabajo mecánico en la medida en que el desarrollo tecnológico fuera progresando. Sus manifestaciones arquitectónicas son por tanto catalizadoras de una acción real en la medida en que es la sociedad 
quien podría, a través de un método, dar forma a las construcciones y al mismo tiempo a través de su interacción con la obra construida interpretar sus proposiciones y transformarlas en procesos de acción trasladándolas a un contexto organizativo justo y democrático.

La obra de Leykam muestra por tanto una profunda preocupación por el papel y la proporcionalidad de la intervención humana en las construcciones arquitectónicas y por extensión en la organización de la sociedad, dotando a la subjetividad de rango pero no hegemonizando su poder con respecto a la objetividad y oponiéndose a la supremacía de los mecanismos que parten del pensamiento subjetivo y legitiman el irracionalismo como punto de partida tanto a nivel arquitectónico como a nivel social en el establecimiento de las relaciones de poder.

Abogando por este sistema en un contexto social y político en grave crisis social y política tras la II Guerra Mundial y posterior desencanto por la ineficiencia y arbitrariedad de las interpretaciones ideológicas, Leykam planteó una obra en consonancia con las corrientes críticas del país, sustentando una resistencia que desde su trabajo era capaz de mostrarse disconforme con las condiciones existentes salvando asimismo la censura, debido a la cual quedó para las generaciones posteriores la tarea de hacer evolucionar la revolución hacia transformaciones efectivas de verdadero calado social. 

VI. CONCLUSIONES. 

La arquitectura de Marek Leykam está estructurada en torno a un método proyectual basado en un proceso deductivo lógico que otorga unidad al conjunto de su obra y permite una lectura que trasciende a su respuesta disciplinar frente a las necesidades formales y funcionales, para manifestarse como una interacción en el tejido social que propicia -a través de concreciones conscientes- una expresión comunicativa capaz de transmitir valores.

El método proyectual de Leykam se expresa a través de los patrones comunes a cada una de sus obras del mismo modo que un tema con variaciones, reconstruyendo así un proceso continuo de búsqueda coherente de mecanismos de producción racional que no dejan de lado el contexto cultural, histórico y social en el que se producen.

La compresión que Leykam alcanzó durante su época de formación de la técnica arquitectónica, sumada a la conciencia social que adquirió en su época de estudiante -acentuada a raíz de los sucesos acontecidos en la II Guerra Mundial ${ }^{17.01}$-, le llevaron a desarrollar una arquitectura marcada por la eficiencia y optimización de los recursos disponibles, capaz de ofrecer una rápida respuesta a la emergencia nacional existente en el país tras su destrucción material y humana, sobre la cual se planteó la necesidad de establecer un acto de resistencia frente al nuevo orden social expresando una postura firme y coherente a lo largo de su vida, contraria a la tiranía del irracionalismo institucionalizado en Polonia después de 1945 tanto en el ámbito artístico como en la esfera social.

Mediante la arquitectura, Leykam agitó la conciencia colectiva sobre la necesidad de reformular las estructuras sociales

17.01. Véase Capitulo 1.3.3. Transcurso de la II Guerra Mundial. p 89 y ss. 
17.02. Véase Capitulo 1.3.1. Entorno académico de Marek Leykam. p 29 y ss.

17.03. Véase Capitulo 1.3.2. Influencias profesionales y primeros proyectos. $\mathrm{p} 63 \mathrm{yss}$.

17.04. Ibid. p 103 yss. desde la ausencia de dominaciones hegemónicas e imposiciones autoritarias de carácter moral, hecho al que aludió a través de la formulación de una arquitectura basada en deducciones lógicas que permitiesen administrar racionalmente las jerarquías y distribuir equitativamente la posición y proporción de los espacios independientemente de cúales fueran sus funciones, poniendo de manifiesto la falta de libertad que implicaba la ausencia de mecanismos de control democrático y la supremacía de irracionalismo sobre la ética y la razón.

Leykam logró dotar a sus proyectos de un carácter simbólico que reflejase ideales democráticos garantizando condiciones igualitarias para todos los potenciales usuarios de su arquitectura. Sus formulaciones lógicas eran verificables y estaban establecidas en función de procedimientos racionales basados en el uso de la aritmética y las matemáticas, mediante las cuales Leykam alcanzó un rápido control sobre la modulación y la geometría de cada una de sus soluciones, interrelacionando las diferentes escalas del proyecto sin perjuicio de la adecuación a la necesaria dosis de subjetividad que permitiera a cada obra aproximarse al concepto humanista de belleza y al ideal social de libertad.

El proceso de aprendizaje de Leykam tuvo una fuerte influencia de las teorías constructivistas que le permitieron adquirir una absoluta conciencia de la inseparabilidad de los asuntos sociales y la arquitectura desde su época de estudiante en la Facultad de Arquitectura de Varsovia. ${ }^{17.02}$ Ya en su etapa universitaria, Leykam había sido incitado a reflejar los estímulos emocionales asociados a valores artísticos y plásticos, procesando un método general de trabajo que le permitiese alcanzar ese objetivo de forma consecuente. ${ }^{17.02}$

Las prácticas que Leykam realizó en 1934 en el estudio de Perret, ${ }^{17.03}$ le permitieron entrar en contacto a su vez con uno de los técnicos que mejor podía enseñarle en aquel momento las posibilidades técnicas del hormigón armado, forjando una sólida interpretación de la profesión basada en un desarrollo fundamentado en la lógica constructiva derivada de la racionalidad en el uso de los materiales y la prioridad de los principios de técnica, que le permitió abordar las necesidades de la obra anticipándose a sus particularidades y buscando ofrecer una solución eficaz y precisa que alcanzase la expresividad estética a través de la perfección de su ejecución.

Como alumno de O.R. Salvisberg en la ETH de Zúrich en 1940, ${ }^{17.04}$ Leykam encontró nuevamente una reflexión complementaría sobre una misma idea de arquitectura basada en la prioridad de la técnica constructiva y la búsqueda de la manifestación expresiva en la medida en que fuera consecuencia lógica de una construcción eficiente que optimizase los recursos y simplificase al máximo su puesta en obra.

De nuevo de la mano de un arquitecto que había basado su aprendizaje en la responsabilidad de dirigir su propia empresa de construcción como Salvisberg, Leykam recibió -al igual que había ocurrido con Perret-, una visión decididamente técnica del oficio desde un punto de vista marcadamente práctico y funcional, teniendo la oportunidad de aprender durante esos años la importancia de la eficacia de la obra regida desde el control de la modulación y las estandarización de todas sus partes. 
Las visitas de obra que realizó durante la construcción del edificio Bleicherhof de Zúrich en 1940, fueron fundamentales para que el joven arquitecto polaco adoptase un método de proyecto basado en la generación de fórmulas matemáticas mediante las cuales definir a través de proporciones sencillas todos los elementos del proyecto.

Durante el tiempo que duró la II Guerra Mundial, Leykam desarrolló sin embargo una concepción marcadamente humanista de la profesión ${ }^{17.01}$ que le permitió valorar la importancia de la arquitectura más allá de su formulación práctica, transcendiendo a la técnica para buscar en los proyectos un simbolismo que asumiera el equilibrio entre pasado y futuro y tomase partido con respecto a la problemática situación social, ${ }^{17.05}$ hecho que marcó definitivamente las características de su obra arquitectónica. En los escritos que llevó a cabo durante su exilio en Suiza, Leykam comprendió que, como arquitecto, tras los combates iba a tener la posibilidad de dar una respuesta a un conjunto de necesidades que no solo implicarían una reconstrucción física de la arquitectura destruida, sino la restitución de la fe en la convivencia pacífica y solidaria de una comunidad.

En un país como Polonia, los arquitectos iban a pasar a ser agentes sociales encargados de coordinar un esfuerzo llamado a recuperar, no solo las condiciones de vida de su pueblo, sino su identidad colectiva, teniendo que asumir las referencias perdidas y recomponer ideológicamente la memoria arrebatada de un pasado aplastado por la sinrazón. Resultaba así necesario un proceso que debía afrontarse -según Leykam- ${ }^{17.04}$ como un retorno a las bases connaturales desde la honestidad intelectual y sin sucumbir en las interferencias ideológicas y los intereses externos planteados por las corrientes políticas dominantes; respetando los principios éticos y la prioridad del bien colectivo, algo fuertemente asociado a una idea de conciencia que estaba ligada a su compromiso moral e incluso espiritual.

Leykam advirtió que, desde la arquitectura, era posible contribuir a conformar una sociedad que recuperase su identidad mediante la definición de un lenguaje comunicativo que hiciera partícipe a los habitantes de Polonia de la posibilidad de reencontrar su presente en continuidad con su historia sin caer en la mímesis literal de las preexistencias anteriores ni en el dictado de los cánones arbitrarios impuestos por las nuevas directrices ideológicas, resistiendo -a través de la formulación de códigos basados en la contextualización racional de los acontecimientos históricos- para dotar a la sociedad de herramientas mediante las cuales, en el transcurso de su uso, comenzase a verse recuperada la confianza en la propia idea del ser humano como ente racional. ${ }^{17.05}$

Las críticas de Leykam a la deriva hacia la insignificancia de la arquitectura contemporánea, ${ }^{17.06}$ se habían centrado en señalar su apología de formas autoimpuestas desde posiciones dogmáticas, cuestión que consideraba necesario reconducir desde la comprensión de la transcendencia del significado de la arquitectura como hecho comunicativo. Esta denuncia la ejemplificó estudiando la conexión entre la arquitectura y el arte litúrgico, en la medida en que, a través de la representatividad simbólica asociada a los motivos utilizados en la liturgia y la importancia dada a su apropiación por parte de la sociedad, se transmitían valores como consecuencia de la interpretación consciente del hecho estético. ${ }^{17.07}$
17.05. Véase Capítulo 2.3. Interpretación de la arquitectura a través de la liturgia. p 149 y ss.

17.06. Véase p. 85 yss.

17.07. Véase p. 155 y ss, y también Mukařovský, 2011. p. 5 y ss. Función estética. 
Leykam consideraba que se había perdido la conciencia social sobre el significado de las formas, dejando de ser entendidas como consecuencia de un proceso histórico o un suceso colectivo elevado a la categoría de acontecimiento social y separándolas del contexto que les otorgaba valor, en la medida en que tras ellas había una sociedad que se apropiaba de su escenografía y daba sentido literalmente al encuentro con ellas desde su comprensión de las implicaciones que poseía su existencia. ${ }^{17.05}$

Surge así para Leykam la necesidad de buscar un nuevo camino para la arquitectura contemporánea que no deje de lado la importancia de su manifestación pública en tanto expresión capaz de transmitir valores, evitando la banalidad de tratar con indiferencia los hechos construidos como si se tratase de un conjunto de formas heredadas utilizadas desde la inconsciencia de quien repite un conjunto de palabras aprendidas sin conocer el lenguaje en el que cobran sentido como expresión. ${ }^{17.05}$

El paralelismo entre la importancia ética y moral de las formas asociadas al arte litúrgico y la arquitectura tuvo continuidad con las reflexiones de Leykam en torno a la pérdida de valores sociales por la falta de compromiso con el proceso metodológico en la formalización de los objetos modernos, concluyendo que resultaba necesario establecer un método proyectual a través del cual las formas construidas pudieran generar un contenido significante, en tanto hechos comunicativos comprensibles por parte de la comunidad. ${ }^{17.05}$

La importancia del arte litúrgico radicaba en su capacidad de ejemplificar esta posibilidad al haber sido capaz, a través de la celebración, de dotar un contenido ético a las manifestaciones construidas siendo posible hacerlas confluir en una forma de comunicación. A través de la atención prestada a los detalles constructivos y la comprensión de la transcendencia simbólica de la composición en los elementos litúrgicos, Leykam trató de abstraer así conceptualmente una vinculación de la arquitectura con la escenografía pública de un mensaje que, desde la simbología de las formas, fuese concretado por los sujetos que utilizaban las construcciones en un determinado contexto histórico y social. ${ }^{17.05}$

Leykam no pretendió únicamente alcanzar así una comprensión de los fenómenos que permitían transcender a la liturgia por su significado espiritual, sino que se planteó aprender a interpretar un lenguaje a través del cual fuera posible posteriormente transmitir a través de su obra arquitectónica un conjunto de valores que hicieran confluir la pretendida renovación expresiva del arte moderno con las motivaciones éticas de una sociedad desconsolada por la irracionalidad de las guerras y el sinsentido de los regímenes políticos que la gobernaban, ofreciendo un contexto integrador que desde la comprensión de la universalidad del espíritu humano pudiera llegar a propiciar una estética entendida verdaderamente como contemporánea.

El doctorado de Leykam es, por tanto, un documento clave de esta tesis ${ }^{17.05}$ que demuestra cómo, a partir del arte litúrgico, el arquitecto polaco no se planteó únicamente contrarrestar la banalización del arte moderno, sino expresar 
un mensaje de contenido ideológico en la medida en que consideraba su época como ausente de referentes fruto de la irracionalidad del poder político y de la pérdida de valores morales de la sociedad. ${ }^{17.05}$ Leykam hizo por tanto extensiva su denuncia al conjunto de la arquitectura de su época, refugiado en un código que le permitiese evitar la eventual censura, conocedor como era de las implicaciones políticas que contenían sus manifestaciones, y únicamente se posicionó públicamente desde la persistencia de quien esperaba que fuese la sociedad quien recuperase sus bases identitarias a través de la interacción consciente con lo construido una vez puesta a prueba su capacidad de 'resistencia'.

La creación de formas arquitectónicas innovadoras se había vuelto posible bajo los nuevos métodos de cálculo actualizados a las posibilidades constructivas de los materiales modernos, pero era necesario alcanzar una renovada interpretación de la profesión que permitiera que ésta fuera entendida desde su compromiso efectivo con la sociedad, y tras la destrucción era necesario dejar de lado los dogmas y la hegemonía de las arbitrariedades para poner la arquitectura al servicio de una sociedad abierta y democrática, consciente y partícipe de sus posibilidades como colectivo autorrealizado que comparte la 'empatía' de su existencia en el mundo.

Desde la arquitectura Leykam se planteó la necesidad de volver a articular sentimientos simples y relevantes, siendo el espíritu que debe atender la arquitectura similar al tipo de oración que tiene lugar en el coro de una iglesia, donde una acción interior es expresada a través de una forma exterior que es comprendida y compartida por el conjunto de la comunidad. La semántica cobra por tanto -para Leykam- un especial significado en la expresión de las formas arquitectónicas. El doble significado de las expresiones, en tanto hecho artístico y a la vez social y político, tiene su reflejo en el conjunto de su obra y es así como, desde la arquitectura, es posible expresar un mensaje que transmita valores a la comunidad, siendo aprehendidos a través del uso por sus ocupantes.

La arquitectura de Leykam no puede ser reducida por tanto a la elección optimista de un conjunto de procesos constructivos prefabricados que permitía el tratamiento sistémico y la incorporación de leves correcciones en las pautas dimensionales o formales para respuesta a la totalidad de la obra -y sus variantes- con una sola pieza o molde. Tras ese aparente positivismo existe el trauma de quien 'contemporiza' el desgaste y la vergüenza ${ }^{17.08}$ de sentirse ser vivo tras la II Guerra Mundial, haciendo a su trabajo partícipe del conjunto de hechos significativos que forman parte de la sociedad superviviente a la tragedia, que trata de recuperar la fe en la humanidad.

De hecho, para Leykam en el positivismo meramente cuantitativo también existía el germen del totalitarismo, en tanto manifestaba la supremacía del impulso ordenador subjetivo. Toda la carga de la prueba estaba relacionada con el significante de los procesos y su concreción al entrar a formar parte de la sociedad. El caso de Leykam, partiendo del funcionalismo, o del racionalismo más sintético, lógico y pragmático, se incorpora -a través de un método- a una interpretación que, en el plano social, no es sino una oposición frontal frente al relativismo y la tiranía del mandato imperativo, abogando por procesos creativos en los que puedan existir interacciones y procedimientos dialécticos 
democratizables desde los cuales la obra quede abierta a ser completada por la sociedad y contribuya a articular una conciencia generalizada sobre sus posibilidades y su actitud ante el mundo.

El surgimiento de la semiótica, la lingüística, y el tratamiento del proyecto o la obra de arte como texto, no fueron meros instrumentos de los que se sirvió Leykam ante su voluntad de resultar notorio sino que formaron parte de su preocupación por el significado de la propia existencia humana y el sentido de su convivencia, habiendo puesto en cuestión todo aquello que comparten como sociedad, incluidas las formas que albergan su vida en común, la arquitectura.

El interés por manifestar a nivel formal la importancia expresiva de las soluciones tectónicas del edificio, llevó a Leykam a mostrarse atento a la adecuación a la escala urbana, dando siempre una respuesta contundente ante los cambios de plano de cada una de las geometrías propuestas y ofreciendo una lectura de la trama urbana de la que se desprendiese de forma objetiva una lectura radical de su direccionalidad, así como un análisis de las condiciones normativas a partir de las cuales quedase conformada la necesidad objetiva de construir un volumen determinado.

Al plantear el uso de las matemáticas como una herramienta de control que verifique los valores obtenidos y manteniéndose al margen de la hegemonía de la subjetividad, Leykam estaba ejemplificando asimismo un modelo de sociedad en la que las decisiones pudieran ser arbitradas por mecanismos racionales, y la irracionalidad fuese determinada en intervalos acotados y reglamentados que permitieran al ser humano alcanzar la expresión de la belleza y por extensión de la libertad, limitando las consecuencias de sus arbitrariedades sobre el conjunto de la sociedad.

La subjetividad en la obra de Leykam queda confinada por tanto por un número concreto de variables, a través de las cuales el autor se reserva únicamente el derecho de intervenir en base a su interpretación de los diferentes condicionantes existentes (materiales, técnicos, normativos..). El método de Leykam permite así reconducir las manifestaciones intencionales de la arquitectura acotando su margen de autoritarismos, al estar definidas por un intervalo limitado de posibilidades y abarcar un número controlado de consecuencias.

Otra de las principales aportaciones de Leykam a la arquitectura polaca de postguerra fue la propuesta de soluciones constructivas cuyo resultado final pudiera ser verificado en todo momento mediante relaciones de proporcionalidad a todas las escalas del proyecto. Independientemente de la posición o su nivel de importancia en la composición, como consecuencia de la interpretación racional todos los elementos de la obra estaban relacionados aritméticamente y la libertad de elección en el diseño estaba determinada por la elección de sus relaciones de proporcionalidad. Este conjunto de intervalos subjetivos permitía asimismo determinar la conexión existente entre los razonamientos proyectuales y sus implicaciones ideológicas.

Es a partir de este nexo, como Leykam encontró la manera de posicionarse en su época en un tiempo marcado por el 
dirigismo de la obra artística debido a su capacidad de manifestar ideología. Sirviéndose de un método proyectual que no dejaba de lado la intervención humana, pero que anteponía el instante ordenante a los impulsos irracionales, Leykam determinó la prioridad de la razón en la organización arquitectónica y por extensión en la organización social.

Los proyectos de Leykam se pueden explicar por tanto mediante la lectura continua de un proceso deductivo lógico en el que cabe arbitrariedad en la medida en que han de ser establecidas proporciones, valoraciones jerárquicas e interpretaciones de la trama urbana, así como la disponibilidad de tipos de hueco y el equilibrio de la fachada en su composición.

Mediante análisis de la trama urbana se obtienen principalmente aquellos datos que permiten determinar si el proyecto debe dar una respuesta de carácter direccional o adireccional al contexto, deduciéndose posteriormente la necesidad o no de establecer jerarquías a través de su forma y volumen y trasladando el proceso deductivo hasta la formalización del detalle constructivo admitiendo siempre un grado de subjetividad consecuencia de la elección de las relaciones proporcionales entre constantes.

A través de la composición de los cerramientos, Leykam enfatizará la manifestación expresiva de cada obra y, al mismo tiempo, adoptará variables que le permitirán singularizar de forma sencilla y práctica cada una de sus construcciones. Desde una base aritmética podrán asumirse asimismo subjetividades que den lugar a variaciones perceptibles en la fachada sin eliminar la componente racional del conjunto de su trabajo. La aritmética, como herramienta ordenante, le permitirá delimitar trazados controlando el espacio intelectual destinado a las manifestaciones irracionales de la expresividad humana, dotando así de pureza al concepto y al mismo tiempo ofreciendo la posibilidad de hacer confluir un conjunto de decisiones proyectuales que permitirán al observador adquirir conciencia de su desarrollo y elaborar su interpretación a partir de su 'concrección' del hecho estético.

La arquitectura era entendida por Leykam como un proceso a través del cual componer el espacio y la vida ${ }^{17.05}$. Su propósito era por tanto definir a través de su obra un conjunto de parámetros constantes a través de los cuales se pudiese dar forma a los espacios habitados, y desde los cuales no solo pudiesen establecerse movimientos, acciones y contactos, sino también capacidades perceptivas, esquemas de imaginación y estructuras normativas que articulasen los 'valores' necesarios para restablecer la fe en la convivencia social.

El propósito de Leykam no fue crear un obra arquitectónica consecuente con un determinado estilo sino hacer desaparecer el estilo de sus construcciones haciendo referencia a conceptos abstractos que permitieran reducir la manifestación expresiva de sus edificios a la forma más simple posible, logrando un resultado elocuente, universalmente comprensible e interpretable desde la razón. Su búsqueda no estaba circunscrita asimismo solo a valores arquitectónicos sino a la vida que se iba a desarrollar sobre ellos con el uso desarrollado en cada espacio por parte de la sociedad. 
Las diferencias de programa, función y requerimientos normativos en el contexto de las obras, así como las diferentes circunstancias históricas, políticas y sociales en las que se desarrolló su trabajo no nos impiden reconocer por tanto la existencia de un método proyectual consecuente enfocado a lograr una construcción eficaz, práctica y sencilla que al mismo tiempo fuese consciente de las carencias sociales en el plano sociológico y psicológico. ${ }^{17.09}$

Las obras de Leykam iban encaminadas así a permanecer ancladas como punto de apoyo inequívoco en una época de caos intelectual, ${ }^{17.10}$ resistiendo tanto en el plano estético y arquitectónico como en el político e ideológico todos los imperativos, sin caer en los condicionamientos subjetivos eventuales desarrollados bajo mandatos autoritarios.

Las posibilidades técnicas de cada momento fueron mostrando a Leykam un camino con el que fue consecuente evitando cualquier obstáculo del proyecto que supusiese una dificultad para la estandarización del mismo, buscando con su método la realización de las obras mediante el mínimo número de elementos para maximizar el beneficio y acotar los plazos de ejecución. A través del control de la aritmética y la matemática, Leykam podría asegurarse por tanto que su trabajo daría verdadero sentido al uso de la prefabricación optimizando el esfuerzo de los trabajadores y evitando su utilización como productores enajenados de su libertad.

En el proceso proyectual de Marek Leykam, los elementos capaces de generar incertidumbre derivaban de los condicionantes urbanísticos y normativos, afrontados desde la lógica y el pensamiento racional para lograr que estructura, forma y función pudieran confluir en una unidad en la que no existieran singularidades entre las partes, sino que manifestasen de forma conjunta el resultado final de forma elocuente e interpretable por parte de la sociedad. Leykam trató de hacer desaparecer la percepción prioritaria de los detalles para que el destinatario de su arquitectura estuviese dominado por la expresividad del conjunto y no por sus particularidades.

El interés por manifestar a nivel formal la importancia expresiva de las soluciones tectónicas de los edificios llevó a Leykam a mostrarse atento a la adecuación a la escala urbana dando siempre una respuesta contundente ante los cambios de plano de cada una de las geometrías propuestas ofreciendo siempre una lectura radical de su direccionalidad, así como un análisis de las condiciones normativas a partir de las cuales pudiera quedar conformada la necesidad objetiva de un volumen edificado determinado.

Leykam fue estableciendo a lo largo de su trabajo variaciones volumétricas sobre figuras geométricas sencillas que mantuvieron invariable su búsqueda del máximo aprovechamiento espacial y la manifestación de la expresividad de cada edificio a través del orden tectónico y la regularidad geométrica, sin dejar que las soluciones proyectuales pudieran venir determinadas por la singularización de accidentes circunstanciales. La formulación clara de estos conceptos, desde la precisión que aportaba el control de la modulación, permitió sistematizar todas sus obras y controlar con gran agilidad y eficacia sus procesos de construcción que, en ocasiones, llegaron a coordinar a más de 2000 personas. ${ }^{17.11}$

la obra de Marek Leykam. p 351 y ss.

17.10. Véase Solzhenitsyn. p 89. (Pierce, 2007).

17.11. Véase el proyecto del Estadio del Decenio de Varsovia. p 257 y ss. 
Cada uno de los edificios de Leykam pasó a constituir un conjunto de variaciones del mismo proyecto que derivaban como consecuencia de la subjetividad con que eran abordados a partir del esquema general, permitiendo así al autor adaptarse a las circunstancias admitiendo acotadamente decisiones arbitrarias sin que por ello los accidentes del proyecto condicionaran el resultado final de la construcción.

La reducción del tamaño de las piezas portantes al mínimo resultante del cálculo, la clara separación de la estructura y los elementos no estructurales, la constante luz entre pilares y la manifestación del esqueleto en el aspecto exterior del edificio, son los principales indicios de una actitud coherente con la tectónica en la forma de trabajo de Leykam que tenía como regla principal incluir la optimización de la técnica dentro de los valores estéticos sin dejar por tanto nunca de lado la economía de medios.

Leykam sintetizó por tanto, a lo largo de su trayectoria profesional, un conjunto de mecanismos basados en la lógica constructiva recogidos por un método que, independientemente de la geometría de volúmenes a los que estuviese adscrito, fuera capaz de dar una respuesta razonada a cada uno de los contextos en los que fue formulado.

Desde el rigor matemático, el control de la modulación y el establecimiento de relaciones de proporcionalidad entre todos los elementos del proyecto, Leykam propuso invariablemente soluciones ordenadas cuya expresividad se manifestaba a través de una rítmica racional. A través de este método, Leykam buscó asimismo escenificar una transición regulada de la autocracia de la acción creativa a la democratización de los procesos arquitectónicos llevados a cabo de forma eficiente, escenificando un paralelismo con un modelo de convivencia social definido en términos de justicia y equidad.

Leykam asimiló el discurso de un conjunto de corrientes de pensamiento contemporáneas ${ }^{17.12}$ que hacían énfasis en la necesidad de alcanzar a través de la obra arquitectónica la expresión de estímulos emocionales asociados a valores sociales. A partir de la capacidad de razonar inherente a las personas que entran en contacto con su obra, el método proyectual de Leykam abría en su conjunto la puerta a la existencia de una interpretación del significado de sus manifestaciones arquitectónicas con carácter social y consecuencias ideológicas. Todo aquello que queda sin definir generaba asimismo una libertad que debía ser resuelta por cada comunidad según los diferentes tipos de necesidades de cada contexto integrándose así en el lugar y en su historia.

Las obras arquitectónicas de Leykam tienden por tanto a difuminarse por la existencia del modelo ideal que puede ser reconstruido a través de la generalización que subyace en sus variaciones. Las soluciones de cada proyecto deben ser completadas sin embargo por la conceptualización que realizan de ellas los usuarios y espectadores, concretando su mensaje a través de su representación mental que literalmente le otorga sentido. La lucha contra el dominio absoluto del irracionalismo validaba en Polonia el compromiso de Leykam con las circunstancias en la medida en que ese desafío implicaba un ataque contra las mismas raíces del poder totalitario. 
Luchando por este sistema en un contexto social y político en grave crisis identitaria tras la II Guerra Mundial y ante una sociedad sumida en el posterior desencanto por la ineficiencia y arbitrariedad de las interpretaciones ideológicas sobre las que se sustentó el comunismo en Polonia, Leykam planteó su obra arquitectónica alejada de las revoluciones pero sí adhiriéndose a un claro espíritu de resistencia, mostrándose disconforme con las condiciones existentes en el sistema de organización social, pero dejando para las generaciones posteriores la tarea de hacer evolucionar esta estructura hacia transformaciones efectivas de la sociedad de su país.

A lo largo de esta tesis han sido puestas de manifiesto las características comunes a la obra de Marek Leykam que permiten reconstruir retrospectivamente su método proyectual, ${ }^{17.07}$ entendido como un proceso continuo de búsqueda coherente de una lógica racional en la arquitectura que no dejase de lado el contexto cultural, histórico y social en que era desarrollada ni fuese insensible a los debates éticos, morales, políticos e ideológicos de su época. El pensamiento irracional había tendido a desarrollar en Polonia posiciones dominantes con carácter autoritario desde las estructuras de poder, mientras que era desde la razón como se ejercía la presión sobre los problemas sociales denunciando las contradicciones de la organización política existente y sus consecuencias a nivel social.

Cuando Leykam planteaba como punto de partida insistentemente un método proyectual basado en la lógica, estaba proclamando al mismo tiempo el derecho de la sociedad polaca a participar en los mecanismos de control del poder democráticos escenificados en su arquitectura a través de una administración racional de las jerarquías, y participando de una idea de justicia a través de la distribución equitativa de espacios en la que no existen prioridades visuales o posiciones dominantes impulsadas desde la forma y mediante la asistencia de una modulación invariablemente unitaria en la que no hay accidentes circunstanciales que modifiquen las condiciones de igualdad.

En la medida en que los avances de la técnica puedan propiciar la delegación por parte de los seres humanos de todas las constantes desarrollables a través de procesos automatizados, el ser humano podrá alcanzar la libertad dedicándose a componer relaciones de proporcionalidad que es el espacio destinado en la obra de Leykam a la expresividad derivada de su necesario desarrollo emocional y creativo sin que las consecuencias de su formulación puedan constituir una amenaza el modelo de organización social.

La obra de Leykam debe ser entendida, por tanto, como un acto intencional relacionado directamente con un conjunto de valores que el arquitecto conscientemente pretendió expresar a lo largo de su vida mediante la utilización de lenguaje lógico, una expresión construida con implicaciones políticas e ideológicas que era capaz, insertada en su contexto, de escenificar un modelo de sociedad a través del uso que la población hacía de su arquitectura y su comprensión del significado social de las propias formas y los procesos a través de los cuales eran llevadas a cabo.

Leykam pretendió alejarse, por tanto, de los patrones estéticos dominantes fruto de las arbitrariedades del momento, 
constituyendo una actitud ciertamente desafiante ante el poder institucional que no abandonó a lo largo de su vida en su obra teórica y práctica. La ausencia de mecanismos democráticos en Polonia fue denunciada sistemáticamente por Leykam a través de sus textos mientras no existió la censura ${ }^{17.13}$ y reafirmada a través de su arquitectura ${ }^{17.14}$ apelando en ambos casos a una sociedad que debía reaccionar ante la falta de legitimidad que suponía la inexistencia de procesos que garantizasen la estructuración de una sociedad no subordinada.

La obra de Leykam muestra, por tanto, su profunda preocupación por el papel de la manifestación humana en las construcciones arquitectónicas, dotando a la subjetividad de rango pero no hegemonizando su poder con respecto a la objetividad, y oponiéndose a la supremacía de los mecanismos que parten del pensamiento totalitario y legitiman el irracionalismo tanto a nivel estético como a nivel social, utilizando las manifestaciones construidas como vehículo para la transmisión de ideología.

No se trataba, sin embargo, de un intento de ensalzar a aquellas corrientes sociales partidarias de la razón para que por sí mismas dieran forma a una nueva sociedad, sino de situar elementos en el tejido social que ayudasen a generar una conciencia colectiva sobre la necesidad de afrontar el origen de los problemas sociales del país, derivados en gran medida de la crisis identitaria que había desatado la II Guerra Mundial.

Los actos reconstructivos que realiza cada espectador al entrar en contacto con la obra de Leykam y con el resto de usuarios que la utilizan, representan una manifestación de valores ideológicos que es escenificada mediante la proyección a pequeña escala de un prototipo de sociedad, que se desarrolla en condiciones de igualdad y justicia, sin necesidad de que sea restringida su capacidad expresiva a nivel artístico, ni su identidad como comunidad a nivel social.

Como resumen de estas conclusiones, cabe señalar que Leykam, a través de la expresividad que derivaba de sus formulaciones arquitectónicas y superando el marco institucional mediante un conjunto de manifestaciones conectadas por un nexo metodológico, insertó en el tejido urbano polaco un mensaje público de carácter simbólico que recreaba una transición desde la autocracia de la acción creativa a la democratización de los procesos arquitectónicos llevados a cabo de forma eficiente, escenificando un paralelismo con un modelo de convivencia social definido en términos de justicia y equidad, sin perjuicio de la libertad como aspiración última de la sociedad. 



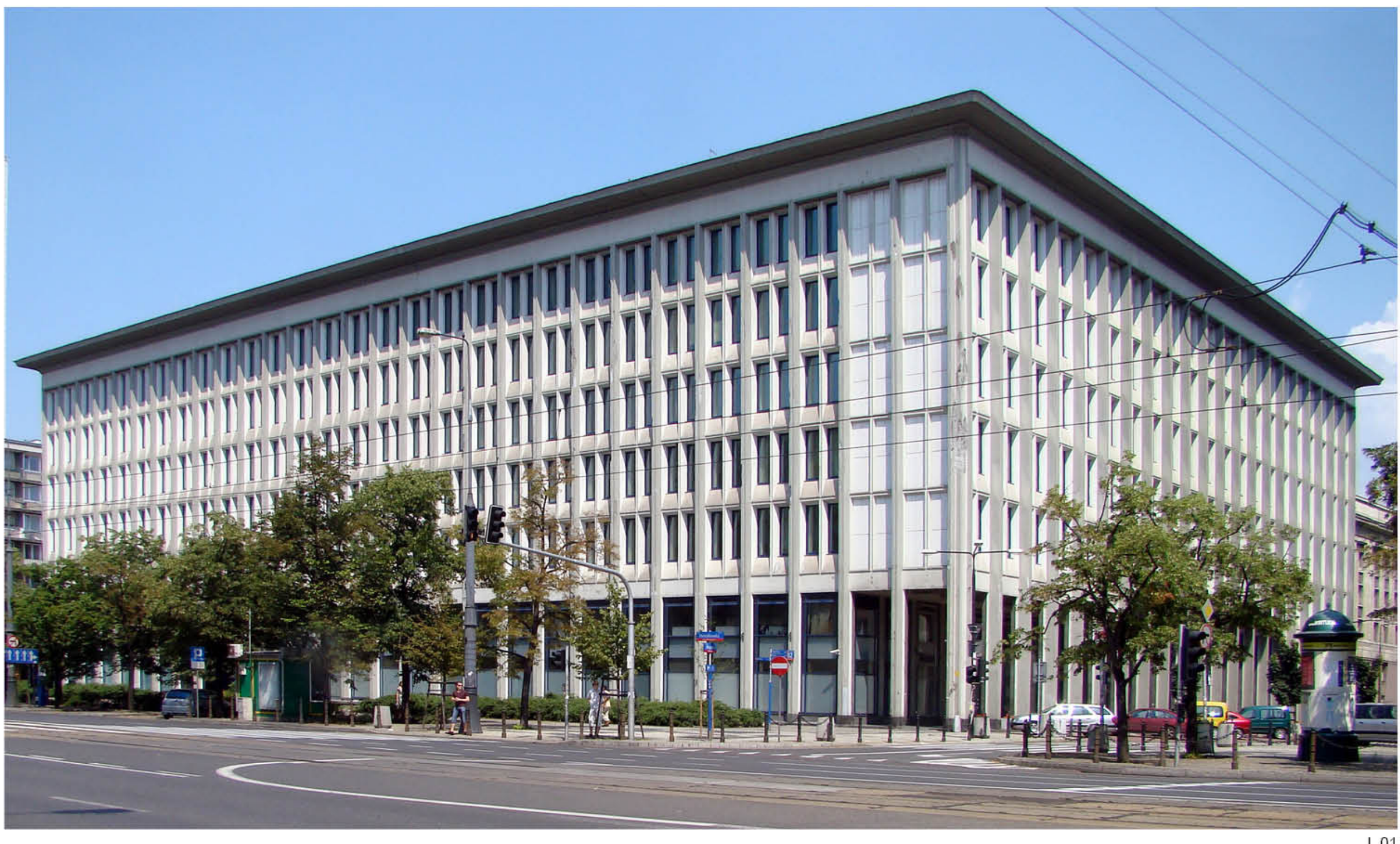


El Edificio de Oficinas de la calle Marszałkowska nº $82-84$ de Varsovia construido entre 1946 y 1950 según el proyecto de Marek Leykam junto a Jerzy Hryniewiecki estuvo ocupado durante los primeros años desde su inaguración por el Ministerio de Hacienda. ${ }^{\text {I.01 }}$ Posteriormente entre 1958 y 1986 pasó a ser la sede de la Cámara Suprema de Control ${ }^{1.02}$ y finalmente en 1986 se convirtió en el edificio principal de Tribunal de Distrito de la Ciudad ${ }^{\mathrm{I} .02}$, actividad que mantiene en la actualidad.

La Empresa Nacional de Utensilios y Repuestos ${ }^{1.04}$ para la Asociación Polaca de Exploradores (Scouts) ${ }^{\text {I.05 }}$ ocupó durante las primeras tres décadas gran parte de la galería de planta baja con la tienda más grande de las 15 que tenía distribuidas por el país, en la que además de adquirir herramientas y complementos podía visitarse una gran maqueta de un trazado ferroviario recorrido por un tren eléctrico.

Las condiciones de conservación de este Żyletkowiec empezaron a quedar visiblemente deterioradas y tras sucesivas puntuales reformas, en el año 2013 se inició un proyecto de restauración llevado a cabo por Wiktoria Malinska, Kazimierz Kajstura, Urszula Pielach-Gemzała y Małgorzata Dzieńdziela en el que se preveía mejorar las condiciones de aislamiento interior y realizar reparaciones puntuales en estructura y cerramientos.

Durante los periodos de lluvias habían sido detectadas humedades en las plantas sótano debido a la presencia de aguas subterráneas que se manifestaron en forma de manchas y filtraciones que llegaron a suponer una significativa amenaza para la funcionalidad del edificio debido a que en algunas salas de los sótanos se encontraban los archivos y registros del Tribunal de Justicia. ${ }^{\text {I.06 }}$

La restauración iniciada en 2013 preveía comprobar el nivel de agua y la estructura geológica del terreno y llevar a cabo un secado de los muros reforzando la impermeabilización lateral y modificación de la permeabilidad e inclinación de la acera, así como una sustitución de las capas de terreno drenante. La instalación de ventilación interior del sótano también debía ser sustituida a lo largo de los muros de sótano. ${ }^{\text {I.06 }}$

Durante la reforma se incrementó a su vez el nivel de aislamiento de los cerramientos interiores, que ya había sido suplementado anteriormente puesto que el cerramiento original era incapaz de mantener el acondicionamiento adecuado para desarrollar las funciones para las que había sido previsto el edificio. ${ }^{\text {I.06 }}$

La estructura continúa actualmente pendiente de un refuerzo en lugares puntuales como los pilares de esquina situados en la intersección de las calles Marszałkowska y Wspólna (I.03) en los cuales el desprendimiento de una parte del hormigón ha dejado descubiertas y expuestas a la oxidación una parte de las armaduras. Diferentes paneles de cerramiento a lo largo de la fachada exterior y en el patio interior del edificio también se encuentran en un estado de deterioro que hace aconsejable su restauración.
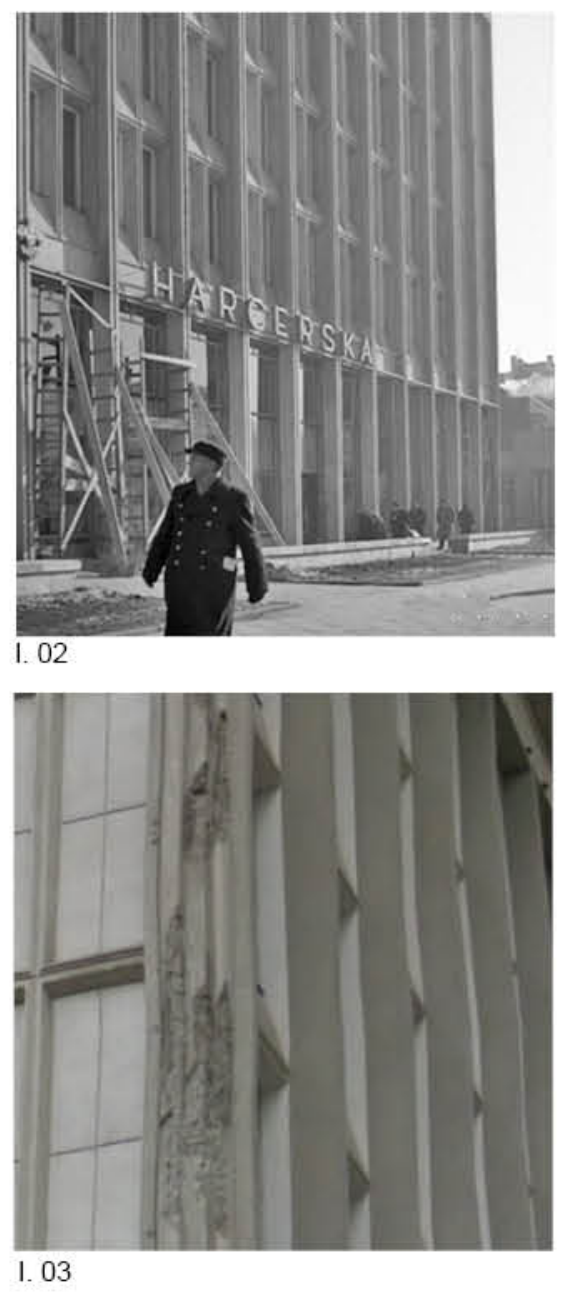

1.01. Ministerstwa Hutnictwa

1.02. NIK, Najwyższa Izba Kontroli.

1.03. Sąd Rejonowy.

1.04. Centralna Składnica Harcerska.

1.05. Związek Harcerstwa Polskiego (ZHP)

1.06. Informe oficial Budynek Sądu Rejonowego dla Warszawy-Śródmieścia przy ul. Marszałkowskiej 82 
I.04 - I.05 Edificio NIK (Najwyższa Izba Kontroli). Cámara en c/Marszałkowska no 82-84. Marek Leykam y Jerzy Hryniewiecki. Proyecto:1946 Obra 1950-52.

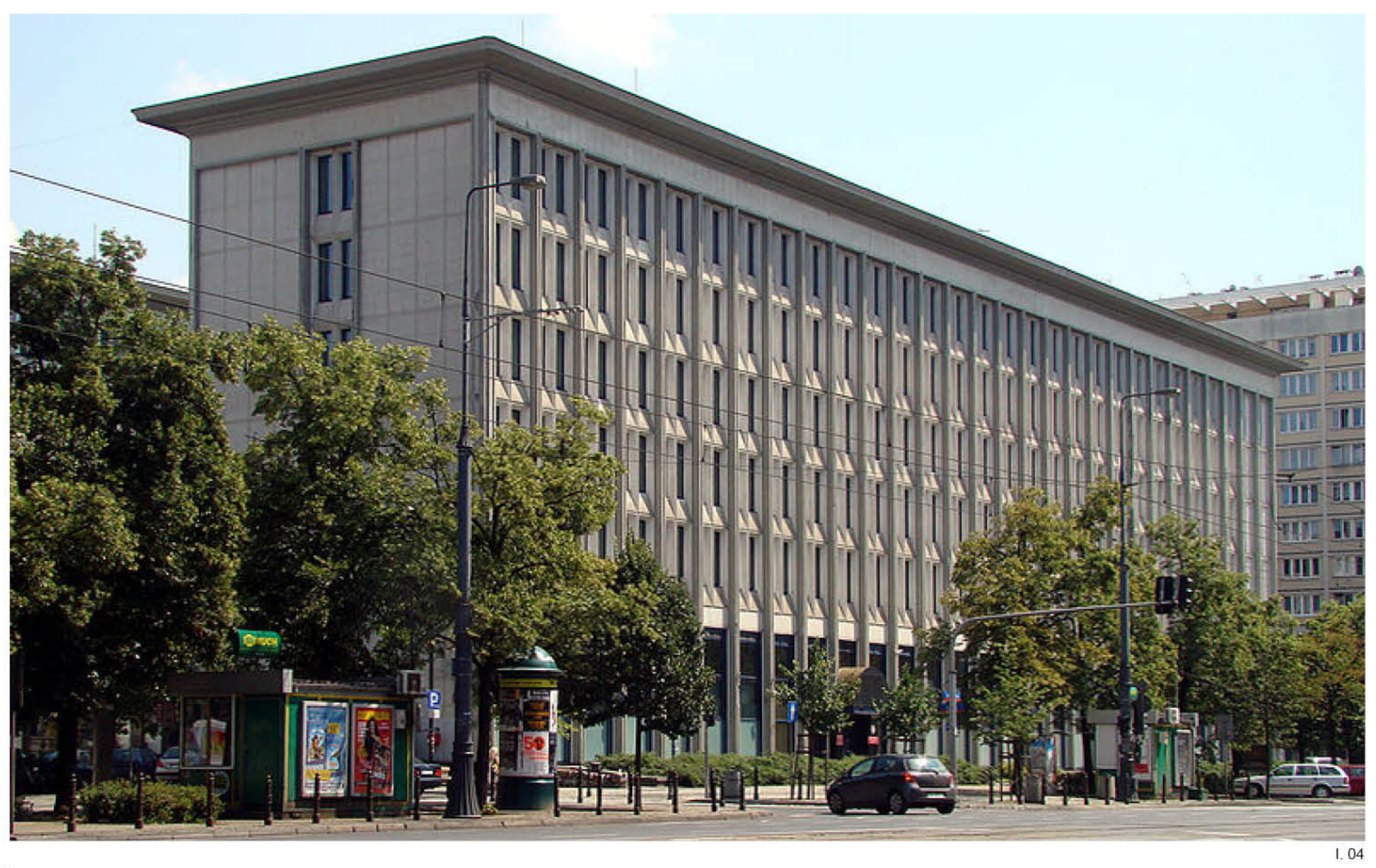




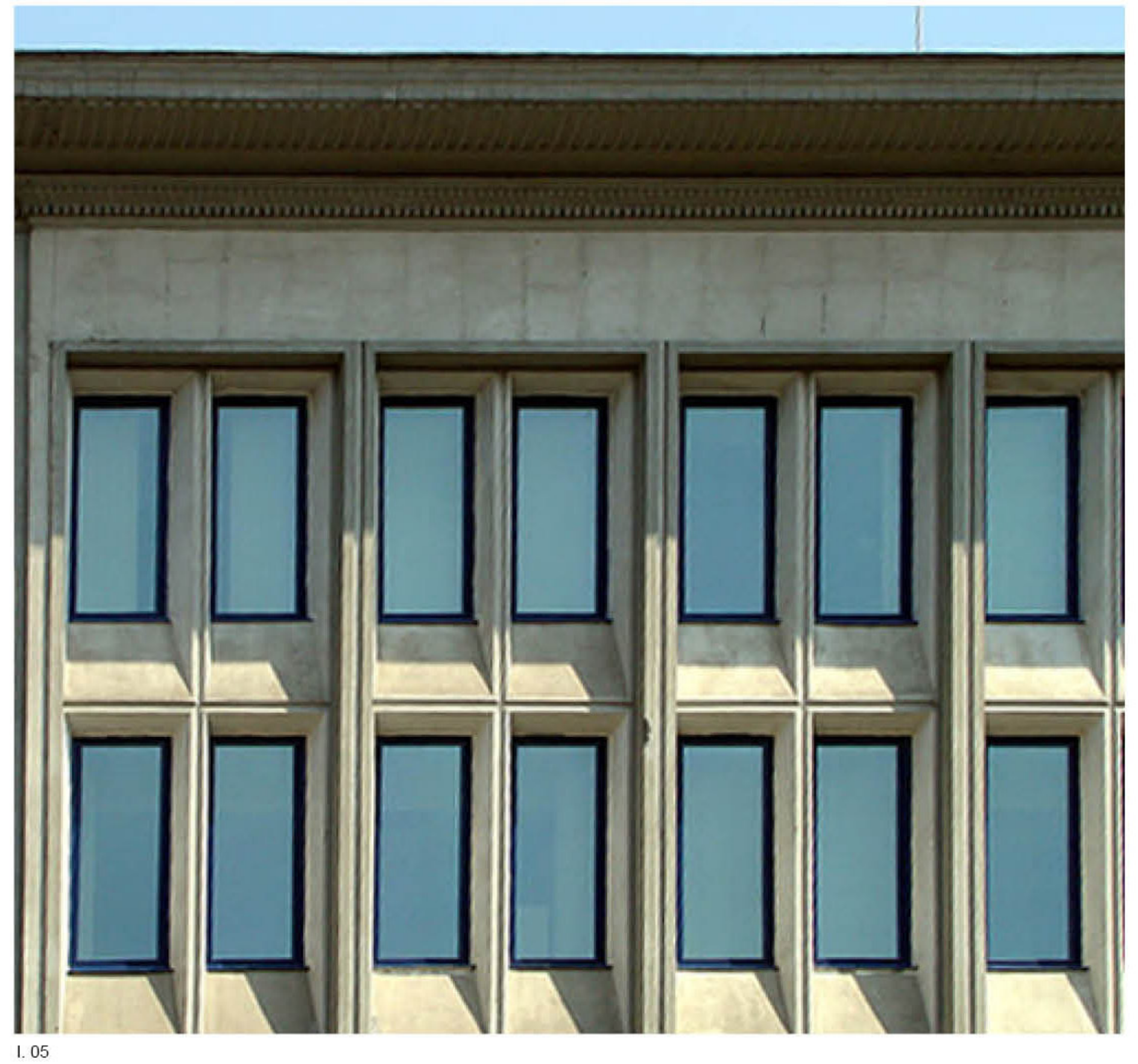


I.06 - I.08 Edificio Okraglak Poznań, 1948-54.

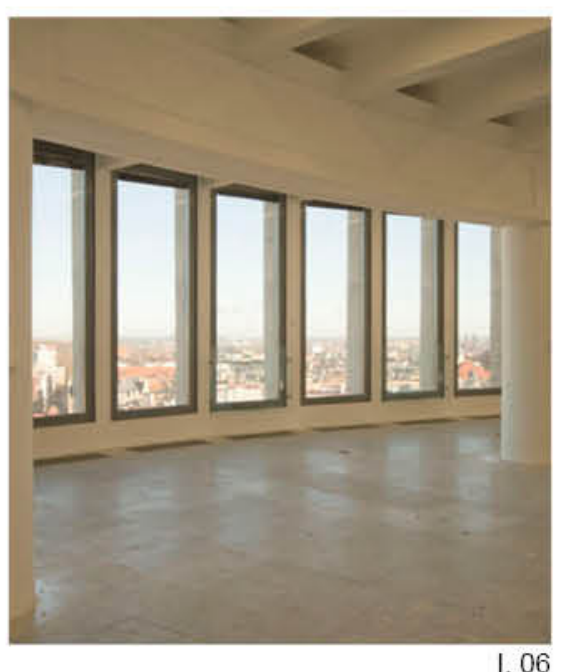

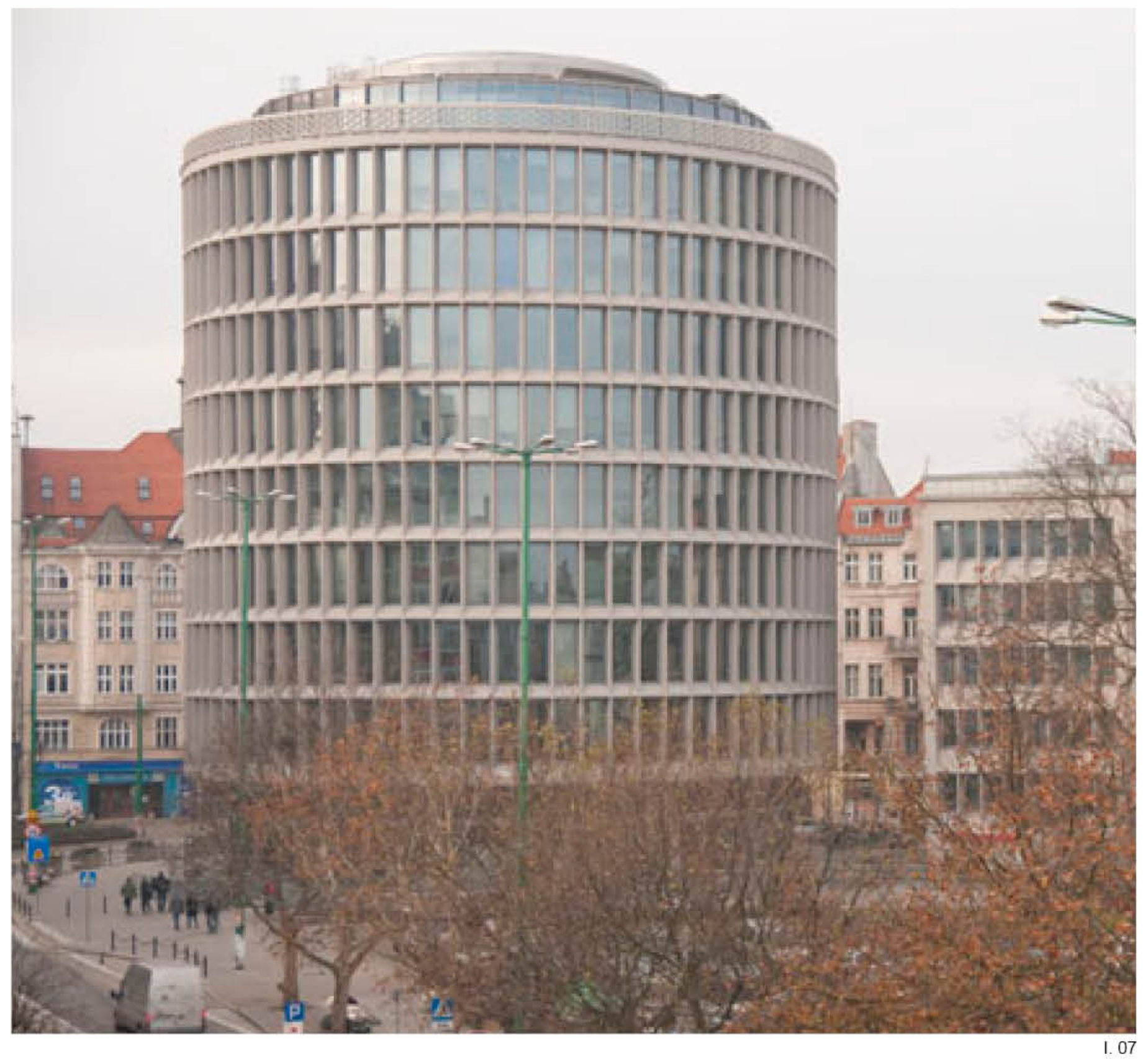


El edificio Dom Towarowy Okrąglak se encontraba en el año 2003 en estado de abandono. Oculto tras varios paneles publicitarios, su única actividad era la de un restaurante de comida rápida, una tienda de ropa de segunda mano y un club de striptease en una de las plantas superiores. ${ }^{107}$ La mayor parte del edificio estaba vacía y se habían hecho añadidos al edificio para poder desarrollar estas actividades como un núcleo de escaleras exterior que lo unía con el edificio adyacente de la calle Mielżyńskiego (llamado Kwadraciak) o una modificación del acceso que no tenían concordancia con la idea arquitectónica del proyecto original. ${ }^{\text {I.08 }}$

A finales de los años 70 se había añadido una planta más y los colores de la fachada también fueron modificados con respecto a la tonalidad original debido a las modificaciones llevadas a cabo por los propietarios del club de striptease entre 1980 y 1984 , al inicio de su actividad.

A partir de 2003 Okrąglak fue incluido en el registro de monumentos de Poznań como el primer edificio modernista de la ciudad a pesar de las protestas de la empresa propietaria del edificio, que se negaba a este reconocimiento por las obligaciones de conservación que conllevaba ser reconocido con esta distinción. ${ }^{\mathrm{I} .07}$

En el año 2005, el edificio fue galardonado con el premio de arquitectura más importante de Poznań ${ }^{\mathrm{I} .09}$, el Quadro de Oro -que debe su nombre al arquitecto renacentista Giovanni Battista Quadro ${ }^{\text {I.10 }}$-, reconociéndolo como el mejor edificio de la ciudad construido en el último medio siglo (1955-2005). La ceremonia de entrega de este premio se convirtió en un homenaje al arquitecto con la asistencia de su hijo Jan Lewinski, que recibió a título póstumo el reconocimiento a su padre. Esta distinción supuso una puesta en valor a nivel mediático del edificio Okrąglak y cambió la percepción popular sobre su importancia en los siguientes años, hasta que los propietarios decidieron venderlo a la inmobiliaria Poznań Immobel Polonia, la cual se comprometió a reformarlo según el proyecto original.

El autor del primer proyecto de restauración fue el estudio de arquitectura JEMS, pero la última versión de la adaptación del edificio comenzada en 2011 fue llevada a cabo por el equipo de RKW Rhode de Düsseldorf, uno de cuyos responsables es el arquitecto de Poznań Wojciech Grabianowski. I.11 Durante la restauración fueron demolidos los anexos añadidos durante los años 80 , incluido el nuevo núcleo de escaleras y se restituyó la uniformidad de los huecos de fachada y de las ventanas respetando los diseños originales así como el color original y el detalle de los montantes verticales y horizontales. Entre los servicios añadidos se mejoró el aislamiento y se añadió un sistema de aire acondicionado y mecanismos para la apertura de ventanas. ${ }^{\text {I.11 }}$

En la planta sótano se situaron dos niveles subterráneos en los que fue emplazado un amplio restaurante y en la planta superior se emplazó una cafetería abierta a una terraza acristalada con vistas panorámicas sobre la ciudad. En la actualidad el edificio está destinado a oficinas albergando la sede de varias corporaciones multinacionales. En el interior de Okrąglak trabajan hoy más de 800 personas. ${ }^{\text {I.11 }}$

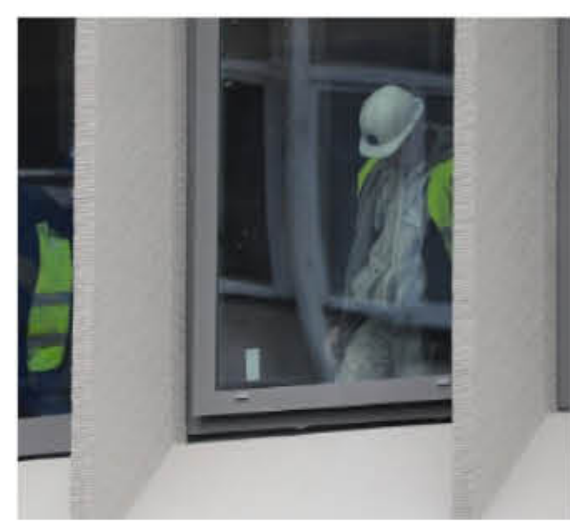

I. 08

107. Stachowiak, Marcin (2012) "Gwiazda poznańskiego modernizmu" . Fuente kulturapoznan.p

1.08. Revista Architektura, 2012. no 10 p 104.

1.09. El premio Giovanni Battista Quadro es concedido por el Consejo de Administración de la ciudad de Poznan.

I.10. El arquitecto renacentista Giovanni Battista Quadro trabajó en la ciudad entre otros edificios, en el Ayuntamiento de Poznań. Fuente: poznan.pl

1.11. Podolska, Elżbieta (2012) "Trzecie życie Okraglaka" 24/09/2012. Ref: gloswielkopolskipl 

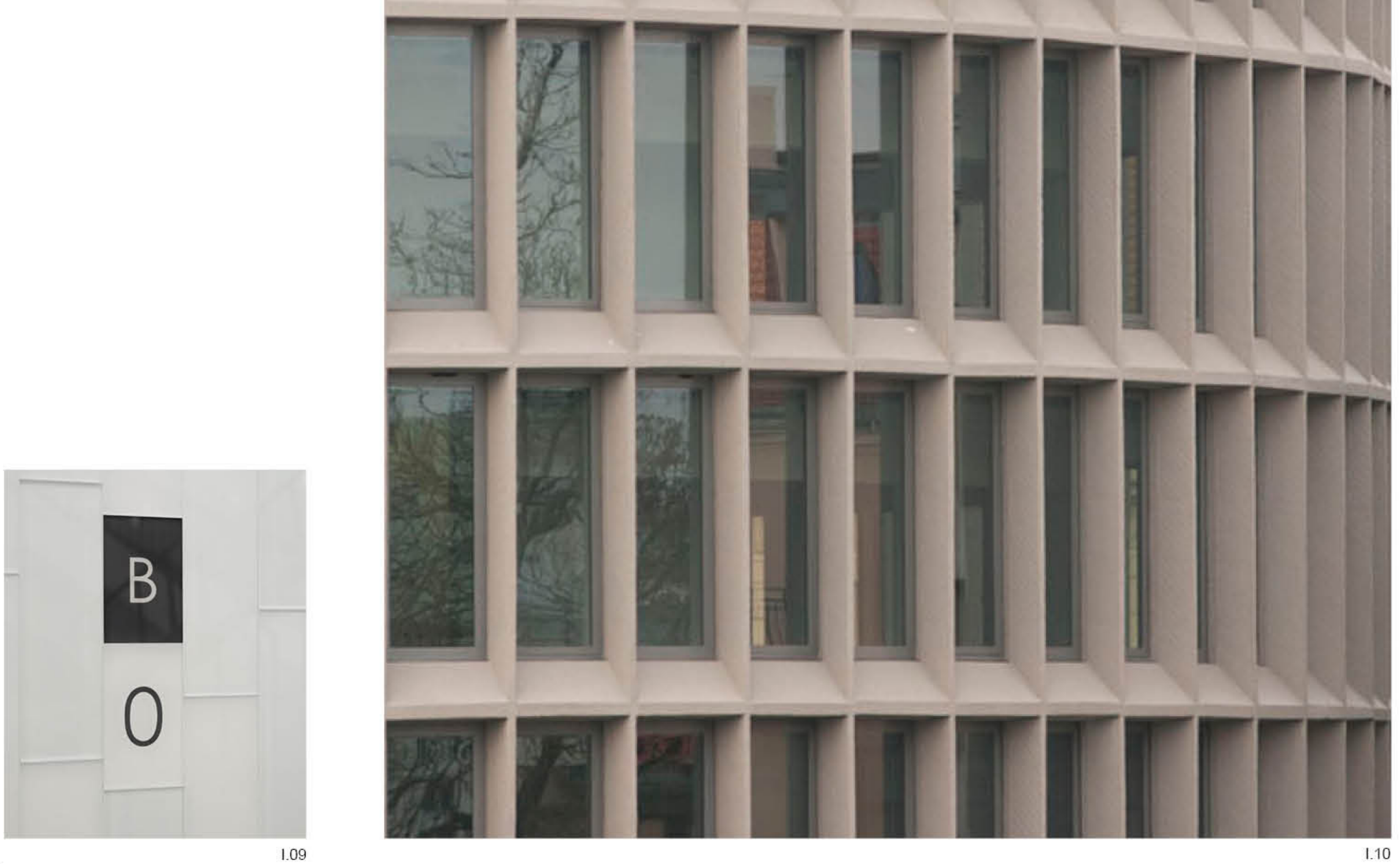

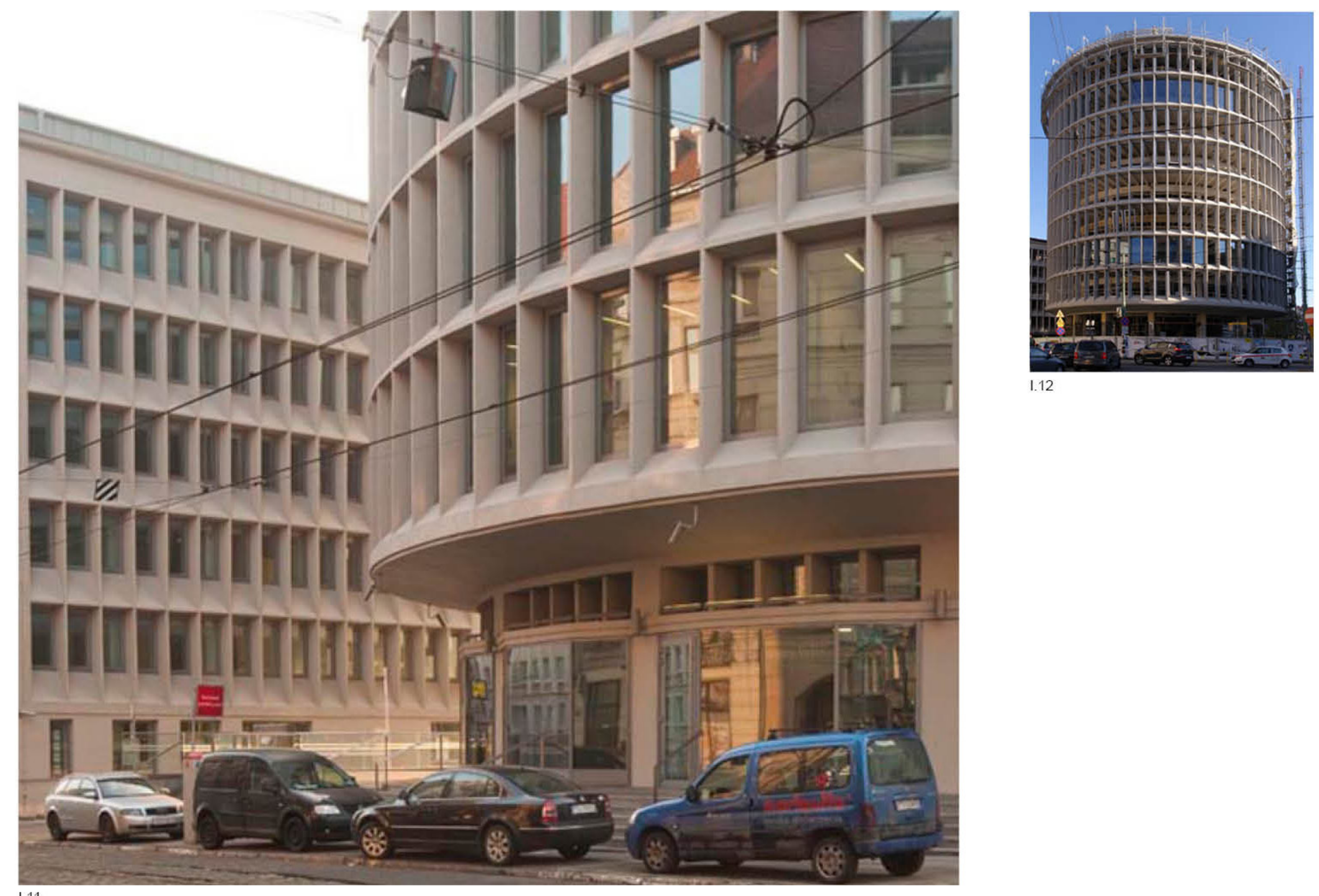
I.13 - I.14 Sede de la Presidencia del Gobierno en Primo) 1950-52. Arquitecto: Marek Leykam.
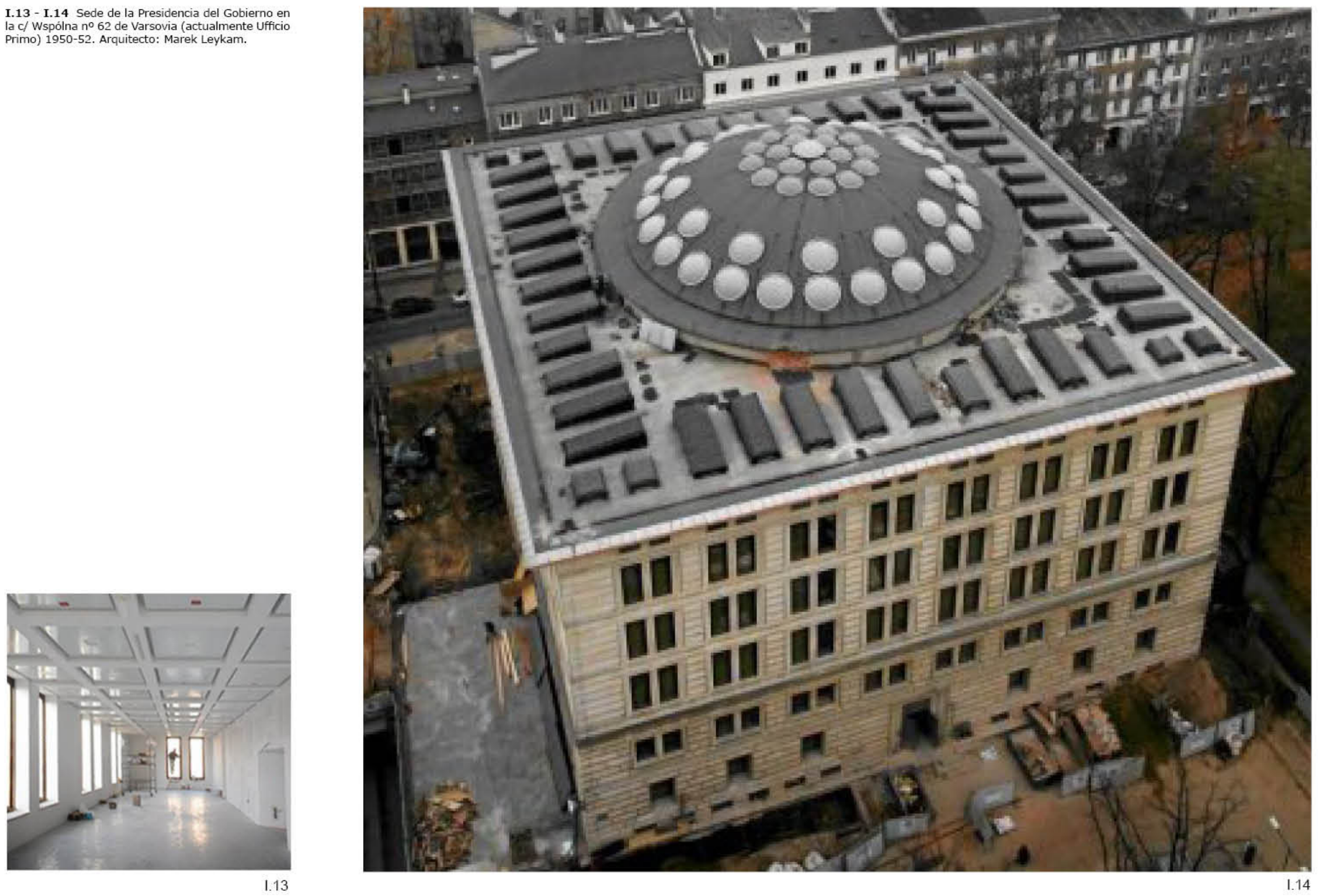
Continuando con la tendencia de recuperar y volver a poner en valor los edificios de Leykam surgida en Polonia a principios del s. XXI, entre 2010 y 2012 el inversor polaco Jan Kulczyk ${ }^{\mathrm{I} .12}$ adquirió la Sede de la Presidencia del Gobierno en la calle Wspólna $\mathrm{n}^{\circ} 62$ de Varsovia y decidió restaurarla aportando financiación a través de su grupo empresarial Kulczyk Holding con el objetivo de convertirla en una sede de oficinas para empresas dirigidas a clientes con alto poder adquisitivo. ${ }^{\text {.1.13 }}$

Desde la finalización la Sede de la Presidencia en 1952, el edificio no había recibido ninguna renovación integral y fueron muy pocas las actuaciones puntuales de mantenimiento llevadas a cabo. Al poco tiempo del finalizar la obra en 1952, el edificio dejó de ser el despacho del presidente y pasó convertirse en Sede de la Empresa Estatal de Armamento, que utilizó todo el conjunto.

En 1989 pasó a albergar oficinas destinadas al alquiler y posteriormente fue adquirido por la compañía coreana Daewoo. El auditorio de la planta sótano, con capacidad para 400 personas, fue habilitado como cine y posteriormente como sala de conferencias, tal como ocurre en la actualidad, mientras que el gran atrio de planta baja fue empleado eventualmente como restaurante y posteriormente como discoteca hasta su restauración en 2010. ${ }^{\mathrm{I} .14}$

Los trabajos de rehabilitación fueron encargados al estudio de arquitectura B'ART Pracownia Architektury Urbanistyki dirigido por Bartłomiej Bielyszew y al estudio de diseño O\&O European Design. En la primera inspección del edificio se constató que las instalaciones se encontraban en muy mal estado por la falta de mantenimiento y los materiales de mayor calidad del conjunto habían sido dañados o sustraídos en su mayor parte, por lo que se tomo la decisión de sustituirlos por completo así como realizar una renovación de todas las instalaciones, resolviendo una calefacción por suelo radiante, una instalación de aire acondicionado, nuevos ascensores y reemplazo de todos los cerramientos interiores. ${ }^{\mathrm{I} .15}$

Los espacios más representativos fueron terminados sin tener en cuenta el criterio original en mármol blanco y en su lugar se colocaron piezas de granito negro. El suelo del patio central cambió la disposición de sus piezas reconstruyendo un patrón geométrico en forma de damero que no formaba parte del proyecto original de Marek Leykam. En los baños se situó mármol de dos colores, blanco en el baño de hombres y negro en el de mujeres insistiendo en ese contraste arbitrario de color que no mantiene relación alguna con el tratamiento habitual del color ni el uso de los materiales característico de los proyectos de Leykam. ${ }^{\mathrm{I} .14}$

El patio central es utilizado en la actualidad para albergar exposiciones públicas y conciertos mientras que los corredores que lo circundan a lo largo de las diferentes plantas tienen situados en las paredes cuadros de los pintores polacos más destacados entre los que se encuentran Jan Matejko, Jacek Malczewski y Leon Wyczółkowski, siendo accesibles a clientes y visitantes eventuales. ${ }^{\text {I.14 }}$

Los propietarios del edificio han rebautizado las oficinas con el nombre de "Ufficio Primo" y se encuentran en 2015 inmersos en la tarea de conseguir que sea reconocido en el Registro Oficial de Monumentos de Polonia. ${ }^{\text {I.13 }}$
I.12. Jan Kulczyk (1950 - 2015) fue un empresario polaco originario de Bydgoszcz. En 2009, según la publicación Zygmunt Solorz-Zakla, era la persona más rica de Polonia con una fortuna estimada en 5900 millones de Złoty ( 1500 de millones de euros). Falleció en julio de 2015 en Viena.

I.13. Fuente: ufficioprimo.pl.

I.14. Entrevista con Artur Nurczewski (diseñador de O\&O European Design). Patrycja Fabiańska n⿳ 24 2012 de la revista Świat Architectury. p 23-28. 


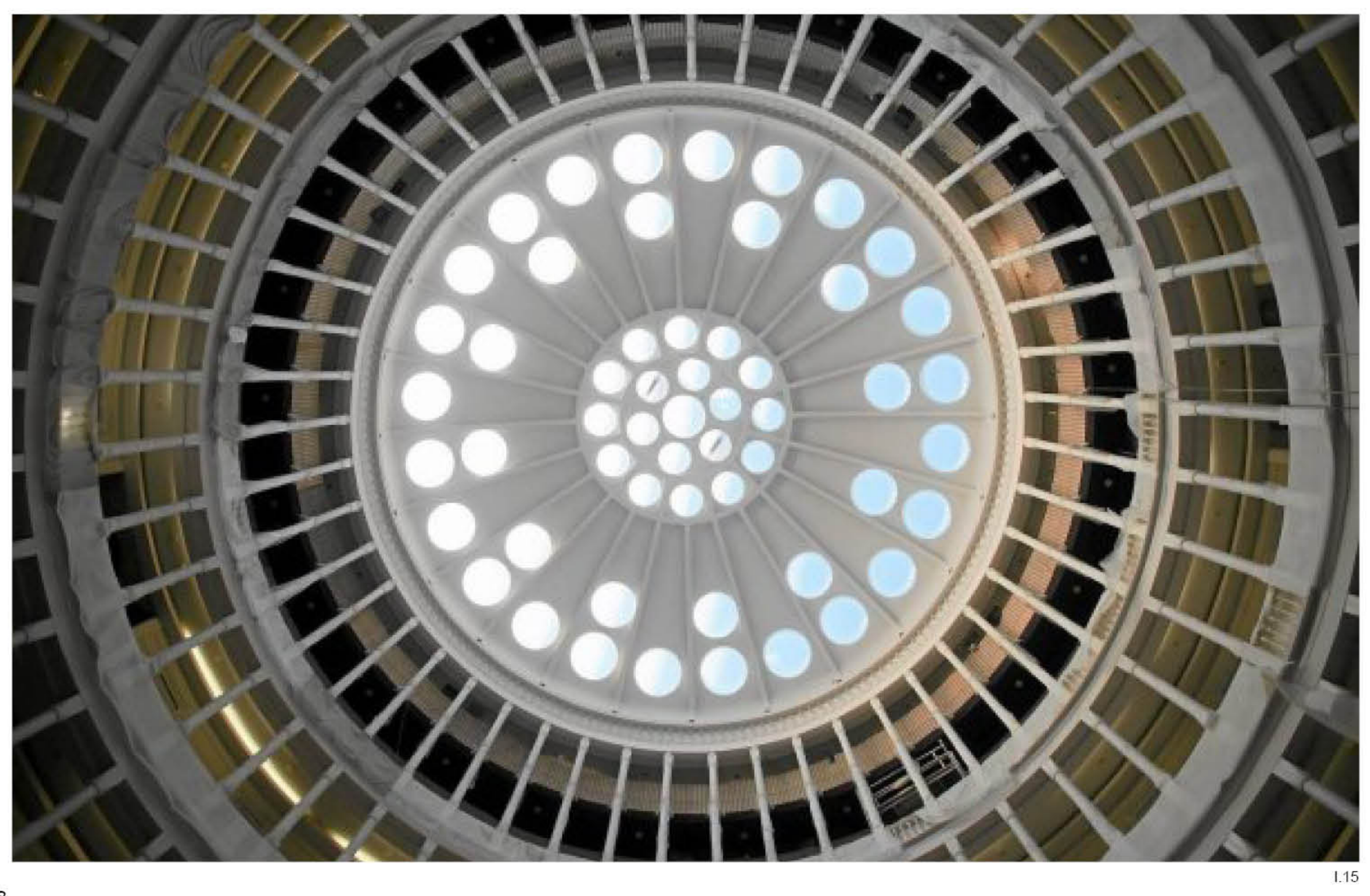




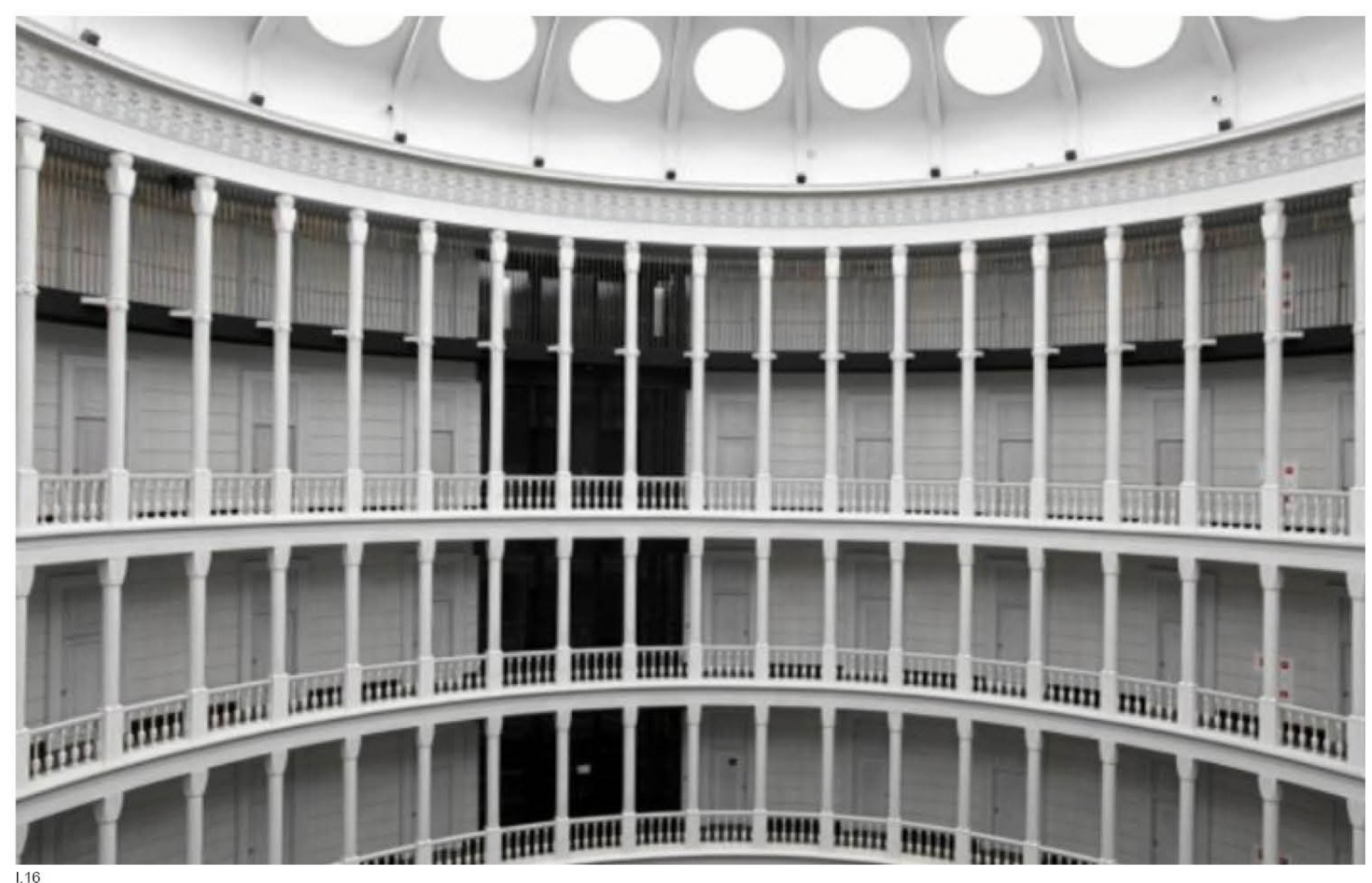


I.17 Estadio del Decenio (Stadion Dziesięciolecia) de Varsovia (junto a Jerzy Hryniewiecki y Czesław Rajewski), 1954 -55.

I.18 - I.19 Mercado "Jamark Europa" organizado por la empresa Damis en el Estadio del Decenio entre 1989 y 2007

I.20 Maqueta del Estadio Nacional de Polonia (2008-12). Arquitectos: Mariusz Rutz, Volkwin Marg, Zbigniew Pszczulny.

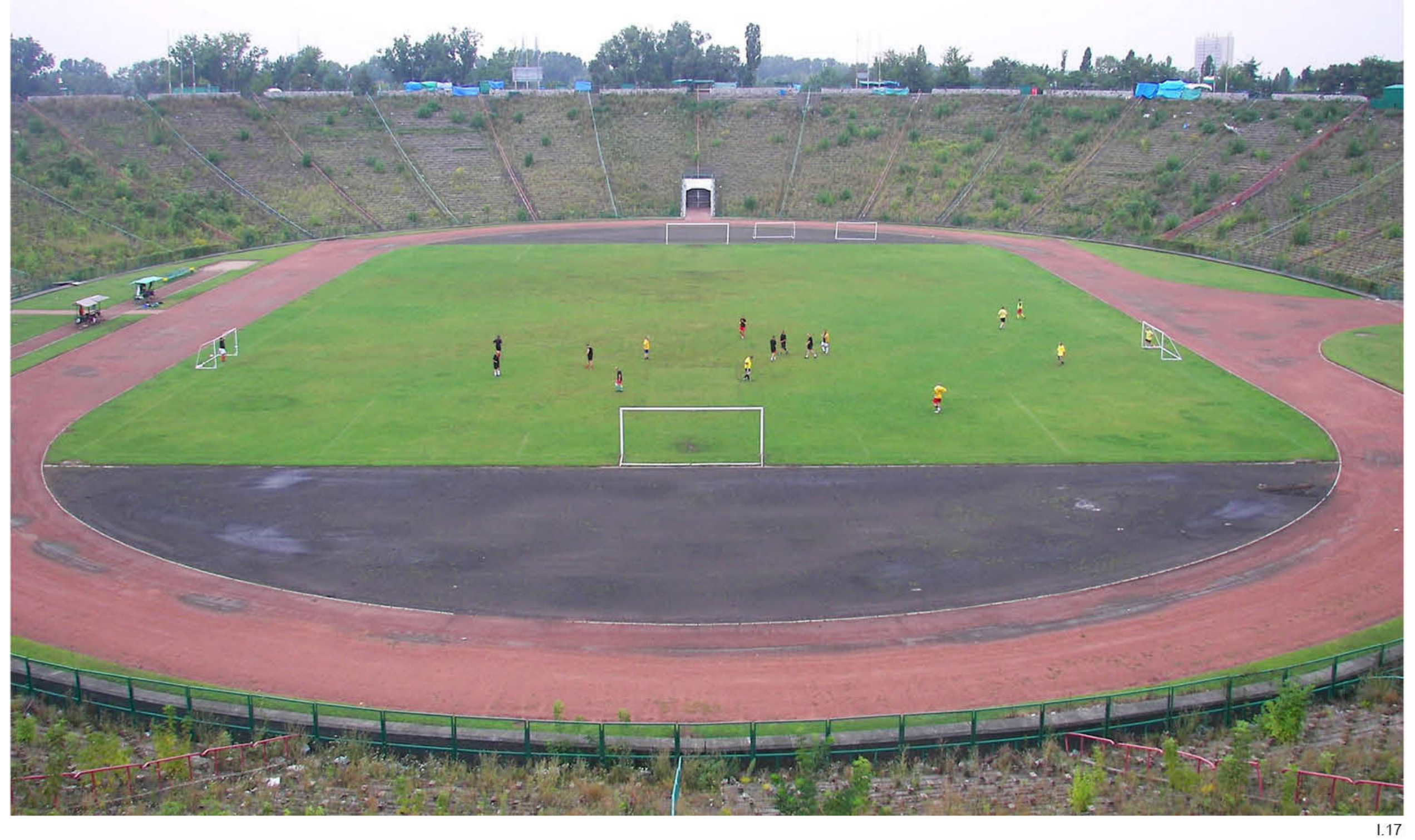


Tras la exitosa inaguración del Estadio del Decenio en el verano de 1955 albergando el V Festival Mundial de la Juventud y los Estudiantes este recinto deportivo proyectado por Leykam y Hryniewiecki se convirtió en el Estadio Nacional de Polonia y símbolo de una nueva era en la arquitectura polaca caracterizada por el fin de imposición oficial del Realismo Socialista en las construcciones promovidas por el Estado.

Durante sus primeros años fue escenario de los partidos internacionales de fútbol más importantes del país, así como competiciones de atletismo, galas del Partido Comunista, conciertos y festivales conmemorativos de diversa entidad. En 1957 albergó la última vuelta de la Carrera de la Paz ${ }^{\mathrm{I} .15}$, y en 1968, tuvo lugar en él la famosa auto inmolación de Ryszard Siwiec durante el Festival Nacional de la Cosecha (Dożynki) en protesta de la invasión de varios países firmantes del Pacto de Varsovia a Checoslovaquia. ${ }^{\text {I.16 }}$

La carencia de iluminación artificial y la ausencia de cubierta que protegiese a los espectadores de las condiciones meteorológicas adversas fueron relegando el uso del estadio. El auge de las retransmisiones televisadas fue desplazando el horarios de los eventos a franjas nocturnas y logísticamente el proyecto presentaba también problemas para la práctica ágil de las competiciones.

En deportes como el futbol, el tiempo de descanso entre cada parte, está establecido en 10 minutos, era el necesario por los jugadores para recorrer la distancia entre el centro del campo y los vestuarios. Los servicios de abastecimiento disponibles también se mostraron escasos para el número de espectadores y progresivamente el estadio fue dejando de ser utilizado.

En 1974, en la Oficina de los Proyectos de Construcción Municipales de Varsovia encargó a Jerzy Hryniewiecki el asesoramiento sobre un proyecto de equipamiento del estadio con torres de iluminación pero éste no fue realizado. En 1985 todavía Wojciech Zabłocki y Hryniewiecki intentaron crear un equipo para reformar el estadio, planteando la construcción de pabellones en la corona superior y una cobertura parcial de las tribunas con la alternativa de una cobertura total mediante una cúpula de estructura metálica.

Ninguna de estas propuestas fructificaron y en 1989 el estadio fue arrendado por el ayuntamiento de Varsovia, con fines comerciales, a la empresa Damis, que organizó en él un mercado llamado "Jamark Europa" (I.18-I.19) compuesto por más de 5.000 puestos situados en la corona del estadio. El lugar pasó a convertirse en un mercado clandestino dedicado a la venta ilegal de armas, droga y material falsificado (software, música, artículos de vestir..). ${ }^{\text {I.17 }}$

Finalmente en 2007 se decidió construir en esta ubicación el nuevo Estadio Nacional de Polonia como una de las principales sedes de la Eurocopa de Futbol de Polonia y Ucrania 2012, proyectado por los arquitectos Mariusz Rutz, Volkwin Marg, Zbigniew Pszczulny. Algunos elementos del Estadio del Decenio fueron conservados de forma simbólica y pueden ser visitados a día de hoy, como los túneles, algunas placas conmemorativas y una parte del edificio administrativo.

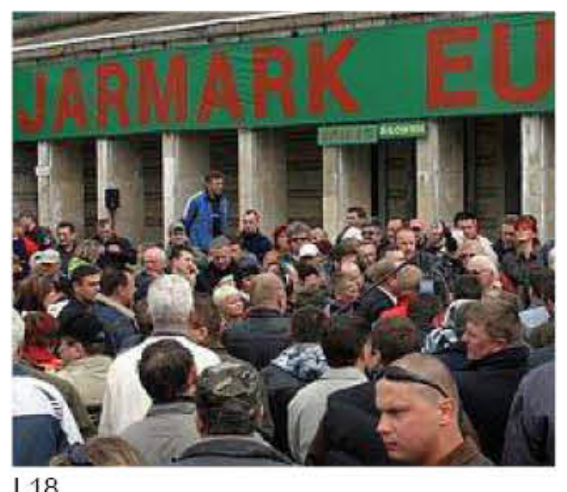

1.18

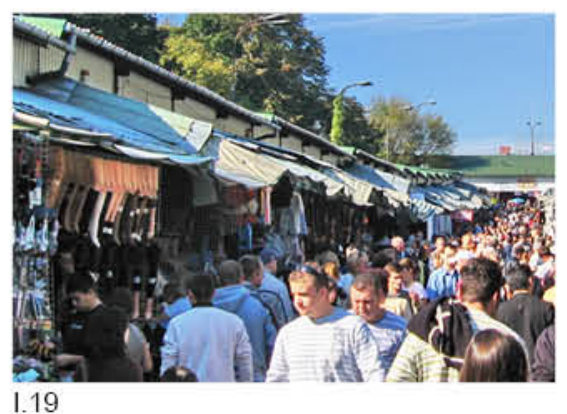
I.19

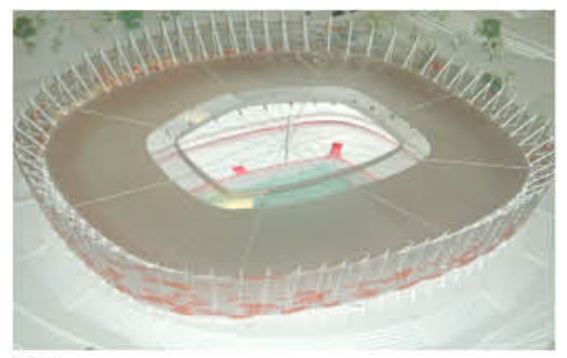

120

1.16. La Carrera de la Paz fue una competición ciclista por etapas creada en 1948 y celebrada ciclista por etapas creada en 1948 y celebrada Checoslovaquia. Fue suprimida en 2007

1.15. La invasión del Pacto de Varsovia a Checoslovaquia fue una incursión militar realizada por las tropas de cinco paises socialistas el 20-21 de agosto de 1968

I.17. Kudzia| Pawelczyk, 2001 
I.21 - I.22 Obras del Estadio Nacional de Polonia sobre el solar del antiguo Estadio del Decenio de Varsovia en 2009.

I.23 Estadio Nacional de Polonia (2008-12) de los arquitectos: Mariusz Rutz, Volkwin Marg, zbigniew Pszczulny.
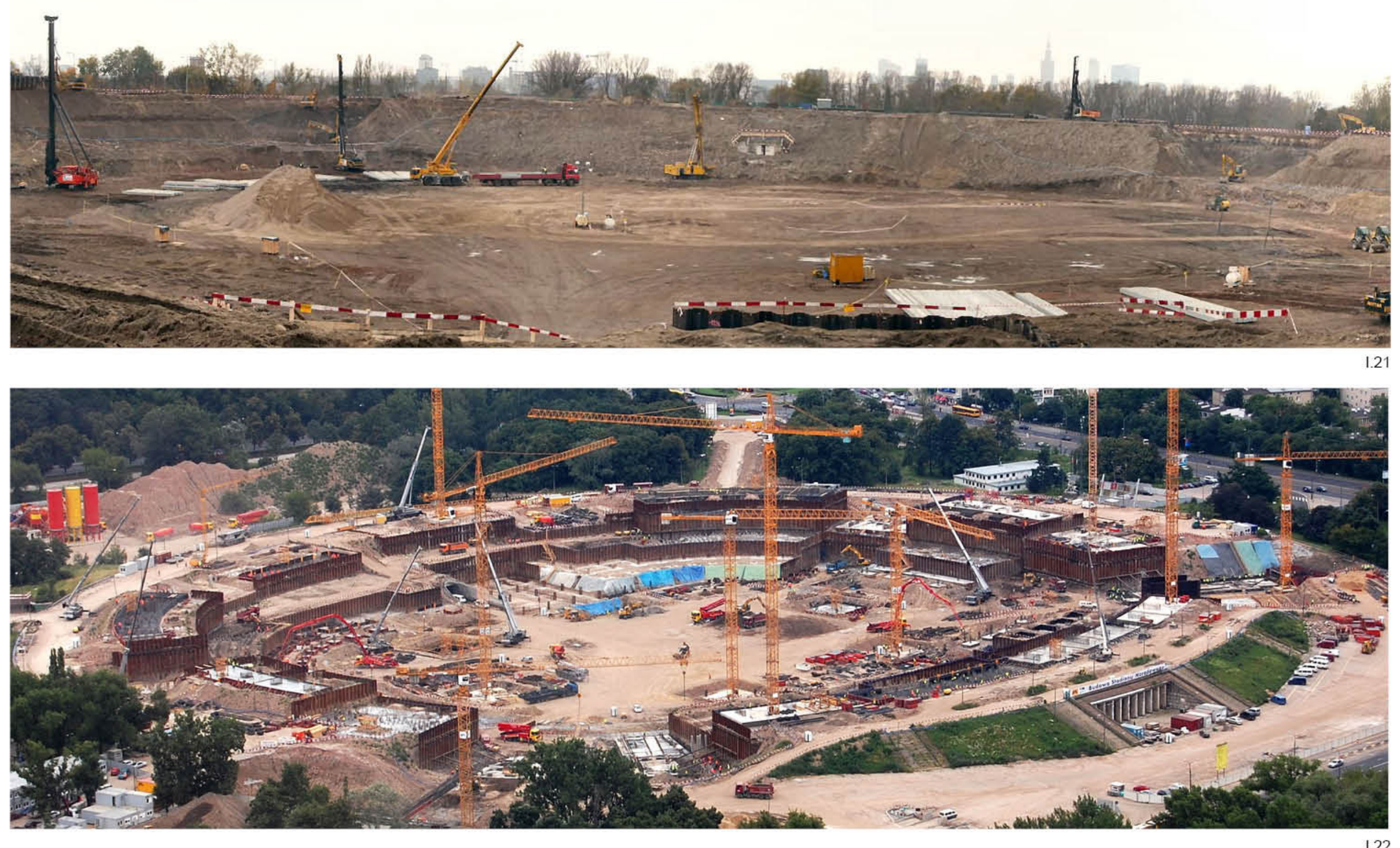


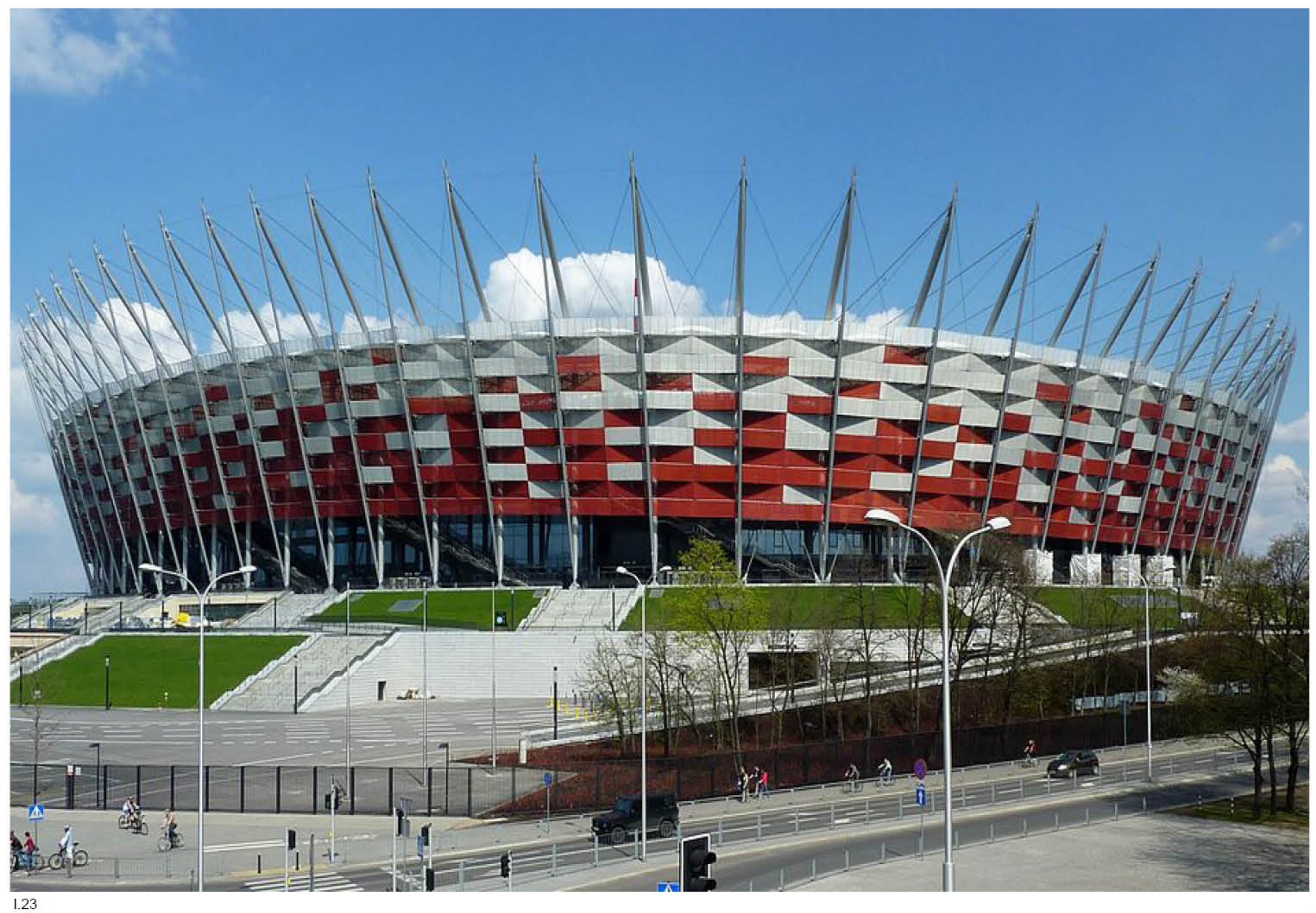




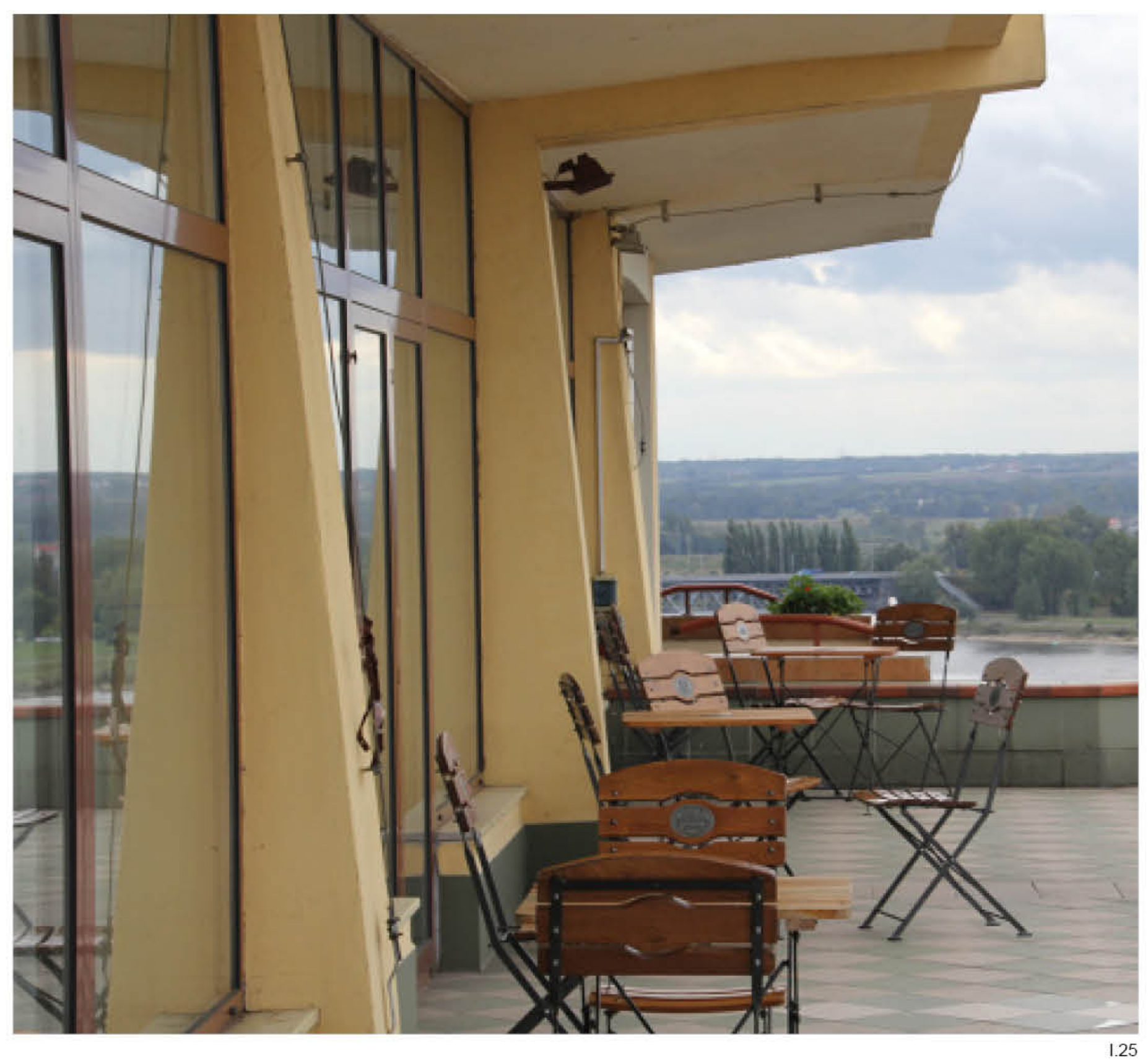


El albergue Dom PTTK Plock fue gestionado por la Asociación de Turismo de Polonia ${ }^{\mathrm{I} .18}$ desde su inaguración en 1962 hasta 1990, año en que una empresa familiar lo adquirió para convertirlo en el hotel de 2 estrellas Starex, y posteriormente tras sucesivas remodelaciones en el hotel Starzynski de 4 estrellas, que sigue funcionando a día de hoy.

De todos los edificios diseñados por Marek Leykam que continúan en pie, este es sin duda el que peor está siendo conservado, conteniendo numerosos cambios sobre el proyecto original que solo pueden ser explicados desde la ignorancia de sus soluciones o la falta de sensibilidad hacia la propuesta arquitectónica original, habiendo quedado tras diversas reformas prácticamente irreconocible.

Las fachadas exteriores han sido pintadas en dos colores, amarillo y blanco, con un criterio variable que parece hacer énfasis en destacar las esquinas del proyecto independientemente de si se han formado como consecuencia de un cambios de plano a escala de volumen o para generar el contornos de una ventana en el interior de un testero. Con esta dualidad de colores se difumina el énfasis que Leykam puso en acentuar la direccionalidad del edificio y se diluye la jerarquía de paso de los elementos de fachada, ya que la pintura modifica la percepción de los espesores reales de cada uno de los elementos y homogeiniza la visión de conjunto de los alzados sin reflexionar sobre la aportación de cada uno de ellos a las diferentes escalas en las que debía ser leída la composición.

La carpintería exterior también ha sido sustituida por un conjunto de marcos de PVC de color marrón muy alejados de la sutil esbeltez de los contornos de las ventanas originales. Frente a la fachada acristalada discurren a su vez un conjunto de bajantes que, tras pasar por delante del plano acristalado, son recogidas por un recrecido que falsea el tamaño de los elementos estructurales y genera una equívoca imagen de ménsula de carácter tectónico que modificar la lectura rítmica del proyecto y crea una idea errónea de sus necesidades portantes.

La configuración interior del hotel también ha sido modificada haciendo desaparecer la relación inicial entre estructura y cerramiento, desdibujando la importancia de los elementos tectónicos en la configuración del espacio interior e introduciendo un importante número de accidentes y singularidades que hacen irreconocible el proyecto original de Leykam también a nivel funcional.

La forma en que elementos accesorios como carteles, máquinas de aire acondicionado,.. acometen sobre la fachada tampoco ha sido integrada mostrando de forma elocuente el poco respeto que esta serie de reformas ha mostrado por el proyecto inicial, ignorando la responsabilidad social que implicaba mantener viva su memoria y dificultando para el futuro su hipotética recuperación.

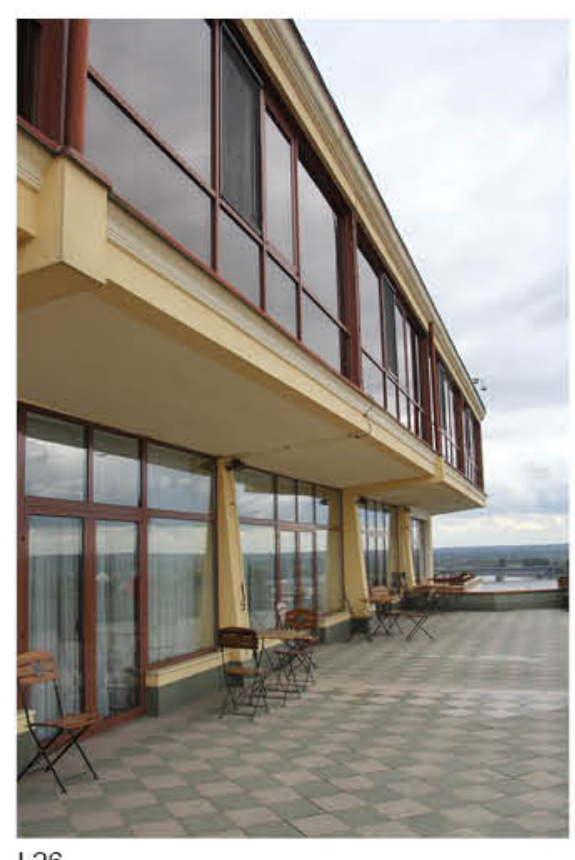

1.26

I.18. Polskie Towarzystwo Turystyczno-Krajoznawcze (PTTK) 


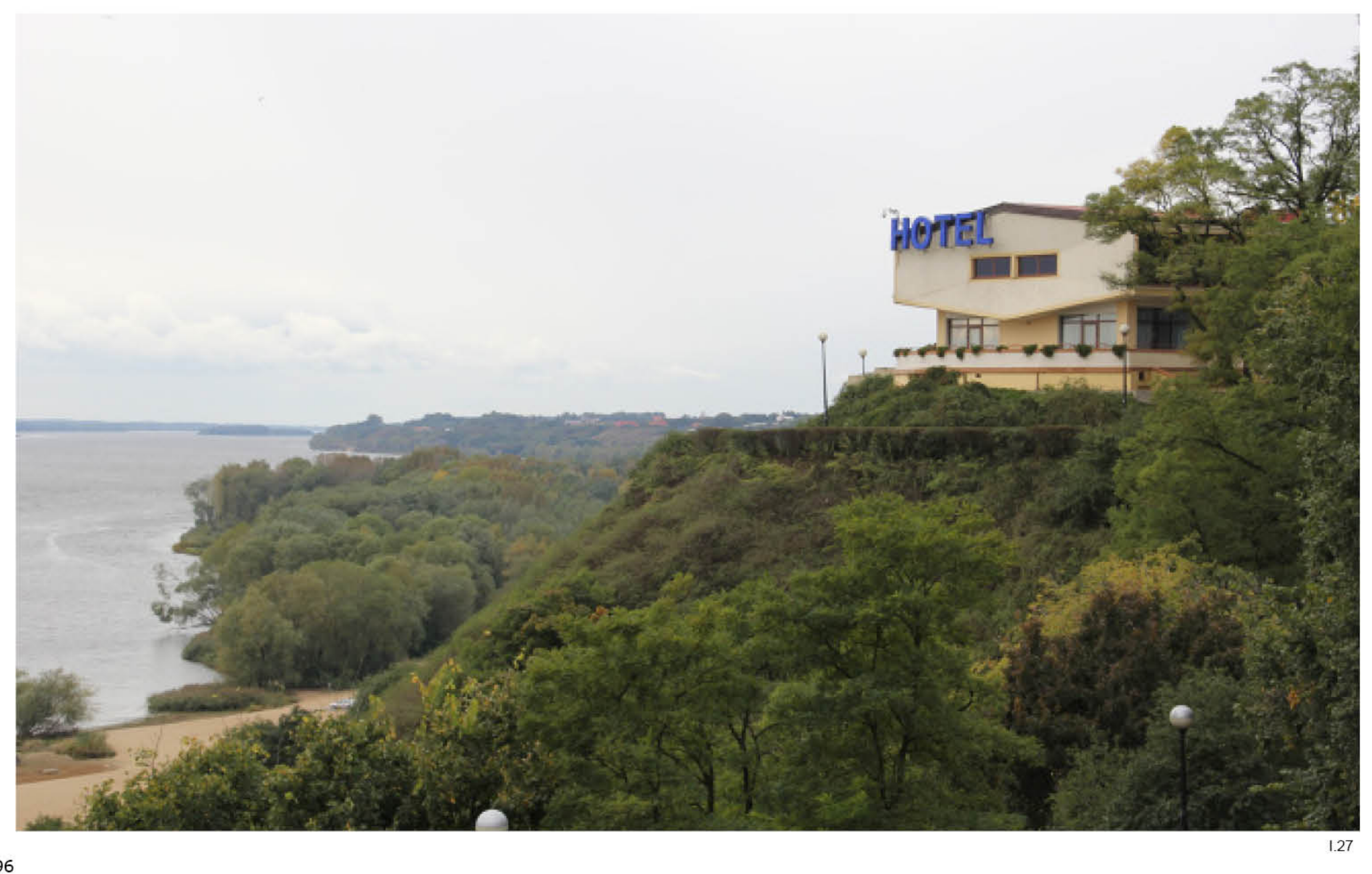




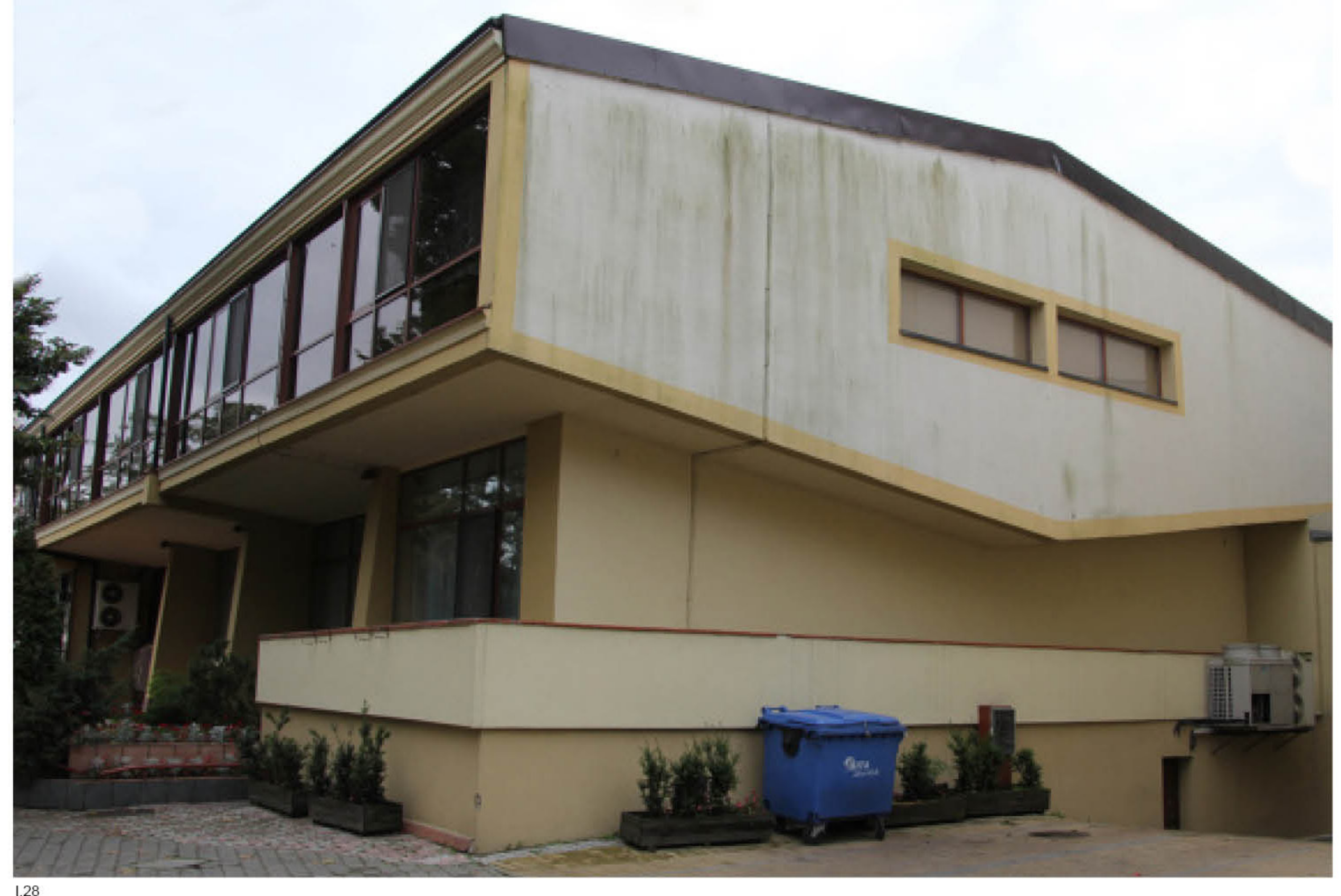




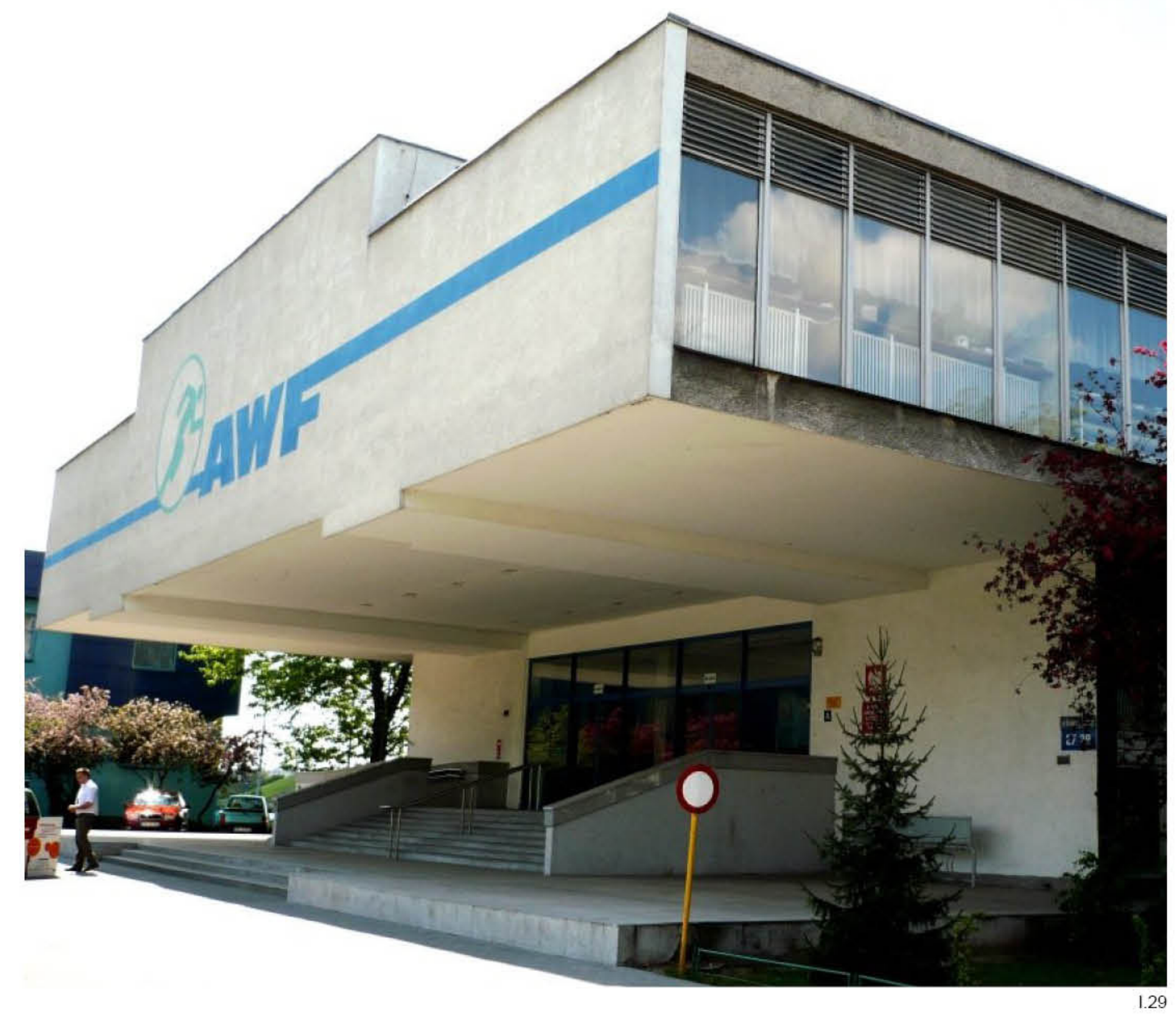


El edificio de la Academia de Educación Física en Poznań en la calle Królowej Jadwigii 29-37 continúa siendo propiedad de esta institución pública a diferencia de la mayoría de edificios de Leykam que han sido restaurados actualmente y por el momento no se han realizado significativas renovaciones en su interior desde su inaguración en 1972.

A medida que han ido surgiendo nuevas necesidades en este complejo educativo deportivo, los responsables de la Academia han continuado optando por construir nuevos edificios para satisfacerlas dentro del complejo adyacente, en lugar de optar por la modificación de este contenedor que, en la actualidad, se encuentra infrautilizado.

En 1999 el Campus de la Academia de Educación Física de Poznań ya contaba con una Casa del Alumno, un estadio de usos múltiples, una pista de atletismo olímpica y un conjunto de pistas de césped artificial así como un edificio de vestuarios y salas de gimnasio a los que se sumó en 2001 otra nueva edificación albergando una piscina de 25 metros. En 2004 se puso en funcionamiento además un nuevo edificio que albergaba la Biblioteca Central de la institución.

De la misma forma que ha ocurrido en multitud de edificios de Polonia, la presencia de cartelería y publicidad en el entorno de los edificios y a lo largo de sus fachadas está resultando altamente invasiva para la expresión de las cualidades arquitectónicas de los edificios, dando como resultado una contaminación visual que en esta obra se manifiesta en una difícil observación nítida de las principales perspectivas del edificio destinadas a ofrecer no solo una adecuada vista desde el interior sino una manifestación estética que pudiera ser contemplada desde el exterior por los visitantes y observadores ocasionales.

Como hemos podido ver la mejora de las condiciones económicas en Polonia derivó a principios del s. XXI en un mayor respeto y preocupación por el futuro de las obras de Marek Leykam. Las adecuadas propiedades mecánicas de sus edificios debido a su capacidad estructural y la resistencia de sus elementos tectónicos, así como la sencilla adaptación de sus espacios a las actividades y requerimientos del uso contemporáneo hacen que su obra esté comenzando a ser restaurada con asiduidad.

Las inversiones destinadas al efecto comienzan a ser significativas, no únicamente por el valor intrínseco de los edificios, sino por la creciente consciencia de que se trata de obras de arte que transcienden a la disciplina arquitectónica para habitar el ámbito político y social, representando la lucha de toda una generación en busca de la institucionalización de una sociedad libre y democrática en el país. Con el paso del tiempo, la obra de Leykam esta deviniendo, por tanto, en un conjunto de objetos de culto, iconos de una época caracterizada por una modesta resistencia colectiva del pueblo polaco frente a la sinrazón.

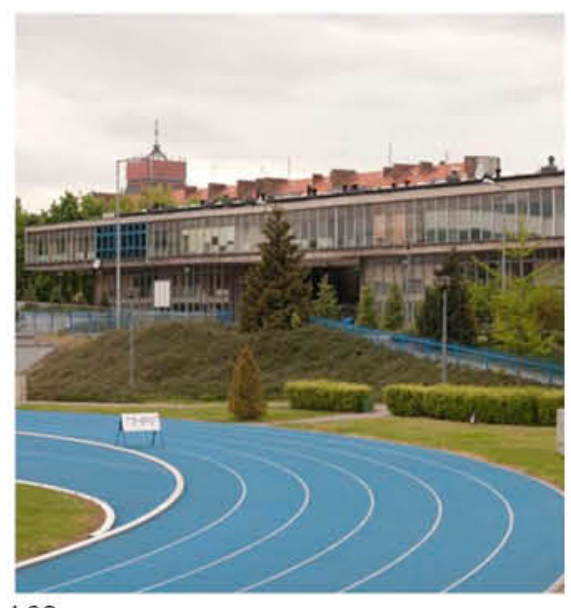




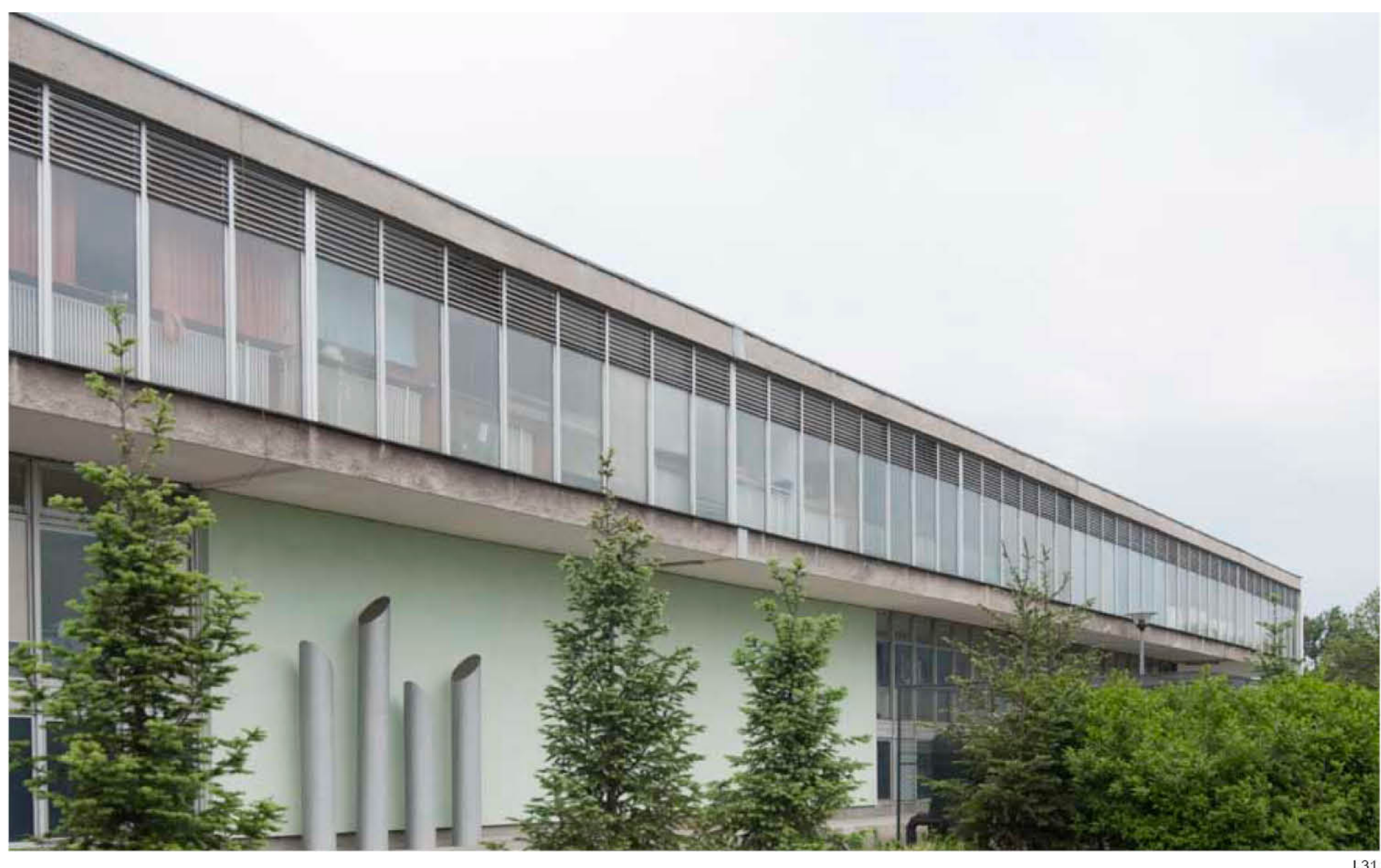




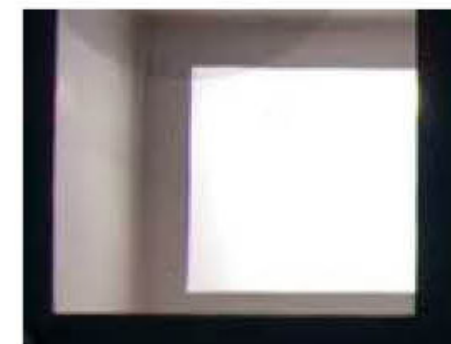

\section{Q.}
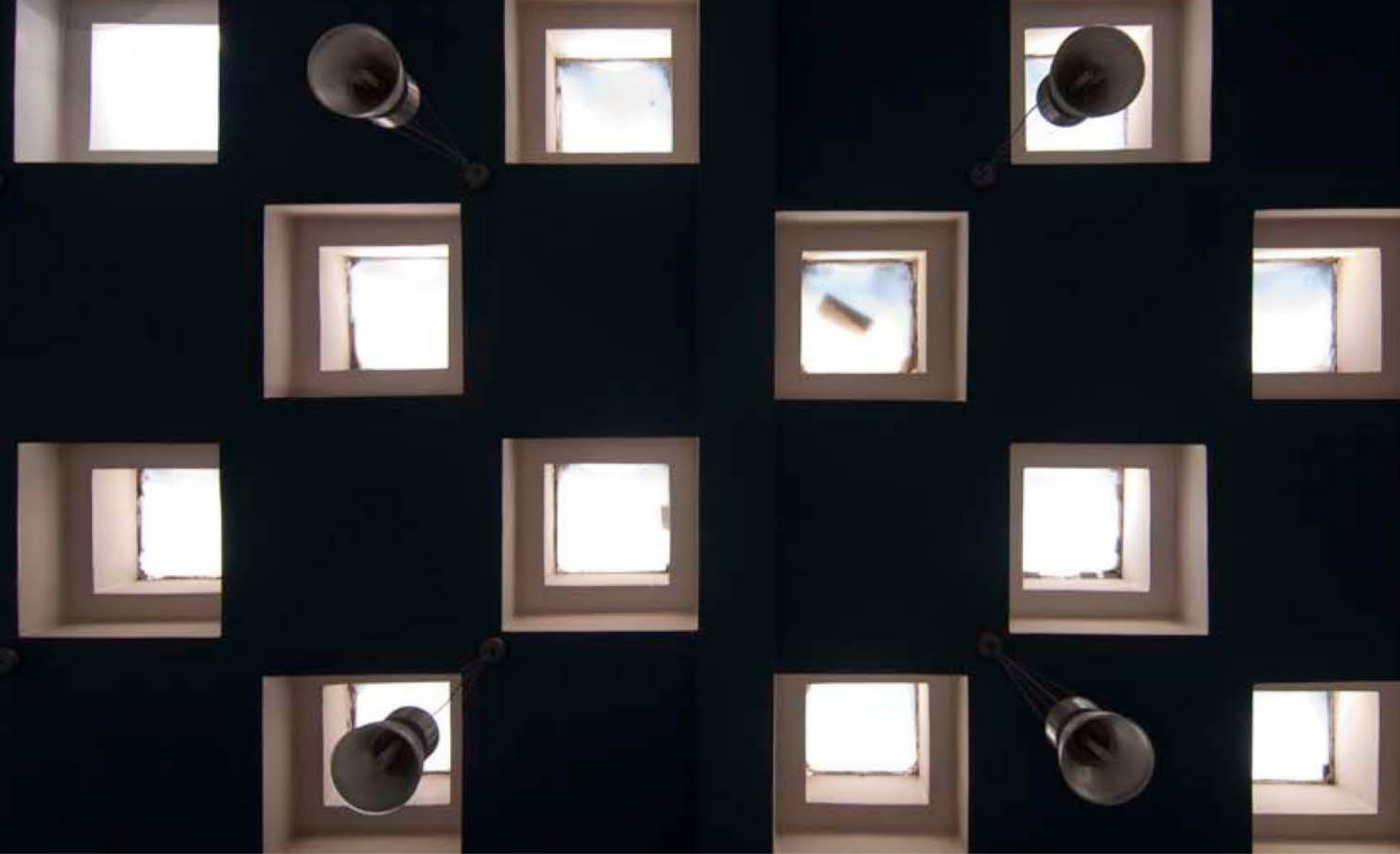

ANEXO II: LISTA DE PROYECTOS. 

Concurso organizado por BGK para la elaboración de tipologías de vivienda pequeña, 1933.

Organización del concurso de planeamiento urbano de Zułów (junto a Mieczysław Kotarbiński), 1935.

2

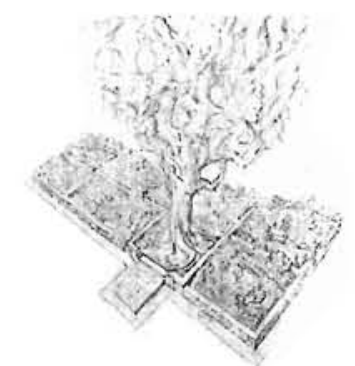

3
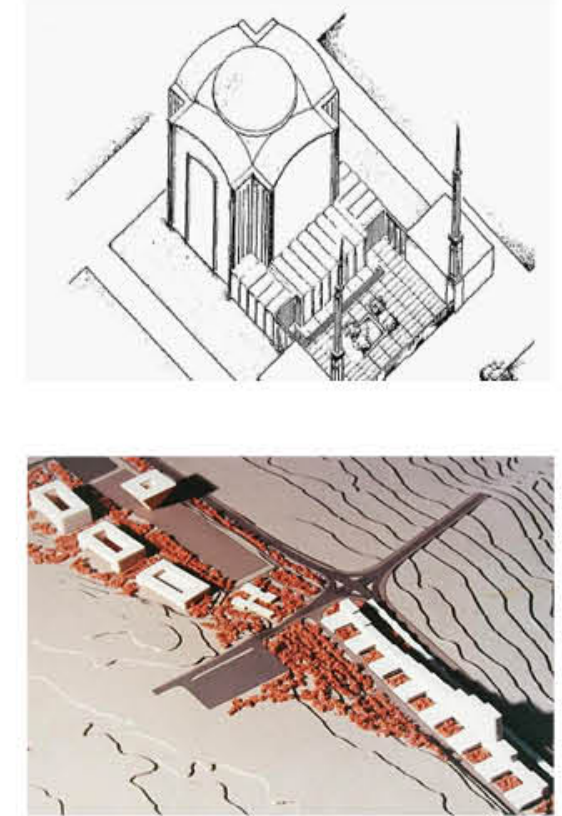

curso para la realización de la Mezquita de Varsovia, ( $2^{\circ}$ premio), 1936.
Concurso de proyectos para la realización de un Muelle y Centro de Vela en Gdynia. junto a Marian Spychalski. ( $2^{\circ}$ premio), 1937.

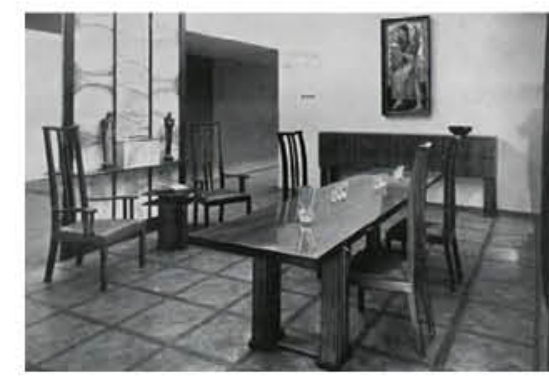

Decoración interior de una habitación en la exposición del Instituto para la promoción artística de Varsovia, 1937.

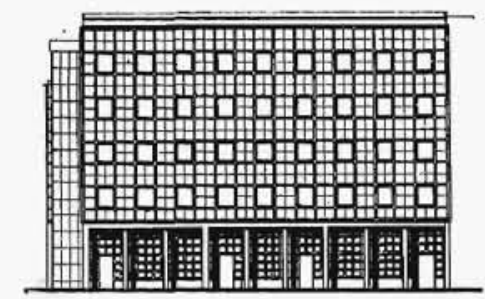

Concurso de la sede del Banco Nacional BGK en Poznań (4º premio), 1938.

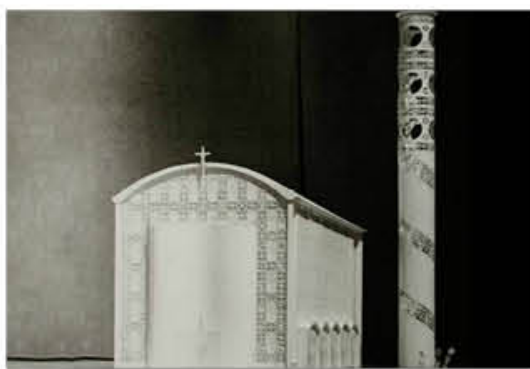

Proyecto para la realización de una capilla en honor a los soldados polacos caídos en la IIGM, en el cementerio de Solothurn (Suiza), 1943

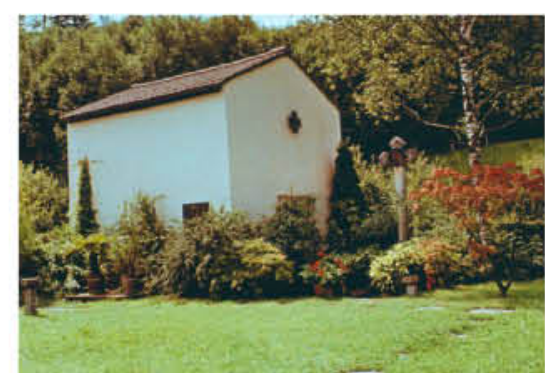

Capilla en honor a los soldados polacos caídos en la IIGM, en el cementerio de Solothurn (Suiza), 1943. 


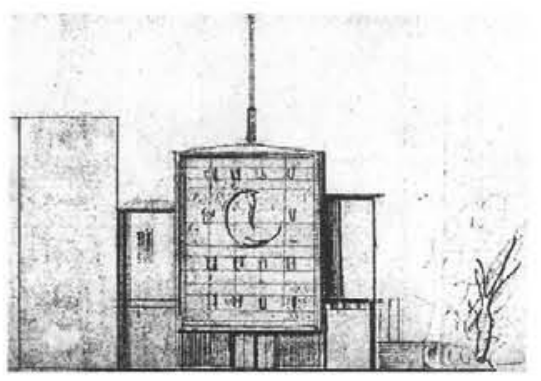

0
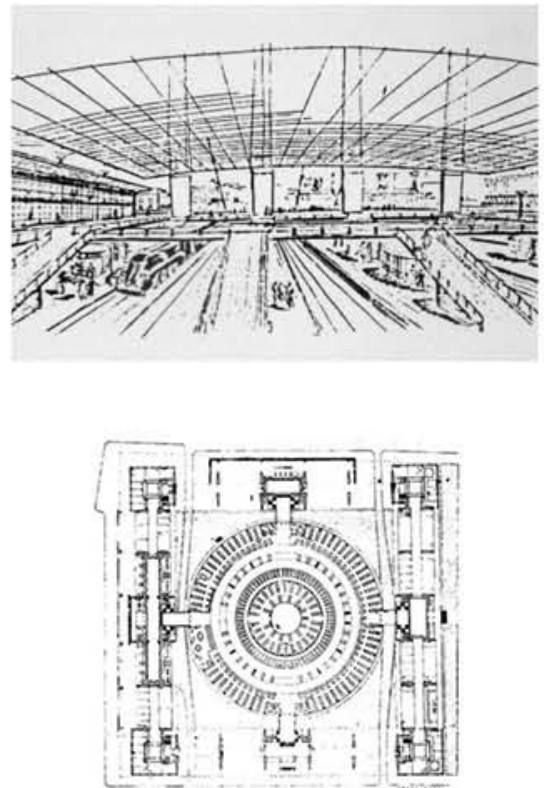

11

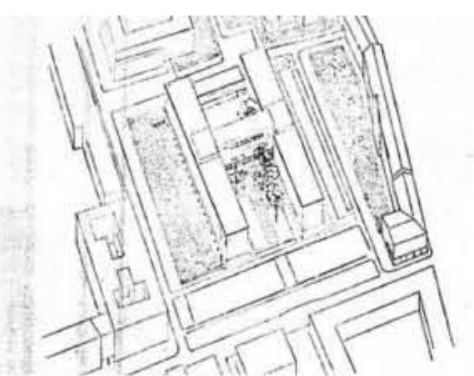

Concurso para la Iglesia del Nuevo Monasterio Dominicano de Poznań (1946). ler premio.

Concurso para la Estación Central de Tren de Varsovia (junto a Jerzy Hryniewiecki y Jerzy Staniszkis). (4 ${ }^{\circ}$ premio) 1946.

Concurso para la realización del Edificio del Banco Nacional de Polonia (NBP) en Varsovia (junto a Jerzy Staniszkis) 1947. ( $2^{\circ}$ premio)

Concurso para el edificio Ministerio de Hacienda de Varsovia (1 ${ }^{\text {a }}$ Fase), 1948.

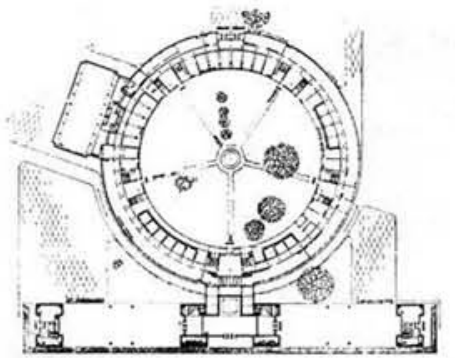

13

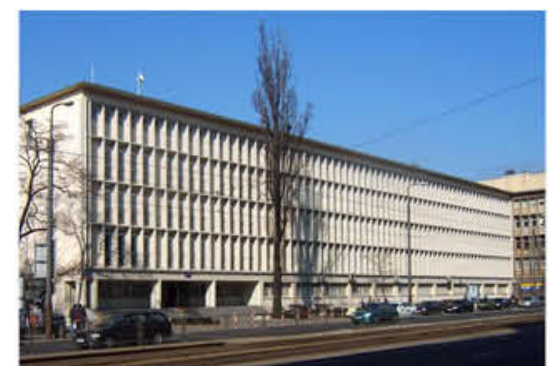

14

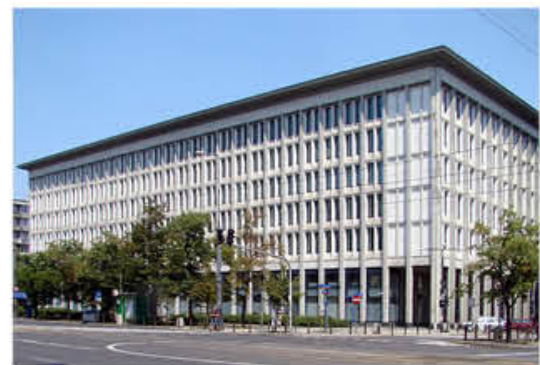

15

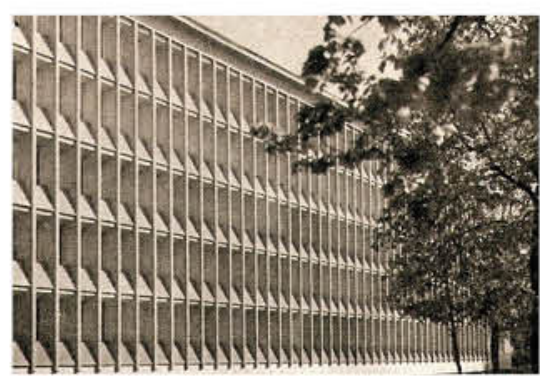

Concurso para el edificio Ministerio de Hacienda de Varsovia (2a Fase, junto a Jerzy Hryniewiecki), 1948.

Edificio de Información Militar del Ministerio de Defensa c/ Chałubińskiego 3a, Varsovia. 1946-52

Edificio NIK (Cámara Suprema de Control y Tribunal de Distrito de la Ciudad de Varsovia en c/ Marszałkowska $\mathrm{n}^{\circ} \quad 82-84$ (junto a Jerzy Hryniewiecki, proy. 1946) obra 1950-52.

Instituto Geológico de Varsovia c/ Rakowiecka $\mathrm{n}^{\circ} 4$ (junto a Czesław W. Krassowski) 1949-55. 


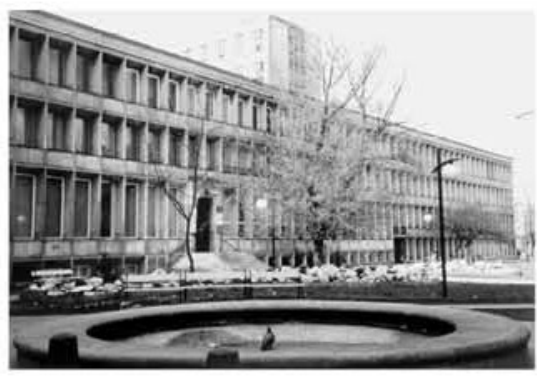

Oficina Central de Estudios y Proyectos Construcción Industrial c/ St.Barbara $n^{\circ} 1$ Varsovia (junto a Wladysław Pieńkowski) 1950-52

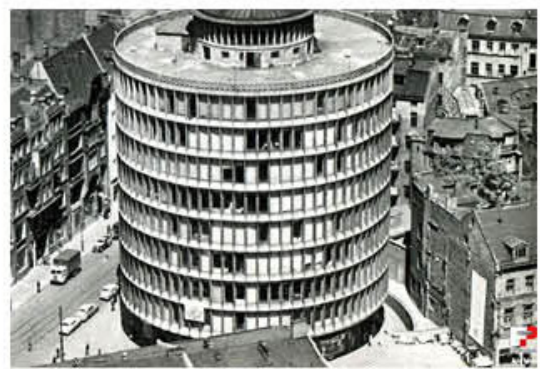

Edificio Okrąglak Poznań, 1948-54.

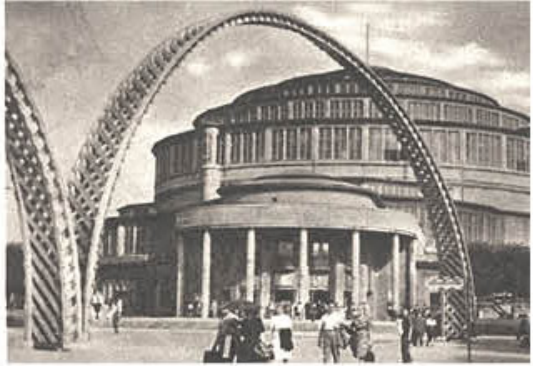

Acceso a la Exposición de Territorios Recuperados de Wroclaw, 1948.

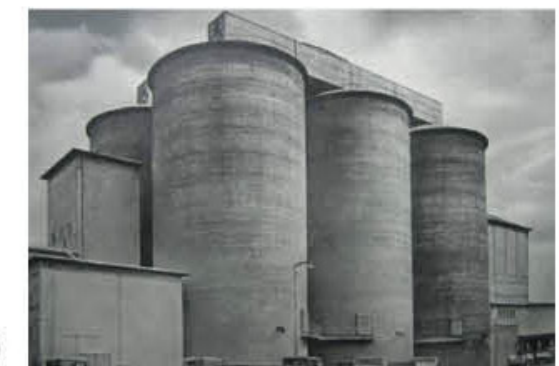

Fábrica Cementera de Varsovia, 1953-56.

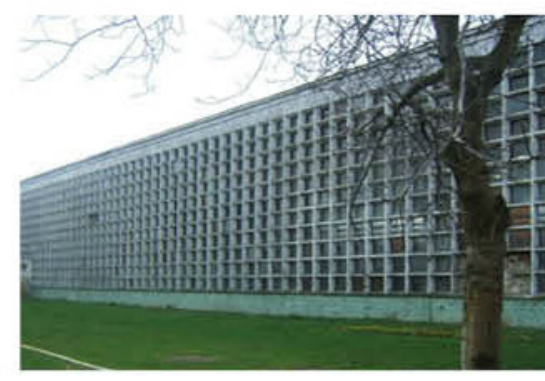

Fábrica de Camiones de Lublin, 1949-50.

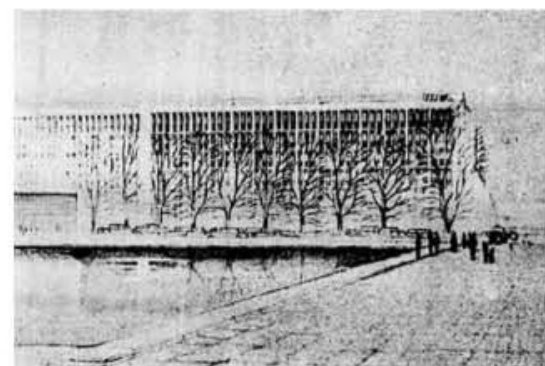

Proyecto para el Instituto General de Investigaciones Tecnológicas de Varsovia (Instytut Podstawowych Problemów Techniki), 1951

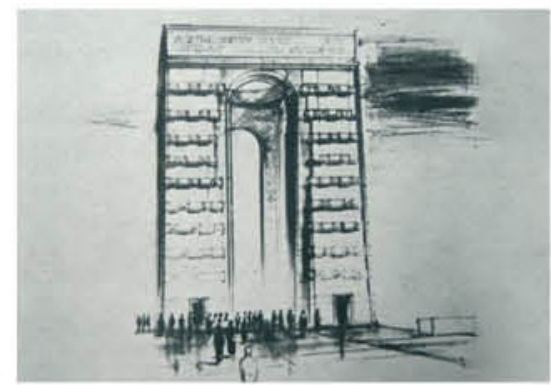

Concurso de Proyectos del Arco de Liberación (Luk Wyzwolenia) de Lublin (junto a Jerzy Hryniewiecki), 1951.

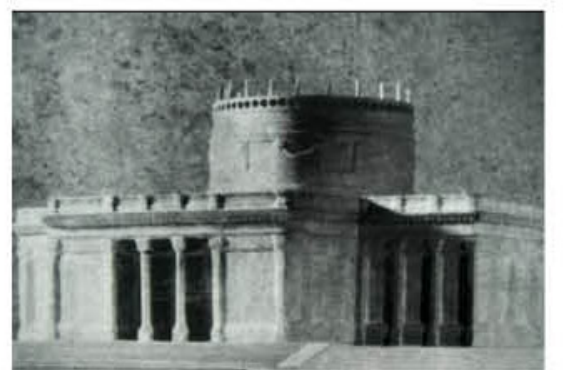

Concurso para el Pabellón de Polonia en la Exposición Agrícola de Moscú, 1951 


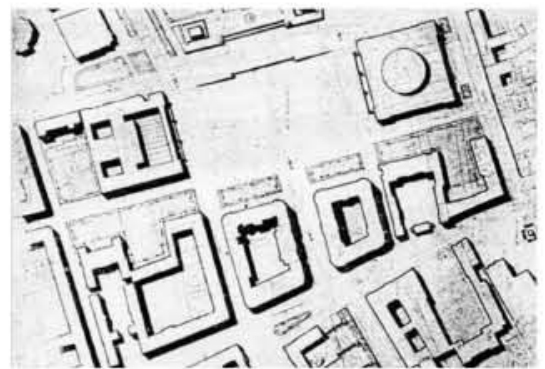

6

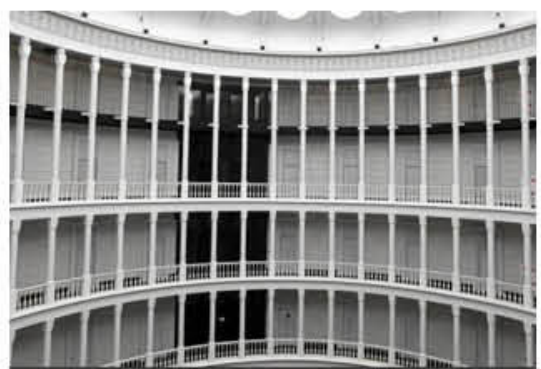

27

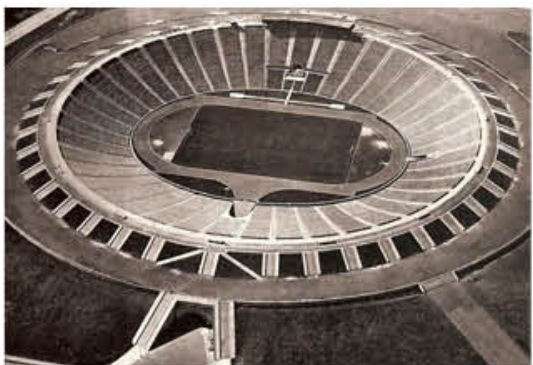

28

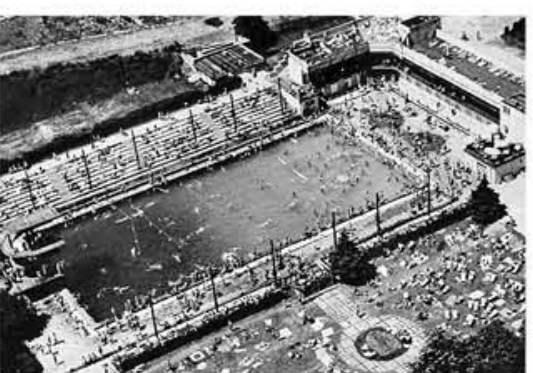

Concurso para el diseño de la Casa del Ejército polaco (Dom Wojska Polskiego) de Varsovia (junto a Bolesław Malisz y Marian Sulikowski), 1953

Sede de la Presidencia del Gobiemo en la c/ Wspólna $n^{\circ} 62$ de Varsovia (actualmente Ufficio Primo) 1952.

Estadio del Decenio (Stadion Dziesięciolecia) de Varsovia (junto a Jerzy Hryniewiecki y Czesław Rajewski), 1954 -55.

Piscinas del Club Deportivo Legia de Varsovia en la calle Czerniakowska, 3 (junto a Jerzy Hryniewieckiy Czesław Rajewski), 1956.

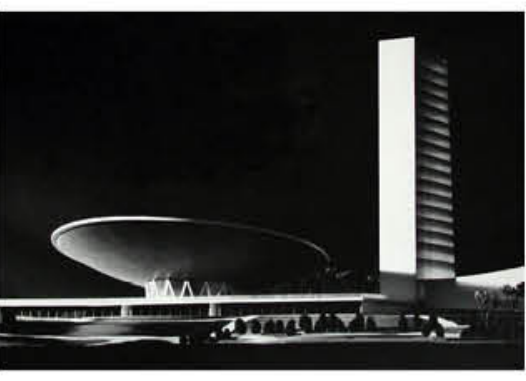

Concurso para la casa Cultura (Dom Kultury) de Lublin, 1956

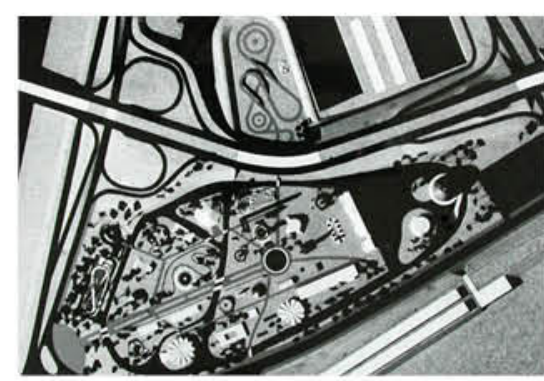

Proyecto de Parque de Atracciones de Varsovia (Wesole Miasteczko), 1957.

31

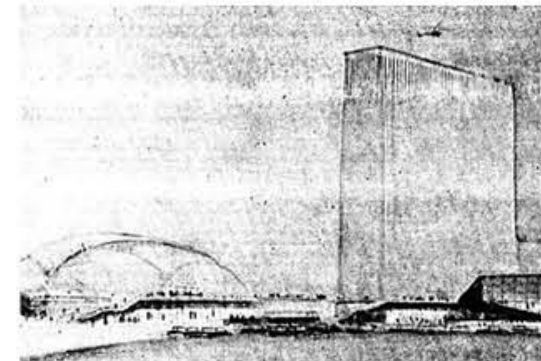

Concurso para la solución arquitectónica y urbanística de la calle Marszałkowska de Varsovia (junto a Jerzy Hryniewiecki y Czesław Rajewski), 1957.

Concurso para construcción de la Fachada Oeste (Ściana Wschodnia) de Varsovia, 1958 
33

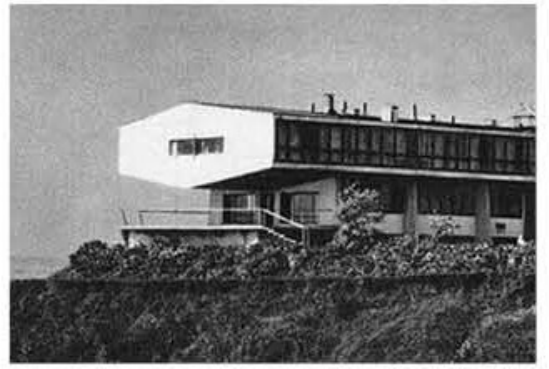

Albergue (Dom PTTK) en Plock, 1959-62

Bloque residencial en la Ronda George Washington 2b de Varsovia, 1961-63.

Escuela de Arte (Liceum Plastyczne) en Nałęczów, 1964-66.

35
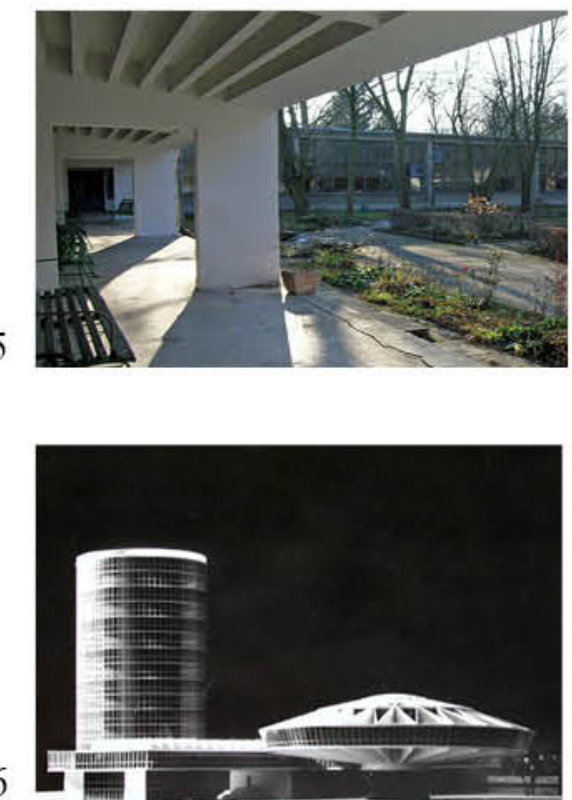

Proyecto para el Instituto de Ciencias Experimentales y Medicina Clínica (Instytut Medycyny Doświadczalnej i Klinicznej PAN), 1964

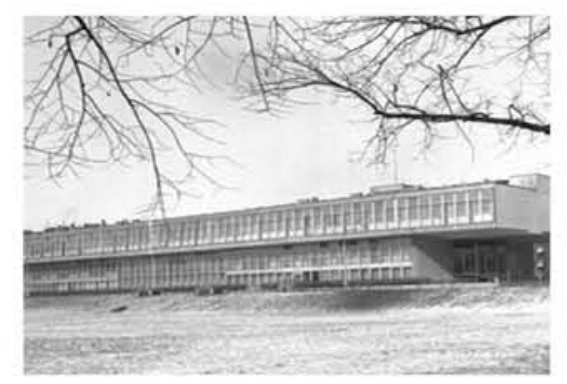

Instituto de Educación Física AWF de Poznań, 1965-72

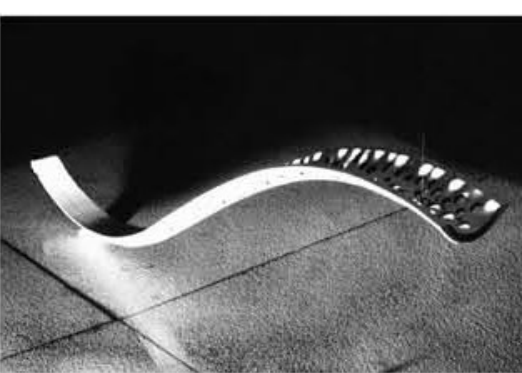

Proyecto de monumento a la Victoria (Pomnik Zwycięstwa) en el eje Saski de Varsovia, 1964

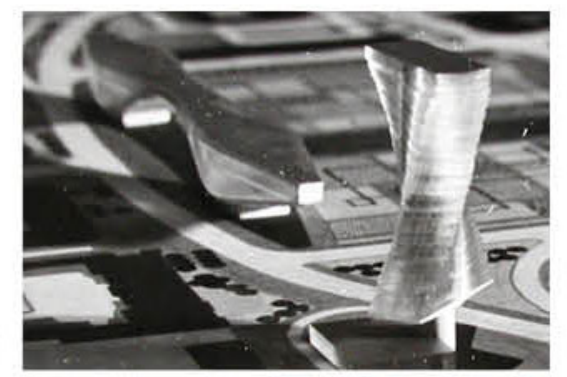

Concurso de Proyectos para el Museo de las batallas revolucionarias y libertarias (Muz. Walk Rewolucyjnych iWyzwoleńczych) Varsovia, 1967.

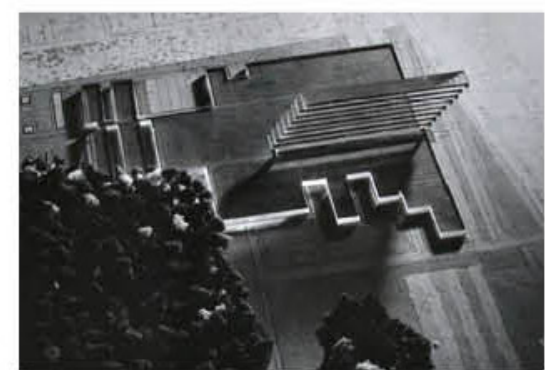

Concurso para el Centro de Salud para niños (Centrum Zdrowia Dziecka) de Anin, Varsovia, 1969. 

APPLEBAUM, Anne (1994) “El telón de acero” Debate, 2014. ISBN: 9788499923666

APPLEBAUM, Anne (2003) “Gulag” DEBOLSILLO, 2005 ISBN: 9788497937702

ARCHITEKTURA I BUDOWNICTWO 1925-39. no ISBN.

BAJTIN, Mijail (1989) "Las formas del tiempo y del cronotopo en la novela". Ed. Taurus, Madrid: Taurus, 1989. ISBN: 84-306-2194-6.

BARANOWICZ, Zofia (1979) “Polska awangarda artystyczna 1918-1939”. Wydawnictwa Artystyczne i Filmowe ISBN: 83-221-0074-4.

BARK, Dennis | GRESS, David (1989) “A History of West Germany Vol 1: From Shadow to Substance, 1945-1963” Blackwell Publishers, 1989. ISBN: 978-0631167877.

BARUCKI, Tadeusz (1980) “Maciej Nowicki” Wydawnictwo Arkady, Warszawa, 1980, ISBN 83-213-2945-4.

BARUCKI, Tadeusz (2000) "Fragmenty stuletniej historii 1899-1999. Relacje, wspomnienia, refleksje." SARP Warszawa 2000 ISBN: 83-901976-6-9.

BARUCKI, Tadeusz (2012) “Marek Leykam 1908-1983” sarp.warszawa.pl. no ISBN.

BARUCKI, Tadeusz (2013) "Polski watek z życia Oscara Niemeyera”. Fuente: ARCH\#16 / archsarp.pl. 24 Octubre 2013 No ISBN.

BARUCKI, Tadeusz (2014) “Architektura wojny 1939-1945” sarp.warszawa.pl. no ISBN.

BAYER, Stanisław (1985) "Slużba zdrowia Warszawy w walce z okupantem 1939-1945" Wydawnictwo Ministerstwa Obrony Narodowej ISBN: 83-11-07170-5. 
BENEVOLO, Leonardo (2002) "Historia de la arquitectura moderna" 8a edición. Editorial Gustavo Gili, SA. Barcelona, 2002. ISBN: 84-252-1793-8.

BENNETT, David (1999) “The Creation of Bridges” Secaucus: Chartwell Books. ISBN: 0-7858-1053-6.

BENJAMIN, Walter (2003) "La obra de arte en la época de su reproductibilidad técnica". Ed: ITACA, 2003. ISBN: 9687943483.

BERNHARDT, Maciej (2009) "Szkoła Wawelberga i Politechnika Warszawska w latach 1940-1944” Art. "Histmag.org” 8 Marzo 2009. no ISBN.

BIEŃKOWSKI, Stefan (2013) "Dom Turysty PTTK Płock” Ed. Powojenny Modernizm, 2013. No ISBN.

BŁAŻYŃSKI, Zbigniew (2012) “Mówi Józef Światło. Za kulisami bezpieki i partii 1940-1955.” Editorial LTW Rok wydania: 2012. ISBN: 978-83-7565-228-4.

BLOK n 1-11 (1924-1926). Revistas consultadas directamente del original. no ISBN

BORKIEWICZ, Adam (1957) "Powstanie Warszawskie 1944" Warsaw: PAX no ISBN.

BRITTON, Karla, (2001). “Auguste Perret”. Phaidon. Londres, 2001. ISBN: 0714840432.

BUKOWSKI, Marcin (1985) "Wroclaw z lat 1945-1952: Zniszczenia i dzielo odbudowy” Państwowe Wydawnictwo Naukowe, 1985 ISBN: 8301058498

CALATRAVA ESCOBAR, JuanA(1991) “Arquitectura y naturaleza. El mito de la cabaña primitiva en la teoría arquitectónica de la Ilustración” G.Antrop.8, A.09, 1991. ISSN: 0214-7564.

CEAC (1982) "Historia de la Arquitectura". Barcelona, 1982. Ediciones CEAC, S.A. ISBN: 8432926078.

CINI, Michelle | IN SCHAIN, Martin (2001) “From the Marshall Plan to the EEC" The Marshall Plan: Fifty Years After, New York: Palgrave, 2001. no ISBN.

CHOMĄTOWSKA, Beata (2014) "Lachert i Szanajca. Architekci awangardy” Wydawnictwo Czarne ISBN: 978-83-7536-837-6.

COLLINS, Peter (1959) “Concrete: The Vision of a New Architecture”" V.O: Splendeur du béton - Les prédécesseurs et l'oeuvre d'Auguste Perret. Paris,1995. ISBN: $978-0773525641$.

COLLINS, Peter (1982) "Perret, Auguste” Macmillan Encyclopaedia of Architects. Nueva York: Free Press, 1982. Citado por Frampton, 1995. ISBN: 84-460-1187-5.

COHEN, Jean-Louis (2012) "Architecture in Uniform. Designing and Building for the Second World War" CCA, Montreal ISBN: 9782754105309.

DAVIES, Norman (1979) "God's Playground: A History of Poland, Vol. 1: The Origins to 1795" Columbia University Press, 2005, ISBN: 0-231-12817-7.

DAVIES, Norman (1979) "God's Playground. A History of Poland, Vol. 2: 1795 to the Present" Columbia University Press, 2005 ISBN: 0-231-12819-3.

DAVIES, Norman (2003) "Rising “44: The Battle for Warsaw”. London: Pan Macmillan ISBN: 0-333-90568-7

DELEUZE, Gilles (1987) “¿Que es el acto de creación?” Conferencia realizada en la FEMIS (Escuela Superior de Oficios de Imagen y Sonido) el 17/05/1987.

DELEUZE, Gilles (2002) "La isla desierta y otros textos” Ed.: Pre-textos, 2002. Orig.: Les Éditions de Minuit, 2002. Trad.: Luis José Pardo. ISBN: 84-8191-651-X.

DELEUZE, Gilles (2005) “Lógica del sentido”. Ed. Paidos Iberica. Tit. Orig.: "Logique du sens”, 1969. ISBN 9788449318030. 
DELGADO, Manuel (2011) “El espacio público como ideología” Ed. La Catarata, 2011. ISBN: 9788483195956.

DUNAYEVSKAYA, Raya (2007) "Marxismo y Libertad. Desde 1776 hasta nuestros días". Ed.: Fontamara. T.O.: Marxism and Freedom, 1958. ISBN: 9684766076. ECHAIDE, Rafael (1990) “La cabaña primitiva en la arquitectura actual” Revista de Edificiación. RE nº 7 Julio 1990. no ISBN.

ECO, Umberto (1974) "La estructura ausente" Trad. F. Serra. Ed. Lumen, Barcelona. T. Orig.: La struttura assente, 1968. ISBN: 8426410766. ENCYKLOPEDIA WARSZAWY (1994) Wydawnictwo Naukowe PWN, 1994 ISBN 83-01-08836-2.

ETH Zürich. Fuente: www.library.ethz.ch

FARR, Arnold (2014) "Herbert Marcuse" Edit.: Edward N. Zalta. The Stanford Encyclopedia of Philosophy, 2014. No ISBN.

FARYNA-PASZKIEWICZ, Hanna (2004) “Saska Kępa w listach, opisach, wspomnieniach...” Editorial Kowalska/Stiasny, Diciembre 2004 ISBN: 83-918151-5-3. FONTÁN DEL JUNCO, Manuel (2011) “Aleksandr Deineka (1899-1969) Una vanguardia para el proletariado”. Fundación Juan March. no ISBN.

FRAMPTON, Kenneth (1995) "Estudios sobre la cultura tectónica” ("Studies in Tectonic Culture”) Trad.:Amaya Bozal. Ed.Akal, 1999 SS Reyes. ISBN: 84-460-1187-5. FROMM, Erich (1941) "El miedo a la libertad” (T.O.: “The Fear of Freedom”) Ed. Paidós. Nueva Biblioteca, 2015. ISBN: 978-84-493-0853-6. FUNDACJI IM. TADEUSZA ŁOPUSZAŃSKIEGO.

GADDIS, John Lewis (1998) "We Now Know: Rethinking Cold War History" Council on Foreign Relations Book. Paperback. 9 Julio 1998. no ISBN. GADOMSKI, Bogdan (1988) “Tadeusz Tolwiński (1887-1951)” Pracownia Historyczna Biblioteki Głównej, Warszawa. no ISBN.

GARLIŃSKI, Bohdan (1953) “Architektura Polska 1950-1951” Państwowe Wydawnictwa Techniczne Warszawa. no ISBN.. GIERGOŃ, Pawel (2007) "Sobór św. Aleksandra Newskiego na placu Saskim w Warszawie” Fuente: sztuka.net. No ISBN.

GIERGOŃ, Pawel (2009) "Stadion Dziesięciolecia w Warszawie” Fuente: sztuka.net. No ISBN.

GIEDION, Sigfried (2009) “Espacio Tiempo y Arquitecura” (Orig.: "Space Time and Architecture"). E. Univ. Arquitectura. Barcelona, 2009. ISBN: 978-84-291-2117-9.

GŁĘBOCKI, Wiesław | MÓRAWSKI, Karol (1985) “Kultura Walcząca 1939-1945” Warszawa: Wydawnictwo Interpress. ISBN: 83-02-00773-0.

GLIŃSKI, Jan Bohdan (2005) “Gimnazjum i Liceum im. Sułkowskich w Rydzynie 1928-1939” Wychowawcy i Wychowankowie, Warszawa.

GODLEWSKI, Grzegorz (2013) "Kulturologia polska XX wieku” Instytut Kultury Polskiej Wydział Polonistyki Uniwersytet Warszawski. No ISBN.

GONZÁLEZ CÁRDENAS, María Margarita (2005) “ Homenaje a Auguste Perret (1874-1954)” Bitacora, 2005. No ISBN.

GRAJEWSKI, Grzegorz | ILKOSZ, Jerzy (2007) "Wrocławska Hala Stulecia” Spotkania z Zabytkami nº 1, 2007. No ISBN. 
GREEN, Jonathan | NICHOLAS J. Karolides (2005) “The encyclopedia of censorship”. Nueva York. Facts on File. ISBN: 978-0816044641.

GRUŻEWSKI, Jan | KOPF, Stanisław (1957) Dni Powstania, Kronika Fotograficzna Walczącej Warszawy, Warsaw: PAX, pp. 211 no ISBN.

HARDEJ, Tatiana (2012) “Jak budowano Stadion Dziesięciolecia” Revista Stolica n6/2012. Fuente: warszawa-stolica.pl. No ISBN.

HISTORIA POLITECHNIKI WARSZAWSKIEJ página oficial de la universidad. no ISBN.

HITCHCOCK, Henry-Russell (1998) “Arquitectura de los siglos XIX y XX” 3a Edicion. Cátedra, 1989. ISBN: 9788437602752.

HITE, Vladimir L. (1986) “Oscar Niemeyer” 2a edición, revisada y ampliada. Moscú, 1986. IB número: 3132 Ed.n AIX-9657. No ISBN.

HOGAN, Michael (1987) “The Marshall Plan” Cambridge University Press, 1987 ISBN 0-521-37840-0.

HOPPKINS, Robert (2003) "Witness to History: Recollections of a WWII Photographer” ISBN-10-965386945. Castle Pacific Pub Co. Ed Febrero 2003. No ISBN.

ILKOSZ, Jerzy | GRAJEWSKI, Grzegroz (2007) "Wrocławska Hala Stulecia” Artículo Revista "Spotkania z zabytkami nº1, 2/01/2007. Fuente: spotkania.pl. No ISBN.

ILKOSZ, Jerzy (2005) "Max's Berg Centennial Hall and exhibition grounds in Wroclaw” Museum of Architecture in Wroclaw, 2005. ISBN: 83-89262-26-6.

ITRAGO PELS, Carlos (2006) "Sobre copias, transformaciones y omisiones. La recomposición de ciudades devastadas". Tesis Doctoral ETSAB UPC. No ISBN.

IWANOW, Nikołaj (2010) “Powstanie warszawskie widziane z Moskwy”. Kraków: Wydawnictwo Znak, 2010. ISBN: 978-83-240-1409-5.

JAMESON, Fredric (1982) “Architecture and the Critique of Ideology”. Architecture Theory Since 1968. Ed. Cambridge, MA. MIT Press, 1998. No ISBN.

JANCZEWSKI, George (1972) "The Origin of the Lublin Government”. The Slavonic and East European Review 50. no ISBN.

JANKOWSKI, Stanisław | CIBOROWSKI, Adolf (1971) "Warszawa 1945 i dziśs". Wydawnictwo Interpress, Warszawa, 1971. no ISBN.

JAROSIŃSKI, Mariusz (2009) “Wystawa Ziem Odzyskanych-Wrocław 1948” Muzeum Historii Polski | Polską Agencją Prasową SA. Fuente: dzieje.pl. no ISBN.

JENNINGS, Ray Salvatore (2003) “The Road Ahead: Lessons in Nation Building from Japan, Ger., and Afg.for Postwar Iraq” Peaceworks No. 49 1/05/2003. no ISBN.

JEWSIEWICKI, Władysław (1989) "Powstanie warszawskie 1944 okiem polskiej kamery”. Warszawa: Interpress. ISBN 83-223-2531-2.

JUR, Andrzej (1977) “Twórczość Architektoniczna Marka Leykama” Vol. 2 pr. 1 Biblioteka Instytutu Historii Sztuki UAM. Poznań, 1977. Ref: 09-000472-02-00. no ISBN.

KAISER, Waldemar (2013) "Poznań: Rocznica otwarcia Okrąglaka” Fuente: Naszemiasto.pl 29/01/2013. No ISBN.

KAŹMIERCZAK, Krzysztof (2009) “Ściśle tajne: nieznane fakty z historii Wielkopolski” Ed: Głos Wielkopolski, 2009. No ISBN.

KOŁAKOWSKI, Leszek (1971) “Theses on Hope and Despair” Ed.: Background Rep. Open Soc. Arch. Central EU Univ., Budapest. ID: HU OSA 300-8-3-17460.

KOSIERADZKI, Mariusz (2006) Art.: "Jan Piotr Lewiński - geolog, dydaktyk, popularyzator" Centralna Biblioteka Rolnicza Warszawa. no ISBN. 
KOSSOWSKA, Irena (2004) “Między tradycją i awangardą. Polska sztuka lat 1920 i 1930” Art. Culture.pl. no ISBN.

KOSSOWSKA, Irena (2004) "Polski konstruktywizm: Blok, Praesens, a.r." Art. Culture.pl. no ISBN.

KOPF, Stanisław (1994) “Z kamerą w powstańczej Warszawie 1944” Warszawa: Związek Polskich Artystów Fotografików. ISBN: 83-900225-2-4.

KRÓLIKOWSKI, Janusz (2010) “Generałowie i admirałowie Wojska Polskiego 1943-1990” Toruń 2010. no ISBN.

KRÓLIKOWSKI, Lech (2008) "Szkolnictwo dawnej Warszawy” Muzeum Historyczne Warszawy p. 627. ISBN: 978-83-88477-81-2.

KRZYŻAKOWA, Kristyna (1983) "Prof. Marek Leykam-Lewiński” Artículo publicado en la revista Stolica n³, 1983. no ISBN.

KUDZIA, Piotr | PAWELCZYK, Grzegorz (2001) "Stadion w państwie". Revista "Wprost" n24 2001. no ISBN.

KULAK, Teresa (1997) “Wrocław. Przewodnik historyczny. A to Polska właśnie” Editorial: Dolnośląskie. Wrocław, 1997. ISBN 83-7023-575-1.

KUSZTELSKI, Andrzej (1999) “Zespol Projektow Nowego Klasztoru Dominikanow”. Kronika Miasta Poznania. p. 296-318. No ISBN.

LEBOW, Katherine (2013) Unfinished Utopia: Nowa Huta, Stalinism, and Polish Society, 1949-56. Ed.Cornell University Press, 2013. ISBN: 9780801451249.

LEGRIS, Javier (2001) “Deducción y representación. Una introducción a la lógica de primer orden” Ed.: Economizarte. Buenos Aires, 2001. ISBN 987-9372-40-9.

LEPORI, Ana Paula de Oliveira (2006) “El Taller de proyectos como laboratorio: Memoria y lugar” Tesis Doctoral UPC. ISBN: 9788469162361.

LEŚNIAKOWSKA, Marta (2003) “Architektura w Warszawie 1945-1965.” Arkada Pracownia Historii Sztuki p. 205. ISBN: 83-908950-6-4.

LEŚNIAKOWSKA, Marta (2005) “Architektura w Warszawie.” Arkada Pracownia Historii Sztuki. ISBN 83-908950-8-0.

LEŚNIAKOWSKA, Marta (2006) “Architektura w Warszawie 1918-1939.” Arkada Pracownia Historii Sztuki, 2006. ISBN: 83-60350-00-0.

LEVI, Primo (2014) “Los hundidos y los salvados” T.O.: I sommersi e i salvati. Ed. Peninsula, 2014. ISBN 9788499423029.

LEVI, Primo (2002) "Si esto es un hombre" T.O.: Se questo è un uomo. Ed. Muchnik, Barcelona. ISBN: 84-7669-525-x.

LEYKAK, Marek (1943) “Sztuka Liturgicna.” (“Arte Liturgico.”). Tesis doctoral original presentada en Zúrich, 1943. no ISBN.

LICHTENSTEIN, Claude (1977) "El pragmatisme de fons de la modernitat aplicada" Vers. 'Werk/Archithese" 10 (1977). Trad: Feliu Formosa. Fuente:raco.cat. no ISBN.

LIUTKUS, Viktoras (2008) "Lithuanian Art and the Avant-Garde of the 1920s. Vytautas Kairiūkštis (..).” LITUANUS Foundation, Inc. ISSN $0024-5089$.

ŁOZA, Stanisław (1954) Architekci i budowniczowie w Polsce. Warszawa: Budownictwo i Architektura, 1954. no ISBN.

LUKOWSKI, Jerzy | ZAWADZKI, Hubert (2003) "Historia de Polonia” Ed. Cambridge University Press, 20 sept. 2001. ISBN: 9788483232972.

MARCINIAK,Piotr (2010) “Doświadczenia modernizmu. Architekura i urbanistyka Poznania w czasach PRL” Edit.: Miejskie, Poznań, 2010. ISBN: 978-83-7503-113-3. 
MARX, Karl (2001) "Manuscritos económicos y filosóficos de 1844” T. digital: Biblioteca Virtual "Espartaco". Enero, 2001. No ISBN.

MIŁOBĘDZKI, Adam (1963) "Zarys dziejów architektury w Polsce”. Wiedza Powszechna. no ISBN.

MINORSKI, Jan (1966) "Polska nowatorska myśl architektoniczna 1918-1939”. Varsovia, 1966. No ISBN.

MOOS, Stanislaus von (1977) “Architektur auf den zweiten Blick. Oder: Salvisberg heute” Werk Archithese. ETH-Bibliothek. No ISBN.

MÓRAWSKI, Karol (2003) "Warszawa. Dzieje miasta” Książka i Wiedza, Warszawa 2003. no ISBN.

MUKAŘOVSKÝ, Jan (2011) “Función, norma y valor estéticos como hechos sociales” Ed: El cuenco de plata, 2011. ISBN 978-987-1772-27-8.

MUMFORD, Eric Paul (2002) “The CIAM discourse on urbanism, 1928-1960” MIT Press, Cambridge, Mass. ISBN: 978-0-262-63263-8.

MUNTAÑOLA THORNBERG, Josep (2004) “Arquitectura,educación y dialogía social” Revista española de pedagogía. Año LXII, n. 228, 2004. p. 221-228. UPC. No ISBN.

MUNTAÑOLA THORNBERG, Josep | SAURA CARULLA, Magda (2011) "Bakhtin, Architectonics and Architecture" Research Project EDU2010-16299. No ISBN.

MUNTAÑOLA THORNBERG, Josep (2006) “Arquitectura y Dialogía” Ediciones UPC. ISBN: 84-8301-843-8.

NEY-KRWAWICZ, Marek (1990) "Komenda Główna Armii Krajowej 1939-1945”. Warszawa: Instytut Wydawniczy PAX, 1990, s. 427-428. ISBN: 83-211-1055-X.

NIEZABIETOWSKI, Andrzej (1995) “La arquitectura polaca vanguardista de 1918-39 en relación con las tendencias contemporáneas en Europa” Art. Elisava.net. no ISBN.

OECHSLIN, Werner | HILDEBRAND, Sonja (2010) “Karl Moser. Architektur für eine neue Zeit: 1880 bis 1936” 2 Bände, GTA, Zürich 2010, ISBN 9783856762506.

OLSZEWSKI, Andrzej (1970) “Architektura polska po II wojnie światowej”. Warszawa 1970 CBWA. no ISBN.

ORTEGA Y GASSET, José (2005) “En torno a Galileo” Editorial: Biblioteca Nueva. ISBN 9788497420402.

OSSOWSKA, Maria (1946) “Wzór obywatela w ustroju demokratycznym” Public. orig. Revista "W Świetle Dnia”, 1944. Fuente: Lewicowo.pl. No ISBN.

PARICIO ANSUATEGUI, Ignacio (1994) "La construcción de la arquitectura. Vol. 3, La composición : la estructura”. Barcelona ITEC, 1994. ISBN 8478532447.

PASSENT, Daniel (2008) “Człowiek z chmur”. Polityka 2008. Warszawa. ISSN: 0032-3500.

PEARCE, Joseph (2007) "Solzhenitsyn: A Soul in Exile" Ed. Ciudadela Libros, 2007. ISBN 9788496836112

PERZANOWSKI, Jerzy (1998) “The Lvov-Warsaw School and contemporary philosophy”. Art.: Kijania-Placek, 1998. p. 399. Ed.: Springer, 1998 . ISBN: 9780792351054.

PIORKOWSKI, Jerzy (1957) "Miasto Nieujarzmione" Warsaw: Iskry, pp. 16 no ISBN.

PIOTROWSKI, Tadeusz (1997) "Poland's Holocaust: Ethnic Strife, Collaboration with Occupying Forces and Genocide" McFarland \& Company ISBN: 0786403713.

PIWOWAR, Magdalena | PIĄTEK, Grzegorz | TRYBUŚ, Jarosław (2012) “SAS. Ilustrowany atlas architektury Saskiej Kępy.” C.Architektury ISBN: 9788393457403. 
PLAKANS, Andrejs (1995) “The Latvians: A Short History”. Hoover Institution Press Publication. ISBN: 9780817993023.

PRAESENS nº 1-2 (1926-1930). Revistas consultadas directamente del original. no ISBN.

PRIOR OLMOS, Ángel (2004) “El problema de la libertad en el pensamiento de Marx” Ed.. Biblioteca Nueva, 2004. ISBN: 9788497422987.

PONIKIEWSKI, Bartłomiej (2014) 'Dom Towarowy Okrąglak”. Artículo publicado en Powojenny Modernizm. 04/03/2014. Fuente: powojennymodernizm.com. No ISBN. PROGRAM NA ROK AKADEMICKI 1927/8 - 1932/33 Warszawa Nakładem Politechniki Warszawskiej, 1927-32. no ISBN.

PRZYGOŃSKI, Antoni (1980) "Powstanie Warszawskie w sierpniu 1944” Tomo 1. Warszawa: Polskie Wydawnictwo Naukowe ISBN: 830100293X .

QUINTÁNS, Carlos (2012) “Garage Ponthieu” Art. publicado en Tectonicablog. 9 diciembre 2012. no ISBN.

RAACK, Richard (1990). "Stalin Fixes the Oder-Neisse Line". Journal of Contemporary History 25. ISSN 0022-0094.

RYBUŚ, Jarosław (2005) “Od Zamku do Browaru. O architekturze Poznania ostatnich stu lat” Poznań: Galeria Miejska Arsenal, 2005. ISBN: 83-88947-39-7 ROTTERMUND, Andrzej; Chrościński,Juliusz (1997) “Atlas architektury Warszawy” Arkady. no ISBN.

SALVISBERG, Otto Rudolf (1933) “Technic und Formausdruck im Buen, Conf. 1933. "Schweizerische Tecbnische Rundrchau'. Op. Cit: Lichtenstein, 1977. no ISBN. SANFORD, George (2006). "The Katyn Massacre and Polish-Soviet Relations, 1941-43". Journal of Contemporary History 41. ISSN: $0022-0094$.

SAWICKI, Jerzy (1949) Zburzenie Warszawy. Warszawa: Instytut wydawniczy “Kolumna”, 1949. no ISBN.

SAWICKI, Tadeusz (2010) "Rozkaz zdławić powstanie. Niemcy i ich sojusznicy w walce z powstaniem warszawskim” Ed.: Bellona, 2010. ISBN: 978-83-11-11892-8.

SCHMIED, Wieland (1978) "Neue Sachlichkeit and German Realism of the Twenties" Arts Council of Great Britain. ISBN: 0-7287-0184-7.

SCHULZE, Hans Rudolf (2009).’Dialog” Nr 90. Deutsch-Polnische Gesellschaft Bundesverband. ISBN: 09381422.

SCHWONEK, Matthew (2006). "Kazimierz Sosnkowski as Commander in Chief: The Government-in-Exile and Polish Strategy, 1943-44”. Journal M.History 70. no ISBN

SEDLMAYR, Hans (2008) “La revolución del arte moderno" Ed.:Acantilado. T.Orig. "Die Revolution der modernen Kunst” Ed. Verlag. Hamburg, 1955. ISBN:978-84-96834-36-1.

SHAEFFER, R.E. (1992) “Reinforced Concrete: Preliminary Design for Architects and Builders” McGraw-Hill, 1992 ISBN: 0070564175.

SHKLOVSKY, Viktor (1916) “Art as Technique” Ensayo publicado en: Vahidnab.com. No ISBN.

SIBILA, Leszek J. (2007) “Muzeum Rozproszone Nowej Huty: Przewodnik”. Kraków: Muzeum Historyczne Miasta Krakowa, 2007. ISBN: 978-83-89599-29-2.

SIBILA, Leszek J. (2008) “Dzieje nowohuckiego kombinatu w latach 1949-1958”. Kraków: Muzeum Historyczne Miasta Krakowa, 2008. ISBN: 978-83-89599-64-3. SKIBINIEWSKI, Zygmunt “Urbanistyczne prace BOS” Revista "Stolica”. Nr 6 (10 febrero 1980), WWP RSW "Prasa Książka Ruch". no ISBN. 
SMOLIŃSKI, Józef (1994) “4 Warszawski Pułk Strzelców Pieszych” Wydawnictwo Ajaks, Warszawa 1994 ISBN: 83-85621-47-4.

SOKOE Kiryl (2002) "Russkaja Warszawa" MID Synergia. ISBN: 5-7368-0252-X.

SOKOE Kirył | SOSNAAleksander (2003) "Kopuly nad Wisłą. Prawosławne cerkwie w centralnej Polsce w latach 1815-1915" MID Synergia. ISBN: 5-7368-0301-2.

SOLA-MORALES, Ignasi | LLORENTE, Marta | MONTANER, J.M. (2011) “Introducción a la arquitectura: Conceptos Fundam.” 2a Ed. UPC, 2011. ISBN: 9788483015339. SOLZHENITSYN, Alexandr (2002) “Archipiélago Gulag (1918-1956)” Ed. Tusquets, 2002. ebook. No ISBN.

SPRINGER, Filip (2011) “Źle urodzone. Reportaże o architekturze PRL-u”, Karakter, ISBN: 978-83-62376-12-4.

SPYCHALSKI Marian (2015) "Marian Spychalski: Warszawa architekta”. Warszawa: Bellona, 2015. ISBN 978-83-11-1316-4.

STILLER, Adolph | BARUCKI, Tadeusz (2012) “Maciej Nowicki: Eine Architektenkarriere zwischen Polen, ..” Salzburg Ed.:Verlag. ISBN 978-3-99014-072-7.

STRATY WARSZAWY 1939-1945 (informe). Warszawa : Miasto Stoleczne Warszawy, 2005 ISBN: 83-922369-7-1

STRELBICKA, Maria (2013) "Krótki przewodnik po socrealistycznej Polsce” Instytut Kulturoznawstwa RAN, 2013. No ISBN.

SURAL, Agnieszka (2015) "Domy własne architektów" Fuente: culture.pl. No ISBN.

SYRKUSOWA, Helena (1976) “Ku idei osiedla społecznego 1925-1975” Państwowe Wydawnictwo Naukowe.

SYRKUSOWA, Helena (1984) Spoleczne cele urbanizacji. Człowiek i środowisko. Państwowe Wydawnictwo Naukowe ISBN: 83-01-03388-6.

SZAROTA, Tomasz (2010) “Okupowanej Warszawy dzień powszedni” Czytelnik p. 370. ISBN: 978-83-07-03239-9.

SZCZEŚNIAK, Andrzej Leszek (1980) "Historia dla Klasy VIII” Warsaw: Wydawnictwo Szkolne i Pedagogiczne ISBN: 83-02-01035-9.

SZPOCIŃSKI, Andrzej (2011) “Antoniny Kłoskowskiej koncepcja kultury narodowej jako źródło inspiracji.” Art.Pub.: Kultura i Społeczeństwo n 55 . No ISBN.

SZWEDEK, Justyna (2008) "Marek Leykam w stulecie urodzin”, SARP p. 15-17, ISSN: 0239-3549.

TARUSKIN, Richard (2010) "Music in the Late Twentieth Century". Oxford: Oxford University Press. ISBN: 978-09-19-538485-7.

THEOHARIS, Athan (1972) "Roosevelt and Truman on Yalta: The Origins of the Cold War". Political Science Quarterly, 87.

THOMASSON, Amie (2012) “Roman Ingarden” Ed.: Edward N. Zalta. The Stanford Encyclopedia of Philosophy Edward N. Zalta. No ISBN.

TUNG, Anthony (2001) "Preserving the world’s great cities” Ed.: Clarkson Potter. ISBN: 978-0517701485.

VLOYANTES, John P. (1958). "The Significance of Pre-Yalta Policies regarding Liberated Countries in Europe”. The Western Political Quarterly 11.

VOLEK, Emil (1995) “Antología del formalismo ruso: Semiótica del discurso y posformalismo bajtiano” Ed. Roman Jacobson Found., 1995. ISBN: 8424506928. 
WALDORFF, Jerzy (1984) “Cmentarz Powązkowski w Warszawie”, Krajowa Agencja Wydawnicza, Warszawa 1984. ISBN: 83-03-00758-0.

WAGNER, Anna "Siedziba Wydziału Architektury Politechniki Warszawskiej. Stuletnia historia gmachu".

WALKER, Robert (1999) “Eine aussergewöhnliche Fassadengestaltung von Roland Rohn.” Art.de la revista "Baudoc-Bulletin” enero 1999. Fuente: bauforschungonline.ch

WARSZA, Joanna (2009) “STADION X. Miejsce, którego nie bylo.” (“Estadio X. Espacio, donde no hubo.”). Fundación Laura Palmer. ISBN 978-83-925107-5-8. WIECZORKIEWICZ, Pawel (2005) "Historia polityczna Polski” 1935-1945. Warszawa, Książka i Wiedza, 2010. ISBN 978-83-05-13378-8.

WILLETT, John (1978) “Art and Politics in the Weimar Period: The New Sobriety 1917-1933” NY Da Capo Press, 1996. ISBN 0-306-80724-6.

WISŁOCKA, Izabella (1968) “Awangardowa Architektura Polska 1918-1939” Arkady. No ISBN.

WŁODARCZYK, Małgorzata (2006) “Architektura lat 60-tych w Krakowie” ISBN 83-7318-767-7. Publicado por. Włodarczyk+Włodarczyk Architekci. Kraków, 2014.

WŁODARCZYK, Wojciech (2005) “Akademia Sztuk Pięknych w Warszawie w latach 1944-2004”. Warszawa. Edit. Szkolne i Pedag., A.Sztuk Pięknych, 2005. ISBN 830209319X. WOLEŃSKI, Jan (2014) "Lvov-Warsaw School” The Stanford Encyclopedia of Philosophy Edward N. Zalta. No ISBN.

WRÓBLEWSKA, Magdalena (2010) "Blok Group”| "Praesens". Fuente: Culture.pl. No ISBN.

ZACHWATOWICZ, Jan (1966) “Architektura Polska” Editorial Arkady. Warszawa, 1966. No ISBN.

ZALESIŃSKI, Łukasz (2014) “Wieża Górnośląska w Poznaniu: historia niezwykłej niemieckiej budowli”. Fuente: poznajpolske.onet.pl. No ISBN.

ZALUSKI, Daniel (2010) “Arseniusz Romanowicz”. Rynek Kolejowy ISSN 1644-1958.

ZAWILSKI, Apoloniusz (1972) "Bitwy Polskiego Września” Warsaw: Nasza Księgarnia, 2014. ISBN 83-218-0817-4.

ZEGZUŁA-NOWAK, Joanna (2012) “Kazimierz Twardowski jako wzór osobowy nauczyciela akademickiego” Ed: Arch.Wydawnictwo Łódzkie, 2012. No ISBN.

ZEVI, Bruno (1980) "Historia de la Arquitectura Moderna" Ed. Poseidon, 1980 ISBN: 9788485083152.

ZIELIŃSKI, Jarosław (1996) “Atlas dawnej architektury ulic i placów Warszawy”. Tom II: Canaletta-Dhugosza. Warszawa: Tow. Opieki nad Zabytkami, 1996 ISBN 83-9066291-4.

ZIELIŃSKI, Jarosław (2008) “Żoliborz. Przewodnik historyczny” Rosner \& Wspólnicy, Warszawa 2008, ISBN 978-83-60336-27-4.

ZIELIŃSKI, Jarosław (2009) “Realizm socjalistyczny w Warszawie. Urbanistyka i architektura (1949-1956)” Warszawa Fund. Hereditas, 2009. ISBN 978-83-927791-3-1.

ŽIŽEK, Slavoj (1989) “The Sublime Object of Ideology” Ed.: Cromwell Press Ltd, UK. ISBN: 0860919714. 



\section{REFERENCIAS DE LAS IMÁGENES}

\section{INTRODUCCIÓN}

0.01 Archivo Tadeusz Barucki / SARP.

\subsubsection{ENTORNO ACADÉMICO DE MAREK LEYKAM.}

1.011 .02 Archivo Tadeusz Barucki / SARP.

1.03 - 1.14 "Architektura i Budownictwo" 1925-26 n 1.

1.15 Nacional Collection Photo Company. Dominio Público.

1.16 Publicación de la revista Światowid” 1933. Dominio público.

1.17 Bundesarchiv, Bild_183-R42025.

1.18 Schulze, Hans Rudolf (2009).’Dialog” Nr 90. Deutsch-Polnische Gesellschaft Bundesverband. ISBN 09381422.

1.19 Postal de principios del siglo XX. Dominio público.

1.20 Niezabietowski, Andrzej (1995) "La arquitectura polaca vanguardista de 1918-39 en relación con las tendencias contemporáneas en Europa" Art. Elisava.net.

1.21 Słomczyński, Jerzy "Jan Witkiewicz Koszczyc - z Witkiewiczów najmniej znany” Warszawa - Szkoła Główna Handlowa. Art. zakopanedlaciebie.pl. 1.22-

1.24 "Architektura i Budownictwo" $1933 \mathrm{n}^{\circ} 1$.

1.25 PKO Bank Polski SA Oddział. krakow.fotopolska.eu. Dominio Público.

1.26 Dom profesorów Uniwersytetu Jagiellońskiego w Krakowie. krakow.fotopolska.eu. Dominio Público.

1.27 - 1.28 "Architektura i Budownictwo" $1927 \mathrm{n}^{\circ} 10$.

1.29 - 1.33 "Architektura i Budownictwo" 1925-26 nº 12 .

1.34 - 1.61 "BLOK" n 1-11 (1924-1926). 1.62-1.65 "Architektura i Budownictwo" 1936 no 4.

1.66 - 1.69 Niezabietowski, Andrzej (1995) "La arquitectura polaca vanguardista de 1918-39 en relación con las tendencias contemporáneas en Europa” Art. Elisava.net.

1.70 Dominio público. Fuente: skyscrapercity.com.

1.71 - 1.73 "Architektura i Budownictwo" $1928 \mathrm{n}^{\circ} 2$.

1.74 Fuente: Sural, 2015 / culture.pl. 
1.75 - 1.78 "Architektura i Budownictwo" $1934 \mathrm{n}^{\circ} 4$.

1.79 - 1.80 "Architektura i Budownictwo" 1925-26 no 10-11.

1.81 - 1.85 "Architektura i Budownictwo" $1930 \mathrm{n}^{\circ} 11$.

1.86 - 1.91 "Architektura i Budownictwo" $1929 \mathrm{n}^{\circ} 11-12$.

1.92 - 1.94 "Architektura i Budownictwo" 1929 n 8.1 .95 Autor Desconocido / Fuente: tobrze.blox.pl

1.96 - 1.97 Rudolf Świerczyński / Fuente: Revista Plastyka 1935, nº 5-6 p. 117-122

\subsubsection{INFLUENCIAS PROFESIONALES Y PRIMEROS PROYECTOS,}

2.01 Charles-Dominique-Joseph Eisen. Dominio Público.

2.02 - 2.06 JUR, Andrzej (1977) “Twórczość Architektoniczna Marka Leykama” Vol. 2 pr. 1.

2.07 - 2.09 FRAMPTON, Kenneth (1995) "Estudios sobre la cultura tectónica" p. 90; p. 124.

2.09 QUINTÁNS, Carlos (2012) "Garage Ponthieu” Publicado en Tectonicablog. 9 diciembre 2012.

2.10 Wladyslaw Slawny. Cortesía de Igor Hansen del Archivo de Oskar Hansen. (C) Graham Foundation.

2.11 Autor Desconocido. (c) Fonds Perret frères. CNAM / SIAF / CAPA/Auguste Perret/UFSE/SAIF 2011. Via: citechaillot.fr.

2.12 FRAMPTON, Kenneth (1995) "Estudios sobre la cultura tectónica" p. 123-155.

2.13 BRITTON, Karla, (2001). "Auguste Perret”. Phaidon. Londres, 2001. ISBN: 0714840432.

2.14 - 2.17 FRAMPTON, Kenneth (1995) "Estudios sobre la cultura tectónica” p. 123-155.

2.18 Autor Desconocido. Fuente: Léopold Lambert. "Boiteaoutils" Architectural political narratives. thefunambulist.net

2.19 - 2.21 BENEVOLO, Leonardo (2002) "Historia de la arquitectura moderna" 8a edición. p 358-359. 2.23-2.33 "Architektura i Budownictwo" 1936 nº 6.

2.22 FRAMPTON, Kenneth (1995) "Estudios sobre la cultura tectónica" p. 123-155.

2.34 - 2.37 Archivo Tadeusz Barucki / SARP.

$2.38-2.42$ "Arkady" $1937 \mathrm{n}^{\circ} 5$.

2.43 Edward Curtis / Michael Hoppen Gallery. Fuente: theguardian.com

2.44 - 2.45 Marek Leykam / Fuente: Revista Plastyka 1935, n 5-6 p. 122

2.46 - 2.52 "Architektura i Budownictwo" 1938 n ${ }^{\circ} 1$

\subsubsection{TRANSCURSO DE LA II GUERRA MUNDIAL.}

3.01 Bruno Schulz / Archivo. Fuente: brunoschulz.eu. 
3.02 Bundesarchiv, Bild 183-H27337.

3.03 Autor desconocido. Dominio público.

3.04 ZAWILSKI, Apoloniusz (1972) "Bitwy Polskiego Września” Warsaw: Nasza Księgarnia, 2014. ISBN 83-218-0817-4.

3.05 PIORKOWSKI, Jerzy (1957) "Miasto Nieujarzmione" Warsaw: Iskry, pp. 16 no ISBN.

SZCZEŚNIAK, Andrzej Leszek (1980) "Historia dla Klasy VIII" Warsaw: Wydawnictwo Szkolne i Pedagogiczne, pp. 113 ISBN 83-02-01035-9.

3.06 Dominio Público. Laski Diffusion East News nowahistoria.interia.pl.

3.07 - 3.10 The Polish Army In France 1939 - 1940 polandinexile.com 2008.

3.11 "Der Führer in Paris". Hitler in Paris. Heinrich Hoffman Collection. 23 Junio 1940 Autor desconocido.

3.12 The Polish Army In France 1939 - 1940 polandinexile.com 2008.

3.13 Autor: Eugeniusz Lokajski.

Opracowanie Zbiorowe (1957) Powstanie Warszawskie w Ilustracji, Varsovia.

Wydanie Specjalne Warszawskiego Tygodnika Ilustrowanego "Stolica", pagina 30 szczep413.pl

3.14 Autor: Stefan Klemens Bahuk (1914-2014).

BAŁUK, Stefan | Piorkowski, Jerzy (1957) "Miasto Nieujarzmione" Warszawa: Iskry, ss. 76 no ISBN

KOPF, Stanisław (1984) "Dni Powstania" Kronika Fotograficzna Walczącej Warszawy, Warszawa: PAX, ss. 68 no ISBN

PONIATOWSKI, Zdzisław | Zelwiański, Ryszard "Batalion AL im. Czwartaków”, 1971.

3.15 Stefan Bryła. Narodowe Archiwum Cyfrowe, sygn. 1-N-71.

3.16 T. Mrówczyński. Fuente: Barucki, 2014 “Architektura wojny 1939-1945” sarp.warszawa.pl.

3.17 Bundesarchiv, Bild_183-J27793 / Schremmer / CC-BY-SA.

3.18 Autor: Sylwester Braun.

GRUŻEWSKI, Jan | KOPF, Stanisław (1957) Dni Powstania, Kronika Fotograficzna Walczącej Warszawy, Warsaw: PAX, pp. 211 no ISBN.

3.19 Autor Desconocido. 67 rocznica Powstania Warszawskiego portal.zs.mil.pl.

3.203 .21 The Polish Army In France 1939 - 1940 polandinexile.com 2008.

3.22 ETH Zürich. gta Archiv. Referencia: www.archiv.gta.arch.ethz.ch.

3.23 Cartel anunciador Museo Bewerbe, 1940 Fuente: otto-wyler.culturalspot.org.

3.24 Autor desconocido. Tomada de LICHTENSTEIN, Claude (1977) "El pragmatisme de fons de la modernitat aplicada". Fuente:raco.cat.

3.25 Autor Desconocido. CC-BY-SA-3.0 commons.wikimedia.org.

3.26 Autor Desconocido. Foto de trabajo de 1941, tomada de Walker, 1999. Artículo de la revista "Baudoc-Bulletin" enero 1999. Fuente: bauforschungonline.ch. 3.27 - 3.36 Archivo Tadeusz Barucki / SARP.

3.37 G£ĘBOCKI, Wiesław | MÓRAWSKI, Karol (1985) "Kultura Walcząca 1939-1945” Warszawa: Wydawnictwo Interpress, ss. p.64 ISBN 83-02-00773-0.

JANKOWSKI, Stanisław | CIBOROWSKI, Adolf "Warszawa 1945 i dzis”" Wydawnictwo Interpress, Warszawa, 1971, page 66. 


\subsubsection{LOS PRIMEROS PASOS DE LA RECONSTRUCCIÓN.}

4.01 Naval History and Heritage Command, USA C-543.

4.02 Dominio público. PKWN Manifest. Ministerstwo Bezpieczeństwa Publiczneg.

4.03 Dominio público. Central Photographic Agency (CAF) de Varsovia. Pub. "Warszawa 1945-1970" Wydawnictwo Sport i Turystyka, Warszawa, 1970. Pág. 58.

4.04 Elaboración propia.

4.05 M. Swierczynski. Fuente: JANKOWSKI, Stanisław | CIBOROWSKI, Adolf (1971).

4.06 Karol Szczecinski. Fuente: nowahistoria.interia.pl.

4.07 Karol Szczeciński/East News. Wojskowej Agencji Fotograficznej. Fuente: Narodowego Archiwum Cyfrowego.

4.08 Stefan Massalski. Narodowe Archiwum Cyfrowe. Fuente: natemat.pl.

4.09 Stefan Rassalski. Narodowe Archiwum Cyfrowe. Fuente: natemat.pl.

4.10 - 4.13 Autor desconocido. Fuente: stanislawjankowskiagaton.pl.

4.14 Archivo Tadeusz Barucki / SARP.

4.15 - 4.17 Autor Desconocido / Fuente: Oechslin | Hildebrand, 2010.

4.18 - 4.20 Marek Leykam / Fuente: Kusztelski, 1999. p. 296-318

4.21 - 4.22 Archivo Tadeusz Barucki / SARP

4.23 - 4.24 Autor Desconocido. Pawel Giergoń, 2006. Warzawa-Supersam. Fuente: sztuka.net.

4.25 - 4.44 Archivo Tadeusz Barucki / SARP.

\section{HIPÓTESIS DE TRABAJO.}

6.01 Elaboración propia. Basado en "Kotarbinski, Gnosiology. The Scientific Approach to the Theory of Knowledge" PWN-Pergamon Press, Warszawa-Oxford, 1966 6.02 - 6.03 Archivo Fotografico Sito ufficiale della Chiesa del Gesù / Fuente: chiesadelgesu.org3.51 Autor: M. Swierczynski.

6.04 - 6.07 LEYKAK, Marek (1943) “Sztuka Liturgicna.” (“Arte Litúrgico.”). Tesis doctoral original presentada en Zúrich, 1943. no ISBN.

6.08 - 6.09 Archivo Tadeusz Barucki / SARP.

6.10 - 6.39 LEYKAK, Marek (1943) "Sztuka Liturgicna." (“Arte Litúrgico.”). Tesis doctoral original presentada en Zúrich, 1943. no ISBN.

\subsection{DIRECCIONALIDAD.}

7.01 Andrzej Jur. Fuente: JUR, Andrzej (1977). “Twórczość Architektoniczna Marka Leykama” Poznań, 1977. Ref: 09-000472-02-00. no ISBN. 
7.02 Karol Pecherski / Biuro Odbudowy Stolicy / APW / Forum. Fuente: culture.pl.

7.03 Autor Desconocido. FoKa/Forum. Fuente: culture.pl.

7.04 Andrzej Jur. Fuente: JUR, Andrzej (1977). “Twórczość Architektoniczna Marka Leykama” Poznań, 1977. Ref: 09-000472-02-00. no ISBN.

7.05 Hans Staub. Fuente: MOOS, Stanislaus von (1977) “Architektur auf den zweiten Blick. Oder: Salvisberg heute” Werk Archithese. ETH-Bibliothek. No ISBN.

7.06 Andrzej Jur. Fuente: JUR, Andrzej (1977). "Twórczość Architektoniczna Marka Leykama” Poznań, 1977. Ref: 09-000472-02-00. no ISBN.

7.07 Archivo Tadeusz Barucki / SARP.

7.08 Elaboración propia.

7.09 - 7.11 Archivo Tadeusz Barucki / SARP.

7.12 Elaboración propia.

7.13 Archivo Tadeusz Barucki / SARP.

7.14 Elaboración propia.

7.15 Andrzej Jur. Fuente: JUR, Andrzej (1977). “Twórczość Architektoniczna Marka Leykama” Poznań, 1977. Ref: 09-000472-02-00. no ISBN.

7.16 Archivo Tadeusz Barucki / SARP.

7.17 Andrzej Jur. Fuente: JUR, Andrzej (1977). “Twórczość Architektoniczna Marka Leykama” Poznań, 1977. Ref: 09-000472-02-00. no ISBN.

7.18 - 7.20 Elaboración propia.

7.21 G.Fernez / Archives municipales Le Havre. Fuente: visle-en-terrasse.blogspot.com.

7.22 ; 7.24 Dibujo tomado de la Cátedra del professor Adam Caruso en la ETH Zúrich. Fuente: caruso.arch.ethz.ch

7.23 Léopold Lambert. Fuente: thefunambulist.net.

7.25 Elaboración propia.

7.26 Archivo Tadeusz Barucki / SARP.

7.27 - 7.28 Andrzej Jur. Fuente: JUR, Andrzej (1977). “Twórczość Architektoniczna Marka Leykama” Poznań, 1977. Ref: 09-000472-02-00. no ISBN.

7.29 - 7.30 Elaboración propia.

\subsection{ADIRECCIONALIDAD.}

8.01 - 8.07 LEYKAK, Marek (1943) "Sztuka Liturgicna.” (“Arte Litúrgico.”). Tesis doctoral original presentada en Zúrich, 1943. no ISBN.

8.08 Autor Desconocido. Fuente: viaggi.donnamoderna.com.

8.09 Autor Desconocido. Fuente: ventisqueras.wordpress.com.

8.10 Narodowe Archiwum Cyfrowe, sygn. 1-0-6225-1. Fuente: poznan.fotopolska.eu.

8.11 Archiwum / Elżbieta Podolska. Fuente: Głosu Wielkopolskiego.

8.12 Narodowe Archiwum Cyfrowe. Fuente: Zalesiński, 2014. 
8.13 Archiwum / Elżbieta Podolska. Fuente: Głosu Wielkopolskiego.

8.14 Autor Desconocido / Fuente: Kaiser, 2013. Naszemiasto.pl

8.15 Archiwum właściciela: Centrum Developments/ Fuente: bryla.pl.

8.16 Autor Desconocido / Fuente: Kaiser, 2013. Naszemiasto.pl.

8.17-8.18 Archivo Tadeusz Barucki / SARP.

8.19 Archiwum / Fuente: poznan.fotopolska.eu.

8.20 Narodowe Archiwum Cyfrowe. Fuente: bryla.pl.

8.21 Archiwum / Fuente: poznan.fotopolska.eu.

8.22 - 8.27 JEMS Architekci / RKW. Architektura murator 03/2013 nr 222 pp. 58-67.

8.28 - 8.29 Autor Desconocido / Fuente: Kaiser, 2013. Naszemiasto.pl.

8.30 Archiwum / Fuente: poznan.fotopolska.eu.

8.31 - 8.34 JEMS Architekci / RKW. Architektura murator 03/2013 nr 222 pp. 58-67.

8.35 - 8.36 Archiwum / Fuente: poznan.fotopolska.eu.

\subsection{LINEALIDAD.}

9.01 E.J. Kwasniewski. Fuente: wroclaw.fotopolska.eu.

9.02 Autor Desconocido. Kulak, 1997. Fuente: wroclaw.fotopolska.eu.

9.03 - 9.05 Autor Desconocido. Fuente: Grajewski | Ilkosz, 2007.

9.06 - 9.08 Autor Desconocido. Fuente: efreyssinet-association.com.

9.09 Autor Desconocido. CCA Collection PH1980:1015:156 / Fuente: cca.qc.ca.

9.10 - 9.12 Autores Desconocidos. Fuente: wroclaw.fotopolska.eu.

9.13 Autor Desconocido. Fuente: www.interklasa.pl.

9.14 Autor Desconocido. Fuente: wroclaw.fotopolska.eu.

9.15 - 9.18 Encyklopedia Wrocławia Wydawnictwo Dolnośląskie. Fuente: wroclaw.fotopolska.eu.

9.19 - 9.23 Archivo Tadeusz Barucki / SARP.

9.23 Source Manuscripts \& Archives. Yale University Library / Eero Saarinen Collection. Fuente: images.library.yale.edu.

9.25 Archivo Tadeusz Barucki / SARP.

9.26 Source Manuscripts \& Archives. Yale University Library / Eero Saarinen Collection. Fuente: images.library.yale.edu.

9.27 Archivo Tadeusz Barucki / SARP. 


\subsection{INTERTEXTUALIDAD.}

10.01 ARC. National Archives and Records Administration USA, identificador: 541691.

10.02 Bundesarchiv_Bild_183-B0527-0001-753/Röhnert.

10.03 Autor desconocido. Fuente: "The Marshall Plan at the Mid-Mark". Averell Harriman Papers. Manuscript Division. Library of Congress loc.gov

10.04 Autor desconocido. Fuente: Revista "Stolica” Varsovia junio 1954.

10.05 Colección de Arkadiusz Sitarski. Photo Service - Warsaw. archirama.muratorplus.pl

10.06 을 Galería Estatal Tretyakov, Moscú. Fuente: Exposición “Aleksandr Deineka (1899-1969) Una vanguardia para el proletariado”. Fundación Juan March.

10.07 Autor desconocido. Fuente: NAC Narodowe Archiwum Cyfrowe.

10.08 Colección de Arkadiusz Sitarski. Photo Service - Warsaw. archirama.muratorplus.pl.

10.09 (c) Galería Estatal Tretyakov, Moscú. Fuente: deineka.ru.

10.10 (C) Museo Regional de Bellas Artes de Volgogrado. Fuente: deineka.ru.

10.11 Autor Desconocido / Adolf Forbert. Fuente: repozytorium.fn.org.pl.

10.12 Roman Wionczek / East News. Fuente: nowahistoria.interia.pl.

10.13 W. Slawny. Fuente: Bohdan Garlinski: Architektúra Polska 1950-1951, PWT, Varsovia, Polonia, 1953 / CC-BY-SA.

10.14 Zbyszko Siemaszko / Dom Spotkań z Historią. Fuente: culture.pl

10.15 Autor desconocido. Fuente: stanislawjankowskiagaton.pl

10.16 SARP/Fuente: sarp.pl.

10.17 - 10.22 Archivo Tadeusz Barucki / SARP.

10.23 - 10.24 Revista Architektura 1951/7-8. p. 198. Op. Cit. Zieliński, 2009. p 184.

10.25 - 10.26 Autor Desconocido. Fuente: Architektura 08/2012 no 215.

10.27 Albert Zawada / Agencja Gazeta. Fuente: warszawa.gazeta.pl.

10.28 Robert Kowalewski / Agencja Gazeta. Fuente: warszawa.gazeta.pl.

10.29 Bartosz Bobkowski / Agencja Gazeta. Fuente: warszawa.gazeta.pl.

10.30 - 10.34 LEYKAK, Marek (1943) "Sztuka Liturgicna." (“Arte Liturgico.”). Tesis doctoral original presentada en Zúrich, 1943. no ISBN.

10.35 Elaboración propia.

10.36 LEYKAK, Marek (1943) "Sztuka Liturgicna.” (“Arte Liturgico.”). Tesis doctoral original presentada en Zúrich, 1943. no ISBN.

10.37 Autor Desconocido. Fuente: alhambra-patronato.es

10.38 Autor Desconocido. Fuente: europaenfotos.com.

10.39 Fernando Martín. CC-BY-SA.

10.40 Autor Desconocido. Fuente: alqueriaalhambra.webnode.es. 
10.41 Architektura i Budownictwo" 1929 n 5. p.195.

10.42 - 10.43 Michał Wojtczuk / Agencja Gazeta. Fuente: warszawa.gazeta.pl.

10.44 - 10.45 Jakub Certowicz. Fuente: Revista Architektura 08/2012 nº 215.

\subsection{ANTAGONISMO.}

11.01 Galería Estatal Tretiakov, Moscú. Fuente: deineka.info

11.02 Biblioteca Lenin, Moscu. Fuente: deineka.info

11.03 - 9.06 Zbyszko Siemaszko/Forum. Fuente: culture.pl

11.07 - 11.08 Autor Desconocido. Fuente: pkin.pl

11.09 - 11.11 Marek Leykam, Jerzy Hryniewiecki,Jerzy Główczewski, Eugeniusz Ziółkowski y Bronisław Gawryluk. Fuente: Giergoń, 2009.

11.10 Autor Desconocido. Fuente: Giergoń, 2009.

11.12 Autor Desconocido. Fuente: pkin.pl.

11.13 - 11.18 Autor Desconocido. Fuente: Giergoń, 2009.

11.19 Archivo Tadeusz Barucki / SARP.

11.20 Autor Desconocido. Fuente: Giergoń, 2009.

11.21 Elaboración propia

11.22 NAC Narodowe Archiwum Cyfrowe. Fuente: nac.gov.pl.

11.23 - 11.24 Archivo Tadeusz Barucki / SARP.

11.25 - 11.27 NAC Narodowe Archiwum Cyfrowe. Fuente: nac.gov.pl.

11.28 - 11.30 Archivo Tadeusz Barucki / SARP.

11.31 NAC Narodowe Archiwum Cyfrowe. Fuente: nac.gov.pl.

11.32 Autor Desconocido. Fuente: Giergoń, 2009.

11.33 Archivo Tadeusz Barucki / SARP.

11.34 NAC Narodowe Archiwum Cyfrowe. Fuente: nac.gov.pl.

\subsection{INTERDISCURSIVIDAD.}

12.01 - 12.05 Oscar Niemeyer / Varios. Fuente: Fundacion Oscar Niemeyer.

12.06 Autor Desconocido. Fuente: Sammlung Staeck 
12.07 Mario Roberto Duran Ortiz. Fuente: commons.wikimedia.org

12.08 Archivo Tadeusz Barucki / SARP.

12.09 ; 12.10 Autor Desconocido. Fuente:

12.11 - 12.15 Archivo Tadeusz Barucki / SARP.

12.16 - 12.18 Dom Kultury w Lublinie SARP Fuente: sarp.warszawa.pl.

12.19 - 12.21 @ Stamo Papadaki, 1956.

12.22 Cartel propagandistico. Fuente: Rivero Martins, 2004. "Patrones Arquitectónicos y Urbanisticos del Turismo en Florianópolis." UPC, 2004.

12.23 - 12.24 Autor Desconocido. Fuente: Fundación Oscar Niemeyer.

12.25 - 12.27 Archivo Tadeusz Barucki / SARP.

12.28 (c) Stamo Papadaki, 1956.

12.29 Archivo Tadeusz Barucki / SARP.

\subsection{HIPERTEXTUALIDAD.}

13.01 Autor desconocido. Fuente: stanislawjankowskiagaton.pl.

13.02 - 13.07 Según autores. Fuente: ZIELIŃSKI, Jarosław (2009).

13.01 Autor desconocido. Fuente: stanislawjankowskiagaton.pl.

$13.09 ; 13.10$ Archivo Tadeusz Barucki / SARP.

$13.11 ; 13.12$ Autor desconocido./Fuente: isailehavre.canalblog.com.

13.13 - 13.17 Según autores. Fuente: ZIELIŃSKI, Jarosław (2009).

13.18 Archivo Tadeusz Barucki / SARP.

13.19 Archiwum SARP. Fuente: archsarp.pl

13.20 Autor desconocido. Fuente: NAC Narodowe Archiwum Cyfrowe.

13.21 Zbigniew Karpiński. Fuente: Revista"Architektura", 1959, nr 5

13.22 - 13.23 Autor desconocido. Fuente: Ściana Wschodnia, Warszawa-portret miasta. Revista Arkady, 1981 Fuente: varsisava.pl

13.24 - 13.26 Archivo Tadeusz Barucki / SARP.

\subsection{EPIFONEMA.}

14.01 - 14.05 LEYKAK, Marek (1943) "Sztuka Liturgicna." (“Arte Litúrgico.”). Tesis doctoral original presentada en Zúrich, 1943. no ISBN.

14.06 - 14.10 Olek Świtkowski / Revista Architektura, 1962. Fuente: powojennymodernizm.com 
14.11 Autor desconocido / Revista Architektura, 1962. Fuente: powojennymodernizm.com

14.12 Olek Świtkowski / Revista Architektura, 1962. Fuente: powojennymodernizm.com

14.13 - 14.15 Autor desconocido / Revista Architektura, 1962. Fuente: powojennymodernizm.com

14.16 - 14.19 Olek Świtkowski / Revista Architektura, 1962. Fuente: powojennymodernizm.com

14.20 Autor desconocido / Archiwum AWF. Fuente: powojennymodernizm.com

14.21 - 14.22 Planos originales Marek Leykam.

14.23 Autor desconocido / Archiwum AWF. Fuente: powojennymodernizm.com

14.24 Maciej Werc / Fuente: Informator SARP O/Poznañ - WOIA. 2007/04

\section{CONCLUSIONES.}

15.01- 15.11 Elaboración propia.

15.12 Autor desconocido.

\section{ANEXO I: LA SUPERVIVENCIA DE LAS OBRAS.}

I.01 Archivo Tadeusz Barucki / SARP.

I.02 NAC Narodowe Archiwum Cyfrowe. Fuente: nac.gov.pl.

I.03 Elaboración propia.

I.04 - I.05 Archivo Tadeusz Barucki / SARP.

I.06 - I.07 Marciniak, Piotr | Joanna Goldych. Fuente: powojennymodernizm.com

I.08 Autor desconocido / Dominio público.

I.09 - I.11 Marciniak, Piotr | Joanna Goldych. Fuente: powojennymodernizm.com

I.12 Autor desconocido / Dominio público.

I.13 - I.16 Agencja Gazeta. Fuente: warszawa.gazeta.pl.

I.16 Piotr Waglowski. Fuente: vagla.pl

I.17 - I.19 Autor Desconocido. / Dominio Publico.

I.20 M. Chilinski / Dominio Publico.

I.21-I.22 Sławek Siskom / Dominio Publico. 
I.23 Przemysław Jahr / Dominio Publico.

I.24 - I.28 Świtkowski, Olek. / Fuente: powojennymodernizm.com

I.29 - I.32 Marciniak, Piotr. / Fuente: powojennymodernizm.com

\section{ANEXO II: LISTA DE PROYECTOS.}

1. Jur. 1977.

2. Architektura i Budownictwo $n^{\circ} 35-12$

3. Architektura i Budownictwo $n^{\circ} 36-6$

4. Architektura i Budownictwo ${ }^{\circ}$ 37-2

5. Architektura i Budownictwo ${ }^{\circ} 37-5$

6. Architektura i Budownictwo ${ }^{\circ}$ 38-1

78 Archivo Barucki / SARP.

9 Kusztelski, 1999. p. 296.

10 - 17 Archivo Barucki / SARP.

18 - 19 FotoPolska.eu

20 - 17 Archivo Barucki / SARP.

9 Kusztelski, 1999. p. 296.

16 Ref: 36168 FotoPolska.eu

17 - 25 Archivo Barucki / SARP.

26 Autor: Agata Grzybowska / Fuente: Agencja Gazeta.

27 - 29 Archivo Barucki / SARP.

30 Marek Holzman/. Fuente. Bryla.pl.

31 - 36 Archivo Barucki / SARP.

37 Archivo AWF/ Fuente: powojennymodernizm.com.

38 - 40 Archivo Barucki / SARP.

\section{EPITAFIO.}

18.01 Archivo Tadeusz Barucki / SARP. (mod.) 
18.01 Lápida sepulcral de Marek Leykam en el Cementerio Evangelico-Augsburgiano (Cmentarz

Evarsovia.

18.00. Articulo "Z rozważań architekta" " $R$ Reflexiones

de un arquitecto") Publicado en la revista Plastyka

de un arquitecto
$1937, n^{1} 1$ p. 34

18.01. Marek Leykam falleció el 27 de febrero de

1983. Su tumba se puede visitar en el Cementerio

Evangelico-Augsburgiano (Cmentarz Ewangelicko-

Augsburski) de Varsovia. 
"Cada vez que la mente humana se pregunta sobre la validez de una doctrina, se lo pregunta a sí misma. El consentimiento o la creencia en una doctrina la encuentra en sí mismo y, de repente, se da cuenta que el creador de las hipótesis y los dioses es él mismo, el pensamiento humano. Entonces, puede creer en la anarquía de su fierza, o, siendo incapaz de comprender la razón, profundizar en los sentimientos y creer en lo absoluto." 18.00

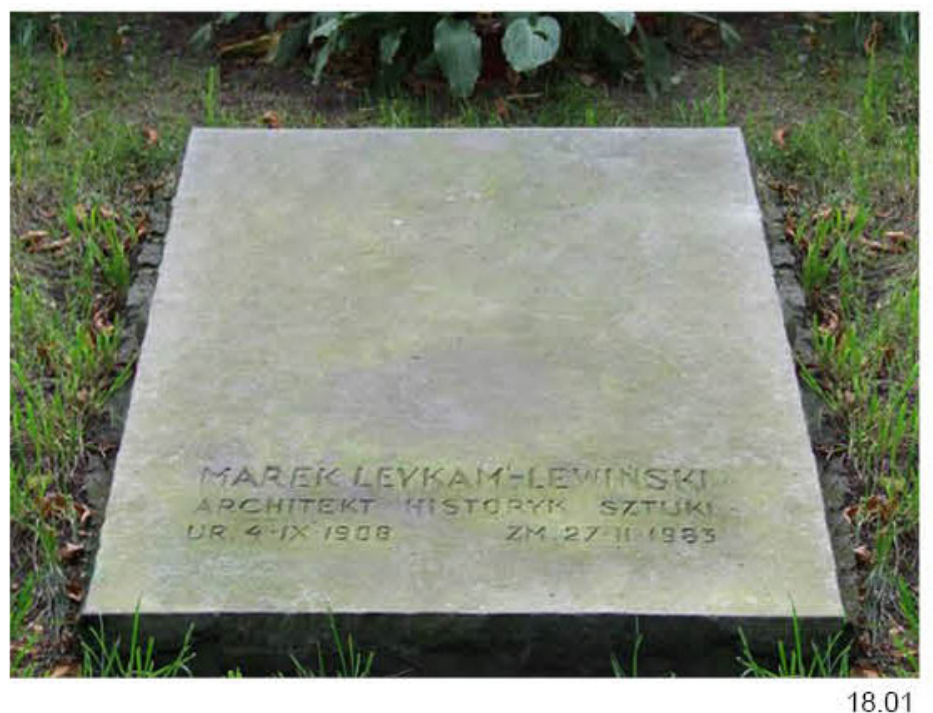

Marek Leykam - Lewiński

Arquitecto e Historiador del Arte

Nac.: 4.IX.1908 Fall.: 27.II.1983 18.01 